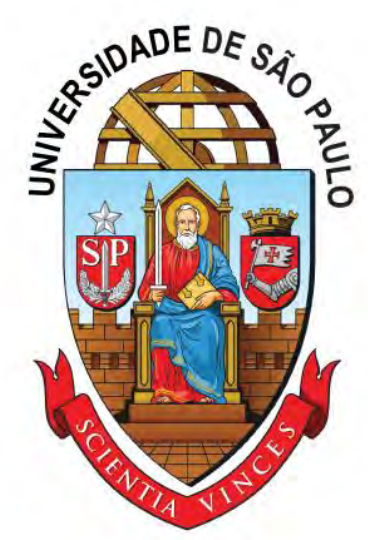

UNIVERSIDADE DE SÃO PAULO

ESCOLA DE COMUNICAÇÕES E ARTES

PROGRAMA DE PÓS-GRADUAÇÃO EM MÚSICA

ELIEL ALMEIDA SOARES

\title{
O Emprego da Retórica na Música Colonial Brasileira
}




\section{ELIEL ALMEIDA SOARES}

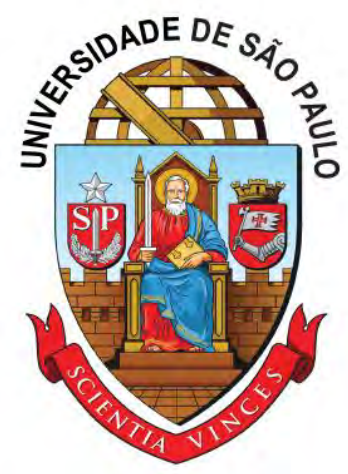

\section{O Emprego da Retórica na Música Colonial Brasileira}

\section{Versão Corrigida}

A versão original encontra-se na Biblioteca da ECA/USP.

Tese apresentada ao Programa de Pós-Graduação em Música da Escola de Comunicações e Artes da Universidade de São Paulo, para obtenção do título de Doutor em Artes.

Área de Concentração: Musicologia

Orientador: Prof. Dr. Diósnio Machado Neto 
Autorizo a reprodução e divulgação total ou parcial deste trabalho, por qualquer meio convencional ou eletrônico, para fins de estudo e pesquisa, desde que citada a fonte.

Catalogação na Publicação

Serviço de Biblioteca e Documentação

Escola de Comunicações e Artes da Universidade de São Paulo

Dados fornecidos pelo(a) autor(a)

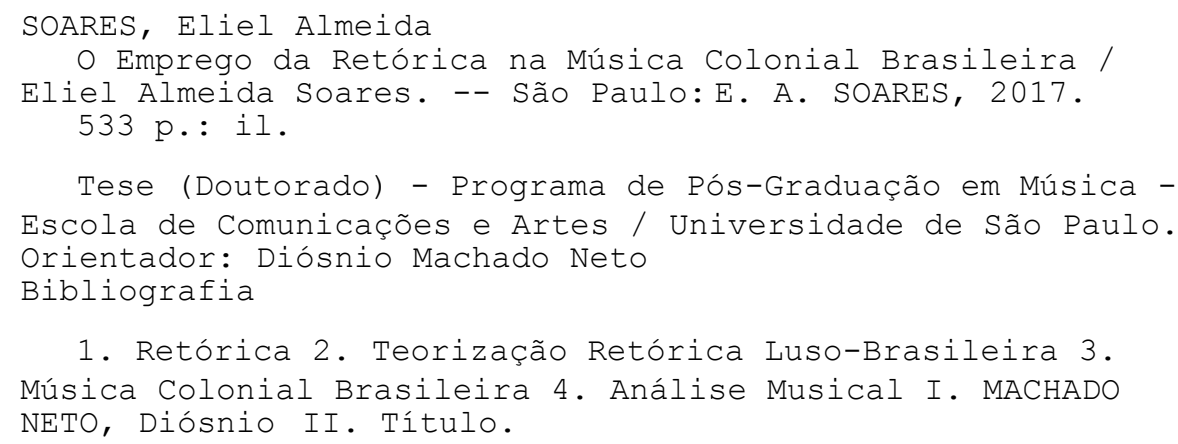


Nome: SOARES, Eliel Almeida.

Título: O Emprego da Retórica na Música Colonial Brasileira

Tese apresentada à Escola de Comunicações e Artes da Universidade de São Paulo para obtenção do título de Doutor em Artes.

Aprovado em: 11/05/2017

\section{Banca Examinadora}

Prof. Dr. Diósnio Machado Neto

Instituição: FFCLRP/USP

Prof. Dr. Paulo de Tarso Camargo Cambraia Salles

Instituição: ECA/USP

Prof. Dr. Rodolfo Nogueira Coelho de Souza

Instituição: FFCLRP/USP

Prof. Dr. Márcio Leonel Farias Reis Páscoa

Instituição: UEA

Profa. Dra. Lenita Waldige Mendes Nogueira

Instituição: IA/UNICAMP 
A Deus, que sempre me ensina um caminho excelente, permeado sob a égide da justiça, amor e paz.

Aos meus pais, Valmir e Luzia, por proporcionar esse momento impar em minha vida. 


\section{AGRADECIMENTOS}

Ao meu orientador, Prof. Dr. Diósnio Machado Neto, pela amizade, pelas indicações, por incentivar sempre a pesquisa minuciosa, com critérios éticos, responsáveis, imparciais e de qualidade. Pelo estimulo ao processo criativo na redação da tese pelo viés da contextualização seja das fontes ou referências bibliográficas. Enfim, pelas orientações, por avalizar e acreditar neste trabalho.

À Profa. Dra. Mônica Isabel Lucas, por seus conselhos, pelos esclarecimentos e contributos nas questões relacionadas à retórica em geral e musical.

Ao Prof. Dr. Mário Rodrigues Videira Júnior, pelo apoio, por suas elucidações filosóficas, além das observações pertinentes relativas à ordenação e disposição dos tópicos concernentes aos capítulos da tese.

Ao Prof. Dr. Edilson Vicente de Lima, pelas sugestões e observações dos conceitos e termos, no exame de qualificação.

Ao Prof. Dr. Rodolfo Nogueira Coelho de Souza, pelos incentivos nas análises sejam harmônicas, tópicas, hermenêuticas e retóricas.

Ao Prof. Dr. Carlos Alberto Figueiredo, pelas observações minuciosas sobre as figuras retóricas, das fontes utilizadas e dos manuscritos musicais.

Ao Prof. Dr. Edmundo Pacheco Hora, por suas recomendações e sugestões relacionadas à retórica e o intérprete musical.

Ao Prof. Dr. Márcio Leonel Farias Páscoa, ressaltando questões relativas às citações da tese, assim como das análises retóricas.

Ao Prof. Dr. Mário Marques Trilha Neto, na observação e sugestão de algumas formas de elaboração das análises retórico-musicais, assim como na relação texto-musica.

À Fundação de Amparo à Pesquisa do Estado de São Paulo (FAPESPProcesso $n^{\circ}$. 2013/23600-3), pela concessão da bolsa de doutorado e pelo apoio financeiro para a realização desta pesquisa.

Aos meus amigos e colegas, companhia certa nos estudos e trabalhos realizados.

Em síntese, a todos aqueles que direta e indiretamente me ajudaram nesta pesquisa. 
Esta tese contou com o apoio e auxílio financeiro da

\section{Fundação de Amparo à Pesquisa do Estado de São Paulo}

(FAPESP)

Processo n. 2013/23600-3

Bolsa de Doutorado

2014-2017

As opiniões, hipóteses e conclusões ou recomendações expressas neste material são de responsabilidade do autor e não necessariamente refletem a visão da FAPESP. 


\section{RESUMO}

SOARES, Eliel Almeida. O Emprego da Retórica na Música Colonial Brasileira. 533 f. Tese (Doutorado em Artes) - Programa de Pós-Graduação em Música, Escola de Comunicações e Artes, Universidade de São Paulo (USP), São Paulo, 2017.

O discurso musical, entre o final do século XVI e início do XIX, era constituído por elementos retóricos, aliados à organização e a disposição fundamentados na eloquência e persuasão, consequentes de uma transmissão escolástica decorrida desde a Idade Média e no Renascimento, conferindo certo grau de excelência às músicas produzidas tanto na Europa como no Brasil. Tal processo é fruto de contextos histórico-sociais ocorridos desde a Antiguidade, relacionados às obras de tratadistas, pensadores e compositores formando, dessa forma, a base necessária para a concepção estrutural de uma música. Com o propósito de compreender em quais caminhos percorreram esses ensinamentos, a musicologia em meados da década de 1960, iniciou inúmeras pesquisas as quais contribuíram para o desenvolvimento de novos meios analíticos, com o objetivo de clarificar a relação entre música e afeto. Apesar desse crescente interesse, no ambiente luso-brasileiro, os estudos sobre a retórica musical ainda estão em fase inicial, entretanto, procurando desenvolver metodologias mais apropriadas para o entendimento de sua adequação e concepção sistemática, constituídas estruturalmente na música vigente do período investigado. Por esse motivo, essa tese tem por objetivo examinar o uso da retórica na música colonial brasileira, bem como verificar os estudos de caso acerca dessa utilização. Em outras palavras, averiguar o emprego de elementos retóricos em Manoel Dias de Oliveira, José Joaquim Emerico Lobo de Mesquita, André da Silva Gomes e José Maurício Nunes Garcia, utilizandose de ferramentas analíticas relacionadas ao texto sacro e harmonia, as quais se mostram necessárias à compreensão da linguagem retórica nas obras desses mestres da composição.

Palavras-chave: Retórica, Teorização Retórica Luso-Brasileira, Música Colonial Brasileira, Análise Musical. 
ABSTRACT 


\begin{abstract}
SOARES, Eliel Almeida. The use of Rhetoric in Brazilian Colonial Music. 533 f. Tese (Doutorado em Artes) - Programa de Pós-Graduação em Música, Escola de Comunicações e Artes, Universidade de São Paulo (USP), São Paulo, 2017.
\end{abstract}

The Musical discourse, between the late sixteenth and early nineteenth centuries, consisted of rhetorical elements, coupled with organization and layout based on eloquence and persuasion, consequent of a scholastic transmission elapsed since the Middle Ages and the Renaissance, conferring a certain degree of excellence to songs produced both in Europe and in Brazil. This process is the result of historical and social contexts which have occurred since Antiquity, it is related to the work of scholars, thinkers and writers, thus forming the basis for the structural design of a music. The musicology in the mid -1960s, with the purpose to understand the ways these teachings unfold, initiated many studies that contributed to the development of new analytical means, intended to clarify the relationship between music and affect. Despite this growing interest in the Luso-Brazilian environment, the studies on musical rhetoric are still in the initiate stage, however, they are seeking to develop the most appropriate methodologies for understanding their suitability and systematic design, which are structurally composed on the music of the current period investigated. Due to that fact, this thesis aims to examine the use of rhetoric in Brazilian Colonial Music and verify the case studies about such use as well. In other words, its objective is to ascertain the use of rhetorical elements in Manoel Dias de Oliveira, José Joaquim Emerico Lobo de Mesquita, André da Silva Gomes and José Maurício Nunes Garcia, using analytical tools related to the sacred text and harmony, which are necessary for the understanding of rhetorical language in the works of these masters of composition.

Keywords: Rhetoric, Luso-Brazilian Rhetorical Theorization, Brazilian Colonial Music, Musical Analysis. 
LISTAS DE FIGURAS 


\section{LISTAS DE FIGURAS}

\section{Exemplos:}

Figura 1-Figura Alegórica da Retórica............................................ 58

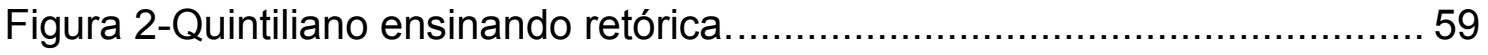

Figura 3-Os Três Gêneros do Discurso.............................................. 65

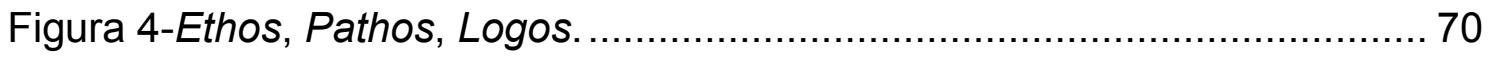

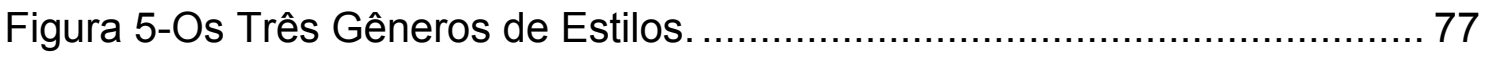

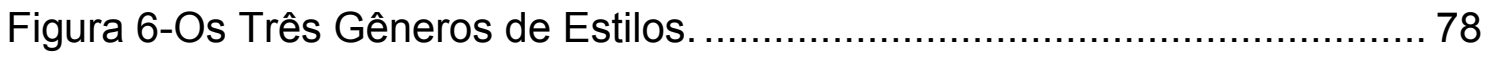

Figura 7-As Sete Artes Liberais: Trivium e Quadrivium.............................. 83

Figura 8-lluminura medieval de autor desconhecido (século XIV) das Artes Liberais- existente na Cambridge University Library. ................................. 84

Figura 9-A Eloquência entre a Música e a Harmonia (1652).......................... 90

Figura 10-Frontispício do Tratado Musica de Nicolaus Listenius. .................. 92

Figura 11-Frontispício da Le Institutioni Harmoniche de Gioseffo Zarlino (1558).

Figura 12-Trechos do Praecepta Musicæ Poeticæ de Gallus Dressler (1563). 95

Figura 13-Estrutura dos Capítulos do Hypommenmatum Musicæ Poeticæ de

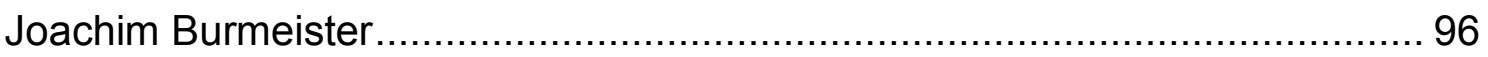

Figura 14-Parte da Elaboração Estrutural da Musica Autoschédiastiké de Joachim Burmeister 96

Figura 15-Frontispício de Musica Poetica de Joachim Burmeister (1606). ...... 97

Figura 16-Indicação da Palilogia por Joachim Burmeister. .......................... 98

Figura 17-Frontispício da Sinopse Musicæ Nova de Johannes Lippius (1612).99

Figura 18-Frontispício de Musices Poeticæ de Johannes Nucius (1613)...... 100

Figura 19-Frontispício do Compendium Musicæ de Rene Descartes (1618). 101

Figura 20-Frontispício do Opusculum Bipartitum de Primordiis Musicis de Joachim Thuringus (1624)..... 102

Figura 21-Definições de algumas figuras retórico-musicais por Joachim Thuringus. 103 
Figura 22-Frontispício do Traité de l' Harmonie Universelle de Marin Mersenne (1636-7). 104

Figura 23-Exordio, Medio e Fine, segundo o Tratado Musica Poetica de Joahnn Andreas Herbst. 105

Figura 24-Frontispício do Musurgia Universalis de Athanasius Kircher (1650). 106

Figura 25-Frontispício do Musicalisches Lexicon de Johann Gottfried Walter (1732). 107

Figura 26-Frontispício do Conclave thesauri magnæ artis musicæ de Mauritius Johann Vogt (1719). 108

Figura 27-Denifições das figuras retóricas da Anabasis, Catabasis, Anadiplosis, Epanadiplosis, Anaphora, Antistaechon, Antitbeton e Aposiopesis. 109

Figura 28-Frontispício do Tractatus Musicus Compositorio-Practicus de Meinrad Spiess (1745). 110

Figura 29-Frontispício do Critische Der Musikus de Johann Adolf Scheibe (1745). 111

Figura 30-Frontispício do Allgemeine Geschichte der Musik de Johann Nikolaus Forkel (1788). 112

Figura 31-Frontispício do Versch Einer Anleitung zur Composition de Heinrich Christoph Koch (1782-1793). 113

Figura 32-Frontispício do Musikalisches Lexikon de Heinrich Christoph Koch (1802). 114

Figura 33-Frontispício do Der Vollkommene Capellmeister de Johann

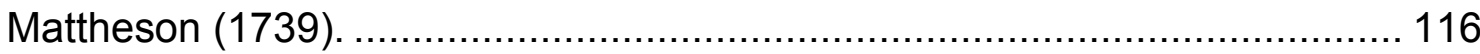

Figura 34-Os Loci Topici segundo Johann Mattheson. ................................ 117

Figura 35- As seis partes da Dispositio segundo Johann Mattheson. ............ 120

Figura 36-Os quatro tipos de humor e temperamento segundo Athanasius Kircher. 127

Figura 37-Frontispício de Das Neu-eröffnete Orchestre de Johann Mattheson (1713). 130

Figura 38-As tonalidades e seus respectivos afetos. 131

Figura 39-O Universo da Tópica na Música Clássica. 171 
Figura 40- Portada dos Estatutos da Universidade de Coimbra confirmados por

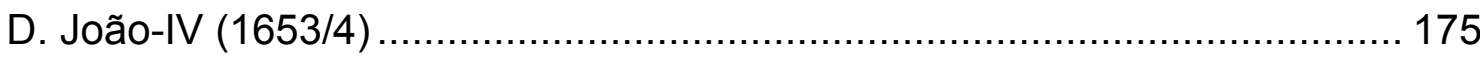

Figura 41- Frontispício da Ratio Studiorum (1591)................................... 182

Figura 42- Índice dos Assuntos Abordados pela Ratio Studiorum (1591)...... 183

Figura 43-Frontispício do Tratado De Arte Rhetorica Libri de Cipriano Soares (1575[1562])

Figura 44-A Finalidade da Retórica- De Arte Rhetorica de Cipriano Soares.. 186

Figura 45-As Cinco Partes Retóricas segundo Cipriano Soares 187

Figura 46-As Quatro Partes da Dispositio segundo Cipriano Soares............. 188

Figura 47-A Elocução (Elocutio) segundo Cipriano Soares. .......................... 190

Figura 48-Frontispício dos Sermões (1679) de Antonio Vieira...................... 194

Figura 49-Parte das Divisões das Metáforas segundo Emanuele Tesauro.... 196

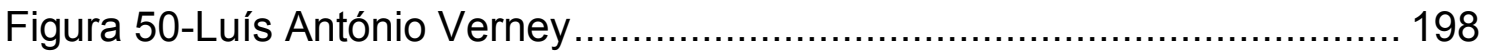

Figura 51-Os Cursos Frequentados por Verney no Colégio de Santo Antão. 199

Figura 52-O Verdadeiro Método de Estudar (1746) de Luís António Verney. 200

Figura 53-Trecho da Dissertação sobre o estilo Sublime segundo Verney .... 204

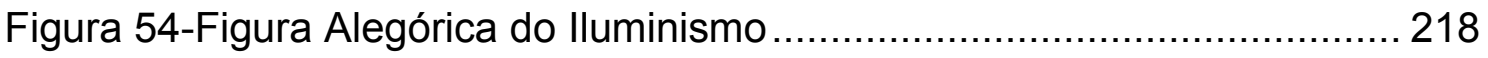

Figura 55-Passaporte do terceiro Bispo de São Paulo, cuja comitiva participava André da Silva Gomes. ................................................................... 224

Figura 56-Citação da Retórica na Lição nº 1 f 2 por André da Silva Gomes . 240 
LISTAS DE TABELAS 


\section{LISTAS DE TABELAS}

\section{Exemplos:}

Tabela 1-Quadro de definições sobre Retórica, segundo Quintiliano.

Tabela 2-Estrutura retórica e suas etapas

Tabela 3-Estrutura retórica e suas etapas.

Tabela 4-Estrutura retórica e suas etapas.

Tabela 5-Estrutura retórica e suas etapas

Tabela 6-Estrutura retórica e suas etapas.

Tabela 7-Estrutura retórica e suas etapas

Tabela 8-Classificação dos afetos.

Tabela 9-Tipos de Paixões.

Tabela 10-Afetos, Estilos e Tópicas Ressaltados por Ratner (1980). 169

Tabela 11-Algumas Produções Acadêmicas sobre Retórica na Música Colonial Brasileira.

Tabela 12-Esquema relacional entre retórica, harmonia, texto e música utilizados na tese.

Tabela 13-Andamentos das obras analisadas na tese

Tabela 14-Loci Topici localizados no Confitemini das Matinas e Vésperas de Sábado Santo de Manoel Dias de Oliveira.

Tabela 15-Figuras retóricas localizadas no Confitemini das Matinas e Vésperas de Sábado Santo de Manoel Dias de Oliveira.

Tabela 16-Esquema das Progressões Harmônicas- Curva Tonal do Confitemini das Matinas e Vésperas de Sábado Santo.

Tabela 17-Estrutura analítica da obra. 276

Tabela 18-Loci Topici localizados no Pater Mihi de Manoel Dias de Oliveira. 277

Tabela 19-Figuras retóricas localizadas no Pater Mihi de Manoel Dias de Oliveira.

Tabela 20-Esquema das Progressões Harmônicas- Curva Tonal do Pater Mihi. 
Tabela 22-Loci Topici localizados no Gloria da Missa Abreviada em Ré de Manoel Dias de Oliveira.

Tabela 23-Figuras retóricas localizadas no Gloria da Missa Abreviada em Ré de Manoel Dias de Oliveira. 306

Tabela 24-Esquema das Progressões Harmônicas- Curva Tonal do Gloria da Missa Abreviada em Ré. 307

Tabela 25-Estrutura analítica da obra. 307

Tabela 26-Loci Topici localizados no Exaudi nos, Domine de José Joaquim Emerico Lobo de Mesquita. 309

Tabela 27-Figuras retóricas localizadas no Exaudi nos, Domine de José Joaquim Emerico Lobo de Mesquita. 318

Tabela 28-Esquema de Progressões Harmônicas- Curva Tonal do Exaudi nos, Domine para Benção de Cinzas da Missa para Quarta-feira de Cinzas. 318

Tabela 29-Estrutura analítica da obra. 319

Tabela 30-Loci Topici localizados no Gloria Patri e Sicut erat para Bênçãos de Cinzas, da Missa para Quarta-feira de Cinzas de José Joaquim Emerico Lobo de Mesquita. 320

Tabela 31-Figuras retóricas localizadas no Gloria Patri e Sicut erat de José Joaquim Emerico Lobo de Mesquita. 324

Tabela 32-Esquema de Progressões Harmônicas- Curva Tonal do Gloria Patri para Benção de Cinzas da Missa para Quarta-feira de Cinzas...................... 324

Tabela 33-Estrutura analítica da obra. 325

Tabela 34-Loci Topici localizados no Kyrie da Ladainha em Si bemol Maior de José Joaquim Emerico Lobo de Mesquita.

Tabela 35-Figuras retóricas localizadas no Kyrie da Ladainha em Si bemol Maior de José Joaquim Emerico Lobo de Mesquita. 334

Tabela 36-Esquema de Progressões Harmônicas- Curva Tonal do Kyrie da Ladainha em Si bemol Maior de José Joaquim Emerico Lobo de Mesquita. . 336

Tabela 37-Estrutura analítica da obra. 336

Tabela 38-Loci Topici localizados no Cum Appropinquaret,da Procissão de Ramos de José Joaquim Emerico Lobo de Mesquita.

Tabela 39-Figuras retóricas localizadas no Cum Appropinquaret, da Procissão de Ramos de José Joaquim Emerico Lobo de Mesquita. 
Tabela 40-Esquema de Progressões Harmônicas- Curva Tonal do Cum Appropinquaret, da Procissão de Ramos de José Joaquim Emerico Lobo de Mesquita. 349

Tabela 41-Estrutura analítica da obra. 349

Tabela 42-Loci Topici localizados no Ofertório da Missa do Domingo da Paixão de André da Silva Gomes. 352

Tabela 43-Figuras retóricas localizadas no Ofertório da Missa do Domingo da Paixão de André da Silva Gomes. 361

Tabela 44-Esquema das Progressões Harmônicas- Curva Tonal do Ofertório da Missa do Domingo da Paixão. 364

Tabela 45-Estrutura analítica da obra. 365

Tabela 46-Loci Topici localizados no Ofertório da Missa do Quarto Domingo da Quaresma de André da Silva Gomes. 368

Tabela 47-Figuras retóricas localizadas no Ofertório da Missa do Quarto Domingo da Quaresma de André da Silva Gomes. 385

Tabela 48-Esquema de Progressões Harmônicas- Curva Tonal do Ofertório da Missa do $4^{\circ}$ Domingo da Quaresma. 390

Tabela 49-Estrutura analítica da obra. 390

Tabela 50-Loci Topici localizados no Laudate Pueri de André da Silva Gomes. 393

Tabela 51-Figuras retóricas localizadas no Laudate Pueri de André da Silva Gomes. 408

Tabela 52- Esquema de Progressões Harmônicas- Curva Tonal do Laudate Pueri. 410

Tabela 53-Estrutura analítica da obra. 411

Tabela 54-Loci Topici localizados no Domine Jesu de José Maurício Nunes Garcia. 414

Tabela 55-Figuras retóricas localizadas no Domine Jesus de José Maurício Nunes Garcia. 420

Tabela 56-Esquema das Progressões Harmônicas- Curva Tonal do Domine Jesu. 421

Tabela 57-Estrutura analítica da obra. 421 
Tabela 58-Loci Topici localizados no Crux Fidelis de José Maurício Nunes Garcia.

Tabela 59-Figuras retóricas localizadas no Crux Fidelis de José Maurício Nunes Garcia.

Tabela 60-Esquema das Progressões Harmônicas- Curva Tonal do Crux Fidelis. 430

Tabela 61-Estrutura analítica da obra. 431

Tabela 62-Loci Topici localizados no $1^{\circ}$ Responsório de José Maurício Nunes Garcia. 433

Tabela 63-Figuras retóricas localizadas no $1^{\circ}$ Responsório de José Maurício Nunes Garcia. 441

Tabela 64-Esquema das Progressões Harmônicas- Curva Tonal do $1^{\circ}$ Responsório. 442

Tabela 65-Estrutura analítica da obra 443 


\section{LISTAS DE EXEMPOS MUSICAIS}




\section{LISTAS DE EXEMPLOS MUSICAIS}

\section{Exemplos:}

Exemplo 1-Lamentatio Prima Primi Dei- Lamantationes Jeremiæ Prophetæ (1585) de Olando di Lasso.

Exemplo 2-Feria Sexta in Parasceve-Lamantationes Jeremiæ Prophetæ (1585) de Olando di Lasso.

Exemplo 3-In me Transierunt tui (1585) de Orlando di Lasso. 134

Exemplo 4-Madrigal O Mirtillo, Mirtillo, anima mia (1595) de Luca Marenzio. 134

Exemplo 5-Quando vostri bel'iocchi um caro velo de Luca Marenzio. 135

Exemplo 6-Segunda forma de Metalepsis de acordo com Burmeister. 135

Exemplo 7-Sorrow sorrow stay do Segundo livro de canções (1600) de John Dowland . 136

Exemplo 8-Cease these false sports; A Pilgrimes Solace (1612) de John Dowland. 136

Exemplo 9-Flow, my tears (1600) de John Dowland. 136

Exemplo 10-Exaudi-me, Cento Concerti Ecclesiastici (1602) de Ludovico Viadana. 137

Exemplo 11-Combattimento de Tracredi et Clorinda: Madrigal Guerrieri et Amorosi (1638) de Claudio Monteverdi. .............................................. 137

Exemplo 12-Cruda Amarilli (1605) de Claudio Monteverdi.......................... 138

Exemplo 13-Ohimè dove il mio bem (1619) de Claudio Monteverdi.............. 138

Exemplo 14-O quam tu pulchra es (ca.1629) de Heinrich Schütz. 138

Exemplo 15-Freuet euch des Herren ihr Gerechten; Symphoniarum Sacrarum$2^{\mathrm{a}}$ Parte (1647) de Heinrich Schütz.

Exemplo 16-Num komm, der Heider Heiland; Kleine geistliche Concerte (1636) de Heinrich Schütz

Exemplo 17-Paixão Segundo São Mateus de Heinrich Schütz. 140

Exemplo 18-Amadis, Act I, scene 1 (1684) de Jean-Baptiste Lully. 141

Exemplo 19-Passacaille-Armide (1686) de Jean-Baptiste Lully. 142

Exemplo 20-Prelúdio e Fuga em Dó Maior Bux WV 136 de Dietrich Buxtehude. 
Exemplo 21-Durch Adams Fall ist ganz verdert (BuxWV183) de Dietrich Buxtehude. 143

Exemplo 22-Prelúdio em Fuga em Fá \# Menor-Bux-146 de Dietrich Buxtehude. 144

Exemplo 23-Dialogue entre Madeleine et Jésus de Marc-Antoine Charpentier 145

Exemplo 24-Música para o Funeral da Rainha Maria (1695) de Henry Purcell. 145

Exemplo 25-Rei Arthur de Henry Purcell. 145

Exemplo 26-Exsultate Deo de Alessandro Scarlatti. 146

Exemplo 27-Domine Deus, Agnus Dei- do Gloria RV 589 (ca.1715/6) de Antonio Vivaldi. 147

Exemplo 28-Domine Deus, Agnus Dei- do Gloria RV 589 (ca.1715/6) de Antonio Vivaldi. 148

Exemplo 29-Epizeuxis no Der Vollkommene Capellmeister (1739) de Johann Mattheson. 148

Exemplo 30-Sonata Medodiche № 1 (1728) de Georg Phillip Telemann...... 149

Exemplo 31-Variações de Goldberg №. 11 BWV 988 (ca.1741) de Johann Sebastian Bach. 149

Exemplo $32-4^{\circ}$ Movimento do Magnificat (ca.1723) de Johann Sebastian Bach. 150

Exemplo 33-Cantata №.78- Jesu der du meine Sede, Wir eilen mit schwanthen, doch emsigen Schritten de Johann Sebastian Bach. 150

Exemplo 34-Cantata 131-Aus der Tiefe rufe ich, Herr, zu dir (ca.1707/8) de Johann Sebastian Bach 151

Exemplo 35-Ária O thou that tellest good tidings do Messias - HWV 56 (1741) de George Friedrich Haendel.

Exemplo 36-Aleluia do Messias HWV 56 (1741) de George Friedrich Haendel 153

Exemplo 37-La Serva Padrona (1733) de Giovanni Battista Pergolesi. 154

Exemplo 38-Fantasia Wq.117-13 em Sol Menor (1770)- Carl Philipp Emanuel Bach 155 
Exemplo 39-Fantasia Wq.117-13 em Sol Menor (1770) -Carl Philipp Emanuel

Bach. 155

Exemplo 40-Cantata №. 23 de Johann Sebastian Bach (ca.1717-1723)....... 156

Exemplo 41-Quarteto №. 1 em Si Menor Op.33 (1781) de Joseph Haydn .... 156

Exemplo 42-Aposiopesis na Sinfonia $\mathrm{N}^{\circ} .80$ (1 ${ }^{\circ}$ Movimento) (1784) de Joseph Haydn 157

Exemplo 43-Sonata No.14 em Dó Menor - K. 457 (1Movimento)-(1784) de Wolfgang Amadeus Mozart 157

Exemplo 44-Minueto- Sinfonia em Mi bemol Maior de Johann Christian Bach, Op.9, $\mathrm{N}^{\circ} .2$ de 1775 159

Exemplo 45-Minueto- Quinteto em Sol Maior, K. 516 de Wolfgang Amadeus Mozart de 1787 159

Exemplo 46-Minueto-Sinfonia- №.1 em Dó Maior, Op.21 de Ludwig van Beethoven-1800 159

Exemplo 47-Estilo Sarabanda-Sinfonia- № 41 em Dó Maior, K. 551 (2 Movimento) de Wolfgang Amadeus Mozart-1788 159

Exemplo 48-Polonese-Serenata em Ré Maior, Op.8 de Ludwig van Beethoven1796-1797 160

Exemplo 49-Bourrée- Partita em Si Menor de Johann Sebastian Bach-ca.1720. 160

Exemplo 50-Contradança-Christmann, Elementarbuch, 1782 160

Exemplo 51-Ländler - Minueto em Sol Maior, Wo0 10, $\mathrm{N}^{\circ} .2$ de Ludwig van Beethoven-1796 161

Exemplo 52-Gavota em Presto-Sonata para Piano e Violino em Lá Maior, K.526 (Último Movimento) de Wolfgang Amadeus Mozart-1787 161

Exemplo 53-Estilo de Giga- Sinfonia №. 101 em Ré Maior (1 Movimento)-1794 de Joseph Haydn. 161

Exemplo 54-Estilo Siciliano- Quarteto em Ré Menor, K. 421, (Movimento Final)1783 de Wolfgang Amadeus Mozart 162

Exemplo 55-Tipo de Marcha- Christmann, Elementarbuch, 1782 162

Exemplo 56-Fanfara de Caça- Quinteto em Mi bemol Maior, K. 614 (1 Movimento)-1791 de Wolfgang Amadeus Mozart. 163 
Exemplo 57-Fanfarra-Sinfonia N$^{\circ} .38$ em Ré Maior, K. 504 de Wolfgang Amadeus Mozart-1787 163

Exemplo 58-Estilo Cantabile- Orfeo e Eurídice, Ato-III de Christoph Willibald Gluck-1762 163

Exemplo 59-Estilo Brilhante- Quinteto para Clarineta e Cordas em Lá Maior, K. 581 ( $1^{\circ}$ Movimento) de Wolfgang Amadeus Mozart-1789. 164

Exemplo 60-Estilo de Abertura Francesa- Sinfonia em Mi bemol Maior, K. 543 ( $1^{\circ}$ Movimento) de Wolfgang Amadeus Mozart-1788. 164

Exemplo 61-Musette/Pastoral-Sinfonia $N^{\circ} .104$ em Ré Maior de Joseph Haydn1795. 165

Exemplo 62-Estilo de Música Turca-Sonata em Lá Menor K. 331 (Último Movimento) de Wolfgang Amadeus Mozart ca.1783. 165

Exemplo 63-Sturm und Drang - Sinfonia $\mathrm{N}^{\circ} .102 \mathrm{em} \mathrm{Si}$ bemol Maior (1 ${ }^{\circ}$ Movimento) de Joseph Haynd-1794. 166

Exemplo 64-Estilo Sensível- Fantasia em Ré Menor, K. 397 de Wolfgang Amadeus Mozart-1782 167

Exemplo 65-Estilo Estrito/Galante- Sinfonia N. 38, K. 504 de Wolfgang Amadeus Mozart-1787. 168

Exemplo 66-Estilo Aprendido-Quarteto em Lá Maior, Op.18, N .5 (Movimento Final) de Ludwig van Beethoven-1800 168

Exemplo 67-Estilo Galante-Sonata em Mi Bemol Maior Op.7 ( $2^{\circ}$ Movimento) de Ludwig van Beethoven-1796 169

Exemplo 68-Estilo de Fantasia- Fantasia em Ré Menor, K. 397 de Wolfgang Amadeus Mozart-1782. 169

Exemplo 69-Giga na Suite Francesa N ${ }^{\circ} .1$ em Ré Menor, BWV 812 de Johann Sebastian Bach-1722 172

Exemplo 70-Tropo de Minueto e Marcha (interpolação) na Sinfonia $\mathrm{N}^{\circ} .36 \mathrm{em}$ Dó Maior, K. 425 ( $3^{\circ}$ Movimento) de Wolfgang Amadeus Mozart-1783 ......... 173

Exemplo 71-Análise Retórico-Musical por Maurício Dottori. ........................... 238

Exemplo 72-Análise Retórico-Musical por Maurício Dottori. .......................... 239

Exemplo 73-Epizeuxis no Ofício de 1816 de José Maurício Nunes Garcia.... 241

Exemplo 74-Climax no Ofício de 1816 de José Maurício Nunes Garcia ........ 241 
Exemplo 75-Passus Duriusculus nos Responsórios Fúnebres de José Maurício Nunes Garcia

Exemplo 76-Cum Sancto Spiritu da Missa a Cinco Vozes de André da Silva Gomes.

Exemplo 77-Aspectos Retórico-Musicais em José Joaquim Emerico Lobo de Mesquita.

Exemplo 78-Anabasis, Exclamatio e Anadiplosis no Salmo Laudate Pueri (1813) de José Maurício Nunes Garcia 244

Exemplo 79- Recitativo de Heroe, egregio (1759). 244

Exemplo 80-Catabasis no Ofertório da Missa de Domingo de Ramos de André da Silva Gomes

Exemplo 81-Noema, Aposiopesis e Epizeuxis no Exordium do Kyrie- I da Missa em Dó de André da Silva Gomes

Exemplo 82-Catabasis na Cantoria-1 da Ópera Proteu de Antônio José da Silva e Antônio Teixeira 247

Exemplo 83- Palilogia na Parte Instrumental da Cantoria-2 da Ópera Proteu de Antônio José da Silva e Antônio Teixeira

Exemplo 84-Confitemini das Matinas e Vésperas de Sábado Santo de Manoel Dias de Oliveira 267

Exemplo 85-Confitemini das Matinas e Vésperas de Sábado Santo de Manoel Dias de Oliveira. 268

Exemplo 86-Confitemini das Matinas e Vésperas de Sábado Santo de Manoel Dias de Oliveira 269

Exemplo 87-Confitemini das Matinas e Vésperas de Sábado Santo de Manoel Dias de Oliveira 270

Exemplo 88-Confitemini das Matinas e Vésperas de Sábado Santo de Manoel Dias de Oliveira. 271

Exemplo 89-Confitemini das Matinas e Vésperas de Sábado Santo de Manoel Dias de Oliveira 272

Exemplo 90-Confitemini das Matinas e Vésperas de Sábado Santo de Manoel Dias de Oliveira 273

Exemplo 91-Pater Mihi do Moteto dos Passos de Manoel Dias de Oliveira... 279 Exemplo 92-Pater Mihi do Moteto dos Passos de Manoel Dias de Oliveira. .. 280 
Exemplo 93-Pater Mihi do Moteto dos Passos de Manoel Dias de Oliveira... 281

Exemplo 94-Pater Mihi do Moteto dos Passos de Manoel Dias de Oliveira... 282

Exemplo 95-Pater Mihi do Moteto dos Passos de Manoel Dias de Oliveira... 283

Exemplo 96-Pater Mihi do Moteto dos Passos de Manoel Dias de Oliveira... 284

Exemplo 97-Pater Mihi do Moteto dos Passos de Manoel Dias de Oliveira... 285

Exemplo 98-Pater Mihi do Moteto dos Passos de Manoel Dias de Oliveira... 286

Exemplo 99-Pater Mihi do Moteto dos Passos de Manoel Dias de Oliveira... 287

Exemplo 100-Pater Mihi do Moteto dos Passos de Manoel Dias de Oliveira. 288

Exemplo 101-Pater Mihi do Moteto dos Passos de Manoel Dias de Oliveira. 289

Exemplo 102-Pater Mihi do Moteto dos Passos de Manoel Dias de Oliveira. 290

Exemplo 103-Gloria da Missa Abreviada em Ré de Manoel Dias de Oliveira.296

Exemplo 104-Gloria da Missa Abreviada em Ré de Manoel Dias de Oliveira.297

Exemplo 105-Gloria da Missa Abreviada em Ré de Manoel Dias de Oliveira.298

Exemplo 106-Gloria da Missa Abreviada em Ré de Manoel Dias de Oliveira.299

Exemplo 107-Gloria da Missa Abreviada em Ré de Manoel Dias de Oliveira.300

Exemplo 108-Gloria da Missa Abreviada em Ré de Manoel Dias de Oliveira.301

Exemplo 109-Gloria da Missa Abreviada em Ré de Manoel Dias de Oliveira.302

Exemplo 110-Gloria da Missa Abreviada em Ré de Manoel Dias de Oliveira.303

Exemplo 111-Gloria da Missa Abreviada em Ré de Manoel Dias de Oliveira.304

Exemplo 112-Gloria da Missa Abreviada em Ré de Manoel Dias de Oliveira.305

Exemplo 113-Exaudi nos, Domine para Benção de Cinzas da Missa para Quarta-feira de Cinzas de José Joaquim Emerico Lobo de Mesquita............ 310

Exemplo 114-Exaudi nos, Domine para Benção de Cinzas da Missa para Quarta-feira de Cinzas de José Joaquim Emerico Lobo de Mesquita............. 311

Exemplo 115-Exaudi nos, Domine para Benção de Cinzas da Missa para Quarta-feira de Cinzas de José Joaquim Emerico Lobo de Mesquita............. 312

Exemplo 116-Exaudi nos, Domine para Benção de Cinzas da Missa para Quarta-feira de Cinzas de José Joaquim Emerico Lobo de Mesquita............. 313 
Exemplo 117-Exaudi nos, Domine para Benção de Cinzas da Missa para Quarta-feira de Cinzas de José Joaquim Emerico Lobo de Mesquita............ 314

Exemplo 118-Exaudi nos, Domine para Benção de Cinzas da Missa para Quarta-feira de Cinzas de José Joaquim Emerico Lobo de Mesquita............ 315

Exemplo 119-Exaudi nos, Domine para Benção de Cinzas da Missa para Quarta-feira de Cinzas de José Joaquim Emerico Lobo de Mesquita............ 315

Exemplo 120-Exaudi nos, Domine para Benção de Cinzas da Missa para Quarta-feira de Cinzas de José Joaquim Emerico Lobo de Mesquita............. 316

Exemplo 121-Exaudi nos, Domine para Benção de Cinzas da Missa para Quarta-feira de Cinzas de José Joaquim Emerico Lobo de Mesquita ............. 317

Exemplo 122-Gloria Patri para Benção de Cinzas da Missa para Quarta-feira de Cinzas de José Joaquim Emerico Lobo de Mesquita .................................. 322

Exemplo 123-Sicut erat para Benção de Cinzas da Missa para Quarta-feira de Cinzas de José Joaquim Emerico Lobo de Mesquita. 323

Exemplo 124-Kyrie da Ladainha em Si bemol Maior de José Joaquim Emerico Lobo de Mesquita. 328

Exemplo 125-Kyrie da Ladainha em Si bemol Maior de José Joaquim Emerico Lobo de Mesquita. 329

Exemplo 126-Kyrie da Ladainha em Si bemol Maior de José Joaquim Emerico Lobo de Mesquita. 330

Exemplo 127-Kyrie da Ladainha em Si bemol Maior de José Joaquim Emerico Lobo de Mesquita.

Exemplo 128-Kyrie da Ladainha em Si bemol Maior de José Joaquim Emerico Lobo de Mesquita. 332

Exemplo 129-Kyrie da Ladainha em Si bemol Maior de José Joaquim Emerico Lobo de Mesquita...

Exemplo 130-Kyrie da Ladainha em Si bemol Maior de José Joaquim Emerico Lobo de Mesquita. 334

Exemplo 131-Cum Appropinquaret da Procissão de Ramos de José Joaquim Emerico Lobo de Mesquita. 340

Exemplo 132-Cum Appropinquaret da Procissão de Ramos de José Joaquim Emerico Lobo de Mesquita. 341

Exemplo 133-Cum Appropinquaret da Procissão de Ramos de José Joaquim Emerico Lobo de Mesquita 
Exemplo 134-Cum Appropinquaret da Procissão de Ramos de José Joaquim Emerico Lobo de Mesquita.

Exemplo 135-Cum Appropinquaret da Procissão de Ramos de José Joaquim Emerico Lobo de Mesquita.

Exemplo 136-Cum Appropinquaret da Procissão de Ramos de José Joaquim Emerico Lobo de Mesquita.

Exemplo 137-Cum Appropinquaret da Procissão de Ramos de José Joaquim Emerico Lobo de Mesquita. 346

Exemplo 138-Cum Appropinquaret da Procissão de Ramos de José Joaquim Emerico Lobo de Mesquita.

Exemplo 139-Ofertório da Missa do Domingo da Paixão de André da Silva Gomes.

Exemplo 140-Ofertório da Missa do Domingo da Paixão de André da Silva Gomes. 354

Exemplo 141-Ofertório da Missa do Domingo da Paixão de André da Silva Gomes. 355

Exemplo 142-Ofertório da Missa do Domingo da Paixão de André da Silva Gomes. 356

Exemplo 143-Ofertório da Missa do Domingo da Paixão de André da Silva Gomes. 357

Exemplo 144-Ofertório da Missa do Domingo da Paixão de André da Silva Gomes. 358

Exemplo 145-Ofertório da Missa do Domingo da Paixão de André da Silva Gomes.

Exemplo 146-Ofertório da Missa do Domingo da Paixão de André da Silva Gomes. 360

Exemplo 147-Ofertório da Missa do Domingo da Paixão de André da Silva Gomes. 361

Exemplo 148-Ofertório da Missa do $4^{\circ}$ Domingo da Quaresma de André da Silva Gomes. 370

Exemplo 149-Ofertório da Missa do $4^{\circ}$ Domingo da Quaresma de André da Silva Gomes. 
Exemplo 150-Ofertório da Missa do $4^{\circ}$ Domingo da Quaresma de André da Silva Gomes.

Exemplo 151-Ofertório da Missa do $4^{\circ}$ Domingo da Quaresma de André da Silva Gomes 373

Exemplo 152-Ofertório da Missa do $4^{\circ}$ Domingo da Quaresma de André da Silva Gomes. 374

Exemplo 153-Ofertório da Missa do $4^{\circ}$ Domingo da Quaresma de André da Silva Gomes. 375

Exemplo 154-Ofertório da Missa do $4^{\circ}$ Domingo da Quaresma de André da Silva Gomes. 376

Exemplo 155-Ofertório da Missa do $4^{\circ}$ Domingo da Quaresma de André da Silva Gomes. 377

Exemplo 156-Ofertório da Missa do $4^{\circ}$ Domingo da Quaresma de André da Silva Gomes 378

Exemplo 157-Ofertório da Missa do $4^{\circ}$ Domingo da Quaresma de André da Silva Gomes. 379

Exemplo 158-Ofertório da Missa do $4^{\circ}$ Domingo da Quaresma de André da Silva Gomes 380

Exemplo 159-Ofertório da Missa do $4^{\circ}$ Domingo da Quaresma de André da Silva Gomes. 381

Exemplo 160-Ofertório da Missa do $4^{\circ}$ Domingo da Quaresma de André da Silva Gomes. 382

Exemplo 161-Ofertório da Missa do $4^{\circ}$ Domingo da Quaresma de André da Silva Gomes. 384

Exemplo 162-Laudate Pueri de André da Silva Gomes. ............................ 395

Exemplo 163-Laudate Pueri de André da Silva Gomes .............................. 396

Exemplo 164-Laudate Pueri de André da Silva Gomes. ............................. 397

Exemplo 165-Laudate Pueri de André da Silva Gomes ............................ 398

Exemplo 166-Laudate Pueri de André da Silva Gomes ............................. 399

Exemplo 167-Laudate Pueri de André da Silva Gomes ............................. 400

Exemplo 168-Laudate Pueri de André da Silva Gomes ............................ 401

Exemplo 169-Laudate Pueri de André da Silva Gomes. .......................... 402 
Exemplo 170-Laudate Pueri de André da Silva Gomes ............................... 404

Exemplo 171-Laudate Pueri de André da Silva Gomes. ............................... 405

Exemplo 172-Laudate Pueri de André da Silva Gomes ............................... 406

Exemplo 173-Laudate Pueri de André da Silva Gomes ............................... 407

Exemplo 174-Domine Jesu de José Maurício Nunes Garcia......................... 415

Exemplo 175-Domine Jesu de José Maurício Nunes Garcia ......................... 416

Exemplo 176-Domine Jesu de José Maurício Nunes Garcia ........................ 417

Exemplo 177-Domine Jesu de José Maurício Nunes Garcia........................ 418

Exemplo 178-Domine Jesu de José Maurício Nunes Garcia......................... 418

Exemplo 179-Domine Jesu de José Maurício Nunes Garcia......................... 419

Exemplo 180-Domine Jesu de José Maurício Nunes Garcia .......................... 419

Exemplo 181-Crux Fidelis de José Maurício Nunes Garcia .......................... 425

Exemplo 182-Crux Fidelis de José Maurício Nunes Garcia .......................... 426

Exemplo 183-Crux Fidelis de José Maurício Nunes Garcia. .......................... 427

Exemplo 184- Crux Fidelis de José Maurício Nunes Garcia. ......................... 428

Exemplo 185- Crux Fidelis de José Maurício Nunes Garcia. ........................ 429

Exemplo $186-1^{\circ}$ Responsório das Matinas e Encomendação de Defuntos de José Maurício Nunes Garcia .................................................................... 435

Exemplo $187-1^{\circ}$ Responsório das Matinas e Encomendação de Defuntos de José Maurício Nunes Garcia. ................................................................ 436

Exemplo $188-1^{\circ}$ Responsório das Matinas e Encomendação de Defuntos de

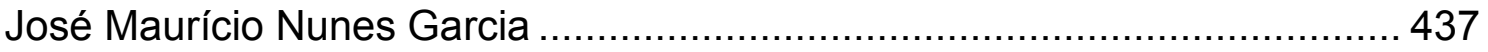

Exemplo $189-1^{\circ}$ Responsório das Matinas e Encomendação de Defuntos de

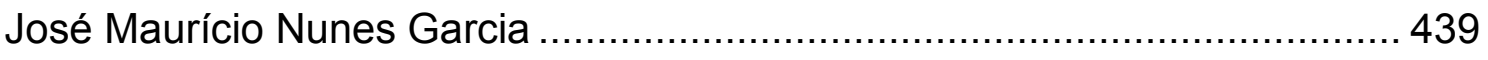

Exemplo $190-1^{\circ}$ Responsório das Matinas e Encomendação de Defuntos de José Maurício Nunes Garcia ................................................................... 440

Exemplo 191-Anaphora no Confitemini das Matinas e Vésperas de Sábado

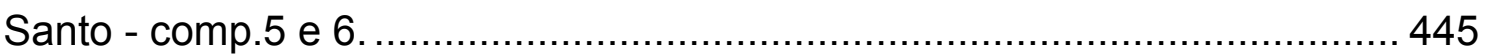

Exemplo 192-Synaeresis no Confitemini das Matinas e Vésperas de Sábado

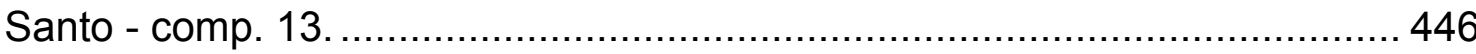


Exemplo 193-Polyptoton no Confitemini das Matinas e Vésperas de Sábado Santo - comp.15 a 19. 446

Exemplo 194-Anaphora no Confitemini das Matinas e Vésperas de Sábado Santo - comp.19 a 23. 447

Exemplo 195-Anaphora no Bajulans do Moteto dos Passos comp.3 a 8. ..... 448

Exemplo 196-Anaphora e Synaeresis no Pater Mihi do Moteto dos Passoscomp. 15 a 20 .

Exemplo 197-Synaeresis e Polyptoton no Pater Mihi do Moteto dos Passoscomp.31 a 34 450

Exemplo 198-Synaeresis no Pater Mihi do Moteto dos Passos- comp.29 e 30.

Exemplo 199-Synaeresis no Pater Mihi do Moteto dos Passos- comp.42 e 44. 452

Exemplo 200-Anaphora e Synaeresis em O Vos Omnes do Moteto dos Passoscomp. 15 a 19. 453

Exemplo 201-Polyptoton no Kyrie da Missa de Oitavo Tom- comp.2 a 7...... 454

Exemplo 202-Anaphora e Synaeresis no Kyrie da Missa de Oitavo Tom-

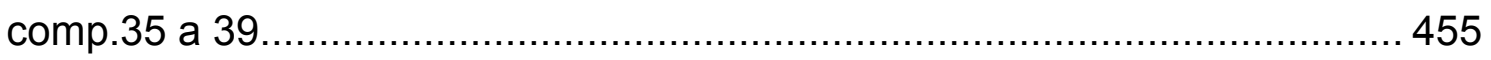

Exemplo 203-Synaeresis no Gloria da Missa Abreviada-comp. 28 e 31....... 455

Exemplo 204-Synaeresis no Gloria da Missa Abreviada-comp. 34 e 35....... 456

Exemplo 205-Epizeuxis no Exaudi nos, Domine para Benção de Cinzas da Missa para Quarta-feira de Cinzas- comp.7 a 15.

Exemplo 206-Epizeuxis no Exaudi nos, Domine para Benção de Cinzas da Missa para Quarta-feira de Cinzas- comp.38 a 42. 458

Exemplo 207-Epizeuxis no Exaudi nos, Domine para Benção de Cinzas da Missa para Quarta-feira de Cinzas- comp.43 a 51. 459

Exemplo 208-Syaneresis e Epizeuxis no Sicut erat do Exaudi nos, Domine para Benção de Cinzas da Missa para Quarta-feira de Cinzas- comp. 88, 98 a 105. 460

Exemplo 209-Epizeuxis no Misereris Omnium da Missa para Quarta-feira de Cinzas- comp.21 a 27. 461

Exemplo 210-Epizeuxis no Kyrie da Ladainha em Si bemol Maior- comp.11 a 14. 462 
Exemplo 211-Epizeuxis no Kyrie da Ladainha em Si bemol Maior- comp.19 a 22.

Exemplo 212-Abruptio no Kyrie da Ladainha em Si bemol Maior- comp.23. . 463

Exemplo 213-Synaeresis no Kyrie da Ladainha em Si bemol Maior- comp.30.

Exemplo 214-Epizeuxis no Pater de cælis da Ladainha em Si bemol Maiorcomp.13 a 16 464

Exemplo 215-Abruptio e Synaeresis na Sancta Dei Genitrix da Ladainha em Si bemol Maior, comp.10 e 12 465

Exemplo 216-Abruptio na Sancta Dei Genitrix da Ladainha em Si bemol Maior, comp.43 e 47 466

Exemplo 217-Abruptio e Synaeresis no Responsório-III das Matinas do Sábado Santo- comp.52. 467

Exemplo 218-Abruptio, Epizeuxis e Synaeresis no Cum Appropinquaretcomp. 8 a 16 468

Exemplo 219-Epizeuxis e Synaeresis no Cum Appropinquaret- comp.20 a 30. 469

Exemplo 220-Epizeuxis e Synaeresis no Lætatus sum - comp. 4 a 7. 470

Exemplo 221-Epizeuxis no Ofertório da Missa de Quarta-feira de Cinzas-comp. 21 a 23. 470

Exemplo 222-Epizeuxis, Palilogia e Synaeresis no Ofertório da Missa de Quarta-feira de Cinzas-comp. 24 a 26. 471

Exemplo 223-Synaeresis e Palilogia no Ofertório da Missa do Domingo da Paixão- comp. 1 a 4. 472

Exemplo 224-Synaeresis no Ofertório da Missa do Domingo da Paixão-comp. 25 a 32 473

Exemplo 225-Epizeuxis e Synaeresis no Ofertório da Missa do Domingo da Paixão - comp. 33 a 37. 474

Exemplo 226-Synaeresis e Palilogia no Ofertório da Missa do $4^{\circ}$ Domingo da Quaresma-comp. 21 a 25 475

Exemplo 227-Epizeuxis e Synaeresis no Ofertório da Missa do $4^{\circ}$ Domingo da Quaresma-comp. 38 a 40 . 476 
Exemplo 228-Epizeuxis e Synaeresis no Gratias da Missa em Dó- comp.11 a 15.

Exemplo 229-Epizeuxis e Synaeresis no Gratias da Missa em Dó- comp.16 a 22.

Exemplo 230-Epizeuxis e Synaeresis no Ofertório da Missa do $2^{\circ}$ Domingo do Advento- comp.19 a 22.

Exemplo 231-Epizeuxis e Synaeresis no Ofertório da Missa de Natal $\left(1^{\circ}\right.$ Movimento)- comp.4 a 11 480

Exemplo 232-Synaeresis no Ofertório da Missa de Natal (2 Movimento)comp. 16 a 18 . 481

Exemplo 233-Palilogia e Epizeuxis no Ofertório da Missa de Natal $\left(2^{\circ}\right.$ Movimento)- comp.27 e 28. 481

Exemplo 234-Synaeresis no Gloria da Missa em Dó- comp.10. 482

Exemplo 235-Epizeuxis, Palilogia e Synaeresis no Laudate Pueri- comp.2 e 3. 482

Exemplo 236-Aposiopesis e Synaeresis no Domine Jesu- comp.2 a 7. 483

Exemplo 237-Polyptoton e Synaeresis no Domine Jesu- comp.9 a 16. 484

Exemplo 238-Synaeresis e Aposiopesis no Domine Jesu- comp.23 a 27..... 484

Exemplo 239- Aposiopesis no Crux Fidelis - comp.4,8 e 12. 485

Exemplo 240-Synaeresis no Crux Fidelis - comp.16 a 19. 485

Exemplo 241-Synaeresis no Crux Fidelis - comp.25 a 33. 486

Exemplo 242-Polyptoton e Synaeresis no In Monte Oliveti - comp.21 a 30... 487

Exemplo 243-Polyptoton no $1^{\circ}$ Responsório das Matinas e Encomendação de Defuntos- comp.6 a 9. 487

Exemplo 244-Polyptoton e Synaeresis no Ofício dos Defuntos- Responsórios de Matinas- $1^{\circ}$ Responsório- comp. 1 a 6. 488

Exemplo 245-Aposiopesis e Synaeresis no $1^{\circ}$ Responsório do Ofício dos Defuntos-Responsórios de Matinas - comp.12 a 15. 489

Exemplo 246-Polyptoton e Synaeresis no Ofício dos Defuntos- Responsórios de Matinas- $1^{\circ}$ Responsório- comp.33 a 43. 490

Exemplo 247-Polyptoton e Synaeresis no $4^{\circ}$ Responsório do Ofício dos Defuntos-Responsórios de Matinas- comp. 1 a 7. 491 
Exemplo 248-Polyptoton e Synaeresis no $6^{\circ}$ Responsório do Moteto Ascendens Christus ( $1^{\circ}$ Movimento)-comp. 26 a 33.

Exemplo 249-Polyptoton e Synaeresis no Verso- I do Responsório-VI das Matinas e Encomendação de Defuntos-comp. 18 a 22 ................................ 492

Exemplo 250-Synaeresis no Immutemur Habitu- comp.7 e 11. .................... 493

Exemplo 251-Aposiopesis no Immutemur Habitu- comp.17.......................... 493

Exemplo 252-Polyptoton e Synaeresis no $2^{\circ}$ Responsório no Ofício dos

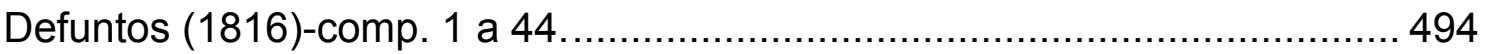

Exemplo 253-Polyptoton e Synaeresis no Dum veneris (6 ${ }^{\circ}$ Responsório)Responsório de Matinas- comp.1 a 8.......................................................... 495 


\section{ABREVITURAS}

Bibliotecas e acervos de fontes primárias:

ACMSP

- Arquivo da Cúria Metropolitana de São Paulo

BNP

- Biblioteca Nacional de Portugal

BNB

- Biblioteca Nacional do Brasil

Exemplos Musicais, Etimológicos e Gramaticais:

Adj.

Adjetivo

Apud

Citado por, conforme

Art.

Artigo

b

bemol

Ca.

Cerca, aproximadamente

Cap.

Capítulo

Cf.

Conforme

Coord.

Coordenação

D.

Dom

D (v)

Dominante Menor

D (V)

Dominante

D/D (V/V) Dominante da Dominante

Dp/dP (iii/VII) Dominante Paralela (Relativa)

D/S-D/s (V/IV, V/iv) Dominante da Subdominante

Ecles. Eclesiástico

Ed.

Edição

f

Folha 


\begin{tabular}{|c|c|}
\hline Filos & Filosofia \\
\hline gr & Grego \\
\hline Hist. & História \\
\hline Ibidem & Mesma obra e autor \\
\hline Intr. & Introdução \\
\hline Lat. & Latim \\
\hline Lóg. & Lógica \\
\hline Mús. & Música (o) \\
\hline $\mathbf{N}^{\circ}\left(\mathbf{n}^{\circ}\right)$ & Número \\
\hline Op. & Opus (obra) \\
\hline Org. & Organização \\
\hline p. & Página \\
\hline part. & Parte \\
\hline Passim / passim & Em diversas passagens, por aqui e ali \\
\hline Prof (a). Dr (a) & Professor (a) Doutor (a) \\
\hline rel. & Relacionado \\
\hline ret. & Retórica \\
\hline \# & Sustenido \\
\hline S (IV) & Subdominante \\
\hline Sp/sP (ii/VI) & Subdominante Paralela (Relativa) \\
\hline S/S (IV/IV) & Subdominante da Subdominante \\
\hline Séc. & Século \\
\hline$s / d$ & Sem $d$ \\
\hline
\end{tabular}




$\begin{array}{ll}\text { S.f } & \text { Substantivo Feminino } \\ \text { S.m } & \text { Substantivo Masculino } \\ \text { T (I) } & \text { Tônica } \\ \text { Tp/tP (vi/lII) } & \text { Tônica Paralela (Relativa) } \\ \text { trad. } & \text { Tradução } \\ \text { trat. } & \text { Tratamento, tratado } \\ \text { Univ. } & \text { Universidade } \\ \text { Var } & \text { Variação } \\ \text { vb. } & \text { Verbo } \\ \text { vol. } & \text { Volume }\end{array}$

Instituições, Escolas e Departamentos Superiores de Pesquisa e Publicação:

ANPPOM Associação Nacional de Pesquisa e Pós-Graduação em Música

CAPES Coordenação de Aperfeiçoamento do Pessoal de Nível Superior

CMU Departamento de Música da Universidade de São Paulo

CNPq Conselho Nacional de Desenvolvimento Científico e Tecnológico

ECA Escola de Comunicações e Artes

EDUSP Editora da Universidade de São Paulo

EPU Editora Pedagógica e Universitária

FAPESP Fundação de Amparo à Pesquisa do Estado de São Paulo

FFLCH Faculdade de Filosofia, Letras e Ciências Humanas 
FFCLRP

IA

IFCH

LAMUS

PUC-RJ

PUC-SP

SIMPOM

UBI

UC

UDESC

UE

UEA

UEMG

UERJ

UFBA

UFF

UFG

UFMG

UFPB

UFPR

UFRJ

UFRN

UFU
Faculdade de Filosofia, Ciências e Letras de Ribeirão Preto

Instituto de Artes

Instituto de Filosofia, Ciências e História

Laboratório de Musicologia

Pontifícia Universidade Católica do Rio de Janeiro

Pontifícia Universidade Católica de São Paulo

Simpósio Brasileiro de Pós-Graduandos em Música

Universidade Beira Interior

Universidade de Coimbra

Universidade do Estado de Santa Catarina

Universidade de Évora

Universidade do Estado do Amazonas

Universidade Estadual de Minas Gerais

Universidade Estadual do Rio de Janeiro

Universidade Federal da Bahia

Universidade Federal Fluminense

Universidade Federal de Goiás

Universidade Federal de Minas Gerais

Universidade Federal da Paraíba

Universidade Federal do Paraná

Universidade Federal do Rio de Janeiro

Universidade Federal do Rio Grande do Norte

Universidade Federal de Uberlândia 
UL Universidade de Lisboa

UN Universidade de Nice

UnB Universidade de Brasília

UNESP Universidade Estadual Paulista Júlio de Mesquita Filho

UNICAMP Universidade Estadual de Campinas

UNIRIO Universidade Federal do Estado do Rio de Janeiro

UNL Universidade Nova de Lisboa

UP $\quad$ Universidade do Porto

USP Universidade de São Paulo

\section{Localizações Geográficas:}

BA Bahia

BRA Brasil

ESP Espanha

FRA França

GRE Grécia

ITA Itália

MG Minas Gerais

PT Portugal

RJ Rio de Janeiro

RU Reino Unido

SP São Paulo

Nomes e Indicações de Autoria:

ASG André da Silva Gomes

JJELM José Joaquim Emerico Lobo de Mesquita

JMNG José Maurício Nunes Garcia 
MDO Manoel Dias de Oliveira

Referências Bíblicas e Religiosas:

a.C. Antes de Cristo

a.D. Depois de Cristo

Anun. Anúncio

At Livro de Atos dos Apóstolos

Cap. Capítulo

$1^{\circ} \mathrm{Co.} \quad 1^{\mathrm{a}}$ epistola aos Coríntios

Dn. Livro de Daniel

Gn. Livro de Gênesis

Is. Livro de Isaías

Jo. Evangelho de João

Jr. Livro de Jeremias

Lc. Evangelho de Lucas

Mc. Evangelho de Marcos

Mt. Evangelho de Mateus

Of. Ofertório

Ps/Sal. Livro dos Salmos

Prov. Livro de Provérbios

Vers. Versículo 


\section{SUMÁRIO}

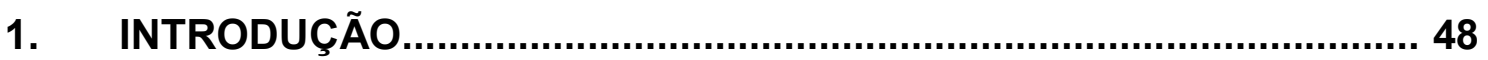

1.1. Histórico e justificativa da pesquisa...................................................... 48

1.2. Metodologia e análises empregadas.................................................. 53

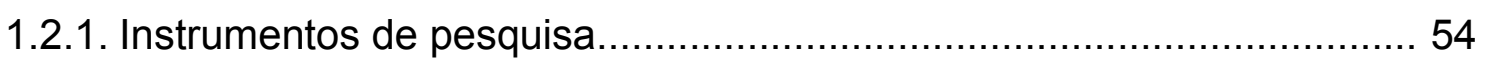

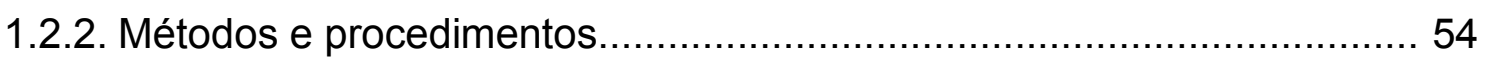

1.3. Disposição dos capítulos subsequentes............................................... 55

2. RETÓRICA

2.1. Breve contextualização sobre Retórica.............................................. 59

2.2. O escopo da Retórica e seus saberes.............................................. 61

2.2.1. Os componentes retóricos e suas utilidades.......................................66

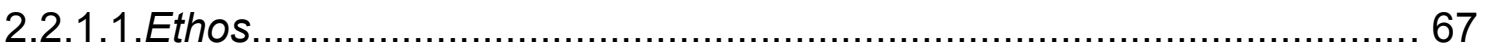

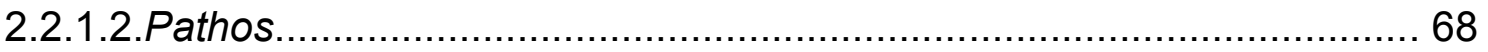

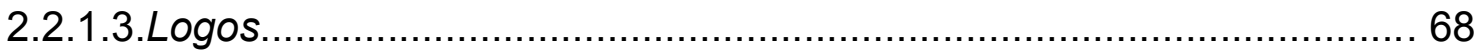

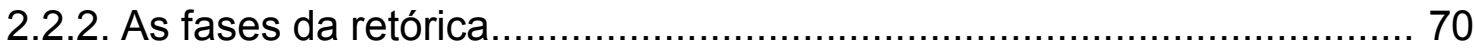

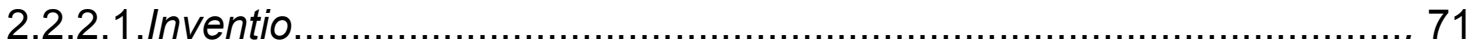

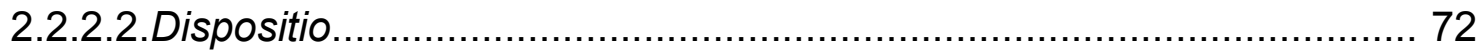

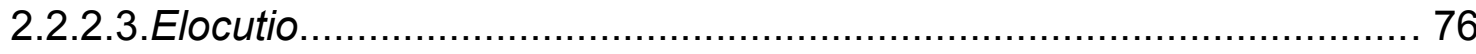

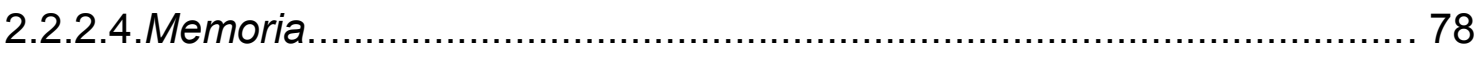

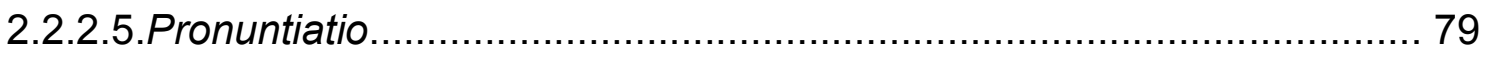

2.3. A utilização da retórica na Idade Média até a Moderna.......................... 80

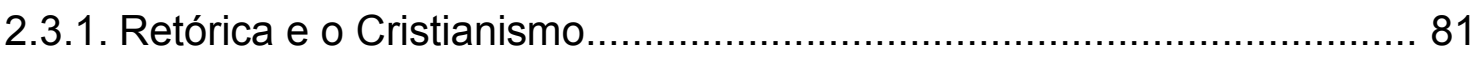

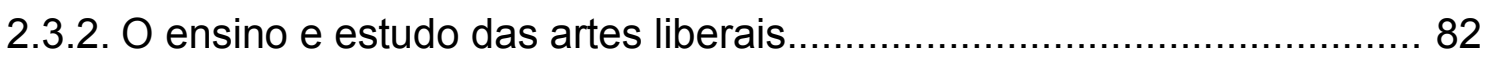

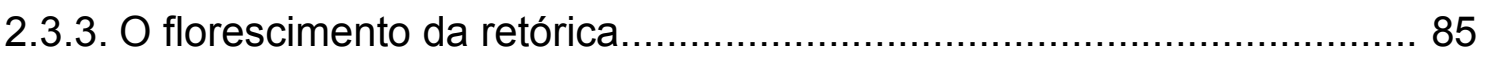

2.3.4. O Humanismo Italiano e os primórdios do Barroco................................ 85 


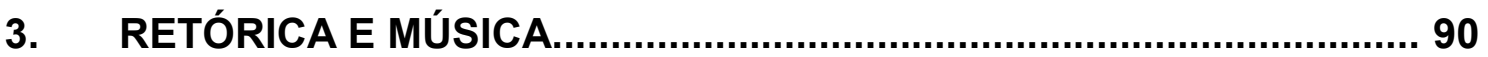

3.1. Os tratados sobre retórica e música poética.........................................92

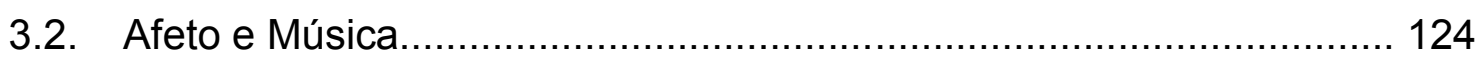

3.3. O emprego da retórica na música no final da Renascença, no Barroco e início do Classicismo............................................................................ 132

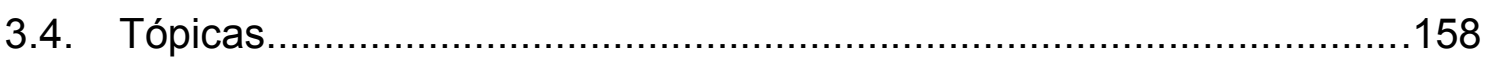

4. A TEORIZAÇÃO RETÓRICO-MUSICAL EM PORTUGAL.................. 175

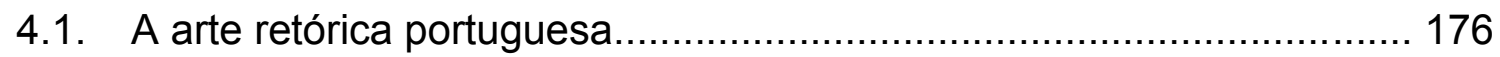

4.1.1. Idade Média e o domínio da escolaridade....................................... 176

4.1.2. Transição da Idade Média para o Renascimento................................. 178

4.1.3. O desenvolvimento e novo incremento da arte da eloquência no

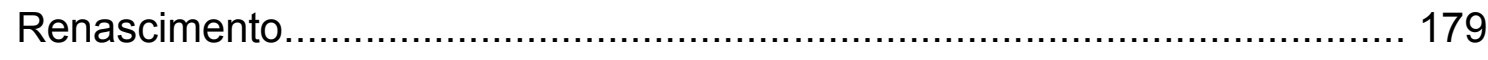

4.1.4. Cipriano Soares e seu manual de retórica.......................................... 184

4.1.5. Os novos estabelecimentos no ensino da retórica em Portugal e as relações de obras barrocas portuguesas e europeias.................................... 191

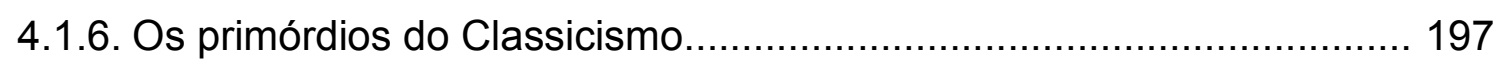

4.1.7. Luís António Verney, o reformador nos primórdios do Classicismo......198

4.2. Retórica na música portuguesa entre o século $X V I I$ e começo do XIX

4.2.1. Relações entre a arte retórica literária e musical................................. 207

4.2.2. Semelhanças entre poesia, música e retórica.................................... 208

4.2.2.1.Proximidade dessas relações com diferentes culturas....................... 212

5. RETÓRICA NA MÚSICA COLONIAL BRASILEIRA........................... 217

5.1. Contextualização histórico-político-social......................................... 217

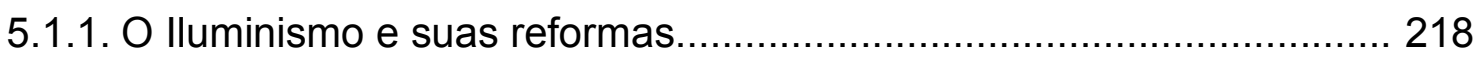

5.1.2. A música na Capitania de Minas Gerais e o lluminismo........................ 221

5.1.3. O programa iluminista na Capitania de São Paulo............................... 224 
5.1.4. A manifestação do lluminismo e a música no Rio de Janeiro.

5.2. Compositores analisados no período abordado.

229

5.3. Os estudos de caso acerca da utilização retórica nos compositores brasileiros

5.4. A consciência do emprego retórico.

251

5.5. Retórica, harmonia e a relação texto-música como ferramentas

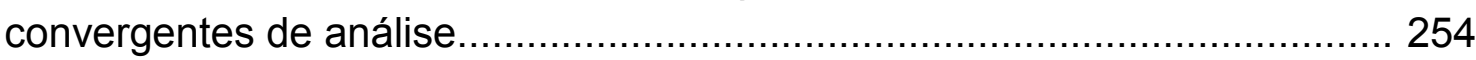

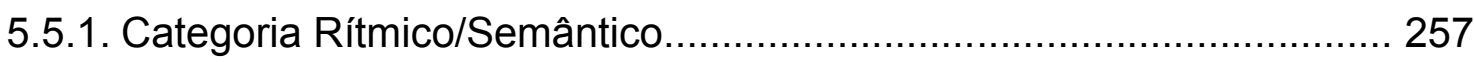

5.5.2. Categoria- Harmônica........................................................ 259

5.5.3. Categoria- Elementos Retórico-Musicais..................................... 261

\section{ANÁLISES RETÓRICAS DE ALGUMAS OBRAS DOS

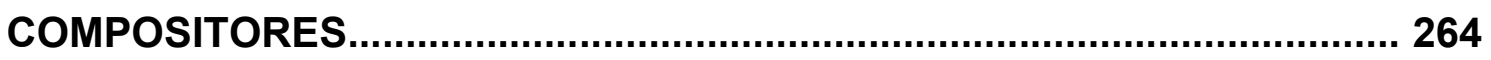

6.1. Manoel Dias de Oliveira...................................................... 264

6.1.1. Análise Retórico-Musical do Confitemini das Matinas e Vésperas de Sábado Santo..................................................................................... 264

6.1.2. Análise Retórico-Musical do Pater Mihi do Moteto dos Passos............ 277

6.1.3. Análise Retórico-Musical do Gloria da Missa Abreviada em Ré........... 294

6.2. José Joaquim Emerico Lobo de Mesquita................................... 308

6.2.1. Análise Retórico-Musical do Exaudi nos, Domine para Benção de Cinzas da Missa para Quarta-feira de Cinzas........................................................... 308

6.2.1.1.Análise Retórico-Musical da segunda e terceira parte para Bênçãos de Cinzas (Gloria Patri e Sicut erat), da Missa para Quarta-feira de Cinzas....... 320

6.2.2. Análise Retórico-Musical no Kyrie da Ladainha em Si bemol Maior..... 326

6.2.3. Análise Retórico-Musical do Cum Appropinquaret, da Procissão de Ramos de José Joaquim Emerico Lobo de Mesquita................................. 337

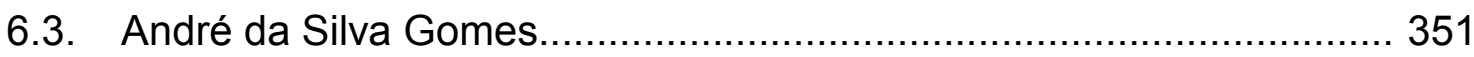

6.3.1. Análise Retórico-Musical do Ofertório da Missa do Domingo da Paixão 351

6.3.2. Análise Retórico-Musical do Ofertório da Missa do $4^{\circ}$ Domingo da Quaresma. 367 
6.3.3. Análise Retórico-Musical no Laudate Pueri...................................... 392

6.4. José Maurício Nunes Garcia............................................................ 413

6.4.1. Análise Retórico-Musical do Domine Jesu....................................... 413

6.4.2. Análise Retórico-Musical do Crux Fidelis........................................... 423

6.4.3. Análise Retórico-Musical do $1^{\circ}$ Responsório das Matinas e Encomendação de Defuntos................................................................. 432

6.5. Recorrências no emprego das figuras retóricas................................. 444

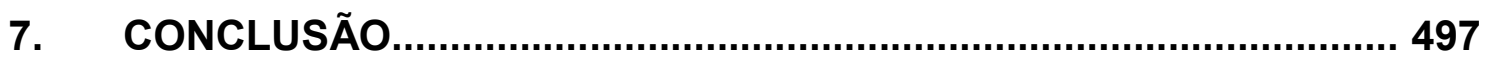

8. REFERÊNCIAS BIBLIOGRÁFICAS............................................... 505

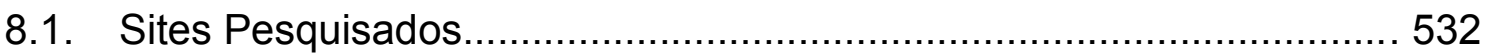

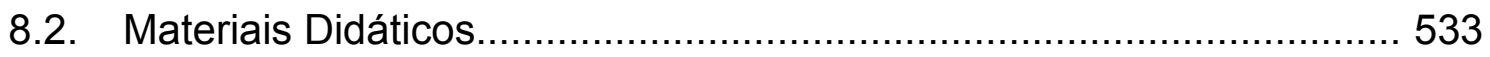

8.3. Citação no Exame de Qualificação de Doutorado............................... 533 
INTRODUÇÃO 


\section{INTRODUÇÃO}

\subsection{Histórico e justificativa da pesquisa}

Enquanto escopo que abarca vários campos do conhecimento, a Retórica requer do pesquisador um estudo mais aprofundado não só da história, mas também dos contextos filosóficos, políticos, sociais e estéticos. Como parte integrante na elaboração e disposição das músicas produzidas, entre o segundo quartel do século XVI e início do XIX, a arte da eloquência contribuiu para o esclarecimento de seu emprego relacionado com a gramática e adequação na linguagem musical vigente da época.

Não obstante, entre o final do século XVI e do XVIII, diversos autores da disciplina apresentaram um modelo de sistematização e teorização, cujos postulados balizavam as auctoritas da Retórica e da Poética Clássica, estabelecendo, dessa maneira, uma nomenclatura a qual conhecemos por Musica Poetica. Dentre esses arquétipos, podem ser destacados, por exemplo, o modelo discursivo de Aristóteles (384-322 a.C.), o qual estabelece a retórica como ferramenta primordial não só para persuadir, mas, igualmente, discernir os meios de persuasão mais apropriados (ARISTÓTELES, 2005 [século IV a.C, RETÓRICA, I, 1355 b], p.94).

Do mesmo modo, o Manual de Oratória de Cícero (106-43 a.C.) essencial para auxiliar o orador no exercício da exposição de sua tese, cujo objetivo é atrair, impressionar e convencer o público por intermédio de seus argumentos. Finalmente, nos Institutos de Oratória de Quintiliano (35-100), redigidos em 12 livros, entre os quais o décimo livro ressalta a relevância do bem-dizer e pensar (PLEBE, 1978, p.51). Enfim, os padrões instituídos por esses pensadores foram fundamentais para o desenvolvimento e consolidação de um arcabouço retórico, ocorrido também na Idade Média e Renascença, por três razões: primeiramente, pela relação retórica com a educação, por meio da universidade; segundo, por causa da propagação enfática de Martin Lutero dessa convergência entre essas duas vertentes doutrinárias, e, terceiro, pela música renascentista, sob uma perspectiva humanística (SOARES, 2012, p.24).

Já no Barroco, os tratadistas, teóricos, estudiosos, pensadores e compositores passaram a desenvolver um parâmetro relacional entre literatura, 
poesia e retórica com a música. Ou seja, os mesmos elaboraram uma ordenação de mecanismos que privilegiasse uma escolha diligente de diversos artifícios semânticos, alegóricos, metafóricos e de figuras retóricas, instaurando, dessa forma, conceitos tangíveis e eficientes (SOARES; NOVAES; MACHADO NETO, 2012, p.301). Destarte, havia preocupação por parte desses preclaros mestres com a recepção do público, como no resultado propiciado pelos afetos utilizados com a finalidade de despertar as emoções, paixões, além de transportar o ouvinte para um plano espiritual. Por fim, no Classicismo, mesmo com a racionalização do pensamento, alguns gêneros, estilos e composições mantiveram essa tradição do uso de elementos retóricos, seja através do simbolismo, decoro ou da religiosidade.

Nesse sentido, para entender a invocação dos mestres da composição aos recursos retóricos no enriquecimento do discurso musical, a musicologia dos últimos 50 anos vem demostrando interesse acerca dessa disciplina relacionada à música dos séculos já supracitados, iniciando várias investigações, tendo como meta a observância relacional entre música e afeto, isto é, através de análises musicais, visando a clarificação dos mecanismos empregados na constituição do discurso musical. Assim, caracterizando-se a retórica musical como campo complexo e abrangente, onde inúmeros artigos especializados são editados anualmente, devido aos numerosos tratados, publicados entre 1535 e 1802, estabelecerem um elo com o corpus teórico do sistema retórico-musical, servindo de embasamento às atuais pesquisas acerca da poética musical Barroca e Clássica (LÓPEZ CANO, 2000, p.7). Por fim, decorrentes dessas averiguações, diversas foram as publicações a respeito desse tema, demonstrando que o objeto a ser investigado é de amplitude complexa e condigna aos auspiciosos anseios da sociedade musicológica, o que se procurará demonstrar, aqui, com alguns exemplos.

Dentre as obras já produzidas se destacam as de George J. Buelow (1966), expondo a utilização dos diversos Loci nas obras do Barroco e princípios do Classicismo. Na mesma obra são visíveis os argumentos ponderáveis sobre os preceitos aplicados e representados por cada afeto inserido nos textos, adequados ao caráter discursivo da Inventio. Já em Rhetoric and Music (1980), ressaltam-se as conexões entre retórica e música, 
afirmando que as mesmas serviram de agente transformador da música. Outro aspecto bastante salientado pelo autor é o da disposição das figuras retóricas, porém, não deixando de contextualizar a importância dos conceitos empregados pelos tratadistas e compositores entre o século $X V I$ e início do XIX, os quais eram regidos pela retórica literária (BUELOW, 1980, p.793).

Leonard G. Ratner (1980), que relaciona as construções tópicas ${ }^{1}$ e retóricas com os diversos gêneros e formas musicais, dentre eles a forma sonata, ou seja, Ratner mostra-se mais amplo que seus colegas, revelando uma nova maneira de localização e significância para as figuras retóricomusicais, apresentando uma figuração mais "racionalizada" no Classicismo, por recursos de representação pictóricos e artificiosos, tornando a música mais inteligível (VIDAL, 2002, p.24).

Marc Evan Bonds (1991) revelou outro modo relacional da retórica, pelo viés metafórico, associando música sem palavras com linguagem, isto é, a possível aplicação desse recurso na música instrumental. Ferruccio Civra (1991) apresentou o encontro entre as instâncias de expressão da música e da poesia por meios técnicos, oferecidos pelas definições dadas pelos diversos tratadistas e autores da retórica musical, além de proporcionar reflexões sobre as análises retórico-musicais. Por fim, Dietrich Bartel (1997) explica os processos pelos quais passou a retórica até sua sistematização na música germânica, como as inúmeras interpretações de tratadistas a respeito da aplicabilidade das figuras retóricas na música.

Como observado, apesar da relevância dada pela musicologia contemporânea e dos inúmeros tratados, teses, dissertações e artigos, a maioria dos estudos se concentra nas obras de autores europeus. Por essa razão, nesta pesquisa objetivou-se observar e desenvolver uma investigação sobre o emprego da retórica na música colonial brasileira.

No Brasil, porém, há de se ressaltar alguns pesquisadores que, por intermédio de suas investigações, contribuíram para o desenvolvimento e fomentação de estudos relacionados à retórica musical, por exemplo, a cravista e professora Helena Jank (UNICAMP), em 1988, instituiu um grupo de

\footnotetext{
${ }^{1}$ Essa terminologia tópica é advinda de Locus TopoilTopici (do grego, lugar comum), o qual será exposto com maior detalhamento ao longo da tese.
} 
pesquisa $^{2}$, que tem por objetivo estudar os elementos de retórica na música barroca, examinar as figuras retóricas e verificar a representação e relação texto-música nas obras do Barroco e começo do Classicismo.

De igual modo, a musicóloga Mônica Isabel Lucas, a partir de sua tese de doutorado (2005), vem trabalhando aspectos relevantes concernentes à estética, poética e retórica do século XVII ao primeiro quartel do século XIX. Somado a isso, o grupo de estudos sobre o tratado $O$ mestre de capela perfeito de Johann Mattheson (1739), assim como a disciplina Introdução da Retórica da Música Setecentista, no programa de Pós-Graduação em Música da USP, capitaneados por ela, tem contribuído consideravelmente para 0 estabelecimento de um possível diálogo entre o uso da retórica na música europeia, e na brasileira. Enfim, tal contributo pode ser evidenciado nos encontros de poética musical, organizados pela mesma, onde algumas comunicações de pesquisa abordam o emprego da retórica por André da Silva Gomes, José Maurício Nunes Garcia, entre outros.

Não obstante, os musicólogos luso-brasileiros Diósnio Machado Neto (2008), Ana Margarida Madeira Paixão (2008), Cristina Isabel Videira Fernandes (2009), Márcio Leonel Farias Reis Páscoa (2010) e Mário Marques Trilha Neto (2011), para citar alguns, vêm desenvolvendo averiguações em torno das transformações paradigmáticas na teoria da música luso-brasileira. Em sua tese de doutorado, Machado Neto destaca a "natureza idiossincrática do espírito iluminista e sua relação com as transformações no sentido da música, tanto nas estruturas de linguagem como nos processos de sua recepção, no século XVIII" (MACHADO NETO, 2008, p. 19). Isto é, a atuação do iluminismo na esfera estética, retroagindo de forma diferente numa disputa de poder entre as esferas públicas (Igreja e Estado), culminando em uma relação onde o veículo operacionalizador na afirmação das estruturas ideológicas era o espetáculo do poder (MACHADO NETO, 2008, p.4). Nesse conflito entre as duas frentes, é possível examinar o programa iluminista

\footnotetext{
${ }^{2}$ Outros integrantes desse grupo de estudo são: Marcos Tadeu Holler (UDESC), Eduardo Augusto Ostergren (UNICAMP). Adriana Giarola Kayama (UNICAMP), Luciane Beduschi (Université Paris-Sorbonne), Cassiano de Almeida Barros (UNIMEP), Mônica Isabel Lucas (USP), Silvana Ruffier Scarinci (UFPR) e Edmundo Pacheco Hora (UNICAMP).
} 
vinculado à música de métrica e síntese e, por outro, a renitência contumaz na insistência da retórica barroca, isto é, na linguagem figurativa.

Surge então, em virtude desse trabalho, um grupo de pesquisa (LAMUS/ Laboratório de Musicologia do Departamento de Música da Faculdade de Filosofia Ciências e Letras de Ribeirão Preto da Universidade de São Paulo), cujo propósito é o estudo da retórica na música colonial brasileira. Ou seja, sua diretriz é observar a forma do processamento discursivo, dos padrões retóricos e das tópicas nas obras religiosas dessa época. Entretanto, para que tal averiguação ganhasse maior consistência e fundamentação, iniciou-se paralelamente uma busca por trabalhos já realizados em torno de compositores como: David Perez (1711-1788), Manoel Dias de Oliveira (1734/5-1813), José Joaquim Emerico Lobo de Mesquita $(1746 ?-1805)^{3}$, José Joaquim dos Santos (1748-1801), André da Silva Gomes (1752-1844), Marcos Portugal (17621830), José Maurício Nunes Garcia (1767-1830), entre outros.

Logo, como se vê, para compreender o porquê da utilização retórica por parte desses compositores, se faz necessária uma contextualização histórica dos fatos discorridos, permeando as principais contribuições relacionadas à música poética, pelas autoridades no assunto, configuradas em exames minuciosos tendo como ferramentas a relação textual com a música, além das diversas técnicas de análise.

Portanto, apesar da crescente atenção musicológica, tanto das questões inerentes à elaboração e organização do discurso retórico quanto da teoria tópica, na esfera luso-brasileira as pesquisas acerca desses temas ainda são incipientes. Adicionado a isso, Rodrigo Affonso Cardoso (2005) destaca os poucos trabalhos com dedicação exclusiva aos estudos mais aprofundados e minuciosos das relações entre texto litúrgico e música, no repertório brasileiro, o que evidencia, dessa maneira, que os estudos sobre a retórica na música colonial brasileira ainda estão em desenvolvimento:

Até o momento, não temos notícia de trabalhos que tenham se dedicado exclusivamente, ou primordialmente, à investigação das relações entre texto litúrgico e música (como a retórica musical), no

\footnotetext{
${ }^{3}$ Alguns autores como Vasco Mariz e Bruno Kiefer datam seu nascimento em 1746. No entanto, outros estudiosos destacam que Lobo de Mesquita provavelmente tenha nascido na década de 30 ou 40 do século XVIII.
} 
repertório colonial brasileiro. Faltam estudos que busquem perceber de que forma interagem estas duas forças em uma mesma obra, formando um só discurso [grifos nossos] (AFFONSO, 2005, p.6).

Entretanto, como salientado anteriormente os pesquisadores brasileiros procuram desenvolver metodologias mais apropriadas para o entendimento da adequação de sua problemática e formulação sistêmica, constituídas estruturalmente na música que vigorava naqueles tempos.

Enfim, pautada nessas afirmativas como ideia inicial, essa tese tem como objetivo apresentar o emprego dos recursos retóricos na música circulante no período colonial brasileiro, além de observar os estudos de caso acerca dessa aplicação. Em outras palavras, examinar o uso de elementos retóricos em Manoel Dias de Oliveira, José Joaquim Emerico Lobo de Mesquita, André da Silva Gomes e José Maurício Nunes Garcia, utilizando-se de ferramentas analíticas relacionadas ao texto sacro e harmonia, as quais se apresentam essenciais para compreender a linguagem retórica nas obras desses mestres da composição.

\subsection{Metodologia e análises empregadas}

Dentro da concepção que os diferentes povos tinham da música como linguagem, pode-se considerar que a mesma necessitou de elementos para a realização de um diálogo entre quem a executa e a ouve. Indubitavelmente, dentre tais recursos estão os signos - fundamento necessário para o entendimento e compreensão do ser humano dos símbolos e significados contidos na formação de uma composição, como na disposição de seu discurso, mediante o mover afetuoso que esses poderiam propiciar ao público, como paixão, alegria, júbilo, exultação, dor, angústia, tristeza, entre outros, empregados por diversos compositores habilidosos e peritos na engenhosidade retórica.

Mediante todo esse procedimento, deu-se o emprego de um mecanismo organizado, articulado e ordenado em quatro fases, Inventio, Dispositio (com suas seis partes), Elocutio (conhecida igualmente como Decoratio) e Pronuntiatio, ou melhor, os elementos e figuras de retórica ${ }^{4}$.

\footnotetext{
${ }^{4}$ No decorrer da tese serão expostos com mais detalhes essas fases retóricas.
} 
Somado a isso, segundo Kibédi Varga Áron (1930), a retórica apresentase a nós como uma disciplina de abrangência geral, que abarca diversos modos e processos de produção e emissão discursivos que englobam todo tipo de textos independentemente e dos signos que os integram, o que a torna operativa para os princípios de criação e enunciação dos discursos literários e musicais (PAIXÃO, 2008, p.82).

\subsubsection{Instrumentos de pesquisa}

Nesta tese dispõem-se três vertentes metodológicas que se complementam, desse modo:

- A primeira, baseada em várias leituras de bibliografias específicas sobre o tema abordado, o que possibilita pesquisar com maior enriquecimento contextual sobre os vários períodos retóricos, especialmente Barroco e início do Clássico;

- A segunda vertente, embasada em estudos, pesquisas e análises de partituras, já examinadas por diversos pesquisadores os quais receberam observação crítica e imparcial;

- A terceira e última vertente, estabelecida mediante as audições de repertórios das obras dos compositores investigados, além de análises retóricas, harmônicas e exames dos textos litúrgicos nas obras dos compositores brasileiros escolhidos para apreciação.

\subsubsection{Métodos e procedimentos}

Para melhor exemplificar as formas e métodos de investigação seguiram-se alguns procedimentos:

1. Realizou-se uma listagem das fontes primárias e secundárias encontradas, depois disso, preparou-se, gradualmente nesta tese, capítulos onde cada tratado e livro pesquisado terá sua parte de contribuição no texto descrito, seja fundamentando ou estruturando o trabalho e a pesquisa;

2. Posteriormente, reuniram-se bibliografias complementares, seja de história social, política ou religiosa dos períodos pesquisados, desse modo, com vistas a organizar melhor as ideias, além de encadear 
harmoniosamente os dados mais relevantes, procurando assim estabelecer um diálogo mais preciso e contextual com a retórica ${ }^{5}$;

3. Ajustaram-se adequadamente todas as informações obtidas, procurando classifica-las e submetê-las de maneira ordenada e criteriosa;

4. Examinaram-se minuciosamente as análises de figuras e elementos retóricos já existentes, com apreciação crítica, porém, buscando sempre a imparcialidade;

5. Procuraram-se através de ferramentas de análise adequadas, os pontos de afeto e a forma pela qual os compositores da música brasileira do século XVIII e início do XIX elaboravam o discurso em suas obras.

\subsection{Disposição dos capítulos subsequentes}

Em relação à estrutura desta tese, pode-se dizer que foi elaborada, aferida e disposta em sete partes e seis capítulos, na ordem apresentada a seguir.

O primeiro capítulo, como já observado, tem uma introdução, além do histórico e justificativa da pesquisa, a metodologia empregada e seus procedimentos.

O segundo capítulo versa sobre o desenvolvimento e ascendência da retórica, desde sua origem até sua consolidação como disciplina integrante das universidades e institutos educacionais. Em outras palavras, para melhor clarificação desses eventos, optou-se por delinear três tópicos constituídos cronologicamente, onde, num primeiro momento, é feita uma breve contextualização sobre a retórica. O tópico seguinte descreve a retórica como escopo dos saberes, sua multiplicidade de funções e relações com outras disciplinas. No terceiro e derradeiro tópico, aborda-se o emprego da doutrina retórica na Idade Média até a Moderna.

No terceiro capítulo faz-se uma observação acerca da relação entre retórica e música, partindo primeiramente dos tratados retórico-musicais, das terminologias e métodos empregados, além dos afetos relacionados ao humor

\footnotetext{
${ }^{5}$ Além dessas bibliografias com maior proximidade ao assunto e objeto de pesquisa, fez-se uso de outras referências sobre história geral, do Brasil e Portugal, na qual se desenvolveu o trabalho.
} 
do ser humano e com a música. Por conseguinte, disserta-se sobre o emprego da retórica na música Barroca e início do Classicismo. E, por fim, o uso das tópicas.

O quarto capítulo trata da retórica e sua teorização em Portugal, desde a Antiguidade até a transição do Barroco para o Classicismo, partindo primeiramente de sua instauração, desenvolvimento e incremento. Analogamente, far-se-á uma averiguação acerca dos estabelecimentos de ensino retórico em Portugal, além das reformas instituídas por Luís António Verney. Posteriormente, haverá uma contextualização da disciplina, tanto na música quanto na arte literária portuguesa. De igual forma, serão abordadas questões relativas à retórica na música portuguesa, como também sua relação com os compositores de escolas estrangerias e a influência sobre o estilo de composição dos autores luso-brasileiros, entre o século XVII e início do XIX.

No quinto capítulo, o ponto fulcral é a retórica na música colonial brasileira. No entanto, para melhor entendimento do processo pelo qual a retórica pôde ser utilizada nessa época, optou-se por dispor de cinco tópicos distribuídos para contemplar esses assuntos: a contextualização históricopolítico-social; os principais compositores analisados no período abordado; os estudos de caso acerca da utilização retórica pelos compositores brasileiros; a consciência do emprego retórico e as metodologias usadas para compreensão da construção e linguagem retórica na música.

No sexto capítulo, apresentam-se exemplos de análises de algumas obras de compositores brasileiros, tais como: Manoel Dias de Oliveira, José Joaquim Emerico Lobo de Mesquita, André da Silva Gomes e José Maurício Nunes Garcia. Por fim, será observada a possibilidade de recorrências de figuras retóricas nas peças examinadas.

A sétima e última parte trata-se da conclusão da tese, onde todos os tópicos e assuntos da pesquisa realizada estão sintetizados e condensados com critério, lisura e imparcialidade.

Em síntese, espera-se, aqui, cumprir esse plano de exame e averiguação proposto, concernente ao emprego da retórica na música colonial brasileira. 
2. RETÓRICA 


\section{RETÓRICA}

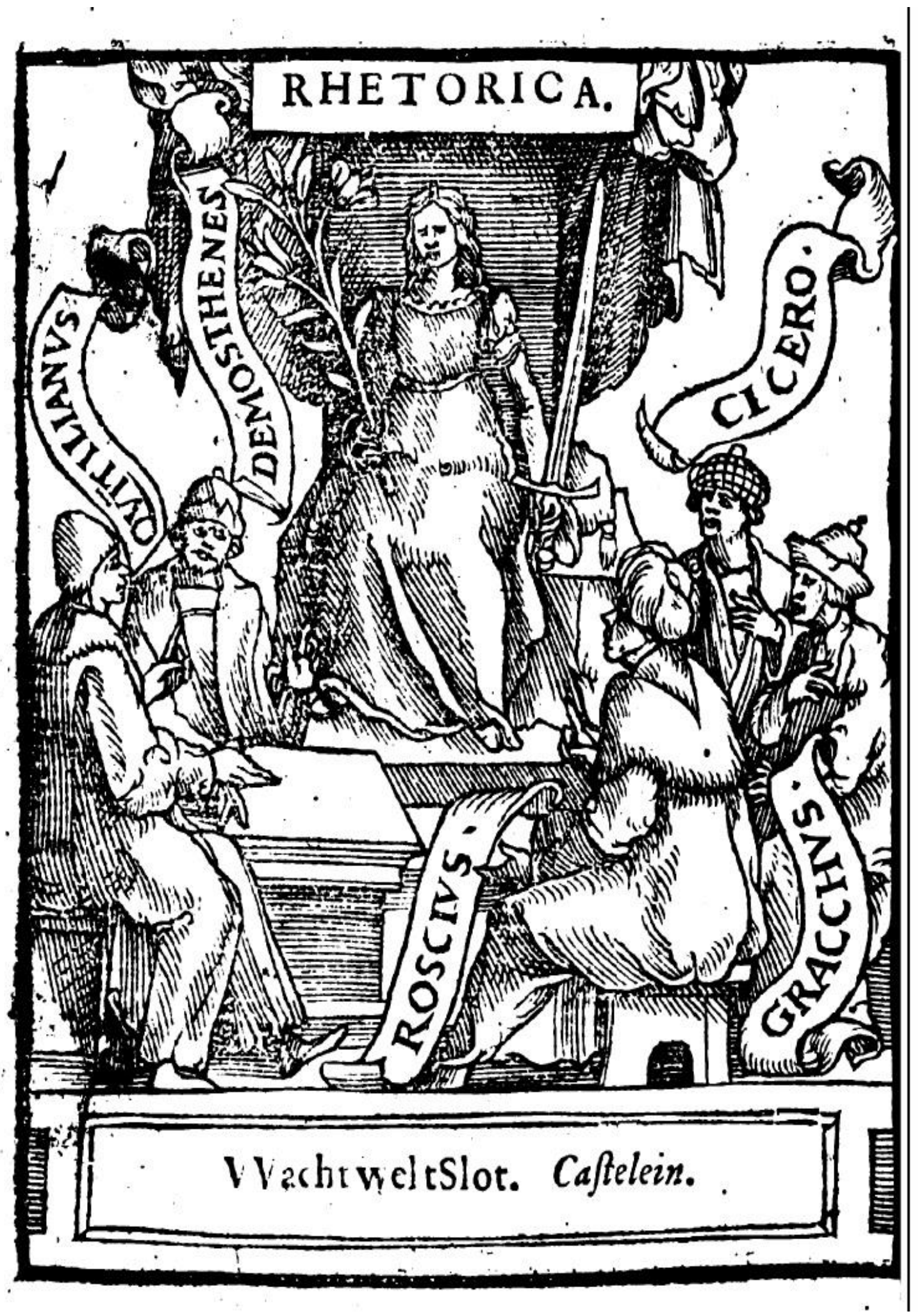

Figura 1-Figura Alegórica da Retórica (CASTELEIN, 1555, p. XXIII) ${ }^{6}$.

\footnotetext{
${ }^{6}$ Observa-se nessa alegoria, além da Retórica como figura central, as presenças de Demóstenes, Quintiliano, Cícero, Graco e Rocio.
} 


\subsection{Breve contextualização sobre Retórica}

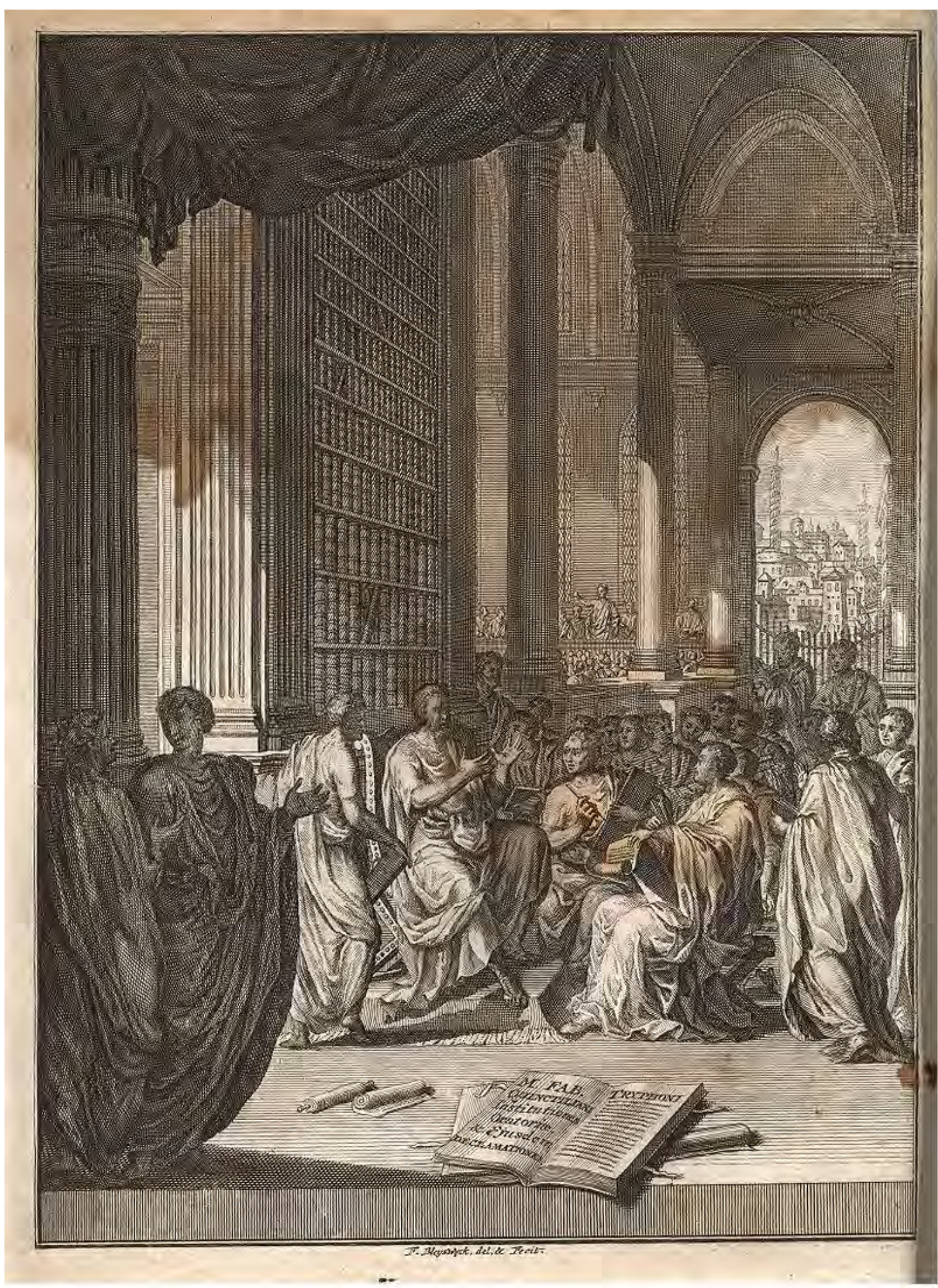

Figura 2-Quintiliano ensinando retórica (QUINTILIANO, 1720 [ca.95], p.6). ${ }^{7}$

\footnotetext{
${ }^{7}$ Nota-se Quintiliano no centro, ensinando retórica, além de seu nome e o título de sua obra, no livro na parte inferior do frontispício.
} 
Segundo uma tradição que remonta a Aristóteles, alguns estudiosos consideram o filósofo e poeta Empédocles de Agrigento (ca. 493-433 a.C.) como o pai da Retórica. No entanto, outra tradição atribui a Córax e Tísias de Siracusa, seu discípulo, o momento do nascimento da Retórica, pelo fato de serem os primeiros autores de um texto escrito sobre o assunto (HERNÁNDEZ GUERREIRO; GARCIA, 2000, p.17).

Não obstante, é relevante acentuar que Empédocles tinha como proposta convencer os ouvintes não pela demonstração tecnicamente rigorosa, mas pela pretensão de comover através da atração irresistível das palavras bem articuladas e dispostas habilidosamente. Para ele, a retórica provocava intencionalmente uma adesão racional e uma reação emotiva (HERNÁNDEZ GUERREIRO; GARCIA, 2000, p.19).

Por outro lado, Armando Plebe ressalta que os estudos novecentistas de Pohlenz, Suess, Rostagni e Nestle, em particular, focalizam-se em duas frentes, enquanto, de um lado, revalorizaram a originalidade da retórica sofística confrontada com a teorização aristotélica, de outro, esclareceram o profundo laço que liga o pensamento retórico dos sofistas às correntes pitagóricas e para pitagóricas sicilianas e italiotas.

Plebe continua seu destaque afirmando que, na atualidade, as averiguações costumam procurar as origens da retórica antiga na Grécia Antiga, e isso corresponde de certo modo, aos testemunhos em Empédocles ou em Córax e Tísias, os fundadores da retórica. Porém, as fontes sobre o primeiro eram escassas e vagas, já os outros dois tinham como principal testemunha Cícero, do qual não se pode duvidar (PLEBE, 1978, p.1).

Tal evidência é notabilizada nas palavras do cônsul e orador romano a seguir.

Quando diz Aristóteles, a tirania foi destruída na Sicília e as questões entre particulares, após um longo intervalo, foram novamente submetidas aos tribunais, pela primeira vez, nesse povo de espírito penetrante e naturalmente inclinado à discussão, viram-se os sicilianos Córax e Tísias dar um método e regras. Antes, ninguém seguia uma rota traçada, nem se submetia a uma teoria e, entretanto, 
a maioria se exprimia com cuidado e $\operatorname{ordem}^{8}$ (CÍCERO, Cap. X-XII §§. 41-45, 1839, p.34).

Enfim, sua origem mais conhecida remonta ao século $V$ a.C. ${ }^{9}$ e seu desenvolvimento permeia toda a vida cultural, educativa, religiosa, social e, de especial maneira, a atividade artística na cultura ocidental. Sua influência abrange sobretudo a literatura, mas, também, se manifesta no teatro, artes plásticas, arquitetura e na música. Esse desenvolvimento se inicia com apresentação de um processo em dois estágios: primeiramente com a exibição adequada e coerente das partes performáticas do discurso e, segundo, em uma imitação da poética, onde se enfocava o fenômeno local da estrutura da sentença e questões de estilo, ou seja, figuras e elementos de retórica que poderiam ser empregadas como artifícios de persuasão, por exemplo, figuras de pensamento e as de discurso (VIDAL, 2002, p.17).

\subsection{O escopo da Retórica e seus saberes}

Como uma das disciplinas humanas mais antigas, à retórica, semelhantemente a gramática, lógica e poética, é discutida, pesquisada, estudada e definida de várias maneiras. Por exemplo, Edward P. J. Corbett $(1919-1998)^{10}$ disserta que, para Aristóteles, a retórica não é simplesmente um mero produto idealizado de princípios convencionados em persuadir ou convencer outras pessoas. Mas, sim, um constructo elaborado, pautado e balizado na experiência consumada de hábeis oradores, em outras palavras, na formação e estruturação resultante da análise das suas estratégias, na

\footnotetext{
${ }^{8}$ Ait Aristoteles, cum sublatis in Sicilia tyrannis res privatae longo intervallo iudiciis repeterentur, tum primum, quod esset acuta illa gens et controversiæ nata, artem et praecepta Siculus Coracem et Tisiam conscripsisse: nam antea neminem solitum via nec arte,accurate tamen et descripte plerosque dicere.

${ }^{9}$ Os tiranos sicilianos Hierón e Gelón haviam decretado uma abusiva expropriação das propriedades, distribuindo-as entre seus mercenários. Posteriormente, um movimento democrático conseguiu derrubar a ditadura. O novo regime se empenhou em devolver as propriedades a seus antigos donos, porém, surgiu um sério problema: como realizar a restituição dos bens, sendo que, devido aos conflitos internos, havia confusão e desordem nos antigos títulos de propriedade. A solução foi instaurar uma espécie de júri popular. A partir desse instante, cada demandante poderia solicitar a devolução de suas terras, não sendo necessária a apresentação de documentos, nem sequer testemunhas oficiais, para convencer as autoridades da legitimidade de seu crédito. Embasavam-se unicamente na argumentação, ou seja, na palavra. Dessa maneira, a retórica, desde seu nascimento esteve ligada a questões judiciárias (LÓPEZ CANO, 2000, p.19).

${ }^{10}$ Professor da Universidade de Ohio (EUA), estudioso e especialista em retórica clássica.
} 
codificação de preceitos advindos da experiência com a finalidade de auxiliar os praticantes da oratória a exercitarem-se de maneira correta, sobre as diversas técnicas de persuasão (ARISTÓTELES, 2005, p.16) ${ }^{11}$.

Por sua vez, Cícero argumenta que, no discurso retórico, é importante que o orador mostre domínio e habilidade para convencer e persuadir o ouvinte. Ou seja, um bom orador é aquele que tem a capacidade de mover as emoções de quem o escuta (LÓPEZ-CANO, 2000, p.21).

Já Quintiliano em sua Instituo Oratoria, apresenta um quadro comparativo acerca na natureza retórica e de suas definições, por quatro convenções clássicas:

Tabela 1-Quadro de definições sobre Retórica, segundo Quintiliano (QUINTILIANO, 1720 [ca.95], livro-II, cap. XV, §§-1-38, pp.178-185).

- Causadora e geradora de persuasão, segundo Córax, Tísias, Górgias e Platão;

- Onde são descobertas as formas de persuasão relativas a um dado assunto, segundo Aristóteles;

- A faculdade de falar bem no que concerne aos assuntos públicos, segundo Hermágoras;

- A ciência de bem - falar, de acordo com o próprio Quintiliano.

Outra definição a ser verificada é a de Plutarco (46-120), o qual enfatiza que a retórica é a arte relativa aos discursos, que tem sua força no ser artífice de uma persuasão, nos discursos políticos sobre todos os assuntos, arte essa criadora de uma crença e não de ensinamentos. Os seus argumentos próprios dizem respeito, sobretudo, ao justo e ao injusto, ao bem e ao mal, ao belo, e ao feio (PLEBE, 1978, p.17).

\footnotetext{
${ }^{11}$ Manuel Alexandre Júnior fez o prefácio e introdução do Livro Retórica (páginas 9 a 35), cujo autor é Aristóteles.
} 
Examinando outras definições pôde-se constatar que a retórica é essencial para a elaboração de uma argumentação, tese, propositura, discurso, entre outros. Além disso, ela é um saber que pode ser associada a outras áreas do conhecimento humano, as quais serão apresentadas em alguns exemplos abaixo.

Rafael Bluteau (1638-1734) define a retórica como "A arte de falar com propriedade e elegância, inculcando boas razões, para provar e persuadir os ouvintes" (BLUTEAU, 1720, p.305).

Helena Beristáin (1927-2013) salienta que retórica "é a arte de elaborar discursos gramaticalmente corretos, elegantes e, sobretudo, persuasivos" (BERISTÁIN, 1995, p.421). Nicola Abbagnano (1901-1990) apresenta a retórica como "arte de persuadir com o uso de instrumentos linguísticos" (ABBAGNANO, 1998, p.856).

Oliver Reboul (1925-1992) afirma que a "retórica é a arte de persuadir pelo discurso" (REBOUL, 2004, p. XIV). Com a mesma linha de raciocínio, Antônio Houaiss (1916-1999) define-a como: conjunto de regras que constitui a arte do bem-dizer, arte da eloquência, oratória e, por extensão, também, o conjunto de regras que consistem e organizam a nossa arte (HOUAISS, 2001, p.2447).

Já Hilton Japiassú (1934-2015) e Danilo Marcondes destacam que a retórica é uma técnica argumentativa, baseada não só na lógica ${ }^{12}$ ou no conhecimento, mas na habilidade em empregar uma linguagem eficaz, com finalidades persuasivas (JAPIASSÚ; MARCONDES, 2001, p.235). Aurélio Buarque de Holanda Ferreira (1910-1989) descreve-a como a capacidade de pôr em prática uma ideia através de estudo do uso persuasivo da linguagem, em especial para o treinamento de oradores (FERREIRA, 2004, p.1751).

Por fim, Chaïm Perelman (1912-1984) expõe que a retórica é a arte de falar em público de maneira convincente, em outras palavras, o objeto da

\footnotetext{
${ }^{12} \mathrm{De}$ fato, a retórica é uma técnica argumentativa, que possui uma lógica de expressão, diversa em alguns aspectos da lógica formal, isto é, há uma lógica para estruturar um discurso, isso se dá pelo fato de a argumentação retórica ser respaldada pelo estudo e convencimento, entretanto, ela não se baseia somente nessa lógica, como afirmam Japiassú e Marcondes (SOARES, 2012, p.32).
} 
retórica desde a Antiguidade Clássica era, acima de tudo, a obtenção da adesão favorável dos ouvintes mediante a tese apresentada pelo orador (PERLMAN, 2005, p.6).

Por esse motivo, segundo Alexandre Júnior (2005), fazer uma definição sobre retórica é trabalhosa, por alguns motivos:

1. Pelo fato de nunca ter tido um sistema uniforme preciso;

2. Ela sempre se apresentou como disciplina flexível;

3. Ela é mais preocupada com a persuasão dos ouvintes do que com a produção de formas de discurso;

4. Sua preocupação é mais manifesta com a função retórica do que com a composição ou estrutura do próprio texto (ARISTÓTELES, 2005, pp.21-22).

Todavia, todas essas descrições e definições concordam em um aspecto: que a retórica e o seu estudo têm como objetivo a criação e elaboração de discursos com finalidades persuasivas. Embora idênticas no essencial, elas enfatizam quatro elementos retóricos relevantes:

1. O seu estado metodológico, ou seja, um conhecimento organizado num sistema ou método, com a finalidade de atingir um determinado objetivo prático;

2. O seu propósito, que trata da finalidade do discurso, ou seja, dos oradores;

3. O seu objeto, que visa a prática na oratória, em um horizonte retórico de três gêneros de discurso público: judicial, deliberativo e epidíctico $^{13}$;

4. O seu conteúdo ético, a neutralidade ${ }^{14}$ (ARISTÓTELES, 2005, p.24).

\footnotetext{
${ }^{13}$ Ostentoso e demonstrativo.

${ }^{14}$ Platão sustenta que ela deve ser eticamente responsável e comprometida. Aristóteles defende a sua neutralidade e fez depender do orador, não do sistema retórico, o uso responsável das técnicas de persuasão. Finalizando, Quintiliano representa sua definição com uma posição intermediária, onde a eloquência é uma virtude com um lugar primordial e o orador é capaz de se expressar bem, ou seja, de forma eticamente aceitável (ARISTÓTELES, ibidem, p.24).
} 
Os três gêneros do discurso

\begin{tabular}{|c|c|c|c|c|c|}
\hline & Auditório & Tempo & Ato & Valores & Argumento-tipo \\
\hline Judiciário & Juízes & $\begin{array}{l}\text { Passado } \\
\text { (fatos por } \\
\text { julgar) }\end{array}$ & $\begin{array}{l}\text { Acusar } \\
\text { Defender }\end{array}$ & $\begin{array}{l}\text { Justo } \\
\text { Injusto }\end{array}$ & $\begin{array}{l}\text { Entimema } \\
\text { (dedutivo) }\end{array}$ \\
\hline Deliberativo & Assembléia & Futuro & $\begin{array}{l}\text { Aconselhar } \\
\text { Desaconselhar }\end{array}$ & $\begin{array}{l}\text { Útil } \\
\text { Nocivo }\end{array}$ & $\begin{array}{l}\text { Exemplo } \\
\text { (indutivo) }\end{array}$ \\
\hline Epidíctico & Espectador & Presente & $\begin{array}{l}\text { Louvar } \\
\text { Censurar }\end{array}$ & $\begin{array}{l}\text { Nobre } \\
\text { Vil }\end{array}$ & Amplificação \\
\hline
\end{tabular}

Figura 3-Os Três Gêneros do Discurso (REBOUL, 2004, p.47).

Sob o exame dessas ponderações e considerações, pode-se perceber que a retórica tem sido um mecanismo usual importante desde sua origem na Antiguidade, permeando diversos períodos históricos, chegando à contemporaneidade. Apesar de ela ser para muitos uma mera manipulação linguística, ornato estilístico e discurso, servindo-se de artifícios irracionais e psicológicos, mais interessados à verbalização de discursos vazios de conteúdo do que fundamentados em princípios e valores que se nutrem de um raciocínio crítico, válido e eficaz. Seu restabelecimento ao antigo estatuto de teoria e prática da argumentação persuasiva, como antiga e nova rainha das ciências humanas, vem corrigir essa noção enganosa, revalorizando-a como ciência e arte que, tão logicamente, opera na heurística e na hermenêutica dos dados que faz intervir no discurso.

Em síntese, o escopo retórico se fundamenta em um saber inspirado em vários saberes, reciprocamente colocando-se a serviço e disposição de todos eles. É um conhecimento interdisciplinar no sentido pleno da palavra, na medida em que se afirmou como arte de pensar e arte de comunicar o pensamento. E, como tal, pode se multiplicar em interdisciplinar e transdisciplinar, ela está presente no direito, na filosofia, na oratória, na dialética, na literatura, na hermenêutica, na crítica literária, na ciência e nas artes (ARISTÓTELES, 2005, pp.9-10). 


\subsubsection{Os componentes retóricos e suas utilidades}

Desde a Retórica de Aristóteles observa-se que os meios artísticos de persuasão são três:

1. Os derivados do caráter do orador $\tilde{\eta} \theta 0 \varsigma$ (ethos);

2. Os derivados da emoção despertada pelo orador nos ouvintes $\pi \alpha \theta$ os (pathos);

3. Os derivados de argumentos verdadeiros ou prováveis ^óyos (logos) (ARISTÓTELES, 2005, p.37).

Aristóteles destaca que esses três elementos auxiliam o raciocínio entinemático, ou seja, com eles é possivel o discernimento entre o que é verossímil e o que é verdade:

Ora, sendo evidente que o método artístico é o que se refere às provas por persuasão e que a prova é uma espécie de demosntração (pois somos persuadidos sobretudo quando entendemos que algo está demonstrado), que a demonstração retórica é o entimema e que este é, geralmente falando, a mais decisiva de todas as provas por persuasão; que, enfim, o entimema é uma espécie de silogismo ${ }^{15}$, e que é do silogismo em todas as suas variantes que se ocupa a dialética, no seu todo ou em algumas das partes, e é igualmente evidente que quem melhor puder teorizar sobre as premissas do que e como se produz um silogismo também será o mais hábil em entimemas, porque sabe a que matérias se aplica o entimema e que diferenças este tem dos silogismos lógicos. Pois é próprio de uma mesma faculdade discernir o verdadeiro e o verossímil, já que os homens têm uma inclinação natural para a verdade e a maior parte das vezes alcançam-na. E, por isso, ser capaz de discenir sobre o plausível é ser igualmente capaz de discenir sobre a verdade (ARISTÓTELES, 2005[séc. IV a.C.], Retórica-I, 1355a, pp.92-93).

Portanto, como salientado pelo filósofo, teórico e tratadista grego, as provas de persuasão proporcionadas pelo discruso são de três espécies, as quais serão apresentadas a seguir.

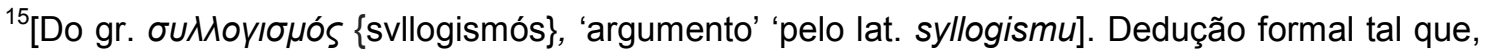
postas duas proposições, chamadas premissas, delas, por inferência, se tira uma terceira, chamada conclusão.
} 


\title{
2.2.1.1. Ethos
}

Aristóteles enfatiza que é mediante o caráter honesto do orador que se pode obter maior persuasão e eficácia no discurso proferido. Em outras palavras, aquele que faz a elocução perante o público deve ser transparente, tanto em seu pronunciamento quanto em sua conduta moral e ética:

\begin{abstract}
Persuade-se pelo carárter quando o discurso é proferido de tal maneira que deixa a impressão de o orador ser digno de fé. Pois acreditamos mais e bem mais depressa em pessoas honestas, em todas as coisas em geral, mas sobretudo nas de que não há conhecimento exato e que deixam margem para dúvida. É, porém, necessário que esta confiança seja resultado do discurso e não de uma opinião prévia sobre o caráter do orador; pois não se deve considerar sem importância para a persuasão e probidade do que fala, como aliás alguns autores desta arte propõem, mas quase se podia dizer que o caráter é o principal meio de persuasão (ARISTÓTELES, 2005[séc. IV a.C.], Retórica-I, 1356a, p.96).
\end{abstract}

No mesmo sentido, Quintiliano ressalta que, no ethos, os oradores devem procurar deixar claro e evidente em seu discurso suas qualidades morais:

O ethos, que nós compreendemos e que demanda dos oradores, é esse sentimento que vai ser avaliável por sua pura bondade, suave e complacente ante tudo e também normalmente humana e terna, agradável para os ouvintes, cuja maior virtude consiste em que tudo pareça fluir do modo de ser das coisas e dos homens, em que a atitude moral do orador resplandeça em seu discurso dando a se conhecer (QUINTILIANO, 1720 [ca.95], Livro-VI, Capítulo-II, p.519) ${ }^{16}$.

Indo ao encontro dessas afirmações, Michel Meyer destaca que o ethos: "É a imagem de si, o caráter, a personalidade, os traços de comportamento, a escolha de vida e dos fins. Nele está a identificação do orador, do porquê e o papel do orador" (MEYER, 2007, p.34). No mesmo sentido, é o caráter que o orador deve parecer ter, mostrando-se "sensato, sincero e simpático". Igualmente, caráter do auditório, ao qual o orador deve se adaptar (REBOUL, 2004, p.247).

\footnotetext{
${ }^{16} \tilde{\eta} \theta 0$, quod intellegimus quodque e dicentibus desideramus, id erit, quod ante ommia bonitate commendaditur, non solum mite ac placideum, sed plerumque blandum et humanum et andientibus amabile atque iucundum, in quo expreimendo summa virtus $æ$ est, ut fluere omnia ex natura rerum hominumque videantur utque mores dicentis ex oratione perluceant et quodam modo agnoscantur.
} 
Meyer ainda ressalta que o ethos é o orador como príncipio de autoridade e, ao mesmo tempo de sua ética:

O ethos é orador como princípio (e também como argumento) de autoridade . A ética do orador é seu "saber específico" de homem, e esse humanismo é a moralidade, que constitui fonte de autoridade (MEYER, 2007, p.35).

Portanto, ethos é um estado afetivo que se manifesta com certo grau de satisfação estética. É, de igual forma, a emoção que pretende suscitar o orador ao público (BERISTÁIN, 1995,p.202).

\subsubsection{Pathos}

Persuade-se pela disposição dos ouvintes, quando estes são levados a sentir emoção por meio do discurso, pois os juízos que emitimos veriam conforme sentimos tristeza ou alegria, amor ou ódio ARISTÓTELES, 2005, [séc. IV a.C.] Retórica- I, 1356a, p.97).

É através da ação do orador sobre as paixões, desejos e emoções do auditório, que a persuasão pode ser auferida com maior eficiência (REBOUL, 2004, p.251). De acordo com Meyer (2007), "o pathos é a fonte das questões e essas respondem a interesses múltiplos, dos quais dão prova as paixões, as emoções ou simplesmente as opiniões" (MEYER, 2007, p.36). Nele está o prazer e o desprazer, o amor, o ódio, desespero, desejo, a dor, entre outros.

Beristáin salienta que "o pathos é um estado afetivo mais intenso, é uma comoção que atrai o espectador". Consequentemente, essa atração se dá tanto para o público da tragédia, ao leitor de epopeia, quanto àqueles que escutam a peroração do orador (BERISTÁIN, 1995, p.202).

\subsubsection{Logos}

Logos num primeiro momento significava a palavra escrita ou Verbo. No entanto, a partir de filósofos gregos como Heráclito (535 a.C.-475 a.C.), por exemplo, passou a ter um significado mais lato. Em razão disso, há no logos um conceito filosófico traduzido como razão, o qual pode ser também examinado na retórica como racionalização da argumentação. 
Nele se expressam as perguntas e as respostas preservando sua diferença (MEYER, 2007, p.40). Murphy destaca que, em Aristóteles, o logos configura-se como argumentos lógicos do orador, relacionados à retórica e à dialética (MURPHY, 1989, pp.39-40).

Por sua vez, Heidegger enfatiza que, em Platão e Aristóteles, o conceito de logos é polissêmico, ou seja, tem vários significados e multiplicidade de sentidos, no entanto, essa gama de possiblidades só terá sentido caso se compreenda o que é a significação básica de um conteúdo, assim como interpretar, por exemplo, determinar o que é um discurso:

Em Platão e Aristóteles, o conceito de \óyos é polissêmico e, de tal modo, que os vários significados tendem a se dispersar, sem a orientação positiva de um sentido básico. Mas, de fato, isso é somente uma aparência que se há de manter enquanto não se puder aprender devidamente o conteúdo primordial de sua significação básica. Quando dizemos que o significado básico de tóyos é discurso, essa tradução literal só terá valor completo quando se determinar o que é um discurso (HEIDEGGER, 2005, p.62).

Adiante, Heidegger sublinha que, como discurso, o logos revela aquilo que trata o discurso, isto é, deixa-se apresentar naquilo de que discorre ou fala, tornando-se, exequível aos outros.

Logos deixa e faz ver ( $\varphi \alpha^{\prime} v \varepsilon \sigma \theta \alpha_{l} /$ phainestai) ${ }^{17}$ aquilo sobre o que se discorre e o faz para quem discorre [...] e para todos aqueles que discursam uns com os outros [...]. O discurso autêntico é aquele que retira o que diz respeito sobre que discorre de tal maneira que, em seu discurso, a comunicação discursiva revele e, assim torne acessível aos outros aquilo sobre que discorre. Esta é a estrutura, por exemplo, do logos. Pois nem todo discurso possui este modo próprio de revelação no sentido de deixar e fazer ver demonstrando. (HEIDEGGER, 2002, pp.62-63).

Enfim, essa capacidade daquele que enuncia o discurso é de desvelar algo do enunciado o que gera a ação ou a performance na retórica, ou seja, a habilidade em convencer, comover.

\footnotetext{
${ }^{17}$ Fenomenologia em grego, termo esse criado no séc. XVIII, pelo filósofo J.H. Lambert (17281777), designando o estudo puramente descritivo do fenômeno tal qual esse se apresenta à nossa experiência (JAPIASSÚ; MARCONDES, 2001, pp.101-102).
} 


\begin{tabular}{|l|c|c|c|}
\hline & ethos & logos & pathos \\
\hline Platón & intención & $\begin{array}{l}\text { sofistica } \\
\text { (equívocos) }\end{array}$ & manipulación \\
Aristóteles & pericia & razonamiento & pasión \\
Cicerón & virtudes & $\begin{array}{l}\text { elocuencia } \\
\text { (y figuras) }\end{array}$ & convicción \\
\hline
\end{tabular}

Figura 4-Ethos, Pathos, Logos (MEYER, 2013, p.24).

\subsubsection{As fases da retórica}

Através de Aristóteles, a retórica foi reabilitada e integrada numa visão sistemática do mundo, onde a mesma ocupa seu lugar. Em outras palavras, Aristóteles transformou a retórica num sistema, o qual, ulteriormente, seus sucessores trataram de desenvolver, porém, mantendo suas características principais (REBOUL, 2004, p.43).

Essa uniformidade organizacional instituída desde Aristóteles, com suas partes e seus gêneros, como observado no tópico anterior é destacada por Rafael Bluteau em seu Vocabulario Portuguez \& Latino, de 1720, como mestrado a seguir.

As partes da Retórica são Invenção, Disposição, Elocução e Pronunciação, a Memoria, que, segundo alguns, é a quinta parte da Retórica, não é necessário separá-la das demais partes, porque em todas elas, não só a memoria, mas também o juízo, tem seu lugar, pois sem um e outro não há Arte e nem Ciência perfeita. Dessas quatro partes se usam em todos os discursos e orações três gêneros principais: Demonstrativo (Epidíctico), que se ocupa em louvor, ou condenar as pessoas, ou ações, ou as coisas; Deliberativo, que se exercita em persuadir ou dissuadir; Judicial, que consiste em acusar ou defender. Nesses três gêneros, também usa a Retórica Eclesiástica o Panegírico, com o qual louva a Deus, aos Anjos e aos Santos; Didascalico, com o qual se expõem as Escrituras e declara os mistérios de nossa religião; Parenético, que oferece razões e motivos, para exortar os cristãos a abraçar as virtudes e aborrecer os vícios [grifos nossos] (BLUTEAU, 1720, p.305).

Em suma, tendo por finalidade o entendimento do funcionamento da retórica e de sua sistematização, com o passar dos tempos, instituiu-se como 
hoje são conhecidas as fases da retórica, distribuídas em cinco, expostas a seguir.

\subsubsection{Inventio}

É o encontrar do orador de todos os argumentos e meios de persuasão relacionados ao tema de seu discurso (REBOUL, 2004, p.43). Nessa fase, acontece a descoberta ou invenção das ideias e argumentos que sustentarão o discurso e sua tese. Ou seja, o orador tem como tarefa efetuar um argumento adequado para dar sustentação a um tema ou ideia a ser exposta (PERSONE, 1996, p.28).

$\mathrm{Na}$ Rhetorica ad Herennium (autor anônimo, atribuída, por alguns estudiosos, a Cícero) afirma-se que: "A invenção consiste em encontrar argumentos verdadeiros ou verossímeis próprios para tornar a causa convincente" (Livro- I, §2, 2005 [ca.86-82 a.C.], p.55). Semelhantemente, Cícero, no De Inventione, expõe que: "A invenção consiste em imaginar as coisas verdadeiras ou verossímeis, de maneira a fazer admitir a nossa causa" (CÍCERO, 1960, I, VII) ${ }^{18}$.

Todavia, segundo Barthes (1982), essa condição remete menos a uma invenção de argumentos do que a um descobrimento, pois se trata mais de uma noção extrativa do que criativa. O que corrobora a designação de um lugar (tópica) de onde se podem extrair as argumentações (BARTHES, 1982 [1970], p.44). Não significa que tal descobrimento deixasse de lado a criação, mas, a partir dos materiais já existentes, o orador poderia demonstrar sua habilidade em articulá-los.

De igual modo, a Inventio é um passo inicial, onde o tópico sobre o qual se vai discorrer, isto é, compor, será fundamento sobre o qual se construirá a representação e evocação do afeto correspondente (ASSUMPÇÃO, 2007, p.58). Bartel ressalta que, na Inventio, é onde são determinados os sujeitos e, da mesma maneira, nessa etapa as informações são coletadas (BARTEL, 1997, p.66).

$\mathrm{Na}$ Inventio, também se encontra o lugar-comum (Locus Topoi/Topici), que segundo Reboul (2004), são os argumentos cautelosamente buscados

\footnotetext{
${ }^{18}$ Essa citação também pode ser localizada em (PAIXÃO, 2008, p.134).
} 
pelo orador (REBOUL, 2004, p.51). Barthes enfatiza que essa parte da Inventio é encarregada de proporcionar conteúdos mais claros e compreensivos dos afetos ao raciocínio humano, tendo como instrumento essencial a tópica (BARTHES, 1982 [1970], p.55).

Em suma, tudo isso vai ao encontro de uma definição de Aristóteles quando afirma que um dos papéis da retórica é de ver teoricamente o que, em cada caso, pode ser capaz de gerar a persuasão (ARISTÓTELES, s/d, p.33).

\subsubsection{Dispositio}

Distribuição ou arranjo das ideias e argumentos localizados na Inventio, de modo apropriado e eficaz. Para que essa disposição seja orientada e organizada, acontece uma subdivisão tradicional da Dispositio em seções. Essa subdivisão passou por pequenas variações desde a Antiguidade, entretanto, sua base foi padronizada da forma apresentada a seguir.

- Exordium: introdução.

Para Aristóteles, o proêmio é o início do discurso, que corresponde ao prólogo, na música seria como um prelúdio tocado por um aulo. Todos eles são inícios e servem de preparações do caminho para o que se segue (ARISTÓTELES, 2005 [séc. IV a.C.] Retórica-III, 1414b, p.279).

Cícero define-o dessa maneira:

O prólogo (exórdio) é um trecho onde a mente do ouvinte é transportada para uma posição apropriada no restante do discurso, fazendo com que o mesmo possa ficar bem atento e receptivo. [...] $\mathrm{O}$ exórdio é dividido em introdução e insinuação (persuasão). Uma introdução é algo que de uma forma direta e com uma linguagem simples faz com que o ouvinte fique receptivo e atento. $A$ insinuação é aquilo que por intermédio da simulação e de um processo indireto, se armazena discretamente na mente do ouvinte (CÍCERO, 1960 [ca.86 a.C.] Livro- I, §20, p.40-42) ${ }^{19}$.

\footnotetext{
${ }^{19}$ Exordium est oratio animum auditoris idonee comparans ad reliquam dictionem: quod eveniet, si eum benivolum, attentum, docilem confecerit. [...] Igitur exordium in duas partes dividitur, in principium et insinuationem. Principium est oratio perspicue et protinus perficiens auditorem benivolum aut docilem aut attentum. Insinuatio est oratio quadam dissimulatione et circumitione obscure subiens auditoris animum.
} 
Em Rhetorica ad Herennium é definida como "o começo do discurso, pelo meio do qual se dispõe o ânimo (espírito) do ouvinte a ouvir" (Livro- I, §4, 2005 [ca.86-82 a.C.], p.56).

Quintiliano, por sua vez, disserta que o Exordium latino equivale ao Prologo dos gregos, constituindo-se na introdução do tema (QUINTILIANO, 1720 [ca.95], Livro-IV, Capítulo-I, p.298).

- Narratio: exposição do caso em discussão.

A narração é a exposição de fatos que dizem respeito à causa, exposição aparentemente objetiva (REBOUL, 2004, p.56). Aristóteles afirmava que, a partir dessa parte:

\begin{abstract}
A narração nos discursos epidícticos não é contínua, mas sim articulada em secções, pois é forçoso percorrer os fatos de que o conteúdo do discurso trata. [...] A partir de certos fatos, um indivíduo pode ser apresentado como valoroso, noutras como sábio ou justo. Quanto a fatos bem conhecidos, é necessário apenas recordá-los. [...] o melhor não é a rapidez ou a concisão, mas sim a justa medida. Isto significa falar tanto quanto aquilo de que o assunto necessita para ficar claro. Narra tudo quanto chama a atenção para o teu próprio valor. [...] É conveniente que a narração incida sobre a componente ética, além disso, fala de forma a suscitar emoções narrando tanto as consequências que os ouvintes conhecem como os aspectos singulares... [grifo nosso] (ARISTÓTELES, 2005 [séc. IV a.C.] RETÓRICA III, 1417a/b, pp.286-288).
\end{abstract}

Cícero enfoca que, na Narratio, acontece a narração do enunciado dos fatos (MURPHY, 1989, p.139). Em outra definição, é observável que é nela que as coisas que ocorreram ou poderiam ter ocorrido são expostas (RHETORICA AD HERENNINUM Livro- I, §4, 2005 [ca.86-82 a.C.], p.56).

Já Quintiliano comenta que ela é uma exposição persuasiva de uma ocorrência verdadeira ou verossímil, a mesma tem que ser exposta na medida certa (QUINTILIANO, 1720 [ca.95], Livro-IV, Capítulo-II, pp.318-320).

- Propositio: esboços dos pontos de um argumento.

Igualmente conhecida como Divisio é o meio pelo qual se explicita o que se concorda ou o que está em controvérsia, do mesmo modo o que irá se pronunciar (RHETORICA AD HERENINUM Livro- I, §4, 2005 [ca.86-82 a.C.], 
p.56). Aristóteles trabalha com a Propositio de forma a propiciar no momento certo o mover dos afetos no público. Todavia, o ilustre mestre da retórica frisa que é necessário que o orador saiba produzir efeito retórico conhecido como etinema na medida e hora certa para não quebrar a emoção de quem esta ouvindo:

\begin{abstract}
Exemplificação é o que é mais apropriado ao discurso deliberativo, entimemas ao discurso judiciário. Efetivamente, um concerne ao futuro, de forma que é forçoso narrar exemplos de acontecimentos passados; o outro, por seu lado, relaciona-se com fatos que são ou não são, onde é mais necessária a demonstração, pois os fatos do passado implicam um tipo de necessidade. É forçoso, porém, expor os entimemas não de forma contínua, mas intercalados. Se assim não for, prejudicam-se uns aos outros, pois há também um limite na quantidade. Por outro lado, não procures entimemas sobre tudo. De outro modo, farás o que alguns filósofos fazem, que formulam silogismos cujas conclusões são mais conhecidas e mais plausíveis que as premissas das quais as tiram. E também sempre que suscitares uma emoção, não formules um entimema, pois o entimema ou quebrará a emoção, ou será dito em vão; é que movimentos simultâneos chocam uns com os outros, e/ou se anulam ou se tornam fracos (ARISTÓTELES, 2005 [séc. IV a.C.] RETÓRICA III, 1418a, pp.290-291).
\end{abstract}

- Confutatio: refutação dos argumentos expostos, ou seja, uma oposição ao tema inicial ou principal.

Nessa parte, é onde se deduz os tópicos básicos da conclusão adversa (MEYER, 2007, p.47). Aristóteles declara que tal adversidade pode ser entendida como a utilização dos mesmos recursos ou elementos pela acusação, de maneira sutil, com o propósito de refutar a suspeita capciosa (ARISTÓTELES, 2005 [séc. IV a.C.] RETÓRICA III, 1416a, p.283). Em contrapartida, em Rhetorica ad Herennium, o autor afirma que a refutação é nada menos que a desconstrução dos argumentos contrários (Livro- I, §4, 2005 [ca.86-82 a.C.], p.56). De igual maneira, Cícero observa que na Refutatio os argumentos são direcionados contra os adversários em uma audiência (MURPHY, 1989, p.139).

- Confirmatio: confirmação das ideias principais, expostas no início do discurso. 
Confirmação, comprovação ou argumentação que contém as provas e razões para convencer. Alguns tratadistas consideram que forma parte dela a refutação. Entretanto, outros a veem como independente, sendo a refutação sua antecipação (BERISTÁIN, 1995, p.157). Analogamente, segundo Reboul (2004), a Confirmatio era empregada por alguns autores e oradores, juntamente ou logo após a Narratio (REBOUL, 2004, p.56).

Por exemplo, para Cícero, a confirmação é a parte da narração que, mediante a ordenação dos argumentos, dá força e autoridade. Ela permite, portanto, estabelecer a matéria-prima da qual se extraem os argumentos (MURPHY, 1989, p.148). Em Rhetorica ad Herennium, a confirmação é "a apresentação dos argumentos com asseveração" (Livro- I, §4, 2005 [ca.86-82 a.C.], p.56). Já Quintiliano exprime que "a confirmação segue a enunciação" e ela é a confirmação da ordem narrativa (QUINTILIANO, 1720 [ca.95], Livro-IV, Capítulo-II, p.353). O mesmo autor disserta que tanto a narração como a confirmação devem ser cumpridas pelo orador, todavia, nada o obriga a realizá-las sucessivamente. Em outras palavras, pouco importa a ordem, o importante é que o orador atinja seus objetivos (REBOUL, 2004, p.58).

- Peroratio: conclusão do discurso.

Peroração é a parte do epílogo, onde se encerra o discurso (BERISTÁIN, 1995, p.158), isto é, a conclusão do discurso feita com maestria (MEYER, 2007, p.47).

Aristóteles detalha que a conclusão do discurso é formada por quatro elementos essenciais para a sustentação do orador, o qual tem por proposta mover as emoções (afetos) dos ouvintes:

O epílogo é composto por quatro elementos: tornar o ouvinte favorável para a causa do orador e desfavorável para a do adversário; amplificar ou minimizar; dispor o ouvinte para um comportamento emocional; recapitular. Após ter-se mostrado que se diz a verdade e o adversário falsidades, faça-se um elogio ou uma censura, e finalmente sublinhe-se de novo o assunto. [...] Depois, estando em evidência tanto as qualidades como as dimensões dos fatos, convém provocar no ouvinte comportamentos emocionais (ARISTÓTELES, 2005 [séc. IV a.C.] RETÓRICA III, 1419b, p.296). 
Por sua vez, Cícero enfatiza que a peroração completa o discurso e tem três partes: o resumo do que foi discutido em todo o discurso, a provocação e animosidade com o adversário e, finalmente, a provocação da simpatia para com o público (MURPHY, 1989, p.149).

Na Rhetorica ad Herennium, examina-se que essa é a conclusão do discurso, ou seja, onde se tem o término do mesmo, de acordo com as regras de arte (Livro- I, §4, 2005 [ca.86-82 a.C.], p.56).

\subsubsection{Elocutio}

A terceira fase retórica, na tradição gregoriana, corresponde à expressão linguística verba dos pensamentos (res) encontrados na Inventio e combinados na Dispositio, pelo orador (BERISTÁIN, 1995, p.168; LAUSBERG, 2004, p.115). Ela apresenta uma multiplicidade, dirigida por possibilidades linguísticas de expressão, as quais são sistematizadas como genera elocutionis (LAUSBERG, 2004, p.116).

Semelhantemente, a elocução do discurso é a base de sua organização; descoberta da expressão para cada ideia, e inclui o estudo das figuras ou tropos $^{20}$; onde as regras estilísticas são ensinadas. Também podem ser acrescidas ornamentações e junções entre partes e alterações de estilo. Nessa fase do discurso retórico, o orador escolhe as palavras e as junta, para depois ordená-las, visando, assim, o melhor resultado tanto na compreensão do ouvinte, quanto do orador. Segundo Cícero, nessa fase, o orador enuncia seu discurso com maior peculiaridade (CÍCERO, 1967 [ca. 52 a.C.], p.61). Adicionado a isso, Reboul complementa ressaltando que, no sentido técnico, se trata da redação do discurso (REBOUL, 2004, p.61).

Duas regras são as que orientam essa fase do discurso, são elas: as do decoro e a regra da clareza. A primeira tem por objetivo ajustar um assunto à função do discurso, ou seja, cada assunto e função exige um estilo diferente, a segunda é uma solicitação para uma adequação do estilo ao auditório.

\footnotetext{
${ }^{20}$ Tropo [do gr. trópos, "desvio", pelo lat. tropu]. É o emprego da palavra ou expressão em sentido figurado, na música medieval. Era empregado na ampliação de um canto litúrgico de formação melismática, mediante acréscimos ou substituições. A primeira manifestação dramática foi na Idade Média, e se constituía de pequeno recitativo ou diálogo inserido na liturgia da missa, donde se originaram os dramas litúrgicos (v. drama litúrgico).
} 
Outro aspecto relevante refere-se aos gêneros de estilos os quais o orador deveria ter domínio, habilidade, além de saber o momento propício para empregá-los. Cícero os dispõe como indicado a seguir.

- Estilo baixo: (estilo tênuel humilis). Esse só quer ensinar (docere) e provar (probare). Suas virtudes são, portanto, a pureza e a perspicácia. Também, trabalha com a matéria comum, diária e pequena.

- Estilo médio (estilo mediocris). Gracioso, pelo fato de querer deleitar (delectare). O grau de afeto correspondente é o ethos, igualmente é o mais indicado para persuadir o ouvinte.

- Estilo alto (estilo sublime/grave). É patético, porque há a intenção de comover e mover (comovere/movere). Nesse, o orador deve suscitar no ouvinte os afetos de alegria, tristeza, ira, ódio, inveja, compaixão, esperança, desesperança, medo, entre outros (CíCERO, 1967 [52 a.C.] Livro- I, Capítulo XVII- XXI, §§ 74-97, pp.55-70).

\begin{tabular}{|c|c|c|c|}
\hline Estilo & Objetivo & Prova & Momento do discurso \\
\hline nobre $=$ grave & comover $=$ movere & patos & $\begin{array}{l}\text { Peroração (paixão), } \\
\text { digressão }\end{array}$ \\
\hline simples $=$ tenue & explicar $=$ docere & $\log 0 \mathrm{~s}$ & $\begin{array}{l}\text { Narração, confirmação, } \\
\text { recapitalução }\end{array}$ \\
\hline ameno $=$ medium & agradar $=$ delectare & etos & Exórdio, digressão \\
\hline
\end{tabular}

Figura 5-Os Três Gêneros de Estilos (REBOUL, 2004, p. 62). 


\begin{tabular}{|c|c|c|c|}
\hline $\begin{array}{l}\text { stilus } \\
\text { (estilo) }\end{array}$ & $\begin{array}{l}\text { humilis } \\
\text { (humilde) }\end{array}$ & $\begin{array}{l}\text { mediocris } \\
\text { (mediocre) }\end{array}$ & $\begin{array}{l}\text { gravis } \\
\text { (grave) }\end{array}$ \\
\hline Classe social & $\begin{array}{l}\text { pastor, otiosus } \\
\text { (pastor, ocioso) }\end{array}$ & $\begin{array}{l}\text { agricola } \\
\text { (lavrador) }\end{array}$ & $\begin{array}{l}\text { miles, dominans } \\
\text { (soldado, senhor) }\end{array}$ \\
\hline $\begin{array}{c}\text { Nomes pró- } \\
\text { prios }\end{array}$ & $\begin{array}{l}\text { Tityrus, Meliboeus } \\
\text { (T'́tiro, Melibeu) }\end{array}$ & $\begin{array}{l}\text { Triptolemus, Caelius } \\
\text { (Triptólemo, Célio) }\end{array}$ & $\begin{array}{l}\text { Hector, Aiax } \\
\text { (Heitor, Ájax) }\end{array}$ \\
\hline Animais & $\begin{array}{l}\text { ovis } \\
\text { (ovelha) }\end{array}$ & $\begin{array}{l}\text { bos } \\
\text { (boi, vaca) }\end{array}$ & $\begin{array}{l}\text { equus } \\
\text { (cavalo) }\end{array}$ \\
\hline Instrumentos & 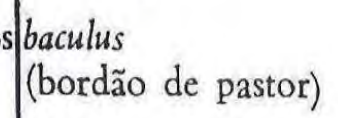 & $\begin{array}{l}\text { aratrum } \\
\text { (arado) }\end{array}$ & $\begin{array}{l}\text { gladius } \\
\text { (gládio) }\end{array}$ \\
\hline Lugar & $\begin{array}{l}\text { pascua } \\
\text { (pastagem) }\end{array}$ & $\begin{array}{l}\text { ager } \\
\text { (campo) }\end{array}$ & $\begin{array}{l}\text { urbs, castra } \\
\text { (cidade, acampamento) }\end{array}$ \\
\hline Plantas & $\begin{array}{l}\text { fagus } \\
\text { (faia) }\end{array}$ & $\begin{array}{l}\text { pomus } \\
\text { (árvore de fruto) }\end{array}$ & $\begin{array}{l}\text { laurus, cedrus } \\
\text { (loureiro, cedro) }\end{array}$ \\
\hline
\end{tabular}

Figura 6-Os Três Gêneros de Estilos (LAUSBERG, 2004, p.271).

Enfim, é na Elocutio que as diversas ideias e pensamentos são traduzidos em palavras e sentenças, somando, assim, todos os dispositivos necessários para uma fundamentação e argumentação com maior ênfase (BARTEL, 1997, p.66).

\subsubsection{Memoria}

Mecanismos e processos para memorizar o discurso e, por extensão, o modo operativo de cada uma das fases retóricas. Esses instrumentos e processos de memorização, atribuídos ao orador, permitem que o mesmo possa realizar seu discurso com maior desenvoltura e confiança. Tendo o orador discursado e corretamente memorizado as ideias, argumentos, e da mesma forma demonstrando domínio em sua execução, ia ganhando, com o tempo, maior credibilidade e autoridade.

Na mesma linha de pensamento, Olivier Reboul explica que a memória depende do estado físico do orador, por exemplo, se o mesmo está com boa saúde, se dormiu bem. Posteriormente, um discurso só será fácil de memorizar mediante sua estrutura e pelo encadeamento lógico de suas partes. Uma vez dominado, o discurso pode ser proferido com solidez e segurança, assim conquistando a atenção do auditório (REBOUL, 2004, p.68). 
Em síntese, a Memoria corresponde à aprendizagem das ideias fundamentais do discurso ou de sua elaboração e formulação elocutiva, mediante a ajuda de uma técnica ordenadora, habitual entre os oradores (BESRESTÁIN, 1995, p.305).

\title{
2.2.2.5. Pronuntiatio
}

A quinta e última fase retórica é também conhecida na tradição grega como Actio ou Hipocrisis. Realização do discurso ante o público, onde são revisados os princípios fonéticos e gestuais que se devem observar durante a execução pública. Na Antiguidade, por exemplo, o orador era posto em cena ao recitar seu discurso como um ator.

Com a dicção adequada e os gestos pertinentes para realizá-la, poderia lograr êxito no efeito proposto. Do mesmo modo, consiste no emprego da palavra e na pronúncia das expressões. Nele são considerados tudo o que se relacionava com a voz e com o corpo (BERISTÁIN, 1995, p.401).

\section{Quintiliano afirma que:}

\begin{abstract}
Na verdade elas (a escrita, a leitura e a fala) formam de tal modo um todo conexo e indiscriminável, as quais estão intimamente relacionadas e são inseparáveis: se uma delas falta, empregaremos todos os nossos esforços em vão. Por isso, a oratória (eloquência) só será eficaz se apenas retirar suas forças do exercício escrito. Sem o exemplo dado pela leitura, o objetivo do trabalho escrito (na falta de um guia) será vago e instável. Portanto, aquele que não sabe falar adequadamente e sem sensibilidade aguçada (eloquência), isto é, com nenhum aprimoramento na oratória, será como um guarda de um tesouro fechado (QUINTILIANO, 1885 [ca.95], livro X, cap.1,§2, p.2)
\end{abstract}

Há de se ressaltar, ainda, que os teóricos da retórica dedicam também grandes espaços ao estudo da origem e funcionamento dos afetos. Despertar, mover e controlar as paixões nos ouvintes é tarefa fundamental no trabalho persuasivo do orador.

\footnotetext{
${ }^{21}$ Verum ita sunt inter se conexa et indiscreta omnia, ut, si quid ex his defuerit, frustra sit in ceteris laboratum. Nam neque solida atque robusta fuerit umquam eloquentia, nisi multo stilo vires acceperit, et citra lectionis exemplum labor ille carens rectore fluitabit, et qui sciet, quæ quoque sint modo dicenda, nisi tamquam in procinctu paratamque ad omnes casus habuerit eloquentiam, velut clausis thesauris incubabit. Essa citação e tradução de Quintiliano também podem ser localizadas em (REZENDE, 2009, p.186; LUCAS, 2010, p.5).
} 


\title{
2.3. A utilização da retórica na Idade Média até a Moderna
}

Se o ensino da retórica perdurou durante o Império Romano, se sobreviveu em Bizâncio, tanto sob o islamismo quanto na Europa Medieval, com métodos semelhantes, significa que não era tão inútil (REBOUL, 2004, p.76).

A retórica, como doutrina, acompanhou e serviu a gregos e romanos em suas expansões territoriais. Com o domínio da cultura clássica na Antiguidade, novos tratamentos e rumos foram aprimorando o discurso e argumentação, entre os quais está o texto poético. Assim, o fenômeno da poesia converteu a retórica em criação literária, e essa para as demais artes (LÓPEZ-CANO, 2000, p.23).

Roland Barthes (1915-1980) disserta sobre esse acontecimento da seguinte maneira:

\begin{abstract}
A fusão entre a Retórica e a Poética é consagrada pelo vocabulário da Idade Média, em que as artes poéticas são artes retóricas e onde os grandes retóricos são poetas. Essa fusão é capital porque está na origem da mesma ideia de literatura: a Retórica aristotélica põe o acento sobre o raciocínio. [...] A Retórica é onde se identificam os problemas não de um teste, senão da composição e de estilo: a literatura (ato total da escrita) se define por escrever bem (BARTHES, 1982 [1970], pp.16-17).
\end{abstract}

Desse modo, o valor educativo da retórica que, durante a Antiguidade Clássica, foi disseminado pelos ilustres mestres e pensadores tornou-se uma das razões fundamentais para que sua transmissão continuasse formando parte nos saberes medievais ${ }^{22}$ (HERNÁNDEZ GUERREIRO; GARCIA, 2000, p.71).

Motivado por esse sentimento, no início da Idade Média, Santo Agostinho (354-430) impulsionou uma releitura cristã de Platão, Aristóteles e Cícero. Fato esse comprovado em seu tratado De Doctrina Christiana (397ca.427), onde exprime seu intento de cristianizar a retórica (HERNÁNDEZ GUERREIRO; GARCIA, 2000, p.72).

\footnotetext{
${ }^{22}$ Segundo Guerreiro e Garcia (2000) houve uma série de textos latinos que se constituem na base do ensino da retórica durante a Idade Média, por exemplo, os tratados De Oratore e $D e$ Inventione de Cícero; Rhetorica ad Herennium (autor anônimo, entretanto, alguns estudiosos atribuem sua autoria a Cícero) e Instituto Oratoria de Quintiliano (HERNÁNDEZ GUERREIRO; GARCIA, 2000, p.71).
} 
Mais adiante, São Gregório de Naciazo (330-390), Cassiodoro (480? 575 ? $)^{23}$, Santo Isidoro (570-636) e, finalmente, Beda, o Venerável (673-735), solidificaram a teoria da retórica medieval. Ao interpretar as escrituras descobriu-se que a Bíblia estava repleta de figuras retóricas. Assim a retórica se converteu em instrumento capital para futuras evangelizações ao mesmo tempo em que se ampliava o campo de ação a análises e interpretações de textos já existentes (LÓPEZ-CANO, 2000, p.23). Enfim, tal fato contribuiu para a consolidação do legado judaico-cristão, o qual, de acordo com James Murphy:

\begin{abstract}
Balizou-se na arte da pregação, pois ela foi o segundo ato de Deus após a criação do homem e, durante muitas épocas, constituiu o meio primordial de comunicação entre Deus e o homem (MURPHY, 1986, pp. $275-276)^{24}$.
\end{abstract}

\title{
2.3.1. Retórica e o Cristianismo
}

Como exposto no tópico anterior, a partir de Agostinho de Hipona, houve uma convergência do legado clássico e do substrato judaico-cristão, o qual propiciou três partes pedagógicas constituintes para o estudo do discurso na Idade Média: a arte da predicação (ars praedicandi), a gramática preceptiva ou retórica da versificação (ars poetriæ) e a arte epistolar (ars dictaminis) (MELEVAL, 2008, p.7).

É verdade que essa percepção trouxe um grande problema que se apresenta na transição da Antiguidade para a Idade Média, o da relação entre a retórica e a nova religião, o cristianismo. O que de acordo do Reboul (2004) poderia trazer uma ruptura total entre a cultura antiga, sob a esteira pagã, idólatra e imoral. Contudo, os cristãos logo notaram a relevância da escola greco-romana e da cultura que ela veiculava. Pois mesmo quando todas as estruturas administrativas do Império Romano vieram abaixo, foi na igreja onde se depositaram as fontes primárias, documentos e as espécies de arte dessa cultura antiga, incluindo a retórica (REBOUL, 2004, p.77).

\footnotetext{
${ }^{23}$ Há diversas referências sobre a data de nascimento e morte de Cassiodoro: 490-581,490-575 e 477-570.

${ }^{24}$ Citação igualmente encontrada no capítulo de livro: Da retórica medieval da Profa. Dra. Maria do Amparo Tavares Maleval (MALEVAL, 2008, p.7).
} 
Com a finalidade de disseminar a transmissão desses novos métodos pedagógicos, as autoridades eclesiásticas revisaram os conteúdos de diversos escritos, tratados e manuais, os quais, segundo eles, continham algumas heresias. Dessa forma, poderiam orientar melhor a formação dos catequizadores e dos catequizados (HERNÁNDEZ GUERREIRO; GARCIA, 2000, p.72).

Posterior a esse processo de sistematização, originou-se, por meio de testemunhos do uso das figuras retóricas, a partir de nomes notáveis como São Ciriano de Catargo, Basílio de Cesarea, Minúcio Félix, entre outros, um sermão padronizado, tendo como tópicos e disciplinas fundamentais: o ponto de vista jurídico-dialético, a eloquência combativa e a apologética, influenciando, assim, os doutrinadores retóricos do medievo e da renascença (HERNÁNDEZ GUERREIRO; GARCIA, 2000, p.73).

\subsubsection{O ensino e estudo das artes liberais}

Outro fator de transformação surgiu com a instituição da Universidade, onde o saber retórico se torna público. Nesse momento, a disciplina foi colocada ao lado da gramática e da dialética, formando, assim, a divisão das sete artes liberais, a qual abrangia Trivium (Gramática, Retórica e Dialética) que, junto com o Quadrivium (Aritmética, Geometria, Música e Astronomia), constituiu a base acadêmica da educação universitária durante aproximadamente dez séculos. Assim a retórica deixou de ser uma disciplina hermética reservada só para alguns interessados e passou a ser um pilar da educação (BERISTÁIN, 1995, p.424).

Sabe-se, por exemplo, que tanto o Trivium quanto o Quadrivium foram partes essenciais para a consolidação do currículo dos cursos introdutórios (studium generale) das instituições superiores de ensino, sobretudo nas faculdades de artes (principalmente filosofia). De igual maneira, seu estabelecimento teve por parâmetro a obra de Marciano Capela (século V), intitulada As núpcias de Mercúrio e da Filologia (ca.410-427), a qual é 
considerada uma espécie de síntese enciclopédica do saber e da ciência da época ${ }^{25}$ (JAPIASSÚ; MARCONDES, 2001, p.263).

Nesse sentido, o ensino e o estudo das sete artes liberais, durante essa época, convergiram-se com aquilo que Santo Agostinho referencia em sua Doutrina Cristã, na pertinência de se agregar, numa mesma obra, os conhecimentos essenciais para uma hermenêutica não só das sagradas escrituras, mas, do mesmo modo, para o entendimento relativo à história, geografia, dos animais, plantas, metais, medicina, navegação, astronomia, aritmética e seu uso nas figuras (geometria), aos sons (música) e aos movimentos (física). E, por fim, a dialética que é fundamental para a discussão de questões relativas àquilo que os textos sagrados colocam como eloquência posta ao serviço da salvação (AGOSTINHO, 2002, [397- ca.427], Livro-II, Capítulos-XVII-XLIII, §§,24-63, pp.111-148, passim).

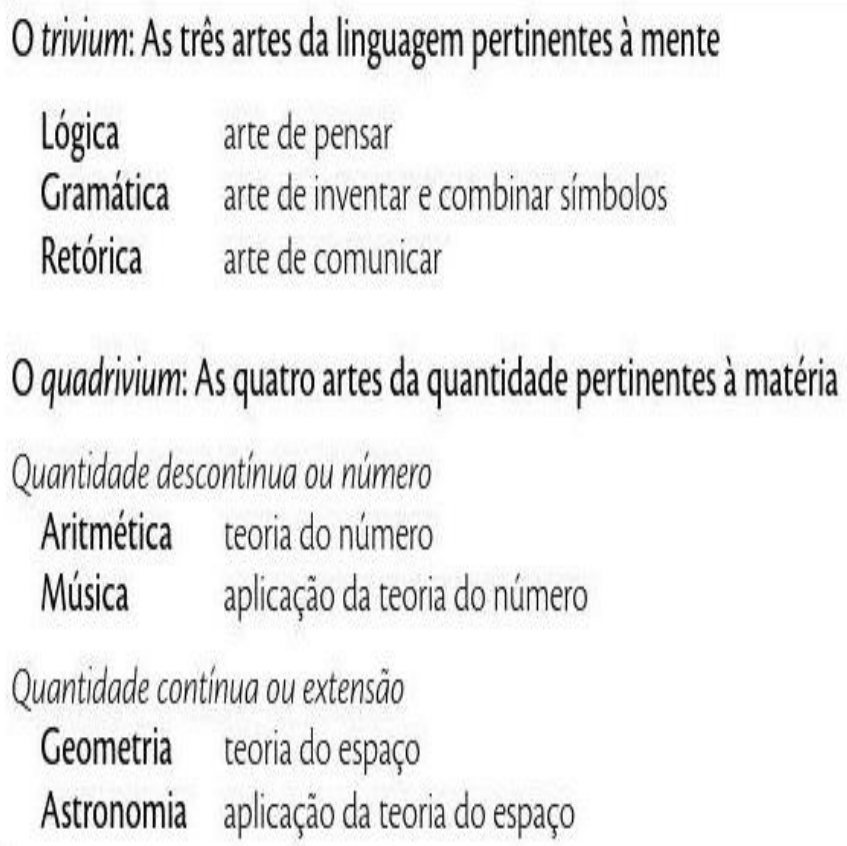

Figura 7-As Sete Artes Liberais: Trivium e Quadrivium (JOSEPH, 2008, p.27).

\footnotetext{
${ }^{25}$ Mário Alighiero Manacorda (1914-2013) enfatiza que Boécio (470-525) pode ser considerado como o primeiro a chamar de Quadrivium as quatro disciplinas hoje denominadas científicas. Já o termo Trivium foi empregado posteriormente. Destarte, o conjunto dessas disciplinas e sua ordenação nem sempre coincide entre os diversos autores (MANACORDA, 1997, p.126).
} 


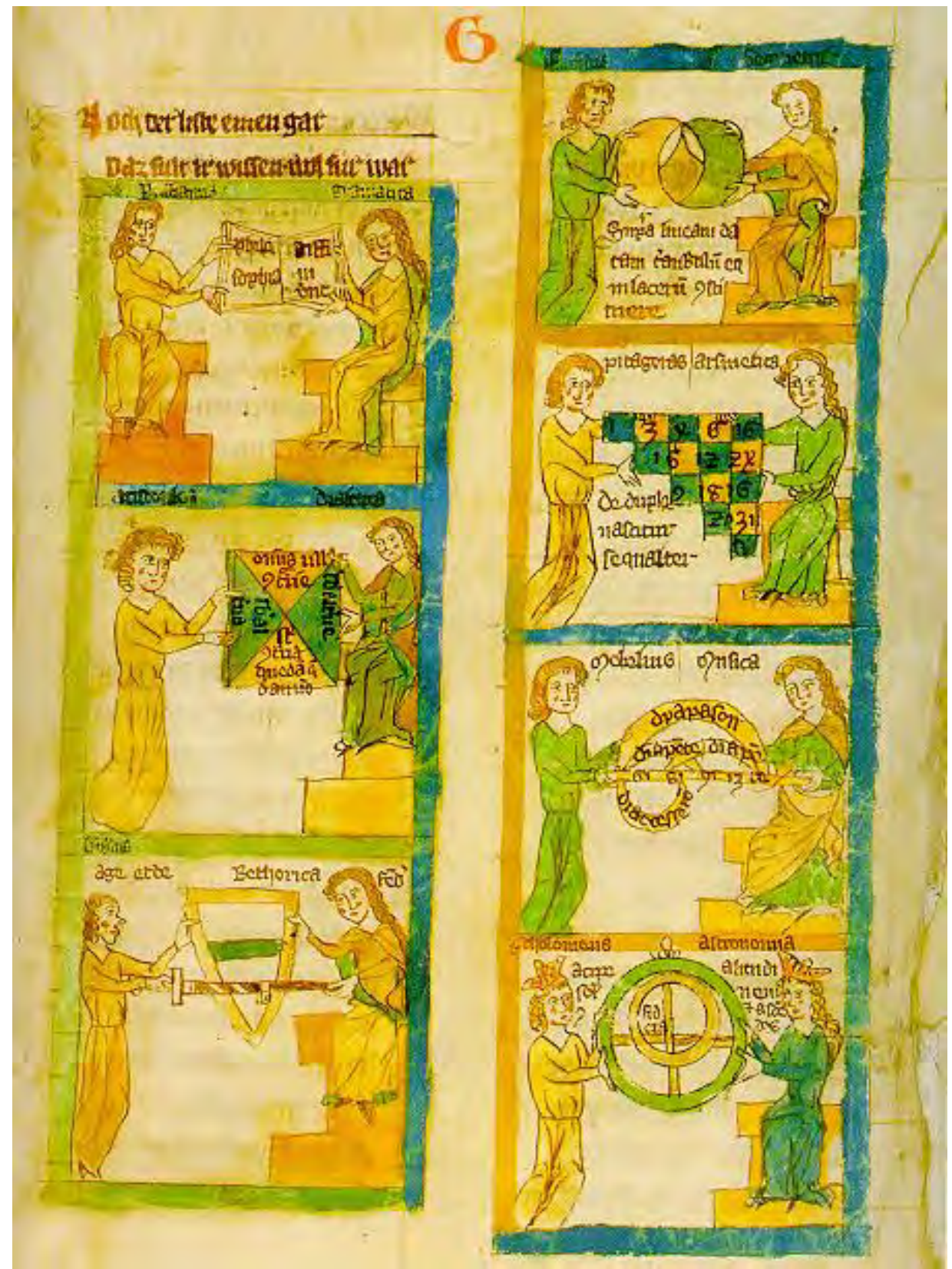

Figura 8-Iluminura medieval de autor desconhecido (século XIV) das Artes Liberaisexistente na Cambridge University Library ${ }^{26}$.

Enfim, o padrão instituído por intermédio da teorização sistêmica das artes liberais e sua transmissão influiu diversos tratadistas de retórica, posteriores ao século VIII, tais como Alcuíno de lorque (ca. 735-804), Rabano Mauro (ca.780-856), Monge Alberico de Monte Cassino (1030-1088), Mateo de

\footnotetext{
${ }^{26}$ Disponível em:<http://www.er.uqam.ca/nobel//r14310/Ptolemy//mages/Zerclaere/lnconnu.jpg>. Acessado em: 26 de Março de 2015.
} 
Vendôme (ca.1100-1185), Juan de Garlandia (ca. 1180-1252) ${ }^{27}$, Gervasio de Melkle (1185-1219), Godofredo de Vinsauf (ca.1195-?), Martín de Córdoba (ca. 1270 - ca. 1350), Roberto de Basevorn (século XIV), entre outros.

\subsubsection{O florescimento da retórica}

Entre o florescimento da Idade Média até o Renascimento, a retórica foi a base da articulação da Escolástica ${ }^{28}$ e, através dessa, a filosofia continuou ligada à religião, uma vez que são as questões teológicas que suscitam a discussão filosófica (SOARES, 2012, p.45).

Tal discussão é descrita por Danilo Marcondes (2001) como um momento de compartilhamento e aceitação de certos princípios doutrinários comuns, análogos a assuntos concernentes aos dogmas do cristianismo. $O$ desenvolvimento do pensamento escolástico deu-se principalmente pelo estabelecimento do ensinamento das sete artes liberais (MARCONDES, 2001, p.114).

Adicionado a isso, com a proximidade do Humanismo, a retórica aparecerá intimamente unida ao estudo da poesia e da filosofia, assim passando a exercer papel preponderante na formação acadêmica e intelectual, a partir do Renascimento (HERNÁNDEZ GUERREIRO; GARCIA, 2000, p.90).

\subsubsection{O Humanismo Italiano e os primórdios do Barroco}

A Retórica que, durante a Idade Média, tinha que compartilhar as atenções juntamente com a Gramática e a Dialética, alcançou grande preponderância entre os séculos XV e XVIII, tanto no âmbito do ensino quanto na cultura. Tal auge teve início na Itália e se expandiu em outros países europeus, para tanto, utilizou-se de um processo complexo que integra fenômenos diversos, entre os quais se destaca a recuperação de textos

\footnotetext{
${ }^{27}$ Foi um filologista e professor universitário do século XIII, de origem inglesa. Não confundir com Johannes de Garlândia (1190-1272), musicólogo francês, o qual escreveu um tratado intitulado De musica mensurabili positio (ca.1240).

${ }^{28}$ Conjuntos de doutrinas filosóficas e teológicas desenvolvidas em escolas eclesiásticas e universidades da Europa entre os séculos IX e XVI. Caracteriza-se pela tentativa de conciliar a fé cristã com a razão, representada pelos princípios da filosofia clássica grega, em especial os ensinamentos de Platão e Aristóteles. Desenvolve-se a partir da filosofia patrística, que faz a primeira aproximação entre o cristianismo e uma forma racional de organizar a fé e seus princípios, baseada no platonismo.
} 
originais de autores latinos como Cícero e Quintiliano, no primeiro quartel do século XV (HERNÁNDEZ GUERREIRO; GARCIA, 2000, p.91).

A complexidade apresentada no estudo da retórica, durante o século $X V$, motivou a necessidade de uma sistematização que pudesse atender vários critérios: de um lado a relação entre o ensino da retórica no âmbito da sua obrigatoriedade e da prática oratória, tanto no campo civil como no eclesiástico, do outro, sua expansão na Itália, França, Espanha e nos países nórdicos. Por último, não se pode deixar de mencionar a inter-relação entre os âmbitos da oratória e da criação literária, além do desenvolvimento progressivo das fases retóricas da Inventio, Dispositio e, principalmente, da Elocutio (HERNÁNDEZ GUERREIRO; GARCIA, 2000, p.92).

Diante desses fatos, o Renascimento Italiano teve como propósito e finalidade principal recuperar os textos originais latinos e restabelecer o estilo ciceroniano.

Em virtude disso, através do incremento da cultura humanista do Renascimento, desde sempre aristocrática, várias disciplinas clássicas foram reguladoras, entre elas a oratória e a poética. Com a primeira ressurgiu a retórica como princípio construtor do discurso falado, com a segunda, reapareceram os princípios criadores do texto poético. Sendo que, por meio da poética, a terminologia e princípios retóricos estão presentes em toda a teoria literária, o que contribuiu para sua influência em outras artes (LÓPEZ CANO, 2000, p.24).

De fato, as artes, especialmente a música, desenvolveu sua própria teorização poética e, como consequência, a assimilação de palavras e princípios retóricos. Essa teorização na música pautada nos princípios retóricos passou por uma mudança de focalização, em outras palavras, a música revelada nas abstrações numéricas da musica theoretica, passou a ser vista e entendida por uma esfera antropológica propagada por elementos retóricos da música poética.

Analogamente, a partir do Renascimento foi alterado o enfoque e destaque do Quadrivium matemático para o Trivium linguístico. Contudo, na Itália, tal alteração só ocorreu nos princípios do Barroco. Dessa maneira, a composição musical era compreendida e captada esteticamente, ao invés de 
especulativamente. Destarte, ao mesmo tempo em que os escritores renascentistas e barrocos italianos estavam propensos a aderir às divisões bipartidas da musica theoretica (naturalis, speculativa) e musica practica (artificialis), alguns escritores luteranos germânicos começaram a promover uma terceira categoria, musica poetica ${ }^{29}$ (BARTEL, 1997, p.19).

Consequentemente, diversos autores passaram a usar a terminologia musica poetica, dentre os quais se destaca Nikolaus Listenius (1510-?), considerado o primeiro teórico musical a introduzir o conceito de retórica musical em seu tratado Música (1537). Já na época da Reforma e Contrarreforma, o cristianismo revitalizou a retórica como instrumento primordial da eloquência (LÓPEZ CANO, 2000, pp.24-25; BUELOW, 2001, p.261).

Bartel (1997) descreve esse fato como substancial para a constituição e formação da poética musical, a qual se deu principalmente por causa do aperfeiçoamento do próprio pensamento musical. Isso resultaria em um modelo pedagógico-teológico, ou seja, uma relação entre retórica e educação, sob uma perspectiva humanística, muito propagado por Martinho Lutero (1483-1546):

\begin{abstract}
Lutero já havia estabelecido a expressão do texto como uma das finalidades primárias da música: a música é mais poderosa quando unida com o Evangelho, por combinar a Palavra com Música, os dois presentes mais poderosos de Deus para a humanidade são forjados em uma força invencível. Enquanto o texto convence o intelecto, a música convence (persuade) as paixões. Além disso, a música é para ser utilizada tanto para expressar como para explicar o texto. Desse modo, assim como o sermão/pregação é a voz do Evangelho, igualmente a música é aquela que traz o texto à vida [grifos nossos] (BARTEL, 1997, p.22) ${ }^{30}$.
\end{abstract}

\footnotetext{
${ }^{29}$ George Buelow (2001) corrobora com a afirmação de Bartel salientando que "a música, que desde a antiguidade havia pertencido ao Quadrivium, juntamente com a aritmética, geometria e astronomia, isto é, disciplina matemática das sete artes liberais, começou a adotar valores teóricos para abarcar os novos estilos musicais de preocupação retórica. Embora a música tenha permanecido relacionada à matemática até o século XVIII, os teóricos europeus, principalmente os alemães, elevaram a composição musical à condição de uma ciência baseada na relação entre palavras e música" (BUELOW, 2001, p.261). Todavia, ao longo da tese observar-se-á que a utilização retórica seja nos tratados ou na música do final do século XVI e início do XIX, não foi totalmente objeto de aplicação de compositores e tratadistas germânicos, mas, sim, de outros países tais como: Itália, França, Portugal e até no Brasil Colonial.

${ }^{30}$ Luther had already established text expression as one of music's primary purposes: music is most powerful when united with the Gospel, for in combining the Word with music, God's two most powerful gifts to humanity are forged into one invincible force. I o While the text convinces the intellect, the music persuades the passions. Furthermore, music was to be used both to
} 
Por sua vez, Luís Morales expõe o surgimento da Contrarreforma como forma de defesa contra a Reforma Protestante. Igualmente, a estratégia da Igreja Católica Apostólica Romana em persuadir as pessoas, tendo como seu instrumento e voz os jesuítas:

\begin{abstract}
A Contrarreforma surgiu como defesa contra o Luteranismo, não só para rechaçá-lo, mas também, como uma alternativa para a grande massa, sem falar da manifestação contra a pressão material e psíquica da igreja e da aristocracia. Já a arte Barroca foi um meio de persuasão da igreja para reconverter a massa. Os jesuítas foram os encarregados de tal tarefa [grifos nossos] (MORALES, 1990, p.II) $)^{31}$
\end{abstract}

$\mathrm{E}$, assim, pleno desse caráter comunicativo, forjado nos instrumentos retóricos, o espírito persuasivo que se pretendeu imprimir na arte Barroca requereu profundo conhecimento da natureza e funcionamento dos afetos e paixões da alma. Uma vez mais, a retórica constituiu-se na disciplina que podia oferecer conhecimento pleno e mais ou menos sistematizado a esse respeito.

Esse fenômeno, ligado à forte tradição das poéticas artísticas, iniciadas no século $X V I$, foi inevitável para que princípios e mecanismos próprios da retórica fossem assimilados pela arte. Efetivamente, se um dos objetivos da arte Barroca era a persuasão, os artistas aspiravam imprimir em suas obras a eloquência e o mover dos afetos dos próprios oradores. Nikolaus Harnoncourt afirma que "a retórica, como um todo e sua complexa termologia era uma disciplina ensinada em todas as escolas e formada, em parte, igual à música e cultura geral" (apud LÓPEZ CANO, 2000, p.27).

express and to explain the text. Just as the sermon is the "living voice of the Gospel," so too is music to "bring the text to life".

${ }^{31}$ Tal citação, igualmente é localizada no livro Música y Retórica en el Barroco de Rubén López Cano (LÓPEZ CANO, 2000, p.25). 


\section{RETÓRICA E MÚSICA}




\section{RETÓRICA E MÚSICA}

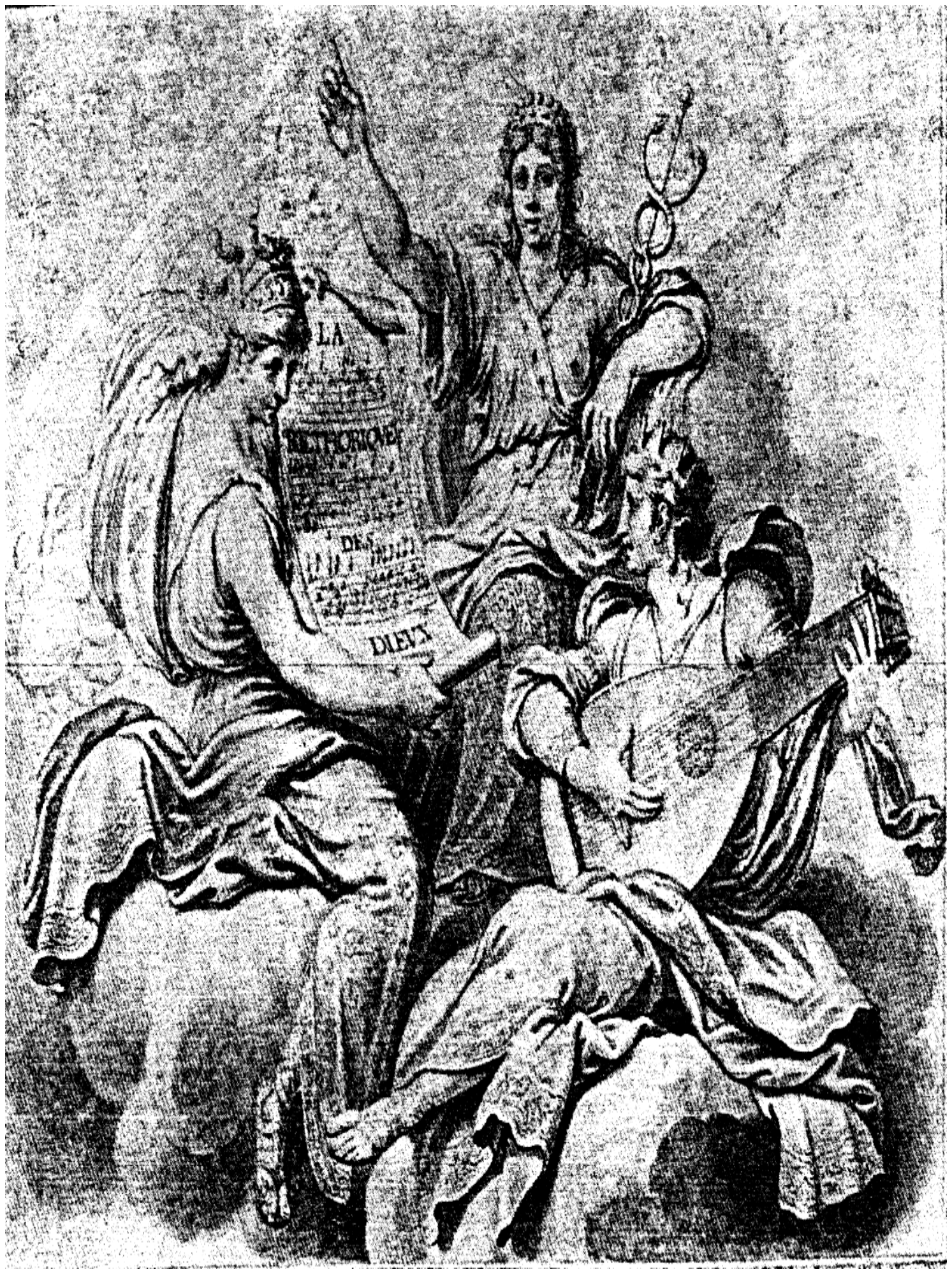

Figura 9-A Eloquência entre a Música e a Harmonia (1652) ${ }^{32}$.

\footnotetext{
${ }^{32}$ Observa-se nessa imagem de Eustache Le Sueur (1616-1655), três personagens alegóricas representando a música, retórica e a harmonia (apud, LUCAS, 2010).
} 
Na história da civilização ocidental, a música também se desenvolveu por considerável tempo, no âmbito vocal, ligada às palavras. As relações entre retórica e música foram, assim, desde a Antiguidade, bastante estreitas. No Barroco, essa relação chegou a um ponto sofisticado de aplicação. Aqui as influências dos princípios básicos da retórica afetaram profundamente os elementos mais íntimos da linguagem musical. Entretanto, as inter-relações entre música e as artes (artes dicendi), gramática, retórica e dialética são, ao mesmo, tempo óbvias e confusas para que se possa compreendê-las. Os compositores eram influenciados por doutrinas retóricas que governavam a adequação dos textos e da música e, também, depois do crescimento da música instrumental independente, os princípios retóricos continuaram a ser empregados por algum tempo não só na música vocal, mas, de igual modo, na música instrumental.

A partir do princípio do século XIX, os músicos e estudiosos "modernos" não estavam tão interessados nas disciplinas retóricas. Somente no início do século XX os pesquisadores e historiadores da música redescobriram a relevância da retórica como a base de conceitos teóricos e estéticos da música anterior $^{33}$ (BUELOW, 2001, p.260).

É imprescindível ainda reiterar em parte, e acrescentar na área musical, que todos os conceitos musicais relacionados à retórica procedem de extensa literatura sobre oratória e retórica dos antigos escritores gregos e romanos, especialmente Aristóteles, Cícero e Quintiliano. O redescobrimento, em 1416, do Institutio Oratoria proporcionou uma das fontes primárias sobre o qual se baseou a nascente união entre retórica e música no século XVI.

Quintiliano, assim como Aristóteles, havia enfatizado as similitudes entre a música e a oratória. O objetivo e a finalidade de sua obra e de todos os outros estudos da oratória, desde a Antiguidade, eram as mesmas: instruir e orientar o orador sobre os meios para controlar e dirigir as respostas emocionais de sua audiência ou em que linguagem da retórica clássica e também de todos os tratados musicais posteriores, capacitar o orador (isto é

\footnotetext{
${ }^{33} \mathrm{Na}$ metade da década de 1960, a retórica passa a ser considerada como nova ferramenta de análise musical.
} 
decidir, sobre o compositor e intérprete) para mover os "afetos" (as emoções) de seus ouvintes (BUELOW, 2001, p.260).

\subsection{Os tratados sobre retórica e música poética}

Como já salientado anteriormente, em 1537, Listenius propõe em sua obra uma nova maneira de concepção da teoria musical, onde a denominação de musica poética é empregada a partir da dualidade de Boécio de musica theoretica e musica practica (BUELOW, 2001, p.261).

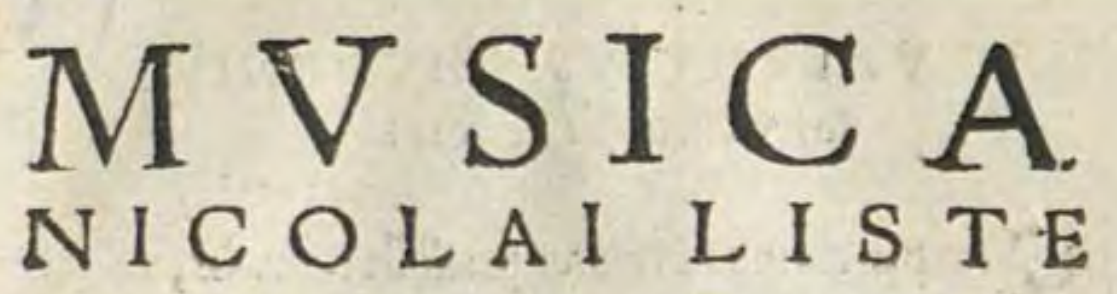

N I I, AB A V THOR E denuo recognita, multiśá nouis regulis \& exem = plis adaucta.

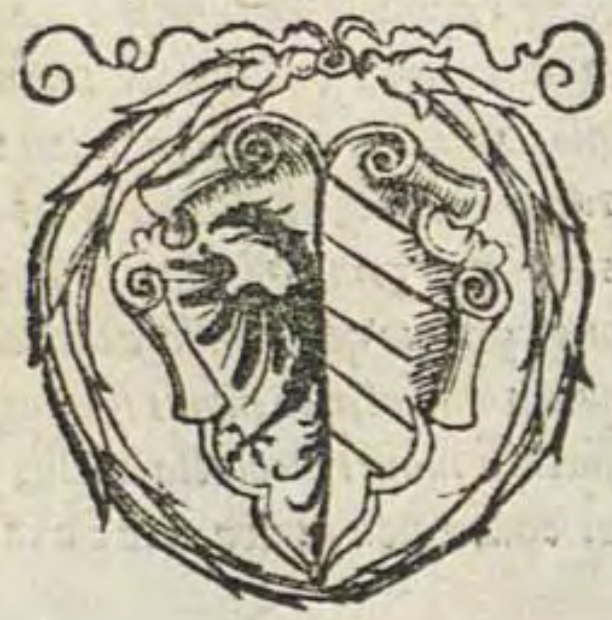

Norimberge apud lohan. Petreium. Anno $M_{2} D . X L 1$.

Figura 10-Frontispício do Tratado Musica de Nicolaus Listenius (LISTENIUS, 1541 [1537]). 
Posteriormente, a adaptação das técnicas retóricas e gramaticais para a produção e teorização musical contará com a contribuição de Heinrich Faber (1500-1552), com duas obras: Musica Poetica (1548) e Compendiolum Musicae (1548) (PAIXÃO, 2008, p.31).

$\mathrm{Na}$ mesma época, igualmente pode ser ressaltado o tratado L'antica musica ridotta alla moderna prattica, de Nicola Vicentino (1511-1576). Entre os capítulos 11 a 42 do livro- I, o autor destaca o direcionamento dos afetos associados com a relação intervalar das notas.

De modo semelhante, o Le Istitutioni Harmoniche (1558), de Gioseffo Zarlino (1517-1590), que mesmo não enunciando a terminologia musica poetica é possível localizar as relações entre retórica, gramática e poesia. Para melhor exemplificação, Buelow (2001) salienta que as estruturas retóricas podem ser examinadas em teorias musicais de diferentes regiões:

\begin{abstract}
A estrutura retórica, entretanto, não se limitou à teoria musical alemã. Mersenne, por exemplo, enfatizou, em sua Harmonie Universelle (1636-1637), que músicos eram oradores que deveriam compor melodias como se estas fossem orações dotadas de todas as seções, divisões e períodos apropriados a uma oração. Kircher, escrevendo em Roma, deu o título de Musurgia Rhetorica a uma parte da sua extremamente influenciadora enciclopédia de teoria e prática musical, Musurgia Universalis (1650), na qual também enfatizou a analogia entre retórica e música nas usuais divisões do processo criativo na Inventio, Dispositio e Elocutio (BUELOW, 2001, p.262).
\end{abstract}

Enfim, nessa obra, examina-se que Zarlino empresta o vocabulário ciceroniano de sonus (euforia e suavidade da fala) e numerus (discurso bem estruturado), aplicando-as a um conceito da eloquência, pureza estilística e contenção para evitar erros contrapontísticos, divisões excessivas, cromatismo como agente de não clarificação modal e o uso indiscreto da voz, gesto e aspereza, buscando um estilo elevado, caraterizado pela beleza e seriedade (BUELOW, 2001, p.262). 


\section{E I S T I T V T I O N I HARMONICHE}

DI M. GIOSEFFO ZARLINO DA CHIOGGIA,

Nelle quali; olera te materie appartenenti

A L L A M S I C A ,

Si trouano dichiarari molet luoghi

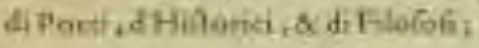

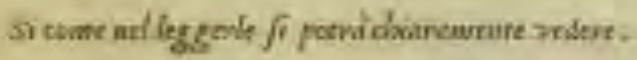

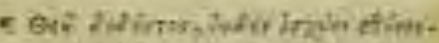

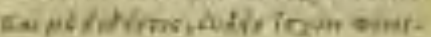

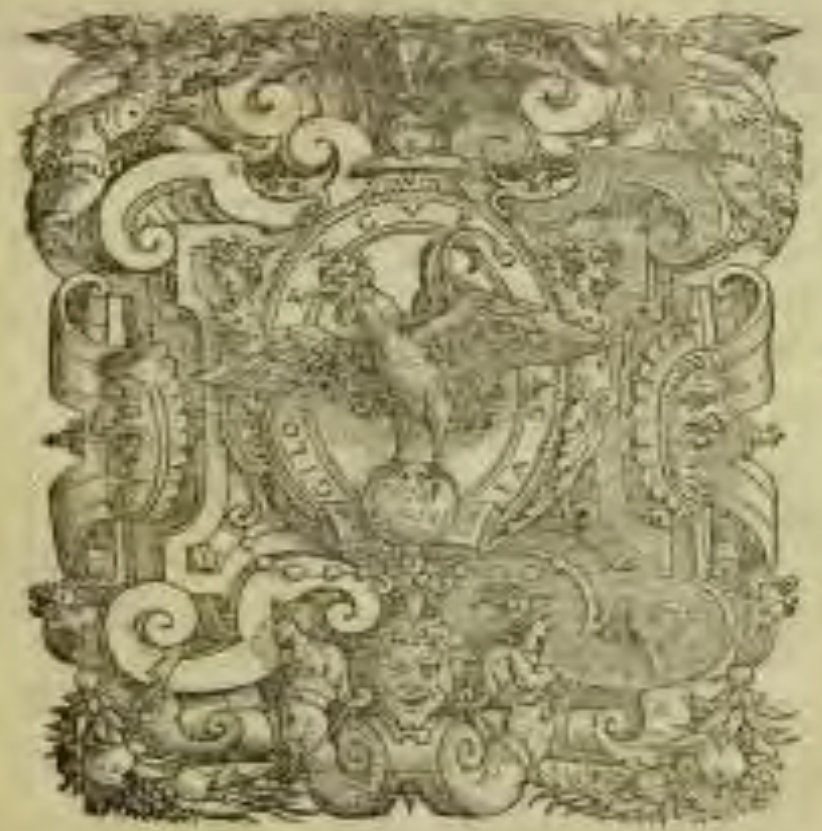

Con Priuilegio dellillufterils. Signoria di Veneria, per anni $\mathrm{X}$.

IN VENETIA M D LVIII.

Figura 11-Frontispício da Le Institutioni Harmoniche de Gioseffo Zarlino (1558).

Já, em 1563, Gallus Dressler (1533-1589), em um manuscrito intitulado Praecepta Musicæ Poeticæ, desenvolveu uma forma de música que iria tomar as divisões em um discurso Exordium (Introdução/Ouverture), Medium 
(Médio/Meio) e Finis (Final) (BUELOW, 1980, p. 794; VICKERS, 1984, p.16; BEULOW, 2001, p.261).

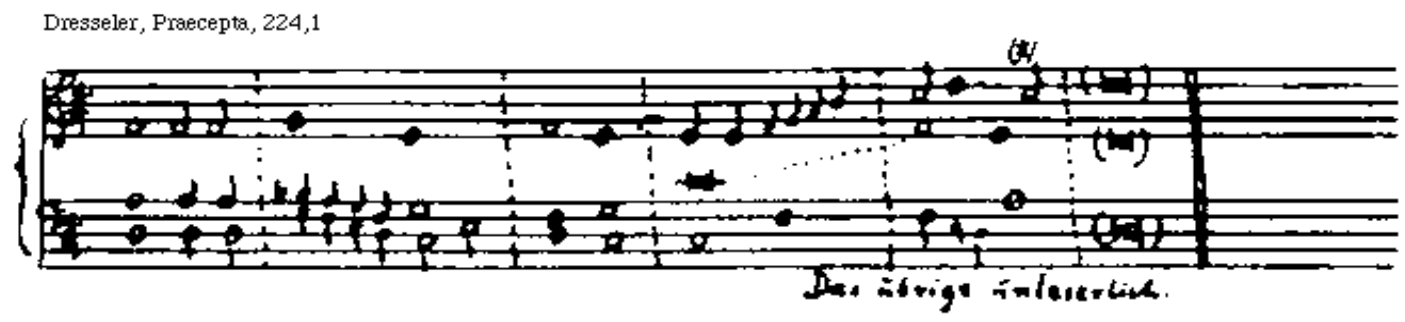

Dresseler, Praecepta, 224,2

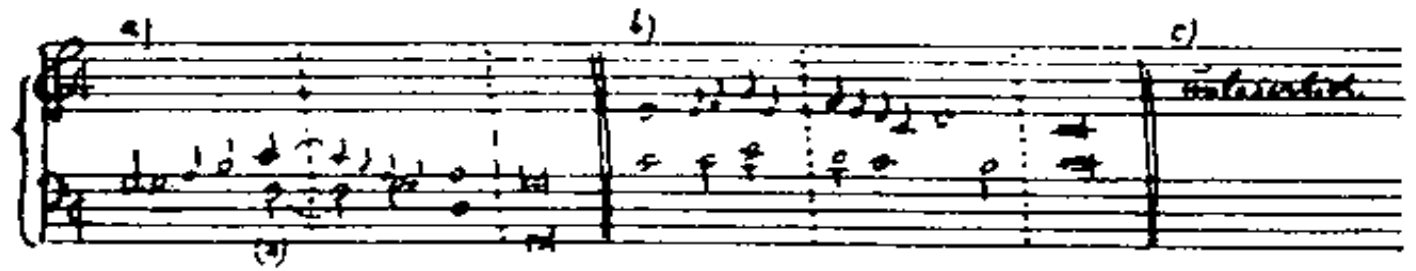

Dresseler, Praecepta, 225

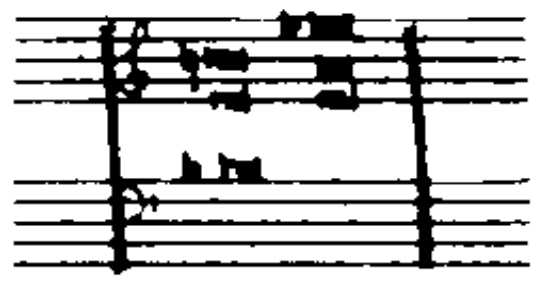

Figura 12-Trechos do Praecepta Musicæ Poeticæ de Gallus Dressler (1563).

Posteriormente, Joachim Burmeister (1564-1629) publicou uma sequência de três tratados musicais, os quais são considerados como base da sistematização retórico-musical (BUELOW, 2001, p.260):

1. Hypomnematum musicæ poeticæ (1599) é exposto num total de quatorze capítulos, onde são tratados assuntos concernentes às notações, vozes, consonâncias, dissonâncias, modos, cadências, transposições, aplicações textuais, ortografia, conclusões ou resoluções, tipos de harmonias e polifonias. 
Hypomnematum Musicae Poeticae

- lettre dédicatoire, lettres des collègues, poèmes liminaires.

- Chapitres : I, de Characterismo; II, de vocibus; III, de doctrina consonantiarum et dissonantiarum; IV, de concordantiarum syntaxi; V, de soloecismis; VI, de modis ; VIII, de clausulis ; IX, de transpositione; $X$, de applicatione textus; XI, de orthographia ; XII, de ornamentis; XIII, de fine; XIV, de harmoniarum generibus et antiphonorum.

N.B. : la numérotation des chapitres n'est pas suivie; chaque chapitre commence par les termes "ex capite" ("tiré du chapitre"), ce qui renforce l'idée que Burmeister abrège la matière dense de ce qu'il appelle son "Isagoge" qui ne fut jamais publiée. Les "roues" de Burmeister sont intégrées au chapitre VI sur les modes.

- Quelques jugements d'hommes célèbres sur la musique (Luther, Plutarque notamment).

Figura 13-Estrutura dos Capítulos do Hypommenmatum Musicæ Poeticæ de Joachim Burmeister (BURMEISTER, 2007 [1599], p.10).

2. Musica autoschédiastikè (1601) destaca os ornamentos já expostos no capítulo XII do tratado anterior, além de apresentar definições e exemplos das figuras retórico-musicais.

\section{Musica autoschédiastikè \\ - lettre dédicatoire, poèmes liminaires. \\ - reprise de l'Hypomnematum Musicae Poeticae jusqu'au chapitre XII sur les orne- ments (inclus). \\ - Ornamenta sive figurae musicae, proba- tissimorum artificum exemplis ad contex- tum notarum exaratis, illustratae.}

- Les Ornements ou Figures musicales, illustrés par les exemples des auteurs les plus approuvés, travaillés selon un contexte de notes. N.B. : cette liste est ajoutée à la précédente.

Figura 14-Parte da Elaboração Estrutural da Musica Autoschédiastiké de Joachim Burmeister (BURMEISTER, 2007 [1599], p.10). 
3. Musica Poetica (1606) apresenta um regime semelhante ao de Dressler, todavia, com maior detalhamento das estruturas harmônicas, contraponto e exemplos de figuras retórico-musicais.

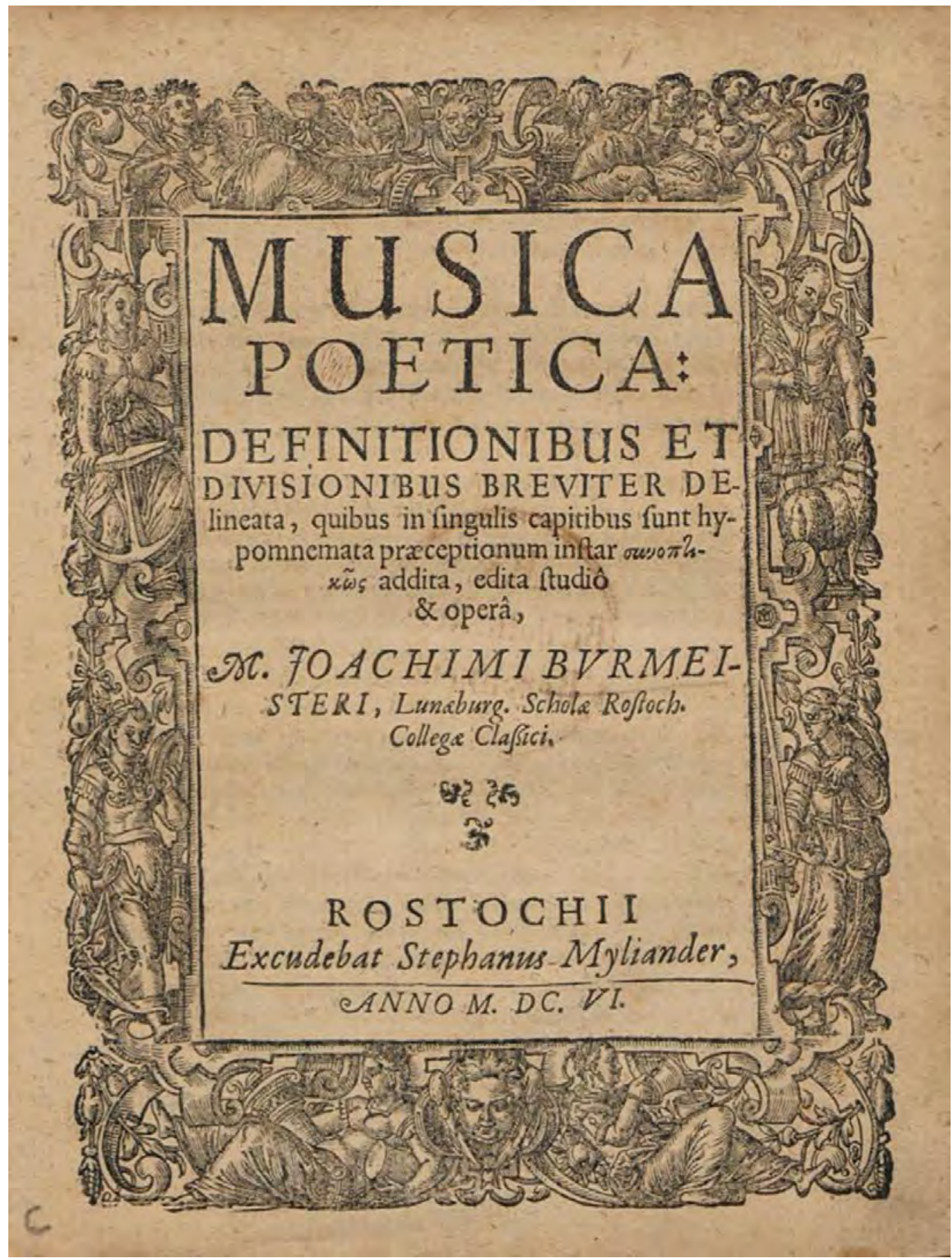

Figura 15-Frontispício de Musica Poetica de Joachim Burmeister (1606) ${ }^{34}$.

\footnotetext{
${ }^{34}$ Disponível em:<http://www.musicologie.org/Biographies/b/burmeister_joachim.html>Acessado em: 18 de Abril de 2015.
} 
Abaixo, nota-se a indicação de Burmeister da figura retórica de repetição melódica Palilogia.

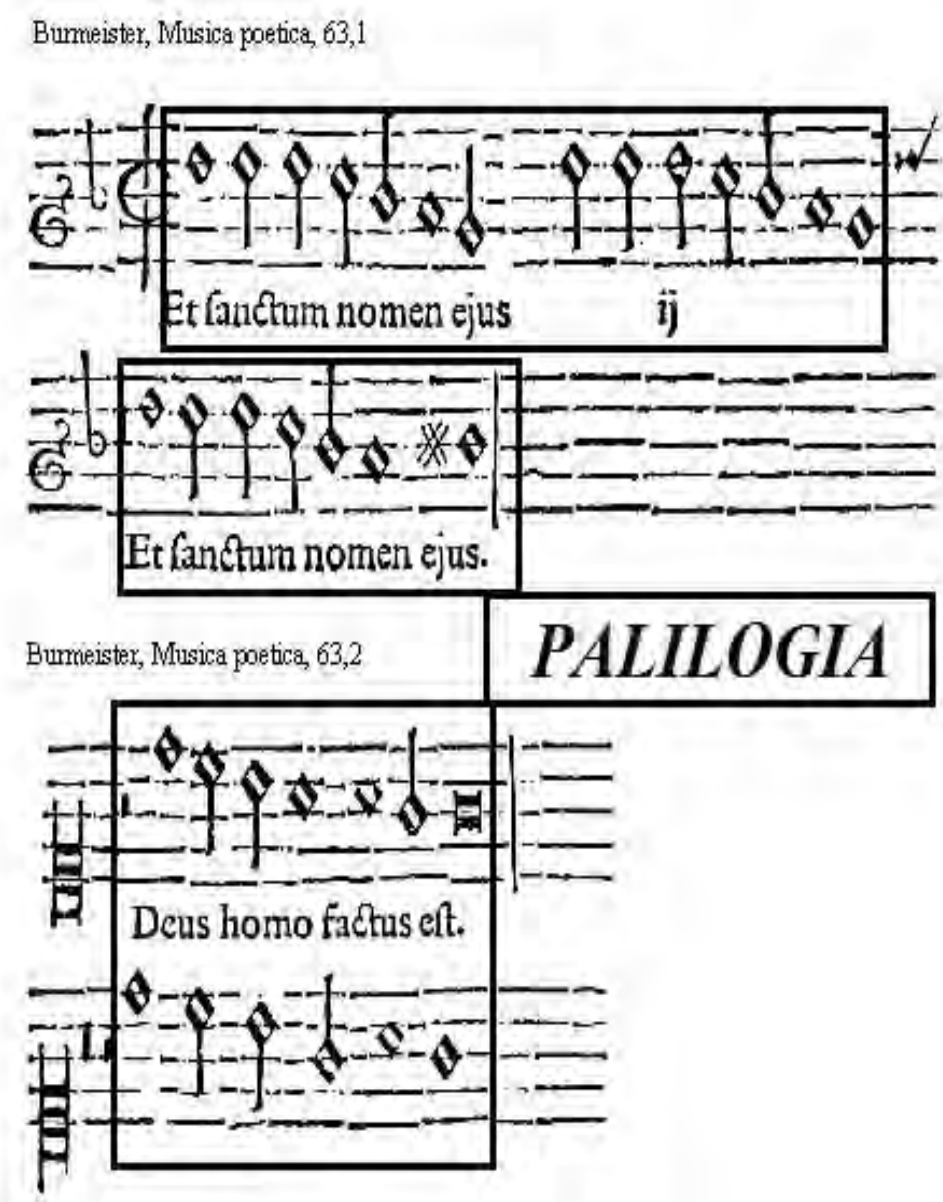

Figura 16-Indicação da Palilogia por Joachim Burmeister (1955 [1606], p.63).

Portanto, tanto em Dressler quanto em Burmeister, os escritos da terminologia retórica são levados ao ponto de definir a estrutura de uma composição, uma abordagem que permanecerá válida até bem dentro do século XVIII (BUELOW, 2001, p.261).

Outro tratado a ser realçado é a Sinopse Musicæ Nova (1612), de Johannes Lippius (1585-1612), o qual descreve a doutrina retórica não somente como o fundamento para uma adaptação efetiva e eficaz da música relacionada às palavras, mas, igualmente, para a base da forma ou estrutura da composição (BUELOW, 1980, p.793). 


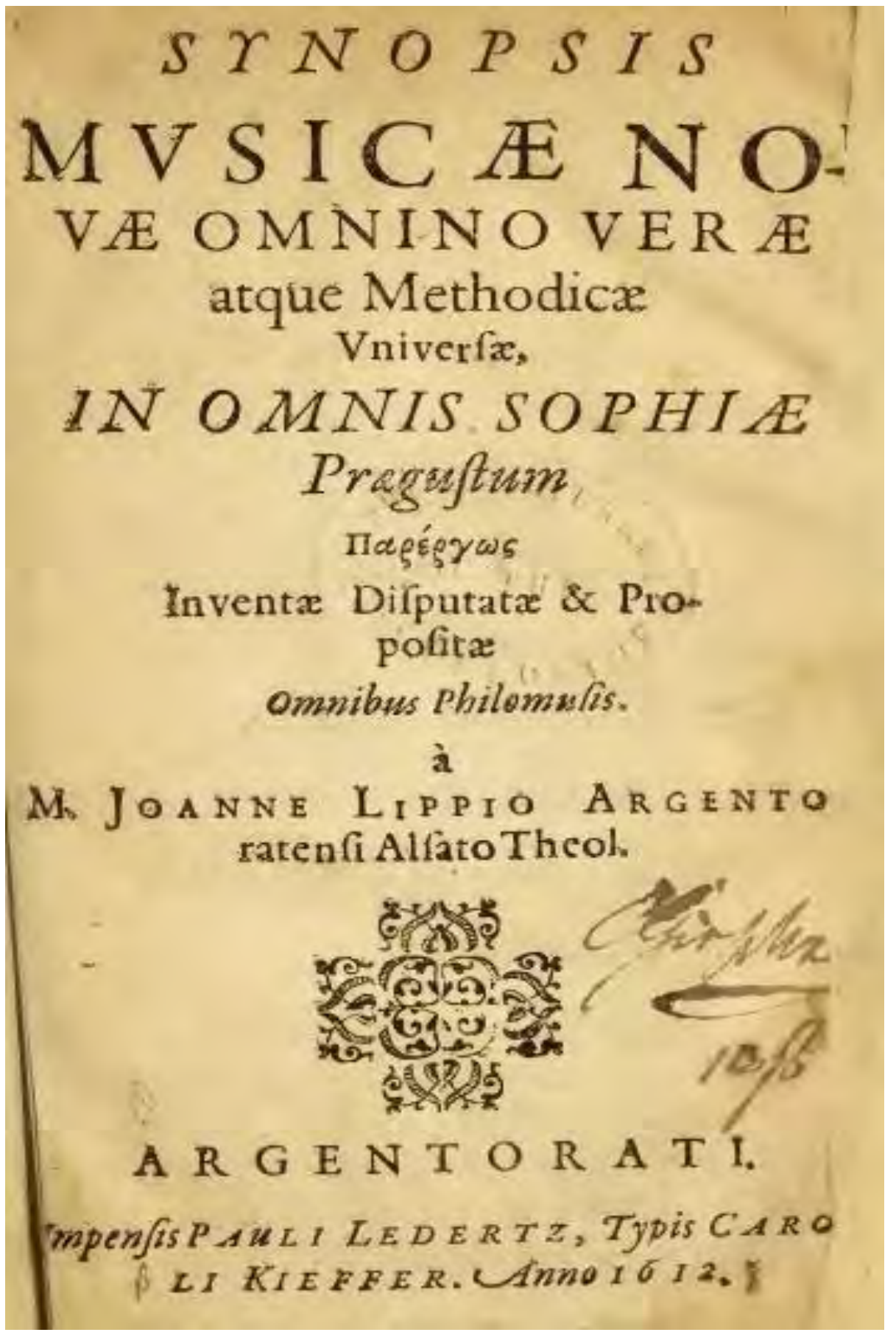

Figura 17-Frontispício da Sinopse Musicæ Nova de Johannes Lippius (1612).

Já Musices Poeticæ (1613), de Johannes Nucius (1556-1620), desempenha um papel relevante na promoção do conceito das figuras retóricomusicais. Enquanto a classificação de Burmeister enfatizava as figuras relacionadas às estruturas harmônicas e melódicas, o tratado de Nucius introduz duas categorias com base no conteúdo e função das próprias figuras musicais. Ou seja, é feita distinção entre as figuras musicais que são 
essencialmente dispositivos técnicos musicais $e$ as que estão mais intimamente ligadas ao texto e afeto, expressas nas figuras retóricas (BARTEL, 1997, p.101).

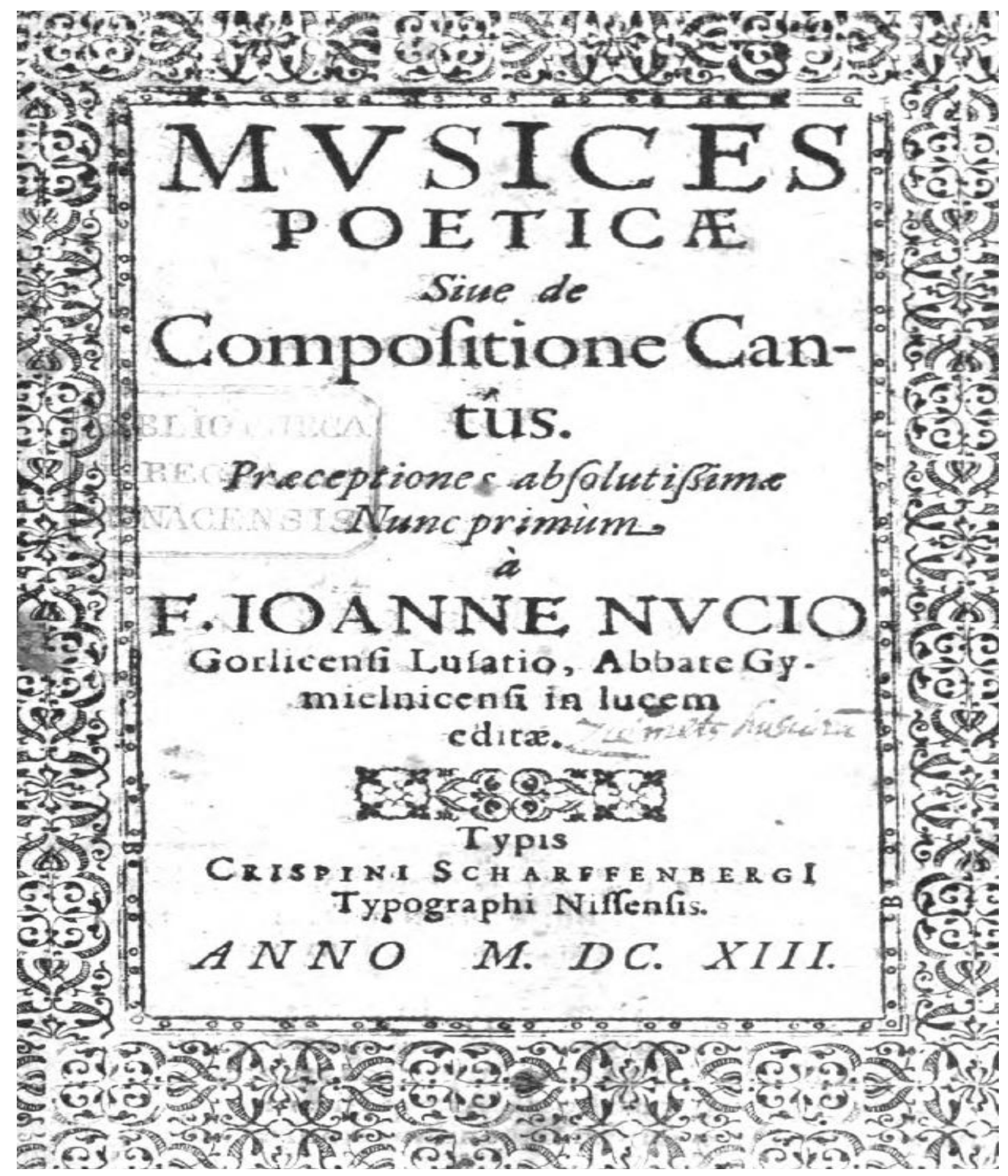

Figura 18-Frontispício de Musices Poeticæ de Johannes Nucius (1613).

Na mesma década, o Compendium Musicæ (1618) de René Descartes (1596-1650) assevera sobre as características dos sons graves e agudos, das consonâncias, das relações de intervalos de $3^{a}, 4^{a}, 5^{a}, 6^{a}$ e $8^{a}$, das dissonâncias, dos graus e seus respectivos tons, dos modos e também dos afetos. Sendo que esse último aspecto resultaria em sua obra Les Passions de 
l'âme (1649), a qual buscaria explicar de forma racional a natureza fisiológica das paixões e a natureza objetiva da emoção (BUELOW, 2001, p.269).

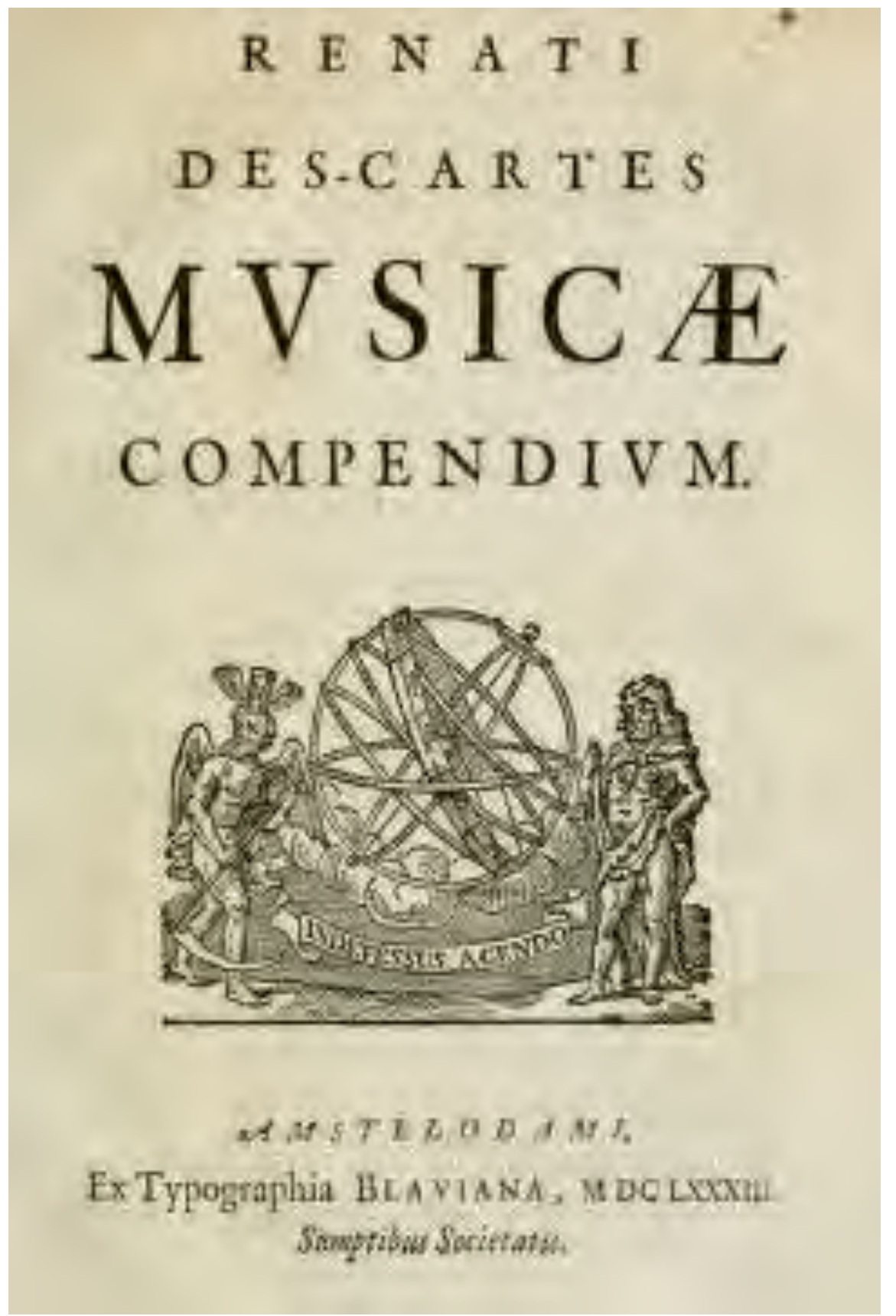

Figura 19-Frontispício do Compendium Musicæ de Rene Descartes (1618).

Por sua vez, Joachim Thuringus (nascido em finais do século $\mathrm{XVI}$ ), em seu Opusculum Bipartitum de Primordiis Musicis (1624), desenvolve e amplia as figuras retórico-musicais, anteriormente classificadas por Burmeister e Nucius (BARTEL, 1997, p.104). 


\section{OPUSCULUM BIPARTITUM \\ PRIMO R DIIS MVSICIS, \\ Quippe}

I. DE TONIS SIVEMODIS.

1I. DE COMPONENDI REGULIS,

UTRLMQUE

ex

Optimis tàm veterum quàm recentiorum Muficorumab?

Arufforibut fcriptis

ERUTUM,

\&

Facili jucunditate, jucundaọ́; facilitate Ju-

ventuti

Preparatume

a

JoACHIMO THURINGO, FûRSTENBERGA Mrgalburgico. Ұ̈S. Theol: \& L Lib. Art. Studiofo, \& P. L. C.
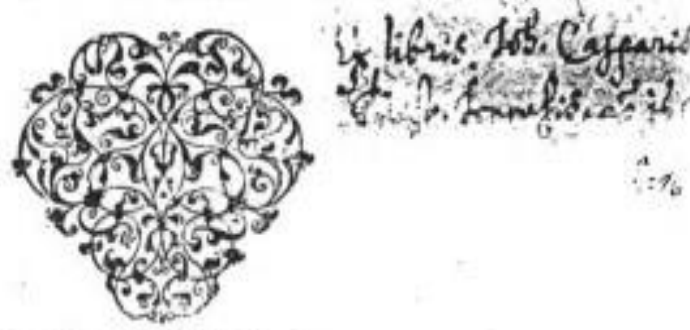

Cum Gratià \& Privilegio.

BLR OLIN1,

Typis Georgÿ Rungÿ, Impenfis ES Sumptibus Jobannis Kallÿ Bibliopo.

Is Berclinenfis, Anno M. DC. XXIV.

Figura 20-Frontispício do Opusculum Bipartitum de Primordiis Musicis de Joachim Thuringus (1624).

Observa-se, abaixo, as definições de Thuringus para as figuras retóricas da Anaphora, Catachresis, Noema, Pathopoeia, Parrhesia, Aposiopesis e Homioteleouton. 
ne6

Hujus fchematis multa funt exempla Mufica, ut, in Domine Dominus nofter. Orland, $\mathrm{Et}$ in $\mathrm{L}$ omine Dominus noSter. Nucij, \&c.

5. 2uidest Anapbora?

Eft folius Bafis aliquoties iteı ata repetitio. Exemp:AlleIuja in Angelus Domini 5. voc. Orl:

6. Quideft Catacbrefis?

Catachrefis feu Faux Rourcion eft, quando plures fexte \&.Tercix afcendendo fimul progrediuntur. In Magnificat Orlandi 6. voc. Omnia qua fecift : quia peccavimus ei. Item Conturbayerunt me: in In me tranfiertint.

7. 2uidest Noeme?

Eft colle ctio nudarum concordantiarum una vice fua. viflimè in Motetss prolata. Exempla in Orlando: Omnia qua fecifti nobis ad verbum Mifericordiam tuam. Item in In me tranfierunt, ad verbum, ne difcefscris à me. Item Congratulamini, adverba, furrexit ficut dixit.

8. 2uidest Parthopeian?

Eft, qux dictiones affectuum, doloris, gaudij, timoris, rifus, luctus, mifericordix, exultatiornis, tremoris, terroris, \& fimiles ita ornat, ut tam $C$ antores quam auditores moveato Exempla obvia funt.

\section{2uidest Parrhifice?}

Eft, cumMicontra Fa in quarta, quinta, vel feptimaita in contrapuncto inferatur, ue nullam difcordantiam pariat. 10. 2xid ef spoftopefis?

Ef univerfalefilentium in ommibus Cantilenx partibus. Et est duplex: Homioteleuton, \& Homixoptoton. 2uid est Homiotelenton??

Eft finale filentium in medio cantionis. Vel: cum poft communem vocum concurfum femibrevis aut minimx pau$f_{x}$ interventu generale filentium indicitur, ac harmonia interrum-

Figura 21-Definições de algumas figuras retórico-musicais por Joachim Thuringus (THURINGUS, 1624, p.126).

Ulteriormente, o tratadista francês Marin Mersenne (1588-1648), em seu Traité de I'Harmonie Universelle (1636-1637), ressalta que os compositores deveriam elaborar suas composições da mesma maneira como os oradores organizam seus discursos e suas estruturas (BUELOW, 1980, p.794). 


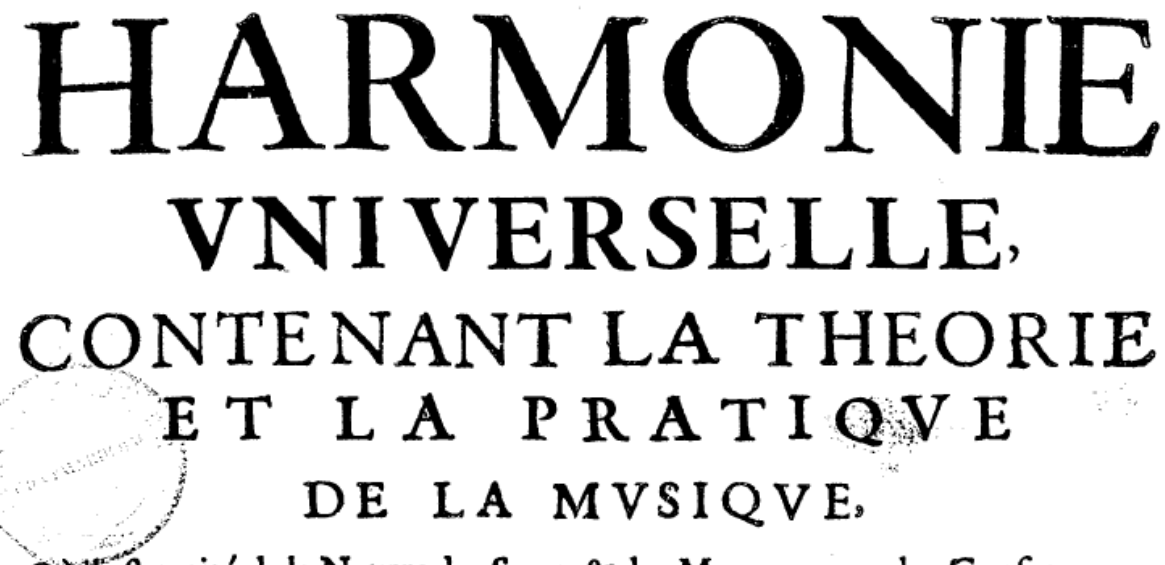

Oùillêt traité de la Nature des Sons, \& des Mouuemens, des Confonances, des Diffonances, des Genres, des Modes, de la Compofition, de la Voix, des Chants, \& de toutes fortes d'Inftrumens Harmoniques.

Par F. MARIN MERSENNE de l'Ordre des Minimes.

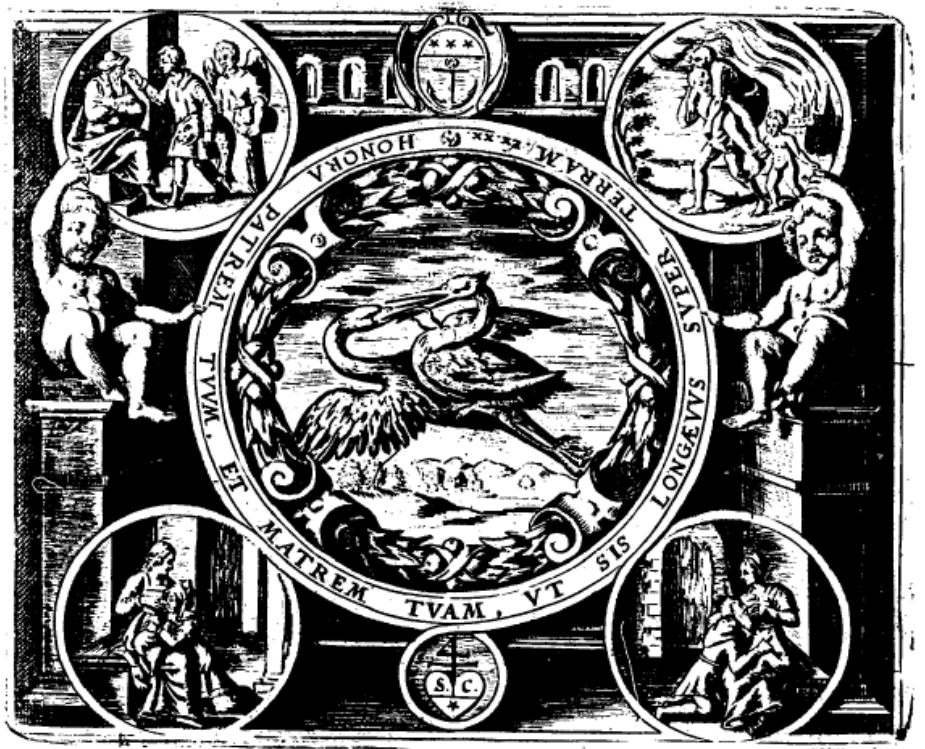

A $\mathrm{P}$ A R I S,

Chez Sabastien Cramoisy, Imprimeur ordinaire du Roy, ruë S. Iacques, aux Cicognes.

M. D C. X X XVI.

Anec Prinilege du Roy, or Approbation des Docteurs.

Figura 22-Frontispício do Traité de l' Harmonie Universelle de Marin Mersenne (1636-7).

Igualmente, há de se destacar os tratados Musica Poetica (1643) e Musica Moderna Prattica (1653), de Johann Andreas Herbst (1588-1666). 


\section{componiren ynd fergen foll. \\ VIII. Caput Octavum.}

De Exordio, Medio \& Fine Cantilenarum.

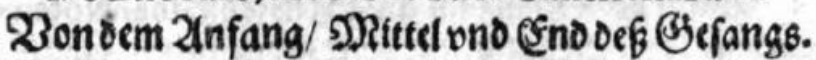

I. De Exordio Cantilenarum, Won oem 2lnfang.

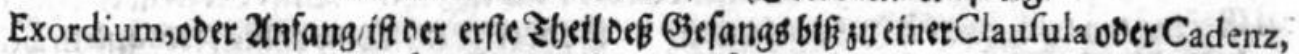
ba bean bie Stimmen tn ben perfect Concotdanten bufammen fommen/ vno lieblich rufen.

Woie mancherley ift das Exordium? Bweryerien:

Plenum vocibus \& Nudum. Dastf : WJolftimmig vno 2310 B.

Plenum vocibus, oder vollftimming if / meen alle Stimunen mit einanoer (es fer)n gleich) 4. 5. 6 7.8. voc.) auffetumal anfangen.

Nudum ooce blo eine nach oer andern in oer Dronung fortegeben.

Notio 1.

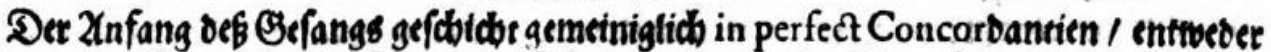
mit etnanter auff einmal sugleidh/ ooer burdb fugen. Exempla ubique funt obvia.

2.

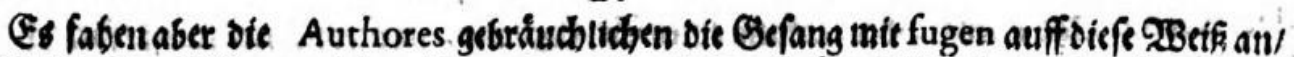
nemblitb daß Ber Difcant mit bem Tenor, Der Alc mit dem Bafs, mite einertery ineervallen in oer. Octav úbereintotmmen I vno aud) gemeiniglich in Claufulis formalibus fich enden vad sur Fub begeben/oarauff folge ein fletnes Exempel/oa oer Znfang ourdb eine fugen gemadbet if.
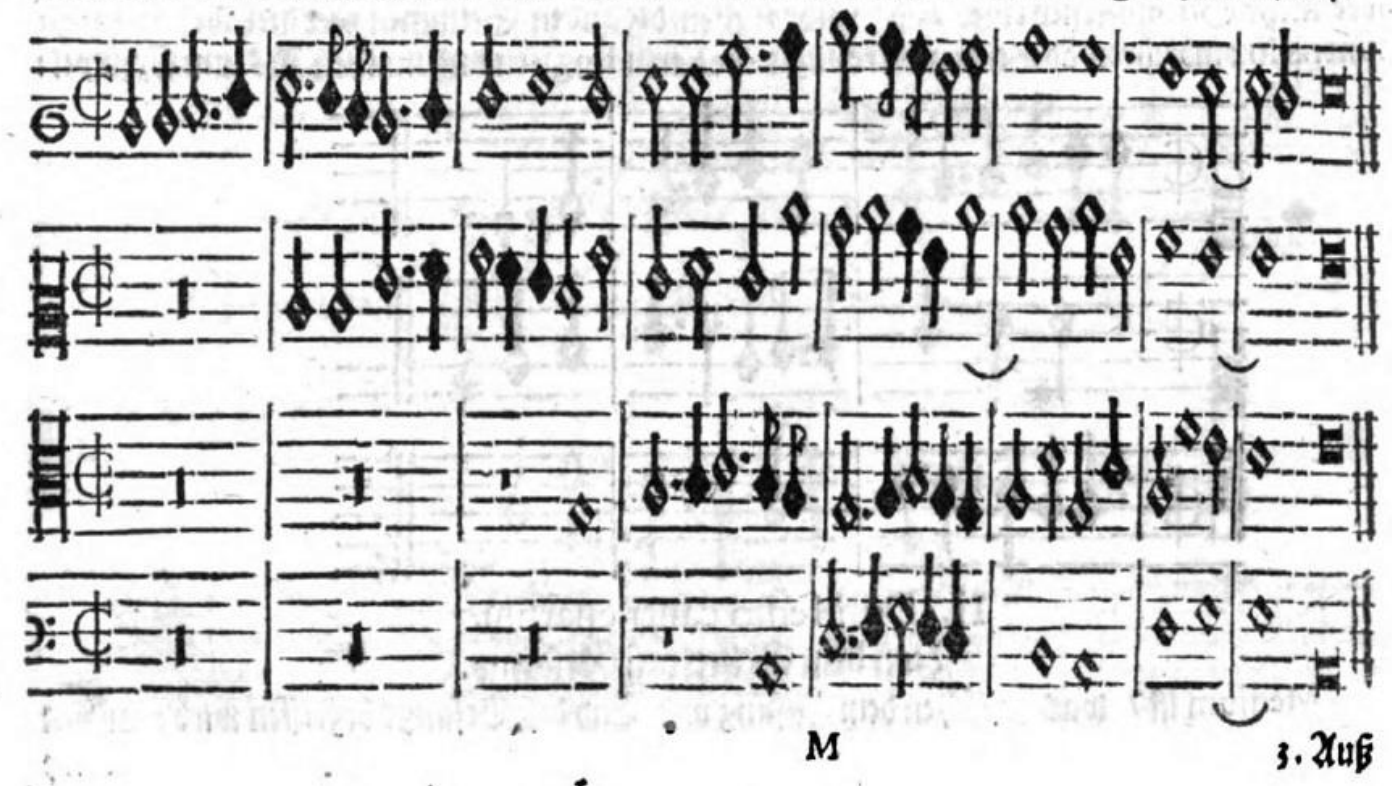

Figura 23-Exordio, Medio e Fine, segundo o Tratado Musica Poetica de Joahnn Andreas Herbst (1643, p.81).

Na mesma época, Athanasius Kircher (1601-1680), no seu tratado Musurgia Universalis (1650), dá ênfase às relações e analogias entre retórica e música, nas partes frequentemente usuais do processo criativo, na disposição do discurso musical (BUELOW, 2001, p.262). 


\section{ATHANASII KIRCHERI}

F VLDE-NSIS E SOC. I E S P PESBYTERI

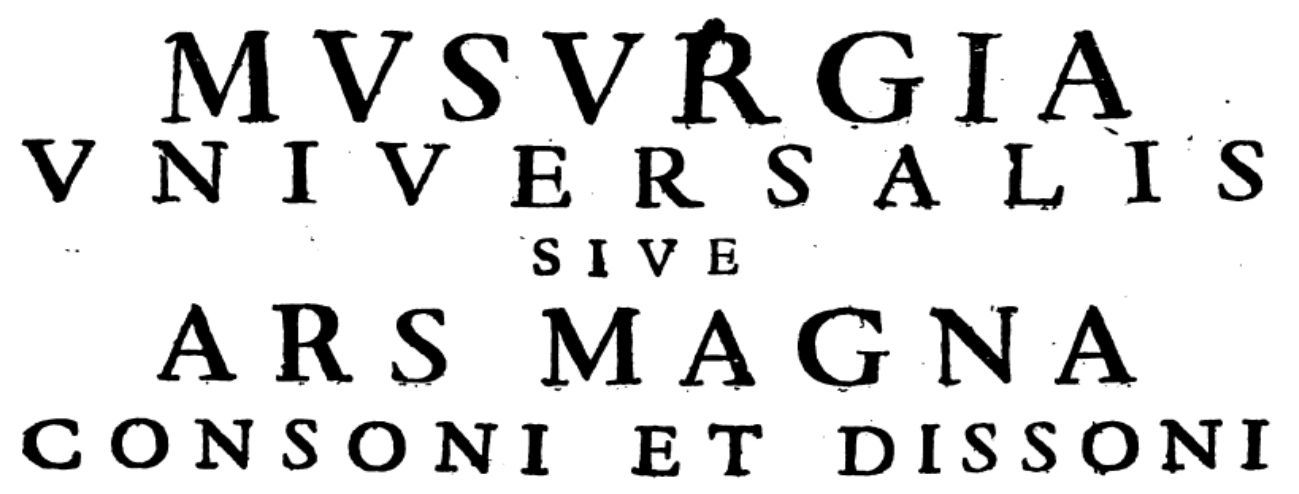

I N X. I I B R OS DI GESTA.

Quà Vniuerfa Sonorum dođrina,\& Philofophia, Muficxque tam Theoricx, quam practica Icientia, fumma variețate traditur ; admi sandæe Cosfoni, \& Diffoni in mundo,adeòque Vniuersà Naturà vires effectufque, vti noua, ita peregrina variorum fpeciminum exhibitione ad fingulat es vfus, tum in omnipoenè facultate, tum potifimùn in Philologià, Mathematicà, Phylịcà, Mechanicà, Medicinà, Politicà, Metaphyficà, Thęologià, aperiuntur \& demopftrantur.

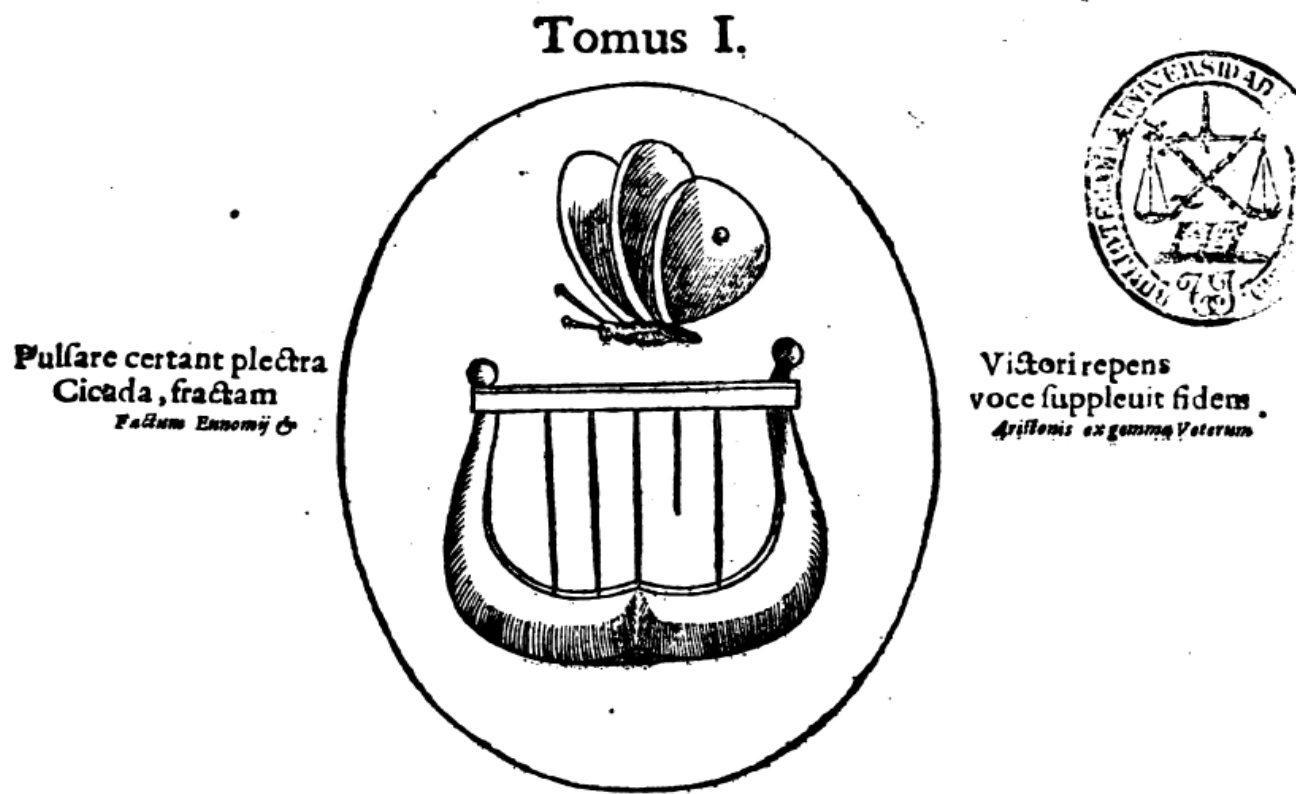

R OM AE, Ex Typographia Hxredum Prancifci Corbelletti. Anno Iubilxi, MDCL.

S V P E RIORVM PERMISSV.

Figura 24-Frontispício do Musurgia Universalis de Athanasius Kircher (1650).

Em suma, ainda no século XVII, podem ser mencionados Christoph Bernhard (1628-1692) com seu Tractatus Augmentatu Compositionis (1657), e Johann Georg Ahle (1651-1706), por meio de sua obra Musikalisches Frühlings, Sommer, Herbst, und Winter-Gespräche (1695-1701). 
No século XVIII, corroboraram para o desenvolvimento da teorização e sistematização retórico-musical, Tomas Baltazar Janovka (1669-1741), por intermédio de seu tratado ad Clavis thesaurum magnæ musicæ artis (1701), e Johann Gottfried Walther (1684-1748), com suas obras: Der Praecepta musicalischen Composição (1708) e Musicalisches Lexicon (1732).

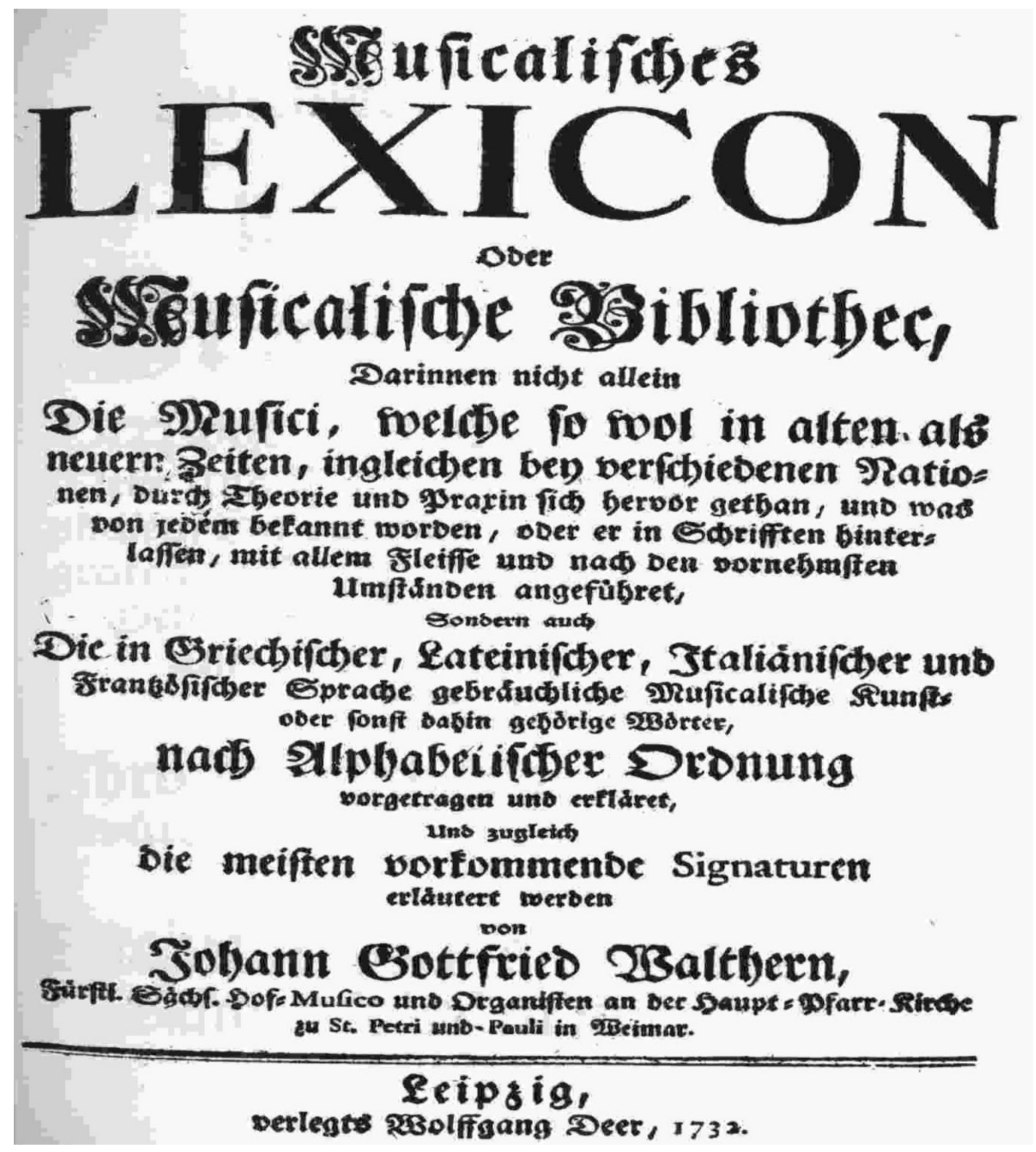

Figura 25-Frontispício do Musicalisches Lexicon de Johann Gottfried Walter (1732).

De igual maneira, Mauritius Johann Vogt (1668-1730) e seu Conclave thesauri magnæ artis musicæ (1719). 


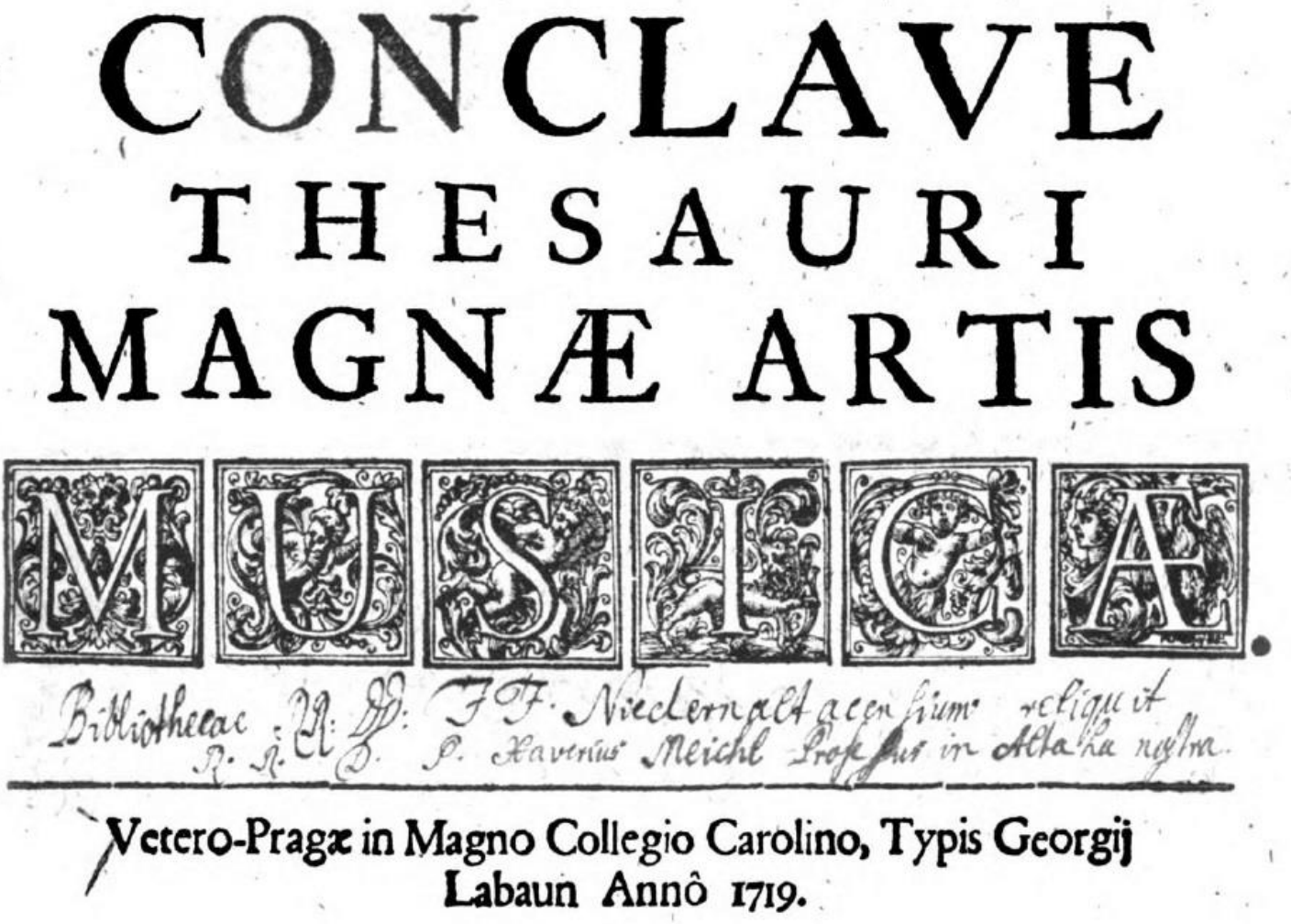

Figura 26-Frontispício do Conclave thesauri magnæ artis musicæ de Mauritius Johann Vogt (1719).

São mostradas abaixo, as definições de algumas figuras retóricomusicais, por Vogt. 


\section{A P.UT IV.}

DE FIGURIS AD ARSIN, ET THESIN, ET PERIODUM.

GIgurx ad arfin, \& thefin funt, qux non concernunt totam 1 periodum, fed folùm in parte, \& vel maximè in principio ponuntur ; ùt funt antitheta, fchematoides \&c. Alix obventunt medio, ùt climax, tmefis. Alix veniunt ad finem, ùt anáphorx \&c. Harum aliquarum ponamus exempla :

Anabafss afcenfus eft, ùt cùm voce $\&$ textu afcendimus : ùt afcendit in calum. ad inferos.

Catabajss defcenfus cùm vox defcendit, ùt cum textu defcendit

1. Anadiplofs cùm initium facinas ex precedentis fine ; ùt :

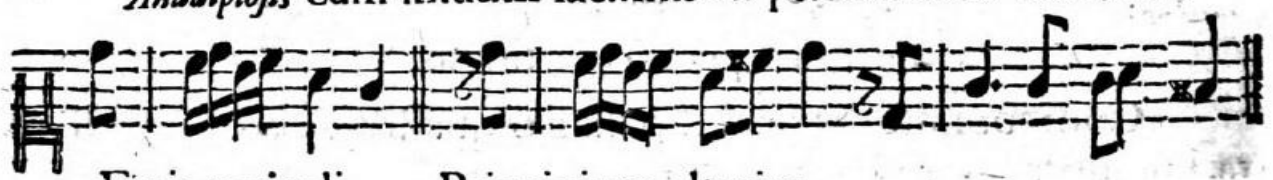

Finis periodi, Principium alterius,

Epanadiplofis eft, cùm finis eft, ùt initium ; ùt fi cum cadentia inciperes periodum, \& cum eadem cadentia finires.

Anapbora repetitio eft. Fit non folum vera repetitio partis periodi, fed etiam figurarum fimplicium.

Antifecbon permutatio figni, literx, notx; ùt cùm in cadentia nota penultima non eft tertia nec quinta, fed exotica ùt quarta:
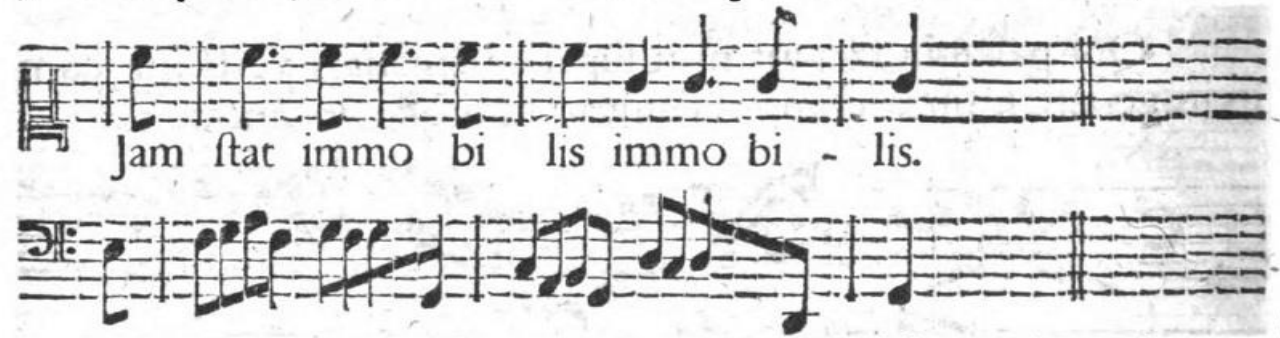

Maximus hujus figurx ufus eft in folicinijs, ubi modus canendi frequentillimè alias accipit notas, quàm linex habeant.

Antisbeton oppofitio tam fit in thematibus, \& contrathematibus, quàm in oppofitione diffonantiarum. Eft communis.

Apofope/ss reticentia. Reticentia fierì debet, ubi aliàs necefsè eft cantari, ùt in exemplo:

Civis

Figura 27-Denifições das figuras retóricas da Anabasis, Catabasis, Anadiplosis, Epanadiplosis, Anaphora, Antistaechon, Antitbeton e Aposiopesis (VOGT, 1719, Part.III, Trat.III, Cap.IV, p.150).

Outras relevantes contribuições para a consolidação do emprego retórico do século XVIII foram as de Meinrad Spiess (1683-1761), com seu 
Tractatus Musicus Compositorio-Practicus (1745), e Johann Adolf Scheibe (1708-1776), com seu Critische Der Musikus (1745).

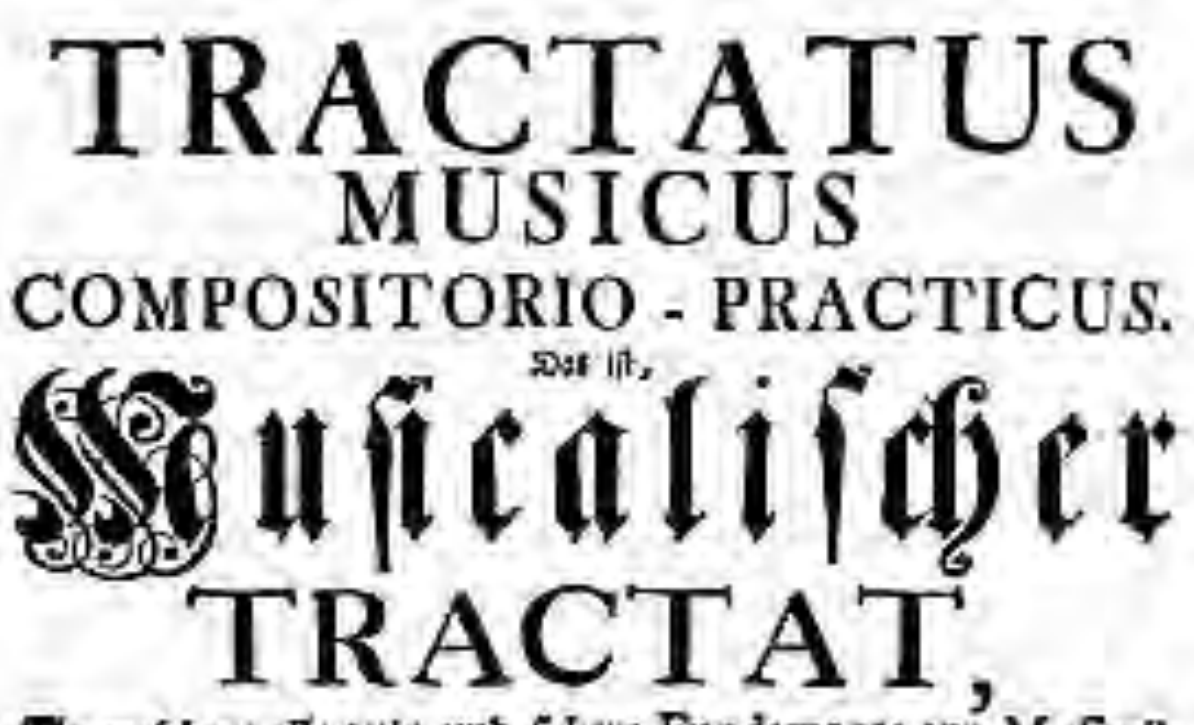

Fitr meficm alle gutt unb fidetrt Fundamenta jut Muficali-

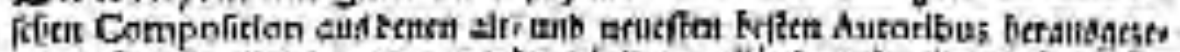

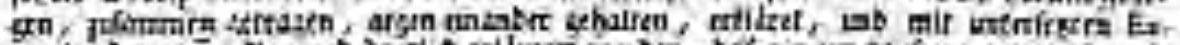

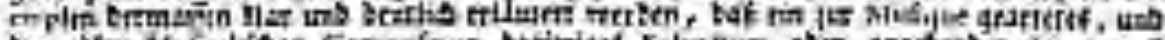

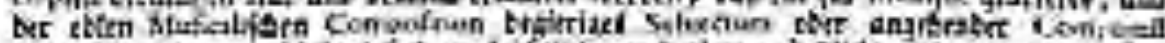

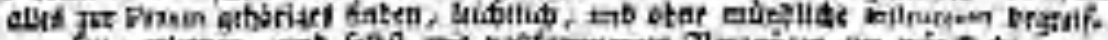

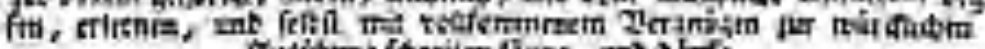

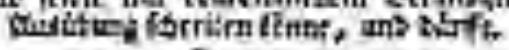

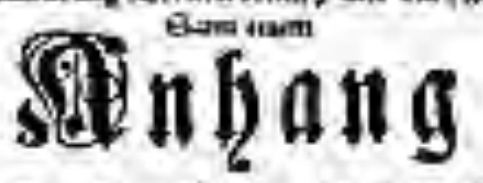

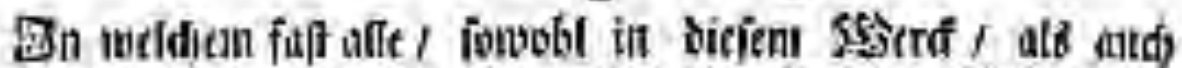

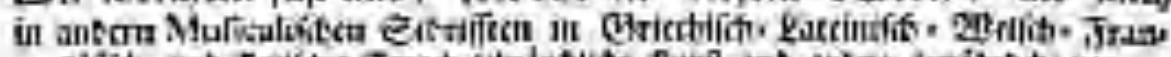

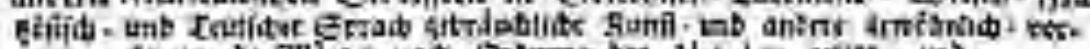

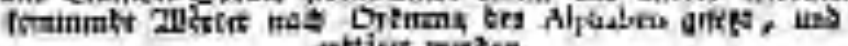

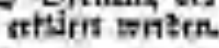

\section{R. P. MEINRADO SPIESS,}

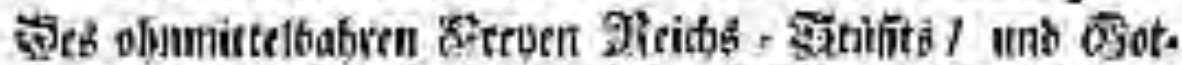

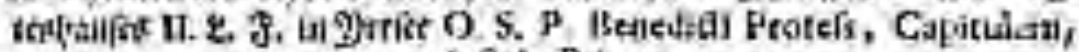
unte Sus-Piorn.

tint

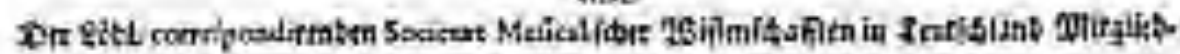

Opus V11I.

IU

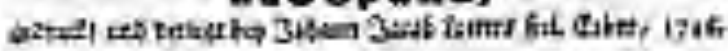

Figura 28-Frontispício do Tractatus Musicus Compositorio-Practicus de Meinrad Spiess (1745). 


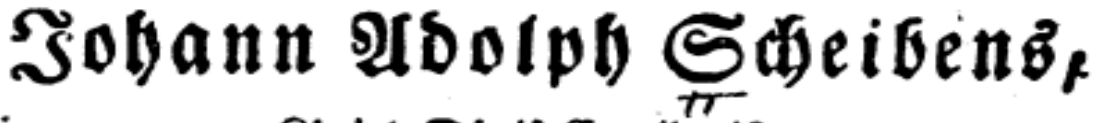 Rönigl. Dànif. Eapellmeifters, $\mathbb{C} \mathfrak{i} i \mathfrak{i} i \mathfrak{c} \mathfrak{b} \mathfrak{c}$ $\mathfrak{M} \mathfrak{U} \mathfrak{S} \mathfrak{M} \mathfrak{U}$. Reue,} vermebrte und verbefierte $\mathfrak{A} \mathfrak{u} \mathfrak{f} \mathfrak{l} \mathfrak{a} \mathfrak{g} e$.

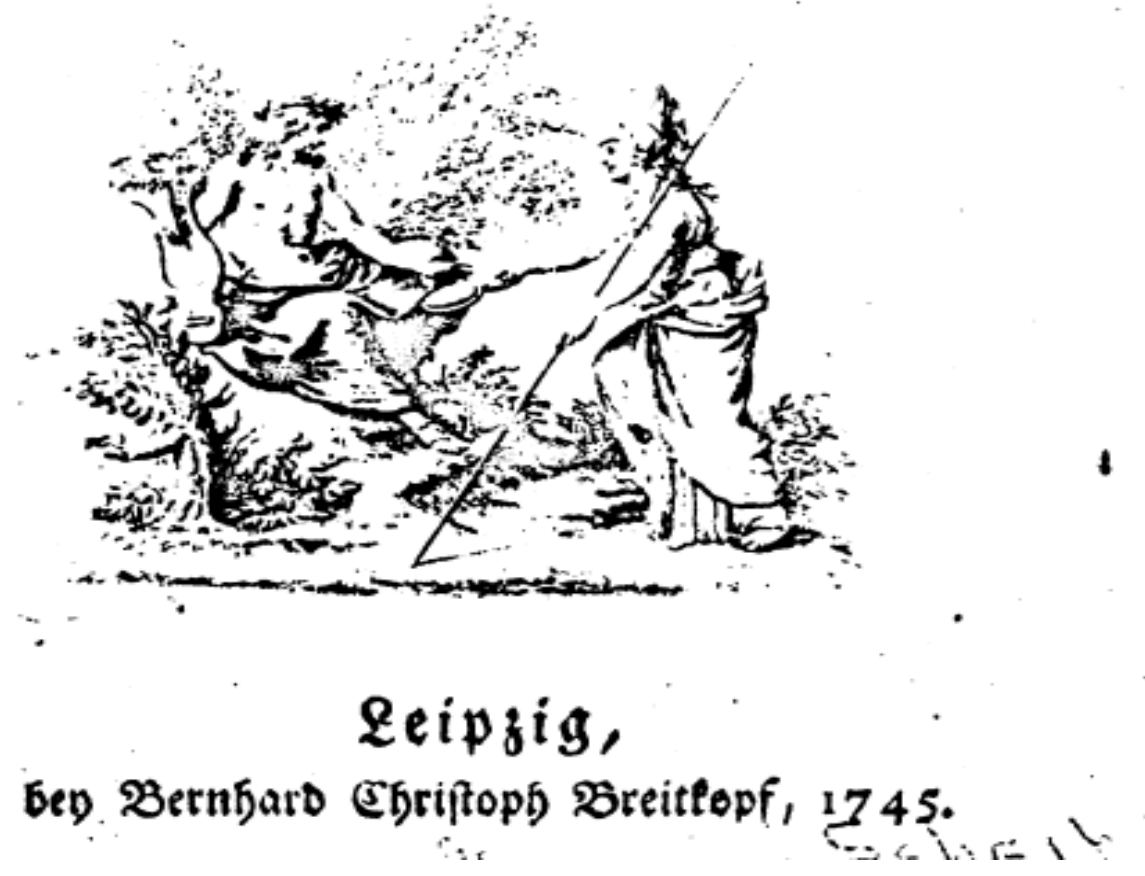

Figura 29-Frontispício do Critische Der Musikus de Johann Adolf Scheibe (1745).

$\mathrm{Na}$ transição do século XVIII para o século XIX, Johann Nikolaus Forkel (1749-1818) publica sua obra Allgemeine Geschichte der Musik (Leipzig, 17881801), a qual faz uma referência aos diversos conceitos já trabalhados por autores como Mattheson e Scheibe (BUELOW, 2001, p.272). 


\section{Il $\mathfrak{l} \mathfrak{l} \mathfrak{g} \mathfrak{e} \mathfrak{m} \mathfrak{e} \mathfrak{i} \mathfrak{n} \mathfrak{e}$ \\ OSeifididite Der Millif \\ $\mathfrak{b} \mathfrak{n}$}

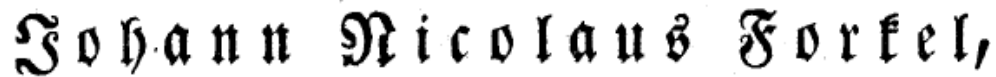

Doctor ber ghilofopgie un 2 yfitoirector in Gottingen.

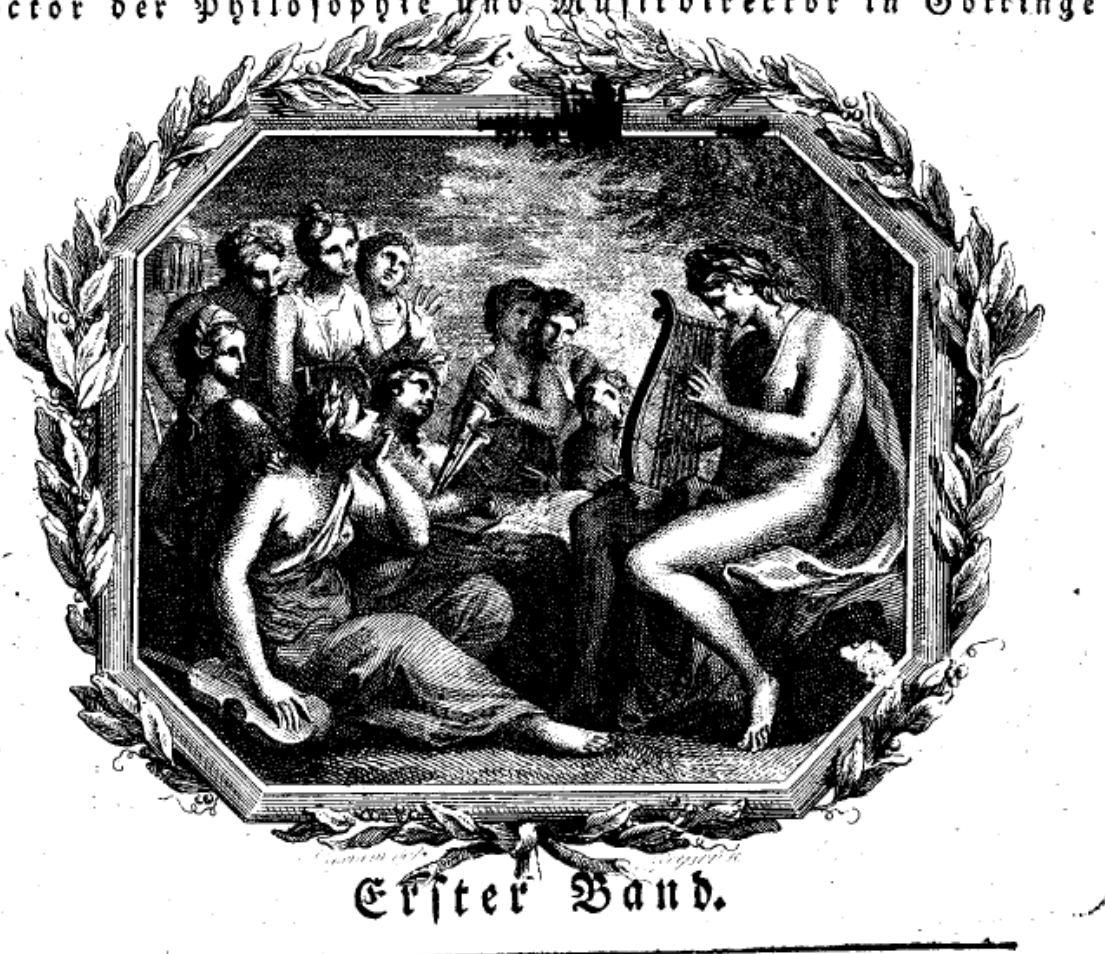

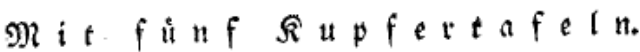

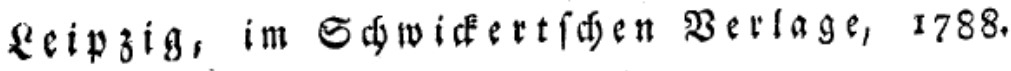

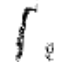

Figura 30-Frontispício do Allgemeine Geschichte der Musik de Johann Nikolaus Forkel (1788).

De igual modo, Heinrich Christoph Koch (1749-1816), mediante sua obra Versch Einer Anleitung zur Composition (1782-1793), realçando a orientação retórica de seus procedimentos ao indicar o emprego de exórdios nas peças destinadas ao público que necessita ser persuadido para entrar em sintonia com a música (BARROS, 2006, p.56). 


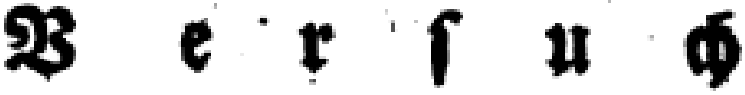 einer Finleitung} gut

Compoftion

bon

\section{Seintid Efriftoph $\mathfrak{T} 0$ d,}

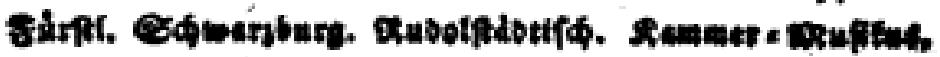

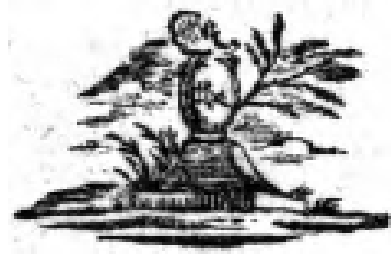

$\therefore \because$.

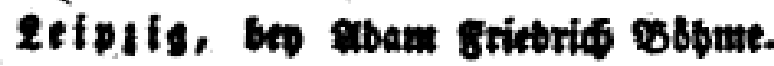

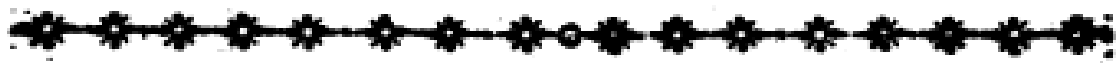

Xubolfabr, iz82.

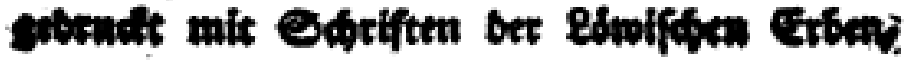
$\operatorname{mos}$ extant,

Figura 31-Frontispício do Versch Einer Anleitung zur Composition de Heinrich Christoph Koch (1782-1793).

Por fim, o tratado Musikalisches Lexikon (1802), já no século XIX, onde Koch apresenta vinculação relacional entre música, gramática e retórica. 


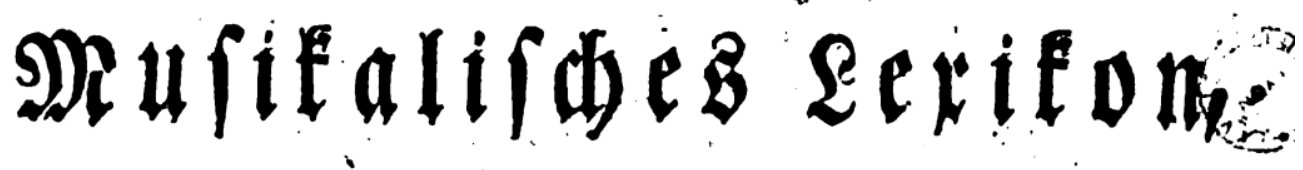 welie, \\ 426119}

bie theoretiffie unb prattifác Tontinft, encyclopábifd bearseitet, alle alten uno neuen Sinnftrobrter erflárt, uns bie alten und néuen Inftrumente befdrieben, entbóát, .

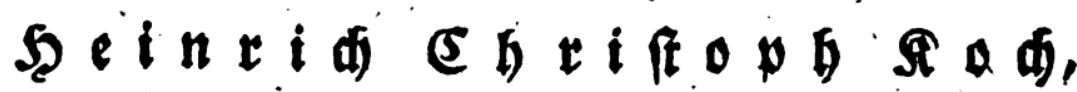

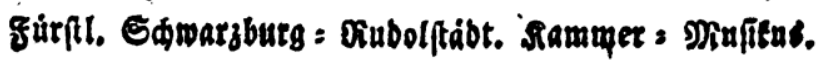

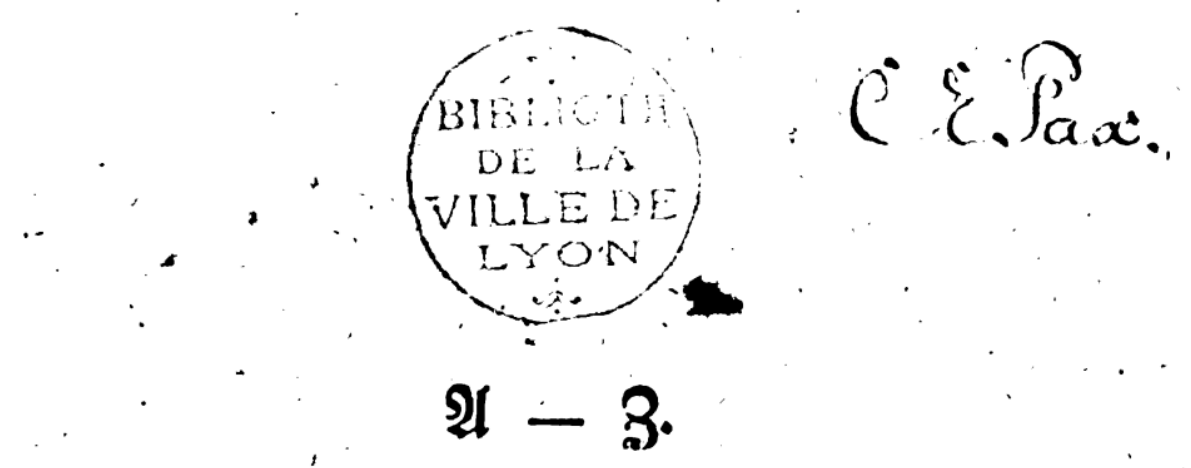

Frantfurt am Mair,

b e A

1802.

Figura 32-Frontispício do Musikalisches Lexikon de Heinrich Christoph Koch (1802). 
Contemporâneo de todos esses tratadistas, Johann Mattheson (16811764), em seu tratado Der Vollkommene Capellmeister (1739) (O Perfeito Mestre de Capela), elaborou um padrão composicional fundamentado na disciplina retórica, de maneira a provocar no discurso musical a mesma eficácia persuasiva da arte da oratória. Respaldado pelos cânones clássicos, estabelece, por intermédio das Cinco Fases da Retórica, maior relação entre música e o discurso, evidenciada a seguir.

- Inventio - início do discurso onde são descobertas pelo orador as ideias e os argumentos que sustentarão a sua tese, podendo abranger o ato de criação, das ideias musicais, entre outros.

- Dispositio - onde são distribuídas e ordenadas as ideias e argumentos encontrados na Inventio.

- Elocutio - é associada ao estilo. Nela são efetuados os processos de tratamento e desenvolvimento de cada ideia, item e ornamentação, também denominada Decoratio ou Elaboratio por outros autores.

- Memoria - são os mecanismos e processos utilizados para memorizar

o discurso e, por extensão, o sistema operacional de cada uma das fases retóricas ${ }^{35}$.

- Pronuntiatio - pronunciamento do discurso. É a última fase do sistema retórico, igualmente conhecida como Actio ou ação (atuação). Diz respeito à performance, isto é, à interpretação perante o público (BUELOW, 2001, p.261).

\footnotetext{
${ }^{35}$ Segundo Cano, a Memoria é a única parte que não foi transmitida para as outras artes (a não ser na literatura): "a Memoria é a única parte do sistema retórico que não foi sequer mencionada pelos tratadistas musicais do Barroco" (LÓPEZ CANO, 2000, p.94). Todavia, como já exposto no tópico 2.2.2, autores como Bluteau, por exemplo, ressaltam que a Memoria, a quinta parte retórica para alguns, esta presente em todas as outras partes, por essa razão não é necessário separa-la das demais partes.
} 


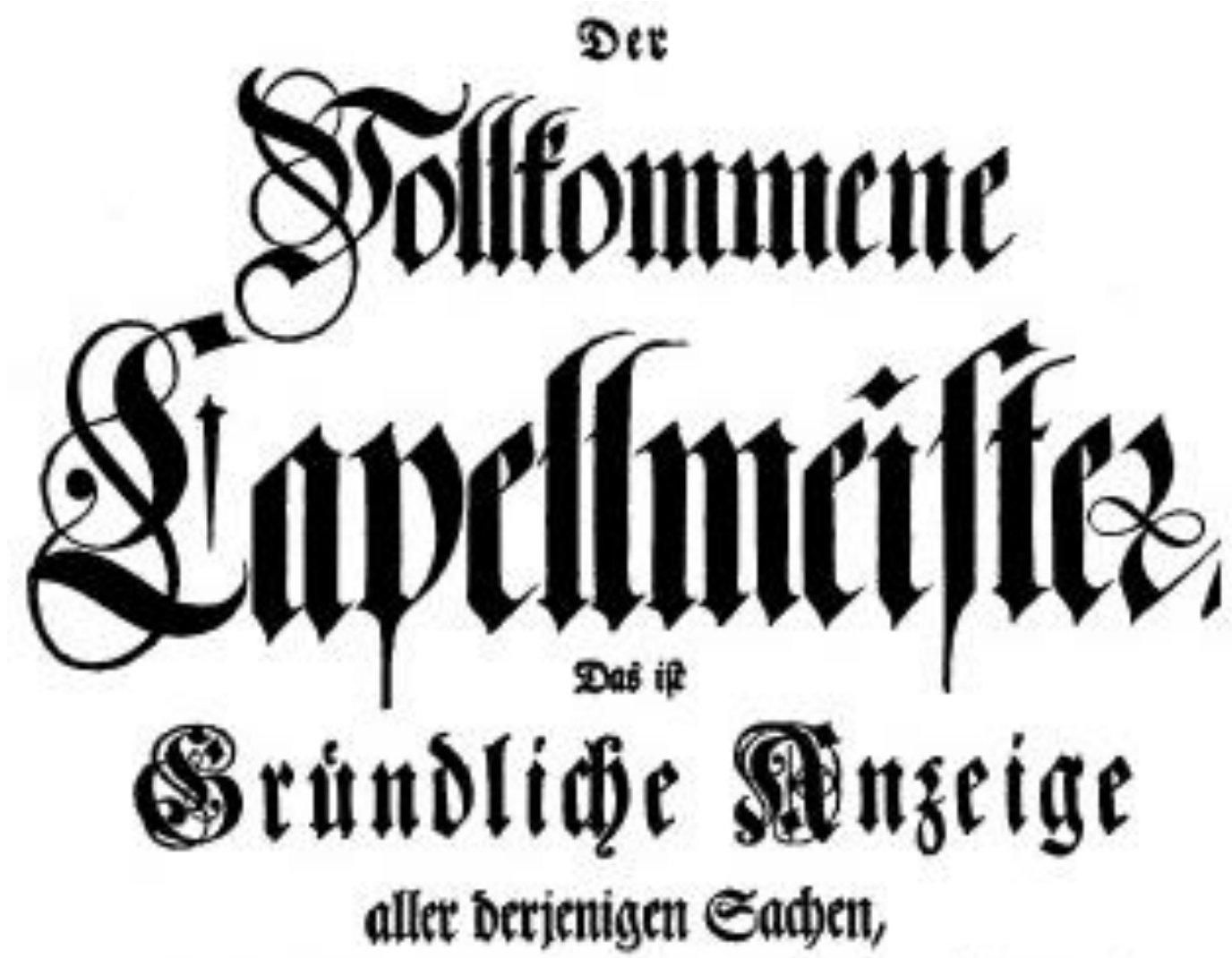

bie einer wiften, tonnen, und vofifonanen inue baben muf,

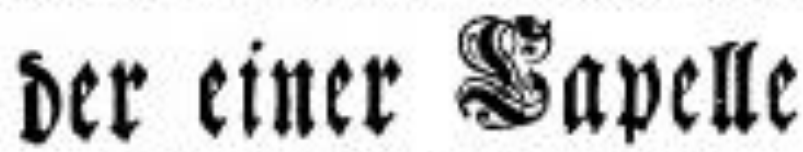

mit Egren ub Ruręen porfithent toill:

3utt Defing mtneefftn

not

M A T THESON.

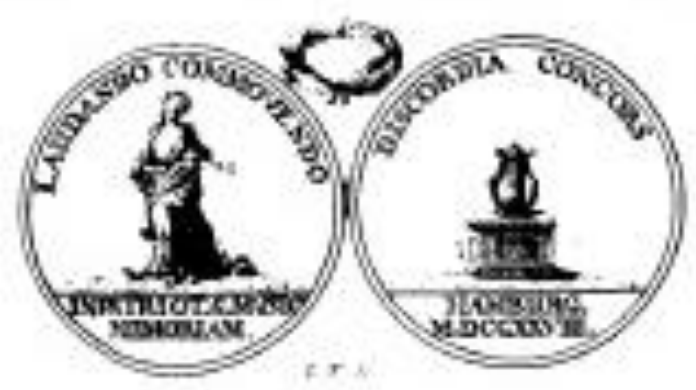

פamburg/

Berlegts Sorifian พัฒerold, 1739.

Figura 33-Frontispício do Der Vollkommene Capellmeister de Johann Mattheson (1739). 
Não obstante, é importante salientar que ao fazer referência à primeira fase retórica, Mattheson expõe detalhadamente acerca dos Loci Topici e de suas funções, a seguir.

1. Notationis: desenho das notas, na oratória, nas letras que geram ideais.

2. Descriptionis: descrições, descobertas.

3. Generis ou Antecedenita: lugar de gênero e da espécie.

4. Totius ou Partium: semelhança do instrumento ou da voz com matéria.

5. Casue Effcintis: a história ou a ação é a causa principal.

6. Cause Materialis: a matéria musical é o som; não sujeito de palavras, também não haverá intenção expressiva com relação ao afeto específico.

7. Cause Formalis: a forma e a norma de cada obra e melodia.

8. Cause Finalis ou Causorum: final.

9. Effectorum: efeito específico da composição, de acordo com a ocasião.

10. Adjunctorum: representação de determinados personagens como em: ofertórios, óperas e cantatas.

11. Circumstantiarum: diferentes circunstâncias de tempo, do lugar e de acontecimentos anteriores.

12. Comparatorum: comparação de coisas semelhantes e dessemelhantes, pequenas e grandes.

13. Oppositorum: contraste de compassos, movimentos contrários, agudo e grave, lento e rápido, calmo e agitado etc.

14. Exemplorum: emulação de outros compositores.

15. Testimoniorum: utilização de exemplos conhecidos como canções de igrejas, para testemunhos ou reforço (MATTHESON, 1954 [1739], parte II, cap.4,§§ 23-85, pp.121-132 $)^{36}$. (9) 2

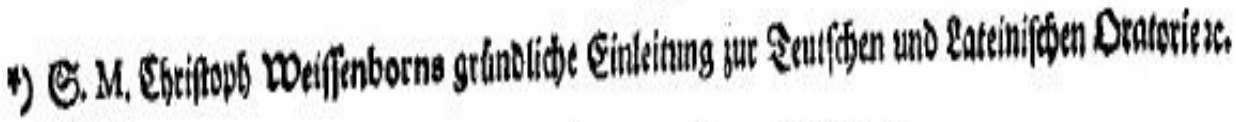

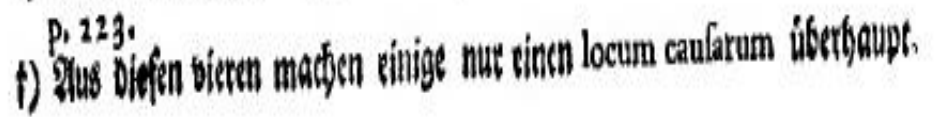

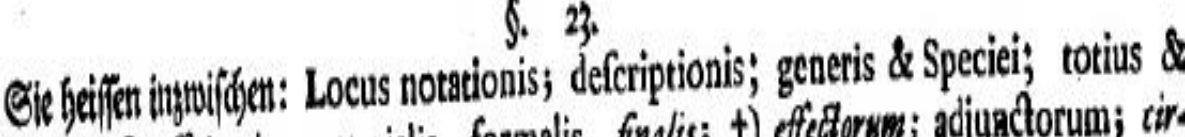
partium; caufze (fficientis, materialis, formalis, frnalis; †) effectorrm; adjuactorum; tir.

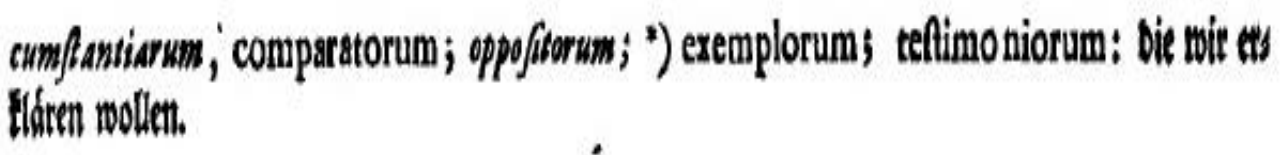

Figura 34-Os Loci Topici segundo Johann Mattheson (1954 [1739], pp.123-124).

\footnotetext{
${ }^{36}$ Essa referência também foi citada pela Profa. Dra. Mônica Isabel Lucas em seu material didático para suas ministrações na disciplina: CMU 5942- Introdução à Retórica da Música Setecentista (LUCAS, 2010, p.1).
} 
No que diz respeito à Dispositio, a estrutura de Dressler (Exordium, Médium e Finis) foi apenas uma versão simplificada da mais usual divisão em seis partes. No entanto, Mattheson ampliou esse esquema para estabelecer um plano racional e organizado para a composição musical ${ }^{37}$ (BUELOW, 2001, p.262). Mattheson observa que, para esse plano ser eficaz, é necessária uma disposição bem elaborada e planejada:

Nossa disposição musical difere do arranjo retórico de um discurso apenas em tema, assunto ou objeto: mas ainda assim ela observa aquelas seis partes que são prescritas a um orador, nomeadamente introdução, relato, discurso, corroboração, confutação e conclusão (MATTHESON, 1954 [1739], parte II, cap.4,§ 4, p.235) ${ }^{38}$.

Adiante, entre os parágrafos 7 e 12, no capítulo 14, Mattheson prossegue com uma explicação minuciosa de cada etapa e suas aplicações na composição musical, bem desenvolvida, como uma ária ${ }^{39}$ :

1. Exordium - "introdução e início de uma melodia, pela qual sua finalidade e intenção devem ser apresentadas, de maneira a preparar e estimular a atenção do ouvinte. Frequentemente, quando se examina uma obra sem instrumentos, somente com a parte vocal e o baixo, esta introdução acontece na passagem do baixo contínuo que antecede a entrada da voz; se um acompanhamento maior está presente, essa introdução ocorre no ritornello. Pois nós chamamos a parte que ocorre no início e com instrumentos de ritornello: porque, posteriormente, ela é repetida, e a obra pode facilmente tanto terminar quanto iniciar com ela".

2. Narratio - "é um relato, uma narração, através do qual o sentido e o caráter do discurso aqui são sugeridos. Ocorre com a entrada ou início da parte vocal ou da parte concertada (instrumental) mais

\footnotetext{
${ }^{37}$ Mark Evan Bonds explica que os teóricos de música do século XVIII recorriam a imagens e ao vocabulário da retórica, isto é, eles se fundamentavam naquilo que poderia ser compreendido, na atualidade, como uma metáfora da música (linguagem/discurso), de forma que a base lógica, por trás da estrutura do discurso musical, revelaria certos paralelos com a base lógica por trás das convenções formais da retórica verbal (BONDS, 1991, pp.4-5).

${ }^{38}$ Unser musikalische Disposition ist von der rhetorischen Einrichtung einer bloßen Rede nur allein in dem Vorwurff, Gegenstande oder Objecto unterschieden: dannenhero hat sie eben diejenigen sechs Stücke zu beobachten, die einen Redner vorgeschrieben werden, nemlilch den Eingang, Bericht, Anfang, die Bekräfftigung, Wiederlung und den Schlu. Exordium, Narratio, Propositio, Confirmatio, Confutatio \& Peroratio. Tradução e citação igualmente localizada na dissertação de mestrado (UFRJ), A ideia do Clássico no Classicismo: Retórica e Música no final do século XVIII, de João Vicente Vidal (VIDAL, 2002, p.62).

${ }^{39}$ Esse excerto já havia sido citado e referenciado em nossa dissertação de mestrado, porém, houve por bem que novamente ele fosse descrito, na íntegra corroborando no desenvolvimento do presente tópico.
} 
importante, e é relacionada ao Exordium, que o precedeu, por meio de uma hábil conexão"40.

3. Propositio ou Divisio - "é quando o discurso propriamente dito contém, de forma sucinta (resumida), o conteúdo e propósito do discurso musical, e é de duas variedades: simples ou composto. [...] Esse discurso ocorre imediatamente após o primeiro inciso da melodia, nomeadamente quando o baixo toma a frente e apresenta a melodia tão simples e brevemente. Depois, a parte vocal começa sua propositio nem variatam, une-se com o baixo contínuo e realiza o discurso combinado".

4. Confutatio - "é a clarificação das objeções (isso é, ideias musicais oponentes ou contrastantes), e pode ser expressa na melodia tanto através da combinação, citação ou refutação de elementos estranhos à música que se precedeu".

5. Confirmatio - "é a corroboração (reforço e reafirmação) artística do discurso, e em melodias, é comumente encontrada em repetições imaginativas e inesperadas; o que não deve ser entendido como uma reprise normal. Referimo-nos à introdução de certas passagens vocais agradáveis ornamentadas com todos os tipos de boas variações [...]".

6. Peroratio - "é o final ou conclusão de nossa oração musical, que deve produzir uma impressão especialmente enfática, mais do que as outras partes. $E$ isto ocorre não apenas no curso ou progresso da própria melodia, mas especialmente no epílogo, seja ele tocado pelo baixo contínuo ou por um forte acompanhamento; tenha ou não alguém ouvido este ritornello antes" (MATTHESON, 1954 [1739[, parte II, cap.14,§ 7-12, p.236) ${ }^{41}$.

\footnotetext{
${ }^{40}$ Mattheson faz referência à entrada do solo vocal e instrumental da Narratio, nas árias, porém, a narração do discurso, dependendo do texto e contexto, não necessariamente acontece na voz preponderante, ela pode ser realizada em todas as vozes.

${ }^{41}$ Das Exordium ist der Eingang und Anfang einer Melodie, worin zugleich der Zweck und die gantze Absicht derselben angezeiget werden muss, damit die Zuhörer dazu vorbereitet, und zur Aufmercksamkeit ermuntern werden. Mehrentheils, wenn wir einen Satz ohne Instrumente, nur mit der Singstimme und dem Bass betrachten, stehet dieser Eingang in dem Vorspiele des Generalbasses; wenn eine grössere Begleitung daben ist, in dem Ritornell. Denn wir nennen auch dasjenige ein Ritornell, was mit Instrumenten vorher gespielet wird: weil es hernach zur Wiederkehr dienet, und damit sowol geschlossen, als angefangen werden kan. Die Narratio ist gleichsam ein Bericht, eine Erzehlung, wodurch die Meinung und Beschaffenheit des instehenden Vortrages angedeutet wird. Sie findet sich gleich bey dem An=oder Eintritt der Singe=oder vornehmsten Concert=Stimme, und beziehet sich auf das Exordium, welches vorhergegangen ist, mittelst eines geschickten Zusammenhanges. Die Propositio oder der eigentliche Vortrag enthält kürtzlich den Inhalt oder Zweck der Klang-Rede, und ist zweierlei: einfach, oder zusammengesetzet [...] Solcher Vortrag hat seine Stelle gleich nach dem ersten Absatz in der Melodie, wenn nehmlich der Bass gleichsam das Wort führet, und die Sache selbst so kurtz als einfach vorleget. Daraus hebt denn die Sing=Stimme ihre propositionem variatam an, vereiniget sich mit dem Fundament, und erfüllet den zusammengesetzten Vortrag. [...] Die Confutatio ist eine Auflösung der Einwürffe, und mag in der Melodie entweder durch Bindungen, oder auch durch Anführung und Wiederlegung fremdscheinender Fälle ausgedruckt werden [...] Die Confirmatio ist eine künstliche Bekräfftigung des Vortrages, und wird gemeiniglich in den Melodien bey wolersonnenen und über Vermuthen angebrachten Wiederholungen gefunden; worunter aber die gewöhnlichen Reprisen nicht zu verstehen sind. Die mehrmahlige mit allerhand artigen Veränderungen gezierte Einführung gewisser angenehmer Stimm=Fälle ist es, was wir hier meinen [...] Die Peroratio endlich ist der Ausgang oder Beschluss unsrer Klang-Rede, welcher, vor allen andern Stücken eine besonders nachdrückliche Bewegung verursachen muss. Und diese findet sich nicht allein im Lauffe oder Fortgange der Melodie, sondern vornehmlich in dem Nachspiele, es seyim fundament, oder in einer stärckern Begleitung; man habe dieses Ritornell vorher gehöret oder nicht. Die Gewohnheit hat es so eingeführet, dass wir in den Arien fast mit eben denjenigen Gängen und
} 
5. 7 .

Das Exorbium iff ber Eingant und 2 Infang einer SRelobie, morin zugleid bet

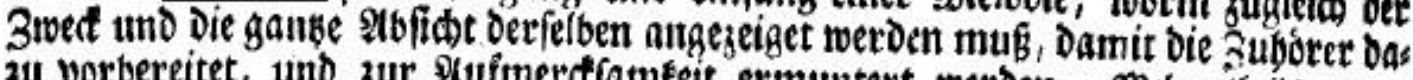
zu vorbereiter, uno zur \&ufmerctfamfeit ermuntert werben. Nebrentheils, went

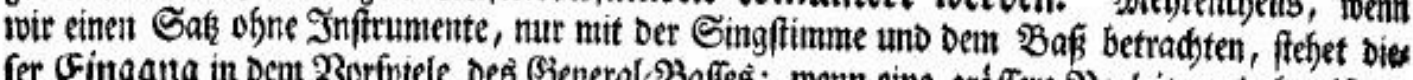
fer Eingang in Demt Borfptele Deș Seneral:23affeś; wenn eine groffere \$egltitung baben if, it

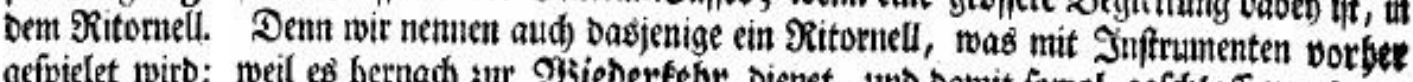

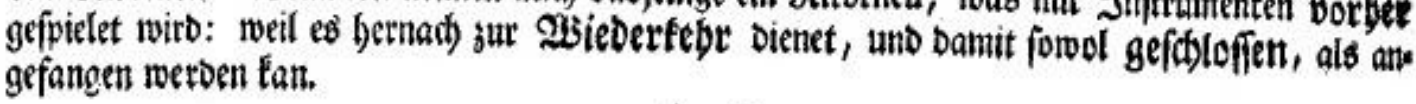

6. 8.

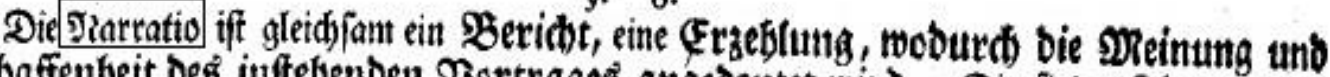

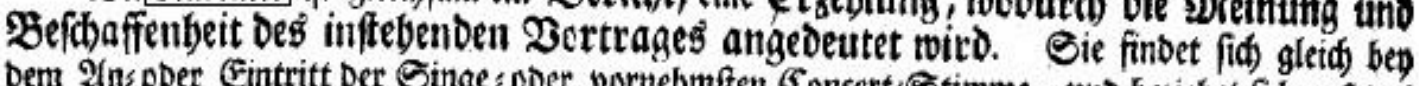
Dem 2insober (Eintritt Der Singe: oder vornebmften Eoncert:Stimme, und bejiebet fid) auf Dab Exoroium, meldess votbergezangen ift, nittelft eines gefdjidten 3ufammenbanges.

9.9.

6. 9.

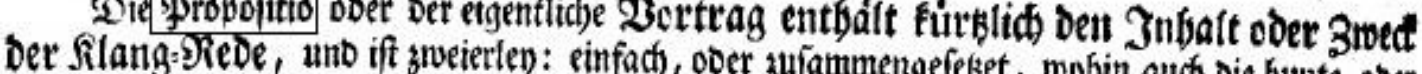

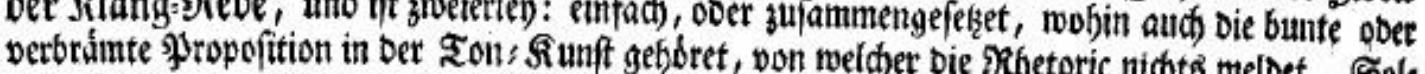

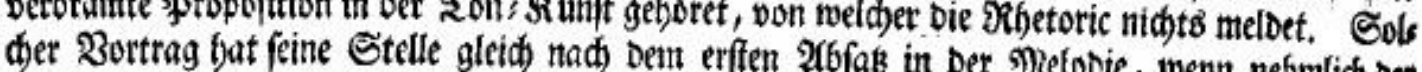

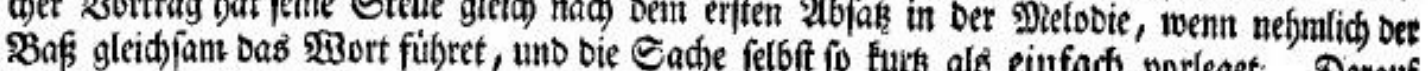
hebt benn Die Sing: Stimme ibre propofitionem rariato turts als eitffad) vorleget: Darauf

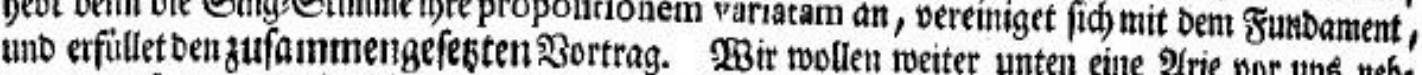
men, uno fie nad) Diefer Dronung unterfucben, obs fich alfo Damit verfinte? was bier gefagt worbett, viel Deutlicher in Die 2ugen uno Dbren fallen; eŝ mag fo neu unb fiemb fóciten, ais eś inmer wolle.

Die Confutatio ift eine Suflofung o.

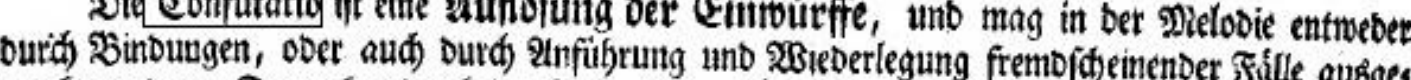

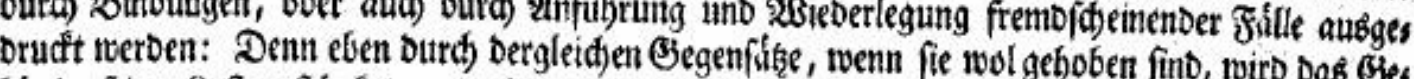
hór in feiter Suft geftéffet, und alles, mas Demfelben in Diffonand gehoben fint, wird Das Ges

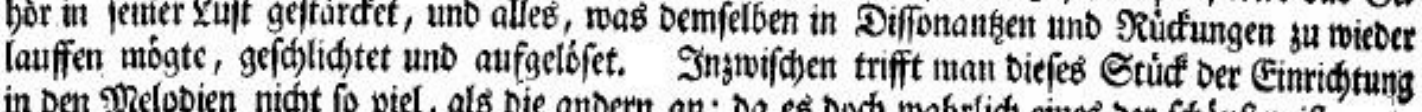

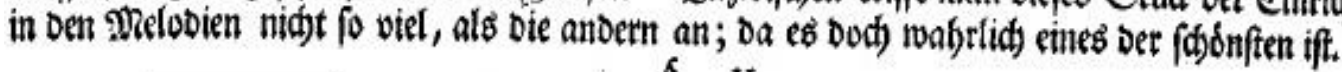
6. II.

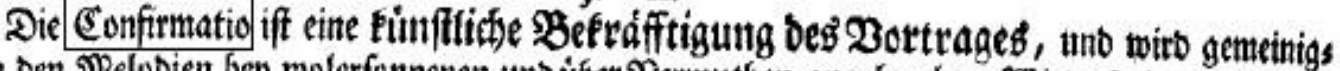
lid) in Den Melobien bey wolerfonnenen unb úber $\mathfrak{B e t m u t b e n ~ a n g e b r a d ) t e n ~} \$$ Bieberfolungen gefuns

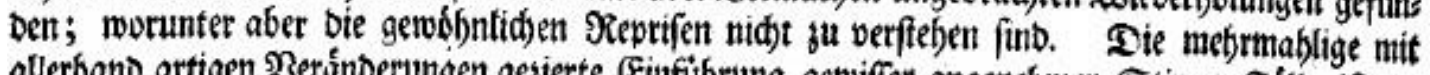
allerband artigen Betúnderungen gejierte Einfuthrung genvifer angenebmer Stimm : Fálle if es, was wir bier meinen, wie bernad) aus bemskeipiele erbellen foul.

\section{12.}

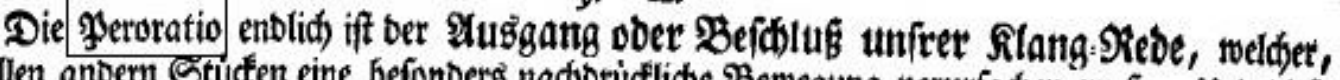
vor allen andern Studen eine befonders nadjorudfide Bewegung verurfad)en múp. Uno biefé finvet fids nid)t allein im Eauffe over fortgange Der Sielobie, fonbern vornebmlids in bem

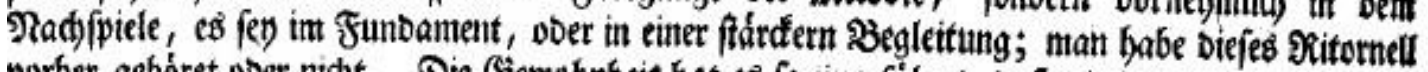

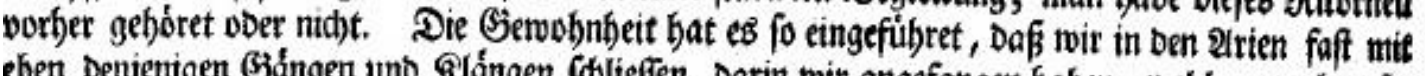

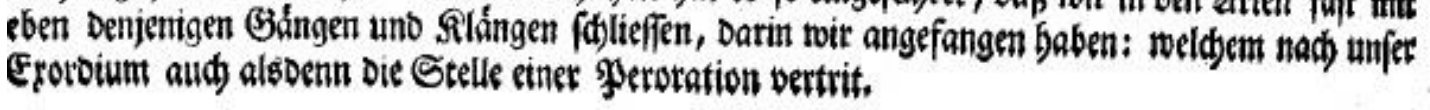

Figura 35- As seis partes da Dispositio segundo Johann Mattheson (1954 [1739], p.236).

Klängen schliessen, darin wir angefangen haben: weichem nach unser Exordium auch alsdenn die Stelle einer Peroration vertrit. Igualmente, essa tradução e citação podem ser encontradas em (VIDAL, 2002, p.63; LUCAS [aula sobre Dispositio], 2010, pp. 6-7). 
Entre as etapas, estruturas e definições dos estudiosos, pesquisadores, teóricos e musicólogos contemporâneos, a respeito da estrutura das fases retórico-musicais, podem ser observadas, por exemplo, em forma de tabela as de Buelow (1980), Vickers (1984), Bons (1991), Bartel (1997), López Cano (2000) e Unger (2003).

Tabela 2-Estrutura retórica e suas etapas (BUELOW, 1980, p.794).

\begin{tabular}{|c|}
\hline \multicolumn{1}{|c|}{ ETAPAS } \\
\hline \multicolumn{1}{|c|}{ Inventio } \\
Achamento ou descobrimento de uma ideia \\
\hline \multicolumn{1}{c|}{ Dispositio } \\
- Exordiumão de uma ideia nas partes de uma oração \\
- Narratio- declaração dos fatos \\
- Propositio/Divisio- antevisão dos principais pontos em favor do orador \\
- Confutatio- refutação \\
- Confirmatio- prova afirmativa \\
\hline Peroratio/Conclusio- conclusão \\
Elocutio/ Decoratio \\
Elaboração ou decoração (ornamentação) de uma ideia \\
Aronuntiatio execução ou exibição de uma oração
\end{tabular}

Verifica-se, na próxima tabela o esquema estrutural relatado em Brian Vickers.

Tabela 3-Estrutura retórica e suas etapas (VICKERS, 1984, p.3) ${ }^{42}$.

\begin{tabular}{|l|}
\hline ETAPAS \\
\hline a) Inventio \\
\hline b) Dispositio \\
- Proemium \\
- Divisio/Narratio \\
- Confirmatio \\
- Confutatio \\
- Peroratio \\
\hline c) Elocutio \\
\hline d) Pronuntiatio \\
\hline e) Memoria \\
\hline
\end{tabular}

\footnotetext{
${ }^{42}$ É examinável nesse exemplo o termo Proemium em vez de Exordium e a Confutatio antes da Confirmatio, assim como a fase retórica da Memoria antes da Pronuntiatio.
} 
Já Marc Evan Bonds apresenta um esquema estrutural com algumas diferenças em relação às outras etapas e definições. Nota-se que o referido pesquisador utiliza o exemplo organizado e ordenado por Forkel, em seu Allgemeine Geschichte der Musik.

Bonds (1991) esclarece que, como tal, a música tem suas próprias regras e convenções, sendo que Forkel, como outros teóricos de sua época, divide-a em duas categorias: Gramática e Retórica. Gramática rege a relação entre notas e acordes individuais e sua concatenação em unidades periódicas. Retórica, por sua vez, regula a união sucessiva e ordenação dessas várias unidades de pequena escala para um conjunto em grande escala (BONDS, 1991, p.121).

Tabela 4-Estrutura retórica e suas etapas (BONDS, 1991, pp.121-122).

\begin{tabular}{|c|}
\hline $\begin{array}{c}\text { PTAPAS } \\
\text { Periodicity (Periodologie) } \\
\text { Parte estrutural dos periodos }\end{array}$ \\
\hline $\begin{array}{c}\text { Styles: for church, theater, or chamber (Schreibarten) } \\
\text { Estilos musicais para igreja, teatro, ou câmara } \\
\text { Genres (Gattungen) } \\
\text { Gêneros Musicais }\end{array}$ \\
\hline $\begin{array}{c}\text { The ordering of musical ideas (Die Anordnung musilalischer Gedanken) } \\
\text { A ordenação das ideias musicais (Criação Artística) }\end{array}$ \\
- Exordium- começo \\
- Thema (Hauptsatz)- tema principal \\
- Gegensätze- tema secundärio \\
- Zergliederungema de contraste \\
- Widerlegungen- refutação \\
- Bekräftigungen- confirmação \\
- Conclusion- conclusão \\
\hline The performance or declamation of musical Works \\
A execução ou declamação de obras musicais \\
\hline Musical criticism \\
Crítica Musical
\end{tabular}

\footnotetext{
${ }^{43}$ Nota-se que, nesse esquema estrutural, baseado no tratado de Forkel, não há a Inventio. Pois o mesmo associou a descoberta ou invenção dos argumentos como inspiração, a qual não pode ser simulada ou auxiliada por artifícios como os Loci Topici (VIDAL, 2002, p. 55).
} 
Veja-se, na tabela abaixo, essa estrutura formulada por Dietrich Bartel, em seu livro Musica Poetica: Musical-Rhetorical Figures in German Baroque Music, onde são expostas e reforçadas as partes da Dispositio e da Elocutio, assim como as fases retóricas.

Tabela 5-Estrutura retórica e suas etapas (BARTEL, 1997, p.68).

\begin{tabular}{|l|}
\hline \multicolumn{1}{|c|}{ Etapas } \\
\hline a) Inventio, incluem os Loci Topici \\
\hline b) Dispositio \\
i. Exordium \\
ii. Narratio \\
iii. Propositio (Divisio) \\
iv. Confirmatio \\
v. Confutatio (Refutatio) \\
vi. Peroratio (Conclusio) \\
\hline c) Elocutio (Decoratio) \\
i. puritas, latinitas \\
ii. perspicutias \\
iii. ornatus, incluem figuras \\
retóricas e tropos \\
iv. aptum, decorum \\
\hline d) Memoria \\
\hline e) Actio, Pronunciatio \\
\hline
\end{tabular}

No presente exemplo, é tangível a estrutura retórico-musical esquematizada por Rubén López Cano.

Tabela 6-Estrutura retórica e suas etapas (LÓPEZ CANO, 2000, pp.13-84, passim).

\section{EPATAS}

Inventio: invenção dos argumentos ou tese e dos temas musicais

Dispositio: distribuição dos argumentos e ideias musicais nos lugares mais adequados do discurso

Exordium: introdução do discurso

Narratio: apresentação dos fatos

Propositio: enunciação da tese fundamental de que argumenta o discurso

Confutatio: caracterizada pela inclusão um grande número de ideias ou antítese opostas (refutação)

Confirmatio: retorna a tese fundamental

Peroratio: epílogo, parte final e conclusiva do discurso

Elocutio: elocução do discurso, ou seja, onde ocorrem as escolhas das figuras retórico-musicais, segundo as circunstâncias do discurso 
Memoria: mecanismos e processos para memorizar o discurso e, por extensão o modo operativo de cada fase retórica

Pronuntiatio: execução do discurso ante o público

$\mathrm{Na}$ última tabela, notam-se as etapas elaboradas no livro Musica e Retorica: fra XVI e XVIII secolo de Haus-Heinrich Unger.

Tabela 7-Estrutura retórica e suas etapas (UNGER, 2003, pp.27-29).

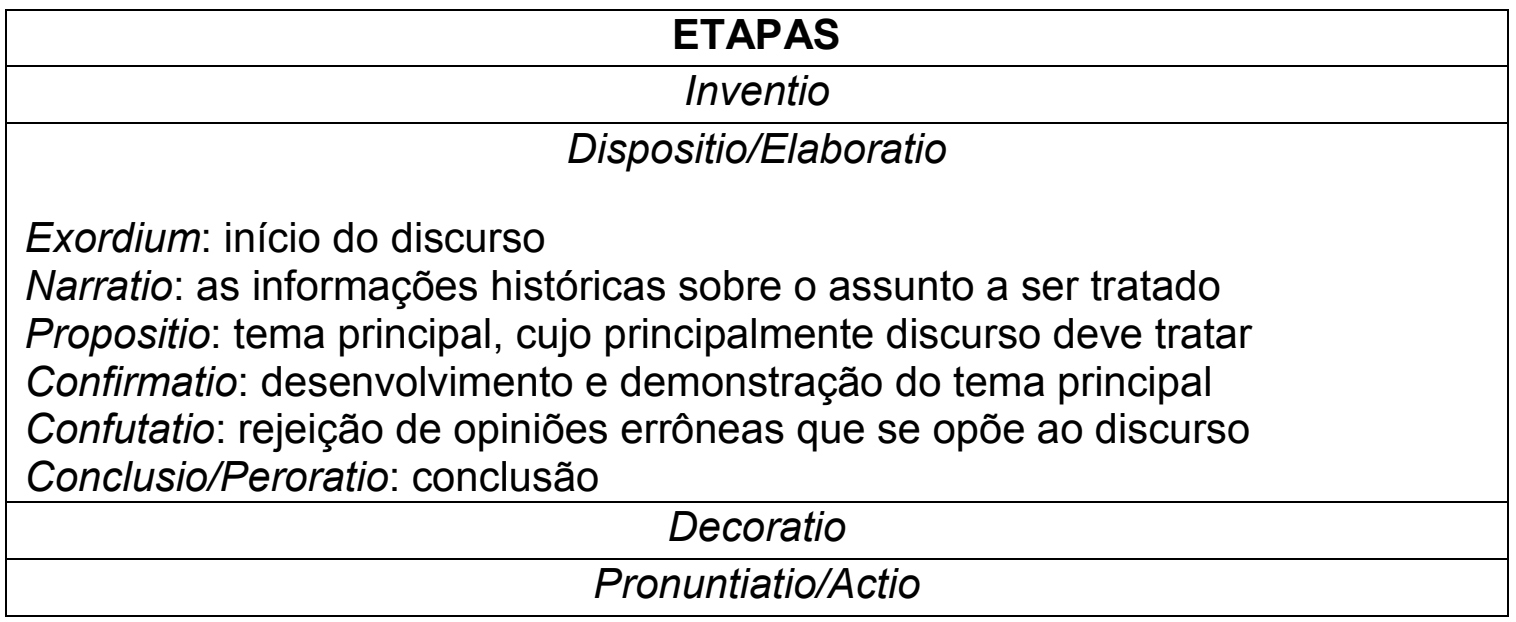

Em síntese, os tratados, sobretudo os de Dressler, Burmeister e Mattheson, foram de grande relevância para os compositores contemporâneos e posteriores a eles. Por esse motivo, houve maior preocupação em relação ao discurso e à música, além de sua ordenação distribuída primeiramente em três partes e, posteriormente, em seis partes, dentro da Dispositio, todas essas tinham também como integrantes figuras retórico-musicais, inseridas em cada parte.

\subsection{Afeto e Música}

Desde os primórdios da civilização grega, a vinculação da música a estados emocionais específicos são registrados. Todavia, é a partir do final do século XVI que acontecem as maiores expansões e observações minuciosas, haja vista as grandes teorizações que foram de grande relevância para o desenvolvimento das figuras de retórica inseridas na música.

Desde o início, a teoria das paixões ou afetos foi parte integral da música Barroca, a qual tinha por finalidade transmitir o mover desses 
sentimentos aos ouvintes. Os compositores barrocos elaboravam os conteúdos da cada obra, seção ou movimento da mesma e igualmente aguardavam uma resposta de sua audição baseada na apresentação racional do significado afetivo de sua música (BUELOW, 1980, p.800).

Francis Bacon (1561-1626), Rene Descartes (1596-1650), Benedict Spinoza (1632-1677), Gottfried Wilhelm Leibitz (1646-1716) e David Hulme (1711-1776) foram filósofos que versaram sobre o assunto dos afetos. Descartes, por exemplo, em seu tratado Les Passions de l'âme (1649), trouxe uma perspectiva retórica para os músicos e artistas da época, retomando muito das tradições antigas do estudo nesse campo. Nessa obra, ele ressalta que as paixões da alma são como as percepções dos sentimentos, ou das emoções da alma, que se referem particularmente e ela, que são causadas, sustentadas e fortificadas por um movimento dos espíritos (LÓPEZ CANO, 2000, p.47). Esses espíritos, os quais se refere Descartes, são os espíritos animais ${ }^{44}$.

O ódio para Descartes se origina quando um indivíduo persegue um objetivo que causa aversão e seus espíritos animais conduzem o suco dos alimentos imediatamente aos músculos do estômago e do intestino, impedindo assim que ele se misture com o sangue:

Ao contrário, no ódio, o primeiro pensamento do objeto que produz aversão conduz de tal modo os espíritos existentes no cérebro para os músculos do estômago e dos intestinos que impedem o suco dos alimentos de se misturar com o sangue, apertando todas as aberturas por onde costuma correr (DESCARTES, 1987 [1649], Art.103, p.265).

Em outra passagem de seu tratado, o filósofo francês destaca que mediante as paixões precedentes, caso sejam apresentadas como boas e convenientes, as paixões podem levar o ser humano ao amor, porém se foram manifestadas de forma nociva ou má, podem incitar o ódio:

Ora, todas as paixões precedentes podem ser excitadas em nós sem que se perceba, de modo algum, se o objeto que os provoca é bom ou mau. Mas, quando uma coisa se nos apresenta como boa em

\footnotetext{
${ }^{44}$ Os espíritos animais são as partes mais liberais do sangue. Os movimentos dos espíritos animais provocam as reações corporais características que acompanham cada paixão e tipo de movimento que corresponde a uma paixão.
} 
relação a nós, isto é, como nos sendo conveniente, isso nos leva a ter amor por ela; e, quando se nos apresenta como má ou nociva, isso nos incita ao ódio (DESCARTES, 1987 [1649], Art.56, p.252).

Por sua vez, a alegria estimula mais os nervos pelos espíritos animais que estão em torno dos orifícios do coração, ou seja, onde há maior volume de sangue nas artérias do coração:

$\mathrm{Na}$ alegria não são tanto os nervos do baço, do fígado, do estômago ou dos intestinos que atuam, mas os que existem em todo o resto do corpo, e particularmente aquele que fica em torno dos orifícios do coração, o qual, abrindo e alargando tais orifícios, permite ao sangue, que os outros nervos expulsam das veias para o coração, entrar e sair em maior quantidade que de costume; e, como o sangue que então penetra no coração já passou e repassou aí muitas vezes, vindo das artérias para as veias, ele se dilata mui facilmente e produz espíritos cujas partes, sendo muito iguais e sutis, são próprias para formar e fortalecer as impressões do cérebro que dão à alma pensamentos alegres e tranquilos (DESCARTES, 1987 [1649], Art.104, pp.265-266).

Já na tristeza há pouco fluxo de sangue no coração:

Na tristeza, as aberturas do coração são fortemente contraídas pelo pequeno nervo que as envolve, e o sangue das veias não é de modo algum agitado, o que determina que vá muito pouco para o coração; e, no entanto, as passagens por onde o suco dos alimentos corre do estômago e dos intestinos ao fígado permanecem abertas, o que faz com que o apetite não diminua, exceto quando o ódio, o qual muitas vezes está junto à tristeza, os fecha (DESCARTES, 1987 [1649], Art.105, p.266).

No desejo há uma grande força que pode controlar o cérebro que é a vontade:

A paixão do desejo tem isto de próprio, que a vontade de obter algum bem ou de fugir de algum mal envia prontamente os espíritos do cérebro a todas as partes do corpo capazes de servir às ações requeridas para tal efeito, e particularmente ao coração e às partes que lhe fornecem mais sangue, a fim de que, recebendo-o em maior abundância do que de costume, envie maior quantidade de espíritos ao cérebro, tanto para entreter e fortalecer nele a ideia dessa vontade, como para passar daí a todos os órgãos dos sentidos e todos os músculos que podem ser empregados para obter o que se almeja (DESCARTES, 1987 [1649], Art.106, p.266). 
Embasado em Descartes e Kircher, López Cano sublinha que cada tipo de movimento dos espíritos animais é determinado por uma combinação das seguintes causas:

a) Objetos que percebemos com nossos sentidos: o que vemos, ouvimos, cheiramos (olfato), sentimos ou provamos;

b) Fantasias da imaginação: memórias, medos, obsessões, etc;

c) Temperamento pessoal: se você é colérico, melancólico, fleumático ou sanguíneo, dependendo do humor predominante de um indivíduo;

d) Movimentos gerados pela alma, emoções e pensamentos motivados pela nossa própria vontade (LÓPEZ CANO, 2000, p.50) ${ }^{45}$.

Observa-se, na figura abaixo, a terceira causa pela qual se movimentam os espíritos animais, destacados por Athanasius Kircher, em seu tratado Musurgia Universalis (1650), isto é, os quatro tipos de humores, cada um deles indicando um determinado temperamento.

Suppono fecundò, Quod quemadmodum diuerfa nationes diuerfo ftylo mufico gaudent, ita \& in vaaquaque natione diuerfi temperamenti homines, diuerfis ftylis, pnufouiloue fux naturali inclinationimaximè conformibus afficiuntur. Hiac nOR rquè omnes ijsdem harmoniis qaudent fieuti non omnes ifdem eduli is xqua deloctatione vefcuntur. Amant melancholici grauem, folidam, luetuofam harmoniam san. guivei bb firituum fanguineotum facilem agitationem titillationemque hyporchematico ftylopallim afficiuntur, Cholericiob bi is efferueftentis vehementiam limi: les harmonicos motus appecunt. Hinc martiales viri ad tubas, \& tympana aftuetacti, omnem delicatiorem muficam refpuere videntur, Phlegmatici cutarum muliebriü vocum fymphonijs afficiuntur, fiquidem acurus fonus humorein phlegmaticum benignè afficit; Vade voluptas, \& dulcedo. Hinc iterum certz cantiuncul $x$ in vnoquo. piam magnam vim habent, nullam in alio; hinc vnus ifto, alius alio tono afficitur, que omnia à diuerfa temperamenticonftitutione dependent,vt poftea vberius oftendecur, qua quidem ita vera funt, vt non tantum diuerfi diuerfis harmonijs, fed \& interual. lis diuerfis gaudeant: funt, quibus tertix placent,nonnulli fextis delectentur, nonde. funt quoque, qui a fperis \& ablonis afficiantu-; qux omnia à genio patrix, ab inclinatione,\& temperamento particulari, \& à confuetudine introducta dependent.

Figura 36-Os quatro tipos de humor e temperamento segundo Athanasius Kircher (KIRCHER, 1650, Livro VII, Parte I, Erotema V, p.544).

\footnotetext{
${ }^{45}$ a) Objetos que percibimos con nuestros sentidos: lo que vemos, oímos, olemos, palpamos o degustamos; b) Fantasías de la imaginación: recuerdos, temores, obsesiones, etc; c) Temperamento personal: si se es colérico, melancólico, flemático o sanguíneo, dependiendo del humor prevaleciente en un individuo; d) Movimientos generados por el alma: emociones y pensamientosmotivados por nuestra propia voluntad.
} 
Em suma, para Descartes, o movimento dos espíritos animais é uma relação entre a alma e o corpo (que gera os afetos).

Somado a isso, López Cano enfatiza que, para Descartes, "nenhum sujeito vai mais imediatamente contra nossa alma do que o corpo à qual está unida, como consequência, devemos pensar que ela é paixão, é geralmente uma ação" (LÓPEZ CANO, 2000, p.51). Essa identidade alma/corpo, manifestada em termos de paixão/ação ou afeto/efeito é um princípio reitor para a descrição musical dos afetos. Marin Mersenne, em sua Harmonie Universelle, enunciou que, quando a alma se vê afetada por uma paixão, produz dois tipos distintos de movimentos de espiritos animais: o fluxo e refluxo. O primeiro move os afetos, o coração, alegria, já o segundo, concentração, tristeza, dor (MERSENNE, 1636-7, Livro VI, Parte III, Proposição XII, pp.367-369).

Spinoza, em sua Ethica Ordine Geometrico Demostrata (1677), classifica os afetos dessa forma:

Tabela 8-Classificação dos afetos (SPINOZA, 1677, parte III, prop. LIX).

- LAETITIA: causa agrado, prazer, amor, devoção, esperteza, confiança, alegria, atenção, orgulho, etc.

- TRISTITIA: desagrado, desprazer, ódio, aversão, susto, decepção, indignação, humildade.

- DESEO: crueldade, temor, cortesia, ambição, lascívia.

Por sua vez, David Hulme (LÓPEZ CANO, 2000 p. 57), exprime em seu tratado A Natureza Humana (1739), que existem somente dois tipos de paixões:

Tabela 9-Tipos de Paixões.

\begin{tabular}{|l|l|}
\hline As diretas & As indiretas \\
\hline Nascem imediatamente do bem ou do & Produzem as mesmas ou mesmos \\
mal, prazer ou dor, desejo, pena, & princípios, porém, têm combinação \\
alegria, esperança, medo, segurança, & com outras qualidades: orgulho, \\
piedade, malícia, generosidade. & humildade, ambição, vaidade, amor e \\
\hline
\end{tabular}


ódio.

O princípio basilar e essencial na representação musical dos afetos na música reside na imitação. Entre os elementos suscetíveis à representação do afeto estão o desenho melódico, escalas, ritmo, estrutura harmônica, tempo, tonalidade, forma e estilo. Para Marin Mersene (1636), só acontece uma correta expressão na música se os acentos musicais expressarem ou imitarem o fluxo do sangue e o espírito com refluxos. A representação musical desse afeto partirá do princípio da imitação analógica e efeitos corporais. Têm-se três níveis de intensidade para esse afeto: o ritmo, a melodia e a velocidade (MERSENNE, 1636-7, Livro VI, Parte III, Proposição XII; XIV, pp.367-370). Para Athanasius Kircher (1650), "música é o som que possui força natural como uma corda da alma que vibra". Adiante, o tratadista alemão realça que "a música não pode comover qualquer sujeito senão aquele cujo humor natural esteja conforme a música" (KIRCHER, 1650, Livro VII, Parte I, Erotema V, p.544-545).

Sobre a identificação dos afetos em uma obra musical, diversos tratadistas, teóricos e compositores, tais como: Monteverdi, Charpentier, Mattheson, Rameau, Quantz, entre outros, se expressaram do seguinte modo.

Monteverdi, por exemplo, trabalha com as características afetivas mediante o emprego dos modos, por exemplo, no Dório podia-se persuadir a prudência, no Frígio, incitava-se a luta dos espíritos valentes, já o Eólio, acalmava-se ímpeto e as batalhas internas dos espíritos, assim liberavam-se as almas pacificadas. Por último, o Lídio reascendia os intelectos, privando-os da alienação das coisas terrestres, nascendo, assim, o desejo pelas coisas espirituais (LÓPEZ CANO, 2000, p.66).

Por sua vez, Charpentier e Rameau, realizam exames minuciosos das qualidades afetivas de cada tonalidade, o que pode ser evidenciado também em Mattheson em seu tratado Das Neu-eröffnete Orchestre (1713) (A Orquestra Recém-Inaugurada). 


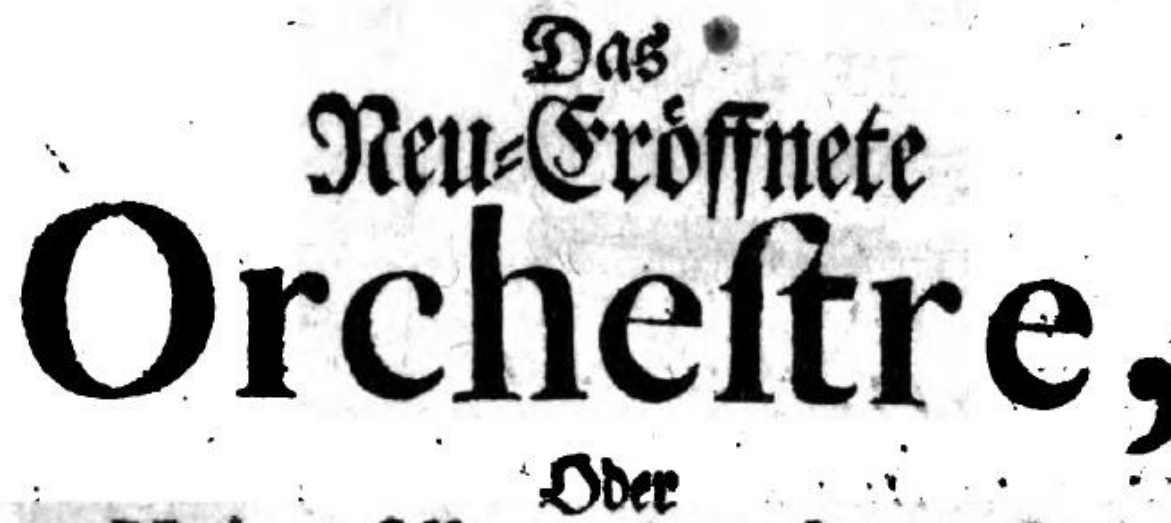

Univerelle and grüttolidbe ขี

Sie cinGalant Homme ei nen volfonmmenen $B$ egriff bon

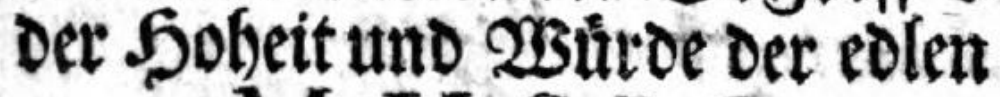

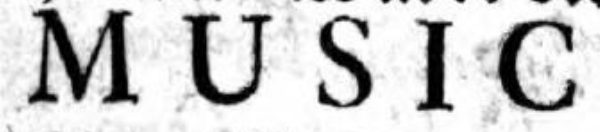

exlangen/ feinen Gout Darnach formiren 1 Die Terminos technicos verfteben

uno gef(tickllic) von Diefer vortrefflis chen 2 Biffenf ren móge.

$$
\text { Durd) }
$$

J.Matthefon,Secr.

mit beygefügten 2inmerctungen Sertn Capell= Dieifter Keifers.

HAMBURG, auf Untoften bes Autoris, uns

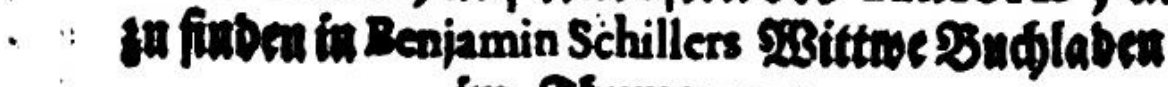
in 26um/1713. 
Abaixo, observa-se a figura com as tonalidades e seus respectivos afetos correspondentes.

\section{CHARPENTIER MATTHESON}

\begin{tabular}{|c|c|}
\hline $\begin{array}{l}\text { Domayor } \\
\text { do menor }\end{array}$ & $\begin{array}{l}\text { Alegre, }{ }^{38} \text { guerrero } \\
\text { Deprimido, triste }\end{array}$ \\
\hline Re mayor & Gozo, enfado \\
\hline remenor & $\begin{array}{l}\text { Solemne, devoto } \\
\text { [religioso] }\end{array}$ \\
\hline Mi bemol mayor & Cruel, duro \\
\hline mi bemol menor & Horror, espanto \\
\hline Mi mayor & $\begin{array}{l}\text { Enfadado, } \\
\text { escandaloso }\end{array}$ \\
\hline
\end{tabular}

mimenor

Fa mayor

fa menor

fa\# ${ }^{39}$ menor

Sol mayor

solmenor

La mayor

la menor

Sib mayor

sib menor

Si mayor

simenor

$$
\begin{gathered}
\text { Afeminado, } \\
\text { amoroso y } \\
\text { lacrimoso }
\end{gathered}
$$

Furia, cólera

Deprimido, lloroso

Dulce, jovial

Severo, magnificente

Tierno, lacrimoso

Magnificente, jovial

Deprimido, terrible

Duro, lacrimoso,

$$
\begin{aligned}
& \text { Solitario, } \\
& \text { melancólico }
\end{aligned}
$$

Jovial, pastoral

\section{RAMEAU}

Avivado, regocijante

Ternura, lamenta-

Dulzura desbordante, intensa tristeza

ción

Terquedad, agudeza, escán- Avivado, regocijante dalo, beligerancia, animación

Calma, religiosidad, grandilo- Dulzura, tristeza cuencia, alegría refinada

Patetismo, seriedad, reflexión, lastimoso

Tristeza desesperada y fatal; agudamente doloroso

Magnificencia, canciones tiernas alegres o grandilocuentes

Dulzura, ternura

$$
\text { tristeza, expresa dolor }
$$

Generosidad, resignación, amor

Ansiedad, desesperación, tibieza, relajación

Tristeza profunda, soledad, languidez

Insinuación, persuasión, brillantez, alegría

Canciones tiernas $y$ alegres

Gracia, complacencia, nostalgia moderada, alegría y ternura templadas

Tormentoso, rabia

Ternura, lamento, deprimente

Lamentacion, conmovedor, tristeza

Llanto, nostalgia, dignidad, relajación

Diversión, alarde

Tormenta, rabia

Extroversión

Canciones tristes

Viveza, regocijo

Raro, temperamental, melancolía, cambia de humor constantemente

Figura 38-As tonalidades e seus respectivos afetos (LÓPEZ CANO, 2000, p.67). 


\subsection{O emprego da retórica na música no final da Renascença, no Barroco e início do Classicismo}

Compositores como: Orlando di Lasso (1532-1594), Luca Marenzio (1553-1599), Ludovico Viadana (ca.1560-1627), John Dowland (1563-1626), Claudio Monteverdi (1567-1643), Heinrich Schütz (1585-1672), Jean-Baptiste Lully (1632-1687), Dietrich Buxtehude (1637-1707), Marc-Antonie Charpentier (1643-1704), Henry Purcell (1659-1695), Alessandro Scarlatti (1660-1725), Antonio Vivaldi (1678-1741), George Phillip Telemann (1681-1767), Johann Sebastian Bach (1685-1750), George Friedrich Haendel (1685-1759), Giovanni Battista Pergolesi (1710-1736), Carl Philipp Emanuel Bach (1714-1788), até mesmo Joseph Haydn (1732-1809) e Wolfgang Amadeus Mozart (1756-1791), entre outros, utilizaram-se dos mecanismos retóricos na formulação das estruturas de suas composições. No entanto, no século XIX, com o Classicismo, inicia-se o "enfraquecimento" da inserção da retórica como elemento discursivo ou na elaboração da composição, ou seja, na relação texto e música. Por essa razão, os autores empregavam a retórica em gêneros sacros e em óperas, preferencialmente, embora existam alguns trabalhos que dissertam sobre a possibilidade de se encontrar elementos retóricos em obras instrumentais no final do século XVIII e início do $X I X^{46}$.

Para exemplificar o emprego retórico-musical por esses compositores citados, são elencados alguns excertos de análises já realizadas por musicólogos e teóricos musicais para apreciação.

No primeiro exemplo, pode se localizar a figura da Noema numa passagem homofônica e tratamento cordal.

\footnotetext{
${ }^{46}$ Leonard G. Ratner: Texture, a rhetorical element in Beethoven's quartets, Artigo (1980); Mark Evan Bonds: Wordless Rhetoric: Musical Form and Metaphor of the Oration, Livro (1991) e Haydn, Laurence Sterne, and the Origins of Musical Irony, Livro (1991). No Brasil: Mônica Isabel Lucas: Humor e Agudeza nos Quartetos de Cordas Op.33 de Joseph Haydn, Tese de Doutorado UNICAMP (2005); João Vicente Vidal: A Ideia do "Clássico" no Classicismo: Retórica e Música no Final do Século XVIII, Dissertação de Mestrado UFRJ (2002); Sérgio Eduardo Martinelli de Assumpção: Ascendência Retórica das Formas Musicais, Dissertação de Mestrado USP (2006); Cassiano de Almeida Barros: A orientação retórica no processo de composição do Classicismo, observada a partir do tratado Versch Einer Anleitung zur Composition (1782-1793), de H.C. Koch (2006), Dissertação de Mestrado e A teoria fraseológico-musical de H.C. Koch (1749-1816) (2011), Tese de Doutorado, para citar alguns.
} 


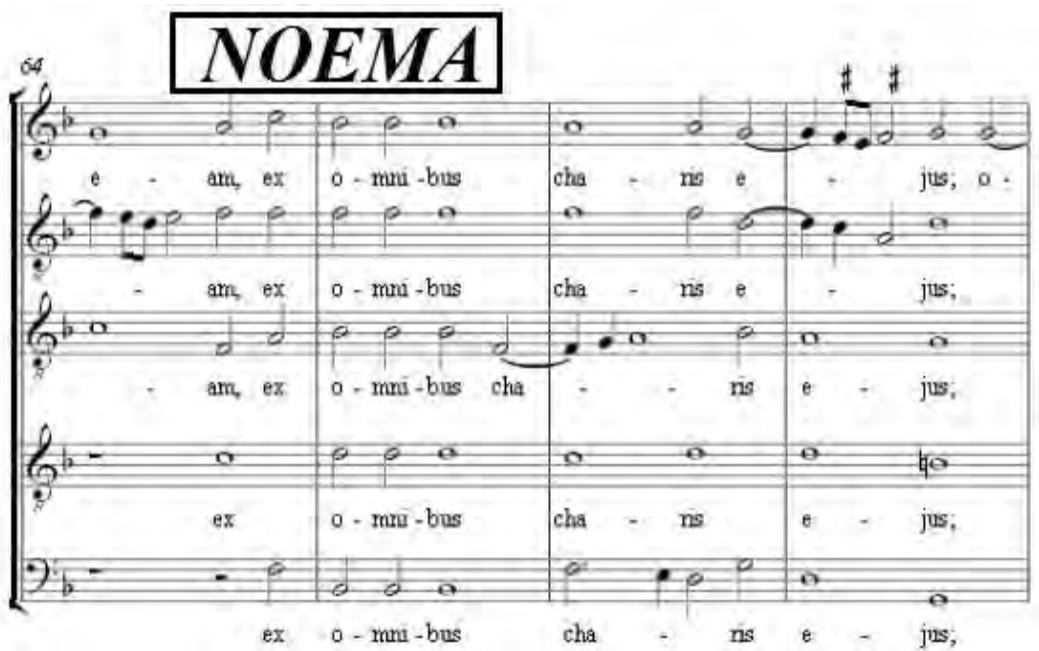

Exemplo 1-Lamentatio Prima Primi Dei- Lamantationes Jeremiæ Prophetæ (1585) de Olando di Lasso (AMBIEL, 2010, p.37).

Abaixo, é verificável a aplicação da Catabasis, através das linhas melódicas descendentes, representando o afeto de humilhação e tristeza.

\section{CATABASIS}

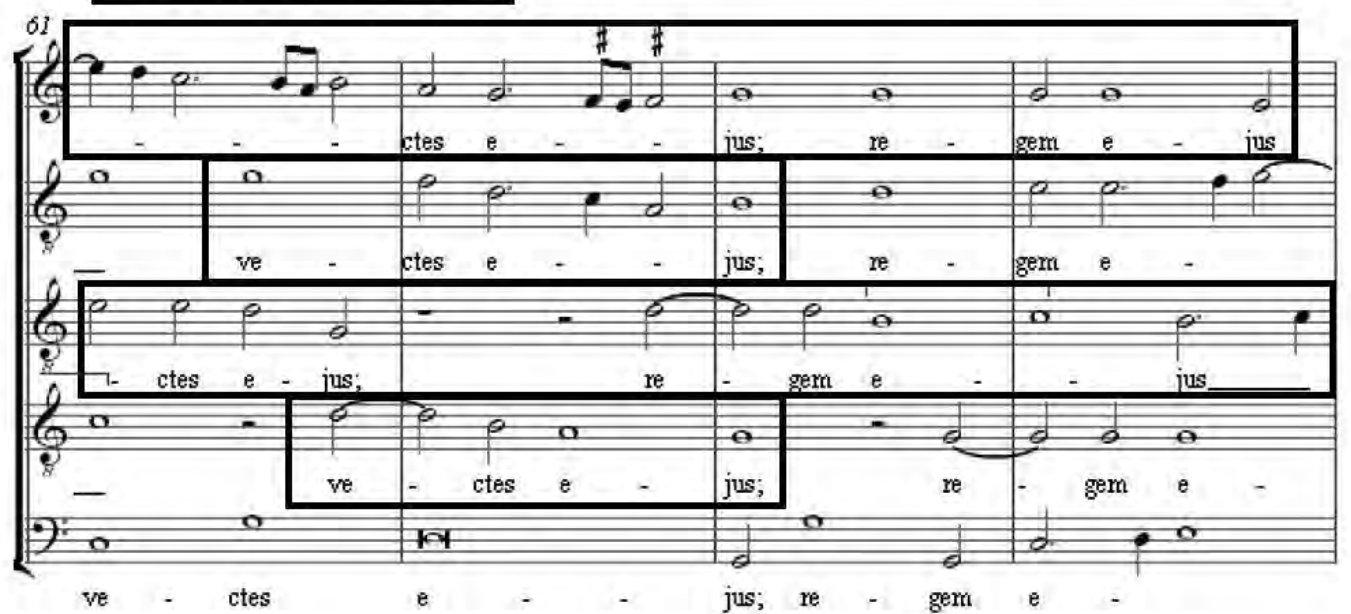

Exemplo 2-Feria Sexta in Parasceve-Lamantationes Jeremiæ Prophetæ (1585) de Olando di Lasso (AMBIEL, 2010, p.129).

Para Burmeister a Mimesis é a repetição de uma Noema numa altura diferente. Já a Anadiplosis seria um ornamento da harmonia construído por uma dupla mimesis, ou seja, repete o que foi introduzido pela primeira vez (BARTEL, 1997, p.181), o que pode ser examinado no exemplo abaixo. 


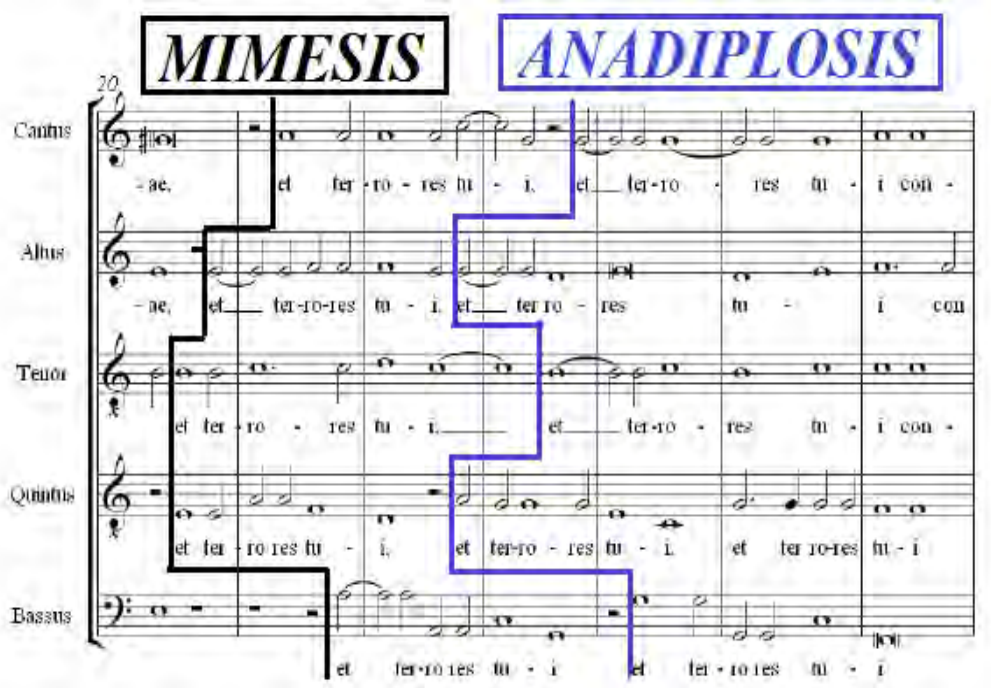

Exemplo 3-In me Transierunt tui (1585) de Orlando di Lasso (AMBIEL, 2010, p.290).

No quarto exemplo, nota-se que o uso da Anaphora, a qual repete por duas vezes a expressão Murtillo e So ben che tu di lei (COLUZZI, 2007, p.539).

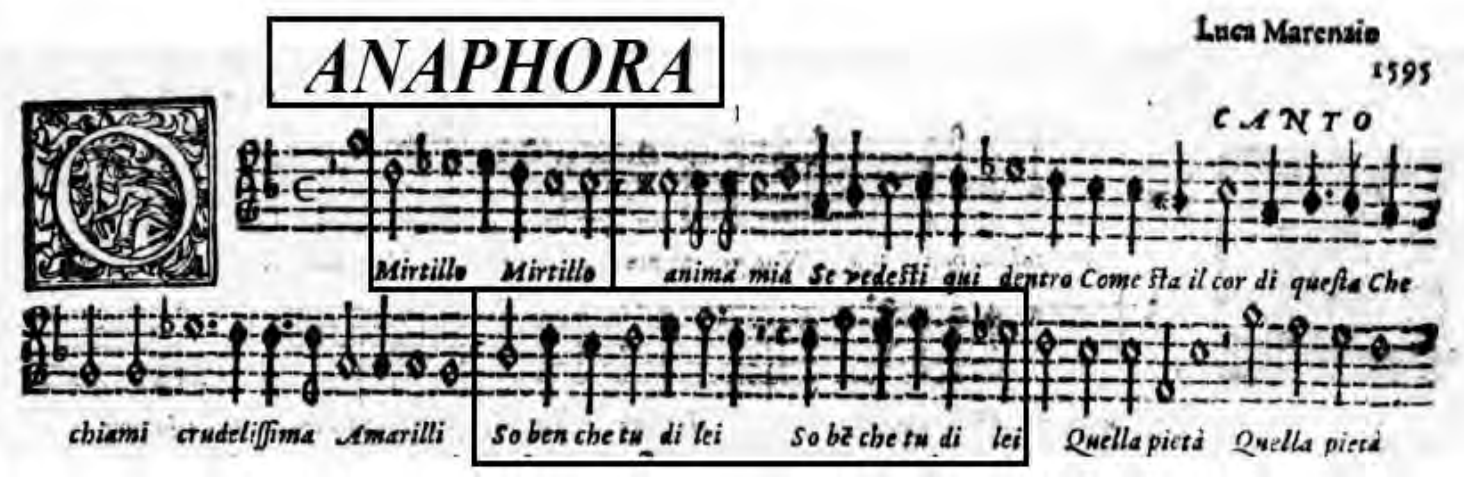

Exemplo 4-Madrigal O Mirtillo, Mirtillo, anima mia (1595) de Luca Marenzio.

Em outra obra desse mesmo compositor pode ser encontrado o uso da Metalepsis, a qual pode ser definida de duas formas: a primeira é quando um consequente pode ser entendido por meio de seu antecedente (UNGER, 2003, p.135); a segunda embasada em Burmeister consiste num tipo de fuga onde duas melodias são alternadas na composição (BARTEL, 1997, p.321). Veja-se os modos nos exemplos 5 e 6 , a seguir. 

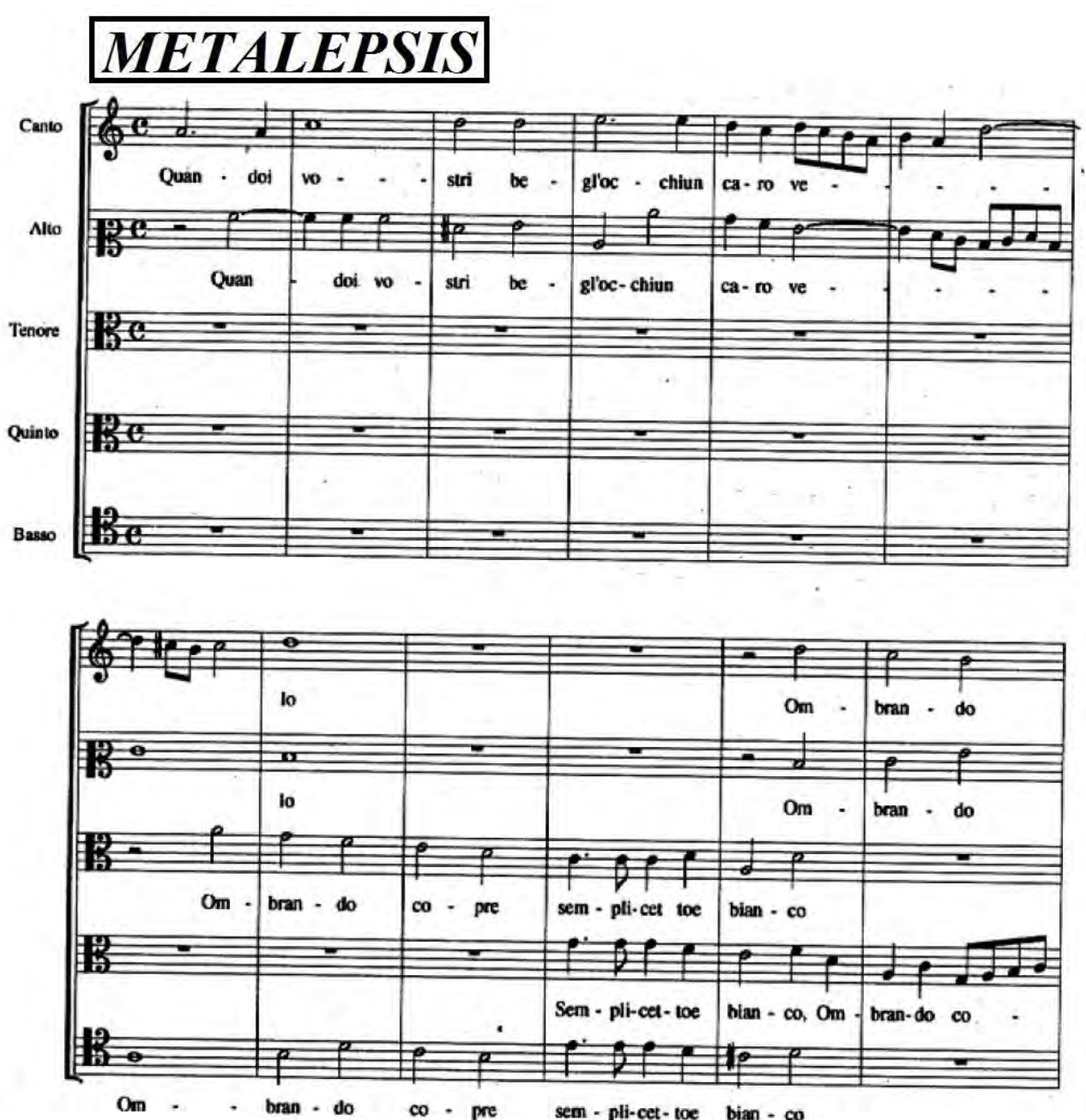

Exemplo 5-Quando vostri bel'iocchi um caro velo de Luca Marenzio (LÓPEZ CANO, 2000, p.234; UNGER, 2003, p.203).

\section{METALEPSIS}

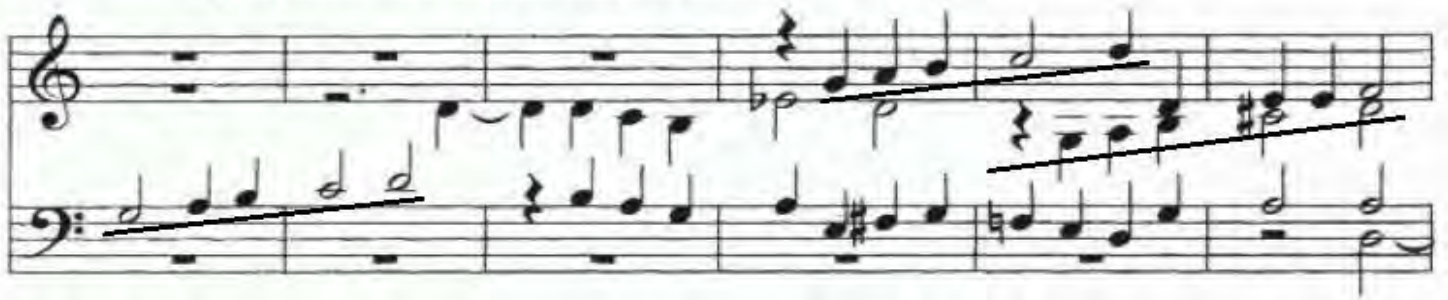

Exemplo 6-Segunda forma de Metalepsis de acordo com Burmeister (BARTEL, 1997, p.322).

Nesse trecho musical, nota-se que há repetição de fragmento musical com notas diferentes, transportado na mesma voz, caracterizando, assim, o emprego da Synonymia. 


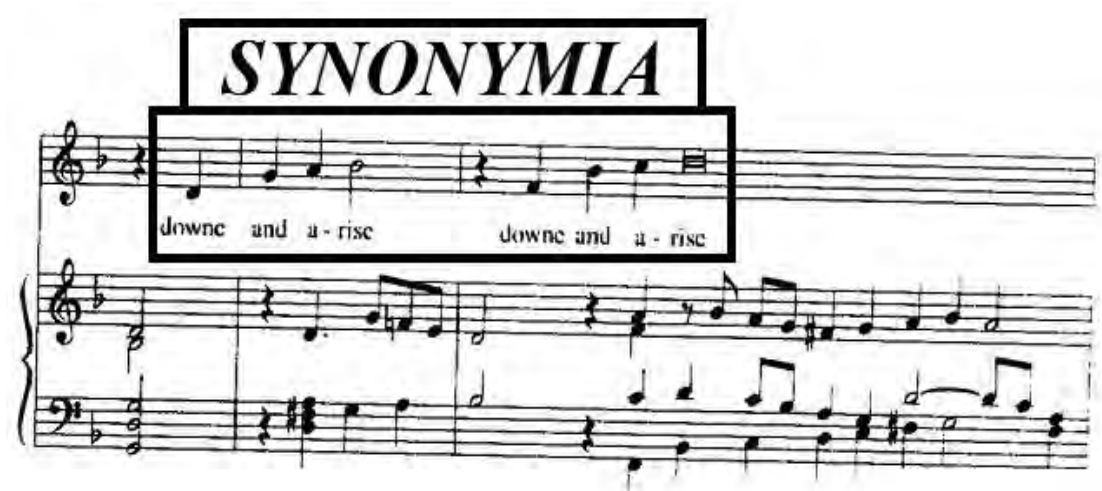

Exemplo 7-Sorrow sorrow stay do Segundo livro de canções (1600) de John Dowland (LÓPEZ CANO, 2000, p.211).

Examina-se nesse excerto, a figura da Gradatio, a qual repete em sequência as notas.

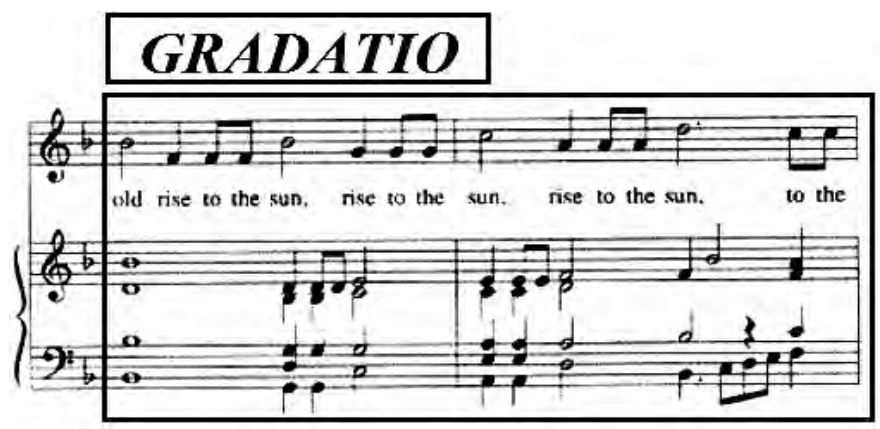

Exemplo 8-Cease these false sports; A Pilgrimes Solace (1612) de John Dowland (LÓPEZ CANO, 2000, p. 212).

É observável, nessa ária de John Dowland, a utilização da Catabasis, a qual expressa o afeto de tristeza, através da expressão: Never may my woes (Nunca mais meus sofrimentos).

\section{CATABASIS}

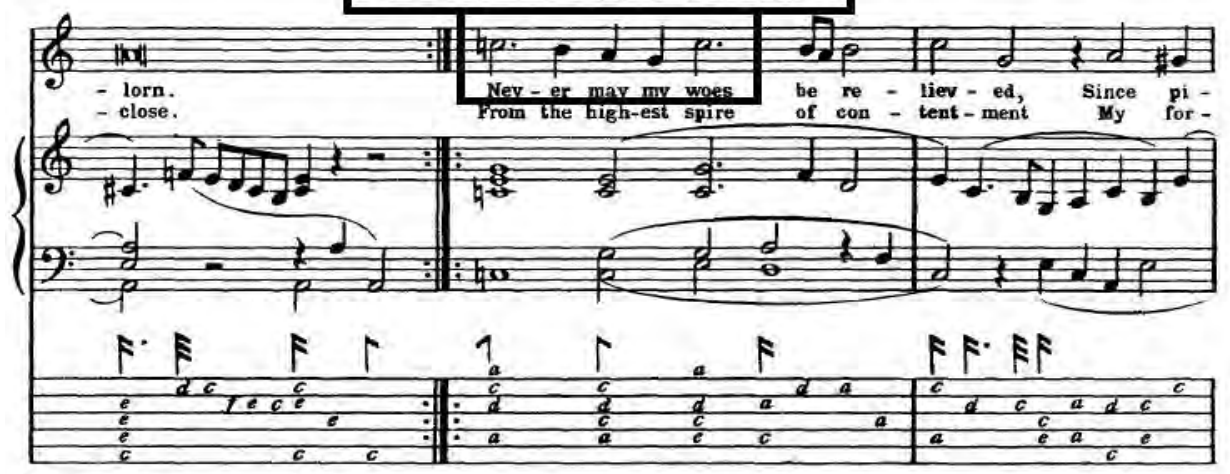

Exemplo 9-Flow, my tears (1600) de John Dowland (BURMESTER, 2008, p.172). 
Verifica-se no presente exemplo, a utilização da figura Paronomasia ${ }^{47}$ que, segundo Scheibe, "É a repetição de uma ideia melódica com as mesmas notas, porém com alterações ou adições para ressaltar o texto" (BUELOW, 2001, p.264).

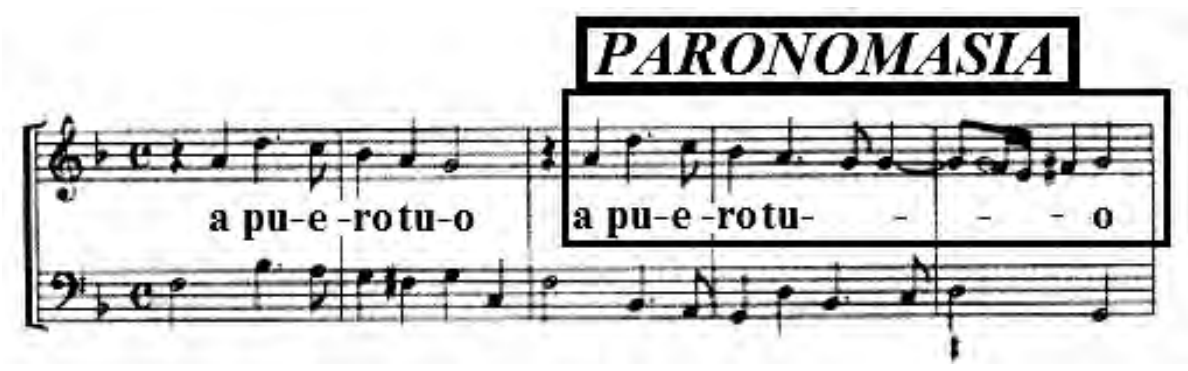

Exemplo 10-Exaudi-me, Cento Concerti Ecclesiastici (1602) de Ludovico Viadana (BUELOW, 2001, p.264).

Nesse exemplo, tem-se, na obra de Monteverdi, o emprego da Ecphonesis, a qual é considerada por alguns tratadistas como uma Exclamatio, isto é, uma exclamação. Nesse caso, tal ênfase vai ao encontro da definição de Vogt: "Ecphonesis seria como uma exclamação, por exemplo, "Oh, que dor"!" (BARTEL, 1997, p.268).

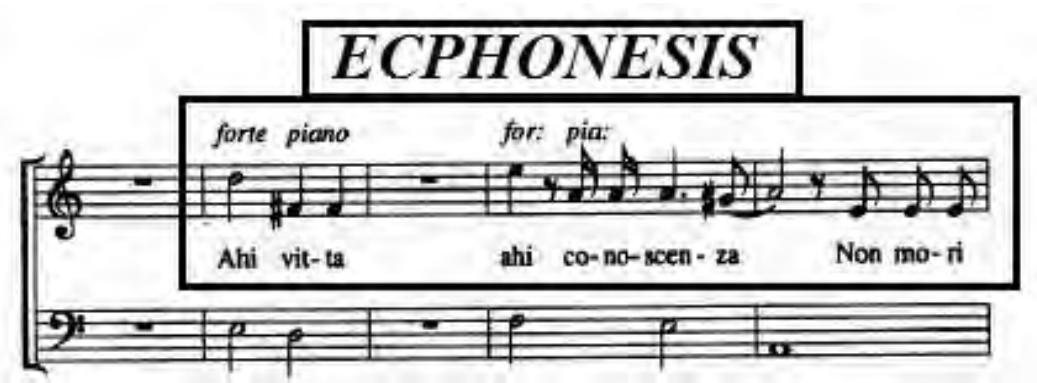

Exemplo 11-Combattimento de Tracredi et Clorinda: Madrigal Guerrieri et Amorosi (1638) de Claudio Monteverdi.

Verifica-se o emprego da Superjectio que ocorre quando uma nota é colocada numa altura mais próxima para uma consonância ou dissonância. Em outras palavras, geralmente quando as notas naturalmente descem por segundas.

\footnotetext{
${ }^{47} \mathrm{Nas}$ análises retórico-musicais dos compositores da música colonial brasileira, será realizado maior detalhamento sobre os elementos e figuras, além das citações dos tratadistas.
} 


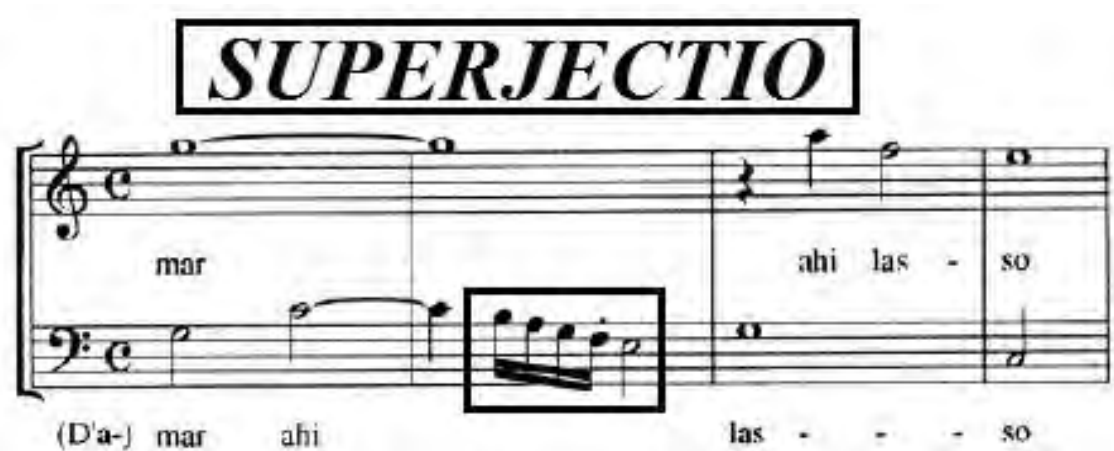

Exemplo 12-Cruda Amarilli (1605) de Claudio Monteverdi (LÓPEZ CANO, 2000, p.221).

Abaixo, nota-se outra obra de Monteverdi e o uso da Anticipatio, que é uma dissonância forte ocasionada por uma ou várias notas que pertencem à estrutura harmônica seguinte (BARTEL, 1997, p.192).

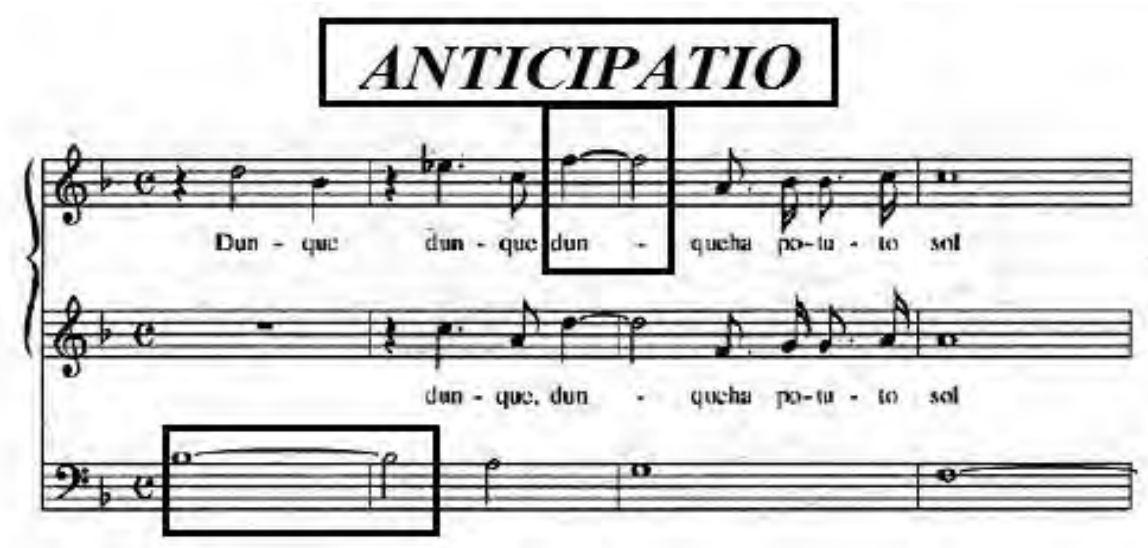

Exemplo 13-Ohimè dove il mio bem (1619) de Claudio Monteverdi (LÓPEZ CANO, 2000, p.218).

A mesma figura pode ser examinada em Schütz.

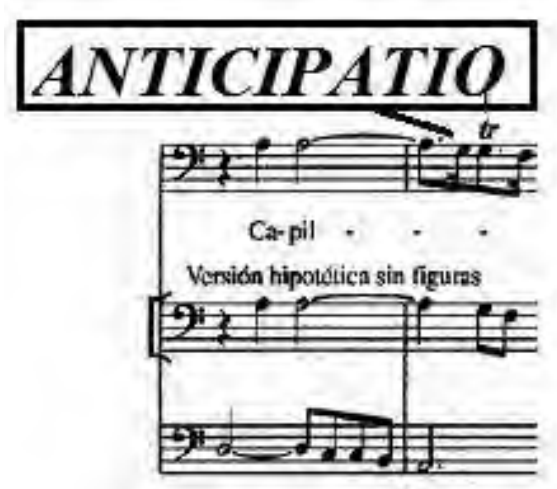

Exemplo 14-O quam tu pulchra es (ca.1629) de Heinrich Schütz. 
Buelow apresenta, no exemplo 15, a Anaphora que é uma figura de repetição melódica. Esse elemento retórico tem várias definições pelos tratadistas. Por exemplo, para Burmeister ela é um ornamento que repete as mesmas notas por meio de várias vozes diferentes. Já, Thuringus a define como uma repetição continuada apenas no Baixo. Por fim, Kircher sublinha que sua aplicação ocorre quando uma passagem é frequentemente repetida com ênfase (BARTEL, 1997, pp.187-188).

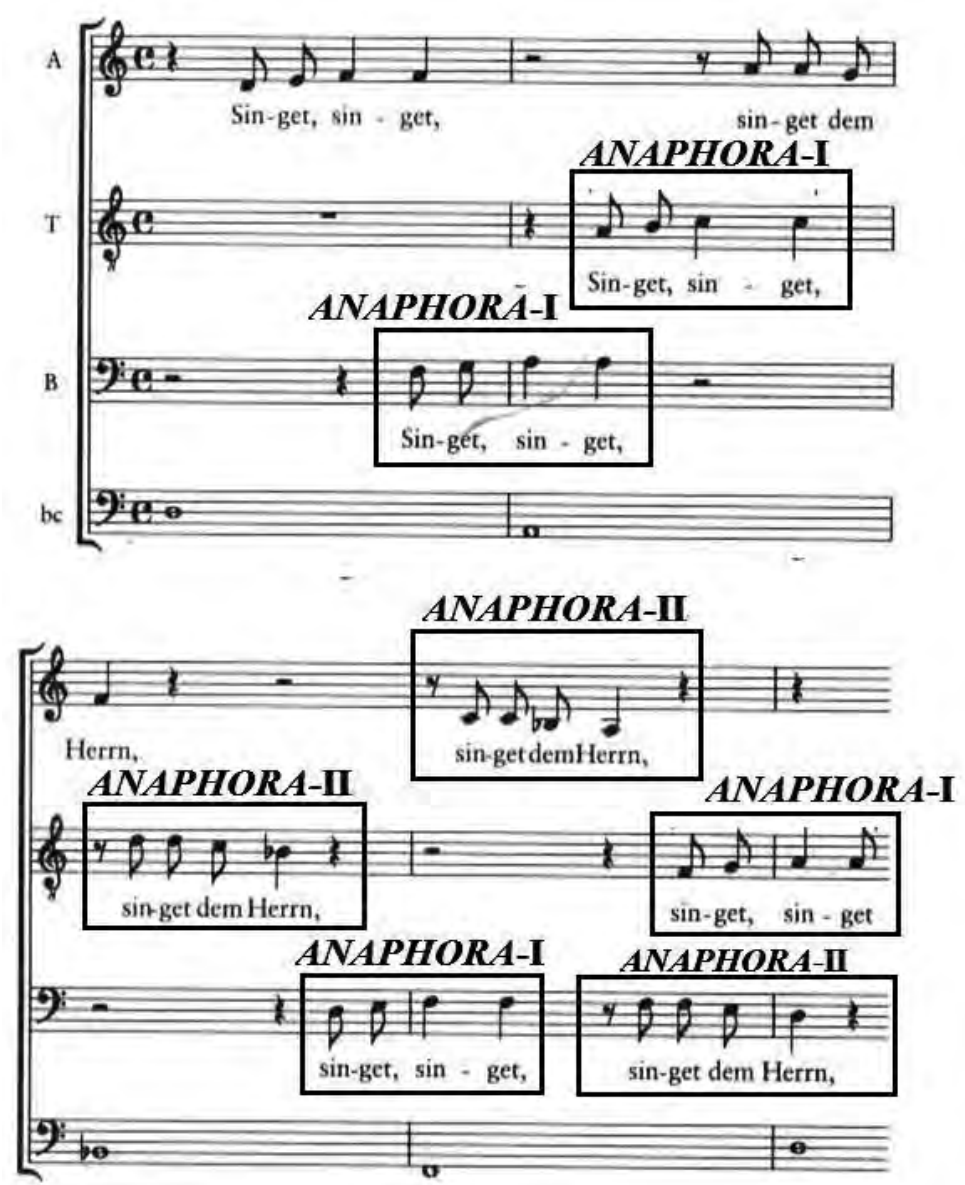

Exemplo 15-Freuet euch des Herren ihr Gerechten; Symphoniarum Sacrarum- $2^{\mathrm{a}}$ Parte (1647) de Heinrich Schütz (BUELOW, 2001, p.264).

Nesse excerto musical, pode-se verificar o emprego de três figuras de repetição melódica: Polyptoton, o qual repete as mesmas notas em alturas diferentes, Palilogia, repetindo as mesmas palavras e notas e, por fim, a Anaphora, a qual, segundo Thuringus, reitera somente a linha melódica do baixo (BARTEL, 1997, p.188). 


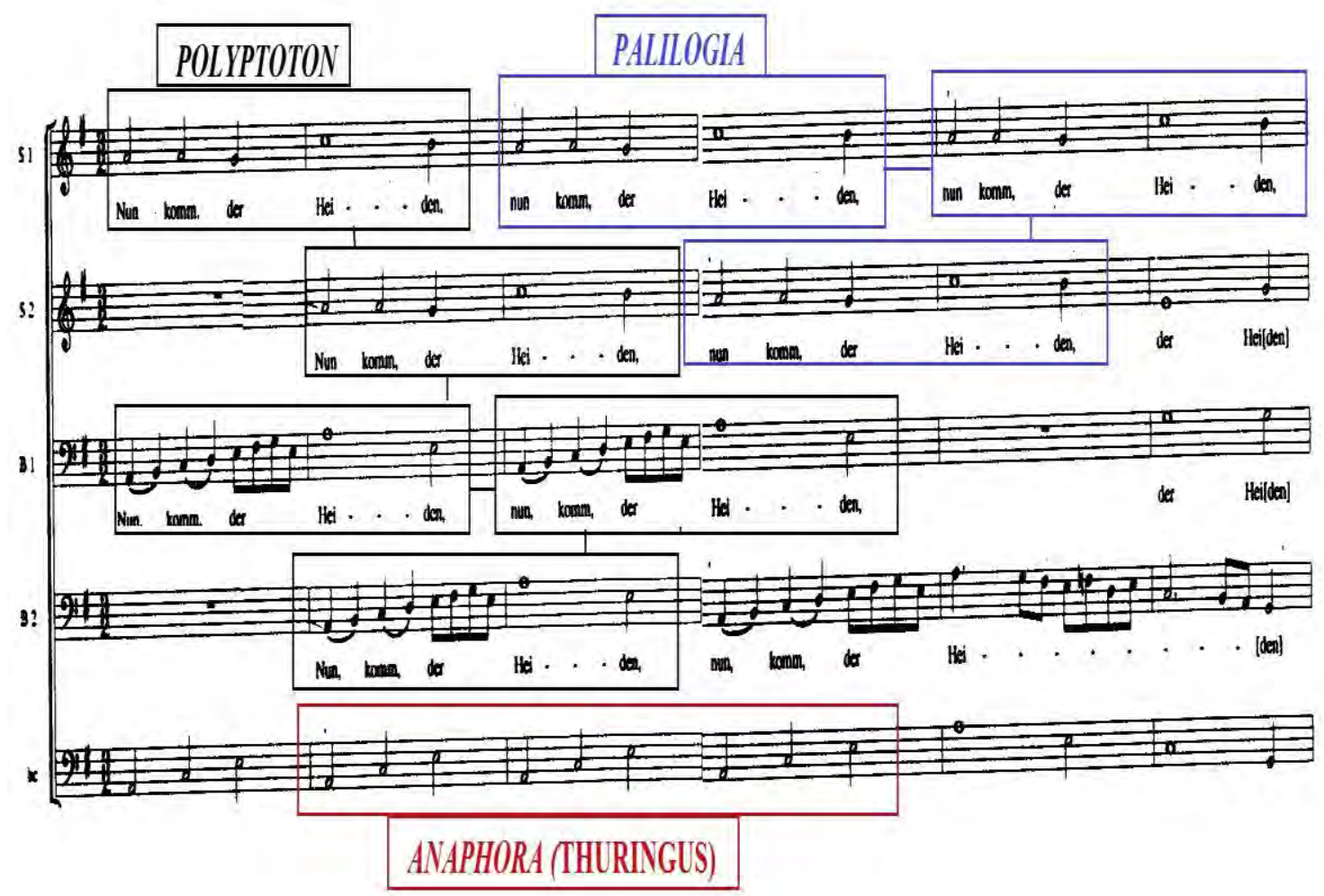

Exemplo 16-Num komm, der Heider Heiland; Kleine geistliche Concerte (1636) de Heinrich Schütz (BUELOW, 2001, p.265).

Observa-se, abaixo, a aplicação da Interrogatio, gerada em consonância às pausas, através da repetição enfática da indagação: Herr, bin ichs?.

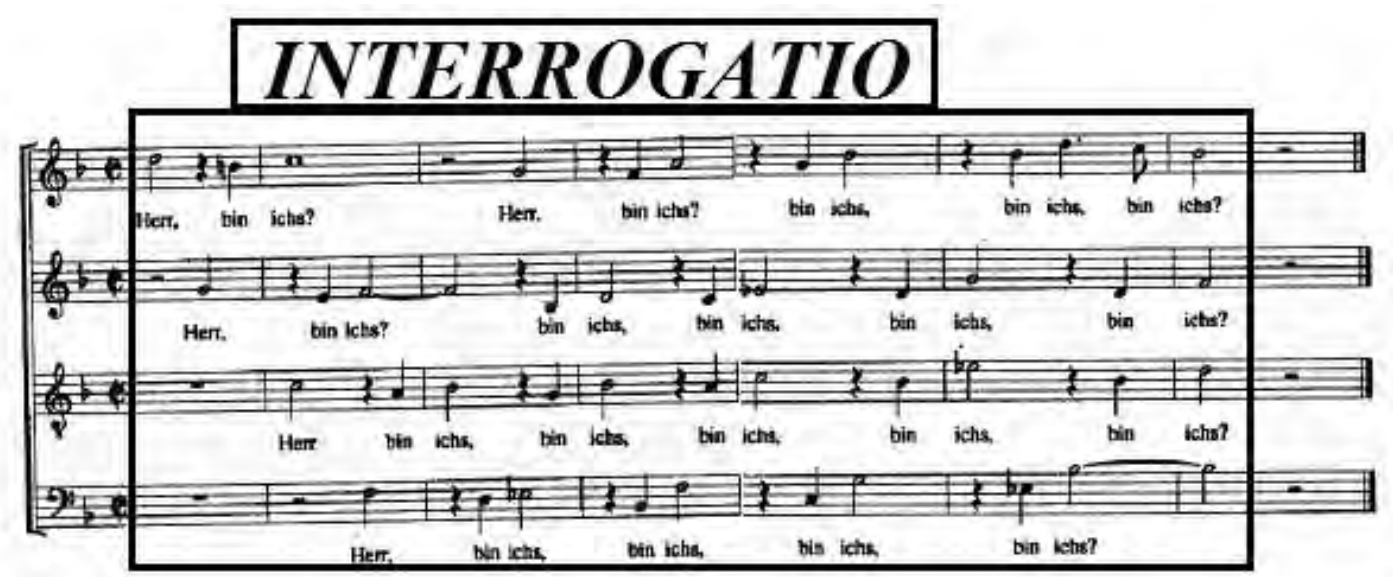

Exemplo 17-Paixão Segundo São Mateus de Heinrich Schütz (BUELOW, 2001, p.267).

No primeiro ato da primeira cena da ópera Amadis de Lully, a pesquisadora Leslie Ellen Brown localiza o emprego do Saltus Duriusculus, ou 
seja, um salto dissonante que pode ocorrer em uma sexta, sétima e até em quinta diminuta ascendente ou descendente ${ }^{48}$.

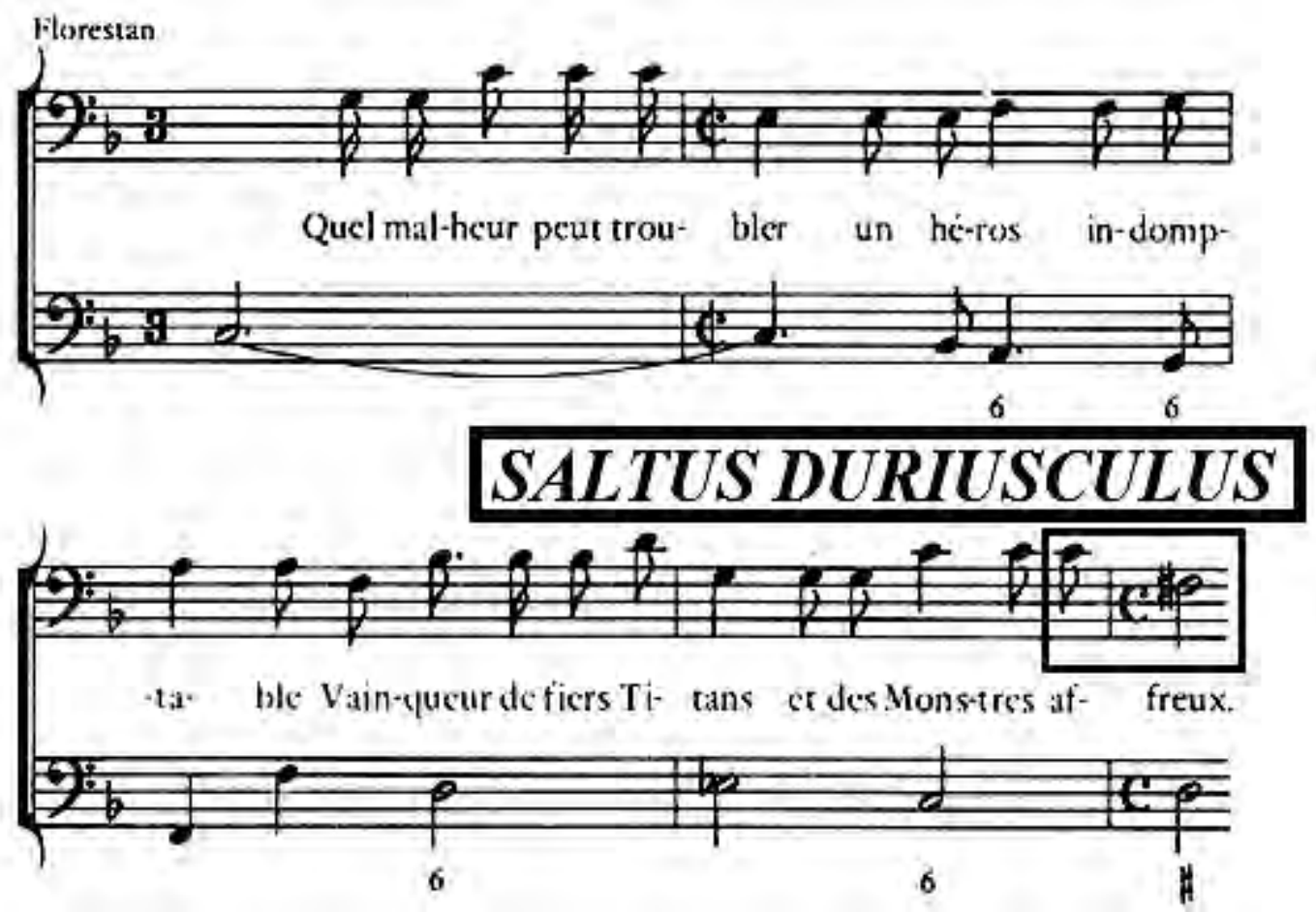

Exemplo 18-Amadis, Act I, scene 1 (1684) de Jean-Baptiste Lully (BROWN, 1980, p.112).

Examina-se, nesse exemplo, o Exordium da Passacaille, da Ópera Armide, de Lully.

\footnotetext{
${ }^{48} \mathrm{~A}$ diferença do Saltus Duriusculus para o Passus Duirusculus é que a primeira figura acontece um salto inesperado intervalar de quinta ou mais, já a segunda figura ocorre numa passagem cromática.
} 
5-2 Passacaille (EXORDIUM)
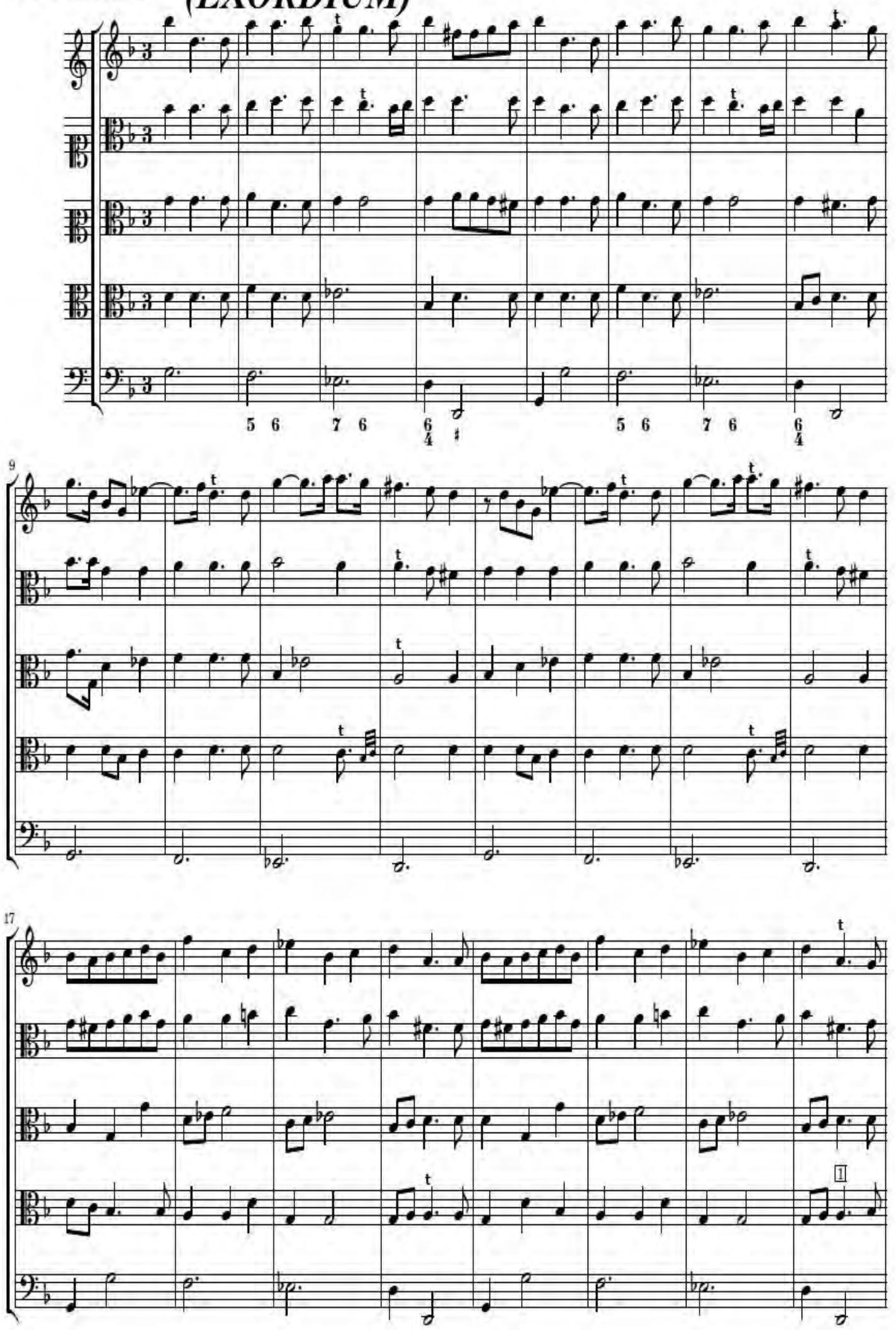

Exemplo 19-Passacaille-Armide (1686) de Jean-Baptiste Lully (OKAMOTO, 2012, p.14). 
Observa-se a figura da Enumeratio, que é a sucessão ou enumeração do mesmo motivo ou elemento dentro da mesma unidade musical.

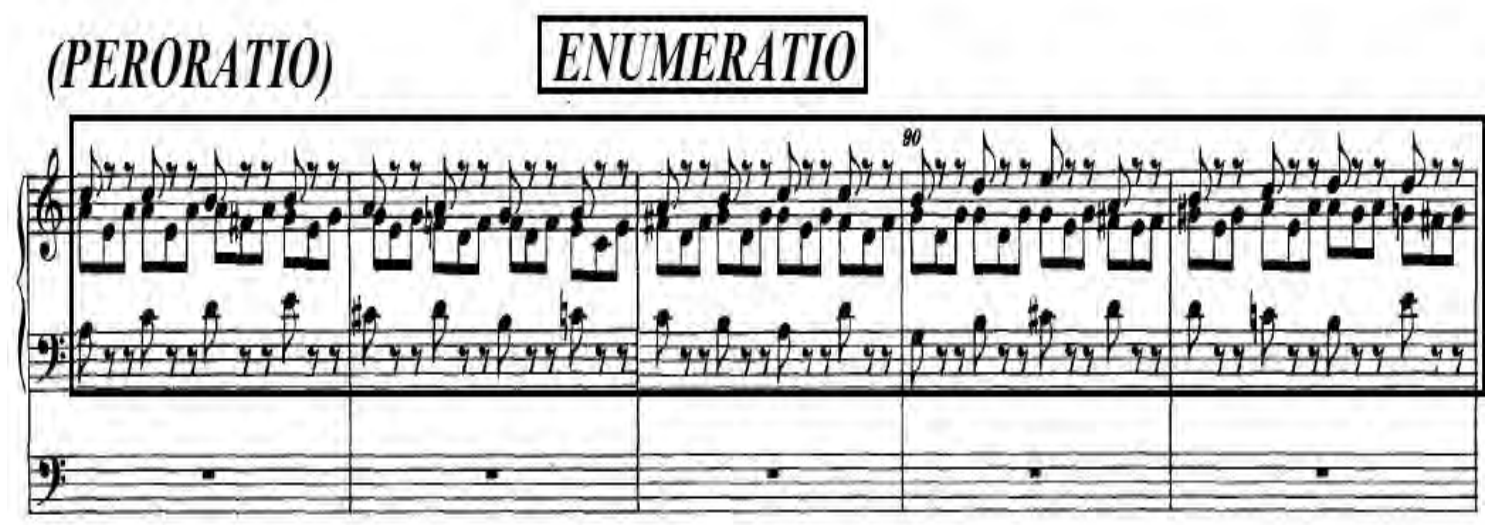

Exemplo 20-Prelúdio e Fuga em Dó Maior Bux WV 136 de Dietrich Buxtehude.

De acordo com Johann Walter, o Salto Semplice: "é uma extensão de um silábico através de um intervalo saltando" (BARTEL, 1997, p.380).

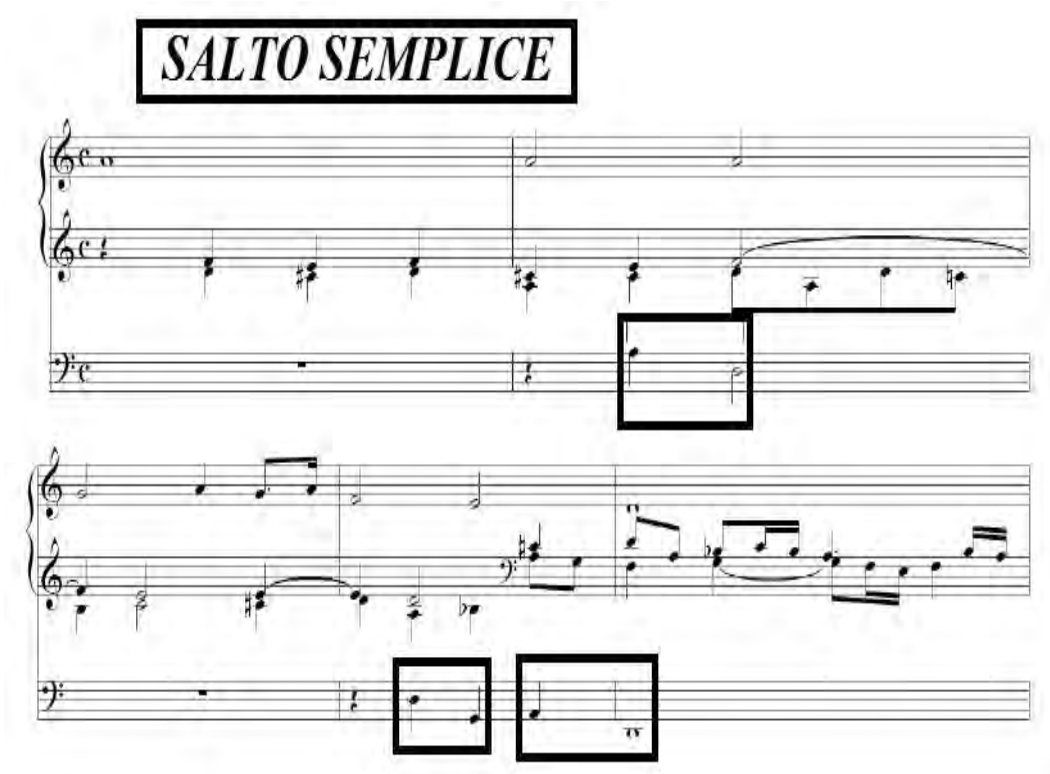

Exemplo 21-Durch Adams Fall ist ganz verdert (BuxWV183) de Dietrich Buxtehude (THORLEY, 2015, p.56).

Examina-se, nessa obra de Buxtehude, a terceira parte da Dispositio, ou seja, a Propositio. 

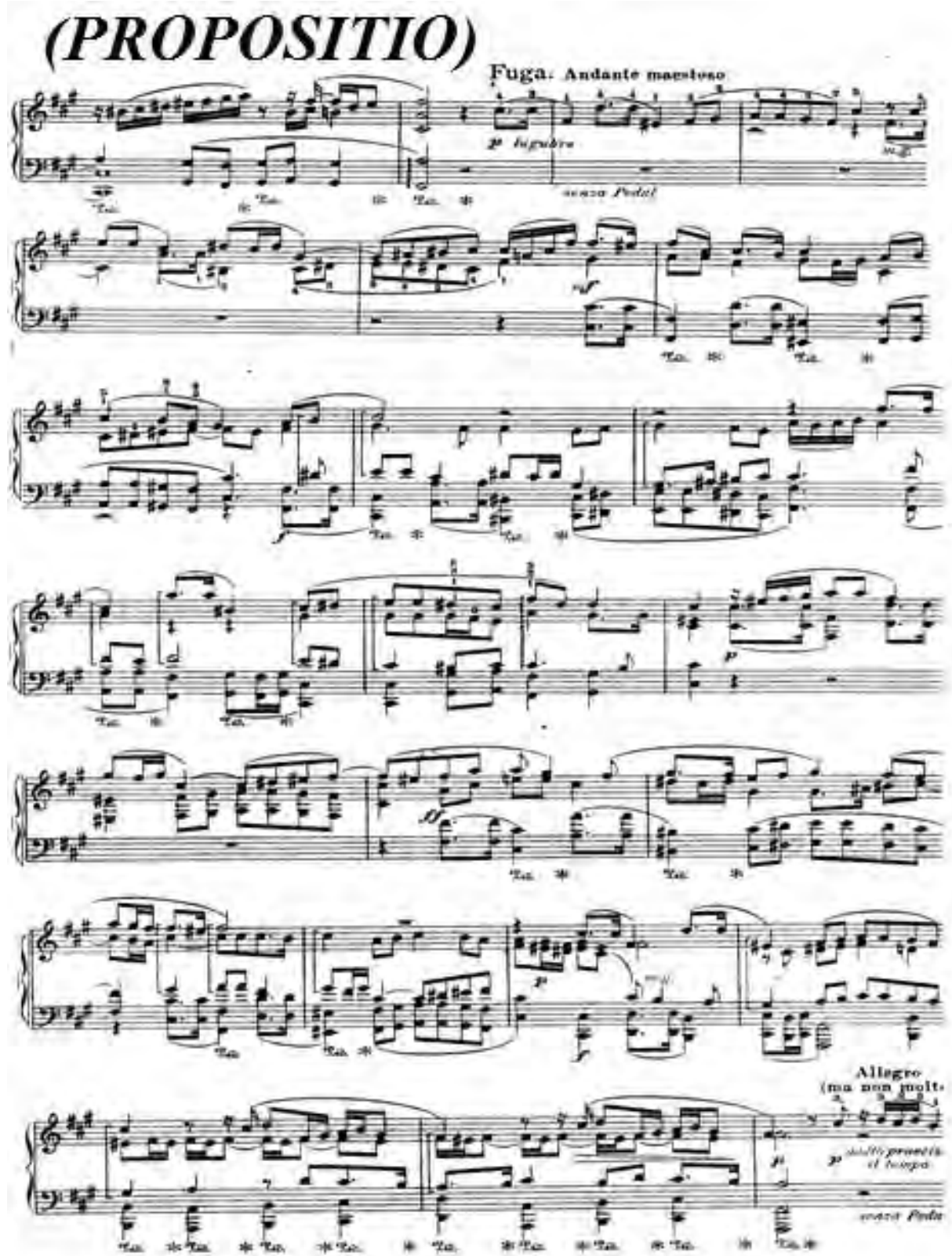

Exemplo 22-Prelúdio em Fuga em Fá \# Menor-Bux-146 de Dietrich Buxtehude.

Nesse trecho da peça de Charpentier, verifica-se o uso da Heterolepsis que, segundo Bernhard, "é um salto ou movimento escalonado em uma dissonância, fazendo um efeito" (BARTEL, 1997, p.294; BUELOW, 2001, p.266). 


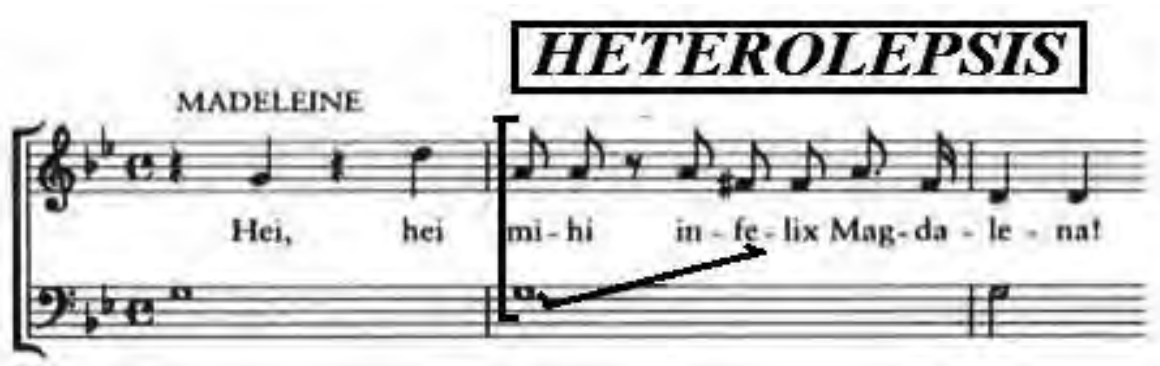

Exemplo 23-Dialogue entre Madeleine et Jésus de Marc-Antoine Charpentier (BUELOW, 2001, p.266).

Nesse excerto da peça de Purcell, pode-se constatar a passagem frequente como uma sequência, repetida com ênfase, caracterizando, assim, uma Anaphora.

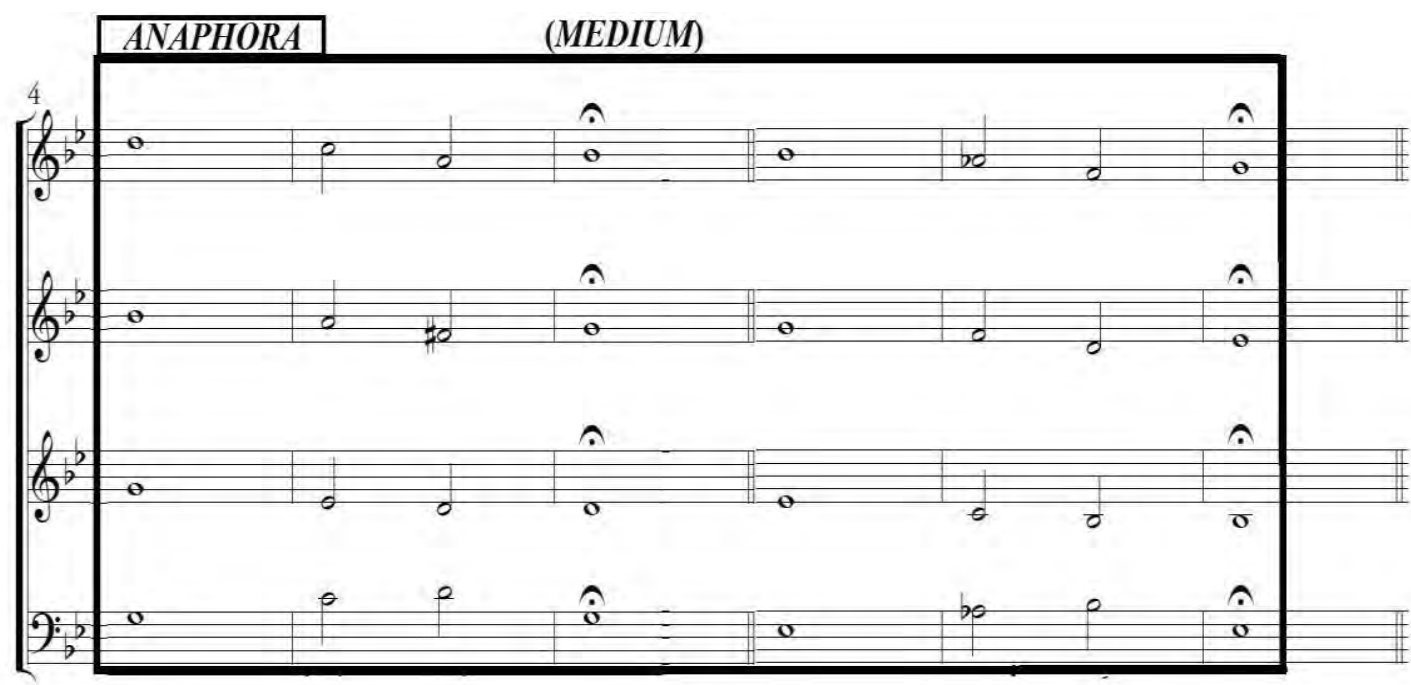

Exemplo 24-Música para o Funeral da Rainha Maria (1695) de Henry Purcell (OLIVEIRA; SOARES, 2012, p.426).

No exemplo 25, localiza-se o uso da Circulatio, onde uma linha melódica oscila ao redor de outra nota, formando, dessa forma, uma espécie de movimento ondulatório.

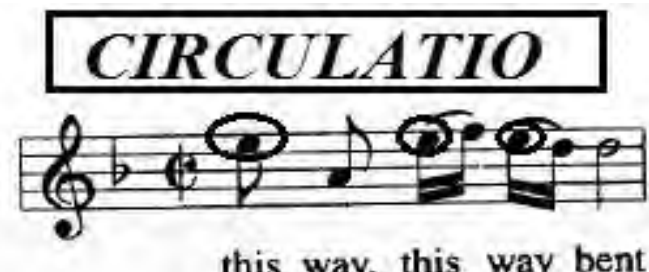

Exemplo 25-Rei Arthur de Henry Purcell (LÓPEZ CANO, 2000, p.216). 
No presente trecho musical, averigua-se o uso da Epizeuxis, a qual, de modo enfático, repete por quatro vezes a expressão Exsultate (Cantem alegremente).
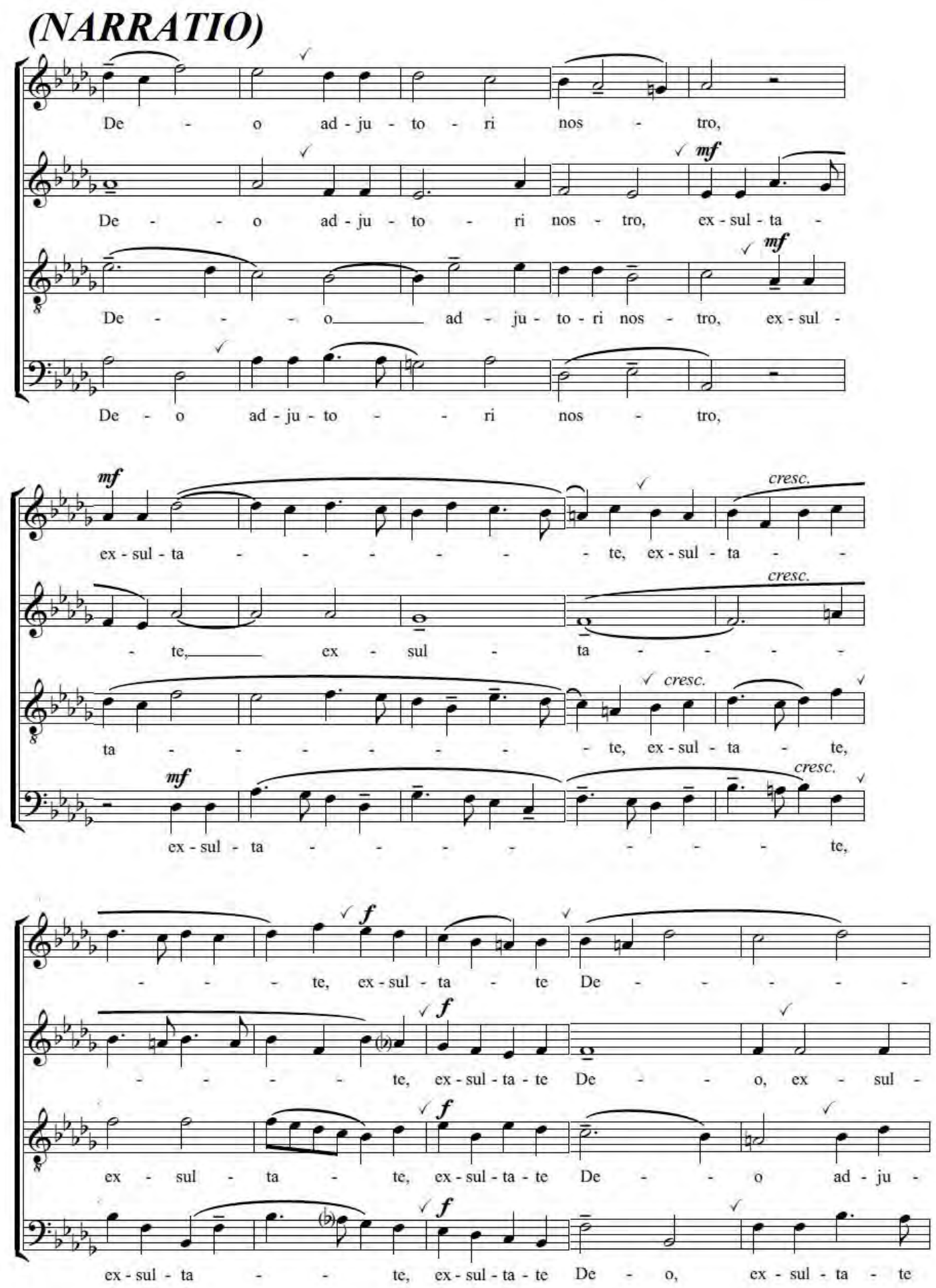

Exemplo 26-Exsultate Deo de Alessandro Scarlatti. 
No exemplo abaixo, observa-se o emprego da Narratio, além das diversas figuras retóricas por parte de Vivaldi, tais como: Abruptio, que é uma quebra inesperada (interrupção) de uma frase ou passagem (CIVRA, 1991, p.192). Synaeresis, quando são cantadas duas notas em uma silaba ou viceversa (BARTEL, 1997, p.394; LÓPEZ CANO, 2000, p.199). Por fim, da Pausa, impondo um repouso e silêncio às vozes.

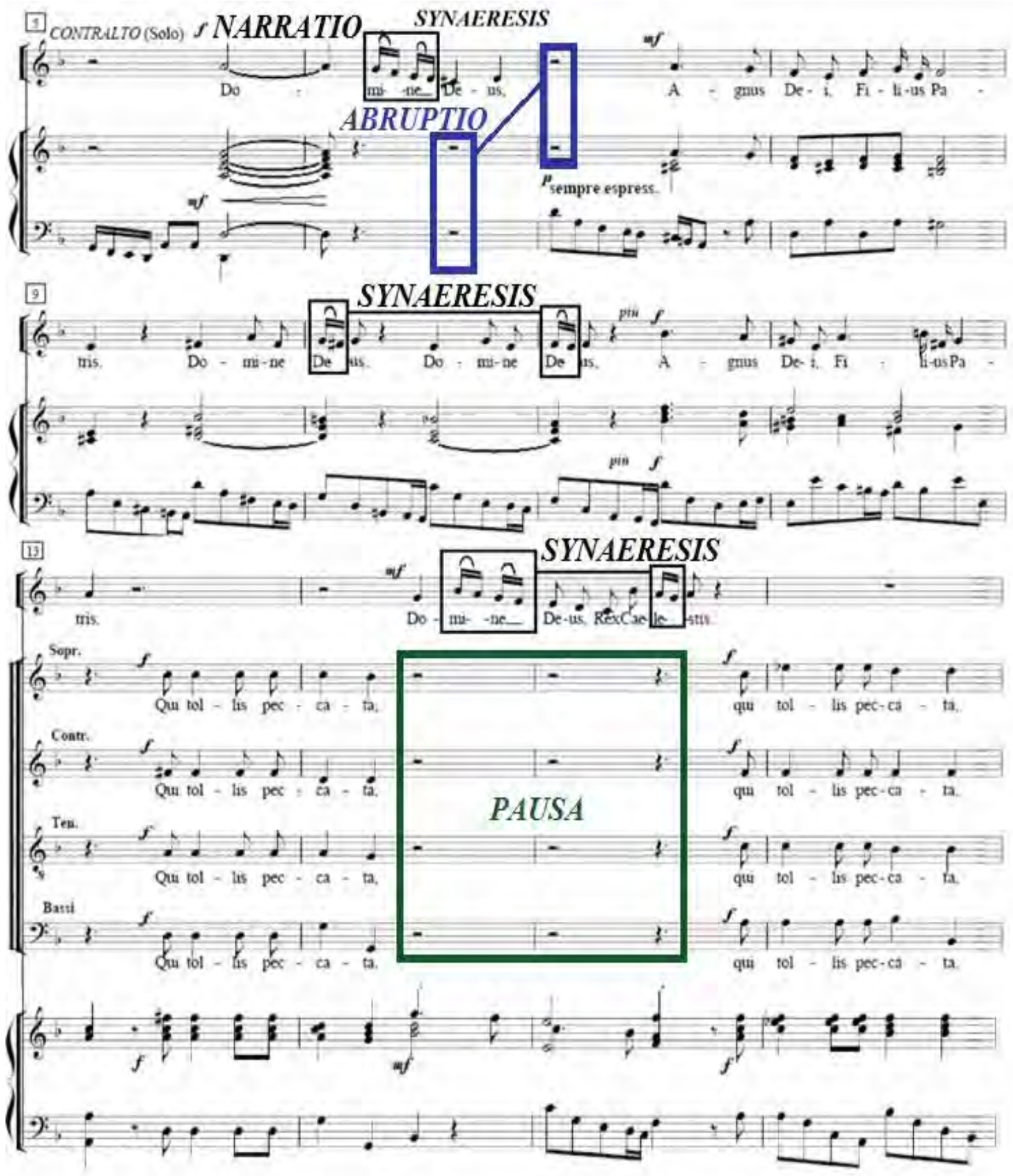

Exemplo 27-Domine Deus, Agnus Dei- do Gloria RV 589 (ca.1715/6) de Antonio Vivaldi (RODRIGUES, 2006, p.42). 
Na mesma obra de Vivaldi, a analista localiza a figura da Epizeuxis, que é uma repetição imediata com ênfase seja de notas, palavras, frases, entre outros.

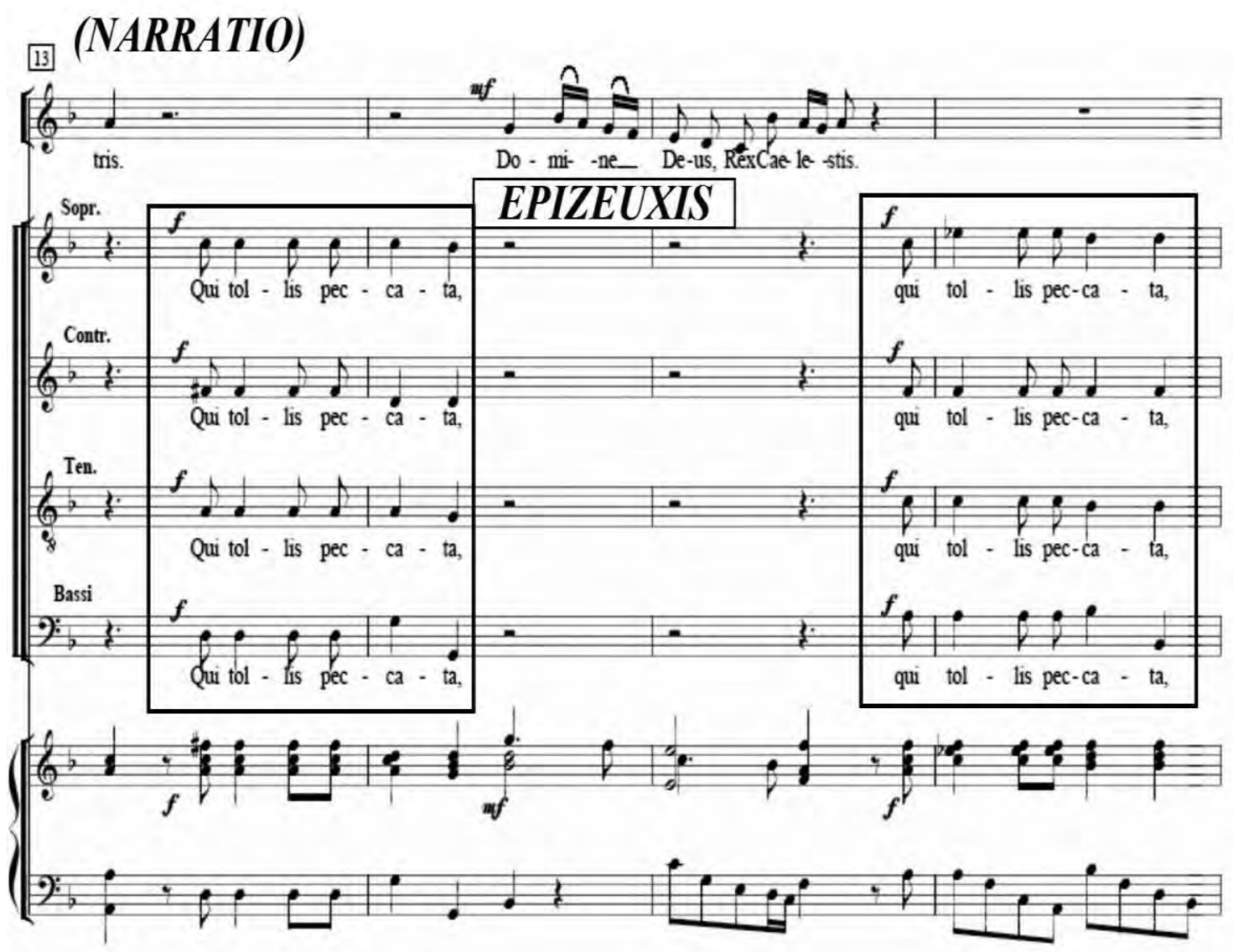

Exemplo 28-Domine Deus, Agnus Dei- do Gloria RV 589 (ca.1715/6) de Antonio Vivaldi (RODRIGUES, 2006, p.42).

Outro exemplo é o do tratado de Mattheson, onde ele faz uma exposição sobre duas maneiras de aplicar a Epizeuxis em uma composição.

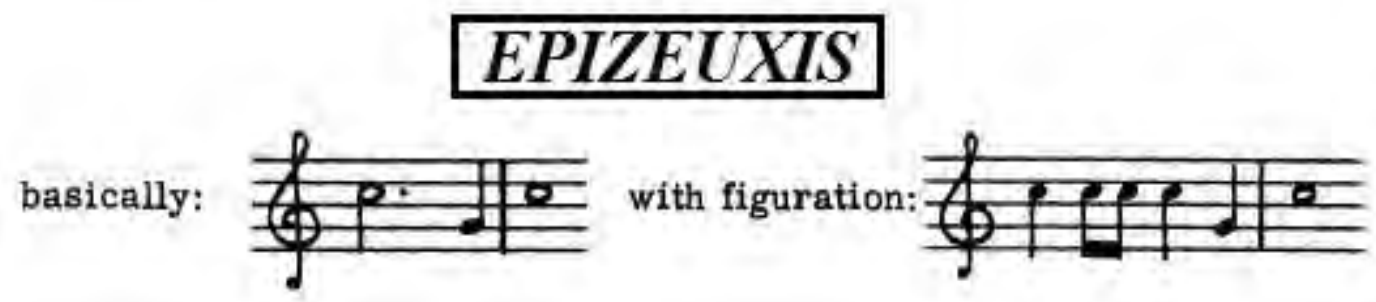

Exemplo 29-Epizeuxis no Der Vollkommene Capellmeister (1739) de Johann Mattheson (LENNEBERG, 1958, p.203). 
Novamente é localizada a figura da Anticipatio, porém, dessa vez em um trecho de uma das Sonatas de Telemann.

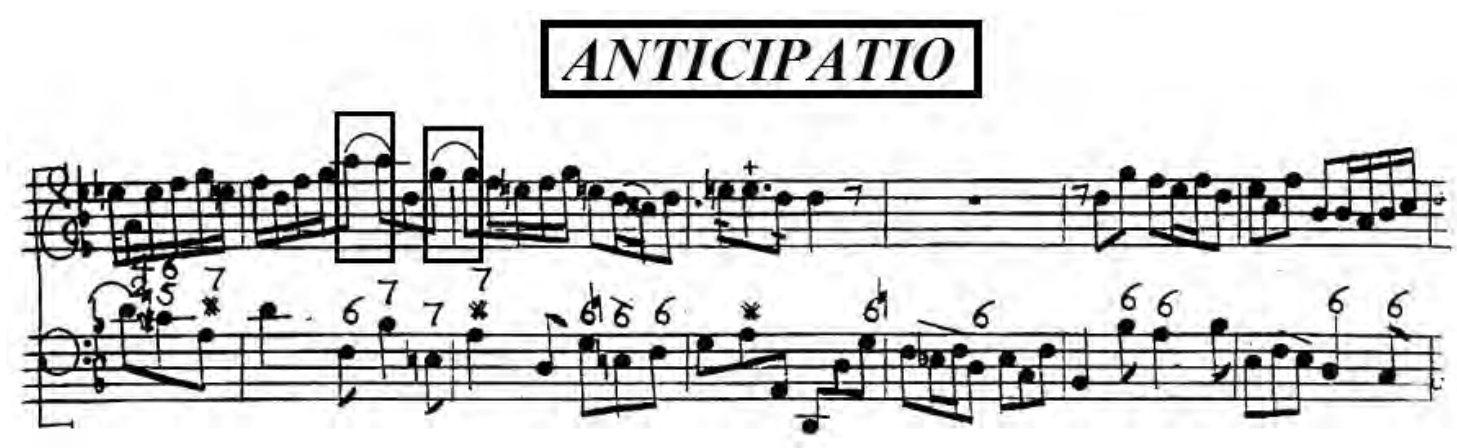

Exemplo 30-Sonata Medodiche №. 1 (1728) de Georg Phillip Telemann.

É tangível nessa parte da décima primeira variação das Variações Goldberg, o cruzamento das vozes o que configura um Metabasis.

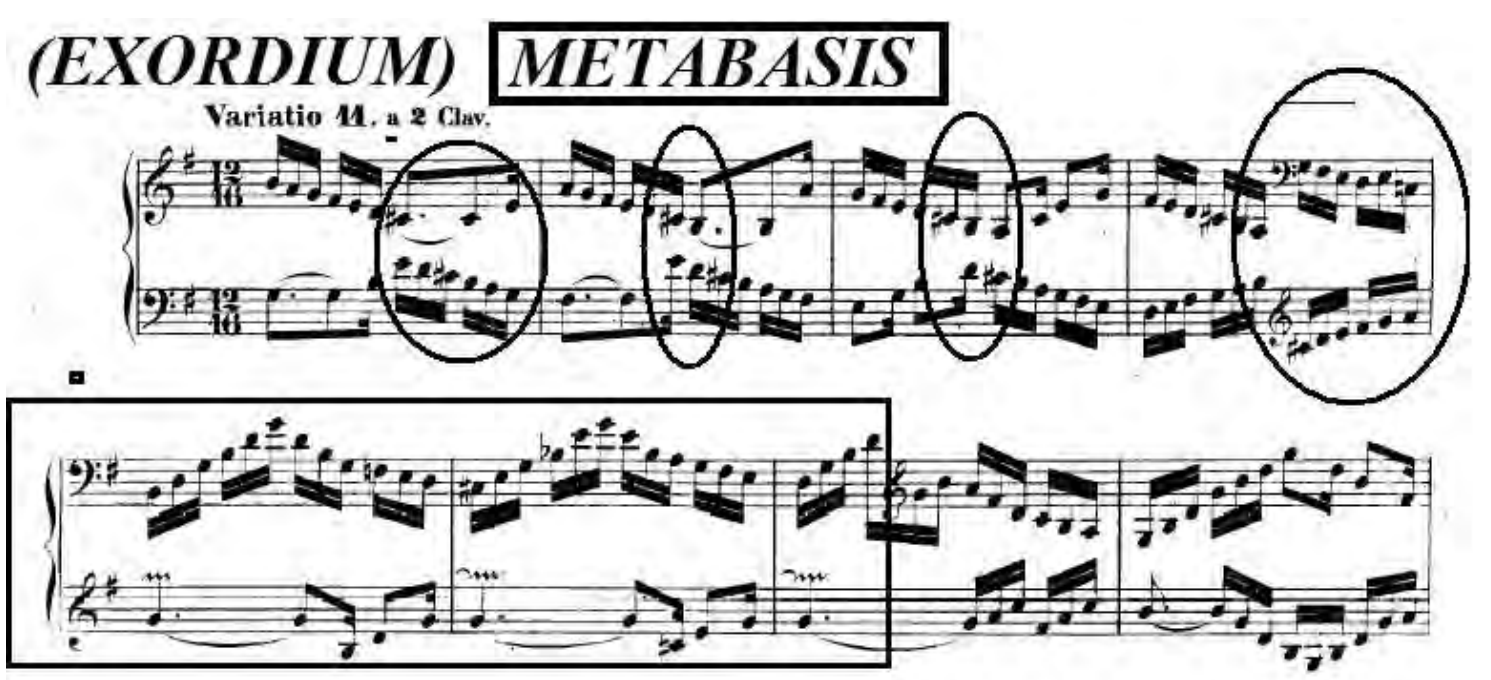

Exemplo 31-Variações de Goldberg №. 11 BWV 988 (ca.1741) de Johann Sebastian Bach.

Outra figura retórica encontrada em Bach é o Polyptoton que é uma repetição de uma passagem em alturas diferentes. 


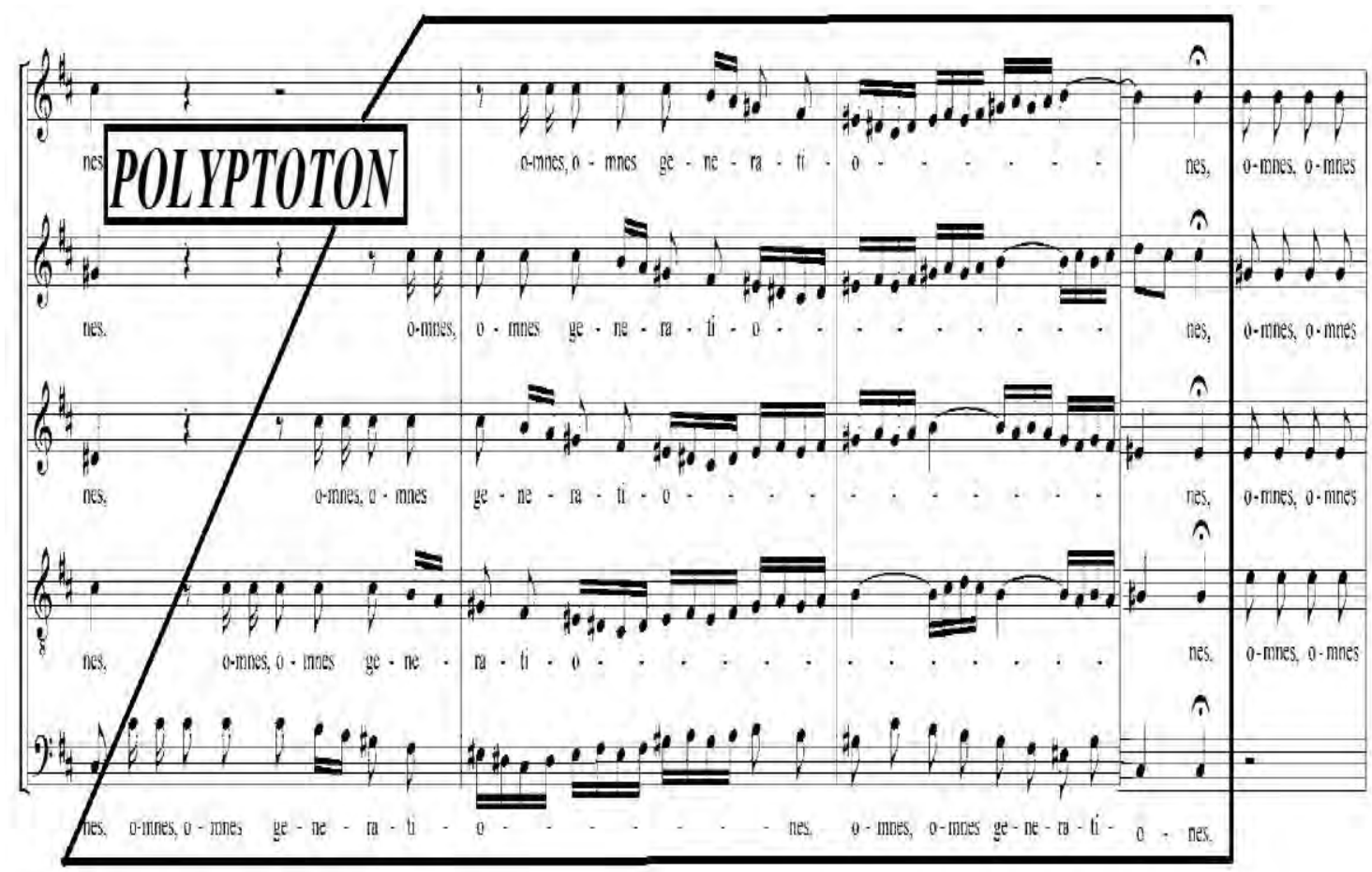

Exemplo 32- $4^{\circ}$ Movimento do Magnificat (ca.1723) de Johann Sebastian Bach (OLIVEIRA, 2006, p.364).

Ainda em Bach, tem-se o emprego da Gradatio, a qual repete, de maneira ascendente ou descendente, por graus conjuntos uma sequência de um mesmo fragmento musical.

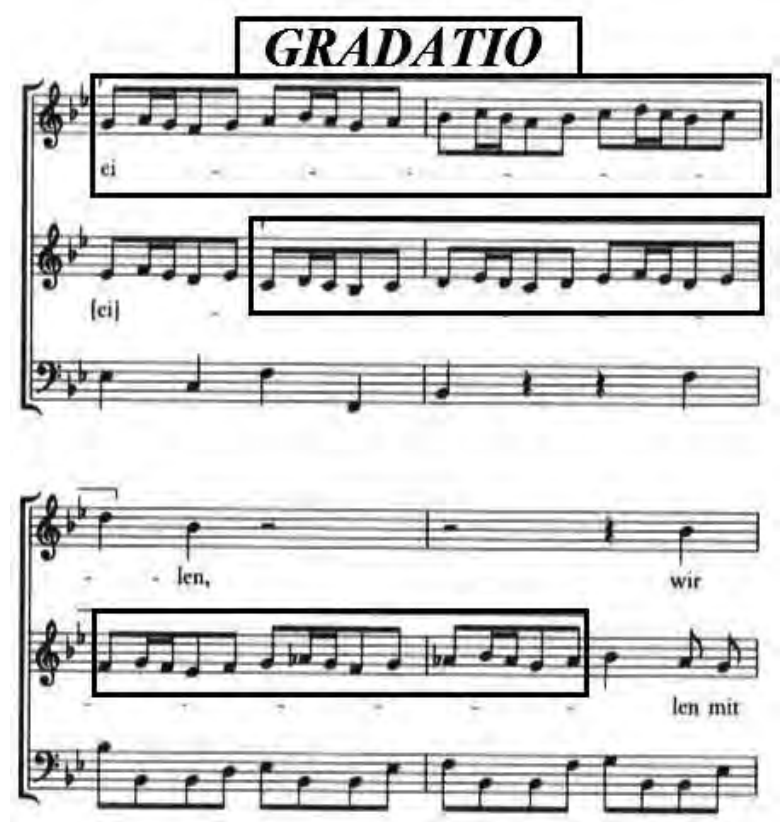

Exemplo 33-Cantata №.78- Jesu der du meine Sede, Wir eilen mit schwanthen, doch emsigen Schritten de Johann Sebastian Bach (BUELOW, 2001, p.264). 
Nota-se, nesse exemplo, o emprego da Circulatio e da Anaphora na repetição somente na linha do baixo, como define o tratadista Joachim Thuringus.

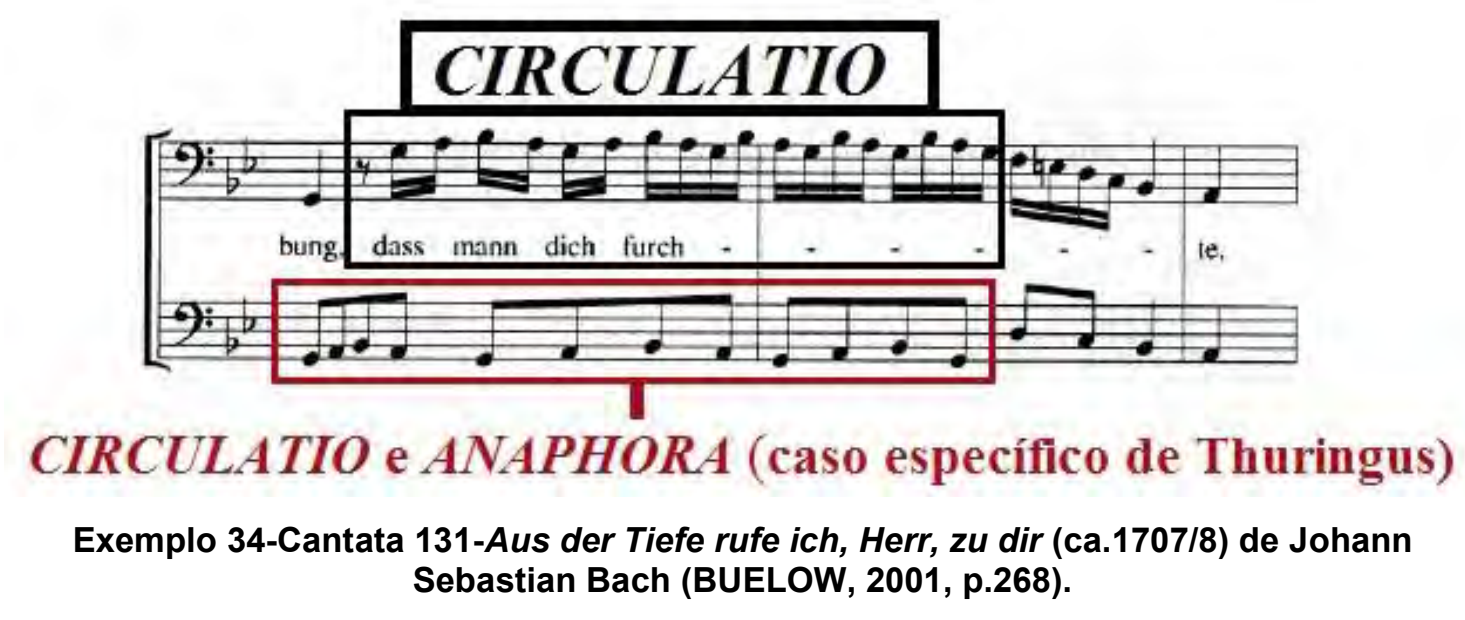

Na presente obra de Haendel há a repetição das mesmas notas e na mesma voz na parte instrumental, dessa forma, indicando o uso da Palilogia. Identicamente, na voz do solo como no acompanhamento uma passagem homofônica numa textura polifônica, em contraste aos compassos anteriores, o que é peculiar do Noema, como do elemento retórico da Confutatio. 


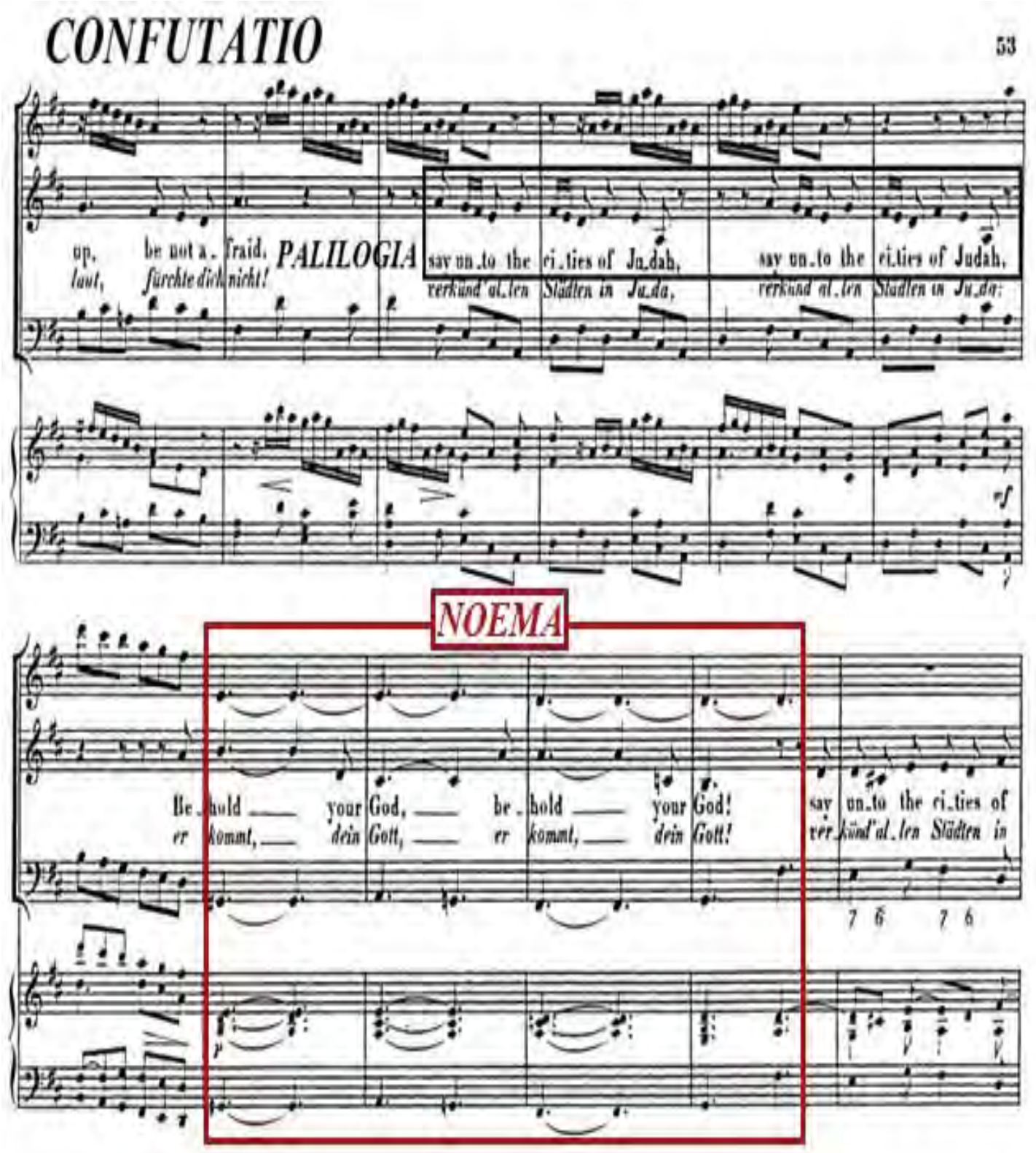

Exemplo 35-Ária O thou that tellest good tidings do Messias - HWV 56 (1741) de George Friedrich Haendel (SILVA, 2005, p.43).

$\mathrm{Na}$ conclusão do Aleluia, de Haendel, evidencia-se a aplicação da Palilogia, a qual ressalta a expressão King of Kings, and Lord of Lords (Rei dos reis, Senhor dos senhores). 


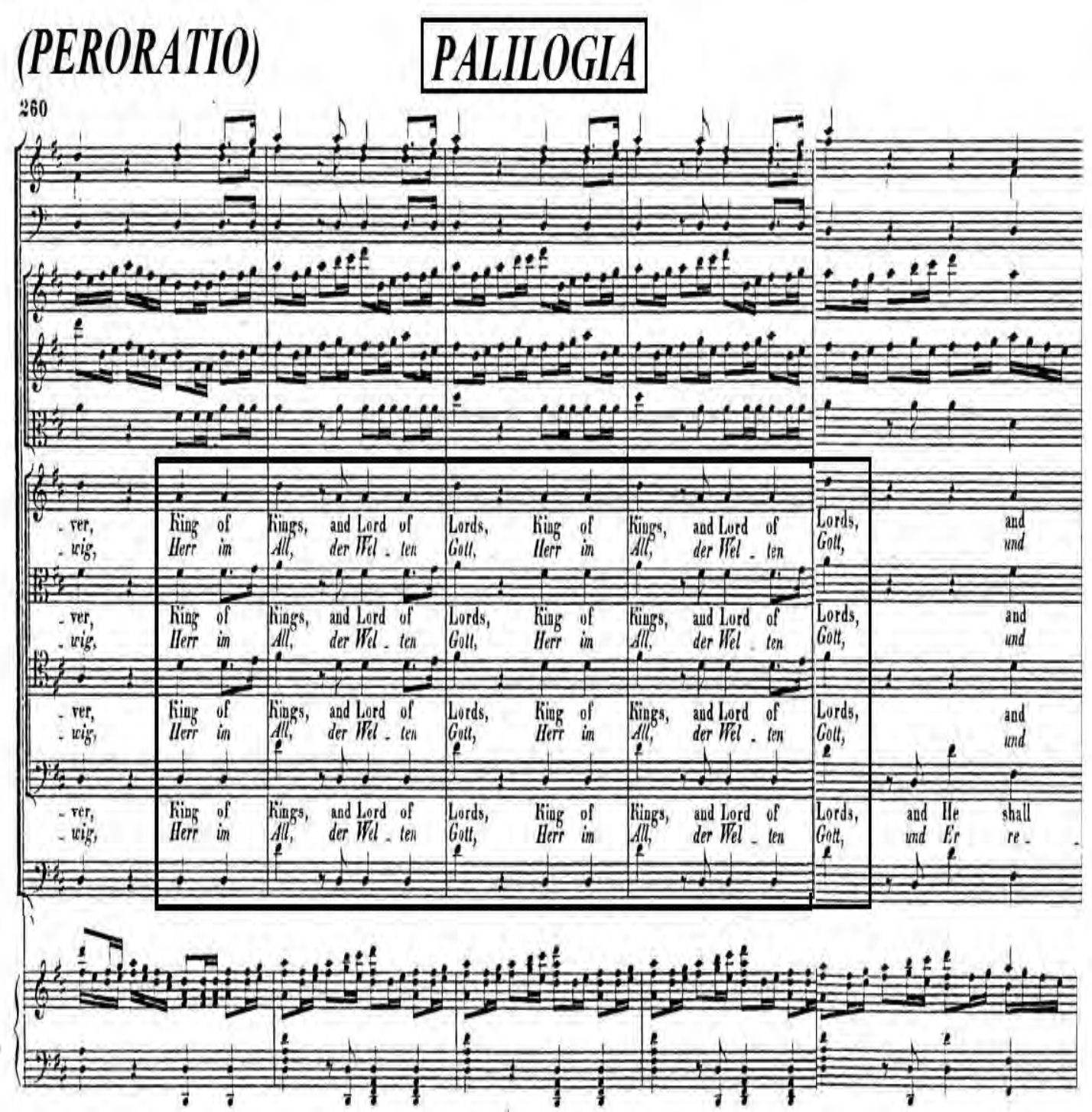

Exemplo 36-Aleluia do Messias HWV 56 (1741) de George Friedrich Haendel (KIFFER, 2015, p.90).

Vê-se no exemplo abaixo, no compasso 9, a rápida passagem escalar medindo uma oitava de extensão, desse modo caracterizando a figura da Tirata. 

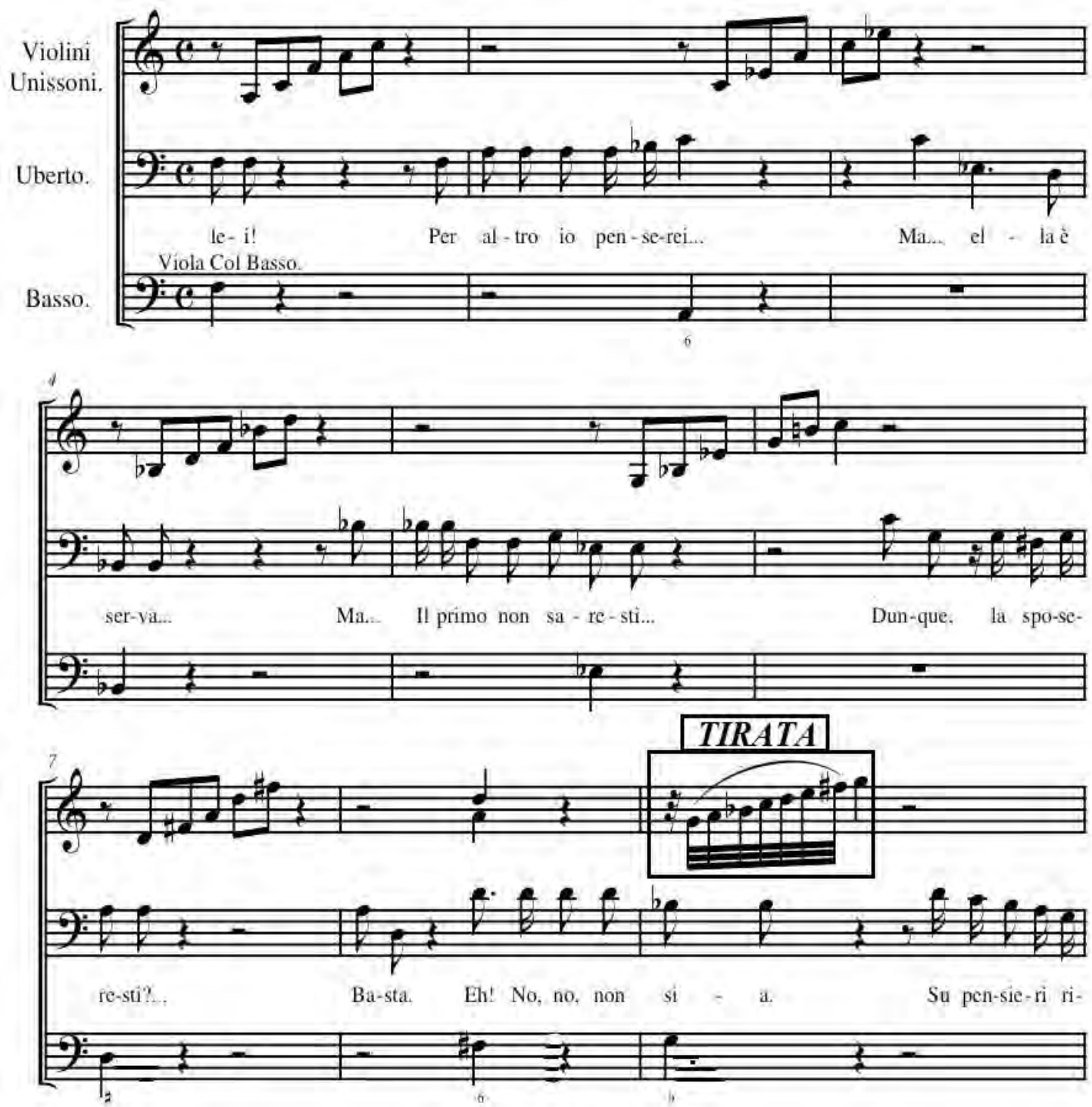

Exemplo 37-La Serva Padrona (1733) de Giovanni Battista Pergolesi (MAYS, 2012, p.97).

Na Fantasia em Sol Maior, de Carl Philipp Emanuel Bach, nota-se a utilização da Anaphora. 
Fantasia in G Minor

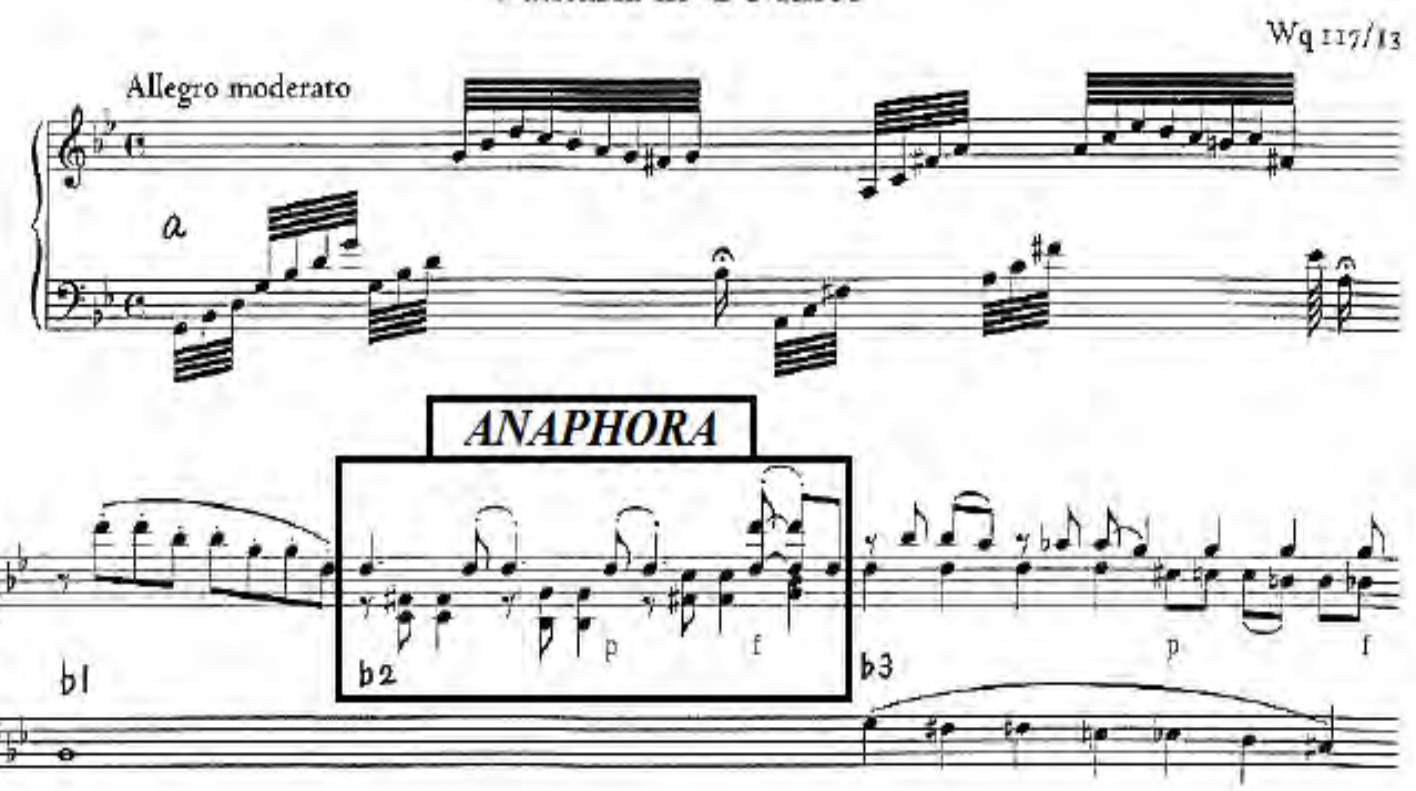

Exemplo 38-Fantasia Wq.117-13 em Sol Menor (1770)- Carl Philipp Emanuel Bach (YAMAMURA, 2013, p.25).

Na mesma peça, Kaoru Yamamura examina a aplicação, por parte do compositor, de três figuras retóricas: Suspiratio, que é o efeito como de um suspiro entre pausas, Synaeresis (já citada e referenciada em exemplo anterior) e Pathopoeia, que são movimentos por semitons para expressar afetos impetuosos, por exemplo, de tristeza, angústia, e alguns estudiosos como Peacham afirmam que a mesma pode ser utilizada para expressar melancolia e até alegria (BARTEL, 1997, p.357; BUELOW, 2001, p.267).

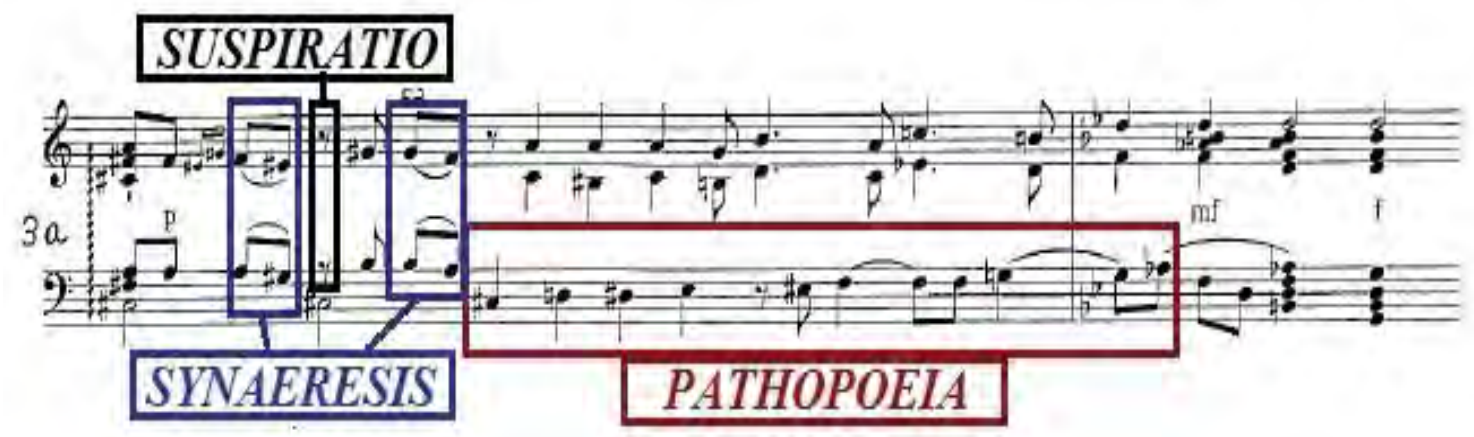

Exemplo 39-Fantasia Wq.117-13 em Sol Menor (1770) -Carl Philipp Emanuel Bach (YAMAMURA, 2013, p.27). 
Parecida com a Pathopoeia, o Passus Duriusculus, uma voz ascendente ou descente que, em semitom, pode ser observada numa cantata de J.S.Bach.

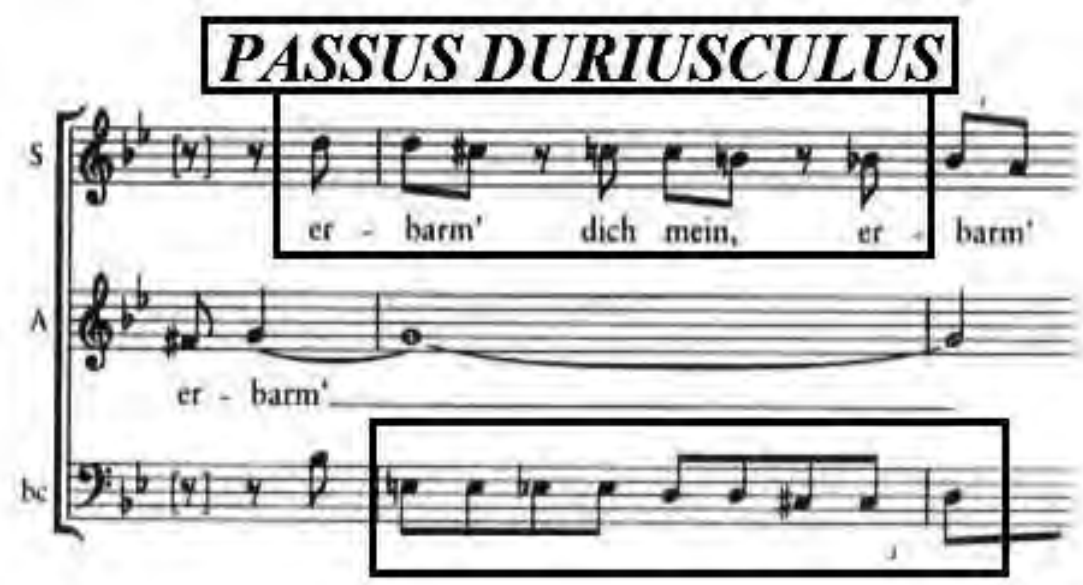

Exemplo 40-Cantata №. 23 de Johann Sebastian Bach (ca.1717-1723) (BUELOW, 2001, p.267).

Nesse exemplo, é possível localizar o uso da Aposiopesis (pausa geral em todas as vozes), no compasso 10, do Quarteto $N^{\circ} .1$ em Si Menor Op.33, de Haydn.

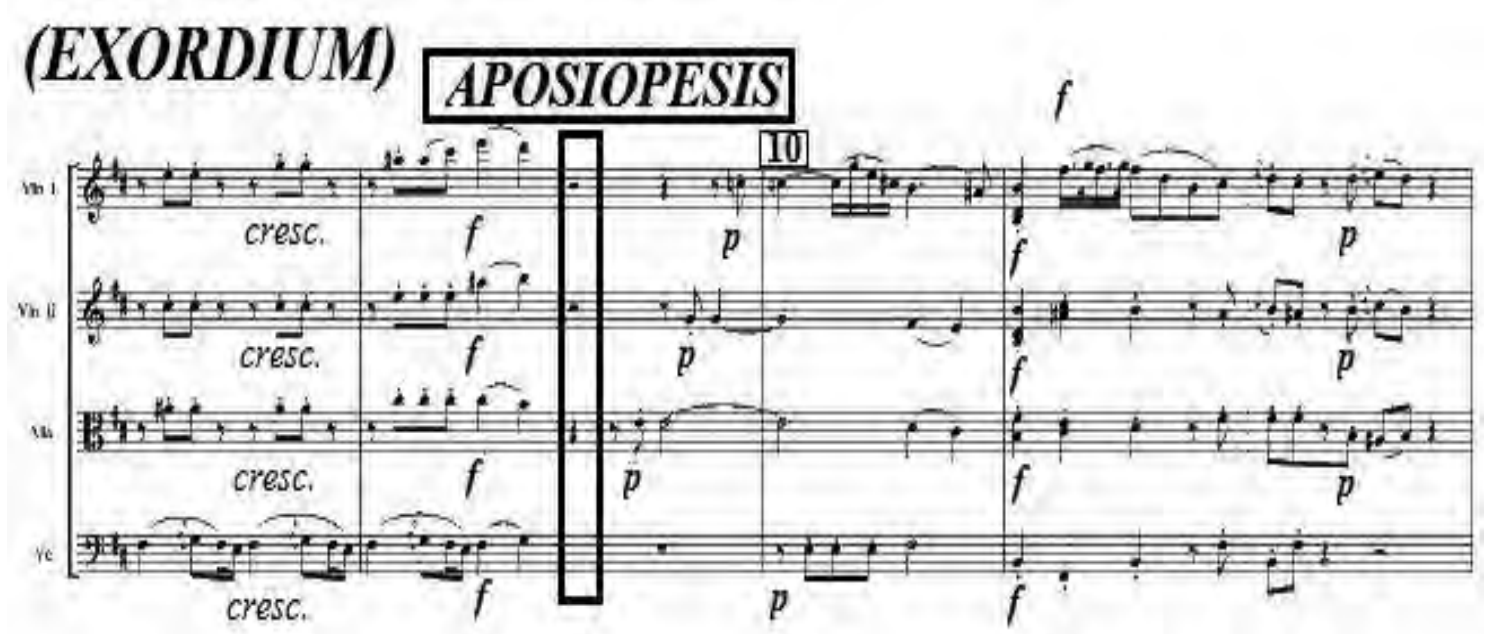

Exemplo 41-Quarteto №. 1 em Si Menor Op.33 (1781) de Joseph Haydn (LUCAS, 2005, p. 188). 
A mesma figura retórica pode ser notada no primeiro movimento da Sinfonia 80, de Haydn.

SINFONIA No. 80

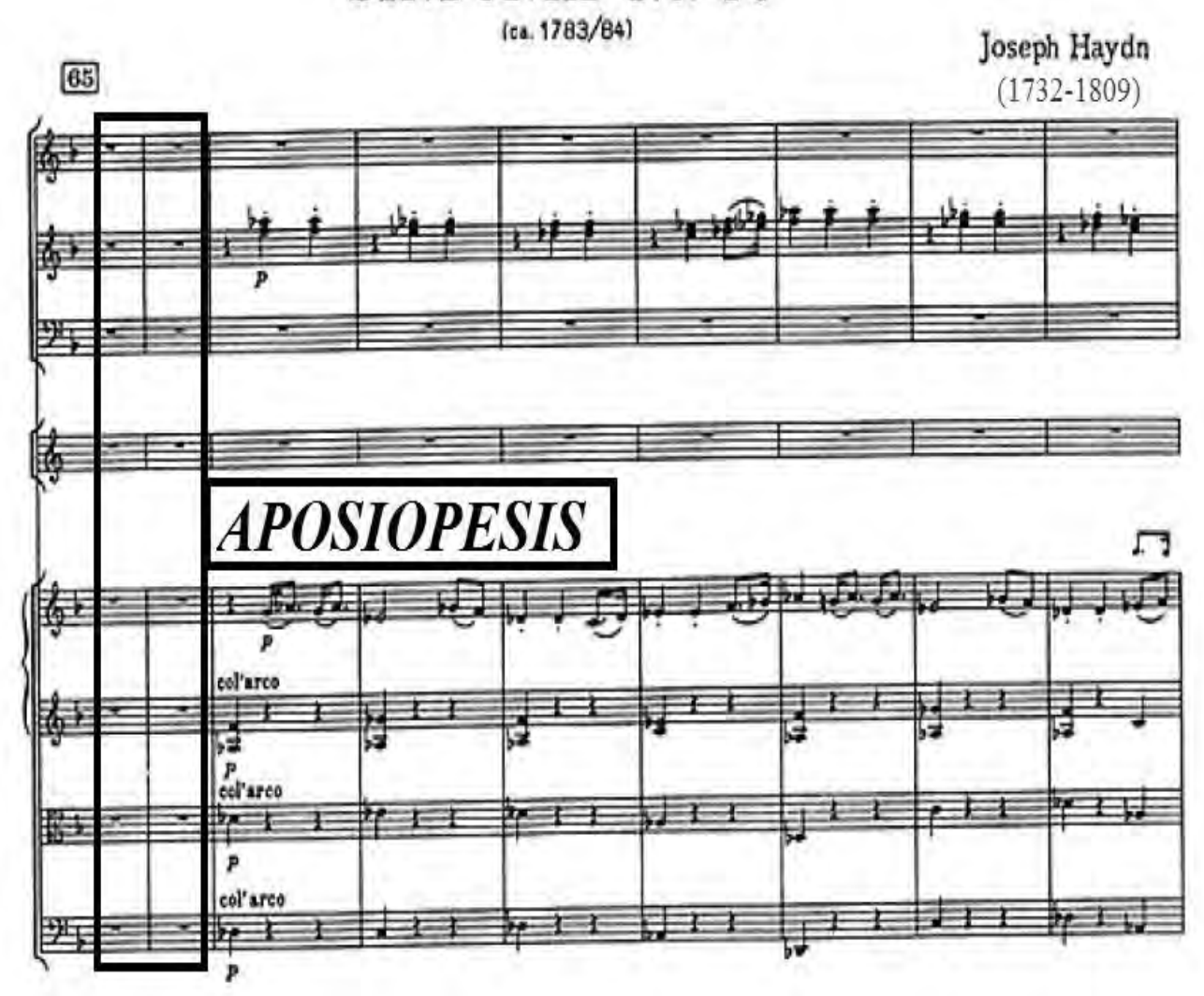

Exemplo 42-Aposiopesis na Sinfonia $\mathrm{N}^{\circ} .80$ (1ºvimento) (1784) de Joseph Haydn.

No último exemplo, observa-se a aplicação do Passus Duriusculus, nessa obra, Mozart, trabalha com essa figura retórica de dissonância e deslocamento, destacando a passagem cromática descendente.

\section{PASSUS DURIUSCULUS}

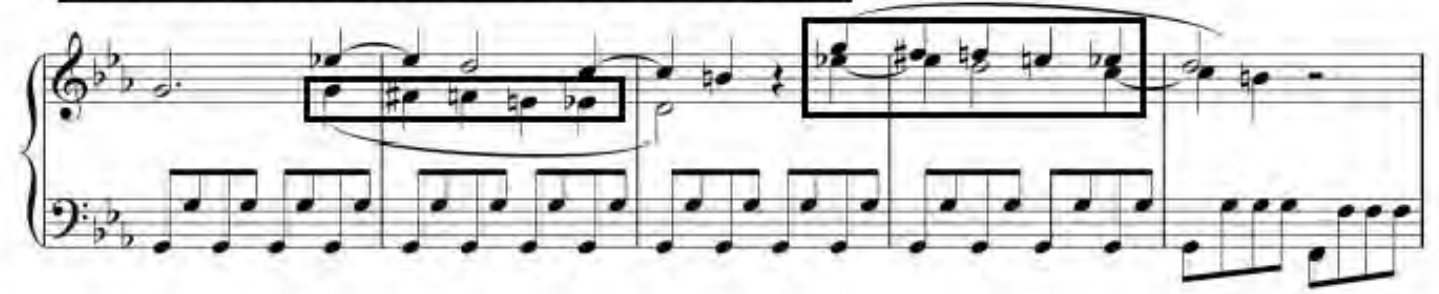

Exemplo 43-Sonata $\mathrm{N}^{\circ} .14$ em Dó Menor - K. 457 (1ºvimento)-(1784) de Wolfgang Amadeus Mozart (MOYLAN, 2014, p.38). 


\subsection{Tópicas}

A expressão tópica é proveniente de Locus Topici/Topoi (do grego topos, em latim locus communis/lugar comum), a qual foi utilizada pela primeira vez na música por Johann David Heinichen (1683-1729) em seu tratado Der Generel-Bass in der Composition (1728), o qual propõe a utilização de artifícios na adequação do afeto de um texto, ou seja, havia uma busca de inspiração e clareza sobre qual afeto deveria ser representado em textos precedentes (antecedentia textus), paralelos (concomitantia textus) e subsequentes (consequentia textus). Essa ideia, exposta por Heinichen, foi ampliada por outros tratadistas como Johann Mattheson (como observado no tópico 3.1) (VIDAL, 2002, p.54).

Em 1966, George J. Buelow, no seu artigo The 'Loci Topici' and Affect in Late Baroque Music: Heinichen's Practical Demonstration, apresenta o modo pelo qual Heinichen desenvolve e trabalha com os Loci, os quais são descritos como recursos padronizados disponíveis para auxiliar o orador (compositor) a descobrir as tópicas, ou seja, as ideias para um discurso formal. Também, é examinável a maneira de utilizar os afetos adequadamente na Inventio.

A partir da década de 1980, Leonard Ratner ${ }^{49}$ apresenta um imenso repertório de figuras formantes do discurso musical, trabalhadas pelos compositores no Classicismo, adquiridas das classes baixa, média e alta, advindas dos períodos anteriores as quais eram associadas a sentimentos e afeições, enquanto outras mantiveram apenas um "aroma pitoresco" (RATNER, 1980, p.9).

Dentre tais recursos mostrados pelo autor, podem ser destacados, os exemplos abaixo.

- Minueto: originalmente era associado com o mundo elegante de corte e de salão. Descrito como nobre, encantador, alegre, expressando alegria moderada por força do seu tempo (RATNER, 1980, p.9).

\footnotetext{
${ }^{49}$ William Caplin enfatiza que a teoria das tópicas musicais (ou temas) emergiu nas últimas décadas como uma poderosa ferramenta para a análise de expressão musical no repertório tonal. Em grande parte originárias de Leonard G. Ratner, no inovador Classic Music de 1980, desde então têm sido consideravelmente desenvolvidas e ampliadas por alguns de seus discípulos, especialmente Wye Allanbrook e Kofi Agawu (CAPLIN, 2005, p.113).
} 


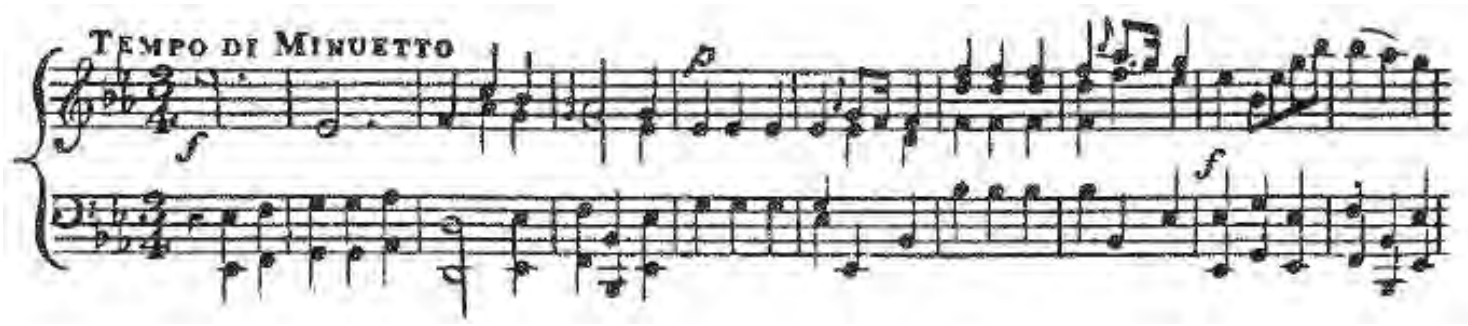

Exemplo 44-Minueto- Sinfonia em Mi bemol Maior de Johann Christian Bach, Op.9, $\mathbf{N}^{\circ} .2$ de 1775 (RATNER, 1980, p.10).

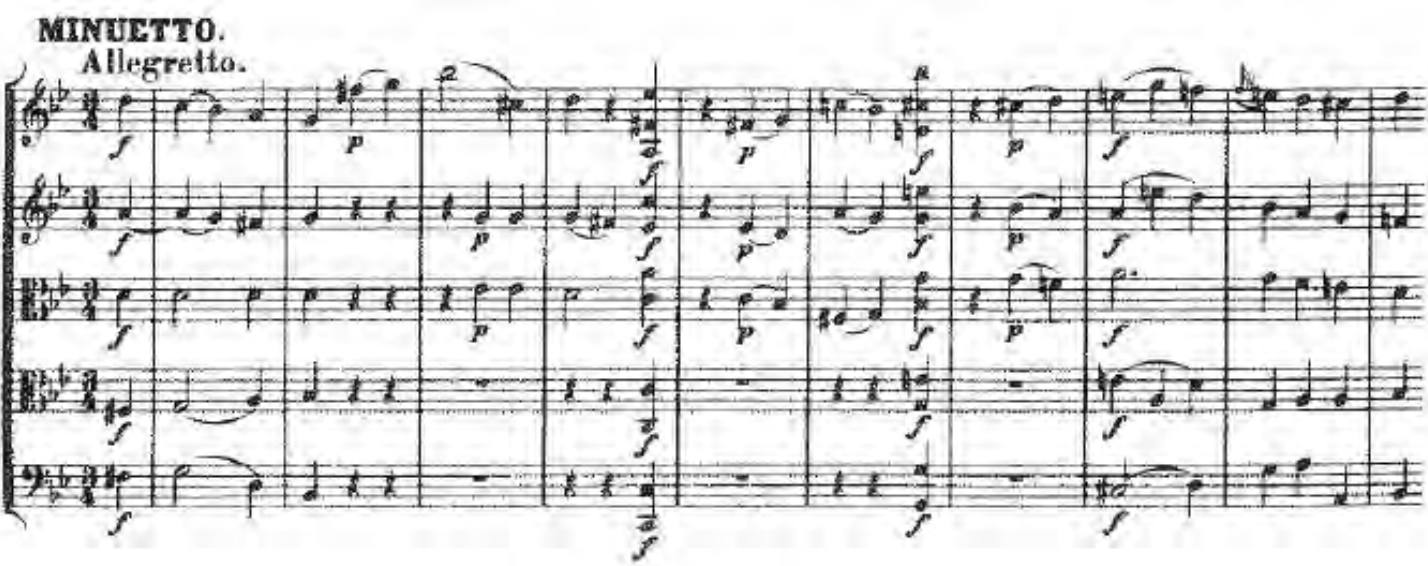

Exemplo 45-Minueto- Quinteto em Sol Maior, K. 516 de Wolfgang Amadeus Mozart de 1787 (RATNER, 1980, p.11).

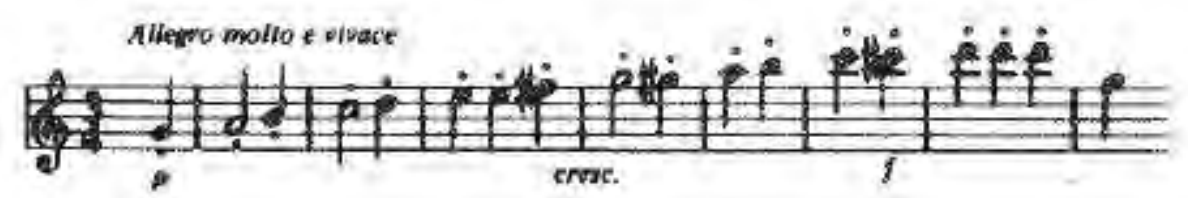

Exemplo 46-Minueto-Sinfonia- №.1 em Dó Maior, Op.21 de Ludwig van Beethoven-1800 (RATNER, 1980, p.11).

- Sarabanda: assim como Minueto, uma dança em compasso ternário, tendo por característica um estilo sério e deliberativo, a qual representa o estilo alto (RATNER, 1980, p.12).

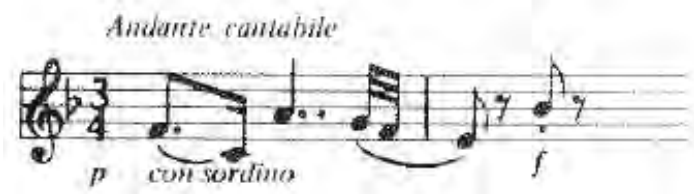

Exemplo 47-Estilo Sarabanda-Sinfonia- № 41 em Dó Maior, K. 551 ( $2^{\circ}$ Movimento) de Wolfgang Amadeus Mozart-1788 (RATNER, 1980, p.12). 
- Poloneise: uma dança em compasso ternário, bastante grave e deliberada no início do século XVIII. Sua característica é uma pausa momentânea no âmbito da medida, após uma síncope sobre a última batida do tempo (RATNER, 1980, p.12).

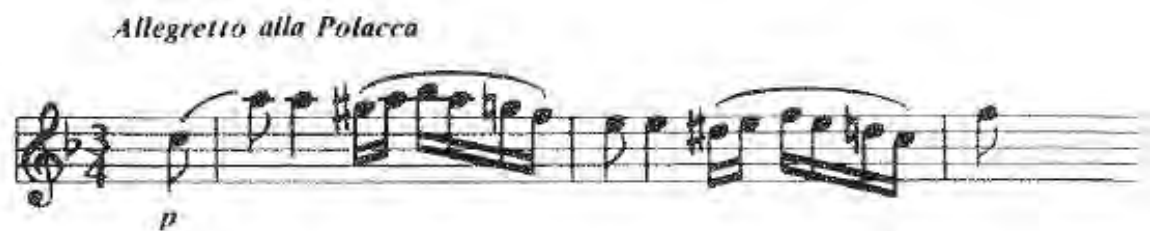

Exemplo 48-Polonese-Serenata em Ré Maior, Op.8 de Ludwig van Beethoven-1796-1797 (RATNER, 1980, p.13).

- Bourrée: dança bastante animada na forma e no compasso binário, apelando para a leveza no desempenho. Enquanto termo, o Bourrée não aparece na música clássica como um título de um movimento, todavia, seu estilo é frequentemente utilizado (RATNER, 1980, p.13).

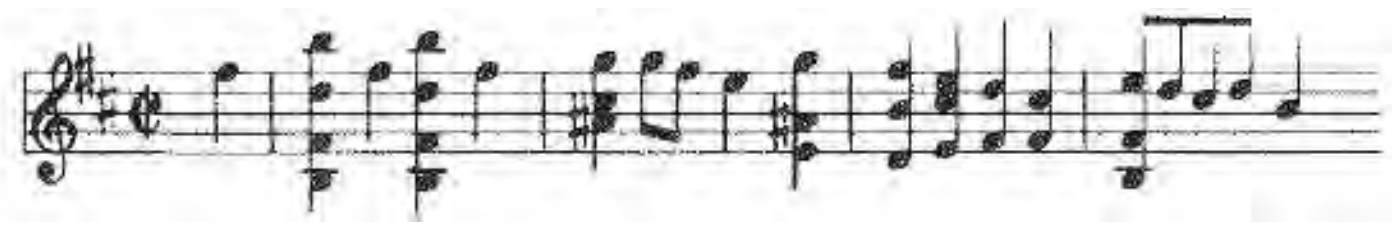

Exemplo 49-Bourrée- Partita em Si Menor de Johann Sebastian Bach-ca.1720 (RATNER, 1980, p.13).

- Contradança: suas melodias são, na maioria das vezes, em tempo binário: elas devem ser bem articuladas, brilhantes e bastante simples (RATNER, 1980, p.13).

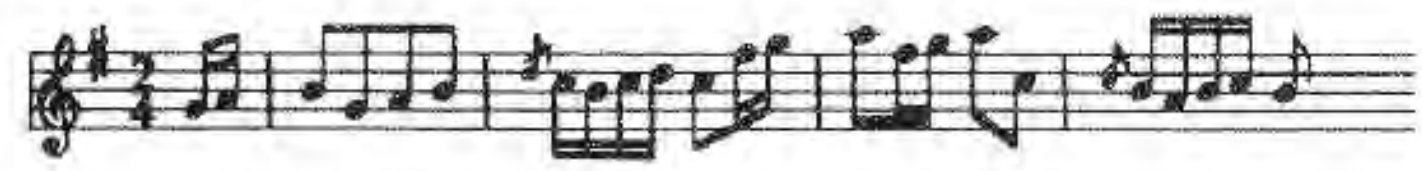

Exemplo 50-Contradança-Christmann, Elementarbuch, 1782 (RATNER, 1980, p.13).

- Ländler: um estilo de contradança, também conhecida como dança popular (RATNER, 1980, p.13). 

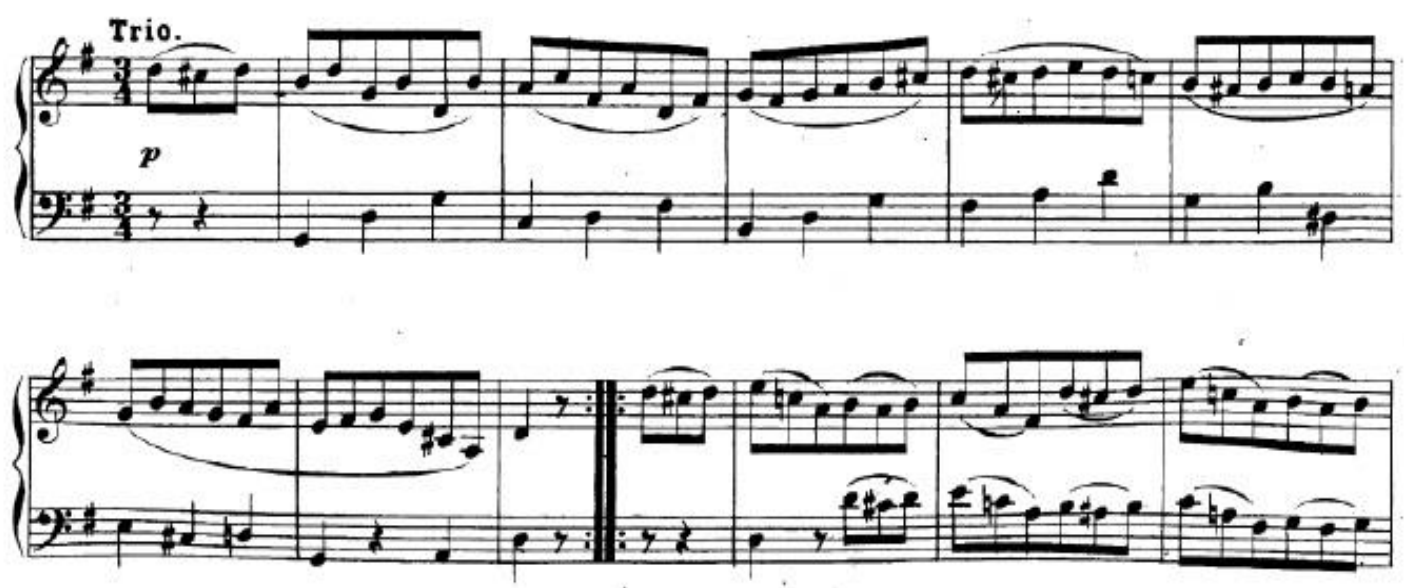

Exemplo 51-Ländler - Minueto em Sol Maior, Wo0 10, $\mathrm{N}^{\circ} .2$ de Ludwig van Beethoven-1796 (WESLEY NGA, 2015, p.56) ${ }^{50}$.

- Gavota: o encanto principal dessa dança consiste na manutenção do seu padrão rítmico, que acomoda uma melodia de elegância, equilíbrio e autocontenção (RATNER, 1980, p.14).

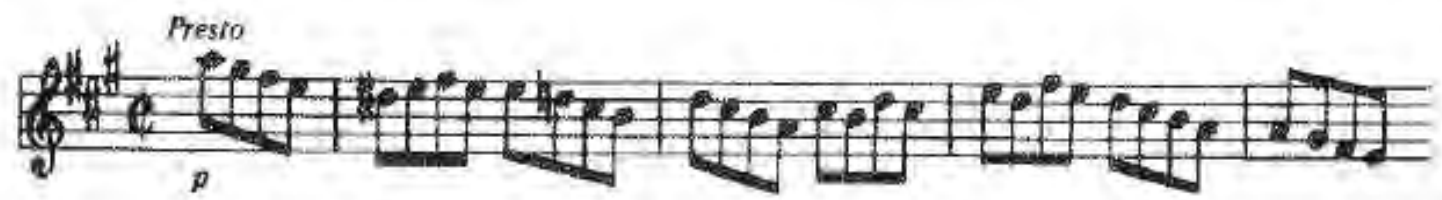

Exemplo 52-Gavota em Presto-Sonata para Piano e Violino em Lá Maior, K.526 (Último Movimento) de Wolfgang Amadeus Mozart-1787 (RATNER, 1980, p.15).

- Giga: uma dança rápida, alegre e animada, geralmente em 6/8 (RANTER, 1980, p.15).

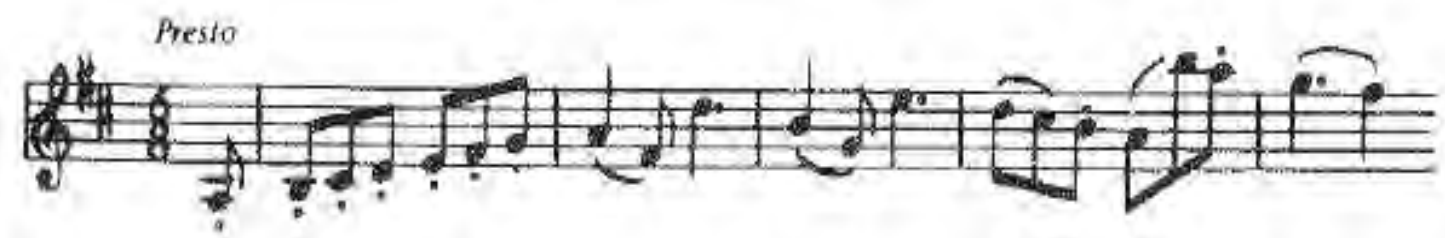

Exemplo 53-Estilo de Giga- Sinfonia №. 101 em Ré Maior ( $1^{\circ}$ Movimento)-1794 de Joseph Haydn (RATNER, 1980, p.15).

\footnotetext{
${ }^{50}$ Nessa obra de Ratner não tem esse exemplo em partitura, por isso é exposto esse excerto.
} 
- Siciliano: como a Giga, o Siciliano foi criado com o tempo de 6/8, mas executada em ritmo mais lento. Sua principal característica é o padrão pontilhado (Staccato) (RATNER, 1980, p.15).

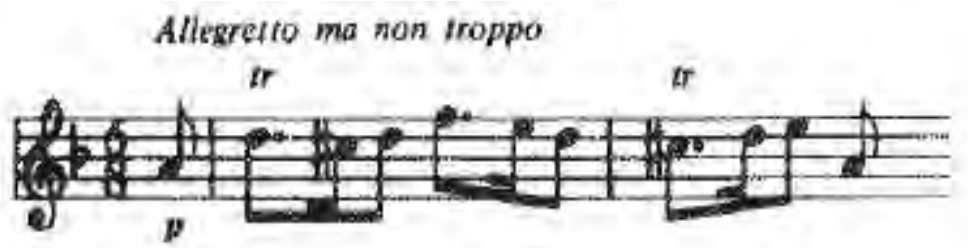

Exemplo 54-Estilo Siciliano- Quarteto em Ré Menor, K. 421, (Movimento Final)- 1783 de Wolfgang Amadeus Mozart (RATNER, 1980, p.16).

- Marcha: a marcha teve muito significado e como dança cerimonial no século XVIII. Como entrada principal, serviu para abrir apresentações de balé, cerimônias e exposições de palco. Seus hábitats naturais são o desfile solo e o campo de batalha, onde seu andamento é moderadamente rápido, ritmos pontuados e de forma ousada. Se o minueto, a rainha da dança do século XVIII, simboliza a vida social do mundo elegante, a marcha lembra o ouvinte da autoridade, do cavaleiro e as virtudes viris atribuídas a ele (RATNER, 1980, p.16).

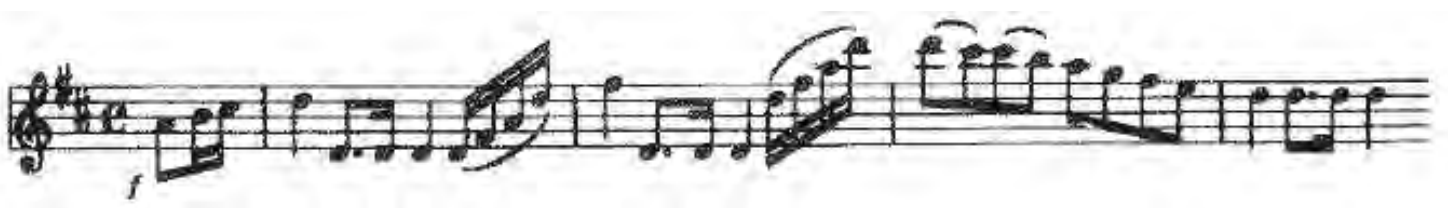

Exemplo 55-Tipo de Marcha- Christmann, Elementarbuch, 1782 (RATNER, 1980, p.16).

- Militar/Caça e Fanfarra: a música militar e de caça era familiar ao longo do século XVIII. Casas nobres tinham seus guardas próprios, desfilando ao som de trombetas acompanhado pelos tambores. Cidades alemãs tiveram seus Stadpfeiffer (bandas da cidade), onde se realizam festas, aniversários, casamentos e feiras; a caça era uma diversão favorita da nobreza. Já as fanfarras e sinais de caça foram imitados por cordas, sopros e instrumentos de teclado (RATNER, 1980, p.18). 
Allegro di molto

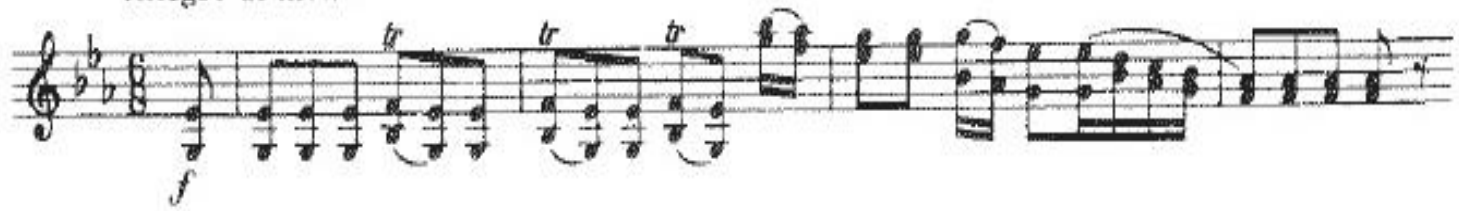

Exemplo 56-Fanfara de Caça- Quinteto em Mi bemol Maior, K. 614 (1º Movimento)-1791 de Wolfgang Amadeus Mozart (RATNER, 1980, p.18).

No exemplo abaixo, nota-se a mesma tópica localizada por William Caplin.

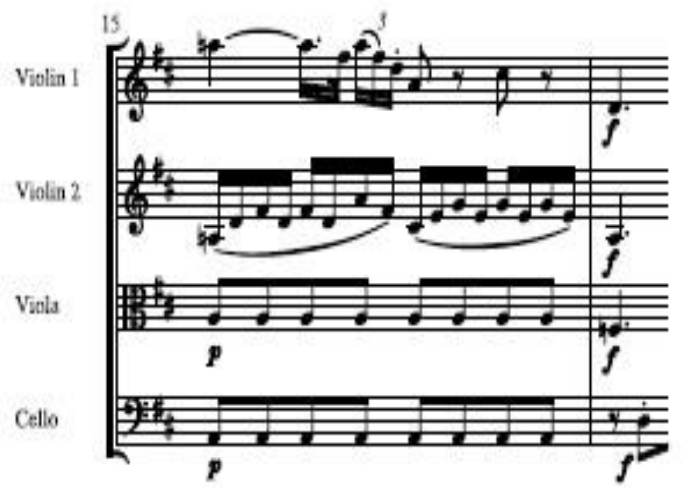

Exemplo 57-Fanfarra-Sinfonia N. 38 em Ré Maior, K. 504 de Wolfgang Amadeus Mozart1787 (CAPLIN, 2005, p.117).

- Cantabile: o termo indica a música em uma veia lírica, com um ritmo moderado e uma linha melódica com valores de notas relativamente lenta e uma gama muito estreita. Também se tem o Allegro Cantabile, terminologia atualmente usada para designar uma melodia musical definida no tempo rápido, é constantemente acompanhada por notas repetidas rapidamente ou por figuras e acordes suspensos (RATNER, 1980, p.19).

\section{Andante con thoto}

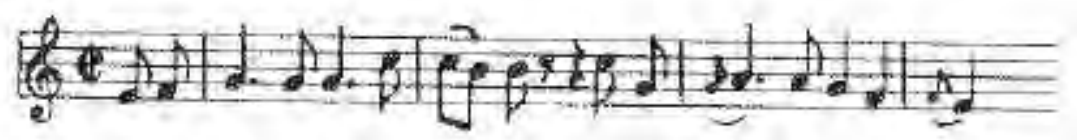

Exemplo 58-Estilo Cantabile- Orfeo e Eurídice, Ato-III de Christoph Willibald Gluck-1762 (RATNER, 1980, p.19). 
- Brilhante: refere-se ao uso de passagens rápidas para mostrar a virtuosidade ou o intenso sentimento. Anteriormente compositores italianos, como Alessandro Scarlatti, Arcângelo Corelli e Antonio Vivaldi codificaram entre eles o estilo brilhante por repetições sistemáticas e sequências (RATNER, 1980, p.20).

Cl.

V. I

VI. II

Vla.

Vlncello.
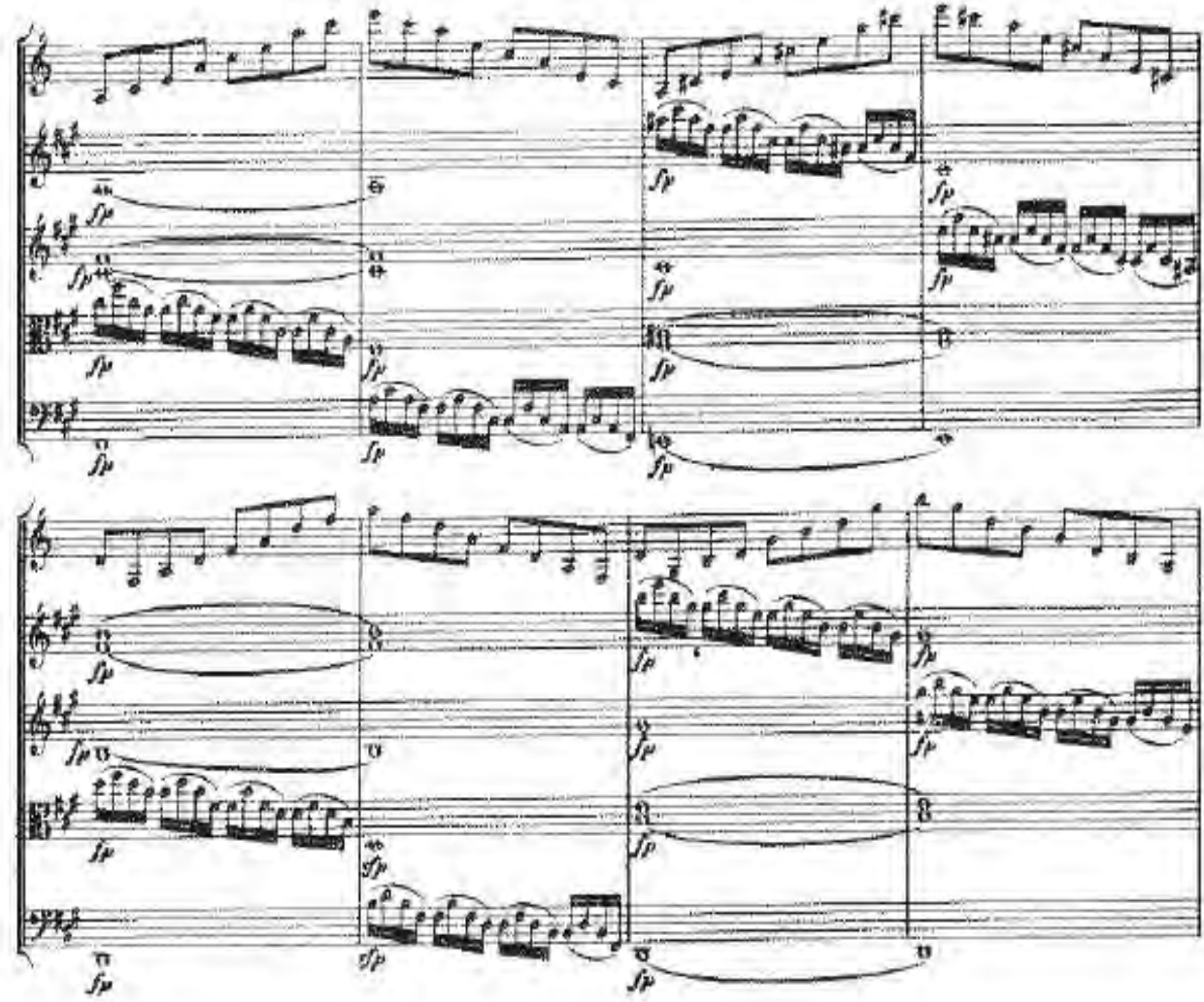

Exemplo 59-Estilo Brilhante- Quinteto para Clarineta e Cordas em Lá Maior, K. 581 (1 ${ }^{\circ}$ Movimento) de Wolfgang Amadeus Mozart-1789 (RATNER, 1980, p.20).

- Abertura Francesa: um estilo de música cerimonial que utiliza um andamento lento e pesado de marcha com figuras rítmicas. Nos tribunais e teatros da França, sob Luís XIV, acompanhavam a entrada dos espectadores reais e os artistas (RATNER, 1980, p.20).

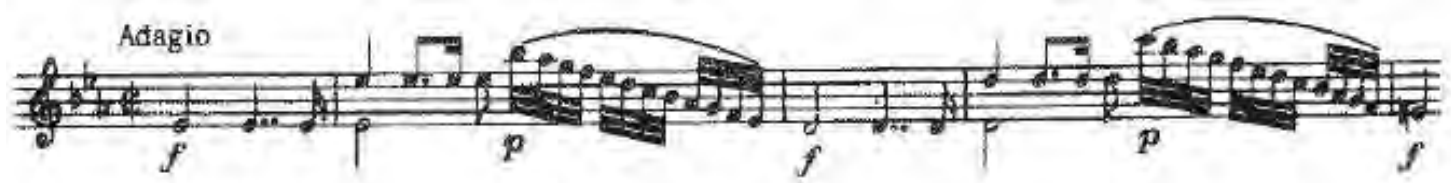

Exemplo 60-Estilo de Abertura Francesa- Sinfonia em Mi bemol Maior, K. 543 (1 ${ }^{\circ}$ Movimento) de Wolfgang Amadeus Mozart-1788 (RATNER, 1980, p.20). 
- Musette/Pastoral: referem-se à música rústica tocada em gaita de foles, cornemuse ou musette ${ }^{51}$. A principal característica é a sustentação do bordão do baixo - em tom único ou uma quinta. A melodia pastoral tem um sentido ingênuo e requinte ou ornamento melódico. Esses estilos estão em abundância na música clássica (RATNER, 1980, p.21).

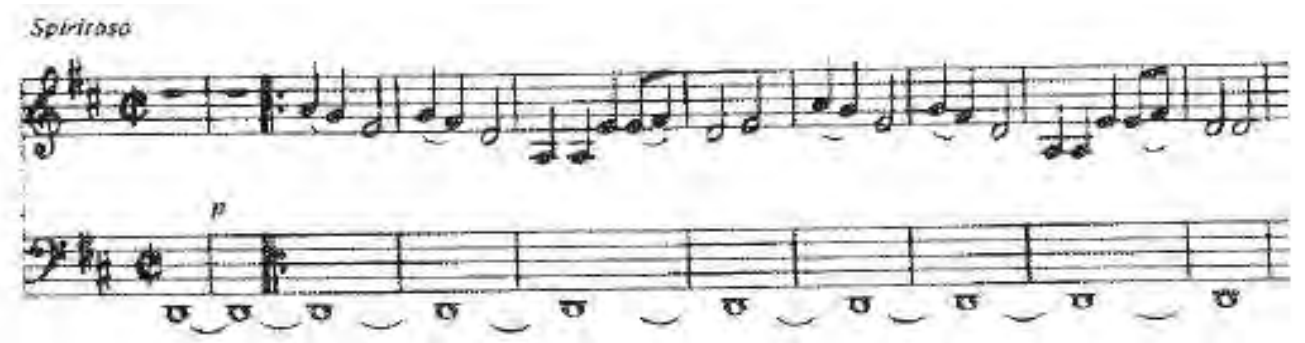

Exemplo 61-Musette/Pastoral-Sinfonia $N^{\circ} .104$ em Ré Maior de Joseph Haydn-1795 (RATNER, 1980, p.75).

- Música Turca: efeitos turcos na música da Europa Ocidental foram os subprodutos do confronto militar e diplomático entre os mesmos. Os turcos tinham um estilo militar pitoresco chamado música janízaro ${ }^{52}$, utilizando tambores, triângulo, o vento, e címbalos. Compositores clássicos imitando ainda esse estilo realizaram algumas modificações adequando-as ao gosto ocidental (RATNER, 1980, p.21).
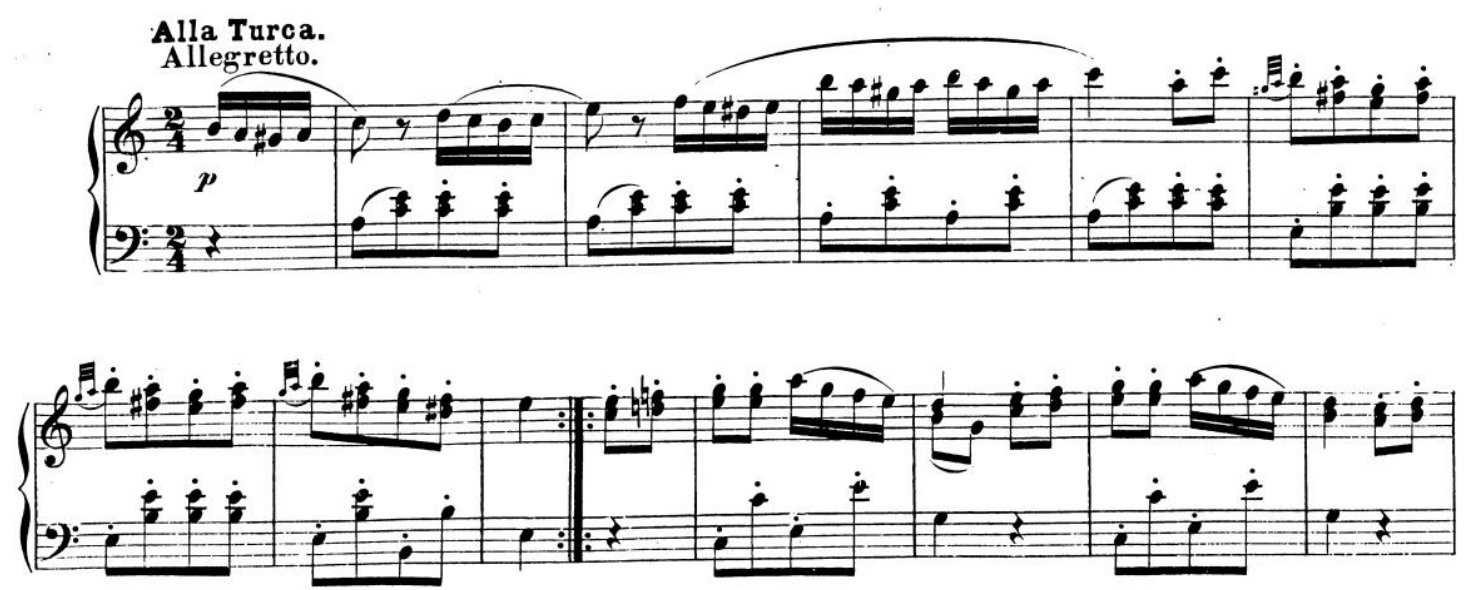

Exemplo 62-Estilo de Música Turca-Sonata em Lá Menor K. 331 (Último Movimento) de Wolfgang Amadeus Mozart ca.1783.

\footnotetext{
${ }^{51} \mathrm{Ambos}$ os instrumentos são parecidos com a gaita de foles.

${ }^{52}$ Os janízaros (do turco Yeni Tcheri, ou nova força) constituíam a elite do exército dos sultões otomanos.
} 
- Sturm und Drang: termo que aparece em 1776, através de uma peça teatral Friedrich Maximilian Klinger, e foi adotado pelos historiadores da música para se referir a algumas manifestações iniciais da expressão do romantismo, subjetiva e intensa dos sentimentos pessoais. Koch, 1802, refere-se a Stürmende Leidenschaften (paixões tempestuosas). Sturm und Drang usa condução dos ritmos, textura completa, harmonias no modo menor, cromatismo, muitas dissonâncias e um estilo apaixonado da declamação (RATNER, 1980, p.21).

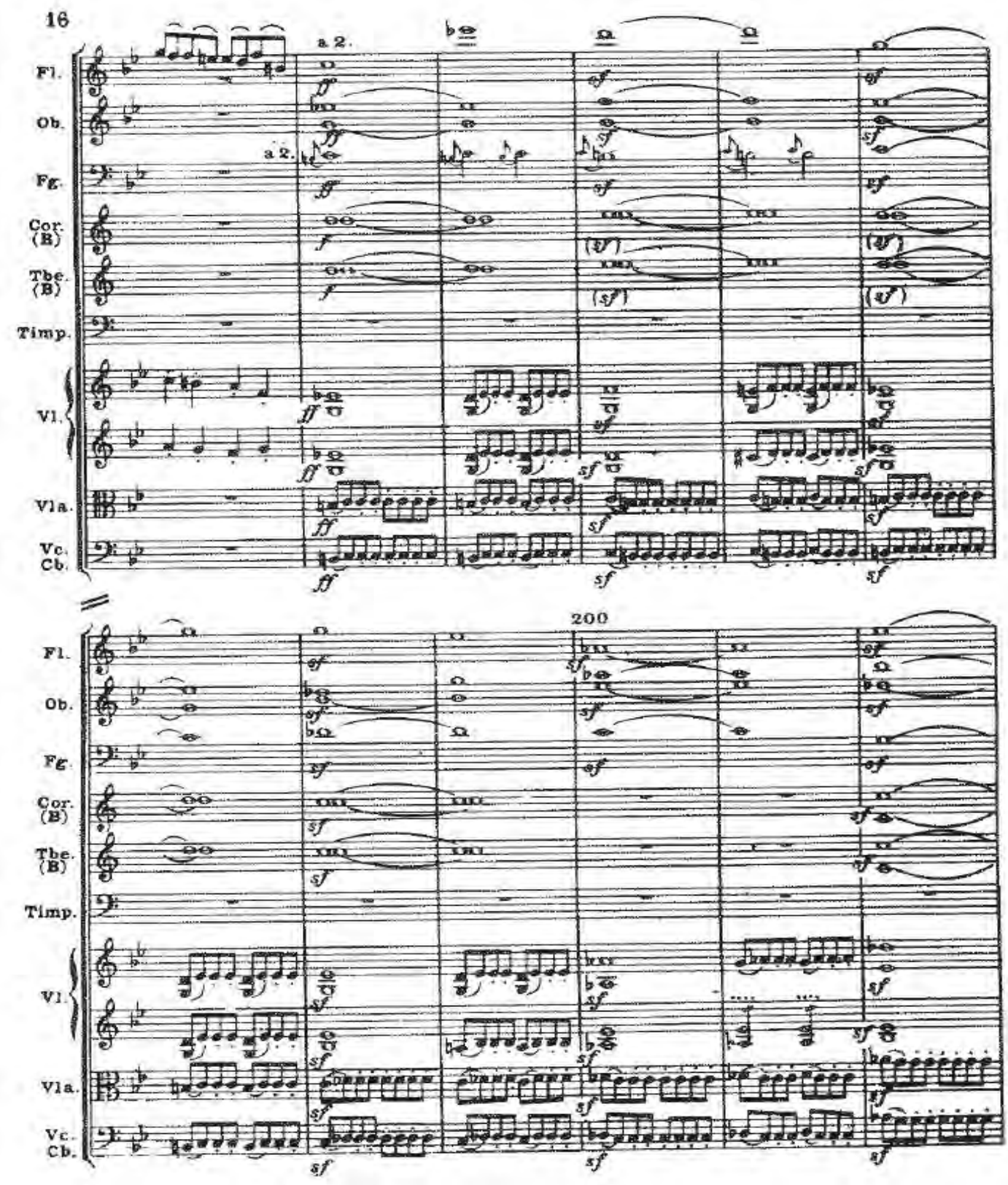

Exemplo 63-Sturm und Drang - Sinfonia $\mathrm{N}^{\circ} .102 \mathrm{em}$ Si bemol Maior ( $1^{\circ}$ Movimento) de Joseph Haynd-1794 (RATNER, 1980, p.153). 
- Sentimental (Empfindsamkeit): estilo íntimo e pessoal, muitas vezes sentimental em qualidade. C.P.E. Bach era o principal representante desse estilo (RATNER, 1980, p.22).
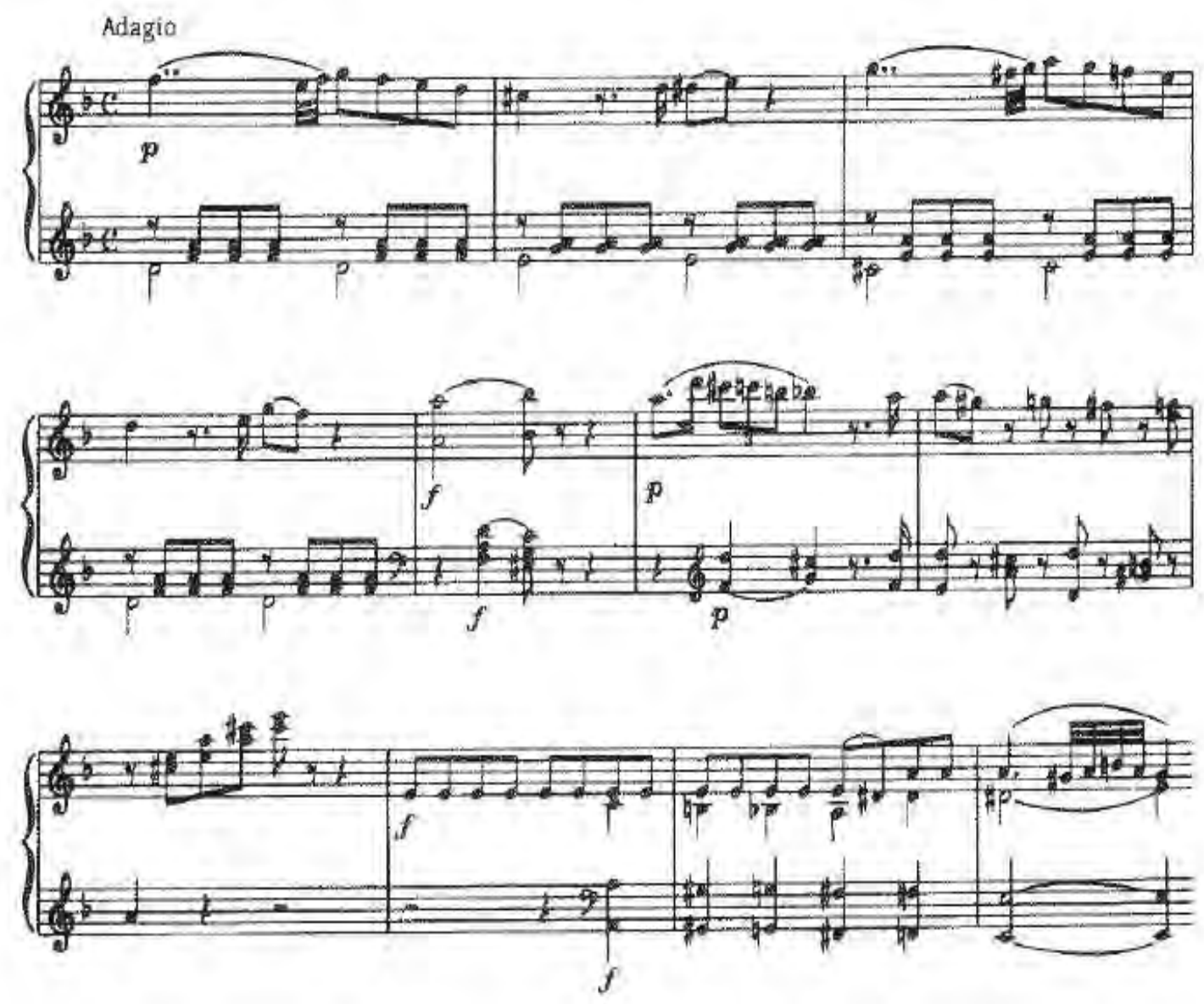

Exemplo 64-Estilo Sensível- Fantasia em Ré Menor, K. 397 de Wolfgang Amadeus Mozart-1782 (RATNER, 1980, p.22).

- Estrito e Aprendido: também chamado de Estilo Ligado ou de Estilo de Fuga, distinto do Estilo Livre. A melodia conserva seu caráter grave, em parte, através de frequentes progressões estreitamente ligadas, que não permite a ornamentação, onde a melodia é dividida em diversos fragmentos. Seu uso é frequente e vinculado por dissonâncias (suspensões) (RATNER, 1980, p.23). 

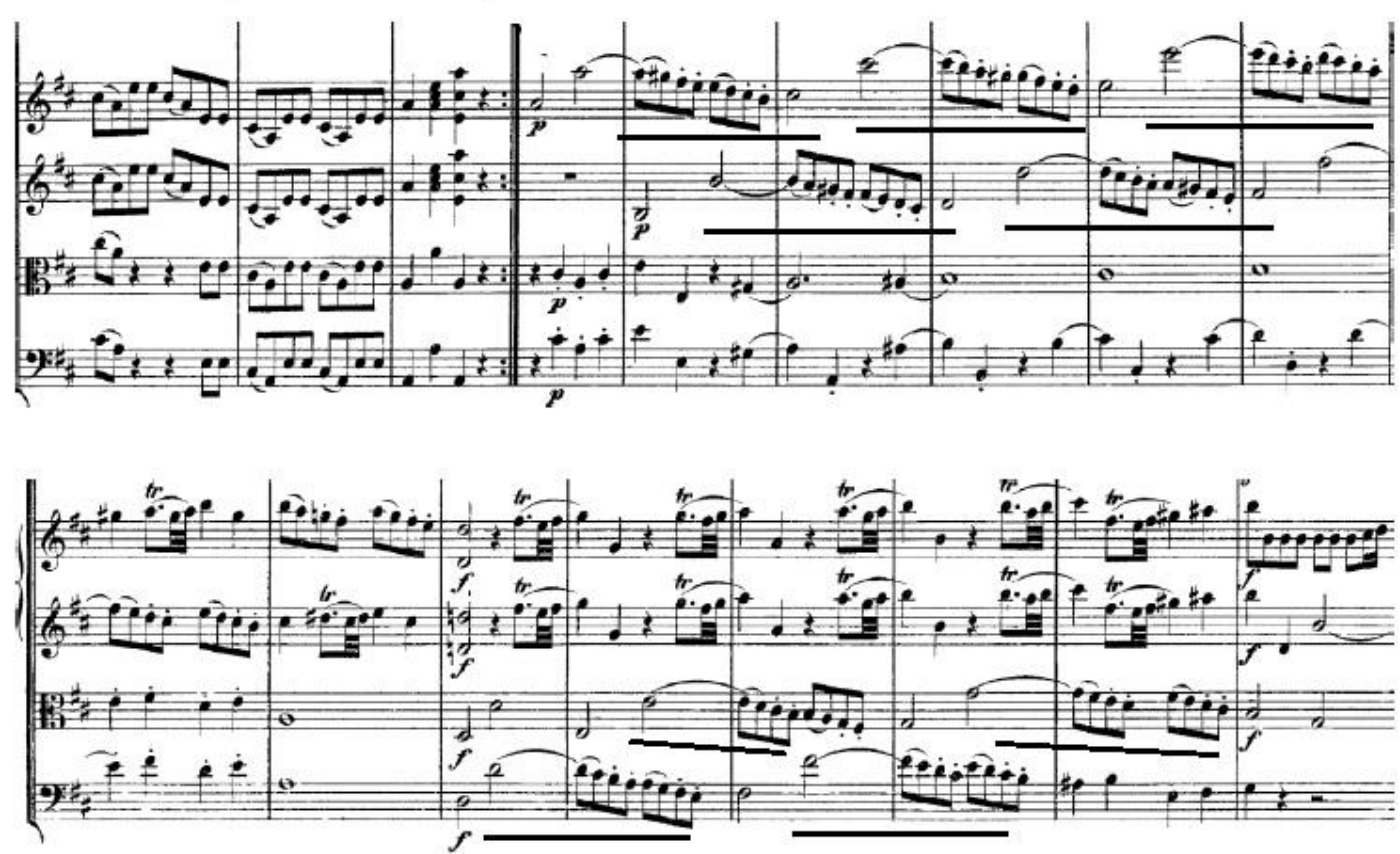

Exemplo 65-Estilo Estrito/Galante- Sinfonia N. 38, K. 504 de Wolfgang Amadeus Mozart1787 (WUNCHNER, 2011, p.73).
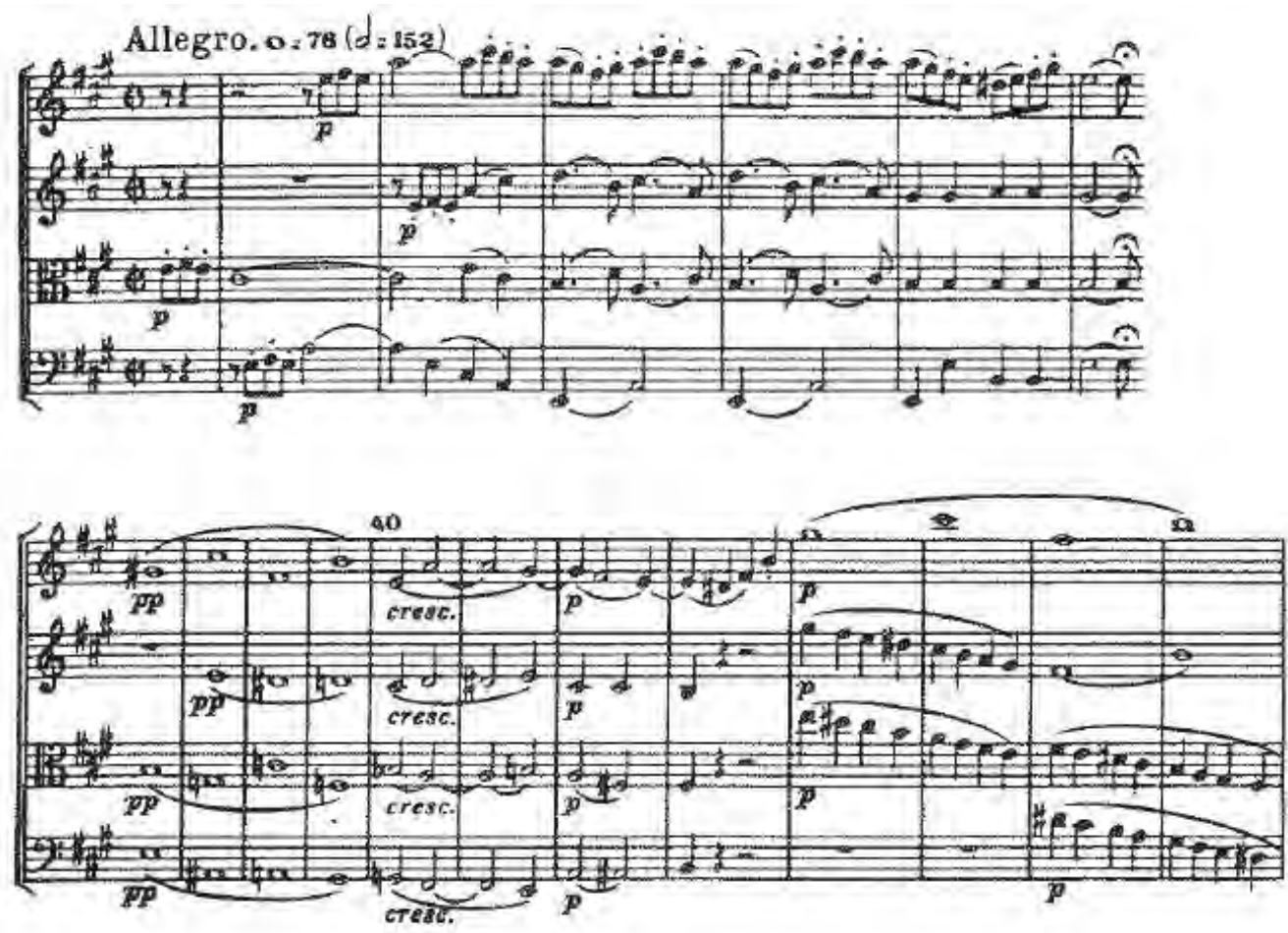

Exemplo 66-Estilo Aprendido-Quarteto em Lá Maior, Op.18, № .5 (Movimento Final) de Ludwig van Beethoven-1800 (RATNER, 1980, p.24). 
- Galante: através de muitas das elaborações da melodia e divisões dos principais tons melódicos, com suspensões, fazendo uma pausa na melodia. Igualmente pode ser empregada por meio de uma harmonia mais interligada (RATNER, 1980, p.23).

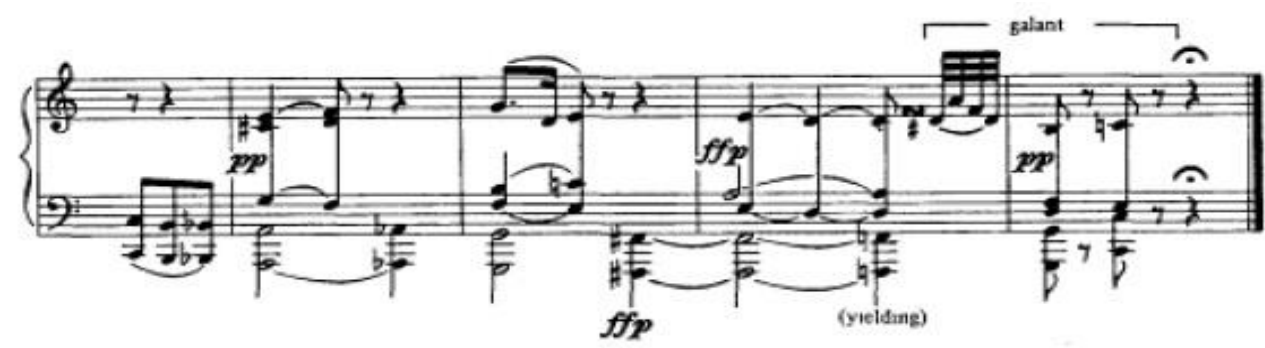

Exemplo 67-Estilo Galante-Sonata em Mi Bemol Maior Op.7 ( $2^{\circ}$ Movimento) de Ludwig van Beethoven-1796 (HATTEN, 1994, p.61).

- Fantasia: tem as seguintes características: figurações elaboradas, harmonias em deslocamento (inconstantes), linha do baixo cromático, contrastes repentinos (abruptos), texturas completas das figuras melódicas (espectrais). Em suma, um sentido de improvisação e das relações estruturais entre as figuras e frases (RATNER, 1980, p.24).

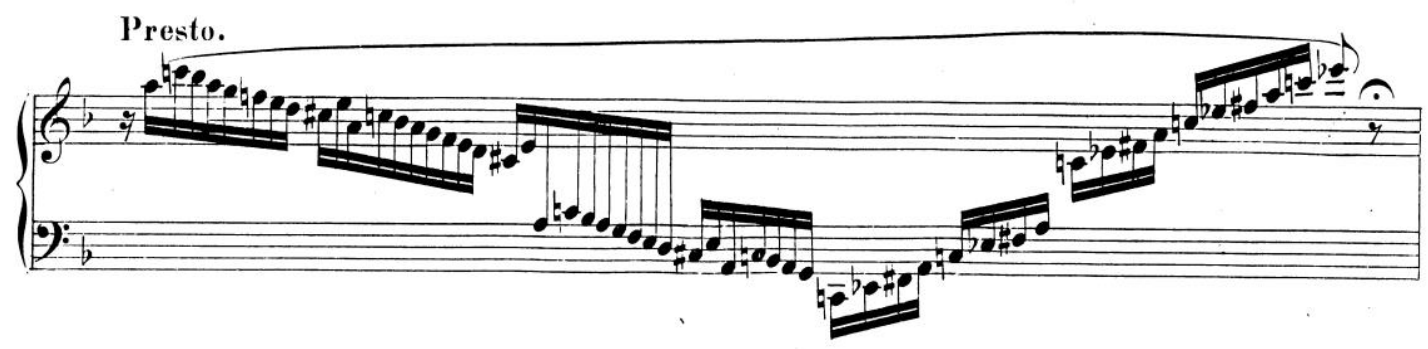

Exemplo 68-Estilo de Fantasia- Fantasia em Ré Menor, K. 397 de Wolfgang Amadeus Mozart-1782.

Abaixo, nota-se a tabela com a ordenação e distribuição dos assuntos concernentes à tópica, dissertados por Ratner.

Tabela 10-Afetos, Estilos e Tópicas Ressaltados por Ratner (1980) (HATTEN, 1994, p.75).

\section{A. pace, movement, tempo}

B. intervals 


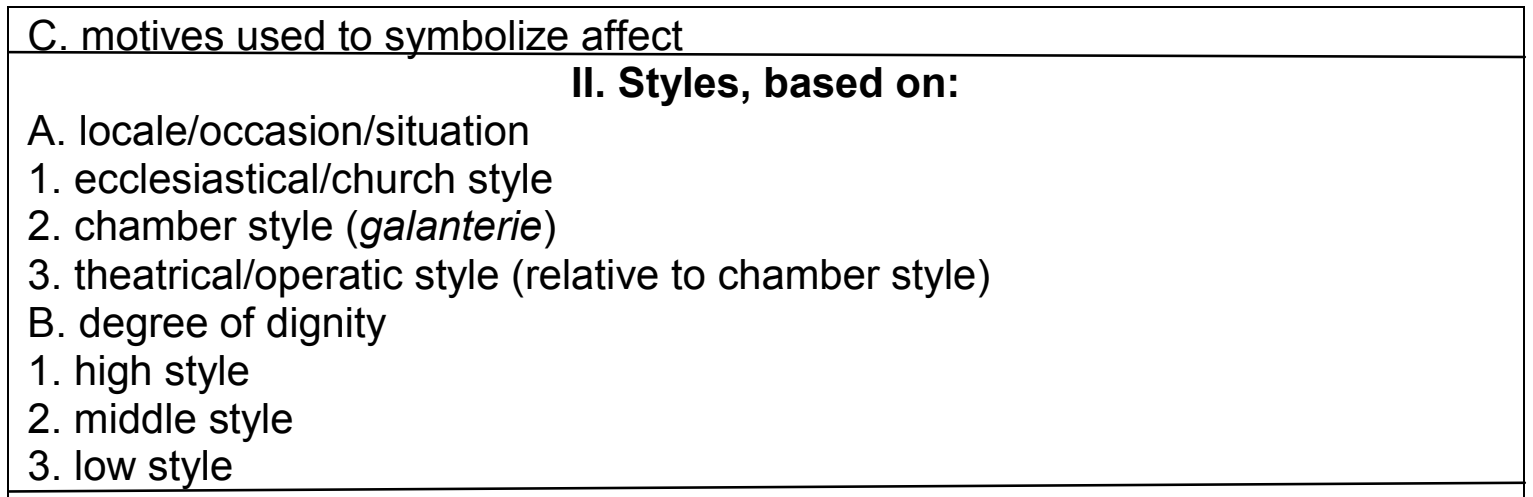

A types (fully worked-out pieces), such as dances (

in high, middle, or low styles, or

B. styles (figures and progressions within a piece)

1. military, hunt

2. singing style

3. French overture

4. musette, pastorale

5. Turkish music

6. Storm and stress

7. sensibility, Empfindsamkeit

8. strict, learned style (vs. galant, or free style)

9. fantasia style

IV. Pictorialism, word painting, and imitation of sounds in nature.

Por conseguinte, Wye Jamison Allanbrook, em sua obra Rhythmic Gesture in Mozart: Le Nozze Di Figaro \& Don Giovanni, de 1983, por meio de análises minuciosas e criteriosas, trabalha e desenvolve os conceitos expostos anteriormente por Ratner. O mesmo é composto por três grandes seções. Na primeira, a autora descreve a variedade de danças conhecidas ao final do século XVIII e explicita as conotações sociais e afetivas de cada um. Já nas outras duas, emprega o vocabulário de gestos rítmicos apresentados anteriormente, além de mais métodos familiares de análise, obtendo várias conclusões (PLATTOF, 1985, pp.535-537).

Em 1991, Victor Kofi Agawu em Playing with Signs: A Semiotic Interpretation of Classic Music, analisa questões relativas às tópicas e a estrutura tonal, pelo viés da semiótica. Ulterior a esse livro, Agawu publica Music as Discourse: Semiotic Adventures in Romantic Music (2009), nele são expandidos as quantidades de tópicas possíveis. 
The Universe of Topic for Classic Music

1. Alberti bass

2. alla breve

3. alla zoppa

4. allemande

5. amoroso style

6. aria style

7. arioso

8. bound style or stile legato

9. bourrée

10. brilliant style

11. buffa style

12. cadenza

13. chaconne bass

14. chorale

15. commedia dell'arte

16. concerto style

17. contredanse

18. ecclesiastical style

19. Empfindsamer style

20. Empfindsamkeit (sensibility)

21. fanfare

22. fantasia style

23. French overture style

24. fugal style

25. fugato

26. galant style

27. gavotte

28. gigue

29. high style

30. horn call

31. hunt style

32. hunting fanfa
33. Italian style

34. Ländler

35. learned style

36. Lebewohl (horn figure)

37. low style

38. march

39. middle style

40. military figures

41. minuet

42. murky bass

43. musette

44. ombra style

45. passepied

46. pastorale

47. pathetic style

48. polonaise

49. popular style

50. recitative (simple, accompanied, obligé)

51. romanza

52. sarabande

53. siciliano

54. singing allegro

55. singing style

56. strict style

57. Sturm und

Drang (storm and stress)

58. tragic style

59. Trommelbass

60. Turkish music

61. waltz

Figura 39-0 Universo da Tópica na Música Clássica (AGAWU, 2009, pp.43-44).

Adiante, Elaine Rochelle Sisman teve publicado dois trabalhos sobre análises tópicas: Mozart: The "Jupiter" Symphony, no. 41 in C major, K. 551 
(1993) e Genre, gesture and meaning in Mozart's "Prague" Symphony. Mozart Studies (1997).

Em 1994, Robert S. Hatten, no seu Musical Meaning in Beethoven: Markedness, Correlation, and Interpretation Advances in Semiotics, desenvolve e destaca o contexto e organização, tanto da semiótica musical quanto das tópicas em Beethoven. Já em Interpreting Musical Gestures, Topics, and Tropes: Mozart, Beethoven, Schubert (2004) ele continua a desenvolver a teoria semiótica do significado musical apresentada no livro anterior. Contudo, ele expande as teorias de marcação, temas e tropos. Isto é, Hatten, através desse estudo, contribui para a compreensão dos gestos musicais, embasandose em contextos biológicos, psicológicos, culturais e estilísticos da música, ao examinar os gestos, tópicas, tropos e sua relação nas obras de Mozart, Beethoven e Schubert.
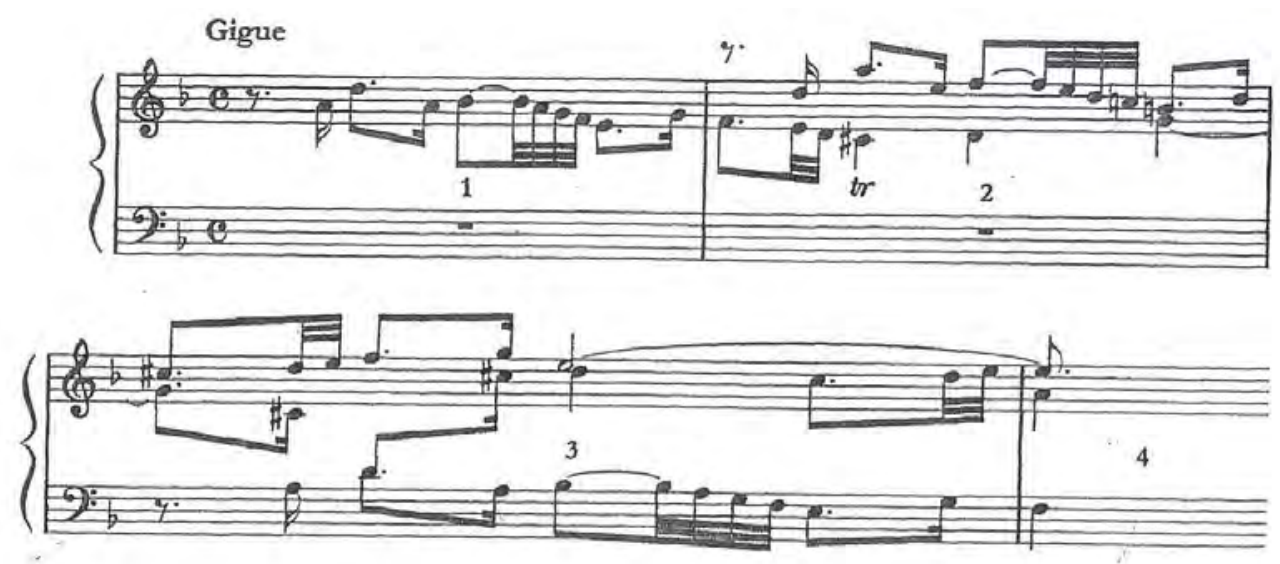

Exemplo 69-Giga na Suite Francesa N$^{\circ} .1$ em Ré Menor, BWV 812 de Johann Sebastian Bach-1722 (HATTEN, 2004, p.70).

Observa-se, abaixo, um exemplo de tropo no terceiro movimento da Sinfonia $N^{\circ}$.36, em Dó Maior de Mozart, de acordo com Hatten. 

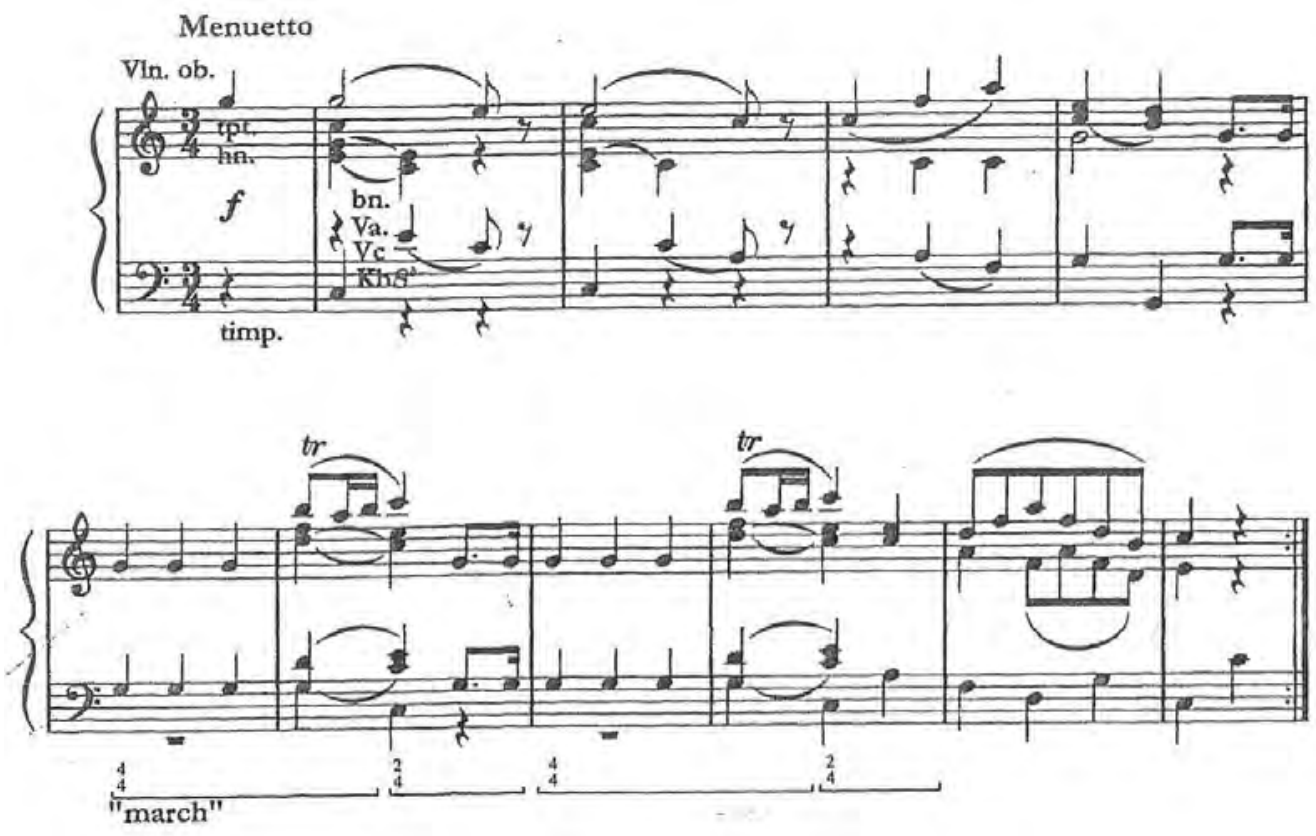

Exemplo 70-Tropo de Minueto e Marcha (interpolação) na Sinfonia $\mathbf{N}^{\circ} .36$ em Dó Maior, K. 425 ( $3^{\circ}$ Movimento) de Wolfgang Amadeus Mozart-1783 (HATTEN, 2004, p.76).

Além desses pesquisadores citados, os estudos relacionados às tópicas musicais tiveram outros nomes relevantes, tais como:

- William E. Caplin: On the Relation of Musical Topoi to Formal Function (1995).

- John Irving: Mozart's Piano Sonatas: Contexts, Sources, Style (1997).

- Raymond Monelle: The Musical Topic (2006).

- Danuta Mirka (Org.): The Oxford Handbook of Topic Theory. (2014). 
4. A TEORIZAÇÃO RETÓRICA-MUSICAL EM PORTUGAL 


\section{A TEORIZAÇÃO RETÓRICO-MUSICAL EM PORTUGAL}

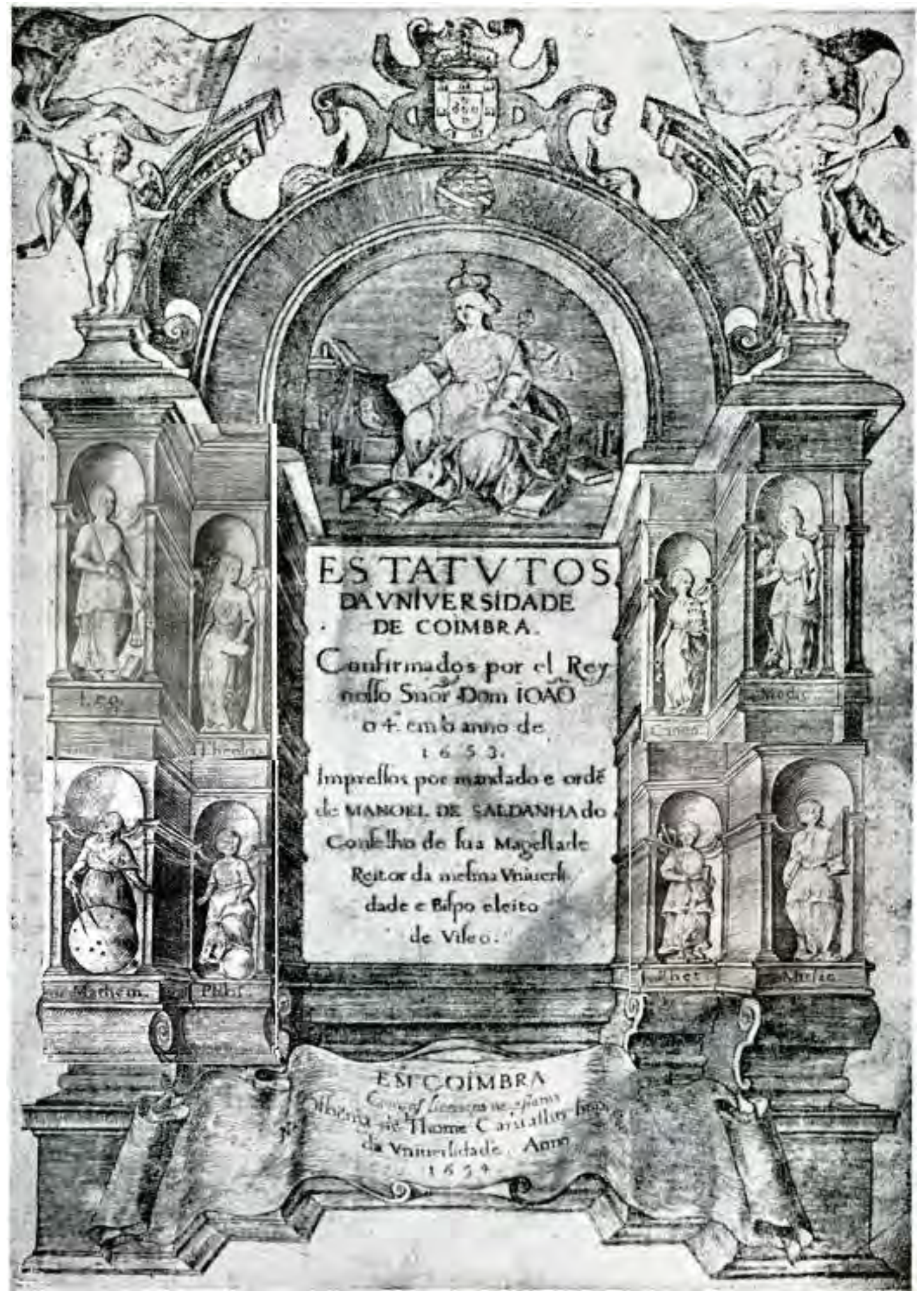

Figura 40- Portada dos Estatutos da Universidade de Coimbra confirmados por D. JoãoIV (1653/4) (Repr. de A. Hipólito) (BANDEIRA, 1947, p. 199) ${ }^{53}$.

\footnotetext{
${ }^{53}$ Verificam-se figuras alegóricas representando no centro a Sabedoria, no lado esquerdo à Faculdade das Leis (Direito), Teologia, Matemática e Filosofia, no lado direito Medicina, Cânones, Retórica e Musica.
} 


\subsection{A arte retórica portuguesa}

É notória a tradição da retórica na Península lbérica, acompanhando, de modo evidente, a evolução das letras latinas ${ }^{54}$. Entre os séculos I e VII d.C., escritores, filósofos e estudiosos, como Sêneca (4 a.C.-65), Lucano (39-65) e Santo Isidoro de Sevilha (570-636), escreveram e compilaram tratados sobre a oratória e as sete artes liberais ${ }^{55}$. Posterior a esses acontecimentos, nas escolas romanas da Península, existia um substrato retórico residente, continuado pelas escolas monacais cristãs, onde se afirmaram com particular fulgor as obras desses autores (LAUSBERG, 2004, p.13) ${ }^{56}$.

\subsubsection{Idade Média e o domínio da escolaridade}

Em Portugal, circunscreveu-se a retórica dos tempos medievais, ao exclusivo domínio da escolaridade. Essa disciplina era distribuída em duas frentes diferentes ${ }^{57}$ a primeira de ordem profana onde era mesclada retórica e poética, imbuída de conceitos gramaticais, e a segunda que tinha conexão com a arte de pregar, embasada na técnica da palavra, essencial para tornar aptos os sacerdotes na disseminação da fé (LAUSBERG, 2004, p.14).

Contudo, para o melhor entendimento da direção à qual se orientou o ensino da retórica em Portugal, durante o medievo, há de se examinar, primeiramente, quais as referências bibliográficas que chegaram até os dias atuais. De acordo com Rosado Fernandes (2004), os dois grandes centros de ensino que melhor se conhecem na história da cultura portuguesa medieval são os mosteiros de Santa Cruz de Coimbra e de Alcobaça. Nesses referidos mosteiros, eram compilados tratados que propiciavam aos clérigos o aumento de seu cabedal de conhecimentos tanto gramaticais como retóricos, visto que gramática, retórica e dialética, conjuntamente, formavam o que se conhece por Trivium (LAUSBERG, 2004, pp.14-15).

\footnotetext{
${ }^{54}$ Essa tradição não é exclusivamente Ibérica pelo fato dela também ser parte constituinte dos modelos europeus, sobretudo greco-latina.

${ }^{55}$ Isidoro, bispo de Hispalis (Sevilha), compilou, nas suas Origines ou Etyniologie (Ed.Lindsay, Oxford, 1911, 1957), todo o saber do seu tempo, desde as sete artes liberais até a geografia, agricultura etc. A retórica está compreendida no livro-II, 1-21 e é uma compilação valiosa, onde se trata, com brevidade exemplar, da teoria do discurso e das figuras (SOARES, 2012, p.55).

${ }^{56}$ Raul Miguel Rosado Fernandes fez a tradução, prefácio e aditamentos sobre os estudos retóricos em Portugal, cuja obra é de autoria de Heinrich Lausberg.

${ }^{57}$ Essas duas frentes faziam parte da retórica escolar.
} 
Nas livrarias de ambos os mosteiros, podem ser localizadas obras de Cícero, entre elas os Duo Libri de Retorjca scilicet Tulij, mencionados num inventário de Santa Cruz de Coimbra. Esses correspondem aos dois livros que constituem o tratado ciceroniano do De inventione, e datam, segundo especialistas, do final do século XII e princípios do XIII. Em contrapartida, encontra-se entre os manuscritos alcobacenses, um códice do século XV, copiado em gótico, da Rhetorica ad Herennium, atribuído a Cícero ${ }^{58}$. Esse texto, bem conhecido na Idade Média, constituía o que se chamava a Retórica Nova e contrapunha-se ao De Inventione, ou Retórica Velha, em outras palavras, ambos os textos eram constantemente empregados durante a época medieval e foram realmente traduzidos por eruditos italianos e franceses como Guidotto da Bologna e Jean de Harenc, por exemplo (LAUSBERG, 2004, p.15).

É necessário ainda salientar que nessas fartas bibliotecas monásticas, localizam-se os escritos de Santo Isidoro, cuja retórica era certamente bem conhecida dos clérigos que ali estudavam (LAUSBERG, 2004, pp.15-16).

Tratados gramaticais dedicados às palavras latinas eram utilizados pelos coimbrenses e alcobacenses para compreender questões relativas aos tropos e sua inserção na composição latina ${ }^{59}$. Embora muitos deles sejam responsórios gramaticais, neles podem ser encontradas ligações com a matéria retórica, pelo fato de serem trabalhadas as figuras ornamentais, e isso ajudava os estudantes a formarem o seu estilo, unindo correção gramatical com a beleza estilística. Ainda se pode considerar como elemento secundário para a aprendizagem da retórica, mas não menos relevante, o Dicionário de Pápias, que figura tanto na biblioteca de Santa Cruz como na de Alcobaça, sendo fundamental para os estudantes de latinidade. Nesse léxico, encontram-se explicações de algumas figuras de retórica (LAUSBERG, 2004, p.16).

Em suma, as obras desses autores foram fundamentais para o estudo e transmissão da retórica na Idade Média, em Portugal. Da mesma forma, as escolas monásticas, dispõem de meios suficientes para o ensino de uma das disciplinas mais importantes do Trivium, servindo de subsídio para o

\footnotetext{
${ }^{58}$ Essa anteriormente fora atribuída a Cícero, entretanto, posteriormente, ela seria atribuída a Confúcio (CASTRO, 2008, p.25).

${ }^{59}$ Obras de Prisciano (nascido nos fins do século V) e de Grecismus de Eberhard de Béthune (nascido no final do século XII).
} 
aprimoramento da técnica oratória dos pregadores e, também, dos preceitos para a sua aplicação prática, tendo como objetivo convencer os ouvintes às verdades eternas cristãs, e, por fim, as escolas e suas bibliotecas auxiliaram tanto a pesquisa como o exame minucioso da gramática e poética e sua relação com a retórica (SOARES, 2012, p.56).

\title{
4.1.2. Transição da Idade Média para o Renascimento
}

Durante um período do medievo, a retórica foi transmitida pelos mestres juntamente com a gramática nas instituições superiores, motivo esse, como destaca Fernandes, de sua não citação como disciplina independente:

\begin{abstract}
Na Universidade Medieval, o mestre de retórica também acumulava as funções de mestre de gramática e que, além disso, a retórica não é citada, em determinada época como disciplina com existência independente (LAUSBERG, 2004, p.18).
\end{abstract}

Todavia, efetivamente, no século XV, a partir do ano 1432, a retórica é incluída nos programas de estudos da Universidade de Lisboa. Fato esse verificável na ação do Infante Dom Henrique (1394-1460) em 1431, que instituiu, por testamento, uma verba para manter na referida Universidade, uma cadeira (LAUSBERG, 2004, p.18).

Tais afirmações também são pormenorizadas por Aníbal Pinto de Castro (1938-2010), da seguinte forma:

\begin{abstract}
A entrada da Idade Média no seu crepúsculo vespertino, quando o estudo da Retórica, até então confinado a algumas escolas episcopais e clausurais, conseguia penetrar somente em programas curriculares da Universidade portuguesa. As artes do Trivium, em que a Retórica, segundo o esquema pedagógico medieval, se integrava, estavam reduzidas à Gramática e à Lógica. Foi talvez por sentir essa lacuna que o Infante Dom Henrique, ao doar à Universidade, por escritura de 12 de Outubro de 1431, umas casas situadas no bairro dos Escolares em Lisboa, as destinava para o ensino das sete artes liberais, a saber, gramática, lógica, Retórica, aritmética, música, geometria, astrologia [grifos nossos] (CASTRO, 2008, pp.13-14).
\end{abstract}

Esse interesse pela retórica já se fizera sentir em alguns decênios antes, por Dom Pedro de Menezes (ca.1370-1437). De fato, nos fins da Idade Média, interessaram-se os letrados por Cícero, promovendo algumas traduções. É 
dessa maneira que surge a tradução do De Officiis, feita pelo Infante Dom Pedro (1392-1449) e do De Inventione, realizada por Dom Afonso de Cartagena (1384-1456) (LAUSBERG, 2004, p.19).

Portanto, é pertinente considerar que essa época de transição entre a época Medieval e o Renascimento, os estudos retóricos serviram de contributos para o conhecimento do domínio da palavra com o propósito da criação e produção literária.

\subsubsection{O desenvolvimento e novo incremento da arte da eloquência no Renascimento}

Na Renascença, Portugal tratou a retórica como um novo incremento, por intermédio dos humanistas, ensinando os textos clássicos de Homero, Demóstenes, Virgílio, Aristóteles, Pseudo Longino ${ }^{60}$, Cícero e Sêneca, assim, estreitando o contato com a Antiguidade. Consequente a essa ligação, textos literários que eram resultados práticos de um conhecimento transformado em arte, por meio do talento individual, eram melhorados e polidos pelos humanistas, entretanto, o conhecimento dos pensadores e tratadistas antigos facilitava a teorização mais orientada.

Esse movimento humanístico se afirmava, com vigor, ao longo da segunda metade do século XVI, consagrando a retórica para uma atenção mais solícita e, ao mesmo tempo, tornando premente sua inclusão no plano de estudos oficiais, de modo a obter um lugar independente e basilar, e, assim, superando o organismo medieval, que lhe atribuía importância relativamente modesta no quadro das disciplinas do Trivium. Portanto, o Humanismo faz da retórica uma ligação estreita entre a invenção dialética e uma base de um método novo de filosofar, isto é, aos poucos iam sendo despojados, abandonando a especulação abstrata, para procurar uma aproximação da realidade humana através da comunicação, tratando de problemas de ordem moral, política, religiosa ou mesmo filosófica. Em suma, aliando a dialética

\footnotetext{
${ }^{60}$ (Longinos em grego, Cassius Longinus em latim) foi professor de retórica, crítico literário, político e orador grego no século I. Ele é o autor do tratado mais antigo sobre a estética e estilo sublime, ou elevado. Sua primeira publicação é de 1554, editado por Francesco Robortello. O livro se enquadra na categoria de numerosos textos sobre a formação retórica dos oradores, de acordo com o estilo atual de aticismo (atitude purista em relação à língua grega), mas exalta o valor da imitação dos grandes escritores do passado, destacando a necessidade do espírito de grandeza da alma e uma paixão forte e sincera como um elemento essencial da poesia.
} 
simplificada a retórica, transforma-se no desenvolvimento progressivo do Humanismo (CASTRO, 2008, pp.17-18).

$O$ ensinamento da retórica nas escolas, por professores nacionais e estrangeiros, foi um instrumento de intercâmbio verdadeiramente europeu, onde lecionar nas principais universidades europeias, desde a Espanha, França e Itália, consistia não só em objeto de seus estudos, mas, muitas vezes, como ensino genérico das humanidades. Portugal, por sua vez, não fugiu a esse processo de movimentos intelectuais de constructos, onde as relações eram expressamente ligadas a um sincretismo retórico ${ }^{61}$ (LAUSBERG, 2004, p.20).

No século $\mathrm{XVI}$, era a retórica ministrada em todos os estabelecimentos escolares portugueses, desde o colégio de Santo Antão, em Lisboa, como das Artes, em Coimbra, à escola de Braga, onde lecionou Clenardo e depois Vaseu, e à Universidade de Évora. No reinado de Dom João III (1502-1557), ensinava-se retórica no colégio fundado pelos Jerónimos no Mosteiro de Penha Longa, que depois foi transferido para o Mosteiro da Marinha da Costa, nas proximidades de Guimarães. Essa instituição tinha, em 1534, o privilégio de conferir graus em artes. Posteriormente, em 1543, foi incorporada à Universidade de Coimbra. (LAUSBERG, 2004, p.23).

Em consonância com a exposição de Fernandes, Pinto de Castro destaca que o frade André de Resende (ca.1500-1573), na sua Oratio Pro Rostris (1534), estimulava a mocidade a consagrar-se ao estudo da retórica, qual fosse a carreira que pretendesse seguir, pois a arte de dizer propelia sobre todas as outras uma luz admirável, permitindo que homens de erudição apenas média obtivessem o apreço e a confiança geral, devido ao fato de possuírem alguns conhecimentos de seu domínio (CASTRO, 2008, p.19).

No entanto, é importante reiterar que a consolidação dos estudos da retórica nos institutos superiores deu-se em virtude de algumas reformas, essas realizadas pelos humanistas portugueses as quais se mostraram perfeitamente interligadas na linha de pensamento retórico, vindo desde

\footnotetext{
${ }^{61}$ Obras retóricas de autores portugueses eram impressas em países estrangeiros, geralmente nas cidades em que esses professores ensinavam, assim acontecia com os humanistas estrangeiros que, porventura, interessavam, pelas suas obras, ao ensino das escolas portuguesas (LAUSBERG, 2004, p.22).
} 
Petrarca (1304-1374), a manifestar-se em obras importantes como as Disputationes dialecticae e as Elegantie, de Lourenço Valla (1407-1457), ou De inventione de Rodolfo Agrícola (ca.1443-1485) (CASTRO, 2008, pp.19-20).

Em 1548, com a fundação do Colégio das Artes feita por Dom João III, sistematizava-se definitivamente o ensino humanístico, segundo os critérios modernos da cultura europeia, com mestres de prestígio internacional e competência sobejamente comprovada em centros estrangeiros congêneres, sobretudo de Paris e Bordéus.

Também, no Primeiro Regimento, referente ao Colégio das $\operatorname{Artes}^{62}$, com promulgação em 1552, por Dom João III, a retórica passa a ser considerava parte integrante das disciplinas de estudo ${ }^{63}$. Seguindo essa mesma orientação, observa-se, nos Estatutos da Universidade de Coimbra, de 1559, que eram partes obrigatórias do programa dessa instituição de ensino superior, para os alunos que fossem admitidos na graduação de licenciatura em artes, as cadeiras de gramática e retórica:

Acabados os exames dos bacharéis para licenciados, o Reitor, na tarde do dia, se ajuntava com o Chancelário e a outros examinadores e ali examinavam todos os bacharéis, um a um, analisando seus conhecimentos de gramática e retórica (LAUSBERG, 2004, p.23).

Rosado Fernandes conclui sua exposição, sobre a trajetória percorrida pela retórica como disciplina nos estabelecimentos educacionais superiores em Portugal do século XVI, da seguinte forma:

\begin{abstract}
Vemos, por conseguinte, que, muito embora não nos fosse possível traçar um panorama circunstanciado dos programas escolares do século $\mathrm{XVI}$, o ensino da retórica deve ter feito parte integrante do ensino pré-universitário incorporando-se, certamente, no ensino das universidades que formavam os espíritos da época (LAUSBERG, ibidem, p.23).
\end{abstract}

Em suma, mediante a organização dos Colégios da Companhia, realizada por São Inácio de Loyola (1491-1556) e o do Padre Jerónimo Nadal

\footnotetext{
${ }^{62}$ Primeiro Requerimento que El-Rei D. João III deu ao Collegio das Artes no tempo em que nelle leram os Francezes (1552) - (LAUSBERG, ibidem, p.23 [Documentos dos Jesuítas]).

${ }^{63}$ No Primeiro Regimento, datado nos fins de 1547, era estabelecido pelo monarca que nesse estabelecimento estudantil se ensinasse Gramática, Retórica, Poesia, Lógico, Grego e Hebraico (CASTRO, 2008, p.28).
} 
(1507-1580), em 1552, muitas dessas escolas passaram a fazer parte de um projeto o qual tinha por intenção orientar e organizar a vida pedagógica dessas mesmas instituições, o que ficou conhecido como Ratio Studiorum ${ }^{64}$ (1586$1599)^{65}$ (CASTRO, 2008, p.35).

\section{R A T I O \\ ATQ. INSTITVTIO \\ STVDIOR V M.}

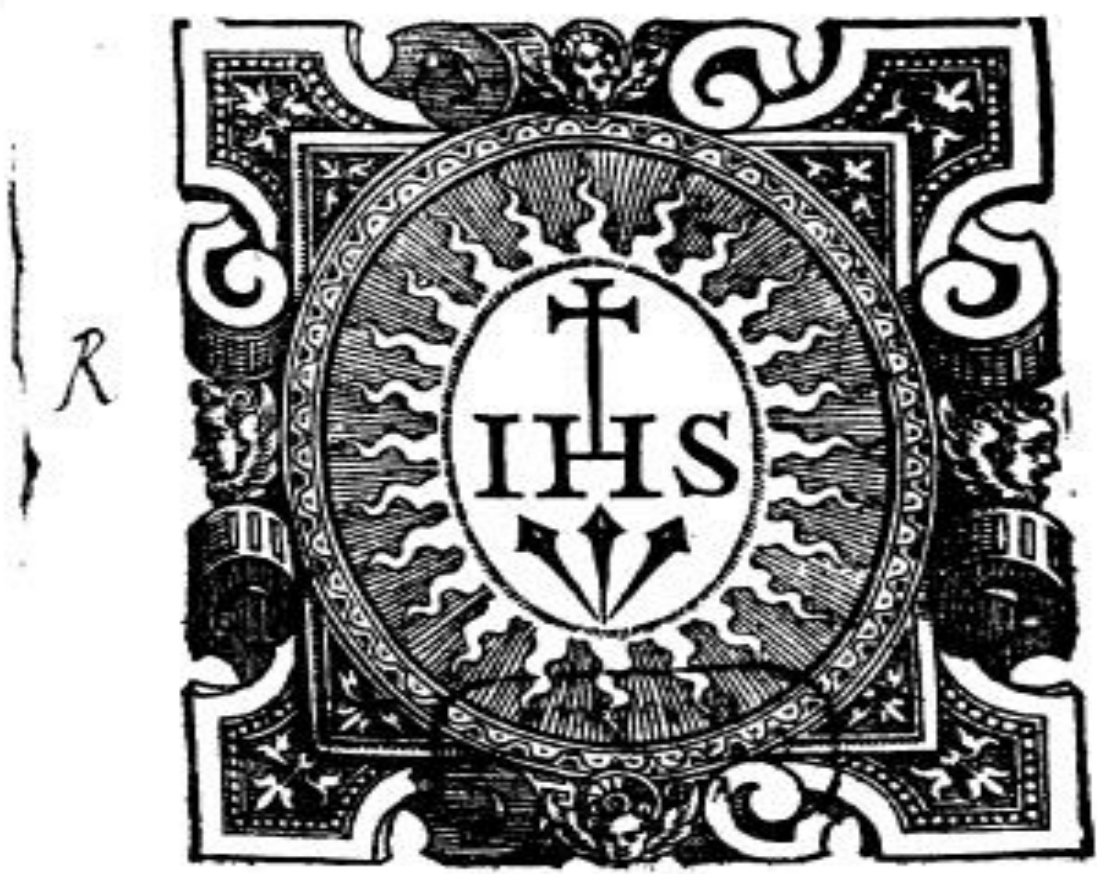

R O M AE,

In Collegio Societatis Iefu. Anno Dñi

M. D. XCI.

Cum facultate Superiorum.

Figura 41- Frontispício da Ratio Studiorum (1591).

\footnotetext{
${ }^{64}$ Margarida Miranda disserta que a Ratio Studiorum, foi um regime escolar e curriculum de estudos a que estiveram vinculados todos os colégios dos jesuítas, da Europa à Ásia e ao Brasil, durante cerca de dois séculos (MIRANDA, 2008, p.270). O ano de 1586 é quando ele é redigido, sendo promulgado definitivamente em 1599.

${ }^{65} \mathrm{O}$ ano de 1586 é quando ele foi redigido, sendo promulgado definitivamente em 1599.
} 
Relevante manual utilizado para formação de clérigos e leigos, a Ratio abrangia estudos que contemplavam os campos das disciplinas humanas, filosóficas, teológicas, entre outros. Observa-se, na figura abaixo, o índice dos assuntos relacionados às disciplinas referenciadas, tais como, teologia, língua hebraica, filosofia, matemática, gramática, retórica.

\section{IINDEX REGVLAR VM.

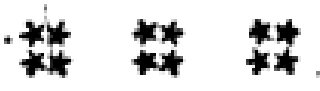

Prouincialis.

Rectoris.

Prafecti Superiorum facultatum.

pag. I

Prxfecti ftudiorum inferiorum.

Profefforis Scriptararum.

Scholafticx Theologix.

Cafuum confcientix.

Lingux Hebrxx.

153

Philofophix.

Philofophiz moralıs.

Mathematicæ.

Tertix Clafsis Grämaticę : vbi funt tres Grammaticæ, prater Rhetoricam , \& Humanitatem.

Secund $x$ Grammatic .

Prim $x$ Grammatica.

Humanitatis.

Rhetorica.

Collegiorum quattuor Clafsium.

Collegiorum trium Cla fsium.

Collegiorum duaru $\mathrm{m} \mathrm{C}$ lafsium.

Collegiorum vnius Scholx.

Communia Collegijs, in quibus paucio- 


\subsubsection{Cipriano Soares e seu manual de retórica}

Nascido em Ocãna, em 1524, entrou para a Companhia de Jesus no ano 1549, quando já estava em Portugal. Sua grande experiência pedagógica determinaria a sua integração como um dos mestres fundadores do Colégio de Santo Antão, em Lisboa, de onde viera para Coimbra. Graduado posteriormente doutor em Teologia, pela Universidade de Évora, matéria essa ministrada por ele conjuntamente com as Escrituras. Por fim, foi reitor do Colégio de Braga, vindo a falecer em 1593 (CASTRO, 2008, p.35).

De acordo com Pinto de Castro (2008), muitas das escolas tinham como manual de base, para a disciplina retórica, os ensinamentos dos tratados de Soares que, embora espanhol, tivera grande influência em todas as instituições escolares da Companhia de Jesus, não apenas em Portugal, mas em toda a Europa e no Brasil (CASTRO, 2008, p.36).

Essas aplicações deram-se não só na Renascença, mas do mesmo modo em pleno Barroco, contudo, os professores fizeram algumas modificações ao exporem essa obra para seus alunos, ou seja, eles reduziram o seu conteúdo a metáforas e as adaptaram conforme a demanda e gostos da época. Por exemplo, a obra De Arte Rhetorica libri tres ex Aristotele recogniti, Cicerone et Quintiliano praecipue deprompti ab eodem Auctore recogniti, et multis in locis locupletati - "A Arte de três das obras retóricas reconhecidas de Aristóteles, Cícero e Quintiliano" (1562), de Cipriano Soares era introduzida com alterações de relevo, como a recorrência a um manual elaborado com várias finalidades e diferentes conceitos culturais, em vez só da leitura comentada dos tratadistas latinos, porém, não despiciendo do ensino da retórica (CASTRO, 2008, pp.36-37). 


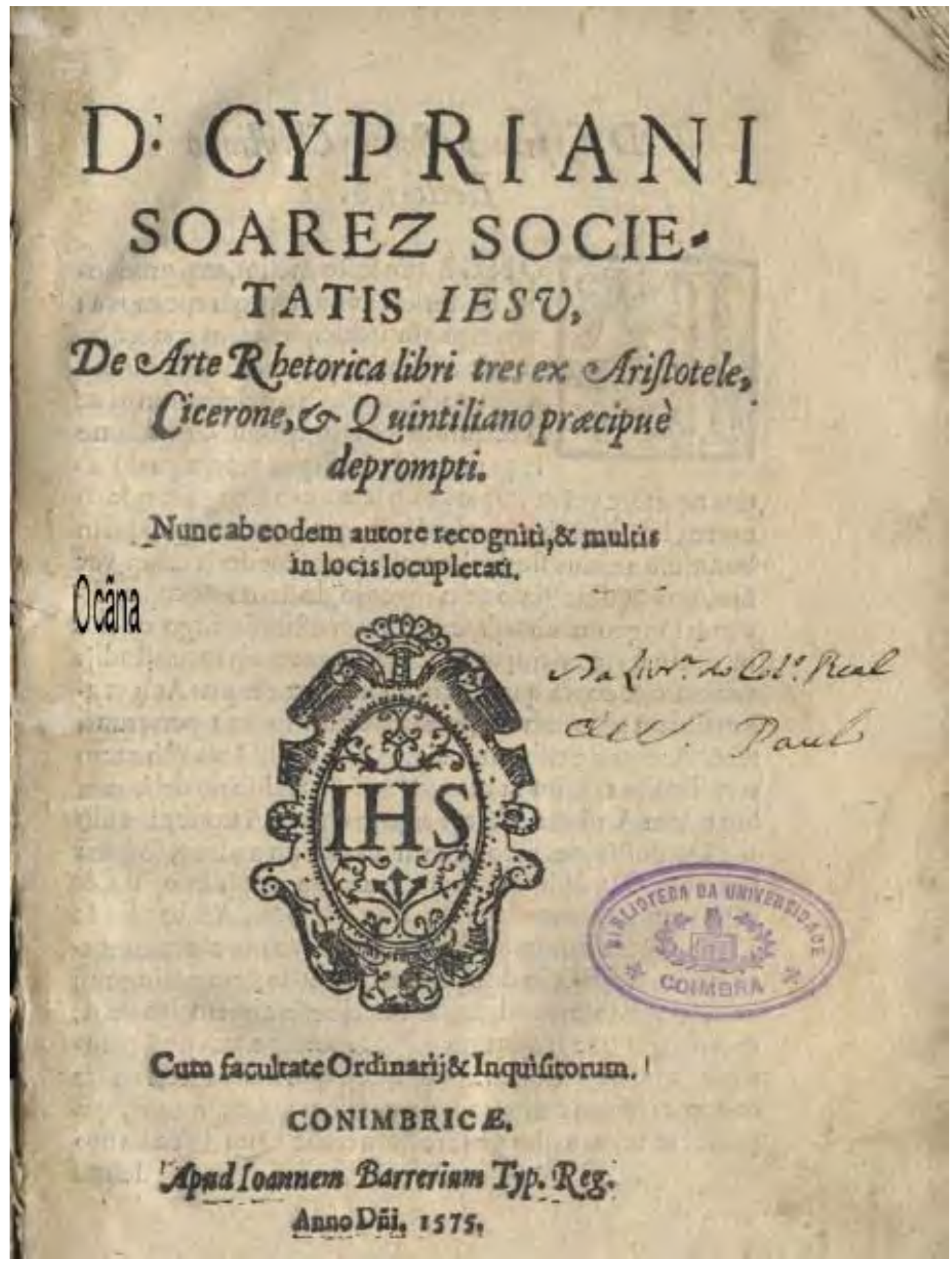

Figura 43-Frontispício do Tratado De Arte Rhetorica Libri de Cipriano Soares (1575[1562]).

Aníbal Pinto de Castro enfatiza que o esquema geral do tratado não difere substancialmente do que seguira Veseu. No mesmo, deveriam ser distribuídos, de maneira ordenada, os assuntos concernentes às matérias seguidas nas aulas da carreira empreendida nas instituições: 
Após definir a Retórica e determinar a sua finalidade, sublinha quanto ela era útil e digna para a formação integral do homem. Segue-se a divisão da matéria retórica e o estabelecimento dos três gêneros. Enunciadas e definidas as suas cinco partes, ocupa-se do problema da natureza e da arte na eloquência, ao qual andavam em geral ligados os da imitação e do exercício. Os preceitos da invenção consagram vasto espaço aos lugares comuns intrínsecos, bem como à melhor maneira de os utilizar, amplificando-os. E com este assunto chega-se ao fim do Livro- I (CASTRO, 2008, p.38).

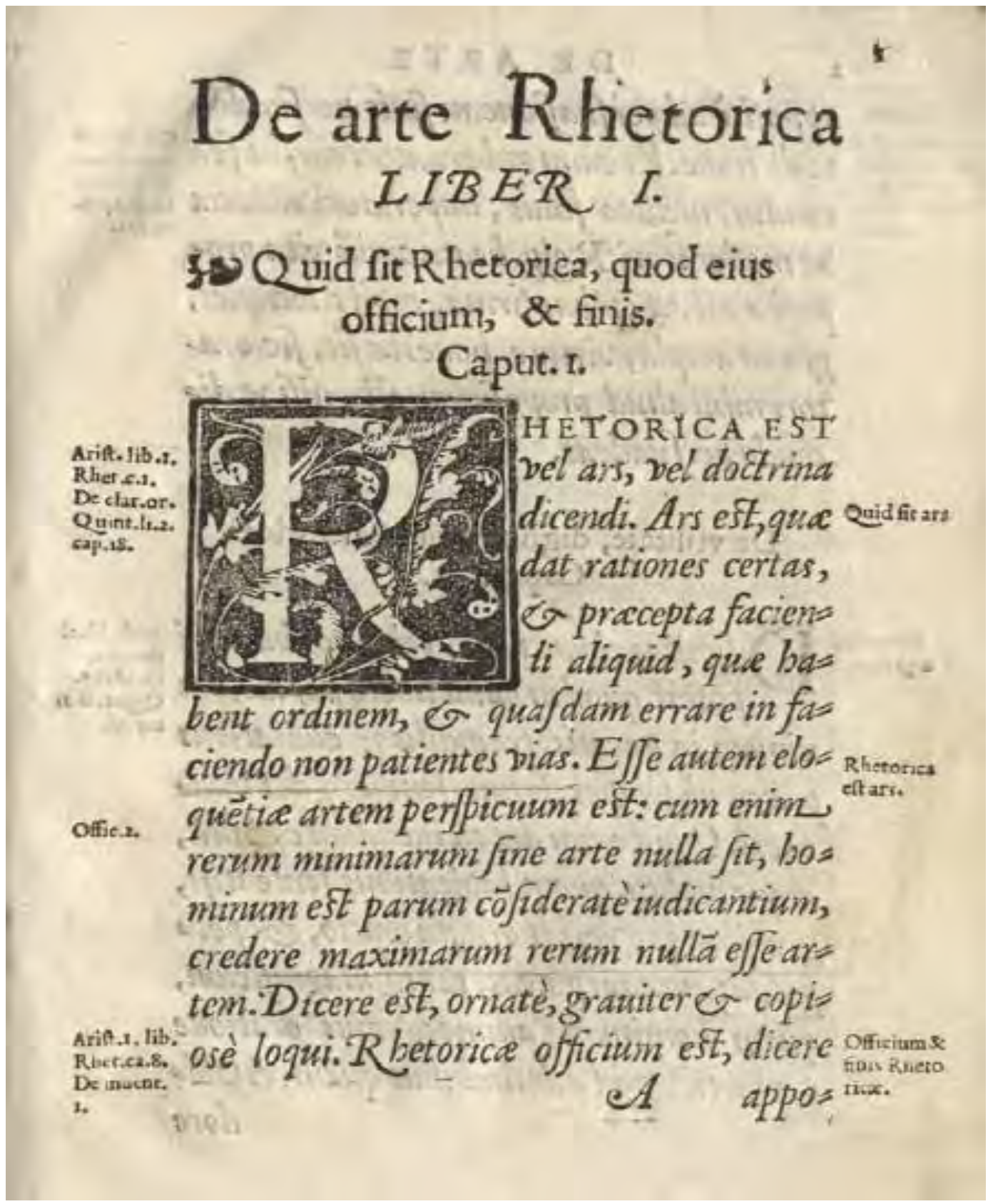

Figura 44-A Finalidade da Retórica- De Arte Rhetorica de Cipriano Soares (SOARES, 1575 [1562], p.1). 
$\mathrm{Na}$ figura abaixo notam-se as cinco partes/fases retóricas ordenadas: Inventio, Dispositio, Elocutio, Memoria e Pronuntatio.

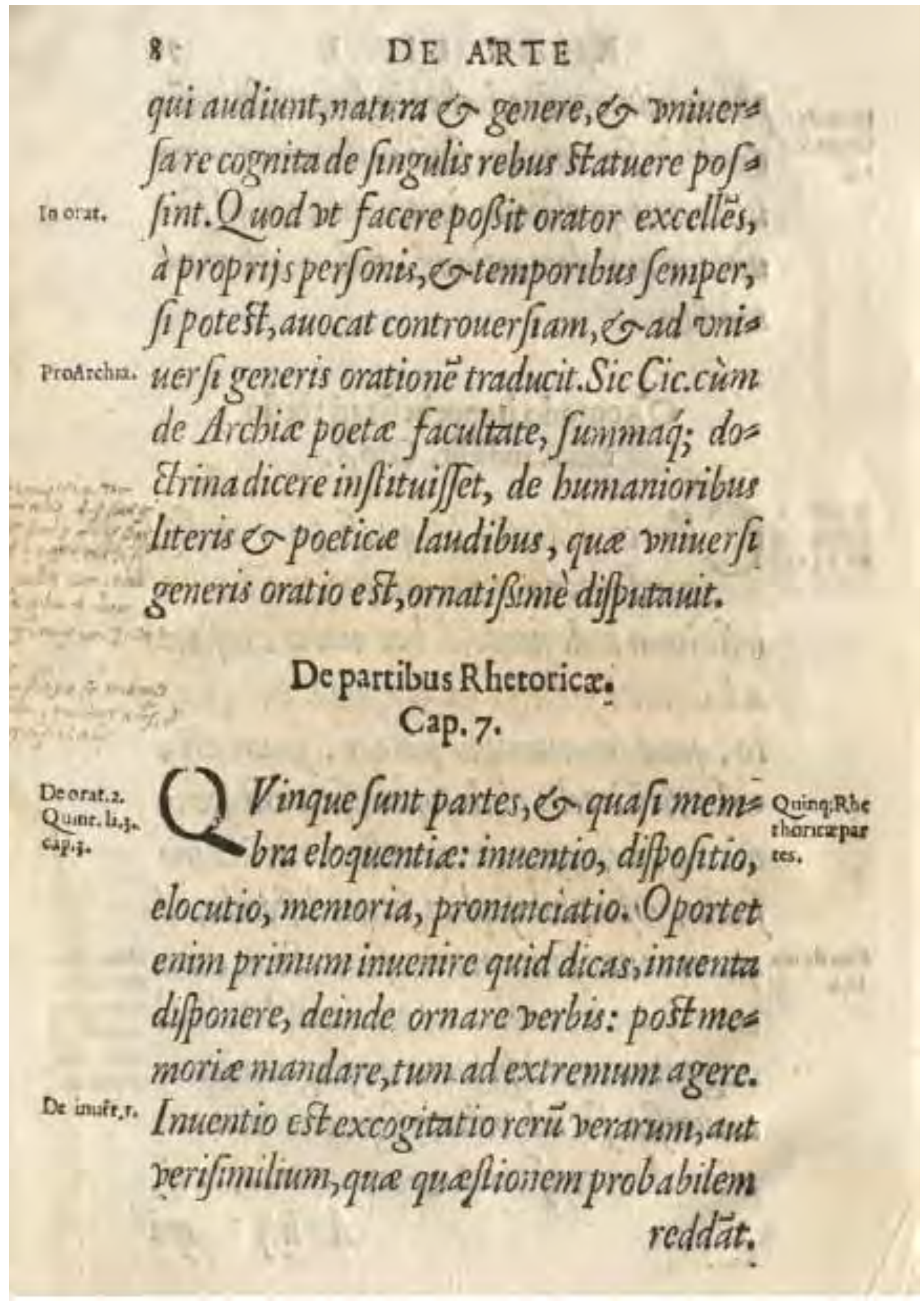

Figura 45-As Cinco Partes Retóricas segundo Cipriano Soares (SOARES, 1575 [1562], p.8). 
No Livro-II, expõe-se o assunto da disposição, a qual é distribuída em quatro partes: Exordium, Narratio, Confirmatio e Peroratio.

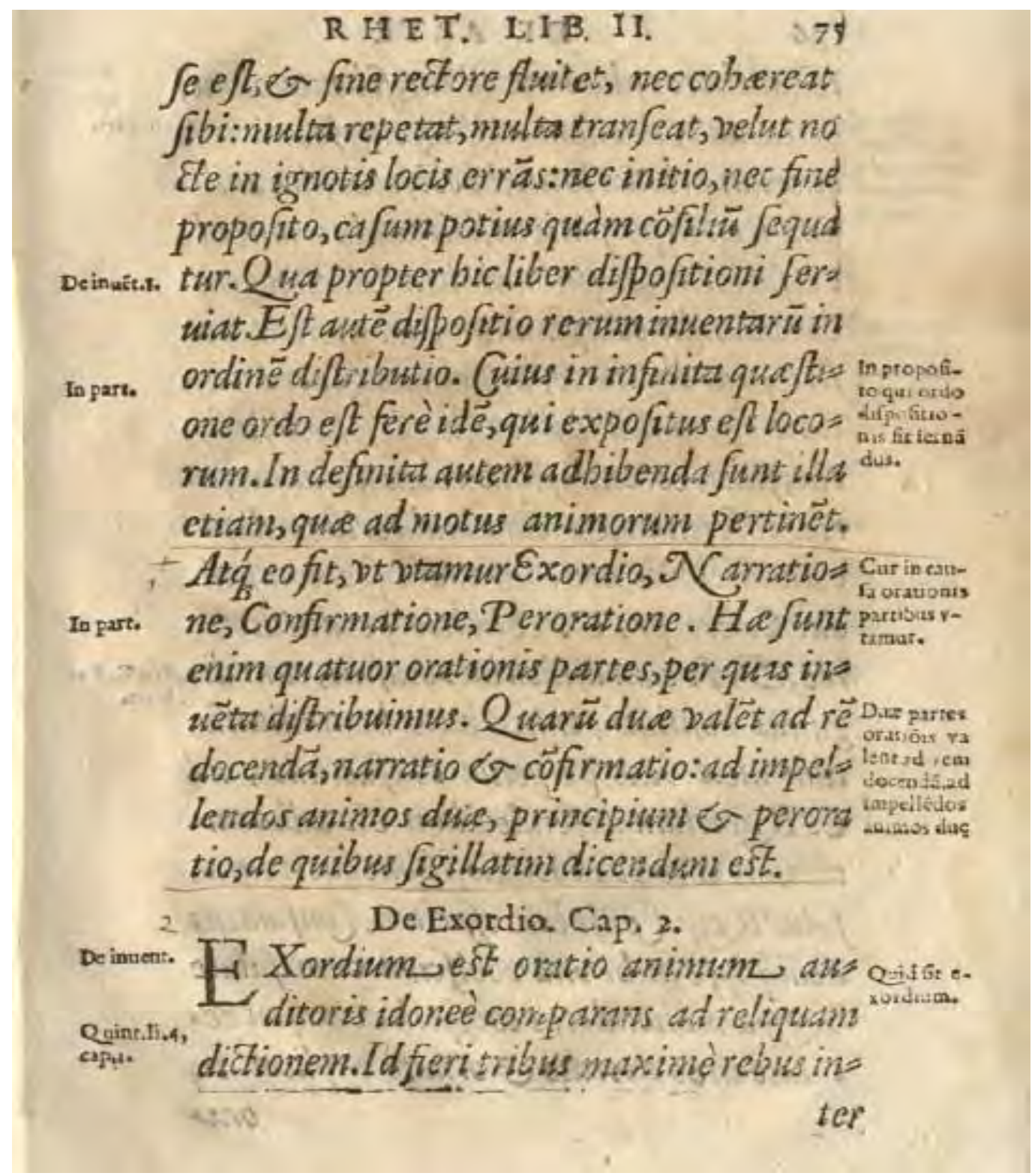

Figura 46-As Quatro Partes da Dispositio segundo Cipriano Soares (SOARES, 1575 [1562], p.75).

No Exórdio Soares o trata como não apenas do tipo de auditório, mas do gênero da causa, esse era constituído por duas partes: a primeira, introdutória, e a segunda, a insinuação, destinada a captar a benevolência ou atenção dos ouvintes. A primeira parte da Dispositio deveria ser sempre elaborada com o maior cuidado, rico em agudeza e de conteúdo doutrinal, porém, expresso em 
palavras adequadas à circunstância do discurso. Assim, o orador procuraria aliciar e com engenhosidade atrair os afetos dos ouvintes.

A narração devia distinguir-se pela brevidade, clareza e probabilidade, qualidades essas indispensáveis para que os ouvintes entendessem, fixassem e acreditassem ao que Ihes fora dito. Todavia, brevidade não significava ausência de ornato ou incultura.

A confirmação, fundamentava-se, essencialmente, no raciocínio, mediante forte estrutura lógica, na qual desempenhavam papel preponderante o entimema ${ }^{66}$, a indução, o exemplo, o epiquerema ${ }^{67}$, o sorites ${ }^{68}$ e o dilema. Também fazem parte da confirmação a argumentação e a confutação.

A última parte da Dispositio é a peroração, as quais se enumeravam rapidamente os pontos principais abordados ao longo do discurso. Neles faziam avultar aqueles que mais covinham à finalidade encarada pelo orador (CASTRO, 2008, pp.38-39).

Finalizando, o Livro-III, o qual era quase todo dedicado à elocução, somente nos últimas sete capítulos eram enunciados os preceitos relativos à memória e à pronunciação.

A elocução consistia em localizar as palavras próprias, polir e ornar as sentenças, de maneira a apresentar o resultado da invenção e da sua disposição, numa forma embelezada, sem a qual aquele trabalho de nada valeria (CASTRO, 2008, pp.39-40).

\footnotetext{
${ }^{66}$ Silogismo formulado apenas em função de seu efeito retórico, carente de rigor formal, por elidir premissas consabidas, ou rigor teórico, por utilizar argumentos apenas prováveis.

${ }^{67}$ Onde uma ou várias das premissas são reforçadas por uma prova, a qual amplia a expressão silogística. A epiquerema evita o encadeamento de silogismos mais floridos. Aristóteles definea como um "racionalizar dialético" (BERISTÁIN, 1995, p.270).

${ }^{68} \mathrm{Na}$ sorites muitas premissas ou proposições se concatenam de maneira que o predicado da antecedente funcione como sujeito da subsequente, até que na conclusão se vinculam a primeira com a última (BERISTÁIN, 1995, p.270).
} 


\title{
De arte Rhetorica $L I \mathcal{B} E R$ III.
}

\author{
De Elocutione. Cap. r.
}

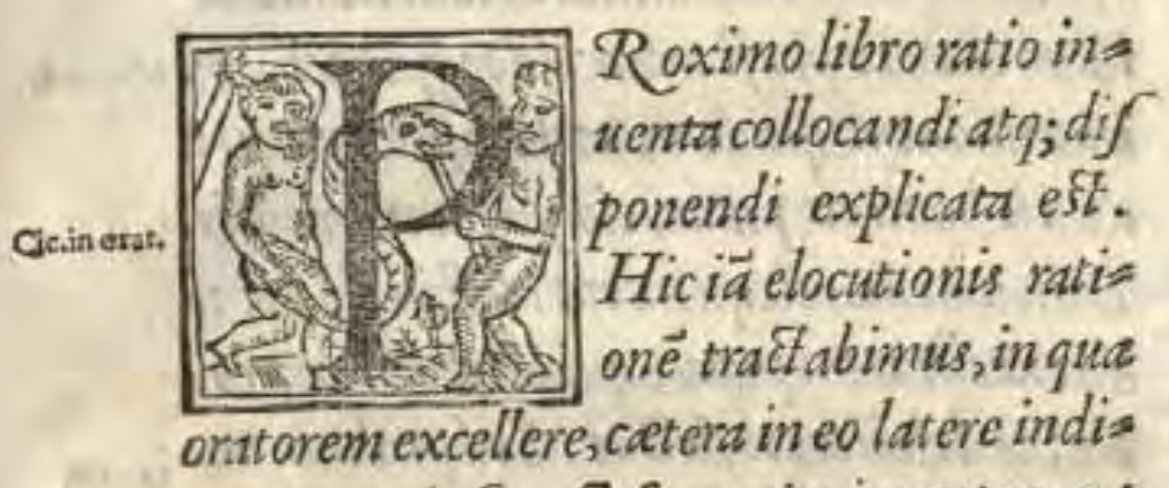
cat nomen ip fum. $\mathcal{N}$ on enim inuentor, aut Er apud cöpo it tor, aut actor bec cöplexus ef om omia, $\mathbf{a}_{\text {,u Roma }}$ led eo Grecè ab cloquendo $R$ betor, er quenda no

Quincti.s Latinè eloquens dictus est. Coterarü enm reru, qua funt in oratore, partë, aliqua $f_{i b} i$ $q u i \int_{q}$ vendicat, dicendi autë, idefl eloquédi maxima wis buic foli conceditur. Eloqui uid fiteautem $e^{\mathrm{St}}$, ea, que inueneris idoneis verbis, ac fentetijs perpolive, o exornare. Sine quo Juperuacua Junt priora, of $f$ mie na fuperu

$$
\text { H iij) lis neclocutio }
$$

Figura 47-A Elocução (Elocutio) segundo Cipriano Soares (SOARES, 1575 [1562], p.119).

Em síntese, a obra De Arte Rhetorica libri tres, de Cipriano Soares, foi, além de um tratado, compêndio e manual de retórica utilizado nas classes de Humanidades da Ratio Studiorum, um importante instrumento para que os preceitos da transmissão literária pudessem compor os discursos musicais portugueses entre os séculos XVII e XIX. (PAIXÃO, 2008, pp.24-25). 
Do mesmo modo, sua constituição e ordenação eram baseadas em três seções: Exordium, corpo do discurso e peroração, ou seja, segue os mesmos princípios aristotélicos, empregados em Dressler e Burmeister, Exordium, Medium e Finis:

\begin{abstract}
Efectivamente, e numa perspectiva genérica, todos os modos de segmentação do discurso que temos vindo a analisar podem englobar-se em três macrossecções. Exórdio, corpo do discurso, peroração ou conclusão constituem, em última instância, as três grandes divisões. Este tipo de partição surge igualmente na análise musical e encontra-se definido nas Artes musicais portuguesas (PAIXÃO, 2008, p.160) ${ }^{69}$.
\end{abstract}

Por fim, a abordagem realizada por Soares em seu compêndio, pode-se alinhar ao entendimento retórico das estruturas discursivas da Disposição lusitana com a Dispositio germânica, como a aplicada posteriormente no século XVIII, por Johann Mattheson em seu Der Vollkommene Capellmeister (CHRISTOVAM, 2012, p.78).

\title{
4.1.5. Os novos estabelecimentos no ensino da retórica em Portugal e as relações de obras barrocas portuguesas e europeias
}

No Barroco, nos grandes centros de ensino se estudaram-se aplicadamente retórica e poética ${ }^{70}$. Entre eles destacam-se Évora, Coimbra e Lisboa. Os jesuítas ensinaram nas escolas e universidades de Portugal a Oratória de Cícero e de Quintiliano, traduziram a obra Poética de Aristóteles e transmitiram, com grande erudição, a retórica para seus alunos, fazendo dessa um elo entre aplicação prática e teoria escolar ${ }^{71}$ (LAUSBERG, 2004, p.24).

\footnotetext{
${ }^{69}$ Tal passagem pode ser localizada igualmente, no trabalho de conclusão de curso de Ozório Bimbato Pereira Christovam (CHRISTOVAM, 2012, p.63).

${ }^{70}$ Pinto de Castro afirma que a disciplina retórica atingira, nessa época, um status universal, seja pelas obras escritas por diferentes tratadistas de regiões variadas da Europa, da ampliação do conhecimento acerca do assunto, na importância da matéria na formação educacional e social do cidadão, isto é, aristocrático ou religioso, nos assuntos deliberativos e judiciais com o aumento das possibilidades nas alegações de provas, com suas respectivas fundamentações, entre outros (CASTRO, 2008, p.72).

${ }^{71}$ Juntamente com a retórica e poética, o ensino da gramática, através do latim, era imprescindível para o sistema jesuíta de ensino, em outras palavras, o conhecimento dependia tanto da transparência dos estudos quanto da compreensão lógica dos temas, cuja imprescindibilidade revelou a afirmação de um código universal, embora restrito, para a cultura letrada da Europa Ocidental e seus territórios de influência, até metade do século XVIII (DURAN, 2009, p.13).
} 
Com isso, nos estabelecimentos de ensino, ocorria uma verdadeira expansão das informações tanto do discurso como do domínio de seus diferentes argumentos. Dessa forma, abria-se campo vastíssimo à invenção, apoiada em raciocínios tirados dos lugares comuns, intrínsecos e extrínsecos, por exemplo, a prática oratória e as disposições de inúmeros tratados e sermões, como os do padre Francisco de Mendonça (1657-1722) e do padre António Vieira (1608-1697), os quais iriam fortalecer os pregadores barrocos (CASTRO, 2008, pp.72-73).

Todavia, no decorrer dos anos até o início do século XVIII, até que surgisse um conjunto de obras de teorização capaz de constituir um método com visível projeção na eloquência no púlpito, a transmissão da retórica, nos colégios e nos conventos, continuava a ser feita pelas obras de Cipriano Soares e Luís de Granada (1504-1588), embora, com o passar do tempo, os professores passassem a utilizar cada vez mais o Adriadne Rhetorum (1651), do jesuíta italiano Luís Giuglaris (1607-1653), ou o Candidatus Rhetoricae (1672) do francês François-Antonie Pomey (1618-1673) (CASTRO, 2008, p.83).

Retornando a António Vieira, em sua obra Sermões (1655-1674) ${ }^{72}$, no prólogo ao leitor apresenta uma orientação doutrinaria tanto para os pregadores quanto para os ouvintes cristãos:

Se chegara receber a ultima fórma hũ livro, que tenho ideado cõ titulo de Pregador, \& Ouvinte Cristão, nelle verás as regras, não sey se de arte, se de gênio, que me guiàrão por este caminho. Entretanto se quiserem saber as causas, porq me apartey do mais seguido, no Sermão Semen est verbum Dei as acharás [sic] (VIEIRA, 1679, pp.7$8)^{73}$.

Pelo visto, Vieira divide a obra em duas partes essenciais, das quais a primeira retrata os preceitos para o ofício do orador sacro, já a segunda deveria enunciar as características e preposições do ouvinte animado de verdadeiro espírito cristão (CASTRO, 2008, p.91).

\footnotetext{
${ }^{72} \mathrm{~A}$ primeira publicação da obra de Vieira com todos os sermões se deu em Lisboa, no ano de 1679.

${ }^{73}$ No livro: Retórica e teorização Literária em Portugal de Aníbal Pinto de Castro, igualmente localiza-se essa citação (CASTRO, 2008, p.90).
} 
Seguindo o índex de seu sermonário, examina-se que após dar uma definição de Retórica baseada em Aristóteles, distingue a matéria das partes. $\mathrm{Na}$ primeira parte considera os quatro gêneros: demonstrativo, deliberativo, judicial e didascálico ${ }^{74}$. De igual maneira, enumera as cinco partes da Retórica, enfatiza de modo sucessivo a invenção, disposição (com suas subdivisões habituais: exórdio, narração, divisão, confirmação, confutação, epílogo ou peroração), elocução (onde define e exemplifica os tropos e as figuras), a memória e, por fim, a pronunciação (CASTRO, 2008, p.91).

Enfim, essa dicotomia expressa no título-pregador e ouvinte-dentro da exposição do Sermão da Sexagésima, parte integrante dos Sermões, projeta uma teoria à qual imprimiu novos rumos à oratória luso-brasileira. De igual natureza, Vieira exprime, em suas prédicas, todo seu cabedal retórico adquirido através de sua formação literária dirigida pelos preceitos da Radio Studiorum, da leitura de Aristóteles, Cícero e Quintiliano, tal como o manual de Cipriano Soares (CASTRO, 2008, p.94).

\footnotetext{
${ }^{74} \mathrm{Na}$ Grécia Antiga era um conjunto de instruções ou indicações que os autores dramáticos davam aos atores que Ihes representavam as obras. Já na Roma Antiga, breve notícia, escrita no começo das peças, informava o leitor das circunstâncias da representação.
} 


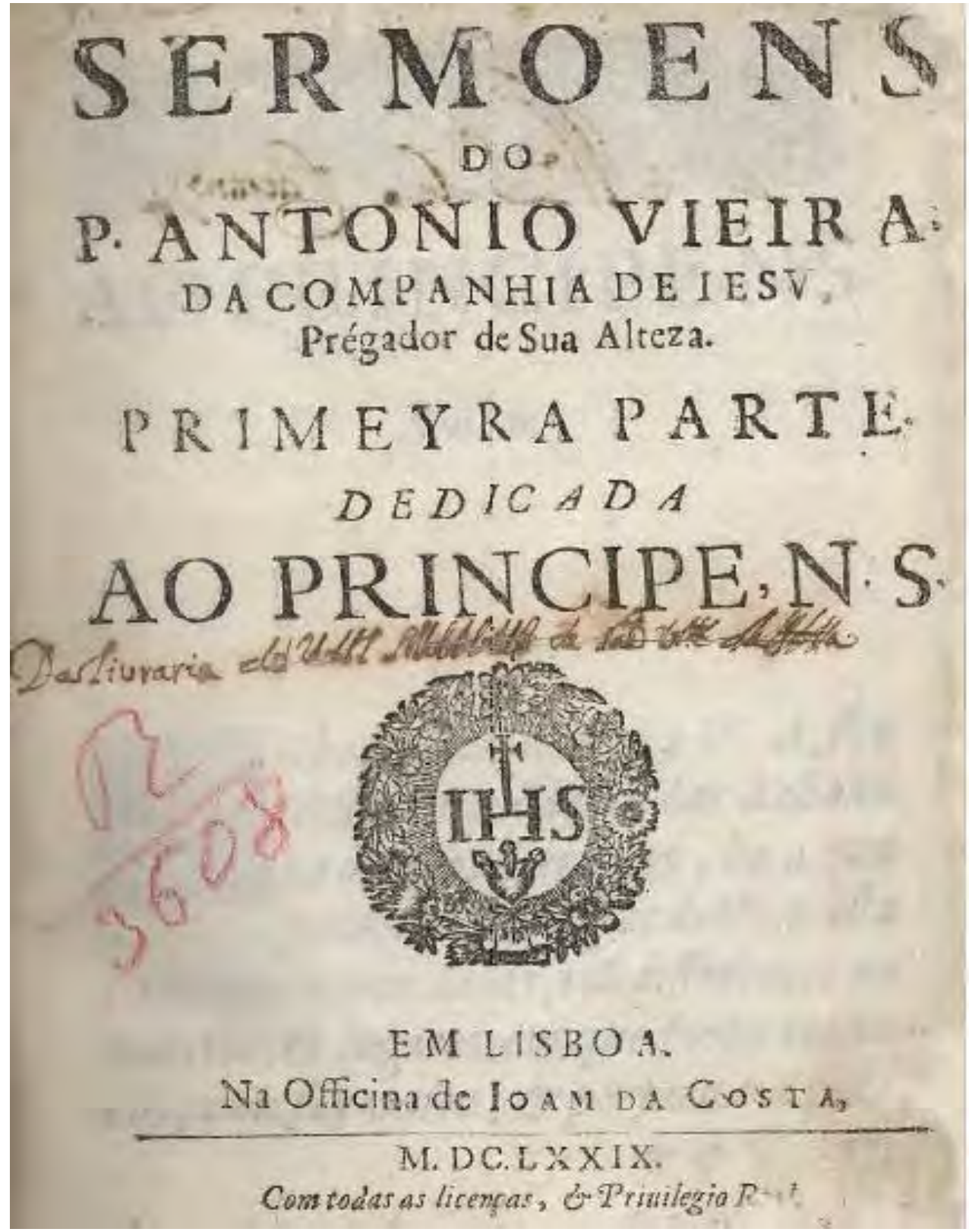

Figura 48-Frontispício dos Sermões (1679) de Antonio Vieira.

Como já observado anteriormente, o interesse do século XVII pela teorização retórica em Portugal foi quase exclusivamente do domínio da eloquência sagrada. Evidentemente que, como disciplina, ela continuava a fazer parte do curriculum humanístico, seguido pelos jovens leigos. De modo que se mantinham em vigor os antigos programas do Colégio das Artes de Coimbra, assim como as escolas da Companhia de Jesus, sobretudo em Santo Antão de Lisboa, Évora, Porto e Braga, para alunos que não tinham como vocação a carreira eclesiástica (CASTRO, 2008, p.143). 
Adicionado a isso, as relações com a colônia italiana de Lisboa permitiram que os discentes das instituições não só aperfeiçoassem o conhecimento da língua italiana, mas certamente tivessem acesso às obras de Pietro Sforza Pallavicino (1607-1667) e Emanuele Tesauro (1592-1675) e, posteriormente no século XVIII, de Ludovico Antonio Muratori (1672-1750) e Biagio Garofalo (1677-1762) (CASTRO, 2008, pp.155-156).

Sobre essas obras, Pinto de Castro salienta a de Tesauro e de sua influência em toda a Europa:

De todas as obras a mais importante foi sem dúvida o Cannochiale aristotélico de Manuel Tesauro. Publicada em 1654, a obra alcançaria uma vasta difusão e exerceia notabilíssima influência em toda a Europa, graças à numerosas edições e traduções, que fizeram dela uma das mais significativas codificações do Barroco (CASTRO, 2008, p.157).

O referido tratado de Tesauro expõe uma doutrina expandida acerca dos conceitos e da metáfora. $\mathrm{O}$ autor distinguiu nessa obra o conceito intencional do verbal engenhoso. Por sua vez, a definição da metáfora ela a dispõe de três formas: engenhosa, de furor ou do exercício (CASTRO, 2008, p.158).

Em outro trecho, Tesauro faz uma divisão das metáforas nas suas oito espécies:

1. Proposição.

2. Atribuição.

3. Equívoco.

4. Hipotipose ${ }^{75}$.

5. Hipérbole.

6. Laconismo.

7. Oposição.

8. Decepção.

Já a divisão das orações retóricas deu-se em duas partes essenciais, isto é, por proposição e prova (CASTRO, 2008, p.162).

\footnotetext{
${ }^{75}$ Descrição de uma cena ou situação de modo vívido, que faz o ouvinte ou leitor ter a sensação de que as presencia no momento em que ocorreram.
} 

renti lueghi dal noftro Autore. Figure, ciafeuna di loro feconde Madri delle Argatezze : cioè.

1. Di Sim IG I I A ż. Homo Quadratus.

2. Di Atт г в т т ION B Regnat gladims.

3. Di E Qv r v o c O Ins Verrinune, malum. IORA

4. Di H I POT I POSI. Pontem indignatus Araxes?

5. Di H I в R BOL B. Inftar Montis Equun.

6. Di Laco is a O. Carpatbü Leporem.

7. Di O p posi r 10 s Mens amens.

8. Di D в в втгон в; Vale apud Orenm;

Che fe ti piaceffe veder paffare vna Parola fola per tutte quefte forme: eccotene lifperiemza nel nome di $\mathrm{R}$ o $x \mathrm{~A}$, dicui null'altro c̀ più conofciuto.

Per Metafora di Simiglianza, puoi tu chiamarla, V R B I v $x$ So z. Peroche così rifplende Roma fra le Cirta, come il Sol fra le ftelle : Onde direfti: Vrbium ceterarum nitorem $T$ iberini Solis fulgor infufcasit.

Per Metafora di Attributione. C A P I T O L I v M: ch'd la Parte per il tutto. Onde puoi dire : Montes omnes Capitolio decefferunt .

Per Metafora di Equinoco, V A L B N T IA : peroche il Greco nomen R o 1 , altro apunto non fonaua, fenon $V$ alentia. Quafi per fatal configlio, niun barbaro poteffe mentouar Roma, fenza confeffare il fuo valore. Onde dir tu potrefti. Quis ift $\boldsymbol{V}$ rbi premaleat ? $V$ alentia eft .

Per Metafora di Hipotipofi, PopvLORvM T R I V M P H A T R I 1 : che ti mette fott'occhi l'attion piu gloriofa, che il Mondo habbia veduto, cioè, il Trionfo. Talche alcun direbbe. Arduas Regum cerkices ferrato curru trabeata Populorum Triwmphatrix proculcauit .

Per Metafora d'Hiperbole, A L I B R O R B is. Quafi per l'ampiezza delle mura , \& per la moltitudine degli habitatori ; paia vn Mondo rinchiufo in vna Cittd. Perche dir potremmo: Miratur Orbis, altero fefe in Orbe concludi.

Per Metafora di Laconifmo, la fola lettera R. in ifcambio del nome intero. La qual lettera nelle infegne tremanti ventilata, fe tremare i Sabini più che le infegne. Siche direfti : Nequicquam de Imperio decre: tatis Sabini : Ro, Sigma antecedit .

Pec Metafora di Oppofito, AN T I C A R T н A G o come preparata dal Fato alla rouina dell Imperio Africano, con lei gareggiante. Che farebbe, come a dire: Cartbaginem fuis e Montibus Anticarthago fulminavit.

Per Metafor $a^{\prime}$ di decettione. R о м $\mathbf{2}$ A. Voee, che cominciando fonate il magnifico nome di Roma, finifce in diminutiuo, alludente alla vilta del Fondarore. Onde appunto ne' fuoi natali fû detta $\mathrm{R}$ O M v L A. \& dapoi

Figura 49-Parte das Divisões das Metáforas segundo Emanuele Tesauro (1669 [1654] p.228).

Portanto, todo esse inventário sobre a sistematização teórica da retórica consolidada no Barroco em Portugal, além das obras dos autores portugueses e de outros estados europeus mostra a frequente invocação aos teorizadores antigos, exprimindo o tributo por eles pagos em suas formações, nos 
estabelecimentos de ensino, sobretudo, da Companhia de Jesus. Assim, constituindo juntamente com outros não citados, verdadeiras colunas salomônicas da teorização barroca (CASTRO, 2008, p.193).

\subsubsection{Os primórdios do Classicismo}

Após a aplicabilidade da retórica nas grandes instituições de ensino, nos séculos XVII e primórdios do XVIII, manifestar-se-ia em Portugal uma renovação e reformulação nas estruturas da disciplina, não só de ordem escolar, mas igualmente na metodologia e didática, seja deliberativa, religiosa ou judicial. Desse modo, ao lado de tratados, de métodos gramáticos e retóricos com finalidade profana e eclesiástica, encontram-se tentativas de esclarecimento quanto à matéria em questão, visando, tal como os humanistas, uma aproximação das fontes (LAUSBERG, 2004, p.25).

Rosado Fernandes (2006) ressalta que essa aproximação se dá por intermédio das edições em latim ou em vernáculo dos autores antigos, sobretudo Cícero e Quintiliano. Entretanto, esse movimento não para por aí, pois a Poetica de Aristóteles e o Tratado Sublime de Pseudo-Longuino viriam ampliar as possibilidades de conhecimento dos textos antigos, traduzidos na mesma época.

Paralelamente, professores como Francisco Leitão Ferreira (1667-1735) e Lourenço Botelho Souto-Maior (1671-1738) iniciaram cursos retóricos baseados nas obras dos autores conceptistas. Esses por sua vez, foram publicados posteriormente, entre 1718 e 1721, assim, constituindo valoroso documento desse movimento na formação literária lusitana, todavia, essa tendência não encontraria boa acolhida ${ }^{76}$ (LAUSBERG, 2004, p.26).

No mesmo sentido, Aníbal Pinto de Castro (2008) salienta que, enquanto a teorização retórica, tanto sagrada como profana, evolui no sentido de

\footnotetext{
${ }^{76}$ Aníbal Pinto de Castro (2008) assevera que toda a teoria desenvolvida por Botelho SoutoMaior exprime um conceito de arte literária essencialmente formal e orientada no sentido de transformar o gosto barroco numa espécie de barroquismo (Terminologia utilizada por alguns críticos literários das belas-artes para se referirem ao extravagante na criação artística, o gosto de surpreender, excentricidade) que, apesar de uma ou outra recomendação em contrário, pálida e modesta, se afirma numa espécie de deslumbramento desenfreado, onde o docere cede inteiramente o lugar ao delectare e o utile ao dulce, da expressão horaciana. Já as lições de Leitão Ferreira pouco Ihe aproveitaram. Enfim, Souto-Maior manteve-se como "surdo às recomendações de moderação e simplicidade naturais feitas pelo confrade Beneficiado e desconheceu as vozes estrangeiras de que, nesse sentido, ele se fizera eco" (CASTRO, 2008, p.234).
} 
transformar a oratória barroca na copiosa e complicada verbosidade barroquista, ao longo da segunda metade do século XVIII, florescem novas correntes com o objetivo de trazer uma eloquência menos ornamentada, em outras palavras, mais simples (CASTRO, 2008, p.342). Por essa razão, nesse período, alguns autores voltam a considerar como fundamental o retorno aos textos clássicos. Essa nova reação tem como seu mais ilustre representante Luís António Verney (LAUSBERG, 2004, p.26).

\subsubsection{Luís António Verney, o reformador nos primórdios do Classicismo}

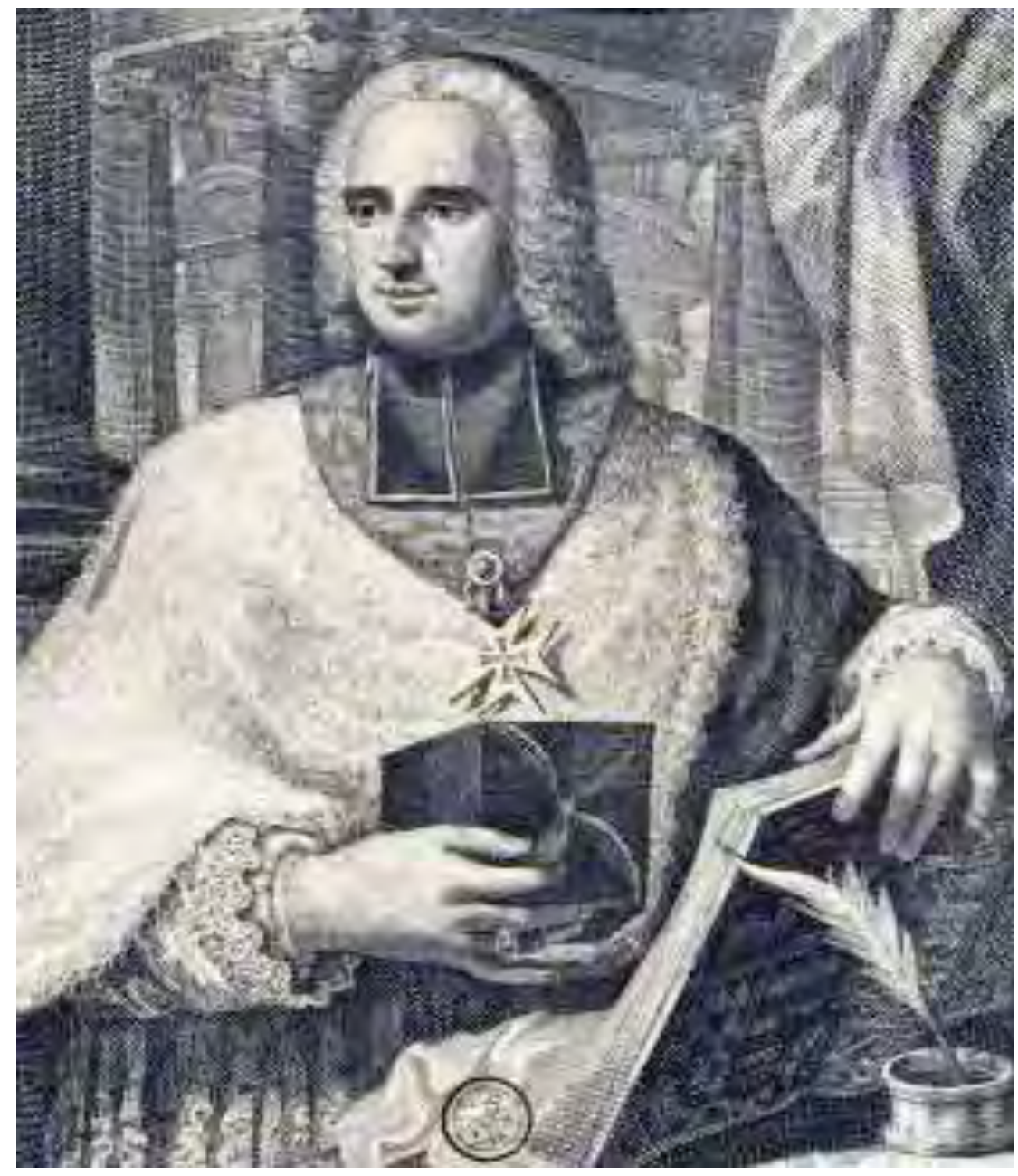

Figura 50-Luís António Verney (ANDRADE, 1966, p.16).

O ensino lusitano nessa época seguia pela égide de um novo sistema, o qual era direcionado para as camadas da sociedade responsáveis pela manutenção da ordem do reino. No entanto, devido à crescente expansão do 
saber retórico, tornou-se necessário, na segunda metade do século XVIII, a língua vernácula e os diversos conhecimentos voltados à prosperidade material da população passaram a ser valorizados. Entre os que se direcionaram para a efetivação desse processo de reformulação da transmissão, nas metodologias instrutivas lusitanas, estavam os mestres de uma das mais importantes universidades do reino, ou seja, em Coimbra. A referida mudança teve como escopo a introdução da disciplina retórica em todos os cursos da instituição, além do processo seletivo dessa como prerrogativa para ingressar nesse estabelecimento de ensino. Com isso, os estudantes tiveram que se submeter à nova disposição da universidade, a qual se fundamentava na obra de Luís António Verney, O Verdadeiro Método de Estudar (DURAN, 2009, p.19).

Segundo Andrade (1966), Luís António Verney nasceu em Lisboa em 1713. Com poucos anos de idade foi entregue aos cuidados de um pedagogo eclesiástico, o Padre Manuel de Aguiar Paixão, confessor da Igreja Patriarcal. Aos 6 anos, já lia e escrevia perfeitamente, sem outras lições mais do que as que ouvia ensinar e explicar a seus irmãos mais velhos. Nesse ambiente religioso, Verney viveu seus primeiros anos (ANDRADE, 1966, p.9).

Posteriormente, Pedro José de Figueiredo o introduziu no Colégio de Santo Antão, a seguir os ensinamentos do padre Paixão, limitando-se a registrar, empolgadamente, o grande talento do aluno, além de sua absorção por parte dos jesuítas (ANDRADE, 1966, p.10).

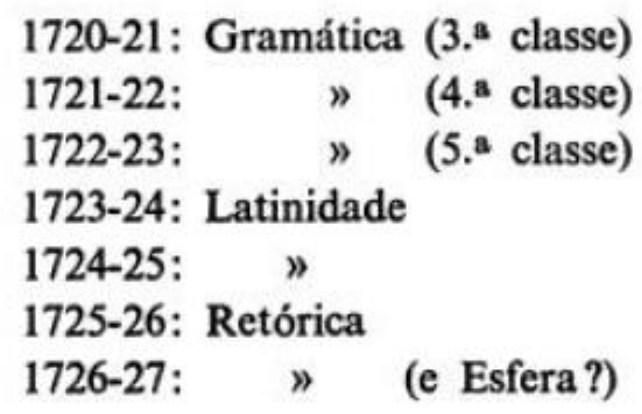

Figura 51-Os Cursos Frequentados por Verney no Colégio de Santo Antão (ANDRADE, 1966, p.11).

Forma-se em Teologia pela Universidade de Évora, também the é conferido o grau de licenciado em Artes, em 1733. Obtém o título de doutor em 
Teologia e Jurisprudência, em Roma. Publica, em 1746, O Verdadeiro Método de Estudar, em seguida, a pedido do rei Dom João V (1689-1750), dá início à reforma pedagógica no país lusitano, a qual tem continuidade com Dom José I (1714-1777) e pelo Marquês de Pombal (1699-1782), com quem se desentendeu e, por essa razão, fixou residência na capital italiana, até seu falecimento em 1792 (DURAN, 2009, p.20).
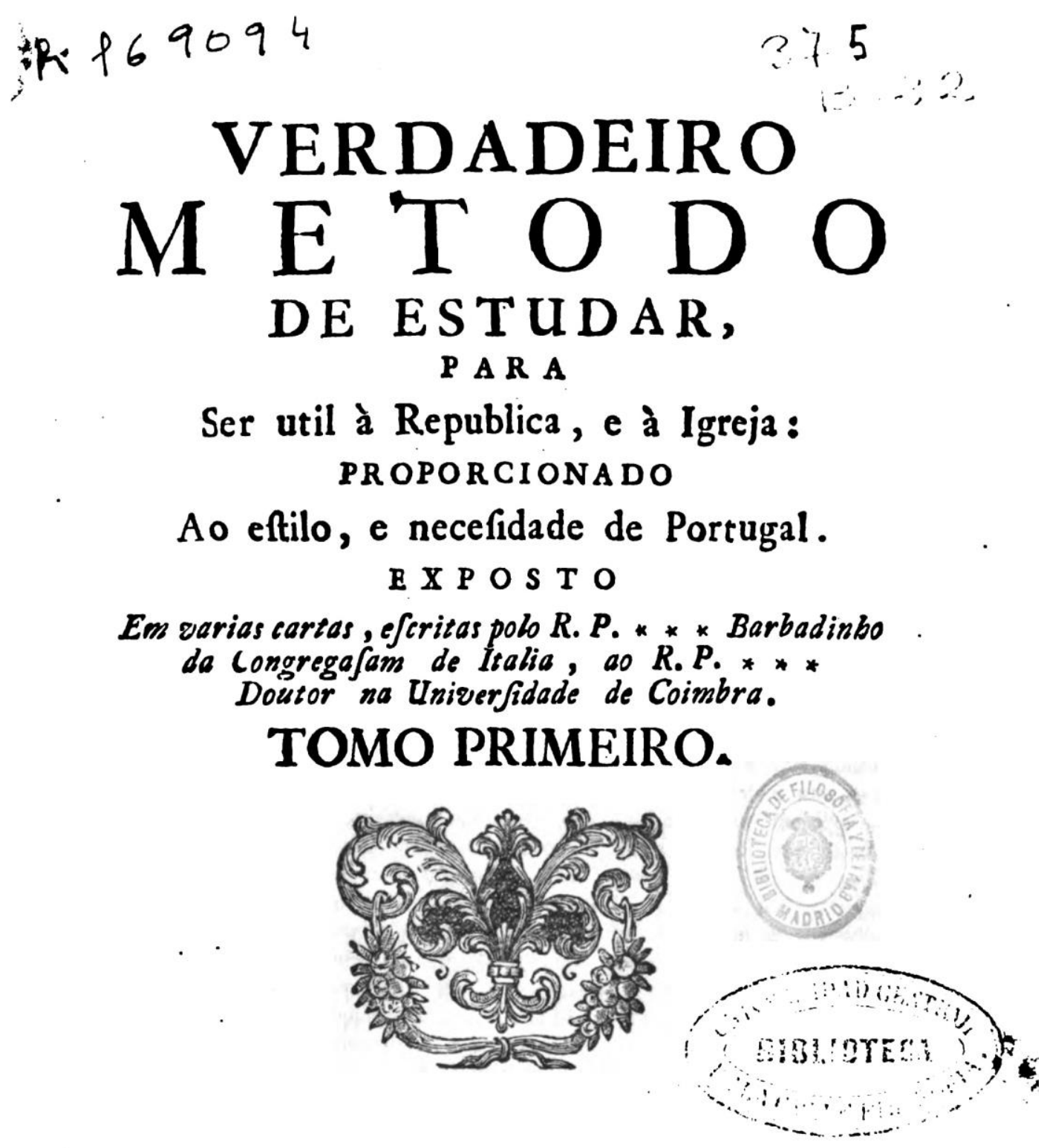

V A L E N S A

NA OFICINA DE ANTONIO BALLE. ANO MDCCXIVI.

COM TODAS AS LICENSAS NECESARIAS, D.

Figura 52-O Verdadeiro Método de Estudar (1746) de Luís António Verney. 
Foi a publicação desse método que trouxe orientação mais segura aos estudos da retórica em Portugal e mesmo à sua aplicação prática, em outras palavras, Verney estabelece uma visão diferenciada acerca da disciplina com novos parâmetros. No entanto, esse autor por ter tido formação oratoriana, a qual era diferente à dos jesuítas, faz críticas à maneira pela qual se direcionava o ensino contemporâneo da retórica (LAUSBERG, 2004, p.26). Ou seja, ele fazia um juízo crítico das metodologias utilizadas pelos jesuítas ${ }^{77}$, evidenciando que os mesmos se restringiam à instrução de um grupo limitado de pessoas, os quais não direcionavam seus estudos para o bem coletivo, mas, sim, para o favorecimento pessoal. Além disso, Verney enfatizava a necessidade da utilização de uma linguagem mais acessível para a instrução dos estudantes, isto é, a língua portuguesa: Ensinar a retórica em latim é um erro, pelo fato de seus preceitos
compreenderem e se exercitarem em todas as línguas, fato que
pode ser considerado como um primeiro problema nas instituições
escolares portuguesas. Pois alunos estudando retórica sem
entender o latim, resultaria em uma interpretação de que a
mesma só serviria para as orações latinas, o que não seria uma
definição correta. Portanto, da mesma forma em que a retórica
nascida na Grécia se espalhara por toda a Europa, isto é, seu
conteúdo fora compartilhado e transmitido em diferentes povos,
deveria também difundir o ensino da disciplina em línguas
diferentes, tais como a do país lusitano [grifos nossos] (VERNEY,
1746, pp.124-125).

Nesse propósito, a retórica poderia popularizar uma linha de raciocínio baseada em uma lógica à qual permitiria exprimir opiniões em português e, ao mesmo tempo, conduziria os atributos do saber e do estudo para o cotidiano das pessoas, modificando assim os princípios organizacionais do conhecimento, colocando num mesmo patamar tanto os que ensinavam quanto os que aprendiam.

Para Verney, o conhecimento da retórica poderia contribuir para o entendimento do aluno, isto é, por meio dela os estudantes saberiam organizar

\footnotetext{
${ }^{77}$ Verney discorre sobre a necessidade da utilização de um novo método de ensino para a retórica em Portugal, sem vícios, como aqueles praticados pelos pregadores. Ele continua dizendo que os mesmos poderiam ser considerados ignorantes no assunto e, por sua vez, devem deixar o estilo antigo para então realmente conhecer a maneira correta da aplicação da retórica (VERNEY, 1746, p.124).
} 
e transmitir melhor suas ideias a número maior de pessoas. De igual maneira, o latim não seria a única língua oficial a ser ensinada e a retórica lograria o posto de disciplina central nessa forma de instruir. Mesmo tendo mudado o processo de ensino em Portugal, era mantido o conteúdo formal do objeto estudado (DURAN, 2009, p.20).

Verney continua sua crítica aos "métodos antigos" dizendo que muitos dos indivíduos defendem uma ideia errônea acerca da utilidade dessa arte:

Retórica é a arte de persuadir e essa, por consequência, que se acha e serve para o comércio humano e mais necessário para ele. Quem diz que a mesma só serve para persuadir na cadeira ou no púlpito, conhece pouco, o que é retórica. Confesso que nos púlpitos e nas cadeiras se faz a retórica gala, com seus ornamentos, mas ela não se limita neles, pois todo o lugar é teatro para a retórica [grifos nossos] (VERNEY, 1746, p.125).

Justificando essa afirmação, pode-se entender que o método barroco de pregar, fundamentado nesses conceitos, estava condenado pelo consenso geral dos bons teorizadores. Essa condenação implicava logicamente a não aceitação das metodologias pedagógicas ou das obras didáticas, difundidas pelos defensores do estilo anterior, assim como a dos pregadores que as utilizavam, ou seja, fica clara sua posição antibarroca (CASTRO, 2008, p.454).

Para ele, todo exercício da língua necessita de uma direção retórica, seja a filosofia que se serve da sua elegância, igualmente a teologia pela necessidade de esclarecer as verdades espirituais que são seu objeto, a justiça com suas leis e cânones, às quais não se pode dispensar e, por fim, o advogado que, em sua arguição, deverá informar ao juiz ou defender o rei sabendo o lugar correto das provas, isto é, o momento exato de utilizá-las, para, assim, aclarar a verdade de sua causa e exercitar os afetos tanto do juiz quanto do júri (VERNEY, 1746, p.126).

Tais constructos aferidos a esse uso persuasivo da linguagem traduziriam em um novo sistema elaborado por Verney, onde matérias como história, geografia e gramática viriam acompanhadas da retórica, ou seja, ela se alinhava a esses saberes, disponibilizando, assim, distintas aplicações do 
discurso, além de auxiliar o aluno na elaboração e opinião das disciplinas estudadas:

\begin{abstract}
[O mestre de Retórica] Logo mandará compor alguma coisa em Português, começando por assuntos breves nos três gêneros de Eloquência. Começará, primeiro, pelas cartas portuguesas, dando somente aos rapazes o argumento delas, e emendando-lhes ao depois os defeitos que podem fazer contra a sua própria língua e contra a Gramática. E por esta razão é supérfluo neste ano ler mais autores portugueses, porque esta composição é o melhor estudo que se pode fazer da língua portuguesa. Depois, passará ao estilo histórico, e tirará algum argumento da mesma História que se explica pela manhã, para que os estudantes a dilatem, escrevendo o dito caso mui circunstanciado, e variando isto segundo o arbítrio do Mestre, ou também a descrição de um lugar e de uma pessoa, ou coisa semelhante. Em terceiro lugar, segue-se dar-lhe algum argumento declamatório, mas breve. Para facilitar isto, o melhor meio é este: Quando o mestre propõe algum argumento que se deve provar, perguntará ao rapaz que razões ele dá sobre aquele ponto. Ouça as que ele dá, e ajude-o a produzi-las, pois desta sorte acostuma-se a responder de repente e escrever com facilidade (DURAN, 2009, p.21).
\end{abstract}

Portanto, a retórica se tornara não só um exercício mais elaborado de comunicação e de autonomia, auxiliando no pensamento do aluno, mas era essencial porque se estendia para as diversas áreas dos saberes e estudos, inclusive no cotidiano.

No que tange à aplicabilidade de figuras retóricas, Luís António Verney afirma que elas devem ser empregadas em toda ocasião, seja em discursos grandes, simples, medíocres, ou na conversação familiar (VERNEY, 1746, p.161). Ele divide os estilos os quais devem ser utilizados em um discurso, mostrados a seguir.

1. Estilo Sublime: este é aplicado a expressões grandiosas, harmoniosas, com ornamentos. Seu próprio lugar estaria nas orações, nos sermões, na poesia heroica e trágica e na história.

2. Estilo Simples: também conhecido como Humilde, seria exprimir o natural. As expressões desse estilo são tratadas na maneira comum de falar a língua.

3. Estilo Baixo: não confundir com o Simples, o mesmo seria o modo de falar dos ignorantes e pouco cultos, já o Simples, é a maneira de falar com naturalidade, sem ornamentos, mas com palavras próprias e puras. 
4. Estilo Medíocre: é aquele que participa de um e outro estilo (VERNEY, 1746, pp.163-168).

D E E S T U D A R.

163

tras mais effudadamente: 0 que faz a variedade de eftilos : que os meltres da-arte reduzem comumente, a trez : Querem dizer, que ou o difcurfo é fumamente nobre, ou fumamente srivial, ou mediocre : à primeira, conrefponde o eftilo fublime : à fegunda, - eltilo fimplez: a terceira, o mediocre - A prudencia e inteligencia com que fe-devem aplicar, eftes crez generos deloque ncia, to principal emprego, do-Retorico.

$S$ U B L I ME :

Quando fe-quer dar uma alta ideia, de alguma coiza, é necefario refletir no-me fmo tempo, em muitas circunftancias. Pormuxto nobre que feja o fugeito, de que fe-trata, pode ter mil imperfeifoens s onde é necefario procurar, de o-por à vifta d'aquela parte, que melhor parece; para poder impremir, uma jufta ideia da-fua grandeza : procurando quanto pode fer, de the-cobrir, ou disfarfar os defeitos, fem prejuizo da-verdade : valtando-o e revoltando-o de todas as melhores partes, para poder moltrar, até as minimas perfeifoens que tem : e tendo muito cuidado, de nam fair com alguma exprefam, ou penfamento, que deftrua o que fetem fabricado. Caiem nefte defeito infinitas pefoas, ainda d'aquen las, que nam fam decepadas.: Oradores, Itoricos \&ac. mas fobre tudo os Poetas: que, por-forfa do-confoante, ou de-quantidade do-verfo, dizem mil coizas ou mal ditas, ou mal aplicadas. Li um foneto de certo Efpanhol, que defcrevia um nariz grande: - qual, defpois de ter dito muita coiza do-dito nariz, conctue desfazendo, quanto encarecère. Porei fomente os tercetos.

Erafe un efpolan de uma galera.

Erafe una piramide de Egito.

Las doze Tribus de narizes era.

Erafe un narizifimo infinito.

Mucbifima nariz, nariz tan fiera,

Que ren la cara de Anas fuera delito.

Defpois dos-quatro verfos antecedentes, em que exagerava terrivelmente 0 tal nariz, faie com uma frioleira, que deftrue tudo: Admetida de grafa, a comua opiniam do-vulgo, de que os Jur deos tem narizes grandes : admetida novamente a frioleira, de que Anés, por-fer Pontifice, o-devefe ter maior: é certo, que nam teria um nariz maior, que todo o corpo - Demos-lhe, que fore tam grande: que proporfam tem ifto, com uma piramide, e nariz infinito? Deftes exemplos acho a cada pafo: de que con-

$$
\mathrm{X}_{2} \text { cluo, }
$$

Figura 53-Trecho da Dissertação sobre o estilo Sublime segundo Verney (VERNEY, 1746, p.163). 
Em suma, para Verney, quem compreendesse a maneira de usar esses elementos retóricos estruturados nas fases retóricas, ficaria perfeitamente instruído sobre o modo que deveriam ser aplicados às diferentes matérias ${ }^{78}$ (VERNEY, 1746, p.169).

\title{
4.2. Retórica na música portuguesa entre o século $X V I I$ e começo do $X I X$
}

Em Portugal, nas artes musicais, a retórica surge ao lado da gramática como um dos principais elementos de comparação com a música. Fato esse igualmente verificável em grande parte da Europa, como bem sublinha Rita Copland "desde o período romano a retórica e gramática se encontravam interligadas, fundindo-se numa disciplina única" (PAIXÃO, 2008, p.113).

Ana Margarida Madeira Minhós da Paixão salienta que, independente da sua contiguidade e associação retórica e gramática, há, desde a Antiguidade, um conjunto metódico e sistemático que ao longo dos séculos se consolidaria:

\begin{abstract}
Independente dos seus graus de proximidade e de fusão, retórica e gramática dispõem, desde a Antiguidade, de um código normativo bastante difundido e historicamente consolidado, o que justifica o recurso aos seus princípios por parte da música que procura precisamente codificar, regulamentar e nomear os seus elementos e princípios, de modo a se constituir-se em um todo coeso. A apropriação de princípios oratórios ou gramaticais por parte da música assumirá ainda maior relevo nas artes musicais portuguesas do período que se segue à implementação do sistema tonal (PAIXÃO, 2008, p.114).
\end{abstract}

Desse modo, a teoria musical portuguesa embasava suas metodologias e aplicabilidade no ensino empregando a retórica e a gramática. Em virtude disso, surge a necessidade da criação de normas de estabilização para um sistema ainda que embrionário, de maneira a notabilizar as duas disciplinas que figurariam nas obras musicais portuguesas desde o começo do século XVII. Por exemplo, em 1618, Pedro Talésio (ca.1563-ca.1629), à semelhança do que se pode encontrar nas Etimologias de Isidoro de Sevilha, apresenta um compasso Grammatical, o qual pode ser formando por três maneiras: igual, desigual ou ternário (PAIXÃO, ibidem, p.114).

\footnotetext{
${ }^{78}$ Por exemplo, a Geometria, a Lógica, Física e Metafísica, Filosofia, Teologia, na Poesia, entre outras áreas do conhecimento (VERNEY, 1746, p.170).
} 
Dentre os diversos tratadistas portugueses, António Fernandes defende a imprescindibilidade de uma elaboração mais profícua em suas obras mediante a criação e sistematização de regras que, à semelhança da gramática e da retórica, possa instituir um quadro teórico subjacente a todo o ensino da música. Tal afirmação é sustentada com uma citação de Cícero. Destaca o autor precisamente que:

O Grammatico, o Rhetorico, \& os demais não saem hum ponto daquillo que the manda \& ensina a Arte, \& isto he proprio de qualquer Arte ou sciencia, que he terem hum caminho certo \& seguro por onde qualquer principiante que scientifico ser deseja com seguridade poßa caminhar; \& faltando isto não seria sciencia, senão confusam. Para intelligencia disto diz Marco Tullio Cicero no primeiro de Oratore que todas as cousas que agora estão enserradas em Arte foram primeiro derramadas \& em algũa maneira dißipadas, aßi como na Musica estiveram os numeros, vozes, \& modos, \& por causa dessa confusam foi inventada a Arte pellos doutos: pera que as cousas que estavam aßi derramadas as ajuntassem e puzessem em rezam, que de outra maneira não fora Arte [sic] (FERNANDES, 1626, pp.7-8) ${ }^{79}$.

Assim Fernandes deixa evidente a alegação para a criação desse quadro conceitual para a música, amparado na gramática e na retórica, cujas artes se alinham como modelos para a utilização de um sistema notacional para a música.

Além da relação entre discursos literários e musicais, a arte musical portuguesa apresenta, como referências, diversos autores de retórica e de poética, o que reforça os pontos de contato entre as duas artes.

Corroborando essa sustentação afirmativa, Ana Paixão cita um variado número de autores e de suas respectivas obras, entre os séculos XVII e início do XIX:

Na Arte de Canto Chão de Pedro Talésio, de entre «Os nomes dos Theoricos, \& Praticos, que o Autor allega nesta Arte», surgem «Horatio Poeta» ou «Virgilio Poeta» (1618: X, XI). Manuel Rodrigues Coelho refere «Tullio» [Marco Túlio Cícero] (1620: V). António Fernandes cita o mesmo autor, mencionando «Marco Tullio Cicero no primeiro de Oratore» (1626: XI). João Frovo cita, no «Discurso Primeiro» da sua obra, autores como «Ouvidio» (1662: 2) ou «Homero» (id.: 78). Manuel Nunes da Silva refere-se a Cícero (1685:

\footnotetext{
${ }^{79}$ Essa citação pode ser igualmente encontrada na tese sobre Retórica Literária e Musical em Portugal nos Séculos XVII e XIX, de Ana Margarida Madeira Minhós Paixão (PAIXÃO, 2008, p.115).
} 
a4r), Camões (id.: 11, 16 do «Tratado das Explanações») e Horácio (id.: 16 do «Tratado das Explanações»). Na Arte de Cantochão de Matias Villa-Lobos são igualmente referidos Aristóteles (1688: Epitome) e Marco Túlio Cícero (1688: 2, 16). Esse último autor é citado nas Flores Musicaes de João Vaz Barradas Morato a propósito da «Musica Theorica» (1735: 3). Na obra de Manuel de Morais Pedroso menciona-se Horácio (1751: Licença do Santo Ofício). Na Nova Instrucção Musical de Francisco Solano podemos encontrar uma citação de Rafael Bluteau, autor do Vocabulario Portuguez e Latino, a propósito da definição de "escarcejo» (cf. 1764: 89). Ainda o mesmo tratadista musical, mas agora no Novo Tratado de Musica Metrica, e Rythmica, alude a Séneca (1779: XVI). Esse mesmo autor - Séneca - é também citado por Hygino da Silva na sua Arte de Musica, publicada em 1838 (PAIXÃO, 2008, pp.118-119).

\subsubsection{Relações entre a arte retórica literária e musical}

As artes musicais evidenciam uma ampla área de contato com a literatura. De acordo com Ana Paixão:

As artes literárias e musicais portuguesas apresentam-se como espaços privilegiados para a identificação e análise desses elementos de Ante-Escrita e de Escrita, frequentemente baseadas em técnicas retóricas (PAIXÃO, 2008, p.80).

Através dos códices retóricos, estabelecidos desde a Antiguidade Clássica, os tratados de Cícero, Quintiliano, Platão e Aristóteles se mantêm inalterados em muitas das obras portuguesas de teoria literária e musical ${ }^{80}$. Diante disso, as divisões da retórica, assim como a elaboração, propósito e as partes do discurso, surgem como princípios orientadores de Ante-Escrita e de Escrita nas Artes literárias e nas musicais portuguesas. Propiciando, dessa forma, categorias e princípios retóricos que permitirão identificar os modos de produção discursiva comuns, na música e na literatura.

Tanto as artes de retórica como a poética em análise são notáveis por sua imensa área de contato com a música, seja nas obras de teoria literária onde se realçam as origens comuns entre literatura e música ou em modos de

\footnotetext{
${ }^{80}$ Sublinha-se a redescoberta de Instituto Oratoria de Fábio Quintiliano por Poggio Bracciolini, em 1416, ou do De Oratore de Cícero, feita por Gherardo Landarini, em 1432, os comentários de Pietro d`Abano à obra de Aristóteles em 1475, as traduções das obras completas de Platão por Marsílio Ficino, publicadas em 1491. Como bem ressalta Peter Mack, nos textos humanistas: "as expectativas estavam dominadas pela Rhetorica ad Herennium e pela recente descoberta da Instituo Oratoria de Quintiliano, a Retórica de Aristóteles, outras obras como De inventione, que são fundamentais para o período medieval". Nas obras portuguesas, a preponderância do pensamento retórico de Cícero e, sobretudo, de Quintiliano será mais do que a de quaisquer outros autores (PAIXÃO, 2008, p.81).
} 
relacionamento entre textos literários e musicais, que resultam em efeitos de recepção idênticos ou gêneros partilhados. Essa comparação relacional surge através de um grande campo de intersecção temático, onde analogias e imagens são frequentes, assim como citações de autores musicais e reflexões elaboradas em torno de aspectos musicais específicos, dentre elas a música portuguesa. Tais constructos comparativos conduzem à reflexão sobre o exame da forma do relacionamento da música e seus respectivos modos de integração que, segundo Paixão (2008), "são possíveis, graças ao reconhecimento dos aspectos musicais nas línguas, gerando, assim, uma distribuição e adaptação da terminologia, além dos conselhos ao poeta, orador ou para quem estuda música" (PAIXÃO, 2008, p.84).

Em síntese, como enfatizado na introdução no tópico (1.2) metodologias e análises empregadas, a retórica é uma disciplina que abrange grande diversidade de possibilidades de expressões, estilos, processos de produção e difusão discursivos para todos os tipos de obras escritas. O que a torna eficiente tanto para criar ou exprimir discursos com características linguísticas como semânticas e musicais (PAIXÃO, 2008, p.82).

\subsubsection{Semelhanças entre poesia, música e retórica}

Autores portugueses, como Francisco Freire de Carvalho, ressaltam que a música e a poesia têm em comum a mesma origem, pelo fato de haverem nascido nas mesmas circunstâncias, isto é, poetas cantavam suas próprias composições e essas, por sua vez, eram acompanhadas de métrica e melodia, resultando em palavras trabalhadas, ornamentadas ${ }^{81}$. Bernardino Carneiro mostra similarmente a relação entre a poesia e música, alegando precisamente a existência da versificação poética a partir dessa gênese musical. Para Duarte de Vasconcelos, os princípios geradores da poesia são também comuns, porém, ele apresenta mais um componente o qual serve de condutor e

\footnotetext{
${ }^{81}$ Por exemplo, António Fernandes explicita do seguinte modo a origem da música métrica: "Assi que nam das letras, mas do som da voz vem a nascer a Musica Metrica: porque acompanhandoa com o som dos artificiais instrumentos se forma o Metro, como antigamente o faziam os Poetas Lyricos, que ao som da Lyra ou da Cytara cantavam os seus versos: donde igualmente os Poetas \& os seus versos cantados vinham a chamarse Lyricos; \& porque assi do principio andavam pouco \& pouco buscando acompanhar os versos com harmonia ao som da Lyra, ou da Cythara, he opiniam de muitos que os dittos acharam as leys ou regras dos versos os quais se chamam Metricos" [sic] (FERNANDES, 1626, cap.7,§ 3, p.15). Citação igualmente localizada em (PAIXÃO, 2008, p.105).
} 
impulsionador para a criação do poema e da melodia, que é a emoção (PAIXÃO, 2008, p.86).

Por consequência, o conjunto dos modos de complementaridade, no estabelecimento entre texto das duas artes (música e poesia), em conformidade às palavras e a um discurso organizado, alinhados à emoção, corrobora para a manifestação do despertar dos afetos e como instrumento central na consolidação dessa reação está a retórica que pode evidenciar esses efeitos (SOARES, 2012, p.68).

Autores como Filipe das Chagas, Jerónimo Rodrigues e João Francisco Branco analisam questões relativas a gêneros partilhados pela música, poética e retórica. Tanto canções como as óperas são salientadas em suas obras e, ao mesmo tempo, estabelecidas pela proximidade entre o músico e o poeta, enfatizando os efeitos que o poema e a música poderão provocar e a forma de sua disposição nas relações entre os textos das duas partes. Finalizando, Antonio da Costa, na sua obra Conclusões de Rhetorica e Poetica, tece comentários sobre a poesia lírica para, posteriormente, empregar reflexões ao gênero operístico, abordando também a questão da representatividade musical (PAIXÃO, 2008, p.88).

Os mesmos paralelismos nas artes retóricas e de poética são expostos e comparados entre os domínios da literatura e da música, por João de Barros, no século XVI, na Grammatica da Lingua Portuguesa, onde as similaridades com a música a propósito da duração e das alturas sonoras das sílabas são estabelecidas:

Toda syllaba tem tres acidentes, Numero de leteras, Espaço de tempo, Acẽto alto ou baixo. O numero de leteras, ia ô vimos pelos exemplos atrás. Espaço de tẽpo, por q hũas sam curtas e outras lõgas, como nesta diçã Bárbora, q a primeira e lõga. \& as duas sã breves. Por que tãto tẽpo se gásta na primiera, como nas duas seguintes, à semelhança dos músicos, os quáes tanto se detẽ no ponto desta primeira figura bar, como nas duas derradeiras, bo, ra. [...] O terceiro acidente da Syllaba, e canto álto ou baixo: por que como os músicos alevantam \& abaixã a voz cantando, assy nos temos a mesma ordem [sic] (BARROS, 1540, pp.4-5) ${ }^{82}$.

No século XVII, em uma obra anônima intitulada Orphea Rhetorices Cithara in quinque Cordas seu partes distributa et eloquentiae plectro

\footnotetext{
${ }^{82}$ Igualmente encontrada em (PAIXÃO, 2008, p.89).
} 
emodulata, a retórica é comparada a uma cítara que contém cinco cordas assim como as partes da retórica, ou seja, suas cinco partes. Já no século XVIII, José de São Lourenço desenvolve semelhante paralelismo entre retórica e música ao ressaltar "que as persuasões e provas retóricas deviam variar pela razão dos ouvintes; assim como o músico precisaria acomodar-se pela diversidade do ouvir" (PAIXÃO, 2008, p.89). Na mesma época, Antonio das Neves Pereira considerava que a música era uma área privilegiada de intersecção com a literatura, sobretudo com a retórica, ou seja, pela eloquência ordenada que se traduzira em uma música articulada, por exemplo. Além dessa relação entre eloquência e música, Neves Pereira destaca outro paralelismo ao evidenciar que "o movimento no discurso produz o mesmo efeito que faz na música". Portanto, na composição das palavras, como na ação ou gesto, ele pode ser localizado, todavia, na ação é bem mais perceptível (PAIXÃO, 2008, p.90).

No século XIX, referindo-se à prosódia, Jerónimo Soares Barbosa também estabelece uma comparação com a música do seguinte modo:

\begin{abstract}
A quantidade é a medida da duração que damos á pronunciação de qualquer syllaba. Esta duração é toda relativa, bem como o é a das notas da musica, em que uma não é mais longa senão comparada com outra que o é menos. Assim pois, como na musica as notas tem a mesma quantidade relativa nos allegros, que tem nos adagios, comparadas entre si, dentro do mesmo ar de compasso posto que uma nota da mesma especie gaste mais tempo realmente no adagio, que no allegro: assim na pronunciação de uma Lingua as syllabas medem-se não pelo vagar ou pela velocidade accidental da mesma pronunciação, mas relativamente ás proporções immutaveis, que as fazem ou longas ou breves [sic] (BARBOSA, 1822, livro I, cap.6 § 1 , pp. $27-28)^{83}$.
\end{abstract}

Adiante, Paixão disserta sobre a terminologia musical presente tanto na arte retórica como na poética, sendo que ambas têm grandes variedades de termos:

A terminologia musical presente nas artes de retórica e de poética é particularmente evidente quando as obras em causa se propõem compilar vocabulário. É o que ocorre em Vocabulário Portuguez e Latino (1712-1728), de Rafael Bluteau (1638-1734), onde o autor

\footnotetext{
${ }^{83}$ Citado também em (PAIXÃO, 2008, p.90).
} 
reúne uma grande variedade de termos musicais, propondo que o seu trabalho seja igualmente considerado relevante do ponto de vista da música. Para isso, Bluteau cita duas das obras de teoria musical mais relevantes do século XVII, como já referimos: a Arte de Musica de António Fernandes, datada de 1626, e a Arte Minima, do Padre Manuel Nunes da Silva, de 1685. Estas obras e os seus respectivos autores constituirão as referências musicais de autoridade do Vocabulário de Bluteau, sendo constantemente citados para sustentar teoricamente a significativa profusão de termos musicais presentes nos oito tomos e nos dois suplementos da obra [grifos nossos] (PAIXÃO, 2008, p.97).

Já no que tange à aprendizagem musical, ela deveria ser comum a toda as pessoas, pois a transmissão da música, da retórica e da poética como da dança deveria ser complementar, dadas as relações de proximidade existentes entre essas artes (PAIXÃO, 2008, p.100).

Similarmente, essa aprendizagem musical adquire particular relevo para o orador. Guilherme Bandeira, em Rhetorica Sagrada ou Arte de Pregar, ressalta a relevância de um bom uso da voz e da adaptação dessa em diferentes momentos e circunstâncias do discurso. Para tanto, o autor sugere tonalidades específicas para cada momento da oração, como se pode comprovar pelo seguinte excerto:

Apta he a voz, que se ajusta no tom ao sentido do que diz nos altos, baixos, e meyos. No Exordio há de ser muy suave, e temperada a voz sem muitos altos, nem baixos, para que não esteja cançada para proseguir, o que resta do Sermão: na Narração se há de entrar com mais viveza: a divisão há de ser proposta com muito espaço, para que possa ficar impressa no Auditorio, e na confirmação há de esforçar mais a voz, ajustando o tom á energia do conceito; e para mais clareza porei varios modos de temperar a voz para subilla, e abaixalla, sem faltar á arte da Musica, que a Rhetorica serve de regra, para que as vozes do Orador não sejão desentoadas.

Sermão nota musical

Thema.........................................................Ut

Narração..................................................Re

Confirmação................................................Mi

Exclamação..............................................Fa

Increpação.................................................. Sol

Exhortação............................................... Sol

Admiração...................................................La

Epilogo................................................Re

[sic] (BANDEIRA, 1745, p.135) ${ }^{84}$.

\footnotetext{
${ }^{84}$ Essa citação referencial também pode ser encontrada em (PAIXÃO, 2008, pp.100-101;
} CASTRO, 2008, p.379). 
Em suma, por meio das comparações e paralelismos entre poesia, música e retórica, por parte de autores portugueses, como no ensino das três artes, pode-se intuir que a música é uma área privilegiada que serve como uma linha de intersecção com a literatura e, sobretudo, com a retórica, ou seja, um elo onde a eloquência se apresenta através da qualidade do pensamento e discurso expresso pelo autor, compositor, orador ou poeta, com o objetivo de persuadir o ouvinte.

\subsubsection{Proximidade dessas relações com diferentes culturas}

Aníbal Pinto de Castro enfatiza a relevância de teorizadores da retórica literária de países como França e Itália. Segundo ele, os teóricos franceses dos séculos XVII e XVIII contribuíram para a fundamentação de certos aspectos da estética pré-romântica na ação formativa da retórica ${ }^{85}$, defendida por M.Klaus Dockhorn, baseando-se num estudo de fontes inglesas e germânicas, completadas. Igualmente no conhecimento de tratados de retórica, publicados na Itália desde o princípio do Renascimento e divulgados modernamente por Eugênio Garin, Paolo Rossi, Cesare Vasoli e, sobretudo, Bernard Weinberg, o que propiciou permitir uma investigação estruturada sobre fundamentos renovados e mais sólidos de toda a estética literária italiana, em fases e estágios sucessivos da sua história, num movimento de crescente entusiasmo e labor (CASTRO, 2008, p.7).

Castro continua sua exposição, destacando e relacionando esse intercâmbio de saberes em Portugal, de igual forma ao que era produzido e ao mesmo tempo recebido de outros estados europeus, isto é, Portugal obteve fortes influências de inegável valor no campo da literatura comparada. E no quadro de todas essas influências merece referência especial a presença permanente do predomínio de teorizadores greco-latinos como Aristóteles, Cícero e Quintiliano (CASTRO, 2008, p.9).

\footnotetext{
${ }^{85} \mathrm{~A}$ professora Marina Machado Rodrigues (UERJ) salienta que: "a estética pré-romântica tinha como características a expressão da profunda melancolia, o desespero, a angústia, da mesma forma o sentimento da natureza inaugura uma nova visão da paisagem: entre a natureza e o eu estabelecem-se relações afetivas; os lagos, as árvores, as montanhas etc., associam-se intimamente aos estados de alma; o poeta submete todas as visões do universo às suas emoções e aos seus sonhos. À literatura pré-romântica se deve à revelação da beleza melancólica do outono, como tempo de folhas caídas, do sol pálido dos crepúsculos magoados, das paisagens montanhosas e selvagens" (RODRIQUES, 2004, p.125).
} 
Propiciando para Portugal a oportunidade de não só ter contato com as obras desses insignes mestres, mas, também, a possibilidade de estudá-los. $O$ que remete à afirmação de Pinto de Castro de que "tal presença constitui em uma das demonstrações mais flagrantes da perenidade do legado clássico na cultura portuguesa" (CASTRO, 2008, p.10).

Não obstante, Ana Margarida Paixão disserta que essa proximidade entre diferentes culturas é igualmente perceptível em relação à língua em que as obras foram escritas, a partir do século XVI, onde predominavam o latim e o espanhol. O latim ainda se impunha nessa época como língua predominante no domínio retórico e poético. Todavia, havia permanente intercâmbio de professores e teóricos espanhóis e portugueses tais como: Aires Barbosa, Aquiles Estaço, Luis de Granada, Cipriano Soares, assim como Mateus de Aranda ao longo desse período. Ainda no século XVII, podia-se verificar a existência de obras musicais em latim ou traduzidas do espanhol para o português, como a Arte de Canto Chão de João Martins, publicada em Coimbra, em 1612 (PAIXÃO, 2008, p.24-25).

Já nos séculos XVIII e XIX é evidenciado aumento significativo das obras traduzidas em Portugal. Paixão comenta sobre essa relação entre a cultura portuguesa, francesa e italiana:

\begin{abstract}
Será nos séculos XVIII e XIX que se constata um aumento significativo das obras traduzidas em Portugal. No âmbito da literatura, há uma profusão de traduções de autores como Horácio, Quintiliano ou Fénelon, e de outros estreitamente relacionados com a oratória sagrada. Relativamente à música será no século seguinte que surgirão mais obras traduzidas para português, com especial incidência para obras de proveniência francesa e italiana, de autores como Fétis, Durand, Drouet ou Reicha, e Macchi, Rossini, Cattaneo ou Asioli, entre outros (PAIXÃO, 2008, p.25).
\end{abstract}

No campo musical, Ana Paixão completa expondo que essa proximidade de relações entre gramática, retórica e a poética com a música não se limita à teoria alemã, mas ela pode ser localizada de igual maneira nos quadros teórico-musicais italianos, franceses ou flamengos ${ }^{86}$ que, embora nem sempre

\footnotetext{
${ }^{86}$ Exemplos podem ser vistos em: Le Instituione Harmoniche, de Geosefio Zarlino, em 1558 (cf. Zarlino, 1562), Elementa musicalia, de Jabus Faber Stapulenis (cf. Stapulenis, 1500), Compendium musicæ de René Descartes, em 1618 (cf. Descartes, 1987), Traité de I'harmonie
} 
apresentem a designação música poética, optam e adaptam terminologias ou técnicas para o domínio musical, sobretudo ao longo do Barroco (PAIXÃO, 2008, pp.32-35).

Reforçando ainda mais essa argumentação, na Idade Média, Santo Agostinho, em seu tratado A Doutrina Cristã, faz uma observação sobre a questão da necessidade do conhecimento dos tropos ou das figuras de pensamento, seja para os autores e eruditos ou para quem pratica a fé cristã, entretanto, esse conhecimento não se limita a uma só via, mas pode ser adquirido de várias formas:

\begin{abstract}
Sabem os literatos que nossos autores usaram de todos os modos de expressão chamados pelos gramáticos com a palavra grega de tropos. Eles os empregavam com maior frequência do que podem pensar ou crer os que não conhecem as obras literárias, mas que os aprenderam de outra maneira. Contudo, os que estudaram os tropos encontram-se nos Livros santos e esse conhecimento lhes é de bastante utilidade para o seu entendimento. [...] Pois as letras das quais a gramática tirou seu nome - já que os gregos as chamam gramata - são signos escritos dos sons que fazemos com a voz articulada ao falar. Ora, encontram-se nos Livros santos não somente exemplos desses tropos, como de todas as outras coisas, como ainda o nome declarado de alguns deles, tais como: alegoria, enigma, parábola. Ademais, quase todos esses tropos, que se pretende aprender nos estudos liberais, encontram-se até na linguagem comum dos que nunca estudaram com os retóricos e contentam-se em falar a linguagem vulgar. De fato, quem não diz: "Assim floresças"? Aí está um tropo chamado metáfora. Quem não diz "piscina", ainda que a propósito de um reservatório que não possua peixes, nem tenha sido feito para isso, e que, contudo, tira seu nome de piscis (peixe)? Esse tipo de tropo é chamado de catacrese [grifos nossos] (AGOSTINHO, 2002 [397- ca.427], livro III, cap.29 § 40, pp.185-186).
\end{abstract}

Semelhantemente, Agostinho atesta que até na língua informal, ou seja, popular, pode-se aplicar figuras de pensamento de significativa complexidade de entendimento. Evidenciando, dessa forma, a utilidade dos tropos como dito anteriormente em variadas maneiras.

Seria muito longo prosseguir desta maneira no exame de outros tropos. A linguagem popular chega até a usar as figuras de

universelle, de Marin Mersenne, em 1637 (cf.Mersenne, 2003), Essai d'une méthode pour apprendre à jouer la flûte tranversière, de Johann Joachim Quantz, em 1752 (cf.Quantz, 1975), Compediolum musicæ pro incipientibus, de Heinrich Faber (cf. Faber, 1980) ou Compedium musices, de Adrianus Petit Coclico (cf.Coclico, 1954) (PAIXÃO, op.cit, p.35). 
pensamento mais curiosas, quando fazem entender o contrário do que foi dito. Tais são os tropos chamados ironia e antífrase. A ironia indica, pelo tom de voz, o oposto do que se quer fazer entender. Dizemos, por exemplo, a um homem que agiu mal: "Que belo feito!" A antífrase, ao contrário, não recorre ao tom da voz para fazer entender o inverso. Ou ela emprega termos próprios cuja etimologia é de significação oposta; por exemplo, denomina um bosque sagrado: lucus (de lucere, luzir) por caracer de luz. Ou bem, diz sim, ao dizer não (AGOSTINHO, 2002 [397- ca.427], livro III, cap.29 § 41, pp.186187).

Tendo em vista essas afirmações, fica claro que o saber não é propriedade exclusiva de uma pessoa ou etnia, mas ele é universal e como tal deve ser expandido para além das fronteiras. Mesmo no caso da retórica onde seu nascimento e desenvolvimento se deram, primeiramente na Grécia e depois em Roma, percorreu toda a Europa no final da Antiguidade e Idade Média, contribuindo para o enriquecimento tanto da oratória, do vocabulário, como da gramática, como da música, nos tratados musicais, a partir do século $X V I$. Enfim, pode-se dizer que a consciência no emprego dos elementos retóricos, por exemplo, na música, não está baseado somente em uma escola ou seguimento, mas em uma grande safra de tratados, cujos autores são de povos e etnias diferentes.

Evidentemente que a teoria alemã, por intermédio de tratadistas como, Gallus Dressler, Johannes Nucius, Joachim Burmeister, Michael Praetorius, Johannes Lippius e Johann Mattheson, entre muitos outros, foi de suma importância para a teorização e sistematização entre gramática, retórica e poética com a música. Igualmente é pertinente salientar que sua contribuição se dá na elaboração das estruturas retórico-musicais, por exemplo, as formas de se localizar figuras retóricas, elementos retóricos, afetos e análises dos discursos, entretanto, deve-se considerar a teorização retórica, na Península Ibérica ocorrida desde a Antiguidade, além dos contributos de teóricos citados anteriormente nesse capítulo e nos tópicos. 

BRASILEIRA 


\section{RETÓRICA NA MÚSICA COLONIAL BRASILEIRA}

\subsection{Contextualização histórico-político-social}

Antes de adentrar os tópicos relativos ao emprego da retórica na música colonial brasileira, é preciso primeiramente abordar questões relativas aos aspectos sociais, políticos, econômicos e culturais no Brasil Colonial. Pois, como observado por diversos estudiosos desse período, por exemplo, Diósnio Machado Neto, Márcio Páscoa, Mário Trilha, Edilson Vicente de Lima, Rodrigo Cardoso Affonso, Carlos Alberto Figueiredo, Rodolfo Coelho de Souza, Ana Margarida Paixão, Mário Rodrigues Videira, entre outros, se a questão retórica é uma capacidade analítica, quem não a estudou não teria as ferramentas necessárias para o entendimento de um discurso musical o qual foi elaborado e constituído numa tradição balizada nesses arquétipos.

Dessa maneira, audições das obras de autores como Vivaldi, Telemann, J.S. Bach, Haendel, D. Scarlatti, C.P.E. Bach, Pergolesi, entre outros, sem uma consciência preliminar dessa forma de ordenamento discursivo, poderia obter um resultado pouco satisfatório. Todavia, como sublinhado pelos pesquisadores elencados acima, há pessoas que gostam de ouvir esses compositores sem mesmo terem tido acesso a uma informação sobre retórica musical.

Em outras palavras, não se versa apenas sobre uma objetivação do mundo pela linguagem com um sistema de símbolos que o configure precisamente, mas, sim, de uma edificação de um lugar comum, no qual o ser se expressa e o homem, com seu arcabouço conceitual, o interprete (LIMA, 2015, pp.1-2). Portanto, como expressado pelo professor Edilson Vicente de Lima em nosso exame de qualificação de doutorado:

\footnotetext{
Essa operacionalização retórica pode e deve funcionar como uma pré-compreensão e não como um único modo de alcançar a compreensão, uma vez que música, retórica e linguagem são interligadas (LIMA, 2015, p.2).
}

Por esse motivo, desenvolvemos um tópico relativo ao lluminismo e às suas reformas na Europa, sobretudo em Portugal, e seu desdobramento posteriormente no Brasil, o que resultaria num embate sobre duas frentes de 
transmissão doutrinárias: a primeira considerada antiquada amparada na ornamentação rebuscada, do despertar dos afetos, da eloquência e persuasão e a segunda fundamentada em ideais de equilíbrio, harmonia, idealização da realidade, clareza e delimitação dos afetos.

\subsubsection{O lluminismo e suas reformas}

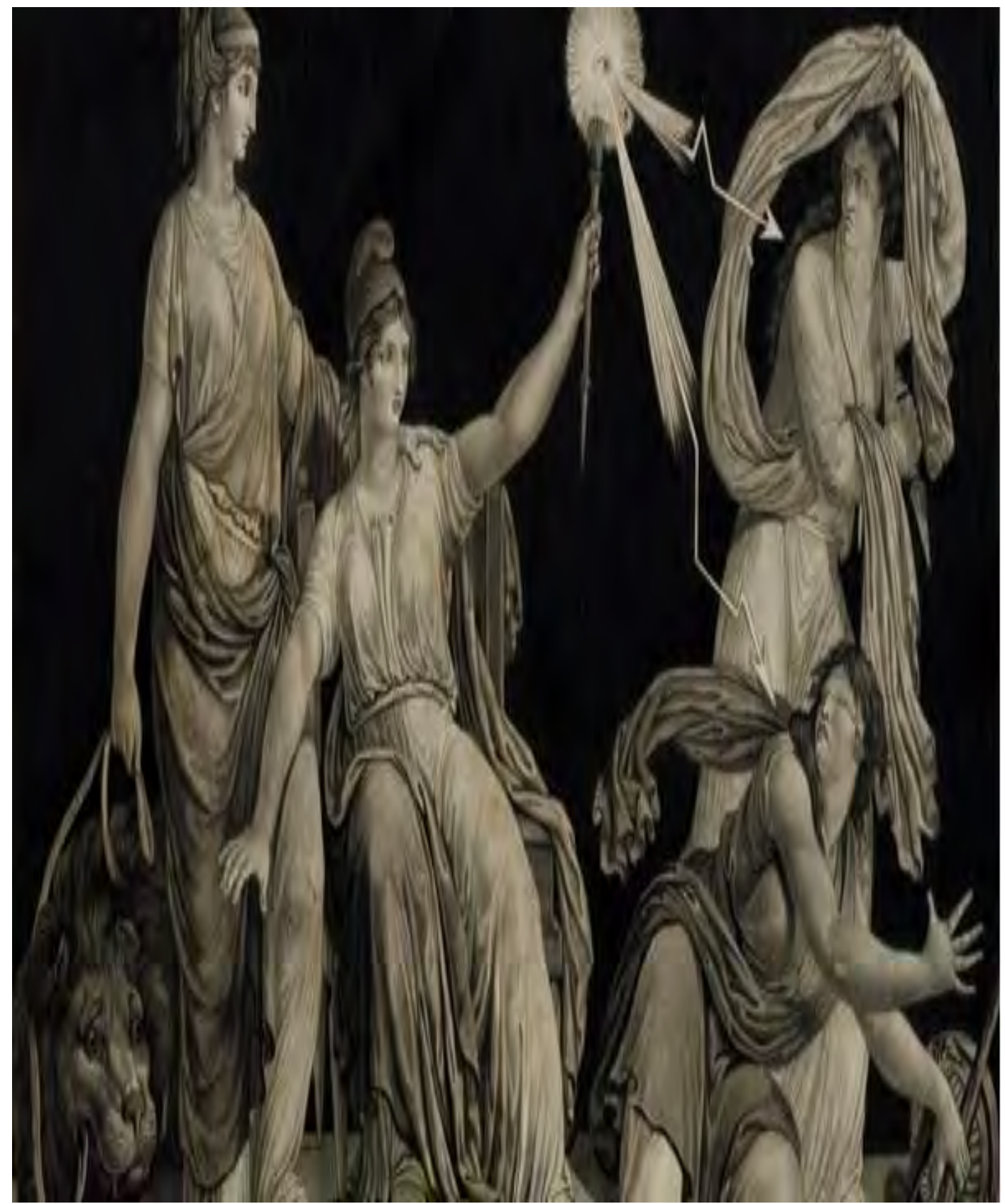

Figura 54-Figura Alegórica do lluminismo ${ }^{87}$

\footnotetext{
${ }^{87}$ Gravura de Simon Boizot (1793) onde a liberdade armada com o cetro da razão derrotando a ignorância e o fanatismo. Esse racionalismo igualmente chegou ao campo das Artes: música, escultura, arquitetura

e literatura.

Fonte disponível:
} 
Desde o segundo quartel do século XVIII, iniciou-se uma série de manifestações no movimento lluminista na Europa, contudo, esse fenômeno tinha em comum a compreensão de que eram necessárias profundas reformas na estrutura do edifício social da sociedade cristã. O musicólogo Diósnio Machado Neto enfatiza que tais reformas, de grandes proporções, ocorreram a partir do momento em que a estrutura socioeconômica e geopolítica era cada vez mais influenciada por meio de um padrão, onde a estrutura era enraizada em um sistema capitalista de produção, o qual desconsiderava, paulatinamente, antigos fundamentos da sociedade do Antigo Regime (MACHADO NETO, 2008, p.207; MACHADO NETO, 2013, p.239).

Em virtude dessas e de outras modificações na estrutura socioeconômica europeia, o Antigo Regime não poderia se manter sem que houvesse amplas negociações nas diversas esferas da sociedade. Dessa maneira, as boas administrações teriam que passar por adequação direcionada a métodos de racionalização, cuja organização governamental seguiria gestão ajustada aos fundamentos de uma política que iniciava uma marcha apoiada nas estruturas de desenvolvimento econômico e industrial, embasada na visão política de que cada vez menos seria admitida a interferência religiosa nas suas resoluções paradigmáticas (MACHADO NETO, 2008, p.208; MACHADO NETO, 2013, p.240).

Por volta de 1780 , todos os governos continentais com qualquer pretensão a uma política racional estavam consequentemente fomentando o crescimento econômico, e especialmente 0 desenvolvimento industrial, embora com sucesso muito variável. As ciências dedicavam-se à solução de problemas produtivos [...] $A$ grande Enciclopédia de Diderot e d'Alambert não era simplesmente um compêndio do pensamento político e social progressista, mas do progresso científico e tecnológico. Pois, de fato, o lluminismo, a convicção no progresso do conhecimento humano, na racionalidade, na riqueza e no controle da natureza derivou sua força primordialmente do evidente progresso da produção, do comércio e da racionalidade econômica e científica que se acreditava estarem associadas a ambos (HOBSBAWM, 2002, p.41)

<http://www.serdigital.com.br/gerenciador/clientes/ttf/noticias/295.jpg> Acessado em 21 de Setembro de 2016.

${ }^{88}$ Citação também localizada na tese de doutorado do Prof. Dr. Diósnio Machado Neto (MACHADO NETO, ibidem, p.208) e em seu livro (MACHADO NETO, ibidem, p.240). 
Em suma, por intermédio dessas modificações, países conservadores e de grande tradição, como Portugal, tiveram que prover os cargos administrativos não mais obedecendo às antigas reservas corporativas, isto é, sem licitação justa, mas, sim, pelo mérito.

Não obstante, setores da aristocracia portuguesa buscavam avançar na política de processo no conhecimento humano, com a criação da Academia Real de História, fundada em 1720, no entanto, a eminente catástrofe econômica que se aproximava, a partir do último período do reinado de Dom João $V$, fruto de seu procedimento insensato e fanatismo religioso, que envolveu o Estado num descaminho institucional, estimulou a queda da economia do Império, ou seja, nas colônias, o comércio debilitava-se e a política exterior era visto com desprezo pelos ingleses (AZEVEDO, 1922, p.94) $)^{89}$.

A solução para esse impasse deu-se, em princípio, por meio do Testamento Político, de Dom Luís da Cunha escrito em 1747 e oferecido ao Príncipe do Brasil, Dom José, herdeiro da Coroa. Esse documento ressaltava a necessidade radical de mudança de mentalidade, no melhor estilo erudito da época e suas inúmeras citações históricas. De igual modo, era apresentada a ideia da incorporação da terra pela nobreza, além dos poderes atribuídos ao Rei para a mesma, no entanto, quem governaria seriam os secretários de Estado e não as cortes, o que propiciou uma estratégia política a qual perpetuaria o Rei como senhor benevolente e promotor da justiça, que interviria, mediante sua autoridade, somente quando acontecessem dissensões entre os Estados. Assim, traçava-se um plano para a afirmação do Rei com poderes absolutos (MACHADO NETO, 2008, pp.210-211; MACHADO NETO, 2013, p.241).

O resultado desse plano referido e da reforma imposta propiciou um processo de transformação com inúmeras variantes aplicadas pelo sucessor de Dom João V, Dom José I:

1. A diminuição na influência da igreja na determinação da política real;

\footnotetext{
${ }^{89}$ Citação encontrada também em (MACHADO NETO, 2008, p.208 e MACHADO NETO, 2013, p.240).
} 
2. A renovação do quadro administrativo como agente de um servilismo da nova nobreza que, consequentemente, resultaria no processo de expulsão dos jesuítas;

3. A transformação de paradigmas filosóficos tais como: a prática e teoria do direito, da economia, da ciência e das artes (MACHADO NETO, 2008, p.214; MACHADO NETO, 2013, p.246).

Como consequência dessa renovação socioeconômica e cultural em Portugal, a música brasileira começaria a percorrer um caminho onde o sistema organizacional, com suas linguagens e funcionalidades, além de suas convenções, teriam como norte o ensino, representado pela sua principal forma de delegação: a religião, o que resultaria em confronto de ordem cultural. Portanto, para entender o processo pela qual se estrutura a música brasileira entre o século XVIII e princípios do XIX, são necessárias algumas observações:

1. Da prática musical nas Capitanias, além da execução de um projeto iluminista e suas reformas.

2. Da estabilidade e consolidação do cargo de mestre de capela, isto é, sua relação com a administração geopolítica luso-brasileira, sua inteiração com os alunos, o modo pelo qual ele elaborava não só a música executada, mas igualmente sua linha de raciocínio, com suas ideologias, o que poderia constituir conjuntos de características culturais. 3. Do embate entre a música embasada numa linguagem regida pela organização métrica e estilo racionalizado e outra fundamentada por uma linguagem que prima pela harmonia sequencial e recorrência ao afeto figurado.

\subsubsection{A música na Capitania de Minas Gerais e o lluminismo}

Como salientado anteriormente, mediante as reformas iluministas na Europa e, sobretudo em Portugal, a partir da segunda metade do século XVIII, o entendimento de como era realizada a música, seja na esfera sacra, instrumental e das óperas, passava por um questionamento sobre o aparato faustoso e a mística barroca, as quais eram pontos fulcrais de sustentação não só da liturgia das missas, mas igualmente dos grandes eventos musicais, por 
exemplo, no teatro e nas cortes. Em outras palavras, houve gradativamente uma busca para expressar a arte musical pelo viés do equilíbrio, racionalidade e elaboração contida das emoções.

Destarte, esse processo também obteve acolhimento na colônia brasileira, seja na Capitania de Minas, de São Paulo, na sede do vice-reino no Rio de Janeiro e depois no início do Reino Unido, bem como no Primeiro Império do Brasil.

No que tange à prática musical, sobretudo religiosa, em Minas Gerais nesse período, certamente seu maior diferencial foi a inexistência de ordens regulares, devido aos desvios dos metais preciosos por seus membros em pleno ciclo do ouro, o que resultaria na proibição do estabelecimento das ordens regulares na Capitania. Dessa maneira, a não autorização dessas ordens provocaria, na organização social e cultural de Minas, um hiato que só seria preenchido pelas irmandades (GODINHO, 2008, p.74).

Somando a isso, Francisco Curt Lange (1903-1997) ressalta que havia desenvolvimento autônomo da música religiosa na extensa região da Capitania, por causa da ausência de um bispado até 1745 , pois a mesma dependia da Capitania do bispado do Rio de Janeiro, razoavelmente distante para que pudesse instituir permanentes disposições de uma Sé, do próprio prelado ou mediante ela do mestre de capela. Por esse motivo, nas obrigações firmadas de comum acordo entre o responsável por dirigir a corporação musical e o Senado da Câmara, como o de Vila Rica, por exemplo, nos termos estabelecidos com as mesas das irmandades, para execução da música anual das festas religiosas, eventualmente se apresentava um padre com um conjunto de cantores e instrumentistas por ele recrutados (LANGE, 1966, p.15).

Sobre as festas religiosas, é pertinente acentuar que elas propiciaram novamente a indagação, a qual não restringia somente a questões relativas ao estilo da escrita musical, mas, como enfatiza Machado Neto, o próprio Bispo Dom Frei João da Cruz, em 1742, descreve os enormes gastos das festas religiosas pomposas, as quais não eram vistas como de utilidade espiritual para os fiéis e, sim, para pavoneamento do ser humano: 
colonial, tratei de demonstrar que a determinação das irmandades, como fator unívoco da movimentação musical da colônia, não obedecia à visão estática e horizontal na constituição dos direitos de exercício da música e, menos ainda, inflexível na sua autonomia regimental. Sabemos, hodiernamente, que essas associações eram frequentemente "ajustadas" por visitadores que questionavam, principalmente, em meados do século XVIII, as formas de manutenção do compromisso regimentar. $O$ fausto das festas religiosas, que reunia um corpo musical insólito que impressionava Lange, nem sempre era visto como ato de devoção aprovado pela Igreja, como podemos deduzir da afirmação do próprio Bispo de Mariana, em meados do século XVIII, ressaltou que estando em visita na freguesia de Santo Antônio do Itatiaia, comarca de Ouro Preto, verificou o livro de contas irmãos da Irmandade de Nossa Senhora do Rosário e São Benedito e observando os dados contidos no mesmo, viu-se que não haveria possibilidade de se fazerem as festas com tanta solenidade quando se vê pelas despesas que são feitas, consumindo nelas o rendimento da Irmandade, ficando os irmãos sem sufrágios anuais, não sendo ereto para o proveito das almas dos que falecem, e sim para a ostentação humana, pelo qual só é que fazem tantos festejos (MACHADO NETO, 2011, p.229).

Em suma, essa suntuosidade proporcionada pelo florescimento da atividade aurífera na Capitania de Minas Gerais, sobretudo em Vila Rica, propiciou tanto à Câmara como às Irmandades recursos financeiros consideráveis para serem investidos na música e suas festividades. Todavia, com a diminuição gradual da produção de ouro, das indagações sobre os gastos excessivos dessas celebrações musicais, além das reformas pombalinas apoiadas na esteira iluminista, consubstanciaram numa contenção do consumo assim como dos grandes aparatos musicais (GODINHO, 2008, pp.77-78). 


\subsubsection{O programa iluminista na Capitania de São Paulo}
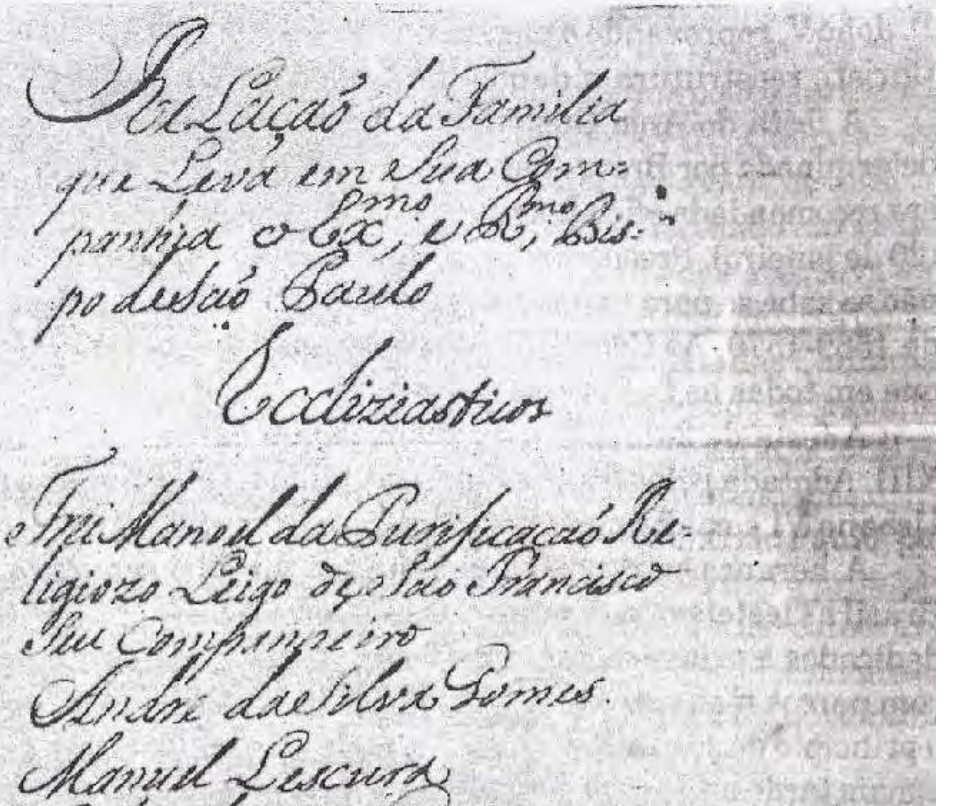

bedis do filix Gones

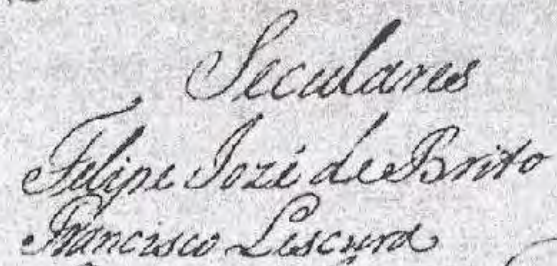

bovento acinto Yones

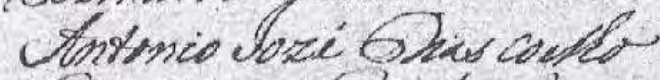

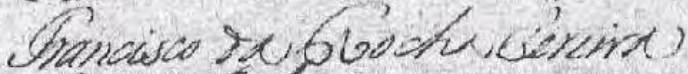

clivícindre.

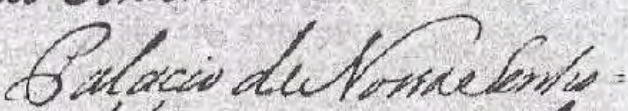

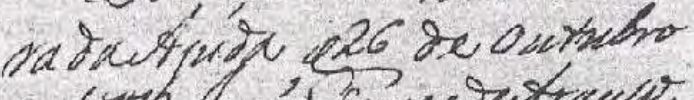

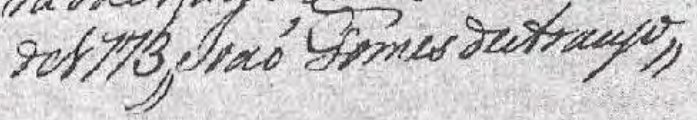

Figura 55-Passaporte do terceiro Bispo de São Paulo, cuja comitiva participava André da Silva Gomes (AHUL- Arquivo Histórico Ultramarino de Lisboa-DUPRAT, 1995, p.33).

Com a morte do segundo Bispo da Sé de São Paulo, Dom Antônio da Madre de Deus, em 1764, a igreja episcopal foi dirigida por um Vigário Capitular até a chegada de Dom Manuel da Ressurreição (1718-1789), em 1774. Evidentemente, esse padre não tinha a mesma autoridade de um Bispo, por essa razão, o então Governador Dom Luiz Antônio censurou desde o 
primeiro momento a maneira pela qual era feito o cerimonial da Sé paulista, assim desatando um libelo com o Cabido que se estendeu em arguições que perscrutaram inúmeros livros de cerimônias e decretos canônicos e que, por fim, resultaria num documento intitulado "As etiquetas da Sé" (apud, MACHADO NETO, 2008, p.359; MACHADO NETO, 2013, p.400).

Por conseguinte, observa-se que o projeto iluminista chegaria a São Paulo para modificar as antigas estruturas, por exemplo, na música. Régis Duprat ressalta que o mestre de capela da Sé, em 1765, padre Matias Álvares Torres, era julgado pelo Governador por apresentar uma música tão antiga quanto sua pessoa (DUPRAT, 1995, p.50). Diante desse quadro, o Governador nomeia Antônio Manso da Mota, músico recém-chegado da Bahia, como diretor da casa da ópera, justificando que o mesmo era provido das melhores músicas escritas, isto é, de bom gosto e atuais. No entanto, o Governador estava concentrado com a condução e aplicação do cerimonial religioso, o que, naturalmente, acarretaria em marco divisório entre as fronteiras nebulosas das nomeações dos cargos paralitúrgicos, como o mestre de capela. Enfim, valendo-se da ausência de uma autoridade episcopal, promoveu o seu desejo modernizador nomeando para o comando da capela da Sé Manso da Mota, o terceiro mestre de capela entre 1768 e 1773 (DUPRAT, 1995, p.52) (D) $^{90}$.

Com a chegada do terceiro Bispo de São Paulo: Dom Frei Manuel da Ressurreição, em 1774, ocorreram uma série de discussões, embates, além de inúmeras disputas jurisdicionais com o governador (DUPRAT, 1995, pp.55-56). Ambos solicitavam vários direitos, dentre deles o de prover professores de primeiras letras e mestres de capela. Alegando que esse direito era historicamente outorgado às autoridades seculares, o Morgado de Mateus ${ }^{91}$, denuncia o Bispo de passar provisões para o mestre de capela de todas as

\footnotetext{
${ }^{90}$ Também pode ser localizado em (MACHADO NETO, 2008, p.359).

${ }^{91}$ Fora uma forma de organização familiar que cria uma linhagem, bem como um código para designar os seus sucessores, estatutos e comportamentos. Nesse regime de morgadio, os domínios senhorais eram inalienáveis, indivisíeis e inusceptíveis de partilha do seu titular, ou seja, havia uma transmissão desses poderes para o filho primogênito, mantendo assim, a vitalicidade e perpetuação do poder econômico das famílias as quais faziam parte, por sucessivas gerações. Por exemplo, no Brasil, teve-se, como detentores do título nobilárquico Morgado de Mateus, António Álvares Coelho, Matias Álvares Mourão (1696-1730), António José Botelho Mourão (1688-1746), Luís Antônio de Sousa Botelho Mourão (1722-1798), Governador da capitania de São Paulo, José Maria de Sousa Botelho Mourão e Vasconcelos (1758-1825), José Luís de Sousa Botelho Mourão e Vasconcelos (1785-1855), que tornou-se o primeiro Conde de Vila Real, entre outros.
} 
vilas e freguesias, sendo assim, com esta declaração do Governador, fica evidente e explícito o intenso movimento de nomeações a partir da chegada do terceiro Bispo (MACHADO NETO, 2008, p.360; MACHADO NETO, 2013, p.401).

Mesmo com a resistência das autoridades civis, o Bispo atuava, igualmente, na direção de reformas estruturais, só que no âmbito religioso, o que incluiria as contestadas nomeações. Então, no exercício de sua atividade e influência, Dom Frei Manuel da Ressurreição reagiu contrariamente ao Governador, enfrentando-o trazendo consigo de Lisboa para a Sé em São Paulo o compositor André da Silva Gomes para assumir o lugar de Antônio Manso da Mota. Silva Gomes tinha como missão reestruturar a capela da catedral paulista (DUPRAT, 1995, p.57), não na incorporação explícita do estilo operístico da música de Manso, mas na restauração do estilo romano, "principalmente através da prevalência da textura polifônica, reafirmada pela preponderância da música coral" (MACHADO NETO, 2008, p.360; MACHADO NETO, 2013, p.401).

Dada as novas conjunturas e processos de nomeação para mestre de capela no Brasil, portanto, em particular na Capitania de São Paulo, pode-se afirmar que elas passaram por um estado de renovação e resistência ao mesmo tempo, onde o ponto de convergência nas articulações das ideias é a comunicação organizada e estabelecida pelo discurso musical. No mesmo sentido, em meio a essas reformulações, aconteceram diversos embates antagônicos entre o Governador de São Paulo, Dom Luís Antônio de Souza Botelho Mourão ${ }^{92}$ com o recém-nomeado bispo de São Paulo, Dom Manuel da Ressurreição, que trouxera de Lisboa André da Silva Gomes. Gerando assim um conflito que se manifestaria através do programa iluminista defendido pelo governador, como se viu anteriormente, aqui. Nesse conflito entre os dois máximos agentes régios na capitania paulista, é possível observar por um lado o programa iluminista vinculado à superação dos modelos figurativos pela música de métrica pela síntese e, por outro, a resistência aferrada na

\footnotetext{
${ }^{92}$ Esse fora Governador da capitania de São Paulo entre (1765 e 1774).
} 
persistência da retórica barroca, ou seja, na linguagem figurativa (MACHADO NETO, 2010, p.62).

\subsubsection{A manifestação do lluminismo e a música no Rio de Janeiro}

Como exposto nos tópicos 5.1.1, 5.1.2 e 5.1.3, em comparação ao que era realizado na Europa, a vida musical no Brasil do século XVIII e começo do século XIX possui algumas peculiaridades. Para entender o movimento musical nas principais capitanias e cidades brasileiras desse período, como Recife, Salvador, São Paulo, Minas Gerais e Rio de Janeiro, é relevante ressaltar o longo processo cultural desenvolvido a partir dos grandes ciclos econômicos. De igual forma, conforme observado, a atividade musical era de responsabilidade, na maioria das vezes, dos padres, centralizada particularmente no mestre de capela (CARDOSO, 2008, pp.35-36).

Não obstante, com a formação de inúmeras ordens terceiras e irmandades, as quais eram agregadas por representantes da classe média liberal e músicos, que se serviam de músicos, em sua maioria mulatos livres, nas diversas festas religiosas, o profissionalismo suplantaria gradualmente a atividade musical dos padres, entretanto, com algumas exceções, como salienta André Cardoso:

Os exemplos isolados são José Maurício Nunes Garcia, no Rio de Janeiro, padre João de Deus Castro Lobo e o padre José Maria Xavier, em Minas Gerias - são exceções que confirmam a regra (CARDOSO, 2008, pp.36-37) ${ }^{93}$.

Portanto, a atividade musical era, em grande parte, no âmbito das funções religiosas, o que pode ser evidenciado pela enorme quantidade de obras sacras localizadas nos arquivos das irmandades, das orquestras mineiras e em algumas bibliotecas (CARDOSO, 2008, p.39).

Todavia, mediante irreversível amadorização da prática musical nas cidades mineiras, a retração econômica, das reformas instituídas pelo Marques de Pombal entre 1759 e 1772, influenciadas pelo lluminismo, a mudança do centro das decisões político-sociais e econômicas para o Rio de Janeiro, a

\footnotetext{
${ }^{93} \mathrm{Há}$ outros estudiosos que consideram a possibilidade dessa suplantação das atividades musicais dos sacerdotes não ter ocorrido nesse período.
} 
capital da Colônia em 1763, além da consumação dessa modificação com a chegada da família real portuguesa em 1808, no mesmo município, propiciou não só a ampliação das atividades musicais na cidade, mas, também, que os compositores, intérpretes e músicos em geral pudessem ter, além das igrejas, um novo e auspicioso local de trabalho: o teatro de ópera, o qual possibilitou o aumento da atividade musical profana como destaca Cardoso:

Com o aumento da atividade musical profana, representada, sobretudo pela ópera, outro importante fator de incremento para a atuação profissional dos músicos foi a entrada definitiva do Estado como patrocinador e empregador (CARDOSO, 2008, p.43).

Outro aspecto a ser sublinhado é que foram fundadas, além da Capela Real, estabelecida por Dom João em 1808, a qual era constituída por um coral e uma orquestra de músicos profissionais que tinham a responsabilidade de produzir música adequada nas diversas solenidades religiosas, orquestras que apresentavam músicas profanas, como a Real Câmara. Essa, por sua vez, atuava anexada ao Paço da Quinta da Boa Vista, e era encarregada de entreter a família real (CARDOSO, 2008, p.44). Dentre os compositores dessas duas instituições reais, pode-se destacar José Maurício Nunes Garcia, Marcos Portugal e Fortunatto Mazziotti.

Adicionado a isso, Machado Neto (2016), enfatiza que, por meio dessas novas possibilidades, os compositores e os músicos podiam produzir e executar não somente uma música que persistia na estrutura do discurso figurativo e persuasivo, mas igualmente elaboravam uma obra vocal com o texto sacro ou instrumental, balizada nos moldes profanos europeus, manifestando, assim, certa influência e adaptação por um novo gosto de composição, tal como o próprio padre José Maurício, por exemplo:

Logo, não é de se admirar que a Missa de Nossa Senhora da Conceição (C.P. M. 106), escrita em 1810, de acordo com Ricardo Bernardes pode ter sido uma comprovação aos músicos e ao príncipe de que José Maurício podia se adaptar ao novo gosto.

Mesmo questionando em parte a questão do novo gosto, como tratarei de discutir adiante, as considerações de Bernardes são verossímeis. No entanto, sou levado a crer que o projeto expressivo dessa missa sobrepujava o compromisso com a demonstração de capacidade técnica. Era um desafio marcado por um diálogo com 
uma simbologia de forte significação para a corte portuguesa de tal forma que o capital simbólico envolvido deveria ser exposto até mesmo como ato de decoro. Em outras palavras, o enunciado discursivo da missa deve ter sido baseado em propriedades de escuta que se fincavam na certeza do vínculo da música com convenções sociopolíticas culturais de forte significação [grifos nossos] (MACHADO NETO, 2016, pp.134-135).

Finalizando, todo esse processo seja composicional, de profissionalização dos músicos e de uma música regida por maior racionalidade crítica e filosófica, certamente está atrelado como salientado por Machado Neto, numa simbologia que envolvia um projeto musical, cuja finalidade era revelar novos padrões de escuta, apoiada em novos contrastes, na quebra da padronização da estrutura motívica, a partir do texto. Por fim, de uma retórica objetivada não só em afetos ilimitados e nas emoções efusivas, mas em afetos contidos num lugar comum, ou seja, mediante o emprego das tópicas (MACHADO NETO, 2016, pp.135-136).

\subsection{Compositores analisados no período abordado}

\section{- Manoel Dias de Oliveira}

Mestre compositor de música na Comarca do Rio das Mortes, atuou nas as principais irmandades da região, assim como para o Senado da Câmara de Vila de São José (atual Tiradentes-MG). Seu nascimento foi notificado mediante um documento da referida comarca (1795), entre 1734 e 1735.

\footnotetext{
O único documento que informa a data aproximada de nascimento de Manuel Dias de Oliveira é o Rol dos confessados desta Freguezia de S. Antonio da Villa de S. Jozé Comarca do Rio das Mortes deste prezente anno de 1795 [sic] (IPHAN-Tiradentes). Já que as idades indicadas dos filhos neste censo populacional conferem exatamente com as respectivas certidões de nascimento - o que jamais poderia ser exemplo de regra sobre o rigor dos recenseamentos coloniais, a idade do compositor - 60 anos - também pode ter sido anotada corretamente. Ele teria nascido, portanto, entre setembro de $1734 \mathrm{e}$ agosto de 1735 (RICCIARDI, 2000, p.116).
}

Provavelmente, Dias de Oliveira tenha nascido ou sido criado na Vila de São José. De igual modo, há possibilidade ter sido aluno de mestres locais como o mestre-de-capela, padre Paulo Rodrigues de Souza (?-1751?) ou o padre Felipe Franco (?-1760?), que atuou pelo menos desde os anos 30 do 
século XVIII como cantor e compositor de bradados. Todavia, de acordo com Rubens Russomano Ricciardi (2000), o mais provável é que tenha sido aluno do capitão Francisco da Silva Nunes e Souza:

\begin{abstract}
É mais provável, no entanto, que Manuel Dias de Oliveira tenha sido aluno do capitão Francisco da Silva Nunes e Souza (Portugal?, 17?? - Vila de São José?,1803), que além de militar - mas sem soldo - e músico - regente, cantor (tiple) e compositor, era também tabelião e pintor. As atividades como pintor são as mais antigas, e remontam ao ano de 1737 (RICCIARDI, 2000, p.117).
\end{abstract}

Era militar, sem soldo, primeiro Alferes (1766-1769) ${ }^{94}$, depois promovido a Capitão (1771), e foi um dos primeiros mulatos brasileiros a obter patente oficial. Tal fato é evidenciado através dos documentos referentes ao registro das patentes de oficiais entre 1769-1770, localizados por Rubens Ricciardi e Diósnio Machado Neto, no Arquivo Público Mineiro e da segunda patente em 1772, encontrado no Arquivo Histórico Ultramarino em Lisboa:

\begin{abstract}
Nombramento porque o Ex. ha por bem de nomear e prover na forma do nosso regulamento em observancia da Real Ordem de Sua Mage de 22 de março de 1766 firmada de sua real mão a Manoel Diaz de Olivra no posto de Alferes da Compa de Ordenança dos Homens Pardos Libertos do Districto de S. Joze de que he Capam Francisco Joze Cardozo da Comarca do Rio das Mortes [sic]-APM. Seção I, 1769-1770 (RICCIARDI, 2000, p.120).

[...] de confirmação Lxa 23 de 7bro de 1772/Diz Manoel Dias de Olivra assistente na Comarca do Rio das Mortes, q' pela Carta e patente juntas se mostra ser o suppcte eleito pelo Conde de Valadares Governador das Minas Geraes no posto de Cappam da Ordenança de pé dos homens pardos libertos do districto da Lage da Fregza da Va de S. José do Rio das Mortes novamte creada e estabelesida no dto districto, e pa Legitimamte confirmado no dto Posto/Pa V. Mage seja servido mandar-Ihe passar hua Carta de Confirmasão/ER Mee/[...] em 5 de 8bro de 1772 [sic]-AHU-MG, 1772 (RICCIARDI, 2000, p.120).
\end{abstract}

Concernente às suas atividades musicais como compositor, foram encontrados documentos da Vila de São José entre 1769 e 1798. Porém, é provável, que ele possa ter atuado antes de 1769, como depois de 1798 (RICCIARDI, 2000, p.117). Em relação à música, possivelmente foi influenciado

\footnotetext{
${ }^{94}$ Segundo Ricciardi (2000), Manoel Dias de Oliveira fora nomeado Alferes por José I, em Lisboa, no dia 22 de março de 1766, e provido ao posto pelo Conde de Valadares, em Vila Rica, no dia 26 de setembro de 1769 (RICCIARDI, 2000, p.120).
} 
por Antônio Pinheiro (?-1617), pelo espanhol Gines Morata (século XVI) e David Perez. Além disso, pode ter tido contato com uma obra de António Vilvadi como o Largo de Te Deum (RICCIARDI, 2000, p.119).

Entre suas obras podem ser destacadas:

- Benedictus.

- Te Deum em Si Menor.

- Magnificat em Ré Maior

- Amante Supremo.

- Moteto dos Passos.

- Magnificat.

- Miserere.

- Domine Jesu.

- Eu vos adoro.

- Missa de Oitavo Tom.

- Missa Abreviada em Ré.

- Matinas e Vésperas de Sábado Santo.

Portanto, Manoel Dias de Oliveira faleceu em 1813, entretanto, gozou de ampla recepção popular em seu tempo, tanto é que cópias manuscritas de suas obras são localizadas em todos os principais arquivos mineiros e paulistas de música colonial.

\section{- José Emerico Lobo de Mesquita}

De acordo com Curt Lange, deve-se ao pesquisador Geraldo Dutra de Moraes a descoberta do lugar e data de nascimento de Lobo de Mesquita, o qual nasceu na Vila Príncipe do Serro, em 12 de outubro de 1746 (KIEFER, 1997, p.39; MARIZ, 2005, p.42). Todavia, essa data foi questionada por Lange, pelo fato de não haver provas documentais. Assim, o musicólogo uruguaio referenciou o nascimento de Lobo de Mesquita entre 1740 e 1750 (COSTA, 2006, p.73).

Lange indica que o compositor mineiro obteve sua formação musical também na Vila do Príncipe do Serro Frio. Em 1765, Mesquita fazia parte de um grupo de músicos que se apresentava em festas reais da Câmara, tal 
função desempenhou possivelmente até 1776. Em 1774, figura como regente oficial das quatro festas oferecidas em 1773 pelo Senado da Câmara e, em 1778, deixa a Vila do Serro (LANGE, 1983, p.30,111, passim) ${ }^{95}$.

Mudou-se para Diamantina em 1783, assumindo o cargo de organista na Igreja de Santo Antônio, atuando também como professor, regente e compositor nessa cidade até 1798 . Em 1789, obtém a patente militar de alferes, ficando "obrigado a tocar órgão em todas as missas e ladainhas de Nossa Senhora, que se acostumavam celebrar na Igreja da Ordem" (KIEFER, 1997, p.40).

Possivelmente Lobo de Mesquita foi professor de arte da música, o que era uma prática habitual em Minas Gerais, onde os professores recebiam seus alunos em suas respectivas casas ou vice-versa. José Joaquim trabalhou em cinco das nove irmandades existentes (LANGE 1983, p.121) ${ }^{96}$.

Curt Lange ressalta alguns motivos para que o compositor tenha deixado o Arraial do Tejuco para ingressar em irmandades:

[...] já definitivamente incorporado à vida social e profissional do Tejuco resolveu ingressar em Irmandades de sua predileção: porque o conflito que se the apresentou sobre fins do século e que não podia ser previsto, se explica pelos seguintes motivos: 1- a vertiginosa queda da mineração, já percebida e denunciada em $1780^{97}$; 2- uma doença que preocupava, fosse dele ou de sua mulher (Tomásia Onofre do Lírio); 3- os dois problemas juntos também podiam ter tido validez (LANGE, 1983, p.122).

Em $1^{\circ}$ de setembro de 1798, assinou com a Ordem Terceira do Carmo de Vila Rica um termo de serviços musicais, sendo substituído em 15 de outubro de 1800 por seu amigo Francisco Gomes da Rocha. De igual maneira, trabalhou para a Irmandade do Santíssimo Sacramento e para o Senado da Câmara nessa mesma vila. Posteriormente, depois de dois anos atuando em

\footnotetext{
${ }^{95}$ Citação também localizada em (COSTA, 2006, p.73).

${ }^{96}$ Citação igualmente encontrada em (PIRES, 1994, p.65-66; COSTA, 2006, p.74).

${ }^{97} \mathrm{Na}$ última metade do século XVIII, as autoridades portuguesas ampliaram o controle no Arraial do Tejuco que, assim como todo o Distrito Diamantino, tinha uma administração diferente do restante do Brasil Colonial. Em outras palavras, havia um intendente que prestava contas diretamente à metrópole, para tentar evitar a evasão de divisas com o tráfico de diamantes. O que acarretou na migração dos habitantes da região para outras vilas a partir de 1798, e foi justamente o que fez Lobo de Mesquita, que se mudou para Vila Rica nesse mesmo ano (COSTA, 2006, p.74).
} 
Vila Rica, mudou-se para o Rio de Janeiro, capital da Colônia, provavelmente por se achar vago o cargo de organista na Ordem Terceira do Carmo, vindo a falecer em 1805 (LANGE, 1983, p.144; KIEFER, 1997, p.40; COSTA, 2006, pp.74-75).

\section{- André da Silva Gomes}

De acordo com a historiografia consolidada, e especialmente embasada em Duprat (1995), o compositor luso-brasileiro, nascido em Lisboa, no dia 15 de dezembro de 1752, quarto mestre de capela de São Paulo, era filho de Francisco da Silva Gomes e Inácia Rosa, naturais da mesma cidade. André chega ao Brasil com apenas 21 anos de idade, nos fins de 1773, para organizar e reger o coro de música da catedral em princípios de 1774, propiciando, dessa maneira, uma nova fase na atividade musical da Sé de São Paulo. Sua vinda foi articulada pelo terceiro bispo de São Paulo, Dom Frei Manoel da Ressurreição (1718-1789), inserindo-se numa conjuntura de mitigação do projeto de administração colonial iluminista, desenvolvido com considerável autonomia pela Capitania de São Paulo ${ }^{98}$, cujo Governador era dom Luís Antônio de Souza Botelho Mourão (1722-1789) ${ }^{99}$ (DUPRAT, 1995, p.57).

Duprat (1995) enfatiza que as condições iniciais de sua formação cultural e musical permanecem ignoradas, salvo o fato de ter sido aluno, no Seminário Patriarcal de Lisboa, do compositor e mestre de capela José Joaquim dos Santos. Nessa fase histórica, preponderava, no ambiente musical português, a figura do napolitano David Perez, dedicado à composição lírica e religiosa, interessado pelas edições didáticas para o ensino da teoria da música, solfejo, baixo cifrado, acompanhamento etc., influenciou compositores

\footnotetext{
${ }^{98}$ Essa conjuntura de mitigação e administração colonial iluminista era denominada Morgado de Mateus. Nessa época, o Governador estabelecia um padrão estético referenciado na corte portuguesa, sempre, objetivando o estabelecimento dos paradigmas do iluminismo católico, tais como: as imponências das festas públicas e religiosas, com o propósito de não só cumprir o afeto, mas, igualmente, imprimir nos corações do povo dessa corte uma veneração e obediência a seu soberano. Em suma, o Morgado de Mateus sempre tinha em mente se edificar pelas festas, como propunham inúmeros protocolos das doutrinas iluministas que se espalhavam pela Europa (MACHADO NETO, 2008, p.313; MACHADO NETO, 2013, p.352).

${ }^{99}$ Machado Neto destaca que: "Esse Governador impulsionou o "divertimento da ópera" por um envolvimento pessoal e singular conferindo a ela até mesmo um caráter revelador de sua visão de mundo em que a arte, de um modo geral, figurava num papel de representação e afirmação de poder" (MACHADO NETO, 2008, p.309; MACHADO NETO, 2013, p.347).
} 
portugueses dentre os quais João Cordeiro da Silva, João de Souza Carvalho, José Joaquim dos Santos, Luciano Xavier dos Santos e o próprio André da Silva Gomes. Outros compositores italianos como Niccolò Piccinni (1728-1800) e Giovanni Battista Pergolesi, do mesmo modo, foram referências para esses autores musicais.

As obras religiosas dos autores italianos citados acima, eram conhecidas por André da Silva Gomes, e peças de João Cordeiro da Silva, José Joaquim dos Santos e outros portugueses foram copiadas de próprio punho por André.

Silva Gomes, desde sua chegada a São Paulo em 1774, produziu intensamente. A sua proficuidade foi ao encontro das preocupações do bispado por obter a desejada estabilidade da capela de música, até então dificultada pela módica remuneração, disputas civil-eclesiásticas citadas, modesta solicitação e recursos do meio social ${ }^{100}$. O compositor luso-brasileiro exercia as funções de mestre de capela, desde 1774, todavia, somente em 1789, o seu nome aparece citado nos documentos de confraria, nas referidas funções. Em 1781, seu nome é citado na documentação remanescente, e ali permanece até 1801, quando abandonou todos os serviços eventuais fora a capela da Sé.

O ambiente musicalmente restrito antepunha-lhe dificuldades consideráveis por não dispor de instrumentistas e cantores. Não obstante a característica geral da época no Brasil, é pequena a variedade de instrumentos nas orquestrações de suas obras; a reduzida quantidade de músicos nesse meio obstaculizava a ampliação das atividades musicais. Após 1797, André se dedica integralmente ao ensino de latim (DUPRAT, 1995, pp.71-72).

Destarte, como evidência do conhecimento e cabedal retórico de Silva Gomes é que, após requerer diversas posições que lhe permitissem melhor situação econômica, foi nomeado interinamente para o cargo de mestre régio de Gramática Latina da cidade de São Paulo, em decorrência do falecimento de Pedro Homem da Costa, seu antecessor no cargo, passando então a receber ordenado dez vezes superior ao de mestre de capela da Sé. Em 1813, ingressa na Irmandade do Santíssimo Sacramento na qualidade de irmão. Posteriormente, em 1820, com 68 anos de idade, André ainda exercia

\footnotetext{
${ }^{100} \mathrm{O}$ mestre de capela ganhava, em média, cerca de 40.000 réis anuais, com esse salário o compositor obrigava-se a escrever música, financiar sua execução, com o coro e eventualmente com orquestra.
} 
efetivamente o cargo de mestre de latim, remetendo matrículas e relações semanais dos alunos de sua classe à secretaria do governo (DUPART, 1995, p.101).

O compositor luso-brasileiro faleceu em 1844 com aproximadamente 92 anos. Seu corpo foi envolto em hábito de São Francisco, acompanhado por todos os capelães da Sé em enterro solene. Enquanto viveu, foi a personalidade mais destacada da música de São Paulo, pátria adotada por ele, na qual viveu por 70 anos (DUPRAT, 1995, p.102).

\section{- José Maurício Nunes Garcia}

Nasceu no Rio de Janeiro, no dia 22 de setembro de 1767, filho de Apolinário Nunes Garcia e de Vitória Maria da Cruz, ambos mulatos. Com apenas 6 anos de idade torna-se órfão de pai, passando a viver com a tia e a mãe, a qual falecerá em 1816 (VIEIRA, 1900, p.450; MATTOS, 1997, p.22; KIEFER, 1997, p.53; MARIZ, 2005, p.53).

Desde sua infância mostrou-se vocacionado para a música, pois o mesmo já se apresentava cantando, acompanhado do cravo ou da viola. Por essa razão, sua mãe lhe envia para ter aulas de música com seu conterrâneo mineiro Salvador José de Almeida e Faria ${ }^{101}$ (1732-1799) (VIEIRA, 1900, p.451; MATTOS, 1997, p.31).

Paralelamente à sua formação musical, obteve sólida formação intelectual estudando filosofia racional e moral, com Agostinho Corrêa da Silva Goulão (?-1847), gramática latina, com Elias Rodrigues Lima e retórica, com Manoel Inácio da Silva Alvarenga (1749-1814), disciplina essa estudada por Nunes Garcia entre 1802 e 1804 (MATTOS, 1997, pp.33-34).

Em 1779 - aos 19 anos, atua como professor de música. De acordo com Person de Mattos (1997), quatro anos depois, compõe sua primeira obra: Tota Pulchra es Maria, uma antífona (MATTOS, 1997, p.34). É ordenado padre em 3 de março de 1792, entretanto, viveu maritalmente com Severiana Rosa de

\footnotetext{
${ }^{101}$ Cleofe Person de Mattos salienta que Salvador José representou para José Maurício não só o professor das primeiras notas, mas também transferiu e transmitiu as bases teóricas e práticas, além das tradições musicais do período áureo da criação setecentista de Minas Gerais (MATTOS, 1997, p.31).
} 
Castro (1789-1878), também parda. Teve seis filhos dentre eles o Dr. José Maurício Nunes Garcia Júnior (1808-1884) (KIEFER, 1997, p.54).

Torna-se, em 2 de julho de 1798, mestre de capela da Sé e Catedral do Rio de Janeiro, na vacância causada pelo falecimento do cônego João Lopes Ferreira (?-1798), contudo, há registros de composições suas para a Sé antes dessa data. Cabiam-lhe, em decorrência de sua nomeação, várias funções: organista, regente, compositor, professor de música ${ }^{102}$, além da responsabilidade da parte musical nas cerimônias religiosas promovidas na Sé pelo Senado da Câmara (KIEFER, 1997, p.55).

Com a chegada da corte de Dom João ao Rio de Janeiro, em 1808, Nunes Garcia é nomeado mestre da real capela, instalada na capela da Ordem do Carmo, até que, em 1811, com a presença do ilustre compositor português Marcos Portugal (1762-1830), teve que repartir tanto as funções de mestre de capela como as atenções do rei.

\begin{abstract}
Quando em 1808, D. João VI chegou ao Brazil mandou logo proceder à organização da Capella Real, por decreto de 25 de junho, juntandoa com a da Sé e incorporando n`ella os músicos de Lisboa que o tinham acompanhado ou que fossem chegado. O padre Mauricio conservou-se no seu lugar de mestre, augmentado com a prerrogativa talvez puramente honorifica de inspector, sendo a confirmação regia datada em 4 de novembro. [...] Marcos Portugal chegando á corte do Brazil em 1811, não se sentiria pouco ferido no seu orgulho por ter de partilhar a supremacia artística com um mulato brasileiro e decerto não the poupou sobranceiras, ele que tão sobranceiro era. $\mathrm{O}$ bondoso moarcha procurava contentar ambos cobrindo-os de favores [sic] (VIEIRA, 1900, pp.451-452).
\end{abstract}

Em 1821, como resultado de sua proficuidade didática e acadêmica, publica seu Método de Pianoforte, o qual tratava sobre assuntos relativos à técnica pianística como ornamentações, arpejos, trinados, apogiaturas, improvisações, entre outros. Da mesma forma, esse compêndio trazia rudimentos de teoria musical, privilegiando o ensino do solfejo e conhecimento do teclado. José Maurício ainda serviu o imperador Dom Pedro I (1798-1834). Entretanto, o empobrecimento da vida cultural após o retorno de Dom João VI

\footnotetext{
${ }^{102}$ Entre seus alunos podem ser destacados Francisco Manoel da Silva (1795-1865), Gabriel Fernandes da Trindade (ca.1799-1854), Dom Pedro I (1798-1834) e Cândido Inácio da Silva (1800-1838) (KIEFER, 1997, p.56; MARIZ, 2005, p.60).
} 
(1767-1826) a Portugal e a crise financeira depois da Independência do Brasil (1822), propiciaram a diminuição de suas atividades, somada as más condições de saúde do compositor.

Em 1826 compôs sua última obra, a Missa de Santa Cecília, a qual foi encomendada pela irmandade homônima. Por fim, o compositor faleceu na capital imperial em 1830, aos 62 anos de idade (BERNARDES, 2002, p.44).

\subsection{Os estudos de caso acerca da utilização retórica nos compositores brasileiros}

As investigações e estudos, relacionados à retórica na música brasileira, iniciaram no início da década de 1990. Posteriormente, em 1992, o musicólogo Maurício Soares Dottori publica um artigo tendo por o título: Ut Rhetorica Musica: análise do moteto O Vos Omnes a dois coros, de Manoel Dias de Oliveira, pela Revista Música da USP. 


\section{O vos omnes}

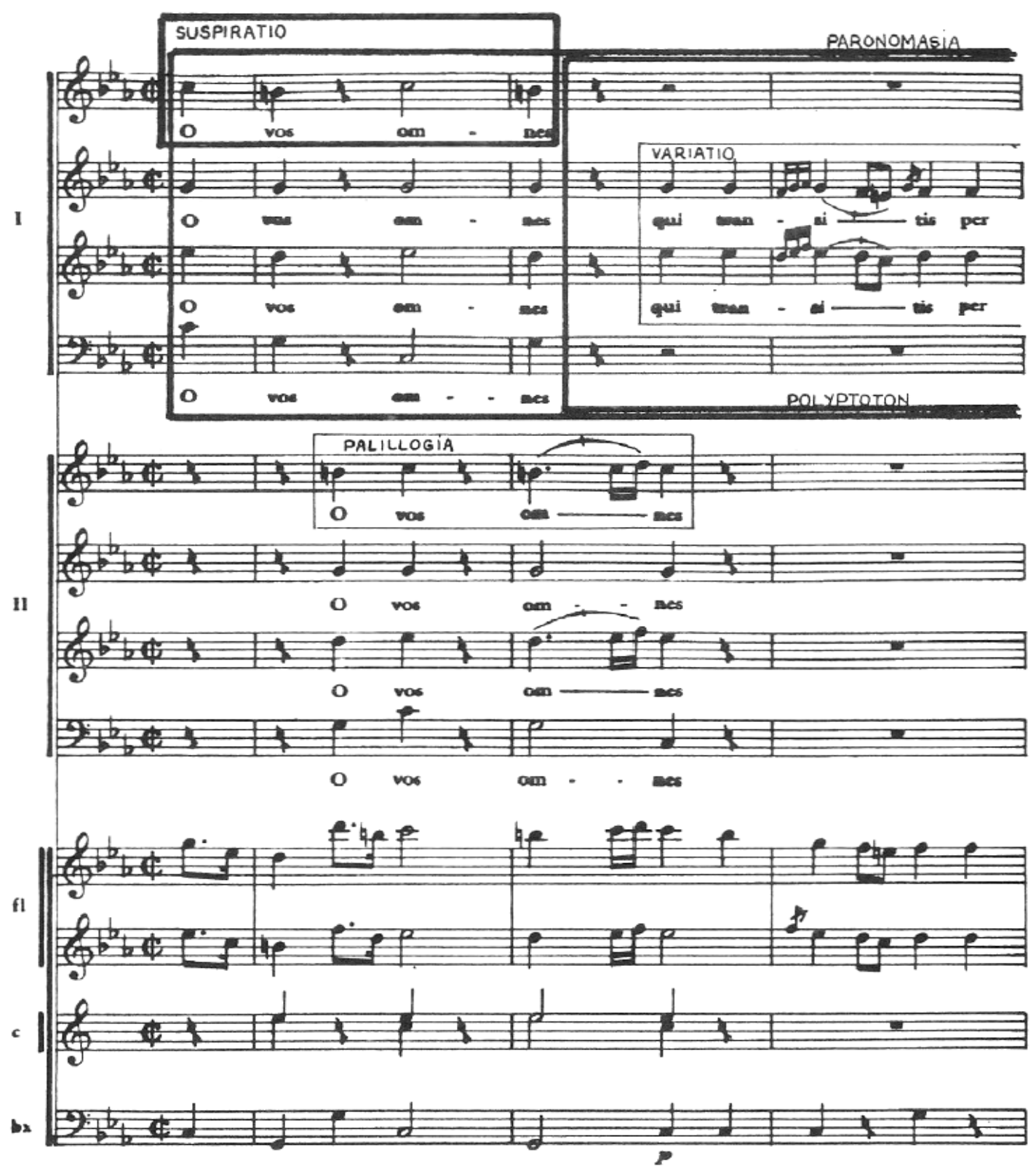

Exemplo 71-Análise Retórico-Musical por Maurício Dottori (DOTTORI, 1992, p.58).

No exemplo abaixo, nota-se o Passus Duriusculus e a Pathopoeia que são duas figuras retóricas de dissonância e deslocamento, localizadas por Dottori na obra de Dias de Oliveira. 
(40)

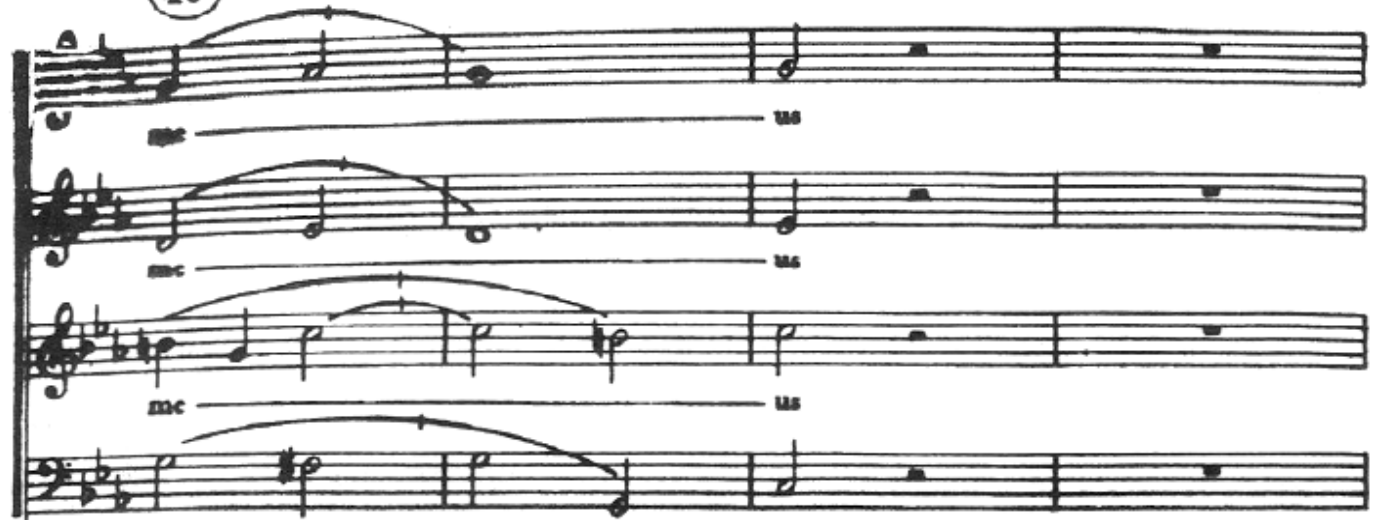

me - us
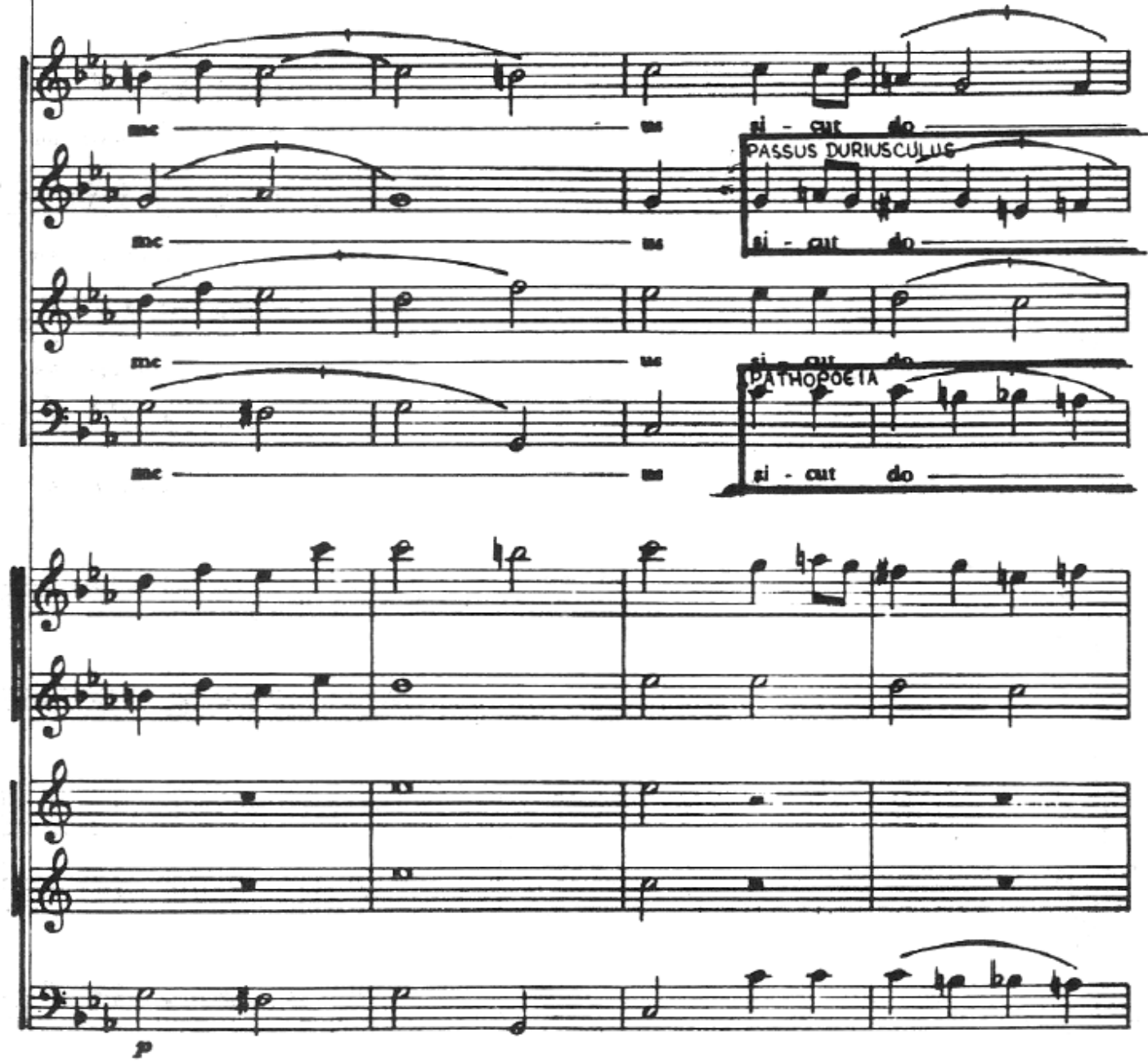

Exemplo 72-Análise Retórico-Musical por Maurício Dottori (DOTTORI, 1992, p.68).

Posteriormente, houve um período de averiguações somente do emprego retórico em compositores europeus. Somente em 1998, mediante a edição do tratado de contraponto de André da Silva Gomes, organizado por 
Régis Duprat, ocorreram algumas citações a respeito da consciência do uso retórico nas composições no Brasil entre os séculos XVIII e primórdios do XIX.

\section{A "Arte Explicada de Contraponto", de André da Silva Gomes}

\section{Cota}

Daquipode concluixo Comproritox instruido, naõsa como Frilosopho, a entidade differente de cada hum dos sobreditos empregos; podendo justamente distinguiro Contraponto Harmonia Docente, e a Compariçã OHarmonia Ultente, isto he, parte que dá preceitos; eparte, que os afprenenta em execucañ; mas tambem pode obsevvar como Thetoxico a analogia da Fraddade OHarmonica com a Faculdade Rhetorica. aqui se observa a Contrapionto velativo à parte da Omvencã̃ e a

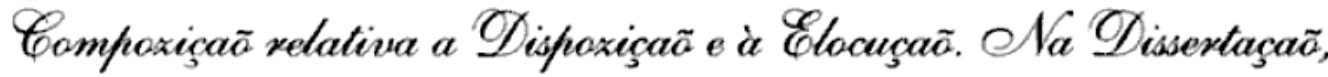
que seme de principio a esta olva, fica (apias?] demonstrado, quanto he precioza as Comprozitox a Ofnstruçã Litexaria.

Figura 56-Citação da Retórica na Lição $n^{\circ} .1 \mathrm{f} 2$ por André da Silva Gomes (DUPRAT et al., 1998, pp.17-18).

Após a Arte Explicada de Contraponto de André da Silva Gomes, em 2000, o livro Recitativo e Ária para José Mascarenhas, organizado por Régis Duprat, Maria Alice Volpe e Flávia Camargo Toni, fala de maneira concisa sobre retórica, no entanto, ainda não havia um estudo direcionado a respeito.

A partir dos anos 2000 é que as pesquisas relacionadas à retórica na música brasileira tiveram mais consistência. Desse modo, alguns grupos de pesquisa se estabeleceram como na UFMG, UNIRIO, UFRJ, UEA e, por fim, o Laboratório de Musicologia de Ribeirão Preto (LAMUS), sob a coordenação e supervisão do Prof. Dr. Diósnio Machado Neto. Assim, dissertações, livro, artigos, trabalhos de conclusão de curso e completos em anais foram publicados e produzidos, os alguns serão expostos a seguir.

Em 2005, Rodrigo Cardoso Affonso defendeu sua dissertação cujo tema aborda os estudos da relação texto e música nos Ofícios Fúnebres do padre 
José Maurício Nunes Garcia. Para tanto, ele utiliza algumas metodologias dentre elas a análise retórico-musical.

Vê-se, nesse exemplo, que Cardoso Affonso examinou a Epizeuxis empregada por José Maurício nas repetições enfáticas das notas, motivos e da palavra credo.

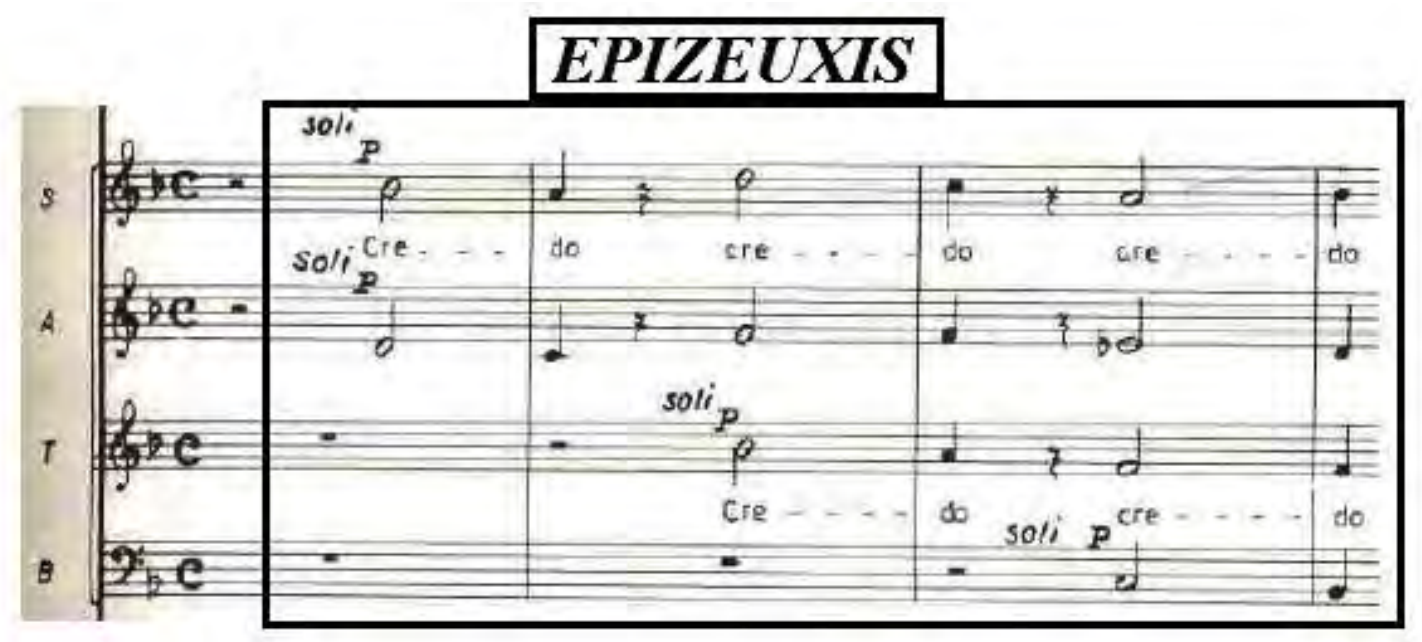

Exemplo 73-Epizeuxis no Ofício de 1816 de José Maurício Nunes Garcia (AFFONSO, 2005, p.84).

Outra figura examinada por Affonso foi a Climax, que repete as notas em alturas diferentes.

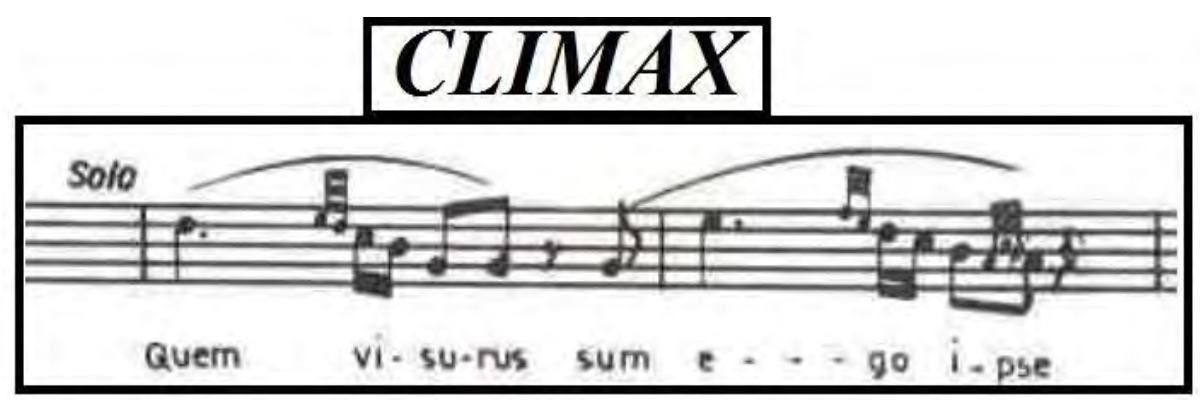

Exemplo 74-Climax no Ofício de 1816 de José Maurício Nunes Garcia (AFFONSO, 2005, p.85).

Em outro exemplo, Affonso Cardoso analisou a figura do Passus Duriusculus nos Responsório Fúnebres de Nunes Garcia. 


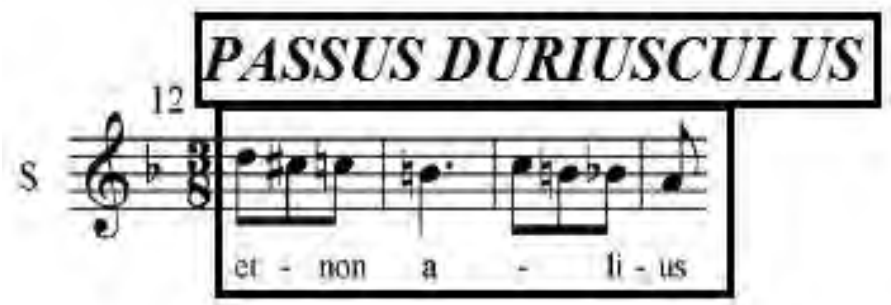

\section{Exemplo 75-Passus Duriusculus nos Responsórios Fúnebres de José Maurício Nunes} Garcia (AFFONSO, 2005, p. 95).

Em 2006, Márcio Spartaco Landi publicou um livro sobre as lições de contraponto, segundo o tratado de André da Silva Gomes. Esse trabalho além de examinar as lições, faz uma contextualização histórico-musical utilizando também alguns aspectos retórico-musicais como referências aos tratados de Dressler, Burmeister, Lippius, Nucius e Mattheson.

Spartaco Landi cita a lição 16 da Arte Explicada de Silva Gomes, onde diz que "Todo Motivo, Tema, Tensão ou Passo em uma Fuga deve constar de três partes ou Condições, a saber, Princípio, Meio e Fim" (DUPRAT et al., 1998, p.93). Da mesma maneira, verifica-se que Burmeister aplica figuras retóricas como Fugas Realis ou Imaginária em sua estrutura discursiva retórica onde o Princípio seria o (Exordium), o Meio (Medium) e o Fim (Finis).

Cum Sancto Spiriu, Missa a Cinco Vozes, CT Duprai $u^{\prime \prime}(1)+$, comm $\left.1.4-9 . d=88\right]$

$\mathrm{S}$

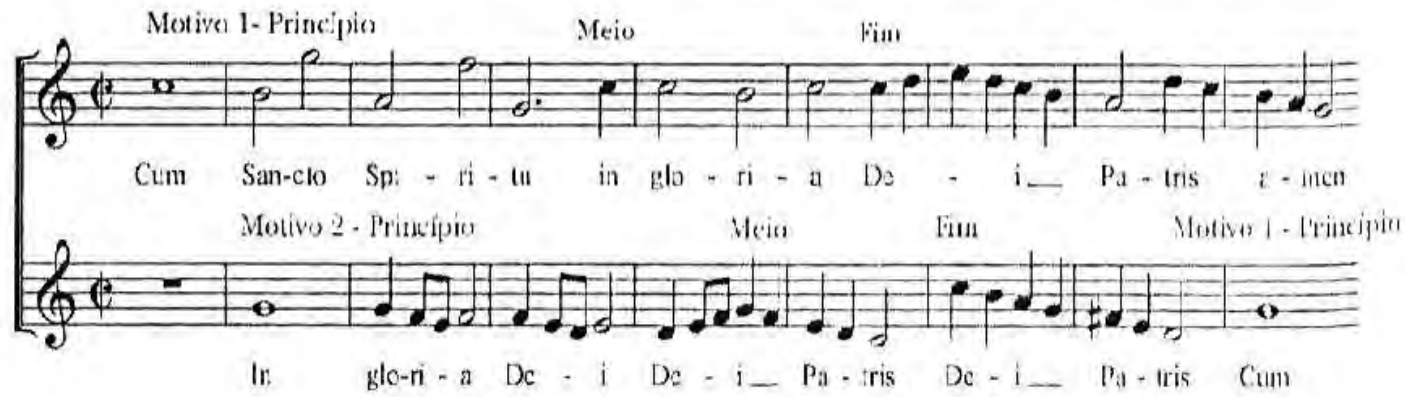

Exemplo 76-Cum Sancto Spiritu da Missa a Cinco Vozes de André da Silva Gomes (LANDI, 2006, p.127). 
Robson Bessa Costa, em sua dissertação de mestrado sobre o baixo contínuo no Ofício de Defuntos, de José Emerico Lobo de Mesquita (2006), observa a figura retórica da Oxymoron ${ }^{103}$.

Em outra passagem de sua dissertação, Bessa Costa descreve o emprego da retórica musical na segunda lição do Ofício:

A $2^{\mathrm{a}}$ Lição se inicia com mais um belo exemplo de uso da retórica por Lobo de Mesquita. Para o texto Responde Mihi, o compositor faz entradas desencontradas que, se não são imitativas, pelo menos sugerem perguntas e respostas. Por esse motivo sugerimos 0 dobramento das vozes pelo continuísta, para ressaltar a sutileza da escrita (COSTA, 2006, p.91).

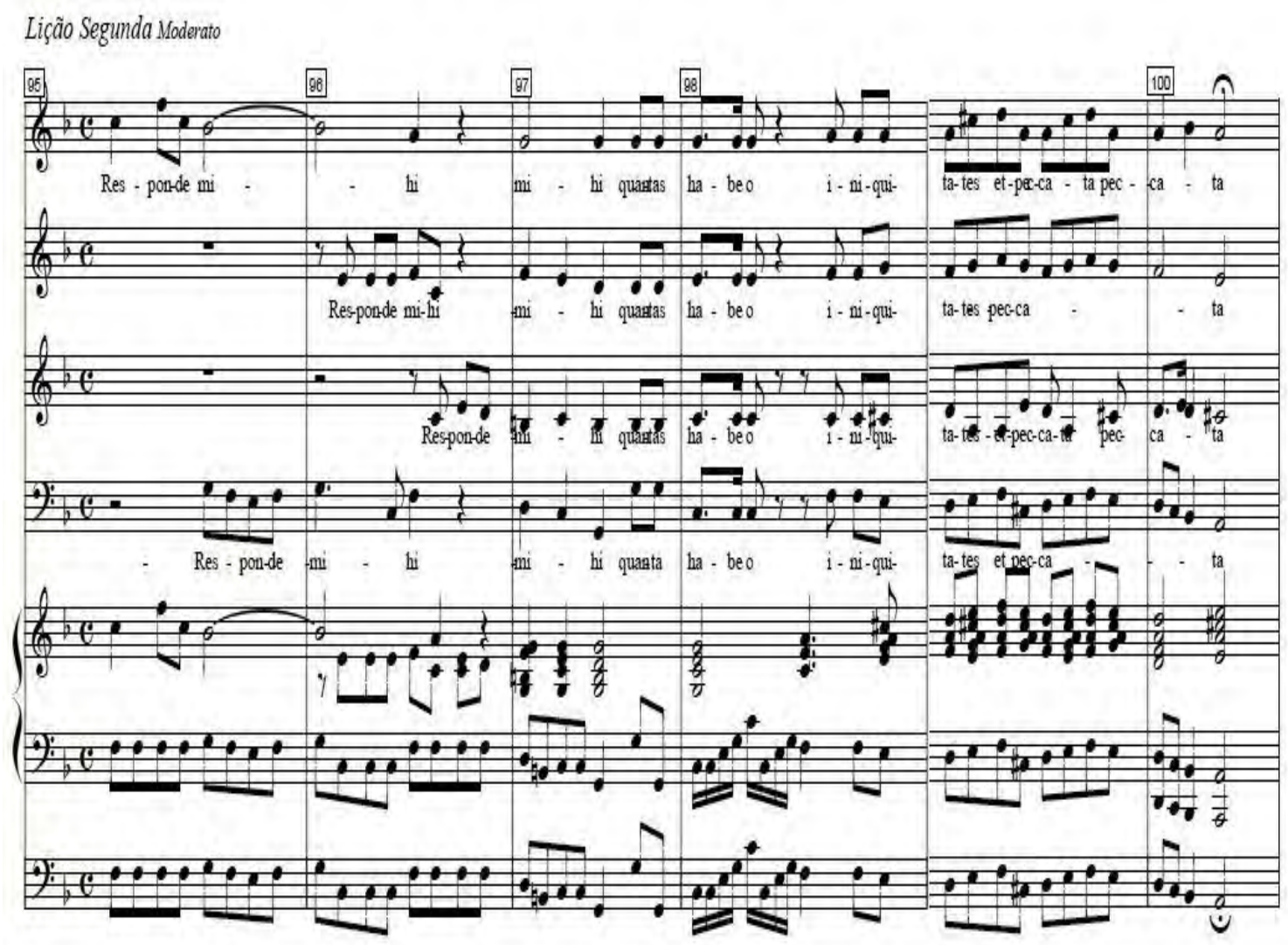

Exemplo 77-Aspectos Retórico-Musicais em José Joaquim Emerico Lobo de Mesquita (COSTA, 2006, p.145).

\footnotetext{
${ }^{103}$ Dispositivo retórico, trata-se de duas palavras, aparentemente contraditórias, que são empregadas em conjunto para dar efeito: Ela é apenas uma pobre menina rica. Fonte disponível: <http://dictionary.reference.com/browse/oxymoron> Acessado em: 10 de Setembro de 2014.

$\mathrm{Na}$ retórica literária seria uma variante especial da antítese de palavras isoladas que se constitui entre os membros antitéticos, um paradoxo intelectual (LAUSBERG, 2004, p.230).
} 
Na dissertação de Cláudia Schereiner sobre as representações musicais no Salmo Laudate Pueri (1813), de José Maurício Nunes Garcia, defendida em 2008, igualmente são realizados exames analíticos concernentes ao uso de elementos retóricos.

Observa-se que Schereiner localiza a aplicação da Anabasis (passagem ascendente, usada para enfatizar expressões de louvor), Exclamatio (exclamação, nesse caso de manifestação honrosa) e a Anadiplosis (repetição da última palavra de uma parte da frase para iniciar a próxima) nesse trecho da obra.

Exemplo 10: anabasis. c. 195-200, exclamatio, c. 199-200; anadiplosis

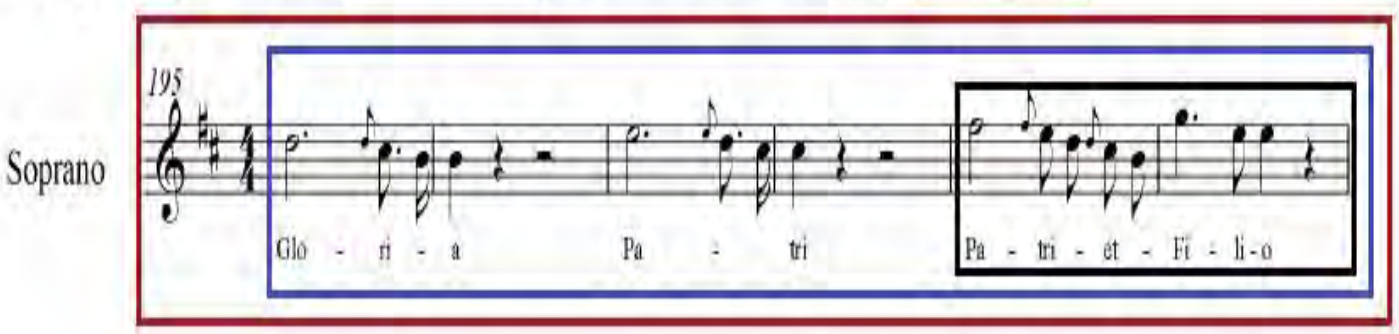

Exemplo 78-Anabasis, Exclamatio e Anadiplosis no Salmo Laudate Pueri (1813) de José Maurício Nunes Garcia (SCHEREINER, 2008, p.69).

Fausto Borém e Cecília Nazaré de Lima (2008) apresentam uma série de figuras retóricas no Heroe, egregio, douto, peregrino do Recitativo e Ária (autor anônimo de 1759), das quais podem ser notadas a Anabasis e Catabasis (passagem descendente que expressa humildade e submissão).

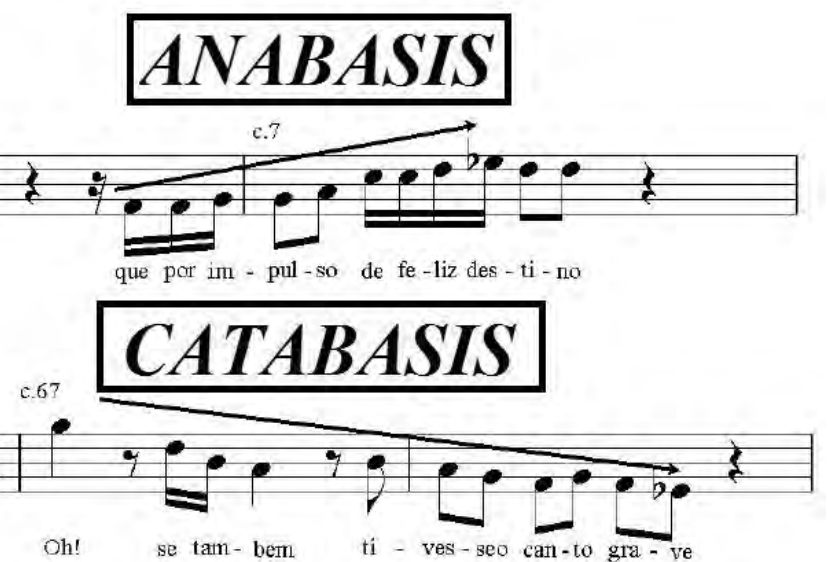

Exemplo 79- Recitativo de Heroe, egregio (1759) (BORÉM; LIMA, 2008, p.44). 
Em 2011, Katya Beatriz de Oliveira destaca, por meio de sua dissertação de mestrado, a interpretação vocal na Missa em Mi bemol, de José Joaquim Emerico Lobo de Mesquita. De modo igual, o emprego de figuras retóricomusicais nesse compositor:

\begin{abstract}
A subdivisão da missa em passagens curtas facilita a valorização, através da música, dos diferentes sentimentos expressos no texto do ordinário, realçando as exigências agógicas e de dinâmica, e as mudanças de atmosfera, permitindo o uso das figuras retóricomusicais mais adequadas às imagens indicadas no texto, ou ao afeto representado por cada momento. No texto do ordinário da missa, há momentos episódicos, como o Gloria e o Credo, nos quais é possível interromper o discurso musical para melhor caracterizá-lo, e momentos mais diretos, concisos e similares em sua formulação, como o Kyrie e o Agnus Dei (OLIVEIRA, 2011, p.37).
\end{abstract}

No mesmo ano, tem-se o trabalho de Ronaldo Novaes, o qual faz uma observação sobre os padrões composicionais em algumas obras do compositor André da Silva Gomes. Ainda há de se destacar que, entre 2008 e 2012, Novaes juntamente conosco publicou em revista, anais de congressos e simpósios um total de 10 artigos.

Para exemplificação, abaixo nota-se um excerto de um artigo publicado em 2014, por Novaes e Machado Neto, na IV Semana de Música Antiga da UFMG.

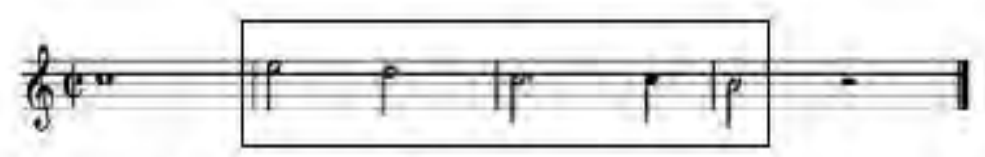

Figura 2 - Improperium (Catabasis)

\title{
Exemplo 80-Catabasis no Ofertório da Missa de Domingo de Ramos de André da Silva Gomes (NOVAES; MACHADO NETO, 2014, p.63).
}

Já em 2012, Ozório Bimbato Christovam, em seu trabalho de conclusão de curso, realizou um exame minucioso sobre os elementos retórico-musicais em André da Silva Gomes, através de uma averiguação do ambiente luteranogermânico e católico-português. 
Verifica-se, nesse exemplo, o uso do Noema, Aposiopesis e Epizeuxis no Exordium do Kyrie- I da Missa em Dó, de André da Silva Gomes, observados por Christovam.

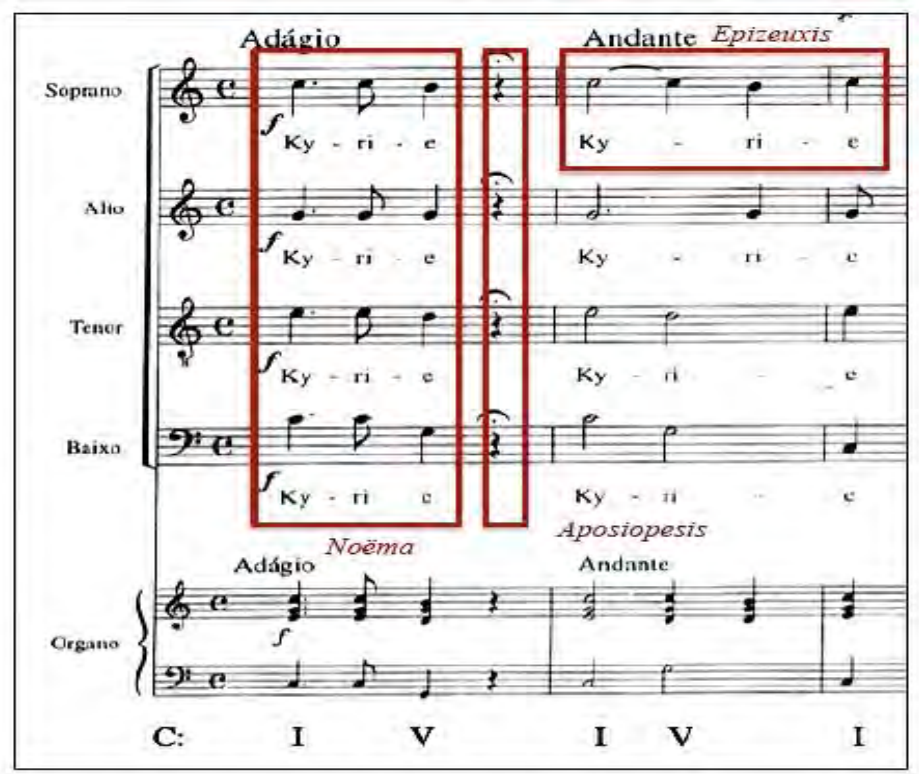

Exemplo 81-Noema, Aposiopesis e Epizeuxis no Exordium do Kyrie- I da Missa em Dó de André da Silva Gomes (CRHISTOVAM, 2012, p.92).

Em 2014, Rafael Registro Ramos, em sua dissertação de mestrado, destacou o discurso e os conceitos em André da Silva Gomes, por meio de uma observância de seu tratado de contraponto.

Em 2015, Mítia Ganade D`Acol, ressalta, em seu mestrado, o decoro musical e os esquemas galantes em José Maurício Nunes Garcia. No mesmo ano, Ronaldo Novaes faz uma observância relacional da música e sintaxe em André da Silva Gomes.

Em 2016, Tiago Rodrigues Soares, em sua dissertação de mestrado sobre a contextualização, análise e transcrição da ópera As variedades de Proteu, com texto de Antônio José da Silva e música de Antônio Teixeira, localiza algumas figuras retóricas dentre as suas dezessete cantorias.

No exemplo a seguir, nota-se o uso da Catabasis, numa descida expressando dessa maneira, o afeto de inferioridade por meio da frase, Por $t i$ moro. 


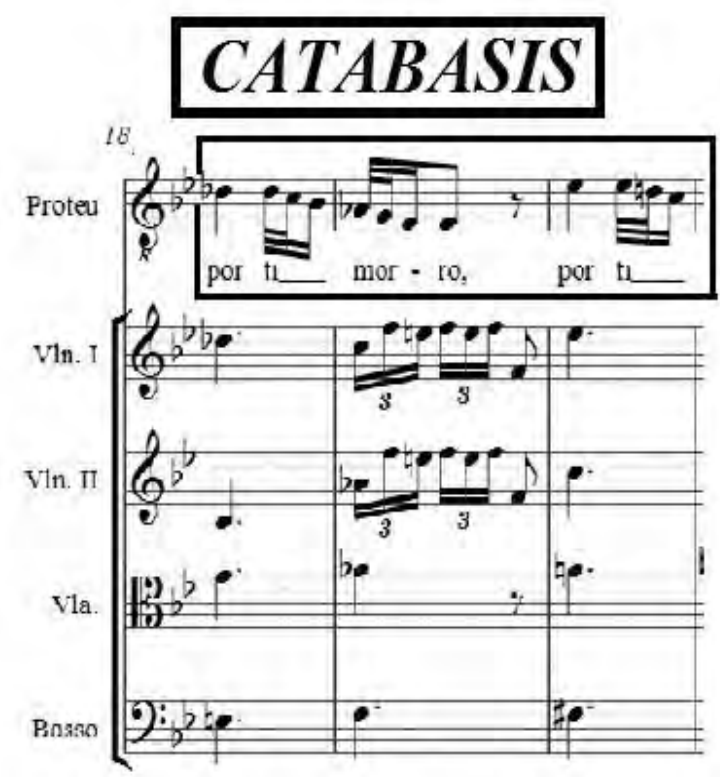

Exemplo 82-Catabasis na Cantoria-1 da Ópera Proteu de Antônio José da Silva e Antônio Teixeira (SOARES, 2016, p.68).

Em outro excerto da mesma obra, é examinável a figura retórica da Palilogia, no primeiro e segundo violino, repetindo as mesmas notas e melodias.

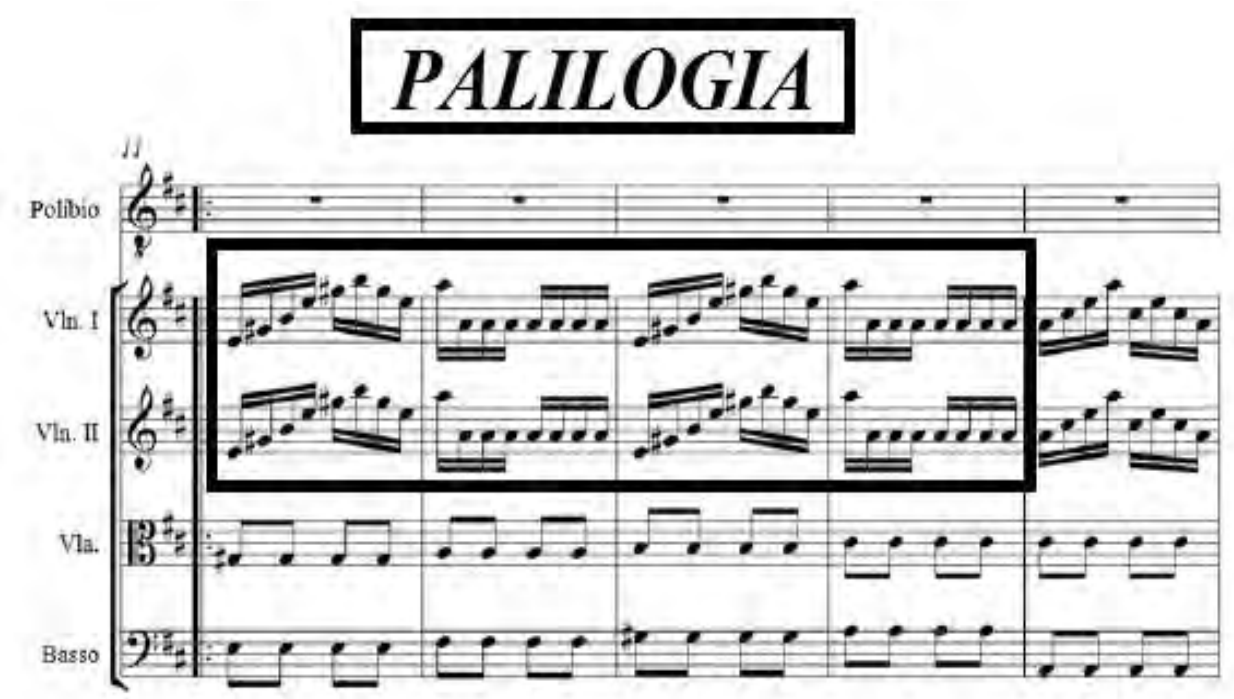

Exemplo 83- Palilogia na Parte Instrumental da Cantoria-2 da Ópera Proteu de Antônio José da Silva e Antônio Teixeira (SOARES, 2016, p.75).

Por fim, destacamos dois trabalhos que tratam de aspectos da retórica e das teorias tópicas, só que em compositores do ambiente português, Fábio 
Amorim de Mello, em sua dissertação de mestrado: Subsídios para uma edição comentada da ópera Demetrio, de David Perez, segundo versão pvv-amgg85, de vila viçosa (2014) e Ágatha Yozhiyoka Almeida, enfatizando, em sua dissertação de mestrado, as recorrências de tópicas, além de localizar algumas figuras retóricas na Missa de Requiem em Mi bemol Maior de Marcos Portugal (2016).

Abaixo, observa-se uma tabela com algumas produções acadêmicas sobre o tema:

Tabela 11-Algumas Produções Acadêmicas sobre Retórica na Música Colonial Brasileira.

\begin{tabular}{|c|c|c|c|}
\hline ANO & AUTOR & TÍTULO & PRODUÇÃO \\
\hline 1992 & Maurício Dottori & $\begin{array}{l}\text { Ut Rhetorica Musica: análise } \\
\text { do moteto O Vos Omnes a } \\
\text { dois coros. }\end{array}$ & $\begin{array}{c}\text { Artigo } \\
\text { (Revista } \\
\text { Música-USP). }\end{array}$ \\
\hline 1998 & Régis Duprat et al & $\begin{array}{lll}\text { A Arte } & \text { Explicada } & \text { de } \\
\text { Contraponto de André } & \text { da } \\
\text { Silva Gomes. } & & \\
\end{array}$ & $\begin{array}{c}\text { Livro } \\
\text { (Editora: Arte } \\
\text { \& Ciência). }\end{array}$ \\
\hline 2005 & $\begin{array}{l}\text { Caio } \quad \text { Benelovo } \\
\text { Sierra Nogueira }\end{array}$ & $\begin{array}{l}\text { Retórica na música brasileira } \\
\text { até } 1830^{104} \text {. }\end{array}$ & $\begin{array}{l}\text { Qualificação } \\
\text { de Doutorado } \\
\text { (UNIRIO). }\end{array}$ \\
\hline 2005 & $\begin{array}{ll}\text { Rodrigo } & \text { Cardoso } \\
\text { Affonso } & \end{array}$ & $\begin{array}{l}\text { Um Estudo sobre a Relação } \\
\text { Texto-Música: os Ofícios } \\
\text { Fúnebres de José Maurício } \\
\text { Nunes Garcia. }\end{array}$ & $\begin{array}{l}\text { Dissertação } \\
\text { de Mestrado } \\
\text { (UNIRIO). }\end{array}$ \\
\hline 2006 & $\begin{array}{l}\text { Márcio } \quad \text { Spartaco } \\
\text { Landi }\end{array}$ & $\begin{array}{l}\text { Lições de Contraponto } \\
\text { segundo a Arte Explicada de } \\
\text { André da Silva Gomes. }\end{array}$ & $\begin{array}{c}\text { Livro } \\
\text { (Editora } \\
\text { Expressão). }\end{array}$ \\
\hline 2006 & $\begin{array}{l}\text { Robson } \\
\text { Costa }\end{array}$ & $\begin{array}{l}\text { O Baixo Contínuo no Ofício } \\
\text { de Defuntos de Lobo de } \\
\text { Mesquita. }\end{array}$ & $\begin{array}{l}\text { Dissertação } \\
\text { de Mestrado } \\
\text { (UFMG). }\end{array}$ \\
\hline 2008 & Cláudia Schereiner & $\begin{array}{l}\text { Psalmo de anjinhos bem } \\
\text { xibantes: } \text { representações } \\
\text { musicais no salmo Laudate } \\
\text { pueri (1813) de José } \\
\text { Maurício Nunes Garcia. }\end{array}$ & $\begin{array}{l}\text { Dissertação } \\
\text { de Mestrado } \\
\text { (UFBA). }\end{array}$ \\
\hline 2008 & $\begin{array}{llr}\text { Fausto } & \text { Borém } & \text { e } \\
\text { Cecilia } & \text { Nazaré } & \text { de } \\
\text { Lima } & & \end{array}$ & $\begin{array}{lrr}\text { Heroe, } & \text { Egregio, } & \text { para } \\
\text { contrabaixo e e } & \text { cravo: } \\
\text { aspectos didáticos } & \text { e } \\
\text { interpretativos em } & \text { uma } \\
\text { transcrição de uma cantata } \\
\text { do repertório } & \text { colonial } \\
\text { brasileiro. } & \end{array}$ & $\begin{array}{l}\text { Artigo } \\
\text { (Revista } \\
\text { Permusi } \\
\text { UFMG). }\end{array}$ \\
\hline 2008 & Júlio Cesar Rocha & As Missas de J. J. Emerico & Tese de \\
\hline
\end{tabular}

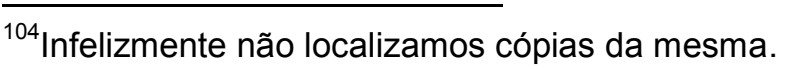




\begin{tabular}{|c|c|c|c|}
\hline & Moretzsohn & $\begin{array}{l}\text { Lobo de Mesquita: um } \\
\text { estudo estilístico. }\end{array}$ & $\begin{array}{l}\text { Doutorado } \\
\text { (UNIRIO). }\end{array}$ \\
\hline 2008 & $\begin{array}{l}\text { Edilson Assunção } \\
\text { Rocha }\end{array}$ & $\begin{array}{l}\text { Retórica Musical nos } \\
\text { Responsórios para Quinta } \\
\text { Feira Santa de Antônio dos } \\
\text { Santos Cunha. }\end{array}$ & $\begin{array}{l}\text { Trabalho } \\
\text { Completo em } \\
\text { Anais } \\
\text { (UFBA). }\end{array}$ \\
\hline 2008 & $\begin{array}{ll}\text { Eliel } & \text { Almeida } \\
\text { Soares } & \end{array}$ & $\begin{array}{l}\text { Retórica na Música Brasileira } \\
\text { no século XVIII e Primórdios } \\
\text { do XIX. }\end{array}$ & $\begin{array}{l}\text { Trabalho de } \\
\text { Conclusão de } \\
\text { Curso. } \\
\text { (USP). }\end{array}$ \\
\hline 2010 & $\begin{array}{l}\text { Márcio Leonel } \\
\text { Farias Reis Páscoa }\end{array}$ & $\begin{array}{l}\text { A retórica nas óperas } \\
\text { setecentistas de Antonio } \\
\text { Teixeira e Antonio José } \\
\text { da Silva. }\end{array}$ & $\begin{array}{l}\text { Trabalho } \\
\text { Completo em } \\
\text { Anais (UEA). }\end{array}$ \\
\hline 2011 & $\begin{array}{l}\text { Edilson Assunção } \\
\text { Rocha }\end{array}$ & $\begin{array}{l}\text { Figuras de retórica nos } \\
\text { Responsórios para Quarta } \\
\text { Feira Santa de Antônio dos } \\
\text { Santos Cunha. }\end{array}$ & $\begin{array}{l}\text { Artigo } \\
\text { (Revista } \\
\text { Permusi } \\
\text { UFMG). }\end{array}$ \\
\hline 2011 & $\begin{array}{l}\text { Katia Beatriz de } \\
\text { Oliveira }\end{array}$ & $\begin{array}{l}\text { A interpretação vocal na } \\
\text { Missa em Mi bemol de José } \\
\text { Joaquim Emerico Lobo de } \\
\text { Mesquita: por uma } \\
\text { interpretação historica. }\end{array}$ & $\begin{array}{l}\text { Dissertação } \\
\text { de Mestrado } \\
\text { (UNIRIO). }\end{array}$ \\
\hline 2011 & Ronaldo Novaes & $\begin{array}{l}\text { Observação de padrões } \\
\text { retóricos na obra de André } \\
\text { da Silva Gomes. }\end{array}$ & $\begin{array}{l}\text { Trabalho de } \\
\text { Conclusão de } \\
\text { Curso (USP). }\end{array}$ \\
\hline 2012 & $\begin{array}{l}\text { Diósnio Machado } \\
\text { Neto }\end{array}$ & $\begin{array}{l}\text { A censura das luzes na } \\
\text { capela da Sé paulista, em } \\
\text { 1774: modelos políticos, } \\
\text { modelos musicais. }\end{array}$ & $\begin{array}{l}\text { Artigo } \\
\text { (Revista } \\
\text { ArtCultura } \\
\text { UFU) }\end{array}$ \\
\hline 2012 & $\begin{array}{l}\text { Eliel } \\
\text { Soares }\end{array}$ & $\begin{array}{l}\text { A Utilização de Elementos e } \\
\text { Figuras de Retórica nos } \\
\text { Ofertórios de André da Silva } \\
\text { Gomes. }\end{array}$ & $\begin{array}{l}\text { Dissertação } \\
\text { de Mestrado } \\
\text { (USP). }\end{array}$ \\
\hline 2012 & $\begin{array}{lr}\text { Ozório } & \text { Bimbato } \\
\text { Pereira Christovam }\end{array}$ & $\begin{array}{l}\text { Análise Retórico-Musical do } \\
\text { Discurso de André da Silva } \\
\text { Gomes: do Ambiente } \\
\text { Luterano-Germânico ao } \\
\text { Católico Português. }\end{array}$ & $\begin{array}{l}\text { Trabalho de } \\
\text { Conclusão de } \\
\text { Curso } \\
(\text { USP })^{105}\end{array}$ \\
\hline 2013 & $\begin{array}{l}\text { Gabriel de Souza } \\
\text { Lima }\end{array}$ & $\begin{array}{l}\text { Reconstrução da parte de } \\
\text { Viola de um Quarteto e das } \\
\text { partes de viola e } \\
\text { canto de Três Árias da Ópera } \\
\text { Precipício de Faetonte (P- } \\
\text { CUG MM 876), de Antônio }\end{array}$ & $\begin{array}{l}\text { Dissertação } \\
\text { de Mestrado } \\
\quad \text { (UEA). }\end{array}$ \\
\hline
\end{tabular}

${ }^{105}$ Destacamos esse TCC por sua originalidade, o qual posteriormente foi desenvolvido em projeto de pesquisa e aprovado no exame de qualificação de mestrado para o curso de doutorado direto, no fim de 2014. 


\begin{tabular}{|c|c|c|c|}
\hline & & $\begin{array}{l}\text { José da Silva (1705-1739) e } \\
\text { Antônio Teixeira (1707- } \\
\text { 1774). }\end{array}$ & \\
\hline 2014 & $\begin{array}{ll}\text { Rafael } & \text { Registro } \\
\text { Ramos } & \end{array}$ & $\begin{array}{l}\text { Discurso e conceitos no } \\
\text { tratado de contraponto de } \\
\text { André da Silva Gomes: um } \\
\text { estudo de recepção. }\end{array}$ & $\begin{array}{l}\text { Dissertação } \\
\text { de Mestrado } \\
\text { (USP). }\end{array}$ \\
\hline 2015 & $\begin{array}{l}\text { Thiago Tavares da } \\
\text { Silva }\end{array}$ & $\begin{array}{l}\text { Retórica musical em André } \\
\text { da Silva Gomes: Duas fugas } \\
\text { da Missa a } 5 \text { à luz da Arte } \\
\text { explicada do contraponto. }\end{array}$ & $\begin{array}{l}\text { Dissertação } \\
\text { de Mestrado } \\
\text { (UFRJ). }\end{array}$ \\
\hline 2015 & $\begin{array}{ll}\text { Mítia } & \text { Ganade } \\
\text { D`Acol } & \end{array}$ & $\begin{array}{l}\text { Decoro musical e esquemas } \\
\text { galantes: um estudo de caso } \\
\text { das seções de canto solo } \\
\text { das Missas de Requiem de } \\
\text { José Maurício Nunes Garcia } \\
\text { e Marcos Portugal. }\end{array}$ & $\begin{array}{l}\text { Dissertação } \\
\text { de Mestrado } \\
\text { (USP). }\end{array}$ \\
\hline 2015 & Ronaldo Novaes & $\begin{array}{l}\text { A relação música e sintaxe } \\
\text { na obra de André da Silva } \\
\text { Gomes. }\end{array}$ & $\begin{array}{l}\text { Dissertação } \\
\text { de Mestrado } \\
\text { (USP). }\end{array}$ \\
\hline 2016 & $\begin{array}{ll}\text { Tiago } & \text { Rodrigues } \\
\text { Soares } & \end{array}$ & $\begin{array}{l}\text { O contexto criativo em As } \\
\text { Variedades de Proteu } \\
\text { e sua transcrição } \\
\text { musicológica. }\end{array}$ & $\begin{array}{l}\text { Dissertação } \\
\text { de Mestrado } \\
\text { (UEA). }\end{array}$ \\
\hline 2016 & $\begin{array}{l}\text { Diósnio Machado } \\
\text { Neto }\end{array}$ & $\begin{array}{lrr}\text { A commedia na } & \text { música } \\
\text { religiosa: } & \text { kyries } & \text { como } \\
\text { ouvertures } & \text { em três } & \text { missas } \\
\text { de José } & \text { Maurício } & \text { Nunes } \\
\text { Garcia. } & & \\
\end{array}$ & $\begin{array}{l}\text { Artigo } \\
\text { (Revista } \\
\text { Brasileira de } \\
\text { Música } \\
\text { UFRJ). }\end{array}$ \\
\hline 2016 & $\begin{array}{l}\text { Diósnio Machado } \\
\text { Neto }\end{array}$ & $\begin{array}{l}\text { A manifestação do } \\
\text { lluminismo Católico em José } \\
\text { Maurício Nunes Garcia: a } \\
\text { Missa de Nossa Senhora da } \\
\text { Conceição (1810). }\end{array}$ & $\begin{array}{c}\text { Capítulo de } \\
\text { Livro } \\
\text { (Congresso } \\
\text { Internacional- } \\
\text { Caravelas - } \\
\text { Núcleo de } \\
\text { Estudos da } \\
\text { História da } \\
\text { Música Luso- } \\
\text { Brasileira). }\end{array}$ \\
\hline 2016 & $\begin{array}{l}\text { Márcio Leonel } \\
\text { Farias Reis Páscoa }\end{array}$ & $\begin{array}{l}\text { Retórica em teoria e prática } \\
\text { no ambiente musical luso- } \\
\text { brasileiro entre o século } \\
\text { XVIII tardio e o início do } \\
\text { século XIX. }\end{array}$ & $\begin{array}{c}\text { Capítulo de } \\
\text { Livro } \\
\text { (Congresso } \\
\text { Internacional- } \\
\text { Caravelas - } \\
\text { Núcleo de } \\
\text { Estudos da } \\
\text { História da } \\
\text { Música Luso- } \\
\text { Brasileira). }\end{array}$ \\
\hline
\end{tabular}




\title{
5.4. A consciência do emprego retórico
}

Como abordado ao longo da tese, o discurso musical, entre o final do século XVI e início do XIX, era constituído por elementos retóricos, associados a uma elaboração, organização e disposição fundamentada a serviço da eloquência e persuasão. Fato esse que pode ser observável desde a Antiguidade greco-romana, o qual se consubstanciou em sistematização e teorização associadas aos notáveis mestres, pensadores, tratadistas e autores de peças musicais, servindo, desse modo, de embasamento para a concepção estrutural de uma música (SOARES; NOVAES; MACHADO NETO, 2012, p.71).

Do mesmo modo, na música colonial brasileira, os mesmos princípios retóricos foram usados pelos mestres da composição. Por exemplo, Manoel Dias de Oliveira expressa a utilização de semelhantes artifícios, o que pode ser verificado, no Moteto dos Passos em O vos omnes:

\begin{abstract}
Um outro caso, eram as passagens cromáticas ascendentes, que pela lógica da teoria contrapontística, seriam apenas, falsas relações consecutivas em uma só voz. Surgem no barroco associadas a fortes sofrimentos ou prazeres o que Christoph Bernhard, aluno de Schütz, em seu manuscrito Tratactus compositionis augmentatus, cunhou a expressão Passus Duriusculus. Do mesmo modo no moteto $O$ vos omnes de Manoel Dias de Oliveira, aparece também uma outra fórmula, no baixo, que frequentemente retratava uma situação de tristeza desesperada. Este baixo, um tetracórdio cromático descendente, aparecera como ostinato no Lamento de Cassandra, da ópera Didone (1641), de Francesco Cavalli $(1602-1676){ }^{106}$ [grifo nosso] (DOTTORI, 1992, p.95).
\end{abstract}

Não obstante, emprega na mesma peça os recursos retóricos em conjunto às constantes cadências e da linha do contraponto, dando ênfase aos afetos (DOTTORI, 1992, p.53).

De igual forma, José Joaquim Emerico Lobo de Mesquita usa as figuras retóricas para enfatizar as complexidades das figuras rítmicas em simultaneidade aos elementos contrastantes (COSTA, 2006, p.24). Adicionado a isso, Lobo de Mesquita, como outros compositores de sua época, utiliza em

\footnotetext{
${ }^{106}$ Como examinado no tópico 5.3 , Maurício Dottori em seu artigo de 1992 , localiza tal mecanismo diligentemente trabalhado pelo compositor brasileiro, para descrever o afeto de angústia, languidez e lamúria, entre os compassos 42 e 44, da referida peça, pela figura da Pathopoeia. Entretanto em sua dissertação de mestrado do mesmo ano, ele encontra na voz do baixo o Passus Duriusculus. Em síntese, ambas realizam uma representação viva de um afeto intenso e veemente.
} 
suas missas os mesmos contrastes de afetos que são uma das mais relevantes características do Barroco, como destaca Júlio Cesar Moretzsohn Rocha:

\begin{abstract}
O contraste de afetos é uma das mais importantes características do estilo barroco. A palavra afeto (affectus em latim) vem da tradução do termo grego pathos. Sua raiz está no verbo adficere, que significa influenciar, afetar. [...] Os compositores foram influenciados por doutrinas retóricas, que se preocupavam com as relações entre texto e música. Nos séculos XVII e XVIII essa dimensão foi ampliada ao extremo, e um dos principais objetivos da música dessa época era despertar no ouvinte uma grande variedade de sentimentos e ideias, designados como afetos. [...] Um dos principais recursos adotados para se despertar esses afetos foi o uso de figuras retórico-musicais. [...] Esses procedimentos tiveram grande influência sobre as Missas do século XVIII (MORETZSOHN, 2008, pp.74-76).
\end{abstract}

Já André da Silva Gomes, em seu tratado de Contraponto, destaca a importância da instrução retórica para que os compositores pudessem obter uma exposição sólida e eficaz:

Daqui pode concluir que o Compositor instruído, não só como Filósopho, a entidade differente de cada hum dos sobreditos empregos; podendo justamente distinguir o Contraponto Harmonia Docente, e a Composição Harmonia Utente, isto he, parte que dá preceitos; e parte, que os apprezenta em execução; mas também pode observar como Rhetorico a analogia da Faculdade Harmonica com a Faculdade Rhetorica; aqui se observa o Contraponto relativo à parte da Invenção e a Composição relativa à Disposição e à Elocução. Na Dissertação, que serve de principio a esta obra, fica [após?] demonstrando, quanto He precioza ao Compositor a Instrução Literária [grifos nossos]. [sic] (SILVA GOMES, lição $n^{\circ}$. 1 f 2. Nota do original, DUPRAT et al., 1998, pp.1718).

Em outra passagem de sua Arte Explicada de Contraponto, Silva Gomes ressalta que os compositores, assim como os estudantes de composição deveriam examinar, estudar e imitar os preciosos tratados deixados pelos insignes mestres, bem como nos preceitos próprios da Faculdade Retórica e Poética:

É verdade que todos os nossos esforços tornariam inúteis, uma vez que nos considerássemos destituídos dos dons da natureza, mas igualmente esses mesmos dons da natureza, ainda que modificados pela Arte, não poderão avançar um dilatado terreno sem que sejam acompanhados, ajustados e socorridos pelos ótimos exemplares de insignes Mestres, aos quais nos comunicam em não sei que virtude 
particular e oculta, que é só a que nos desembaraça na mesma execução dos preceitos da Arte; muitos deles rigorosamente estabelecidos pelos Antigos Mestres que nestes tempos têm elevado ao mais alto ponto de perfeição a Composição da Música, sendo também inegável que estes mesmos Mestres tiveram a precisão de imitar outros famosos Modelos, e polidos também por este Meio os seus felizes talentos, aumentando e ainda polindo, por meio de novas descobertas, aquelas científicas produções, nos transmitem e expõem a nossa admiração autorizados Modelos, que imitemos; e em que igualmente aperfeiçoemos e dilatemos as nossas ideias [...] $\mathrm{Na}$ experiência de todos os dias, nós vemos a grande utilidade que resulta da Imitação e que longe de enfraquecer e sufocar; pelo contrário, ela corrobora, aumenta, dilata e faz realçar a mesma natureza. Revela, pois, saber manejar, define um empréstimo de ideias de pensamentos, de sentimentos e passagens dos escolhidos exemplares que nos propomos a imitar ou aproximandoos ou diferenciando-os, ou diminuindo ou aumentando, os quais preceitos, próprios da Faculdade Retórica e Poética, nos quais supomos 0 nosso aluno de Composição de Música bem instruído, como preparatórios desta Faculdade que tratamos; por isto deixamos aqui de os explicar [grifos nossos] (DUPRAT et al., 1998, pp.179-180).

Semelhantemente, José Maurício Nunes Garcia manifesta tanto na arte da oratória quanto em suas obras sacras, a influência da retórica, disciplina estudada por ele desde sua juventude (MATTOS, 1997, pp.33-34). Igualmente, em seu Método de Pianoforte (1821), utiliza-se dos mesmos conceitos estéticos originários das doutrinas gregas e latinas de retórica e oratória, balizados em autores como Aristóteles, Marco Túlio Cícero, Marco Fábio Quintiliano, entre outros, os quais sugeriam que os oradores usassem os meios retóricos para controlar e direcionar as emoções dos ouvintes. Do mesmo modo, aplica na disposição das tonalidades das lições de seu método, conotações semelhantes às empregadas por tratadistas retórico-musicais como Marin Mersenne, Athanasius Kircher, Wolfgang Caspar Printz e Johann Mattheson (FAGERLANDE, 1993, p.146).

Adiante, Marcelo Fagerlande afirma que as lições 7 e 11 são bons exemplos do emprego de Nunes Garcia, tanto do gênero sacro quanto dos elementos retóricos:

Ré Menor, tonalidade da última lição da primeira parte, encontra tanto em Mattheson quanto Schubart descrições que correspondem ao caráter da lição de José Maurício [...] Não devemos esquecer que o tema desta lição foi extraído de um Requiem. Igualmente, na lição 7 , observam-se os mesmos recursos retórico-musicais vinculados às tonalidades (FAGERLANDE, 1993, p.149-151, passim). 
Enfim, inseridos num contexto onde as obras musicais eram, na sua maioria, sacras e as mesmas tinham textos bíblicos repletos de alegorias, metáforas relacionadas à harmonia, contraponto e afeto, muitos dos compositores brasileiros da época mostraram-se seguidores da transmissão doutrinária dos sábios mestres da Retórica, Oratória e da Poética.

\title{
5.5. Retórica, harmonia e a relação texto-música como ferramentas convergentes de análise
}

Dentre os procedimentos adotados para localizar o uso de mecanismos retóricos em uma obra, é necessário utilizar-se de metodologias mais apropriadas e objetivadas em auferir resultados consistentes e satisfatórios. Certamente alguns indicadores precisam ser assentados, por exemplo, um exame estrutural mediante a análise de figuras retórico-musicais associadas ao texto sacro, harmonia e disposição do discurso musical, os quais são indispensáveis para o entendimento e observação relacional entre música e afeto, como salienta Joachim Burmeister no seu tratado de retórica Musica Poetica:

\begin{abstract}
Análise Musical é o exame de uma peça (composição musical), pertencente a um determinado modo e a um determinado tipo de polifonia (contraponto). [...] Existem cinco áreas de análise: (1) investigação do modo (tonalidade); (2) averiguação do gênero melódico; (3) investigação do tipo de polifonia; (4) consideração da qualidade; (5) divisão da peça (dessa composição) em afetos ou períodos (BURMESITER, 1993 [1606], p.201) ${ }^{107}$.
\end{abstract}

Do mesmo modo, Johann Joachim Quantz destaca que, para reconhecer o afeto predominante numa peça, é necessário observar quatro aspectos importantes:

1. Modos: os de terça maior, normalmente expressam o alegre, $o$ ousado, o sério e o sublime. Enquanto isso, os de terça menor, expressam o adulador, o triste e o terno.

2. Intervalos (e figuras rítmicas): os intervalos próximos têm pulsações (fluxos, movimentações) ligadas e expressam o que se lisonjeia, a tristeza e a ternura. Intervalos por saltos afastados como

\footnotetext{
${ }^{107}$ Musical analysis is the examination of a piece belonging to a ceartin mode and to a certain type of polyphony. [...] Here are five areas of analysis: (1) investigation of the mode; (2) investigation of the melodic genus; (3) investigation of the type of polyphony; (4) consideration of the quality; (5) sectioning of the piece into affections or periods. (citação igualmente localizada em: AMBIEL, 2010, p.6).
} 
em ritmos pontuados, com pulsações curtas, expressam o alegre e o ousado. As notas pontuadas e apoiadas (mantidas) descrevem o sério e o patético. A combinação das notas de longa duração e rápidas expressam o grandioso e o sublime.

3. Dissonâncias e ornamentos: o efeito produzido por elas são sempre diferentes, dependendo da diversidade das Dissonâncias.

4. Indicações de tempo e de caráter, tal como Allegro, Alllegro no tanto, Allegro assai, Di molto, Moderato, Presto, Allegretto, Andante, Andantino, Arioso, Cantabile, Spiritoso, Affettuoso, Grave, Adagio, Adagio Assai, Lento, Mesto, e assim por diante.

(QUANTZ, 1752, Cap. XI, § 16, pp.109-111) ${ }^{108}$.

Corroborando essas afirmações, Machado Neto enfatiza a relevância da análise retórica e harmônica para a melhor compreensão das estruturas do discurso musical. Em outras palavras, das significações, constituições dos elementos retórico-musicais e das tópicas:

Outras teorias auxiliares, como o pressuposto teórico atinente à forma de analisar a música desse mesmo tempo, vejo como problemáticas ao não considerar a condição do pensável da composição musical no final do século XVIII. Sem desconsiderar que a teoria de análise harmônica "funcional" oferece excelentes ferramentas de análise, mas alguns problemas fogem-lhe, principalmente os que se relacionam com as estruturas de discurso musical que expressam características ideológicas. Assim, sem descartar a análise harmônica, acrescentei a análise retórica e de tópicas [grifos nossos] (MACHADO NETO, 2011, p.214).

Dessa forma, assim como fizemos em nossa dissertação de mestrado, propusemos estabelecer, através das ferramentas analíticas necessárias, o possível emprego da retórica na música circulante do período colonial brasileiro, em outras palavras, procuramos examinar as similaridades do estudo de caso realizado, entretanto, buscando ampliar as possiblidades de

\footnotetext{
1081) Modes: par les Modes, s'ils font de Tiérce maneure ou mineure. Les Modes de la primiére espéce fervent ordinairement à exprimer le gaile hardi, le férieux \& le sublime; \& ceux de lá seconde forte font employés à exprimer ce qui flatte, le triste \& le tendre. 2) Intervales: Par les intervales coulés \& qui se trouvent l'um près de l'autre, on expreime ce qui flatte, le triste \& le tendre; \& par les notes qu'il faut pousser court, \& qui forment des fauts éloignés, de même que par les fortes de figures où les points font toujours derriére lá seconde note, on exprime le gai \& le hardi. Les notes pointées \& soutenuës expriment le serieux \& le pathétique; \& le mélange des notes d'une longw durée, comme les Blanches \& les Rondes avec les vites, cela exprime le grand \& le sublime. 3) Dissonances et ornements: L'effet que celles - ci font, au lieu d'êntre toujours le même, est bien different, selon la diversité des Dissonnances. 4) Indications de temps et de caractere: Alegro, Alllegro no tanto, Allegro assai, Di molto, Moderato, Presto, Allegretto, Andante, Andantino, Arioso, Cantabile, Spiritoso, Affettuoso, Grave, Adagio, Adagio Assai, Lento, Mesto, \& c.
} 
localização na utilização dos mecanismos retóricos nos compositores brasileiros do século XVIII e princípios do XIX, de maneira a desvelar os pontos primordiais que respondam alguns questionamentos relevantes, substanciados enquanto hipóteses:

1. Para lograr êxito em seu ofício, o compositor colonial brasileiro, faria uso dos recursos da Retórica, com o objetivo de mover os afetos dos ouvintes?

2. A aplicação dos elementos retóricos ocorre em todas as seções da peça e quais são suas relações com as funções harmônicas, com as cadências, com os motivos, com o texto e com as dinâmicas?

3. Há recorrências no emprego das figuras, se elas acontecem, sua inserção é realizada conscientemente?

Destarte, nas obras selecionadas para análise, direcionamos nossa verificação às suas características intrínsecas e peculiares, ou seja, uma observação pautada em realçar a habilidade dos autores em elaborar e ordenar uma música, com a intenção de atrair a atenção do ouvinte.

Do mesmo modo, procurou-se desenvolver uma forma de exame a qual priorizasse questões, estéticas, do ofício funcional litúrgico, vivenciadas pelos compositores e manifestas em suas peças.

Em síntese, expomos três categorias de análise musical (Rítmico/Semântico, Harmônica e de Elementos Retórico-Musicais), sendo que cada categoria é composta por indicadores acoplados e consonantes a cada enunciado. Os quais podem ser observados no quadro abaixo:

Tabela 12-Esquema relacional entre retórica, harmonia, texto e música utilizados na tese ${ }^{109}$.

\begin{tabular}{|c|c|c|}
\hline Rítmico/Semântico & Harmônica & $\begin{array}{c}\text { Elementos Retórico- } \\
\text { Musicais }\end{array}$ \\
\hline Andamento & Tonalidades e Afetos & Inventio (Locus) \\
Motivos e Frases & Progressões Harmônicas & Dispositio (Exordium, \\
Texto Sacro & & Narratio, Propositio, \\
& & Confutatio, Confirmatio \\
& & e Peroratio) \\
& & Elocutio/Decoratio \\
& & (Figuras Retóricas) \\
\hline
\end{tabular}

\footnotetext{
${ }^{109}$ Essa tabela se baseia no quadro 9, utilizado por Rodrigo Cardoso Affonso, em sua dissertação de mestrado (AFFONSO, 2005, p.55).
} 
Ressaltamos ainda, que, nesse tópico da tese, desenvolveram-se algumas questões relacionadas aos itens classificados e ordenados na tabela acima, os quais são imprescindíveis para a compreensão desta pesquisa, como da metodologia empregada nesses exames analíticos.

\subsubsection{Categoria Rítmico/Semântico}

- Andamento

A primeira categoria analítica é indispensável não só para as inclusões das indicações de andamento das peças por nós observadas, mas, igualmente, ela nos serve de auxílio para localização das descobertas dos materiais trabalhados pelos autores em suas respectivas obras. Essas referências podem ser verificadas na tabela abaixo.

Tabela 13-Andamentos das obras analisadas na tese ${ }^{110}$.

\begin{tabular}{|c|c|c|}
\hline Obra & Autor & Andamento Indicado \\
\hline $\begin{array}{l}\text { 1-Confitermi das Matinas e } \\
\text { Vésperas de Sábado } \\
\text { Santo }\end{array}$ & $\begin{array}{|lll|}\text { Manoel } & \text { Dias } & \text { de } \\
\text { Oliveira } & & \\
\end{array}$ & C Andante \\
\hline $\begin{array}{l}\text { 2-Pater Mihi do Moteto } \\
\text { dos Passos }\end{array}$ & $\begin{array}{|lll|}\text { Manoel } & \text { Dias } & \text { de } \\
\text { Oliveira } & & \\
\end{array}$ & $\$$ Moderato \\
\hline $\begin{array}{l}\text { 3-Gloria da Missa } \\
\text { Abreviada em Ré }\end{array}$ & $\begin{array}{|lll|}\text { Manoel Dias } & \text { de } \\
\text { Oliveira } & & \\
\end{array}$ & C Allegro \\
\hline $\begin{array}{l}\text { 4-Exaudi nos, Domine } \\
\text { para Benção de Cinzas da } \\
\text { Missa para Quarta-feira de } \\
\text { Cinzas }\end{array}$ & $\begin{array}{|lr|}\text { José } & \text { Joaquim } \\
\text { Emerico Lobo de } \\
\text { Mesquita }\end{array}$ & $\begin{array}{l}\text { \$ Andante; } 3 / 4 \text { Moderato; } \\
\$ \text { Allegro }\end{array}$ \\
\hline $\begin{array}{l}\text { 5- Kyrie da Ladainha em } \\
\text { Si bemol Maior }\end{array}$ & $\begin{array}{l}\text { José } \quad \text { Joaquim } \\
\text { Emerico Lobo de } \\
\text { Mesquita }\end{array}$ & C Andante \\
\hline $\begin{array}{l}\text { 6- Cum Appropinquaret da } \\
\text { Procissão de Ramos de } \\
\text { José Joaquim Emerico } \\
\text { Lobo de Mesquita }\end{array}$ & $\begin{array}{|lr|}\text { José } & \text { Joaquim } \\
\text { Emerico Lobo de } \\
\text { Mesquita }\end{array}$ & 3/4 Andantino \\
\hline $\begin{array}{l}\text { 7-Ofertório da Missa do } \\
\text { Domingo da Paixão }\end{array}$ & $\begin{array}{|lll|}\text { André } & \text { da } & \text { Silva } \\
\text { Gomes } & & \\
\end{array}$ & C Grave \\
\hline $\begin{array}{l}\text { 8-Ofertório da Missa do } 4^{\circ} \\
\text { Domingo da Quaresma }\end{array}$ & $\begin{array}{l}\text { André da } \\
\text { Gomes }\end{array}$ & C Andante Moderato \\
\hline
\end{tabular}

\footnotetext{
${ }^{110}$ Tal como a tabela anterior, essa igualmente é embasada no quadro 10 de Rodrigo Affonso, localizado em (AFFONSO, 2005, p.57).
} 


\begin{tabular}{|c|c|c|}
\hline 9-Laudate Pueri & $\begin{array}{l}\text { André da Silva } \\
\text { Gomes }\end{array}$ & C Andante \\
\hline 10-Moteto Domine Jesu & $\begin{array}{l}\text { José } \quad \text { Maurício } \\
\text { Nunes Garcia }\end{array}$ & 2/4 Larghetto \\
\hline 11-Moteto Crux Fidelis & $\begin{array}{l}\text { José Maurício } \\
\text { Nunes Garcia }\end{array}$ & 3/4 Andante Sostenuto \\
\hline $\begin{array}{lr}12-1^{\circ} \text { Responsório } & \text { das } \\
\text { Matinas } & \text { e } \\
\text { Encomendações } & \text { de } \\
\text { Defuntos } & \end{array}$ & $\begin{array}{l}\text { José Maurício } \\
\text { Nunes Garcia }\end{array}$ & $\begin{array}{l}\$ \text { Moderato; Allegro; } \\
\text { Moderato }\end{array}$ \\
\hline
\end{tabular}

\section{- Motivos e Frases}

Nesta parte, tratamos de destacar além dos materiais motívicos aplicados nas composições, as linhas fraseológicas das melodias, as dinâmicas indicadas, as quais, na maioria dos casos foram inseridas pelos editores, entretanto com embasamento crítico musicológico e coerente. Isto é, pautado no contexto do que circunstancial de cada parte do enunciado musical; as sequências das gradações melódicas, as repetições das notas, os efeitos sonoros proporcionados pelo ritmo, pelas expressões e pela expectativa causada pelo silêncio impostos através das pausas.

\section{- Texto Sacro}

O texto em uma obra litúrgica, e, especialmente ligada às palavras, é uma das primeiras informações que o compositor tem para elaborar as ideias que sustentarão seus argumentos dentro do discurso musical, ou seja, aquilo que é atribuição da Inventio. Rodrigo Cardoso Affonso enfatiza esse procedimento no processo composicional:

O texto literário é o primeiro dado que o compositor tem à mão no processo composicional de uma obra litúrgica, vocal, de maneira geral. Os textos litúrgicos são fixados por uma longa tradição. Um dos aspectos que o processo criativo vai contemplar é como o texto será dito, musicalmente. Isto decorre da leitura que o compositor faz do texto. E gera, necessariamente, um tipo de declamação, pela qual saberemos como o compositor interferiu na estrutura do texto, pontuando-o, e que aspectos fonéticos, rítmicos ou semânticos the interessaram, por exemplo. A observação da declamação textual provê, ainda, um esboço da forma musical criada (AFFONSO, 2005, pp.57-58). 
Decorrente dessa escolha, o autor enfatiza o texto relacionando-o com as partes que ele entende pertinentes para mover os afetos do ouvinte, por exemplo, dentro da Dispositio e Elocutio, numa passagem onde ele queira realçar momentos de alegria e exultação, ele insere um texto: Exaltai ao Senhor, em consonância com a linha ascendente das melodias e com figuras retóricas, como Anabasis ou, caso pretenda ratificar essa finalidade, da Anaphora, Epizeuxis, Polyptoton, Palilogia, que são figuras retóricas de repetição melódica.

Semelhantemente, para colocar em destaque os afetos de angústia, tristeza e aflição, o compositor pode escolher um texto com a seguinte expressão: Minha alma está profundamente angustiada, para evidenciar as linhas melódicas descendentes da melodia, juntamente com elementos retóricos da Catabasis, Passus Duriusculus, Pathopoeia, entre outros.

\title{
5.5.2. Categoria- Harmônica
}

\section{- Tonalidades e Afetos}

Mediante as tonalidades o compositor, desde o final do século XVI, e principalmente com o advento do Barroco, poderia representar diversos afetos, isso se dava através da racionalização de um estado emocional ou paixão, como destaca George Buelow:

\begin{abstract}
Um afeto (Affekt em alemão, pathos no grego e affectus no latim) consiste na racionalização de um estado emocional ou paixão. Depois de 1600 , a representação dos afetos tornou-se essencial para a estética da maioria dos compositores barrocos, independentemente da sua nacionalidade, e a base fundamental dos numerosos tratados. Durante o Barroco, o compositor era obrigado (estimulado), como o orador, a despertar no ouvinte, estados emocionais idealizados - tristeza, ódio, amor, alegria, raiva, dúvida e assim por diante - e todos os aspectos da composição musical refletia esse propósito afetivo. Embora fosse mais fácil de valorizá-la na música associada a um texto, o objetivo da música instrumental era o mesmo [grifos nossos] (BUELOW, 2001, p.269) ${ }^{111}$.
\end{abstract}

\footnotetext{
${ }^{111} \mathrm{An}$ affect ('Affekt' in German, from the Greek 'pathos' and the Latin 'affectus') consists of a rationalized emotional state or passion. After 1600 the representation of the Affects became the aesthetic necessity of most Baroque composers, whatever their nationality, and the fundamental basis of numerous treatises. During the Baroque period the composer was obliged, like the orator, to arouse in the listener idealized emotional states - sadness, hate, love, joy, anger, doubt and so on - and every aspect of musical composition reflected this affective purpose. While it was easier to appreciate it in music associated with a text, the aim in instrumental music was the same. Tal citação igualmente é localizada em (AFFONSO, 2005, p.65).
} 
Como observado, por meio da escolha das tonalidades podia-se estabelecer relação com os afetos idealizados. De igual forma, essa predileção era realizada pensando também em alguns aspectos, como ressalta Rodrigo Affonso:

a) buscava-se uma região harmônica na qual os instrumentos ou vozes empregadas estivessem confortáveis, isto é, dentro de sua tessitura, explorando-se seus registros mais efetivos, segundo os propósitos composicionais;

b) a escolha da tonalidade também refletia uma preocupação por facilitar a notação e transmissão musical;

c) ainda, neste aspecto prático, a escolha por determinada tonalidade dependia do sistema de temperamento utilizado. Em temperamentos desiguais, há intervalos de mesma nomenclatura que diferem acusticamente entre si, gerando diferentes sonoridades de acordo com a tônica escolhida, ou até mesmo impossibilitando o uso de certos acordes e intervalos melódicos;

d) outro aspecto que merece nossa atenção é a relação entre tonalidade e afetos. Tal como a discussão em torno dos sistemas de temperamento, esta é uma questão que vai além da praticidade, e recai sobre os ideais expressivos do compositor (AFFONSO, 2005, pp.66-67).

Enfim, os autores não só da transição da Renascença para o Barroco, mas também do começo do Classicismo, planejavam o conteúdo afetivo de cada obra, utilizando-se de todos os dispositivos disponíveis para gerar maior expectativa e atenção do ouvinte, isto é, esperava-se uma resposta de seu público.

\section{- Progressões Harmônicas}

Por intermédio das sucessões dos acordes musicais em diversas passagens harmônicas, sejam elas ascendentes, descendentes, modulatórias, regulares ou não, vinculadas aos outros elementos musicais como escalas, ritmo, estrutura harmônica, tonalidade, formas, entre outros, possibilita melhor entendimento da estrutura musical.

Destarte, há um planejamento harmônico que, em consonância ao texto e à melodia, dão maior sustentação e clareza à condução de cada parte do enunciado musical. Pois é certo que a progressão harmônica é utilizada pelos compositores para garantir maior direcionalidade à música, assim assegurando que a mesma tenha maior fluidez. 
Por fim, quando aludirmos as obras selecionadas para análise, observaremos como os compositores trabalharam as diversas funções harmônicas, as cadências e suas resoluções, os afetos, o texto sacro e sua relação com os mecanismos retóricos.

\subsubsection{Categoria- Elementos Retórico-Musicais}

\section{- Fases e Figuras Retóricas}

A utilização dos elementos retóricos, a partir dos meados da década de 1960, disseminou-se com grande amplitude na musicologia como relevante recurso e instrumento analítico do processo composicional dos séculos supracitados, ao longo da tese. Certamente, por meio desses elementos retóricos, passa ser possível a compreensão das elaborações e constituições das estruturas retórico-musicais.

Todavia, mesmo com o abrangente crescimento e interesse por essa nova linha de pesquisa, ainda não há uma terminologia peremptória, pois, como colocado na introdução, há grande safra de tratados, onde os autores adicionavam constantemente novos termos. Tanto é que as figuras retóricas, mesmo com nomenclaturas diferentes, podem ter funções idênticas.

Por exemplo, para Johann Walter, o Superjectio que é uma figura de ornamentação harmônica e melódica, tem a mesma função do Accentus, que é de subir ou descer numa sequência intervalar de segunda. Outra figura que pode ser ressaltada é a Anaphora que pode ser interpretada de várias maneiras: para Burmeister ela é um ornamento que repete as mesmas notas através de várias vozes diferentes, todavia, isso não ocorre em todas as vozes da harmonia. Isso acontece da mesma forma que a fuga, embora não seja de fato uma fuga. Já para Nucius, essa figura é conhecida como Repetitio que ocorria no contraponto floreado ou misto, onde um tema é repetido continuamente numa única e mesma voz, no entanto, em muitos campos diferentes. Para Thuringus, era a repetição apenas da linha melódica do baixo. Por sua vez, Walter a define como uma repetição das mesmas palavras para dar maior ênfase. Finalizando, Mattheson a descreve como uma repetição de um fragmento musical no início de várias frases (BARTEL, 1997, pp.187-189).

Somente com dois exemplos de definições das figuras retóricas, pode-se evidenciar que o processo de análise é bastante dificultoso, assim como de 
categorização, o qual está longe de ser objeto de harmonização e uniformidade concordante entre os diversos especialistas, pesquisadores e estudiosos do assunto. Porém, mediante o exposto a partir do tópico 5.5 sobre a retórica, harmonia e relação texto-música com suas categorias de análise musical, possibilitou, aqui, um procedimento mais criterioso e esclarecedor.

Evidentemente que, com o propósito de entender o emprego desses recursos retóricos pelos compositores brasileiros nos séculos XVIII e princípios do século XIX, viabilizou-se maior interesse sobre essas dificuldades elencadas anteriormente, bem como o desafio de identificar, reconhecer e diferenciar as figuras dentro de um ambiente comum a todos. Dessa maneira, enfatizamos que somente através de um estudo mais profundo, intenso e minucioso sobre essas questões, aumentando a quantidade dos exemplos observados, poderemos desenvolver uma análise que busque fundamentação mais ponderada e coerente. 


\section{ANÁLISES RETÓRICAS DE ALGUMAS OBRAS DOS COMPOSITORES}




\section{ANÁLISES RETÓRICAS DE ALGUMAS OBRAS DOS COMPOSITORES}

Para realização das análises retórico-musical de algumas obras dos compositores Manoel Dias de Oliveira, José Joaquim Emerico Lobo de Mesquita, André da Silva Gomes e José Maurício Nunes Garcia, utilizamos como referências autores como George Buelow, Dietrich Bartel, Rubén López Cano, entre outros, além dos próprios tratadistas retórico-musicais os quais estão inseridos nos trabalhos desses autores.

Igualmente, é pertinente salientar que cada observação realizada pautou-se nas metodologias, instrumentos de pesquisa e procedimentos descritos na primeira parte da tese, bem como nos itens elencados no tópico 5.5. Retórica, harmonia e a relação texto-música como ferramentas convergentes de análise, além dos subtópicos 5.5.1, 5.5.2 e 5.5.3, os quais serão apresentados a seguir.

\subsection{Manoel Dias de Oliveira}

\subsubsection{Análise Retórico-Musical do Confitemini das Matinas e Vésperas de Sábado Santo ${ }^{112}$}

\section{Inventio}

O Confitemini das Matinas e Vésperas de Sábado Santo têm o texto baseado em Salmos (Ps.117:1-2/118:1-2) $)^{113}$, cujo título faz referência à alegria dos justos no Senhor.

Confitemini Domino, quoniam bonus quoniam in sæculum misericordia ejus. Laudate dominum omnes gentes et collaudate eum omnes populi. Quoniam confirmata est super nos misericórdia ejus et veritas Domini manet in æternum.

Glorificai ao Senhor, por que Ele é bom; por que sua misericórdia perdura nos séculos. Louvai ao Senhor, nações ${ }^{114}$ todas; o louvai todos os povos. Porque

\footnotetext{
${ }^{112}$ De acordo com Maurício Dottori as Matinas e Vésperas de Sábado Santo, não possui indicação de datação (OLIVEIRA, 2000, p.10).

${ }^{113}$ Salmos 117:1-2 seriam o número e versículo na bíblia católica, já na bíblia protestante o texto está escrito no número 118, versículos 1 e 2 .

${ }^{114}$ Verifica-se que no versículo do salmo descrito acima é mencionada a palavra nações, o que mostra um problema de cunho hermenêutico na tradução dos originais bíblicos do hebraico para o grego até chegar à língua portuguesa. Obviamente, quando foi escrito esse salmo, aproximadamente no ano 1.000 a.C., não havia uma ideia esboçada, tampouco desenvolvida e consolidada sobre nação. De acordo com Abbagnano, o conceito de nação começou a formarse a partir do conceito de povo, que havia dominado a filosofia política do século XVIII, quando se acentuou, nesse conceito, a importância dos fatores naturais e tradicionais em detrimento dos voluntários. Desse modo, o povo é constituído essencialmente pela vontade comum, que é
} 
se confirmou sobre nós a sua misericórdia e a fidelidade do Senhor perdura eternamente (OLIVEIRA, 2000, pp.12-13).

Esse salmo conclui a seção associada à celebração da Páscoa, introduzida no salmo 113. Na qualidade de último cântico do grupo (113-118), provavelmente foi o salmo proferido por Cristo em sua celebração pascoal na companhia de seus discípulos (ALMEIDA, 1999, p.700).

Anda não lestes esta Escritura: A pedra que os construtores rejeitaram, essa veio a ser a principal pedra, angular; isto procede do Senhor, e é maravilhoso aos vossos olhos? (Marcos 12:10-11 [36]; Salmos 117:22-23/118:22-23,1999 [1000 a.C.], p.700).

Todavia, nessa passagem o salmista conclama todos os povos a louvar e a glorificar o Senhor, por causa de seus atributos. Enfim, a presente peça é constituída por trinta e cinco compassos em andamento Andante, na tonalidade Sol Maior, distribuída em seis partes por Manoel Dias de Oliveira, o qual emprega os recursos retóricos a serviço da eloquência e persuasão.

\subsection{Loci observados na Inventio do Confitemini}

Tabela 14-Loci Topici localizados no Confitemini das Matinas e Vésperas de Sábado Santo de Manoel Dias de Oliveira.

\begin{tabular}{|c|c|c|c|}
\hline INVENTIO & DESCRIÇÃO & $\begin{array}{c}\text { UTILIZAÇÃO NA } \\
\text { OBRA }\end{array}$ & $\begin{array}{l}\text { COMPASSOI } \\
\text { VOZ }\end{array}$ \\
\hline $\begin{array}{l}\text { Locus Notationis } \\
\text { (MATTHESON, } \\
\text { 1954, [1739]. } \\
\text { Parte II, Cap.4, § } \\
\text { 23, p.123). }\end{array}$ & $\begin{array}{l}\text { Aspecto } \\
\text { externo e } \\
\text { desenho das } \\
\text { notas (Duração } \\
\text { das notas, } \\
\text { alteração, } \\
\text { repetição e } \\
\text { procedimentos } \\
\text { canônicos). }\end{array}$ & $\begin{array}{l}\text { Vários motivos } \\
\text { rítmicos e diferentes } \\
\text { durações de notas } \\
\text { (mínimas, semínimas, } \\
\text { semínimas } \\
\text { pontuadas, colcheias, } \\
\text { colcheias pontuadas, } \\
\text { semicolcheias, fusas, } \\
\text { repetições, ligaduras, } \\
\text { pausas, apogiatura, } \\
\text { entre outros). }\end{array}$ & $\begin{array}{ll}1-4 & \text { S-A-T-B } \\
5-10 & \text { S-A-T-B } \\
10-13 S-A-T-B \\
13-24 S-A-T-B \\
24-27 S-A-T-B \\
28-35 S-A-T-B\end{array}$ \\
\hline
\end{tabular}

a base do pacto originário; a nação é constituída essencialmente por vínculos independentes da vontade dos indivíduos: raça, religião, língua e todos os outros elementos que podem ser compreendidos sob o nome de tradição. Enfim, a nação só começou a ser concebida claramente no início do século XIX; o nascimento desse conceito coincide com o nascimento da fé nos gênios nacionais e nos destinos de uma nação particular, que se chama nacionalismo (ABBAGNANO, 2007, p.694). 


\begin{tabular}{|c|c|c|c|}
\hline $\begin{array}{l}\text { Locus } \\
\text { Descriptionis } \\
\text { (MATTHESON, } \\
\text { 1954 [1739]. Parte } \\
\text { II, Cap.4, § 43, } \\
\text { p.127). }\end{array}$ & $\begin{array}{l}\text { Disposições da } \\
\text { alma }\end{array}$ & $\begin{array}{l}\text { Devoção, veneração } \\
\text { (Glorificai ao Senhor, } \\
\text { por que ele é bom). }\end{array}$ & $\begin{array}{l}5-10 \text { S-A-T-B } \\
19-25 S-A-T-B\end{array}$ \\
\hline $\begin{array}{l}\text { Locus } \\
\text { Circumstantiarum } \\
\text { (MATTHESON, } \\
\text { 1954 [1739]. Parte } \\
\text { II, Cap.4, \& 77, } \\
\text { p.131). }\end{array}$ & $\begin{array}{l}\text { Diferentes } \\
\text { circunstâncias } \\
\text { de tempo, do } \\
\text { lugar e de } \\
\text { acontecimentos } \\
\text { anteriores. }\end{array}$ & $\begin{array}{l}\text { Porque sua } \\
\text { misericórdia perdura } \\
\text { nos séculos. }\end{array}$ & $\begin{array}{l}\text { 14-19S-A-T-B } \\
26-35 S-A-T-B\end{array}$ \\
\hline $\begin{array}{l}\text { Locus } \\
\text { Oppositorum } \\
\text { (MATTHESON, } \\
\text { 1954, [1739]. } \\
\text { Parte II, Cap.4, § } \\
\text { 80, p.131). }\end{array}$ & $\begin{array}{l}\text { Contraste de } \\
\text { compassos, } \\
\text { movimentos } \\
\text { contrários, } \\
\text { agudos e } \\
\text { graves, lento e } \\
\text { rápido, calmo e } \\
\text { agitado. }\end{array}$ & $\begin{array}{l}\text { Movimento contrário } \\
\text { entre soprano, } \\
\text { contralto, tenor e } \\
\text { baixo. }\end{array}$ & $12-13 S-A-T-B$ \\
\hline
\end{tabular}

\section{Dispositio}

\subsection{Exordium}

A introdução se inicia por meio do acompanhamento instrumental. Da mesma forma, nota-se que o compositor usa as funções da Tônica, Dominante, Dominante da Subdominante e Subdominante, resolvendo na Cadência Autêntica Imperfeita em Sol Maior, preparando o ouvinte para a narração dos fatos que virá posteriormente a partir do compasso 5 . 
Confitemini

(EXORDIUM) Manoel Dias de Oliveira (1734/5-1813)

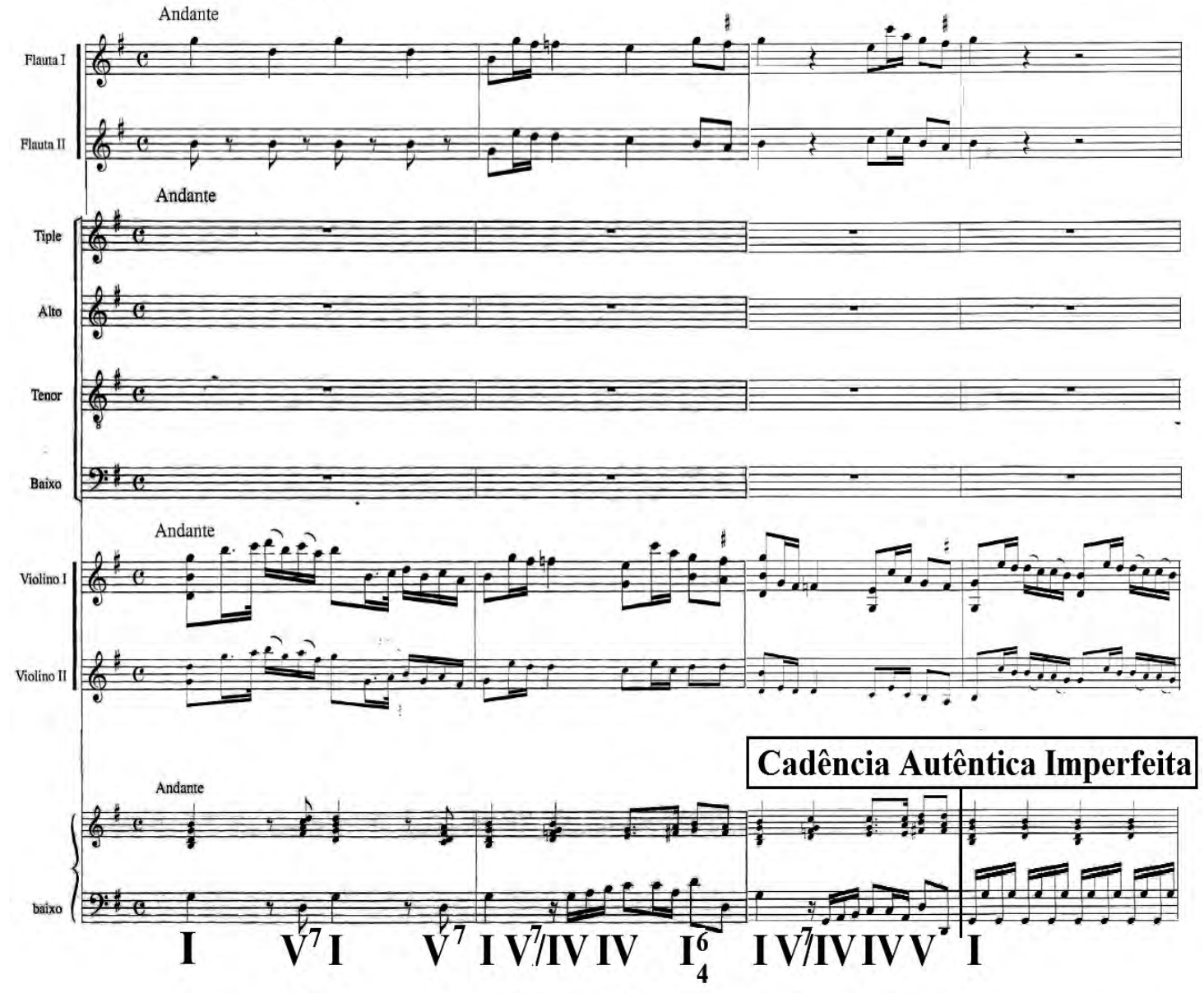

Exemplo 84-Confitemini das Matinas e Vésperas de Sábado Santo de Manoel Dias de Oliveira - Edição- Maurício Dottori (OLIVEIRA, 2000, pp.125-126).

\subsection{Narratio}

No quinto e sexto compasso é notado o emprego da Anaphora, nas vozes da soprano e contrato, a qual realça, por meio de repetição, a palavra Confitemini (Glorificai). De igual maneira, percebem-se as funções harmônicas da Tônica, Dominante e Dominante da Dominante em preparação à tonalidade de Re Maior e, por fim, a conclusão dessa parte na Cadência Autêntica Imperfeita. 
(NARRATIO)

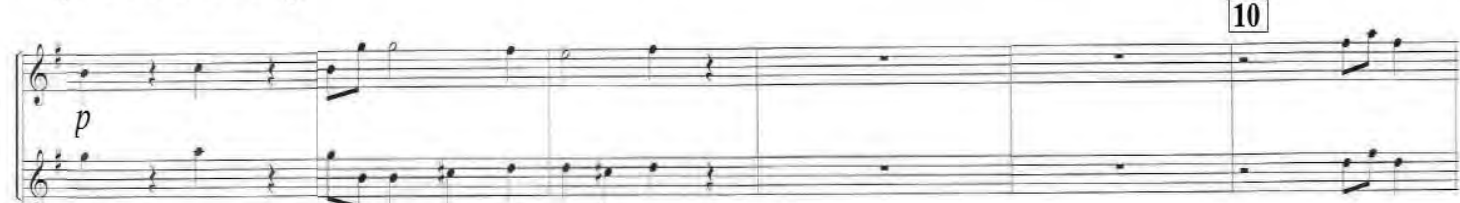

$[p]$

10

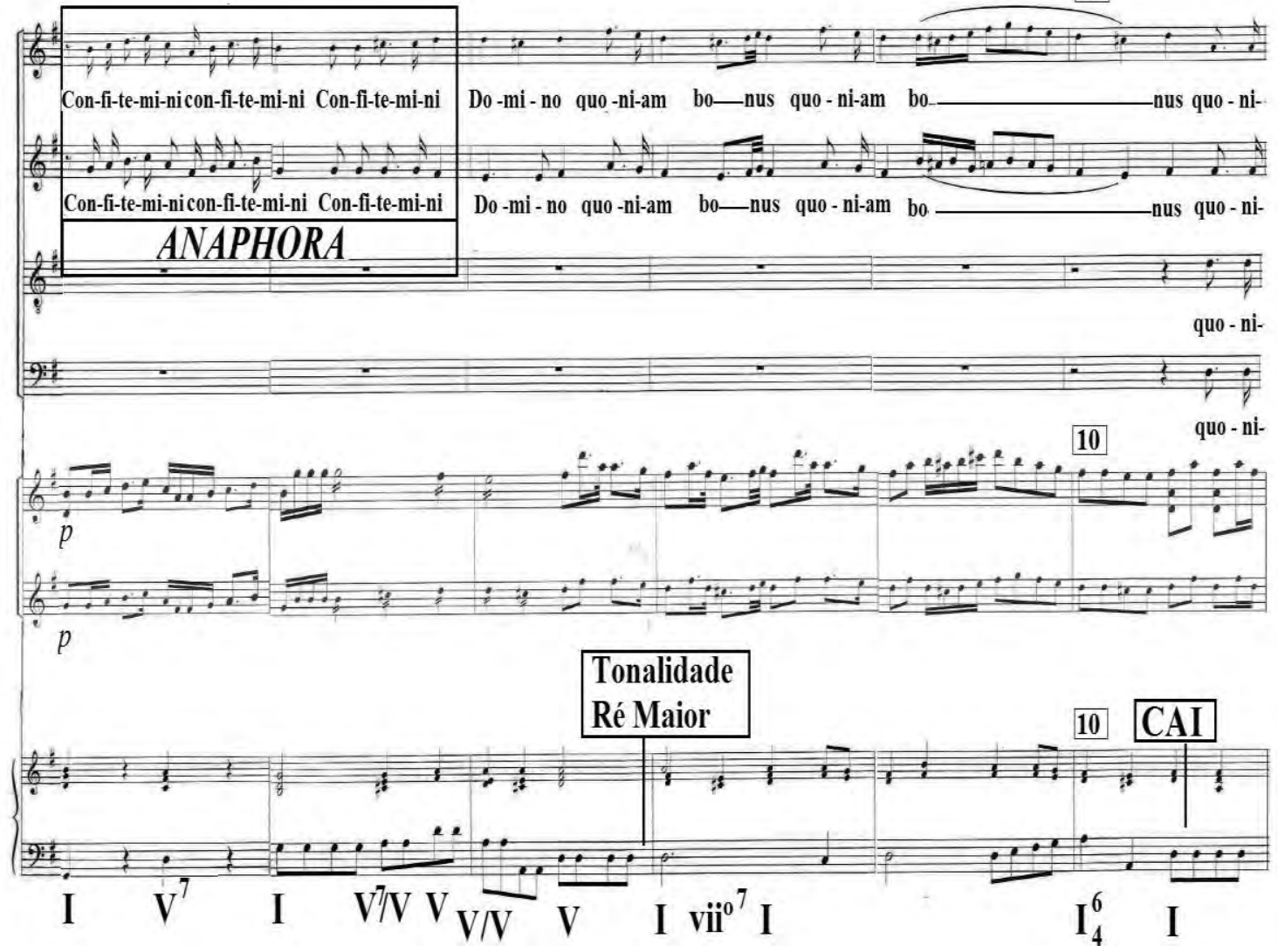

Exemplo 85-Confitemini das Matinas e Vésperas de Sábado Santo de Manoel Dias de Oliveira - Edição- Maurício Dottori (OLIVEIRA, 2000, pp.126-128).

\subsection{Propositio}

No presente exemplo, observa-se o uso das harmônicas utilizadas anteriormente, no entanto, a resolução da Propositio deu-se com uma Cadência Autêntica Imperfeita. Da mesma maneira, verifica-se o uso da Synaeresis nas vozes do contralto, tenor e baixo, no compasso 11, entoando duas notas em uma sílaba. 


\section{(PROPOSITIO)}

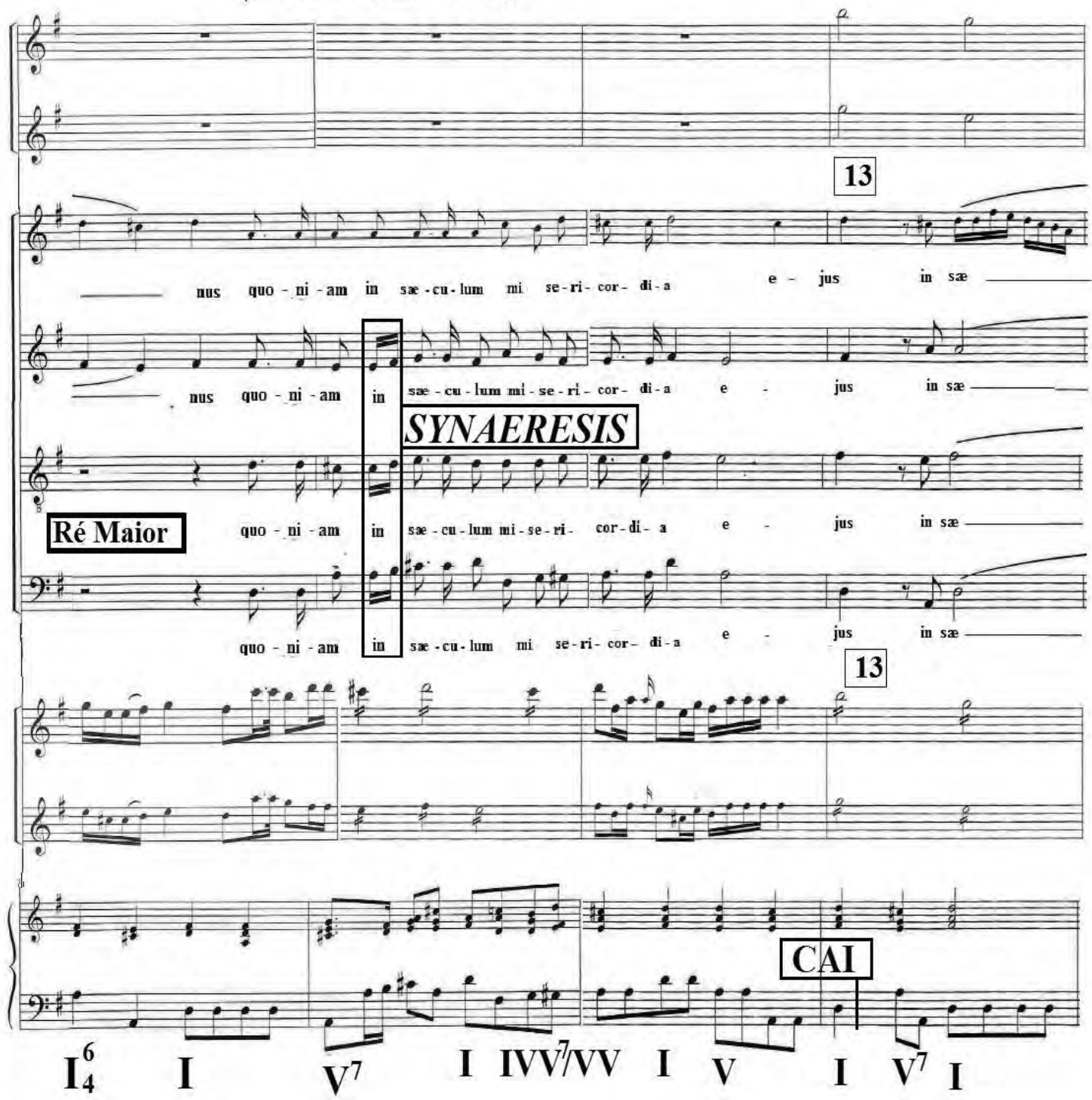

Exemplo 86-Confitemini das Matinas e Vésperas de Sábado Santo de Manoel Dias de Oliveira - Edição- Maurício Dottori (OLIVEIRA, 2000, pp.128-129).

\subsection{Confutatio}

No excerto abaixo, é tangível a aplicação do Polyptoton por Dias de Oliveira, onde a mesma ideia musical se repete em alturas diferentes, ressaltando a expressão in sænculum (século). Também, examina-se que esse recurso retórico de repetição é objetivado em salientar as progressões harmônicas das funções da Tônica, Dominante, Subdominante, Dominante Relativa (Paralela), Tônica Relativa (Paralela) e Subdominante Relativa (Paralela). 
(CONFUTATIO)

16

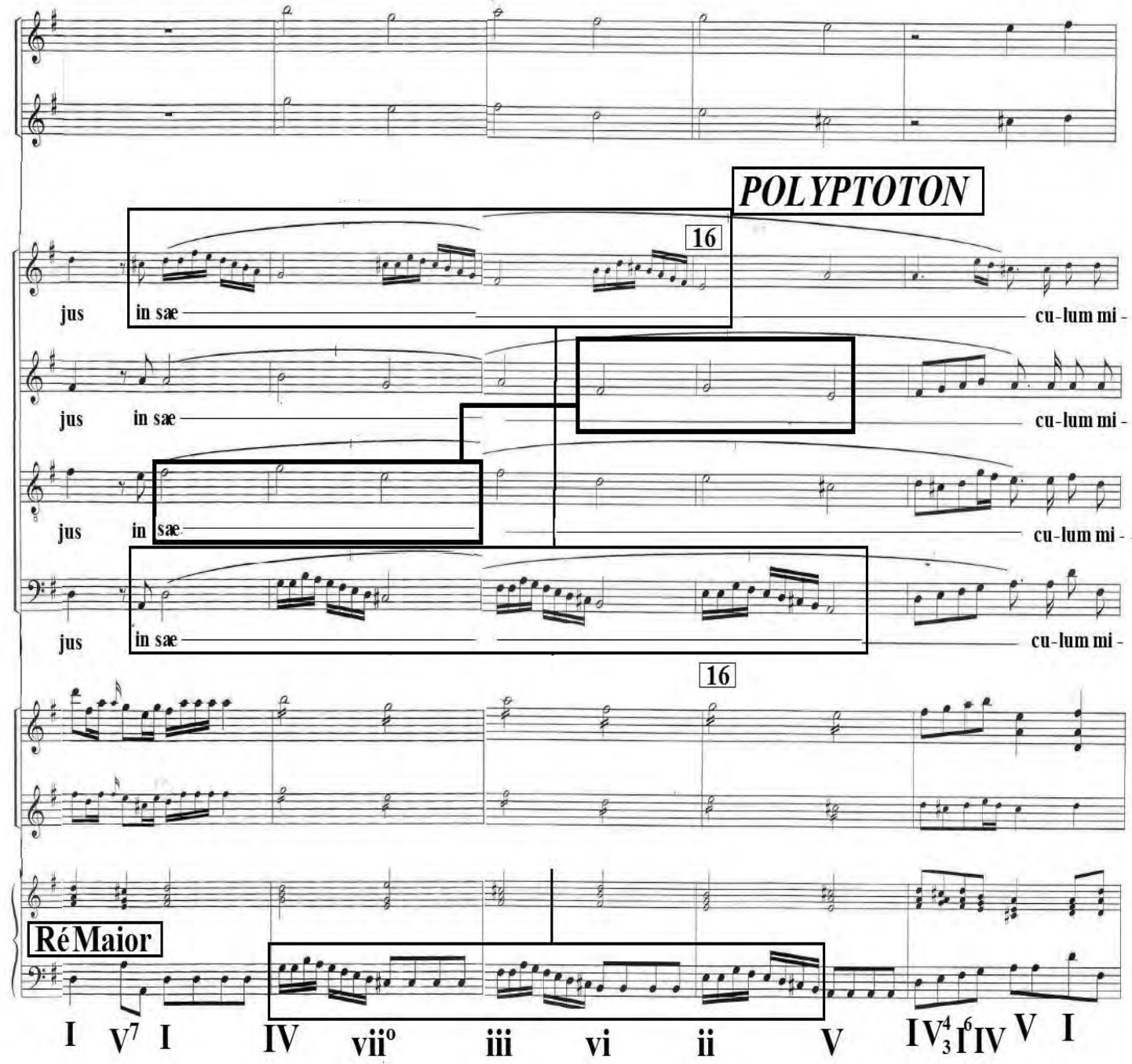

Exemplo 87-Confitemini das Matinas e Vésperas de Sábado Santo de Manoel Dias de Oliveira - Edição- Maurício Dottori (OLIVEIRA, 2000, pp.129-130).

Nesse exemplo, nota-se o emprego da Suspiratio produzindo uma espécie de suspiro entre pausas em todas as vozes e da Anaphora, na tonalidade Sol Maior, entre os compassos 19 e 23, destacando a expressão Confitemini Domino (Glorificai ao Senhor), atraindo o ouvinte, seja pela ênfase, reiteração ou pelo destaque das expressões pronunciadas melodicamente. 


\section{(NARRATIO dentro da CONFUTATIO)}

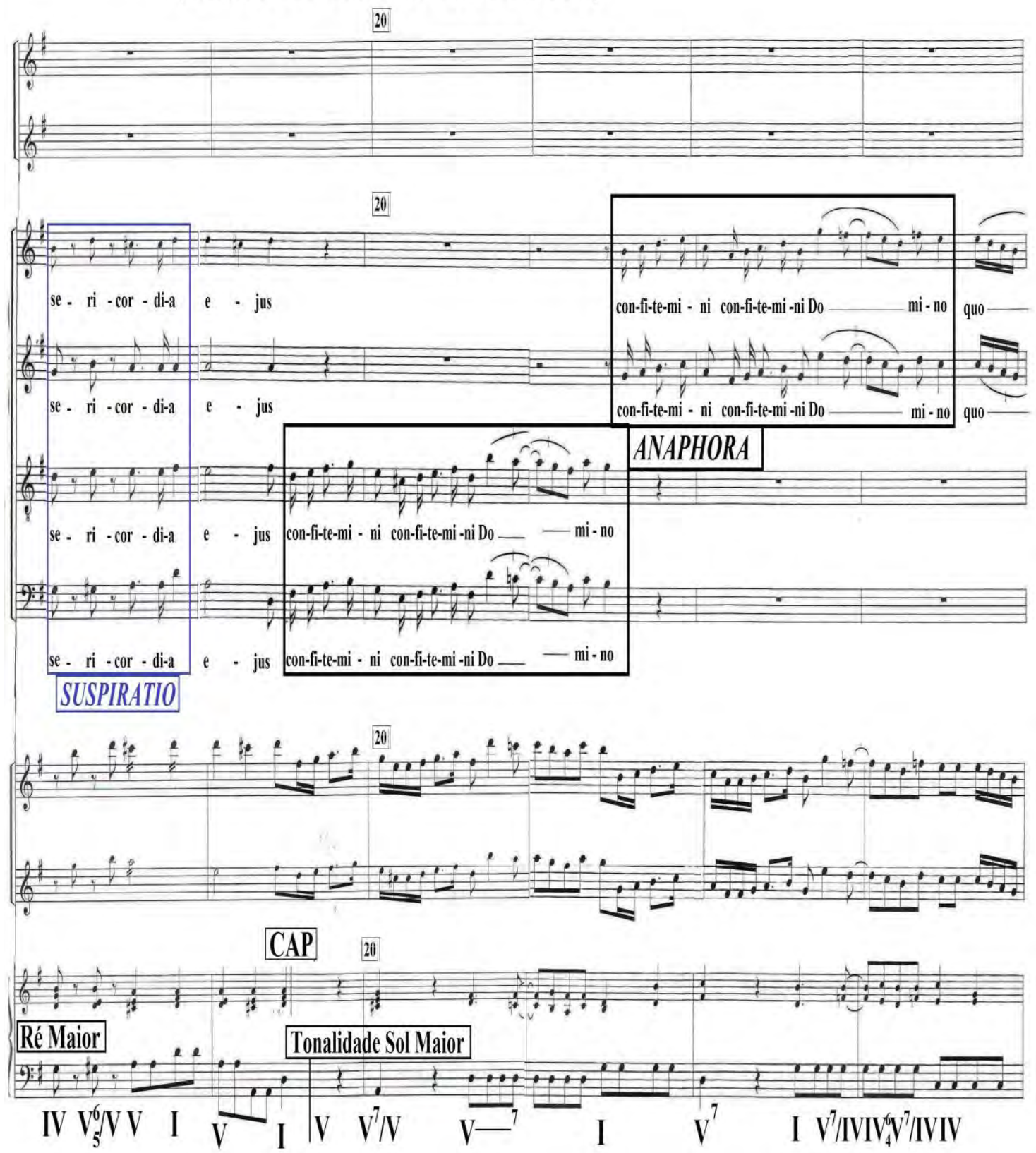

Exemplo 88-Confitemini das Matinas e Vésperas de Sábado Santo de Manoel Dias de Oliveira - Edição- Maurício Dottori (OLIVEIRA, 2000, pp.131-132).

\subsection{Confirmatio}

É observável nesse trecho, o mesmo procedimento utilizado pelo compositor na terceira parte da obra, em outras palavras, os mesmos motivos, linha melódica, intervalos, funções semelhantes e o emprego da Synaeresis configurando, assim, uma Propositio dentro da Confirmatio. Porém, com uma ressalva, a tonalidade de Sol Maior. 


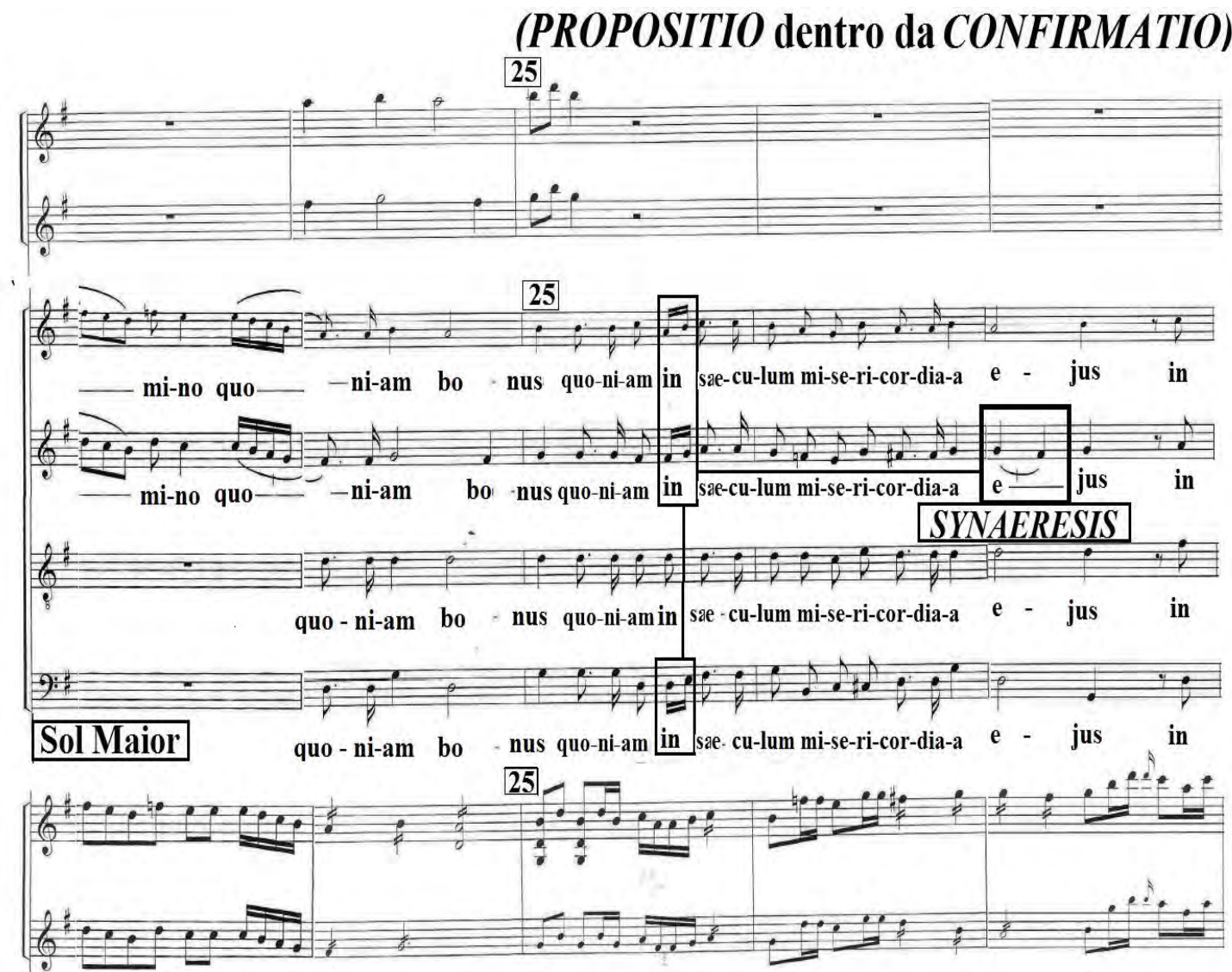

25

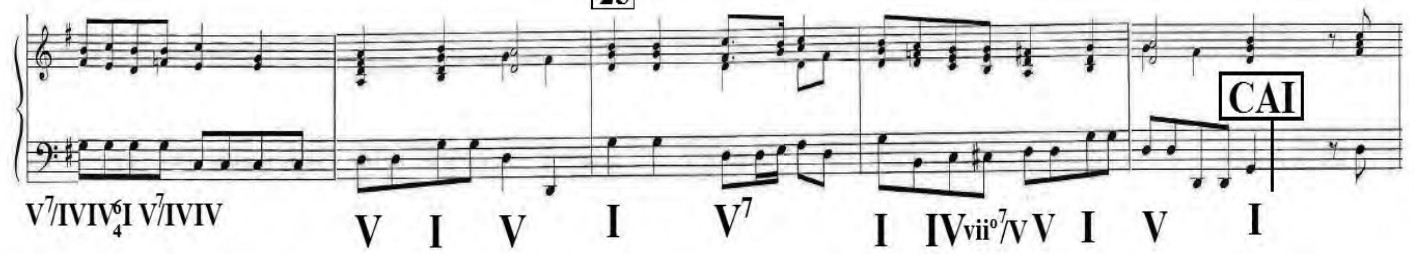

Exemplo 89-Confitemini das Matinas e Vésperas de Sábado Santo de Manoel Dias de Oliveira - Edição- Maurício Dottori (OLIVEIRA, 2000, pp.133-134).

\subsection{Peroratio}

$\mathrm{Na}$ conclusão, são perceptíveis os mesmos materiais e elementos retóricos usados na quarta parte do discurso, isto é, da Suspiratio e do Polyptoton valorando a frase in sæculum misericordia ejus (sua misericórdia perdura pelos séculos). De igual forma, nota-se que essa figura de repetição melódica é empregada para ressaltar as funções harmônicas da Dominante, Tônica, Subdominante, Dominante da Dominante, Dominante da Subdominante, Tônica Relativa (Paralela) e Subdominante Relativa (Paralela), com conclusão tanto da sessão quanto da música na Cadência Autêntica Imperfeita, no compasso 35. 

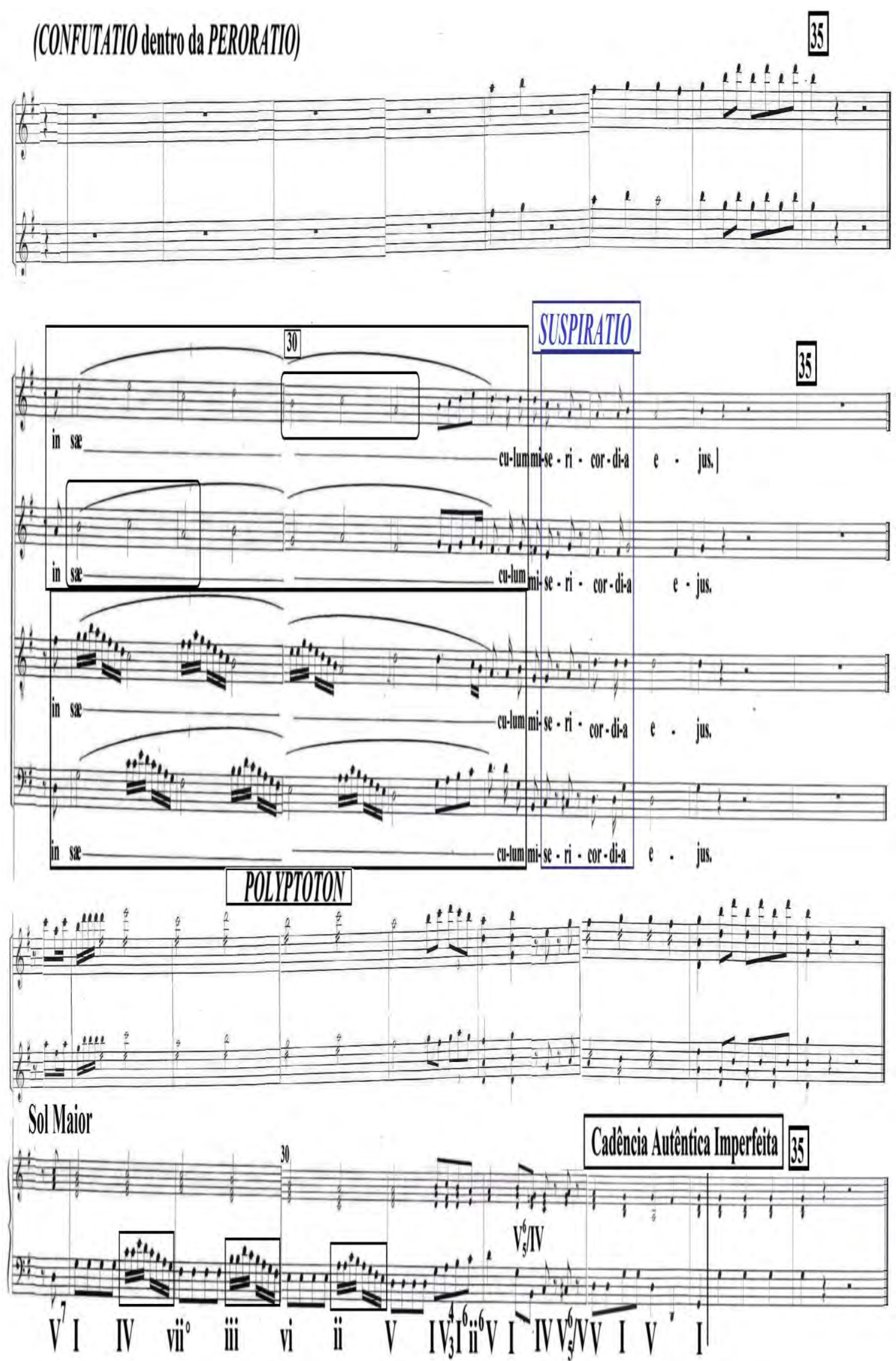

Exemplo 90-Confitemini das Matinas e Vésperas de Sábado Santo de Manoel Dias de Oliveira - Edição- Maurício Dottori (OLIVEIRA, 2000, pp.134-136). 


\section{Figuras observadas no Confitemini (Elocutio/Decoratio)}

Tabela 15-Figuras retóricas localizadas no Confitemini das Matinas e Vésperas de Sábado Santo de Manoel Dias de Oliveira.

\begin{tabular}{|c|c|c|c|}
\hline $\begin{array}{ll}\text { FIGURAS } & \text { E } \\
\text { CITAÇÕES } & \end{array}$ & TIPO & DESCRIÇÃO & TRATADISTA \\
\hline $\begin{array}{l}\text { ANAPHORA } \\
\text { (BARTEL, 1997, } \\
\text { pp.184-190). }\end{array}$ & $\begin{array}{l}\text { Repetição } \\
\text { Melódica }\end{array}$ & 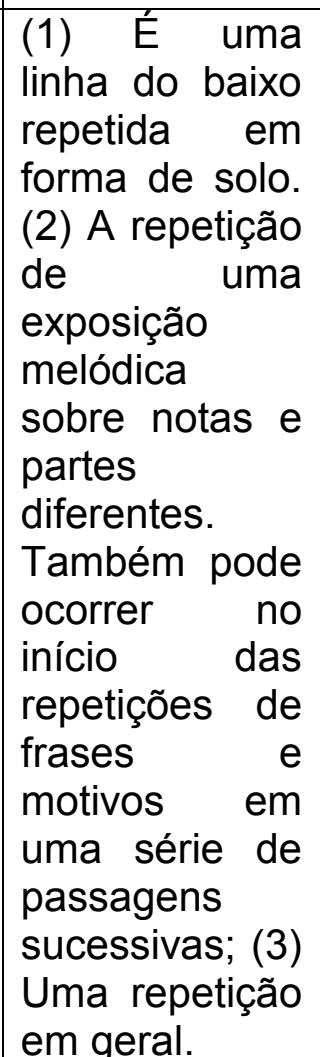 & 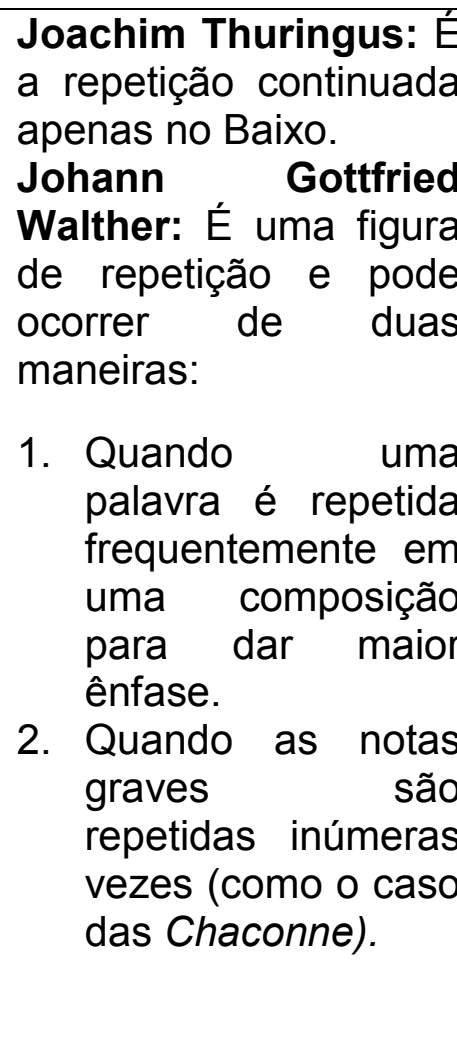 \\
\hline $\begin{array}{l}\text { POLYPTOTON } \\
\text { (BARTEL, 1997, } \\
\text { pp.367-369). } \\
\text { (BUELOW, 2001, } \\
\text { p.264). }\end{array}$ & $\begin{array}{l}\text { Repetição } \\
\text { Melódica }\end{array}$ & $\begin{array}{l}\text { A repetição de } \\
\text { uma } \\
\text { passagem } \\
\text { melódica em } \\
\text { diferentes } \\
\text { alturas. }\end{array}$ & $\begin{array}{l}\text { Mauritius Johann } \\
\text { Vogt: Polyptoton é } \\
\text { quando uma passagem } \\
\text { é repetida em várias } \\
\text { alturas. }\end{array}$ \\
\hline $\begin{array}{l}\text { SUSPIRATIO } \\
\text { (BARTEL, 1997, } \\
\text { pp. 392-394). } \\
\text { (BUELOW, 2001, } \\
\text { p.268). }\end{array}$ & $\begin{array}{l}\text { Interrupção e } \\
\text { Silêncio }\end{array}$ & $\begin{array}{l}\text { Expressão } \\
\text { musical de um } \\
\text { suspiro, } \\
\text { através de } \\
\text { pausas. }\end{array}$ & $\begin{array}{l}\text { Athanasius Kircher: A } \\
\text { Stenasmus ou } \\
\text { Suspiratio lembram os } \\
\text { afetos naturalmente } \\
\text { expressados por vários } \\
\text { suspiros criados } \\
\text { através de pausas. }\end{array}$ \\
\hline
\end{tabular}




\begin{tabular}{|l|l|l|l|}
\hline SYNAERESIS & $\begin{array}{l}\text { Dissonância e } \\
\text { Deslocamento }\end{array}$ & $\begin{array}{l}\text { (1) Uma } \\
\text { suspensão ou } \\
\text { síncope, (2) A } \\
\text { (BARTEL, 1997, } \\
\text { duas sílabas } \\
\text { pp.394-396). }\end{array}$ & $\begin{array}{l}\text { Mauritius Johann } \\
\text { Vogt: A Synaeresis } \\
\text { ocorre quando duas } \\
\text { notas são colocadas } \\
\text { em uma sílaba ou duas } \\
\text { duas notas por } \\
\text { sílaba. }\end{array}$ \\
$\begin{array}{l}\text { (LÓPEZ CANO, } \\
\text { 2000, p.199). }\end{array}$ & $\begin{array}{l}\text { sibas são colocadas } \\
\text { em uma nota. }\end{array}$ \\
\hline
\end{tabular}

\section{Análise Harmônica}

\subsection{Curva Tonal}

Tonalidade: Sol Maior

Andamento: Andante 4/4

Tabela 16-Esquema das Progressões Harmônicas- Curva Tonal do Confitemini das Matinas e Vésperas de Sábado Santo.

\begin{tabular}{|l|c|l|}
\hline \multicolumn{1}{|c|}{ Compassos } & Função & \multicolumn{1}{c|}{ Tonalidade } \\
\hline $1-2$ & I & Sol Maior \\
\hline $2-3$ & IV & Dó Maior \\
\hline $3-6$ & V & Sol Maior \\
\hline $6-11$ & V/ii & Ré Maior \\
\hline 11 & V & Mi Maior \\
\hline $12-18$ & V/ii & Ré Maior \\
\hline 19 & V & Mi Maior \\
\hline 19 & V/V & Ré Maior \\
\hline 20 & I & Lá Maior \\
\hline $20-22$ & IV & Sol Maior \\
\hline $22-23$ & I & Dó Maior \\
\hline $24-26$ & V & Sol Maior \\
\hline 26 & I & Ré Maior \\
\hline $26-29$ & IV & Sol Maior \\
\hline 29 & I & Dó Maior \\
\hline $30-32$ & V & Sol Maior \\
\hline 32 & I & Ré Maior \\
\hline $33-35$ & & Sol Maior \\
\hline
\end{tabular}


4.2. Estrutura Analítica da obra: Retórica e Harmônica

Tabela 17-Estrutura analítica da obra.

\begin{tabular}{|l|l|l|l|c|}
\hline $\begin{array}{c}\text { RETÓRICA } \\
\text { DISPOSITIO }\end{array}$ & \multicolumn{1}{|c|}{$\begin{array}{c}\text { FIGURA } \\
\text { ELOCUTIO }\end{array}$} & \multicolumn{1}{c|}{ COMP. } & \multicolumn{1}{|c|}{ TONALIDADE } & FUNÇÃO \\
\cline { 2 - 4 } EXORDIUM & $1-4$ & Sol Maior & $\mathrm{I}$ \\
\hline NARRATIO & Anaphora & 5 & Sol Maior & $\mathrm{I}$ \\
\hline PROPOSITIO & Synaeresis & $11-13$ & Ré Maior & $\mathrm{V}$ \\
\hline CONFUTATIO & Polyptoton & $13-16$ & Ré Maior & $\mathrm{V}$ \\
& Suspiratio & 18 & Ré Maior & $\mathrm{V}$ \\
\hline CONFIRMATIO & Synaphora & $19-23$ & Sol Maior & $\mathrm{I}$ \\
\hline PERORATIO & Polyptoton & 25,27 & Sol Maior & $\mathrm{I}$ \\
\hline
\end{tabular}




\subsubsection{Análise Retórico-Musical do Pater Mihi do Moteto dos Passos}

\section{Inventio}

O Moteto dos Passos descreve o padecer pelo qual passou Jesus antes, durante e depois de sua crucificação. Todo esse sofrimento é relatado por meio de seus passos desde sua indagação a Deus no Getsêmani ${ }^{115}$, pedindo para que passasse Dele aquele cálice, entretanto, fosse realizada a vontade de seu Pai, até o momento de sua humilhação ao longo do caminho percorrido. Manoel Dias de Oliveira dispõe esse moteto em sete partes, sendo analisada, nesta tese, a primeira. O texto dessa parte pode ser localizado em três dos quatro evangelhos bíblicos, isto é, em Mateus 26:39, Marcos 14:36 ou Lucas 22: 42 .

Pater mihi, si possibile est, transeat a me calix iste: veruntamem non sicut ego volo, sed sicut tu.

Meu Pai, se for possível, afasta de mim este cálice; contudo, não se faça como eu quero, mas como tu queres.

Em suma, a peça é composta por cinquenta e um compassos, num andamento Moderato na tonalidade Mi bemol Maior, objetivados pelo autor em atrair a atenção do ouvinte, mediante o texto litúrgico e dos afetos expressos em consonância aos elementos retóricos.

\subsection{Loci observados na Inventio do Pater Mihi}

Tabela 18-Loci Topici localizados no Pater Mihi de Manoel Dias de Oliveira.

\begin{tabular}{|c|c|c|c|}
\hline INVENTIO & DESCRIÇÃO & $\begin{array}{c}\text { UTILIZAÇÃO NA } \\
\text { OBRA }\end{array}$ & $\begin{array}{l}\text { COMPASSOI } \\
\text { VOZ }\end{array}$ \\
\hline $\begin{array}{l}\text { Locus Notationis } \\
\text { (MATTHESON, } \\
\text { 1954, [1739]. } \\
\text { Parte II, Cap.4, § } \\
\text { 23, p.123). }\end{array}$ & $\begin{array}{l}\text { Aspecto } \\
\text { externo e } \\
\text { desenho das } \\
\text { notas (Duração } \\
\text { das notas, } \\
\text { alteração, } \\
\text { repetição e } \\
\text { procedimentos } \\
\text { canônicos). }\end{array}$ & $\begin{array}{l}\text { Vários motivos } \\
\text { rítmicos e diferentes } \\
\text { durações de notas } \\
\text { (semibreves, } \\
\text { mínimas, mínimas } \\
\text { pontuadas, } \\
\text { semínimas, } \\
\text { semínimas } \\
\text { pontuadas, colcheias, }\end{array}$ & $\begin{array}{l}1-7 \quad \text { S-A-T-B } \\
7-14 \text { S-A-T-B } \\
15-20 S-A-T-B \\
20-39 S-A-T-B \\
39-46 S-A-T-B \\
47-51 \text { S-A-T-B }\end{array}$ \\
\hline
\end{tabular}

\footnotetext{
${ }^{115}$ É um jardim localizado ao pé do Monte das Oliveiras, em Jerusalém. Nesse lugar a agonia de Jesus foi tão grande que seu suor se transformaria em gotas de sangue.
} 


\begin{tabular}{|c|c|c|c|}
\hline & & $\begin{array}{l}\text { colcheias pontuadas, } \\
\text { semicolcheias, fusas, } \\
\text { repetições, ligaduras, } \\
\text { pausas, apogiatura, } \\
\text { fermata, entre outros). }\end{array}$ & \\
\hline $\begin{array}{l}\text { Locus } \\
\text { Descriptionis } \\
\text { (MATTHESON, } \\
\text { 1954 [1739]. Parte } \\
\text { II, Cap.4, § 43, } \\
\text { p.127). }\end{array}$ & $\begin{array}{l}\text { Disposições da } \\
\text { alma }\end{array}$ & $\begin{array}{l}\text { Angústia, languidez, } \\
\text { tristeza (Meu Pai, se } \\
\text { for possível, afasta de } \\
\text { mim este cálice). }\end{array}$ & $1-26$ S-A-T-B \\
\hline $\begin{array}{l}\text { Locus } \\
\text { Oppositorum } \\
\text { (MATTHESON, } \\
\text { 1954, [1739]. } \\
\text { Parte II, Cap.4, § } \\
\text { 80, p.131). }\end{array}$ & $\begin{array}{l}\text { Contraste de } \\
\text { compassos, } \\
\text { movimentos } \\
\text { contrários, } \\
\text { agudos e } \\
\text { graves, lento e } \\
\text { rápido, calmo e } \\
\text { agitado. }\end{array}$ & $\begin{array}{l}\text { Movimento contrário } \\
\text { entre contralto-I e } \\
\text { baixo- I, tenor-I e } \\
\text { baixo-II, contralto-II e } \\
\text { baixo-II, tenor-II e } \\
\text { baixo-II. } \\
\text { Tenor-II e baixo-II. } \\
\text { Soprano-II e contralto- } \\
\text { II. }\end{array}$ & $\begin{array}{ll}25 & \text { T-B } \\
42 & \text { S-A }\end{array}$ \\
\hline
\end{tabular}

\section{Dispositio}

\subsection{Exordium}

No começo da peça, nota-se a repetição literal, tanto das notas quanto das palavras, configurando, dessa forma, o uso da Analepsis ${ }^{116}$. Outro aspecto a ser examinado é que nos compassos 1 e 4 , nas vozes do contralto e tenor-l e II, a palavra Pater é destacada, mediante a execução da sílaba ter por duas notas, caracterizando assim uma Synaeresis.

Semelhantemente, é observável o diálogo estabelecido entre as vozes e as funções da Tônica e Dominante, na reiteração da frase: Pater mihi, si possibile est (Meu Pai, se for possível), resolvendo numa Cadência Autêntica Perfeita.

\footnotetext{
${ }^{116} \mathrm{~A}$ Analepsis é figura de repetição literal de uma seção homofônica, ou seja, é uma duplicação de um Noema. Burmeister afirma que o Exordium é, normalmente, ornamentado pela fuga, de maneira que os ouvidos e a mente do ouvinte são submetidos atenciosamente à melodia. Igualmente, o início do discurso pode se estender até o ponto onde o sujeito de uma fuga, por exemplo, termina com a introdução de uma cadência ou passagem harmônica semelhante. No entanto, algumas vezes, pode ocorrer um Noema no Exordium (BURMEISTER, 1993[1606], p.203).
} 


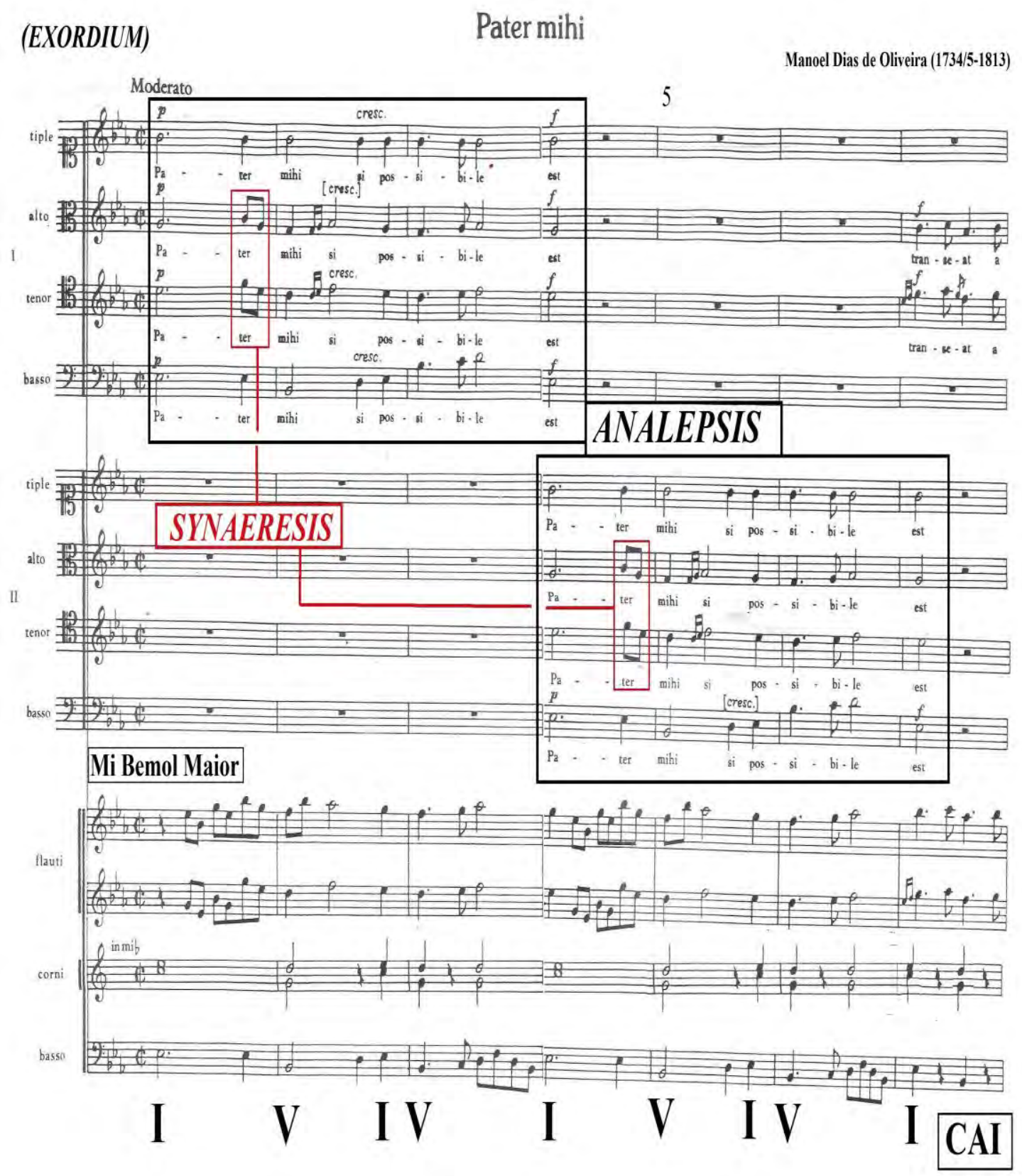

Exemplo 91-Pater Mihi do Moteto dos Passos de Manoel Dias de Oliveira. RestauraçãoMaurício Dottori (OLIVEIRA, s/d, pp.1-2).

\subsection{Narratio}

Verifica-se, nesse trecho, o emprego da Synaeresis, nas vozes do contralto e tenor, ressaltando, através da entoação de duas notas em uma sílaba, a palavra calix (cálice). Outro aspecto a ser destacado é a repetição da mesma frase empregada no início do discurso pelo compositor, com o propósito de atrair a atenção do ouvinte. 


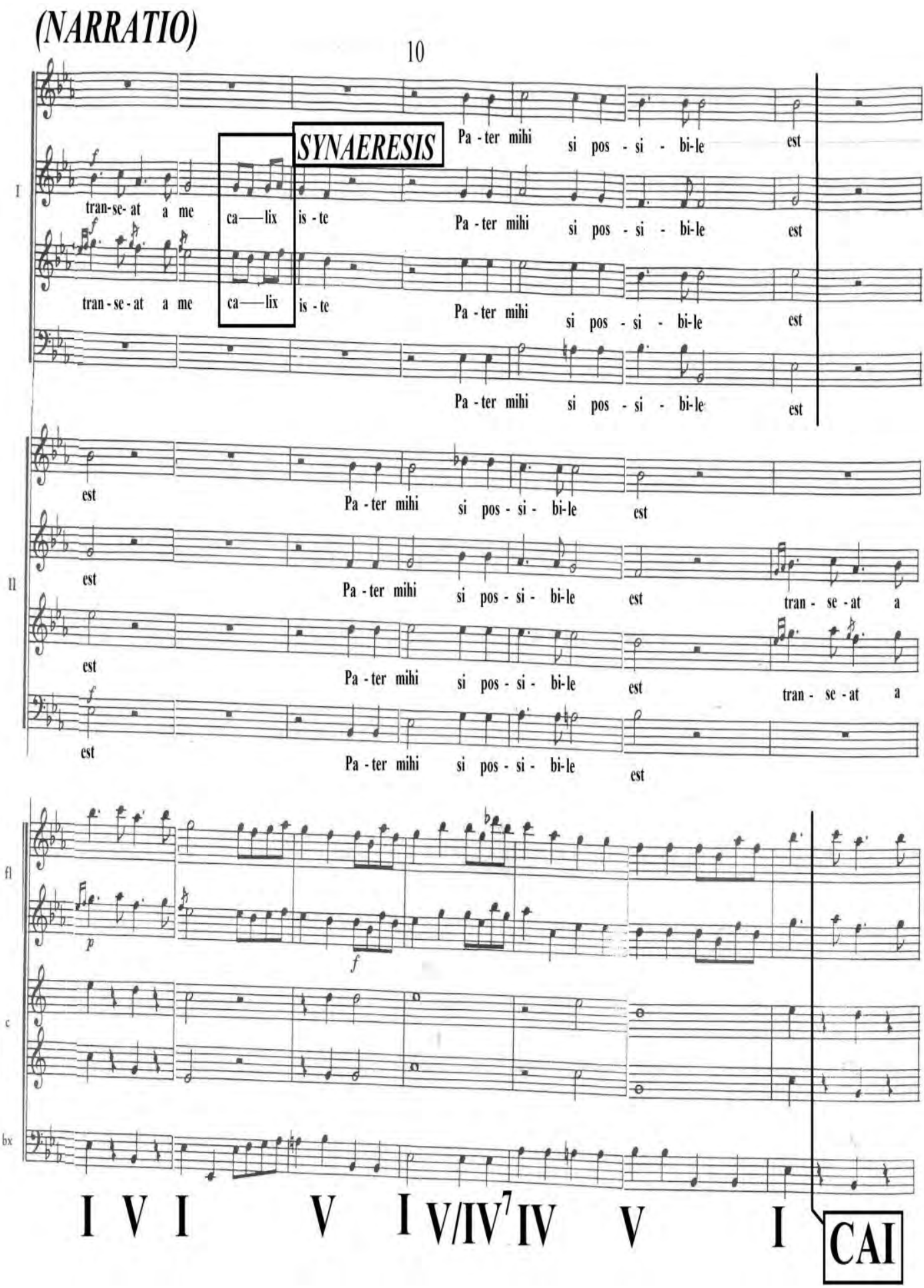

Exemplo 92-Pater Mihi do Moteto dos Passos de Manoel Dias de Oliveira. RestauraçãoMaurício Dottori (OLIVEIRA, s/d, pp.3-4).

\subsection{Propositio}

$\mathrm{Na}$ transição da Narratio para a Propositio, observam-se os mesmos procedimentos aplicados por Dias de Oliveira, no exemplo anterior. 


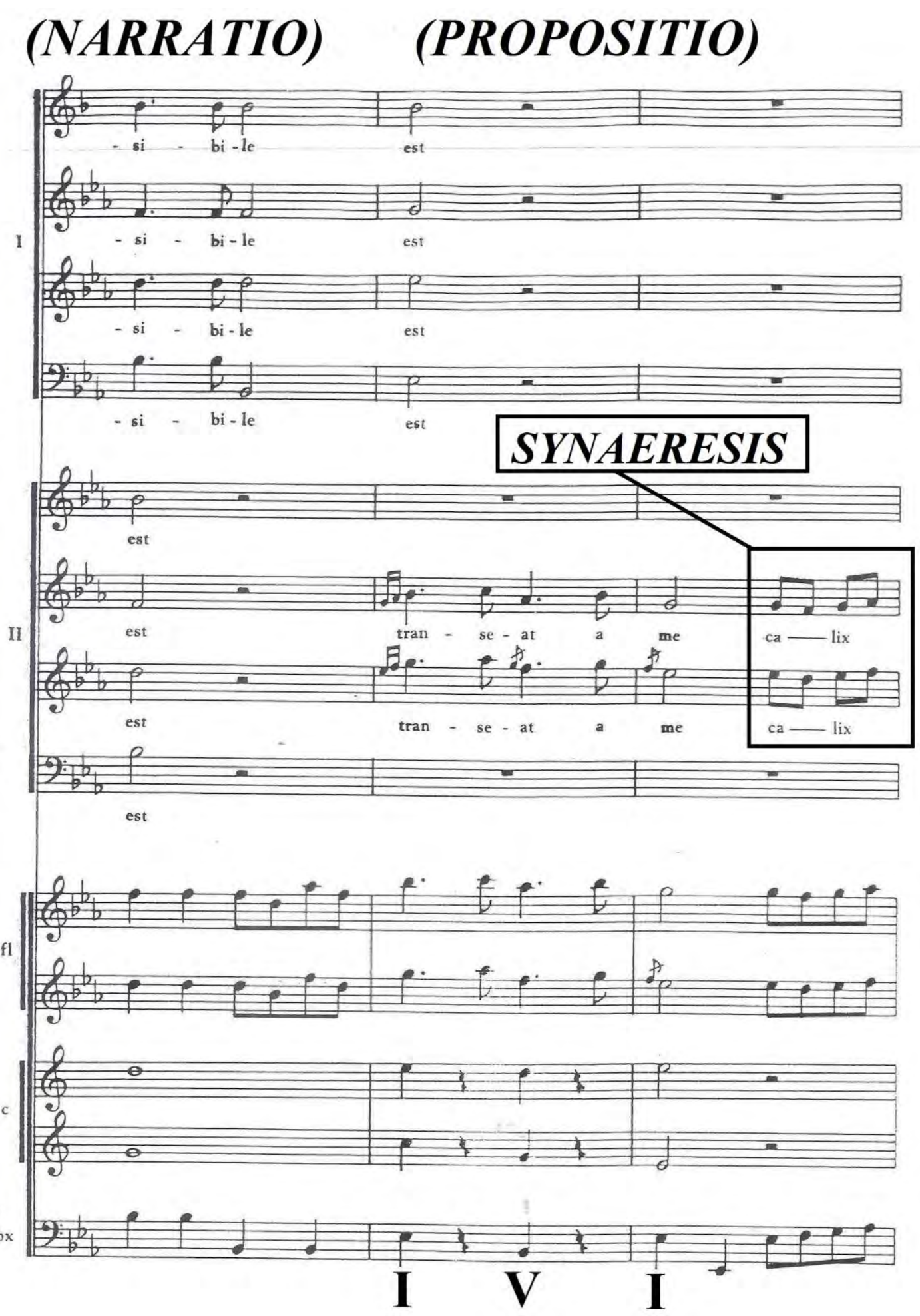

Exemplo 93-Pater Mihi do Moteto dos Passos de Manoel Dias de Oliveira. RestauraçãoMaurício Dottori (OLIVEIRA, s/d, p.4).

Entre os compassos 15 e 20, averigua-se a repetição melódica contínua na voz do baixo nas palavras transeat a me (afaste de mim). Dessa maneira, constata-se o uso da Anaphora para destacar o afeto de angústia e langor, 
expressos por Cristo, descrito em Mateus 26:39, "Pai, se possível, afasta de mim este cálice" (ALMEIDA, 2000, p.1376).

Igualmente, é verificável a aplicação da Synaeresis, para reforçar esse sentimento, o qual é trabalhado por Dias de Oliveira, seja nos diálogos entre as funções harmônicas da Tônica e Dominante como nas vozes.

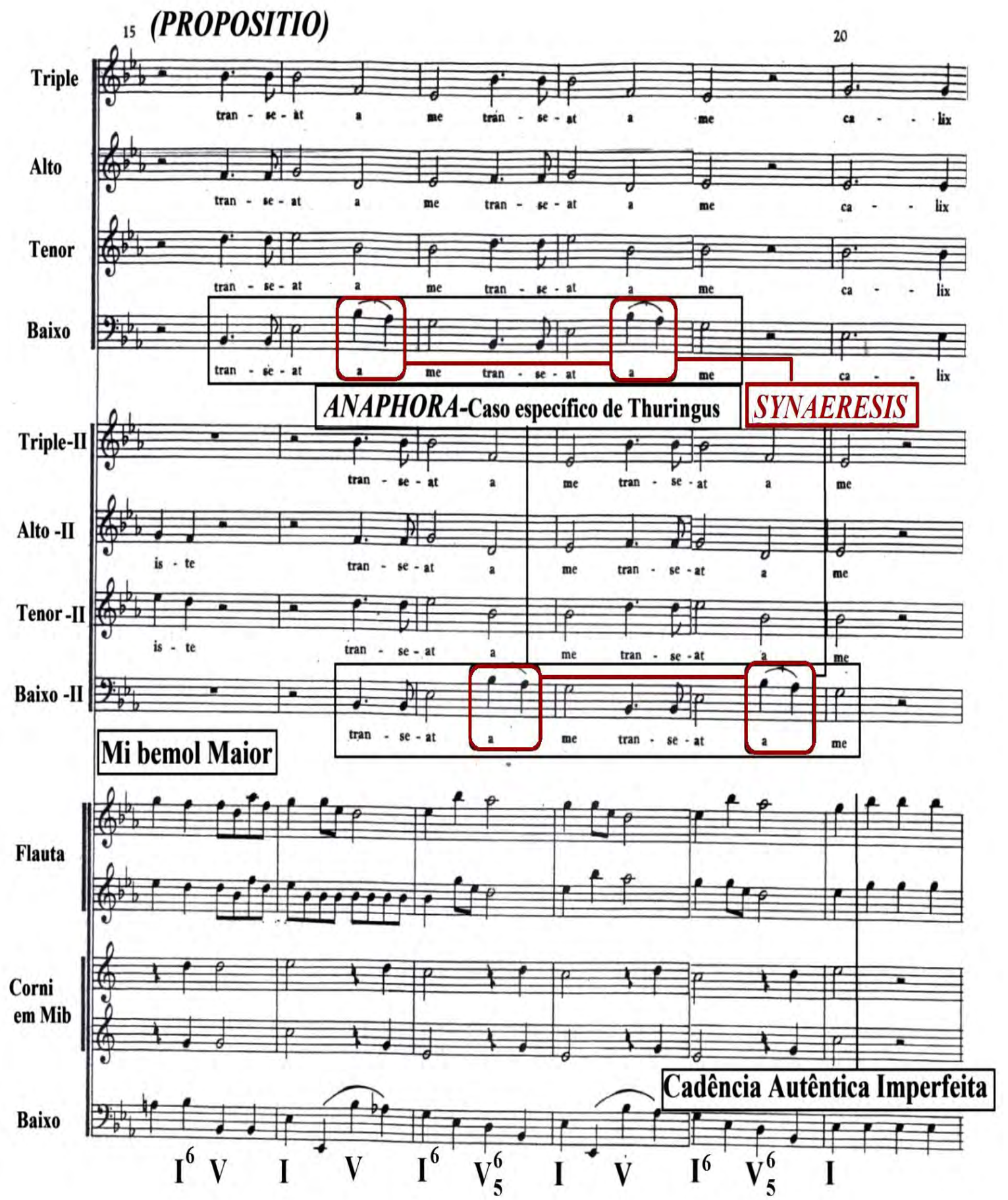

Exemplo 94-Pater Mihi do Moteto dos Passos de Manoel Dias de Oliveira. RestauraçãoMaurício Dottori (OLIVEIRA, s/d, pp.5-6). 


\subsection{Confutatio}

A intensificação dos afetos descritos anteriormente é evidenciada pela ênfase da expressão calix is te (este cálice), repetida por três vezes por todas as vozes, entre os compassos 20 e 26 , por meio da Epizeuxis.

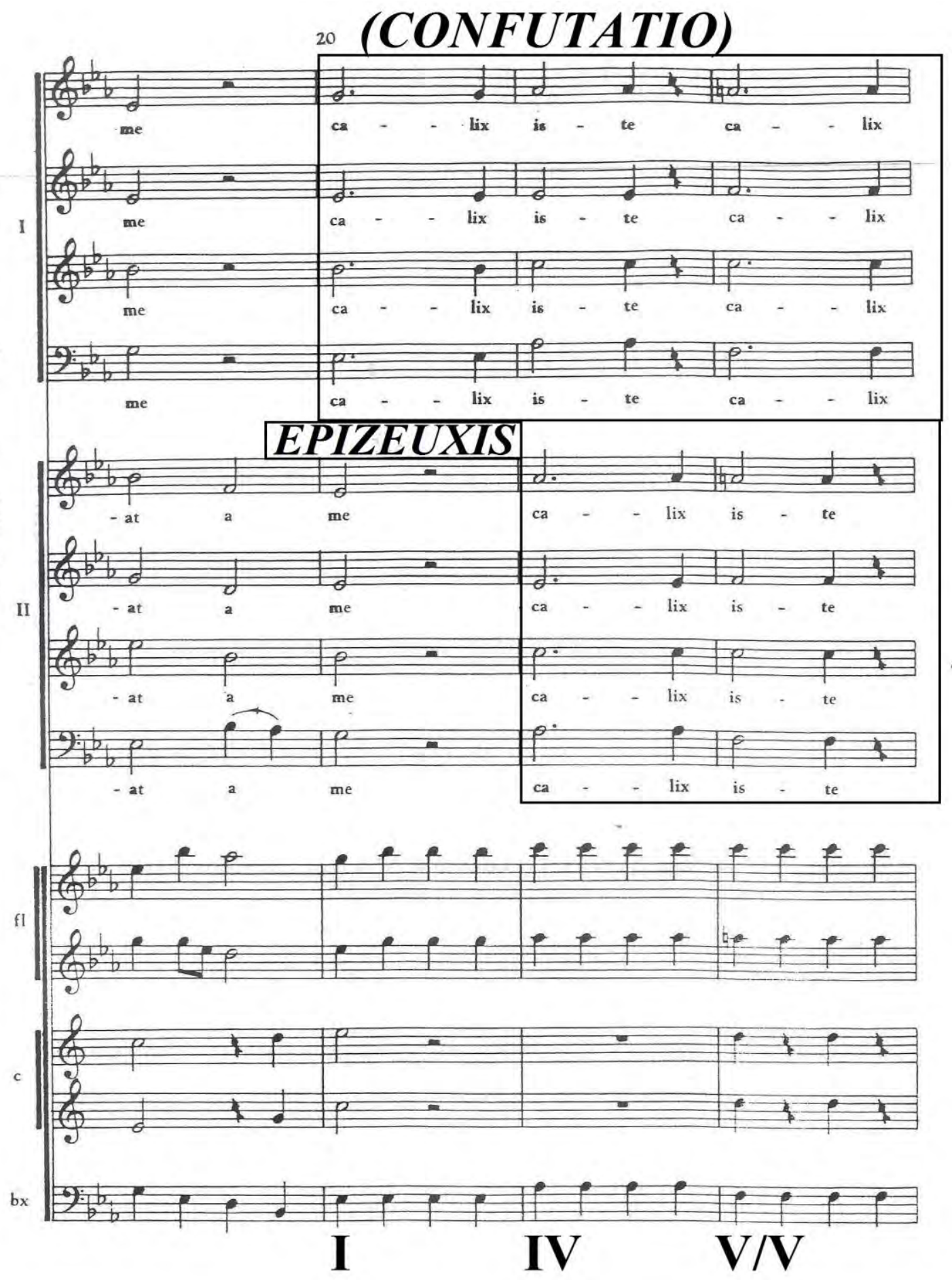

Exemplo 95-Pater Mihi do Moteto dos Passos de Manoel Dias de Oliveira. RestauraçãoMaurício Dottori (OLIVEIRA, s/d, p.6). 
Verifica-se abaixo, além da enfatização efetuada por Manoel Dias de Oliveira das notas e das palavras, por intermédio do elemento retórico de repetição melódica, a condução harmônica através das funções da Tônica, Dominante e Dominante da Dominante, com resolução na Semicadência.

\section{(CONFUTATIO) EPIZEUXIS}

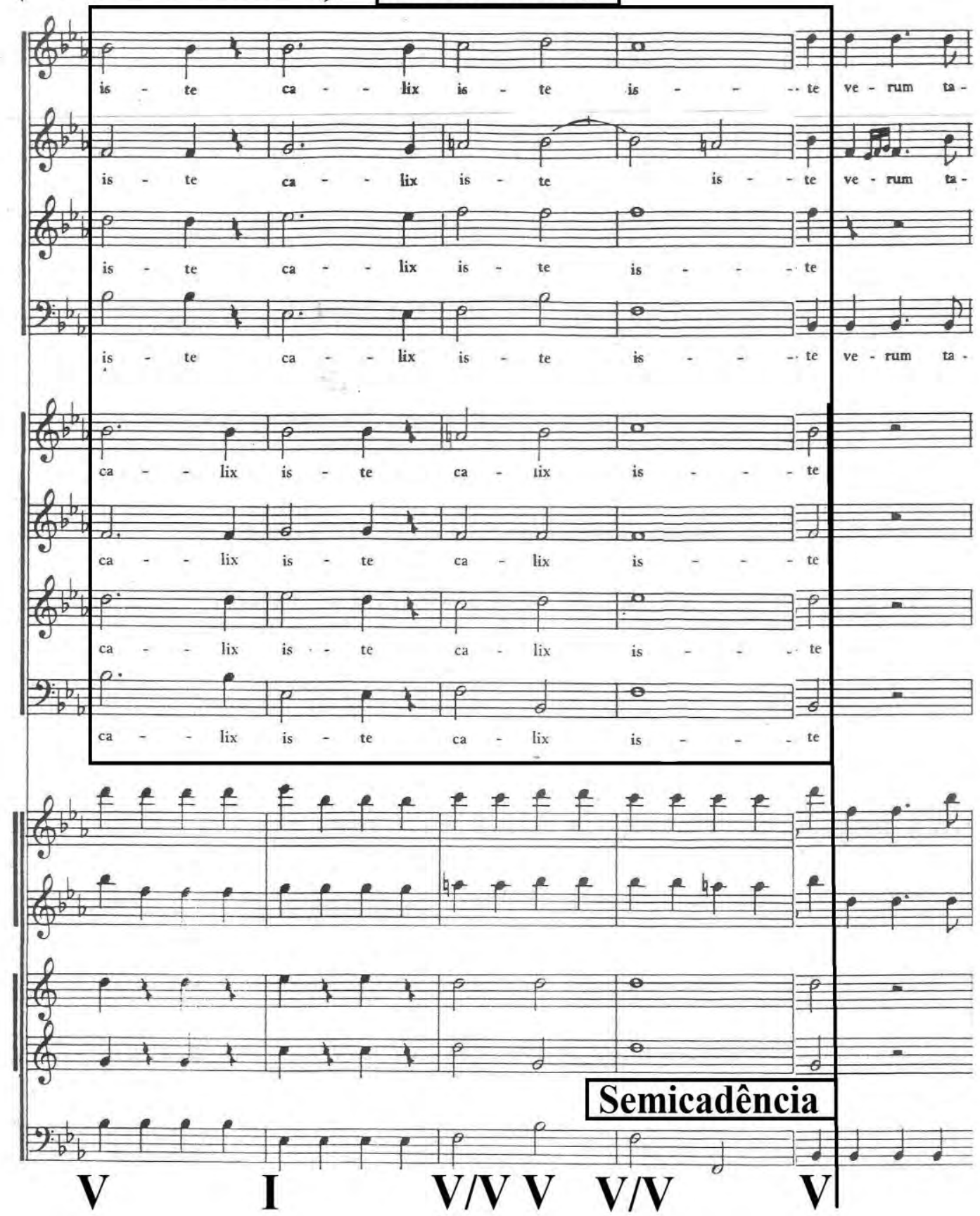

Exemplo 96-Pater Mihi do Moteto dos Passos de Manoel Dias de Oliveira. RestauraçãoMaurício Dottori (OLIVEIRA, s/d, pp.7-8). 
Nota-se, nos compassos 29 e 30, que o compositor volta a aplicar a figura retórica da Synaeresis, não só para realçar a passagem do intervalo de $8^{\mathrm{a}}$ justa para uma $7^{\mathrm{a}}$ menor na fundamental do acorde onde houve a modulação de tonalidade, ou seja, Si bemol Maior, mas igualmente, para destacar a expressão sicut ego (como eu) nas partes da soprano e contralto.
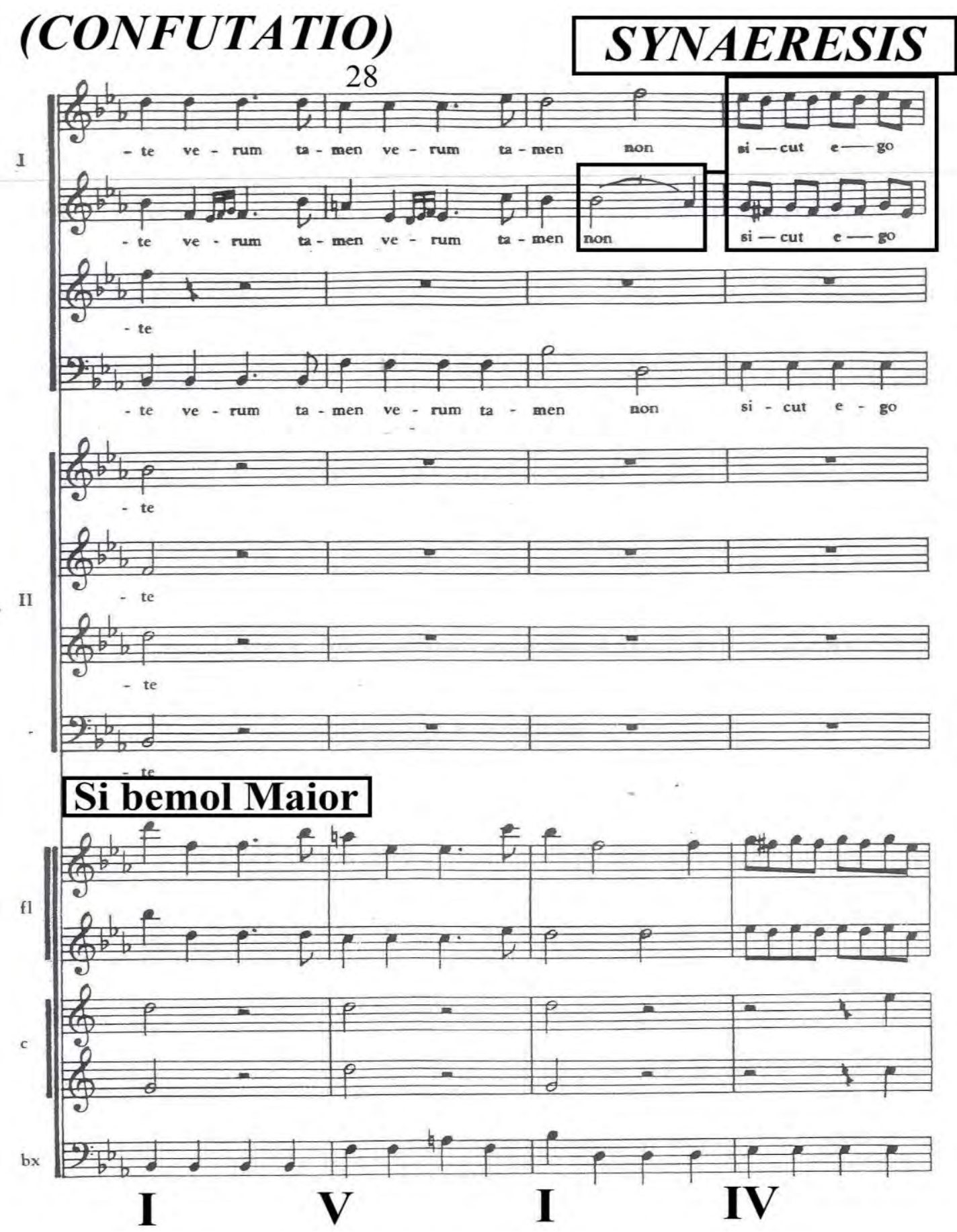

Exemplo 97-Pater Mihi do Moteto dos Passos de Manoel Dias de Oliveira. RestauraçãoMaurício Dottori (OLIVEIRA, s/d, p.8). 
É evidente que o compositor tenta atrair a expectativa do ouvinte utilizando-se de mecanismos retóricos de repetição harmônica, melódica, além de deslocamento, isto é, pela Synaeresis, Polyptoton e Analepsis. É pertinente salientar, também, o retorno para a tonalidade inicial da peça em Mi bemol Maior no compasso 35, com terminação na Cadência Autêntica Imperfeita.

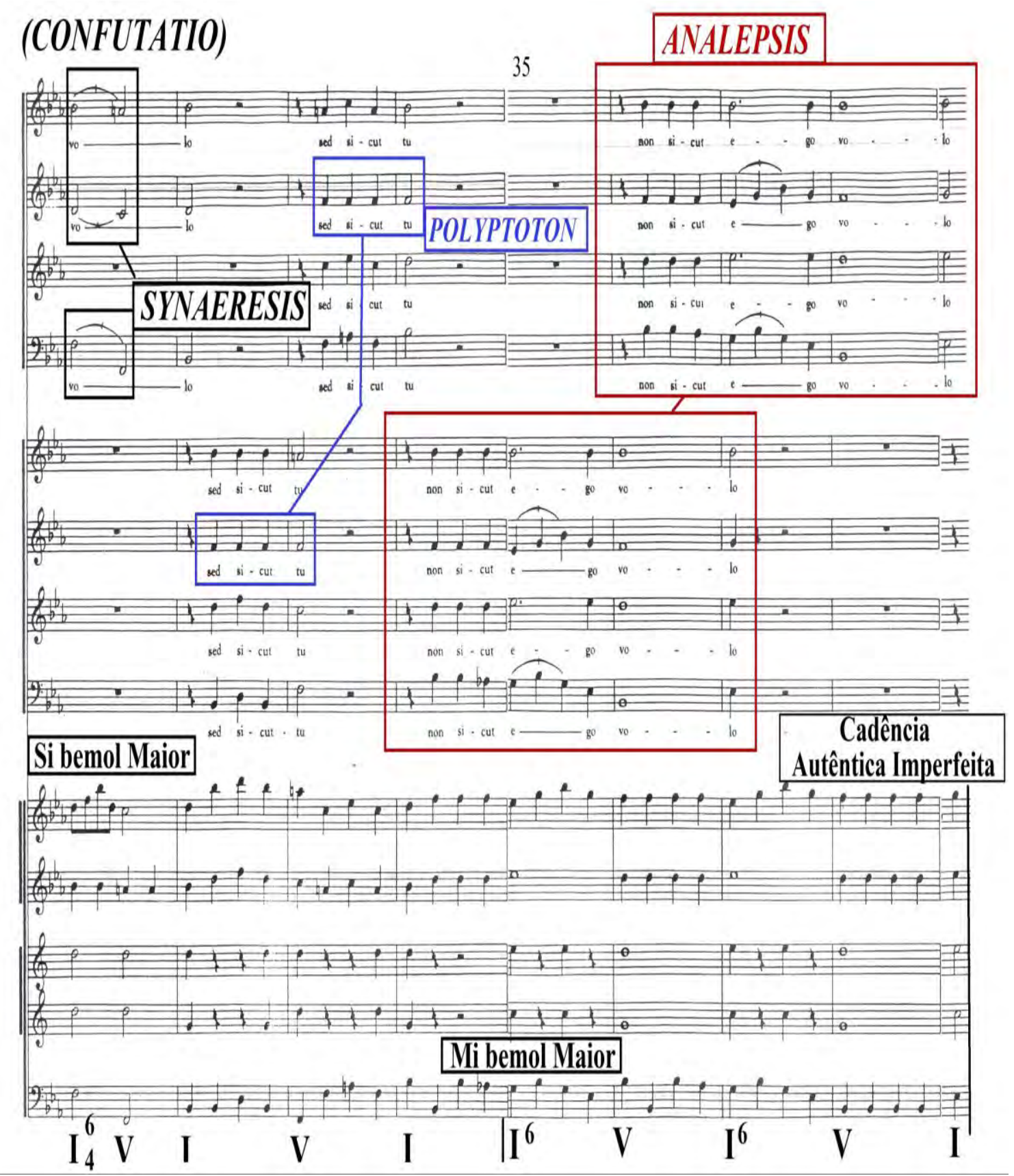

Exemplo 98-Pater Mihi do Moteto dos Passos de Manoel Dias de Oliveira. RestauraçãoMaurício Dottori (OLIVEIRA, s/d, pp.9-11). 


\subsection{Confirmatio}

A partir do compasso 39, novamente é utilizada a Epizeuxis, a qual coloca em evidência a frase: sed sicut tu (mas como tu queres).

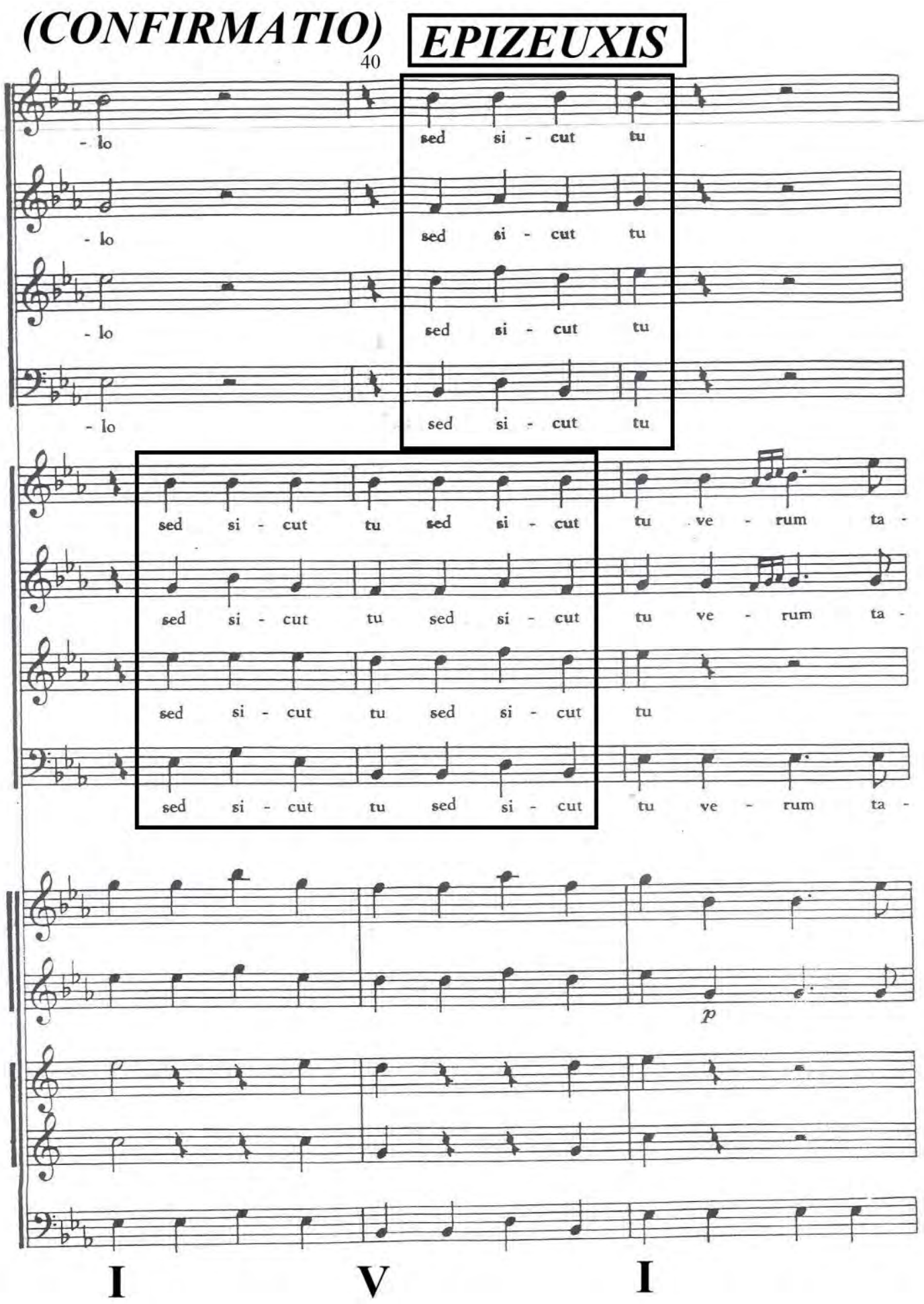

Exemplo 99-Pater Mihi do Moteto dos Passos de Manoel Dias de Oliveira. RestauraçãoMaurício Dottori (OLIVEIRA, s/d, p.11). 
Examina-se, nos compassos 41 e 44, o mesmo procedimento utilizado por Dias de Oliveira, nos compassos 29 e 30, onde a Synaeresis é empregada para ressaltar o deslocamento do intervalo de $8^{\mathrm{a}}$ justa para uma $7^{\mathrm{a}}$ menor, no acorde de Mi bemol Maior, além de dar ênfase à expressão sicut ego (como eu) nas partes da soprano e contralto-II, configurando desse modo uma Confutatio dentro da Confirmatio.

\section{(CONFUTATIO dentro da CONFIRMATIO)}

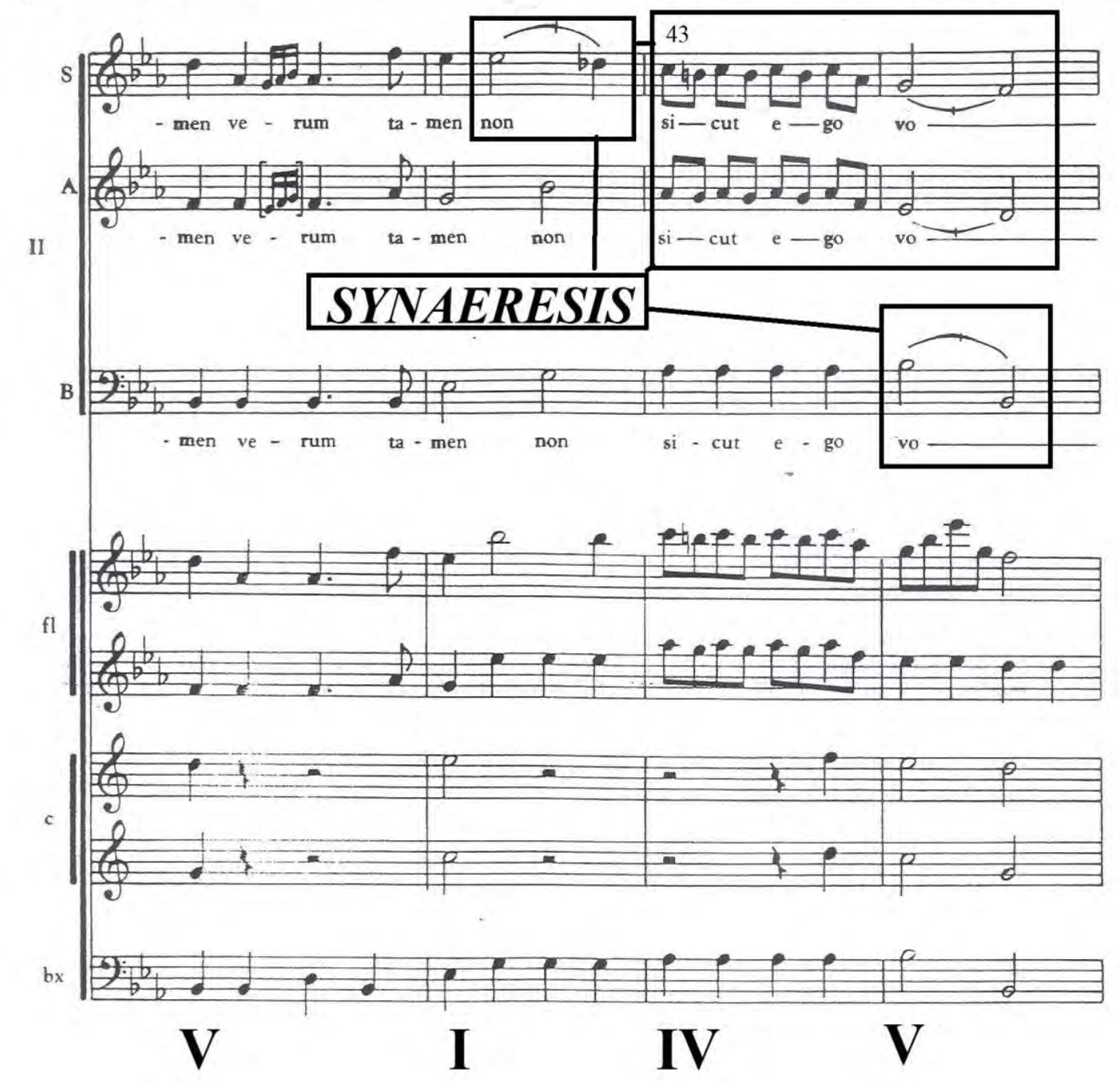

Exemplo 100-Pater Mihi do Moteto dos Passos de Manoel Dias de Oliveira. RestauraçãoMaurício Dottori (OLIVEIRA, s/d, p.12).

Observa-se, abaixo, o uso da figura central da peça, isto é, da Epizeuxis, a qual repete, de maneira enfática e veemente, as palavras sed sicut tu (mas como tu queres). 

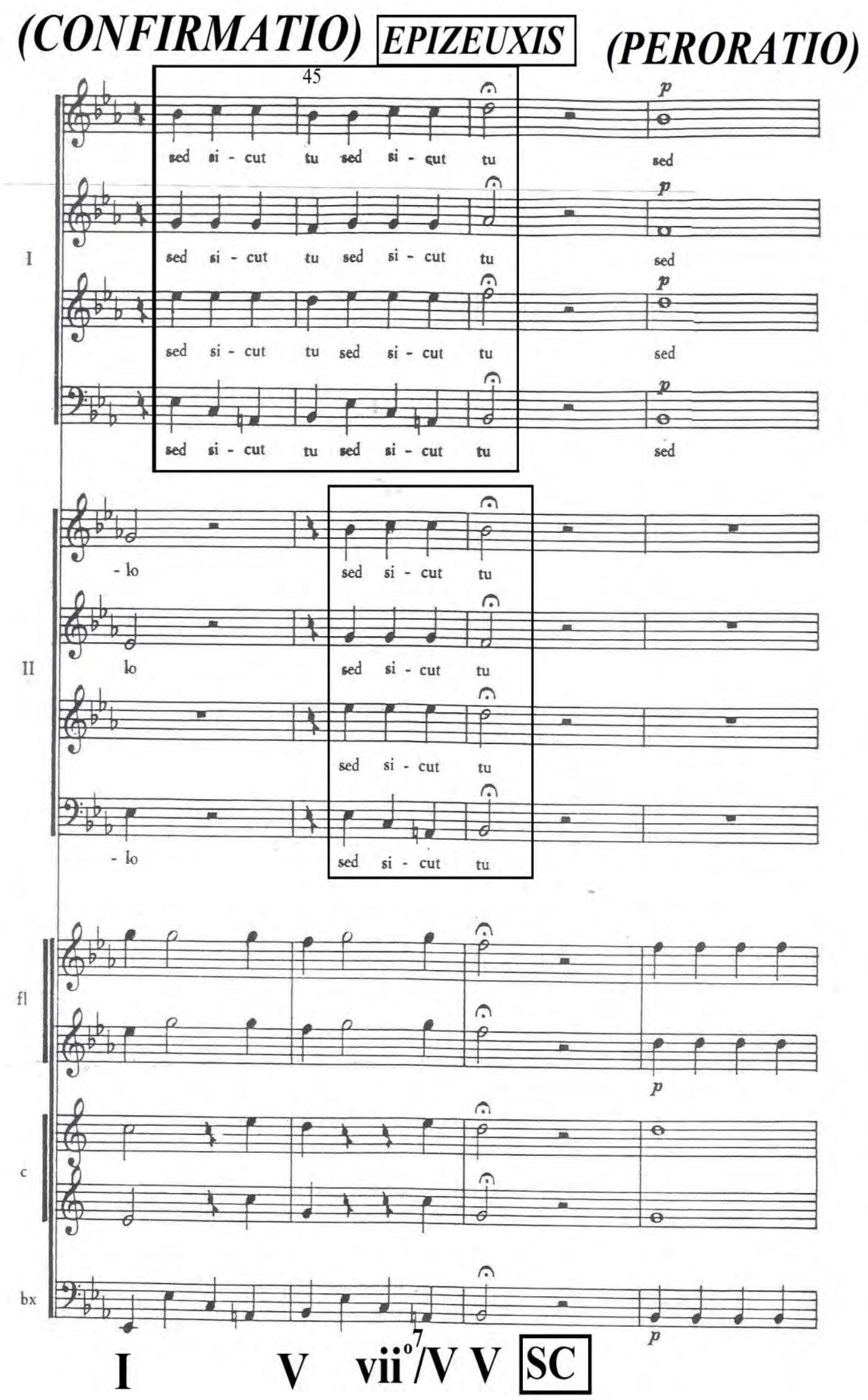

Exemplo 101-Pater Mihi do Moteto dos Passos de Manoel Dias de Oliveira. RestauraçãoMaurício Dottori (OLIVEIRA, s/d, p.13). 


\subsection{Peroratio}

No encerramento do discurso, a expressão supracitada, sed sicut tu (mas como tu queres) é ratificada por Dias de Oliveira através das figuras da Epizeuxis e Synaeresis, descrevendo, para quem ouve, o afeto de submissão e obediência manifestados por Cristo à vontade de seu Pai.

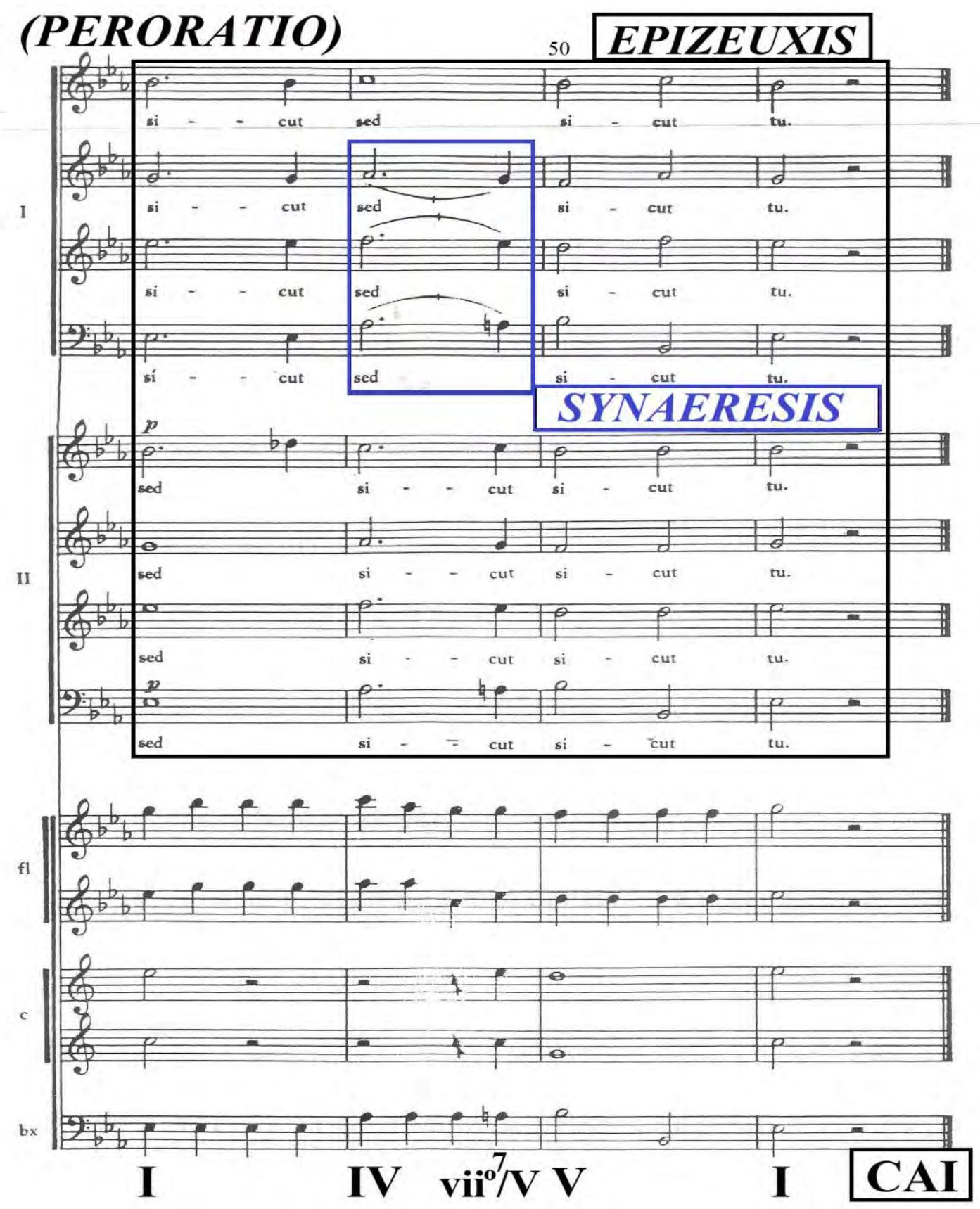

Exemplo 102-Pater Mihi do Moteto dos Passos de Manoel Dias de Oliveira. RestauraçãoMaurício Dottori (OLIVEIRA, s/d, p.14). 


\section{Figuras observadas no Pater Mihi (Elocutio/Decoratio)}

Tabela 19-Figuras retóricas localizadas no Pater Mihi de Manoel Dias de Oliveira.

\begin{tabular}{|c|c|c|c|}
\hline $\begin{array}{ll}\text { FIGURAS } & \text { E } \\
\text { CITACÕES } & \end{array}$ & TIPO & DESCRIÇÃO & TRATADISTA \\
\hline $\begin{array}{l}\text { ANALEPSIS } \\
\text { (BARTEL, 1997, } \\
\text { p. 183-184). }\end{array}$ & $\begin{array}{l}\text { Repetição } \\
\text { Harmônica: } \\
\text { Figuras de } \\
\text { Fuga }\end{array}$ & $\begin{array}{l}\text { Repetição literal } \\
\text { de uma seção } \\
\text { homofônica, ou } \\
\text { seja, de um } \\
\text { Noema na } \\
\text { mesma altura. }\end{array}$ & $\begin{array}{l}\text { Joachim Burmeister: } \\
\text { É uma repetição ou } \\
\text { duplicação de um } \\
\text { Noema e, portanto, é ernamento } \\
\text { um ornacionado a ele. }\end{array}$ \\
\hline $\begin{array}{l}\text { ANAPHORA } \\
\text { (BARTEL, 1997, } \\
\text { pp.184-190). }\end{array}$ & $\begin{array}{l}\text { Repetição } \\
\text { Melódica }\end{array}$ & $\begin{array}{l}\text { (1) É uma linha } \\
\text { do } r \text { baixo } \\
\text { repetida em } \\
\text { forma de solo. } \\
\text { (2) A repetição } \\
\text { de er uma } \\
\text { exposição } \\
\text { melódica sobre } \\
\text { notas e partes } \\
\text { diferentes. } \\
\text { Também pode } \\
\text { ocorrer no início } \\
\text { das repetições } \\
\text { de frases e } \\
\text { motivos em uma } \\
\text { série de } \\
\text { passagens d } \\
\text { sucessivas; (3) } \\
\text { Uma repetição } \\
\text { em geral. }\end{array}$ & $\begin{array}{l}\text { Joachim Thuringus: } \\
\text { É a repetição } \\
\text { continuada apenas no } \\
\text { Baixo. } \\
\text { Johann Gottfried } \\
\text { Walther: É uma figura } \\
\text { de repetição e pode } \\
\text { ocorrer de dus } \\
\text { maneiras: } \\
\text { 1. Quando uma } \\
\text { palavra é repetida } \\
\text { frequentemente em } \\
\text { uma composição para } \\
\text { dar maior ênfase. } \\
\text { 2. Quando as notas } \\
\text { graves são repetidas } \\
\text { inúmeras vezes (como } \\
\text { O caso das d dhaconne). }\end{array}$ \\
\hline $\begin{array}{l}\text { EPIZEUXIS } \\
\text { (BARTEL, 1997, } \\
\text { pp.263-265). }\end{array}$ & $\begin{array}{l}\text { Repetição } \\
\text { Melódica }\end{array}$ & $\begin{array}{l}\text { Uma repetição } \\
\text { imediata e } \\
\text { enfática de uma } \\
\text { palavra, nota, } \\
\text { motivo ou frase. }\end{array}$ & $\begin{array}{l}\text { Johann Gottfried } \\
\text { Walther: A Epizeuxis } \\
\text { é uma figura de } \\
\text { retórica pela qual uma } \\
\text { ou mais palavras são } \\
\text { imediatamente } \\
\text { enfaticamente } \\
\text { repetidas. }\end{array}$ \\
\hline $\begin{array}{l}\text { POLYPTOTON } \\
\text { (BARTEL, 1997, } \\
\text { pp.367-369). } \\
\text { (BUELOW, 2001, } \\
\text { p.264). }\end{array}$ & $\begin{array}{l}\text { Repetição } \\
\text { Melódica }\end{array}$ & $\begin{array}{l}\text { A repetição de } \\
\text { uma passagem } \\
\text { melódica em } \\
\text { diferentes } \\
\text { alturas. }\end{array}$ & $\begin{array}{l}\text { Mauritius Johann } \\
\text { Vogt: Polyptoton é } \\
\text { quando uma } \\
\text { passagem é repetida } \\
\text { em várias alturas. }\end{array}$ \\
\hline
\end{tabular}




\begin{tabular}{|c|c|c|c|}
\hline $\begin{array}{l}\text { SYNAERESIS } \\
\text { (BARTEL, 1997, } \\
\text { pp.394-396). } \\
\text { (LÓPEZ CANO, } \\
\text { 2000, p.199). }\end{array}$ & $\begin{array}{l}\text { Dissonância e } \\
\text { Deslocamento }\end{array}$ & $\begin{array}{l}\text { (1) Uma } \\
\text { suspensão ou } \\
\text { síncope, (2) A } \\
\text { colocação de } \\
\text { duas sílabas por } \\
\text { nota ou duas } \\
\text { notas por } \\
\text { sílaba. }\end{array}$ & $\begin{array}{l}\text { Mauritius } \\
\text { Vogt: A Synaeresis } \\
\text { ocorre quando duas } \\
\text { notas são colocadas } \\
\text { em uma sílaba ou } \\
\text { duas sílabas são } \\
\text { colocadas em uma } \\
\text { nota. }\end{array}$ \\
\hline
\end{tabular}

\section{Análise Harmônica}

\subsection{Curva Tonal}

Tonalidade: Mi b Maior

Andamento: Moderato 2/2

Tabela 20-Esquema das Progressões Harmônicas- Curva Tonal do Pater Mihi.

\begin{tabular}{|l|c|l|}
\hline \multicolumn{1}{|c|}{ Compassos } & Função & \multicolumn{1}{c|}{ Tonalidade } \\
\hline $1-10$ & I & Mi b Maior \\
\hline $10-11$ & V & Si b Maior \\
\hline $12-21$ & I & Mi b Maior \\
\hline $22-34$ & V & Si b Maior \\
\hline $35-46$ & I & Mi b Maior \\
\hline $47-48$ & V & Si b Maior \\
\hline $49-51$ & I & Mi b Maior \\
\hline $51-52$ & V & Si b Maior \\
\hline 53 & I & Mi b Maior \\
\hline
\end{tabular}

\subsection{Estrutura Analítica da obra: Retórica e Harmônica}

Tabela 21-Estrutura analítica da obra.

\begin{tabular}{|l|l|l|l|c|}
\hline $\begin{array}{c}\text { RETÓRICA } \\
\text { DISPOSITIO }\end{array}$ & \multicolumn{1}{|c|}{$\begin{array}{c}\text { FIGURA } \\
\text { ELOCUTIO }\end{array}$} & \multicolumn{1}{c|}{ COMP. } & TONALIDADE & FUNÇÃO \\
\hline EXORDIUM & Analepsis & $1-7$ & Mi b Maior & $\mathrm{I}$ \\
& Synaeresis & 1,4 & Mi b Maior & $\mathrm{I}$ \\
\hline NARRATIO & Synaeresis & 8 & Mi b Maior & $\mathrm{I}$ \\
\hline PROPOSITIO & Analepsis & $15-19$ & Mi b Maior & $\mathrm{I}$ \\
& Anaphora & $15-20$ & Mi b Maior & $\mathrm{I}$ \\
\hline
\end{tabular}




\begin{tabular}{|l|l|l|l|c|}
\hline & Synaeresis & $14,16-19$ & Mi b Maior & $\mathrm{I}$ \\
\hline CONFUTATIO & Epizeuxis & $20-26$ & Mi b Maior & $\mathrm{I}$ \\
& Synaeresis & $29-31$ & Si b Maior & $\mathrm{V}$ \\
& Polyptoton & $32-33$ & Si b Maior & $\mathrm{V}$ \\
& Analepsis & $34-39$ & $\begin{array}{l}\text { Si b Maior, Mi b } \\
\text { Maior }\end{array}$ & V e I \\
\hline CONFIRMATIO & Epizeuxis & $39-41$ & Mi b Maior & $\mathrm{I}$ \\
& Synaeresis & $42-46$ & Mi b Maior & $\mathrm{I}$ \\
\hline PERORATIO & Epizeuxis & $48-51$ & Mi b Maior & $\mathrm{I}$ \\
\hline
\end{tabular}




\title{
6.1.3. Análise Retórico-Musical do Gloria da Missa Abreviada em Ré ${ }^{117}$
}

\section{Inventio}

O Gloria da Missa tem seu texto embasado em Lucas 2:14, o qual descreve o momento em que os anjos trazem as boas novas, com grande contentamento para os povos, acerca do nascimento de Cristo, o Senhor e Salvador, em forma de louvor.

\author{
Gloria in excelsis Deo, \\ et in terra pax hominibus \\ bonæ voluntatis. \\ Laudamus te, \\ benedicimus te, \\ adoramus te, \\ glorificamus te, \\ gratias agimus tibi \\ propter magnam gloriam tuam:
}

Glória a Deus nas alturas; e paz na terra aos homens de boa vontade.

Nós Vos louvamos, Vos bendizemos, Vos adoramos, Vos glorificamos, Vos damos graças, por amor da vossa imensa glória (CASTAGNA, 2002, p. XXV).

O cerimonial do Gloria tem por objetivo incitar o cristão à relevância da anunciação da graça de Deus, revelada na pessoa de seu filho Jesus, isto é, esse fato representa, para a comunidade cristã, o favor e benefício da salvação concedido por Deus à humanidade, mesmo sendo essa pecadora e não merecedora.

Enfim, essa obra é constituída por cinquenta e cinco compassos, num andamento Allegro, na tonalidade Ré Maior, distribuídos em seis partes, onde o compositor busca mover os afetos do ouvinte, através dos mecanismos retórico-musicais.

\footnotetext{
${ }^{117}$ Segundo Paulo Castagna não há datação nessa obra, pois desta Missa são conhecidas cópias do segundo quartel do século XIX, em apenas dois acervos (ambos na cidade de Mariana): o Museu da Música e o Arquivo Histórico Monsenhor Horta (no Instituto de Ciências Humanas e Sociais da Universidade Federal de Ouro Preto) (CASTAGNA, 2002, p. XVI).
} 


\subsection{Loci observados na obra Domine Deus}

Tabela 22-Loci Topici localizados no Gloria da Missa Abreviada em Ré de Manoel Dias de Oliveira.

\begin{tabular}{|c|c|c|c|}
\hline INVENTIO & DESCRIÇÃO & $\begin{array}{c}\text { UTILIZAÇÃO NA } \\
\text { OBRA }\end{array}$ & $\begin{array}{l}\text { COMPASSOI } \\
\text { VOZ }\end{array}$ \\
\hline $\begin{array}{l}\text { Locus Notationis } \\
\text { (MATTHESON, } \\
\text { 1954, [1739]. } \\
\text { Parte II, Cap.4, § } \\
\text { 23, p.123). }\end{array}$ & $\begin{array}{l}\text { Aspecto } \\
\text { externo e } \\
\text { desenho das } \\
\text { notas (Duração } \\
\text { das notas, } \\
\text { alteração, } \\
\text { repetição e } \\
\text { procedimentos } \\
\text { canônicos). }\end{array}$ & $\begin{array}{l}\text { Vários motivos } \\
\text { rítmicos e diferentes } \\
\text { durações de notas } \\
\text { (semibreve, mínimas, } \\
\text { mínimas pontuadas, } \\
\text { semínimas, } \\
\text { semínimas } \\
\text { pontuadas, colcheias, } \\
\text { colcheias pontuadas, } \\
\text { semicolcheias, } \\
\text { repetições, tremolos, } \\
\text { ligaduras, pausas, } \\
\text { staccatos, apogiatura, } \\
\text { fermata, entre outros). }\end{array}$ & $\begin{array}{l}1-16 \text { S-A-T-B } \\
17-27 \text { S-A-T-B } \\
28-36 \text { S-A-T-B } \\
36-47 \text { S-A-T-B } \\
47-51 \text { S-A-T-B } \\
51-55 S-A-T-B\end{array}$ \\
\hline $\begin{array}{l}\text { Locus } \\
\text { Descriptionis } \\
\text { (MATTHESON, } \\
\text { 1954 [1739]. Parte } \\
\text { II, Cap.4, § 43, } \\
\text { p.127). }\end{array}$ & $\begin{array}{l}\text { Disposições da } \\
\text { alma }\end{array}$ & $\begin{array}{l}\text { Devoção, veneração } \\
\text { (Glória a Deus nas } \\
\text { alturas). } \\
\text { Nós Vos louvamos, } \\
\text { Vos bendizemos, Vos } \\
\text { adoramos, Vos } \\
\text { glorificamos, Vos } \\
\text { damos graças). }\end{array}$ & $\begin{array}{l}16-27 S-A-T-B \\
28-51 S-A-T-B\end{array}$ \\
\hline $\begin{array}{l}\text { Locus } \\
\text { Comparationis } \\
\text { (MATTHESON, } \\
\text { 1954, [1739]. } \\
\text { Parte II, Cap.4 § } \\
\text { 79, p.131). }\end{array}$ & $\begin{array}{l}\text { Comparações } \\
\text { de coisas } \\
\text { semelhantes ou } \\
\text { não, grandes } \\
\text { ou pequenas. }\end{array}$ & $\begin{array}{l}\text { Comparação de } \\
\text { coisas semelhantes } \\
\text { (imensa glória), nesse } \\
\text { contexto grandeza } \\
\text { ilimitada. }\end{array}$ & 53-55S-A-T-B \\
\hline $\begin{array}{l}\begin{array}{l}\text { Locus } \\
\text { Oppositorum }\end{array} \\
\text { (MATTHESON, } \\
\text { 1954, [1739]. } \\
\text { Parte II, Cap.4, § } \\
\text { 80, p.131). }\end{array}$ & $\begin{array}{l}\text { Contraste de } \\
\text { compassos, } \\
\text { movimentos } \\
\text { contrários, } \\
\text { agudos e } \\
\text { graves, lento e } \\
\text { rápido, calmo e } \\
\text { agitado. }\end{array}$ & $\begin{array}{l}\text { Movimento contrário } \\
\text { entre soprano, } \\
\text { contralto, tenor e } \\
\text { baixo. } \\
\text { Soprano e baixo, } \\
\text { contralto e baixo, } \\
\text { tenor e baixo. } \\
\text { Soprano e baixo, } \\
\text { contralto e baixo. } \\
\text { Soprano e baixo, }\end{array}$ & $\begin{array}{l}26 \text { S-A-T-B } \\
49 \text { S-A-T-B } \\
52 \text { S-A-B } \\
53 \text { S-T-B }\end{array}$ \\
\hline
\end{tabular}


tenor e baixo.

\section{Dispositio}

\subsection{Exordium}

A introdução da obra é conduzida pelo acompanhamento instrumental. Outro aspecto a ser destacado são os tremolos no segundo violino, na viola e baixo, os quais serão empregados em todas as seis partes da música. Igualmente, nota-se que o autor utiliza as funções da Tônica, Dominante e Subdominante, em conjunto ao pedal de Tônica, instigando o ouvinte ao afeto de júbilo.

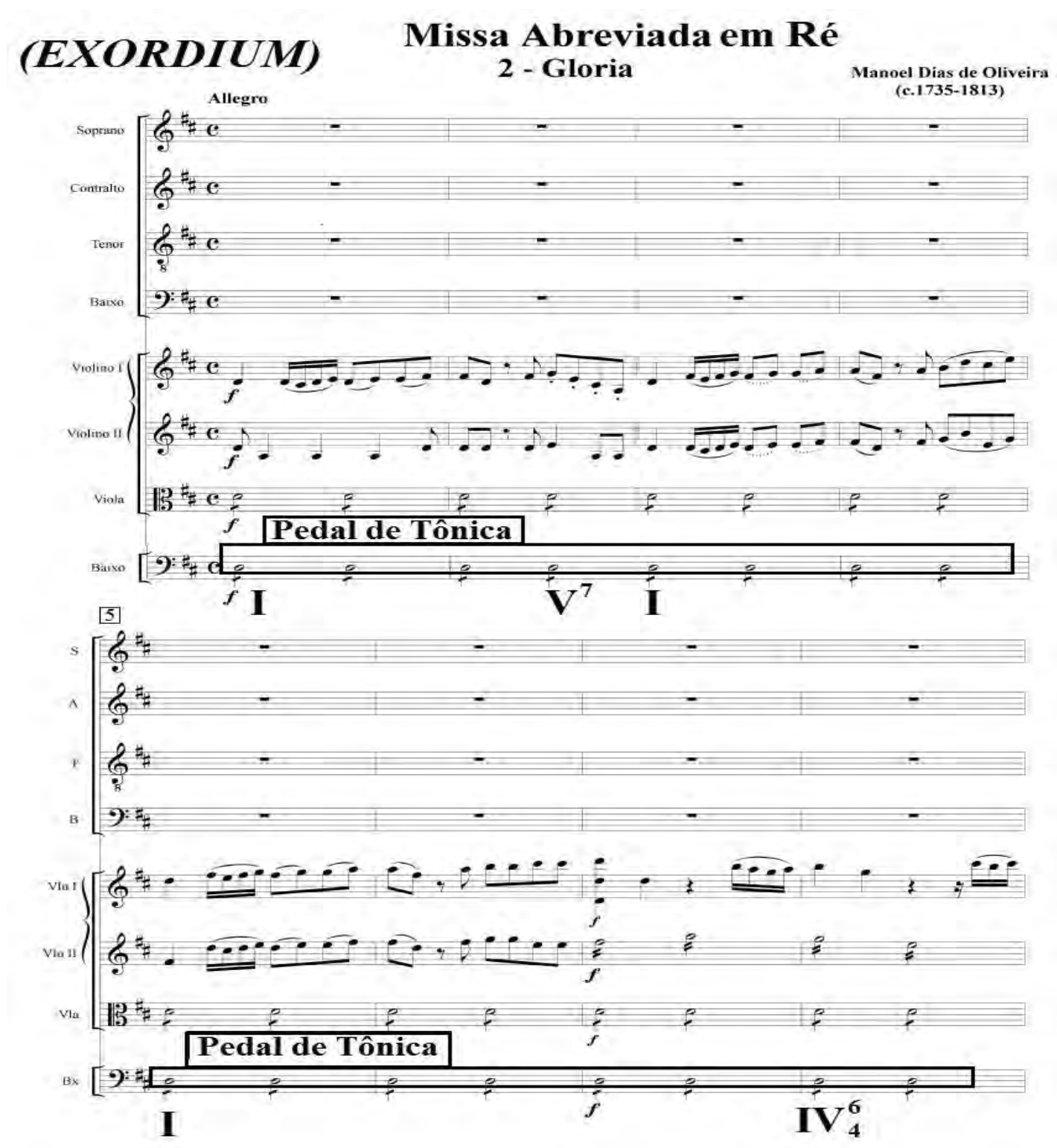

Exemplo 103-Gloria da Missa Abreviada em Ré de Manoel Dias de Oliveira. Organização e Edição- Paulo Castagna (CASTAGNA, 2002, p.5). 
Nesse trecho, é observável o uso das mesmas funções harmônicas, todavia o compositor demostra sua habilidade em preparar o ouvinte para a narração dos fatos que virão logo após a Semicadência, no compasso 15.

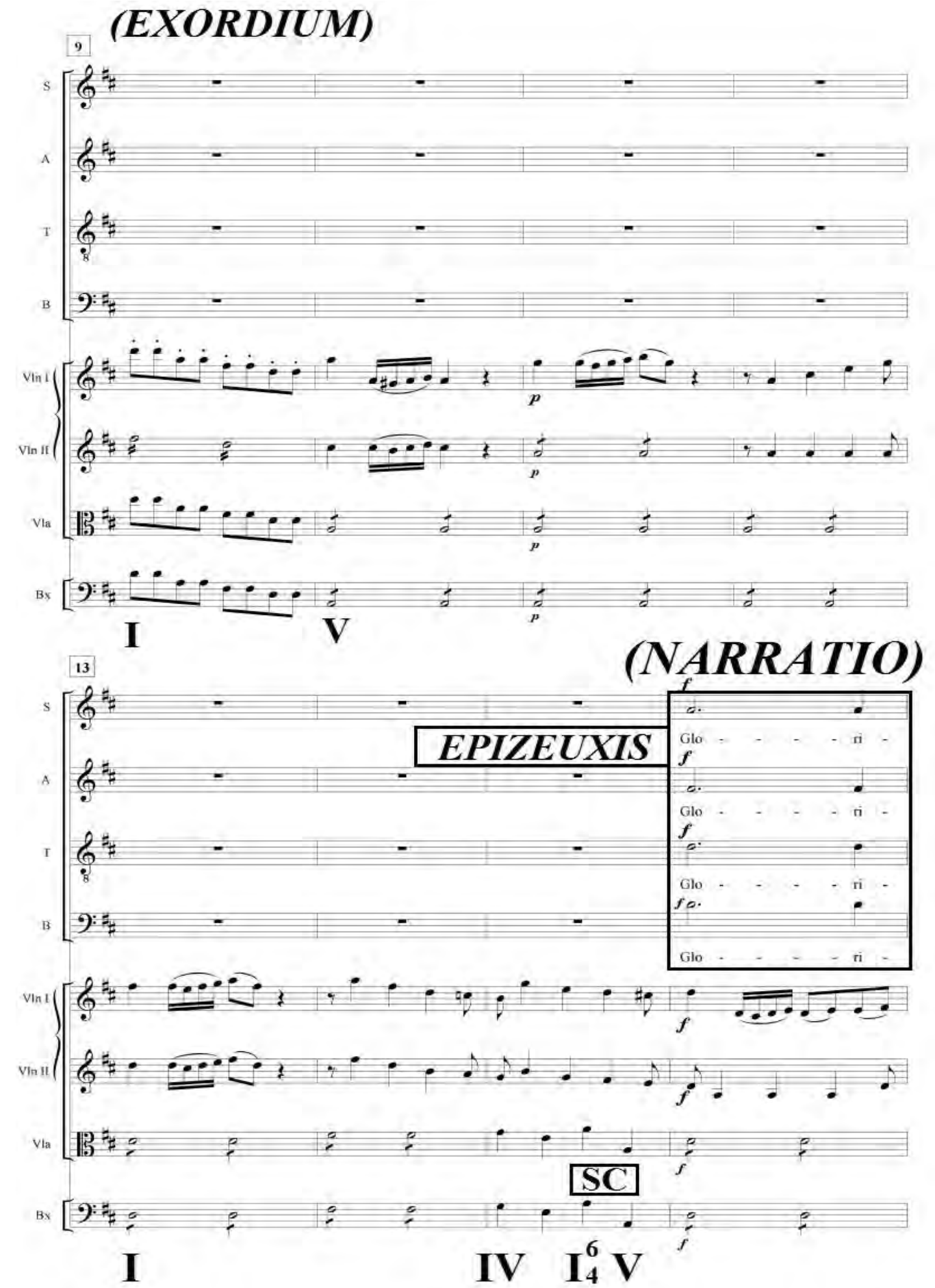

Exemplo 104-Gloria da Missa Abreviada em Ré de Manoel Dias de Oliveira. Organização e Edição- Paulo Castagna (CASTAGNA, 2002, pp.5-6). 


\subsection{Narratio}

Por meio das repetições enfáticas das notas e da palavra Gloria, verificase o emprego da figura central da peça, ou seja, da Epizeuxis. Da mesma forma, há de se salientar os mesmos materiais motívicos, fraseológicos, além das mesmas funções harmônicas e do pedal de Tônica, localizados no Exordium, porém, dessa vez, há a presença do texto e das vozes.

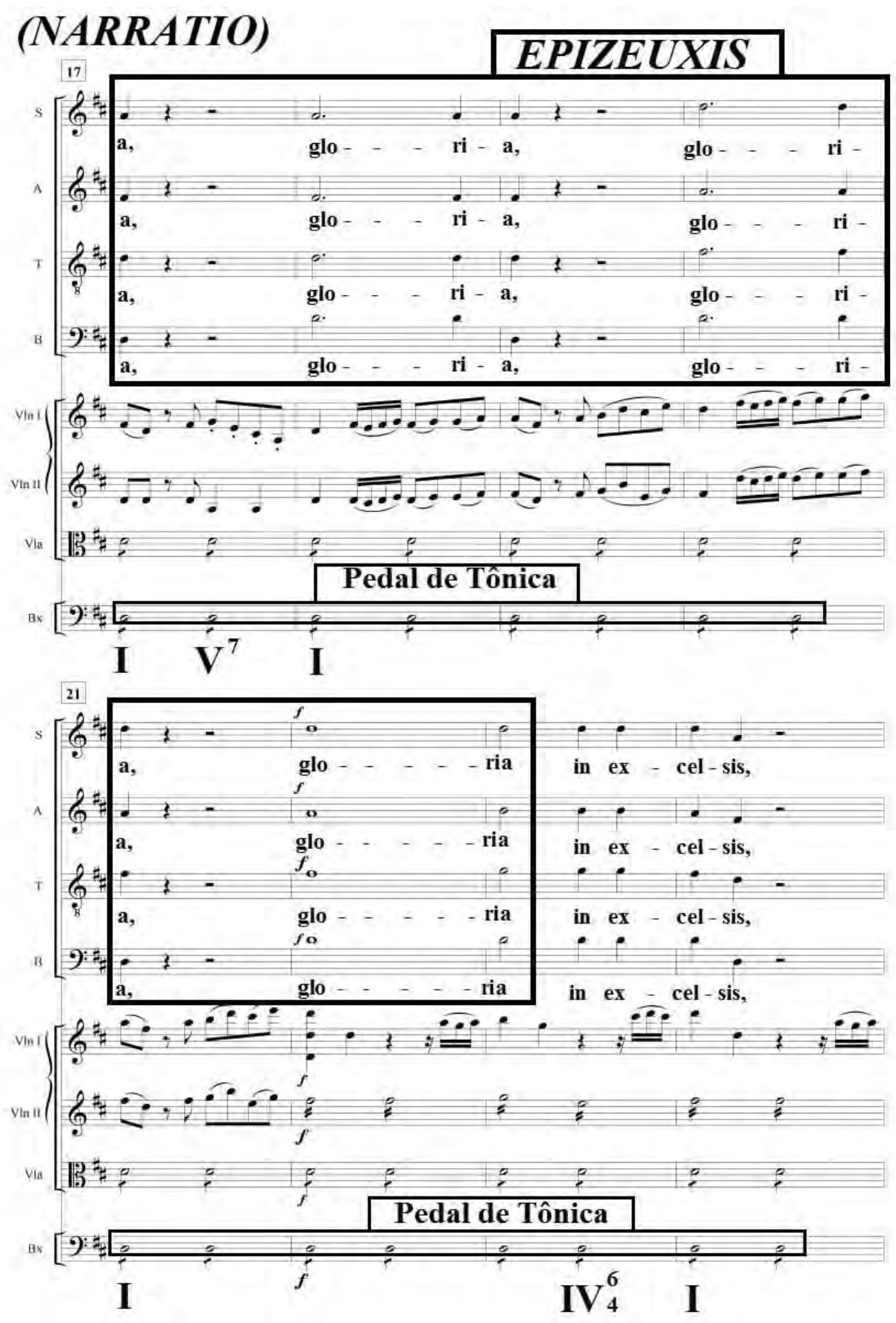

Exemplo 105-Gloria da Missa Abreviada em Ré de Manoel Dias de Oliveira. Organização e Edição- Paulo Castagna (CASTAGNA, 2002, p.7). 
Após a utilização da primeira figura retórica da peça, a Narratio se encerra com a expressão Gloria in excelsis Deo (Glória a Deus nas alturas), entre os compassos 25 e 27, com resolução numa Semicadência.

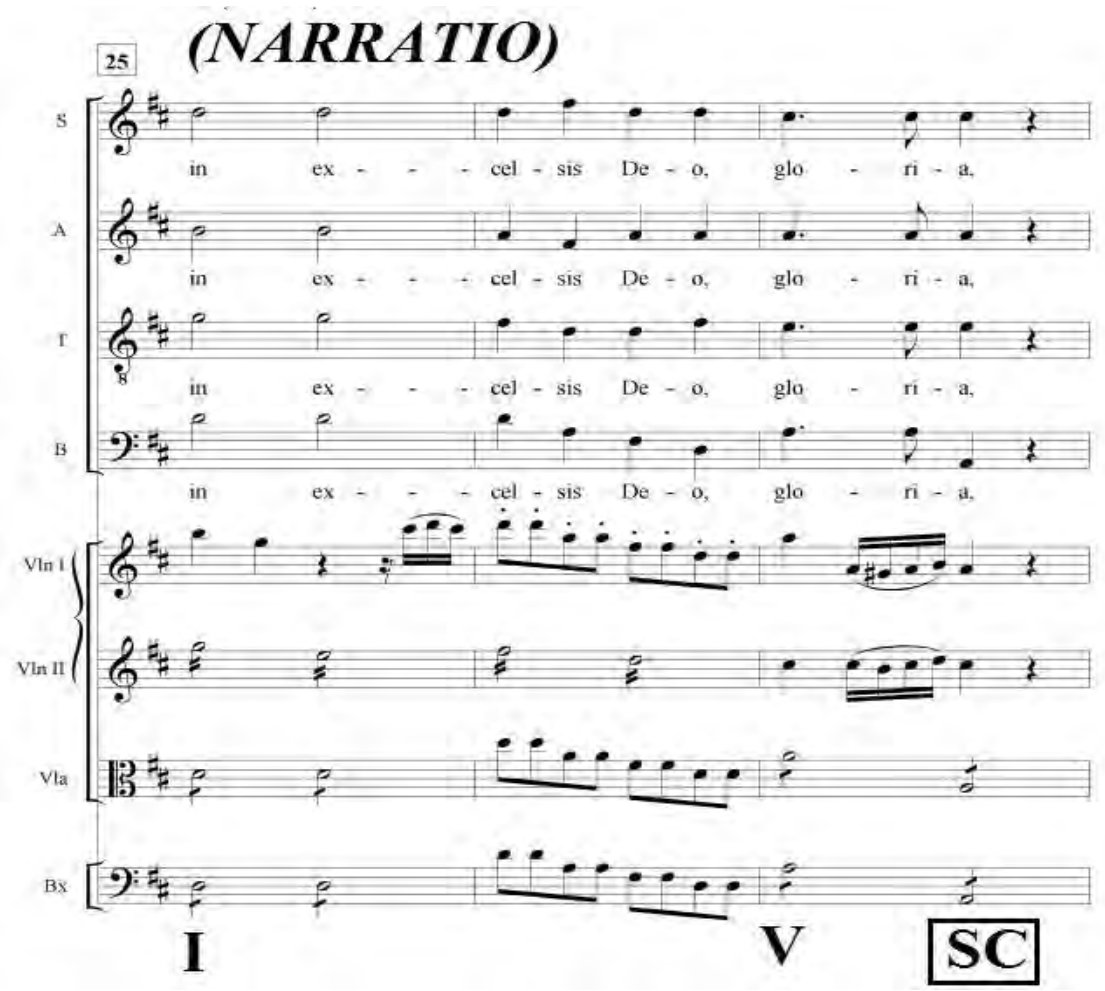

Exemplo 106-Gloria da Missa Abreviada em Ré de Manoel Dias de Oliveira. Organização e Edição- Paulo Castagna (CASTAGNA, 2002, p.8).

\subsection{Propositio}

Posterior ao encerramento da Narratio, examina-se que o autor continua a aplicar a Epizeuxis, entretanto, é notada a utilização da Synaeresis nas vozes do contralto e do tenor, nos compassos 28 e 31 , entoando duas notas em uma sílaba. Assim, essas duas figuras retóricas, além de ressaltar a expressão et in terra pax hominibus (e paz na terra aos homens), são dispostas com a finalidade de despertar no ouvinte o afeto de suavidade, evidenciado pela interação entre a dinâmica piano ${ }^{118}$ e recorrências das palavras e notas.

\footnotetext{
${ }^{118}$ Nas análises dos compositores Manoel Dias de Oliveira, José Joaquim Emerico Lobo de Mesquita, André da Silva Gomes e José Maurício Nunes Garcia, por nós realizadas, utilizaramse de edições publicadas por diversos pesquisadores e musicólogos, ou seja, pelo fato da maioria dessas obras não estarem disponíveis numa cópia ou manuscrito autografado. Por essa razão, as observações em torno das dinâmicas nas obras desses autores, são enfatizadas em consonância ao texto sacro, das figuras e elementos de retórica, das linhas fraseológicas, além das funções harmônicas.
} 


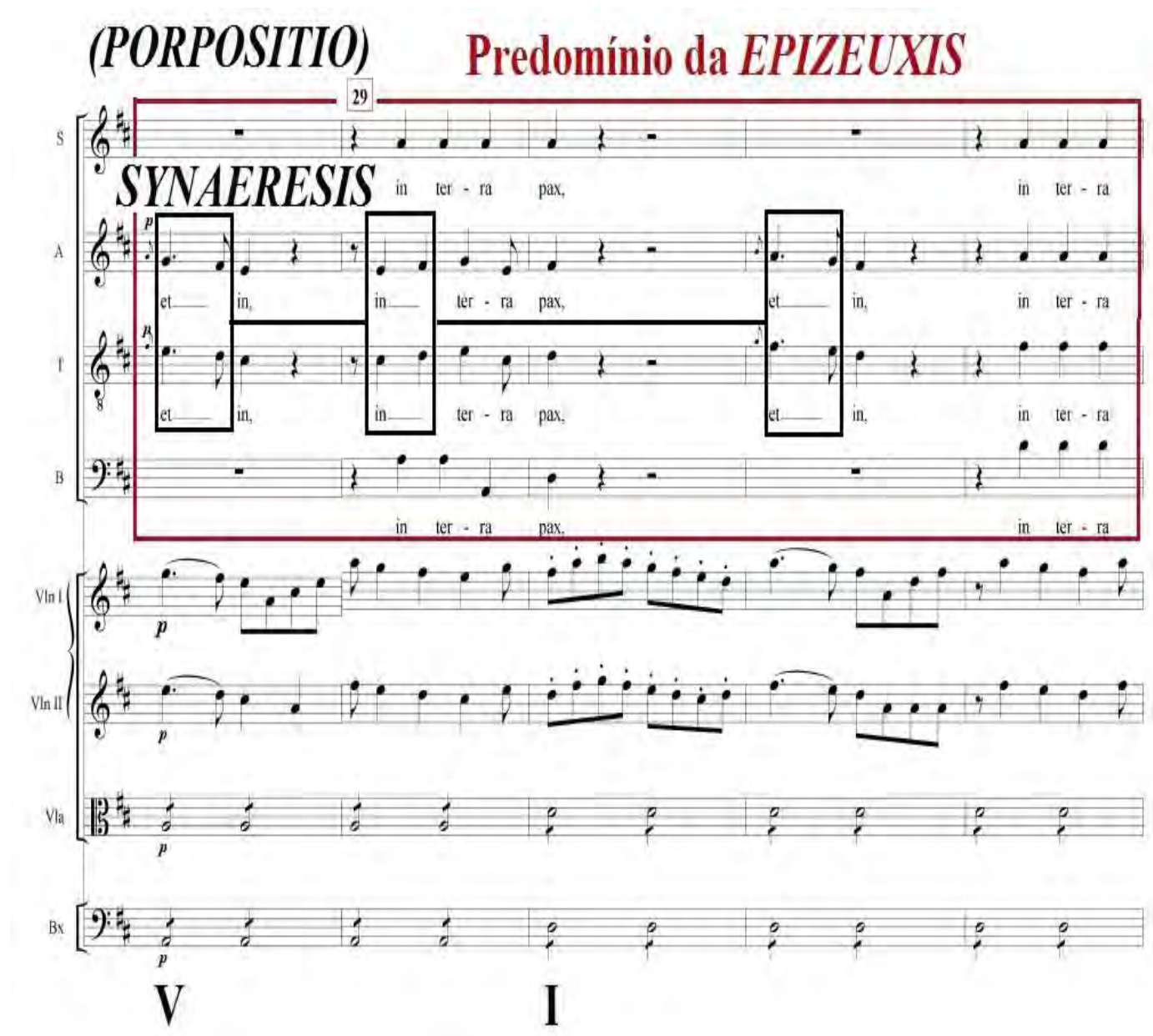

Exemplo 107-Gloria da Missa Abreviada em Ré de Manoel Dias de Oliveira. Organização e Edição- Paulo Castagna (CASTAGNA, 2002, p.8).

\subsection{Confutatio}

Na transição da Propositio para a Confutatio, nota-se a aplicação das mesmas figuras, no entanto Dias de Oliveira atrai a atenção do ouvinte com uma Cadência de Engano na Tônica paralela, rompendo a formulação do raciocínio lógico da resolução conclusiva na Tônica com uma Semicadência, no compasso 37. 


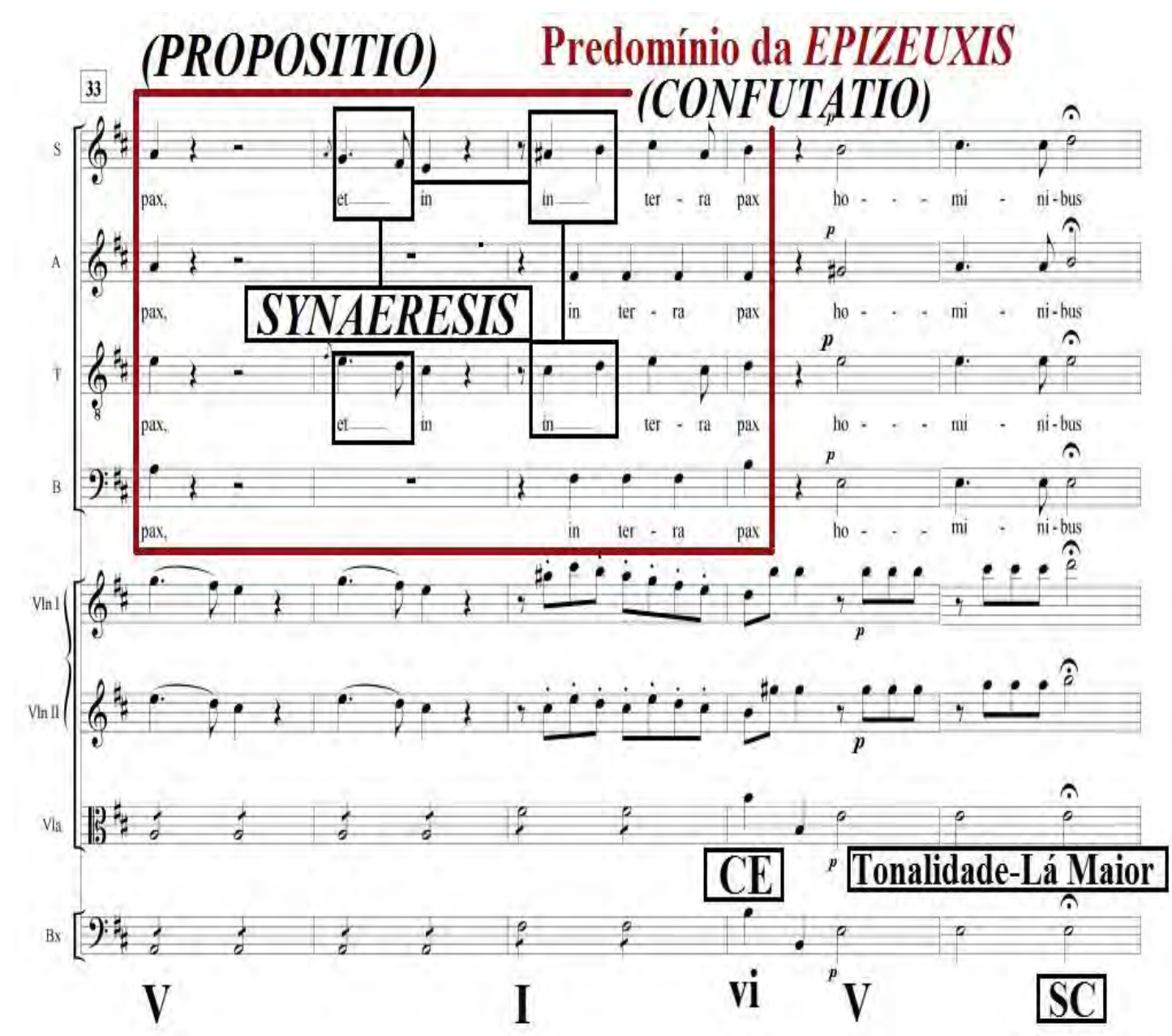

Exemplo 108-Gloria da Missa Abreviada em Ré de Manoel Dias de Oliveira. Organização e Edição- Paulo Castagna (CASTAGNA, 2002, p.9).

No presente excerto, pode ser notada a modulação da tonalidade Lá Maior para Ré Maior, no último tempo do compasso 38. Semelhantemente, o compositor destaca as expressões bonæ voluntatis (de boa vontade) e Laudamus te (Nos Vos louvamos), através da dinâmica forte, assim como da marcação do tremolo no segundo violino, na viola e no baixo. 


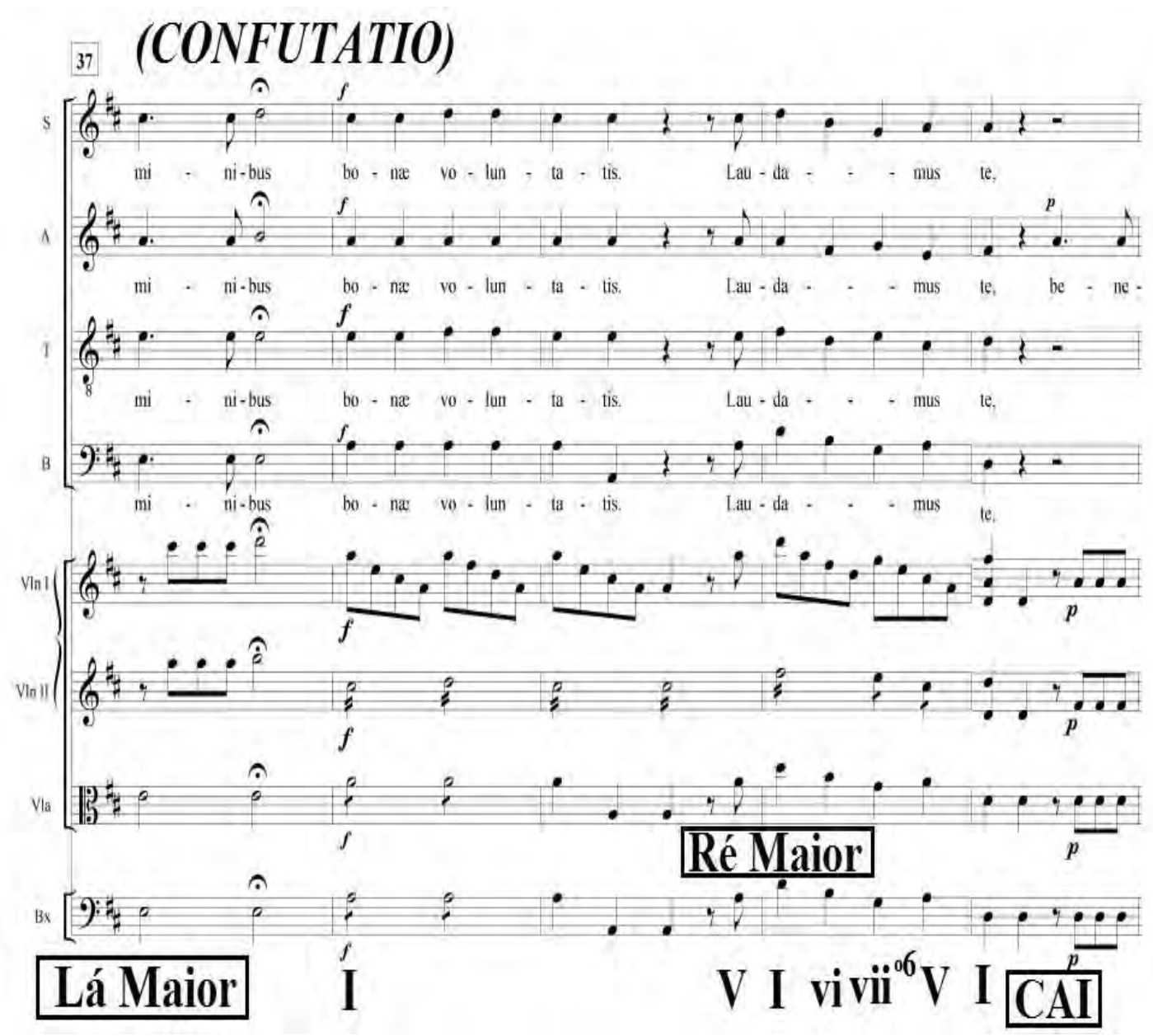

Exemplo 109-Gloria da Missa Abreviada em Ré de Manoel Dias de Oliveira. Organização e Edição- Paulo Castagna (CASTAGNA, 2002, pp.9-10).

Ainda na Confutatio, é examinável o emprego da Variatio que, em consonância com as funções harmônicas da Tônica, Dominante e Subdominante, além da Synaeresis, é diligentemente articulada não só para variar os ornamentos das notas no solo do contralto, mas, também, para destacar as expressões benedicimus te (Vos bendizemos) e adoramus te (Vos adoramos).

Destarte, essa parte do discurso musical se encerra no compasso 47, após a mudança da tonalidade Ré Maior para Si Menor, com uma Cadência Autêntica Imperfeita. 


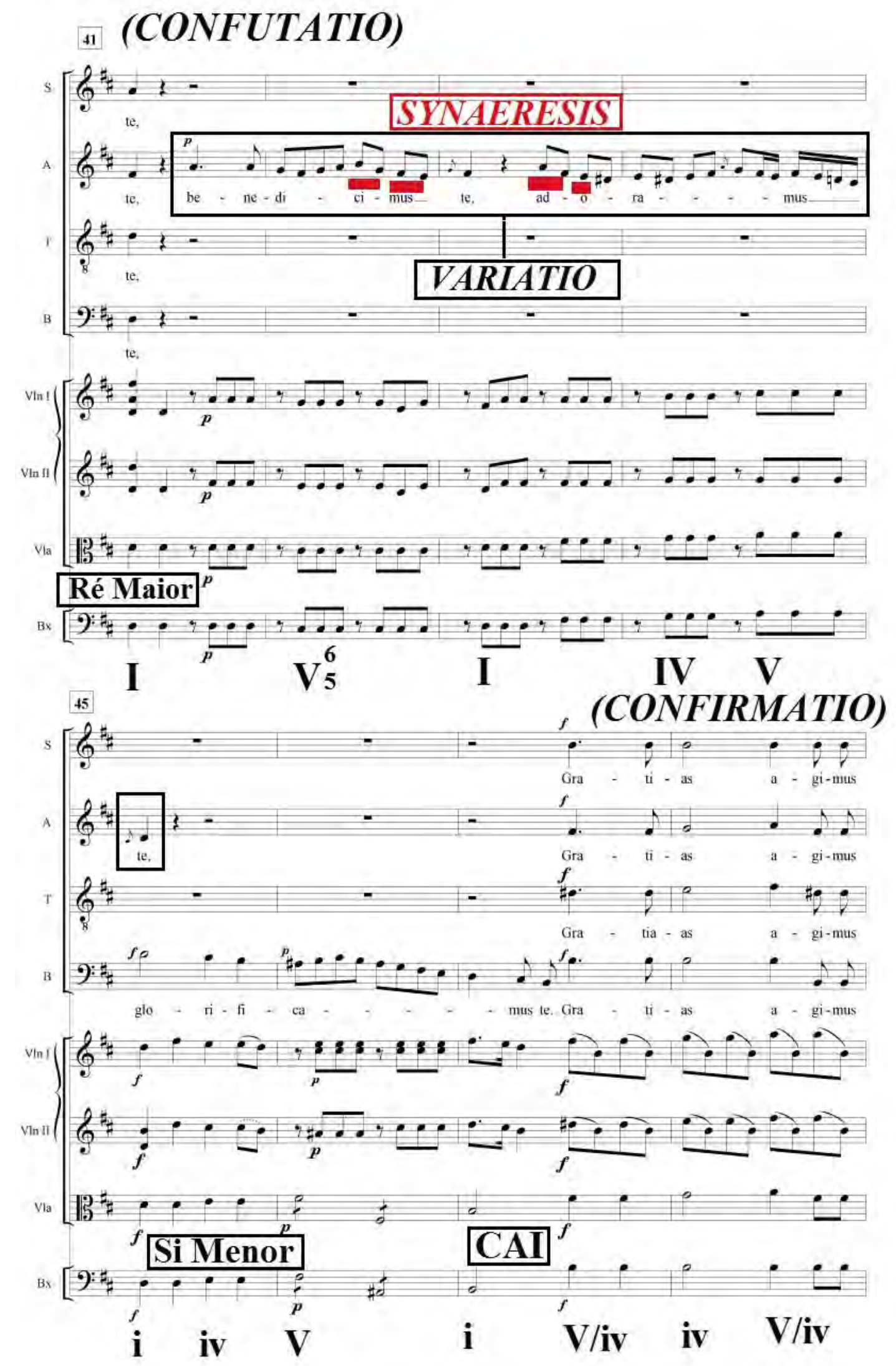

Exemplo 110-Gloria da Missa Abreviada em Ré de Manoel Dias de Oliveira. Organização e Edição- Paulo Castagna (CASTAGNA, 2002, p.10). 


\subsection{Confirmatio}

Nessa parte, averigua-se a mudança da tonalidade Si Menor para Ré Maior, no compasso 49. Outro aspecto a ser enfatizado são os mesmos materiais motívicos usados no início do texto na Narratio, todavia, onde a palavra Gloria era entoada por valores de mínimas pontuadas, semínimas e mínimas, agora a frase gratias agimus tibi (Vos damos graças) é interpretada nas quatro vozes por semínimas pontuadas, colcheias, mínimas e semínimas, em outras palavras, há uma diminuição motívica.

Por fim, ratificando esses empregos, o compositor usa novamente a Epizeuxis que, como figura retórica de repetição melódica, realça a frase Gratias agimus tibi (Vos damos graças), resolvendo na Cadência Autêntica Imperfeita.

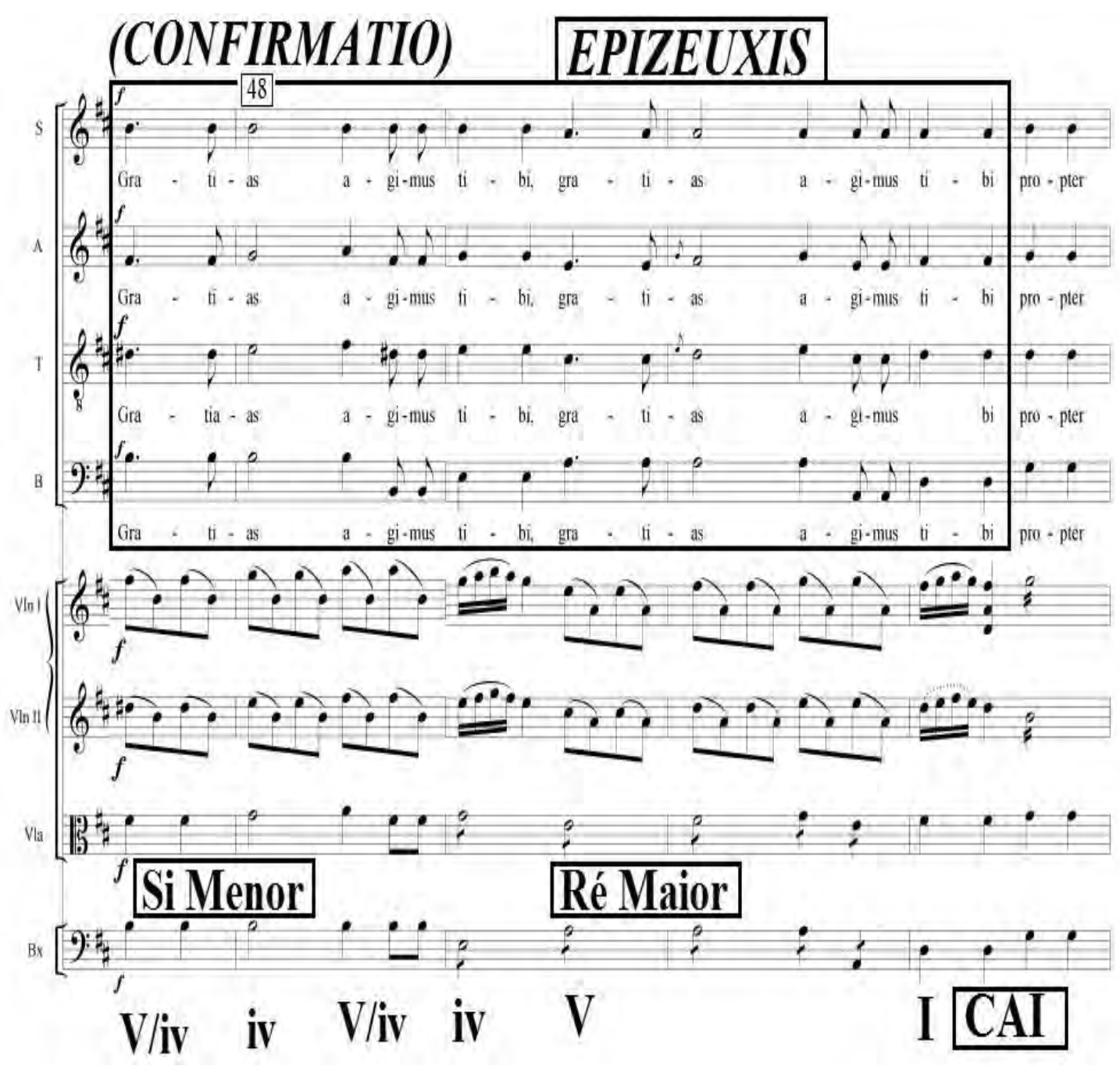

Exemplo 111-Gloria da Missa Abreviada em Ré de Manoel Dias de Oliveira. Organização e Edição- Paulo Castagna (CASTAGNA, 2002, p.11). 


\subsection{Peroratio}

No último exemplo da presente obra, verifica-se que Dias de Oliveira ressalta a expressão, propter magnam gloriam tuam (por amor da vossa imensa glória), por meio da marcação de tremolo em todo o acompanhamento instrumental. Esse realce se dá em conformidade com as funções da Tônica, Subdominante e Dominante, de maneira conclusiva na Cadência Autêntica Imperfeita, no compasso 55.

\section{1] (PERORATIO)}

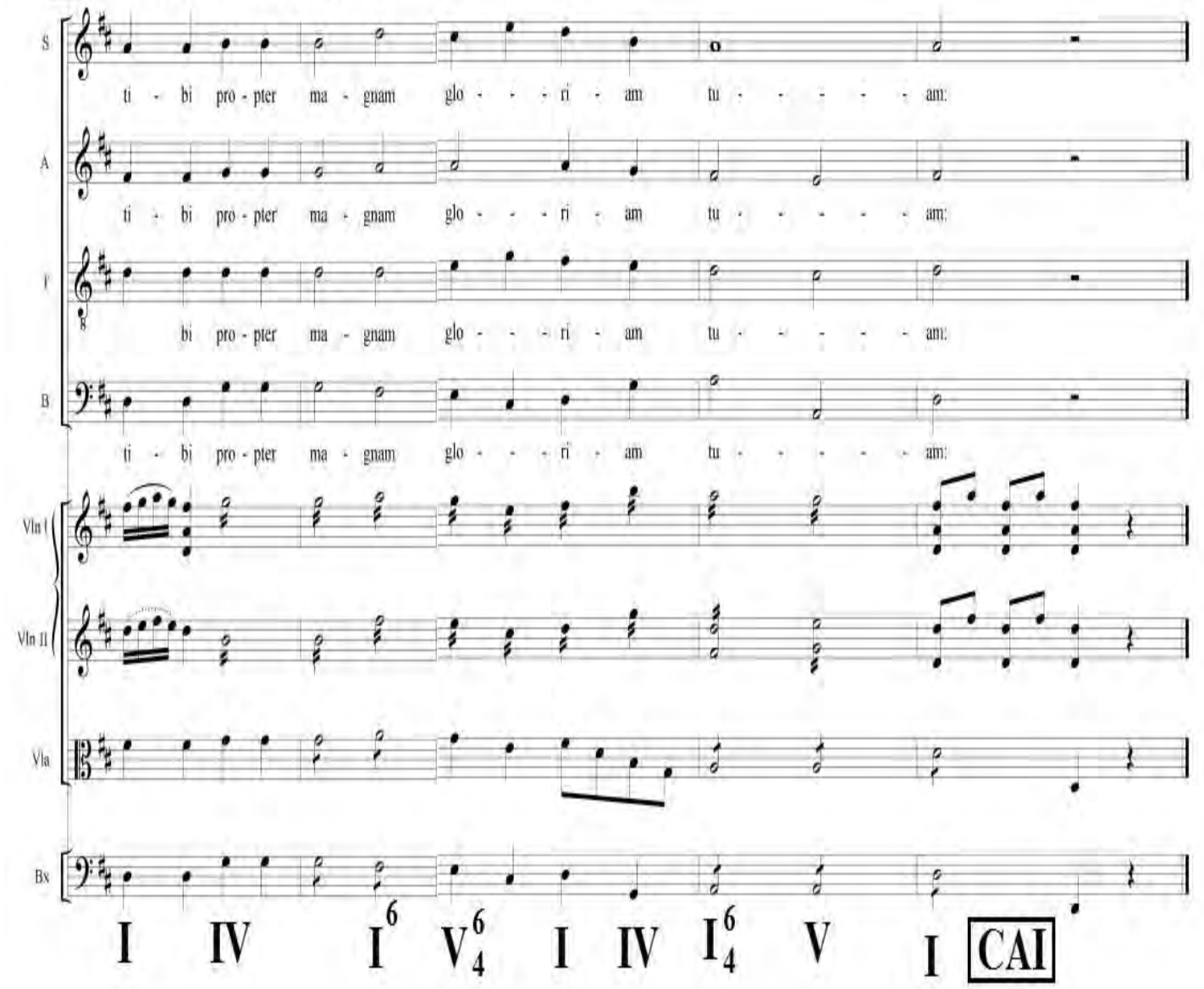

Exemplo 112-Gloria da Missa Abreviada em Ré de Manoel Dias de Oliveira. Organização e Edição- Paulo Castagna (CASTAGNA, 2002, p.11). 


\section{Figuras observadas no Gloria}

Tabela 23-Figuras retóricas localizadas no Gloria da Missa Abreviada em Ré de Manoel Dias de Oliveira.

\begin{tabular}{|c|c|c|c|}
\hline $\begin{array}{l}\text { FIGURAS } \\
\text { CITAÇÕES }\end{array}$ & TIPO & DESCRIÇĀO & TRATADISTA \\
\hline $\begin{array}{l}\text { EPIZEUXIS } \\
\text { (BARTEL, 1997, } \\
\text { pp.263-265). }\end{array}$ & $\begin{array}{l}\text { Repetição } \\
\text { Melódica }\end{array}$ & $\begin{array}{l}\text { Uma repetição } \\
\text { imediata } \\
\text { enfática de uma } \\
\text { palavra, nota, } \\
\text { motivo ou frase. }\end{array}$ & $\begin{array}{lr}\text { Johann } & \text { Gottfried } \\
\text { Walther: A Epizeuxis é } \\
\text { uma figura de retórica } \\
\text { pela qual uma ou mais } \\
\text { palavras } \\
\text { imediatamente rão } \\
\text { enfaticamente repetidas. }\end{array}$ \\
\hline $\begin{array}{l}\text { SYNAERESIS } \\
\text { (BARTEL, 1997, } \\
\text { pp.394-396). } \\
\text { (LÓPEZ CANO, } \\
\text { 2000, p.199). }\end{array}$ & $\begin{array}{l}\text { Dissonância e } \\
\text { Deslocamento }\end{array}$ & $\begin{array}{lr}(1) & \text { Uma } \\
\text { suspensão } & \text { ou } \\
\text { síncope, (2) } & \text { a } \\
\text { colocação } & \text { de } \\
\text { duas sílabas por } \\
\text { nota ou duas } \\
\text { notas por sílaba. }\end{array}$ & $\begin{array}{l}\text { Mauritius Johann Vogt: } \\
\text { A Synaeresis ocorre } \\
\text { quando duas notas são } \\
\text { colocadas em uma sílaba } \\
\text { ou duas sílabas são } \\
\text { colocadas em uma nota. }\end{array}$ \\
\hline $\begin{array}{l}\text { VARIATIO } \\
\text { (BARTEL, 1997, } \\
\text { pp.432-438). }\end{array}$ & $\begin{array}{l}\text { Ornamentação } \\
\text { Melódica e } \\
\text { Harmônica }\end{array}$ & $\begin{array}{l}\text { Ornamentação } \\
\text { de uma } \\
\text { passagem } \\
\text { melódica com } \\
\text { uma variedade } \\
\text { de } \\
\text { embelezamentos } \\
\text { (decorações). }\end{array}$ & $\begin{array}{l}\text { Wolfgang Printz: A } \\
\text { palavra Variatio é usada } \\
\text { de duas maneiras pelos } \\
\text { músicos, ou seja, tanto } \\
\text { no sentido amplo e } \\
\text { estrito. Em um sentido } \\
\text { estrito, Variatio refere-se } \\
\text { a uma alteração artística } \\
\text { (figuração) de uma } \\
\text { determinada passagem } \\
\text { melódica, mas em que a } \\
\text { melodia original é } \\
\text { sempre percebida e } \\
\text { reconhecida. Em um } \\
\text { sentido amplo, Variatio } \\
\text { significa qualquer tipo de } \\
\text { alteração de um trecho } \\
\text { melódico se inclui o tipo } \\
\text { anterior ou não. }\end{array}$ \\
\hline
\end{tabular}

\section{Análise Harmônica}

\subsection{Curva Tonal}

Tonalidade: Ré Maior 
Andamento: Allegro 4/4

Tabela 24-Esquema das Progressões Harmônicas- Curva Tonal do Gloria da Missa Abreviada em Ré.

\begin{tabular}{|l|c|l|}
\hline \multicolumn{1}{|c|}{ Compassos } & Função & \multicolumn{1}{c|}{ Tonalidade } \\
\hline $1-9$ & I & Ré Maior \\
\hline $10-12$ & V & Lá Maior \\
\hline $13-27$ & I & Ré Maior \\
\hline $28-29$ & V & Lá Maior \\
\hline $30-35$ & I & Ré Maior \\
\hline 36 & vi & Si Menor \\
\hline $36-39$ & V & Lá Maior \\
\hline 40 & I & Ré Maior \\
\hline 40 & vi & Si Menor \\
\hline 41 & I & Ré Maior \\
\hline $41-44$ & I & Ré Maior \\
\hline $45-47$ & vi & Si Menor \\
\hline $47-50$ & ii & Mi Menor \\
\hline $50-56$ & I & Ré Maior \\
\hline
\end{tabular}

2.2. Estrutura Analítica da obra: Retórica e Harmônica

Tabela 25-Estrutura analítica da obra.

\begin{tabular}{|c|c|c|c|c|}
\hline $\begin{array}{l}\text { RETÓRICA } \\
\text { DISPOSITIO }\end{array}$ & $\begin{array}{c}\text { FIGURA } \\
\text { ELOCUTIO }\end{array}$ & COMP. & TONALIDADE & FUNÇÃO \\
\hline EXORDIUM & & $1-12$ & Ré Maior & $\mathrm{I}$ \\
\hline NARRATIO & Epizeuxis & $16-23$ & Ré Maior & I \\
\hline PROPOSITIO & $\begin{array}{l}\text { Synaeresis } \\
\text { Epizeuxis }\end{array}$ & $\begin{array}{l}28,31 \\
28-36\end{array}$ & Ré Maior & I \\
\hline CONFUTATIO & Variatio & $41-45$ & Ré Maior & I \\
\hline CONFIRMATIO & Epizeuxis & $48-51$ & $\begin{array}{l}\text { Si Menor e } \\
\text { Ré Maior }\end{array}$ & $\begin{array}{l}\text { vi } \\
\text { I }\end{array}$ \\
\hline PERORATIO & & $52-56$ & Ré Maior & $\mathrm{I}$ \\
\hline
\end{tabular}




\subsection{José Joaquim Emerico Lobo de Mesquita}

\subsubsection{Análise Retórico-Musical do Exaudi nos, Domine para Benção de Cinzas da Missa para Quarta-feira de Cinzas}

\section{Inventio}

O texto do Exudi nos, Domine para Bênção de Cinzas da Missa para Quarta-feira de Cinzas se fundamenta em Salmos (Ps.68:17/69:1). O tema central desse salmo é sobre a vitória de Deus sobre seus inimigos.

Exuadi nos Domine quoniam benigua est misericordia tua. Secundum multitudinem miserationum tuarum respice nos Domine. Salvum me fac Deus quoniam intraverunt aquæ usque ad animan mean.

Atende-nos, Senhor porque benigna é a tua misericórdia. Segundo a grandeza das tuas misericórdias lança um olhar sobre nós. Salva-me Deus, porque as águas submergiram a minha alma (MORETZSOHN, 1997, p.26).

A descrição acima é referente à suplica feita pelo salmista e rei Davi pela atenção e misericórdia de Deus, para auxiliá-lo num momento de intensa angústia. Essa situação angustiosa de Davi, provém da perseguição de seus inimigos. Contudo, para obter a vitória sobre os mesmos, o autor da prédica confessa ser dependente da compaixão e atributos divinos (ALMEIDA, 2000, p.834).

O cerimonial da Quarta-feira de Cinzas tem por finalidade lembrar à comunidade cristã a necessidade de um período penitencial, ou seja, busca-se um arrependimento dos pecados e erros cometidos, pela não obediência as Sagradas Escrituras e seus mandamentos. Enfim, a Quarta-feira de Cinzas, mediante as orações, boas obras e veneração, oferece ao cristão a oportunidade de se conscientizar da precariedade da vida humana e da imprescindibilidade de uma preparação para a vida espiritual (MORETZSOHN, 1997, p.17).

Em síntese, a primeira parte dessa obra é composta por setenta compassos, num andamento Andante na tonalidade Fá Maior, onde o compositor trabalha com as emoções do ouvinte, por intermédio dos afetos e de mecanismos retórico-musicais. 


\subsection{Loci observados na obra Exaudi nos, Domine}

Tabela 26-Loci Topici localizados no Exaudi nos, Domine de José Joaquim Emerico Lobo de Mesquita.

\begin{tabular}{|c|c|c|c|}
\hline INVENTIO & DESCRIÇÃO & $\begin{array}{c}\text { UTILIZAÇÃO NA } \\
\text { OBRA }\end{array}$ & $\begin{array}{l}\text { COMPASSOI } \\
\text { VOZ }\end{array}$ \\
\hline $\begin{array}{l}\text { Locus } \\
\text { Notationis } \\
\text { (MATTHESON, } \\
1954 \quad \text { [1739]. } \\
\text { Parte II, Cap.4, } \\
\S 23, \text { p.123). }\end{array}$ & $\begin{array}{l}\text { Aspecto externo } \\
\text { e desenho das } \\
\text { notas (Duração } \\
\text { das notas, } \\
\text { alteração, } \\
\text { repetição e } \\
\text { procedimentos } \\
\text { canônicos). }\end{array}$ & $\begin{array}{l}\text { Vários motivos } \\
\text { rítmicos e diferentes } \\
\text { durações de notas } \\
\text { (mínimas, semínimas, } \\
\text { semínimas } \\
\text { pontuadas, colcheias, } \\
\text { colcheias pontuadas, } \\
\text { semicolcheia, } \\
\text { repetições, ligaduras, } \\
\text { pausas, apogiatura, } \\
\text { fermata entre outros). }\end{array}$ & $\begin{array}{ll}1-7 & \text { S-A-T-B } \\
7-15 & \text { S-A-T-B } \\
16-22 S-A-T-B \\
23-28 S-A-T-B \\
29-37 S-A-T-B \\
38-51 S-A-T-B \\
52-61 S-A-T-B \\
62-70 S-A-T-B\end{array}$ \\
\hline $\begin{array}{l}\text { Locus } \\
\text { Descriptionis } \\
\text { (MATTHESON, } \\
\text { 1954 [1739]. } \\
\text { Parte II, Cap.4, } \\
\S 43, \text { p.127). }\end{array}$ & $\begin{array}{l}\text { Disposições da } \\
\text { alma }\end{array}$ & $\begin{array}{l}\text { Súplica, oração, } \\
\text { petição (Atende-nos } \\
\text { Senhor porque } \\
\text { benigna é a tua } \\
\text { misericórdia). } \\
\text { Angústia (Salva-me } \\
\text { Deus porque as } \\
\text { águas submergiram a } \\
\text { minha alma). }\end{array}$ & $\begin{array}{l}23-28 \text { S-A-T-B } \\
52-70 \text { S-A-T-B }\end{array}$ \\
\hline $\begin{array}{l}\begin{array}{l}\text { Locus } \\
\text { Oppositorum }\end{array} \\
\text { (MATTHESON, } \\
1954 \quad \text { [1739]. } \\
\text { Parte II, Cap.4, } \\
\S 80, \text { p.131). }\end{array}$ & $\begin{array}{l}\text { Contraste de } \\
\text { compassos, } \\
\text { movimentos } \\
\text { contrários, } \\
\text { agudos e } \\
\text { graves, lento e } \\
\text { rápido, calmo e } \\
\text { agitado. }\end{array}$ & $\begin{array}{l}\text { Movimento contrário } \\
\text { entre soprano } \\
\text { contralto. } \\
\text { Também no contralto, } \\
\text { e baixo. E, por fim, } \\
\text { entre a soprano, } \\
\text { contralto, tenor e } \\
\text { baixo. }\end{array}$ & $\begin{array}{lr}9 & \text { S-A } \\
9 & \text { A-B } \\
11 & \text { S-A } \\
11 & \text { A-B } \\
17,20 & \text { A-B } \\
24,27 & \text { A-B } \\
50 & \text { S-A-T-B }\end{array}$ \\
\hline
\end{tabular}

\section{Dispositio}

\subsection{Exordium}

No início da obra, verifica-se que todas as vozes estão em silêncio por causa da pausa imposta pelo autor. Dessa forma, o acompanhamento instrumental conduz a introdução, percorrendo as funções da Tônica, Subdominante, Dominante da Subdominante e Dominante na tonalidade Fá Maior, até sua resolução numa Cadência Autêntica Perfeita. 
Missa para Quata-feira de Cinzas

\section{I - Exaudi nos, Domine}

(EXORDIUM)

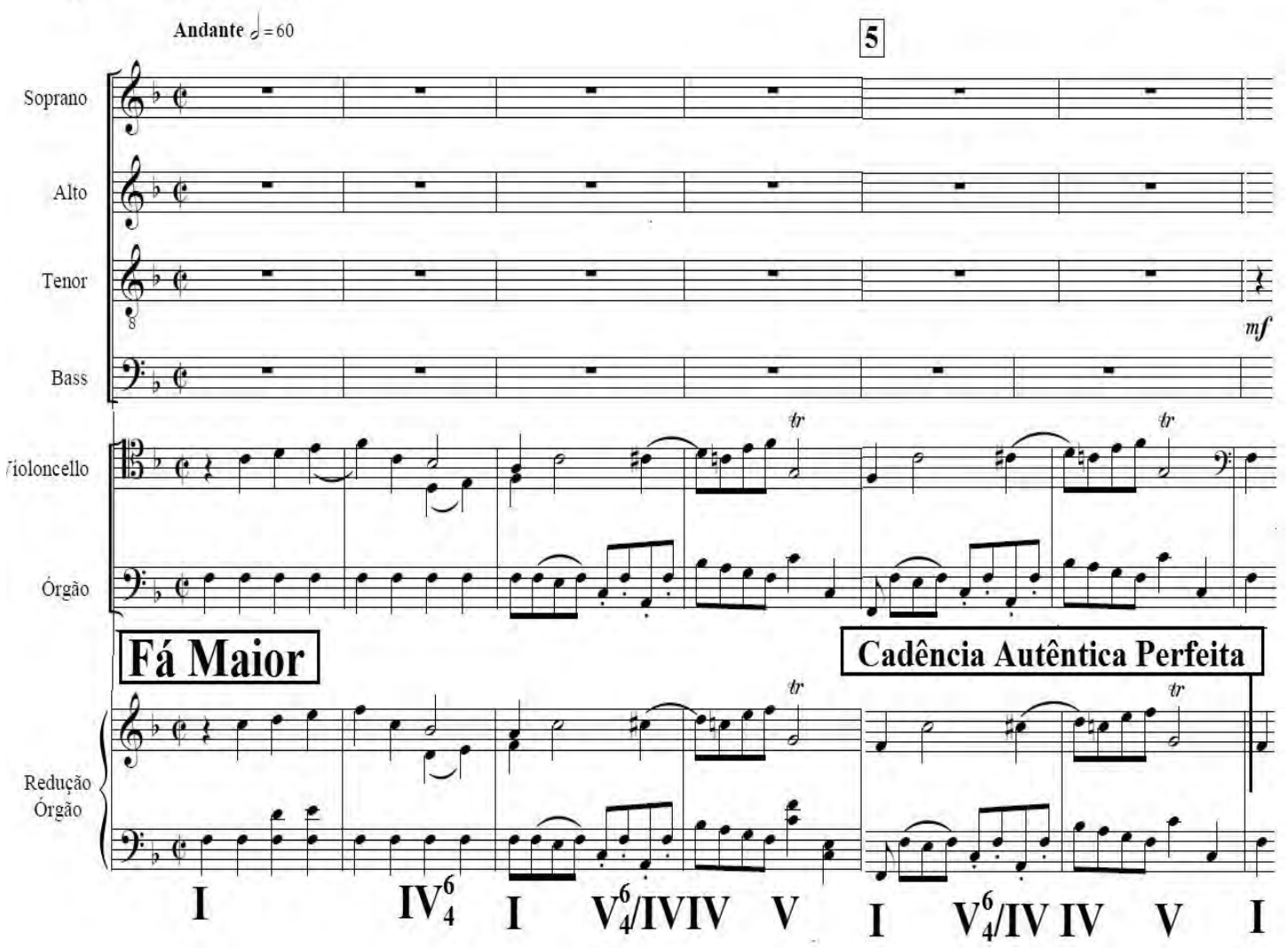

Exemplo 113-Exaudi nos, Domine para Benção de Cinzas da Missa para Quarta-feira de Cinzas de José Joaquim Emerico Lobo de Mesquita- Edição -Rafael Sales Arantes (LOBO DE MESQUITA, 2014[1778], pp.1-2).

\subsection{Narratio}

Através das repetições enfáticas das palavras Exaudi nos Domine (Atende-nos, Senhor) além das notas, observa-se o uso da figura central da peça, isto é, da Epizeuxis, primeiramente na voz do tenor e, em seguida, nas outras vozes. Também, é pertinente salientar a interação entre a ênfase propiciada pela figura em consonância às dinâmicas mezzo-forte e forte, como das funções da Tônica, Subdominante e Dominante, resolvendo na Cadência Autêntica Imperfeita. 

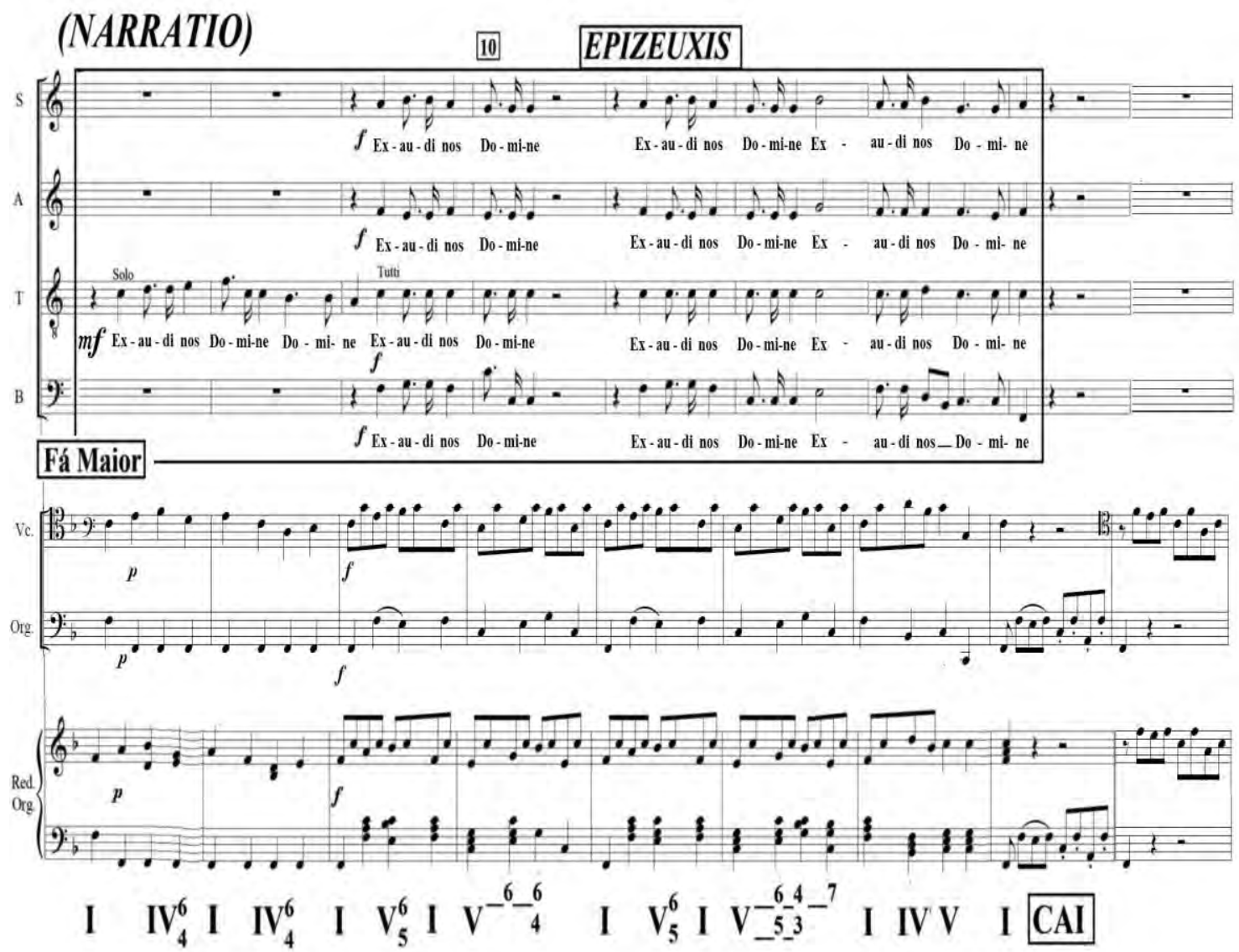

Exemplo 114-Exaudi nos, Domine para Benção de Cinzas da Missa para Quarta-feira de Cinzas de José Joaquim Emerico Lobo de Mesquita - Edição-Rafael Sales Arantes (LOBO DE MESQUITA, 2014[1778], pp.2-4).

\subsection{Propositio}

Após a finalização da Narratio, pode-se notar que o compositor trabalha com a mesma figura retórica de repetição melódica e relações motívicas anteriores. Do mesmo modo, é verificável um diálogo entre o solo da soprano e das outras vozes, numa espécie de pergunta e resposta, destacando a expressão quoniam benigua est misericordia tua (porque benigna é a tua misericórdia). Essa interação entre as vozes também é preconizada pelo autor com o propósito de despertar no ouvinte o afeto de devoção, passando uma ideia da bondade e do caráter benévolo de Deus. 

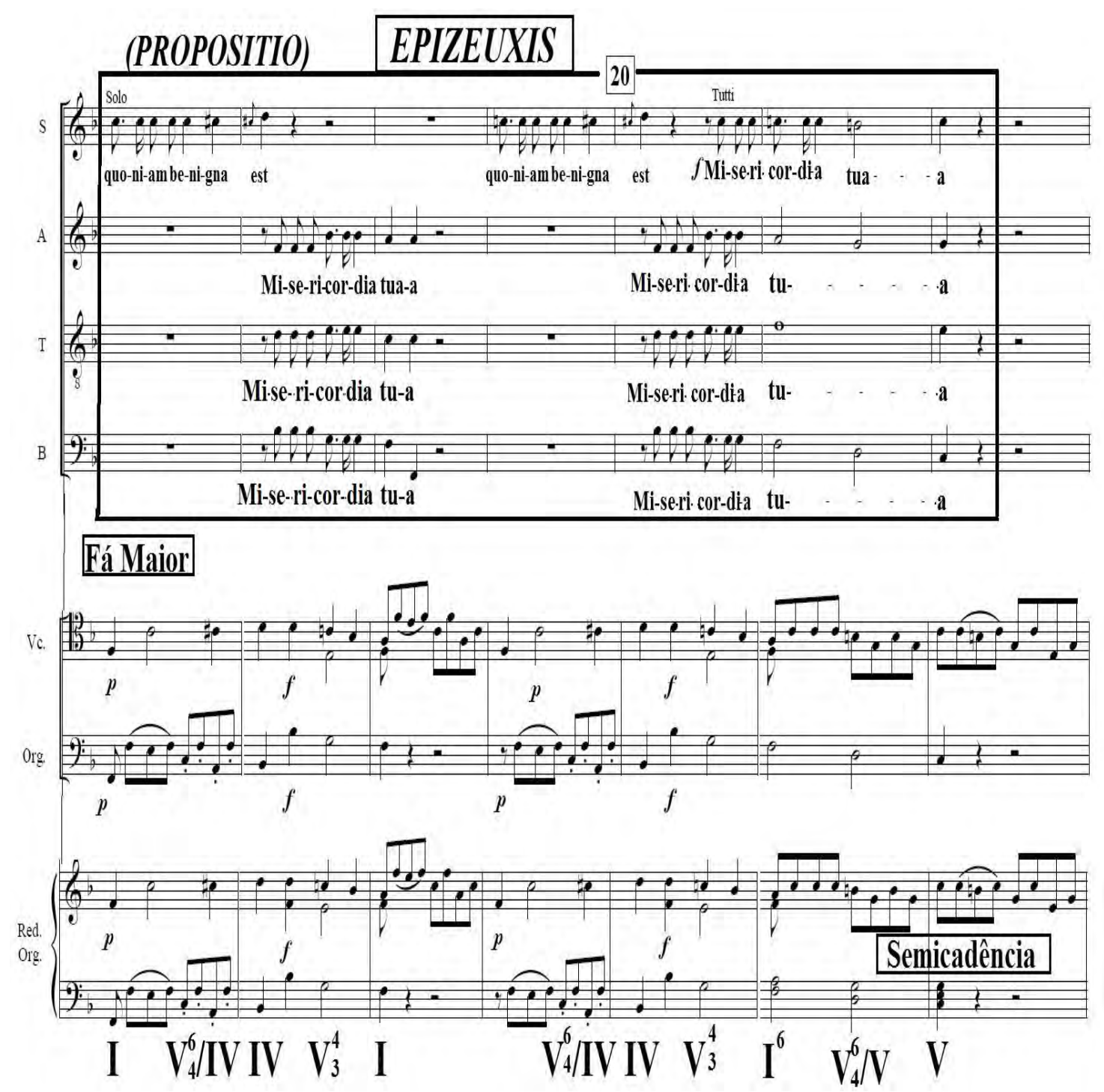

Exemplo 115-Exaudi nos, Domine para Benção de Cinzas da Missa para Quarta-feira de Cinzas de José Joaquim Emerico Lobo de Mesquita - Edição-Rafael Sales Arantes (LOBO DE MESQUITA, 2014[1778], pp.4-6).

Ainda na Propositio, observa-se o predomínio da Epizeuxis como das mesmas interações entre as vozes e das funções harmônicas, entretanto, na tonalidade Dó Maior, com finalização na Cadência Autêntica Imperfeita. 


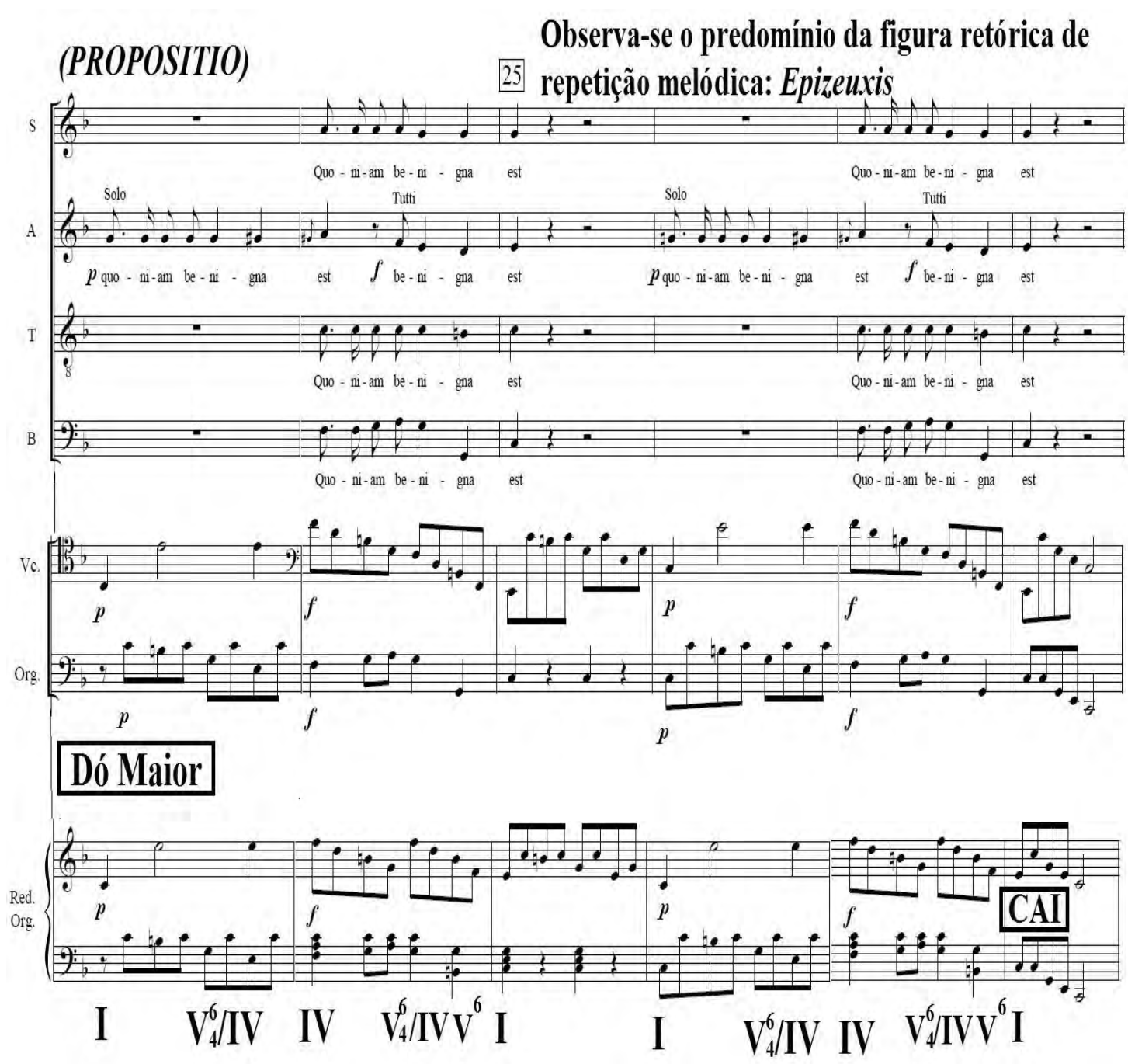

Exemplo 116-Exaudi nos, Domine para Benção de Cinzas da Missa para Quarta-feira de Cinzas de José Joaquim Emerico Lobo de Mesquita - Edição -Rafael Sales Arantes (LOBO DE MESQUITA, 2014 [1778], pp.6-8).

\subsection{Confutatio}

A partir do compasso 29, Lobo de Mesquita utiliza elementos de contraste, por exemplo, as funções da Sexta Napolitana e Subdominante Menor na tonalidade Dó Maior. Somado a isso, na modulação para Ré Menor examina-se o emprego da Syncope, onde a nota Sol, na voz do baixo, era a primeira do acorde da Subdominante, isto é, uma consonância, passando a ser a sétima da Dominante, no compasso 35, uma dissonância, gerando, assim, um efeito de suspensão e tensão, resolvendo posteriormente na Cadência Autêntica Imperfeita. 


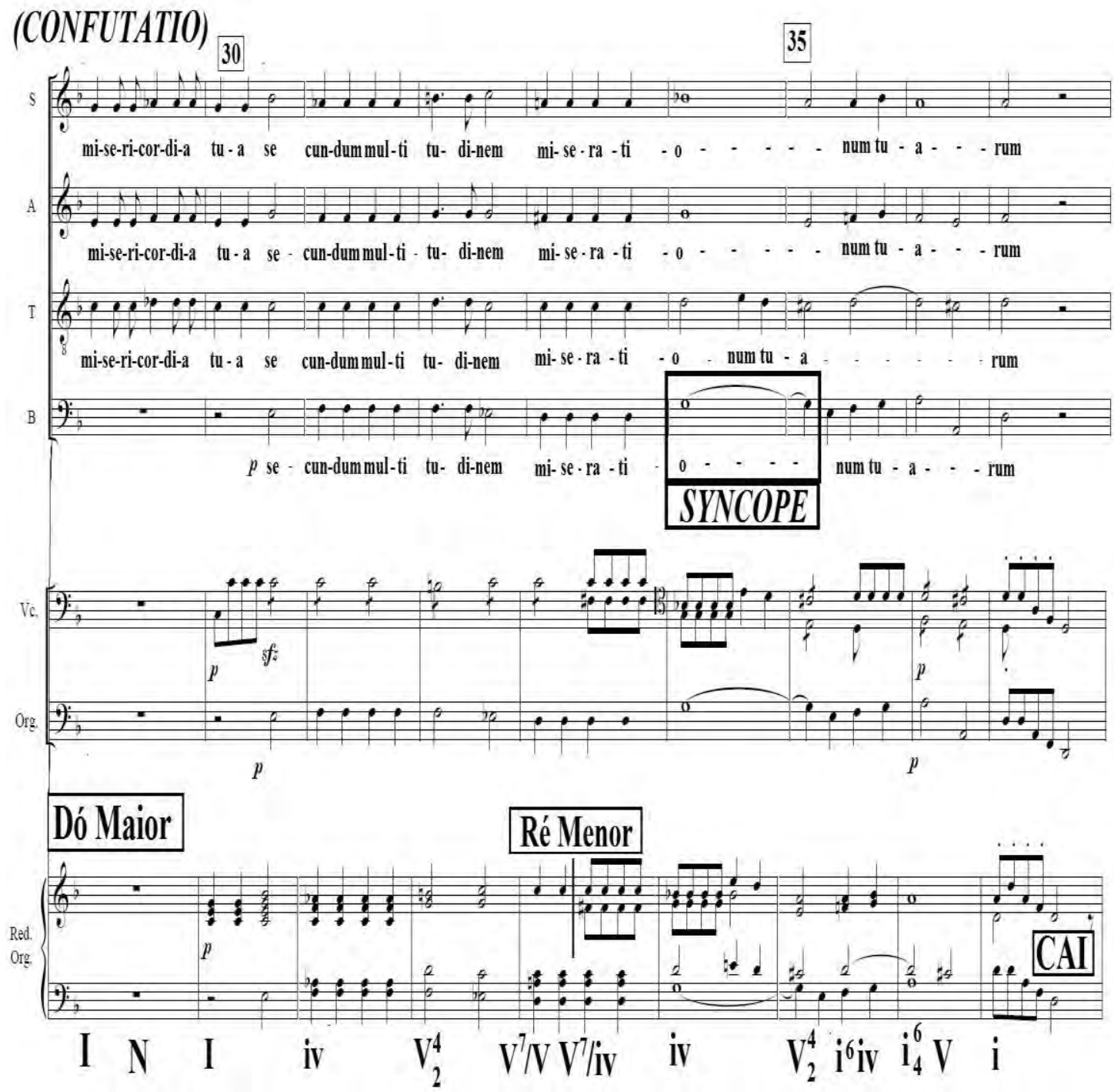

Exemplo 117-Exaudi nos, Domine para Benção de Cinzas da Missa para Quarta-feira de Cinzas de José Joaquim Emerico Lobo de Mesquita - Edição -Rafael Sales Arantes (LOBO DE MESQUITA, 2014 [1778], pp.8-10).

Nesse trecho, o tratamento de repetição e ênfase da melodia, dos motivos e das palavras respice nos Domine (Lance teu olhar sobre nós Senhor) são engenhosamente articulados pelo compositor. No entanto, na tonalidade Si bemol Maior. 


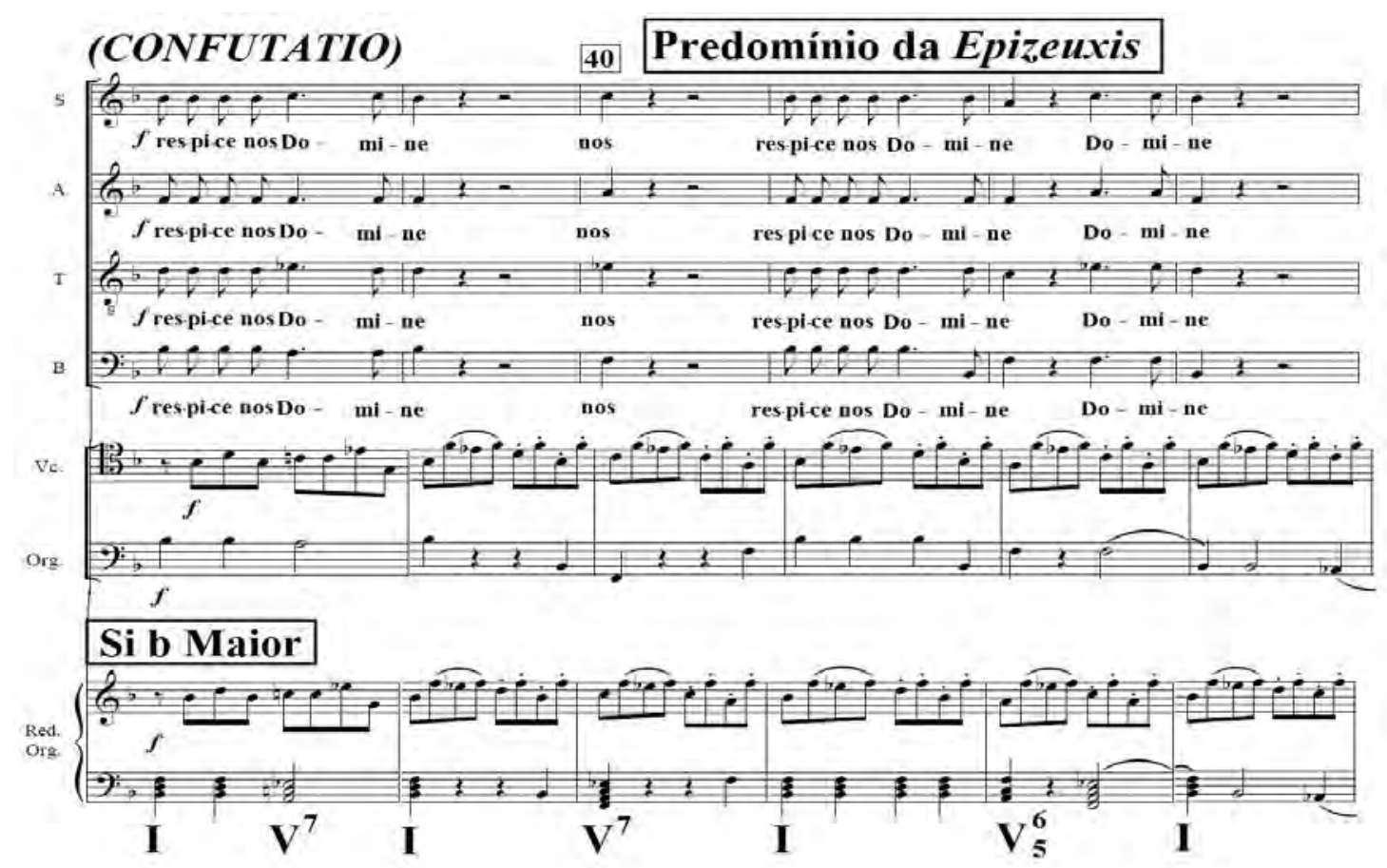

Exemplo 118-Exaudi nos, Domine para Benção de Cinzas da Missa para Quarta-feira de Cinzas de José Joaquim Emerico Lobo de Mesquita - Edição-Rafael Sales Arantes (LOBO DE MESQUITA, 2014 [1778], pp.10-12).

Verifica-se, aqui, o mesmo procedimento do exemplo anterior com resolução na Cadência Autêntica Perfeita.

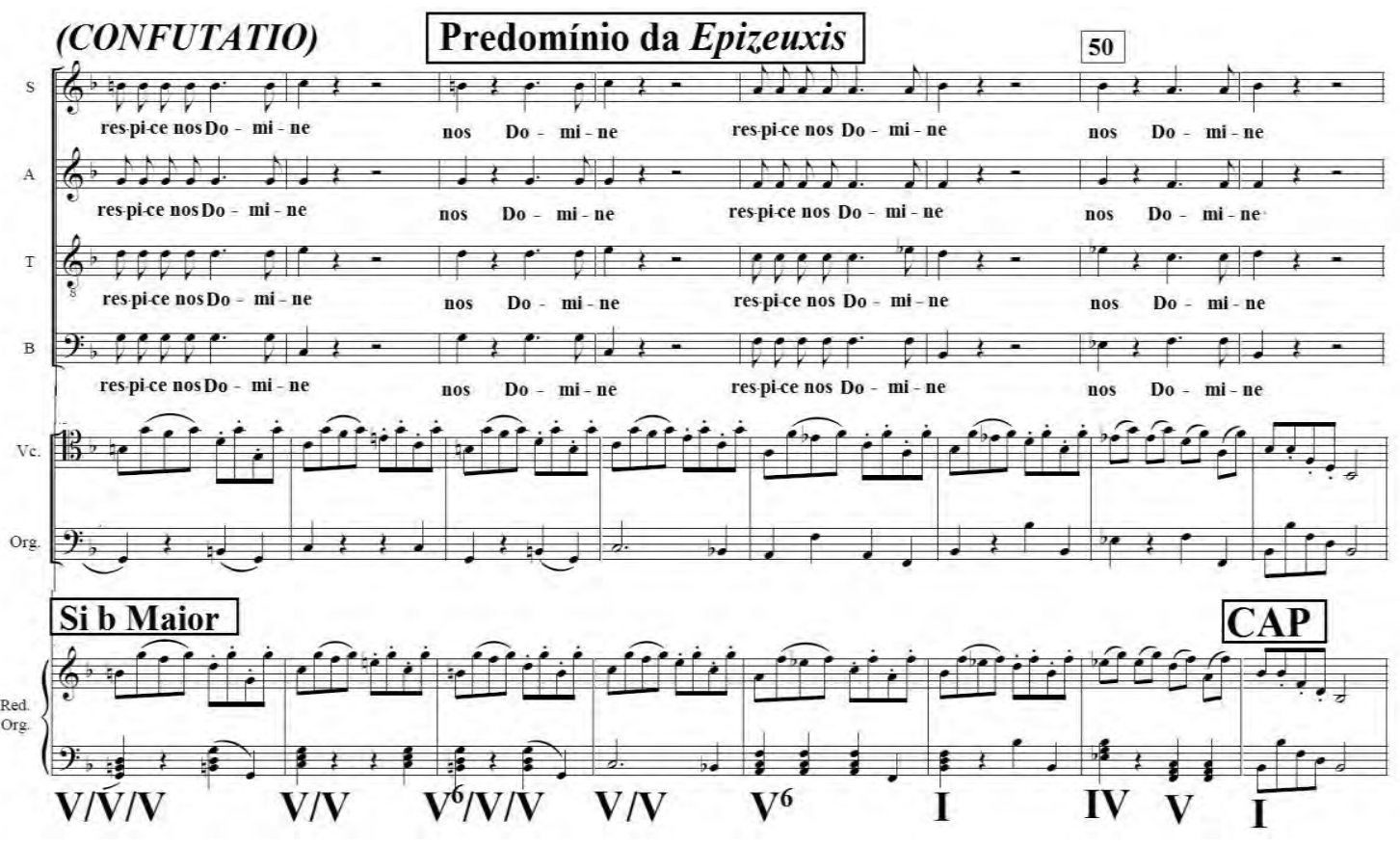

Exemplo 119-Exaudi nos, Domine para Benção de Cinzas da Missa para Quarta-feira de Cinzas de José Joaquim Emerico Lobo de Mesquita - Edição-Rafael Sales Arantes (LOBO DE MESQUITA, 2014 [1778], pp.12-14). 


\subsection{Confirmatio}

Nesse excerto, nota-se a mudança de tonalidade de Si bemol Maior no compasso 51, para sua relativa Sol Menor, até que, no final do compasso 56, acontece o retorno para o tom inicial da peça, Fá Maior. Outro aspecto a ser ressaltado é o solo lamentoso na voz do tenor evidenciando o afeto de tristeza e angústia mediante a expressão Savum me fac Deus (Salva-me Deus), numa dinâmica piano.

Enfim, na parte final da Confirmatio, é visível o uso do Polyptoton, por Lobo de Mesquita, onde as melodias e as frases são repetidas em alturas diferentes, isto é, na voz do tenor e baixo, entre os compassos 56 e 60, destacando a frase quoniam intraverunt aquæ usque ad animan meam (porque as águas submergiram a minha alma), resolvendo na Semicadência.

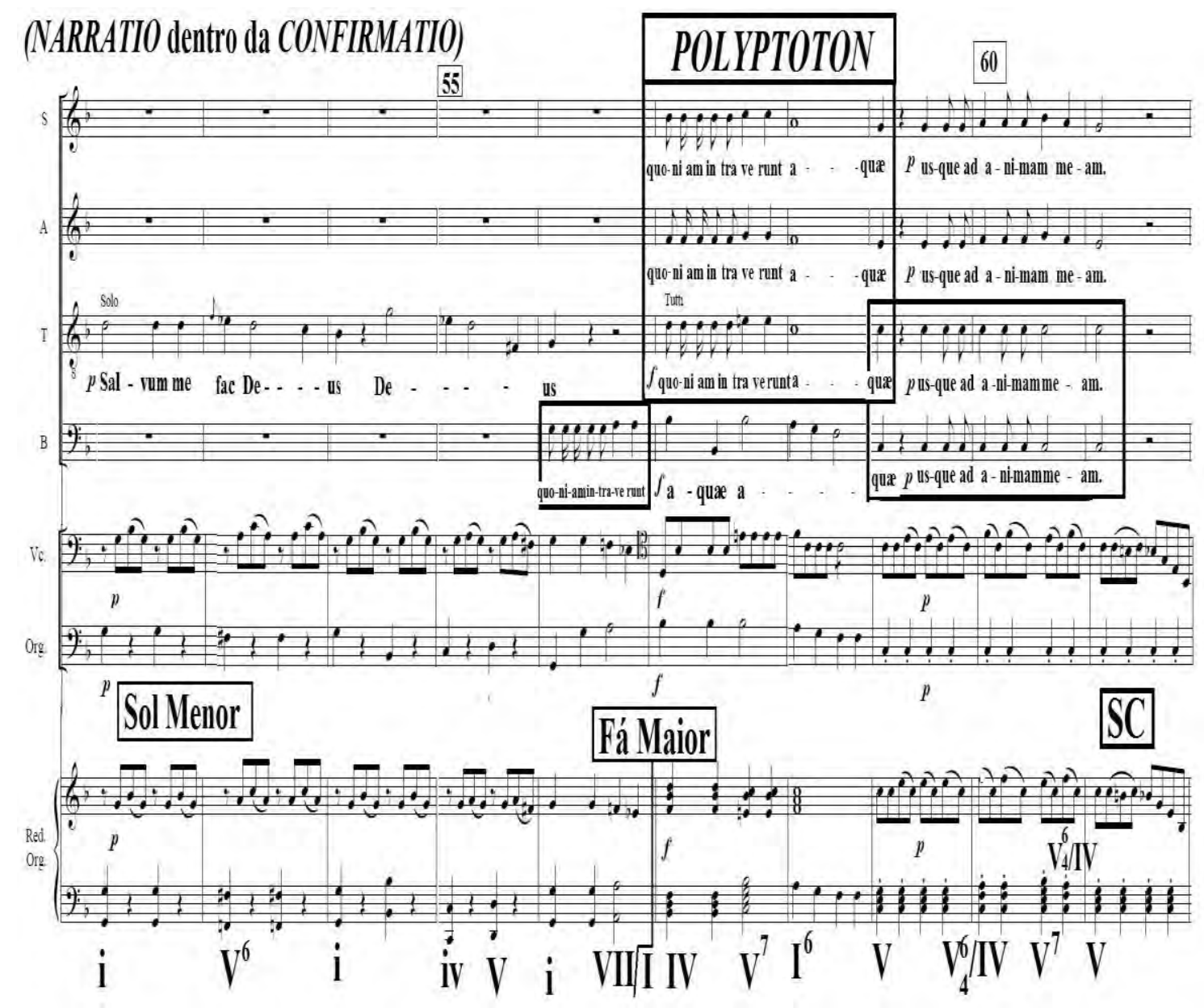

Exemplo 120-Exaudi nos, Domine para Benção de Cinzas da Missa para Quarta-feira de Cinzas de José Joaquim Emerico Lobo de Mesquita - Edição-Rafael Sales Arantes (LOBO DE MESQUITA, 2014 [1778], pp.14-15). 


\subsection{Peroratio}

O término do discurso se dá com a mesma repetição enfática articulada pelo compositor ao longo da obra. Ou seja, por meio da Epizeuxis, ressaltando a expressão usque ad animan mean numa Cadência Autêntica Imperfeita.

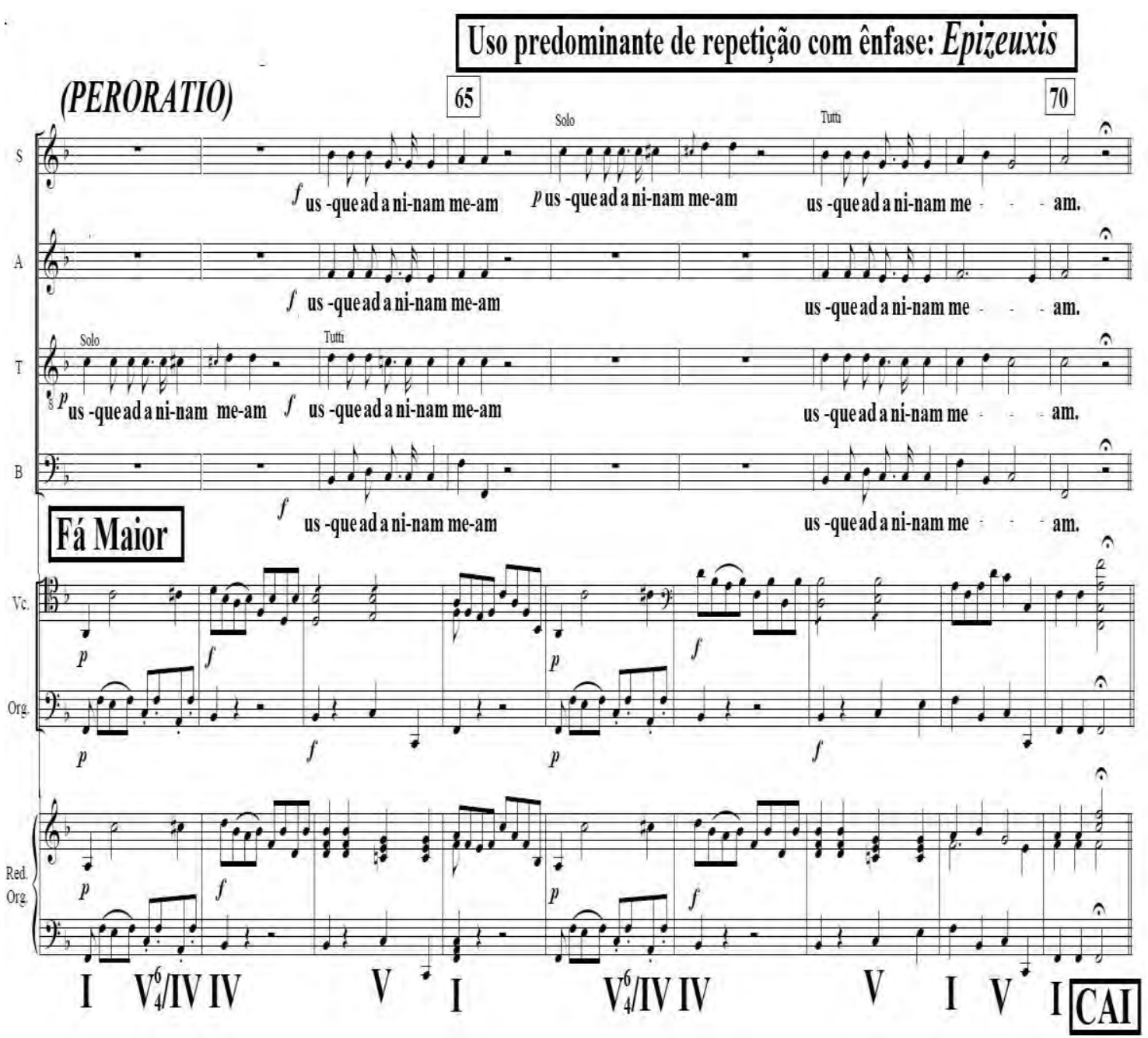

Exemplo 121-Exaudi nos, Domine para Benção de Cinzas da Missa para Quarta-feira de Cinzas de José Joaquim Emerico Lobo de Mesquita - Edição -Rafael Sales Arantes (LOBO DE MESQUITA, 2014 [1778], pp.16-18). 


\section{Figuras observadas no Exaudi nos, Domine (Elocutio/Decoratio)}

Tabela 27-Figuras retóricas localizadas no Exaudi nos, Domine de José Joaquim Emerico Lobo de Mesquita.

\begin{tabular}{|c|c|c|c|}
\hline $\begin{array}{l}\text { FIGURAS } \\
\text { CITAÇÕES }\end{array}$ & TIPO & DESCRIÇÃO & TRATADISTA \\
\hline $\begin{array}{l}\text { EPIZEUXIS } \\
\text { (BARTEL, 1997, } \\
\text { pp.263-265). }\end{array}$ & $\begin{array}{l}\text { Repetição } \\
\text { Melódica }\end{array}$ & $\begin{array}{l}\text { Uma repetição } \\
\text { imediata e } \\
\text { enfática de uma } \\
\text { palavra, nota, } \\
\text { motivo ou frase. }\end{array}$ & $\begin{array}{l}\text { Johann Gottfried } \\
\text { Walther: A Epizeuxis } \\
\text { é uma figura de } \\
\text { retórica pela qual uma } \\
\text { ou mais palavras são } \\
\text { imediatamente } \\
\text { enfaticamente } \\
\text { repetidas. }\end{array}$ \\
\hline $\begin{array}{l}\text { POLYPTOTON } \\
\text { (BARTEL, 1997, } \\
\text { pp.367-369). } \\
\text { (BUELOW, 2001, } \\
\text { p.264). }\end{array}$ & $\begin{array}{l}\text { Repetição } \\
\text { Melódica }\end{array}$ & $\begin{array}{|lr|}\text { A repetição } & \text { de } \\
\text { uma passagem } \\
\text { melódica } \quad \text { em } \\
\text { diferentes } & \\
\text { alturas. } & \end{array}$ & $\begin{array}{l}\text { Mauritius Johann } \\
\text { Vogt: Polyptoton é } \\
\text { quando uma } \\
\text { passagem é repetida } \\
\text { em várias alturas. }\end{array}$ \\
\hline $\begin{array}{l}\text { SYNCOPE } \\
\text { (BARTEL, 1997, } \\
\text { pp.396-405). }\end{array}$ & $\begin{array}{l}\text { Dissonância e } \\
\text { Deslocamento }\end{array}$ & $\begin{array}{l}\text { A suspensão, } \\
\text { com ou sem } \\
\text { dissonância } \\
\text { resultante. }\end{array}$ & $\begin{array}{lr}\text { Johann } & \text { Gottfried } \\
\text { Walther: } \\
\text { Consonâncias } \\
\text { são alteradas para } \\
\text { dissonâncias. }\end{array}$ \\
\hline
\end{tabular}

\section{Análise Harmônica}

\subsection{Curva Tonal}

Tonalidade: Fá Maior

Andamento: Andante 4/4

Tabela 28-Esquema de Progressões Harmônicas- Curva Tonal do Exaudi nos, Domine para Benção de Cinzas da Missa para Quarta-feira de Cinzas.

\begin{tabular}{|l|c|l|}
\hline \multicolumn{1}{|c|}{ Compassos } & Função & \multicolumn{1}{c|}{ Tonalidade } \\
\hline $1-3$ & I & Fá Maior \\
\hline 3 & IV & Si b Menor \\
\hline $4-5$ & I & Fá Maior \\
\hline 5 & IV & Si b Maior \\
\hline $6-16$ & I & Fá Maior \\
\hline
\end{tabular}




\begin{tabular}{|l|c|l|}
\hline 16 & IV & Si b Maior \\
\hline $17-19$ & I & Fá Maior \\
\hline 19 & IV & Si b Maior \\
\hline $20-21$ & I & Fá Maior \\
\hline $21-23$ & V & Dó Maior \\
\hline $23-24$ & I & Fá Maior \\
\hline $25-26$ & V & Dó Maior \\
\hline $26-27$ & I & Fá Maior \\
\hline $28-32$ & V & Dó Maior \\
\hline 33 & V/V & Sol Maior \\
\hline $34-35$ & ii & Sol Menor \\
\hline $36-37$ & vi & Ré Menor \\
\hline $38-43$ & IV & Si b Maior \\
\hline $44-48$ & I & Fá Maior \\
\hline $49-51$ & IV & Si b Maior \\
\hline $52-56$ & ii & Sol Menor \\
\hline $57-59$ & I & Fá Maior \\
\hline $59-60$ & IV & Si b Maior \\
\hline $61-62$ & I & Fá Maior \\
\hline $62-63$ & IV & Si b Maior \\
\hline $64-66$ & I & Fá Maior \\
\hline $66-67$ & IV & Si b Menor \\
\hline $68-70$ & I & Fá Maior \\
\hline
\end{tabular}

\subsection{Estrutura Analítica da obra: Retórica e Harmônica}

Tabela 29-Estrutura analítica da obra.

\begin{tabular}{|l|l|l|l|c|}
\hline $\begin{array}{c}\text { RETÓRICA } \\
\text { DISPOSITIO }\end{array}$ & \multicolumn{1}{|c|}{$\begin{array}{c}\text { FIGURA } \\
\text { ELOCUTIO }\end{array}$} & COMP. & TONALIDADE & FUNÇÃO \\
\hline EXORDIUM & $-1-6$ & Fá Maior & I \\
\hline NARRATIO & Epizeuxis & $7-14$ & Fá Maior & I \\
\hline PROPOSITIO & Epizeuxis & $16-22$ & Fá Maior & I \\
\hline CONFUTATIO & Syncope & $23-28$ & Dó Maior & Vi \\
\hline CONFIRMATIO & Polyptoton & $34-35$ & Ré Menor & IV \\
\hline PERORATIO & Epizeuxis & $38-51$ & Si b Maior & $\mathrm{I}$ \\
\hline
\end{tabular}


6.2.1.1. Análise Retórico-Musical da segunda e terceira parte para Bênçãos de Cinzas (Gloria Patri e Sicut erat), da Missa para Quarta-feira de Cinzas

\title{
1. Inventio
}

Logo após o término do Salmo com o título Exuadi nos Domine (Atendenos Senhor), inicia-se o Gloria Patri, que é uma doxologia:

\author{
Gloria Patri et Fliho et Spiritui Sactuo \\ Sicut erat in princípio et nunc et semper \\ Et in sæcula sæculorum. Amem \\ Gloria ao Pai e ao Filho e ao Espírito Santo \\ Como era no princípio agora e sempre \\ Por séculos e séculos. Amém (MORETZSOHN, 1997, p.26).
}

Enfim, a segunda e terceira parte dessa obra é constituída por trinta e cinco compassos em dois andamentos: Moderato e Allegro na tonalidade Fá Maior, onde cada elemento retórico é trabalhado pelo autor, com a intenção de despertar no ouvinte maior carga emotiva, mediante os afetos manifestados na mesma.

\subsection{Loci observados no Gloria Patri e Sicut erat}

Tabela 30-Loci Topici localizados no Gloria Patri e Sicut erat para Bênçãos de Cinzas, da Missa para Quarta-feira de Cinzas de José Joaquim Emerico Lobo de Mesquita.

\begin{tabular}{|c|c|c|c|}
\hline INVENTIO & DESCRIÇÃO & $\begin{array}{c}\text { UTILIZAÇÃO NA } \\
\text { OBRA }\end{array}$ & $\begin{array}{l}\text { COMPASSOI } \\
\text { VOZ }\end{array}$ \\
\hline $\begin{array}{l}\text { Locus Notationis } \\
\text { (MATTHESON, } \\
\text { 1954 [1739]. Parte } \\
\text { II, Cap.4, \& 23, } \\
\text { p.123). }\end{array}$ & $\begin{array}{l}\text { Aspecto } \\
\text { externo e } \\
\text { desenho das } \\
\text { notas (Duração } \\
\text { das notas, } \\
\text { alteração, } \\
\text { repetição e } \\
\text { procedimentos } \\
\text { canônicos). }\end{array}$ & $\begin{array}{l}\text { Vários motivos } \\
\text { rítmicos e diferentes } \\
\text { durações de notas } \\
\text { (semibreves, } \\
\text { mínimas, mínimas } \\
\text { pontuadas, } \\
\text { semínimas, } \\
\text { semínimas } \\
\text { pontuadas, } \\
\text { colcheias, } \\
\text { repetições, } \\
\text { ligaduras, pausas, } \\
\text { staccatos, } \\
\text { apogiatura, fermata, } \\
\text { entre outros). }\end{array}$ & $\begin{array}{ll}71-74 & \text { S-A-T-B } \\
75-82 & \text { S-A-T-B } \\
83-89 & \text { S-A-T-B } \\
90-97 & \text { S-A-T-B } \\
98-105 & \text { S-A-T-B }\end{array}$ \\
\hline
\end{tabular}




\begin{tabular}{|c|c|c|c|}
\hline $\begin{array}{l}\text { Locus Descriptionis } \\
\text { (MATTHESON, } \\
1954 \text { [1739]. Parte } \\
\text { II, Cap.4, § 43, } \\
\text { p.127). }\end{array}$ & $\begin{array}{l}\text { Disposições da } \\
\text { alma }\end{array}$ & $\begin{array}{l}\text { Devoção, louvor, } \\
\text { glorificação (Gloria ao } \\
\text { Pai e ao Filho e ao } \\
\text { Espírito Santo). }\end{array}$ & 71-82 S-A-T-B \\
\hline $\begin{array}{l}\text { Locus } \\
\text { Circumstantiarum } \\
\text { (MATTHESON, } \\
\text { 1954 [1739]. Parte } \\
\text { II, Cap.4, § 77, } \\
\text { p.131). }\end{array}$ & $\begin{array}{l}\text { Diferentes } \\
\text { circunstâncias } \\
\text { de tempo, do } \\
\text { lugar e de } \\
\text { acontecimentos } \\
\text { anteriores. }\end{array}$ & $\begin{array}{l}\text { Como era no } \\
\text { príncipio agora e } \\
\text { sempre. } \\
\\
\begin{array}{l}\text { Por séculos e } \\
\text { séculos. }\end{array}\end{array}$ & $\begin{array}{l}83-89 \text { S-A-T-B } \\
90-97 \text { S-A-T-B }\end{array}$ \\
\hline $\begin{array}{l}\text { Locus Oppositorum } \\
\text { (MATTHESON, } \\
1954 \text { [1739]. Parte } \\
\text { II, Cap.4, § 80, } \\
\text { p.131). }\end{array}$ & $\begin{array}{l}\text { Contraste de } \\
\text { compassos, } \\
\text { movimentos } \\
\text { contrários, } \\
\text { agudos e } \\
\text { graves, lento } \\
\text { e rápido, } \\
\text { calmo e } \\
\text { agitado. }\end{array}$ & $\begin{array}{l}\text { Movimento } \\
\text { contrário entre } \\
\text { soprano e baixo, } \\
\text { contralto e baixo. }\end{array}$ & 104-105 S-A-B \\
\hline
\end{tabular}

\section{Dispositio}

\subsection{Exordium, Narratio e Propositio}

Observa-se, nesse trecho, o predomínio da figura central da peça, isto é, da Epizeuxis, inserida pelo compositor mineiro para enfatizar a expressão Gloria, a qual expressa o afeto de louvor e devoção. Também, verifica-se o efeito sonoro propiciado pelas dinâmicas piano e forte, além da manutenção entre os compassos 71 e 82, a tonalidade Fá Maior, com resolução na Semicadência. 


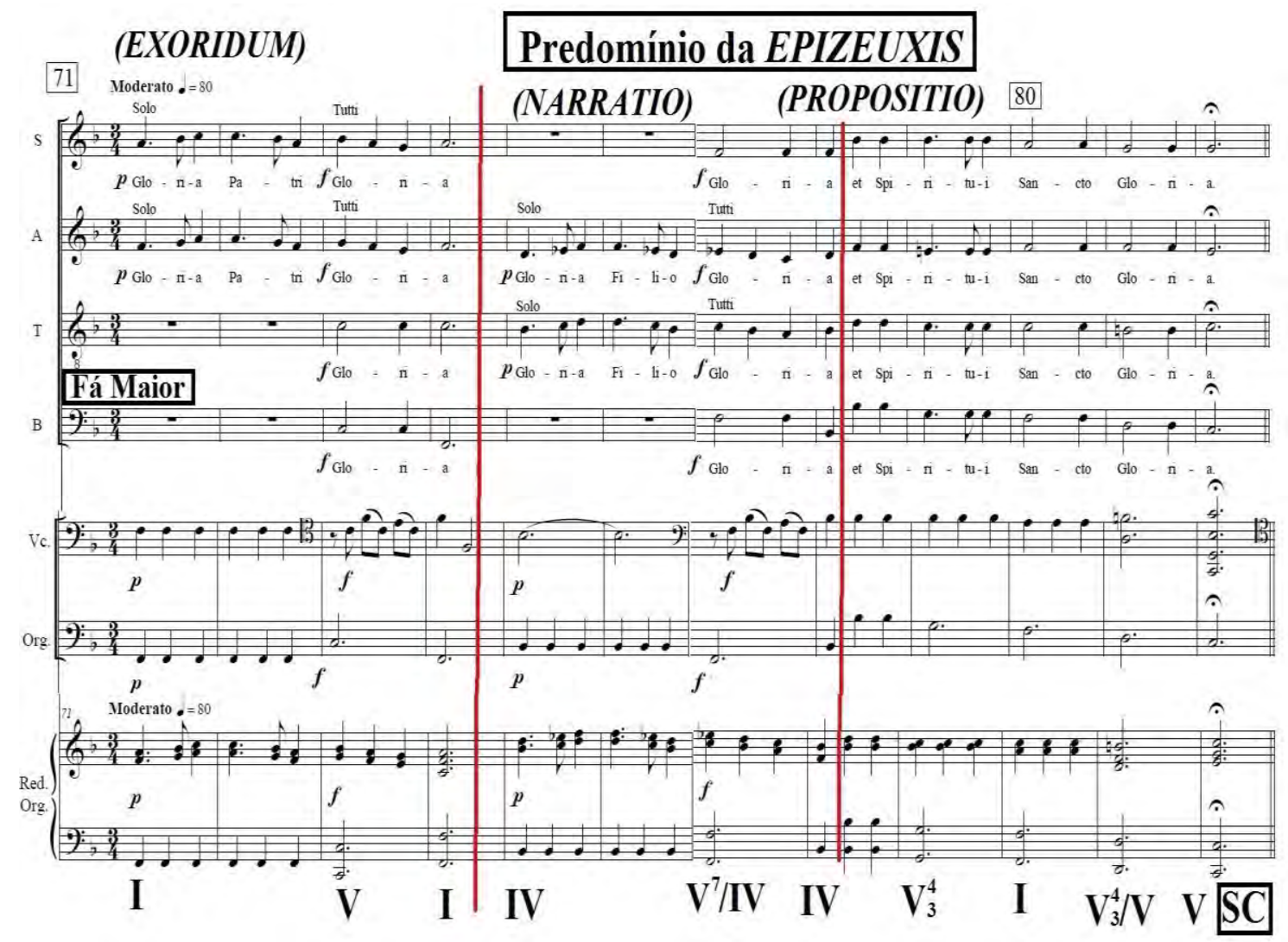

Exemplo 122-Gloria Patri para Benção de Cinzas da Missa para Quarta-feira de Cinzas de José Joaquim Emerico Lobo de Mesquita - Edição e Redução para Órgão-Rafael Sales Arantes (LOBO DE MESQUITA, 2014 [1778], pp.18-20).

\subsection{Confutatio, Confirmatio e Peroratio}

No presente excerto, são localizados os três elementos retóricos da Dispositio: Confutatio, Confirmatio e Peroratio. No primeiro, nota-se a utilização do Polyptoton, repetindo a mesma sequência de notas na voz do contralto e do baixo, como da Synaeresis, ressaltando a entoação realizada pelas vozes da soprano e tenor das notas Lá, Si bemol e Fá, Sol na sílaba et. Igualmente, é verificável que Lobo de Mesquita aplica a dinâmica forte em consonância ao Pedal de Tônica e as figuras citadas, para destacar a frase Sicut erat in princípio et nunc et semper (Como era no princípio, agora e sempre). Além disso, há que se salientar o final dessa seção numa Cadência de Engano.

No segundo elemento, é examinável o diálogo estabelecido entre as dinâmicas piano e forte como do solo do tenor e soprano com as outras vozes, entre os compassos 90 e 97, as quais realçam a expressão Et in sæcula sæculorum (Por séculos e séculos). 
Por fim, é evidente o uso da Epizeuxis, repetindo, de maneira enfática, a palavra Amem, bem como das funções harmônicas Subdominante, Dominante e Tônica, e o encerramento do discurso na Cadência Autêntica Imperfeita.
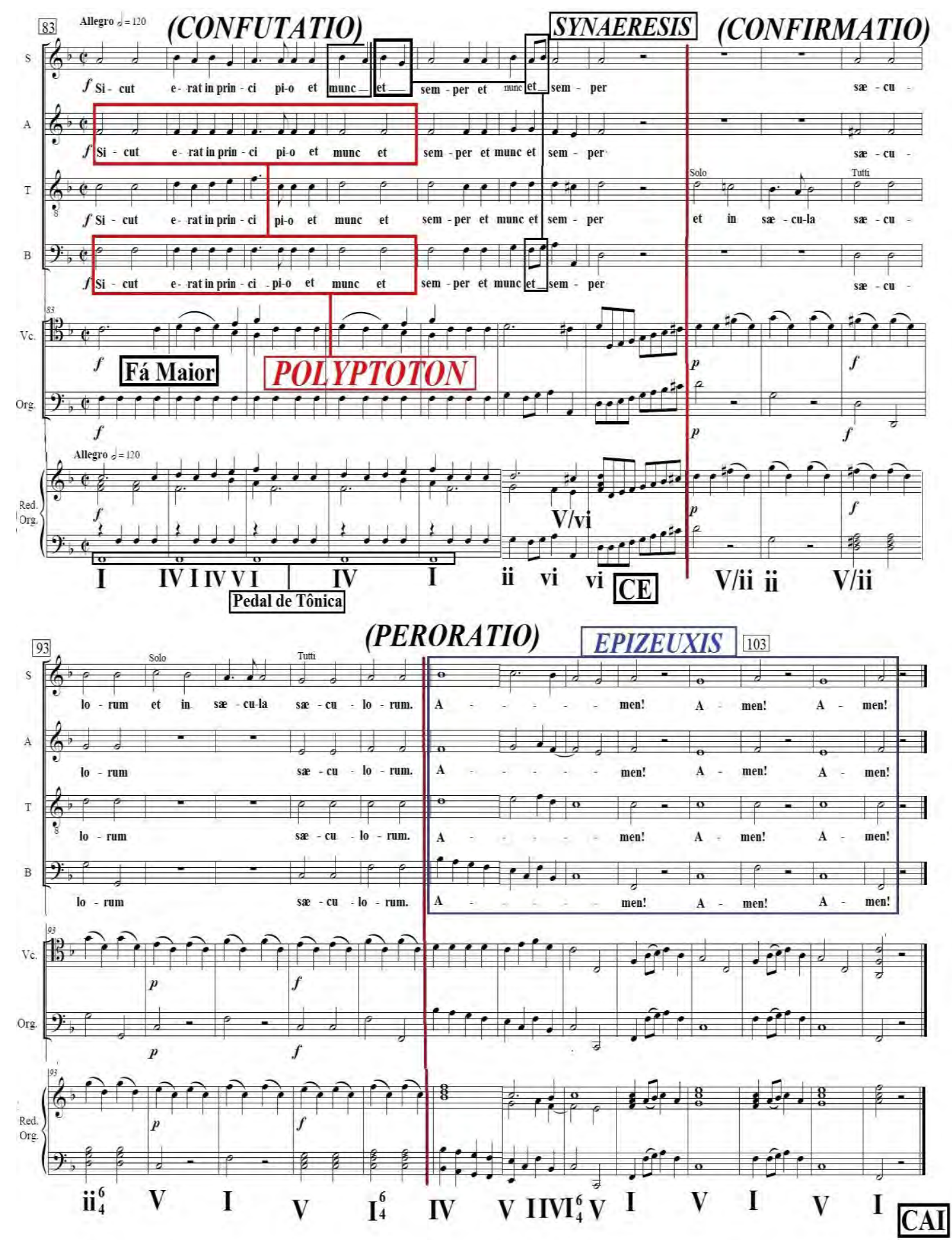

Exemplo 123-Sicut erat para Benção de Cinzas da Missa para Quarta-feira de Cinzas de José Joaquim Emerico Lobo de Mesquita - Edição e Redução para Orgão-Rafael Sales Arantes (LOBO DE MESQUITA, 2014 [1778], pp.20-24). 


\section{Figuras observadas no Gloria Patri e Sicut erat (Elocutio/Decoratio)}

Tabela 31-Figuras retóricas localizadas no Gloria Patri e Sicut erat de José Joaquim Emerico Lobo de Mesquita.

\begin{tabular}{|c|c|c|c|}
\hline $\begin{array}{l}\text { FIGURAS } \\
\text { CITAÇÕES }\end{array}$ & TIPO & DESCRIÇÃO & TRATADISTA \\
\hline $\begin{array}{l}\text { EPIZEUXIS } \\
\text { (BARTEL, 1997, } \\
\text { pp.263-265). }\end{array}$ & $\begin{array}{l}\text { Repetição } \\
\text { Melódica }\end{array}$ & $\begin{array}{l}\text { Uma repetição } \\
\text { imediata e } \\
\text { enfática de uma } \\
\text { palavra, nota, } \\
\text { motivo ou frase. }\end{array}$ & $\begin{array}{l}\text { Johann Gottfried } \\
\text { Walther: A Epizeuxis } \\
\text { é uma figura de } \\
\text { retórica pela qual uma } \\
\text { ou mais palavras são } \\
\text { imediatamente } \\
\text { enfaticamente } \\
\text { repetidas. }\end{array}$ \\
\hline $\begin{array}{l}\text { POLYPTOTON } \\
\text { (BARTEL, 1997, } \\
\text { pp.367-369). } \\
\text { (BUELOW, 2001, } \\
\text { p.264). }\end{array}$ & $\begin{array}{l}\text { Repetição } \\
\text { Melódica }\end{array}$ & $\begin{array}{l}\text { A repetição de } \\
\text { uma passagem } \\
\text { melódica em } \\
\text { diferentes } \\
\text { alturas. }\end{array}$ & $\begin{array}{l}\text { Mauritius Johann } \\
\text { Vogt: Polyptoton é } \\
\text { quando } \text { uma } \\
\text { passagem é repetida } \\
\text { em várias alturas. }\end{array}$ \\
\hline $\begin{array}{l}\text { SYNAERESIS } \\
\text { (BARTEL, 1997, } \\
\text { pp.394-396). } \\
\text { (LÓPEZ CANO, } \\
\text { 2000, p.199). }\end{array}$ & $\begin{array}{l}\text { Dissonância e } \\
\text { Deslocamento }\end{array}$ & $\begin{array}{l}\text { (1) Uma } \\
\text { suspensão ou } \\
\text { síncope, (2) A } \\
\text { colocação de } \\
\text { duas sílabas por } \\
\text { nota ou duas } \\
\text { notas por } \\
\text { sílaba. }\end{array}$ & $\begin{array}{l}\text { Mauritius Johann } \\
\text { Vogt: A Synaeresis } \\
\text { ocorre quando duas } \\
\text { notas são colocadas } \\
\text { em uma sílaba ou } \\
\text { duas sílabas são } \\
\text { colocadas em uma } \\
\text { nota. }\end{array}$ \\
\hline
\end{tabular}

\section{Análise Harmônica (Gloria Patri e Sicut erat)}

\subsection{Curva Tonal}

Tonalidade: Fá Maior

Andamento: Moderato 3/4 e Allegro $\phi$

Tabela 32-Esquema de Progressões Harmônicas- Curva Tonal do Gloria Patri para Benção de Cinzas da Missa para Quarta-feira de Cinzas.

\begin{tabular}{|l|c|l|}
\hline \multicolumn{1}{|c|}{ Compassos } & Função & \multicolumn{1}{|c|}{ Tonalidade } \\
\hline $71-74$ & I & Fá Maior \\
\hline $75-78$ & IV & Si b Maior \\
\hline
\end{tabular}




\begin{tabular}{|l|c|l|}
\hline $79-82$ & V & Dó Maior \\
\hline $83-87$ & I & Fá Maior \\
\hline $88-89$ & vi & Ré Menor \\
\hline $90-93$ & ii & Sol Menor \\
\hline 94 & V & Dó Maior \\
\hline 95 & I & Fá Maior \\
\hline $96-100$ & V & Dó Maior \\
\hline $101-105$ & I & Fá Maior \\
\hline
\end{tabular}

\subsection{Estrutura Analítica da obra: Retórica e Harmônica}

Tabela 33-Estrutura analítica da obra.

\begin{tabular}{|l|l|l|l|c|}
\hline \multicolumn{1}{|c|}{$\begin{array}{c}\text { RETÓRICA } \\
\text { DISPOSITIO }\end{array}$} & \multicolumn{1}{|c|}{$\begin{array}{c}\text { FIGURA } \\
\text { ELOCUTIO }\end{array}$} & COMP. & TONALIDADE & FUNÇÃO \\
\hline EXORDIUM & Epizeuxis & $71-74$ & Fá Maior & I \\
\hline NARRATIO & Epizeuxis & $75-78$ & Fá Maior & I \\
\hline \multirow{2}{*}{ PROPOSITIO } & & $78-82$ & Fá Maior & I \\
\cline { 2 - 6 } & & 88 & Fá Maior & I \\
\hline CONFUTATIO & Synaeresis & $90-97$ & Fá Maior & I \\
\hline CONFIRMATIO & & $98-105$ & Fá Maior & I \\
\cline { 2 - 5 } & & & & \\
\hline
\end{tabular}




\subsubsection{Análise Retórico-Musical no Kyrie da Ladainha em Si bemol Maior $^{119}$}

\section{Inventio}

Como prece litúrgica disposta em forma de invocações a Deus, a Jesus Cristo, à Virgem e aos santos, a Ladainha é o momento onde o fiel pede insistente e humildemente pela piedade e perdão das transgressões cometidas. José Joaquim Emeirco Lobo de Mesquita ordena essa Ladainha em sete partes, sendo aqui analisada, a primeira:
1. Kyrie
2. Pater de cælis
3. Sancta Dei Genitrix
4. Rosa mystica
5. Consolatrix afflictorum
6. Regina Angelorum
7. Agnus Dei

Já concernente à estrutura textual do Kyrie dessa obra, pode-se verificar que o mesmo é embasado no Salmo penitencial 51, onde é descrito o encontro do profeta Natã com o rei Davi, depois de esse ter possuído Bate-Seba, o qual, arrependido, pede por misericórdia a Deus pelo pecado cometido. Analogamente, nos ritos tridentinos, ambrosianos, romanos, bizantinos, entre outros, o texto utilizado para o Kyrie segue esse padrão, entretanto, com algumas modificações a partir do século $\mathrm{VII}^{120}$ :
Kyrie eleison.
Christe eleison.
Kyrie eleison.
Christe audi nos.
Christe exaudi nos.

Senhor, tende piedade de nós.

Cristo, tende piedade de nós.

\footnotetext{
${ }^{119} \mathrm{~A}$ presente peça não possui data precisa, no entanto, há existência de cópias pertencentes ao Arquivo da Pia União do Pão de Santo Antônio (Diamantina - MG), à Coleção Curt Lange do Museu da Inconfidência (Ouro Preto-MG) e ao Museu da Música de Mariana (CASTAGNA, 2003, p. XV).

${ }^{120} \mathrm{De}$ acordo com Paulo Castagna, a Ladainha originada na procissão de rogações e de penitência, praticada em Roma desde o século VI, já incluía as invocações iniciais Kyrie eleison, Christe eleison, Christe audi nos, Christe exaudi nos, usadas até nos dias atuais. No entanto, novas invocações foram acrescentadas entre os séculos VII e IX, como as dos Santos, sempre respondidas pelo povo com ora pro nobis (rogai por nós) (CASTAGNA, 2003, p. XIII).
} 
Senhor, tende piedade de nós.

Cristo, ouvi-nos.

Cristo, atendei-nos.

Em conclusão, essa música é constituída por trinta e nove compassos, num andamento Andante na tonalidade Si bemol Maior, onde cada elemento retórico é empregado pelo autor conforme a circunstância do discurso.

\subsection{Loci observados na Inventio do Kyrie}

Tabela 34-Loci Topici localizados no Kyrie da Ladainha em Si bemol Maior de José Joaquim Emerico Lobo de Mesquita.

\begin{tabular}{|c|c|c|c|}
\hline INVENTIO & DESCRIÇÃO & $\begin{array}{c}\text { UTILIZAÇÃO NA } \\
\text { OBRA }\end{array}$ & $\begin{array}{l}\text { COMPASSOI } \\
\text { VOZ }\end{array}$ \\
\hline $\begin{array}{l}\text { Locus } \\
\text { Notationis } \\
\text { (MATTHESON, } \\
1954 \text { [1739]. } \\
\text { Parte II, Cap.4, } \\
\text { § 23, p.123). }\end{array}$ & $\begin{array}{l}\text { Aspecto externo } \\
\text { e desenho das } \\
\text { notas (Duração } \\
\text { das notas, } \\
\text { alteraçãa, } \\
\text { repetição e } \\
\text { procedimentos } \\
\text { canônicos). }\end{array}$ & $\begin{array}{l}\text { Vários motivos } \\
\text { rítmicos e diferentes } \\
\text { durações de notas } \\
\text { (semibreves, } \\
\text { mínimas, mínimas } \\
\text { pontuadas, } \\
\text { semínimas, } \\
\text { semínimas } \\
\text { pontuadas, colcheias, } \\
\text { colcheias pontuadas, } \\
\text { semicolcheias, } \\
\text { repetições, tremolos, } \\
\text { ligaduras, pausas, } \\
\text { staccatos, apogiatura, } \\
\text { fermata, entre outros). }\end{array}$ & $\begin{array}{ll}1-10 & \text { S-A-T-B } \\
11-14 & \text { S-A-T-B } \\
15-18 & \text { S-A-T-B } \\
19-26 & \text { S-A-T-B } \\
27-34 & \text { S-A-T-B } \\
35-39 & \text { S-A-T-B }\end{array}$ \\
\hline $\begin{array}{l}\text { Locus } \\
\text { Descriptionis } \\
\text { (MATTHESON, } \\
1954 \text { [1739]. } \\
\text { Parte II, Cap.4, } \\
\text { § 43, p.127). }\end{array}$ & $\begin{array}{l}\text { Disposições da } \\
\text { alma }\end{array}$ & $\begin{array}{l}\text { Súplica, oração, } \\
\text { petição por } \\
\text { misericórdia em toda } \\
\text { a obra (Senhor, tende } \\
\text { piedade de nós. } \\
\text { Cristo, tende piedade } \\
\text { de nós. Senhor, tende } \\
\text { piedade de nós. } \\
\text { Cristo, ouvi-nos. } \\
\text { Cristo, atendei-nos. }\end{array}$ & 1-39 S-A-T-B \\
\hline $\begin{array}{l}\text { Locus } \\
\text { Oppositorum } \\
\text { (MATTHESON, } \\
1954 \text { [1739]. } \\
\text { Parte II, Cap.4, }\end{array}$ & $\begin{array}{l}\text { Contraste de } \\
\text { compassos, } \\
\text { movimentos } \\
\text { contrários, } \\
\text { agudos e } \\
\text { graves, lento e }\end{array}$ & $\begin{array}{l}\text { Movimento contrário } \\
\text { entre soprano e baixo, } \\
\text { tenor e baixo. }\end{array}$ & $35 \quad$ S-T-B \\
\hline
\end{tabular}




\begin{tabular}{|l|l|l|l|}
\hline$\S 80$, p.131). & $\begin{array}{l}\text { rápido, calmo e } \\
\text { agitado. }\end{array}$ & & \\
\hline
\end{tabular}

\section{Dispositio}

\subsection{Exordium}

Observa-se, entre os compassos 1 e 10, a introdução da peça realizada pelo acompanhamento instrumental. Igualmente, verifica-se que o autor trabalha com elementos contrastantes em relação ao texto proposto, tais como a tonalidade que, em vez de só expressar momentos de reflexão submissa, humilhação perante o Senhor e de penitência, manifesta um momento de conclamação enfática por misericórdia a Deus, no entanto, com reflexão de regozijo, ou seja, o afeto de alegria: Laetitia. Por fim, podem ser ressaltadas as funções da Tônica, Subdominante, Dominante e Subdominante Paralela, resolvendo numa Cadência Autêntica Perfeita.

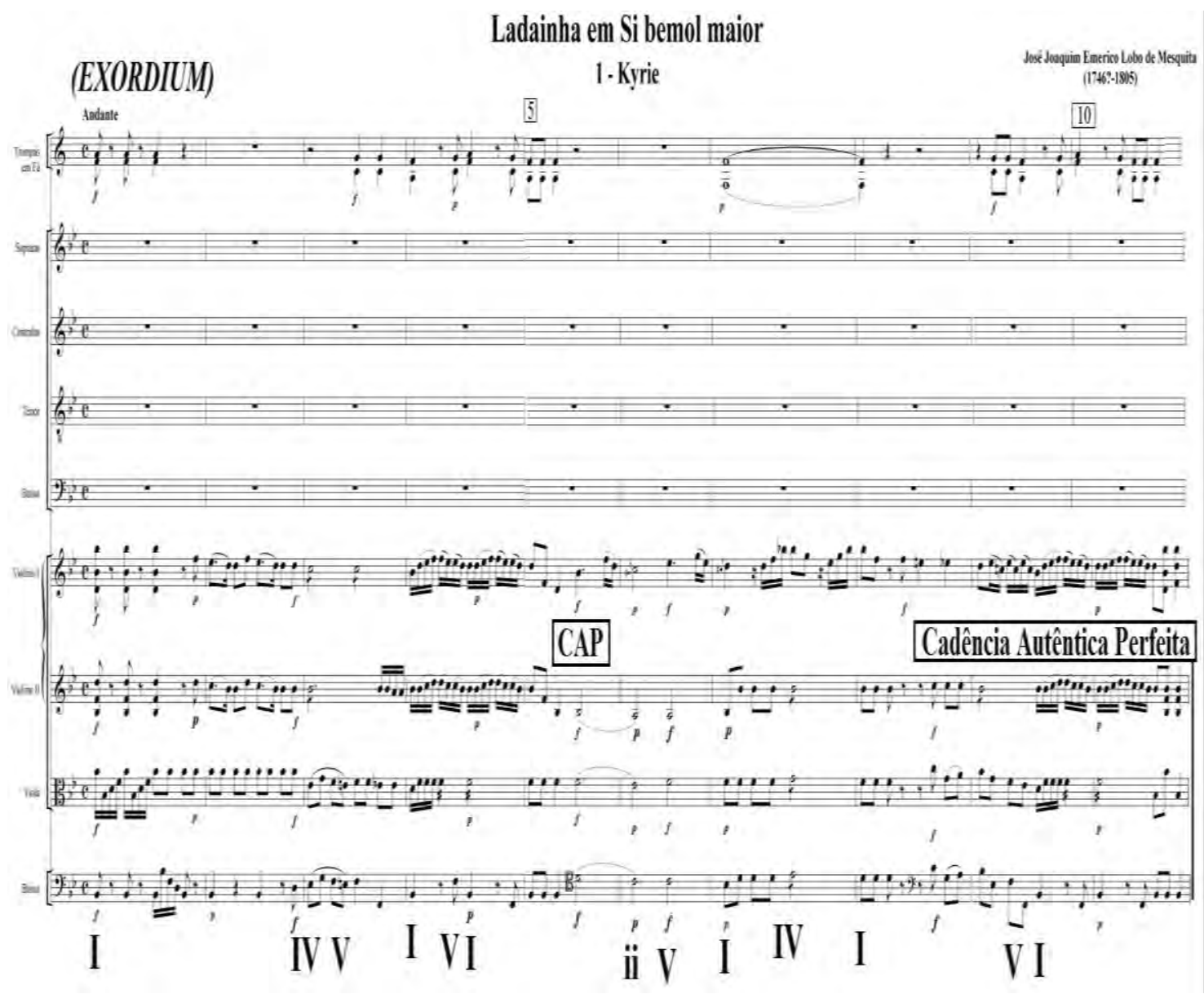

Exemplo 124-Kyrie da Ladainha em Si bemol Maior de José Joaquim Emerico Lobo de Mesquita- Edição André Guerra Cotta- Organização-Paulo Augusto Castagna (CASTAGNA, 2003, pp.1-2). 


\subsection{Narratio}

No compasso 11, pode ser verificado o emprego da Suspiratio por Lobo de Mesquita, para enfatizar a palavra Kyrie (Senhor). Semelhantemente, há de se ressaltar que, nesse momento, o autor, além de criar um efeito sonoro de um suspiro mediante as pausas, trabalha com as repetições enfáticas da palavra elesion, através da Epizeuxis, e também com as dinâmicas forte e piano para realçar o afeto de devoção e submissão do fiel, o qual, em sua súplica, pede ao Senhor por sua piedade e misericórdia, com conclusão na Cadência Autêntica Perfeita.

\section{(NARRATIO)}

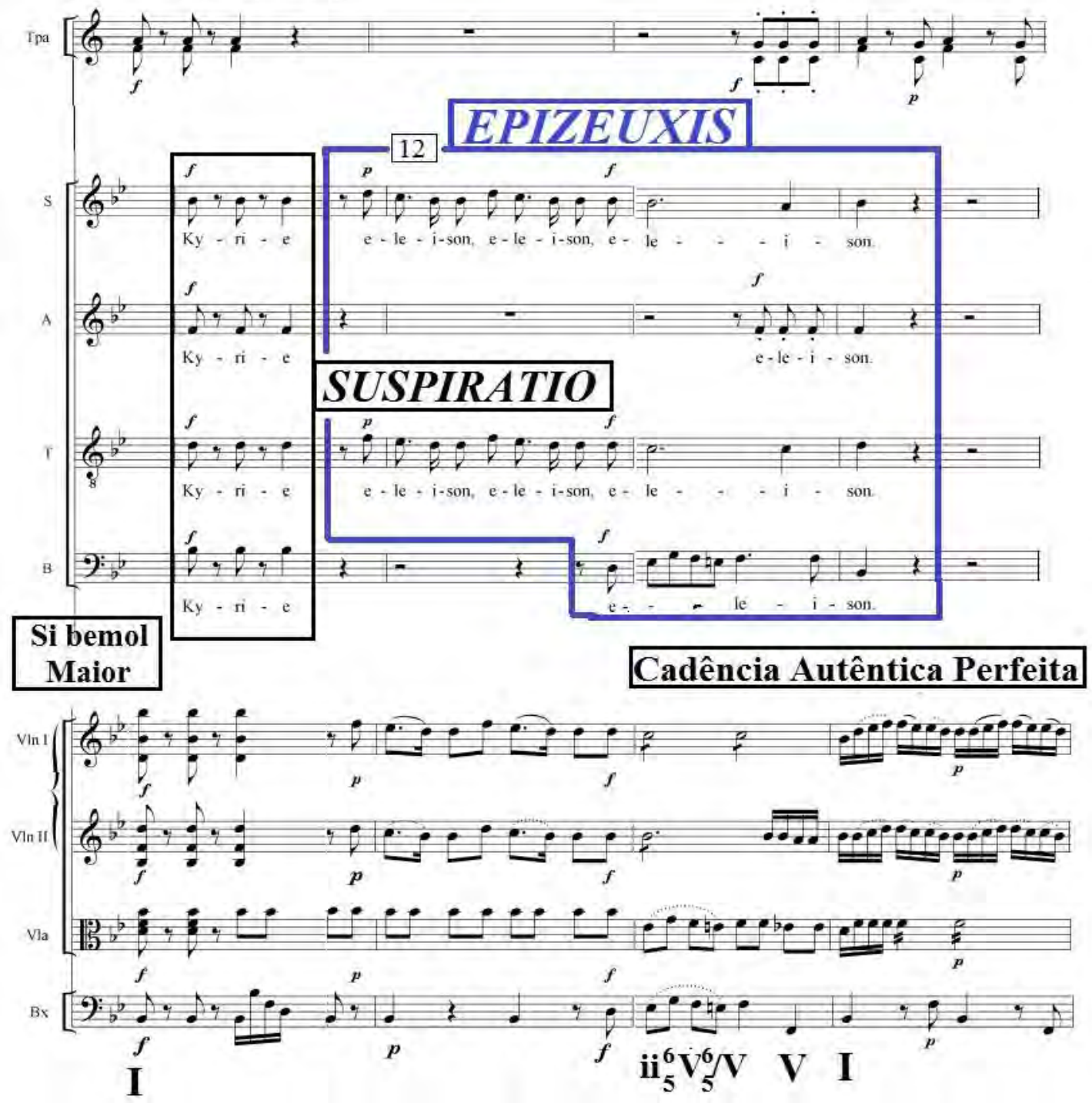

Exemplo 125-Kyrie da Ladainha em Si bemol Maior de José Joaquim Emerico Lobo de Mesquita - Edição André Guerra Cotta- Organização-Paulo Augusto Castagna (CASTAGNA, 2003, p.3-4). 


\subsection{Propositio}

Entre os compassos 16 e 19, é verificável o uso da Epizeuxis, repetindo as mesmas notas e a palavra eleison, por três vezes, enfatizando, dessa forma, tanto os efeitos propiciados pelas dinâmicas quanto a passagem entre Tônica, Subdominante Paralela, Dominante da Dominante e Dominante, terminando na Cadência Autêntica Imperfeita.

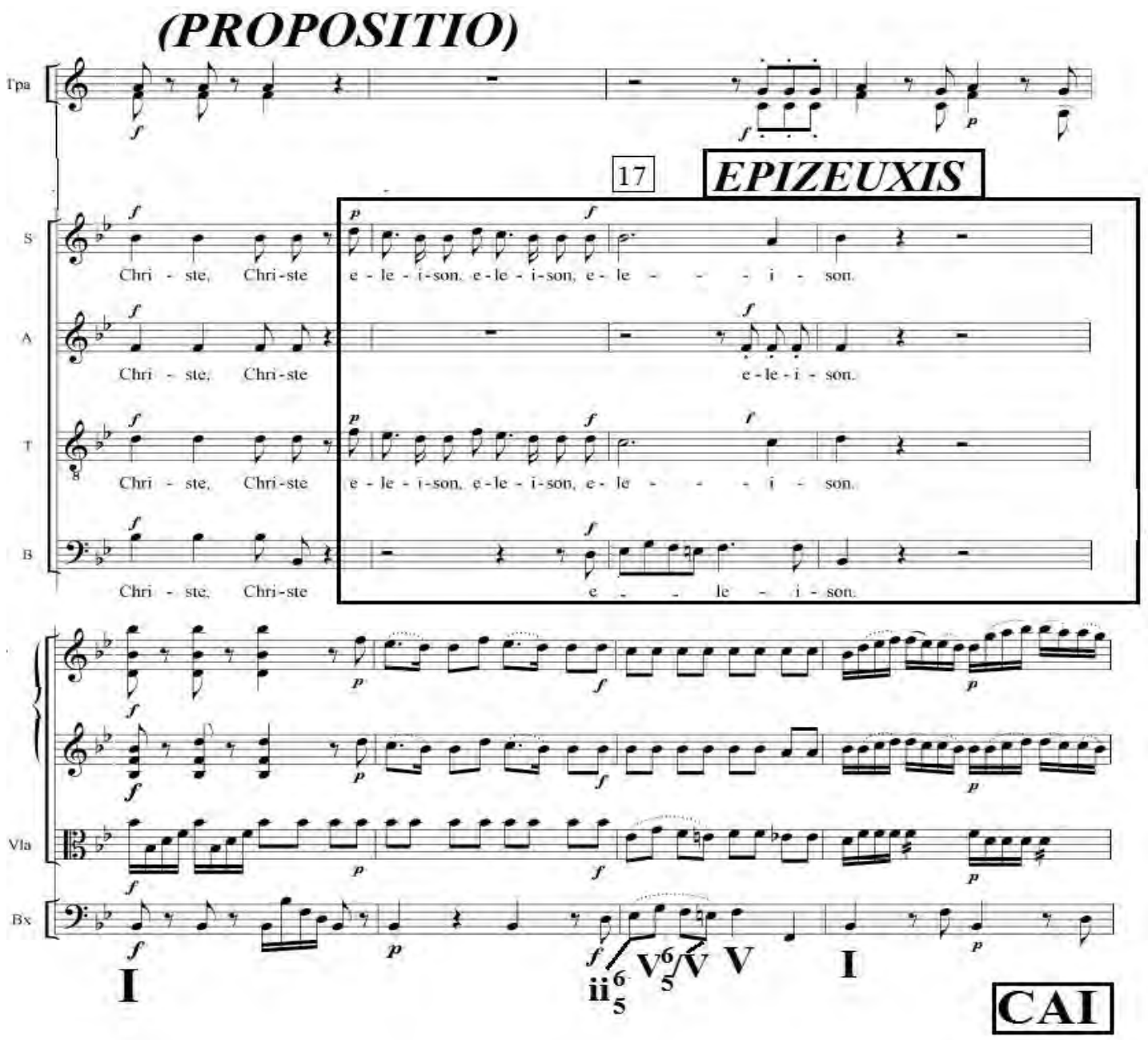

Exemplo 126-Kyrie da Ladainha em Si bemol Maior de José Joaquim Emerico Lobo de Mesquita - Edição André Guerra Cotta- Organização-Paulo Augusto Castagna (CASTAGNA, 2003, pp.4-5).

\subsection{Confutatio}

$\mathrm{Na}$ mesma obra, observam-se os mesmos recursos retórico-musicais usados pelo compositor anteriormente na Narratio, no entanto, na tonalidade Sol Menor e com resolução na Cadência Autêntica Imperfeita. 


\section{(CONFUTATIO)}

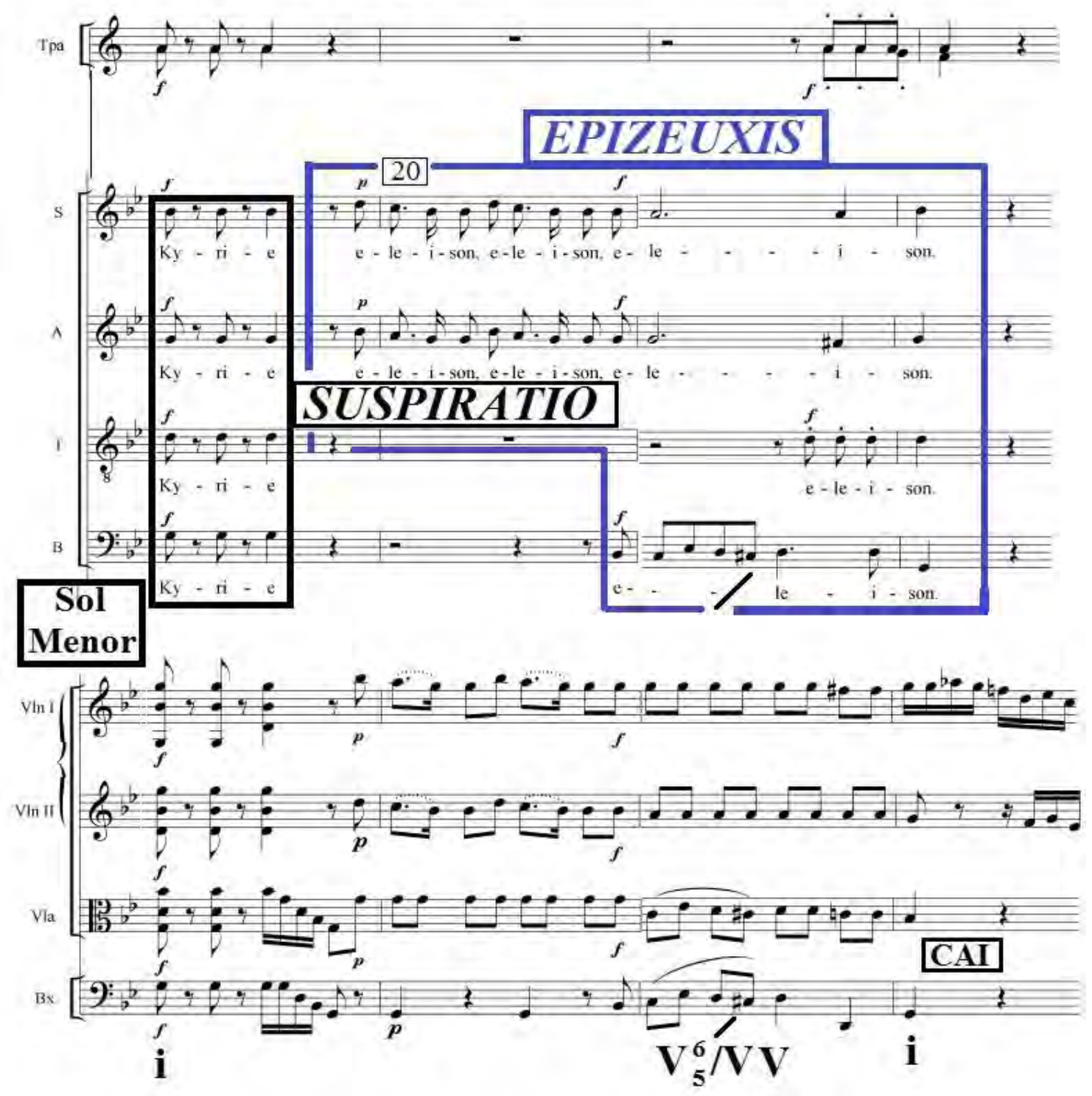

Exemplo 127-Kyrie da Ladainha em Si bemol Maior de José Joaquim Emerico Lobo de Mesquita - Edição André Guerra Cotta- Organização-Paulo Augusto Castagna (CASTAGNA, 2003, pp.5-6).

Lobo de Mesquita continua a atrair a atenção do ouvinte mediante a tonalidade paralela (relativa) à do início da peça. Do mesmo modo, nota-se que a expressão Christe audi nos (Cristo, ouvi-nos) é separada de maneira rápida, abrupta e sutil pelo compositor, com uma pausa de colcheia, todavia, num primeiro momento com um afeto de devoção e submissão, isto é, com suavidade, representada pela dinâmica piano, configurando assim uma Abruptio. Em seguida, após o breve descanso das vozes, o final da súplica é 
realizado com veemência e intensidade, representando, desse modo, por meio da dinâmica forte, o afeto de confiança e ânimo.

Enfim, ainda são destacáveis as funções da Tônica, Dominante da Subdominante, Subdominante, Dominante da Tônica Paralela, Tônica Paralela e a Sexta Aumentada Germânica terminando com a Dominante, na Semicadência.

(CONFUTATIO)

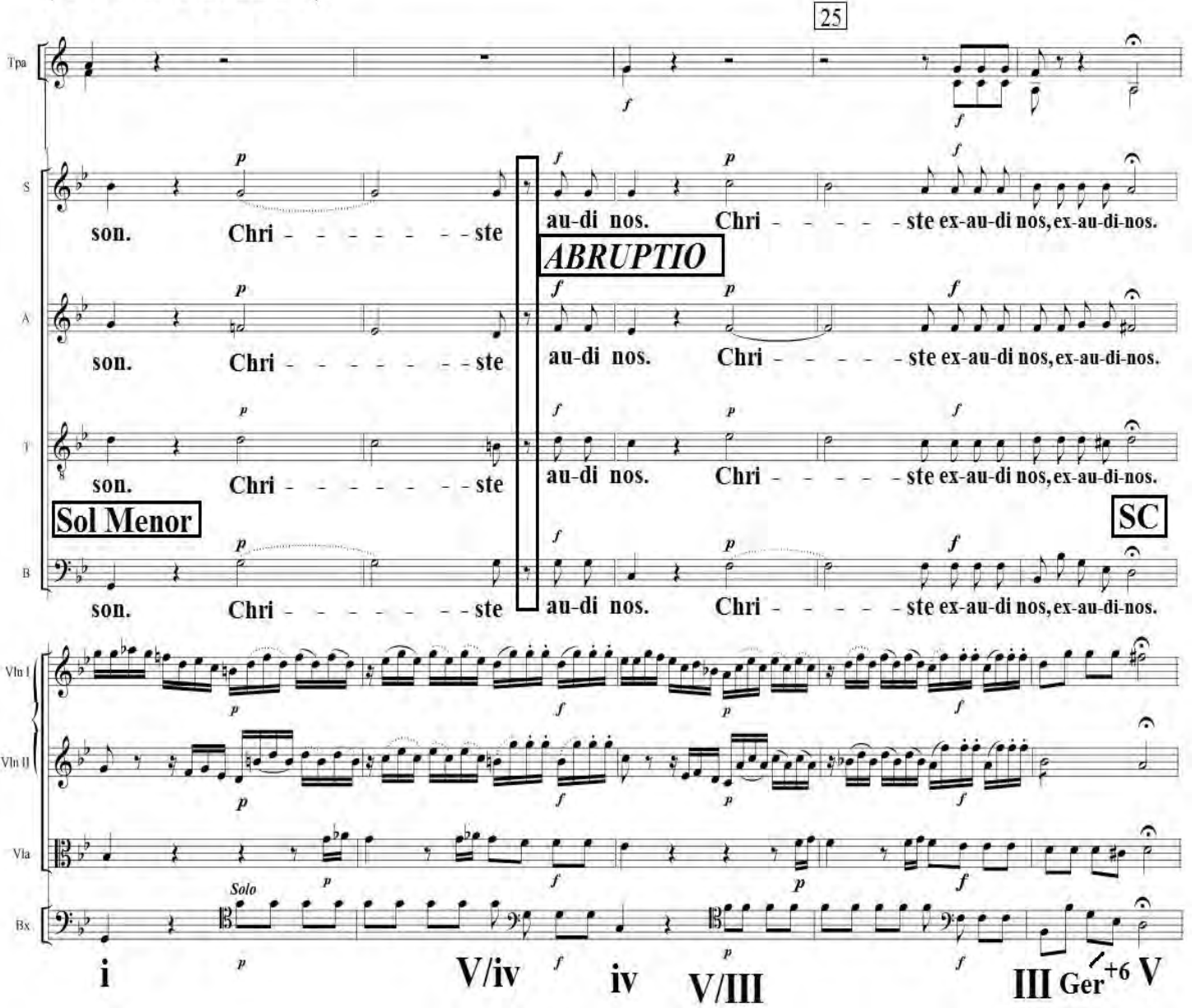

Exemplo 128-Kyrie da Ladainha em Si bemol Maior de José Joaquim Emerico Lobo de Mesquita - Edição André Guerra Cotta- Organização-Paulo Augusto Castagna (CASTAGNA, 2003, pp.-6-7).

\subsection{Confirmatio}

Nessa parte, o compositor mineiro continua a desenvolver seu propósito de atrair a atenção do ouvinte, mediante a repetição e ênfase, introduzindo a Climax e a Synaeresis. Semelhantemente, procura realçar ainda mais esse 
afeto de dedicação zelosa e unidade cristã, por meio do diálogo entre solo do tenor e das demais vozes.

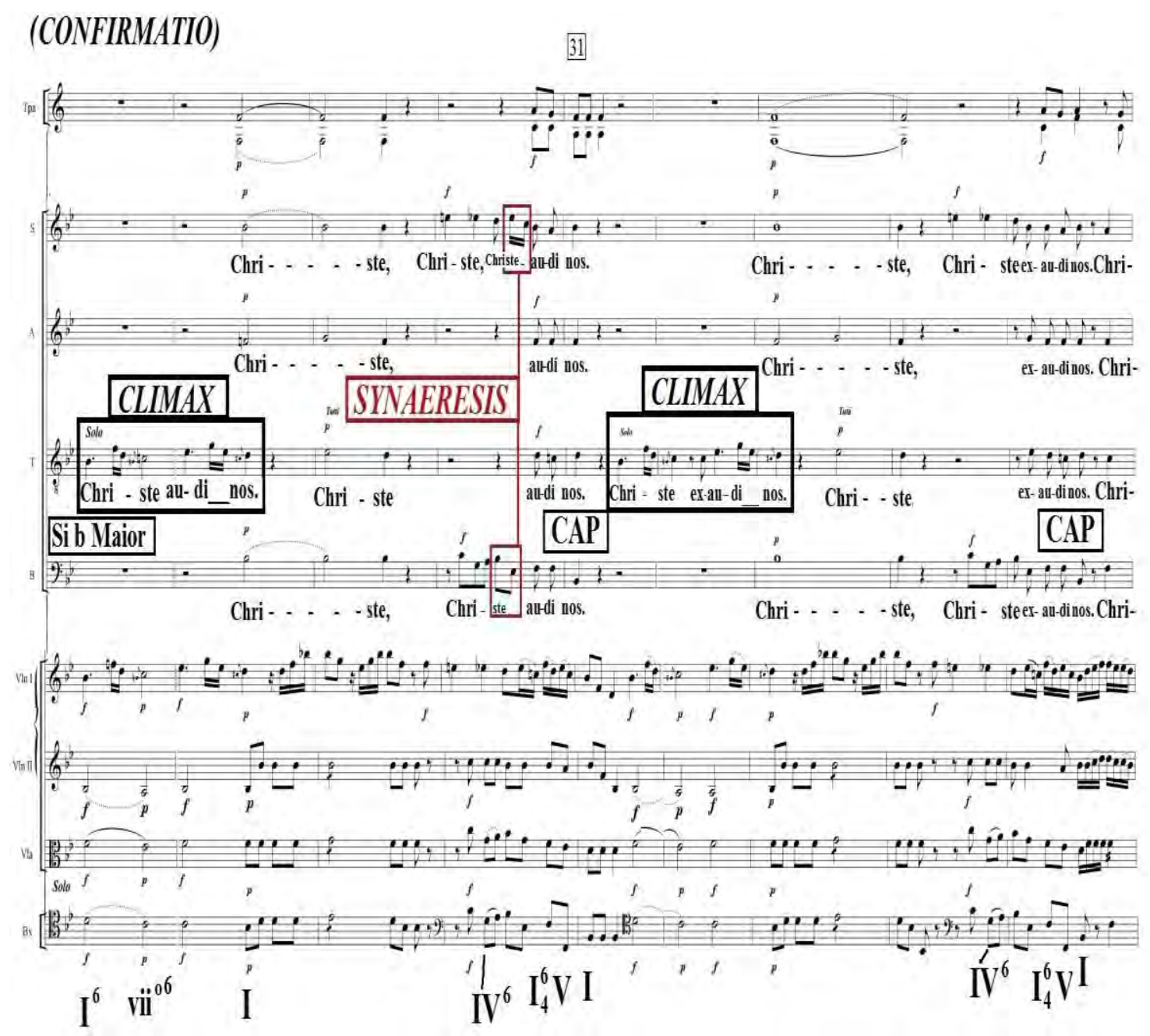

Exemplo 129-Kyrie da Ladainha em Si bemol Maior de José Joaquim Emerico Lobo de Mesquita - Edição André Guerra Cotta- Organização-Paulo Augusto Castagna (CASTAGNA, 2003, pp.8-9).

\subsection{Peroratio}

Esse mecanismo de repetição enfática, articulada por Lobo de Mesquita ao longo da obra, é evidenciado na conclusão do discurso. Isto é, através da Ou da Epizeuxis, destacando a expressão Christe exaudi nos (Cristo, atendeinos) em consonância com as funções da Tônica, Dominante e Subdominante numa Cadência Autêntica Perfeita. 
(PERORATIO) Uso predominante de repetição com ênfase: Epižeuxis

33

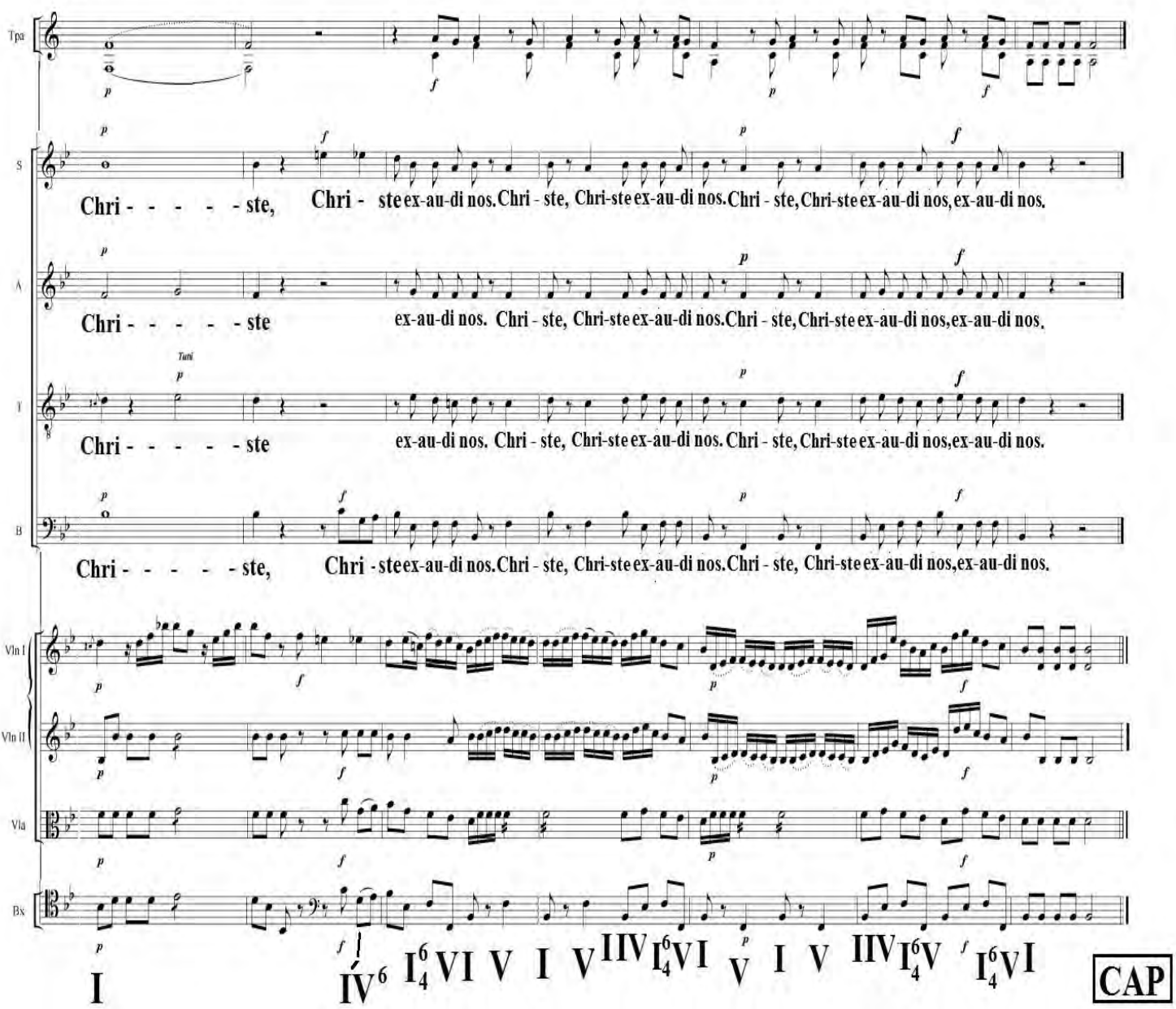

Exemplo 130-Kyrie da Ladainha em Si bemol Maior de José Joaquim Emerico Lobo de Mesquita - Edição André Guerra Cotta- Organização-Paulo Augusto Castagna (CASTAGNA, 2003, pp.9-10).

\section{Figuras observadas no Kyrie (Elocutio/Decoratio)}

Tabela 35-Figuras retóricas localizadas no Kyrie da Ladainha em Si bemol Maior de José Joaquim Emerico Lobo de Mesquita.

\begin{tabular}{|l|l|l|l|}
\hline $\begin{array}{l}\text { FIGURAS } \\
\text { CITAÇÕES }\end{array}$ & \multicolumn{1}{|c|}{ TIPO } & DESCRIÇÃO & \multicolumn{2}{|c|}{ TRATADISTA } \\
\hline ABRUPTIO & $\begin{array}{l}\text { Interrupção } \\
\text { Silêncio }\end{array}$ & $\begin{array}{l}\text { Uma quebra } \\
\text { súbita e } \\
\text { inesperada na } \\
\text { composição } \\
\text { musical. }\end{array}$ & $\begin{array}{l}\text { Mauritius Johann } \\
\text { Vogt: A Abruptio } \\
\text { ocorre quando um } \\
\text { trecho musical é } \\
\text { interrompido no final } \\
\text { pela colocação de } \\
\text { algumas pausas. }\end{array}$ \\
\hline
\end{tabular}




\begin{tabular}{|c|c|c|c|}
\hline $\begin{array}{l}\text { CLIMAX } \\
\text { (BARTEL, 1997, } \\
\text { pp.220-224). }\end{array}$ & $\begin{array}{l}\text { Repetição } \\
\text { Melódica }\end{array}$ & $\begin{array}{l}\text { (1) Uma } \\
\text { sequência de } \\
\text { notas em uma } \\
\text { só voz repetida } \\
\text { em qualquer } \\
\text { tonalidade } \\
\text { maior ou menor, } \\
\text { (2) Duas vozes } \\
\text { que se } \\
\text { deslocam em } \\
\text { movimento } \\
\text { ascendente ou } \\
\text { descendente } \\
\text { paralelo, (3) Um } \\
\text { aumento } \\
\text { gradual na } \\
\text { intensidade e } \\
\text { altura do som. }\end{array}$ & $\begin{array}{l}\text { Joachim Burmeister: } \\
\text { A Climax repete notas } \\
\text { semelhantes ou } \\
\text { alturas similares. } \\
\text { Athanasius Kircher: } \\
\text { A Climax ou Gradatio } \\
\text { é uma passagem } \\
\text { musical ascendente } \\
\text { que é frequentemente } \\
\text { utilizada em afetos de } \\
\text { amor e desejo de } \\
\text { unidade do reino } \\
\text { celestial. }\end{array}$ \\
\hline $\begin{array}{l}\text { EPIZEUXIS } \\
\text { (BARTEL, 1997, } \\
\text { pp.263-265). }\end{array}$ & $\begin{array}{l}\text { Repetição } \\
\text { Melódica }\end{array}$ & $\begin{array}{l}\text { Uma repetição } \\
\text { imediata e } \\
\text { enfática de uma } \\
\text { palavra, nota, } \\
\text { motivo ou frase. }\end{array}$ & $\begin{array}{l}\text { Johann Gottfried } \\
\text { Walther: A Epizeuxis } \\
\text { é uma figura de } \\
\text { retórica pela qual uma } \\
\text { ou mais palavras são } \\
\text { imediatamente } \\
\text { enfaticamente } \\
\text { repetidas. }\end{array}$ \\
\hline $\begin{array}{l}\text { SYNAERESIS } \\
\text { (BARTEL, 1997, } \\
\text { pp.394-396). } \\
\text { (LÓPEZ CANO, } \\
\text { 2000, p.199). }\end{array}$ & $\begin{array}{l}\text { Dissonância e } \\
\text { Deslocamento }\end{array}$ & $\begin{array}{l}\text { (1) Uma } \\
\text { suspensão ou } \\
\text { síncope, (2) A } \\
\text { colocação de } \\
\text { duas sílabas por } \\
\text { nota ou duas } \\
\text { notas por } \\
\text { sílaba. }\end{array}$ & $\begin{array}{l}\text { Mauritius Johann } \\
\text { Vogt: A Synaeresis } \\
\text { ocorre quando duas } \\
\text { notas são colocadas } \\
\text { em uma sílaba ou } \\
\text { duas sílabas são } \\
\text { colocadas em uma } \\
\text { nota. }\end{array}$ \\
\hline $\begin{array}{l}\text { SUSPIRATIO } \\
\text { (BARTEL, 1997, } \\
\text { pp. 392-394). } \\
\text { (BUELOW, 2001, } \\
\text { p.268). }\end{array}$ & $\begin{array}{l}\text { Interrupção } \\
\text { Silêncio }\end{array}$ & $\begin{array}{l}\text { Expressão } \\
\text { musical de um } \\
\text { suspiro, através } \\
\text { de pausas. }\end{array}$ & $\begin{array}{l}\text { Athanasius Kircher: } \\
\text { A Stenasmus ou } \\
\text { Suspiratio lembram os } \\
\text { afetos naturalmente } \\
\text { expressados por } \\
\text { vários suspiros } \\
\text { criados através de } \\
\text { pausas. }\end{array}$ \\
\hline
\end{tabular}

\section{Análise Harmônica}

\subsection{Curva Tonal}

Tonalidade: Si b Maior 
Andamento: Andante 4/4

Tabela 36-Esquema de Progressões Harmônicas- Curva Tonal do Kyrie da Ladainha em Si bemol Maior de José Joaquim Emerico Lobo de Mesquita.

\begin{tabular}{|l|c|l|}
\hline \multicolumn{1}{|c|}{ Compassos } & Função & \multicolumn{1}{c|}{ Tonalidade } \\
\hline $1-12$ & I & Si b Maior \\
\hline 13 & V & Fá Maior \\
\hline $14-16$ & I & Si b Maior \\
\hline 17 & V & Fá Maior \\
\hline 18 & I & Si b Maior \\
\hline $19-20$ & vi & Sol Menor \\
\hline 21 & V/vi & Ré Maior \\
\hline $22-23$ & vi & Sol Menor \\
\hline 24 & ii & Dó Menor \\
\hline $25-26$ & I & Si b Maior \\
\hline 27 & V/vi & Ré Maior \\
\hline $27-42$ & I & Si b Maior \\
\hline
\end{tabular}

\subsection{Estrutura Analítica da obra: Retórica e Harmônica}

Tabela 37-Estrutura analítica da obra.

\begin{tabular}{|c|c|c|c|c|}
\hline $\begin{array}{l}\text { RETÓRICA } \\
\text { DISPOSITIO }\end{array}$ & $\begin{array}{c}\text { FIGURA } \\
\text { ELOCUTIO }\end{array}$ & COMP. & TONALIDADE & FUNÇÃO \\
\hline EXORDIUM & & $1-10$ & Si b Maior & $\mathrm{I}$ \\
\hline NARRATIO & $\begin{array}{l}\text { Suspiratio } \\
\text { Epizeuxis }\end{array}$ & $\begin{array}{l}11 \\
11-14\end{array}$ & $\begin{array}{l}\text { Si b Maior } \\
\text { Si b Maior }\end{array}$ & $\begin{array}{l}1 \\
1\end{array}$ \\
\hline PROPOSITIO & Epizeuxis & $16-19$ & Si b Maior & I \\
\hline CONFUTATIO & $\begin{array}{l}\text { Suspiratio } \\
\text { Epizeuxis } \\
\text { Abruptio }\end{array}$ & $\begin{array}{l}19 \\
19-22 \\
23\end{array}$ & $\begin{array}{l}\text { Sol Menor } \\
\text { Sol Menor } \\
\text { Sol Menor }\end{array}$ & $\begin{array}{l}\mathrm{vi} \\
\mathrm{vi} \\
\mathrm{vi}\end{array}$ \\
\hline CONFIRMATIO & $\begin{array}{l}\text { Climax } \\
\text { Synaeresis }\end{array}$ & $\begin{array}{l}27-28 \\
31-32 \\
30\end{array}$ & $\begin{array}{l}\text { Si b Maior } \\
\text { Si b Maior } \\
\text { Si b Maior }\end{array}$ & $\begin{array}{l}1 \\
1 \\
1\end{array}$ \\
\hline PERORATIO & Epizeuxis & $36-42$ & Si b Maior & $\mathrm{I}$ \\
\hline
\end{tabular}




\subsubsection{Análise Retórico-Musical do Cum Appropinquaret, da Procissão de Ramos de José Joaquim Emerico Lobo de Mesquita}

\section{Inventio}

Na liturgia da Procissão de Ramos, apresenta-se uma reflexão para que os fiéis creiam nos acontecimentos da Paixão, Morte e Ressurreição de Jesus, em outras palavras, crer no mistério central da fé cristã: em que a vida vence a morte e o mal e, por fim, atinge a vida eterna (SOARES, 2012, p.139). Parte integrante desse cerimonial, o Cum Appropinquaret tem seu texto baseado em Lucas 19:28-40, onde o escritor do Terceiro Evangelho descreve com detalhes a entrada triunfal de Jesus em Jerusalém.

Cum appropinquaret Dominus Jerosolymam, misit duos ex discipulis, dicens: Ite in castellum, quod contra vos est: et invenietis pullum asinæ alligatum, super quem nullus hominum sedit; solvite ducite: et adducite mihi.

Si quis vos interrogaverit: dicite opus Domino est. Solventes adduxerunt ad Jesum: et imposuerunt illi vestimenta sua, et sedit super eum.

Alii expandebant vestimenta sua in via: alii ramos de arboribus sternebant. Et qui sequebantur clamabant: Hosanna, benedictus qui venit in nomine Domini. Benedictum regnum Patris nostri David. Hosanna in excelsis, miserere nobis fili David.

Aproximando-se o Senhor de Jerusalém, enviou dois dos seus discípulos, dizendo: Ide à aldeia que está defronte de vós, e achareis preso um jumentinho, sobre o qual nenhum homem subiu; soltai-o e trazei-o para mim.

Se alguém vos perguntar, dizei que o Senhor precisa dele. Então, o soltaram e o trouxeram e, pondo as suas vestes sobre ele, ajudaram Jesus a montar.

Alguns estenderam os seus mantos no caminho, outros jogaram galhos de árvores. E os que o seguiam, clamavam: Hosana, bendito o que vem em nome do Senhor. Bendito seja o reino de nosso pai Davi. Hosana nas alturas, tem misericórdia de nós, Filho de Davi.

Portanto, esse moteto é constituído por cento e cinco compassos, em andamento Andantino, distribuídos com suas respectivas partes retóricomusicais.

\subsection{Loci observados na Inventio do Cum Appropinquaret}

Tabela 38-Loci Topici localizados no Cum Appropinquaret,da Procissão de Ramos de José Joaquim Emerico Lobo de Mesquita.

\begin{tabular}{|l|l|lc|ll|}
\hline INVENTIO & DESCRIÇÃO & \multicolumn{2}{|l|}{ UTILIZAÇÃO NA OBRA } & \multicolumn{2}{|c|}{ COMPASSO/ VOZ } \\
\hline Locus & Aspecto externo & Vários motivos rítmicos e & $1-18$ & S-A-T-B \\
Notationis & e desenho das & diferentes durações de & $19-30$ & S-A-T-B \\
& notas (Duração & notas (mínimas, mínimas & $31-48$ & S-A-T-B \\
\hline
\end{tabular}




\begin{tabular}{|c|c|c|c|}
\hline $\begin{array}{l}\text { (MATTHESON, } \\
1954 \quad \text { [1739]. } \\
\text { Parte II, Cap.4, } \\
\S 23, \text { p.123). }\end{array}$ & $\begin{array}{l}\text { das notas, } \\
\text { alteração, } \\
\text { repetição e } \\
\text { procedimentos } \\
\text { canônicos). }\end{array}$ & $\begin{array}{l}\text { pontudas, semínimas, } \\
\text { semínimas pontuadas, } \\
\text { colcheias, tercinas, } \\
\text { semicolcheias, } \\
\text { repetições, ligaduras, } \\
\text { pausas, entre outros). }\end{array}$ & $\begin{array}{ll}49-75 & \text { S-A-T-B } \\
76-88 & \text { S-A-T-B } \\
89-105 & \text { S-A-T-B }\end{array}$ \\
\hline $\begin{array}{l}\text { Locus } \\
\text { Descriptionis } \\
\text { (MATTHESON, } \\
1954 \quad \text { [1739]. } \\
\text { Parte II, Cap.4, } \\
\S 43, \text { p.127). }\end{array}$ & $\begin{array}{l}\text { Disposições da } \\
\text { alma }\end{array}$ & $\begin{array}{l}\text { Obediência (Ide à aldeia } \\
\text { que está defronte de vós/ } \\
\text { e achareis preso um } \\
\text { jumentinho, sobre o qual } \\
\text { nenhum homem subiu; } \\
\text { soltai-o e trazei-o para } \\
\text { mim. Se alguém vos } \\
\text { perguntar, dizei que o } \\
\text { Senhor precisa dele. } \\
\text { Então, o soltaram e o } \\
\text { trouxeram e, pondo as } \\
\text { suas vestes sobre ele, } \\
\text { ajudaram Jesus a montar). } \\
\text { Devoção e exaltação } \\
\text { (Hosana nas alturas, tem } \\
\text { misericórdia de nós, Filho } \\
\text { de Davi). }\end{array}$ & 19-86 S-A-T-B \\
\hline $\begin{array}{l}\text { Locus } \\
\text { Oppositorum } \\
\text { (MATTHESON, } \\
1954 \quad \text { [1739]. } \\
\text { Parte II, Cap.4, } \\
\S 80, \text { p.131). }\end{array}$ & $\begin{array}{l}\text { Contraste de } \\
\text { compassos, } \\
\text { movimentos } \\
\text { contrários, } \\
\text { agudos e } \\
\text { graves, lento e } \\
\text { rápido, calmo e } \\
\text { agitado. }\end{array}$ & $\begin{array}{l}\text { Movimento contrário } \\
\text { entre soprano e baixo. } \\
\text { Soprano e baixo, tenor e } \\
\text { baixo. } \\
\text { Contralto e tenor, tenor e } \\
\text { baixo. } \\
\text { Soprano e baixo, } \\
\text { contralto e baixo. } \\
\text { Soprano e baixo. } \\
\text { Contralto e baixo, tenor e } \\
\text { baixo. } \\
\text { Soprano e baixo, } \\
\text { contralto e baixo, tenor e } \\
\text { baixo. } \\
\text { Soprano e baixo, soprano } \\
\text { e tenor. } \\
\text { Contralto e tenor, tenor e } \\
\text { baixo. } \\
\text { Contralto e baixo. } \\
\text { Soprano e baixo, soprano } \\
\text { e tenor. } \\
\text { Contralto e tenor, } \\
\text { contralto e baixo. } \\
\text { Contralto e baixo. } \\
\text { Soprano e baixo, } \\
\text { contralto e baixo. }\end{array}$ & $\begin{array}{ll}2 & \text { S-B } \\
32-33 & \text { S-T-B } \\
42,46 & \text { A-T-B } \\
50 & \text { S-A-B } \\
58,60 & \text { S-B } \\
80 & \text { A-T-B } \\
87 & \text { S-A-T-B } \\
& \\
89 & \text { S-T-B } \\
90 & \text { A-T-B } \\
91 & \text { A-B } \\
93 & \text { S-T-B } \\
94 & \text { A-T-B } \\
95-96 & \text { A-B } \\
101-102,104 \text { S-A-B }\end{array}$ \\
\hline
\end{tabular}




\section{Dispositio}

\subsection{Exordium}

No início da presente peça, é examinável o emprego da Synaeresis no compasso 6 , realçando a palavra Jerosolymam (Jerusalém), através da entoação do contralto e tenor de duas notas em uma sílaba. Também, da Aposiopesis no compasso 7 , indicando a todas as vozes um momento de descanso, com conclusão numa Semicadência. Adicionado a isso, observa-se que essa figura retórica é usada pelo autor em antecipação à figura da Abruptio, que, por sua vez, de maneira abrupta, interrompe a conexão da frase, misit duos discipulus (enviou dois discípulos).

O outro elemento retórico a ser ressaltado é o da figura da Epizeuxis, a qual é aplicada para ratificar a expressão já proferida desde o compasso 9 , de que Jesus enviara dois de seus discípulos para encontrar a sua cavalgadura para montar. Enfim, todos os mecanismos retóricos são dispostos por Lobo de Mesquita em consonância com as funções harmônicas da Tônica, Subdominante, Dominante da Dominante e Dominante, resolvendo numa Semicadência, através de uma suspensão temporária da expressão discens (dizendo), gerando, assim, maior expectativa no ouvinte. 


\section{Cum appropinquaret}

Procissão de Ramos

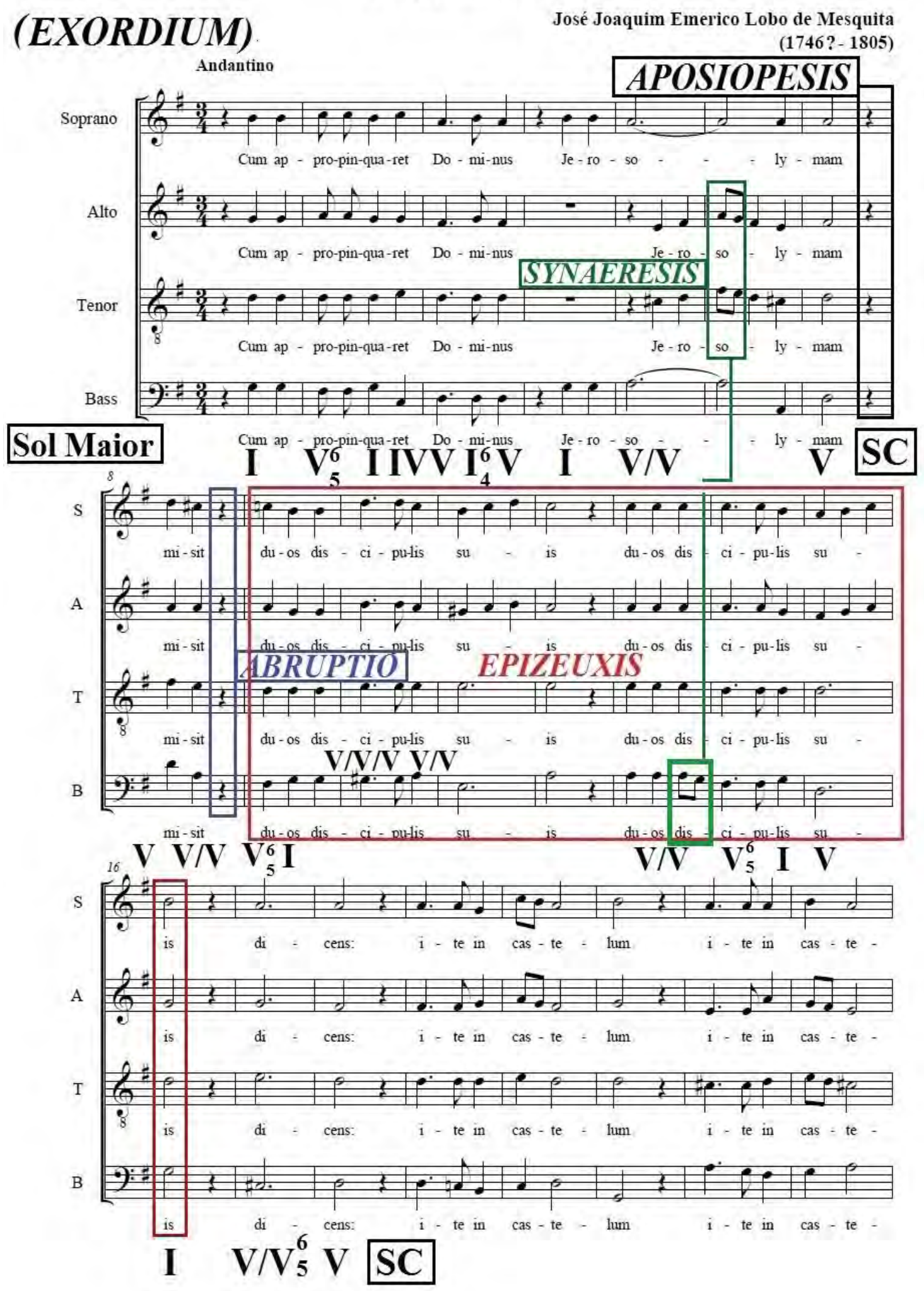

Exemplo 131-Cum Appropinquaret da Procissão de Ramos de José Joaquim Emerico Lobo de Mesquita- Edição Rafael Sales Arantes (LOBO DE MESQUITA, s/d, p.1). 


\subsection{Narratio}

Nesse trecho, é verificável o emprego da Synaeresis nas vozes da soprano, contralto e tenor entoando duas notas para realçar a sílaba cas. Igualmente, nota-se a predominância da Epizeuxis, utilizada pelo autor para destacar a expressão textual: ite in castellum, quod contra vos est (Ide à aldeia que está defronte de vós).

Outro aspecto a ser enfatizado, assim como ocorrido no Exordium, são as diversas pausas inseridas pelo compositor, dando às vozes um período de descanso a cada compasso, o que poderia sugerir duas figuras retóricas: Pausa ou Aposiopesis. Entretanto, nesse caso, optou-se por indicar o possível uso da Aposiopesis, somente no final da expressão ite in castellum e da Narratio, ou seja, nas duas Semicadências dos compassos 24 e 30, em analogia à figura da Homoioptoton que, segundo tratadistas como: Nucius, Thuringus e Walter, assim como a Aposiopesis, serve para dar um descanso a todas as vozes, despertar a atenção do ouvinte; na maioria das vezes é aplicada após as semibreves e mínimas em repouso e na maior parte pode se localizada em cadências no final de uma frase ou seção (BARTEL, 1997, pp.295-298).

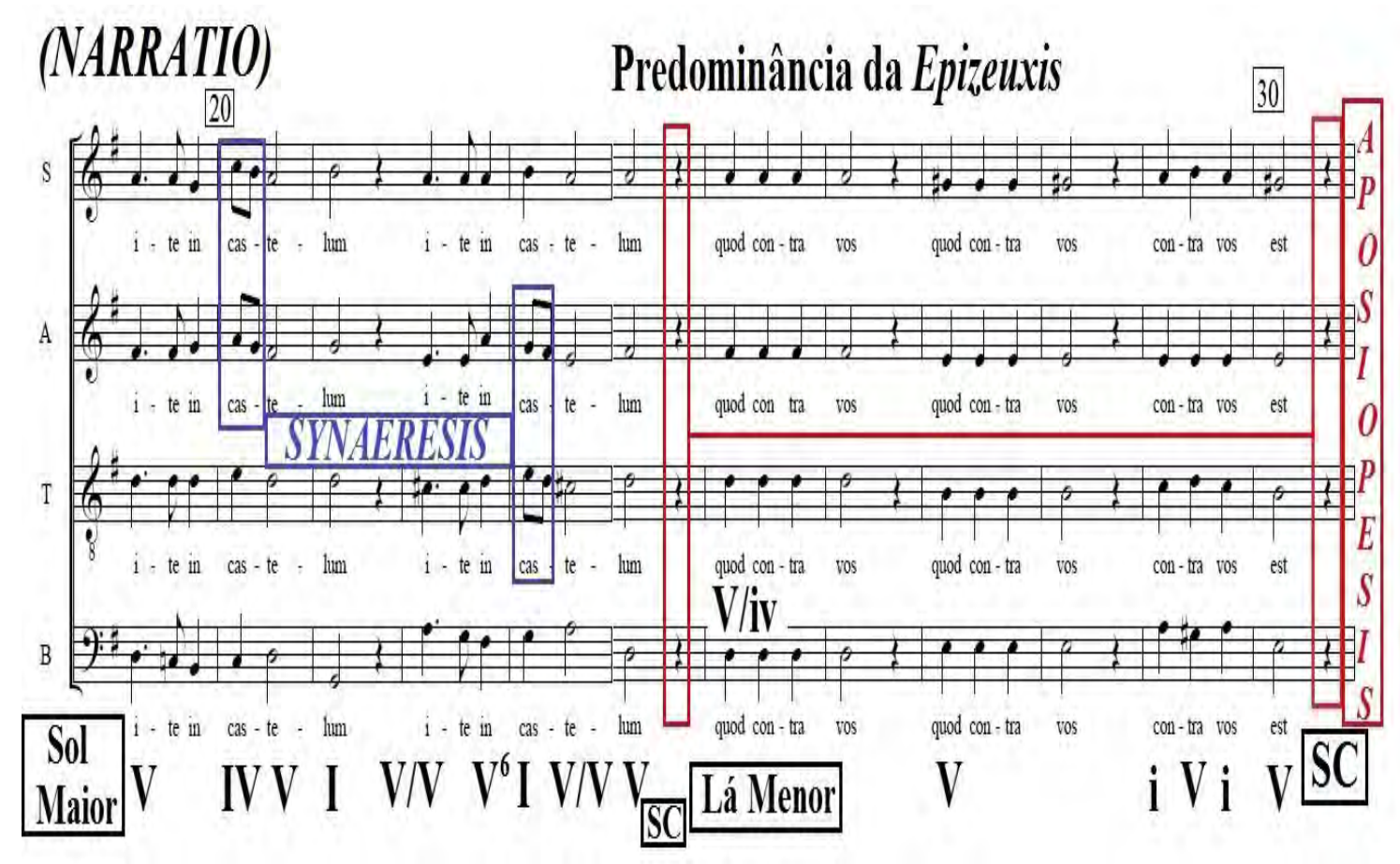

Exemplo 132-Cum Appropinquaret da Procissão de Ramos de José Joaquim Emerico Lobo de Mesquita- Edição Rafael Sales Arantes (LOBO DE MESQUITA, s/d, p.2). 


\subsection{Propositio}

Observa-se, entre os compassos 31 e 44, que José Emerico aplica os mesmos mecanismos retóricos da parte anterior, porém, com duas diferenças: a mudança de tonalidade que era de Sol Maior para Lá Menor, aqui é ao contrário, e as cadências, anteriormente com duas Semicadências, agora com uma Cadência Autêntica Imperfeita e uma Semicadência.

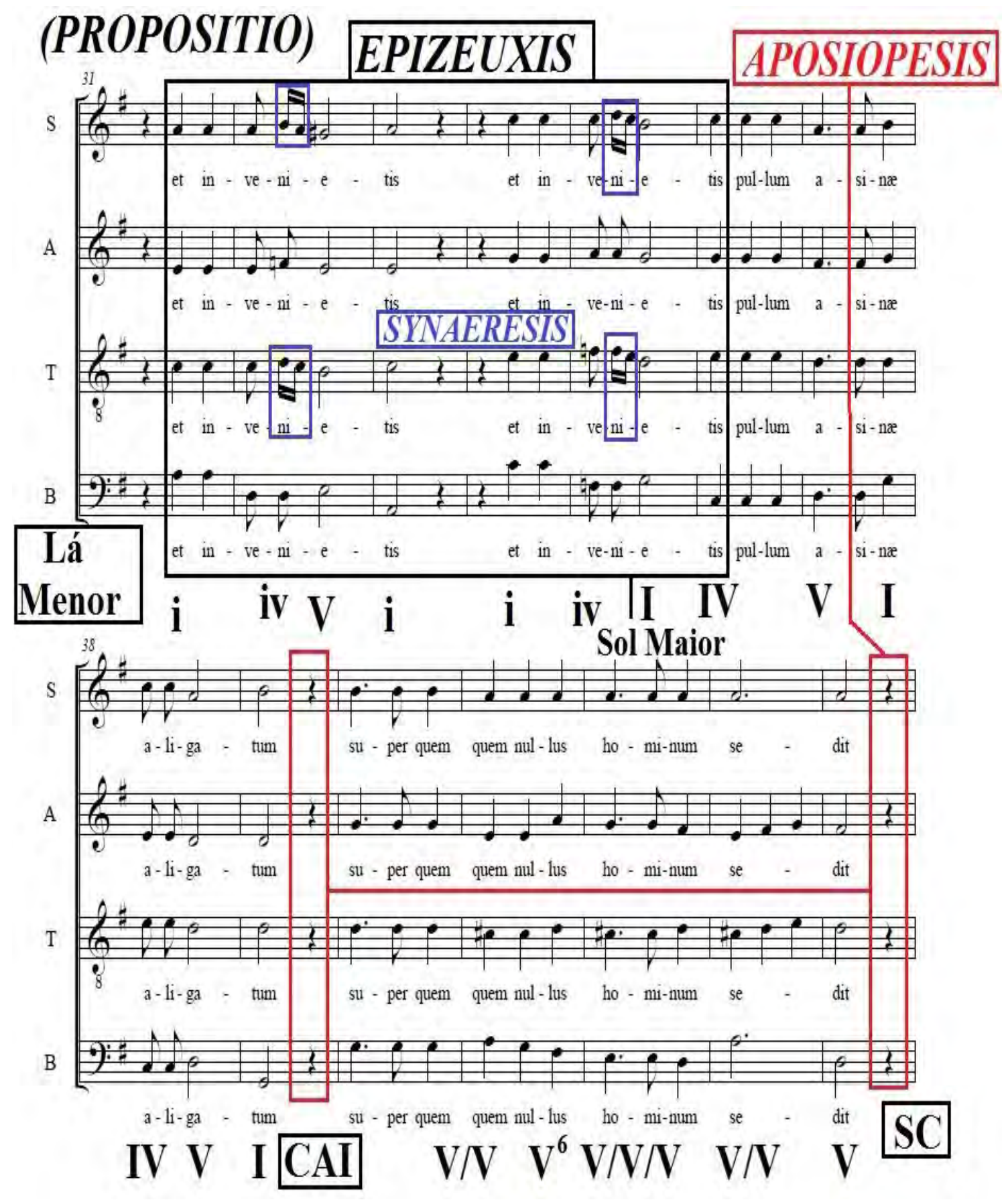

Exemplo 133-Cum Appropinquaret da Procissão de Ramos de José Joaquim Emerico Lobo de Mesquita- Edição Rafael Sales Arantes (LOBO DE MESQUITA, s/d, p.2). 


\subsection{Confutatio}

Assim como no Exordium, o compositor trabalha com as mesmas figuras retóricas. No entanto, pôde-se examinar que há três tonalidades diferentes entre os compassos 45 e 66, o que propicia maior expectativa ao ouvinte. De igual natureza, essa expectativa é representada pelo afeto de devoção e submissão, os quais são evidenciados a partir da passagem textual, super quem nullus hominum sedit; solvite ducite: et adducite mihi. Si quis vos interrogaverit: dicite opus Domino est (e achareis preso um jumentinho, sobre o qual nenhum homem subiu; soltai-o e trazei-o para mim. Se alguém vos perguntar, dizei que o Senhor precisa dele).

Não obstante, é observável o desenvolvimento harmônico realizado mediante as funções harmônicas ocorridas no primeiro momento na tonalidade Mi Menor, na transição da Propositio para a Confutatio, por meio da Dominante e Tônica. Também, na tonalidade inicial e principal da obra Sol Maior, através da Subdominante, Dominante da Subdominante, Dominante da Dominante Menor, Dominante Menor e Tônica, chegando à tonalidade Ré Maior com as funções da Dominante, Tônica e Dominante da Dominante. Por fim, é destacável o emprego da mesma cadência nessas três tonalidades diferentes, isto é, a Cadência Autêntica Imperfeita. 


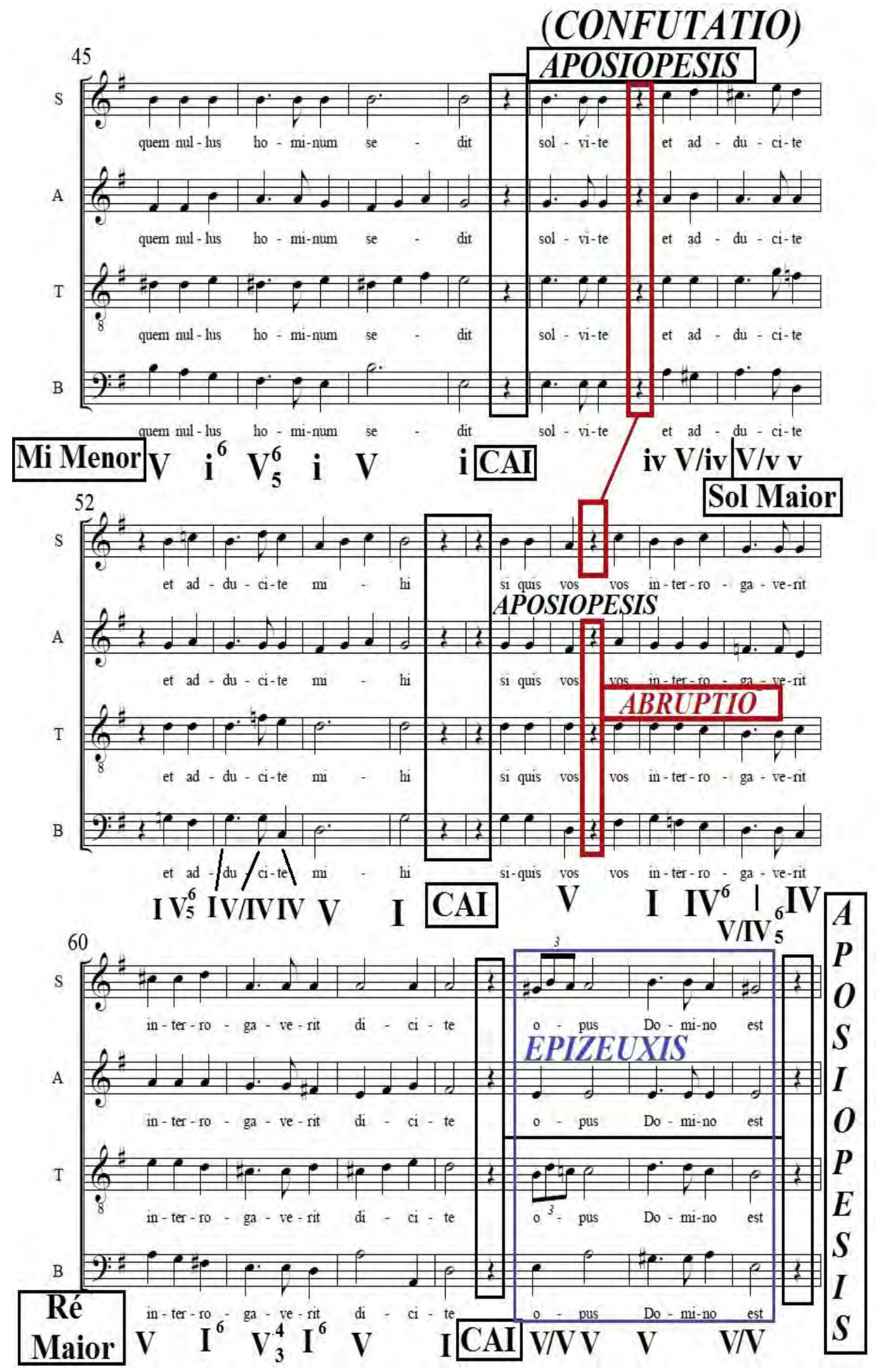

Exemplo 134-Cum Appropinquaret da Procissão de Ramos de José Joaquim Emerico Lobo de Mesquita- Edição Rafael Sales Arantes (LOBO DE MESQUITA, s/d, p.3). 
No presente trecho, nota-se que Lobo de Mesquita, para atrair a atenção de quem ouve, além destacar o instante em que os discípulos de Jesus trouxeram o jumentinho para ele, utiliza-se das mesmas cadências e figuras da Epizeuxis e Aposiopesis, as quais enfatizam, através da repetição e por um momento de descanso no final da frase e da Confutatio, as palavras dicite opus Domino est. Solventes adduxerunt ad Jesum (dizei que o Senhor precisa dele. Então, o soltaram e o trouxeram a Jesus).

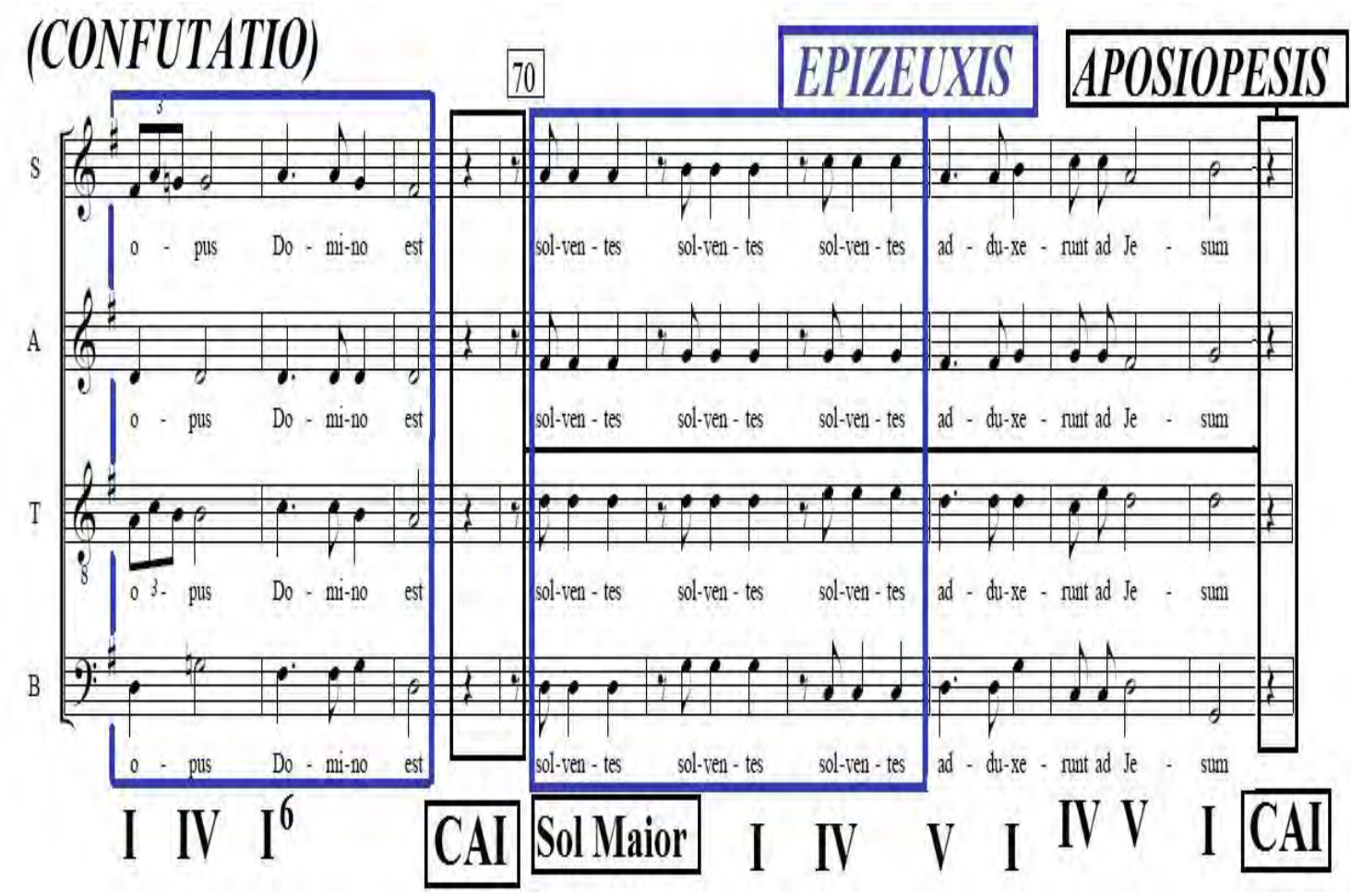

Exemplo 135-Cum Appropinquaret da Procissão de Ramos de José Joaquim Emerico Lobo de Mesquita- Edição Rafael Sales Arantes (LOBO DE MESQUITA, s/d, p.4).

\subsection{Confirmatio}

A ratificação do discurso se faz presente mediante o uso da Abruptio, Epizeuxis e da Aposiopesis, as quais, em consonância com as funções da Tônica, Dominante da Subdominante, Subdominante e Dominante, além dos materiais motívicos e da verticalidade do contraponto, ressaltam a expressão et imposuerunt illi vestimenta sua, et sedit super eum (e, pondo as suas vestes sobre ele, ajudaram-no a montar). Outro ponto a ser examinado, é o compasso 79, na voz do contralto onde a sílaba ti é entoada por duas notas, o que 
poderia configurar uma Synaeresis, mesmo parecendo que sua localização possa parecer trivial.

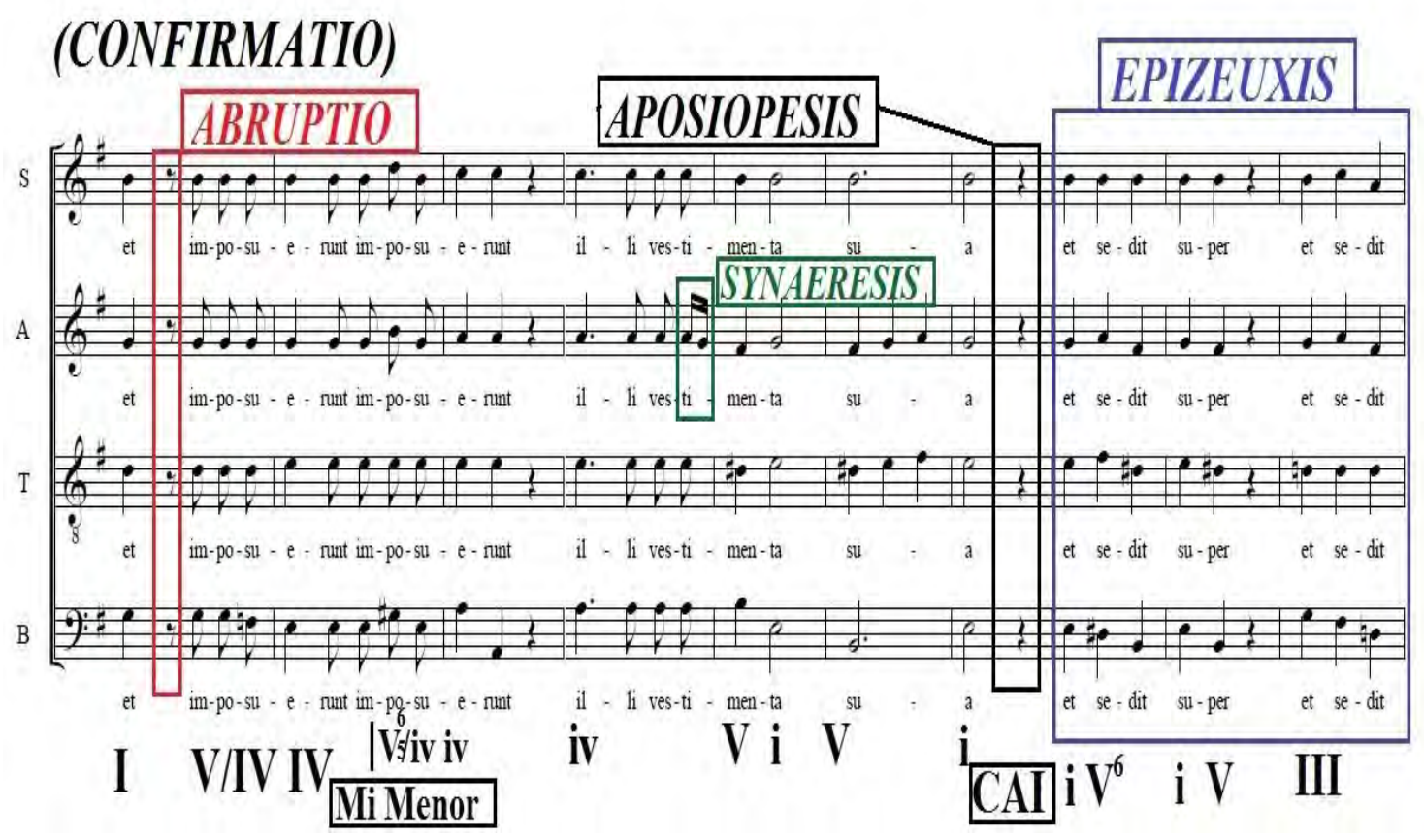

Exemplo 136-Cum Appropinquaret da Procissão de Ramos de José Joaquim Emerico Lobo de Mesquita- Edição Rafael Sales Arantes (LOBO DE MESQUITA, s/d, p.4).

No trecho abaixo, observa-se o término da Confirmatio com uma Cadência Autêntica Imperfeita.

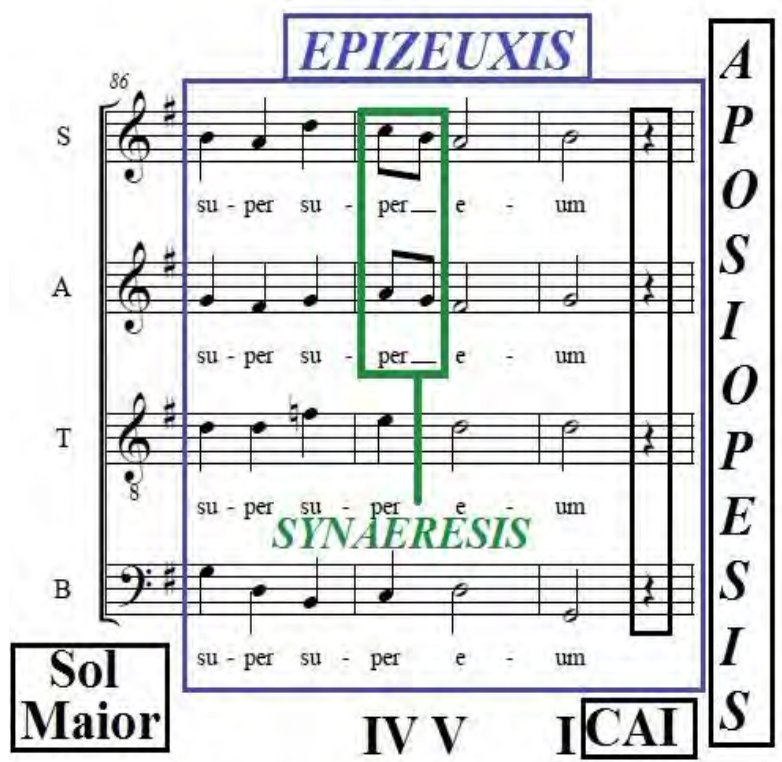

Exemplo 137-Cum Appropinquaret da Procissão de Ramos de José Joaquim Emerico Lobo de Mesquita- Edição Rafael Sales Arantes (LOBO DE MESQUITA, s/d, p.5). 


\subsection{Peroratio}

No último excerto da obra, averigua-se que José Emerico ressalta a expressão Hosana in excelsis misere no bis (Hosana nas alturas, tem misericórdia de nós), por intermédio da repetição enfática da supracitada figura da Epizeuxis. Tal destaque se dá em conformidade com as funções da Tônica, Subdominante e Dominante, Dominante da Dominante com resolução parcial de efeito de suspensão com uma Semicadência no compasso 96. Igualmente, com as funções da Dominante da Subdominante Paralela (Relativa), Subdominante Paralela (Relativa), Dominante da Subdominante, Subdominante, Dominante e Tônica, de modo conclusivo na Cadência Autêntica Imperfeita, no compasso 105.
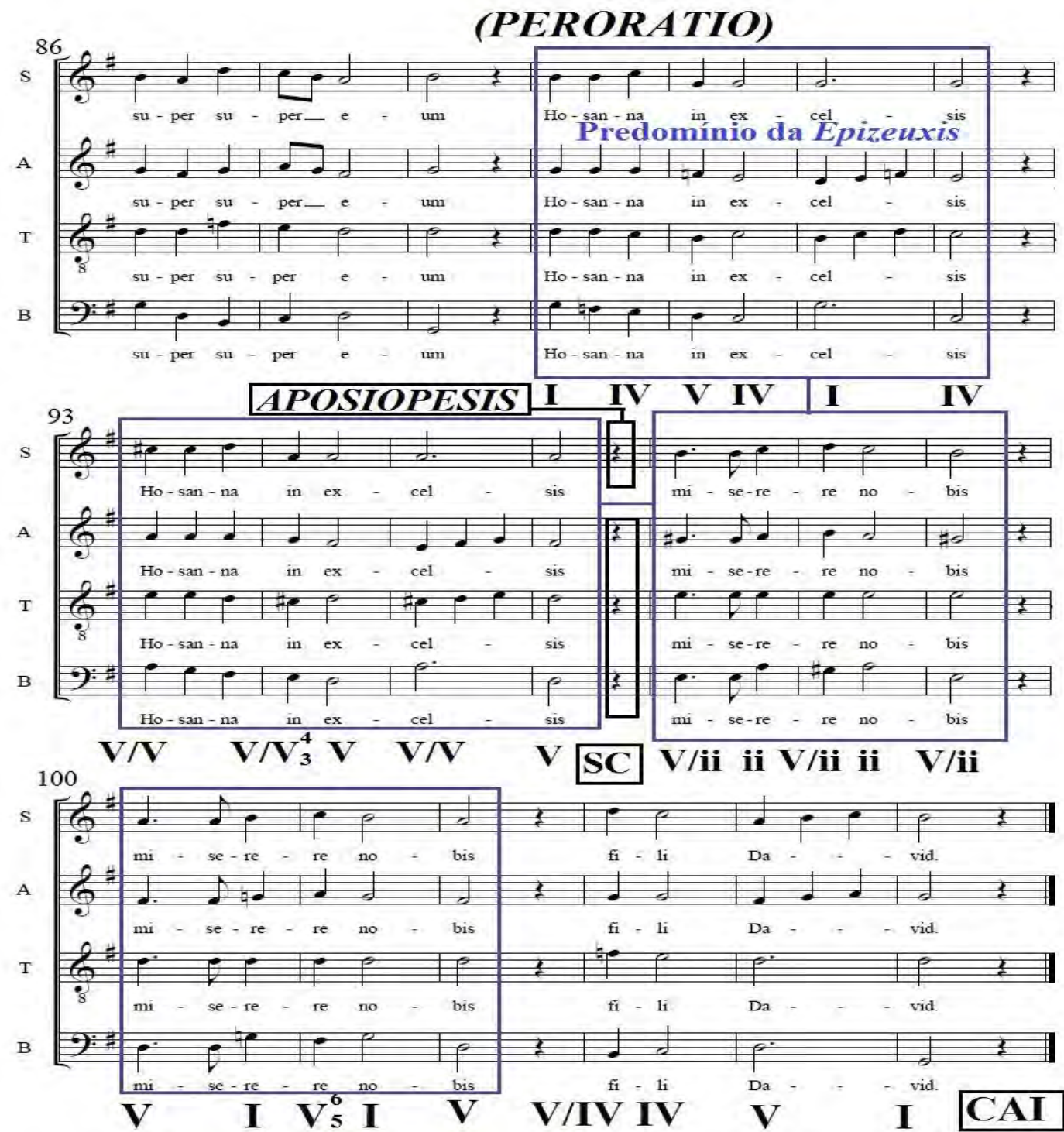

Exemplo 138-Cum Appropinquaret da Procissão de Ramos de José Joaquim Emerico Lobo de Mesquita- Edição Rafael Sales Arantes (LOBO DE MESQUITA, s/d, p.5). 


\section{Figuras observadas no Cum Appropinquaret (Elocutio/Decoratio)}

Tabela 39-Figuras retóricas localizadas no Cum Appropinquaret, da Procissão de Ramos de José Joaquim Emerico Lobo de Mesquita.

\begin{tabular}{|c|c|c|c|}
\hline $\begin{array}{ll}\text { FIGURAS } & \mathrm{E} \\
\text { CITAÇÕES } & \end{array}$ & TIPO & DESCRIÇÃO & TRATADISTA \\
\hline $\begin{array}{l}\text { ABRUPTIO } \\
\text { (BARTEL, 1997, } \\
\text { pp.168-170). }\end{array}$ & $\begin{array}{ll}\text { Interrupção e } \\
\text { Silêncio }\end{array}$ & $\begin{array}{l}\text { Uma quebra } \\
\text { súbita e } \\
\text { inesperada na } \\
\text { composição } \\
\text { musical. }\end{array}$ & $\begin{array}{l}\text { Mauritius Johann } \\
\text { Vogt: A Abruptio } \\
\text { ocorre quando um } \\
\text { trecho musical é } \\
\text { interrompido no final } \\
\text { pela colocação de } \\
\text { algumas pausas. }\end{array}$ \\
\hline $\begin{array}{l}\text { APOSIOPESIS } \\
\text { (BARTEL, 1997, } \\
\text { pp.202-206). }\end{array}$ & $\begin{array}{l}\text { Interrupção e } \\
\text { Silêncio }\end{array}$ & $\begin{array}{l}\text { Um descanso } \\
\text { em uma ou } \\
\text { todas as vozes } \\
\text { de uma } \\
\text { composição: } \\
\text { pausa geral. }\end{array}$ & $\begin{array}{l}\text { Johann Gottfried } \\
\text { Walther: } \\
\text { Aposiopesis se refere } \\
\text { a uma pausa } \\
\text { generalis ou um } \\
\text { completo silêncio em } \\
\text { todas as vozes e nas } \\
\text { partes da composição } \\
\text { simultaneamente. }\end{array}$ \\
\hline $\begin{array}{l}\text { EPIZEUXIS } \\
\text { (BARTEL, 1997, } \\
\text { pp.263-265). }\end{array}$ & $\begin{array}{l}\text { Repetição } \\
\text { Melódica }\end{array}$ & $\begin{array}{l}\text { Uma repetição } \\
\text { imediata e } \\
\text { enfática de uma } \\
\text { palavra, nota, } \\
\text { motivo ou frase. }\end{array}$ & $\begin{array}{l}\text { Johann Gottfried } \\
\text { Walther: A Epizeuxis } \\
\text { é uma figura de } \\
\text { retórica pela qual uma } \\
\text { ou mais palavras são } \\
\text { imediatamente } \\
\text { enfaticamente } \\
\text { repetidas. }\end{array}$ \\
\hline $\begin{array}{l}\text { SYNAERESIS } \\
\text { (BARTEL, 1997, } \\
\text { pp.394-396). } \\
\text { (LÓPEZ CANO, } \\
\text { 2000, p.199). }\end{array}$ & $\begin{array}{l}\text { Dissonância e } \\
\text { Deslocamento }\end{array}$ & $\begin{array}{l}\text { (1) Uma } \\
\text { suspensão ou } \\
\text { síncope, (2) A } \\
\text { colocação de } \\
\text { duas sílabas por } \\
\text { nota ou duas } \\
\text { notas por } \\
\text { sílaba. }\end{array}$ & $\begin{array}{l}\text { Mauritius Johann } \\
\text { Vogt: A Synaeresis } \\
\text { ocorre quando duas } \\
\text { notas são colocadas } \\
\text { em uma sílaba ou } \\
\text { duas sílabas são } \\
\text { colocadas em uma } \\
\text { nota. }\end{array}$ \\
\hline
\end{tabular}

\section{Análise Harmônica}

\subsection{Curva Tonal}

Tonalidade: Sol Maior

Andamento: Andantino 3/4 
Tabela 40-Esquema de Progressões Harmônicas- Curva Tonal do Cum Appropinquaret, da Procissão de Ramos de José Joaquim Emerico Lobo de Mesquita.

\begin{tabular}{|l|c|l|}
\hline \multicolumn{1}{|c|}{ Compassos } & Função & \multicolumn{1}{c|}{ Tonalidade } \\
\hline $1-4$ & I & Sol Maior \\
\hline $5-9$ & V & Ré Maior \\
\hline 9 & I & Sol Maior \\
\hline $10-15$ & V & Ré Maior \\
\hline 16 & I & Sol Maior \\
\hline $17-18$ & V & Ré Maior \\
\hline $19-21$ & I & Sol Maior \\
\hline $22-24$ & V & Ré Maior \\
\hline 25 & V & Ré Menor \\
\hline $26-30$ & V/ii & Mi Maior \\
\hline $31-35$ & ii & Lá Menor \\
\hline $35-40$ & I & Sol Maior \\
\hline $41-44$ & V & Ré Maior \\
\hline $45-50$ & ii & Lá Menor \\
\hline $51-58$ & I & Sol Maior \\
\hline 59 & IV & Dó Maior \\
\hline $60-70$ & V & Ré Maior \\
\hline $70-76$ & I & Sol Maior \\
\hline $76-77$ & IV & Dó Maior \\
\hline $77-85$ & vi & Mi Menor \\
\hline $86-105$ & I & Sol Maior \\
\hline
\end{tabular}

4.2. Estrutura Analítica da obra: Retórica e Harmônica

Tabela 41-Estrutura analítica da obra.

\begin{tabular}{|l|l|l|l|c|}
\hline $\begin{array}{c}\text { RETÓRICA } \\
\text { DISPOSITIO }\end{array}$ & \multicolumn{1}{|c|}{$\begin{array}{c}\text { FIGURA } \\
\text { ELOCUTIO }\end{array}$} & COMP. & TONALIDADE & FUNÇÃO \\
\hline EXORDIUM & Synaeresis & 6 & Sol Maior & I \\
& Aposiopesis & 7 & Sol Maior & I \\
& Abruptio & 8 & Sol Maior & I \\
& Epizeuxis & $9-15$ & Sol Maior & I \\
\hline NARRATIO & Synaeresis & $20-23$ & Sol Maior & I \\
& Aposiopesis & 24,30 & Lá Menor & ii \\
\hline
\end{tabular}




\begin{tabular}{|c|c|c|c|c|}
\hline PROPOSITIO & $\begin{array}{l}\text { Epizeuxis } \\
\text { Synaeresis } \\
\text { Aposiopesis }\end{array}$ & $\begin{array}{l}32,35 \\
39,44 \\
48\end{array}$ & $\begin{array}{l}\text { Lá Menor e } \\
\text { Sol maior } \\
\text { Lá Menor } \\
\text { Sol Maior } \\
\text { Mi Menor }\end{array}$ & vi \\
\hline CONFUTATIO & $\begin{array}{l}\text { Aposiopesis } \\
\text { Abruptio } \\
\text { Epizeuxis }\end{array}$ & $\begin{array}{l}55-56 \\
63,66,69, \\
70,75 \\
50,58 \\
64-68 \\
70-75\end{array}$ & $\begin{array}{l}\text { Sol Maior } \\
\text { Ré Maior } \\
\text { Sol Maior } \\
\text { Sol Maior } \\
\text { Ré Maior } \\
\text { Sol Maior }\end{array}$ & I \\
\hline CONFIRMATIO & $\begin{array}{l}\text { Abruptio } \\
\text { Synaeresis } \\
\text { Aposiopesis } \\
\text { Epizeuxis }\end{array}$ & $\begin{array}{l}76 \\
79 \\
82 \\
88 \\
83-88\end{array}$ & $\begin{array}{l}\text { Sol Maior } \\
\text { Mi Menor } \\
\text { Mi Menor } \\
\text { Mi Menor } \\
\text { Mi Menor e } \\
\text { Sol Maior }\end{array}$ & I \\
\hline PERORATIO & $\begin{array}{l}\text { Epizeuxis } \\
\text { Aposiopesis }\end{array}$ & $\begin{array}{l}89-102 \\
96 \\
102\end{array}$ & $\begin{array}{l}\text { Sol Maior } \\
\text { Sol Maior } \\
\text { Sol Maior }\end{array}$ & I \\
\hline
\end{tabular}




\subsection{André da Silva Gomes ${ }^{121}$}

\subsubsection{Análise Retórico-Musical do Ofertório da Missa do Domingo da Paixão}

\section{Inventio}

Essa obra foi escrita a partir de dois diferentes salmos: Obras Magníficas de Deus em Israel (Ps.110,1/111,1) e Elogio da Lei Divina (Ps. 118,17; 25/ $119,17 ; 27)$.

Confitebor tibi Domine, in toto corde meo:

Retribue servo tuo: vivam et custodiam sermones tuos:

Vivifica me secundum verbum tuum, Domine.

Quero louvar o Senhor de todo o meu coração:

Concedei ao teu servo o beneficio da vida, e guardarei a tua palavra:

Restitui-me a vida, segundo a tua palavra (SOARES, 2000, p.34).

O primeiro texto é um louvor que faz lembrar o êxodo das peregrinações pelo deserto e a conquista da terra prometida. O segundo, representa a dependência do cristão em guardar e obedecer à palavra de Deus, para lograr êxito, isto é, ser-Ihe outorgada a vida. Outro aspecto interessante são suas elaborações denominadas pelos teólogos e estudiosos como acróstico ${ }^{122}$, característica comum entre os poemas de sabedoria (ALMEIDA, 2000, p.697).

Assim como no Domingo de Ramos, o da Paixão abre a Semana Santa. No que tange à sua liturgia, pode-se verificar uma celebração de dois aspectos fundamentais, a paixão e a magnificência, a morte e ressurreição, os quais formam o mistério pascal, refletidos de maneira introspectiva pelo cristão.

Enfim, o ofertório é composto por quarenta e dois compassos, num andamento Grave na tonalidade de Sol Maior, distribuídos em seis partes, com grande intensidade, sejam emocionais ou afetivas, trabalhadas pelo compositor objetivadas em atrair a atenção do ouvinte.

\footnotetext{
${ }^{121}$ Os Ofertórios da Missa do Domingo da Paixão, como o do $4^{\circ}$ Domingo da Quaresma, foram analisados em nossa dissertação de mestrado, porém, foi feita uma revisão, sobretudo na localização e no exame das figuras retóricas. Contribuindo, dessa forma, para melhor averiguação em torno das figuras recorrentes apresentadas nas obras desse compositor. Por fim, segundo Régis Duprat, esses dois ofertórios são datados em 1810(DUPRAT, 1995, p.106).

${ }^{122}$ Composição poética na qual o conjunto das letras iniciais (e por vezes as mediais ou finais) dos versos compõe verticalmente uma palavra ou frase. No caso desses salmos, a cada meia linha eles são iniciados com letras sucessivas do alfabeto hebraico e se complementam em seu conteúdo.
} 


\subsection{Loci observados na Inventio do Ofertório}

Tabela 42-Loci Topici localizados no Ofertório da Missa do Domingo da Paixão de André da Silva Gomes.

\begin{tabular}{|c|c|c|c|}
\hline INVENTIO & DESCRIC̨ÃO & UTILIZACÃO NA OBRA & COMPASSO/ VOZ \\
\hline $\begin{array}{l}\text { Locus } \\
\text { Notationis } \\
\text { (MATTHESON, } \\
1954 \quad \text { [1739]. } \\
\text { Parte II, Cap.4, } \\
\S 23, \text { p.123). }\end{array}$ & $\begin{array}{l}\text { Aspecto externo } \\
\text { e desenho das } \\
\text { notas (Duração } \\
\text { das notas, } \\
\text { alteração, } \\
\text { repetição e } \\
\text { procedimentos } \\
\text { canônicos). }\end{array}$ & $\begin{array}{l}\text { Vários motivos rítmicos e } \\
\text { diferentes durações de } \\
\text { notas (mínimas, } \\
\text { semínimas, semínimas } \\
\text { pontuadas, colcheias, } \\
\text { colcheias pontuadas, } \\
\text { semicolcheias repetições, } \\
\text { apogiaturas, ligaduras, } \\
\text { fermatas, pausas, entre } \\
\text { outros). }\end{array}$ & $\begin{array}{ll}1-4 & S \\
5-14 & \text { S-A-T-B } \\
15-19 & S \\
20-29 & \text { S-A-T-B } \\
30-32 & \text { S } \\
33-42 & \text { S-A-T-B }\end{array}$ \\
\hline $\begin{array}{l}\text { Locus } \\
\text { Descriptionis } \\
\text { (MATTHESON, } \\
1954 \quad \text { [1739]. } \\
\text { Parte II, Cap.4, } \\
\S 43, \text { p.127). }\end{array}$ & $\begin{array}{l}\text { Disposições da } \\
\text { alma }\end{array}$ & $\begin{array}{l}\text { Celebração e Exaltação } \\
\text { (Quero louvar o Senhor } \\
\text { de todo o meu coração). }\end{array}$ & $\begin{array}{ll}1-4 & S \\
5-14 & \text { S-A-T-B }\end{array}$ \\
\hline $\begin{array}{l}\text { Locus } \\
\text { Oppositorum } \\
\text { (MATTHESON, } \\
1954 \quad \text { [1739]. } \\
\text { Parte II, Cap.4, } \\
\S 80, \text { p.131). }\end{array}$ & $\begin{array}{l}\text { Contraste de } \\
\text { compassos, } \\
\text { movimentos } \\
\text { contrários, } \\
\text { agudos e } \\
\text { graves, lento e } \\
\text { rápido, calmo e } \\
\text { agitado. }\end{array}$ & $\begin{array}{l}\text { Movimento contrário } \\
\text { entre soprano e baixo. }\end{array}$ & S-B \\
\hline
\end{tabular}

\section{Dispositio}

\subsection{Exordium}

A introdução do Ofertório inicia-se com o emprego da Synaeresis e da figura de repetição melódica, Palilogia, ambas destacando tanto as ornamentações, o solo executado pela soprano e a expressão de louvor manifesta pelo salmista, Confitebor tibi Domine (Quero louvar o Senhor). 


\section{(EXORDIUM)}

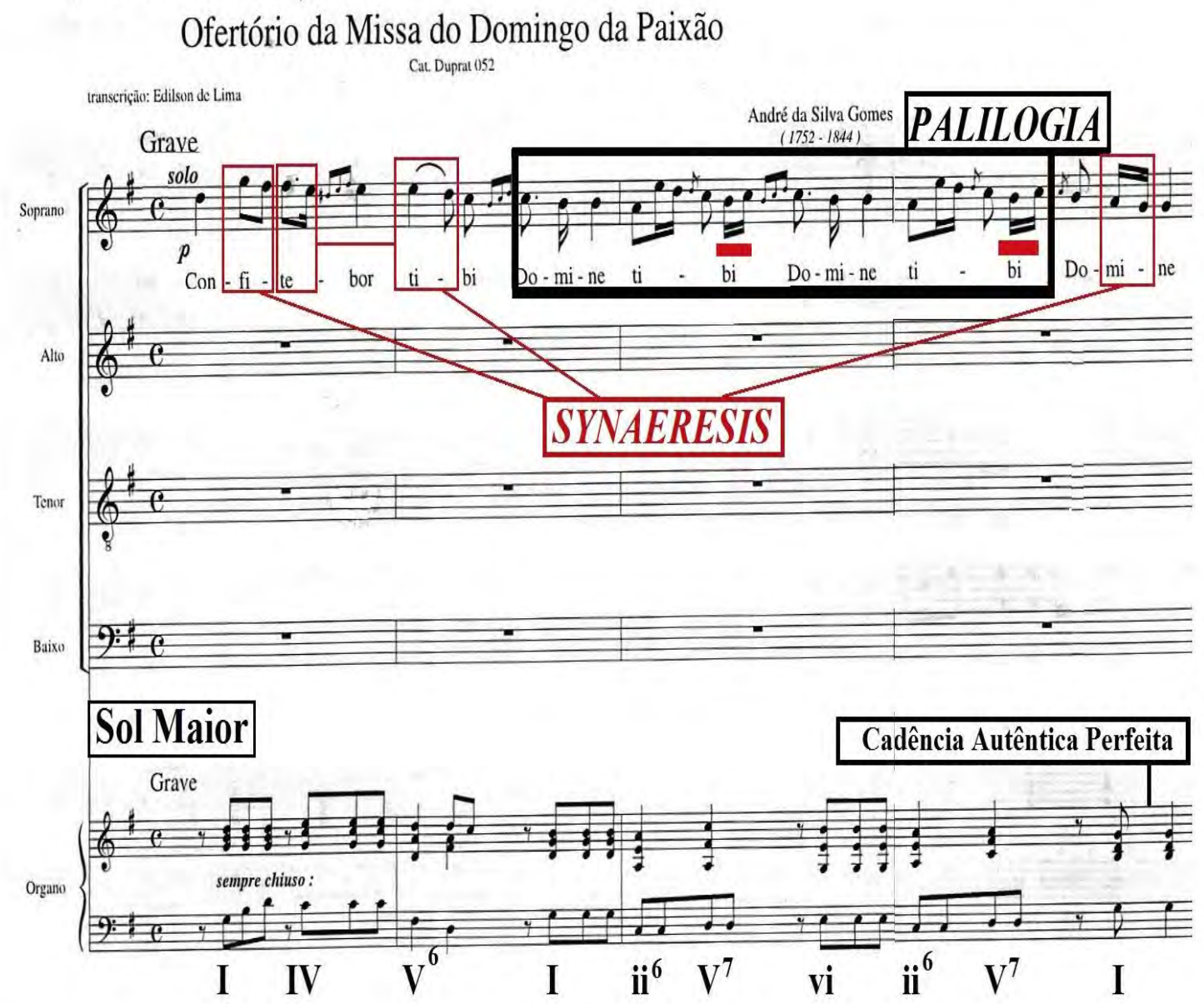

Exemplo 139-Ofertório da Missa do Domingo da Paixão de André da Silva GomesCatalogação e Organização Régis Duprat (DUPRAT, 1999, p.213).

\subsection{Narratio}

Após o desfecho do Exordium, na Cadência Autêntica Perfeita, a narração dos fatos iniciais se dá através do tutti, isto é, com todas as vozes entoando a mesma frase da introdução do discurso, contudo, é observável o uso de dinâmicas forte e piano ressaltando as notas, por meio da repetição, além da Synaeresis, reforçando o afeto de louvor e gratidão. 


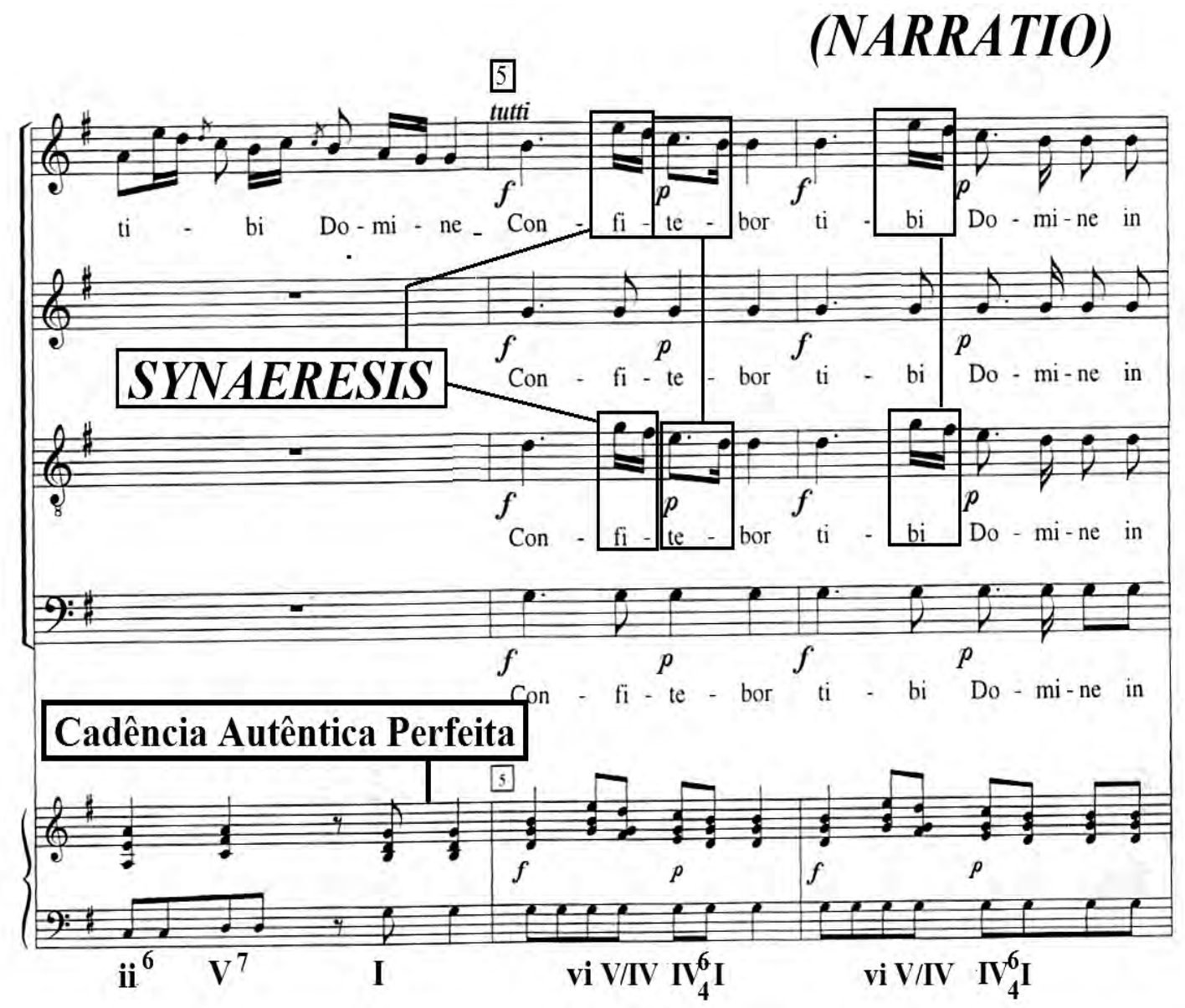

Exemplo 140-Ofertório da Missa do Domingo da Paixão de André da Silva GomesCatalogação e Organização Régis Duprat (DUPRAT, 1999, p.213).

Entre os compassos 7 e 12, o compositor continua utilizando figuras de repetição tais como Auxesis e Gradatio, sendo a primeira uma sucessão de repetições, tanto melódicas quanto das palavras, já a segunda, além do mesmo caráter repetitivo, enfatiza a complementação da primeira frase do salmo, in toto corde meo (de todo meu coração), através das terças paralelas entre soprano e contralto, além da sequência das notas nessas vozes e do baixo.

Outro aspecto relevante é a modulação para a tonalidade Mi Menor, no compasso 6, onde o autor trabalha com alguns tipos de dinâmicas, crescendo, forte e piano, valorando tanto as funções harmônicas quanto as representações dos afetos de celebração e devoção, as quais são colocadas em destaque num contexto macro por meio da Synaeresis. 

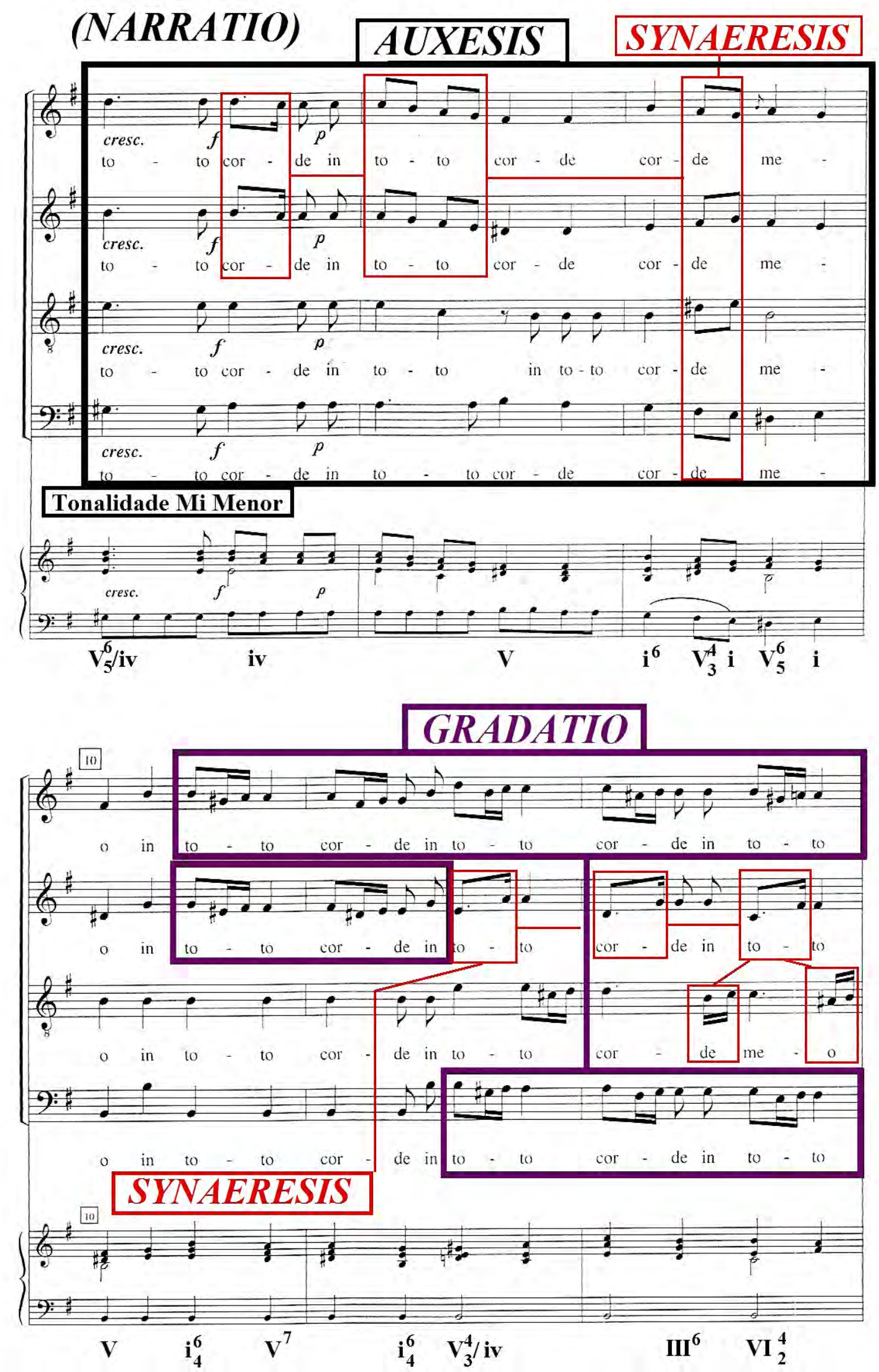

Exemplo 141-Ofertório da Missa do Domingo da Paixão de André da Silva GomesCatalogação e Organização Régis Duprat (DUPRAT, 1999, p.214). 


\subsection{Propositio}

Depois da conclusão da Narratio numa Semicadência, pode-se examinar nessa nova parte do discurso o emprego da Synonymia, destacando a expressão Retribue, por meio de repetição, realizado pelo solo da soprano. Semelhantemente, é verificável o predomínio da Synaeresis entre os compassos 16 e 19, enfatizando o afeto de devoção e agradecimento, na consolidação da frase Retribue servo tuo (retribuíste teu servo). Enfim, novamente são narrados os fatos advindos das seções anteriores, no entanto, numa argumentação sucinta, o que caracteriza uma Narratio dentro da Propositio.

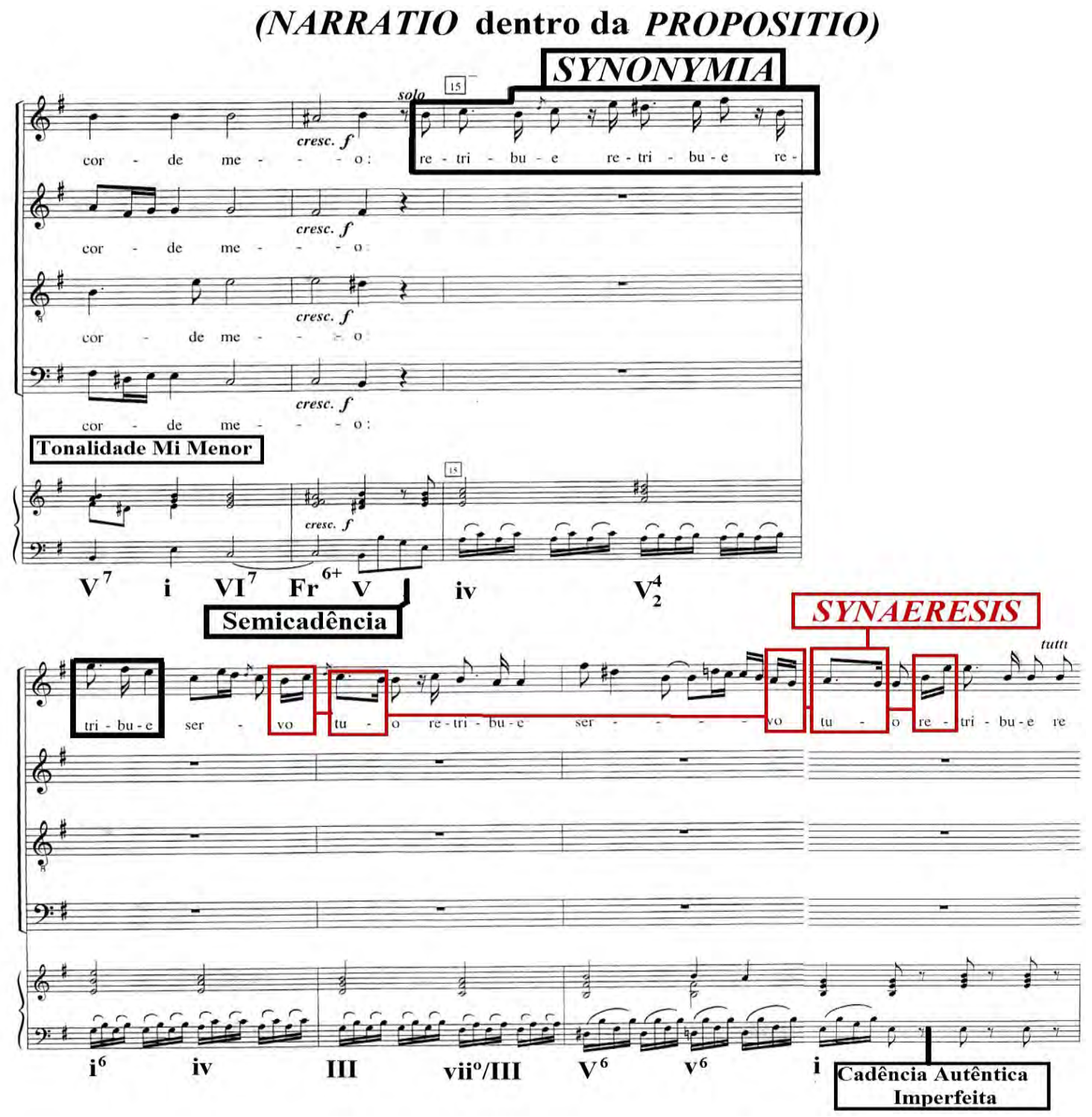

Exemplo 142-Ofertório da Missa do Domingo da Paixão de André da Silva GomesCatalogação e Organização Régis Duprat (DUPRAT, 1999, p.215). 


\subsection{Confutatio}

A Confutatio começa com a utilização de quatro figuras retóricas, com o predomínio da Anaphora, destacando as repetições da expressão retribue, a Palilogia, realçando mediante repetição das mesmas melodias e palavras e, por fim, a Epizeuxis acoplada à Synaeresis, enfatizando a prédica feita pelo salmista, o qual espera receber do Senhor o beneficio da vida Retribue servo tuo: vivam, et custodiam.
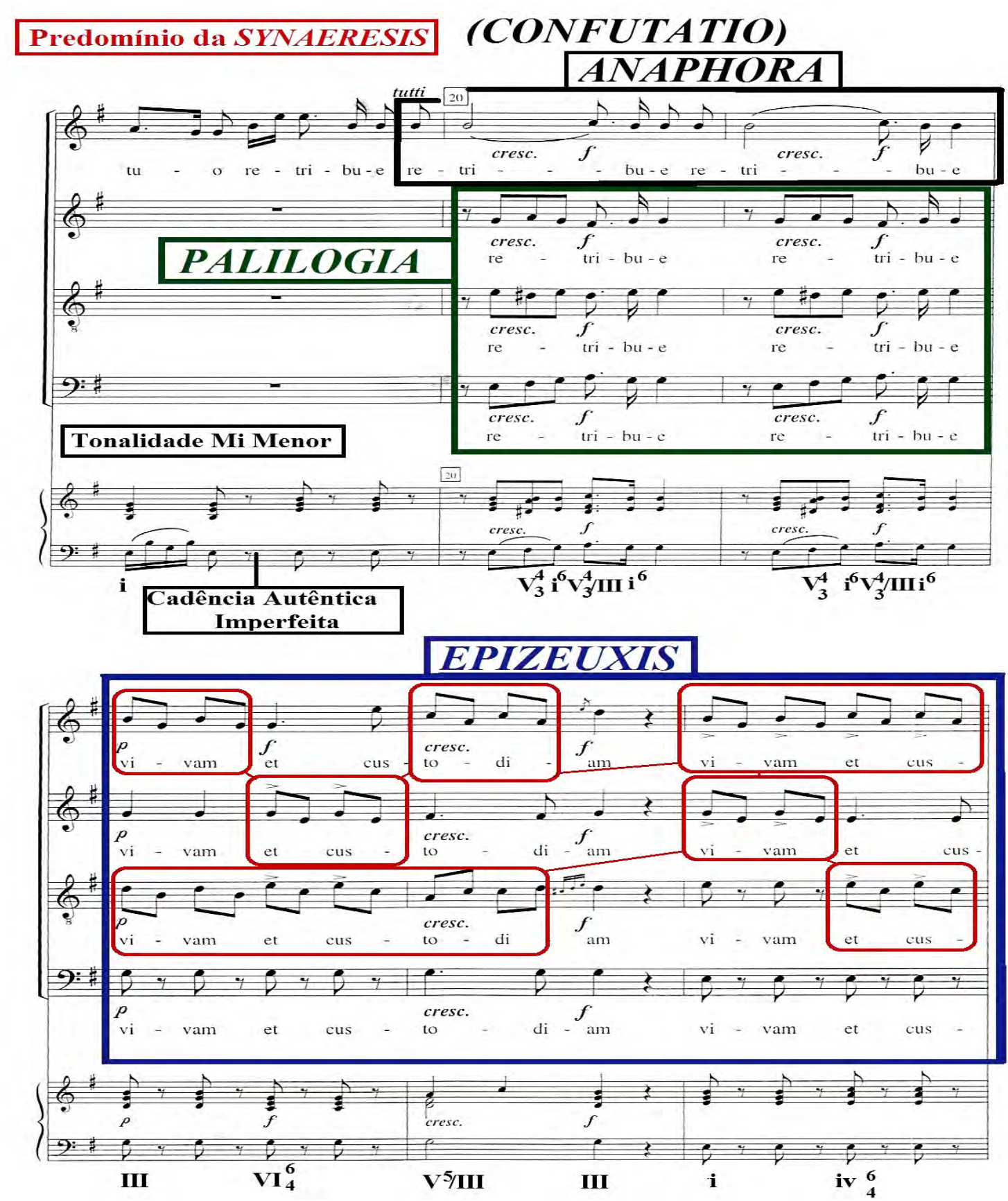

Exemplo 143-Ofertório da Missa do Domingo da Paixão de André da Silva GomesCatalogação e Organização Régis Duprat (DUPRAT, 1999, p.216). 
A caracterização tanto dos elementos de contraste como na refutação da tese inicial, se evidência através das inúmeras funções harmônicas empregadas pelo compositor no presente excerto, por exemplo, a progressão dos acordes menores (Em, Dm, Cm), entre os compassos 26 e 29, a inserção de Dominantes menores e da Sexta Napolitana, dentro da tonalidade Sol Maior e a modulação para Dó Maior, gerando maior dramaticidade e expectativa.

Enfim, Silva Gomes trabalha com figuras de silêncio e repetição, Aposiopesis, Synaeresis e Anaphora, adaptando-as conforme a necessidade e circunstância do discurso, seja no final de cada frase, nas resoluções das Cadências ou no destaque do solo da soprano, enfatizando as repetições da palavra vivifica me, com veemência.

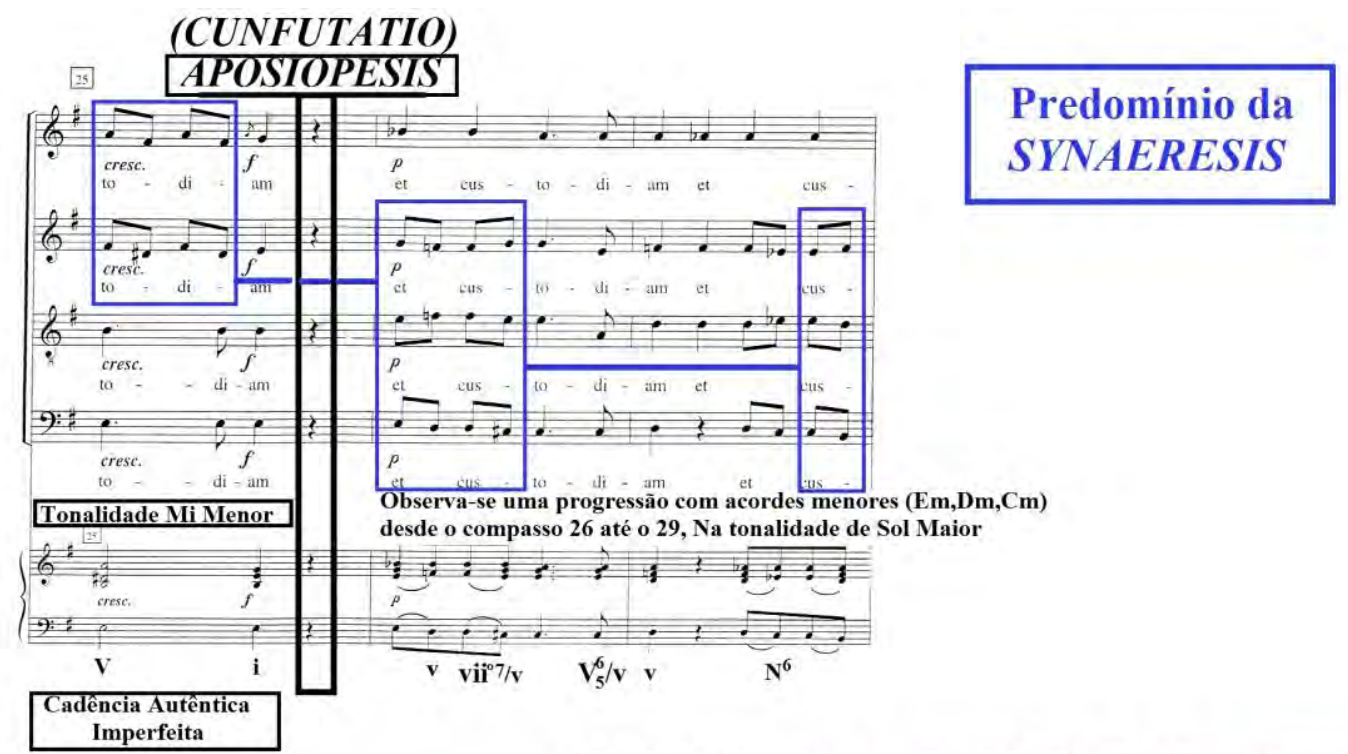

(NARRATIO dentro da CONFUTATIO) ANAPHORA

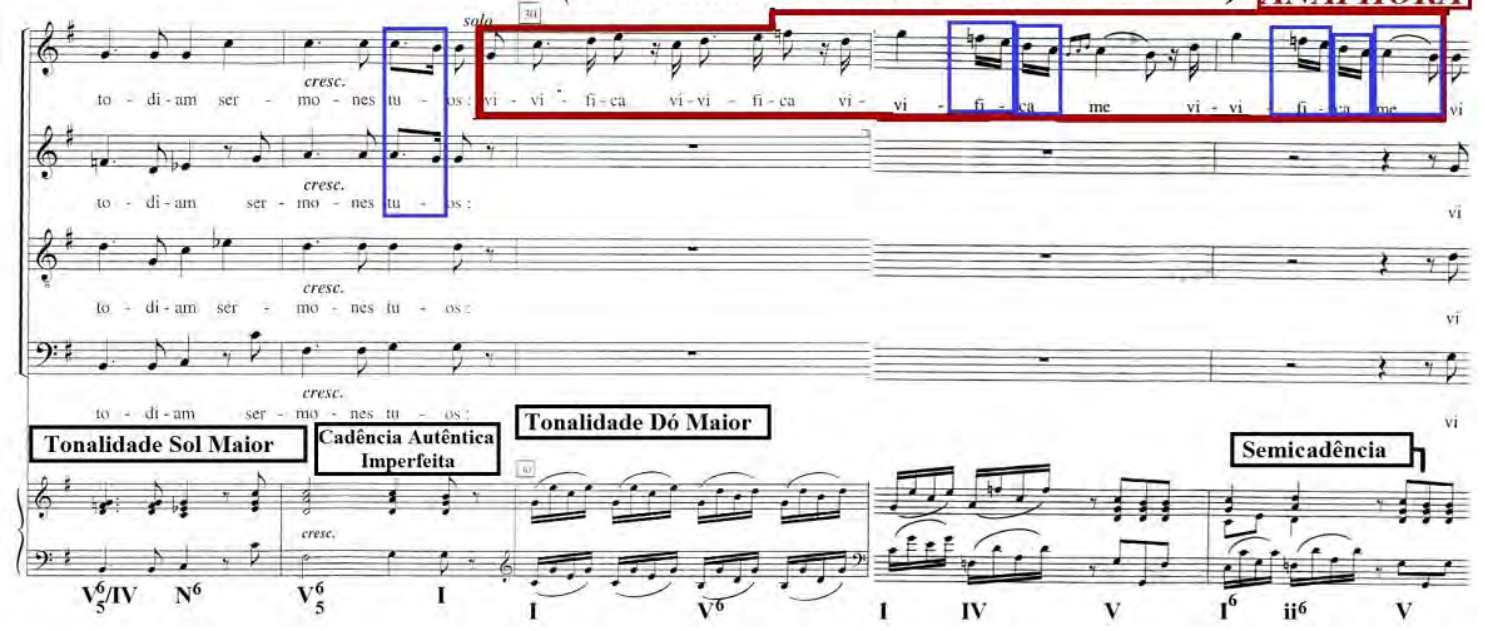

Exemplo 144-Ofertório da Missa do Domingo da Paixão de André da Silva GomesCatalogação e Organização Régis Duprat (DUPRAT, 1999, pp.217-218). 


\subsection{Confirmatio}

A confirmação da tese inicial é perceptível através da expressão secundum verbum tuum, isto é, a petição pela concessão da vida eterna mediante a obediência dos estatutos bíblicos. Silva Gomes, como profundo conhecedor do texto sacro e da liturgia cristã, emprega a Epizeuxis como figura de repetição e ênfase, tal como a Synaeresis, para reforçar essa premissa, na tonalidade Sol Menor.

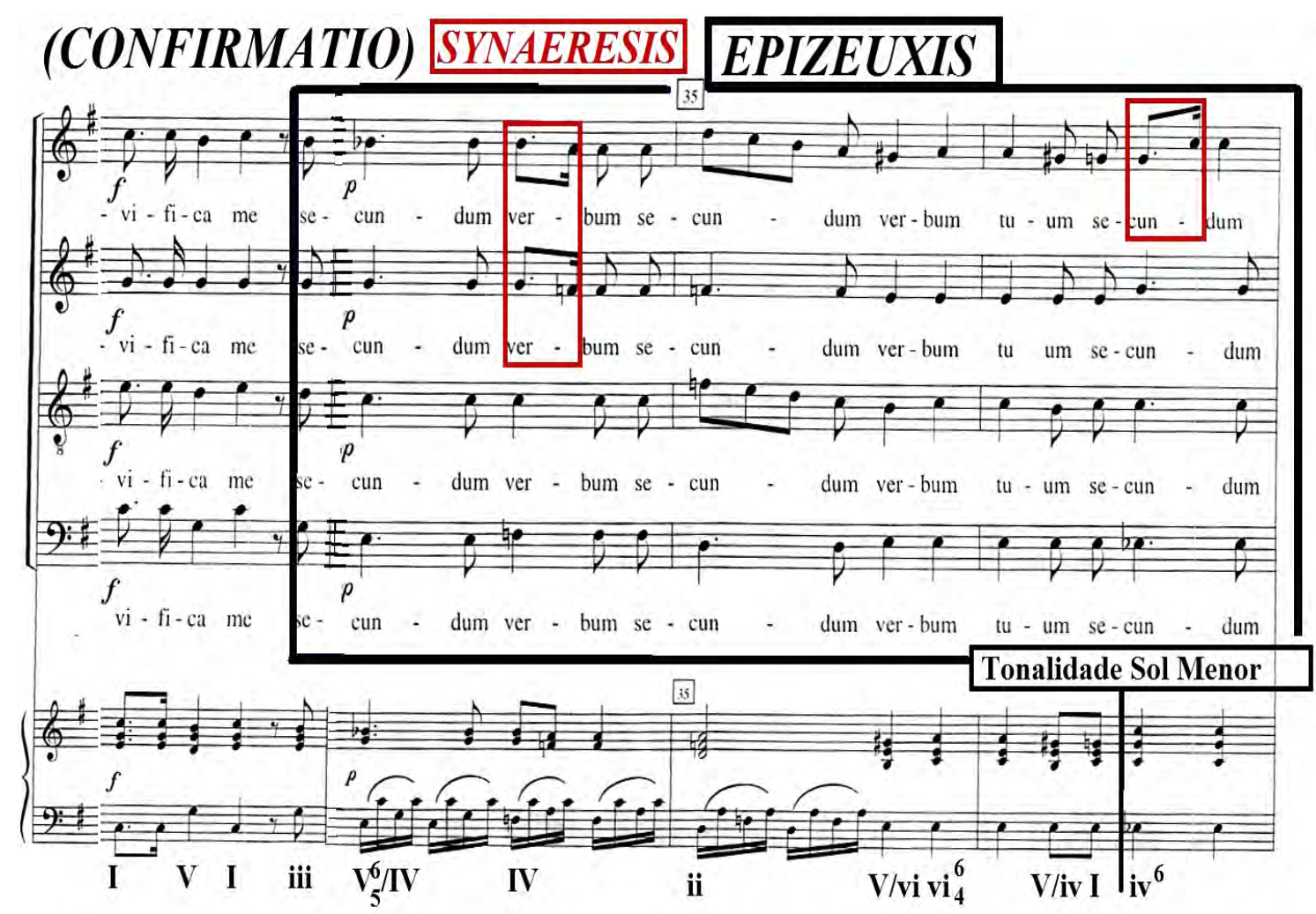

Exemplo 145-Ofertório da Missa do Domingo da Paixão de André da Silva GomesCatalogação e Organização Régis Duprat (DUPRAT, 1999, p.218).

Além dos elementos retóricos já mencionados, observa-se o uso da Gradatio, valorando as palavras e notas, por meio de repetições em forma de sequência, também é verificável o pedal de Dominante, dando sustentação tanto na voz do baixo como no acompanhamento instrumental. 


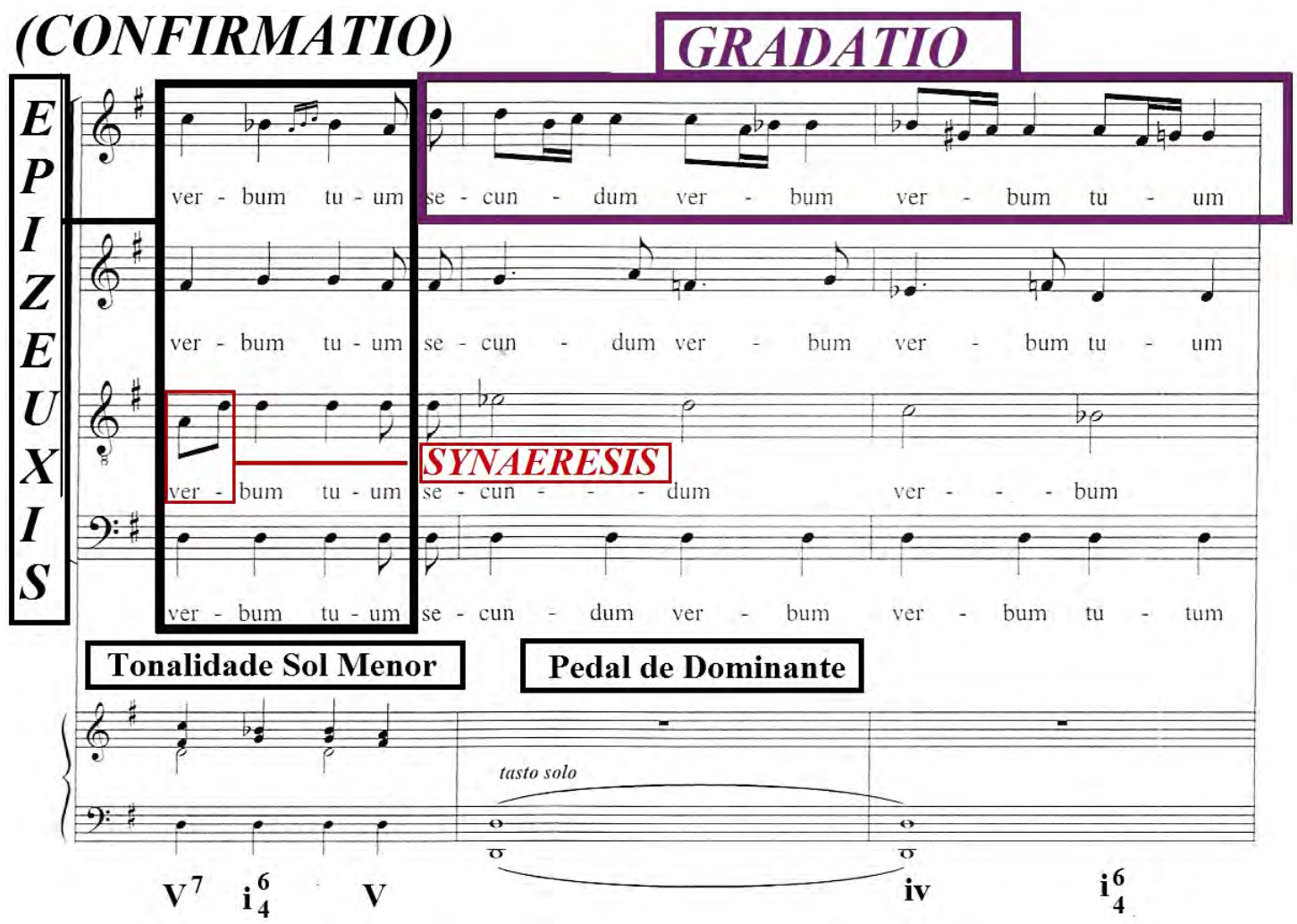

Exemplo 146-Ofertório da Missa do Domingo da Paixão de André da Silva GomesCatalogação e Organização Régis Duprat (DUPRAT, 1999, p.219).

\subsection{Peroratio}

Com o fechamento da Confirmatio na Cadência Autêntica Imperfeita, tem-se a conclusão do discurso numa pequena Coda de dois compassos, onde o autor sacramenta mais uma vez o pedido da oração feita em forma de louvor, através do uso da dinâmica forte, representando o afeto de intensidade consubstanciada pela fé e devoção e da dinâmica pianissimo, reproduzindo o afeto de certeza, serenidade e convicção da resposta positiva da súplica dirigida ao Senhor (Domine), somada pela aplicação da Synaeresis, a qual antecede o término da obra no acorde de Sol Maior. 


\section{(CONFIRMATIO)}

\section{(PERORATIO)}

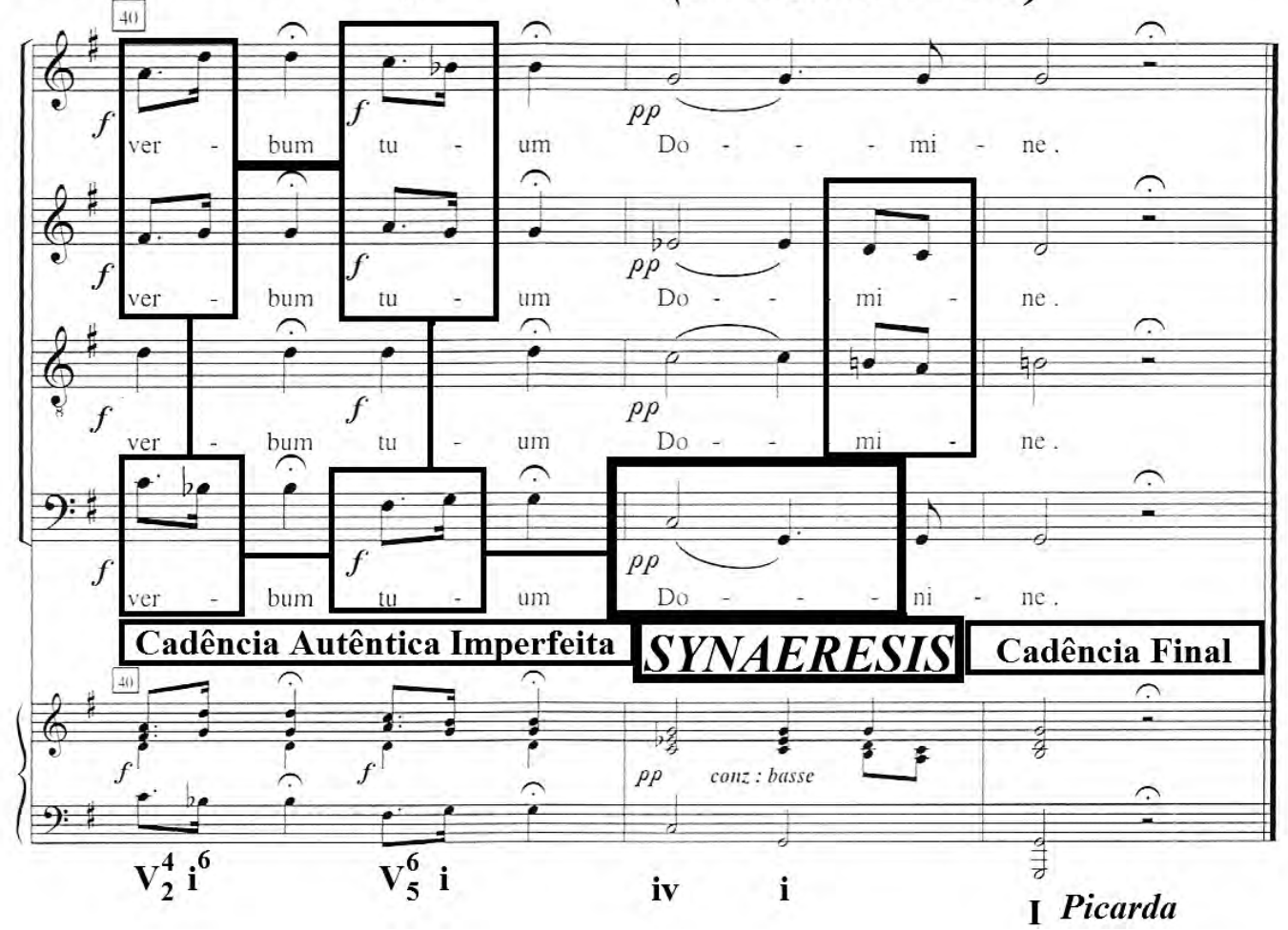

Exemplo 147-Ofertório da Missa do Domingo da Paixão de André da Silva GomesCatalogação e Organização Régis Duprat (DUPRAT, 1999, p.219).

\section{Figuras observadas no Ofertório (Elocutio/Decoratio)}

Tabela 43-Figuras retóricas localizadas no Ofertório da Missa do Domingo da Paixão de André da Silva Gomes.

\begin{tabular}{|c|c|c|c|}
\hline $\begin{array}{l}\text { FIGURAS } \\
\text { CITAÇÕES }\end{array}$ & TIPO & DESCRIÇÃO & TRATADISTA \\
\hline $\begin{array}{l}\text { ANAPHORA } \\
\text { (BARTEL, 1997, } \\
\text { pp.184-190). }\end{array}$ & $\begin{array}{l}\text { Repetição } \\
\text { Melódica }\end{array}$ & 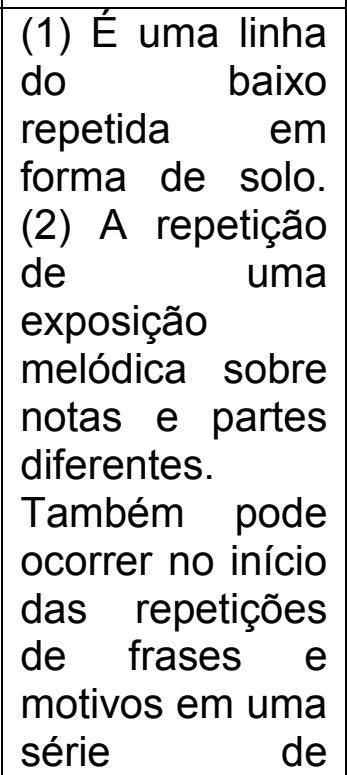 & 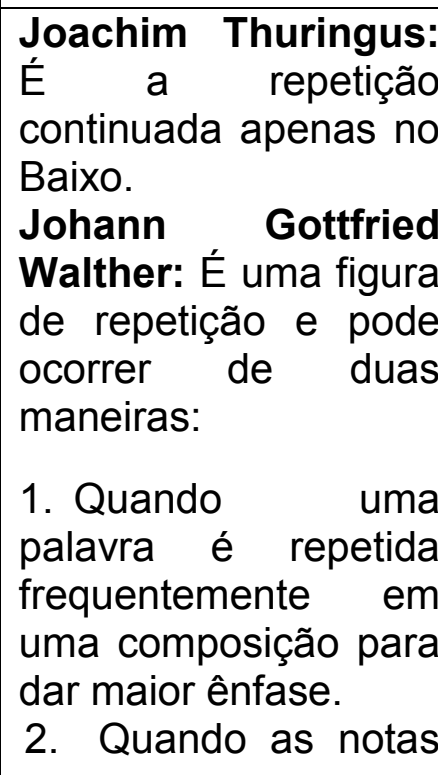 \\
\hline
\end{tabular}




\begin{tabular}{|c|c|c|c|}
\hline & & $\begin{array}{l}\text { passagens } \\
\text { sucessivas; (3) } \\
\text { Uma repetição } \\
\text { em geral. }\end{array}$ & $\begin{array}{l}\text { graves são repetidas } \\
\text { inúmeras vezes } \\
\text { (como o caso das } \\
\text { Chaconne). }\end{array}$ \\
\hline $\begin{array}{l}\text { APOSIOPESIS } \\
\text { (BARTEL, 1997, } \\
\text { pp.202-206). }\end{array}$ & $\begin{array}{l}\text { Interrupção e } \\
\text { Silêncio }\end{array}$ & $\begin{array}{l}\text { Um descanso } \\
\text { em uma ou } \\
\text { todas as vozes } \\
\text { de uma } \\
\text { composição: } \\
\text { pausa geral. }\end{array}$ & $\begin{array}{lr}\text { Johann } & \text { Gottfried } \\
\text { Walther: } & \text { A } \\
\text { Aposiopesis se refere } \\
\text { a uma pausa } \\
\text { generalis ou um } \\
\text { completo silêncio em } \\
\text { todas as vozes e nas } \\
\text { partes da composição } \\
\text { simultaneamente. }\end{array}$ \\
\hline $\begin{array}{l}\text { AUXESIS } \\
\text { (BARTEL, 1997, } \\
\text { pp. 209-212). }\end{array}$ & $\begin{array}{l}\text { Repetição } \\
\text { Melódica }\end{array}$ & $\begin{array}{l}\text { São repetições } \\
\text { sucessivas de } \\
\text { uma passagem } \\
\text { musical. }\end{array}$ & 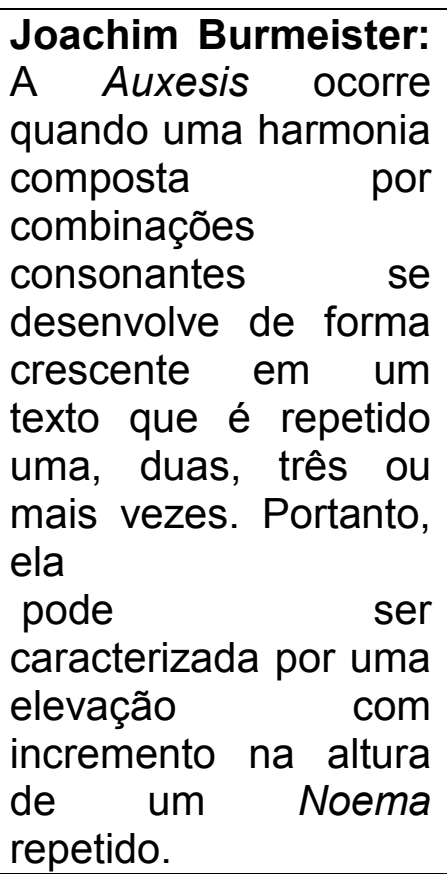 \\
\hline $\begin{array}{l}\text { EPIZEUXIS } \\
\text { (BARTEL, 1997, } \\
\text { pp.263-265). }\end{array}$ & $\begin{array}{l}\text { Repetição } \\
\text { Melódica }\end{array}$ & $\begin{array}{l}\text { Uma repetição } \\
\text { imediata e } \\
\text { enfática de uma } \\
\text { palavra, nota, } \\
\text { motivo ou frase. }\end{array}$ & $\begin{array}{l}\text { Johann } \text { Gottfried } \\
\text { Walther: A Epizeuxis } \\
\text { é uma figura de } \\
\text { retórica pela qual uma } \\
\text { ou mais palavras são } \\
\text { imediatamente } \\
\text { enfaticamente } \\
\text { repetidas. }\end{array}$ \\
\hline $\begin{array}{l}\text { GRADATIO } \\
\text { (BARTEL, 1997, } \\
\text { pp.220-224). }\end{array}$ & $\begin{array}{l}\text { Repetição } \\
\text { Melódica }\end{array}$ & $\begin{array}{l}\text { (1) Sequência } \\
\text { de notas em } \\
\text { uma só voz } \\
\text { repetida em } \\
\text { qualquer } \\
\text { tonalidade } \\
\text { maior ou menor, } \\
\text { (2) Duas vozes }\end{array}$ & $\begin{array}{l}\text { Johann Gottfried } \\
\text { Walther: Climax ou } \\
\text { Gradatio podem ser } \\
\text { interpretadas das } \\
\text { seguintes formas: } \\
\text { 1. Quando há } \\
\text { palavras que falam }\end{array}$ \\
\hline
\end{tabular}




\begin{tabular}{|c|c|c|c|}
\hline & & $\begin{array}{l}\text { que se } \\
\text { deslocam em } \\
\text { movimento } \\
\text { ascendente ou } \\
\text { descendente } \\
\text { paralelo, (3) Um } \\
\text { aumento } \\
\text { gradual na } \\
\text { intensidade e } \\
\text { altura do som. }\end{array}$ & 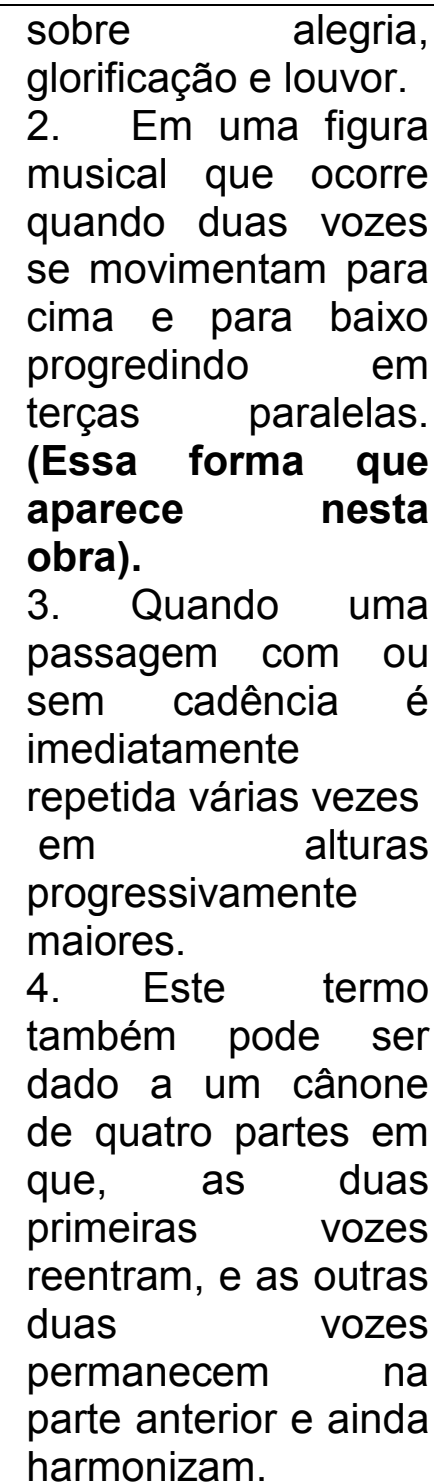 \\
\hline $\begin{array}{l}\text { PALILOGIA } \\
\text { (BARTEL, 1997, } \\
\text { pp.342-344). } \\
\text { (BUELOW, 2001, } \\
\text { p.264). }\end{array}$ & $\begin{array}{l}\text { Repetição } \\
\text { Melódica }\end{array}$ & $\begin{array}{l}\text { Repetição de } \\
\text { um tema no } \\
\text { mesmo nível de } \\
\text { altura, também } \\
\text { pode ocorrer em } \\
\text { alturas } \\
\text { diferentes na } \\
\text { mesma ou em } \\
\text { várias vozes. }\end{array}$ & $\begin{array}{l}\text { Joachim Burmeister: } \\
\text { A Palilogia é uma } \\
\text { repetição de uma } \\
\text { inteiração ou apenas } \\
\text { o começo da estrutura } \\
\text { dos meios e temas } \\
\text { sobre a mesma altura } \\
\text { com a mesma voz, } \\
\text { ocorrendo com ou } \\
\text { sem intermédio de } \\
\text { pausas em todos os } \\
\text { eventos em uma voz. } \\
\text { Johann Gottfried } \\
\text { Walther: A } \\
\text { Palilogia refere-se a } \\
\text { uma repetição por } \\
\text { demais frequente das } \\
\text { mesmas palavras. }\end{array}$ \\
\hline
\end{tabular}




\begin{tabular}{|c|c|c|c|}
\hline $\begin{array}{l}\text { SYNAERESIS } \\
\text { (BARTEL, 1997, } \\
\text { pp.394-396). } \\
\text { (LÓPEZ CANO, } \\
\text { 2000, p.199). }\end{array}$ & $\begin{array}{l}\text { Dissonância e } \\
\text { Deslocamento }\end{array}$ & $\begin{array}{l}\text { (1) Uma } \\
\text { suspensão ou } \\
\text { síncope, (2) A } \\
\text { colocação de } \\
\text { duas sílabas por } \\
\text { nota ou duas } \\
\text { notas por } \\
\text { sílaba. }\end{array}$ & $\begin{array}{l}\text { Mauritius Johann } \\
\text { Vogt: A Synaeresis } \\
\text { ocorre quando duas } \\
\text { notas são colocadas } \\
\text { em uma sílaba ou } \\
\text { duas sílabas são } \\
\text { colocadas em uma } \\
\text { nota. }\end{array}$ \\
\hline $\begin{array}{l}\text { SYNONYMIA } \\
\text { (BARTEL, 1997, } \\
\text { pp.405-407). }\end{array}$ & $\begin{array}{l}\text { Repetição } \\
\text { Melódica }\end{array}$ & $\begin{array}{l}\text { É a repetição } \\
\text { alterada ou } \\
\text { modificada de } \\
\text { uma ideia } \\
\text { musical. } \\
\text { A repetição de } \\
\text { uma ideia } \\
\text { melódica em } \\
\text { notas diferentes } \\
\text { na mesma } \\
\text { parte. }\end{array}$ & $\begin{array}{lr}\text { Johann } & \text { Gottfried } \\
\text { Walther: Um } \\
\text { compositor também } \\
\text { pode empregar muito } \\
\text { bem diferentes figuras } \\
\text { retóricas r na } \\
\text { elaboração de um } \\
\text { texto. Por exemplo, } \\
\text { além da Epizeuxis, } \\
\text { que é a mais comum } \\
\text { e enfática, pode usar, } \\
\text { Anaphora, } \\
\text { Synonymia, } \\
\text { Epistrophe, } \\
\text { Epanalepsis e assim } \\
\text { por diante. }\end{array}$ \\
\hline
\end{tabular}

\section{Análise Harmônica}

\subsection{Curva Tonal}

Tonalidade: Sol Maior

Andamento: Grave 4/4

Tabela 44-Esquema das Progressões Harmônicas- Curva Tonal do Ofertório da Missa do Domingo da Paixão.

\begin{tabular}{|l|c|l|}
\hline \multicolumn{1}{|c|}{ Compassos } & Função & \multicolumn{1}{|c|}{ Tonalidade } \\
\hline $1-6$ & $\mathrm{I}$ & Sol Maior \\
\hline $7-11$ & $\mathrm{vi}$ & Mi Menor \\
\hline 11 & $\mathrm{ii}$ & Lá Menor \\
\hline $12-13$ & $\mathrm{vi}$ & Mi Menor \\
\hline $13-14$ & $\mathrm{~V} / \mathrm{vi}$ & Si Maior \\
\hline $15-16$ & $\mathrm{vi}$ & Mi Menor \\
\hline 17 & $\mathrm{I}$ & Sol Maior \\
\hline $18-21$ & $\mathrm{vi}$ & Mi Menor \\
\hline $22-23$ & $\mathrm{IV}$ & Dó Maior \\
\hline
\end{tabular}




\begin{tabular}{|l|c|l|}
\hline $24-25$ & vi & Mi Menor \\
\hline $26-27$ & v & Ré Menor \\
\hline $27-29$ & $\begin{array}{c}\text { N6 } \\
\text { (Napolitana/Subdominante } \\
\text { Menor) }\end{array}$ & Dó Menor \\
\hline $30-33$ & IV & Dó Maior \\
\hline 34 & IV/IV & Fá Maior \\
\hline 35 & ii & Lá Menor \\
\hline $36-37$ & V & Ré Maior \\
\hline $38-41$ & i (Tonalidade Homônima) & Sol Menor \\
\hline 42 & I & Sol Maior \\
\hline
\end{tabular}

4.2. Estrutura Analítica da obra: Retórica e Harmônica

Tabela 45-Estrutura analítica da obra.

\begin{tabular}{|c|c|c|c|c|}
\hline $\begin{array}{l}\text { RETÓRICA } \\
\text { DISPOSITIO }\end{array}$ & $\begin{array}{c}\text { FIGURA } \\
\text { ELOCUTIO }\end{array}$ & COMP. & TONALIDADE & FUNÇÃO \\
\hline EXORDIUM & $\begin{array}{l}\text { Synaeresis } \\
\text { Palilogia }\end{array}$ & $\begin{array}{l}1-2,4 \\
2-4\end{array}$ & $\begin{array}{l}\text { Sol Maior } \\
\text { Sol Maior }\end{array}$ & $\begin{array}{l}1 \\
1\end{array}$ \\
\hline NARRATIO & $\begin{array}{l}\text { Synaeresis } \\
\text { Auxesis } \\
\text { Gradatio }\end{array}$ & $\begin{array}{l}5-6,7-9 \\
11-12 \\
7-9 \\
10-12\end{array}$ & $\begin{array}{l}\text { Sol Maior } \\
\text { Mi Menor } \\
\text { Sol Maior } \\
\text { Mi Menor }\end{array}$ & $\begin{array}{l}\text { I } \\
\text { vi } \\
\text { I } \\
\text { vi }\end{array}$ \\
\hline PROPOSITIO & Synonymia & $14-16$ & Mi Menor & vi \\
\hline CONFUTATIO & $\begin{array}{l}\text { Anaphora } \\
\text { Palilogia } \\
\text { Epizeuxis }\end{array}$ & $\begin{array}{l}16-19 \\
22-24 \\
25-27 \\
29,31-32 \\
\\
19-21 \\
\text { e } 29-32 \\
20-21 \\
22-24\end{array}$ & $\begin{array}{l}\text { Mi Menor } \\
\text { Mi Menor } \\
\text { Dó Maior } \\
\text { Sol Maior e Dó } \\
\text { Maior } \\
\text { Mi Menor } \\
\text { Dó Maior } \\
\text { Mi Menor } \\
\text { Mi Menor }\end{array}$ & $\begin{array}{l}\mathrm{vi} \\
\mathrm{vi} \\
\mathrm{IV} \\
\text { I e IV } \\
\mathrm{vi} \\
\mathrm{IV} \\
\mathrm{vi} \\
\mathrm{Vi}\end{array}$ \\
\hline
\end{tabular}




\begin{tabular}{|l|l|l|l|c|}
\hline & Aposiopesis & 25 & Mi Menor & vi \\
\hline CONFIRMATIO & $\begin{array}{l}\text { Epizeuxis } \\
\text { Synaeresis }\end{array}$ & $33-37$ & Sol Menor & $\begin{array}{c}\mathrm{i} \\
\text { (Homo) } \\
\mathrm{i} \\
\text { (Homo) } \\
\mathrm{i} \\
\text { (Homo) }\end{array}$ \\
\hline PERORATIO & Synadatio & $37-39$ & Sol Menor & $\begin{array}{c}\mathrm{i} \\
\text { (Homo) }\end{array}$ \\
\hline
\end{tabular}




\subsubsection{Análise Retórico-Musical do Ofertório da Missa do $4^{\circ}$ Domingo da Quaresma}

\section{Inventio}

Esse ofertório tem como epígrafe Hino de Louvor a Deus, Senhor de todas as coisas e Benfeitor de Israel (Ps.134,3; 6/ 135,3; 6).

Laudate Dominum, quia benignus est:

Psallite Domino nomini ejus, quoniam suavis est

Omnia quæcumque voluit, facit in cælo et in terra.

[Vulgata: Laudate Dominum quia bonus Dominus

Psallite nomini ejus quoniam suave

Omnia quæ voluit Dominus, fecit in cælo et in terra].

Louvai ao Senhor, porque ele é bom:

Cantai o seu nome, por que é suave

O que apraz ao Senhor ele o faz, no céu e na terra

(SOARES, 2000, pp.80-81).

Nesse excerto, o salmista faz um encômio ao Senhor por seus atributos, em outras palavras, há um louvor direcionado à magnificência, bondade, poder e justiça de Deus para com seus servos. Esse chamamento para louvar a Deus se baseia em três fatos pertinentes:

1. Deus estabeleceu um relacionamento de salvação com Israel.

2. Deus é um ser agradável, aprazível e, sobretudo, traz contentamento a seu povo.

3. Deus é onipresente, está em todo o lugar e perto de seu povo, compadecendo-se daqueles que o servem.

A ritualística do Quarto Domingo da Quaresma visa estabelecer um diálogo entre o cristão, simbolizando o filho pródigo, que, arrependido, busca a remissão de seus pecados e reconciliação com seu pai, através do ato penitencial, seja por obras, orações ou jejum, enfim, o objetivo litúrgico dessa fase do Ofertório é trazer ao cristão uma reflexão para mudança de atitude e de vida.

No que tange a Inventio dessa obra, pode-se dizer que a mesma é escrita a oito vozes, constituída por sessenta e sete compassos, com 
andamento em Andante Moderato, na tonalidade Dó Maior, ordenados em seis partes, nas respectivas fases do discurso retórico.

\subsection{Loci observados na Inventio do Ofertório}

Tabela 46-Loci Topici localizados no Ofertório da Missa do Quarto Domingo da Quaresma de André da Silva Gomes.

\begin{tabular}{|c|c|c|c|}
\hline INVENTIO & DESCRIÇÃO & $\begin{array}{c}\text { UTILIZAÇÃO NA } \\
\text { OBRA }\end{array}$ & $\begin{array}{l}\text { COMPASSOI } \\
\text { VOZ }\end{array}$ \\
\hline $\begin{array}{l}\text { Locus } \\
\text { Notationis } \\
\text { (MATTHESON, } \\
\text { 1954, [1739]. } \\
\text { Parte II, Cap.4, } \\
\S 23, \text { p.123). }\end{array}$ & $\begin{array}{l}\text { Aspecto externo } \\
\text { e desenho das } \\
\text { notas (Duração } \\
\text { das notas, } \\
\text { alteração, } \\
\text { repetição e } \\
\text { procedimentos } \\
\text { canônicos). }\end{array}$ & $\begin{array}{l}\text { Vários motivos } \\
\text { rítmicos e diferentes } \\
\text { durações de notas } \\
\text { (mínimas, mínimas } \\
\text { pontuadas, } \\
\text { semínimas, } \\
\text { semínimas } \\
\text { pontuadas, colcheias, } \\
\text { colcheias pontuadas, } \\
\text { semicolcheias, } \\
\text { repetições, ligaduras, } \\
\text { pausas, apogiatura, } \\
\text { fermata entre outros). }\end{array}$ & $\begin{array}{ll}1-3 & \text { S-A-T-B } \\
4-7 & \text { S-A-T-B } \\
7-19 & \text { S1 } \\
20-29 & \text { S-A-T-B } \\
30-37 & \text { S1 e S2 } \\
38-43 & \text { S-A-T-B } \\
44-51 & \text { S1 } \\
52-67 & \text { S-A-T-B }\end{array}$ \\
\hline $\begin{array}{l}\text { Locus } \\
\text { Descriptionis } \\
\text { (MATTHESON, } \\
\text { 1954, [1739]. } \\
\text { Parte II, Cap.4, } \\
\S 43, \text { p.127). }\end{array}$ & $\begin{array}{l}\text { Disposições da } \\
\text { alma }\end{array}$ & $\begin{array}{l}\text { Celebração e } \\
\text { Exaltação (Louvai ao } \\
\text { Senhor, por que ele é } \\
\text { bom). }\end{array}$ & $\begin{array}{ll}1-3 & \text { S-A-T-B } \\
4-7 & \text { S-A-T-B } \\
7-19 & \text { S1 } \\
20-29 & \text { S-A-T-B }\end{array}$ \\
\hline $\begin{array}{l}\text { Locus } \\
\text { Comparationis } \\
\text { (MATTHESON, } \\
\text { 1954, [1739]. } \\
\text { Parte II, Cap.4 } \\
\S 79, \text { p.131). }\end{array}$ & $\begin{array}{l}\text { Comparações de } \\
\text { coisas } \\
\text { semelhantes ou } \\
\text { não, grandes ou } \\
\text { pequenas. }\end{array}$ & $\begin{array}{l}\text { Comparação do nome } \\
\text { de Deus com ternura } \\
\text { (Cantai o seu nome, } \\
\text { por que é suave). } \\
\text { Coisas não } \\
\text { semelhantes (Céu e } \\
\text { Terra). }\end{array}$ & $\begin{array}{ll}30-38 & \mathrm{~S} 1-\mathrm{S} 2 \\
38-43 & \mathrm{~S}-\mathrm{A}-\mathrm{T}-\mathrm{B}\end{array}$ \\
\hline $\begin{array}{l}\text { Locus } \\
\text { Oppositorum } \\
\text { (MATTHESON, } \\
\text { 1954, } \\
\text { [1739].Parte II, } \\
\text { Cap.4, § 80, } \\
\text { p.131). }\end{array}$ & $\begin{array}{l}\text { Contraste de } \\
\text { compassos, } \\
\text { movimentos } \\
\text { contrários, } \\
\text { agudos e } \\
\text { graves, lento e } \\
\text { rápido, calmo e } \\
\text { agitado. }\end{array}$ & $\begin{array}{l}\text { Movimento contrário } \\
\text { entre soprano- } 2 \text { e } \\
\text { baixo- } 2 \text {. } \\
\text { Também no contralto- } \\
2 \text { e baixo- } 2 \\
\text { soprano-1e } 2 \text { e baixo- } \\
1 \text { e } 2\end{array}$ & $\begin{array}{l}5-7 \quad \text { S2-B2 } \\
23-25 \text { S2-B2 } \\
27 \quad \text { A2-B2 } \\
38-40 \text { S1e 2- } \\
\text { B1 e } 2\end{array}$ \\
\hline
\end{tabular}




\section{Dispositio}

\subsection{Exordium}

O Ofertório da Missa do Quarto Domingo da Quaresma começa de maneira intensa e ao mesmo tempo vívida e regozijante, na tonalidade Dó Maior. Mattheson, em seu tratado de 1713 para orquestra, afirma que essa tonalidade, apesar de rudimentar e ousada, é bem aplicada em situações de regozijo e alegria (MATTHESON, 1713, parte III, cap.2,§ 12, p.240) ${ }^{123}$.

André da Silva Gomes, como hábil compositor, utiliza-se dos recursos retóricos para fundamentar a primeira parte do discurso da música, inserindo a Pausa nas quatro vozes da segunda parte, submetendo as mesmas a um breve silêncio, para, posteriormente, serem entoadas como repetição em relação às vozes da primeira parte, isto é, em alturas diferentes pelo Polyptoton. De igual modo, é empregada a Palilogia, que, além de repetir as notas e as palavras, dá ênfase às mesmas, consubstanciando todo o sentimento de louvor e júbilo Laudate Dominum (Louvai ao Senhor). Por fim, verifica-se a inserção da Synaeresis nesse contexto ressaltando duas notas com uma sílaba em todas as vozes.

Em relação às funções harmônicas, pode ser observada, entre os compassos 1 a 4, a presença da Tônica, Subdominante e Dominante, culminando numa Cadência Plagal, no segundo tempo do quarto compasso. Já nos compassos 5 e 6, a Tônica e Dominante são trabalhadas pelo compositor de maneira enfática, mantendo diálogo não só entre si, mas igualmente com as figuras e elementos dispostos no Exordium, até sua conclusão na metade do compasso 7, na Cadência Autêntica Perfeita.

${ }^{123}$ Citação também localizada em (JANK, 2009, p.2; CARPENA, 2012, p.234). 
Ofertório da Missa do $4^{\circ}$. Domingo da Quaresma $\quad$ (EXORDIUM)

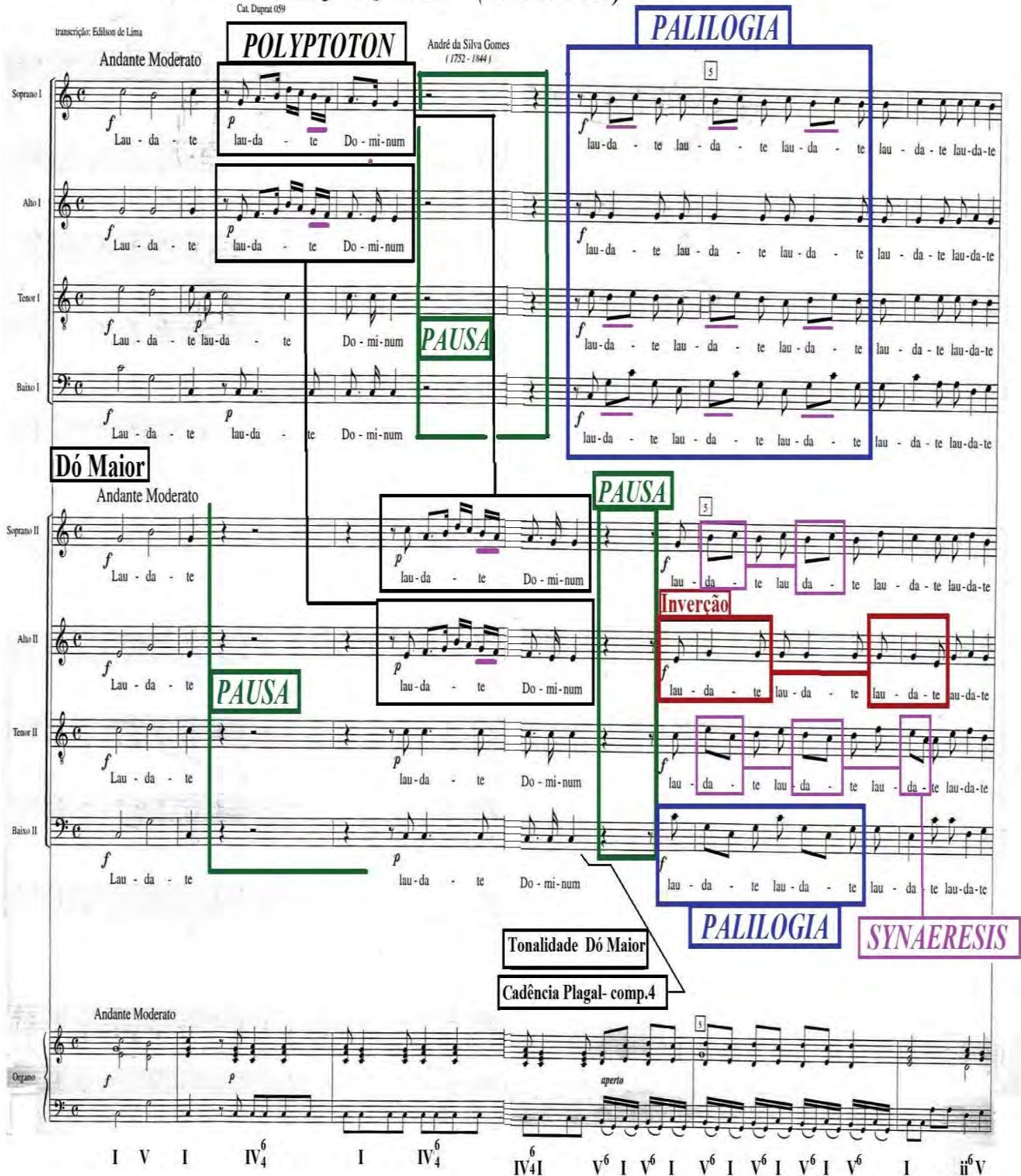

Exemplo 148-Ofertório da Missa do $4^{\circ}$ Domingo da Quaresma de André da Silva GomesCatalogação e Organização Régis Duprat (DUPRAT, 1999, pp.106-107).

\subsection{Narratio}

Nessa parte, o compositor luso-brasileiro continua a desenvolver seu intento de atrair a atenção do ouvinte por intermédio da repetição e ênfase introduzindo a Climax. Do mesmo modo, procura destacar com a Synaeresis, 
ainda mais esse afeto de alegria e unidade cristã, através da narração dos fatos na voz da soprano.

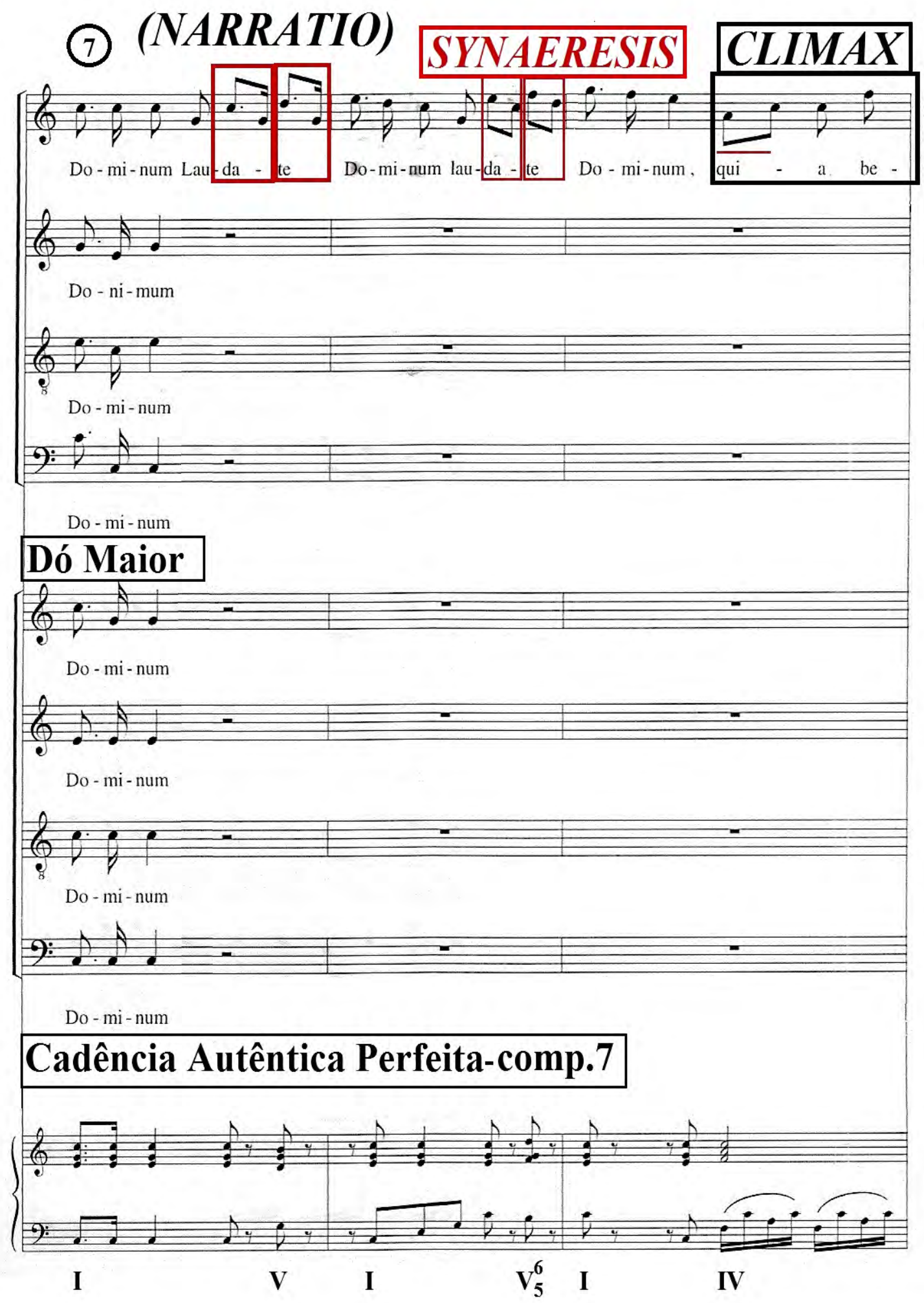

Exemplo 149-Ofertório da Missa do $4^{\circ}$ Domingo da Quaresma de André da Silva GomesCatalogação e Organização Régis Duprat (DUPRAT, 1999, p.108). 
Nos compassos 10 e 11, verifica-se a figura do Climax, cuja função é repetir em forma de sequência as notas, no entanto, em alturas diferentes e na mesma voz. Igualmente, é obervável o emprego da Synaeresis realçando no compasso 12, a sílaba est entoada pelas notas Fá e Mi.

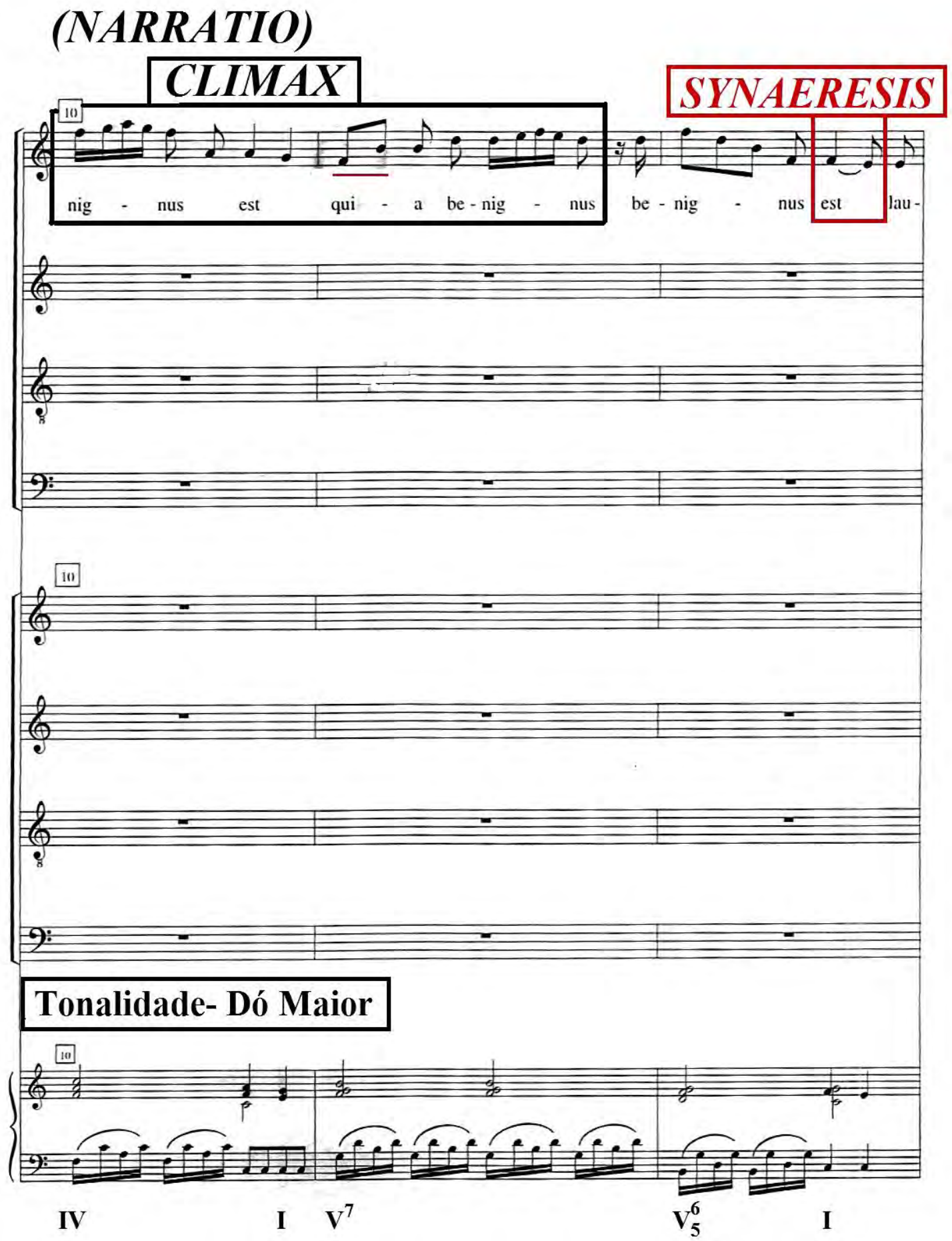

Exemplo 150-Ofertório da Missa do $4^{\circ}$ Domingo da Quaresma de André da Silva GomesCatalogação e Organização Régis Duprat (DUPRAT, 1999, p.109). 
A Narratio é encerrada na tonalidade Dó Maior, numa Cadência Autêntica Perfeita, porém, o autor insere a Variatio, objetivando a variação ornamental das notas. Outro ponto a ser salientado são as duas notas entoando uma sílaba dentro dessa variação, configurando a figura mais comumente usada na obra: Synaeresis.

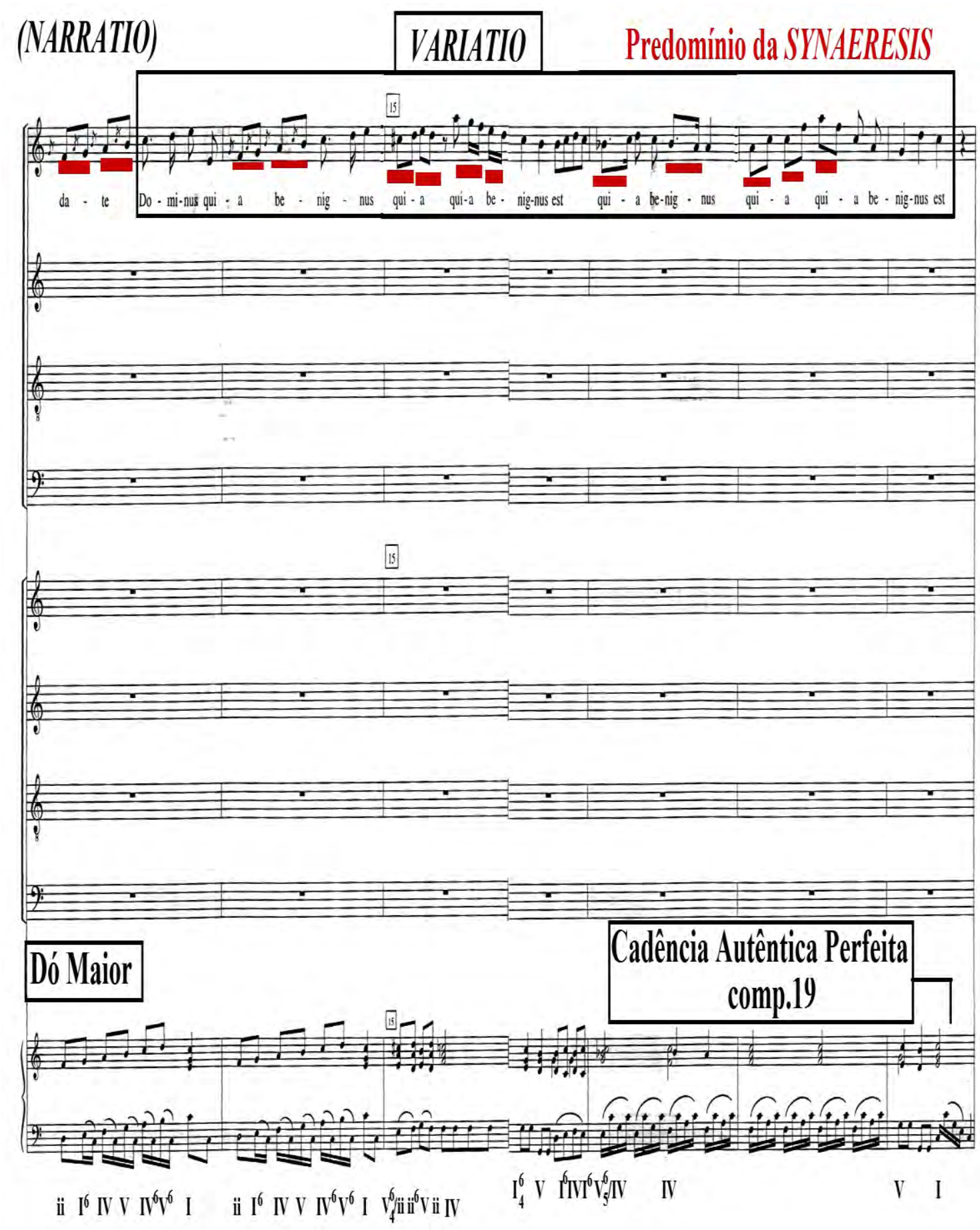

Exemplo 151-Ofertório da Missa do $4^{\circ}$ Domingo da Quaresma de André da Silva GomesCatalogação e Organização Régis Duprat (DUPRAT, 1999, pp.110-111). 


\subsection{Propositio}

Examinam-se na Propositio os mesmos elementos e figuras retóricas utilizadas no início do ofertório, por essa razão acontece um Exordium dentro da Propositio, no entanto, no compasso 25, acontece uma modulação para a tonalidade Lá Menor.

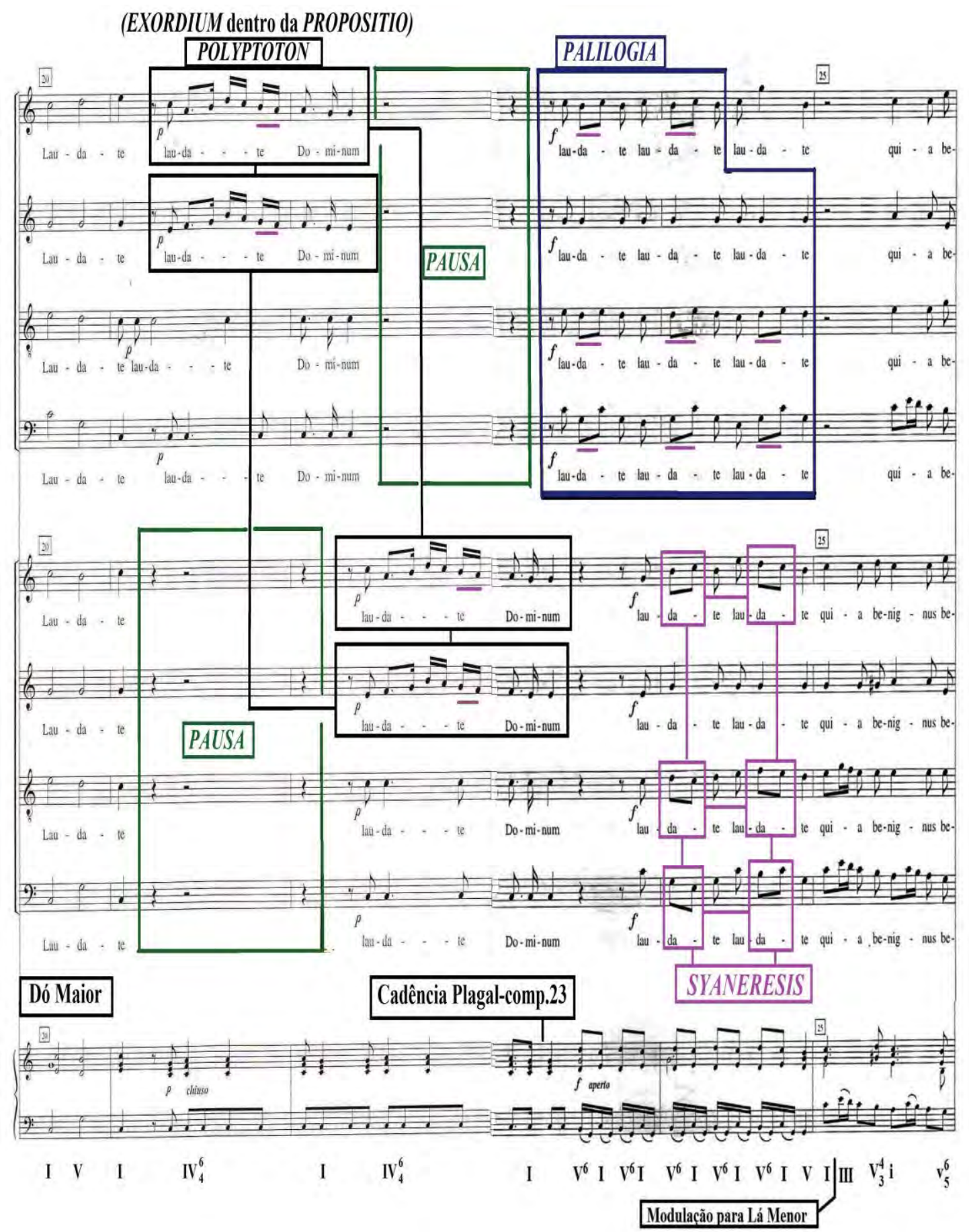

Exemplo 152-Ofertório da Missa do $4^{\circ}$ Domingo da Quaresma de André da Silva GomesCatalogação e Organização Régis Duprat (DUPRAT, 1999, pp.112-113). 
Nota-se a mesma repetição das palavras proferidas na Narratio, todavia, em todas as vozes, também é verificável a inversão motívica nos compassos 27 e 28, como a predominância da Synaeresis e o uso da Pausa. Enfim, a terceira seção é finalizada em Lá Menor, numa Cadência Autêntica Imperfeita.

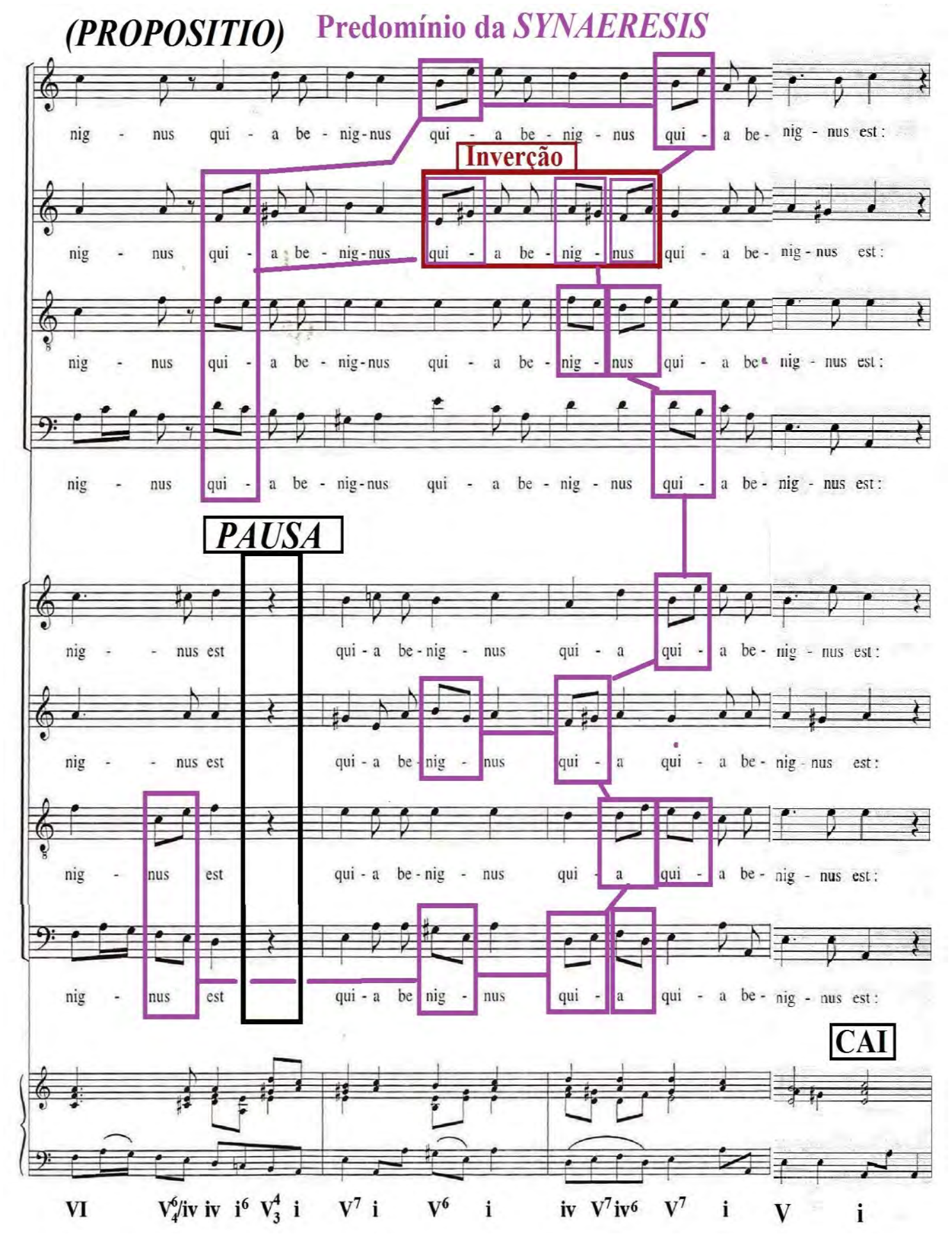

Exemplo 153-Ofertório da Missa do $4^{\circ}$ Domingo da Quaresma de André da Silva GomesCatalogação e Organização Régis Duprat (DUPRAT, 1999, pp.114-115). 


\subsection{Confutatio}

Após a Aposiopesis, empregada no final da seção anterior, novos elementos são apresentados na quarta seção da peça como a Anaphora, por exemplo, enfatizando as palavras Psalite nominie ejus (Cantai ao seu nome), nas vozes da soprano I e II, assim caracterizando a Narratio dentro da Confutatio.

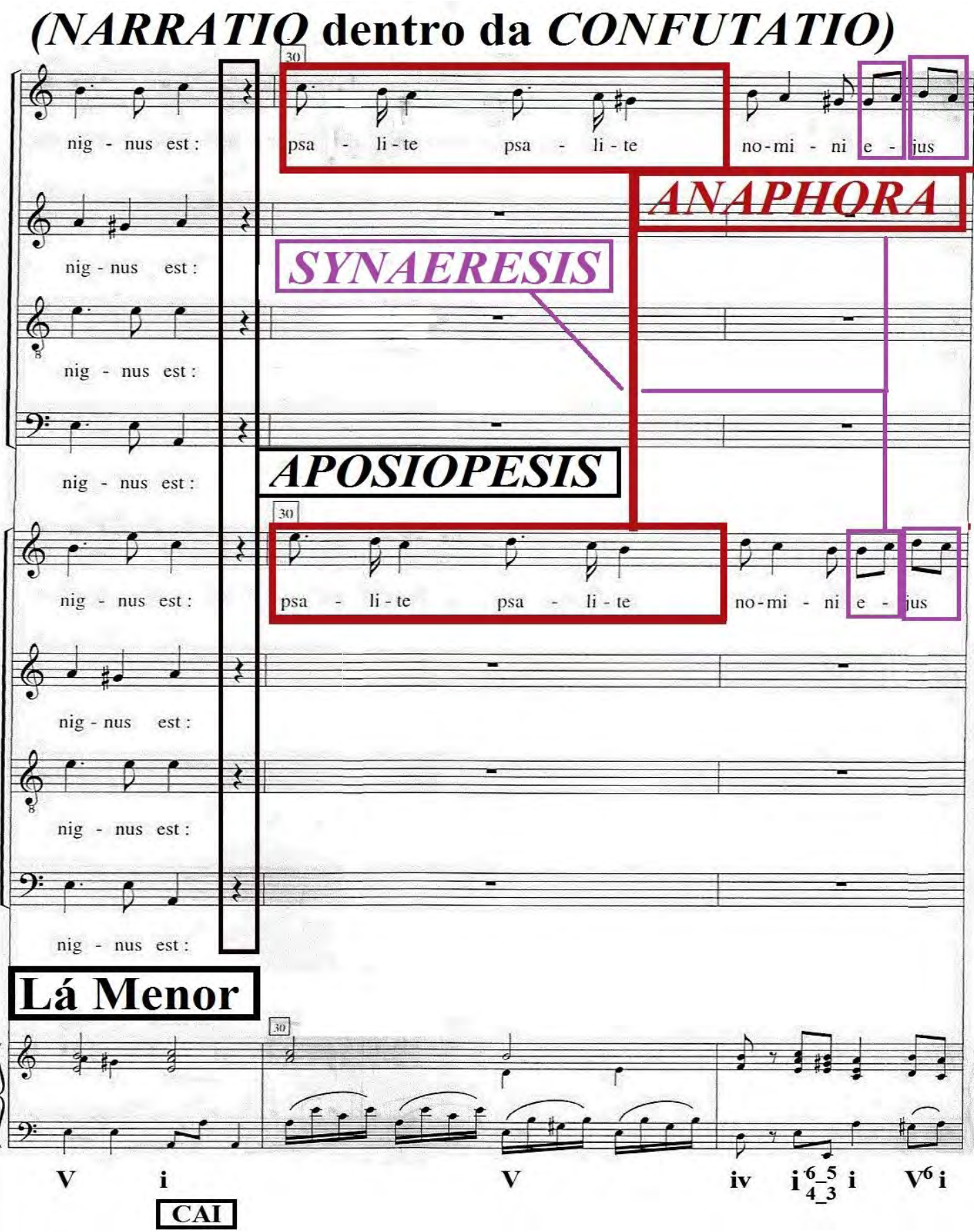

Exemplo 154-Ofertório da Missa do $4^{\circ}$ Domingo da Quaresma de André da Silva GomesCatalogação e Organização Régis Duprat (DUPRAT, 1999, p.115). 
Averigua-se o emprego da Synonymia nos compassos 35 e 36, repetindo a ideia musical já estabelecida de que se deve louvar ao Senhor por sua bondade e suavidade, quoniam suavis est. Similarmente, é observável uma pequena passagem cromática na soprano I, que antecede a figura de repetição, a qual expressa, de maneira suave e singela, o afeto de exultação e serenidade em consonância a Synaeresis.

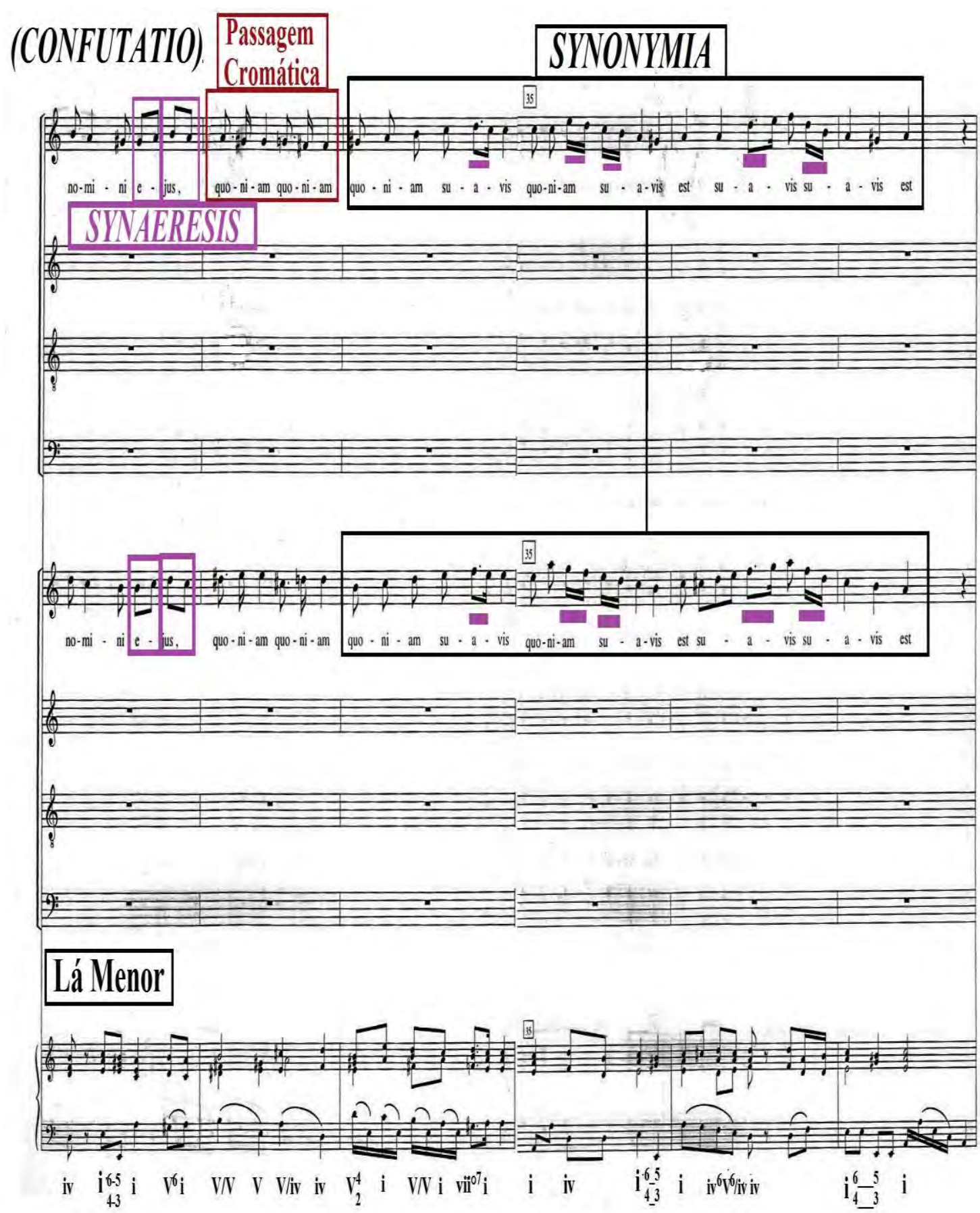

Exemplo 155-Ofertório da Missa do $4^{\circ}$ Domingo da Quaresma de André da Silva GomesCatalogação e Organização Régis Duprat (DUPRAT, 1999, pp.116-117). 
Nesse trecho, observa-se o emprego da Epizeuxis em todas as vozes, destacando enfaticamente que se deve louvar ao Senhor, Psalite Domino. Nota-se igualmente, que Silva Gomes usa a Synaeresis para enfatizar essa repetição mediante as duas notas entoadas numa sílaba pela voz da soprano e contralto. Outra coisa a ser verificada é a modulação para a tonalidade Dó Maior no compasso 40.

\section{(CONFUTATIO) EPIZEUXIS}

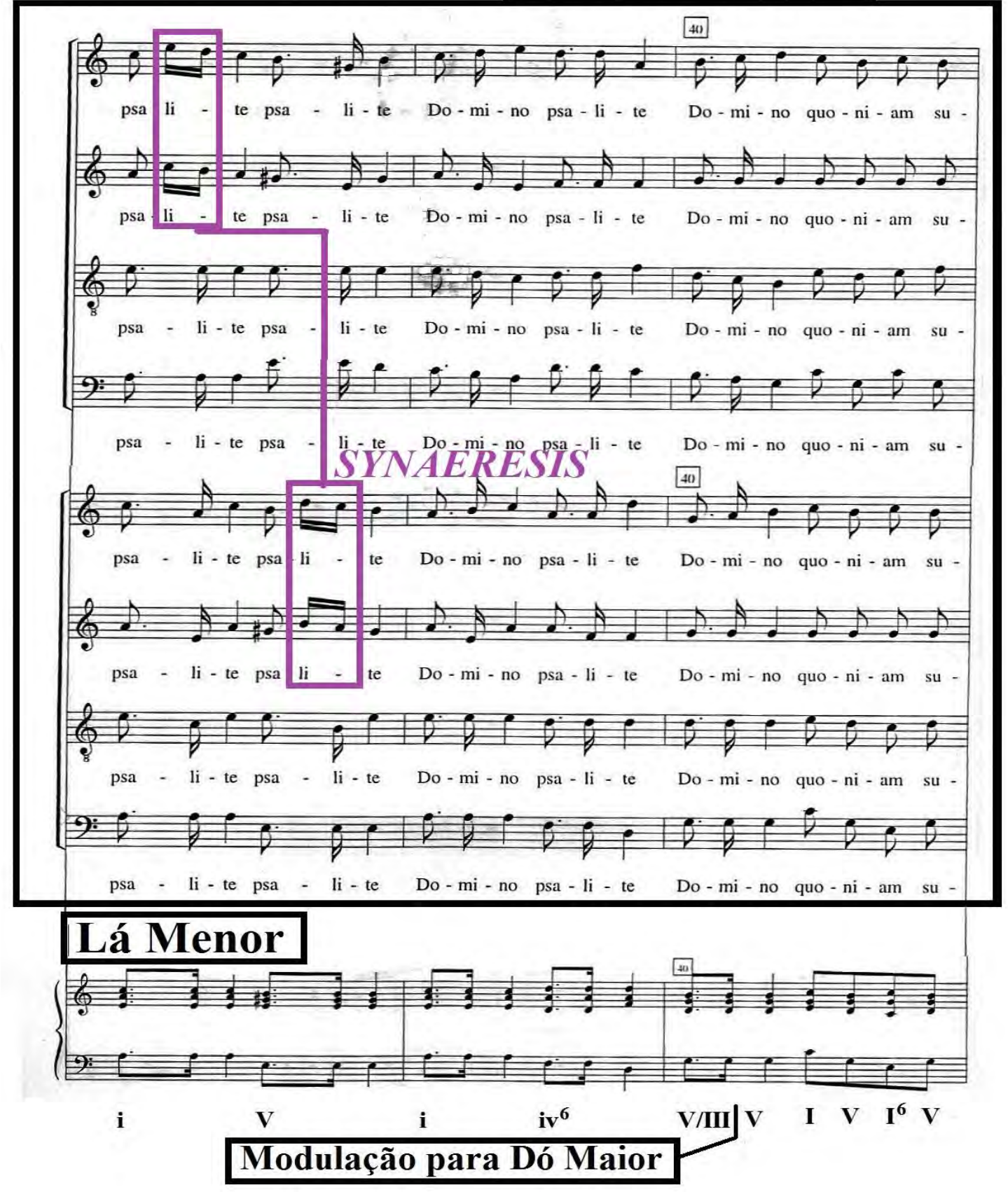

Exemplo 156-Ofertório da Missa do $4^{\circ}$ Domingo da Quaresma de André da Silva GomesCatalogação e Organização Régis Duprat (DUPRAT, 1999, p.118). 
Silva Gomes continua utilizando a Epizeuxis e a Synaeresis, porém, novamente é evidenciada a aplicação da Narratio dentro da Confutatio como da Aposiopesis.

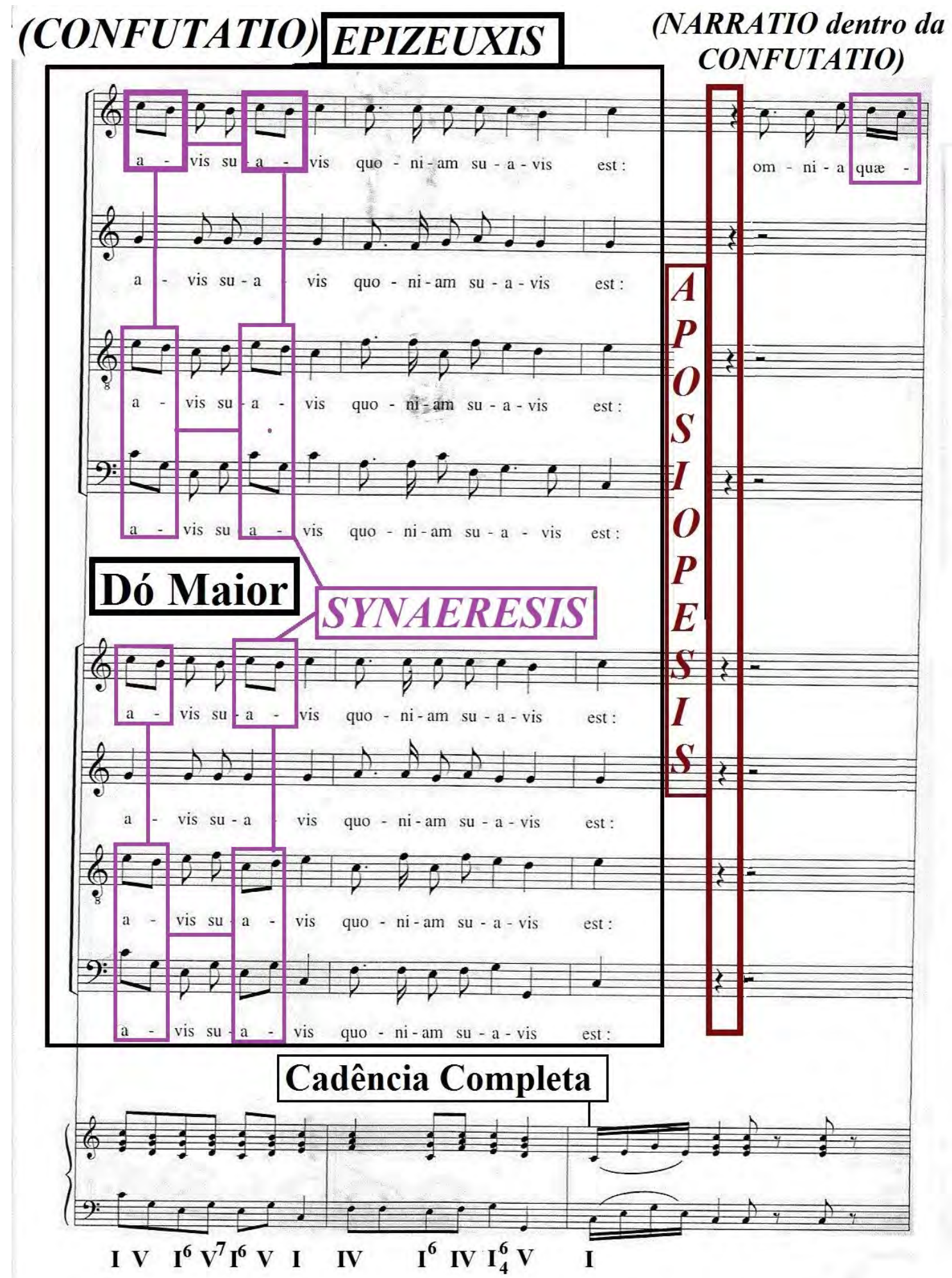

Exemplo 157-Ofertório da Missa do $4^{\circ}$ Domingo da Quaresma de André da Silva GomesCatalogação e Organização Régis Duprat (DUPRAT, 1999, p.119). 
Nessa parte, nota-se que o compositor trabalha com repetições das notas, motivos e de expressões como in cælo et in terra (no céu e na terra), tendo por objetivo atrair o ouvinte através do apelo emocional, representado pelo afeto de devoção e servidão a um ser que está ao mesmo tempo ascenso nas alturas como manifesto na terra, isto é, onipresente.
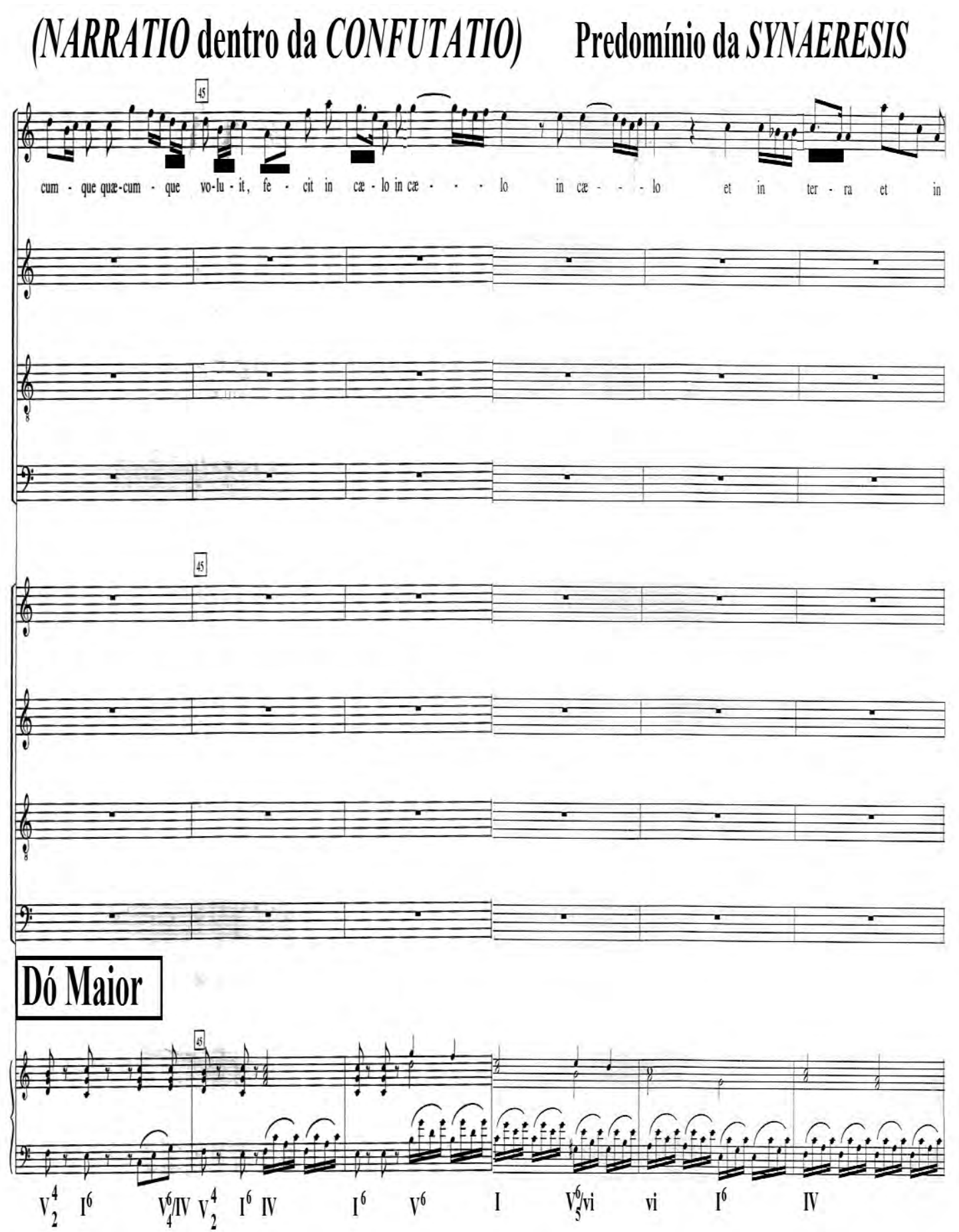

Exemplo 158-Ofertório da Missa do $4^{\circ}$ Domingo da Quaresma de André da Silva GomesCatalogação e Organização Régis Duprat (DUPRAT, 1999, pp.120-121). 


\subsection{Confirmatio}

A Confutatio é concluída em Dó Maior, no compasso 51, numa Cadência Autêntica Imperfeita, igualmente observa-se a aplicação da Schematoides, destacando a palavra terra, com os mesmos intervalos e notas, contudo, com durações diferentes. Decorrente a essa conclusão, a Confirmatio começa da mesma maneira que o Exordium, entretanto, com outras palavras, Ominia quæ voluit Dominus (O que apraz ao Senhor Ele o faz).

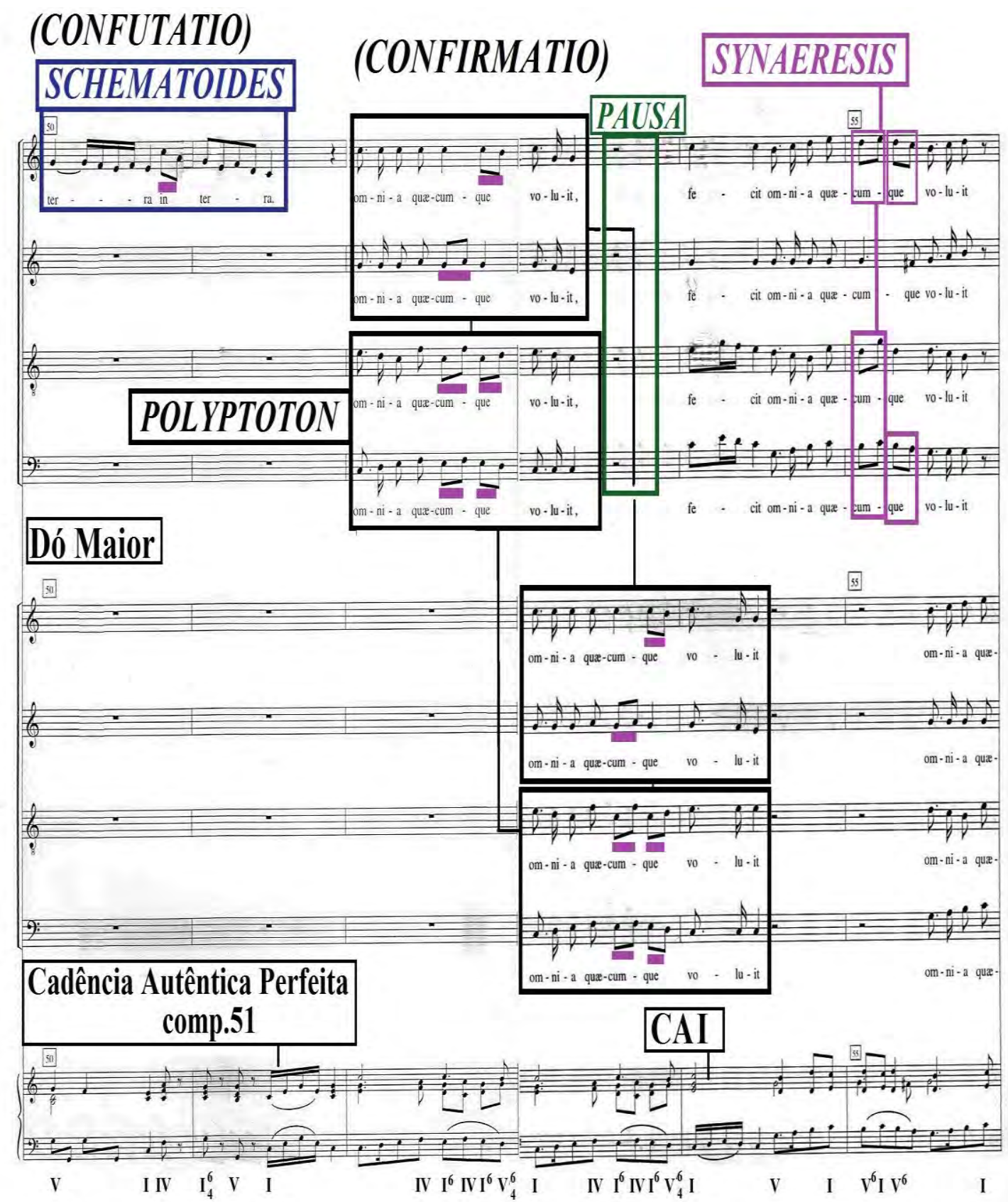

Exemplo 159-Ofertório da Missa do $4^{\circ}$ Domingo da Quaresma de André da Silva GomesCatalogação e Organização Régis Duprat (DUPRAT, 1999, pp.122-123). 
No presente excerto, o salmista continua o seu encômio ao Senhor por seus atributos, em outras palavras, há um louvor direcionado à magnificência, bondade, poder e justiça de Deus para com seus servos, Omnia quæ voluit Dominus, fecit in cælo et in terra (O que apraz ao Senhor Ele o faz, no céu e na terra). Enfim, por intermédio da Epizeuxis, Synaeresis e da Polyptoton, Silva Gomes, de modo incisivo e repetitivo, confirma essa proposição.

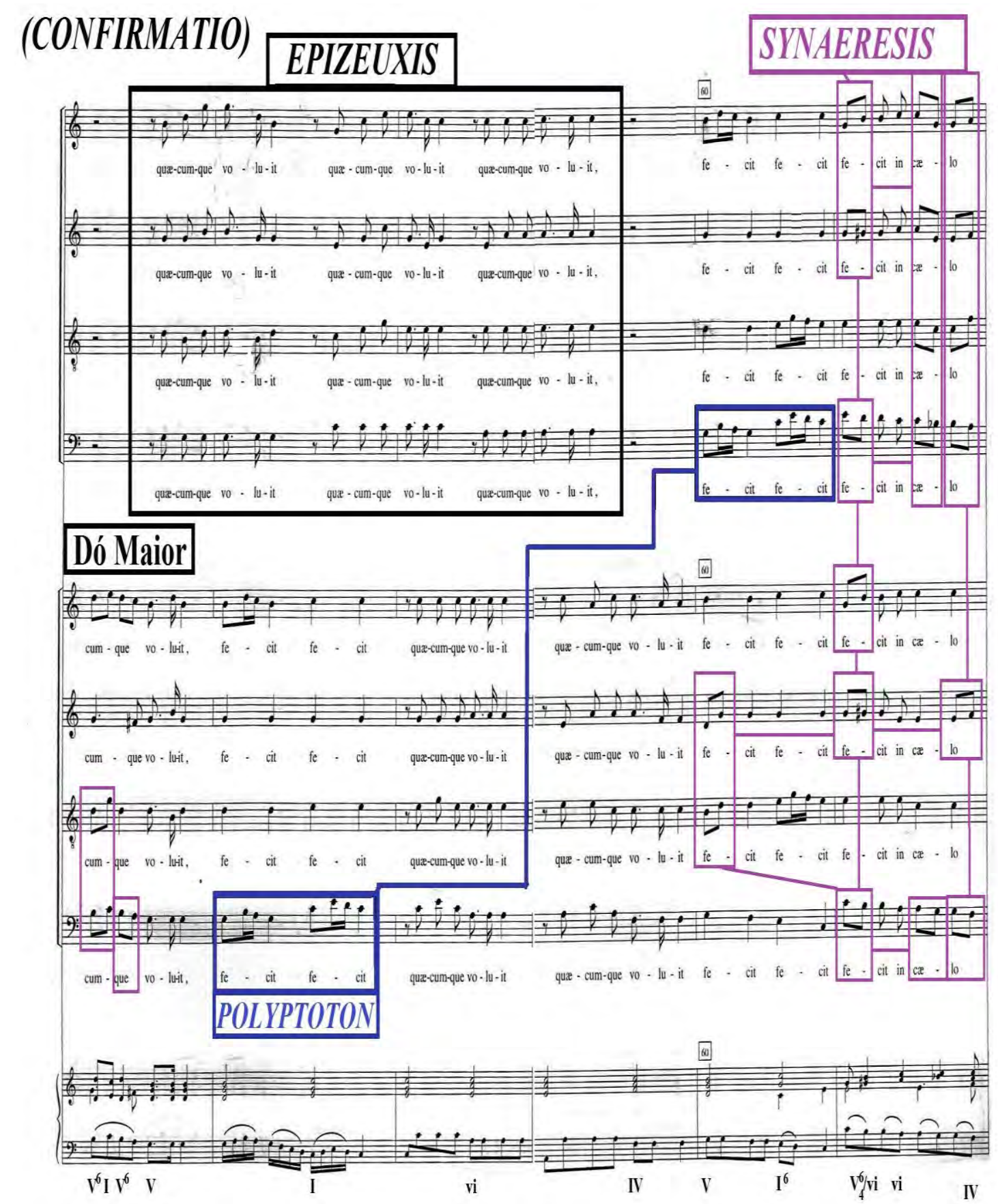

Exemplo 160-Ofertório da Missa do $4^{\circ}$ Domingo da Quaresma de André da Silva GomesCatalogação e Organização Régis Duprat (DUPRAT, 1999, pp.124-125). 


\subsection{Peroratio}

Na Peroratio, é verificável a utilização da Synaeresis, do Noema numa passagem homofônica e também da Aposiopesis, no compasso 63, logo após a Dominante, evidenciando a Semicadência, confirmando o caráter apoteótico da obra. Silva Gomes mostra sua habilidade em adotar um processo de invenção musical realizado e elaborado na diversificação, tanto da massa sonora das duas partes das vozes como seja no canto responsorial estrito ou na ordenação variada de sua disposição temporal (SOARES, 2000, p.87).

O compositor luso-brasileiro conhecedor das técnicas do contraponto, da gramática e, sobretudo, da retórica, apropria-se de uma escrita cordal estrita entre os compassos 60-63, ainda na Confirmatio, a qual se consubstanciará na conclusão do discurso numa Coda em andamento Adagio, possibilitando ao autor desenvolver maior expectativa e persuasão a quem ouve, modificando a tonalidade para Dó Menor. Ou seja, ele conduz o pensamento de seu auditório à terra, fazendo que o mesmo sinta suavidade, doçura, agrado e confiança, característicos dos afetos da Laetitia, porém, como se estivesse próximo do céu e daquele que é aprazível, reto e justo, através de seu louvor e exultação. Enfim, o ofertório termina retornando de forma inesperada no último acorde para Dó Maior (SOARES, 2012, p.227). 


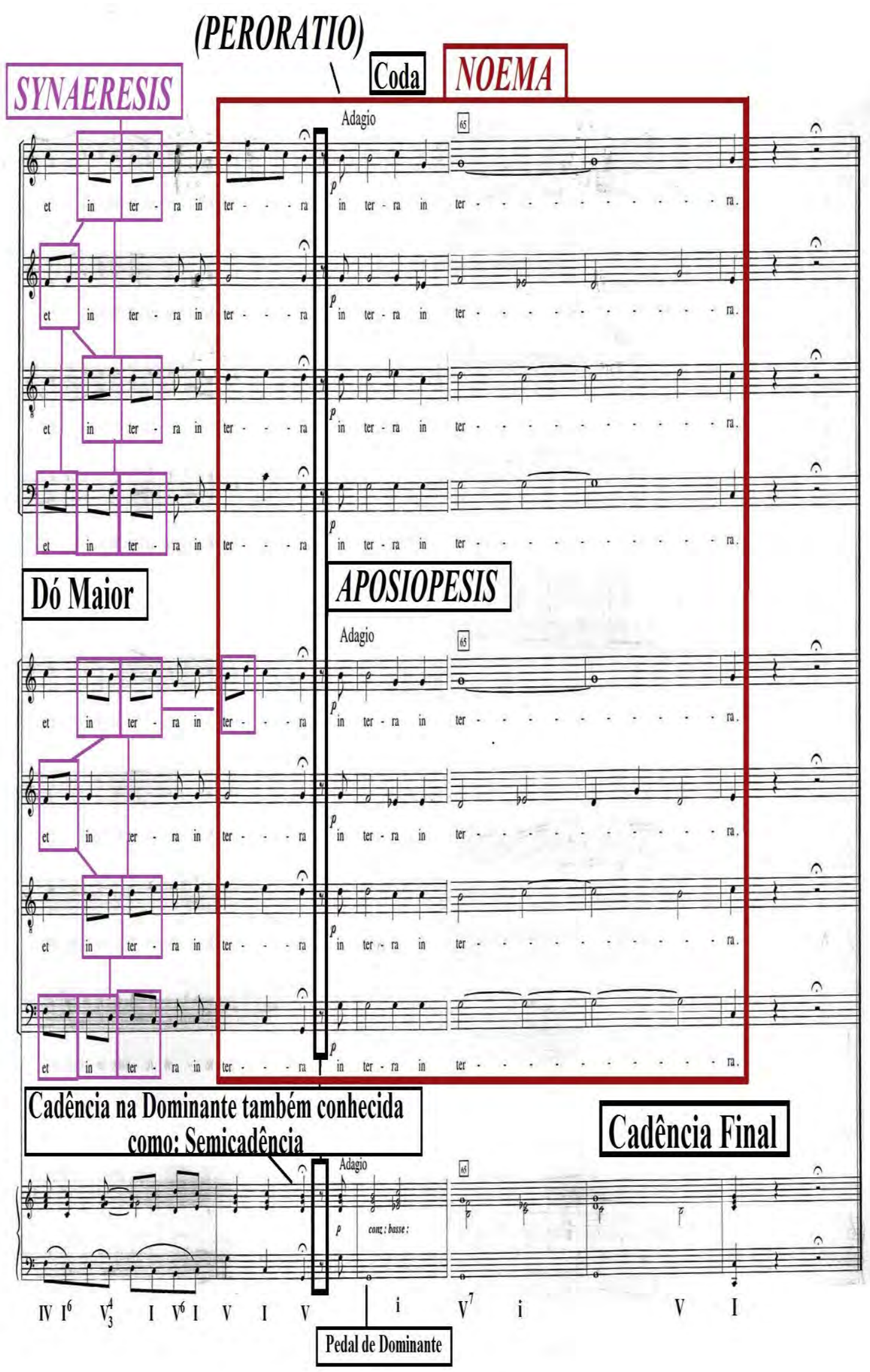

Exemplo 161-Ofertório da Missa do $4^{\circ}$ Domingo da Quaresma de André da Silva GomesCatalogação e Organização Régis Duprat (DUPRAT, 1999, pp.126-127). 


\section{Figuras observadas no Ofertório (Elocutio/Decoratio)}

Tabela 47-Figuras retóricas localizadas no Ofertório da Missa do Quarto Domingo da Quaresma de André da Silva Gomes.

\begin{tabular}{|c|c|c|c|}
\hline $\begin{array}{ll}\text { FIGURAS } & \text { E } \\
\text { CITAÇÕES } & \end{array}$ & TIPO & DESCRIÇÃO & TRATADISTA \\
\hline $\begin{array}{l}\text { ANAPHORA } \\
\text { (BARTEL, 1997, } \\
\text { pp.184-190). }\end{array}$ & $\begin{array}{l}\text { Repetição } \\
\text { Melódica }\end{array}$ & $\begin{array}{l}\text { (1) É uma linha } \\
\text { do baixo repetida } \\
\text { em forma de } \\
\text { solo. (2) A } \\
\text { repetição de uma } \\
\text { exposição } \\
\text { melódica sobre } \\
\text { notas e partes } \\
\text { diferentes. } \\
\text { Também pode } \\
\text { ocorrer no início } \\
\text { das repetições de } \\
\text { frases e motivos } \\
\text { em uma série de } \\
\text { passagens } \\
\text { sucessivas; (3) } \\
\text { Uma repetição } \\
\text { em geral. }\end{array}$ & $\begin{array}{l}\text { Johann Gottfried } \\
\text { Walther: É uma } \\
\text { figura de repetição } \\
\text { e pode ocorrer de } \\
\text { duas maneiras: } \\
\text { 1. Quando uma } \\
\text { palavra é repetida } \\
\text { frequentemente em } \\
\text { uma composição } \\
\text { para dar maior } \\
\text { ênfase. } \\
\text { 2. Quando as } \\
\text { notas graves são } \\
\text { repetidas inúmeras } \\
\text { vezes (como o caso } \\
\text { das Chaconne). }\end{array}$ \\
\hline $\begin{array}{l}\text { APOSIOPESIS } \\
\text { (BARTEL, 1997, } \\
\text { pp.202-206) }\end{array}$ & $\begin{array}{ll}\text { Interrupção } & \text { e } \\
\text { Silêncio } & \end{array}$ & $\begin{array}{l}\text { Um descanso em } \\
\text { uma ou todas as } \\
\text { vozes de uma } \\
\text { composição: } \\
\text { pausa geral. }\end{array}$ & $\begin{array}{l}\text { Johann Gottfried } \\
\text { Walther: } \\
\text { Aposiopesis se se } \\
\text { refere a uma pausa } \\
\text { generalis ou um } \\
\text { completo silêncio } \\
\text { em todas as vozes } \\
\text { e nas partes da } \\
\text { composição } \\
\text { simultaneamente. }\end{array}$ \\
\hline $\begin{array}{l}\text { CLIMAX } \\
\text { (BARTEL, 1997, } \\
\text { pp.220-224). }\end{array}$ & $\begin{array}{l}\text { Repetição } \\
\text { Melódica }\end{array}$ & $\begin{array}{l}\text { (1) Uma } \\
\text { sequência de } \\
\text { notas em uma só } \\
\text { voz repetida em } \\
\text { qualquer } \\
\text { tonalidade maior } \\
\text { ou menor, (2) } \\
\text { Duas vozes que } \\
\text { se deslocam em } \\
\text { movimento } \\
\text { ascendente ou }\end{array}$ & $\begin{array}{l}\text { Joachim } \\
\text { Burmeister: A } \\
\text { Climax repete notas } \\
\text { semelhantes ou } \\
\text { alturas similares. } \\
\text { Athanasius } \\
\text { Kircher: A Climax } \\
\text { ou Gradatio é uma } \\
\text { passagem musical } \\
\text { ascendente que é } \\
\text { frequentemente }\end{array}$ \\
\hline
\end{tabular}




\begin{tabular}{|c|c|c|c|}
\hline & & $\begin{array}{l}\text { descendente } \\
\text { paralelo, (3) Um } \\
\text { aumento gradual } \\
\text { na intensidade e } \\
\text { altura do som. }\end{array}$ & $\begin{array}{l}\text { utilizada em afetos } \\
\text { de amor e desejo } \\
\text { de unidade do reino } \\
\text { celestial. }\end{array}$ \\
\hline $\begin{array}{l}\text { EPIZEUXIS } \\
\text { (BARTEL, 1997, } \\
\text { pp.263-265). }\end{array}$ & $\begin{array}{l}\text { Repetição } \\
\text { Melódica }\end{array}$ & $\begin{array}{l}\text { Uma repetição } \\
\text { imediata e } \\
\text { enfática de uma } \\
\text { palavra, nota, } \\
\text { motivo ou frase. }\end{array}$ & $\begin{array}{l}\text { Johann Gottfried } \\
\text { Walther: } \\
\text { Epizeuxis é uma } \\
\text { figura de retórica } \\
\text { pela qual uma ou } \\
\text { mais palavras são } \\
\text { imediatamente e } \\
\text { enfaticamente } \\
\text { repetidas. }\end{array}$ \\
\hline $\begin{array}{l}\text { (BUELOW, 1980, } \\
\text { p.799). }\end{array}$ & $\begin{array}{l}\text { Representação } \\
\text { e Descrição }\end{array}$ & $\begin{array}{l}\text { Uma passagem } \\
\text { homofônica em } \\
\text { uma textura } \\
\text { contrapontística e } \\
\text { polifônica. }\end{array}$ & $\begin{array}{l}\text { Joachim } \\
\text { Burmeister: O } \\
\text { Noema representa } \\
\text { o afeto harmônico, } \\
\text { onde as vozes } \\
\text { combinadas têm } \\
\text { valores e números } \\
\text { de notas } \\
\text { semelhantes. } \\
\text { Quando introduzida } \\
\text { adequadamente, } \\
\text { isto é, no momento } \\
\text { certo, ela afeta } \\
\text { docemente os } \\
\text { ouvidos do ouvinte, } \\
\text { produzindo uma } \\
\text { sensação de calma } \\
\text { e serenidade. } \\
\text { Seção homofônica, } \\
\text { dentro da polifonia } \\
\text { utilizada para } \\
\text { enfatizar o texto. }\end{array}$ \\
\hline $\begin{array}{l}\text { PALILOGIA } \\
\text { (BARTEL, 1997, } \\
\text { pp.342-344). } \\
\text { (BUELOW, 2001, } \\
\text { p.264). }\end{array}$ & $\begin{array}{l}\text { Repetição } \\
\text { Melódica }\end{array}$ & $\begin{array}{l}\text { Repetição de um } \\
\text { tema no mesmo } \\
\text { nível de altura, } \\
\text { também pode } \\
\text { ocorrer r em } \\
\text { alturas diferentes } \\
\text { na mesma ou em } \\
\text { várias vozes. }\end{array}$ & 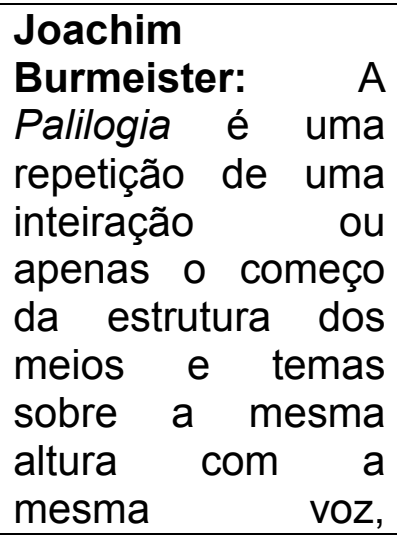 \\
\hline
\end{tabular}




\begin{tabular}{|c|c|c|c|}
\hline & & & $\begin{array}{l}\text { ocorrendo com ou } \\
\text { sem intermédio de } \\
\text { pausas em todos } \\
\text { os eventos em uma } \\
\text { voz. } \\
\text { Johann Gottfried } \\
\text { Walther: } \\
\text { Palilogia refere-se a } \\
\text { uma repetição por } \\
\text { demais frequente } \\
\text { das mesmas } \\
\text { palavras. }\end{array}$ \\
\hline $\begin{array}{l}\text { PAUSA } \\
\text { (BARTEL, 1997, } \\
\text { pp.362-365). }\end{array}$ & $\begin{array}{l}\text { Interrupção e } \\
\text { Silêncio }\end{array}$ & $\begin{array}{l}\text { Uma pausa ou } \\
\text { descanso em } \\
\text { uma composição } \\
\text { musical. }\end{array}$ & $\begin{array}{l}\text { Johann Gottfried } \\
\text { Walther: Uma } \\
\text { figura ou figuras de } \\
\text { silêncio. Pausa } \\
\text { refere-se a um } \\
\text { período de repouso } \\
\text { ou o silêncio na } \\
\text { música, que é } \\
\text { indicado por um } \\
\text { determinado sinal. }\end{array}$ \\
\hline $\begin{array}{l}\text { POLYPTOTON } \\
\text { (BARTEL, 1997, } \\
\text { pp.367-369). } \\
\text { (BUELOW, 2001, } \\
\text { p.264). }\end{array}$ & $\begin{array}{l}\text { Repetição } \\
\text { Melódica }\end{array}$ & $\begin{array}{l}\text { A repetição de } \\
\text { uma passagem } \\
\text { melódica em } \\
\text { diferentes alturas. }\end{array}$ & $\begin{array}{lr}\text { Mauritius Johann } \\
\text { Vogt: Polyptoton é } \\
\text { quando r uma } \\
\text { passagem } \\
\text { repetida em várias } \\
\text { alturas. }\end{array}$ \\
\hline $\begin{array}{l}\text { SCHEMATOIDES } \\
\text { (BARTEL, 1997, } \\
\text { pp.382-384). }\end{array}$ & Diversas & $\begin{array}{lr}\text { Figura } & \text { que } \\
\text { reestrutura uma } \\
\text { passagem } \\
\text { anterior, quer } \\
\text { através da } \\
\text { mudança no texto } \\
\text { ou através de } \\
\text { duração aumento } \\
\text { ou diminuição. }\end{array}$ & $\begin{array}{l}\text { Wolfgang Printz: } \\
\text { Schematoides é } \\
\text { uma figuração } \\
\text { construída a partir } \\
\text { dos mesmos } \\
\text { intervalos de uma } \\
\text { determinada figura, } \\
\text { mas é diferente, } \\
\text { quer na duração ou } \\
\text { na forma de } \\
\text { execução } \\
\text { mesma. da } \\
\text { A Schematoides } \\
\text { Perfectus ocorre } \\
\text { quando as notas e } \\
\text { os intervalos são os } \\
\text { mesmos de uma } \\
\text { figura, porém são }\end{array}$ \\
\hline
\end{tabular}




\begin{tabular}{|c|c|c|c|}
\hline & & & $\begin{array}{l}\text { cantadas várias } \\
\text { sílabas em vez de } \\
\text { apenas uma. Esta } \\
\text { pode ser } \\
\text { encontrada } \\
\text { somente na música } \\
\text { vocal. } \\
\text { A Schematoides } \\
\text { Minus Perfectus } \\
\text { ocorre quando os } \\
\text { intervalos são os } \\
\text { mesmos, mas de } \\
\text { maior duração. } \\
\text { Magis Congruus } \\
\text { Schematoides } \\
\text { ocorre quando os } \\
\text { intervalos são os } \\
\text { mesmos, as notas } \\
\text { mais lentas e ainda } \\
\text { em igual proporção } \\
\text { com as notas da } \\
\text { figura. } \\
\text { Schematoides } \\
\text { menos congruente } \\
\text { (Minus Congruus) } \\
\text { ocorre quando os } \\
\text { intervalos são os } \\
\text { mesmos de uma } \\
\text { figura, mas a } \\
\text { duração das notas } \\
\text { não é de } \\
\text { proporções iguais } \\
\text { às da figura. }\end{array}$ \\
\hline $\begin{array}{l}\text { SYNAERESIS } \\
\text { (BARTEL, 1997, } \\
\text { pp.394-396). } \\
\text { (LÓPEZ CANO, } \\
\text { 2000, p.199). }\end{array}$ & $\begin{array}{l}\text { Dissonância e } \\
\text { Deslocamento }\end{array}$ & $\begin{array}{l}\text { (1) Uma } \\
\text { suspensão ou } \\
\text { síncope, (2) A } \\
\text { colocação de } \\
\text { duas sílabas por } \\
\text { nota ou duas } \\
\text { notas por sílaba. }\end{array}$ & $\begin{array}{lr}\text { Mauritius Johann } \\
\text { Vogt: A Synaeresis } \\
\text { ocorre quando duas } \\
\text { notas rão } \\
\text { colocadas em uma } \\
\text { sílaba ou duas } \\
\text { sílabas } \\
\text { colocadas em uma } \\
\text { nota. }\end{array}$ \\
\hline $\begin{array}{l}\text { SYNONYMIA } \\
\text { (BARTEL, 1997, } \\
\text { pp.405-407). }\end{array}$ & $\begin{array}{l}\text { Repetição } \\
\text { Melódica }\end{array}$ & $\begin{array}{l}\text { É a repetição } \\
\text { alterada ou } \\
\text { modificada de } \\
\text { uma ideia } \\
\text { musical. } \\
\text { A repetição de }\end{array}$ & $\begin{array}{lr}\text { Johann } & \text { Gottfried } \\
\text { Walther: } & \text { Um } \\
\text { compositor } & \text { também } \\
\text { pode } & \text { empregar } \\
\text { muito } & \text { bem } \\
\text { diferentes } & \text { figuras }\end{array}$ \\
\hline
\end{tabular}




\begin{tabular}{|c|c|c|c|}
\hline $\begin{array}{l}\text { (BUELOW, 2001, } \\
\text { p.264). }\end{array}$ & & $\begin{array}{l}\text { uma ideia } \\
\text { melódica em } \\
\text { notas diferentes } \\
\text { na mesma parte. }\end{array}$ & $\begin{array}{lr}\text { retóricas } & \text { na } \\
\text { elaboração de um } \\
\text { texto. Por exemplo, } \\
\text { além da Epizeuxis, } \\
\text { que é a mais } \\
\text { comum e enfática, } \\
\text { pode usar, } \\
\text { Anaphora, } \\
\text { Synonymia, } \\
\text { Epistrophe, } \\
\text { Epanalepsis } \\
\text { assim por diante. }\end{array}$ \\
\hline $\begin{array}{l}\text { VARIATIO } \\
\text { (BARTEL, 1997, } \\
\text { pp.432-438). }\end{array}$ & $\begin{array}{l}\text { Ornamentação } \\
\text { Melódica e } \\
\text { Harmônica }\end{array}$ & $\begin{array}{l}\text { Ornamentação } \\
\text { de uma } \\
\text { passagem } \\
\text { melódica com } \\
\text { uma variedade } \\
\text { de } \\
\text { embelezamentos } \\
\text { (decorações). }\end{array}$ & $\begin{array}{l}\text { Wolfgang Printz: A } \\
\text { palavra Variatio é } \\
\text { usada de duas } \\
\text { maneiras pelos } \\
\text { músicos, ou seja, } \\
\text { tanto no sentido } \\
\text { amplo e estrito. Em } \\
\text { um sentido estrito, } \\
\text { Variatio refere-se a } \\
\text { uma alteração } \\
\text { artística (figuração) } \\
\text { de uma } \\
\text { determinada } \\
\text { passagem } \\
\text { melódica, mas em } \\
\text { que a melodia } \\
\text { original é sempre } \\
\text { percebida } \\
\text { reconhecida. Em } \\
\text { um sentido amplo, } \\
\text { Variatio significa } \\
\text { qualquer tipo de } \\
\text { alteração de um } \\
\text { trecho melódico se } \\
\text { inclui o tipo anterior } \\
\text { ou não. }\end{array}$ \\
\hline
\end{tabular}

\section{Análise Harmônica}

\subsection{Curva Tonal}

Tonalidade: Dó Maior

Andamento: Andante Moderato 4/4 
Tabela 48-Esquema de Progressões Harmônicas- Curva Tonal do Ofertório da Missa do $4^{\circ}$ Domingo da Quaresma.

\begin{tabular}{|l|c|l|}
\hline \multicolumn{1}{|c|}{ Compassos } & Função & \multicolumn{1}{c|}{ Tonalidade } \\
\hline $1-14$ & $\mathrm{I}$ & Dó Maior \\
\hline 15 & $\mathrm{ii}$ & Ré Menor \\
\hline 16 & $\mathrm{I}$ & Dó Maior \\
\hline $17-18$ & $\mathrm{IV}$ & Fá Maior \\
\hline $19-26$ & $\mathrm{I}$ & Dó Maior \\
\hline $26-27$ & $\mathrm{vi}$ & Lá Menor \\
\hline 28 & $\mathrm{ii}$ & Ré Menor \\
\hline $28-33$ & $\mathrm{vi}$ & Lá Menor \\
\hline 33 & $\mathrm{~V} / \mathrm{vi}$ & Mi Maior \\
\hline 33 & $\mathrm{~V} / \mathrm{i}$ & Lá Maior \\
\hline 34 & $\mathrm{~V} / \mathrm{V}$ & Ré Maior \\
\hline $34-37$ & $\mathrm{vi}$ & Lá Menor \\
\hline 37 & $\mathrm{ii}$ & Ré Menor \\
\hline $37-40$ & $\mathrm{vi}$ & Lá Menor \\
\hline $40-48$ & $\mathrm{I}$ & Dó Maior \\
\hline $49-50$ & $\mathrm{IV}$ & Fá Maior \\
\hline $51-56$ & $\mathrm{I}$ & Dó Maior \\
\hline $56-57$ & $\mathrm{~V}$ & Sol Maior \\
\hline $58-63$ & $\mathrm{I}$ & Dó Maior \\
\hline $64-67$ & $\mathrm{i}$ (tonalidade homônima) & Dó Menor \\
\hline 67 & $\mathrm{I}$ & Dó Maior \\
\hline
\end{tabular}

\subsection{Estrutura Analítica do Ofertório: Retórica e Harmônica}

Tabela 49-Estrutura analítica da obra.

\begin{tabular}{|c|c|c|c|c|}
\hline $\begin{array}{l}\text { RETÓRICA } \\
\text { DISPOSITIO }\end{array}$ & $\begin{array}{c}\text { FIGURA } \\
\text { ELOCUTIO }\end{array}$ & COMP. & TONALIDADE & FUNÇÃO \\
\hline \multirow{4}{*}{ EXORDIUM } & Synaeresis & $2,5-6$ & Dó Maior & I \\
\hline & Polyptoton & $2-4$ & Dó Maior & 1 \\
\hline & Pausa & $2-4$ & Dó Maior & 1 \\
\hline & Palilogia & $4-5$ & Dó Maior & 1 \\
\hline \multirow[t]{3}{*}{ NARRATIO } & Synaeresis & $7-9,11-18$ & Dó Maior & I \\
\hline & Climax & $9-11$ & Dó Maior & I \\
\hline & Variatio & $13-19$ & Dó Maior & 1 \\
\hline
\end{tabular}




\begin{tabular}{|c|c|c|c|c|}
\hline PROPOSITIO & $\begin{array}{l}\text { Synaeresis } \\
\text { Polyptoton } \\
\text { Palilogia } \\
\text { Pausa }\end{array}$ & $\begin{array}{l}20-24 \\
26-29 \\
21-23 \\
23-24 \\
21-23 \\
26\end{array}$ & $\begin{array}{l}\text { Dó Maior } \\
\text { Lá Menor } \\
\text { Dó Maior } \\
\text { Dó Maior } \\
\text { Dó Maior } \\
\text { Lá Menor }\end{array}$ & $\begin{array}{l}\text { I } \\
\text { vi } \\
\text { I } \\
\text { I } \\
\text { I } \\
\text { vi }\end{array}$ \\
\hline CONFUTATIO & $\begin{array}{l} \\
\text { Synonymia } \\
\text { Epizeuxis } \\
\text { Schematoides }\end{array}$ & $\begin{array}{l}29 \\
\text { e } 43 \\
30-31 \\
30-31 \\
32,34-36,38 \\
41-43,44-46 \\
49-51 \\
34-37 \\
38-43 \\
50-51\end{array}$ & $\begin{array}{l}\text { Lá Menor } \\
\text { Dó Maior } \\
\text { Lá Menor } \\
\text { Lá Menor } \\
\text { Lá Menor } \\
\text { Dó maior } \\
\text { Dó Maior } \\
\text { Lá Menor } \\
\text { Lá Menor/Dó } \\
\text { Maior } \\
\text { Dó Maior }\end{array}$ & $\begin{array}{l}\text { vi } \\
\text { I } \\
\text { vi } \\
\text { vi } \\
\text { vi } \\
\text { I } \\
\text { I } \\
\text { vi } \\
\text { vi e I } \\
\text { I }\end{array}$ \\
\hline CONFIRMATIO & $\begin{array}{l}\text { Polyptoton } \\
\text { Synaeresis } \\
\text { Pausa } \\
\text { Epizeuxis } \\
\text { Noema }\end{array}$ & $\begin{array}{l}52-54 \\
\text { e } 57-60 \\
52-56,60-61 \\
53 \\
56-59 \\
63\end{array}$ & $\begin{array}{l}\text { Dó Maior } \\
\text { Dó Maior } \\
\text { Dó Maior } \\
\text { Dó Maior } \\
\text { Dó Maior } \\
\text { Dó Maior }\end{array}$ & $\begin{array}{l}1 \\
1 \\
1 \\
1 \\
1 \\
1\end{array}$ \\
\hline PERORATIO & $\begin{array}{l}\text { Synaeresis } \\
\text { Noema } \\
\text { Aposiopesis }\end{array}$ & $\begin{array}{l}62-63 \\
63-67 \\
63\end{array}$ & $\begin{array}{l}\text { Dó Maior } \\
\text { Dó Menor } \\
\text { Dó Menor }\end{array}$ & $\begin{array}{c}\text { I } \\
\text { i } \\
\text { (Homo) } \\
\text { i } \\
\text { (Homo) }\end{array}$ \\
\hline
\end{tabular}




\subsubsection{Análise Retórico-Musical no Laudate Pueri ${ }^{124}$}

\section{Inventio}

Tendo seu texto extraído dos Salmos (Ps.112/113), o Laudate Pueri tem como epígrafe o Senhor, como o maior e mais digno objeto de louvor.

Laudate, pueri, Dominum; laudate nomen Domini.

Sit nomen Domini bebedictum, ex hoc nunc et usuque in sæculum.

A solis ortu usque ad occasum; laudate nomen Domini.

Excelsus super omnes gentes Dominus, Et super caelos gloria eius.

Quis sicut Dominus Deus noster, qui in altis habitat, et humilia respicit in cælo et in terra?

Suscitans a terra inopen, et de stercore erigen pauperem:

Ut collocet eum cum principibus, cum principibus populi sui.

Qui habitare facit sterilem in domo, matrem filorum lætanterm.

Gloria Patri et Filio et Spiritui Sancto. Sicut erat in principio et nunc et semper et in sæcula sæculorum. Amen.

Louvai, ó servos, louvai o nome do Senhor.

Seja louvado o nome do Senhor, desde agora e para sempre.

Desde o nascer do sol até o seu ocaso, seja louvado o nome do Senhor.

Excelso é o Senhor, sobre todas as gentes e a sua glória está acima dos céus.

Quem há como o Senhor nosso Deus, que está nas alturas, e abaixa os olhos sobre o céu e sobre a terra?

Levanta do pó o desvalido, e tira da imundície o pobre,

Para o colocar com os príncipes, com os príncipes do seu povo.

$E$ a que era antes estéril, fá-la viver em sua casa, como mãe de seus filhos.

Glória ao Pai ao Filho e ao Espírito Santo. Assim como era o princípio, agora e sempre e por todos os séculos dos séculos. Amém.

Nos dez versículos desse Salmo, o salmista conclama aos que devotam sua fé no Senhor á louvá-lo, em todas as gerações e séculos. Esse ato se deve ao fato de Deus estar acima da criação, todavia Ele se faz presente com o seu povo. Somado a isso, para o povo hebreu esse Salmo é o primeiro dentre os vários que celebram as grandes festas anuais da Páscoa, das Semanas dos Tabernáculos, da Lua Nova e da Dedicação do Templo ${ }^{125}$ (ALMEIDA, 1999, p.697).

\footnotetext{
${ }^{124}$ De acordo com o catálogo das obras de André da Silva Gomes, organizado por Régis Duprat, esse salmo é datado de 1780 (DUPRAT, 1995, p.185) e faz parte de um conjunto de 3 salmos que inclui igualmente o Salmo 121, Lætatus Sum, e o Salmo 126, Nisi Dominus. Sendo que esse conjunto foi escrito para as Vésperas de Nossa Senhora.

${ }^{125} \mathrm{~A}$ festa da Páscoa ocorria no décimo quarto dia do primeiro mês (Abibe/Março-Abril), ela lembra a libertação dos hebreus da escravidão do Egito. A festa das Semanas dos Tabernáculos acontecia entre os dias 15 e 22 do sétimo mês (Tisri/Setembro-Outubro), nela era observada a provisão que Deus dava ao seu povo. A festa da Lua Nova ou das Trombetas ocorria no primeiro dia do sétimo mês (Tisri/Setembro-Outubro), nela acontecia um descanso, um memorial, com sons de trombetas, onde nenhum trabalho poderia ser realizado, todavia
} 
Enfim, essa obra é constituída por sessenta e nove compassos, num andamento Andante na tonalidade Sol Maior, ordenados em seis partes da Dispositio, trabalhadas pelo compositor com o propósito de despertar no ouvinte seus afetos.

\subsection{Loci observados na Inventio do Laudate Pueri}

Tabela 50-Loci Topici localizados no Laudate Pueri de André da Silva Gomes.

\begin{tabular}{|c|c|c|c|c|}
\hline INVENTIO & DESCRIÇÃO & $\begin{array}{c}\text { UTILIZAÇÃO NA } \\
\text { OBRA }\end{array}$ & $\begin{array}{l}\text { COMF } \\
\text { VOZ }\end{array}$ & PASSOI \\
\hline $\begin{array}{l}\text { Locus Notationis } \\
\text { (MATTHESON, } \\
\text { 1954, [1739]. } \\
\text { Parte II, Cap.4, § } \\
\text { 23, p.123). }\end{array}$ & $\begin{array}{l}\text { Aspecto } \\
\text { externo e } \\
\text { desenho das } \\
\text { notas (Duração } \\
\text { das notas, } \\
\text { alteração, } \\
\text { repetição e } \\
\text { procedimentos } \\
\text { canônicos). }\end{array}$ & $\begin{array}{l}\text { Vários motivos } \\
\text { rítmicos e diferentes } \\
\text { durações de notas } \\
\text { (mínimas, } \\
\text { semínimas, } \\
\text { semínimas } \\
\text { pontuadas, } \\
\text { colcheias, colcheias } \\
\text { pontuadas, } \\
\text { semicolcheias, } \\
\text { repetições, } \\
\text { ligaduras, pausas, } \\
\text { apogiaturas, entre } \\
\text { outros). }\end{array}$ & $\begin{array}{l}1-5 \\
5-9 \\
9-15 \\
16-56 \\
56-67 \\
68-69\end{array}$ & $\begin{array}{l}\text { S-A-T-B } \\
\text { S } \\
\text { S-A-T-B } \\
\text { S-A-T-B } \\
\text { S-A-T-B } \\
\text { S-A-T-B }\end{array}$ \\
\hline $\begin{array}{l}\text { Locus } \\
\text { Descriptionis } \\
\text { (MATTHESON, } \\
\text { 1954, [1739]. } \\
\text { Parte II, Cap.4, § } \\
\text { 43, p.127). }\end{array}$ & $\begin{array}{l}\text { Disposições da } \\
\text { alma }\end{array}$ & $\begin{array}{l}\text { Celebração } \\
\text { Exaltação: Louvai, ó } \\
\text { servos, louvai o nome } \\
\text { do Senhor. } \\
\text { Seja louvado o nome } \\
\text { do Senhor. } \\
\text { Excelso é o Senhor, } \\
\text { sobre todas as gentes } \\
\text { e a sua glória está } \\
\text { acima dos céus. } \\
\text { Quem há como o } \\
\text { Senhor nosso Deus, } \\
\text { que está nas alturas. } \\
\text { Glória ao Pai ao Filho } \\
\text { e ao Espírito Santo. }\end{array}$ & $\begin{array}{r}24-28 \\
56-60\end{array}$ & $\begin{array}{l}\text { S-A-T-B } \\
S\end{array}$ \\
\hline
\end{tabular}

haveria de ser realizada uma oferta de sacrifício ao Senhor. Por fim, a festa da Dedicação do Templo que tem oito dias de duração com celebração no nono mês (Quisleu/NovembroDezembro). Essa festa comemora a purificação e restauração do templo nos tempos de Judas Macabeu e a revolta judaica contra Antíoco Epifânio (164 a.C.) (ALMEIDA, 1999, pp.153; 1249, passim). 


\begin{tabular}{|c|c|c|c|}
\hline $\begin{array}{l}\text { Locus } \\
\text { Circumstantiarum } \\
\text { (MATTHESON, } \\
\text { 1954 [1739]. Parte } \\
\text { II, Cap.4, \& 77, } \\
\text { p.131). }\end{array}$ & $\begin{array}{l}\text { Diferentes } \\
\text { circunstâncias } \\
\text { de tempo, do } \\
\text { lugar e de } \\
\text { acontecimentos } \\
\text { anteriores. }\end{array}$ & $\begin{array}{l}\text { Assim como era o } \\
\text { princípio, agora e } \\
\text { sempre e por todos os } \\
\text { séculos dos séculos. } \\
\text { Amém. }\end{array}$ & 61-69 S-A-T-B \\
\hline $\begin{array}{l}\text { Locus } \\
\text { Comparationis } \\
\text { (MATTHESON, } \\
\text { 1954, [1739]. } \\
\text { Parte II, Cap.4 § } \\
\text { 79, p.131). }\end{array}$ & $\begin{array}{l}\text { Comparações } \\
\text { de coisas } \\
\text { semelhantes ou } \\
\text { não, grandes } \\
\text { ou pequenas. }\end{array}$ & $\begin{array}{l}\text { Comparação de } \\
\text { coisas não } \\
\text { semelhantes (Céu e } \\
\text { Terra) e abaixa os } \\
\text { olhos sobre o céu e } \\
\text { sobre a terra?. }\end{array}$ & 28-34 S-A-T-B \\
\hline $\begin{array}{l}\text { Locus } \\
\text { Oppositorum } \\
\text { (MATTHESON, } \\
\text { 1954, [1739].Parte } \\
\text { II, Cap.4, § 80, } \\
\text { p.131). }\end{array}$ & $\begin{array}{l}\text { Contraste de } \\
\text { compassos, } \\
\text { movimentos } \\
\text { contrários, } \\
\text { agudos e } \\
\text { graves, lento e } \\
\text { rápido, calmo e } \\
\text { agitado. }\end{array}$ & $\begin{array}{l}\text { Movimento contrário } \\
\text { entre soprano e } \\
\text { baixo, tenor e baixo. } \\
\text { Contralto e tenor, } \\
\text { tenor e baixo. } \\
\text { Contralto e baixo, } \\
\text { tenor e baixo. } \\
\text { Soprano e baixo. } \\
\text { Soprano e tenor. } \\
\text { Soprano e tenor, } \\
\text { soprano e baixo. } \\
\text { Soprano e contralto, } \\
\text { soprano e baixo, } \\
\text { contralto e baixo, } \\
\text { tenor e contralto, } \\
\text { tenor e baixo. } \\
\text { Soprano e tenor, } \\
\text { tenor e baixo. } \\
\text { Soprano e tenor, } \\
\text { tenor e contralto. } \\
\text { Soprano e baixo, } \\
\text { contralto e baixo. }\end{array}$ & $\begin{array}{ll}2 & \text { S-T-B } \\
3 & \text { A-T-B } \\
10-11 & \text { A-T-B } \\
20 & \text { S-B } \\
23 & \text { S-T } \\
32-33 & \text { S-T-B } \\
55 & \text { S-A -T-B } \\
& \\
& \\
61 & \text { S-T-B } \\
67 & \text { S-A-T } \\
68-69 & \text { S-A-B }\end{array}$ \\
\hline
\end{tabular}

\section{Dispositio}

\subsection{Exordium}

O Salmo inicia de maneira veemente e jubilosa, onde todas as vozes, por meio da dinâmica forte, entoam a expressão Laudate pueri Dominum (Louvai ó servos do Senhor). Nota-se, de igual forma, que André da Silva Gomes utiliza a Epizeuxis, Palilogia e a Synaeresis, para reforçar ainda mais o afeto de júbilo e enaltecimento quando a palavra laudate é repetida por três 
vezes. Além disso, na mesma palavra, o autor coloca em saliência as sílabas da e te entre as funções da Tônica e Dominante com terminação na Cadência Autêntica Imperfeita. Por fim, no compasso 5, antes da entrada do solo, a pausa nas quatro vozes poderia ser considerada uma Aposiopesis, no entanto, para alguns tratadistas como Thuringus e Walther, por exemplo, seria uma figura retórica da Homoioptoton ou da Pausa e para outros especialistas consiste numa figura musical de silêncio e não descrevendo um afeto (BARTEL, 1997, pp.205; 297; 364, passim).

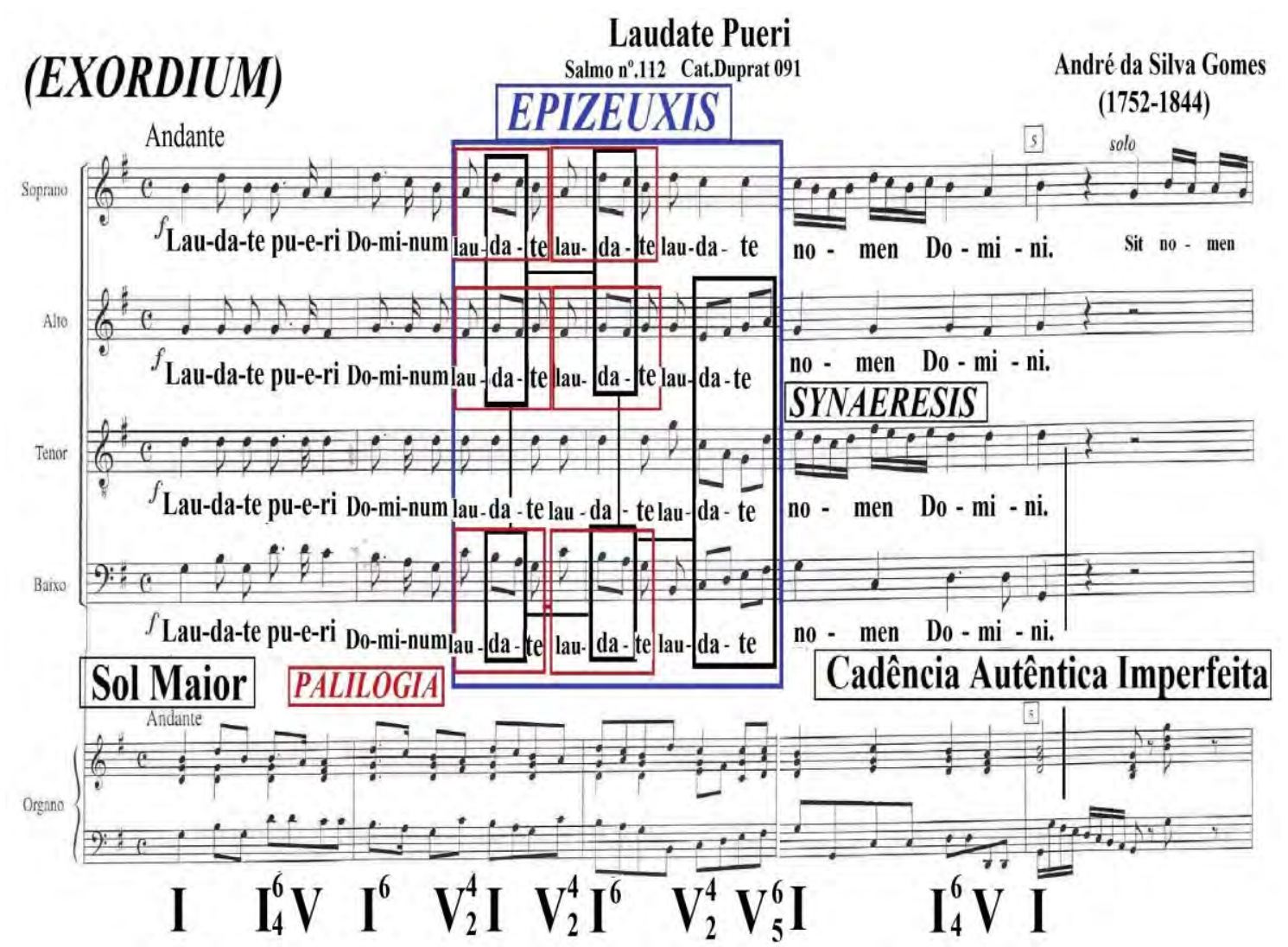

Exemplo 162-Laudate Pueri de André da Silva Gomes- Catalogação e Organização Régis Duprat (DUPRAT, 1999, p.62).

\subsection{Narratio}

No solo da soprano é observável o uso da Synaeresis, onde a cada duas semicolcheias entoa-se uma sílaba. Pode parecer trivial o emprego dessa figura, entretanto, o autor a inseriu para realçar o afeto de devoção representado pela Laetitia, através da frase Sit nomen Domini bebedictum, ex 
hoc nunc et usuque in sæculum (Seja louvado o nome do Senhor, desde agora e para sempre).

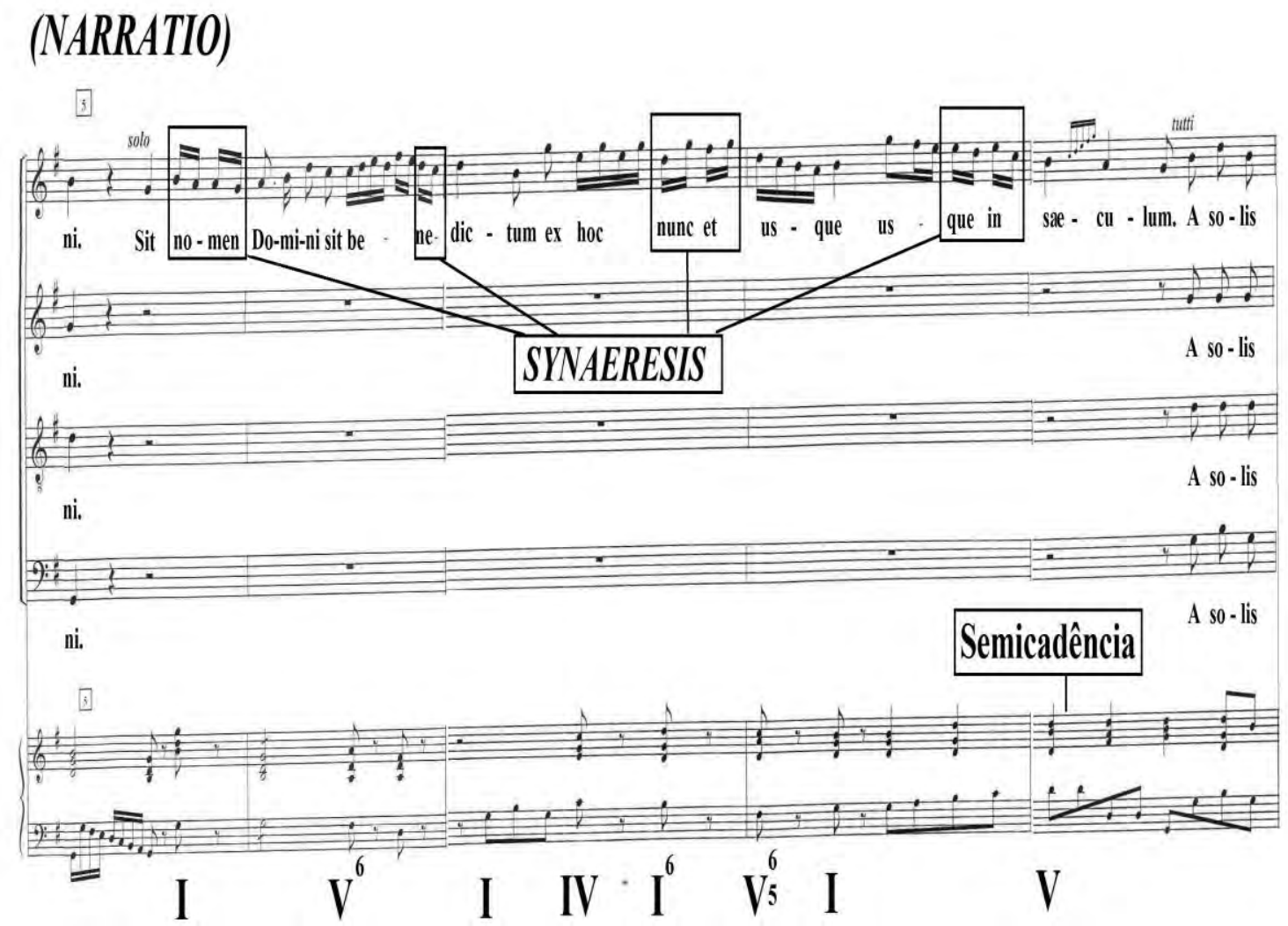

Exemplo 163-Laudate Pueri de André da Silva Gomes- Catalogação e Organização Régis Duprat (DUPRAT, 1999, pp.62-63).

\subsection{Propositio}

Observa-se, entre os compassos 10 e 14, que Silva Gomes continua a aplicar a Synaeresis em todas as vozes com o objetivo de destacar o afeto de encômio e louvor mediante as expressões $A$ solis ortu usque ad occasum; laudate nomen Domini (Desde o nascer do sol até o seu ocaso, seja louvado o nome do Senhor).

Igualmente, verifica-se que essa figura retórica em consonância com as funções harmônicas, auxilia o deslocamento dos intervalos dissonantes de sétima situados na voz do contralto, no último tempo do compasso 10 (Sol \# Lá), na Dominante da Dominante de Ré Maior, assim como no quarto tempo do compasso $11 \mathrm{com}$ as notas Lá e Sol \#, na sua Tônica Relativa (Paralela), na voz da soprano. Finalizando, outro aspecto a ser ressaltado são as duas 
cadências utilizadas nesse trecho: Semicadência com efeito suspensivo, no compasso 12, e a Autêntica Perfeita, no compasso 15.

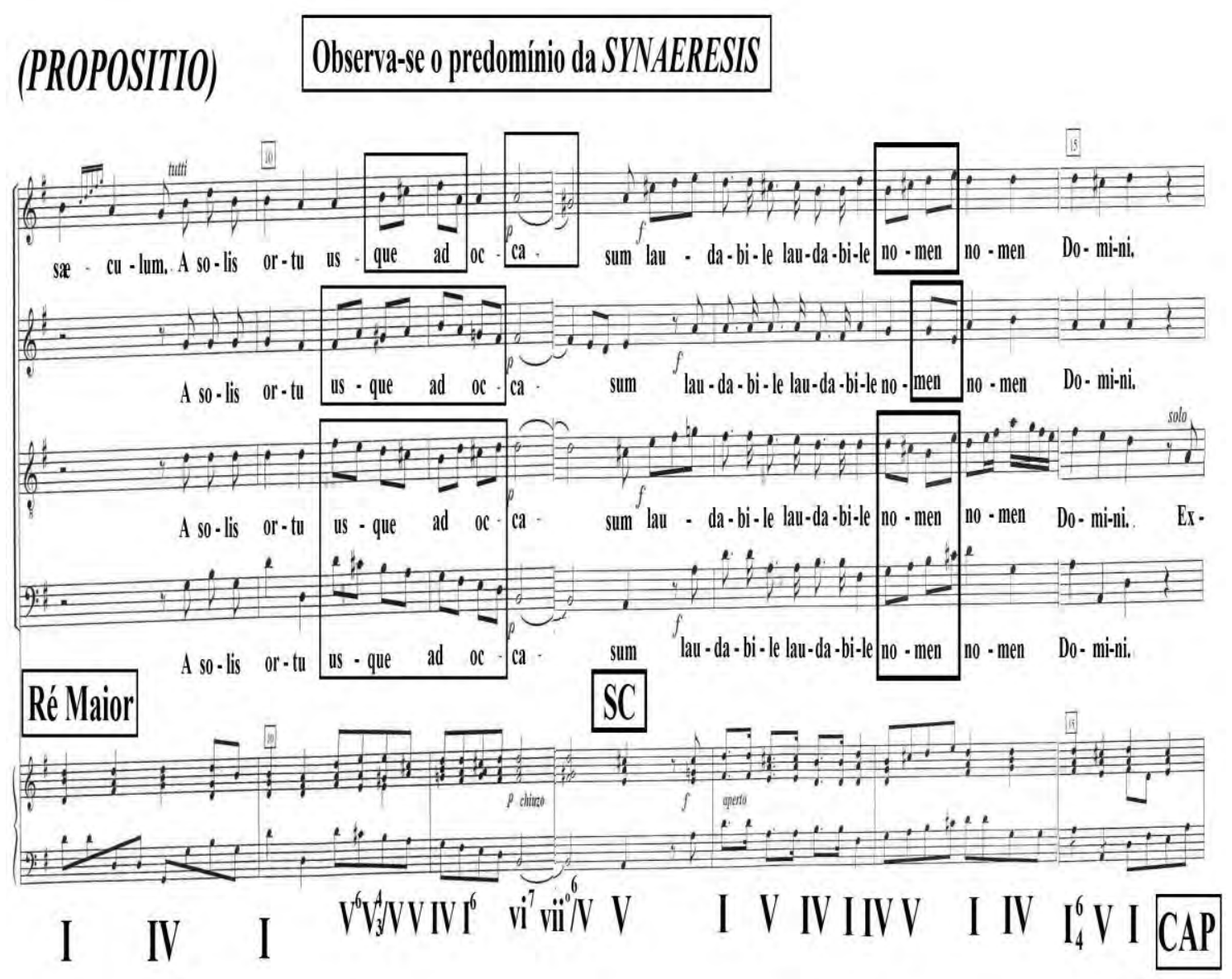

Exemplo 164-Laudate Pueri de André da Silva Gomes- Catalogação e Organização Régis Duprat (DUPRAT, 1999, p.63).

\subsection{Confutatio}

Examina-se, no exemplo abaixo, a predominância da Synaeresis no solo do tenor, onde o compositor novamente a utiliza, com a finalidade de destacar a descrição feita pelo salmista da excelência, notabilidade e grandiosidade do Senhor, Excelsus super omnes gentes Dominus, Et super cælos gloria eius (Excelso é o Senhor, sobre todas as gentes e a sua glória está acima dos céus).

Do mesmo modo, evidencia-se o uso da Synonymia, a qual repete as palavras gloria eius de maneira modificada, ou seja, realçando a ideia de que a glória de Deus está acima dos céus. Por fim, observam-se as funções da 
Tônica, Dominante, Subdominante e Dominante da Dominante, empregadas nesse trecho, além das Cadências Autêntica Imperfeita, no compasso 19, e Autêntica Perfeita, no compasso 23.

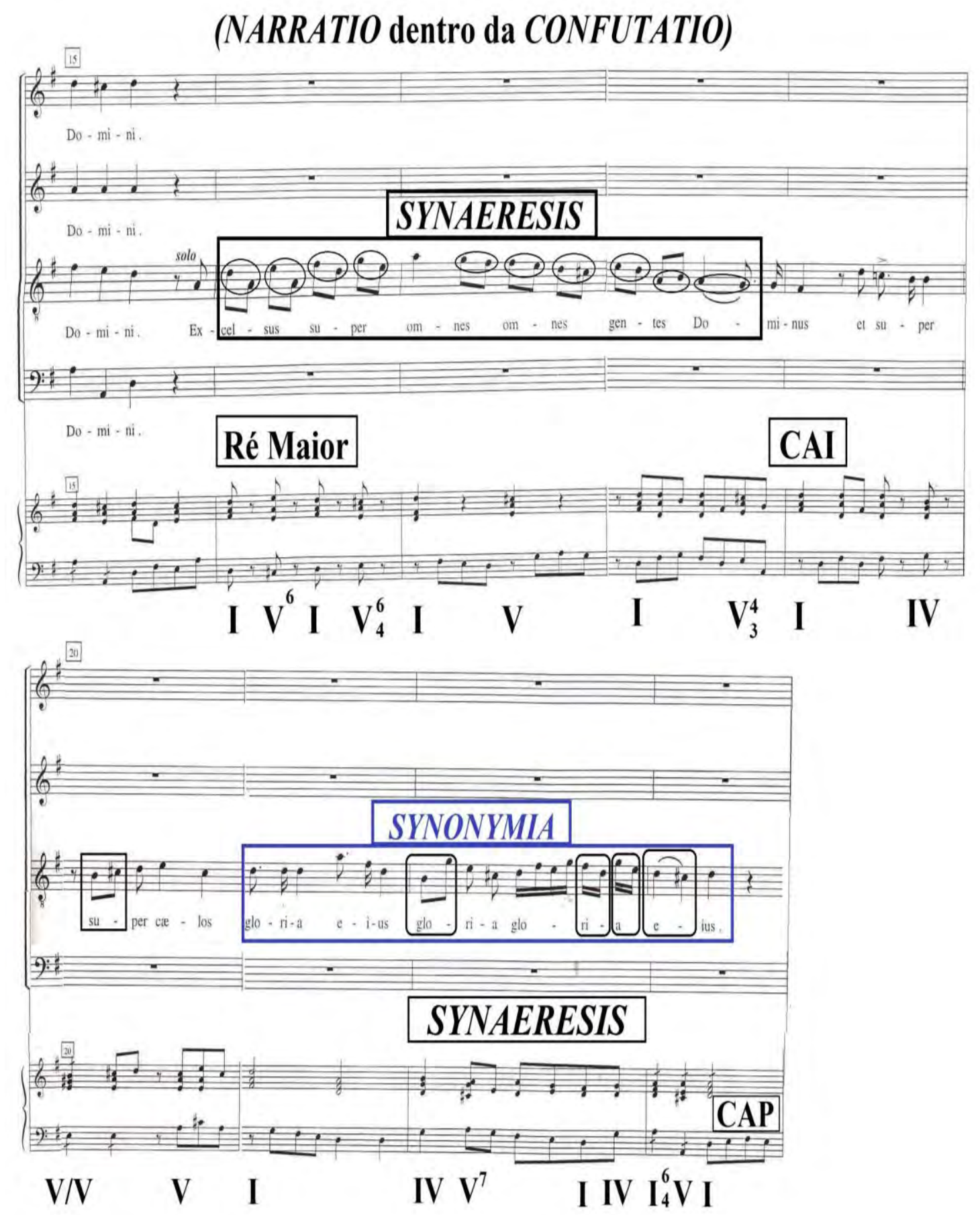

Exemplo 165-Laudate Pueri de André da Silva Gomes- Catalogação e Organização Régis Duprat (DUPRAT, 1999, pp.64-65). 
É tangível a predominância da Synaeresis, utilizada pelo autor para enfatizar não só as duas notas entoando uma sílaba, mas principalmente a expressão Deus noster qui in altis habitat (Nosso Deus que está nas alturas). Também é visível a aplicação da Epizeuxis enfatizando a expressão et humilia (se abaixa). Não obstante, é relevante destacar que, nesse contraponto textual de altura e baixeza, céu e terra, Silva Gomes introduz uma mudança de tonalidade de Ré Maior para Si Menor, assim como da dinâmica forte no início da frase Quis sicut Dominus (Quem há como o Senhor), no compasso 24, para a dinâmica piano, nos compassos 28 e 29.

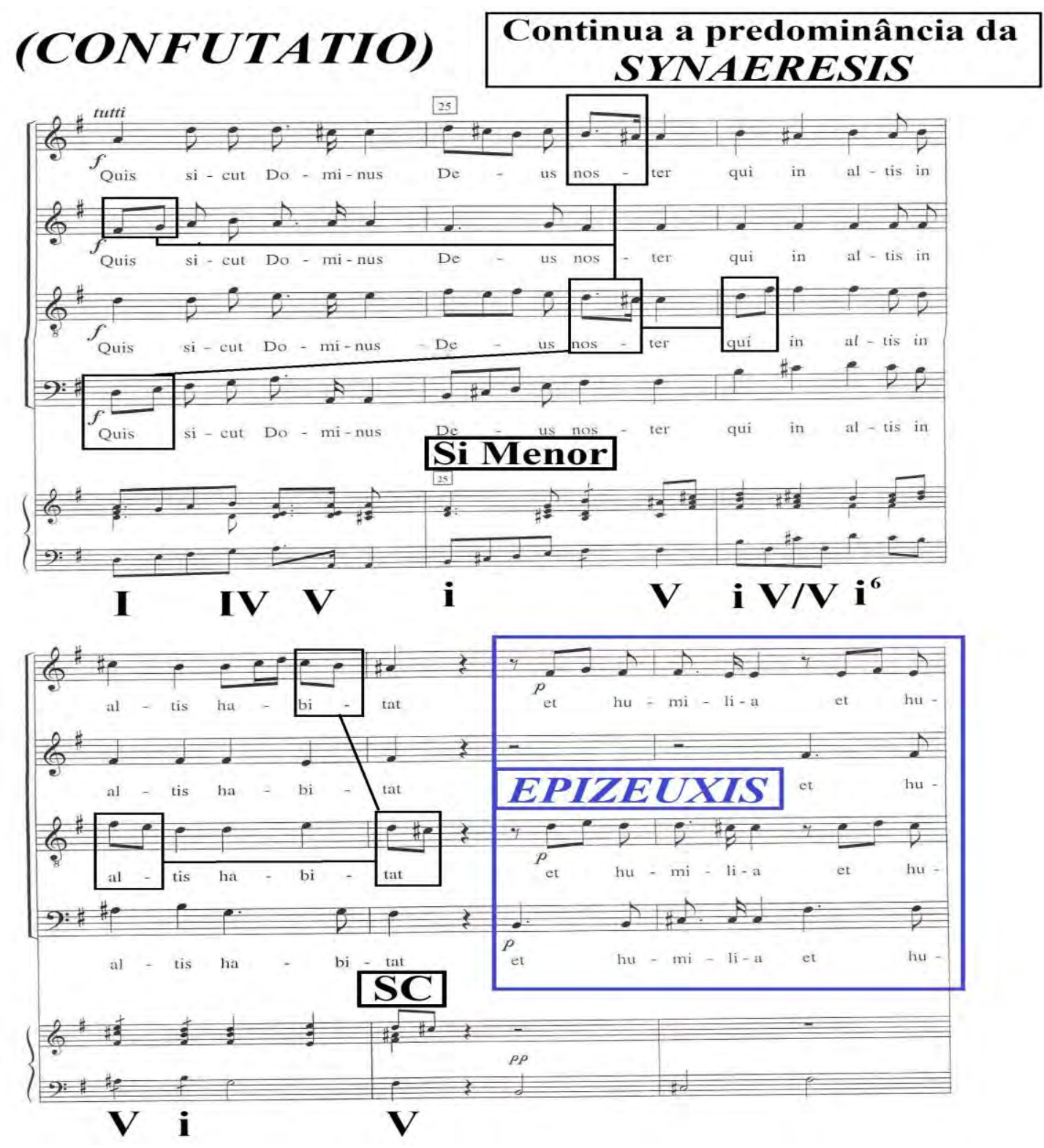

Exemplo 166-Laudate Pueri de André da Silva Gomes- Catalogação e Organização Régis Duprat (DUPRAT, 1999, p.66). 
No excerto abaixo, nota-se, além da Epizeuxis e da Synaeresis, empregadas pelo compositor para ressaltar por meio de repetição as expressões humilia e Suscitans a terra, além do deslocamento e entoação de uma sílaba por duas notas, a figura retórica da Interrogatio, a qual coloca em evidencia a frase Quis sicut Dominus Deus noster, qui in altis habitat, et humilia respicit in cælo et in terra? (Quem há como o Senhor nosso Deus, que está nas alturas, e abaixa os olhos sobre o céu e sobre a terra?), com terminação numa Cadência na Dominante.

\section{(CONFUTATIO) EPIZEUXIS}

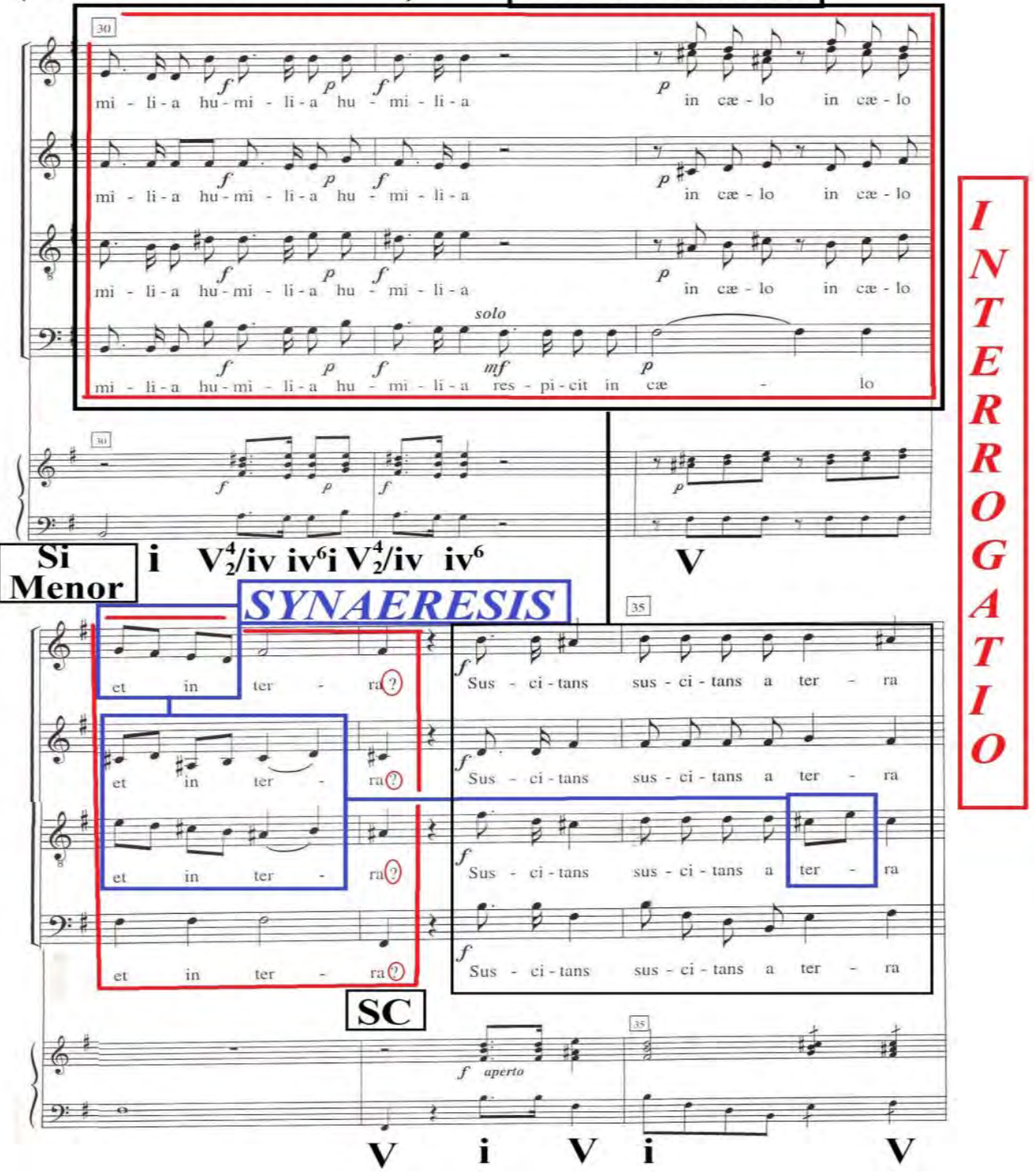

Exemplo 167-Laudate Pueri de André da Silva Gomes- Catalogação e Organização Régis Duprat (DUPRAT, 1999, p.67). 
Averigua-se, nesse trecho, o uso da Epizeuxis e da Synaeresis nas vozes do contralto, no compasso 36 , e nas vozes da soprano, tenor e baixo, no compasso 40 , além do desenvolvimento harmônico realizado pelas funções da Tônica, Dominante sem fundamental, Subdominante, Dominante da Tônica Relativa (Paralela), Tônica Relativa e Dominante, finalizando na fundamental do acorde de Si Menor, numa Cadência Autêntica Perfeita.
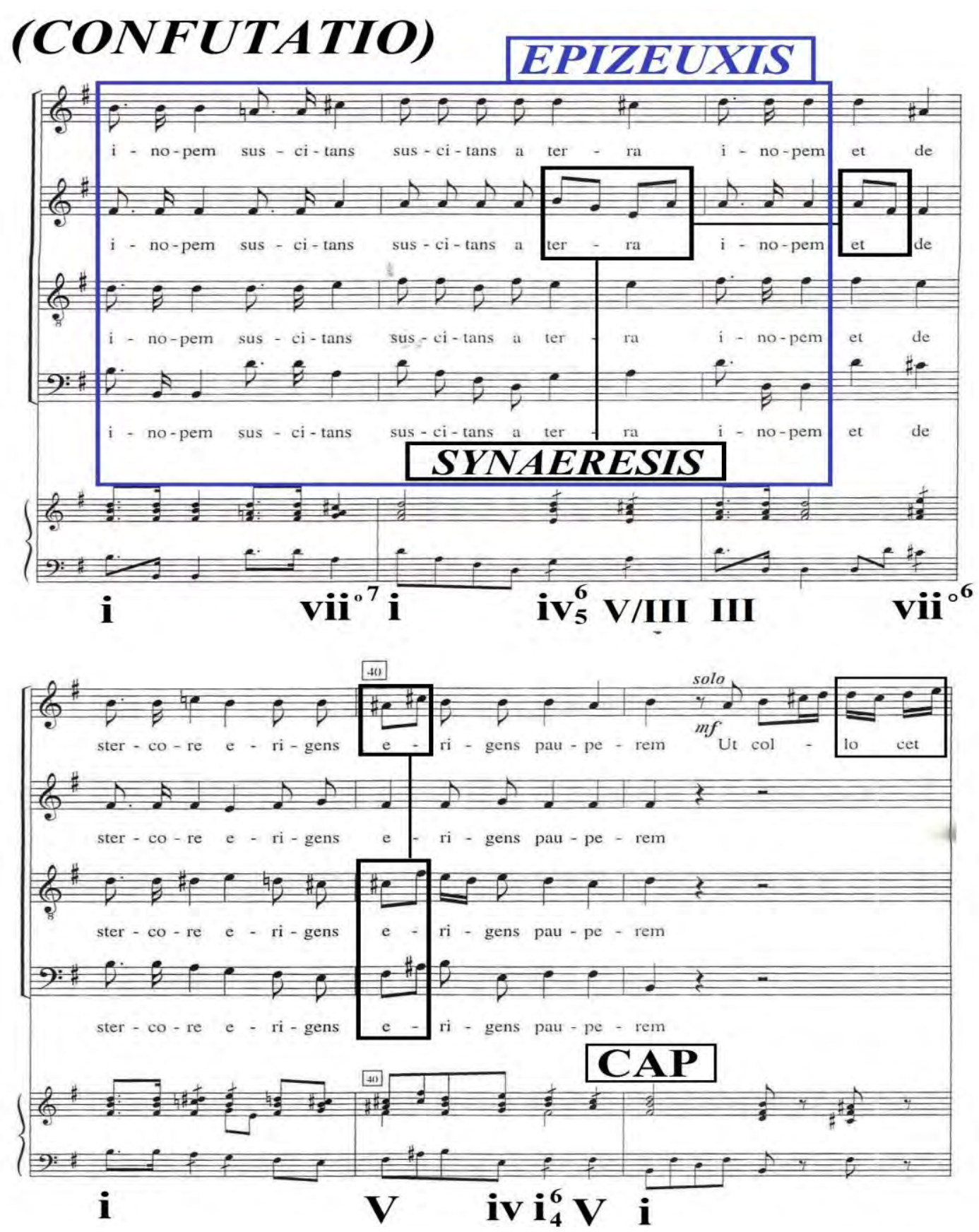

Exemplo 168-Laudate Pueri de André da Silva Gomes- Catalogação e Organização Régis Duprat (DUPRAT, 1999, p.68). 
No solo da soprano constata-se a aplicação das mesmas figuras retóricas, ressaltando o afeto, engrandecimento, através da expressão cum principibus populi sui (como príncipes seu povo).

\section{(NARRATIO dentro da CONFUTATIO)}
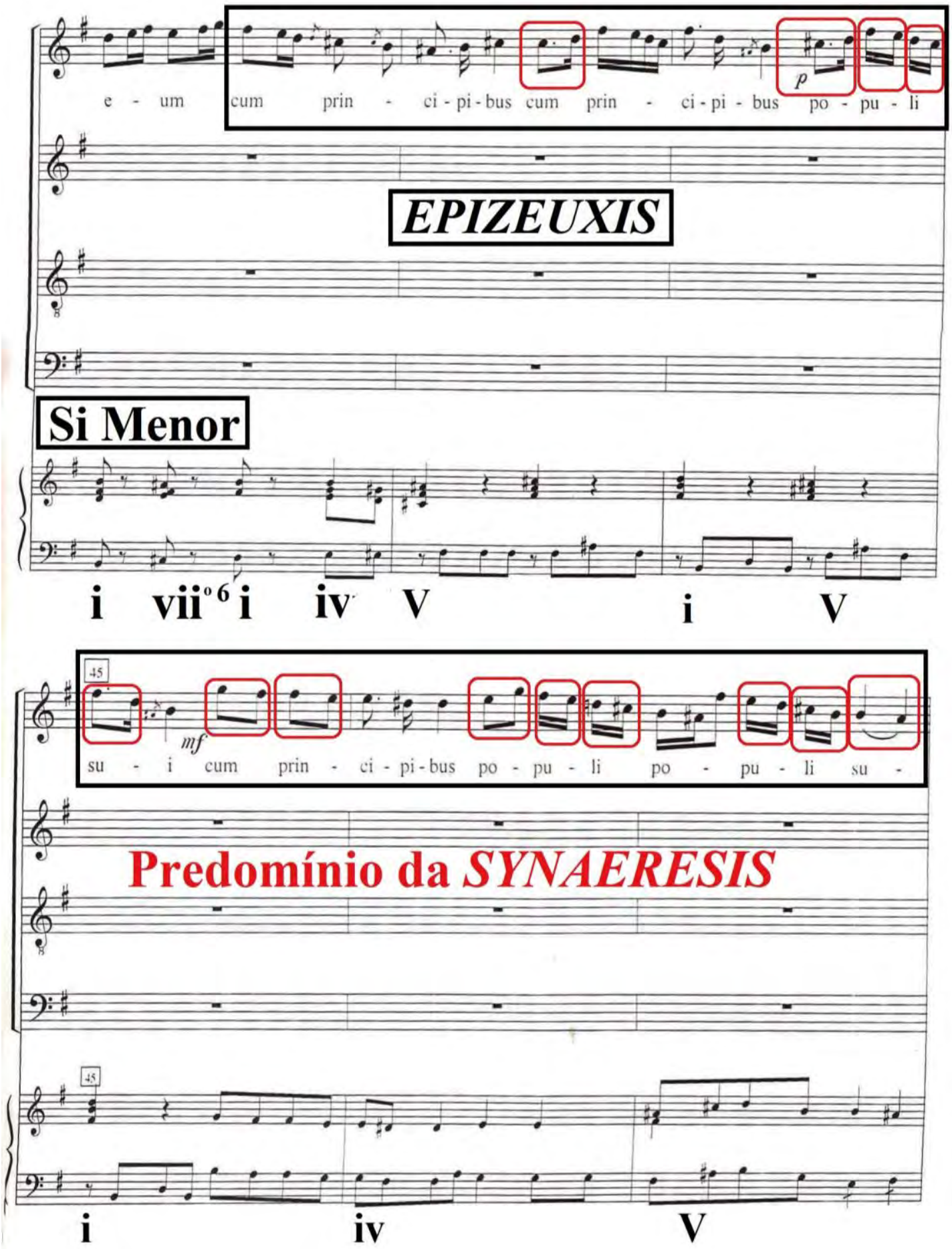

Exemplo 169-Laudate Pueri de André da Silva Gomes- Catalogação e Organização Régis Duprat (DUPRAT, 1999, p.69). 
Nos compassos 48 a 56, do Laudade Pueri, é exposta a parte final da Confirmatio, onde a expressão Qui habitare facti strilem in domo/matrem filorum lætantem (E a que era antes estéril, fá-la viver em casa, como alegre mãe de seus filhos) é enfatizada pelas notas e vozes. Por sua vez, examina-se o emprego da Abruptio juntamente com a Pausa, ressaltando, através desse silêncio imposto abrupta e inesperadamente, além da separação entre pausas das palavras facti strilem, os afetos de prazer, alegria e confiança expressados pelo salmista.

De igual maneira, destaca-se o uso da Synaeresis, nas vozes da soprano entoando as notas Dó sustenido e Ré, Ré e Mi, o tenor entoando as notas Ré e Mi, Mi e Fá sustenido e, por fim, o baixo entoando as notas Mi e Ré, Ré e Lá, Fá, repetindo em forma sequencial por três vezes.

Enfim, esse estado de espírito pode ser notado através da passagem homofônica entre Tônica, Dominante da Dominante e Dominante, na mudança da tonalidade Si Menor para Ré Maior, trabalhado por Silva Gomes, com o propósito de atrair a atenção do ouvinte. 

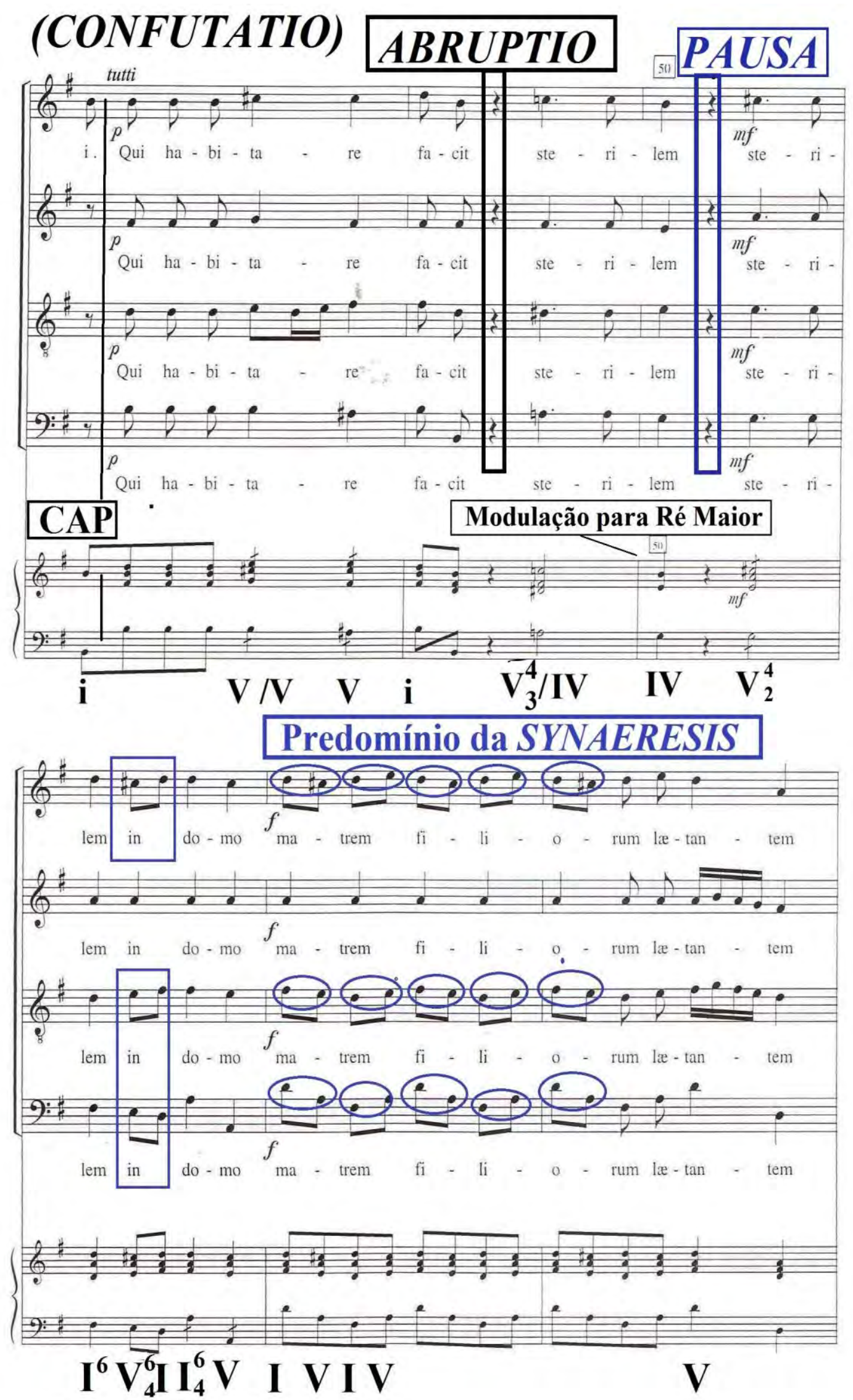

Exemplo 170-Laudate Pueri de André da Silva Gomes- Catalogação e Organização Régis Duprat (DUPRAT, 1999, p.70). 


\subsection{Confirmatio}

Nota-se, a partir do compasso 54, a utilização da Synaeresis, a qual dá ênfase à expressão Gloria Patri et Filio et Spiritui Sancto (Glória ao Pai, ao Filho e ao Espírito Santo). Destarte, utiliza a Aposiopesis oferecendo um descanso para todas as vozes, além de ressaltar a Cadência Autêntica Perfeita e antecipar a entrada do duo, da soprano e contralto, na tonalidade inicial da obra, isto é, em Sol Maior.

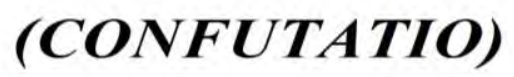

(CONFIRMATIO)

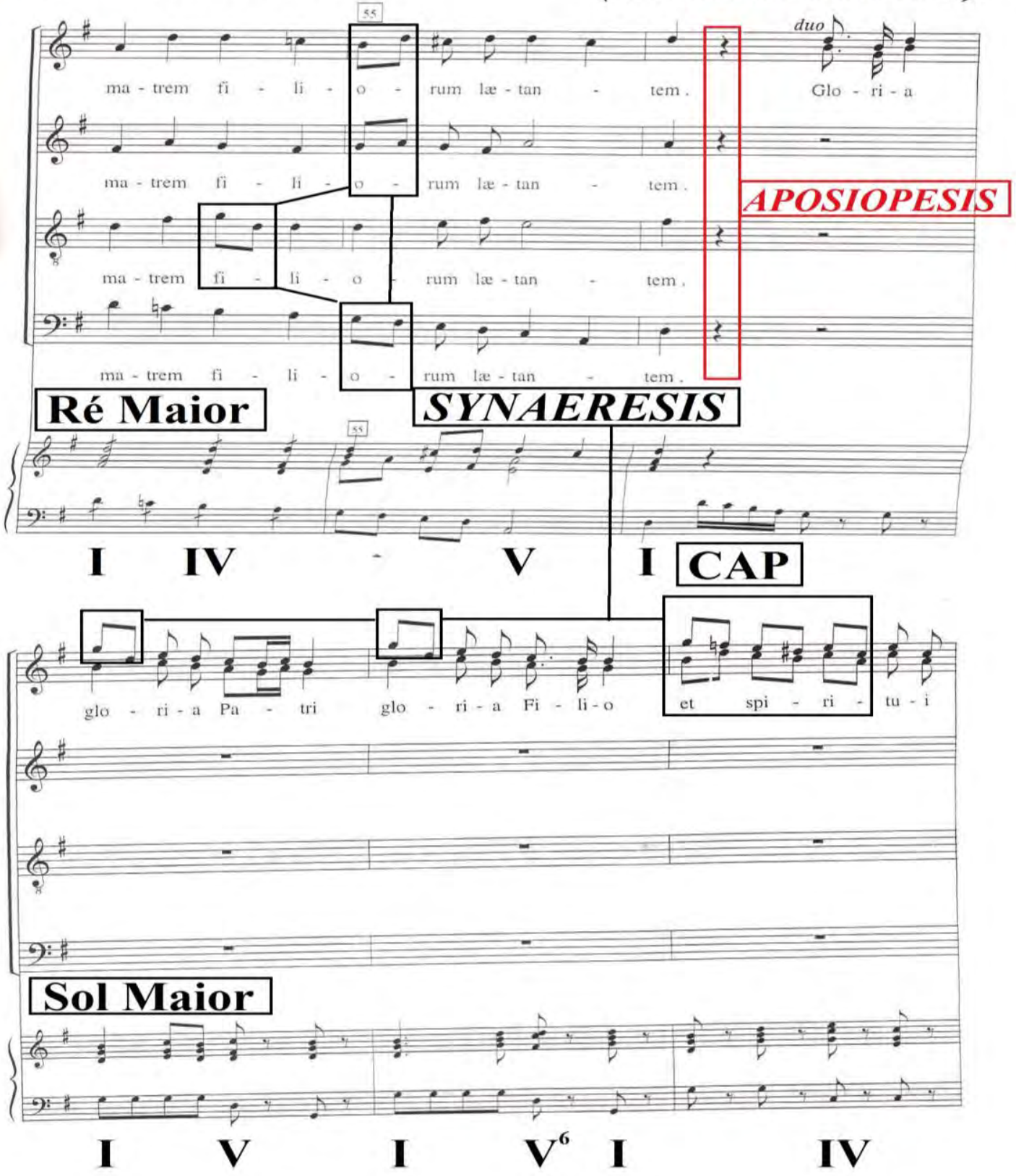

Exemplo 171-Laudate Pueri de André da Silva Gomes- Catalogação e Organização Régis Duprat (DUPRAT, 1999, p.71). 
É observável que o autor trabalha com os mesmos elementos retóricos utilizados em seções anteriores, ou seja, a Synaeresis e Epizeuxis.

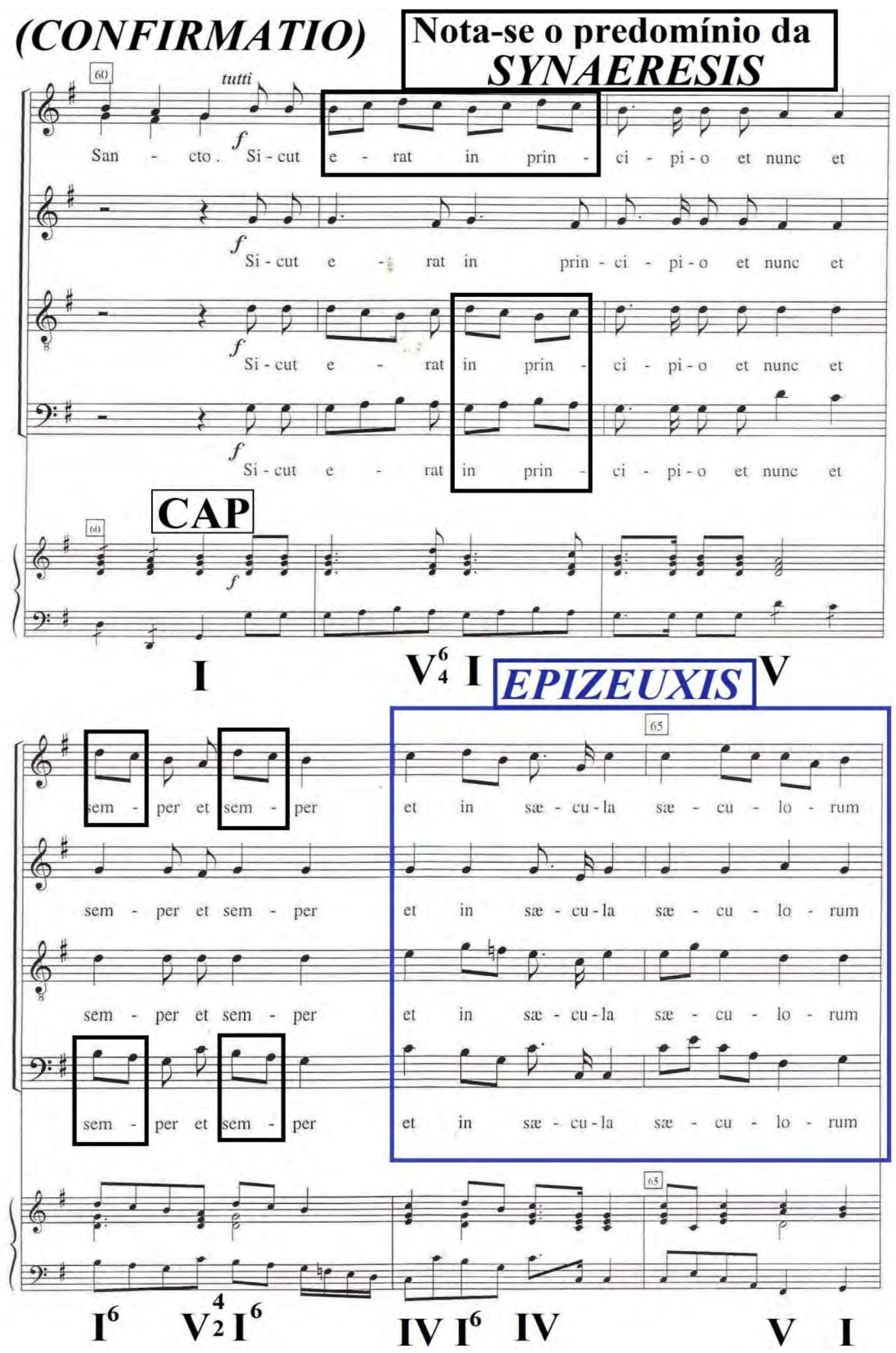

Exemplo 172-Laudate Pueri de André da Silva Gomes- Catalogação e Organização Régis Duprat (DUPRAT, 1999, p.72). 


\subsection{Peroratio}

A conclusão do discurso se dá mediante as figuras supracitadas da Epizeuxis e Synaeresis. Por meio delas, Silva Gomes reproduz o afeto de certeza, confiança, convicção da conclamação do salmista dirigida ao povo hebreu, de enaltecimento à magnificência do Senhor, além de seus atributos como das bênçãos que Ele poderia propiciar, destacando a frase amem (assim seja), numa Cadência Autêntica Imperfeita.

\section{(CONFIRMATIO)}

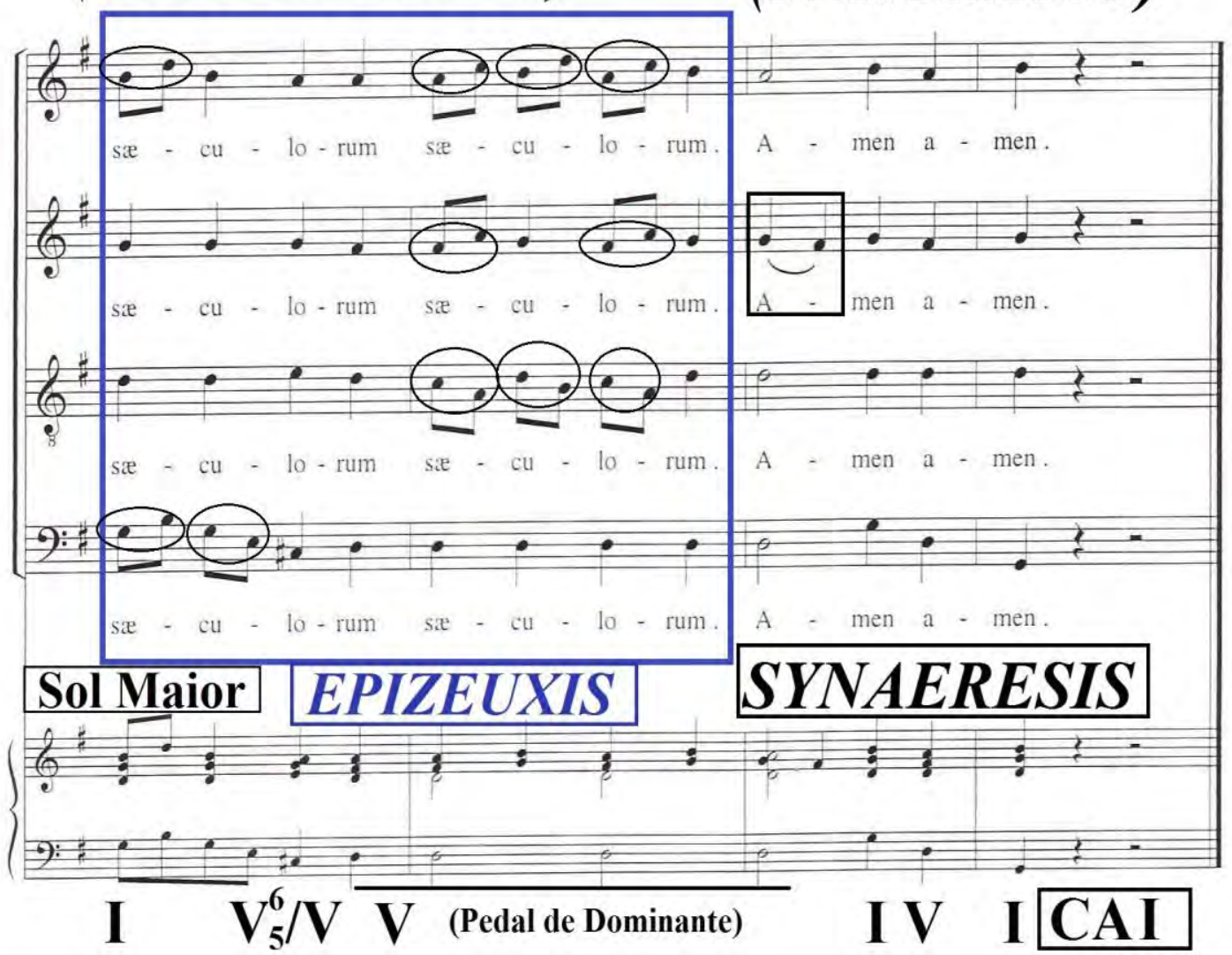

Exemplo 173-Laudate Pueri de André da Silva Gomes- Catalogação e Organização Régis Duprat (DUPRAT, 1999, p.73). 


\section{Figuras observadas no Ofertório (Elocutio/Decoratio)}

Tabela 51-Figuras retóricas localizadas no Laudate Pueri de André da Silva Gomes.

\begin{tabular}{|c|c|c|c|}
\hline $\begin{array}{l}\text { FIGURAS } \\
\text { CITAÇÕES }\end{array}$ & TIPO & DESCRIÇÃO & TRATADISTA \\
\hline $\begin{array}{l}\text { ABRUPTIO } \\
\text { (BARTEL, 1997, } \\
\text { pp.168-170). }\end{array}$ & $\begin{array}{l}\text { Interrupção } \\
\text { Silêncio }\end{array}$ & $\begin{array}{l}\text { Uma quebra } \\
\text { súbita e } \\
\text { inesperada na } \\
\text { composição } \\
\text { musical. }\end{array}$ & $\begin{array}{l}\text { Mauritius Johann } \\
\text { Vogt: A Abruptio } \\
\text { ocorre quando um } \\
\text { trecho musical é } \\
\text { interrompido no final } \\
\text { pela colocação de } \\
\text { algumas pausas. }\end{array}$ \\
\hline $\begin{array}{l}\text { APOSIOPESIS } \\
\text { (BARTEL, 1997, } \\
\text { pp.202-206). }\end{array}$ & $\begin{array}{l}\text { Interrupção } \\
\text { Silêncio }\end{array}$ & $\begin{array}{l}\text { Um descanso } \\
\text { em uma ou } \\
\text { todas as vozes } \\
\text { de uma } \\
\text { composição: } \\
\text { pausa geral. }\end{array}$ & $\begin{array}{lr}\text { Johann } & \text { Gottfried } \\
\text { Walther: } & \text { A } \\
\text { Aposiopesis se refere } \\
\text { a uma pausa } \\
\text { generalis ou um } \\
\text { completo silêncio em } \\
\text { todas as vozes e nas } \\
\text { partes da composição } \\
\text { simultaneamente. }\end{array}$ \\
\hline $\begin{array}{l}\text { EPIZEUXIS } \\
\text { (BARTEL, 1997, } \\
\text { pp.263-265). }\end{array}$ & $\begin{array}{l}\text { Repetição } \\
\text { Melódica }\end{array}$ & $\begin{array}{l}\text { Uma repetição } \\
\text { imediata e } \\
\text { enfática de } \\
\text { uma palavra, } \\
\text { nota, motivo } \\
\text { ou frase. }\end{array}$ & $\begin{array}{l}\text { Johann Gottfried } \\
\text { Walther: A Epizeuxis } \\
\text { é uma figura de } \\
\text { retórica pela qual uma } \\
\text { ou mais palavras são } \\
\text { imediatamente } \\
\text { enfaticamente } \\
\text { repetidas. }\end{array}$ \\
\hline $\begin{array}{l}\text { INTERROGATIO } \\
\text { (BARTEL, 1997, } \\
\text { pp.312-316). }\end{array}$ & $\begin{array}{l}\text { Representação } \\
\text { e Descrição }\end{array}$ & $\begin{array}{l}\text { Uma } \\
\text { interrogação } \\
\text { musical, } \\
\text { gerada por: a) } \\
\text { pausa, b) } \\
\text { Cadência } \\
\text { (Frígia, } \\
\text { Imperfeita ou } \\
\text { Semicadência) } \\
\text {, c) movimento } \\
\text { ascendente na } \\
\text { nota final da } \\
\text { frase musical. }\end{array}$ & \begin{tabular}{lr} 
Sethus Calvisius: A \\
Interrogatio pode ser \\
utilizada r numa \\
Cadência Imperfeita \\
terminando \\
Dominante \\
expressar \\
pergunta. \\
\multicolumn{3}{c}{ nara } \\
Christoph \\
A Interrogatio ocornhard: \\
quando perguntas são \\
constantemente \\
expressas finalizando \\
a frase uma segunda \\
acima da nota e sílaba \\
anteriores. \\
Johann
\end{tabular} \\
\hline
\end{tabular}




\begin{tabular}{|c|c|c|c|}
\hline p.267) & & & $\begin{array}{l}\text { Interrogatio é uma } \\
\text { pergunta musical, no } \\
\text { fim da melódica ou de } \\
\text { uma passagem } \\
\text { harmónica tendo no } \\
\text { final uma segunda ou } \\
\text { algum outro intervalo } \\
\text { superior a nota ou das } \\
\text { notas anteriores; } \\
\text { Também pode ocorrer } \\
\text { na Cadência Frígia. }\end{array}$ \\
\hline $\begin{array}{l}\text { PAUSA } \\
\text { (BARTEL, 1997, } \\
\text { p. 362-365). }\end{array}$ & $\begin{array}{l}\text { Interrupção e } \\
\text { Silêncio }\end{array}$ & $\begin{array}{l}\text { Uma pausa ou } \\
\text { descanso na } \\
\text { composição } \\
\text { musical. }\end{array}$ & $\begin{array}{l}\text { Johann Gottfried } \\
\text { Walther: Uma figura } \\
\text { ou figuras de silêncio. } \\
\text { Estas se referem à } \\
\text { Pausa. Pausa refere- } \\
\text { se a um período de } \\
\text { repouso ou o silêncio } \\
\text { na música, que é } \\
\text { indicado por um } \\
\text { determinado sinal. }\end{array}$ \\
\hline $\begin{array}{l}\text { PALILOGIA } \\
\text { (BARTEL, 1997, } \\
\text { pp.342-344). } \\
\text { (BUELOW, 2001, } \\
\text { p.264). }\end{array}$ & $\begin{array}{l}\text { Repetição } \\
\text { Melódica }\end{array}$ & $\begin{array}{l}\text { Repetição de } \\
\text { um tema no } \\
\text { mesmo nível } \\
\text { de altura, } \\
\text { também pode } \\
\text { ocorrer em } \\
\text { alturas } \\
\text { diferentes na } \\
\text { mesma ou em } \\
\text { várias vozes. }\end{array}$ & $\begin{array}{l}\text { Joachim Burmeister: } \\
\text { A Palilogia é uma } \\
\text { repetição de uma } \\
\text { inteiração ou apenas } \\
\text { o começo da estrutura } \\
\text { dos meios e temas } \\
\text { sobre a mesma altura } \\
\text { com a mesma voz, } \\
\text { ocorrendo com ou } \\
\text { sem intermédio de } \\
\text { pausas em todos os } \\
\text { eventos em uma voz. } \\
\text { Johann Gottfried } \\
\text { Walther: A } \\
\text { Palilogia refere-se a } \\
\text { uma repetição por } \\
\text { demais frequente das } \\
\text { mesmas palavras. }\end{array}$ \\
\hline $\begin{array}{l}\text { SYNONYMIA } \\
\text { (BARTEL, 1997, } \\
\text { pp.405-407). } \\
\text { (BUELOW, 2001, } \\
\text { p.264). }\end{array}$ & $\begin{array}{l}\text { Repetição } \\
\text { Melódica }\end{array}$ & $\begin{array}{l}\text { É a repetição } \\
\text { alterada ou } \\
\text { modificada de } \\
\text { uma ideia } \\
\text { musical. } \\
\text { A repetição de } \\
\text { uma ideia } \\
\text { melódica em } \\
\text { notas } \\
\text { diferentes na }\end{array}$ & $\begin{array}{lr}\text { Johann } & \text { Gottfried } \\
\text { Walther: } & \text { Um } \\
\text { compositor também } & \text { tamer } \\
\text { pode empregar muito } \\
\text { bem diferentes figuras } \\
\text { retóricas r na } \\
\text { elaboração de um } \\
\text { texto. Por exemplo, } \\
\text { além da Epizeuxis, } \\
\text { que é a mais comum } \\
\text { e enfática, pode usar, }\end{array}$ \\
\hline
\end{tabular}




\begin{tabular}{|l|l|l|}
\hline & mesma parte. & $\begin{array}{l}\text { Anaphora, } \\
\text { Synonymia, } \\
\text { Epistrophe, } \\
\text { Epanalepsis e assim } \\
\text { por diante. }\end{array}$ \\
\hline
\end{tabular}

\section{Análise Harmônica}

\subsection{Curva Tonal}

Tonalidade: Sol Maior

Andamento: Andante 4/4

Tabela 52- Esquema de Progressões Harmônicas- Curva Tonal do Laudate Pueri.

\begin{tabular}{|l|c|l|}
\hline \multicolumn{1}{|c|}{ Compassos } & Função & \multicolumn{1}{c|}{ Tonalidade } \\
\hline $1-10$ & I & Sol Maior \\
\hline $10-12$ & V & Ré Maior \\
\hline $13-15$ & V & Sol Maior \\
\hline $16-19$ & V/V & Ré Maior \\
\hline 20 & V & Lá Maior \\
\hline $21-24$ & iii & Si Maior \\
\hline $25-26$ & V/iii & Fá \# Maior \\
\hline $26-29$ & iii & Si Menor \\
\hline 30 & Vi & Mi Menor \\
\hline $30-31$ & V/iii & Fá \# Maior \\
\hline $32-35$ & iii & Si Menor \\
\hline $36-37$ & V & Ré Maior \\
\hline $37-38$ & iii & Si Menor \\
\hline $39-48$ & V/iii & Fá \# Maior \\
\hline 48 & iii & Si Menor \\
\hline 49 & vi & Mi Menor \\
\hline 49 & V & Ré Maior \\
\hline $50-56$ & I & Sol Maior \\
\hline $57-66$ & V & Ré Maior \\
\hline $66-68$ & I & Sol Maior \\
\hline 69 & & \\
\hline & & \\
\hline
\end{tabular}


4.2. Estrutura Analítica do Ofertório: Retórica e Harmônica

Tabela 53-Estrutura analítica da obra.

\begin{tabular}{|c|c|c|c|c|}
\hline $\begin{array}{l}\text { RETÓRICA } \\
\text { DISPOSITIO }\end{array}$ & $\begin{array}{c}\text { FIGURA } \\
\text { ELOCUTIO }\end{array}$ & COMP. & TONALIDADE & FUNÇÃO \\
\hline EXORDIUM & $\begin{array}{l}\text { Epizeuxis } \\
\text { Palilogia } \\
\text { Synaeresis } \\
\text { Aposiopesis }\end{array}$ & $\begin{array}{l}2-3 \\
2-3 \\
2-3 \\
5\end{array}$ & $\begin{array}{l}\text { Sol Maior } \\
\text { Sol Maior } \\
\text { Sol Maior } \\
\text { Sol Maior }\end{array}$ & $\begin{array}{l}1 \\
1 \\
1 \\
1\end{array}$ \\
\hline NARRATIO & Synaeresis & $5-8$ & Sol Maior & $\mathrm{I}$ \\
\hline PROPOSITIO & Synaeresis & $\begin{array}{l}10-12 \\
14\end{array}$ & $\begin{array}{l}\text { Ré Maior } \\
\text { Ré Maior }\end{array}$ & $\begin{array}{l}\mathrm{V} \\
\mathrm{V}\end{array}$ \\
\hline CONFUTATIO & $\begin{array}{l}\text { Synonymia } \\
\text { Epizeuxis } \\
\text { Interrogatio } \\
\text { Abruptio } \\
\text { Pausa } \\
\text { Aposiopesis }\end{array}$ & $\begin{array}{l}16-18 \\
22-23 \\
24-28 \\
33-34 \\
37-38 \\
40-41 \\
43-47 \\
51-55 \\
21-23 \\
28-32 \\
36-38 \\
42-47 \\
30-34 \\
49 \\
50 \\
56\end{array}$ & $\begin{array}{l}\text { Ré Maior } \\
\text { Ré Maior } \\
\text { Ré Maior, Si Menor } \\
\text { Si Menor } \\
\text { Si Menor } \\
\text { Si Menor } \\
\text { Si Menor } \\
\text { Ré Maior } \\
\text { Ré Maior } \\
\text { Si Menor } \\
\text { Si Menor } \\
\text { Si Menor } \\
\text { Si Menor } \\
\text { Ré Maior } \\
\text { Ré Maior } \\
\text { Ré Maior }\end{array}$ & $\begin{array}{l}\text { V } \\
\text { V } \\
\text { V, iii } \\
\text { iii } \\
\text { iii } \\
\text { iii } \\
\text { iii } \\
\text { V } \\
\text { V } \\
\text { iii } \\
\text { iii } \\
\text { iii } \\
\text { iii } \\
\text { V } \\
\text { V } \\
\text { V }\end{array}$ \\
\hline
\end{tabular}




\begin{tabular}{|l|l|l|l|c|}
\hline CONFIRMATIO & Synaeresis & $57-59$ & Sol Maior & I \\
& & 61,63 & Sol Maior & I \\
& Epizeuxis & $64-65$ & Sol Maior & I \\
\hline PERORATIO & Epizeuxis & $66-67$ & Sol Maior & $\mathrm{I}$ \\
& Synaeresis & $66-68$ & Sol Maior & \\
\hline
\end{tabular}




\title{
6.4. José Maurício Nunes Garcia
}

\subsubsection{Análise Retórico-Musical do Domine Jesu ${ }^{126}$}

\section{Inventio}

Esta peça tem seu texto baseado nos Salmos (Ps. 79:3/80:1), tendo por tema principal: A Salvação pelo Senhor:

Domine Jesu, te desidero, te volo, te quæro,

Ostende mihi faciem tuam et salvus ero.

Senhor Jesus, eu te desejo, te procuro, te quero,

Mostra-me a tua face e eu serei salvo.

O excerto descrito acima, expressa a vontade e o propósito do autor desse salmo em buscar a presença do Senhor. Asafe, nessa passagem, enfatiza três coisas na sua súplica para conseguir proteção divina: o desejo, a procura e, por fim, o querer.

Analogamente, tais sentimentos podem ser encontrados em dois livros da Bíblia. Em Números 6: 25-26, na bênção sacerdotal, Deus fala com Moisés que abençoaria os filhos de Israel através da mostra de Seu rosto (ALMEIDA, 2000, p.197). Já em Lucas 23: 41-43, um dos malfeitores que estava crucificado com Jesus, rogou-lhe que o salvasse, além de lembrar-se dele quando estivesse em seu reino:

\begin{abstract}
Respondendo, porém, o outro, repreendia-o, dizendo: Nem ao menos temes a Deus, estando na mesma condenação? E nós, na verdade, com justiça; porque recebemos o que os nossos feitos merecem; mas este nenhum mal fez. Então disse: Jesus, lembra-te de mim, quando entrares no teu reino. Respondeu-lhe Jesus: Em verdade te digo que hoje estarás comigo no paraíso (ALMEIDA, 2000, p.1478).
\end{abstract}

\footnotetext{
${ }^{126}$ Apesar do Domine Jesu (CPM 208) (Sem datação) ser uma peça avulsa do Padre José Maurício, é comum localizar seu título como parte integrante do Moteto dos Passos, em diversos compositores de música sacra e ordenados dessa maneira: Pater mihi, Bejulans, Exeamus ergo, Popule meus, Angariaverunt, Filiæ Jerusalem, Domine Jesu, O vos omnes. Todavia, de acordo com a pesquisadora Ana Guiomar Rêgo Souza, a disposição dessas partes varia de lugar, assim como o acréscimo ou retirada das mesmas. Por exemplo: o Moteto dos Passos (anônimo) originário de Taubaté-SP expõe-se com essa estrutura: I-Pater mihi, IIBejulans, III- Angariaverunt, IV-O vos omnes, V-Exeamus ergo, VI-Filiæ Jerusalem, VII-Popule meus, VIII-Domine Jesu. Em outro exemplar do século XVIII, cujo autor também é anônimo, dessa forma: I-Miserere, II-Bejulans, III-Popule meus, IV-Exeamus ergo, V-O vos omnes, VIAngariaverunt, VII-Filiæ Jerusalem, VIII-Domine Jesus. Por fim, o compositor Manoel Dias de Oliveira organiza na seguinte ordem: I-Pater mihi, II-Bejulans, III-Exeamus ergo, IVAngariaverunt, V-Filiæ Jerusalem, VI- Popule meus, VII-O vos omnes, oferecendo uma organização na qual não ocorre a peça Domine Jesu (SOUZA, 2007, p.319).
} 
Essa obra é composta por quarenta e um compassos na tonalidade Dó Menor, em andamento Larghetto. Enfim, pretende-se, nos tópicos seguintes, mostrar a existência de aspectos relevantes da linguagem utilizada pelo autor, observando o emprego de figuras e elementos retóricos, assim como dos materiais e das funções harmônicas.

\subsection{Loci observados na Inventio do Domine Jesu}

Tabela 54-Loci Topici localizados no Domine Jesu de José Maurício Nunes Garcia.

\begin{tabular}{|c|c|c|c|}
\hline INVENTIO & DESCRIÇÃO & $\begin{array}{c}\text { UTILIZAÇÃO NA } \\
\text { OBRA }\end{array}$ & $\begin{array}{l}\text { COMPASSOI } \\
\text { VOZ }\end{array}$ \\
\hline $\begin{array}{l}\text { Locus } \\
\text { Notationis } \\
\text { (MATTHESON, } \\
\text { 1954, [1739]. } \\
\text { Parte II, Cap.4, } \\
\S 23, \text { p.123). }\end{array}$ & $\begin{array}{l}\text { Aspecto externo } \\
\text { e desenho das } \\
\text { notas (Duração } \\
\text { das notas, } \\
\text { alteração, } \\
\text { repetição e } \\
\text { procedimentos } \\
\text { canônicos). }\end{array}$ & $\begin{array}{l}\text { Vários motivos } \\
\text { rítmicos e diferentes } \\
\text { durações de notas } \\
\text { (mínimas, semínimas, } \\
\text { semínimas } \\
\text { pontuadas, colcheias, } \\
\text { colcheias pontuadas, } \\
\text { repetições, ligaduras, } \\
\text { pausas, apogiatura, } \\
\text { fermata entre outros). }\end{array}$ & $\begin{array}{ll}1-8 & \text { S-A-T-B } \\
9-17 & \text { S-A-T-B } \\
18-20 & \text { S-A-T-B } \\
21-28 & \text { S-A-T-B } \\
29-32 & \text { S-A-T-B } \\
33-37 & \text { S-A-T-B } \\
38-41 \text { S-A-T-B }\end{array}$ \\
\hline $\begin{array}{l}\text { Locus } \\
\text { Descriptionis } \\
\text { (MATTHESON, } \\
\text { 1954, [1739]. } \\
\text { Parte II, Cap.4, } \\
\text { § 43, p.127). }\end{array}$ & $\begin{array}{l}\text { Disposições da } \\
\text { alma }\end{array}$ & $\begin{array}{l}\text { Desejo, avidez, querer } \\
\text { (Senhor Jesus, eu te } \\
\text { desejo, te procuro, te } \\
\text { quero). } \\
\text { Confiança (Eu serei } \\
\text { salvo). }\end{array}$ & $1-20$ S-A-T-B \\
\hline $\begin{array}{l}\text { Locus } \\
\text { Oppositorum } \\
\text { (MATTHESON, } \\
\text { 1954, [1739]. } \\
\text { Parte II, Cap.4, } \\
\S 80, \text { p.131). }\end{array}$ & $\begin{array}{l}\text { Contraste de } \\
\text { compassos, } \\
\text { movimentos } \\
\text { contrários, } \\
\text { agudos e } \\
\text { graves, lento e } \\
\text { rápido, calmo e } \\
\text { agitado. }\end{array}$ & $\begin{array}{l}\text { Movimento contrário } \\
\text { entre tenor e baixo. } \\
\text { Também no contralto, } \\
\text { tenor e baixo. E, por } \\
\text { fim, entre a soprano e } \\
\text { contralto. }\end{array}$ & $\begin{array}{ll}5 & \text { T-B } \\
7 & \text { A-T-B } \\
18-19 & \text { T-B } \\
23 & \text { T-B } \\
27 & \text { A-T } \\
31 & \text { S-A }\end{array}$ \\
\hline
\end{tabular}




\section{Dispositio}

\subsection{Exordium}

O discurso se inicia de maneira suave e reflexiva com a expressão, Domine Jesu (Senhor Jesus), em Dó Menor. Mattheson, em seu tratado para orquestra, Das Neueröffnete Orchestre (1713), afirma que essa tonalidade é extremamente suave e, ao mesmo tempo, triste, caso tenha muita doçura, torna-se fastidiosa, porém, na proporção certa, ela conduz a sentimentos de reflexão (MATTHESON, 1713, parte III, cap.2,§16) ${ }^{127}$.

José Maurício Nunes Garcia, como hábil compositor, utiliza-se dos recursos retóricos para fundamentar a primeira parte da música, inserindo a Aposiopesis nas quatro vozes entre o segundo tempo dos compassos 2 e 4, submetendo as mesmas a um silêncio total, além de dar ênfase à palavra Domine que é repetida em estrutura cordal. Posteriormente, nos compassos 5 e 7, nota-se a Synaeresis nas vozes do contralto, tenor e baixo que, entoando duas notas na mesma sílaba, enfatizam tanto a mudança de dinâmica de piano para pianíssimo, da linha fraseológica, como as funções harmônicas da Tônica e Dominante, culminando na Cadência Autêntica Imperfeita.

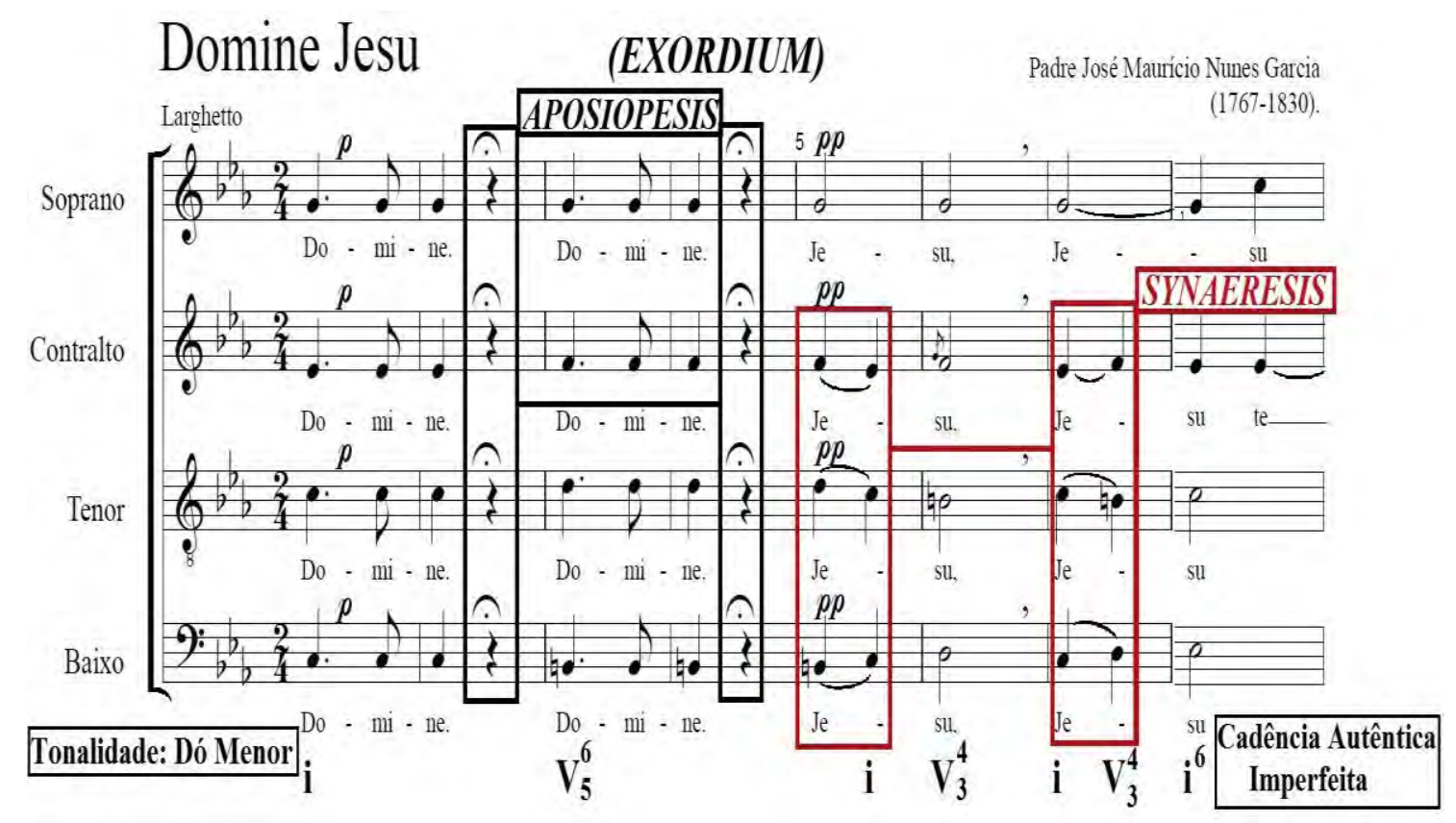

Exemplo 174-Domine Jesu de José Maurício Nunes Garcia-Edição Álvaro Loreto (GARCIA, 2000, p.1).

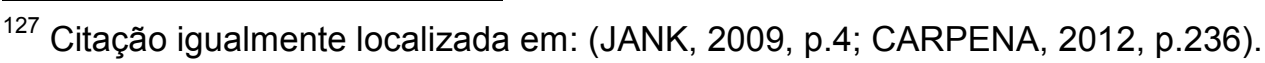




\subsection{Narratio}

Após o desfecho do Exordium, no compasso 8, a narração dos fatos iniciais se dá por meio do diálogo estabelecido pelas vozes da soprano e contralto, repetindo a expressão te desidero (te desejo) em alturas diferentes, configurando um Polyptoton. Igualmente, examina-se que essa figura de repetição melódica é utilizada para destacar a sequência de quintas, as funções harmônicas da Tônica, Subdominante, Dominante Relativa (Paralela), Tônica Relativa (Paralela), Subdominante Relativa (Paralela) e Dominante, como as dinâmicas crescendo, sforzando e piano. Por fim, há de se ressaltar o uso da Synaeresis, no compasso 16 e a resolução da segunda parte da Dispositio com uma Semicadência.

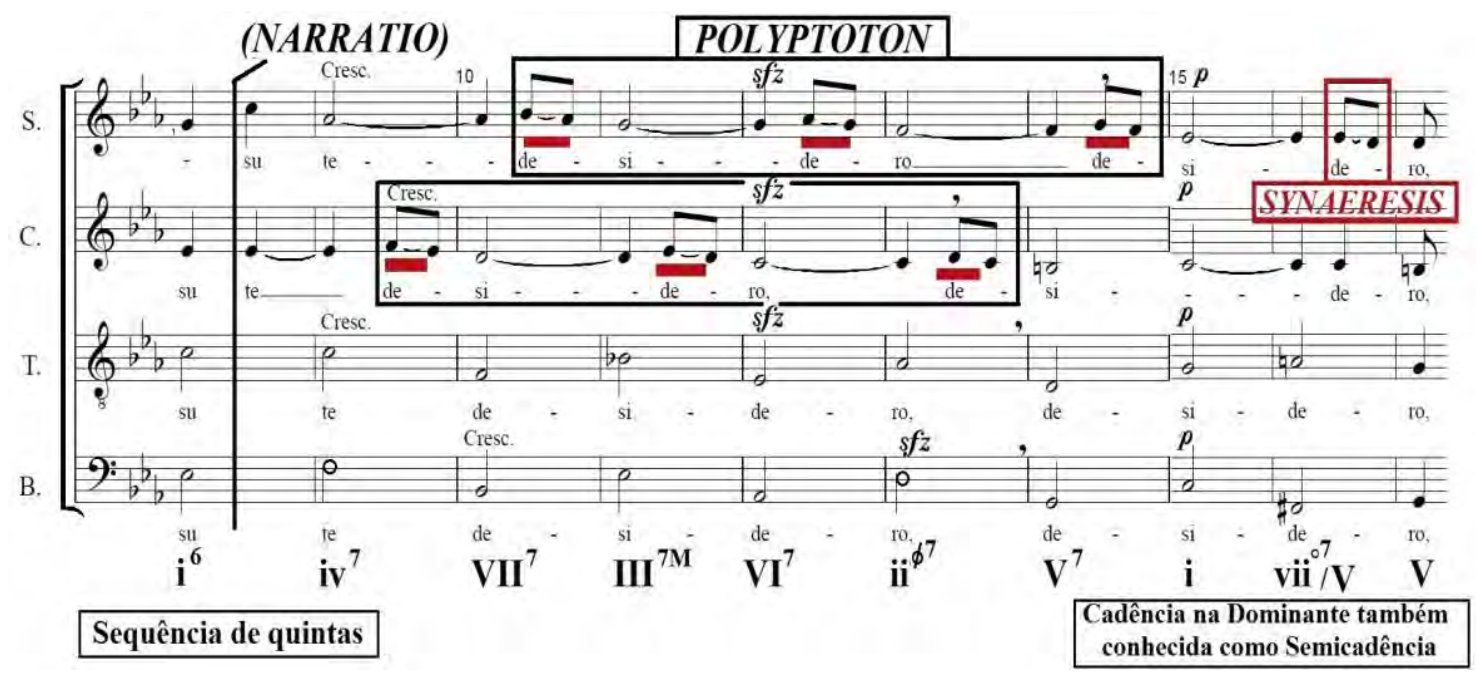

Exemplo 175-Domine Jesu de José Maurício Nunes Garcia-Edição Álvaro Loreto (GARCIA, 2000, p.1).

\subsection{Propositio}

Pode-se examinar, nessa nova parte do discurso, o emprego de duas figuras retóricas: Pausa e Synaeresis, a primeira para estabelecer um momento de silêncio e repouso nas vozes do contralto, tenor e baixo, enquanto a soprano entoa e destaca a nota Sol, a segunda ressaltando as palavras te volo, te quæro (te procuro, te quero). Da mesma forma, nota-se o uso da Analepsis, repetindo na mesma altura o Noema. 


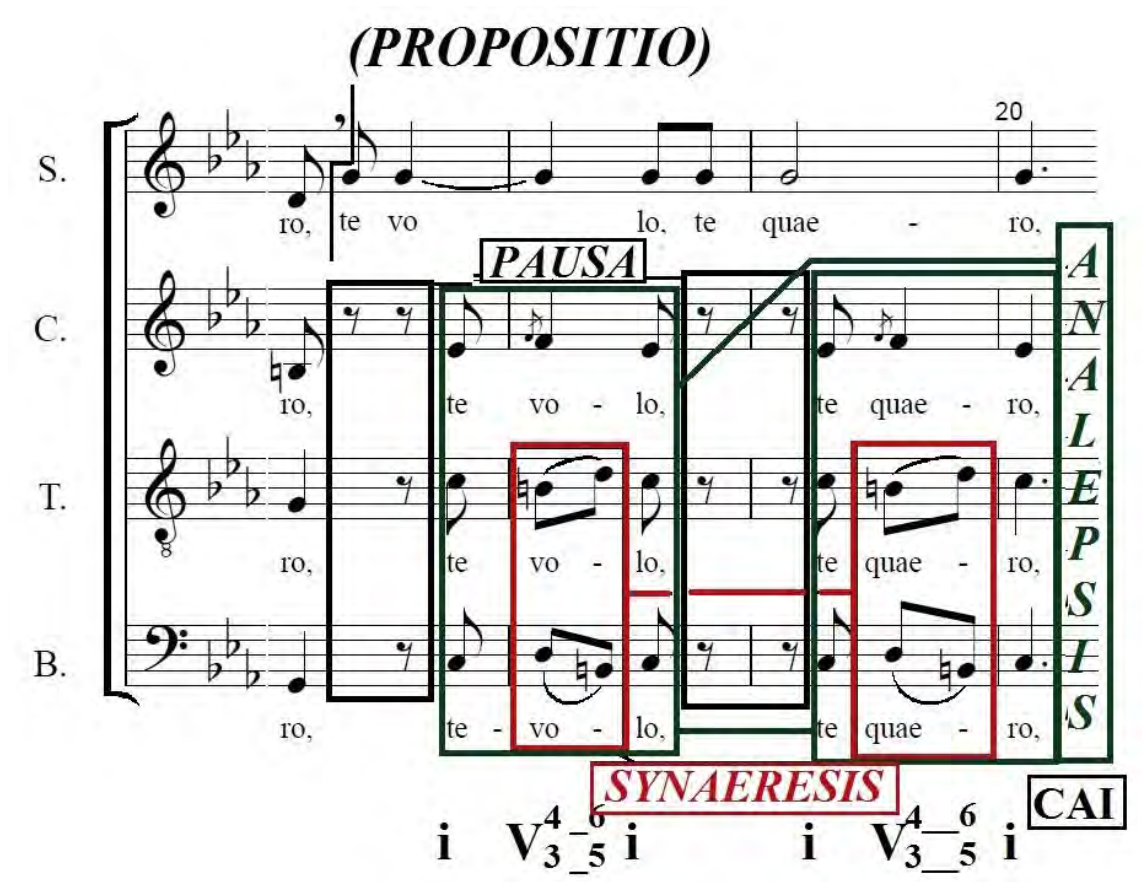

Exemplo 176-Domine Jesu de José Maurício Nunes Garcia-Edição Álvaro Loreto (GARCIA, 2000, p.1).

\subsection{Confutatio}

Posterior à terminação da Propositio, no compasso 20, com uma Cadência Autêntica Imperfeita, tem-se a inclusão de novos elementos e argumentos relacionados à tese fundamental. Por exemplo, a aplicação do Noema, entre os compassos 20 e 28, a qual, em passagem homofônica, causa um efeito de suavidade, como também clarifica o texto devido ao contraste entre a polifonia vocal e a harmonia vertical. De igual modo, notam-se as várias passagens cromáticas nas vozes do contralto, tenor e baixo, entre os compassos 23 e 26. Não obstante, observa-se o uso da Synaeresis nos compassos 23 e 25 e da Aposiopesis, nesse contexto, valorando a frase: Ostende mihi faciem tuam (Mostra-me a tua face), a entoação de duas notas por sílaba, o repouso através da pausa geral a todas as vozes, a Cadência e, por fim, a modulação da tonalidade Fá Menor para Dó Menor. 


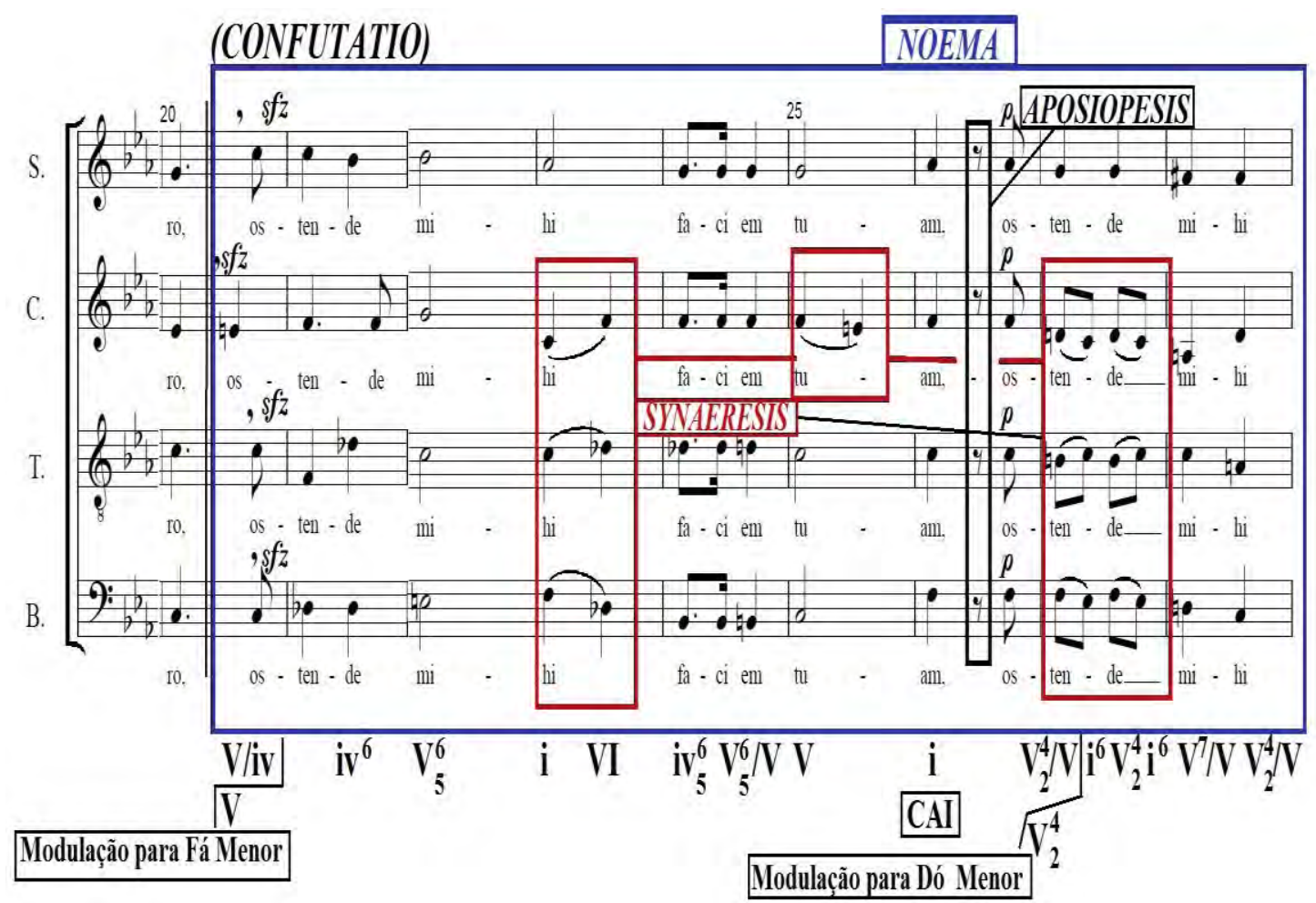

Exemplo 177-Domine Jesu de José Maurício Nunes Garcia-Edição Álvaro Loreto (GARCIA, 2000, p.2).

No excerto abaixo, é observável a utilização das funções da Tônica, Dominante, Subdominante Relativa (Paralela) e da Sexta Aumentada Francesa, com resolução na Semicadência.

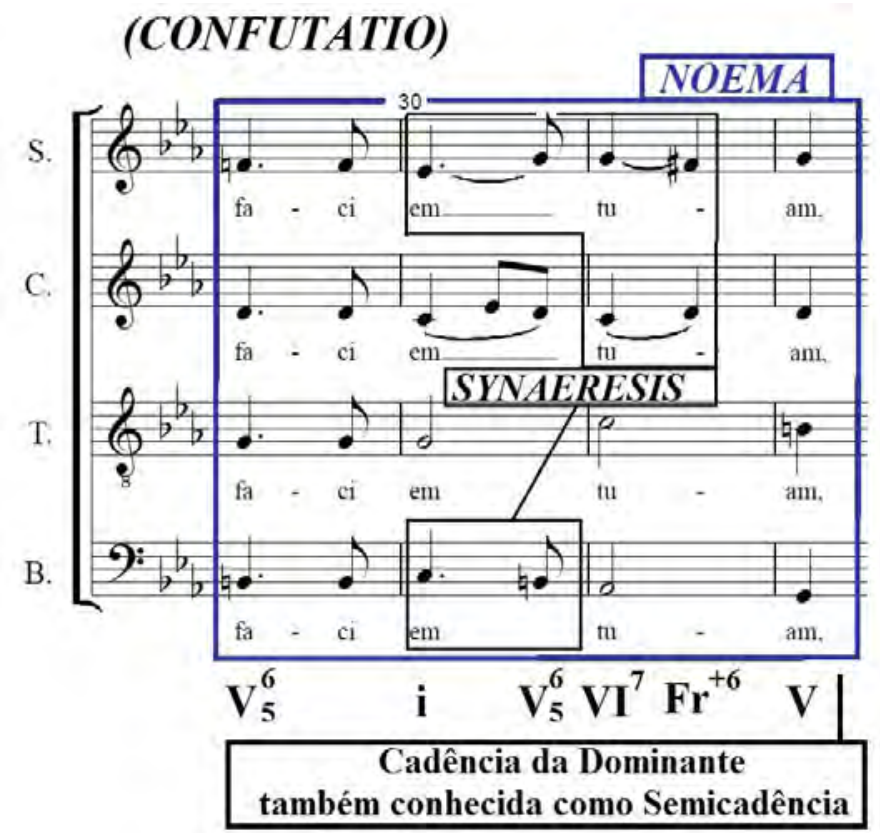

Exemplo 178-Domine Jesu de José Maurício Nunes Garcia-Edição Álvaro Loreto (GARCIA, 2000, p.2). 


\subsection{Confirmatio}

$\mathrm{Na}$ Confirmatio ocorre a enunciação de duas notas por sílaba, como da palavra et salvus ero (eu serei salvo), efetuada pela supracitada figura da Synaeresis. Semelhantemente, pode-se destacar o emprego do pedal de Dominante como elemento de transição para a próxima seção da peça.

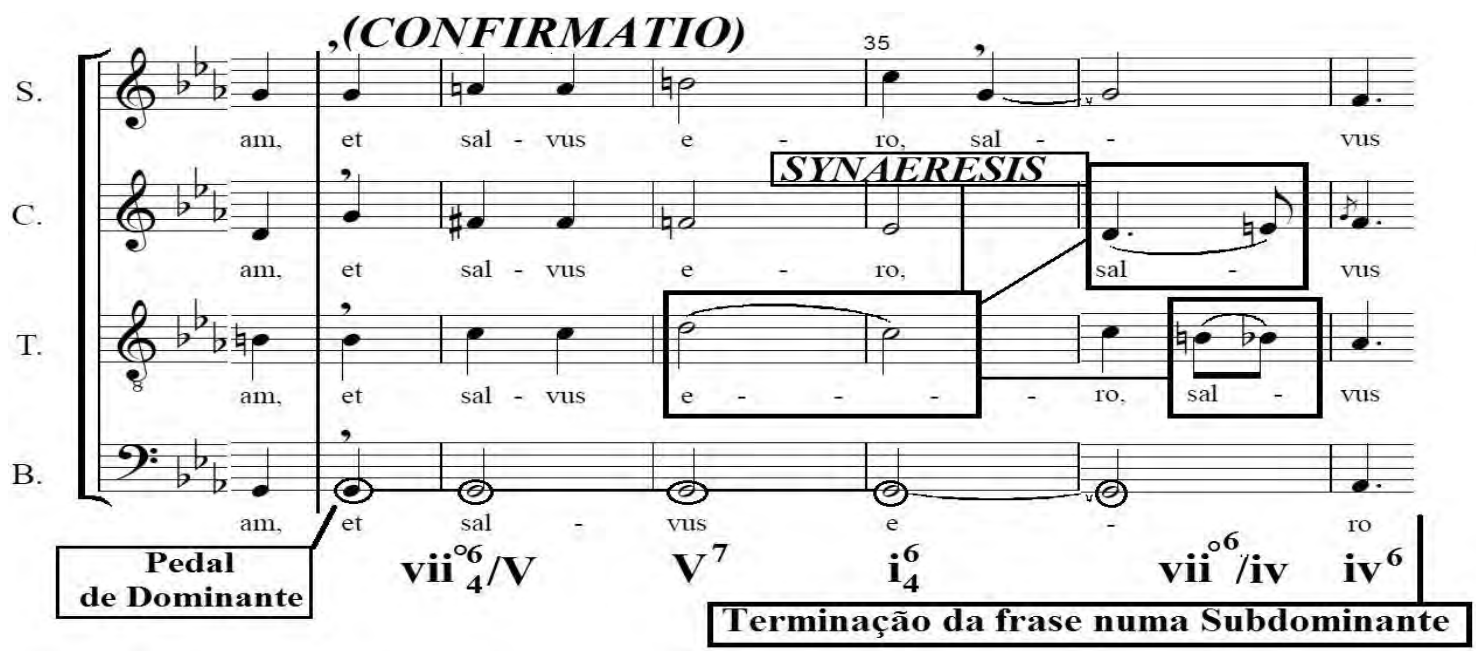

Exemplo 179-Domine Jesu de José Maurício Nunes Garcia-Edição Álvaro Loreto (GARCIA, 2000, p.2).

\subsection{Peroratio}

O discurso se encerra salientando novamente as últimas palavras do texto, et salvus ero (eu serei salvo). Verifica-se que Nunes Garcia trabalha com a dinâmica pianíssimo em consonância à Synaeresis, para dar ênfase ao afeto de confiança, com conclusão numa Cadência Autêntica Imperfeita.

\section{(PERORATIO)}

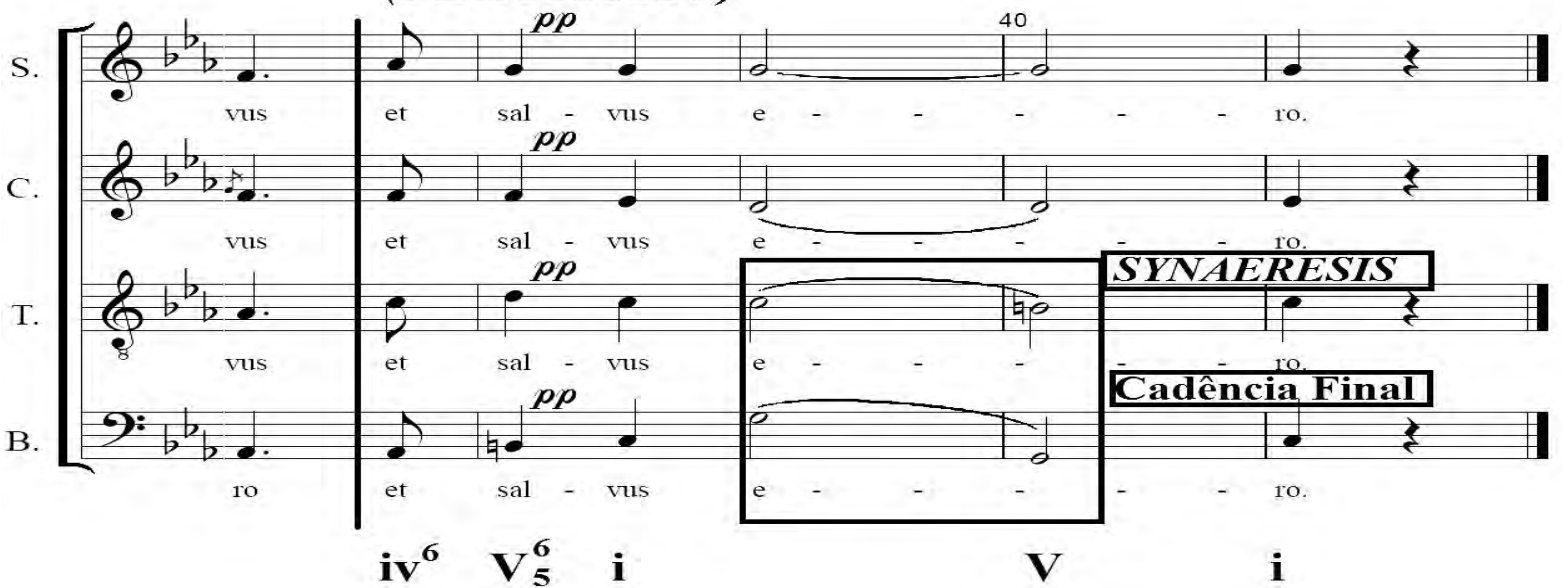

Exemplo 180-Domine Jesu de José Maurício Nunes Garcia-Edição Álvaro Loreto (GARCIA, 2000, p.2). 


\section{Figuras observadas na obra (Elocutio/Decoratio)}

Tabela 55-Figuras retóricas localizadas no Domine Jesus de José Maurício Nunes Garcia.

\begin{tabular}{|c|c|c|c|}
\hline $\begin{array}{l}\text { FIGURAS E } \\
\text { CITAÇÕES }\end{array}$ & TIPO & DESCRIÇÃO & TRATADISTA \\
\hline $\begin{array}{l}\text { ANALEPSIS } \\
\text { (BARTEL, 1997, } \\
\text { p. 183-184). }\end{array}$ & $\begin{array}{l}\text { Repetição } \\
\text { Harmônica: } \\
\text { Figuras de Fuga }\end{array}$ & $\begin{array}{l}\text { Repetição literal } \\
\text { de uma seção } \\
\text { homofônica, ou } \\
\text { seja, de um } \\
\text { Noema na } \\
\text { mesma altura. }\end{array}$ & $\begin{array}{l}\text { Joachim Burmeister: } \\
\text { É uma repetição ou } \\
\text { duplicação de um } \\
\text { Noema e, portanto, é } \\
\text { um ornamento } \\
\text { relacionado a ele. }\end{array}$ \\
\hline $\begin{array}{l}\text { APOSIOPESIS } \\
\text { (BARTEL, 1997, } \\
\text { p. 202-206). }\end{array}$ & $\begin{array}{l}\text { Interrupção } \\
\text { Silêncio }\end{array}$ & $\begin{array}{l}\text { Descanso em } \\
\text { uma ou todas } \\
\text { as vozes de } \\
\text { uma } \\
\text { composição: } \\
\text { pausa geral. }\end{array}$ & $\begin{array}{l}\text { Johann } \text { Gottfried } \\
\text { Walther: A Aposiopesis } \\
\text { se refere a uma Pausa } \\
\text { generalis ou um } \\
\text { completo silêncio em } \\
\text { todas as vozes e nas } \\
\text { partes da composição } \\
\text { simultaneamente. }\end{array}$ \\
\hline $\begin{array}{l}\text { NOEMA } \\
\text { (BARTEL, 1997, } \\
\text { p. 339-342). }\end{array}$ & $\begin{array}{l}\text { Representação } \\
\text { e Descrição }\end{array}$ & $\begin{array}{l}\text { Seção } \\
\text { homofônica, } \\
\text { dentro } \\
\text { polifonia } \\
\text { utilizada } \\
\text { enfatizar } \\
\text { texto. }\end{array}$ & $\begin{array}{l}\text { Joachim Burmeister: } \\
\text { O Noema representa o } \\
\text { afeto harmônico, onde } \\
\text { as vozes combinadas } \\
\text { têm valores e números } \\
\text { de notas semelhantes. } \\
\text { [...] Quando introduzida } \\
\text { adequadamente, isto é, } \\
\text { no momento certo, ela } \\
\text { afeta docemente os } \\
\text { ouvidos do ouvinte, } \\
\text { produzindo una uma } \\
\text { sensação de calma e } \\
\text { serenidade. }\end{array}$ \\
\hline $\begin{array}{l}\text { PAUSA } \\
\text { (BARTEL, 1997, } \\
\text { p. 362-365). }\end{array}$ & $\begin{array}{l}\text { Interrupção e } \\
\text { Silêncio }\end{array}$ & $\begin{array}{ll}\text { Uma pausa } & \text { ou } \\
\text { descanso } & \text { na } \\
\text { composição } & \\
\text { musical. } & \end{array}$ & $\begin{array}{l}\text { Johann Gottfried } \\
\text { Walther: Uma figura ou } \\
\text { figuras de silêncio. } \\
\text { Estas se referem à } \\
\text { Pausa. Pausa refere-se } \\
\text { a um período de } \\
\text { repouso ou o silêncio na } \\
\text { música, que é indicado } \\
\text { por um determinado } \\
\text { sinal. }\end{array}$ \\
\hline $\begin{array}{l}\text { POLYPTOTON } \\
\text { (BARTEL, 1997, } \\
\text { p. 367-369). }\end{array}$ & $\begin{array}{l}\text { Repetição } \\
\text { Melódica }\end{array}$ & $\begin{array}{l}\text { A repetição de } \\
\text { uma passagem } \\
\text { melódica em } \\
\text { diferentes }\end{array}$ & $\begin{array}{l}\text { Mauritius Johann } \\
\text { Vogt: Polyptoton é } \\
\text { quando uma passagem } \\
\text { é repetida em várias } \\
\end{array}$ \\
\hline
\end{tabular}




\begin{tabular}{|c|c|c|c|}
\hline $\begin{array}{l}\text { (BUELOW, 2001, } \\
\text { p.264). }\end{array}$ & & alturas. & alturas. \\
\hline $\begin{array}{l}\text { SYNAERESIS } \\
\text { (BARTEL, 1997, } \\
\text { p. 394-396). } \\
\text { (LÓPEZ CANO, } \\
\text { 2000, p.199). }\end{array}$ & $\begin{array}{l}\text { Dissonância e } \\
\text { Deslocamento }\end{array}$ & 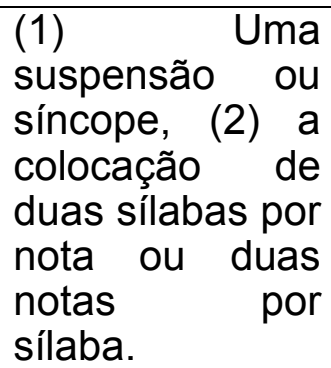 & $\begin{array}{l}\text { Mauritius } \\
\text { Vogt: A Synaeresis } \\
\text { ocorre quando duas } \\
\text { notas são colocadas em } \\
\text { uma sílaba ou duas } \\
\text { sílabas são colocadas } \\
\text { em uma nota. }\end{array}$ \\
\hline
\end{tabular}

\section{Análise Harmônica}

\subsection{Curva Tonal}

Tonalidade: Dó Menor

Andamento: Larghetto 2/4

Tabela 56-Esquema das Progressões Harmônicas- Curva Tonal do Domine Jesu.

\begin{tabular}{|l|c|l|}
\hline \multicolumn{1}{|c|}{ Compassos } & \multicolumn{1}{c|}{ Função } & \multicolumn{1}{c|}{ Tonalidade } \\
\hline $1-8$ & i & Dó Menor \\
\hline $9-14$ & i (Sequências de quintas) & Dó Menor \\
\hline $16-17$ & V & Sol Maior \\
\hline $17-20$ & i & Dó Menor \\
\hline $21-24$ & iv & Fá Menor \\
\hline 24 & V & Sol Maior \\
\hline $25-26$ & iv & Fá Menor \\
\hline $26-29$ & V & Sol Maior \\
\hline $30-32$ & i & Dó Menor \\
\hline $33-34$ & V & Sol Maior \\
\hline $35-36$ & i & Dó menor \\
\hline $36-37$ & i & Fá Menor \\
\hline $38-41$ & i & Dó Menor \\
\hline
\end{tabular}

\subsection{Estrutura Analítica da obra: Retórica e Harmônica}

Tabela 57-Estrutura analítica da obra.

\begin{tabular}{|c|c|c|l|c|}
\hline $\begin{array}{c}\text { RETÓRICA } \\
\text { DISPOSITIO }\end{array}$ & $\begin{array}{c}\text { FIGURA } \\
\text { ELOCUTIO }\end{array}$ & COMP. & TONALIDADE & FUNÇÃO \\
\hline EXORDIUM & Aposiopesis & 2,4 & Dó Menor & $\mathrm{I}$ \\
\hline
\end{tabular}




\begin{tabular}{|c|c|c|c|c|}
\hline & Synaeresis & 5,7 & Dó Menor & $\mathrm{i}$ \\
\hline NARRATIO & $\begin{array}{l}\text { Polyptoton } \\
\text { Synaeresis }\end{array}$ & $\begin{array}{l}9-14 \\
16\end{array}$ & $\begin{array}{l}\text { Dó Menor } \\
\text { Dó Menor }\end{array}$ & $\begin{array}{l}\mathrm{i} \\
\mathrm{i}\end{array}$ \\
\hline PROPOSITIO & $\begin{array}{l}\text { Pausa } \\
\text { Synaeresis } \\
\text { Analepsis }\end{array}$ & $\begin{array}{l}17-19 \\
18-19 \\
17-20\end{array}$ & $\begin{array}{l}\text { Dó Menor } \\
\text { Dó Menor } \\
\text { Dó Menor }\end{array}$ & $\begin{array}{l}\mathrm{I} \\
\mathrm{i} \\
\mathrm{i}\end{array}$ \\
\hline CONFUTATIO & $\begin{array}{l}\text { Noema } \\
\text { Synaeresis } \\
\text { Aposiopesis }\end{array}$ & $\begin{array}{l}20-28 \\
23,25 \\
27 \\
26\end{array}$ & $\begin{array}{l}\text { Fá Menor e Dó } \\
\text { Menor } \\
\text { Fá Menor } \\
\text { Dó Menor } \\
\text { Fá Menor }\end{array}$ & $\begin{array}{c}\text { Vi e i } \\
\text { iv } \\
\text { i } \\
\text { iv }\end{array}$ \\
\hline CONFIRMATIO & $\begin{array}{l}\text { Noema } \\
\text { Synaeresis }\end{array}$ & $\begin{array}{l}29-32 \\
34-36\end{array}$ & $\begin{array}{l}\text { Dó Menor } \\
\text { Dó Menor }\end{array}$ & $\begin{array}{l}\mathrm{i} \\
\mathrm{i}\end{array}$ \\
\hline PERORATIO & Synaeresis & $39-40$ & Dó Menor & $\bar{i}$ \\
\hline
\end{tabular}




\subsubsection{Análise Retórico-Musical do Crux Fidelis ${ }^{128}$}

\section{Inventio}

Esta música é parte integrante das obras de José Maurício escritas para a Semana Santa, tendo por tema central: A cruz conduzida por Cristo.

Crux fidelis, inter omnes arbor una nobilis, nulla talem silva profert flore, fronde, germine, dulce lignum dulce clavo dulce pondus sustinet.

Ó Cruz fiel, entre todas a árvore mais nobre:

Nenhum bosque produz igual, em ramagens, frutos e flores.

Ó doce lenho, que os doces cravos e o doce peso sustentas.

Nota-se que a passagem descrita acima, realça o objeto transportado por Jesus durante o trajeto que ia do pretório ${ }^{129}$ até o Calvário, conhecido por Via Crucis (João 19:17-18).

Então Pilatos o entregou para ser crucificado. Tomaram eles, pois, a Jesus; e Ele próprio, carregando a sua cruz, saiu para o lugar chamado Cálvario, Gólgota em hebraico, onde o crucificaram e com ele outros dois, um de cada lado, e Jesus no meio (ALMEIDA, 2000, p.1520).

Além disso, verifica-se que mesmo sendo um instrumento de tortura e execução, formado de dois troncos transversais onde se pregavam as vítimas que eram sentenciadas à morte, a cruz é qualificada no contexto da Paixão e Crucificação de Cristo como fiel, a árvore mais nobre e com frutos vistosos.

Em suma, essa obra é composta por cinquenta e sete compassos na tonalidade Ré Menor, em andamento Andante Sostenuto, ordenados pelo autor com partes concernentes ao discurso e emprego retórico, os quais serão observados nos tópicos seguintes.

\footnotetext{
${ }^{128}$ De acordo com a catalogação de Cleofe Person de Mattos, Crux Fidelis (CPM 205) não possui o ano de sua composição (MATTOS, 1970, p.300).

${ }^{129}$ Tenda de um general em campanha, na antiga Roma, também era o tribunal do pretor, nesse caso de Pôncio Pilatos.
} 


\subsection{Loci observados na Inventio do Crux Fidelis}

Tabela 58-Loci Topici localizados no Crux Fidelis de José Maurício Nunes Garcia.

\begin{tabular}{|c|c|c|c|}
\hline INVENTIO & DESCRIÇÃO & $\begin{array}{c}\text { UTILIZAÇÃO NA } \\
\text { OBRA }\end{array}$ & $\begin{array}{l}\text { COMPASSOI } \\
\text { VOZ }\end{array}$ \\
\hline $\begin{array}{l}\text { Locus } \\
\text { Notationis } \\
\text { (MATTHESON, } \\
\text { 1954, [1739]. } \\
\text { Parte II, Cap.4, } \\
\text { § 23, p.123). }\end{array}$ & $\begin{array}{l}\text { Aspecto externo } \\
\text { e desenho das } \\
\text { notas (Duração } \\
\text { das notas, } \\
\text { alteração, } \\
\text { repetição e } \\
\text { procedimentos } \\
\text { canônicos). }\end{array}$ & $\begin{array}{l}\text { Vários motivos } \\
\text { rítmicos e diferentes } \\
\text { durações de notas } \\
\text { (mínimas, mínimas } \\
\text { pontuadas, } \\
\text { semínimas, colcheias, } \\
\text { repetições, ligaduras, } \\
\text { pausas, apogiatura, } \\
\text { fermata entre outros). }\end{array}$ & $\begin{array}{ll}1-12 & \text { S-A-T-B } \\
13-22 & \text { S-A-T-B } \\
23-34 & \text { S-A-T-B } \\
35-50 & \text { S-A-T-B } \\
51-57 & \text { S-A-T-B }\end{array}$ \\
\hline $\begin{array}{l}\text { Locus } \\
\text { Comparationis } \\
\text { (MATTHESON, } \\
\text { 1954, [1739]. } \\
\text { Parte II, Cap.4 } \\
\S 79, \text { p.131). }\end{array}$ & $\begin{array}{l}\text { Comparações de } \\
\text { coisas } \\
\text { semelhantes ou } \\
\text { não, grandes ou } \\
\text { pequenas. }\end{array}$ & $\begin{array}{l}\text { Comparação de } \\
\text { coisas semelhantes e } \\
\text { não semelhantes: } \\
\text { bosque, ramagens, } \\
\text { flores, frutos. } \\
\text { Comparação de } \\
\text { coisas grandes e } \\
\text { pesquenas: Ó doce } \\
\text { lenho, que os doces } \\
\text { cravos e o doce peso } \\
\text { sustentas. }\end{array}$ & 23-34 S-A-T-B \\
\hline $\begin{array}{l}\text { Locus } \\
\text { Oppositorum } \\
\text { (MATTHESON, } \\
\text { 1954, [1739]. } \\
\text { Parte II, Cap.4, } \\
\S 80, \text { p.131). }\end{array}$ & $\begin{array}{l}\text { Contraste de } \\
\text { compassos, } \\
\text { movimentos } \\
\text { contrários, } \\
\text { agudos e } \\
\text { graves, lento e } \\
\text { rápido, calmo e } \\
\text { agitado. }\end{array}$ & $\begin{array}{l}\text { Movimento contrário } \\
\text { entre soprano e tenor, } \\
\text { tenor e baixo. } \\
\text { Contralto e baixo. } \\
\text { Soprano e tenor. } \\
\text { Soprano e baixo, } \\
\text { contralto e baixo, } \\
\text { tenor e baixo. } \\
\text { Contralto e baixo. } \\
\text { Soprano e baixo, } \\
\text { contralto e baixo, } \\
\text { tenor e baixo. } \\
\text { Soprano e baixo, } \\
\text { contralto e baixo. } \\
\text { Soprano e tenro, } \\
\text { soprano e baixo, } \\
\text { contralto e tenor. } \\
\text { Soprano e baixo, } \\
\text { soprano e tenor, } \\
\text { soprano e contralto. } \\
\text { Soprano e baixo. }\end{array}$ & 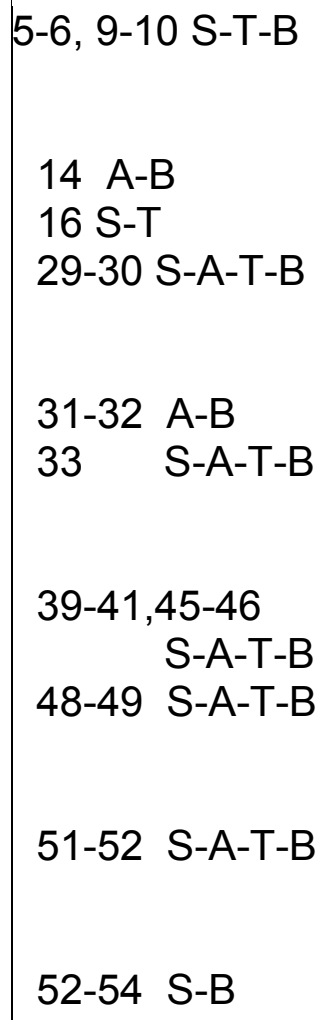 \\
\hline
\end{tabular}




\section{Dispositio}

\subsection{Exordium}

Examina-se no início da peça a aplicação da Epizeuxis onde a expressão Crux fidelis (Ó cruz fiel), é repetida de maneira enfática por três vezes. Do mesmo modo, a frase é interrompida mediante a uma pausa geral, no qual todas as vozes são submetidas a um descanso, caracterizando assim o emprego da Aposiopesis. Outro aspecto relevante, são os efeitos utilizados pelo compositor através dessa figura, valorando tanto as dinâmicas, forte e piano como as funções da Subdominante, Sexta Aumentada Francesa e Dominante com terminação na Semicadência.

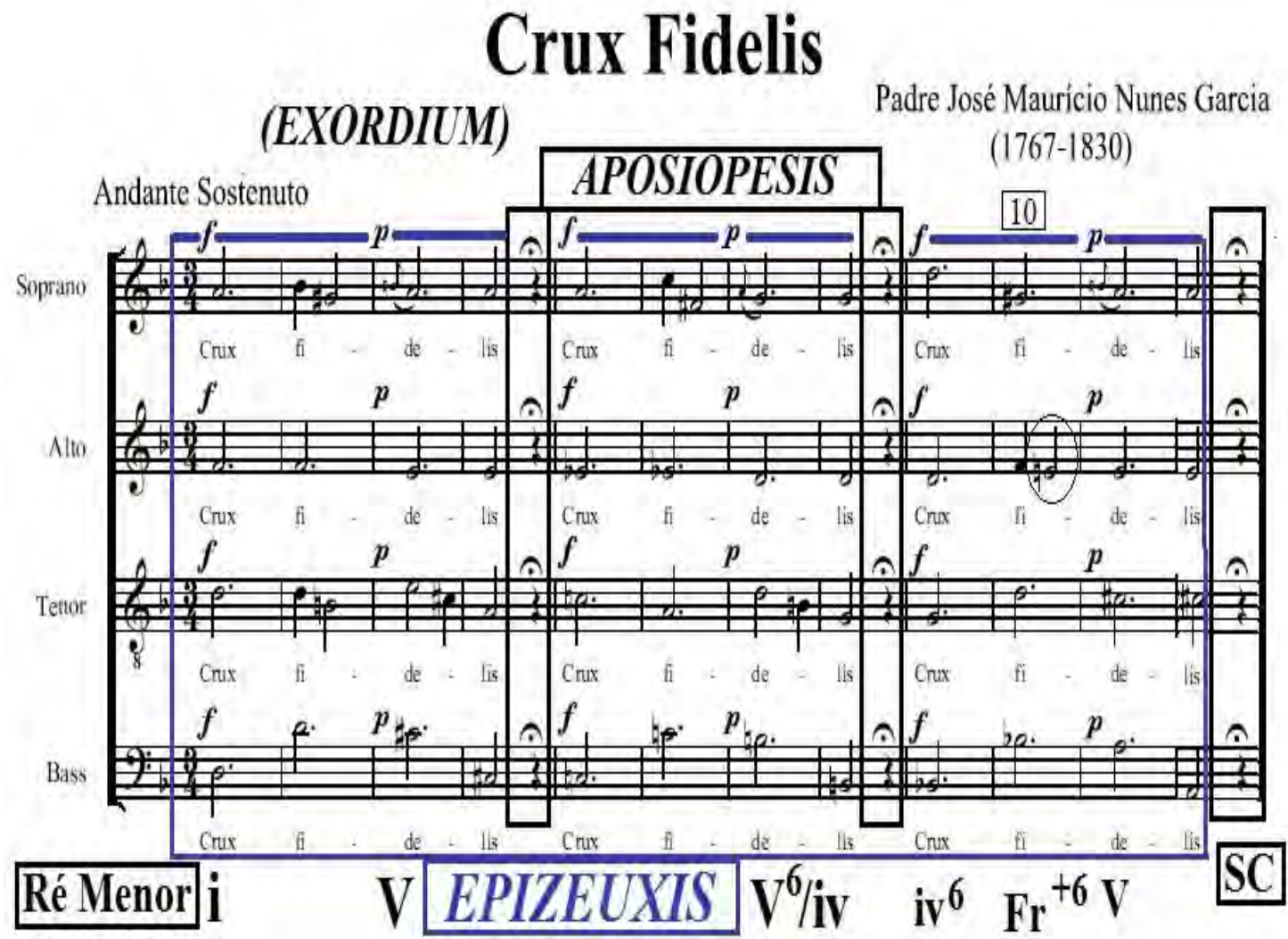

Exemplo 181-Crux Fidelis de José Maurício Nunes Garcia-Edição: Marcus Alessi Bittencourt (GARCIA, 1995, p.1). 


\subsection{Narratio}

Posterior ao fechamento da primeira parte da Dispositio, no compasso 12, é perceptível o uso da Synaeresis, na voz da soprano, a qual entoa as notas Dó sustenido e Mi, a expressão: inter omnes arbor una nobilis (entre todas as árvores), por três vezes, ressaltando dessa maneira a fidelidade e nobreza da cruz descrita no texto. Semelhantemente, observa-se que essa figura de deslocamento é aplicada para valorar tanto as funções harmônicas da Dominante e Subdominante, quanto às dinâmicas piano e pianíssimo, com resolução no compasso 22, numa Semicadência.

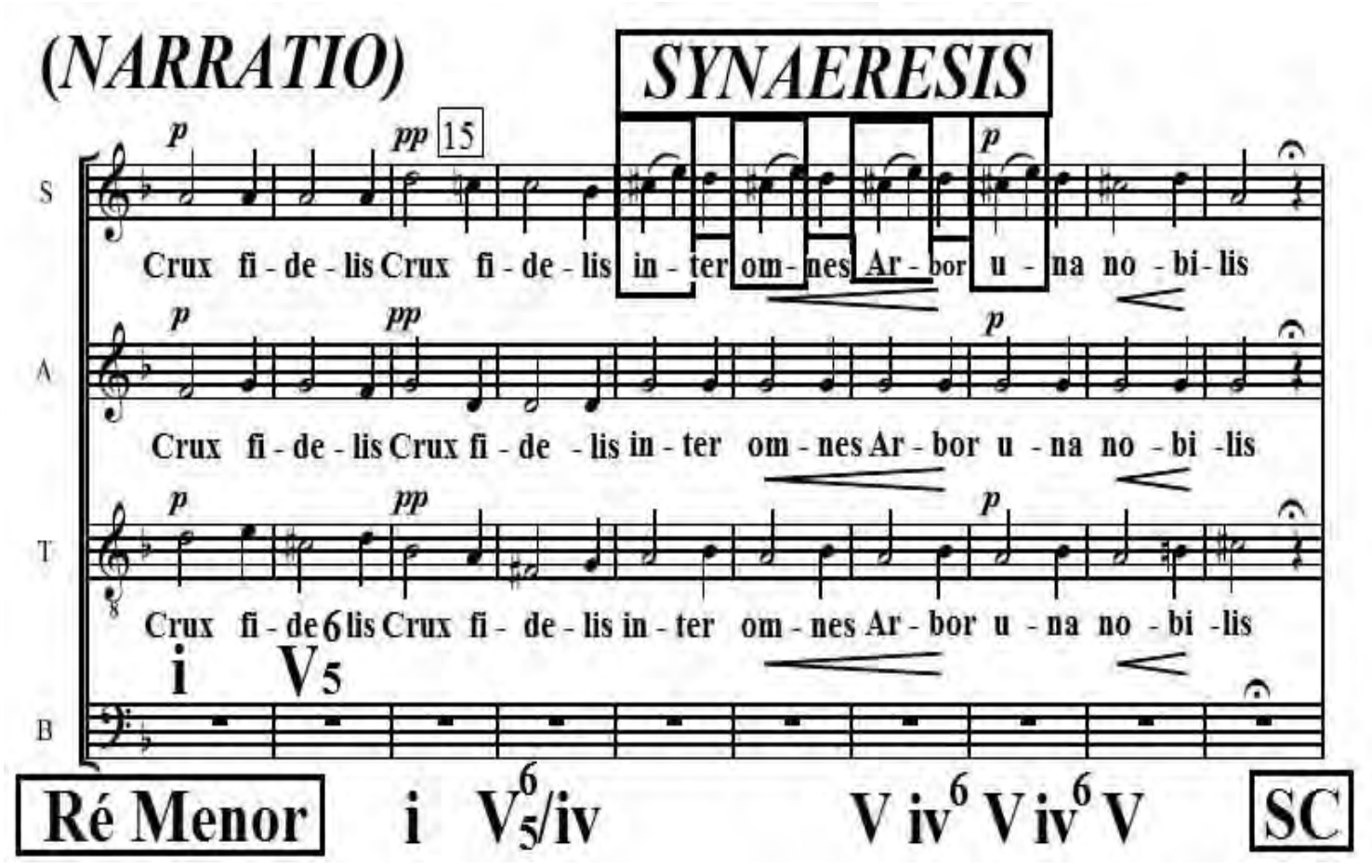

Exemplo 182-Crux Fidelis de José Maurício Nunes Garcia-Edição: Marcus Alessi Bittencourt (GARCIA, 1995, p.1).

\subsection{Propositio}

Averígua-se na Propositio, que o autor continua utilizando a Synaeresis, em todas as vozes para colocar em evidência as palavras: nulla talem silva profert flore, fronde, germine, (Nenhum bosque produz igual, em ramagens, frutos e flores). Da mesma forma, esse recurso retórico ressalta as dinâmicas piano, forte e pianíssimo, além das funções da Tônica, Subdominante e 
Dominante, terminando no compasso 34, com uma Cadência Autêntica Imperfeita.

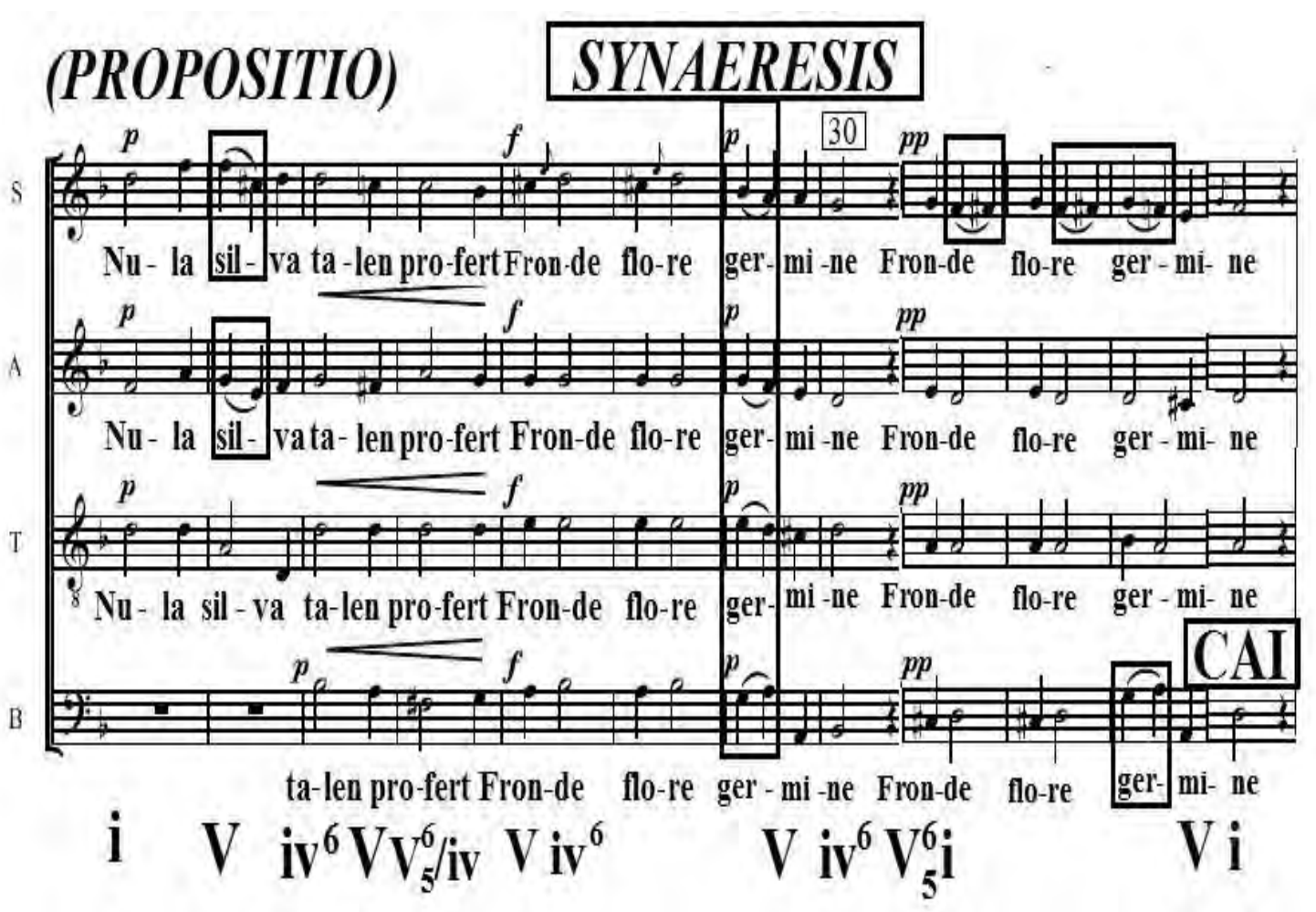

Exemplo 183-Crux Fidelis de José Maurício Nunes Garcia-Edição: Marcus Alessi Bittencourt (GARCIA, 1995, p.2).

\subsection{Confutatio}

Entre os compassos 35 a 50, nota-se a inclusão de um novo elemento retórico relacionado aos argumentos expostos à tese fundamental. Em outras palavras, José Maurício usa o Noema, numa passagem homofônica, para causar um efeito de suavidade, mediante a polifonia vocal e a harmonia vertical, transmitindo assim ao ouvinte uma sensação contrastante da ideia de dor, angústia e sofrimento por quem carrega a cruz, dulce lignum dulce clavo dulce pondus sustinet ( $O$ doce lenho, que os doces cravos e o doce peso sustentas).

De igual natureza, verifica-se que as dinâmicas, piano, pianíssimo, legato e crescendo em todas as vozes, são trabalhadas pelo compositor para reforçar essa impressão de amenidade e calmaria. Finalmente, examinam-se as progressões harmônicas das funções da Tônica, Dominante, Dominante da Subdominante, com terminação inesperada na Subdominante. 


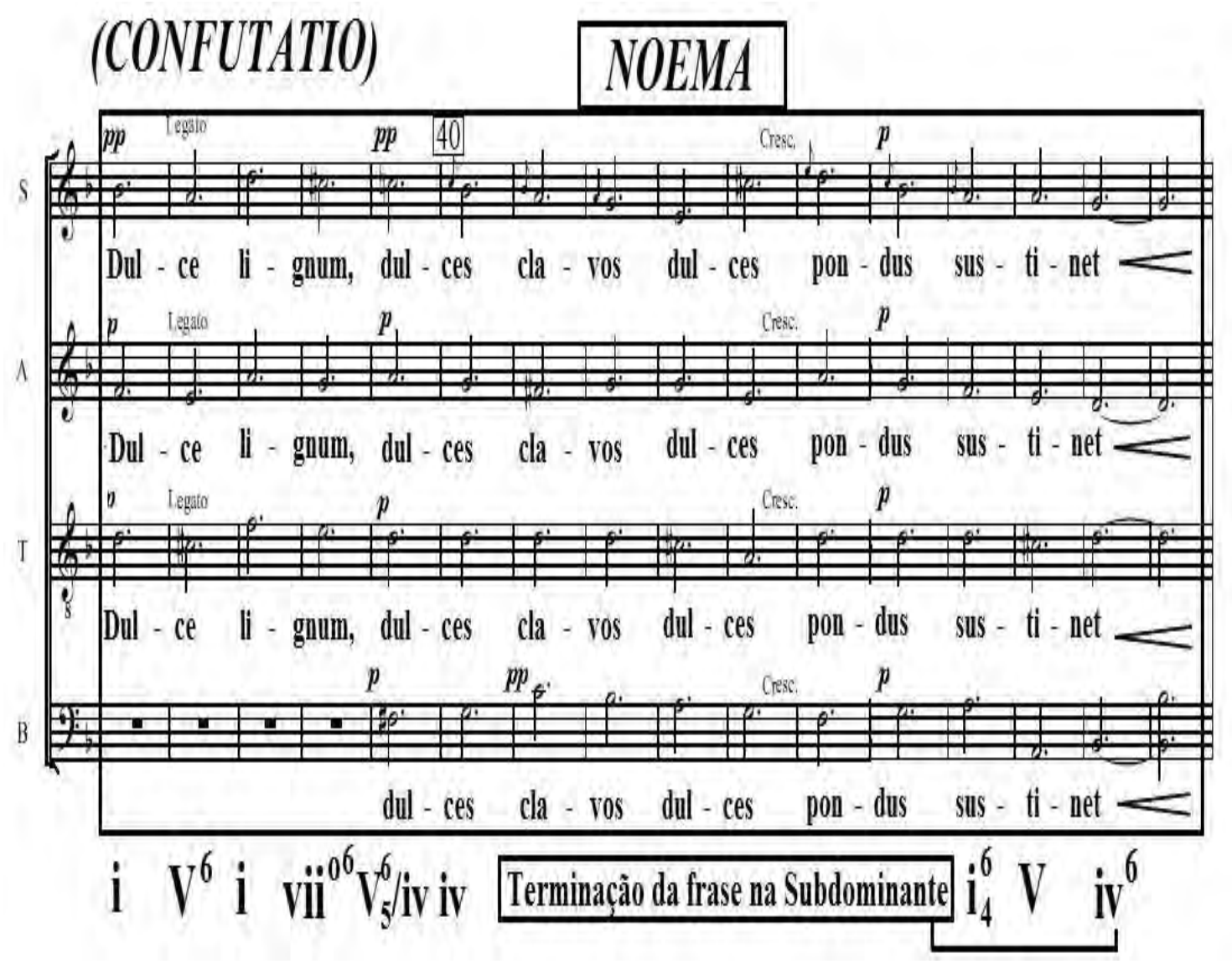

Exemplo 184- Crux Fidelis de José Maurício Nunes Garcia- Edição: Marcus Alessi Bittencourt (GARCIA, 1995, p.2).

\subsection{Peroratio}

No encerramento do discurso, novamente é realçado a expressão: dulce pondus sustinet (doce peso sustentas). Semelhantemente, constata-se que Nunes Garcia continua utilizando a mesma figura retórica de representação e descrição, assim como as dinâmicas e as funções harmônicas para reforçar e confirmar a ideia inicial exposta no texto de fidelidade, nobreza e doçura, cuja representação é à cruz carregada e suportada por Cristo até sua morte, o que para os cristãos simboliza a redenção, para enfatizar o afeto de devoção e mansidão, resolvendo na Cadência Autêntica Imperfeita. 


\section{(CONFIRMATIO dentro da PERORATIO)}

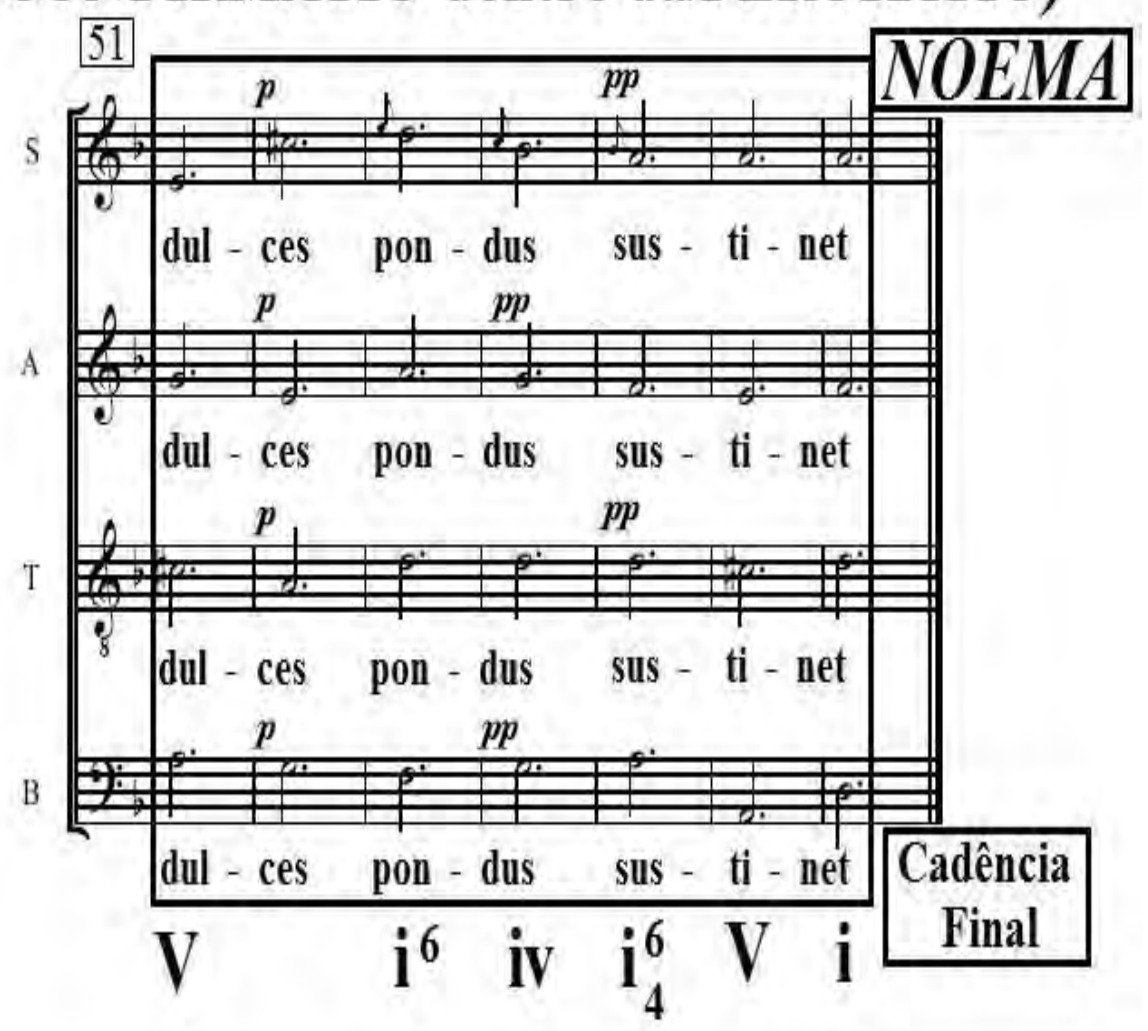

Exemplo 185- Crux Fidelis de José Maurício Nunes Garcia-Edição: Marcus Alessi Bittencourt (GARCIA, 1995, p. 2).

\subsection{Figuras examinadas na obra (Elocutio/Decoratio)}

Tabela 59-Figuras retóricas localizadas no Crux Fidelis de José Maurício Nunes Garcia.

\begin{tabular}{|c|c|c|c|}
\hline $\begin{array}{l}\text { FIGURAS E } \\
\text { CITAÇÕES }\end{array}$ & TIPO & DESCRIÇĀO & TRATADISTA \\
\hline $\begin{array}{l}\text { APOSIOPESIS } \\
\text { (BARTEL, 1997, } \\
\text { pp. 202-206). }\end{array}$ & $\begin{array}{ll}\text { Interrupção } & \text { e } \\
\text { Silêncio } & \end{array}$ & $\begin{array}{l}\text { Descanso em } \\
\text { uma ou todas } \\
\text { as vozes de } \\
\text { uma } \\
\text { composição: } \\
\text { pausa geral. }\end{array}$ & $\begin{array}{l}\text { Johann } \\
\text { Walther: A Apottfried } \\
\text { se refere a uma Pausa } \\
\text { generalis ou um } \\
\text { completo silêncio em } \\
\text { todas as vozes e nas } \\
\text { partes da composição } \\
\text { simultaneamente. }\end{array}$ \\
\hline $\begin{array}{l}\text { EPIZEUXIS } \\
\text { (BARTEL, 1997, } \\
\text { pp. 263-265). }\end{array}$ & $\begin{array}{l}\text { Repetição } \\
\text { Melódica }\end{array}$ & $\begin{array}{l}\text { Uma repetição } \\
\text { imediata e } \\
\text { enfática de uma } \\
\text { palavra, nota, } \\
\text { motivo ou frase. }\end{array}$ & $\begin{array}{l}\text { Johann } \\
\text { Wottfried } \\
\text { Walther: A Epizeuxis é } \\
\text { uma figura de retórica } \\
\text { pela qual uma ou mais } \\
\text { palavras } \\
\text { imediatamente são } \\
\text { enfaticamente repetidas. }\end{array}$ \\
\hline
\end{tabular}




\begin{tabular}{|c|c|c|c|}
\hline $\begin{array}{l}\text { NOEMA } \\
\text { (BARTEL, 1997, } \\
\text { pp. 339-342). }\end{array}$ & $\begin{array}{l}\text { Representação } \\
\text { e Descrição }\end{array}$ & $\begin{array}{l} \\
\text { Seção } \\
\text { homofônica, } \\
\text { dentro } \\
\text { polifonia } \\
\text { utilizada para } \\
\text { enfatizar } \\
\text { texto. }\end{array}$ & $\begin{array}{l}\text { Joachim Burmeister: } 0 \\
\text { Noema representa o } \\
\text { afeto harmônico, onde as } \\
\text { vozes combinadas têm } \\
\text { valores e números de } \\
\text { notas semelhantes. [...] } \\
\text { Quando introduzida } \\
\text { adequadamente, isto é, } \\
\text { no momento certo, ela } \\
\text { afeta docemente os } \\
\text { ouvidos do ouvinte, } \\
\text { produzindo uma } \\
\text { sensação de calma e } \\
\text { serenidade. }\end{array}$ \\
\hline $\begin{array}{l}\text { SYNAERESIS } \\
\text { (BARTEL, 1997, } \\
\text { pp. 394-396). }\end{array}$ & $\begin{array}{l}\text { Dissonância e } \\
\text { Deslocamento }\end{array}$ & $\begin{array}{lr}\text { (1) Uma } & \text { Um } \\
\text { suspensão ou } \\
\text { síncope, (2) a } \\
\text { colocação de } \\
\text { duas sílabas por } \\
\text { nota ou duas } \\
\text { notas } \\
\text { sílaba. }\end{array}$ & $\begin{array}{l}\text { Mauritius Johann Vogt: } \\
\text { A Synaeresis ocorre } \\
\text { quando duas notas são } \\
\text { colocadas em uma sílaba } \\
\text { ou duas sílabas são } \\
\text { colocadas em uma nota. }\end{array}$ \\
\hline
\end{tabular}

\section{Análise Harmônica}

\subsection{Curva Tonal}

Tonalidade: Ré Menor

Andamento: Andante Sostenuto 3/4

Tabela 60-Esquema das Progressões Harmônicas- Curva Tonal do Crux Fidelis.

\begin{tabular}{|l|c|l|}
\hline \multicolumn{1}{|c|}{ Compassos } & \multicolumn{1}{|c|}{ Função } & \multicolumn{1}{|c|}{ Tonalidade } \\
\hline $1-6$ & i & Ré Menor \\
\hline $7-9$ & iv & Sol Menor \\
\hline $10-12$ & V & Lá Maior \\
\hline $13-15$ & i & Ré Menor \\
\hline 16 & iv & Sol Menor \\
\hline $17-22$ & V & Lá Maior \\
\hline $23-24$ & i & Ré Menor \\
\hline $25-30$ & iv & Sol Menor \\
\hline $31-37$ & i & Ré Menor \\
\hline
\end{tabular}




\begin{tabular}{|l|c|l|}
\hline $38-42$ & iv & Sol Menor \\
\hline $43-48$ & i & Ré Menor \\
\hline $49-50$ & iv & Sol Menor \\
\hline $51-57$ & i & Ré Menor \\
\hline
\end{tabular}

4.2 Estrutura Analítica da obra: Retórica e Harmônica

Tabela 61-Estrutura analítica da obra.

\begin{tabular}{|c|c|c|c|c|}
\hline $\begin{array}{l}\text { RETÓRICA } \\
\text { DISPOSITIO }\end{array}$ & $\begin{array}{c}\text { FIGURA } \\
\text { ELOCUTIO }\end{array}$ & COMP. & TONALIDADE & FUNÇÃO \\
\hline EXORDIUM & $\begin{array}{l}\text { Aposiopesis } \\
\text { Epizeuxis }\end{array}$ & $\begin{array}{l}4,8,12 \\
1-12\end{array}$ & $\begin{array}{l}\text { Ré Menor } \\
\text { Ré Menor }\end{array}$ & $\begin{array}{l}\mathrm{i} \\
\mathrm{i}\end{array}$ \\
\hline NARRATIO & Synaeresis & $17-20$ & Ré Menor & $\mathrm{i}$ \\
\hline PROPOSITIO & Synaeresis & $\begin{array}{l}24,29 \\
31-32\end{array}$ & $\begin{array}{l}\text { Ré Menor } \\
\text { Ré Menor }\end{array}$ & $\mathrm{i}$ \\
\hline CONFUTATIO & Noema & $35-50$ & Ré Menor & $\mathrm{i}$ \\
\hline PERORATIO & Noema & $51-57$ & Ré Menor & $\mathrm{i}$ \\
\hline
\end{tabular}




\title{
6.4.3. Análise Retórico-Musical do $1^{\circ}$ Responsório das Matinas e Encomendação de Defuntos
}

\section{Inventio}

O $1^{\circ}$ Responsório das Matinas e Encomendação de Defuntos (1799) (CPM 183), de José Maurício, tem seu texto fundamentado em Jó 19:25, onde o personagem bíblico Jó demonstra sua crença, obediência, confiança e esperança em Deus, como atributos para obter a vida eterna (SOARES, 2014, p.9).

\author{
Credo quod Redemptor meus vivit, \\ et in novissimo die de terra surrecturus sum: \\ Et in carne mea videbo Deum Salvatorem meum. \\ Quem visurus sum: ego ipse, et non alius, \\ et oculi mei conspecturi sunt. \\ Creio que o meu Redentor está vivo \\ e que no último dia eu hei de ressuscitar da terra \\ E em minha carne verei a Deus, meu Salvador \\ Eu mesmo e não outro $O$ hei de ver \\ e meus olhos $O$ hão de contemplar.
}

Já a liturgia dos defuntos, nos séculos XVIII e XIX, sobretudo no Rito Romano, era composta por oito cerimônias distintas, sendo que cada uma delas possui estruturas e textos peculiares, conforme descreve Paulo Castagna:

A Liturgia dos Defuntos, que integra a Liturgia Laudativa, no Rito Romano, possui oito cerimônias distintas, nas quais era executada música polifônica nos séculos XVIII e XIX, cada uma delas com estrutura e textos específicos. Inicialmente, as Exéquias (também denominadas Funeral ou Ofício de Sepultura), seguidas pelo Officium Deffunctorum (constituído de Matinas, Laudes e Vésperas - ou seja, três cerimônias de estruturas litúrgicas distintas, de acordo com a hora em que o Ofício fosse realizado - hora canônica). Há também a Missa (que pode ser dos Funerais, de Aniversário, Quotidiana ou pela Comemoração dos Fiéis Defuntos), a Absolvição e Inumação após a Missa (ou Encomendação Litúrgica de Adultos), as Cinco Absolvições (destinadas às exéquias solenes) e o Ofício de Sepultura de Crianças (ou Encomendação Litúrgica de Anjinhos). No universo lusobrasileiro, entretanto, foram comuns três outras cerimônias fúnebres, não prescritas no Rito Romano: a Encomendação Paralitúrgica de Adultos (ou Memento), a Encomendação Paralitúrgica de Crianças e as Estações na Comemoração dos Fiéis Defuntos (CASTAGNA, 2003, p. XIII) ${ }^{130}$.

\footnotetext{
${ }^{130}$ Essa citação igualmente é localizada em (AFFONSO, 2005, p.25).
} 
No que tange à estrutura da peça, ela é constituída de trinta e um compassos, na tonalidade Sol Menor, repetindo a parte final os compassos de 14 a 21, com andamentos Moderato, Allegro Moderato e Allegro, dispostos pelo compositor com as partes relacionadas ao discurso e aplicação dos elementos retóricos, segundo a circunstância e necessidade do enunciado musical.

\subsection{Loci observados na Inventio do $1^{\circ}$ Responsório}

Tabela 62-Loci Topici localizados no $1^{\circ}$ Responsório de José Maurício Nunes Garcia.

\begin{tabular}{|c|c|c|c|}
\hline INVENTIO & DESCRIÇÃO & $\begin{array}{c}\text { UTILIZAÇÃO NA } \\
\text { OBRA }\end{array}$ & $\begin{array}{l}\text { COMPASSOI } \\
\text { VOZ }\end{array}$ \\
\hline $\begin{array}{l}\text { Locus } \\
\text { Notationis } \\
\text { (MATTHESON, } \\
\text { 1954, [1739]. } \\
\text { Parte II, Cap.4, } \\
\S 23, \text { p.123). }\end{array}$ & $\begin{array}{l}\text { Aspecto externo } \\
\text { e desenho das } \\
\text { notas (Duração } \\
\text { das notas, } \\
\text { alteração, } \\
\text { repetição e } \\
\text { procedimentos } \\
\text { canônicos). }\end{array}$ & $\begin{array}{l}\text { Vários motivos } \\
\text { rítmicos e diferentes } \\
\text { durações de notas } \\
\text { (semibreves, } \\
\text { mínimas, mínimas } \\
\text { pontuadas, } \\
\text { semínimas, } \\
\text { semínimas } \\
\text { pontuadas, colcheias, } \\
\text { repetições, ligaduras, } \\
\text { pausas, fermata entre } \\
\text { outros). }\end{array}$ & $\begin{array}{l}1-6 \text { S-A-T-B } \\
6-13 \text { S-A-T-B } \\
14-21 \text { S-A-T-B } \\
22-31 \text { S-A-T-B } \\
\text { Conclusão da } \\
\text { peça } \\
\text { (repetição dos } \\
\text { compassos 14- } \\
21 \text { ). }\end{array}$ \\
\hline $\begin{array}{l}\text { Locus } \\
\text { Descriptionis } \\
\text { (MATTHESON, } \\
\text { 1954, [1739]. } \\
\text { Parte II, Cap.4, } \\
\S 43, \text { p.127). }\end{array}$ & $\begin{array}{l}\text { Disposições da } \\
\text { alma }\end{array}$ & $\begin{array}{l}\text { Confiança (Creio que o } \\
\text { meu Redentor está vivo } \\
\text { e que no último dia eu } \\
\text { hei de ressuscitar da } \\
\text { terra). } \\
\text { Desejo, avidez, querer } \\
\text { (E em minha carne } \\
\text { verei a Deus, meu } \\
\text { Salvador. Eu mesmo e } \\
\text { não outro, o hei de ver } \\
\text { e meus olhos, o hão de } \\
\text { contemplar). }\end{array}$ & 1-13 S-A-T-B \\
\hline $\begin{array}{l}\text { Locus } \\
\text { Oppositorum } \\
\text { (MATTHESON, } \\
\text { 1954, [1739]. } \\
\text { Parte II, Cap.4, } \\
\S 80, \text { p.131). }\end{array}$ & $\begin{array}{l}\text { Contraste de } \\
\text { compassos, } \\
\text { movimentos } \\
\text { contrários, } \\
\text { agudos e } \\
\text { graves, lento e } \\
\text { rápido, calmo e }\end{array}$ & $\begin{array}{l}\text { Movimento contrário } \\
\text { entre soprano e tenor, } \\
\text { soprano e baixo, } \\
\text { contralto e tenor, } \\
\text { contralto e baixo. } \\
\text { Soprano e baixo, } \\
\text { contralto e baixo. }\end{array}$ & $10 \quad$ S-A-B \\
\hline
\end{tabular}




\begin{tabular}{|l|l|l|l|}
\hline agitado. & $\begin{array}{l}\text { Soprano e contralto, } \\
\text { contralto e baixo. } \\
\text { Soprano e baixo, } \\
\text { contralto e baixo, } \\
\text { tenor e baixo. } \\
\text { Soprano e tenor, } \\
\text { soprano e baixo, } \\
\text { contralto e tenor, } \\
\text { contralto e baixo. } \\
\text { Soprano e contralto, } \\
\text { contralto e baixo, } \\
\text { tenor e baixo. } \\
\text { Soprano e contralto, } \\
\text { soprano e baixo, } \\
\text { contralto e baixo. } \\
\text { Soprano e tenor, } \\
\text { contralto e tenor. } \\
\text { Contralto e baixo, } \\
\text { tenor e baixo. }\end{array}$ & 18 S-A-T-B-B \\
\hline
\end{tabular}

\section{Dispositio}

\subsection{Exordium}

Nesse trecho, nota-se que acontece a separação da frase Credo quod Redemptor meus vivit (creio que o meu Redentor vive), através da Pausa. Observa-se, também, que essa figura de interrupção e silêncio é utilizada não só para estabelecer um momento de descanso para todas as vozes, mas igualmente valorar as funções harmônicas da Tônica, Dominante, Subdominante Paralela (Relativa) e Subdominante, gerando, dessa forma, maior expectativa ao ouvinte, após a expressão quod, com finalização na Cadência Autêntica Imperfeita ${ }^{131}$.

\footnotetext{
${ }^{131}$ Conforme Rodrigo Cardoso Affonso, em quatro obras dos Ofícios Fúnebres de Nunes Garcia (Matinas e Encomendação de Defuntos (1799), Ofício dos Defuntos a 8 Vozes, 1809-10, Ofício 1816 e Responsórios Fúnebres), a aplicabilidade da Pausa teve como propósito separar a frase Credo quod Redemptor meus vivit, contudo, só nas duas primeiras músicas é que o autor introduz esse recurso retórico, proporcionando assim, para quem ouve, maior expectativa, mediante a valoração do silêncio e da amplificação do comportamento harmônico (AFFONSO, 2005, p. 96).
} 


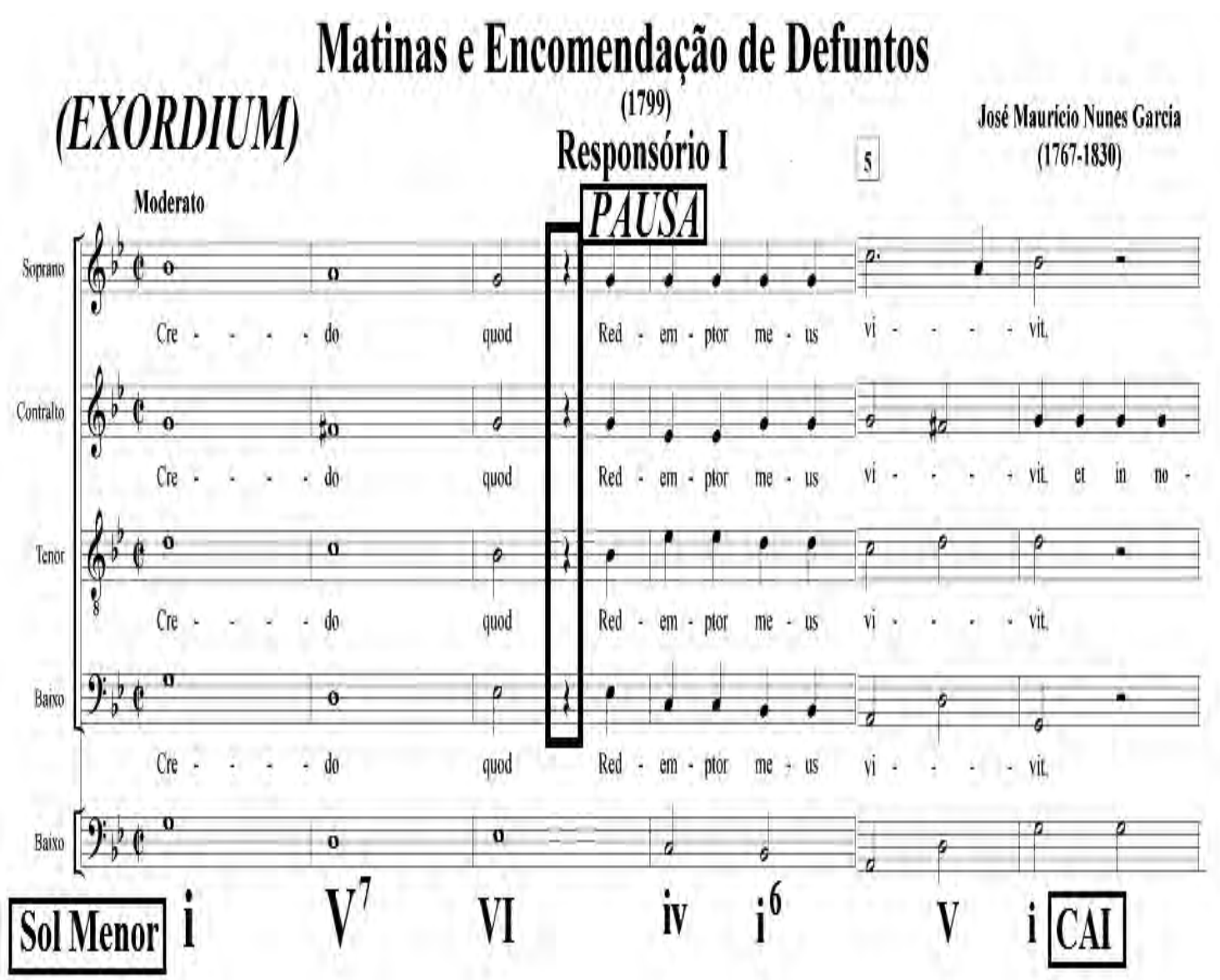

Exemplo $186-1^{\circ}$ Responsório das Matinas e Encomendação de Defuntos de José Maurício Nunes Garcia- Edição de Carlos Alberto Figueiredo-Organização de Paulo Augusto Castagna (CASTAGNA, 2003, p.1).

\subsection{Narratio}

Posterior ao encerramento do Exordium, no compasso 6, a narrativa e descrição dos fatos inicias é estabelecida através do diálogo das vozes do contralto, soprano e tenor, repetindo a expressão et novissimo (e no último), em alturas diferentes, evidenciando, desse modo, um Polyptoton. Da mesma forma, nota-se que essa figura de repetição melódica é empregada para colocar em realce as funções harmônicas da Tônica, Dominante, Dominante da Subdominante e Subdominante, resolvendo numa Semicadência. 


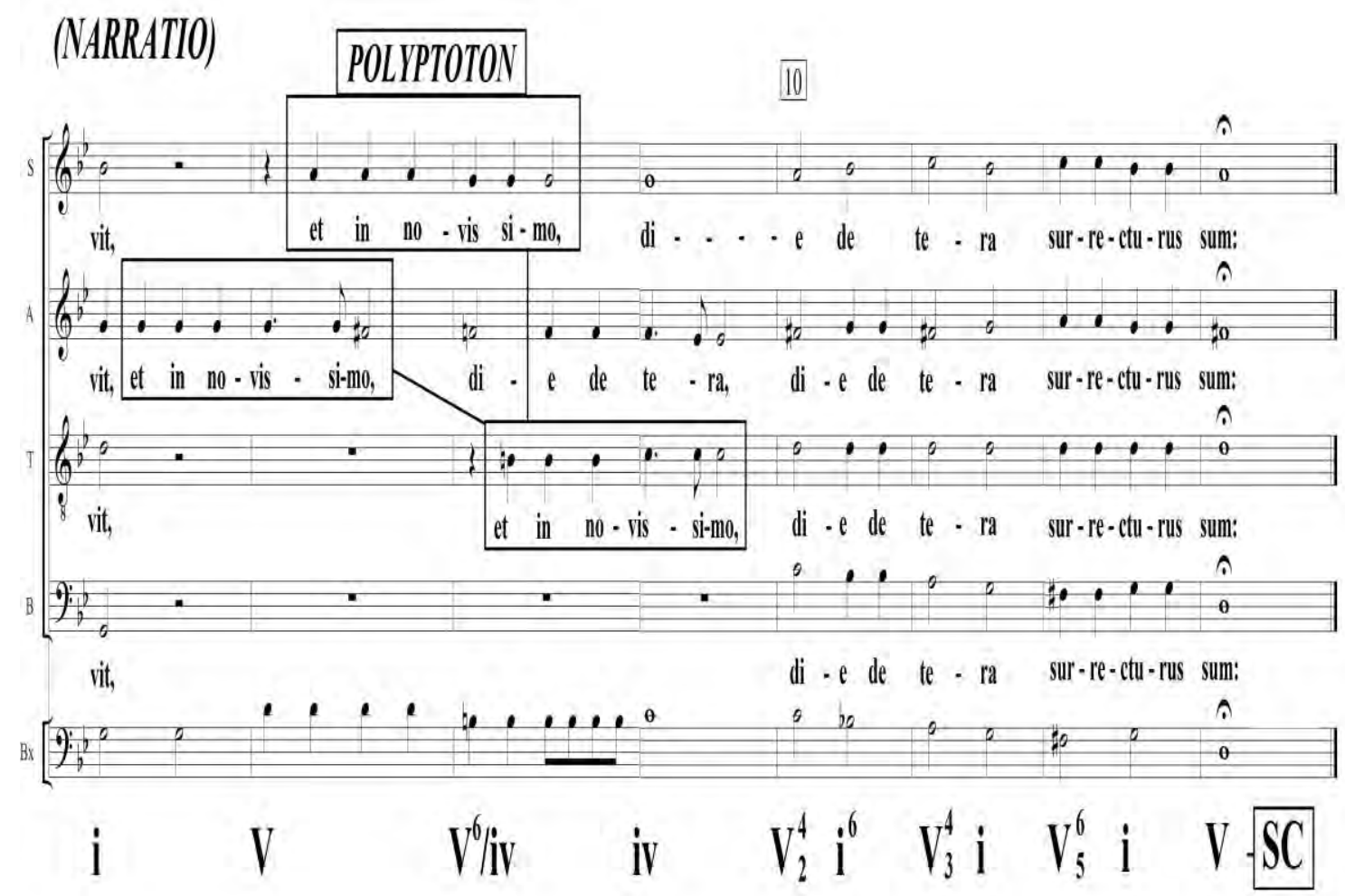

Exemplo $187-1^{\circ}$ Responsório das Matinas e Encomendação de Defuntos de José Maurício Nunes Garcia - Edição de Carlos Alberto Figueiredo- Organização de Paulo Augusto Castagna (CASTAGNA, 2003, p.1).

\subsection{Propositio}

Verifica-se, na Propositio, o uso da Synaeresis nas vozes da soprano e baixo, onde a frase Et in carne mea videbo Deum Salvatorem meum (E em minha carne verei a Deus, meu Salvador) é destacada mediante a entoação da sílaba me, por duas semínimas. De igual forma, essa figura retórica em consonância com as funções harmônicas da Tônica, Dominante e Subdominante com término no compasso 21, na Cadência Autêntica Imperfeita, enfatiza a ideia central do texto da ressurreição e vida eterna, além do afeto de esperança. 


\section{(PROPOSITIO)}
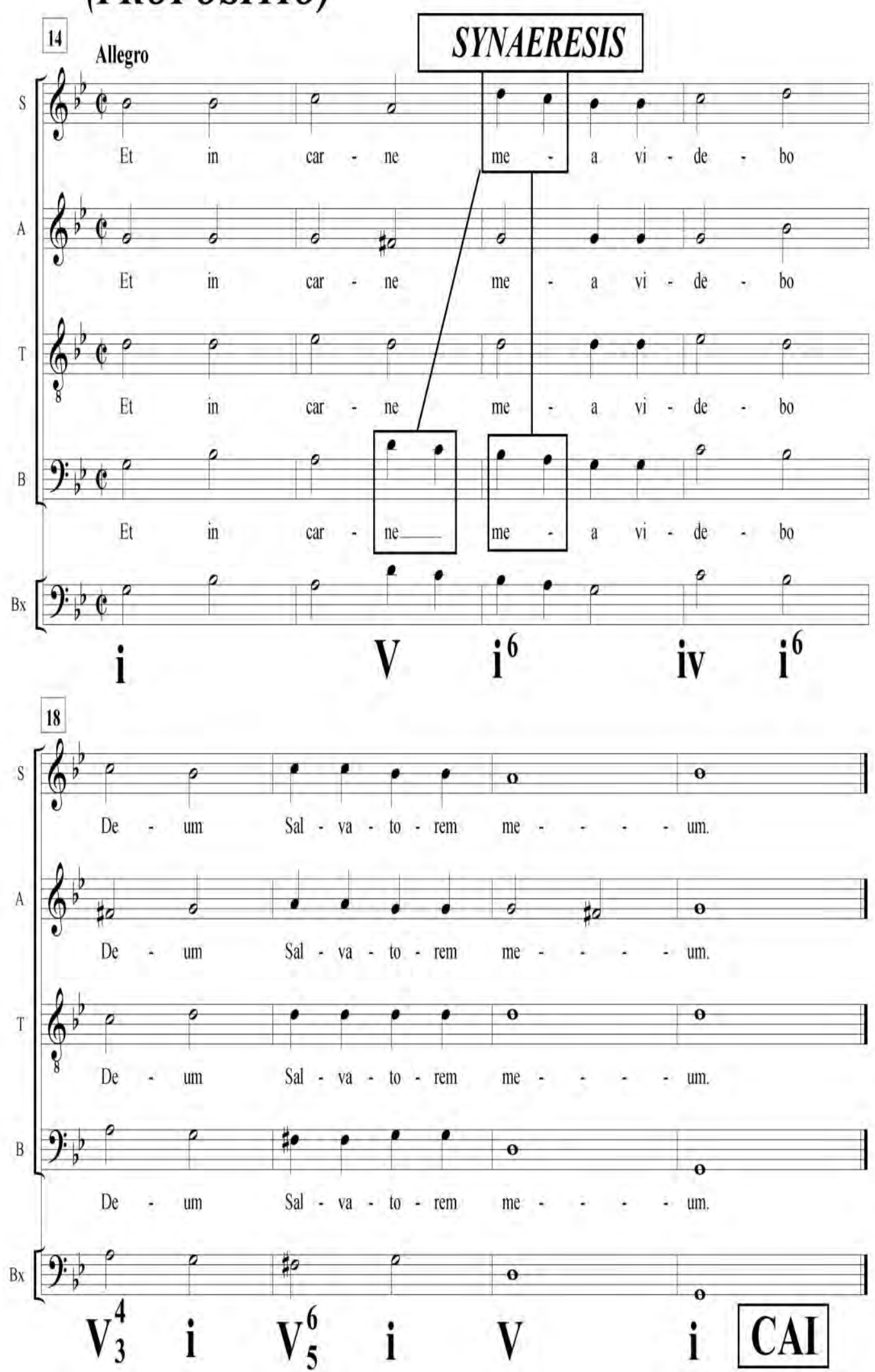

Exemplo $188-1^{\circ}$ Responsório das Matinas e Encomendação de Defuntos de José Maurício Nunes Garcia - Edição de Carlos Alberto Figueiredo- Organização de Paulo Augusto Castagna (CASTAGNA, 2003, p.2). 


\subsection{Confutatio}

Entre os compassos 22 e 31, examina-se que José Maurício continua a empregar a figura da Pausa, a qual estabelece um período de descanso às vozes, mediante a expressão Quem visurus sum: ego ipse, (Eu mesmo e não outro). Semelhantemente, utiliza a Synaeresis para ressaltar tanto a sílaba $i$ da palavra ipse, nas vozes da soprano, contralto e tenor, além da sílaba me, entoada pela voz do contralto e a Exclamatio, que também destaca a sílaba me, através de um salto inesperado de $6^{a}$ maior (Fá para Ré), além da expressão anterior: alius num intervalo de $6^{\mathrm{a}}$ menor (Sol para Mi bemol), numa passagem ascendente representando em forma de exclamação, o afeto de satisfação e confiança, expressos nas frases Quem visurus sum: ego ipse, et non alius, et oculi mei conspecturi sunt (Eu mesmo e não outro $\mathrm{O}$ hei de ver e meus olhos $\mathrm{O}$ hão de contemplar).

De igual natureza, observa-se que todos esses recursos retóricos são trabalhados pelo autor para dar impressão ao ouvinte de serenidade, tranquilidade e calma. Por fim, verificam-se as funções harmônicas da Dominante da Dominante, Dominante, Dominante da Subdominante, Subdominante, Dominante Menor e Tônica, resolvendo numa Semicadência. 


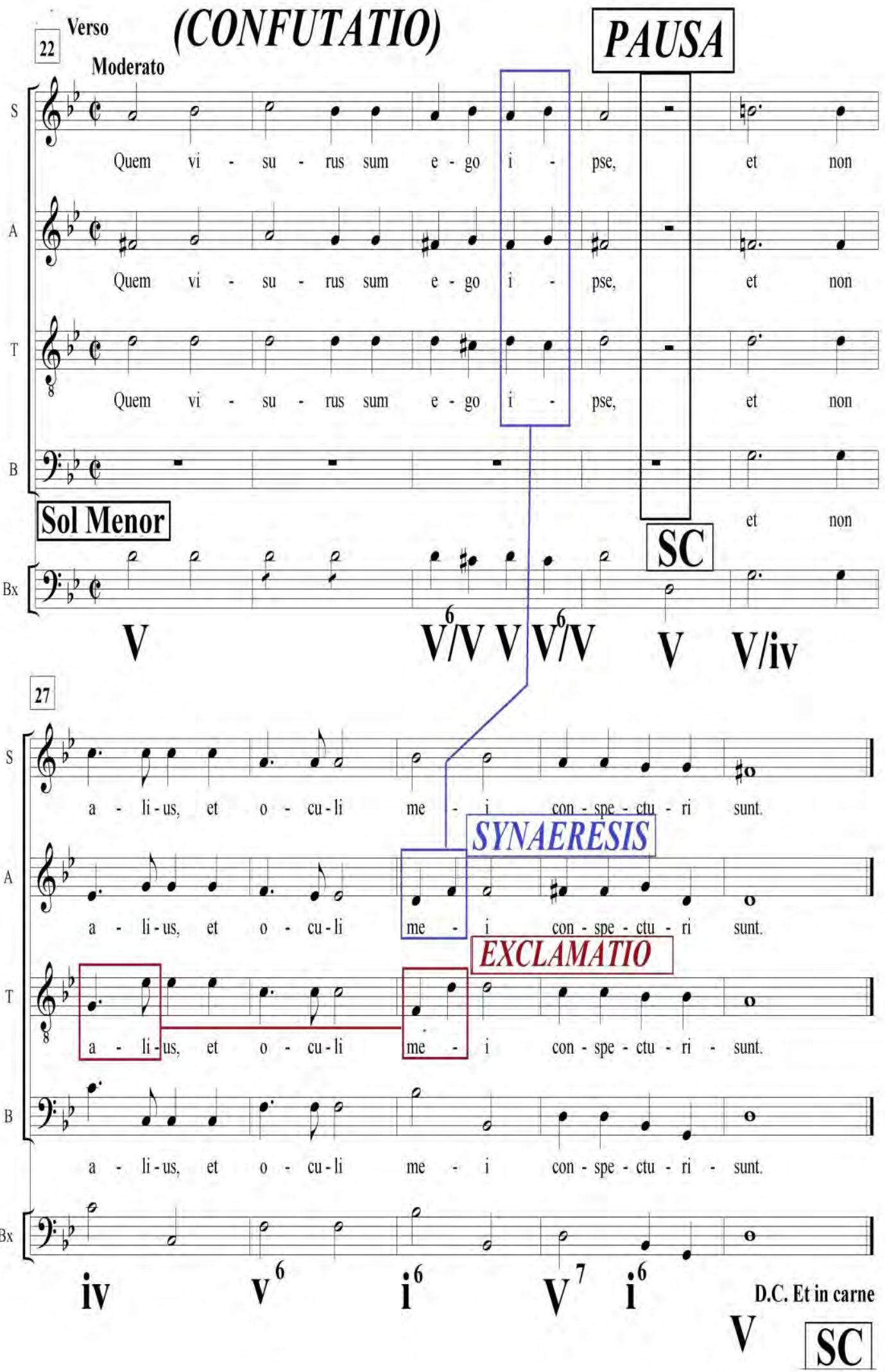

Exemplo $189-1^{\circ}$ Responsório das Matinas e Encomendação de Defuntos de José Maurício Nunes Garcia - Edição de Carlos Alberto Figueiredo- Organização de Paulo Augusto Castagna (CASTAGNA, 2003, pp.2-3). 


\subsection{Peroratio}

Na parte final da obra, é enfatizada mais uma vez a expressão Et in carne mea videbo Deum Salvatorem meum (E em minha carne verei a Deus, meu Salvador). Constata-se, do mesmo modo, novamente o uso da Synaeresis, assim como ocorrido na Propositio, caracterizando, dessa maneira, a confirmação e conclusão do discurso.

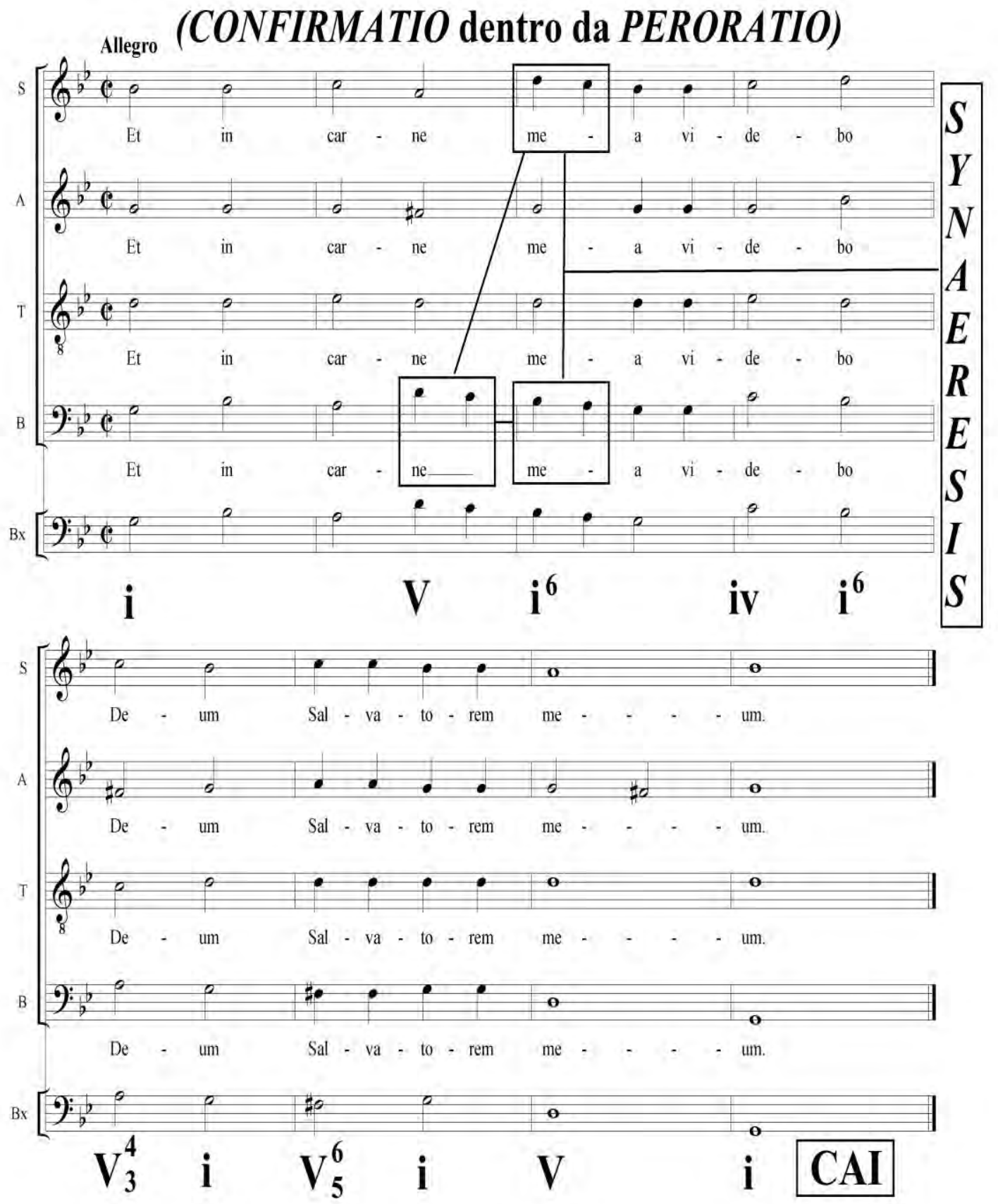

Exemplo $190-1^{\circ}$ Responsório das Matinas e Encomendação de Defuntos de José Maurício Nunes Garcia - Edição de Carlos Alberto Figueiredo- Organização de Paulo Augusto Castagna (CASTAGNA, 2003, p.2). 
3. Figuras examinadas na obra (Elocutio/Decoratio)

Tabela 63-Figuras retóricas localizadas no $1^{\circ}$ Responsório de José Maurício Nunes Garcia.

\begin{tabular}{|c|c|c|c|}
\hline $\begin{array}{l}\text { FIGURAS E } \\
\text { CITAÇÕES }\end{array}$ & TIPO & DESCRIÇĀO & TRATADISTA \\
\hline $\begin{array}{l}\text { EXCLAMATIO } \\
\text { (BARTEL, 1997, } \\
\text { pp.265-269) }\end{array}$ & $\begin{array}{l}\text { Representação } \\
\text { e Descrição }\end{array}$ & $\begin{array}{l}\text { Exclamação } \\
\text { musical } \\
\text { frequentemente } \\
\text { associada com } \\
\text { uma } \\
\text { exclamação no } \\
\text { texto. }\end{array}$ & 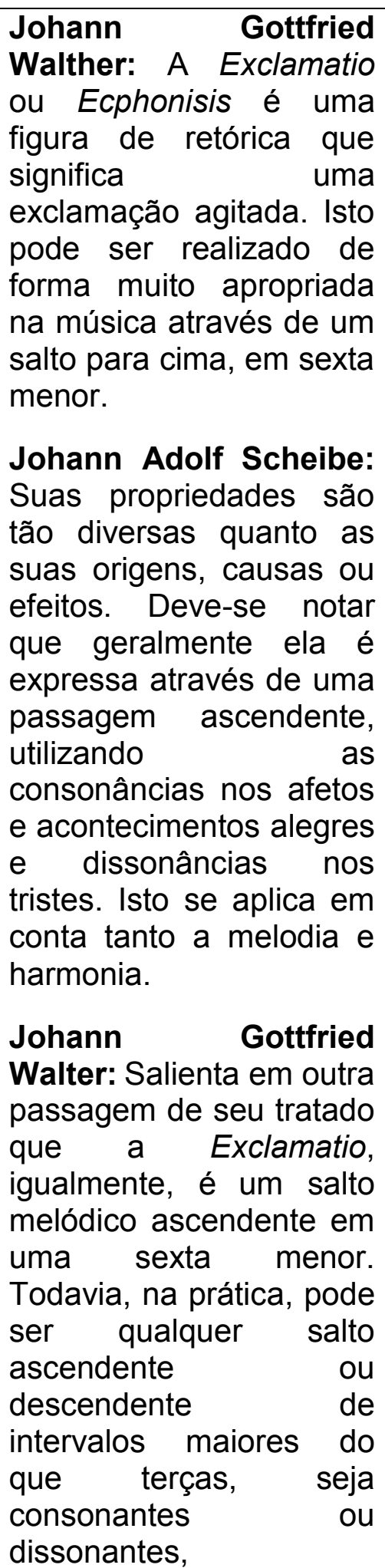 \\
\hline
\end{tabular}




\begin{tabular}{|c|c|c|c|}
\hline & & & $\begin{array}{l}\text { dependendo do caráter } \\
\text { da exclamação. }\end{array}$ \\
\hline $\begin{array}{l}\text { PAUSA } \\
\text { (BARTEL, 1997, } \\
\text { p. 362-365). }\end{array}$ & $\begin{array}{l}\text { Interrupção e } \\
\text { Silêncio }\end{array}$ & $\begin{array}{ll}\text { Uma pausa } & \text { ou } \\
\text { descanso } & \text { na } \\
\text { composição } & \\
\text { musical. } & \end{array}$ & $\begin{array}{l}\text { Johann Gottfried } \\
\text { Walther: Uma figura ou } \\
\text { figuras de silêncio. Estas } \\
\text { se referem à Pausa. } \\
\text { Pausa refere-se a um } \\
\text { período de repouso ou o } \\
\text { silêncio na música, que é } \\
\text { indicado por um } \\
\text { determinado sinal. }\end{array}$ \\
\hline $\begin{array}{l}\text { POLYPTOTON } \\
\text { (BARTEL, 1997, } \\
\text { p. 367-369). } \\
\text { (BUELOW, } \\
2001, \text { p.264). }\end{array}$ & $\begin{array}{l}\text { Repetição } \\
\text { Melódica }\end{array}$ & $\begin{array}{l}\text { A repetição de } \\
\text { uma passagem } \\
\text { melódica em } \\
\text { diferentes } \\
\text { alturas. }\end{array}$ & $\begin{array}{l}\text { Mauritius Johann Vogt: } \\
\text { Polyptoton é quando uma } \\
\text { passagem é repetida em } \\
\text { várias alturas. }\end{array}$ \\
\hline $\begin{array}{l}\text { SYNAERESIS } \\
\text { (BARTEL, 1997, } \\
\text { pp. 394-396). }\end{array}$ & $\begin{array}{l}\text { Dissonância e } \\
\text { Deslocamento }\end{array}$ & $\begin{array}{lr}(1) & \text { Uma } \\
\text { suspensão ou } \\
\text { síncope, (2) a } \\
\text { colocação de } \\
\text { duas sílabas por } \\
\text { nota ou duas } \\
\text { notas rilaba. } \\
\text { sílar } \\
\end{array}$ & $\begin{array}{l}\text { Mauritius Johann Vogt: } \\
\text { A Synaeresis ocorre } \\
\text { quando duas notas são } \\
\text { colocadas em uma sílaba } \\
\text { ou duas sílabas são } \\
\text { colocadas em uma nota. }\end{array}$ \\
\hline
\end{tabular}

\section{Análise Harmônica}

\subsection{Curva Tonal}

Tonalidade: Sol Menor

Andamento: Moderato, Allegro, Moderato 2/2

Tabela 64-Esquema das Progressões Harmônicas- Curva Tonal do $1^{\circ}$ Responsório.

\begin{tabular}{|l|c|l|}
\hline \multicolumn{1}{|c|}{ Compassos } & Função & \multicolumn{1}{|c|}{ Tonalidade } \\
\hline $1-8$ & i & Sol Menor \\
\hline 9 & iv & Dó Menor \\
\hline $10-13$ & V & Ré Maior \\
\hline $14-21$ & i & Sol Menor \\
\hline $22-25$ & V & Ré Maior \\
\hline 26 & V/iv & Sol Maior \\
\hline $27-29$ & i & Sol Menor \\
\hline
\end{tabular}




\begin{tabular}{|l|l|l|}
\hline $30-31$ & V & Ré Maior \\
\hline $\begin{array}{l}\text { Conclusão volta para } \\
\text { os compassos 14 a 21 }\end{array}$ & i & Sol Menor \\
\hline
\end{tabular}

\subsection{Estrutura Analítica da obra: Retórica e Harmônica}

Tabela 65-Estrutura analítica da obra.

\begin{tabular}{|l|l|l|l|c|}
\hline $\begin{array}{c}\text { RETÓRICA } \\
\text { DISPOSITIO }\end{array}$ & $\begin{array}{c}\text { FIGURA } \\
\text { ELOCUTIO }\end{array}$ & \multicolumn{1}{|c|}{ COMP. } & TONALIDADE & FUNÇÃO \\
\hline EXORDIUM & Pausa & 3 & Sol Menor & $\mathrm{i}$ \\
\hline NARRATIO & Polyptoton & $7-9$ & Sol Menor & $\mathrm{i}$ \\
\hline PROPOSITIO & Synaeresis & $15-16$ & Sol Menor & $\mathrm{i}$ \\
\hline CONFUTATIO & Pausa & 25 & Sol Menor & $\mathrm{i}$ \\
\hline PERORATIO & Synaeresis & 27 & Sol Menor & $\mathrm{i}$ \\
Exclamatio & 27 & Sol Menor & $\mathrm{i}$ \\
\hline
\end{tabular}




\subsection{Recorrências no emprego das figuras retóricas}

Para verificar as recorrências no emprego das figuras e elementos retóricos foram escolhidos e direcionados a averiguação para o presente estudo de quatro compositores selecionados nas análises anteriores: Manoel Dias de Oliveira, José Joaquim Emerico Lobo de Mesquita, André da Silva Gomes e José Maurício Nunes Garcia.

Esse exame apoiou-se em autores como Aristóteles, Cícero, Quintiliano, Santo Agostinho, Cipriano Soares, Joachim Burmeister, Johann Mattheson, Luiz António Verney, George J. Buelow, Dietrich Bartel, Régis Duprat, Aníbal Pinto de Castro, Mônica Isabel Lucas, Diósnio Machado Neto e Ana Margarida Paixão, entre outros, para não só contextualizar sobre a retórica, retórica musical e música colonial brasileira, mas, igualmente, fundamentar nossa metodologia que tem por objetivo relacionar o texto litúrgico, harmonia, contraponto com os mecanismos retóricos nas obras musicais brasileiras dos séculos XVIII e princípios do XIX.

Em suma, nas análises realizadas, aqui apresentadas verifica-se que os autores utilizaram algumas figuras retórico-musicais recorrentes, as quais serão expostas abaixo.

\section{- Manoel Dias de Oliveira}

Examinou-se à predominância da figura de repetição melódica Anaphora e Polyptoton, além da figura de dissonância e deslocamento Synaeresis, em seis obras suas: Confitemini das Matinas e Vésperas de Sábado Santo, Bajulans do Moteto dos Passos, Pater Mihi do Moteto dos Passos, no O Vos Omnes do Moteto dos Passos, na Missa de Oitavo Tom e no Gloria da Missa Abreviada em Ré.

A Anaphora pode ser empregada de três maneiras:

1. Como uma linha do baixo repetida em forma de solo.

2. Na repetição de uma exposição melódica sobre notas e partes diferentes. Também pode ocorrer no início das repetições de frases e motivos em uma série de passagens sucessivas.

3. Em uma repetição em geral (BARTEL, 1997, p.184; BUELOW, 2001, p.264). 
Nos compassos 5 e 6, na segunda parte da Dispositio, é observável que as vozes da soprano e contralto, destacam, por meio de repetição de uma passagem, a palavra Confitemini (Glorificai), configurando, assim, uma Anaphora.

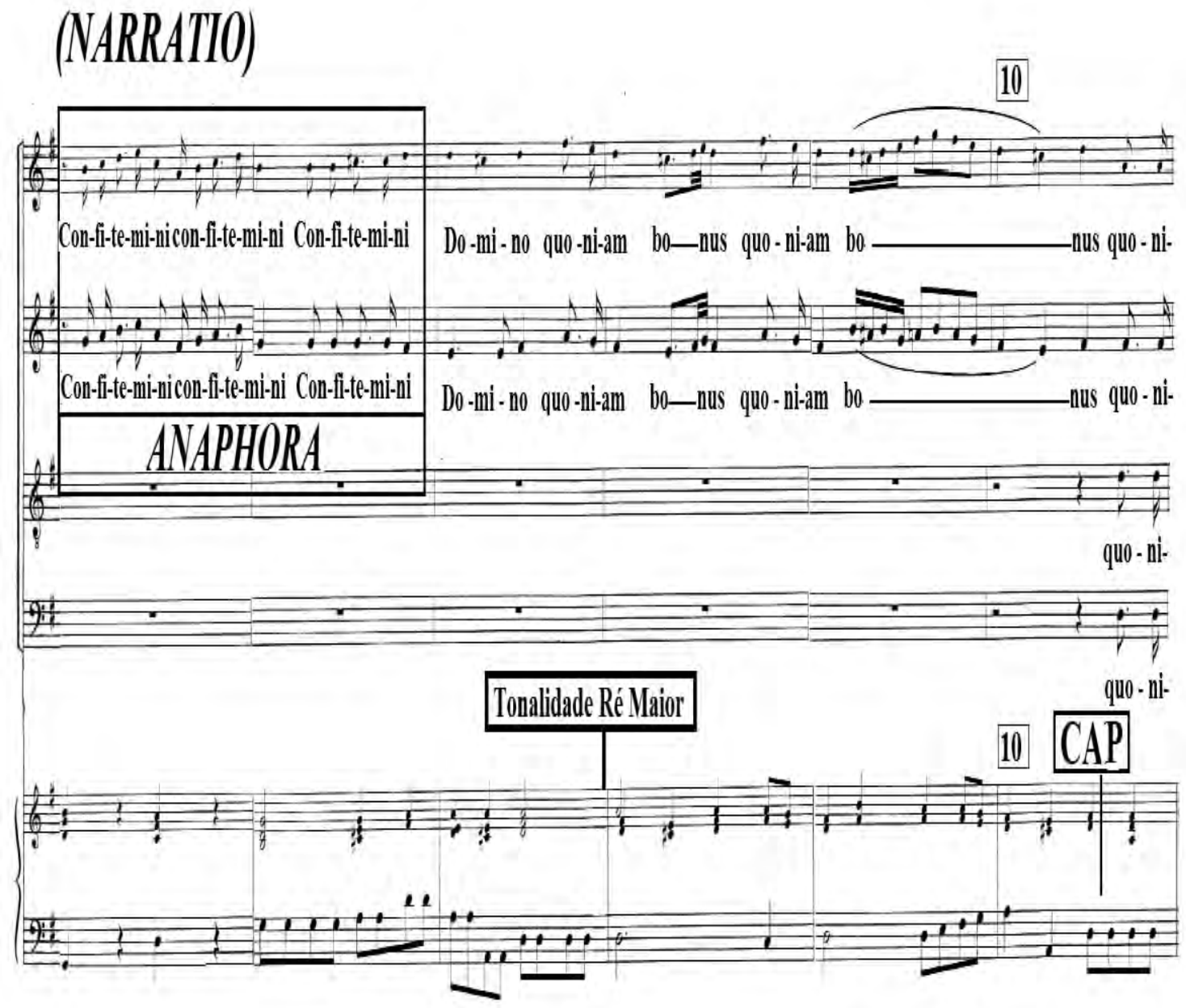

Exemplo 191-Anaphora no Confitemini das Matinas e Vésperas de Sábado Santo comp.5 e 6.

Nesse trecho do Confitemini, nota-se o emprego da Synaeresis, destacando a expressão in sæculum misericordia ejus (porque sua misericórdia perdura nos séculos), mediante a entoação de duas notas numa sílaba em todas as vozes, com exceção do baixo. Do mesmo modo, essa figura retórica é trabalhada pelo autor na Dominante, preparando a resolução da Propositio numa Cadência Autêntica Perfeita. 


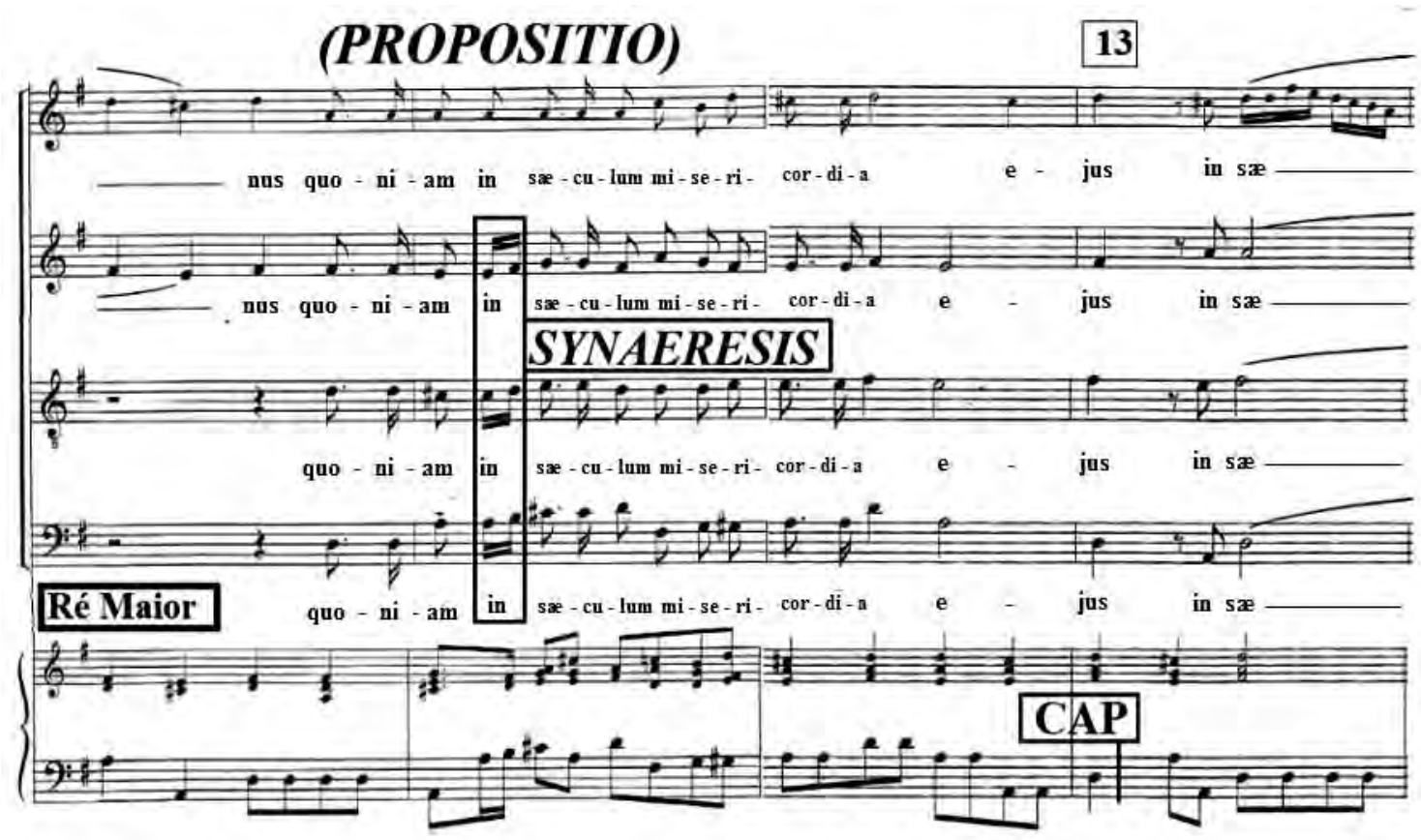

Exemplo 192-Synaeresis no Confitemini das Matinas e Vésperas de Sábado Santo comp. 13.

Ainda na mesma obra, examina-se que Dias de Oliveira efetua a repetição da mesma ideia musical em uma altura diferente, destacando a expressão in sænculum (século), caracterizando, desse modo, um Polyptoton.

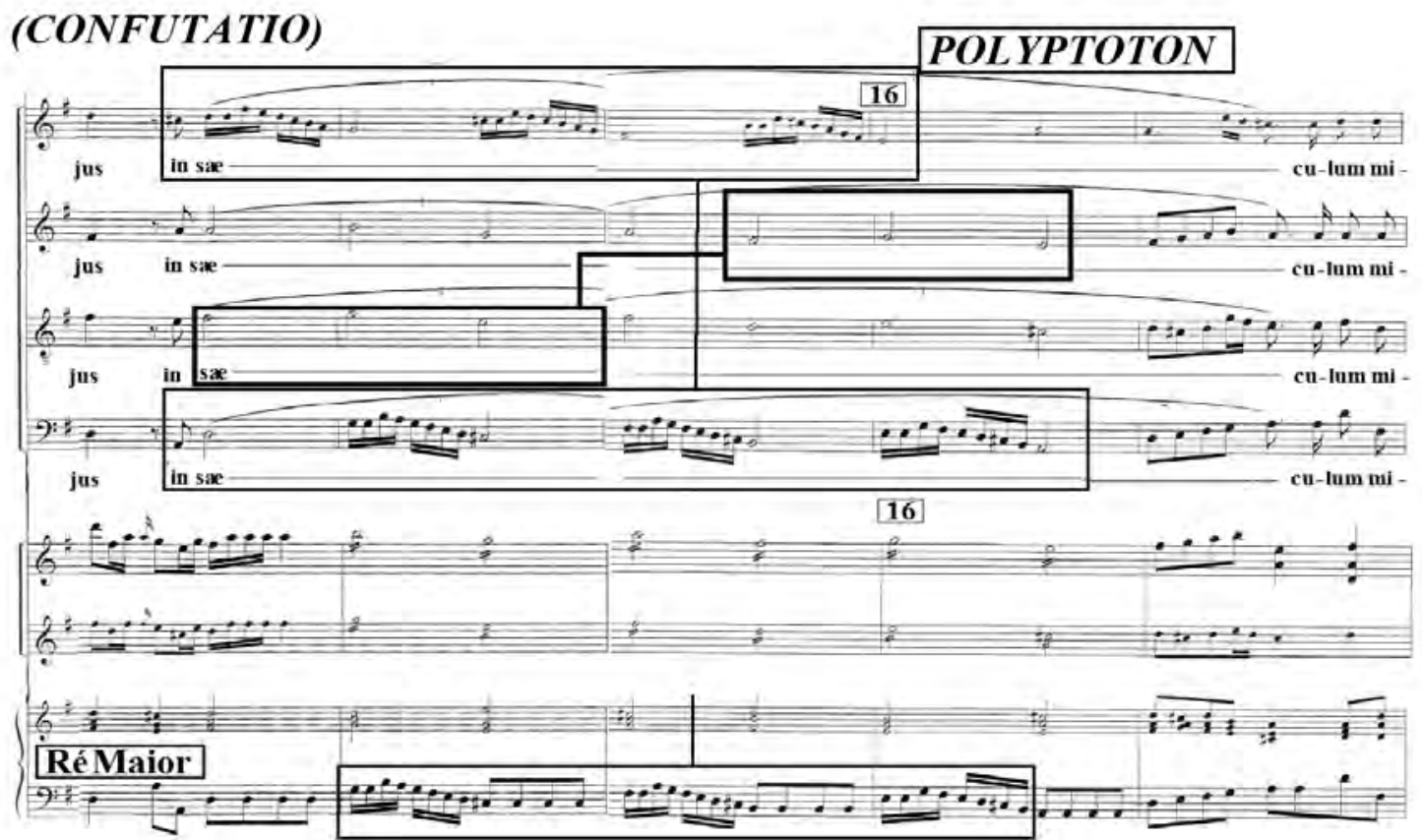

Exemplo 193-Polyptoton no Confitemini das Matinas e Vésperas de Sábado Santo comp.15 a 19. 
No quarto exemplo, nota-se que ela é usada para ressaltar a expressão Confitemini Domino (Glorificai ao Senhor), a qual é repetida duas vezes pelas vozes do tenor e baixo e depois pela soprano e contralto.

\section{(NARRATIO dentro da CONFUTATIO)}

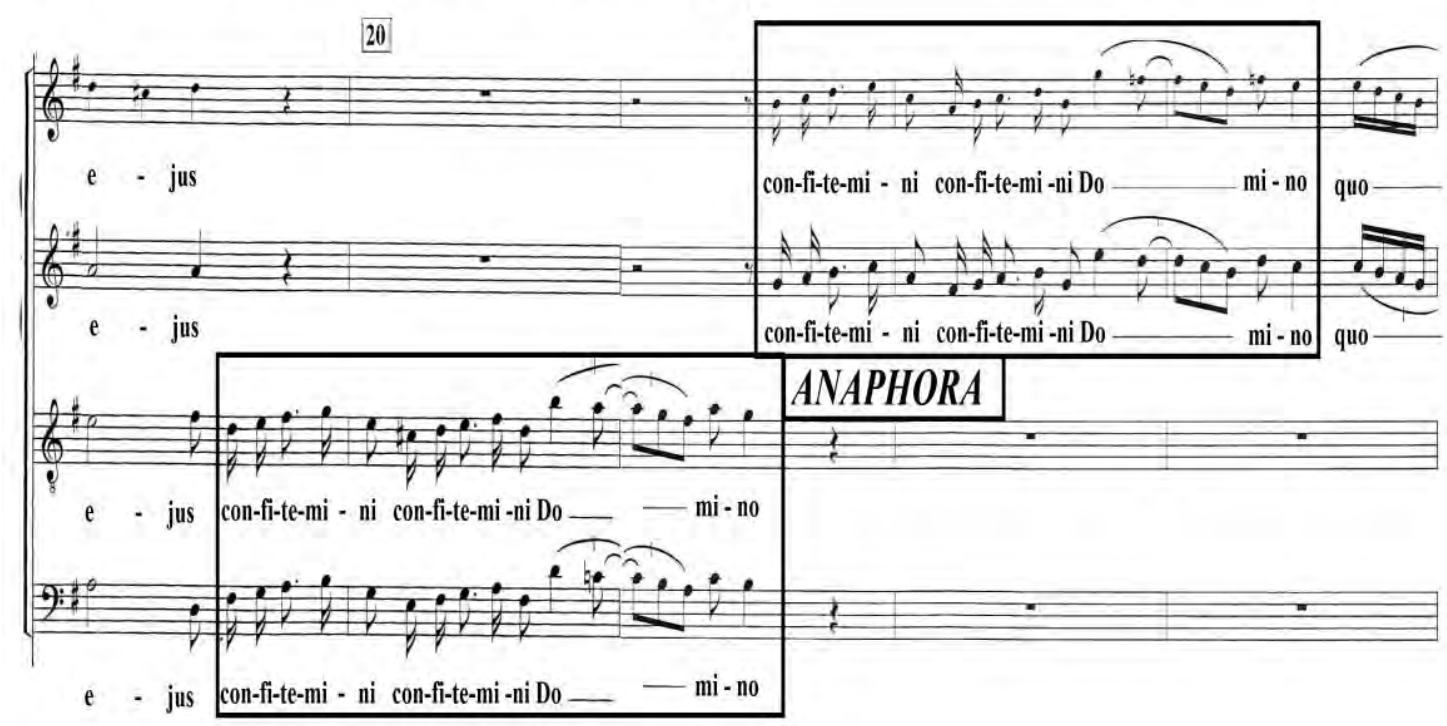

Exemplo 194-Anaphora no Confitemini das Matinas e Vésperas de Sábado Santo comp.19 a 23.

No excerto abaixo, constata-se o uso da Anaphora de forma diferente pelo compositor, entre os compassos 3 e 8 , onde a repetição se dá apenas na voz do baixo e da expressão sibi crucem Jesus (Jesus carregou a cruz), o que corrobora a definição de Joachim Thuringus (nascido em finais do século XVI) (BARTEL, 1997, p.188; BUELOW, 2001, p.264). 


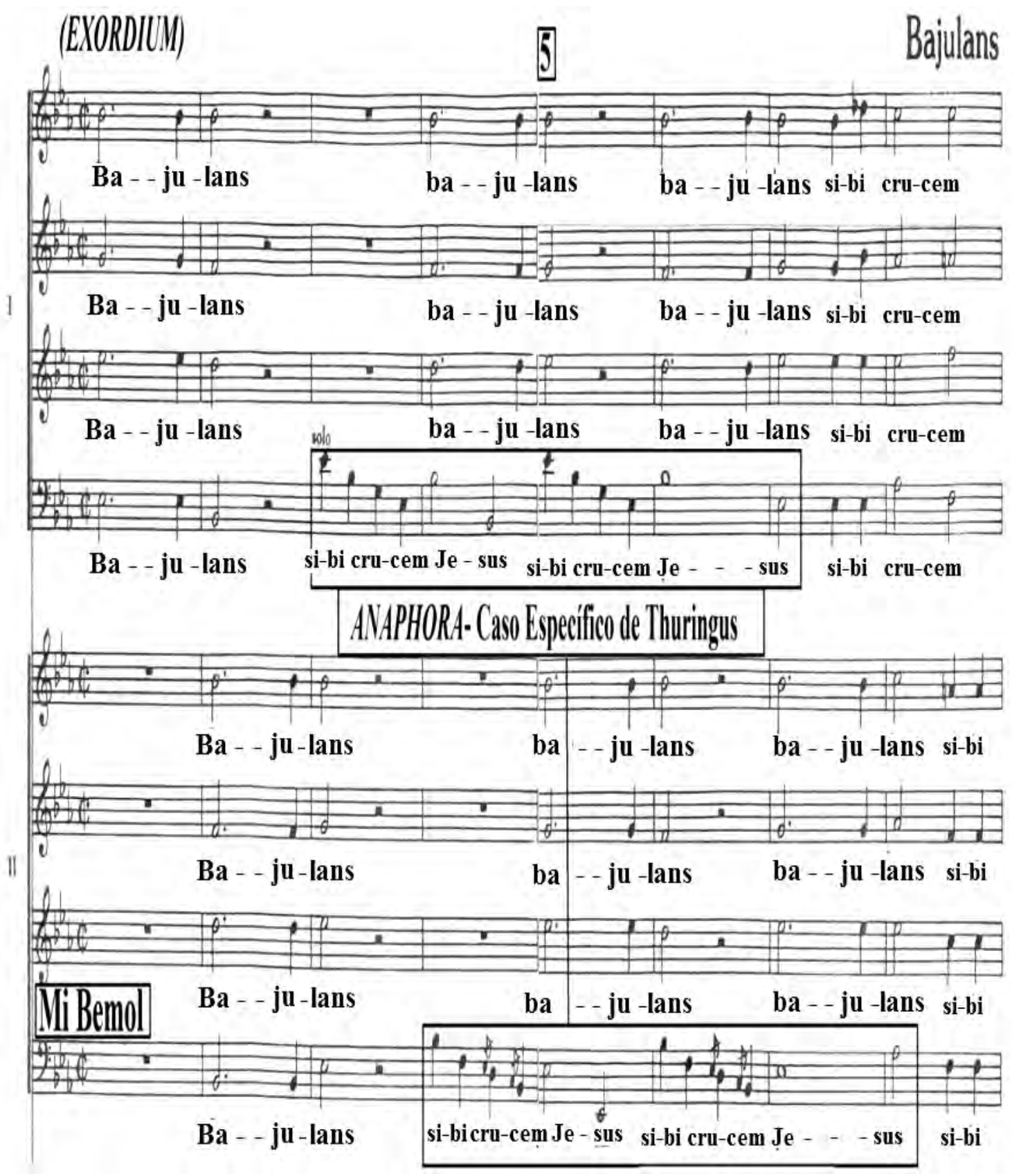

Exemplo 195-Anaphora no Bajulans do Moteto dos Passos comp.3 a 8.

Observa-se, nesse trecho, que a figura é empregada de forma idêntica ao exemplo anterior. Sendo que a repetição melódica na voz do baixo enfatiza tanto as palavras transeat a me (afaste de $\mathrm{mim}$ ) como o afeto de angústia, manifestado por Cristo, no Monte das Oliveiras, o que pode ser evidenciado em Lucas 22: 42 "Pai, se quiseres, passa de mim este cálice" (ALMEIDA, 2000, p.1474). Igualmente, é verificável o uso da Synaeresis em consonância a esse elemento retórico, valorando a reiteração já citada no baixo. 


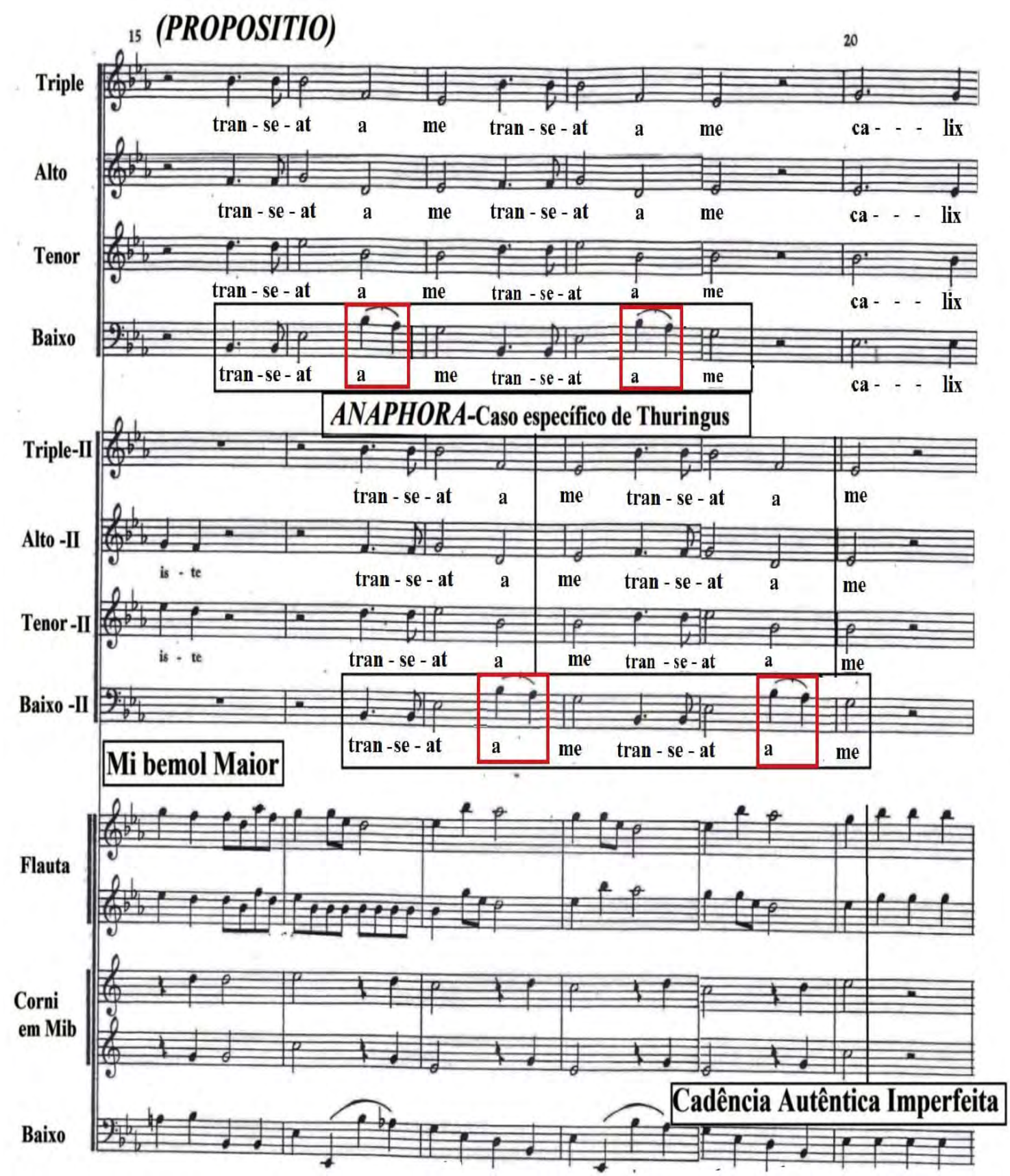

Exemplo 196-Anaphora e Synaeresis no Pater Mihi do Moteto dos Passos- comp.15 a 20.

Abaixo, verifica-se a recorrência das figuras retóricas da Synaeresis e do Polyptoton, objetivadas em trazer audiência perspicaz ao ouvinte, mediante a repetição melódica, das funções harmônicas, das palavras. 


\section{(CONFUTATIO)}

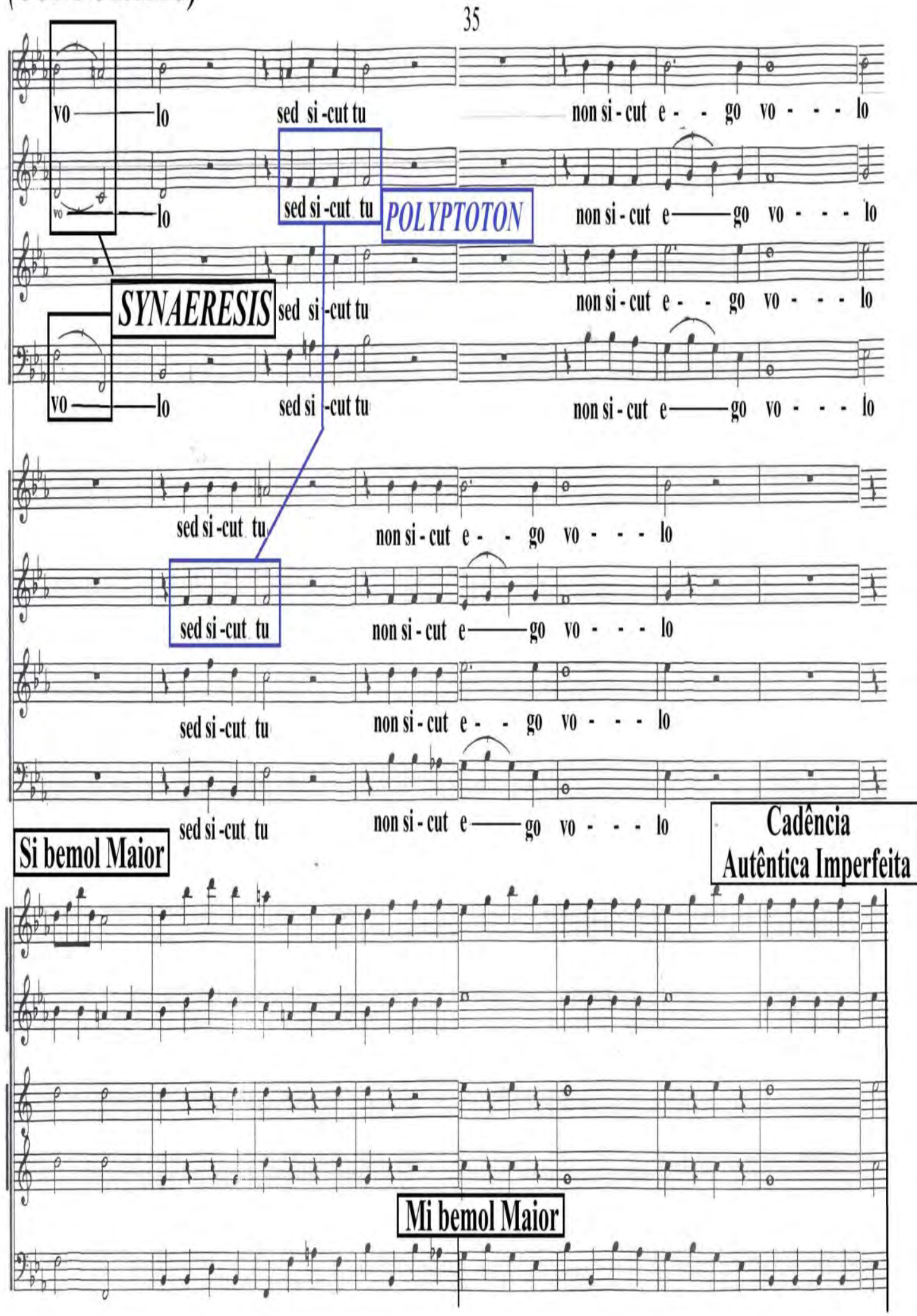

Exemplo 197-Synaeresis e Polyptoton no Pater Mihi do Moteto dos Passos- comp.31 a 34. 
$\mathrm{Na}$ mesma obra, é localizada a aplicação recorrente da Synaeresis, ressaltando tanto a passagem intervalar de $8^{a}$ para $7^{a}$ na tonalidade Si bemol Maior, como a expressão sicut ego (como eu).

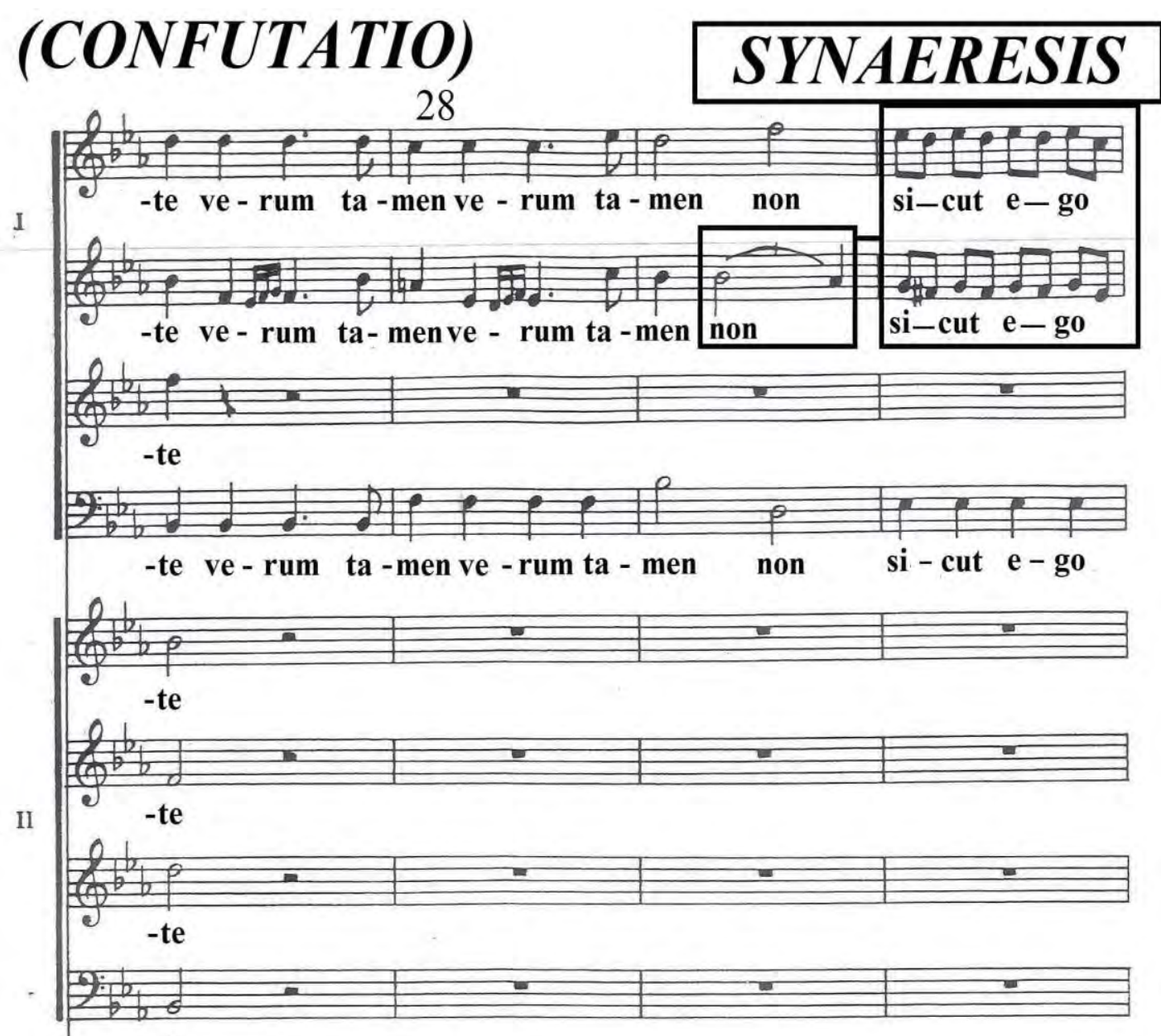

\section{Si bemol Maior}

$\mathrm{fl}$

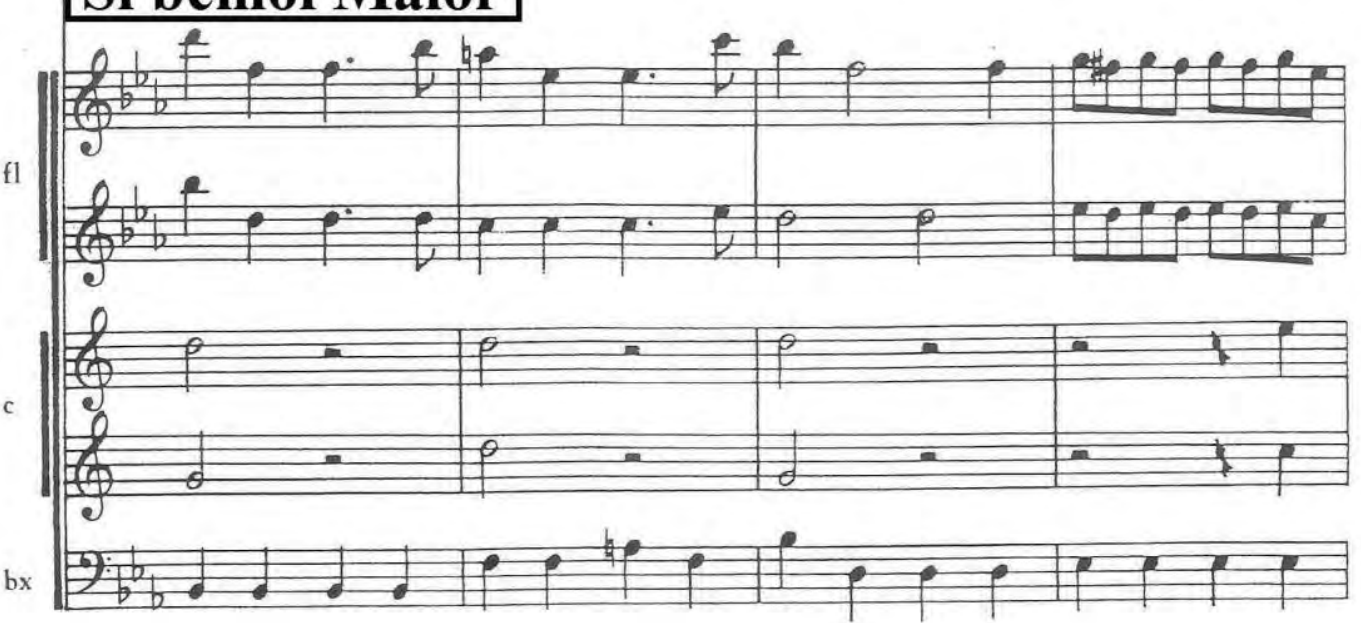

Exemplo 198-Synaeresis no Pater Mihi do Moteto dos Passos- comp.29 e 30. 
Nesse outro trecho do Pater Mihi, evidencia-se o mesmo processo efetuado por Dias de Oliveira, no entanto, na tonalidade Mi bemol Maior.

\section{(CONFUTATIO dentro da CONFIRMATIO)}

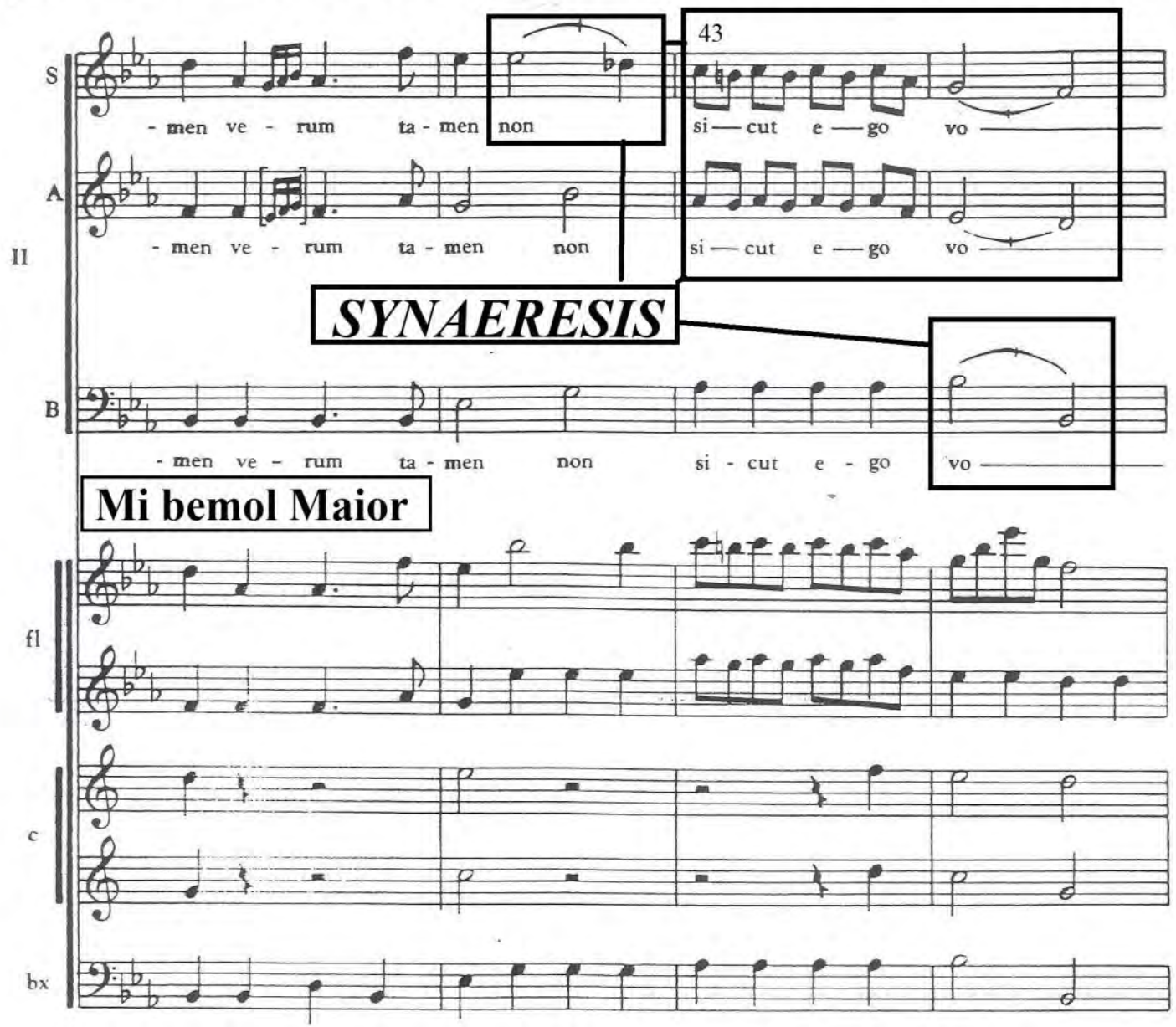

Exemplo 199-Synaeresis no Pater Mihi do Moteto dos Passos- comp.42 e 44.

O texto dessa parte se encontra em Lamentações de Jeremias 1:12: 0 vos omnes, qui transitis per viam, attendite et videte, si est dolor similis sicut dolor meus (Não vos comove isto, a todos vós que passais pelo caminho? Considerai e vede se há dor igual à minha, que veio sobre mim, com o que o Senhor me afligiu no dia do furor da sua ira).

É notável no excerto abaixo, o uso da Anaphora na repetição tanto do motivo rítmico quanto das palavras si est dolor (se há dor), nas vozes do tenor-I e contralto-II, nos compassos 15 a 19, como da Synaeresis, valorando o momento de angústia e languidez sem precedentes, além de despertar no 
ouvinte o afeto de lamento e pesar, por meio de movimentos lentos e reflexíveis.

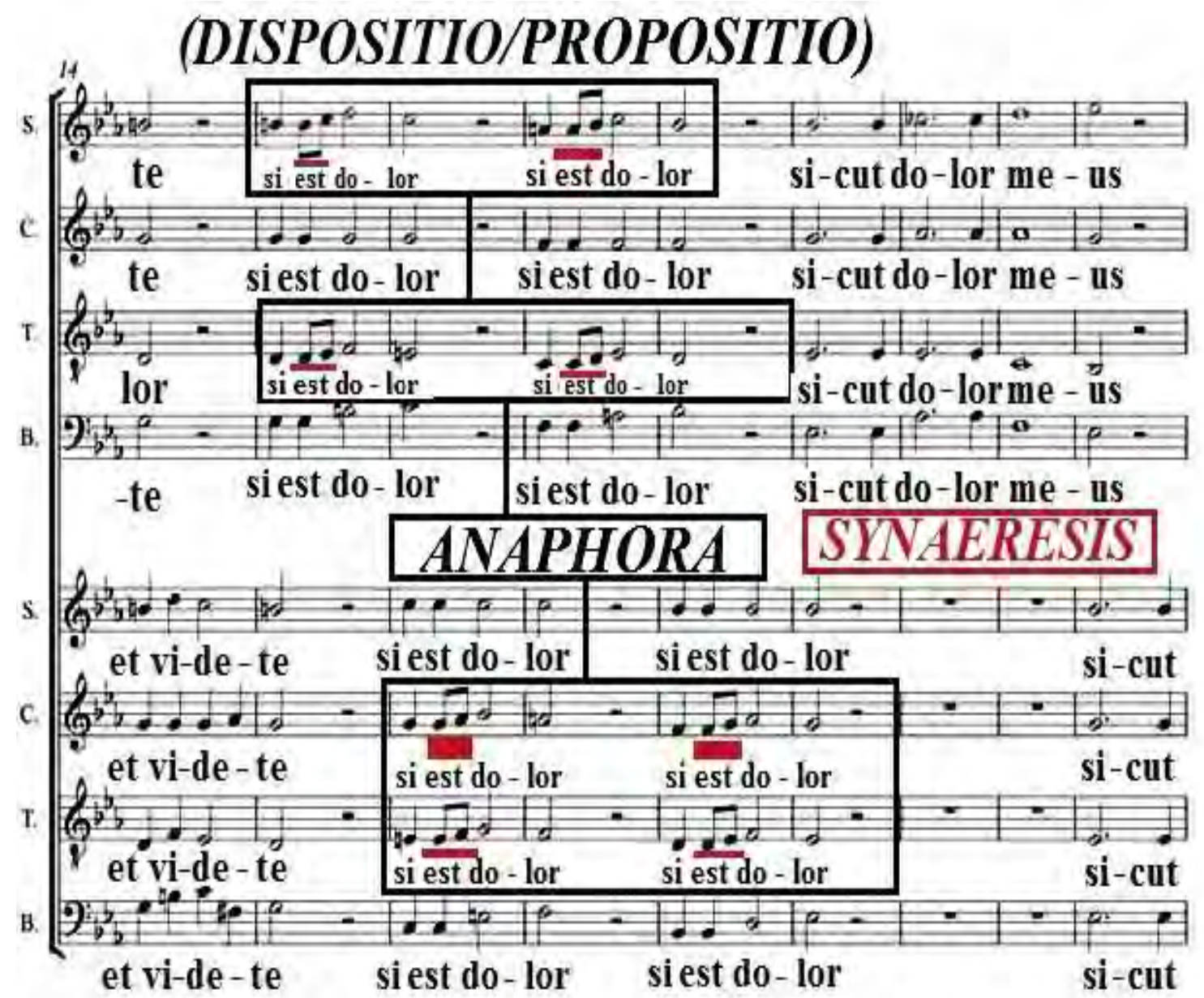

Exemplo 200-Anaphora e Synaeresis em O Vos Omnes do Moteto dos Passos-comp. 15 a 19.

Entre os compassos 2 e 7, da Missa de Oitavo Tom, evidencia-se que o Polyptoton é aplicado para ressaltar tanto a expressão Kyrie elielson (Senhor tende piedade de nós), reiterada nas vozes da soprano e do tenor, assim como as funções harmônicas da Tônica e Dominante e a modulação de Mi Menor para Sol Maior. 


\section{MISSA DE OITAVO TOM}

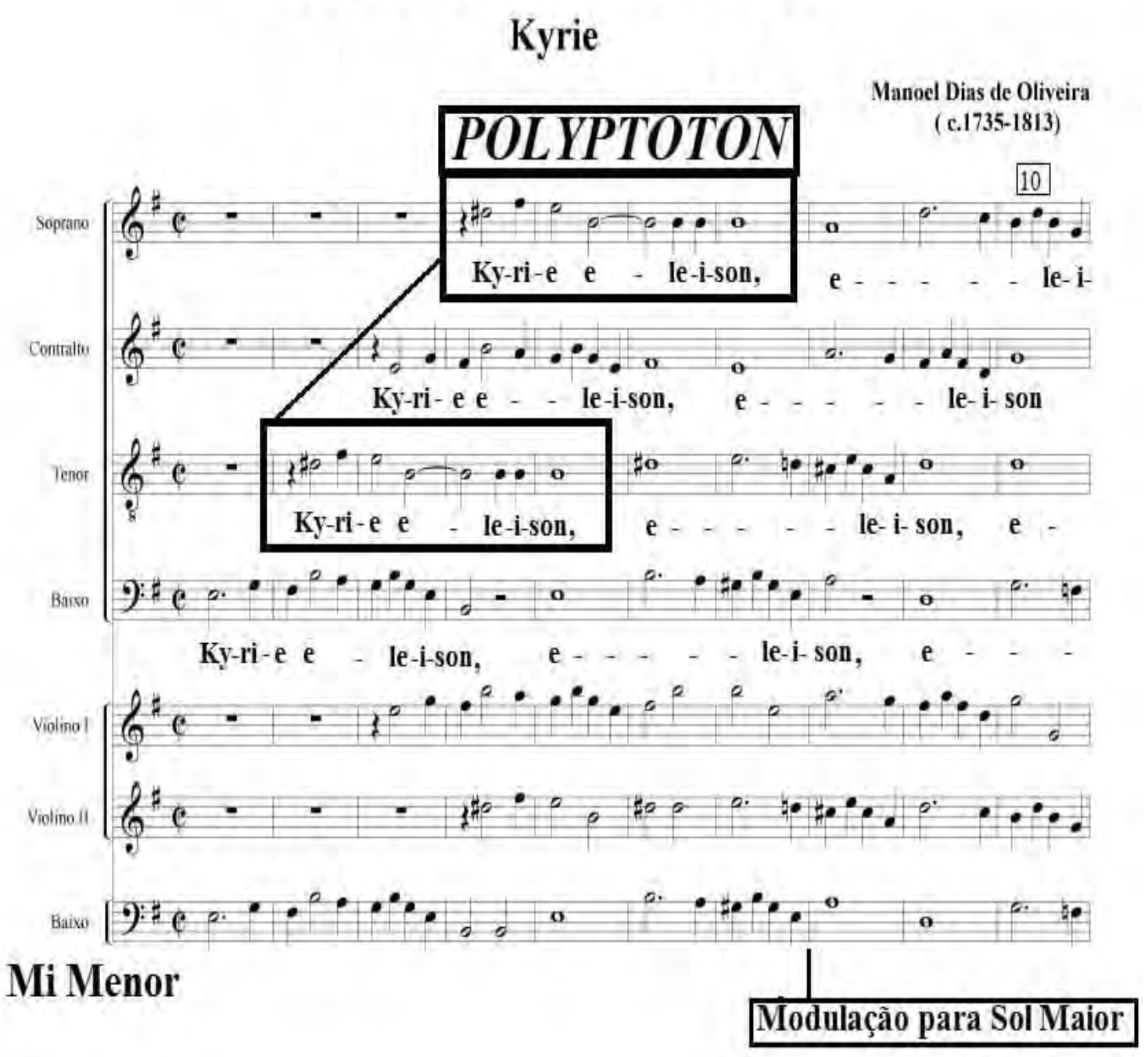

Exemplo 201-Polyptoton no Kyrie da Missa de Oitavo Tom- comp.2 a 7.

É localizável, no trecho final da mesma peça, o emprego da Anaphora e da Synaeresis na tonalidade Sol Maior, entre os compassos 35 e 39, enfatizando a expressão Kyrie eleison, já citados no exemplo anterior, repetida duas vezes pela soprano e tenor, em preparação à Cadência Final (Semicadência), para concluir a primeira parte da missa e do discurso. 


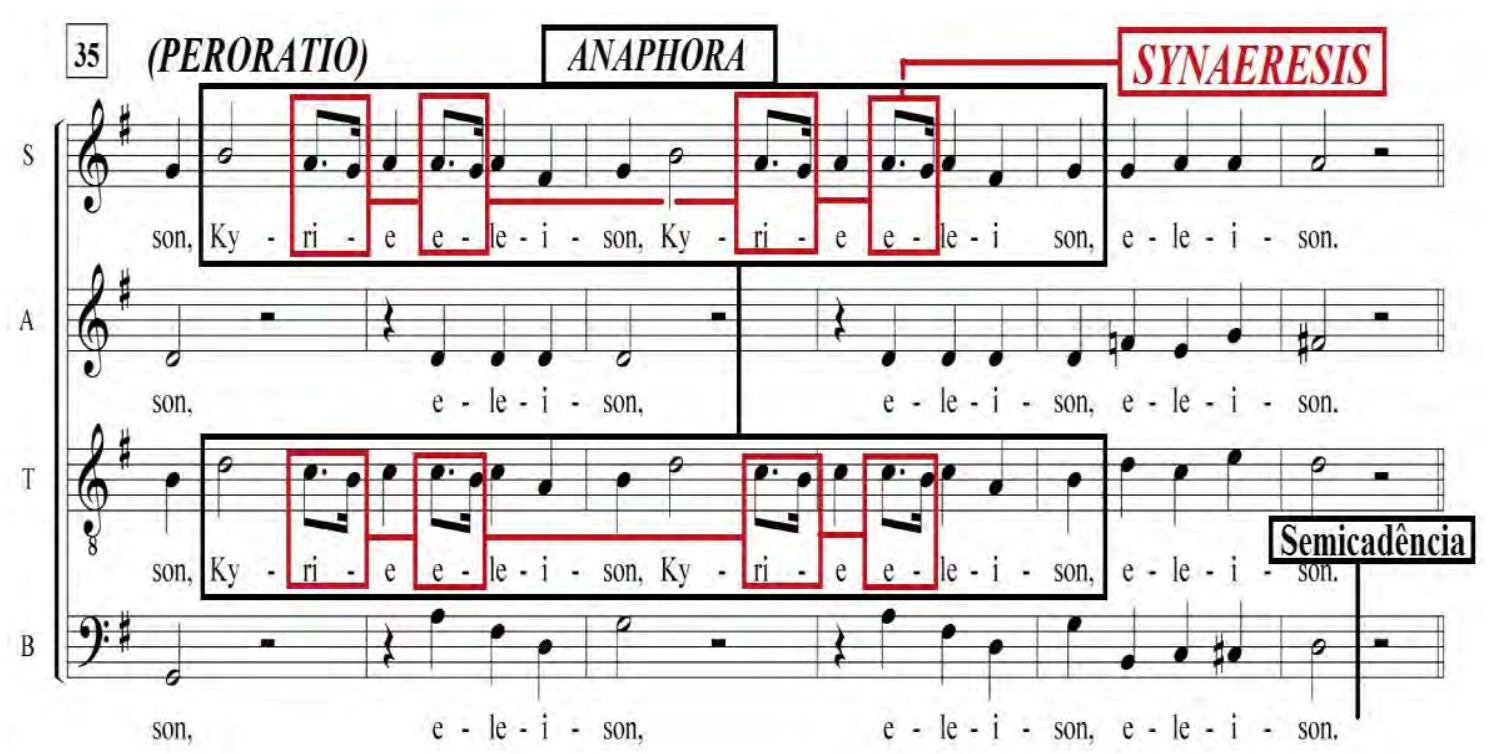

Exemplo 202-Anaphora e Synaeresis no Kyrie da Missa de Oitavo Tom- comp.35 a 39.

Nota-se, nessa peça, a aplicação da Synaeresis nas vozes do contralto e do tenor, nos compassos 28 e 31, pelo compositor, com objetivo de salientar o afeto de suavidade e de ternura, demonstrado, através da dinâmica piano, além da reiteração das palavras, motivos e frases.

\section{(PORPOSITIO)}

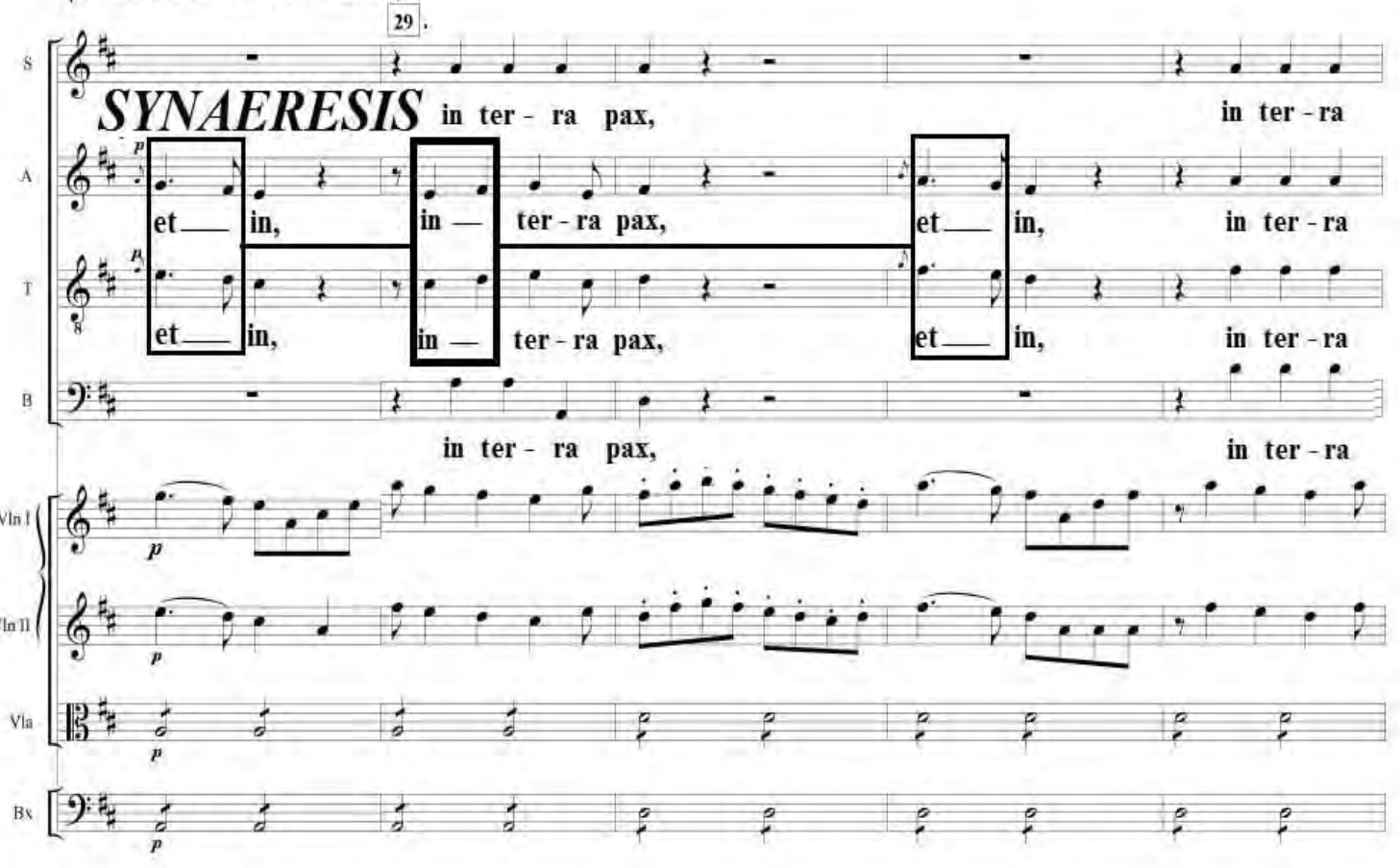

Exemplo 203-Synaeresis no Gloria da Missa Abreviada-comp. 28 e 31. 
Nota-se, também, a utilização e recorrência da mesma figura retórica na transição da Propositio para a Confutatio. Todavia, é gerada maior expectativa ao ouvinte através da Cadência de Engano na Tônica Paralela (Relativa) e da expressão hominibus (homens) com efeito suspensivo, resolvendo numa Semicadência.

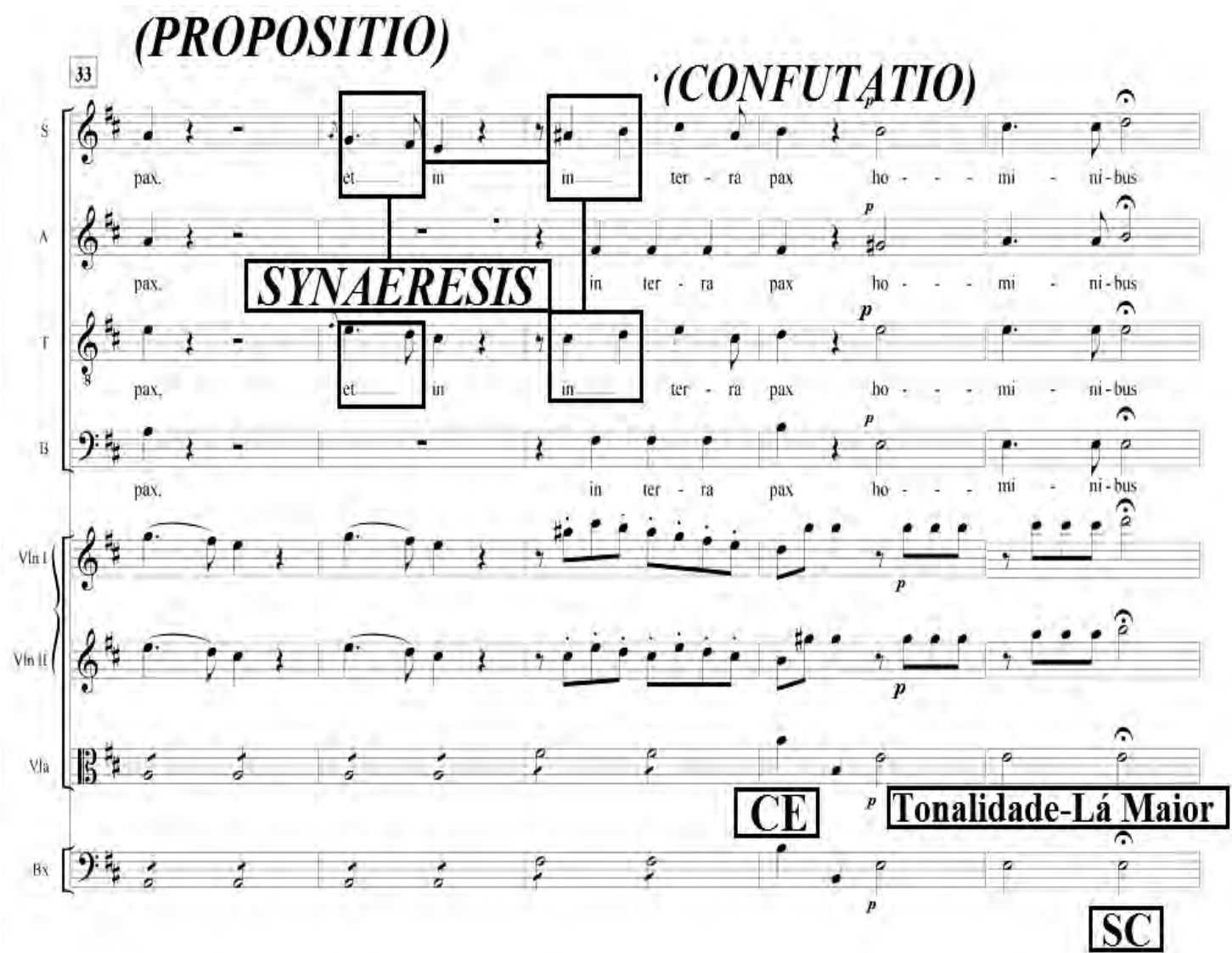

Exemplo 204-Synaeresis no Gloria da Missa Abreviada-comp. 34 e 35.

\section{- José Joaquim Emerico Lobo de Mesquita}

Em quatro peças de Lobo de Mesquita verificou-se a recorrência da Epizeuxis, Synaeresis e da Abruptio. Como já destacado nesta tese, a primeira é definida como uma repetição imediata e enfática de uma palavra, nota, motivo ou frase (BARTEL, 1997, p.263). Já a segunda figura é ressaltada como a colocação de duas sílabas por nota ou duas notas por sílaba. Finalmente, a terceira é uma interrupção súbita e inesperada na composição musical (BARTEL, 1997, pp.168; 263 e 394). 
No presente exemplo, pode ser vista a Epizeuxis através da repetição das palavras Exaudi nos, Domine (Atende-nos, Senhor), primeiramente na voz do tenor e, em seguida, nas outras vozes. Também, é pertinente salientar a interação entre a ênfase propiciada pela figura em consonância às dinâmicas mezzo-forte e forte, como das funções da Tônica, Subdominante e Dominante, resolvendo na Cadência Autêntica Imperfeita.
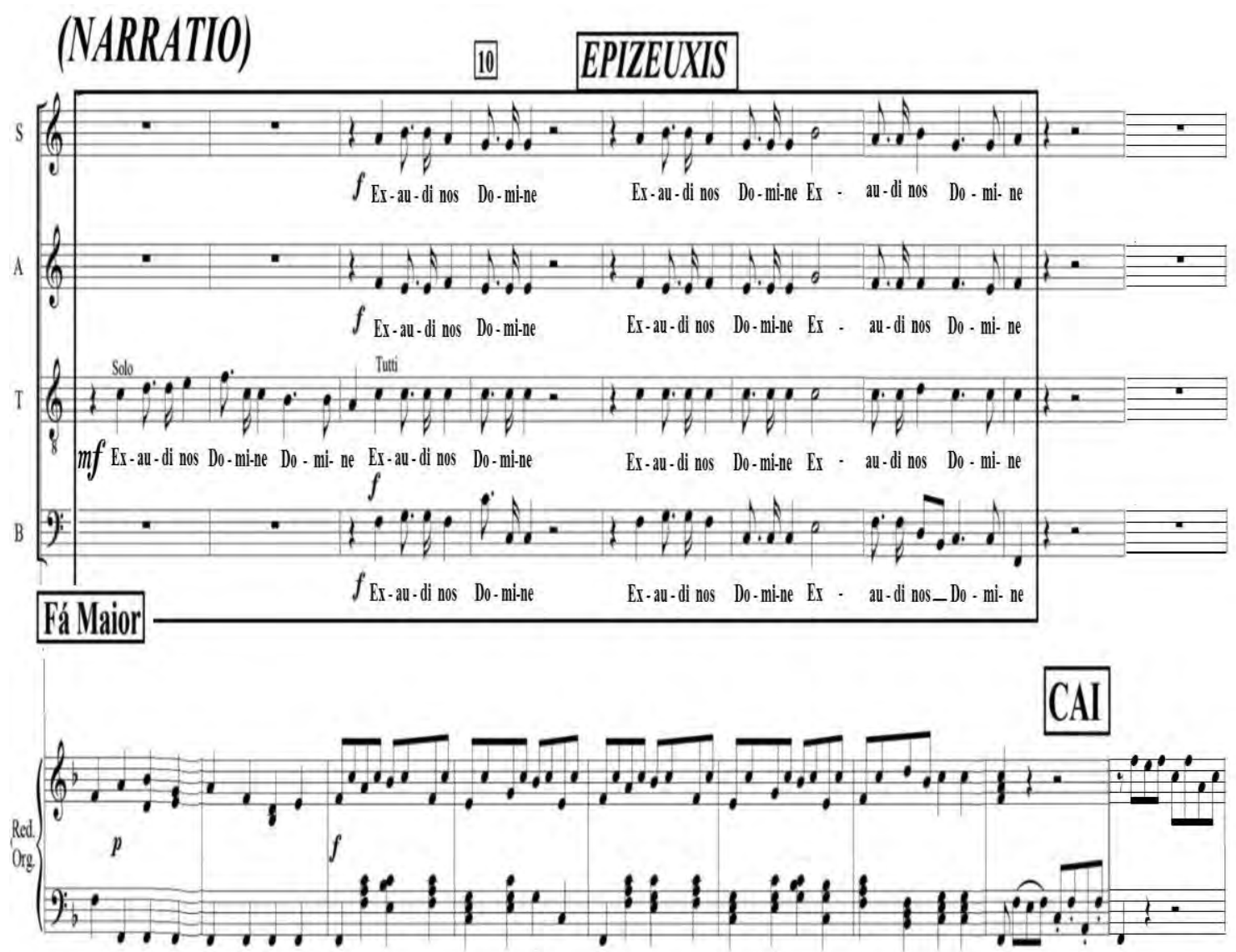

Exemplo 205-Epizeuxis no Exaudi nos, Domine para Benção de Cinzas da Missa para Quarta-feira de Cinzas- comp.7 a 15.

Na mesma peça, examina-se o mesmo procedimento de reiteração seja nas notas, motivos como das palavras respice nos Domine (Lance teu olhar sobre nós Senhor). 


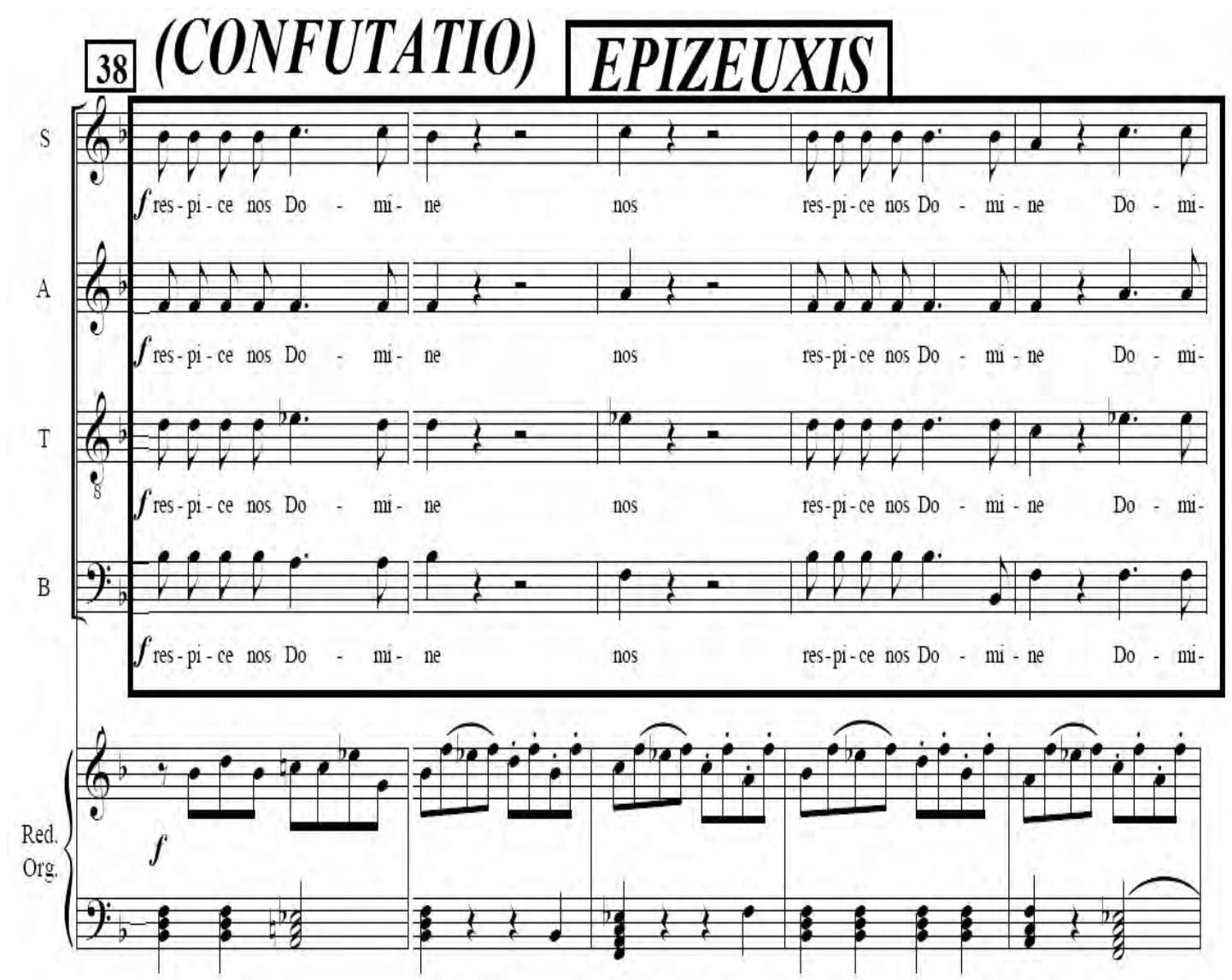

Exemplo 206-Epizeuxis no Exaudi nos, Domine para Benção de Cinzas da Missa para Quarta-feira de Cinzas- comp.38 a 42.

Nessa parte, é visível a utilização da Epizeuxis, repetindo de maneira enfática a expressão respice nos e Domine, citadas anteriormente, duas e quatro vezes, até a resolução da frase numa Cadência Autêntica Perfeita, na tonalidade Si bemol Maior. 


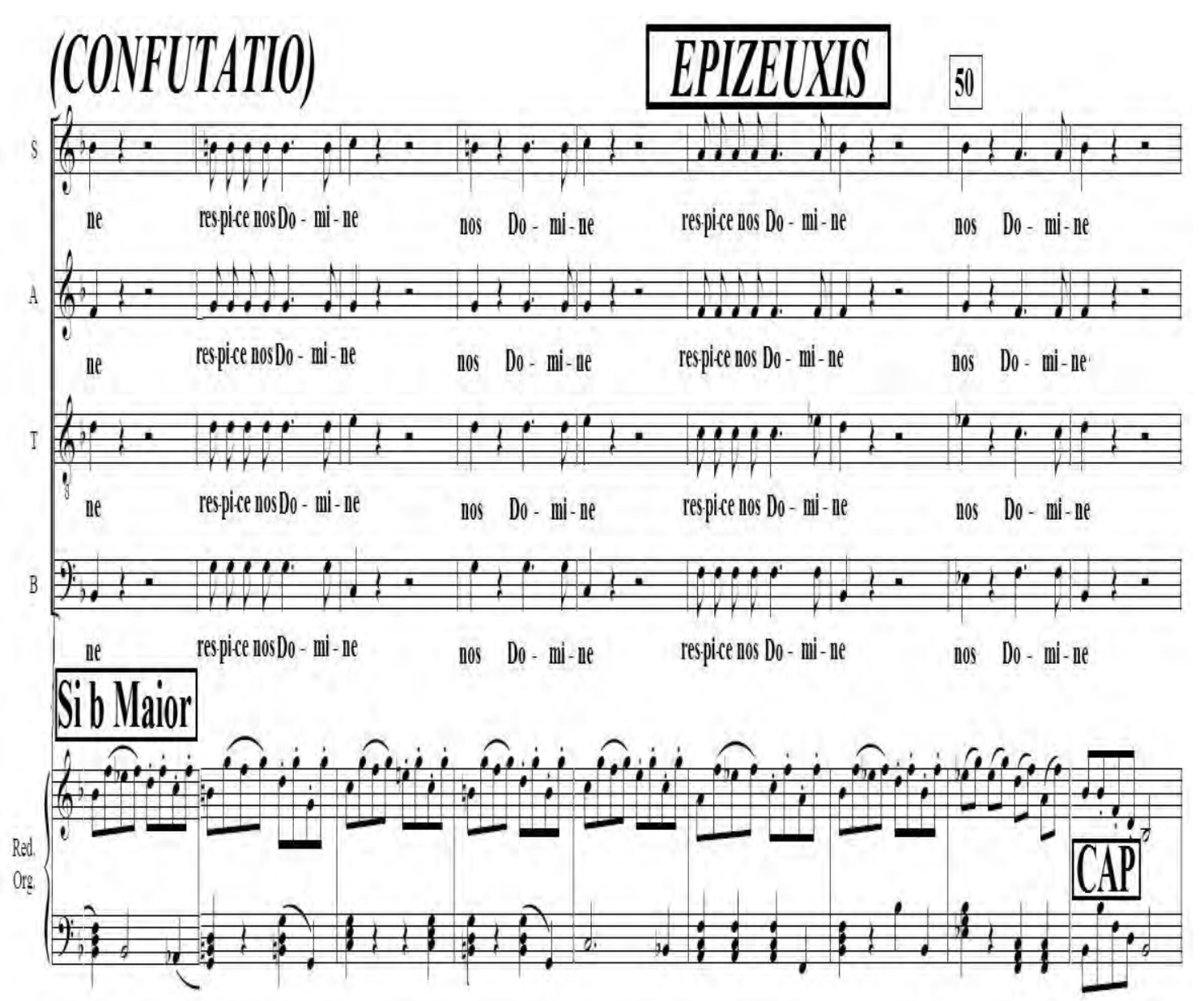

Exemplo 207-Epizeuxis no Exaudi nos, Domine para Benção de Cinzas da Missa para Quarta-feira de Cinzas- comp.43 a 51.

Na terceira parte do Exaudi nos, Domine, é localizável o emprego da Synaeresis, a qual destaca por meio de entoação das vozes da soprano e tenor de duas notas, a sílaba et. Também, nota-se a valoração da dinâmica forte através do Pedal de Tônica, além da Cadência de Engano.

Outro ponto a ser destacado, é o uso da Epizeuxis como figura recorrente, entre os compassos 98 e 105, repetindo enfaticamente a palavra Amen, resolvendo numa Cadência Autêntica Imperfeita. 

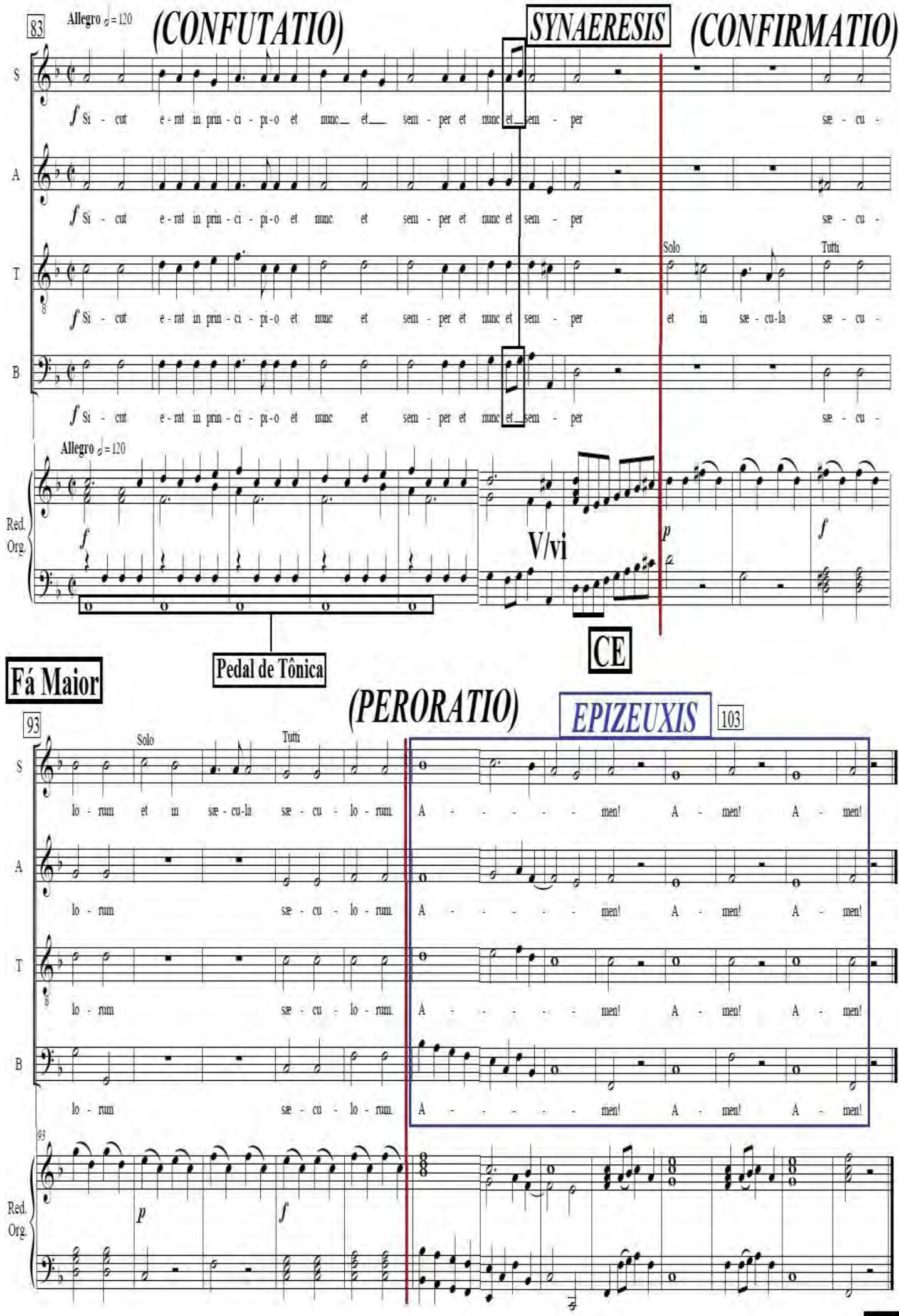

CAI

Exemplo 208-Syaneresis e Epizeuxis no Sicut erat do Exaudi nos, Domine para Benção de Cinzas da Missa para Quarta-feira de Cinzas- comp. 88, 98 a 105. 
O Intróito da Missa para Quarta-feira de Cinzas tem seu texto fundamentado em Sabedoria 11:23-25. Onde o autor dessa passagem bíblica suplica ao Senhor por sua piedade e misericórdia. Esse sentimento e afeto de devoção e submissão é repetido enfaticamente por quatro vezes, numa dinâmica forte, dessa forma Lobo de Mesquita coloca em saliência a expressão Deus noster (Nosso Deus), com conclusão numa Cadência Autêntica Perfeita.

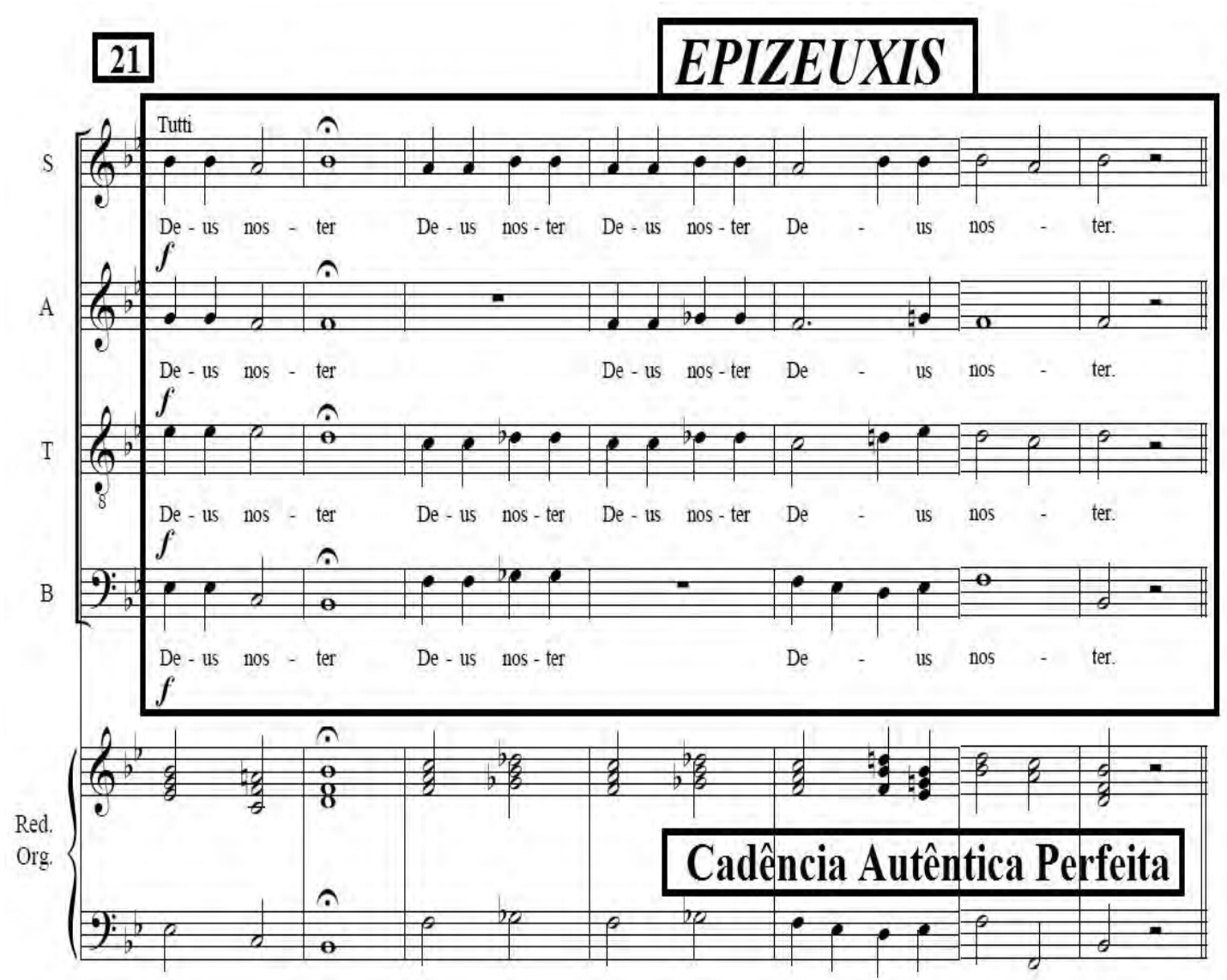

Exemplo 209-Epizeuxis no Misereris Omnium da Missa para Quarta-feira de Cinzascomp.21 a 27.

Como já observado na análise retórico-musical do Kyrie da Ladainha em $\mathrm{Si}$ bemol Maior, de Lobo de Mesquita, examinam-se as repetições realizadas com ênfase da expressão eleison, por meio da Epizeuxis. Igualmente, há de se destacar que sua aplicação, em consonância com as dinâmicas forte e piano, descreve ao ouvinte o afeto de veneração e obediência do fiel para com Deus, mediante o pedido de misericórdia. 


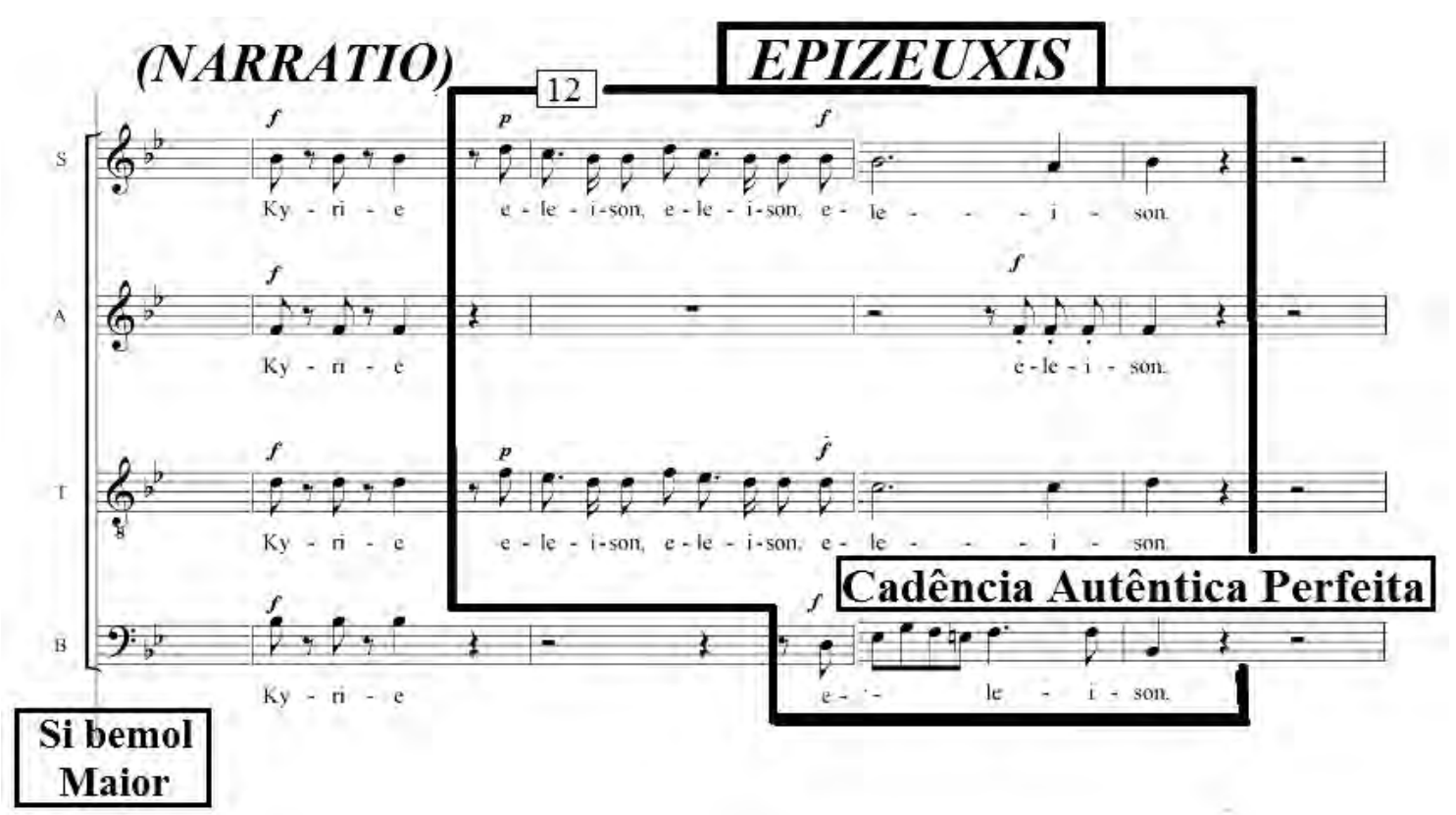

Exemplo 210-Epizeuxis no Kyrie da Ladainha em Si bemol Maior- comp.11 a 14.

$\mathrm{Na}$ mesma peça, verificam-se os mesmos elementos retórico-musicais utilizados pelo compositor anteriormente na Narratio, evidenciando, dessa forma, a recorrência desses mecanismos. Todavia, isso ocorre na tonalidade relativa, isto é, em Sol Menor, finalizando na Cadência Autêntica Imperfeita.

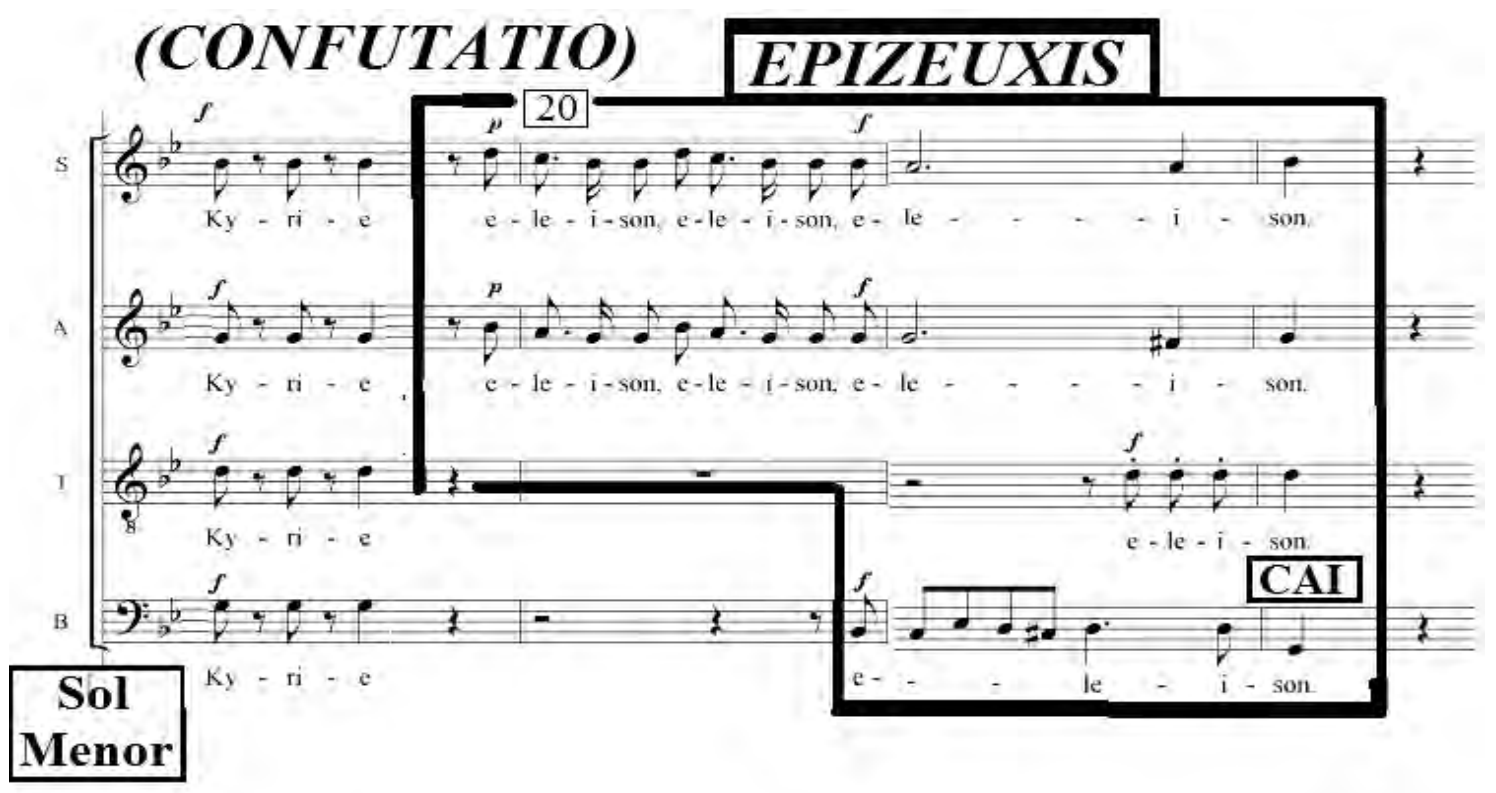

Exemplo 211-Epizeuxis no Kyrie da Ladainha em Si bemol Maior- comp.19 a 22.

É verificável o uso da Abruptio, mediante a interrupção abrupta e com pouca duração, ou seja, com a pausa de colcheia. 
(CONFUTATIO)

25

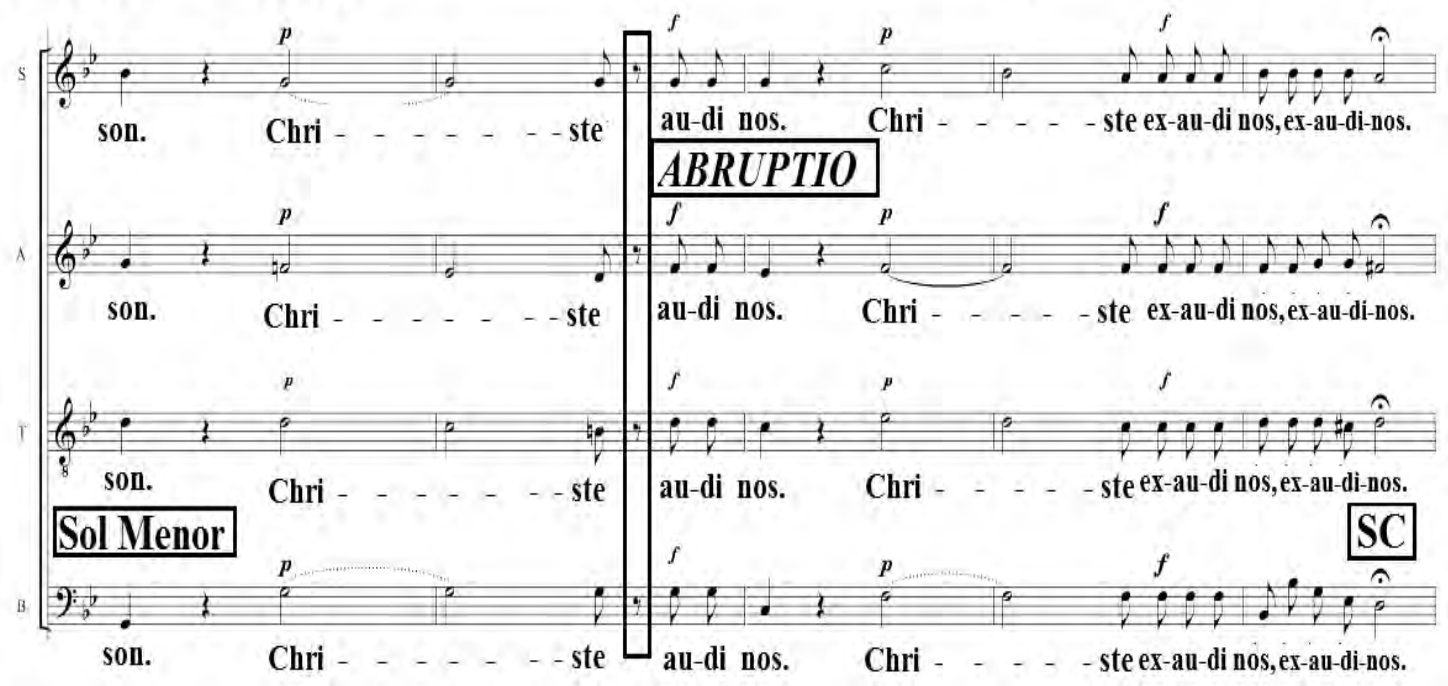

Exemplo 212-Abruptio no Kyrie da Ladainha em Si bemol Maior- comp.23.

No último exemplo do Kyrie, da Ladainha em Si bemol Maior, Lobo de Mesquita utiliza-se da Synaeresis, para ressaltar a expressão Christe audi nos (Senhor, atende-nos), a qual representa o afeto de submissão e devoção, além do diálogo entre as vozes e funções harmônicas.

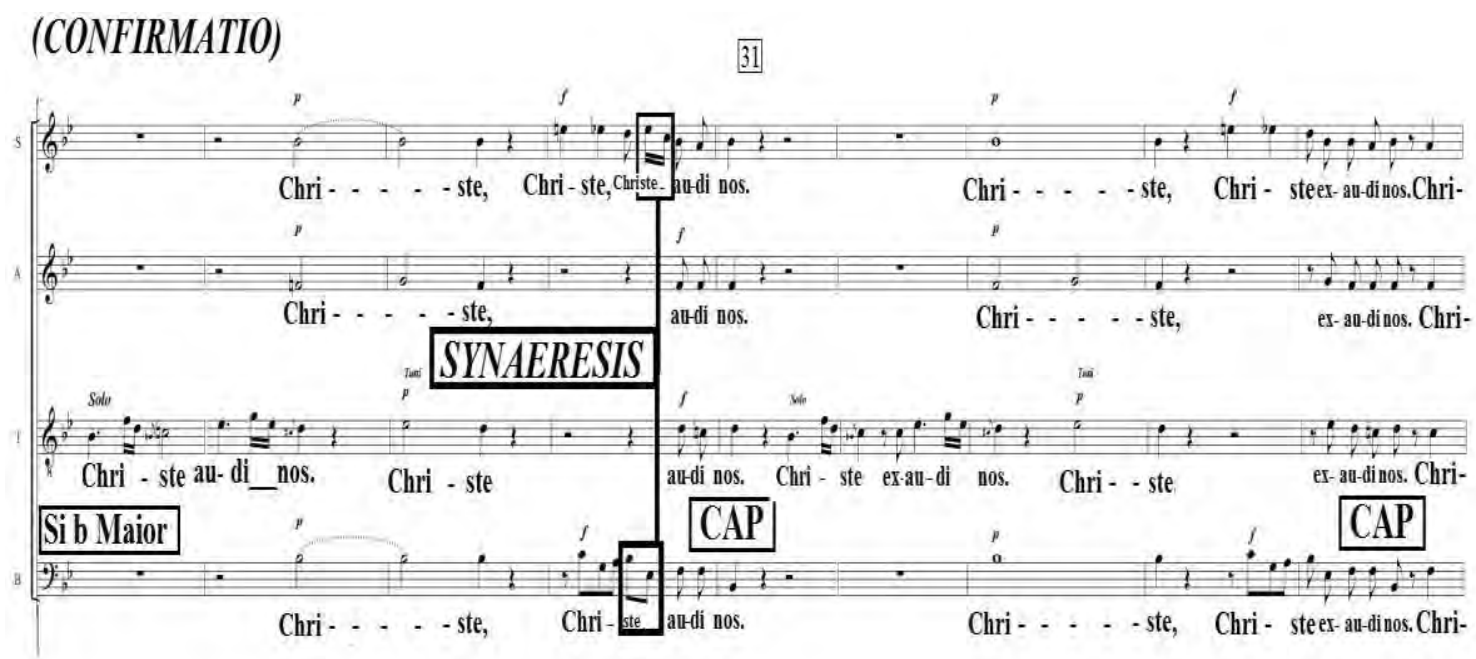

Exemplo 213-Synaeresis no Kyrie da Ladainha em Si bemol Maior- comp.30.

Na presente obra, é tangível a utilização da Epizeuxis por José Emerico, a qual repete de maneira incisiva e progressiva, em consonância com as dinâmicas piano e forte, a expressão miserere nobis (tende piedade de nós), com resolução na Cadência Autêntica Imperfeita na tonalidade Sol Menor. 


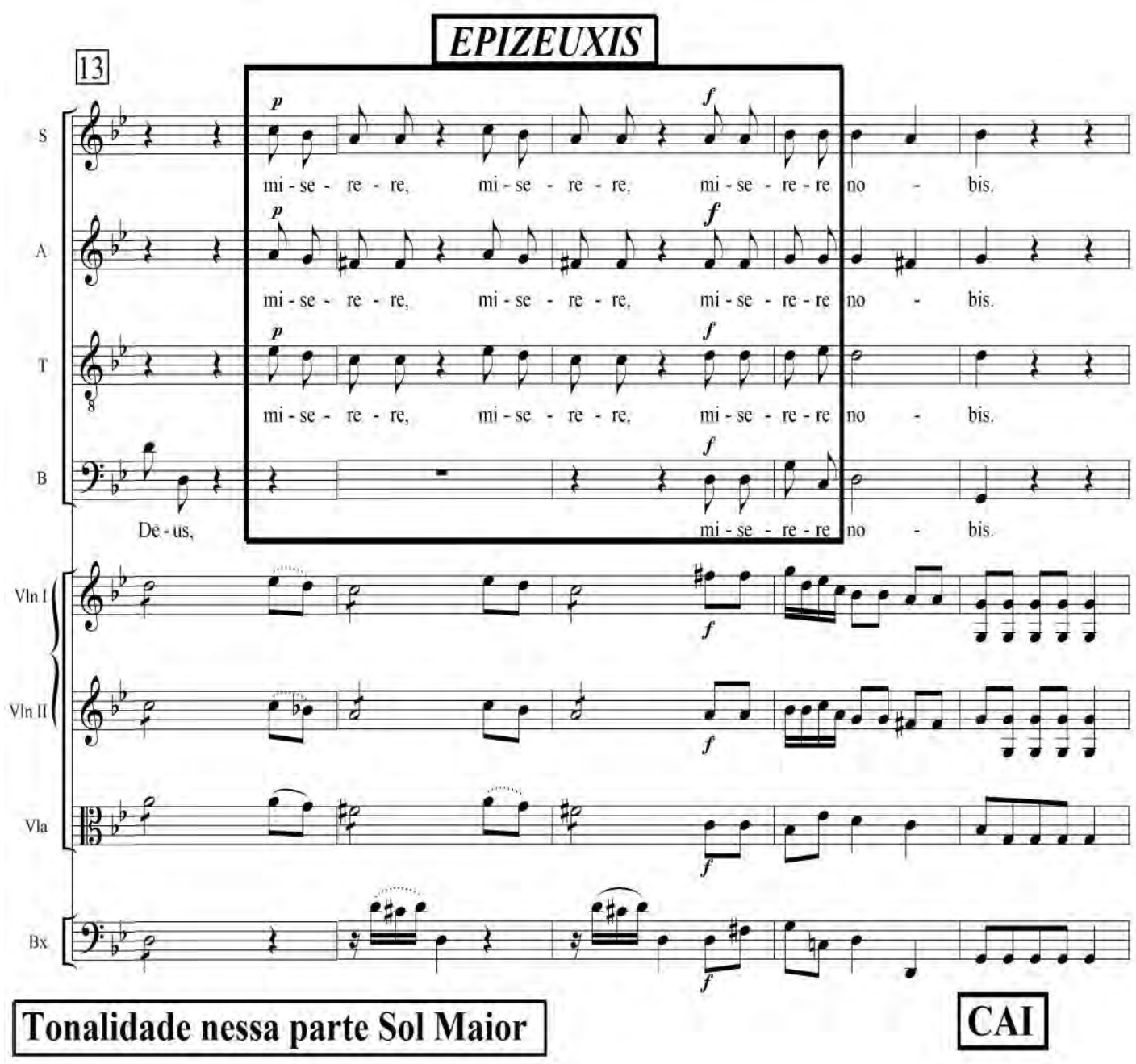

Exemplo 214-Epizeuxis no Pater de cælis da Ladainha em Si bemol Maior- comp.13 a 16.

Na Sancta Dei Genitrix, da Ladainha em Si bemol, é destacável a expressividade dos motivos utilizados nas diferentes partes, além do domínio técnico das texturas e da escrita orquestral, típicos do autor (CASTAGNA, 2003, p.XV). No exemplo abaixo, pode ser examinada, além do emprego da Synaeresis realçando a sílaba gi da expressão Virginum (Virgem), no contralto e tenor, a quebra súbita e inesperada das palavras, ora pro nobis (orai/rogai por nós), em todas as vozes, através das pausas, configurando, assim, o uso da Abruptio. 


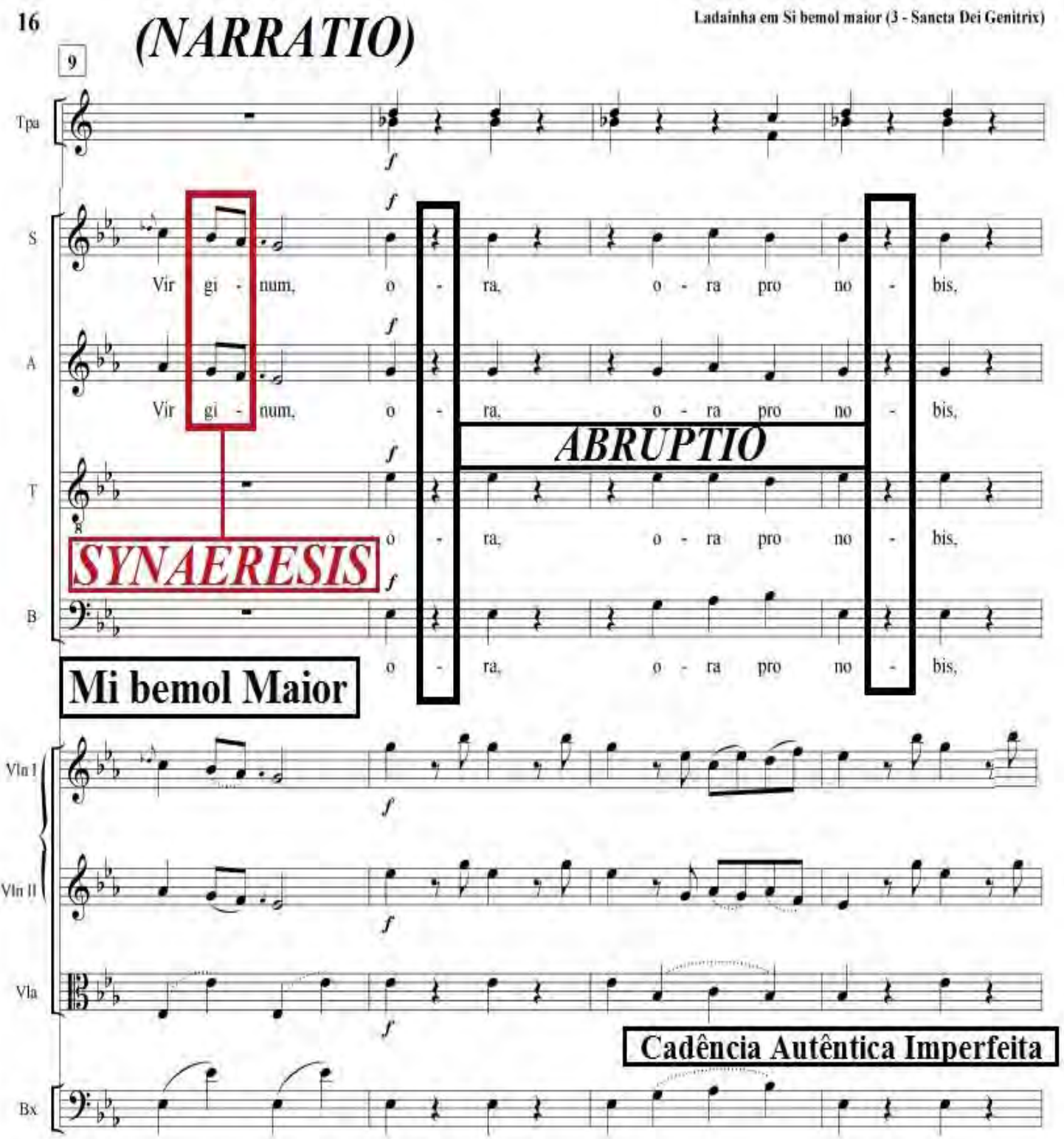

Exemplo 215-Abruptio e Synaeresis na Sancta Dei Genitrix da Ladainha em Si bemol Maior, comp.10 e 12.

Verifica-se, na mesma obra, entre os compassos 43 e 47, uma quebra súbita e inesperada da expressão ora pro nobis (rogai por nós), em todas as vozes, por intermédio das pausas, caracterizando, dessa forma, o emprego desse elemento retórico. 
(NARRATIO dentro da CONFUTATIO) $\begin{gathered}\text { Ladainha em Si bemol Maior } \\ \text { (Sancta Dei Genitrix) }\end{gathered}$ 43

47.

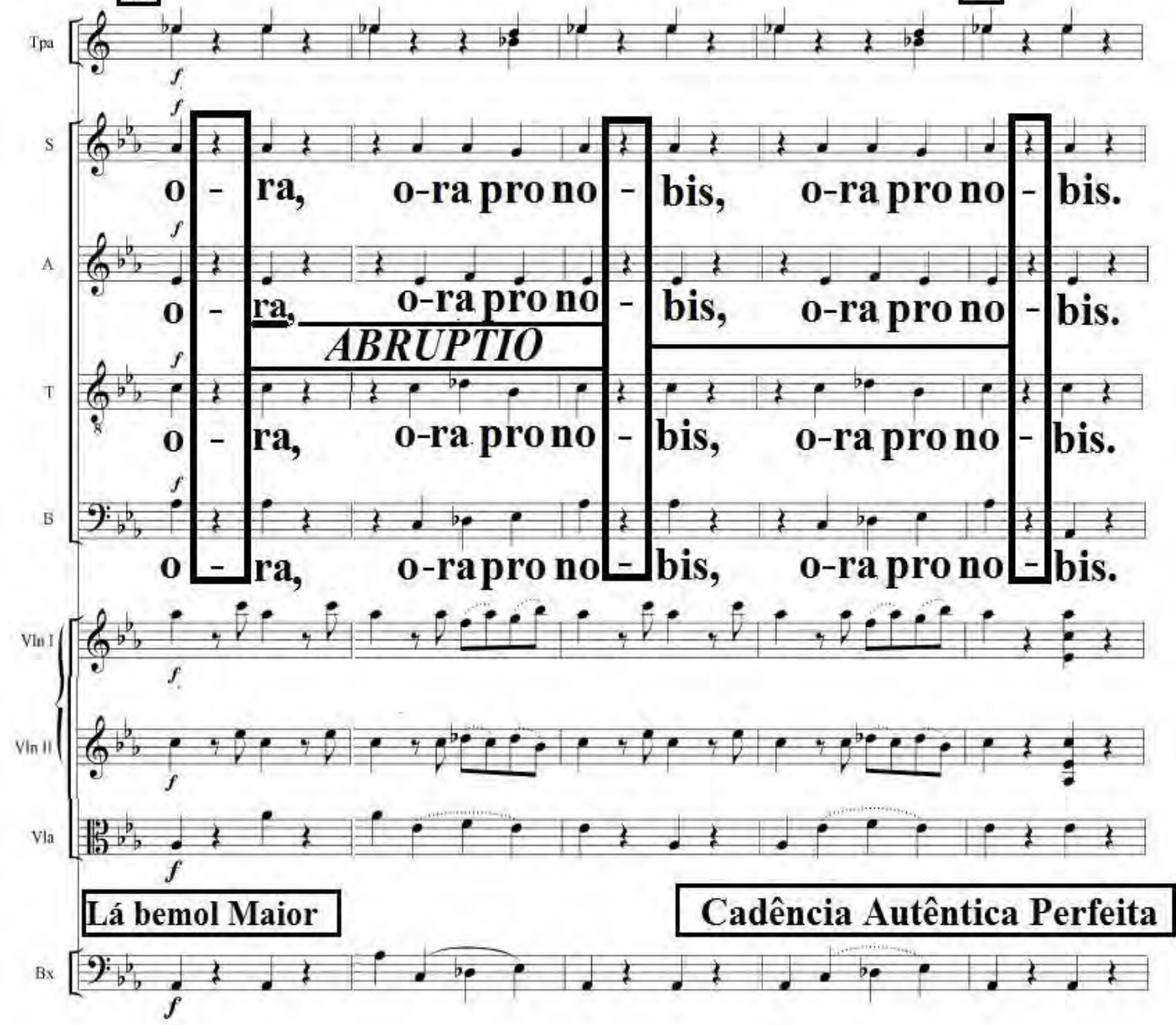

Exemplo 216-Abruptio na Sancta Dei Genitrix da Ladainha em Si bemol Maior, comp.43 e 47.

O texto do terceiro Responsório das Matinas do Sábado Santo, de Lobo de Mesquita, é baseado em duas passagens bíblicas: a primeira em Jeremias 25:34 e a segunda em Amós 8:9-11, ambas descrevem os momentos de profunda tristeza e angústia pelas quais passariam os judeus em seu exílio na Babilônia, por 70 anos. Para ressaltar esse fato o compositor aplica a Synaeresis, realçando a entoação de duas notas por sílaba e a Abruptio, interrompendo, de maneira inesperada e súbita, através de pausas, o final da frase Quia Venit (Porque Virá), nas vozes da soprano, contralto e tenor, enquanto o baixo continua a pronunciar a expressão dies (o dia). 


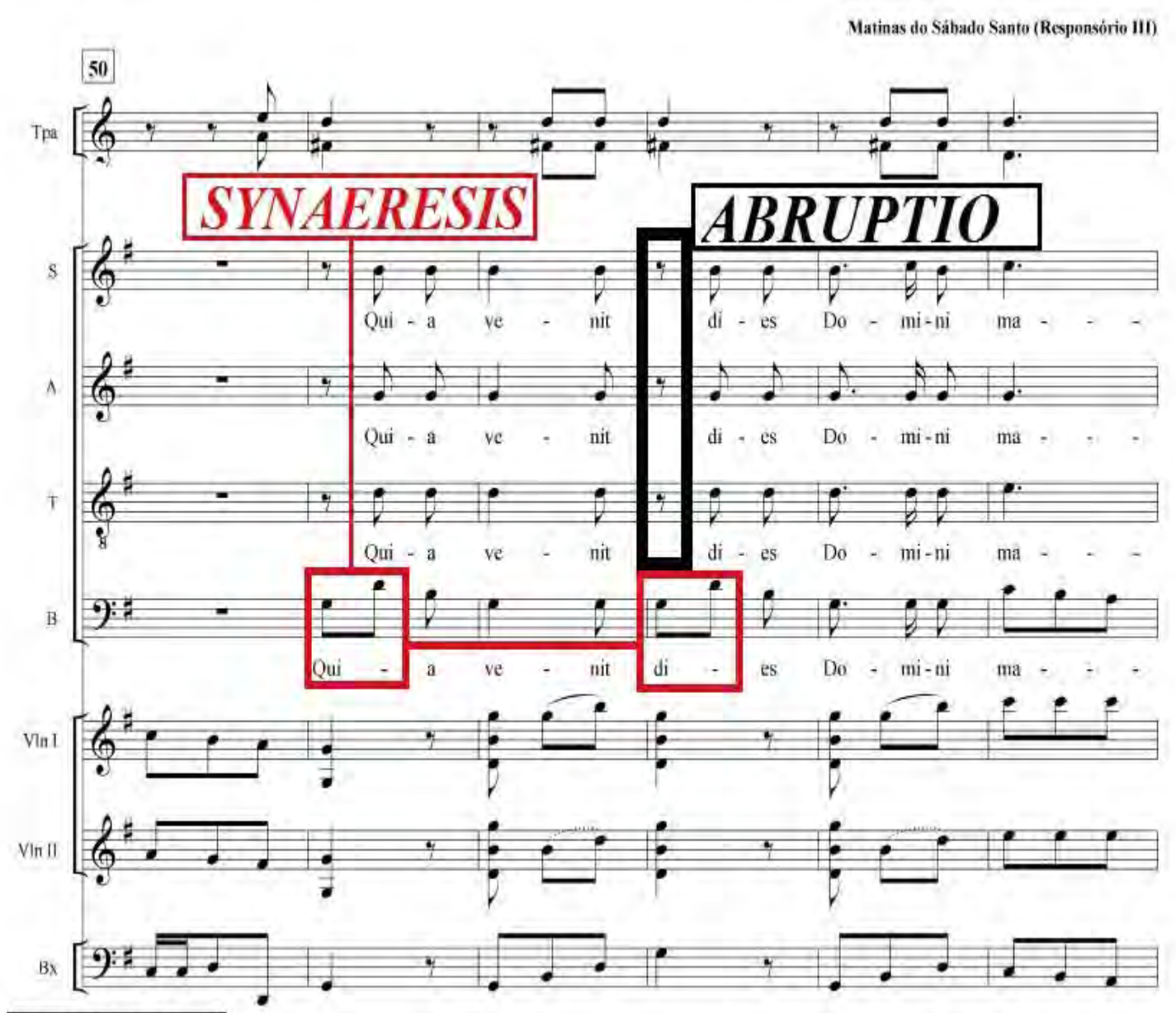

\section{Sol Maior}

Exemplo 217-Abruptio e Synaeresis no Responsório-III das Matinas do Sábado Santocomp.52.

No início da presente peça, é examinável o emprego da Synaeresis, no compasso 6, realçando a palavra Jerosolymam (Jerusalém), através da entoação do contralto e tenor de duas notas em uma sílaba. Também, da Aposiopesis no compasso 7, indicando a todas as vozes um momento de descanso, com conclusão numa Semicadência. Adicionado a isso, observa-se que essa figura retórica é usada pelo autor em antecipação à figura da Abruptio que, por sua vez, de maneira abrupta, interrompe a conexão da frase misit duos discipulus (enviou dois discípulos).

O outro elemento retórico a ser ressaltado é o da figura da Epizeuxis, a qual é aplicada para ratificar a expressão já proferida desde o compasso 9 , de que Jesus enviara dois de seus discípulos para encontrar a sua cavalgadura para montar. Semelhantemente, é destacável a recorrência da figura da 
Synaeresis na voz do baixo, no compasso 13. Enfim, todos os mecanismos retóricos são dispostos por Lobo de Mesquita em consonância com as funções harmônicas da Tônica, Subdominante, Dominante da Dominante e Dominante, resolvendo numa Semicadência, através de uma suspensão temporária da expressão discens (dizendo), gerando, assim, maior expectativa no ouvinte.

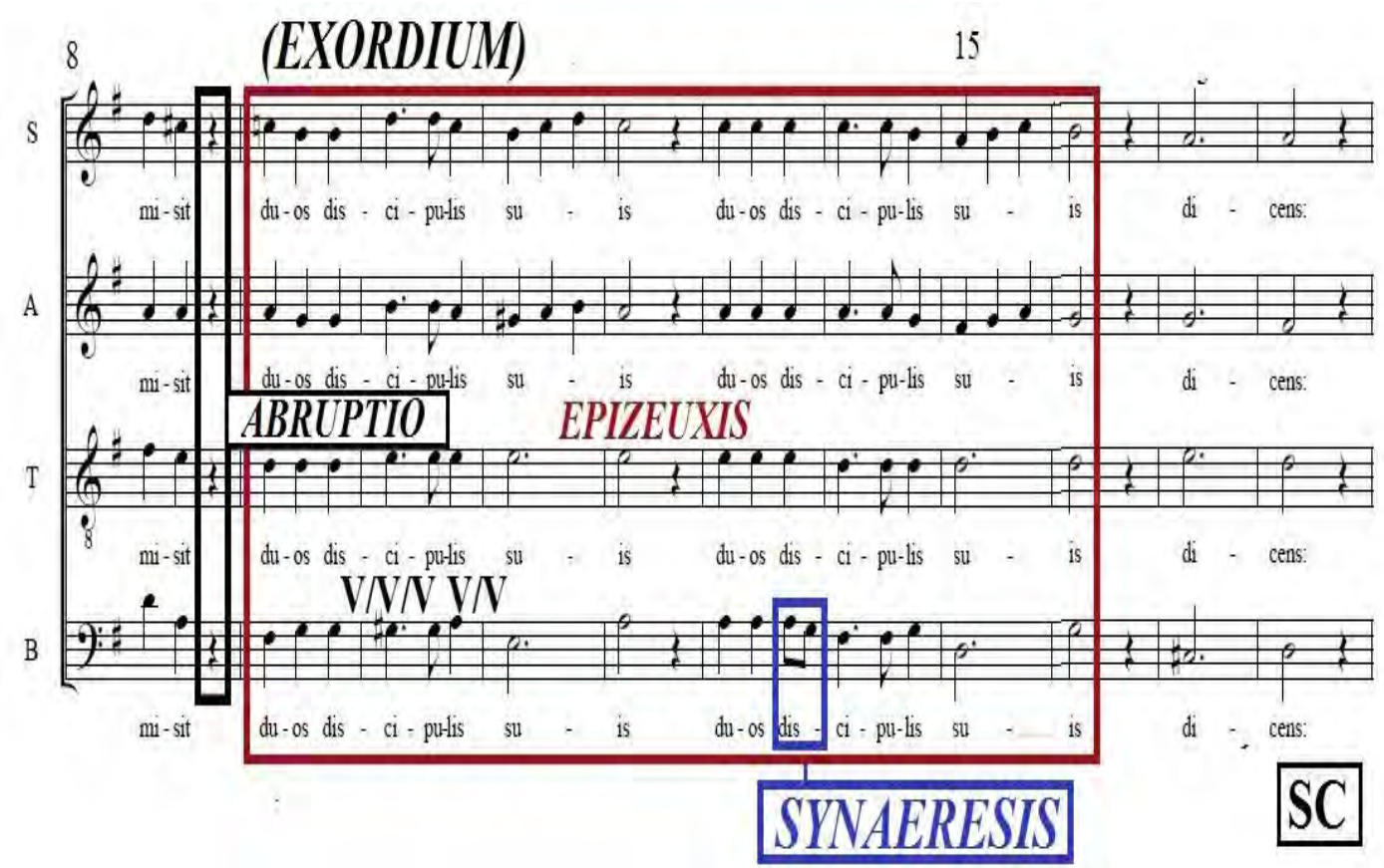

Exemplo 218-Abruptio, Epizeuxis e Synaeresis no Cum Appropinquaret- comp.8 a 16.

Na mesma obra, nota-se a utilização da Synaeresis nas vozes da soprano, contralto e tenor, entoando duas notas destacando a sílaba cas. Do mesmo modo, observa-se a predominância da Epizeuxis, aplicada por Lobo de Mesquita para realçar a expressão textual: ite in castellum, quod contra vos est (Ide à aldeia que está defronte de vós). 


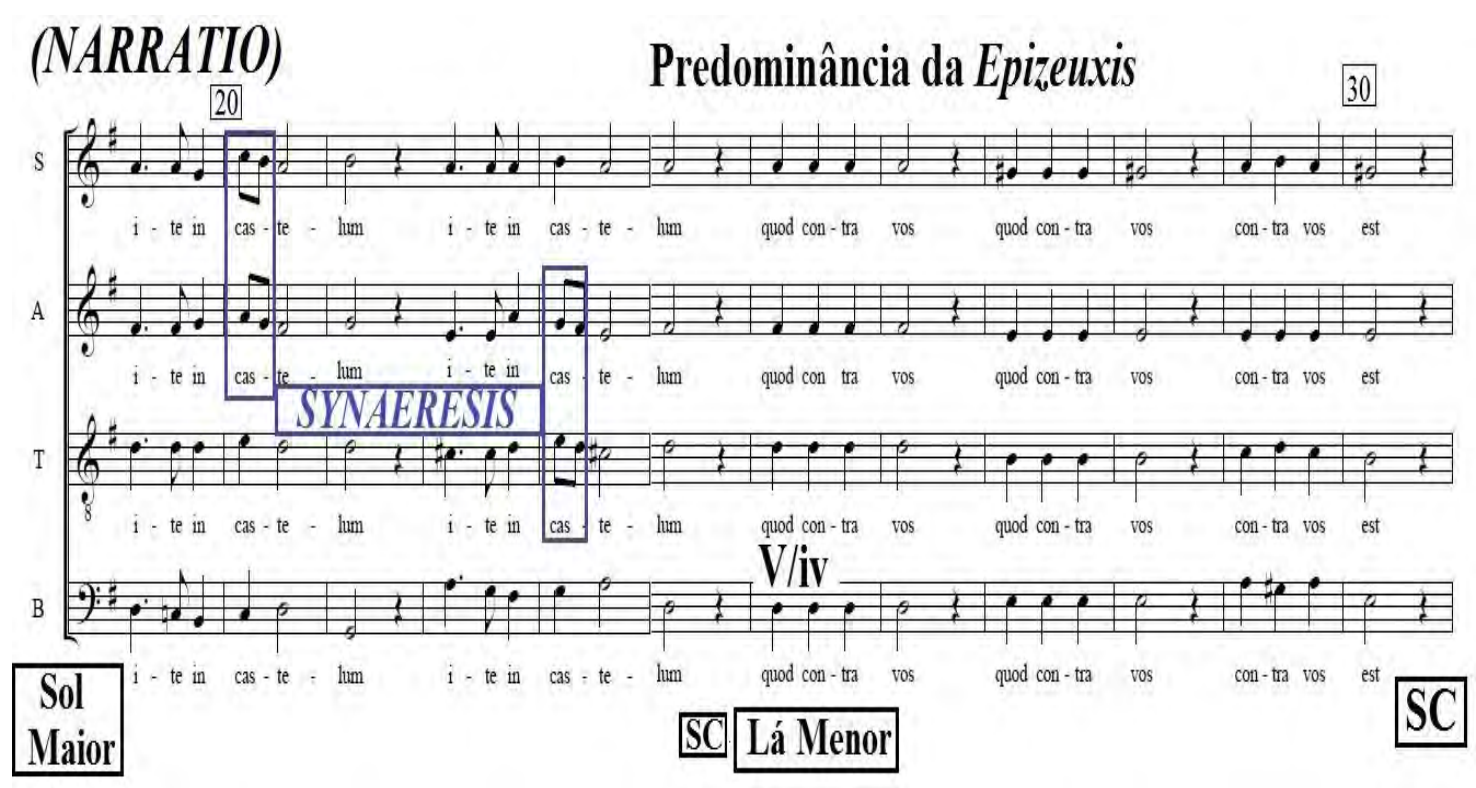

Exemplo 219-Epizeuxis e Synaeresis no Cum Appropinquaret- comp.20 a 30.

\section{- André da Silva Gomes}

No compositor luso-brasileiro também é verificável a recorrência de três figuras retóricas: Epizeuxis, Synaeresis e Palilogia, em suas obras. Por ser esse autor o mais examinado e estudado desde nosso mestrado, foram obtidos mais exemplos, entretanto, escolheram-se oito obras para melhor exemplificar o uso desse recurso retórico.

Silva Gomes, como profícuo conhecedor da disposição retórica no discurso musical, demonstra sua habilidade ao empregar a Epizeuxis e Synaeresis na repetição da frase In domum Domini íbimus (Vamos à casa do Senhor), estabelecendo, assim, não só uma reiteração das palavras ou dos motivos, mas uma junção com as funções harmônicas da Tônica, Subdominante e Dominante, resolvendo na Cadência Autêntica Perfeita. 


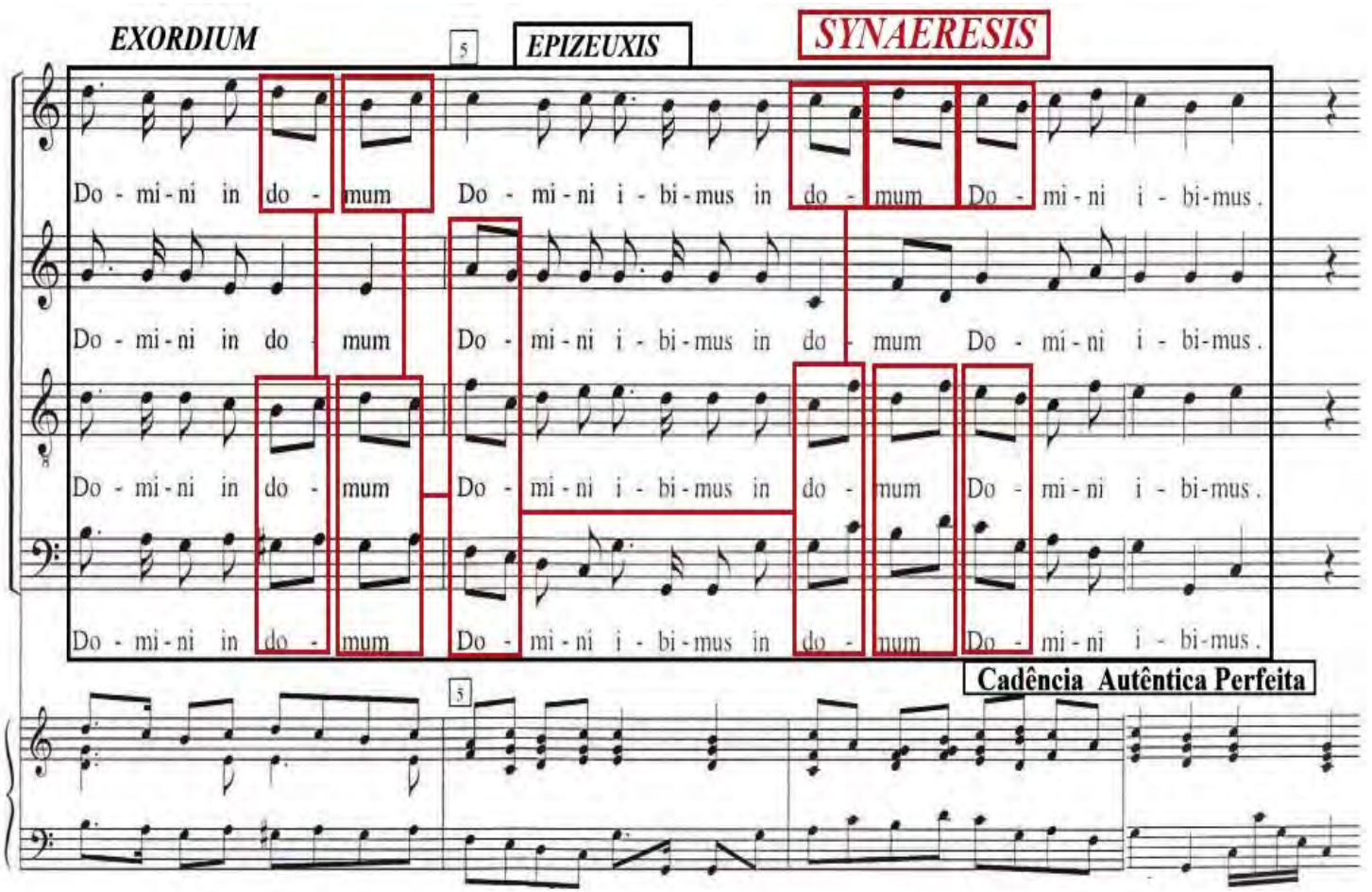

Exemplo 220-Epizeuxis e Synaeresis no Lætatus sum - comp. 4 a 7.

A confirmação do discurso no Ofertório da Missa de Quarta-feira de Cinzas realiza-se por intermédio de repetições enfáticas das notas e da palavra Domine (Senhor), configurando, dessa maneira, o uso da Epizeuxis.

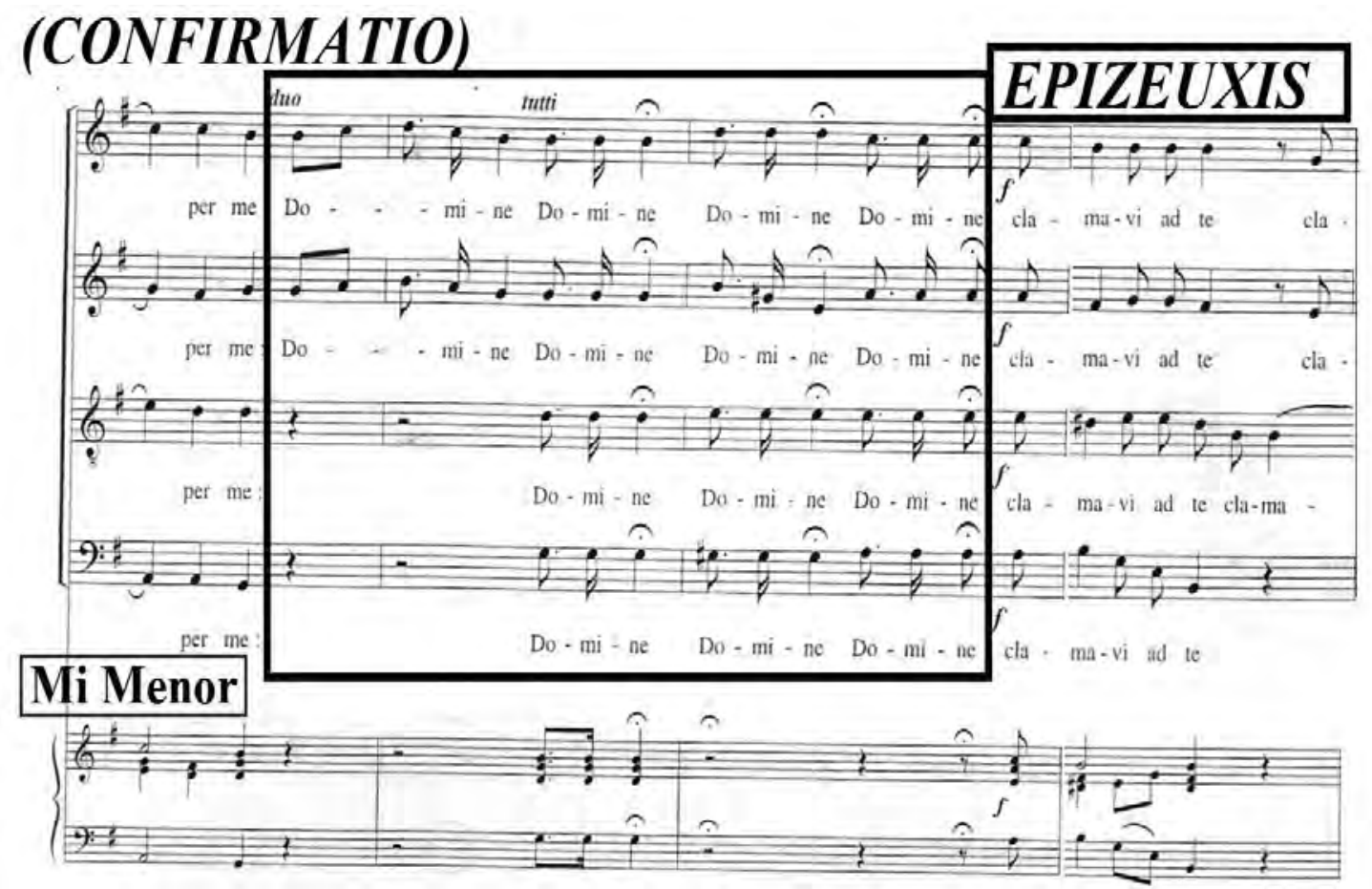

Exemplo 221-Epizeuxis no Ofertório da Missa de Quarta-feira de Cinzas-comp. 21 a 23. 
Ainda no Ofertório da Missa de Quarta-feira de Cinzas, pode-se notar o uso das três figuras mais recorrentes em André da Silva Gomes.

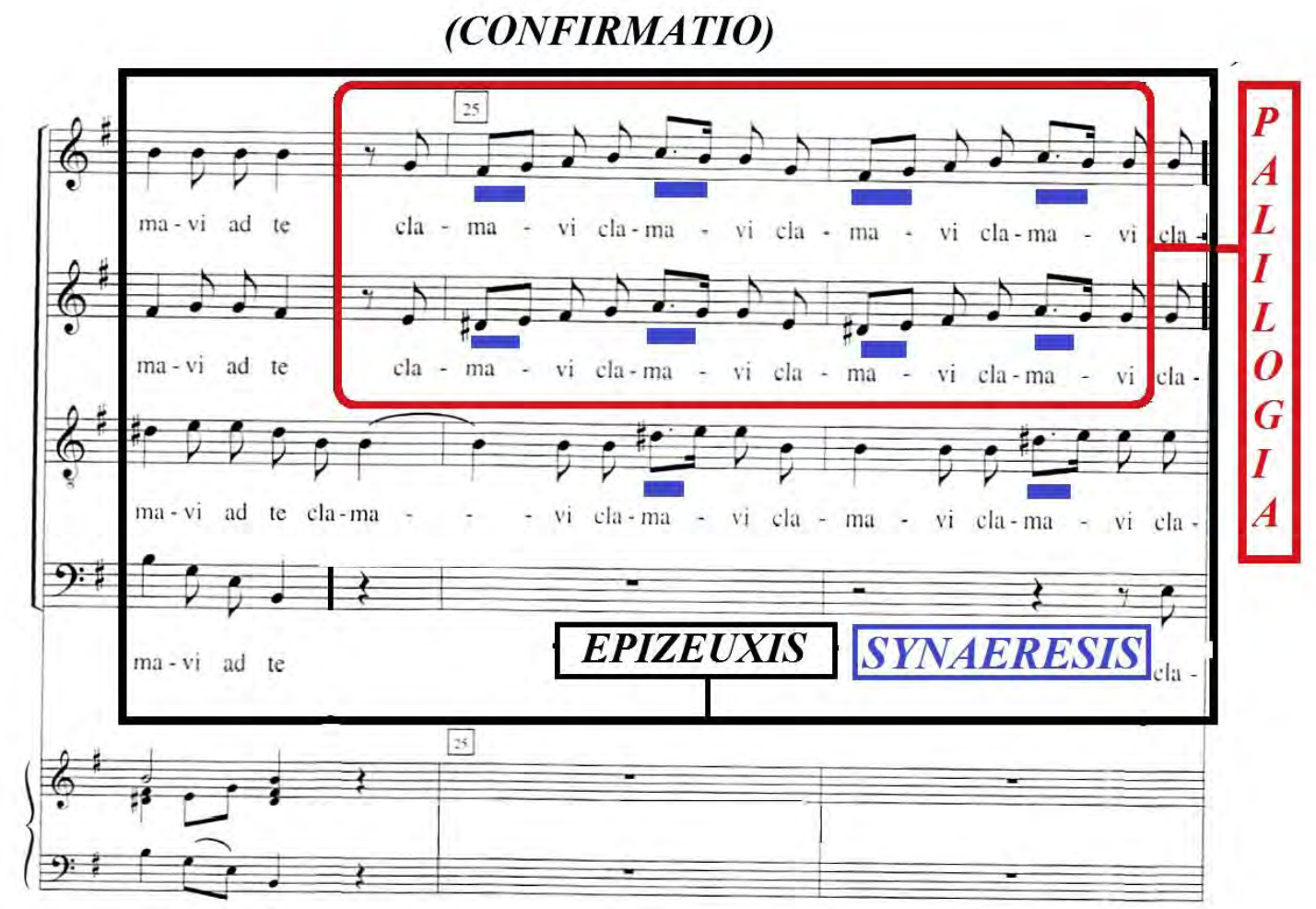

Exemplo 222-Epizeuxis, Palilogia e Synaeresis no Ofertório da Missa de Quarta-feira de Cinzas-comp. 24 a 26.

No início desse Ofertório, é visível a aplicação da Synaeresis e da Palilogia, ambas enfatizando as ornamentações, o solo da soprano, além do encerramento do Exordium na Cadência Autêntica Perfeita. 
(EXORDIUM)

Ofertório da Missa do Domingo da Paixão Cat. Daprat 052
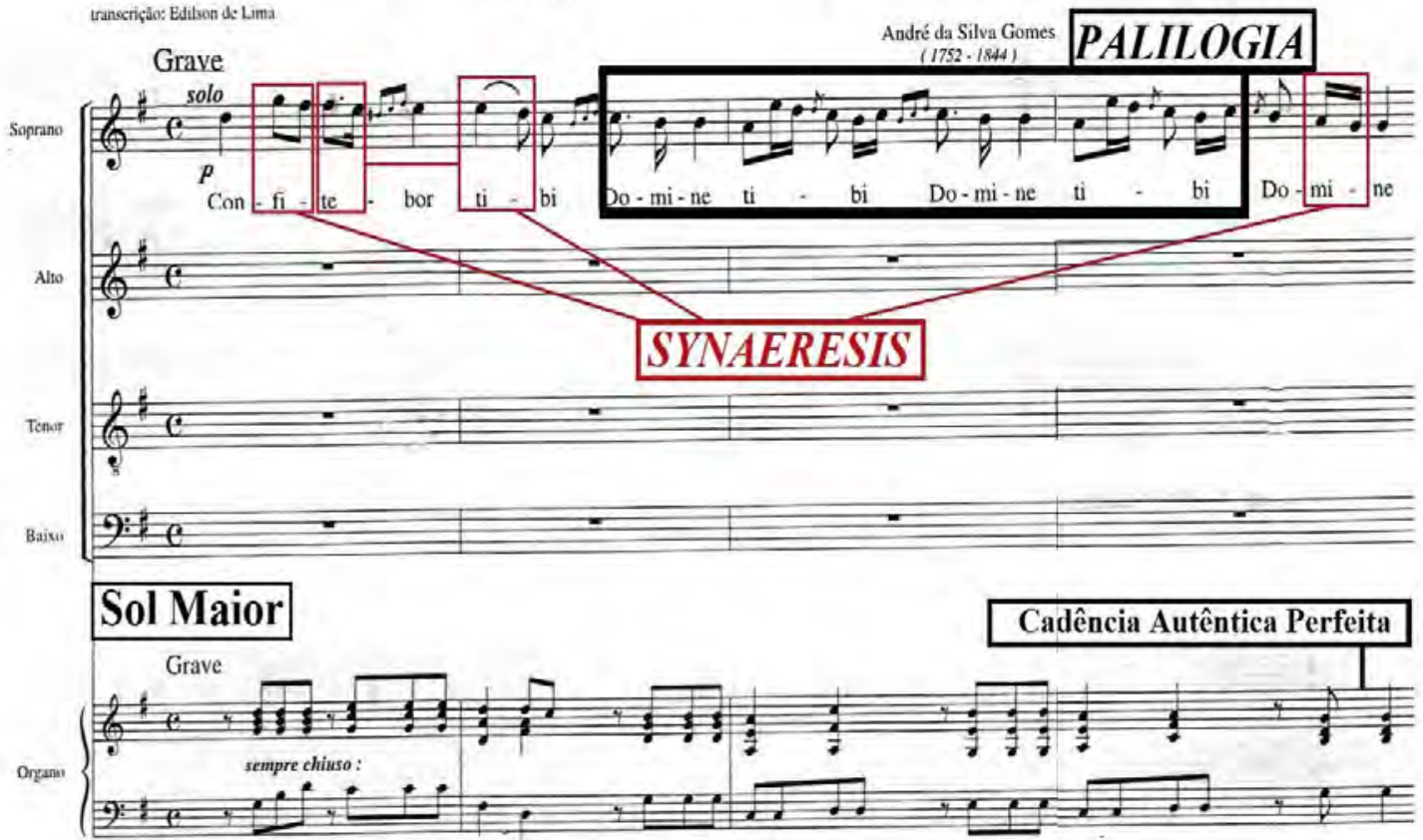

Exemplo 223-Synaeresis e Palilogia no Ofertório da Missa do Domingo da Paixão- comp. 1 a 4.

É tangível o predomínio da Synaeresis nessa parte do Ofertório da Missa do Domingo da Paixão, a qual é utilizada por Silva Gomes para ressaltar as numerosas funções harmônicas, como já salientado na análise no tópico 6.4.1, além das modulações de Mi Menor, Sol Maior e Dó Maior, além do afeto de gratidão, confiança e segurança. 

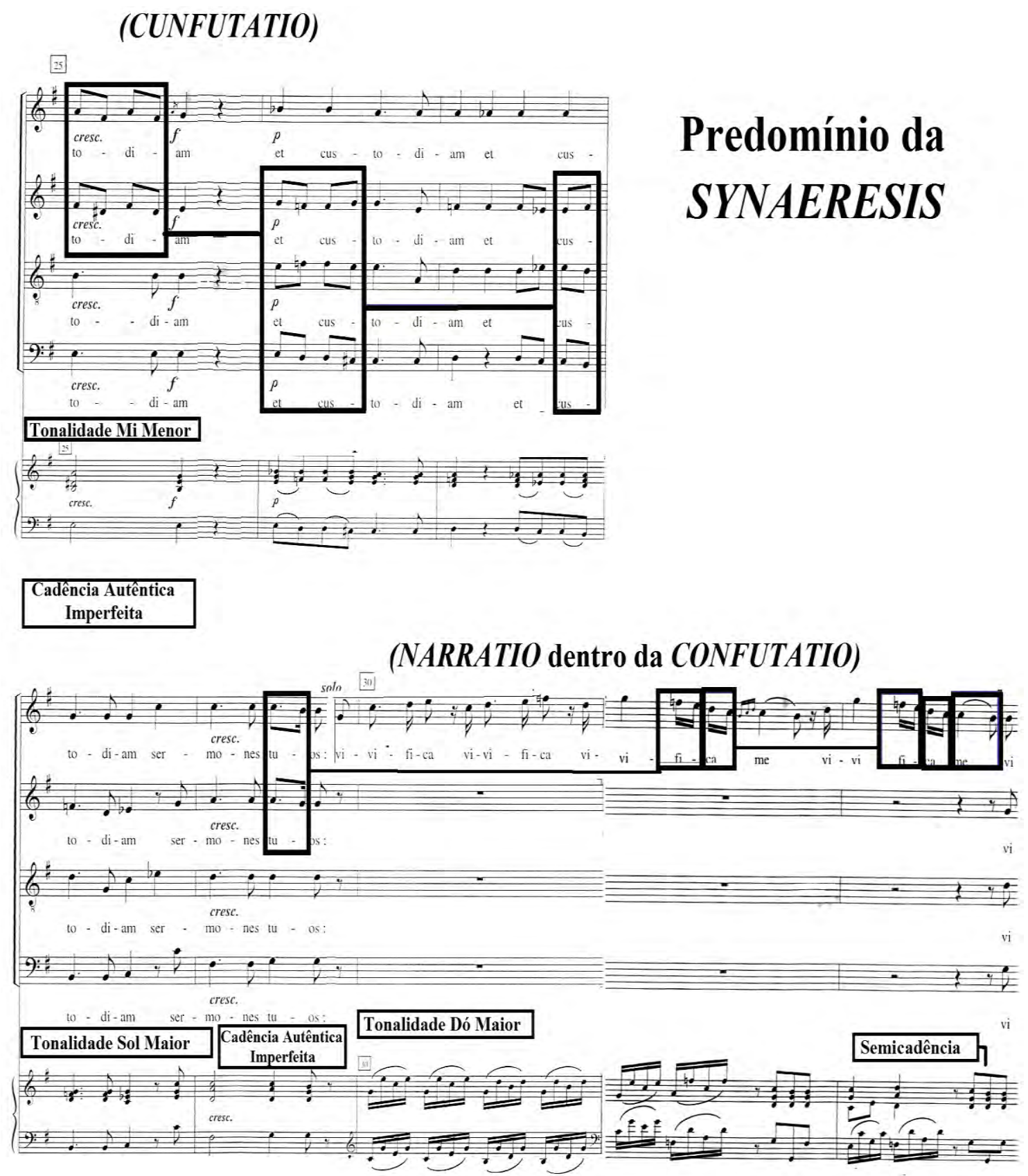

Exemplo 224-Synaeresis no Ofertório da Missa do Domingo da Paixão-comp. 25 a 32.

Através da expressão secundum verbum tuum (Segundo a tua palavra), verifica-se que a Epizeuxis é usada para confirmar a tese inicial do Ofertório da Missa do Domingo da Paixão de que somente pela obediência aos estatutos bíblicos pode-se herdar a vida eterna. Enfim, Silva Gomes, novamente mostrase sabedor do texto sacro e da liturgia cristã utilizando essa figura de repetição e ênfase, além da Synaeresis para reforçar tal premissa, na tonalidade de Sol Menor. 


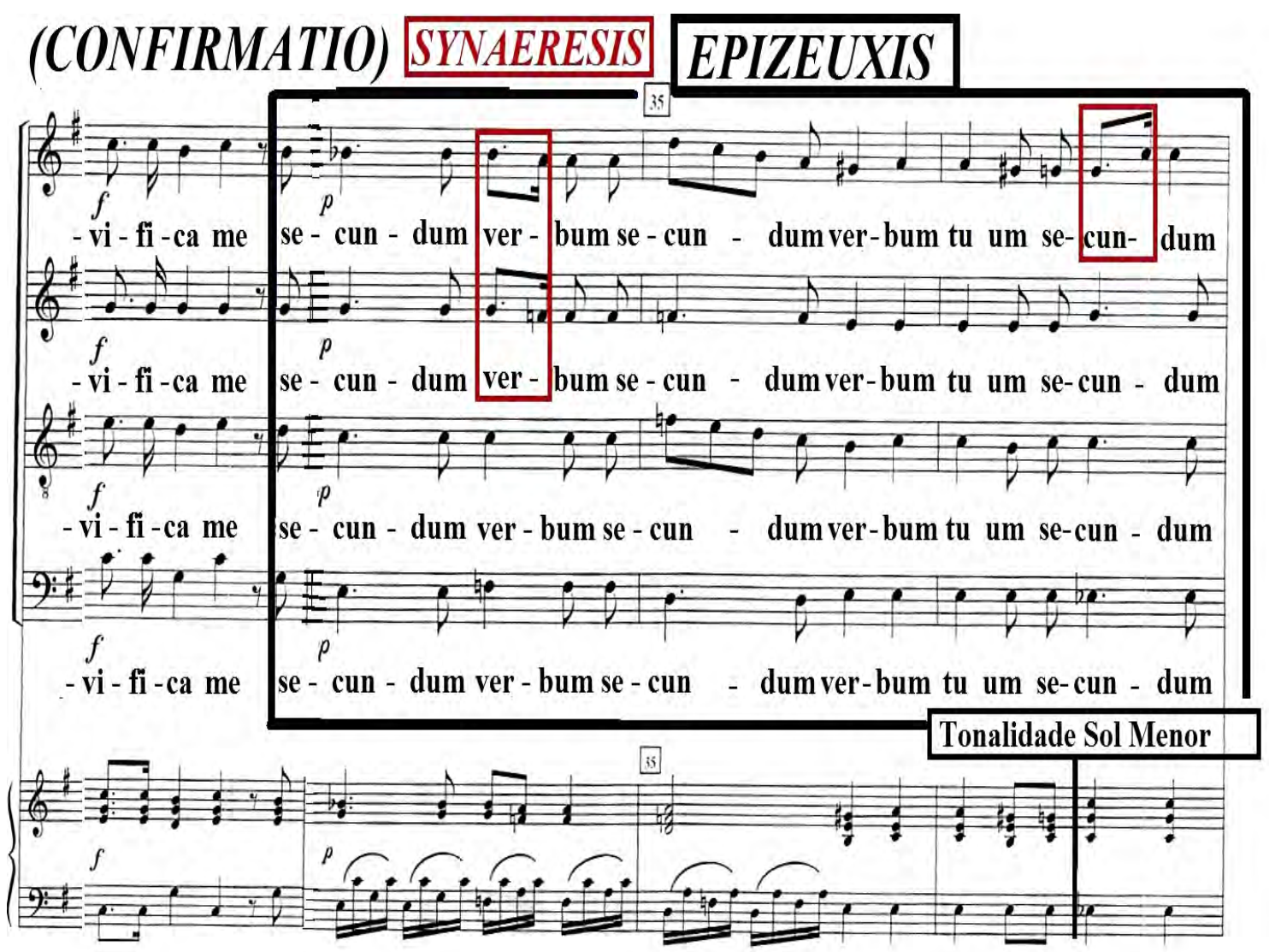

Exemplo 225-Epizeuxis e Synaeresis no Ofertório da Missa do Domingo da Paixão comp. 33 a 37.

Observa-se, nessa peça, a utilização da Synaeresis e da Palilogia, as quais destacam por meio do deslocamento de duas notas numa sílaba, em todas as vozes, além da repetição melódica, tanto o afeto de louvor e júbilo Laudate Dominum (Louvai ao Senhor), valorando a mudança de tonalidade, como a inserção da Cadência Plagal. 
(EXORDIUM dentro da PROPOSITIO)

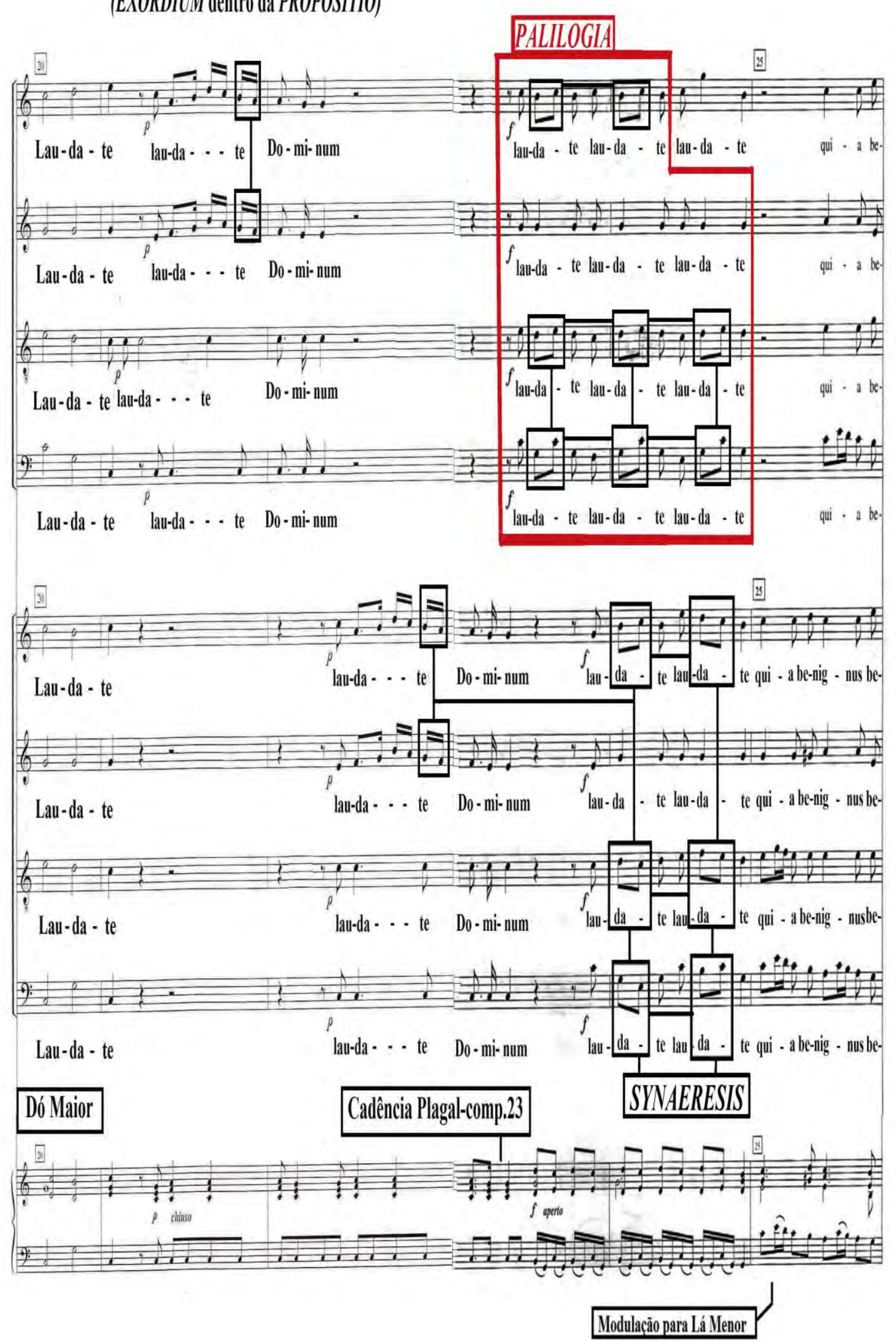

Exemplo 226-Synaeresis e Palilogia no Ofertório da Missa do $4^{\circ}$ Domingo da Quaresmacomp. 21 a 25. 
A Epizeuxis é empregada em todas as oito vozes, com o propósito de realçar a frase Psalite Domino (Cantai/Louvai ao Seu nome). De igual modo, a Synaeresis é aplicada pelo compositor luso-brasileiro, para evidenciar essa reiteração por meio das duas notas numa sílaba, nas vozes da soprano e contralto. Além disso, verifica-se a mudança da tonalidade Lá Menor para Dó Maior.

\section{(CONFUTATIO) EPIZEUXIS}

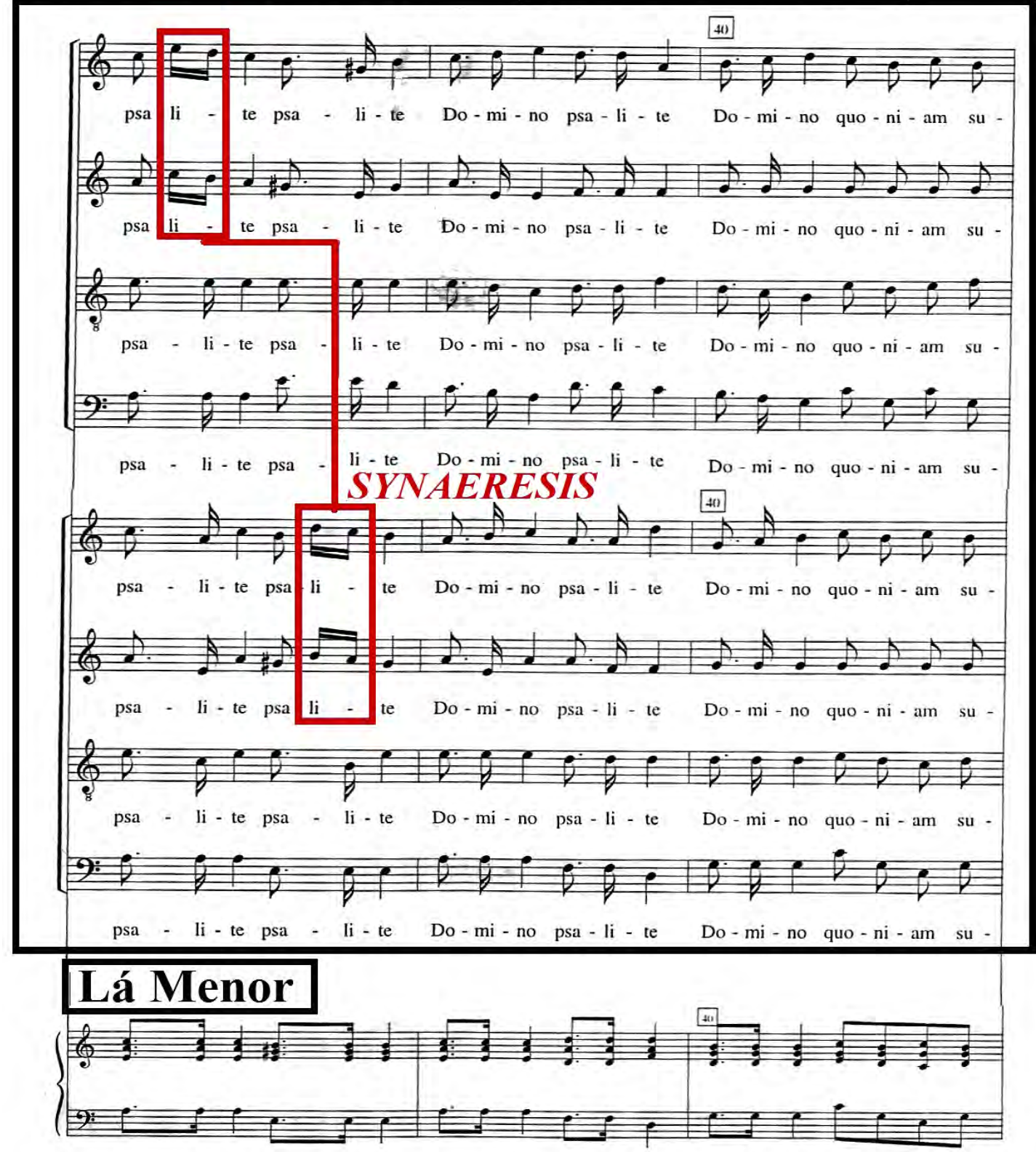

\section{Modulação para Dó Maior}

Exemplo 227-Epizeuxis e Synaeresis no Ofertório da Missa do $4^{\circ}$ Domingo da Quaresmacomp. 38 a 40. 
No Gratias, da Missa em Dó, é tangível a utilização da Epizeuxis em todas as vozes, por parte do autor, onde as palavras magnam gloriam tuam (por tua grande glória), são reiteradas por meio de repetição. Além disso, notase o emprego da Synaeresis nos compassos 11 e 13.

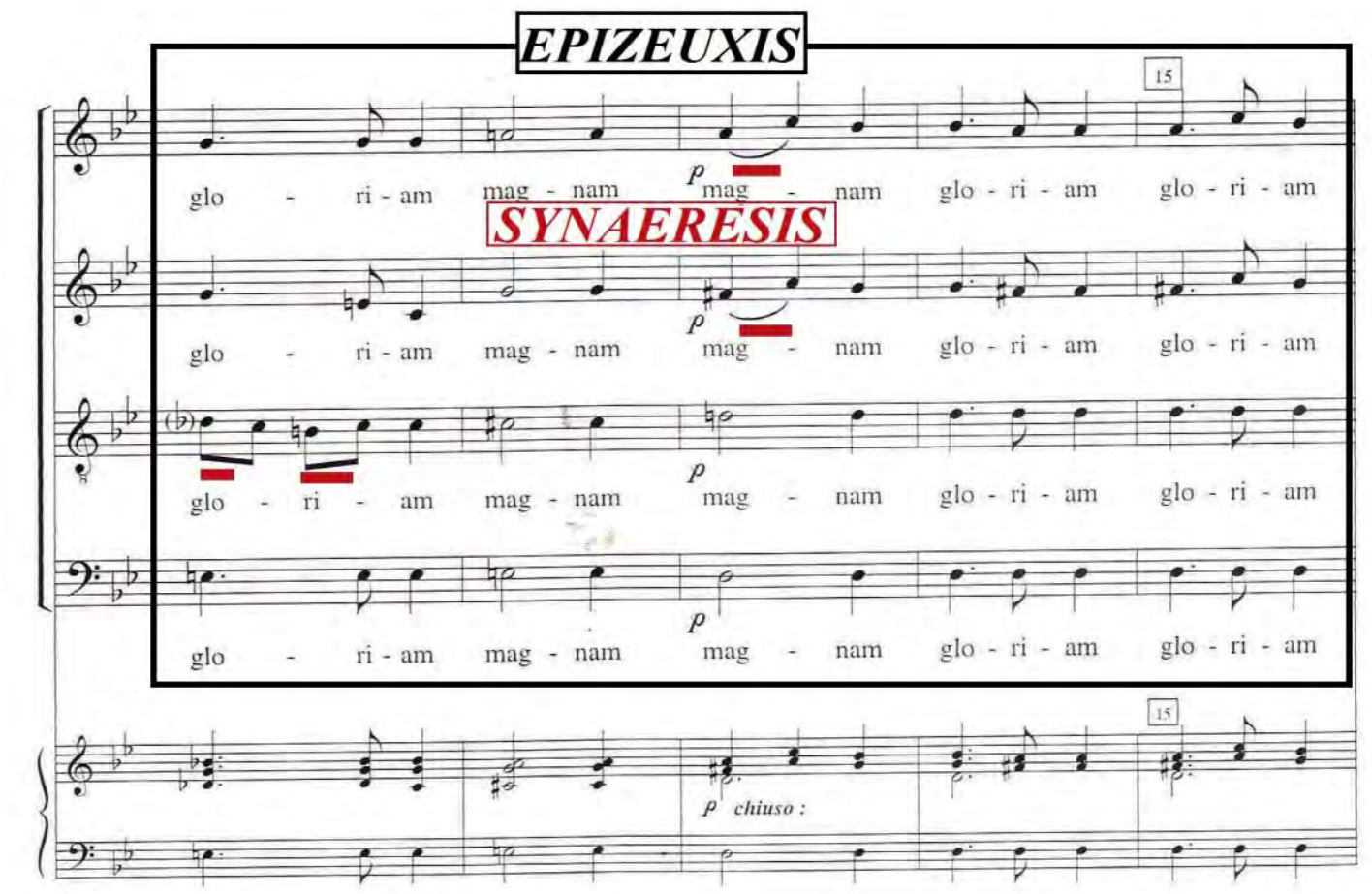

Exemplo 228-Epizeuxis e Synaeresis no Gratias da Missa em Dó- comp.11 a 15.

$\mathrm{Na}$ mesma obra, André emprega de forma recorrente as figuras supracitadas, porém ao invés de usar uma dinâmica piano como nos compassos anteriores, ele opta por ressaltar a linha fraseológica com a dinâmica forte, intensificando o afeto de exultação. 


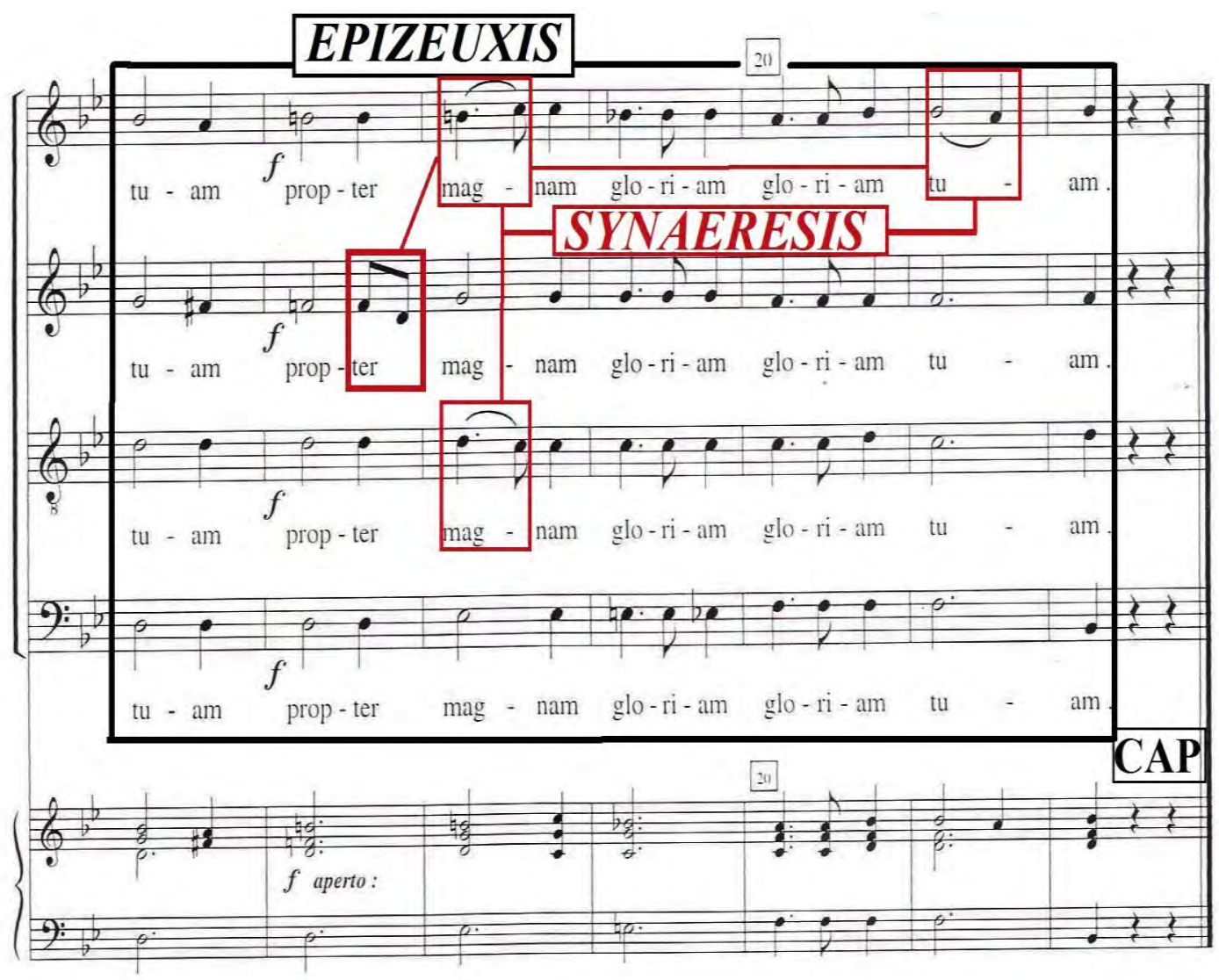

Exemplo 229-Epizeuxis e Synaeresis no Gratias da Missa em Dó- comp.16 a 22.

Silva Gomes utiliza a Epizeuxis para repetir enfaticamente a expressão lætabitur (regozijar-se, alegrar-se). Da mesma forma, a Synaeresis é empregada para ressaltar a voz do contralto, a qual entoa duas notas melódicas na mesma silaba, no compasso 22. 


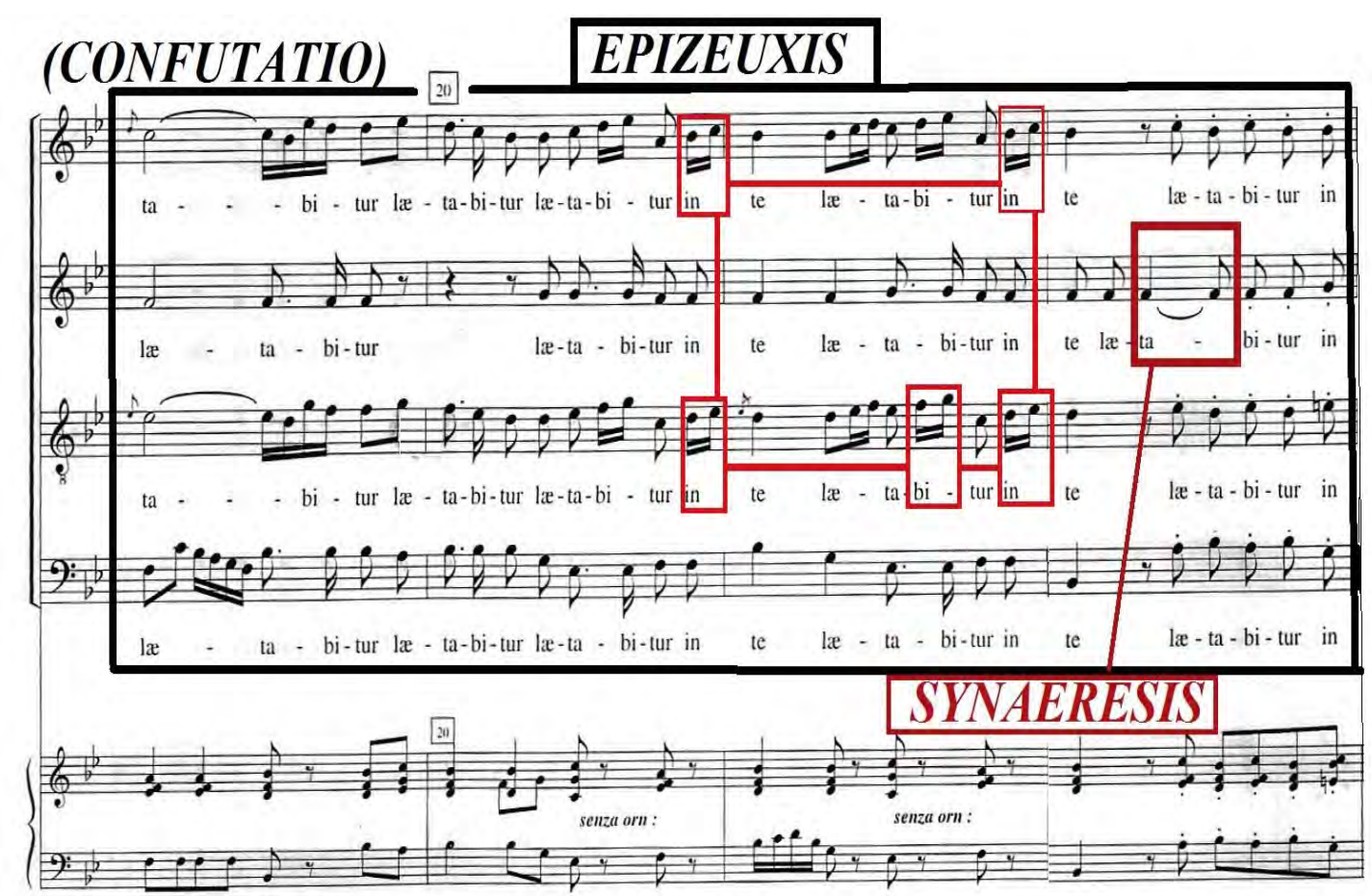

\section{Si bemol Maior}

Exemplo 230-Epizeuxis e Synaeresis no Ofertório da Missa do $2^{\circ}$ Domingo do Adventocomp.19 a 22.

Entre os compassos 4 e 11, é evidente o uso da Epizeuxis e da Synaeresis, realçando o chamamento do salmista para que os céus e a terra possam exultar o Senhor por sua vinda, exsultet terra, representando o afeto de satisfação e júbilo. Os elementos retóricos utilizados nesse excerto, tal como as funções harmônicas, foram trabalhados por Silva Gomes em consonância ao texto sacro apresentado, de modo a chamar a atenção do ouvinte, seja pela ênfase, repetição ou na ênfase das expressões pronunciadas melodicamente. 


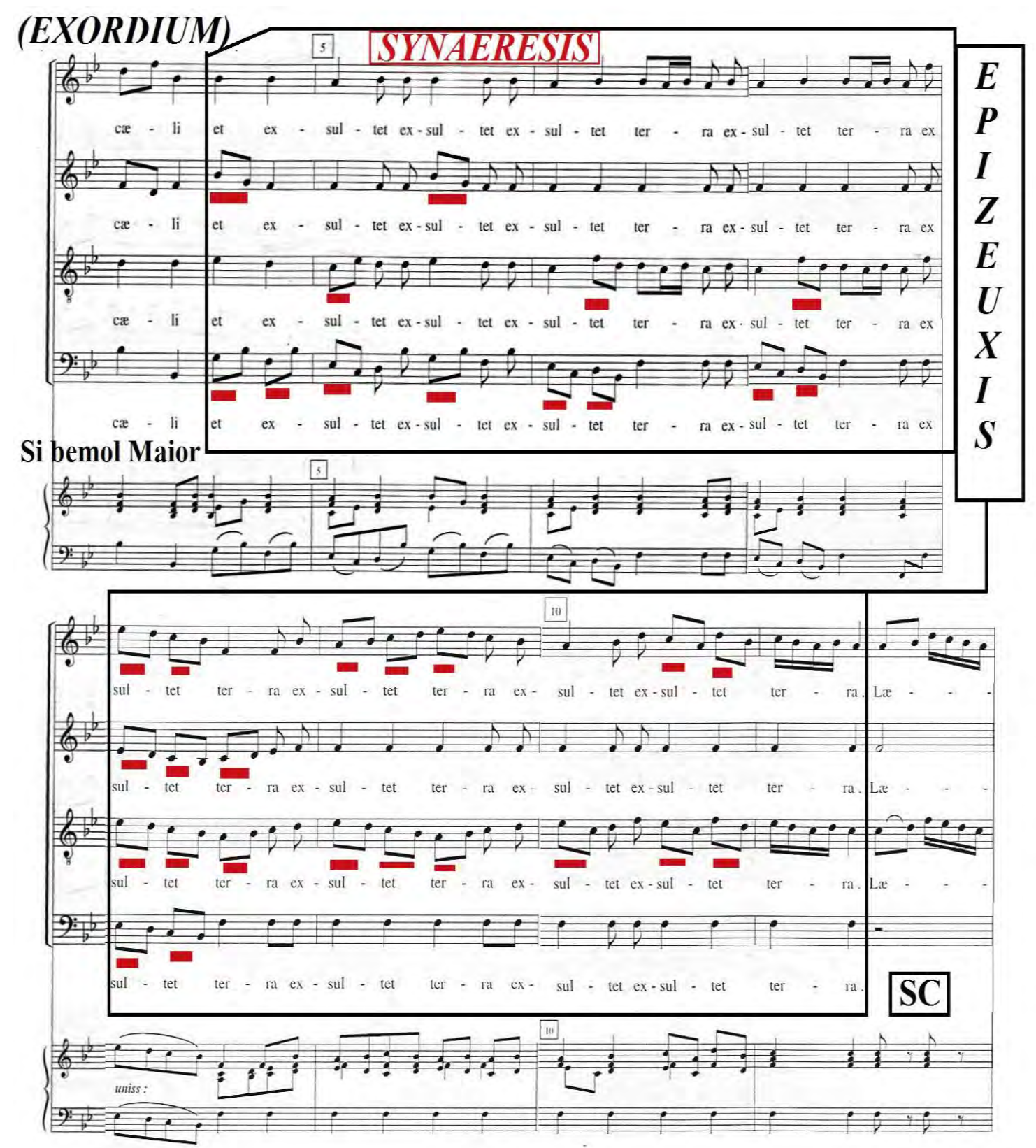

Exemplo 231-Epizeuxis e Synaeresis no Ofertório da Missa de Natal (1 Movimento)comp.4 a 11.

No compasso 10, Silva Gomes utiliza a Synaeresis, para destacar a passagem homofônica, assim como a expressão ante faciem Domini (ante a face do Senhor), a qual interpreta duas notas por sílaba e, por fim, as funções harmônicas da Tônica, Subdominante Paralela (Relativa), Dominante e Dominante da Subdominante Paralela (Relativa), com o propósito de persuadir o ouvinte. 


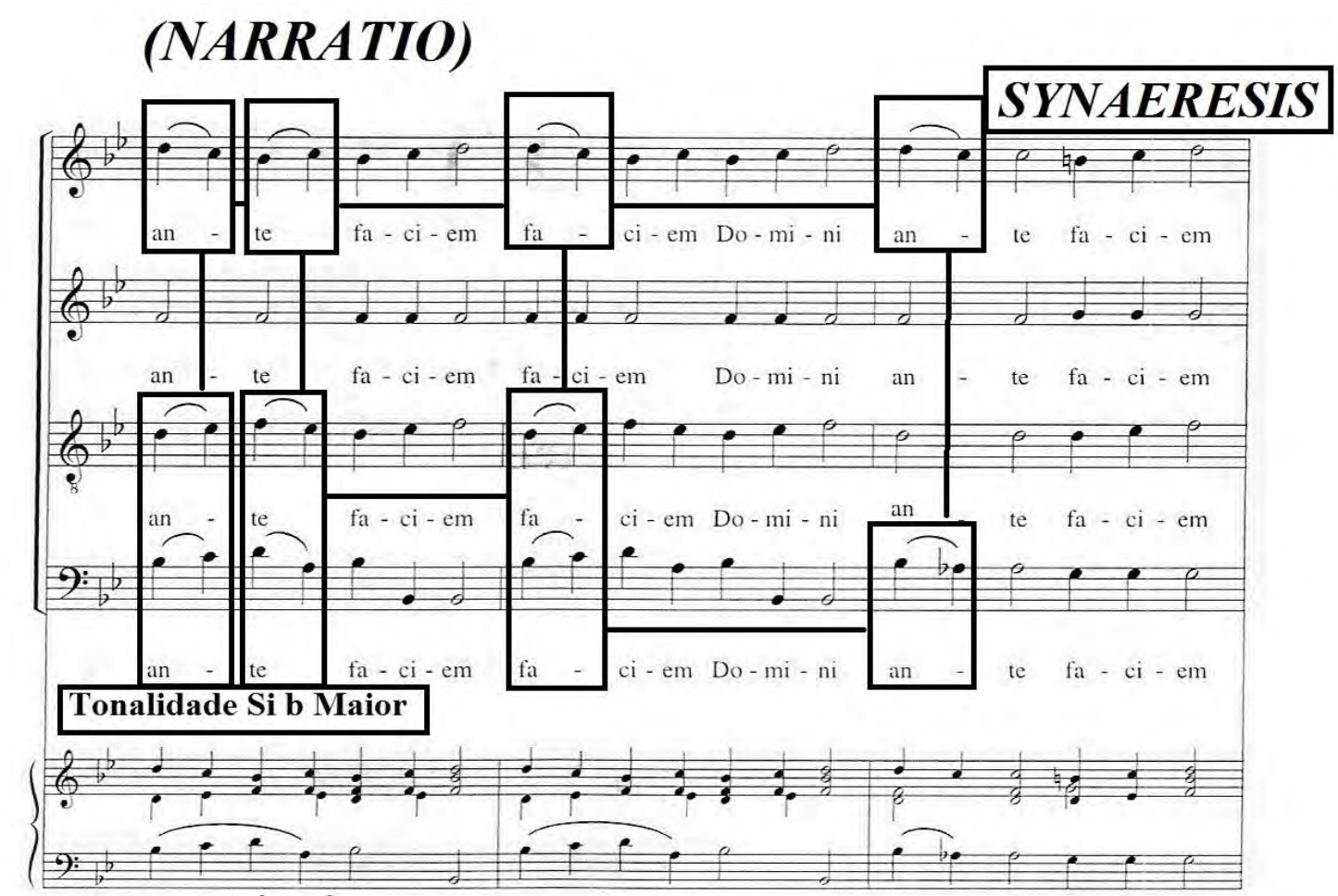

Exemplo 232-Synaeresis no Ofertório da Missa de Natal ( $2^{\circ}$ Movimento)- comp.16 a 18.

É verificável o predomínio da Epizeuxis, além da empregabilidade da Palilogia, enfatizando através de repetição das mesmas notas e palavras, a frase quoniam venit (pois ele vem).

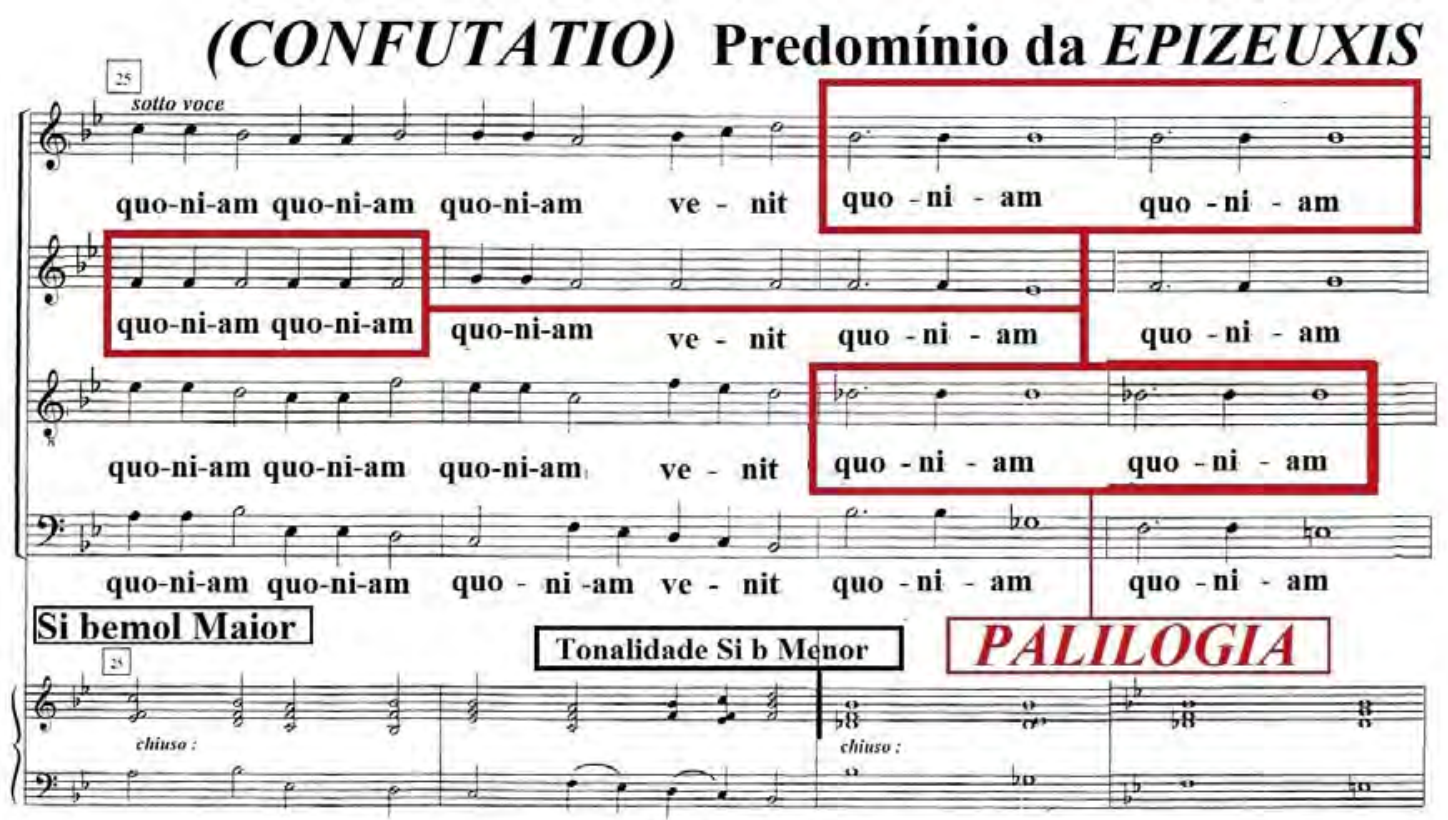

Exemplo 233-Palilogia e Epizeuxis no Ofertório da Missa de Natal ( $2^{\circ}$ Movimento)comp.27 e 28 . 
No Gloria da Missa em Dó, verifica-se o uso da Synaeresis, executado pela soprano e tenor, enfatizando a expressão bonæ vonutatis (boa vontade).

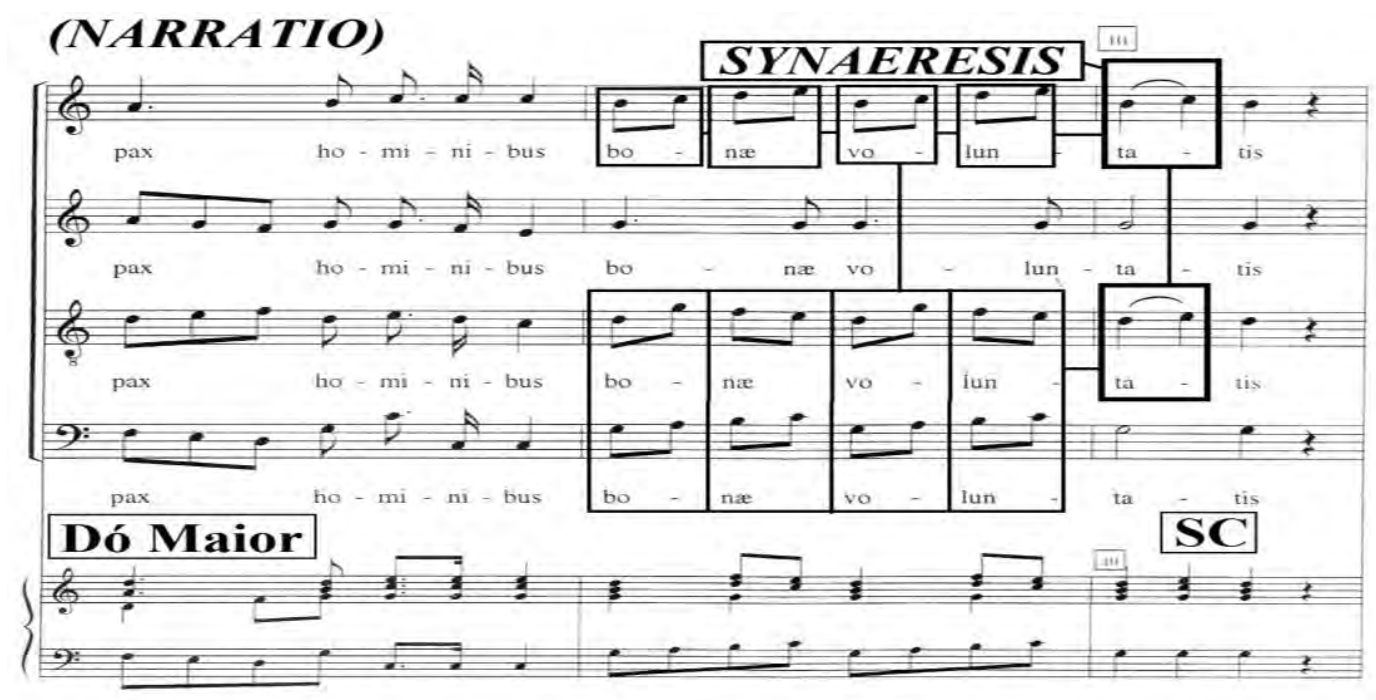

Exemplo 234-Synaeresis no Gloria da Missa em Dó- comp.10.

O Laudate Pueri tendo seu texto embasado em Salmos 112/113, denota que o Senhor deve ser evocado como o maior e mais digno objeto de louvor. Observa-se que André da Silva Gomes usa a Epizeuxis, Palilogia e Synaeresis, ou seja, as mais recorrentes, no início da obra para destacar esse afeto de devoção e júbilo, dando ênfase à expressão laudate (louvem).

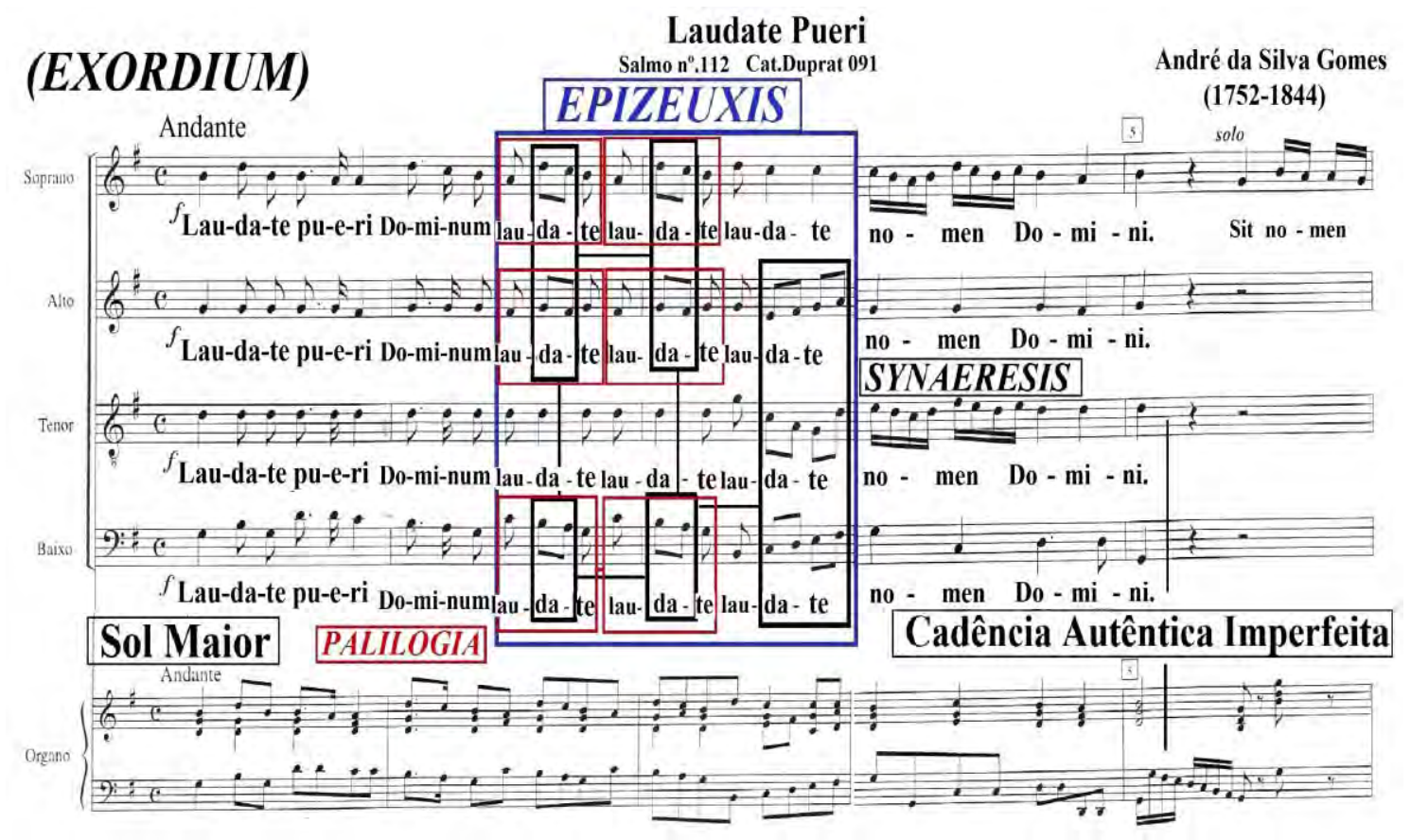

Exemplo 235-Epizeuxis, Palilogia e Synaeresis no Laudate Pueri- comp.2 e 3. 


\section{- José Maurício Nunes Garcia}

Observaram-se como figuras mais recorrentes nas obras analisadas de José Maurício, a Aposiopesis, o Polyptoton e a Synaeresis.

Nesse exemplo, é observável a utilização do Aposiopesis com a Synaeresis, onde a primeira figura submete todas as vozes a um silêncio. Por sua vez, a segunda figura entoa duas na mesma sílaba, destacando as dinâmicas, as palavras, além das funções harmônicas.

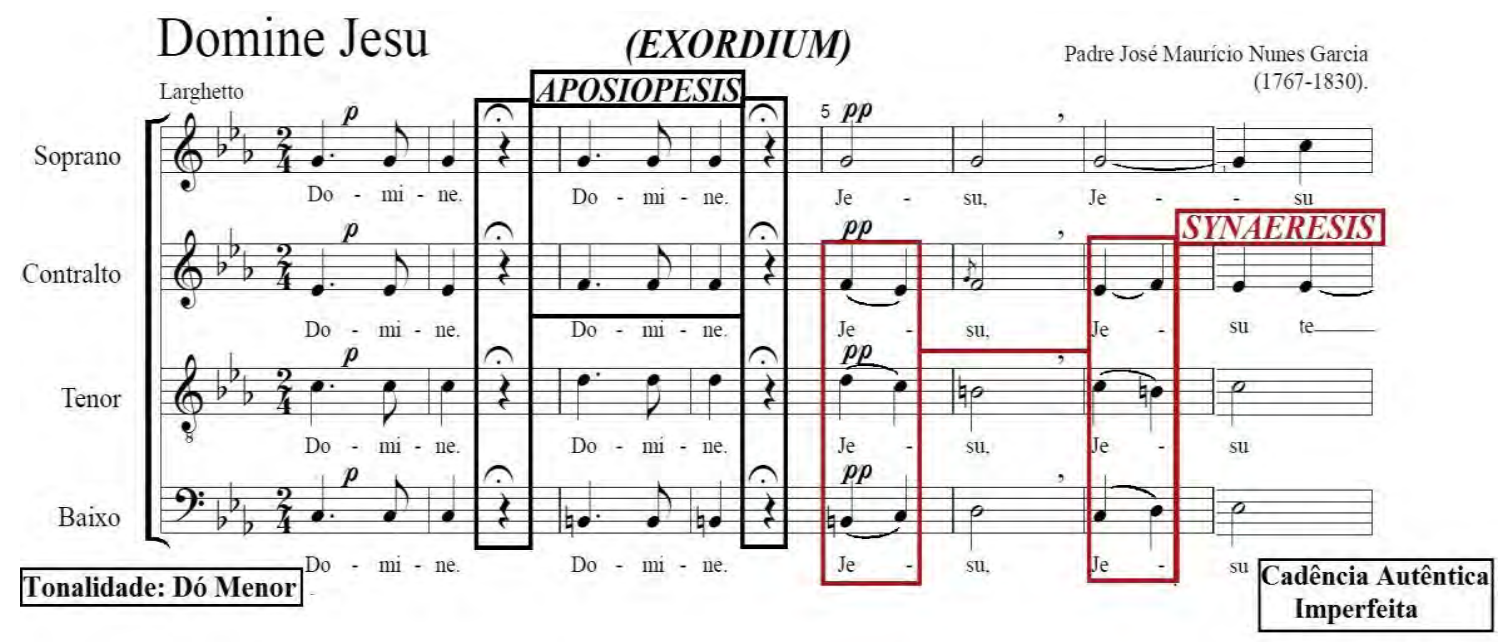

Exemplo 236-Aposiopesis e Synaeresis no Domine Jesu- comp.2 a 7.

Mediante um diálogo, a narração dos fatos iniciais é instaurada em virtude do diálogo estabelecido entre as vozes da soprano e do contralto, repetindo a expressão te desidero (te desejo) em alturas diferentes, configurando assim um Polyptoton. Igualmente, verifica-se que essa figura é usada para enfatizar a sequência de quintas entre os compassos 9 e 16 . Também é observável o uso da Synaeresis, no compasso 16, com resolução numa Semicadência. 


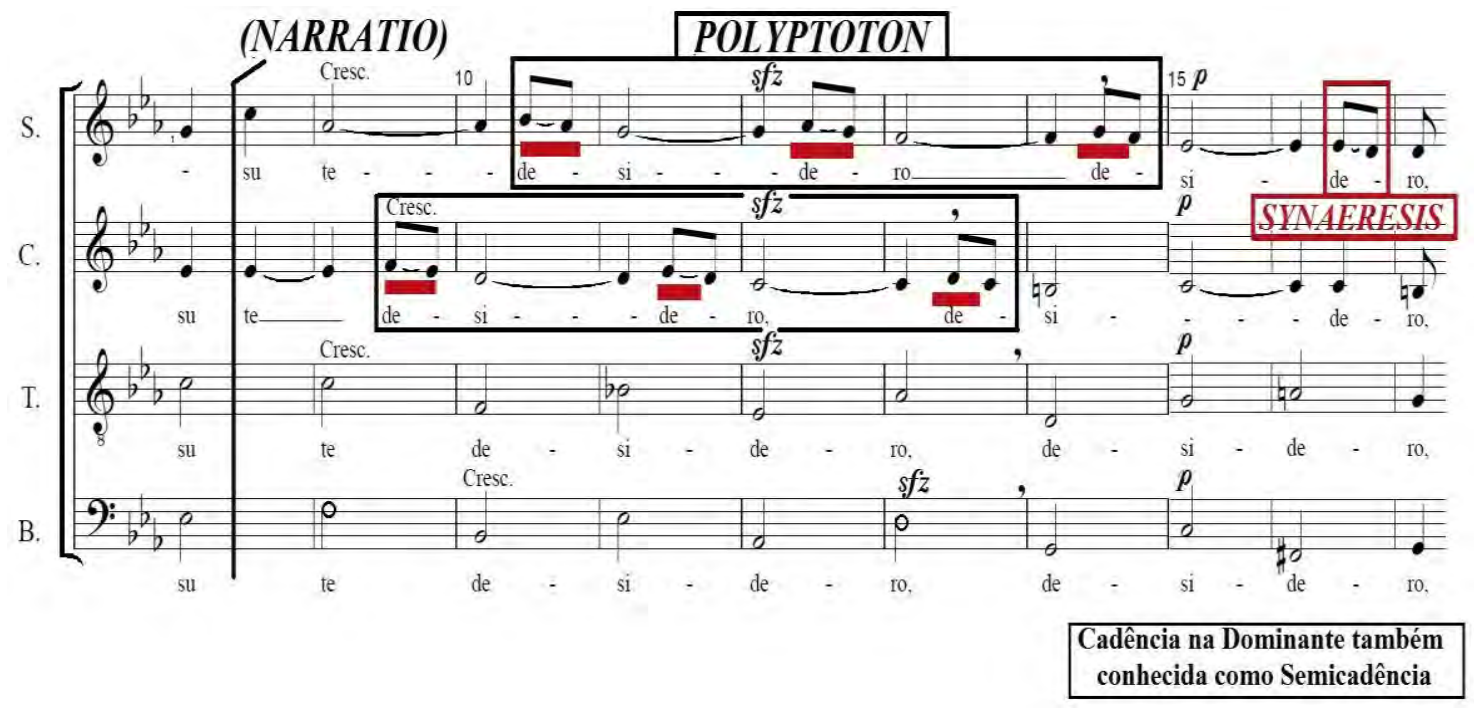

Exemplo 237-Polyptoton e Synaeresis no Domine Jesu- comp.9 a 16.

Ainda no Domine Jesu, verifica-se, nessa passagem homofônica, a aplicação da Synaeresis nos compassos 23 e 25 e da Aposiopesis, tanto enfatizando a frase: Ostende mihi faciem tuam (Mostra-me a Tua face), mediante a entoação de duas notas por sílaba, igualmente, o momento de silêncio imposto pela pausa geral a todas as vozes, bem como as duas mudanças de tonalidade.

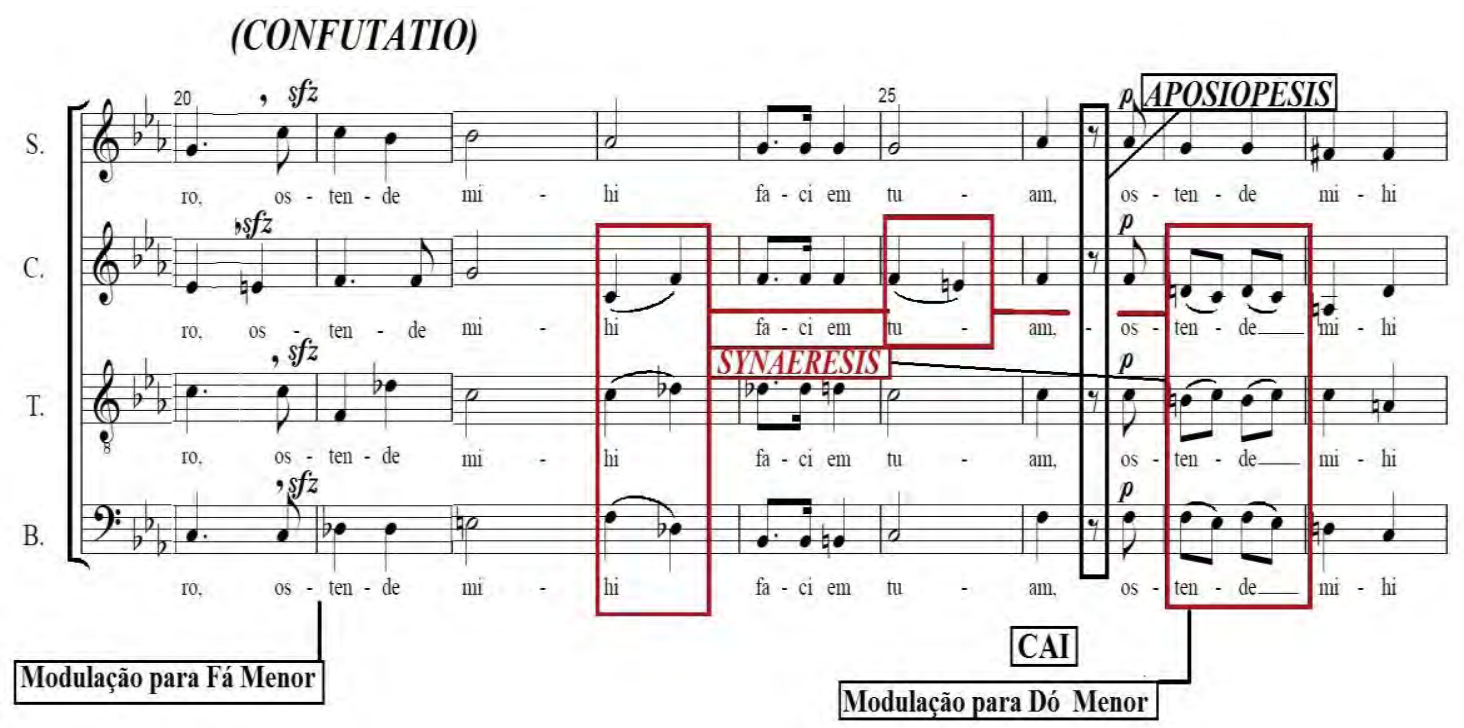

Exemplo 238-Synaeresis e Aposiopesis no Domine Jesu- comp.23 a 27. 
No começo da peça, nota-se que a expressão Crux fidelis (Ó cruz fiel) é repetida por três vezes. Igualmente, essa frase é interrompida por meio de uma pausa geral, em todas as vozes, o que configura o uso da Aposiopesis.

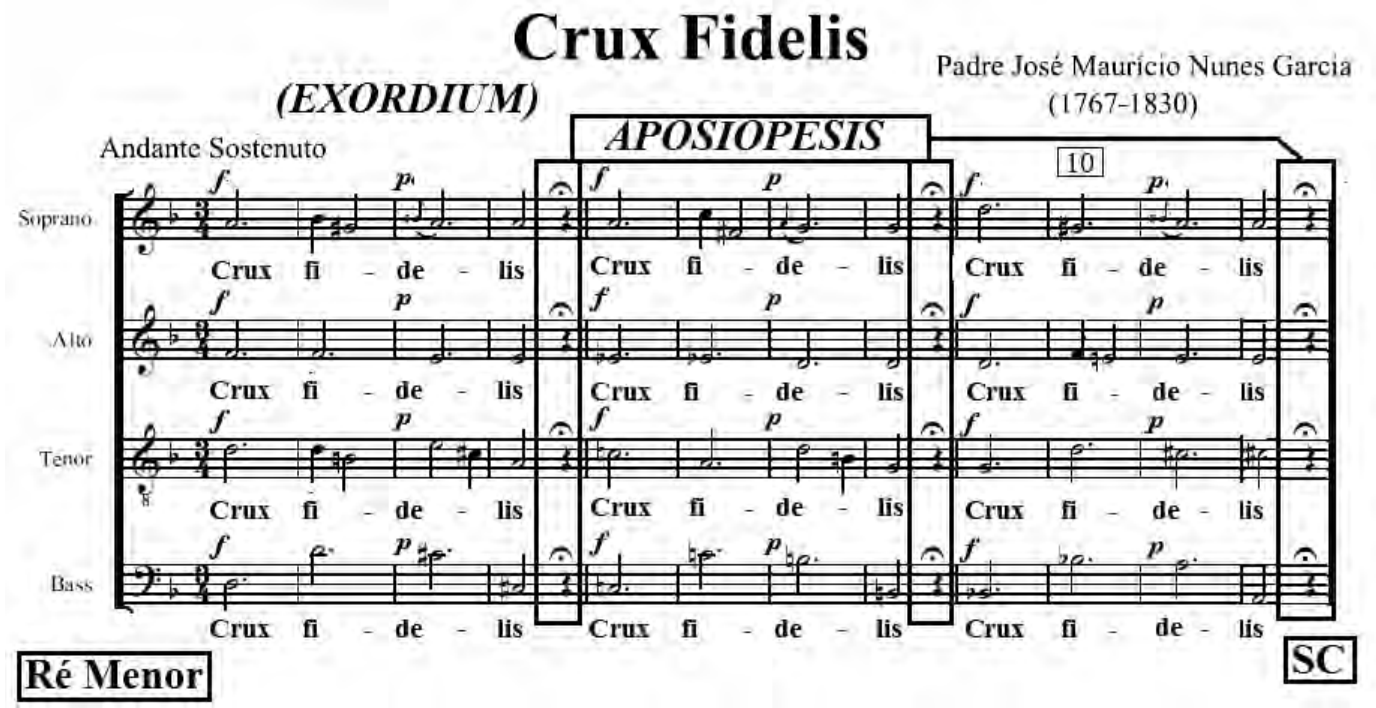

Exemplo 239- Aposiopesis no Crux Fidelis - comp.4,8 e 12.

Examina-se o emprego da Synaeresis, na voz da soprano, a qual interpreta as notas Dó sustenido e Mi, a expressão: inter omnes arbor una nobilis (entre todas as árvores), por três vezes, destacando assim o afeto de nobreza descrito no texto sacro. Somado a isso, é observável que o autor, através desse elemento retórico, torna saliente as dinâmicas e as funções harmônicas.

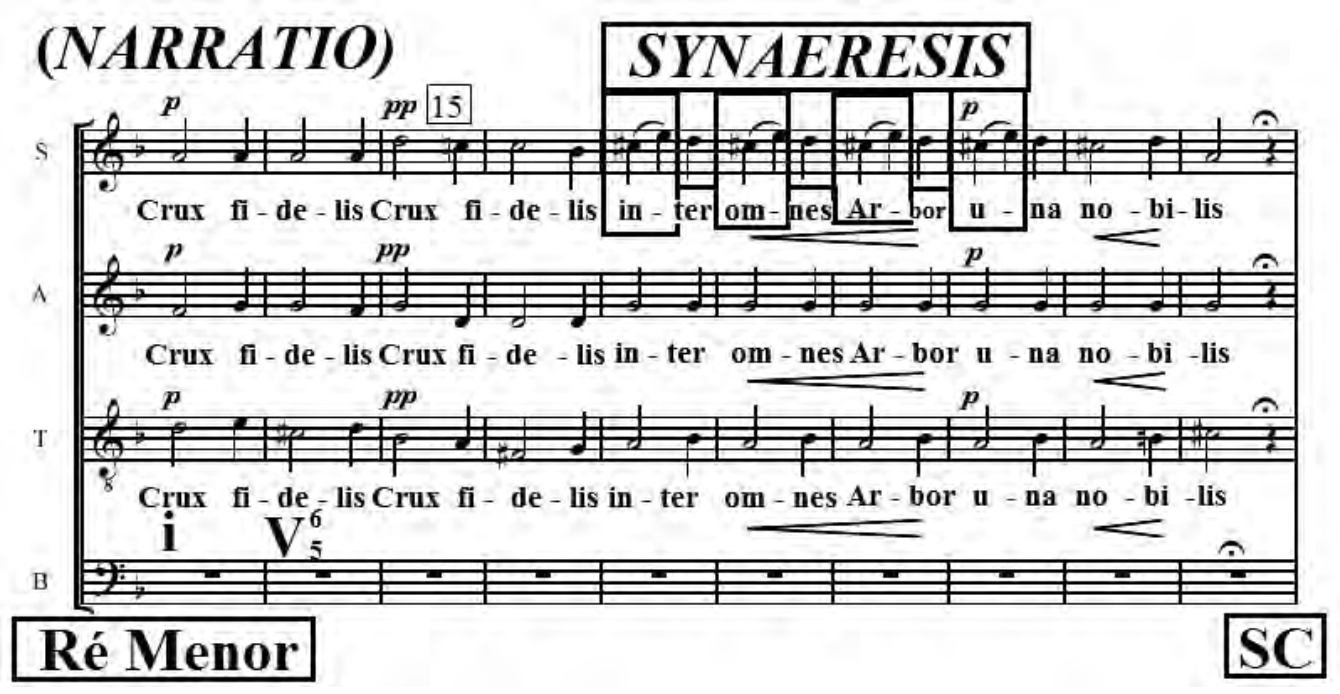

Exemplo 240-Synaeresis no Crux Fidelis - comp.16 a 19. 
Nesse exemplo, observa-se que Nunes Garcia, faz uso recorrente da Synaeresis, em todas as vozes para enfatizar as palavras: nulla talem silva profert flore, fronde, germine (Nenhum bosque produz igual, em ramagens, frutos e flores), além das dinâmicas e das funções harmônicas.

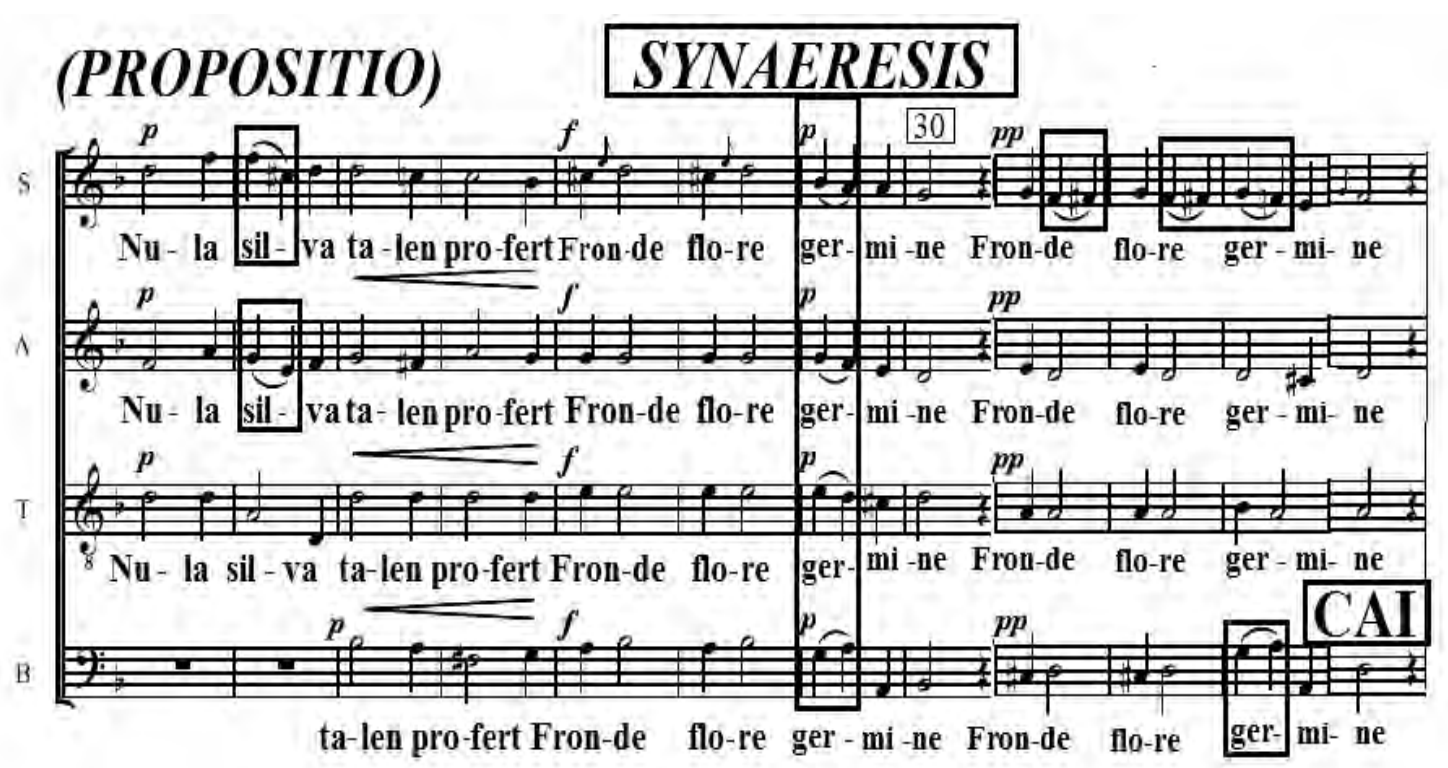

Exemplo 241-Synaeresis no Crux Fidelis - comp.25 a 33.

Examina-se na Narratio da presente obra, novamente a figura do Polyptoton, a qual se refere à repetição uma ideia musical semelhante, em partes ou registros diferentes (BUELOW, 2001, p.264).

Nunes Garcia aplica esse recurso retórico de repetição melódica para duas finalidades: primeiro colocar em evidência a expressão transeat a me (afaste/passe-me de mim), segundo para reiterar e reforçar o afeto de tristeza e profunda depressão de Cristo. Não obstante, é relevante observar que o autor trabalha com esses mecanismos retóricos, com a intenção de provocar um efeito sonoro, através das dinâmicas: piano, mezzo-piano, crescendo e forte, em consonância aos diálogos e entradas das vozes e funções harmônicas.

Por fim, constata-se a Synaeresis, citada no exemplo anterior, nas vozes do contralto, tenor e baixo, corroborando a ideia e a proposta do autor. 


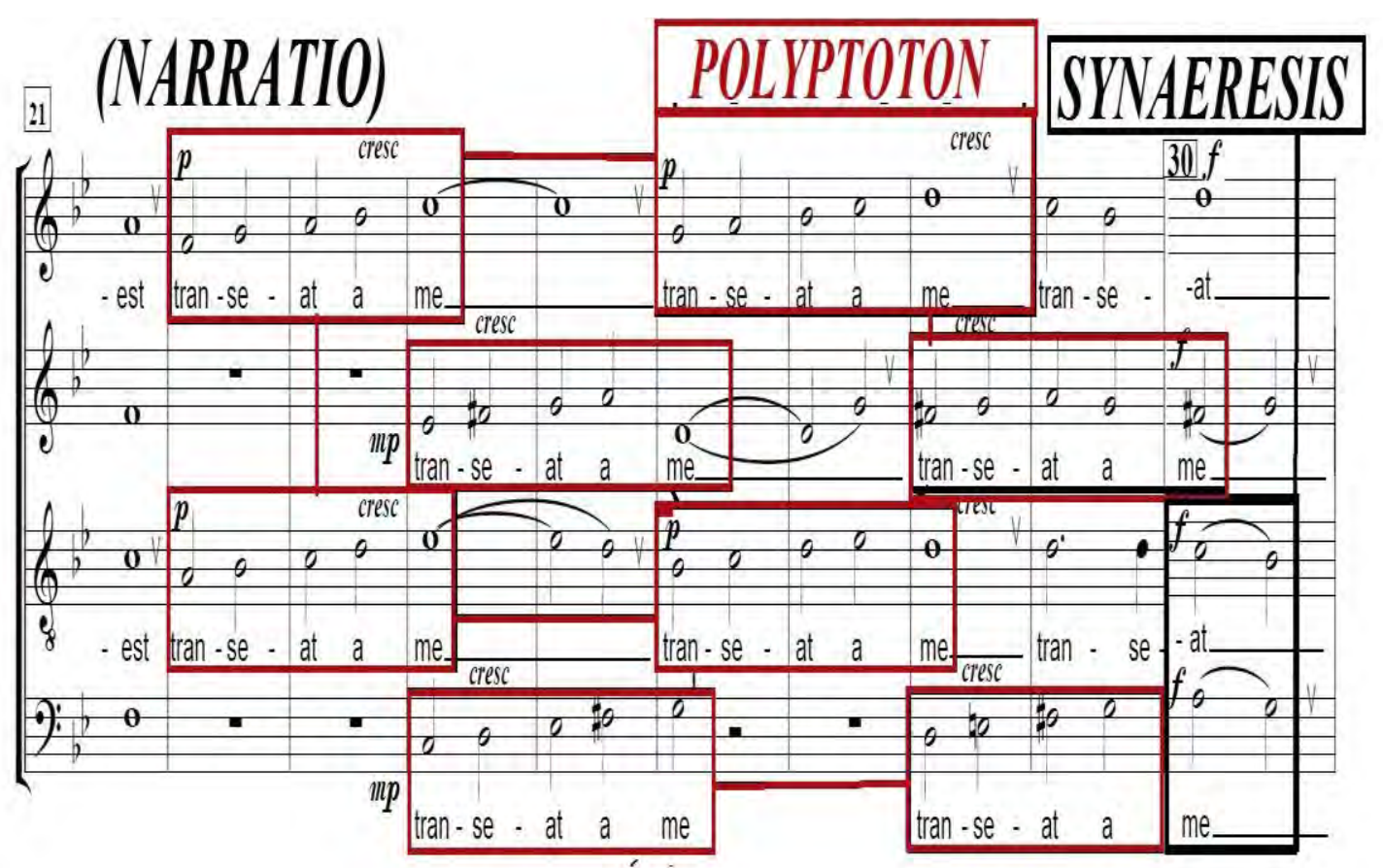

Exemplo 242-Polyptoton e Synaeresis no In Monte Oliveti - comp.21 a 30.

No exemplo a seguir, é verificável o emprego do Polyptoton, mediante o diálogo das vozes do contralto, soprano e tenor, repetindo a expressão et novíssimo (e no último), em alturas diferentes.

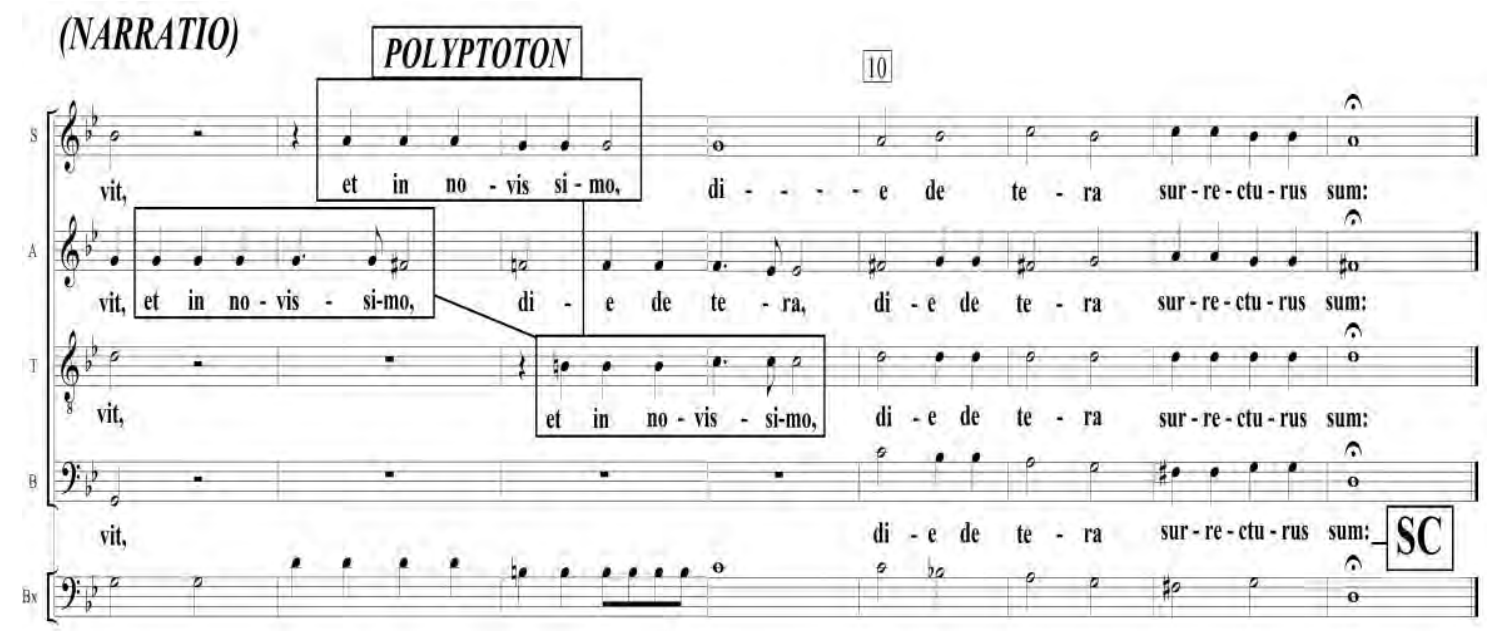

Exemplo 243-Polyptoton no $1^{\circ}$ Responsório das Matinas e Encomendação de Defuntoscomp.6 a 9. 
Escrito para oito vozes, O Ofício dos Defuntos e Responsórios de Matinas tem seu texto fundamentado em Jó 19:25, onde é narrada a história de Jó e de sua confiança, obediência e fé em Deus, para assim obter a vida eterna. Nos compassos 1 a 6 , do $1^{\circ}$ responsório é notada a aplicação do Polyptoton, repetindo uma passagem melódica em alturas diferentes e da Synaeresis, onde a voz da soprano-I entoa duas notas por uma sílaba.

\section{(EXORDIUM) Ofício dos Defuntos-Responsórios de Matinas}

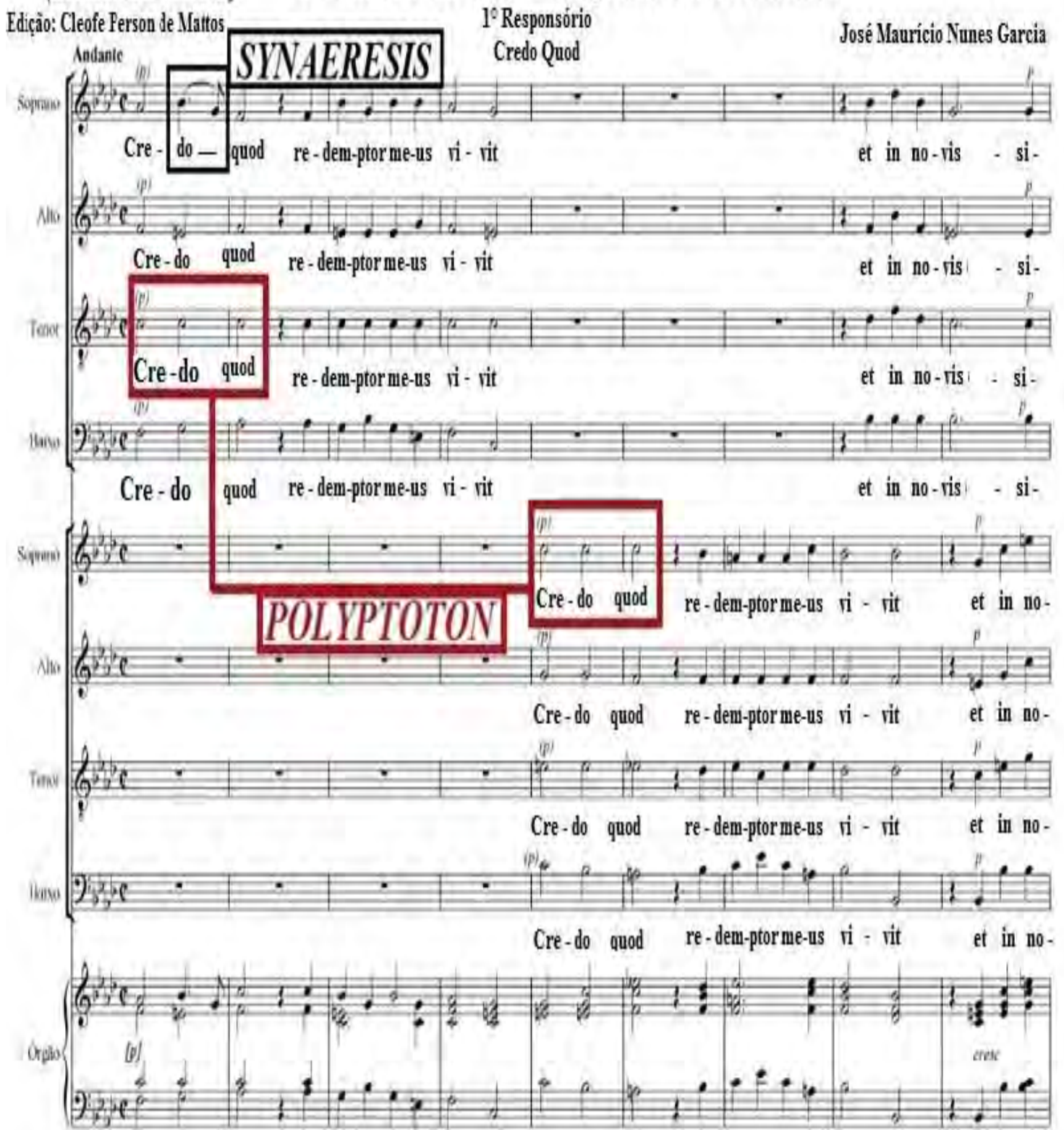

Exemplo 244-Polyptoton e Synaeresis no Ofício dos Defuntos- Responsórios de Matinas$1^{\circ}$ Responsório- comp. 1 a 6. 
Pode-se constatar o uso da Aposiopesis, através da pausa geral em todas as vozes, no compasso 13, igualmente da Synaeresis, valorando a expressão et in novissimo die de terra surrecturus sum (no último dia eu hei de ressuscitar [subir, levantar] da terra), por meio de alternâncias das dinâmicas, forte, piano e crescendo, produzindo um efeito sonoro e de suspenção, resolvendo em uma Cadência na Dominante.

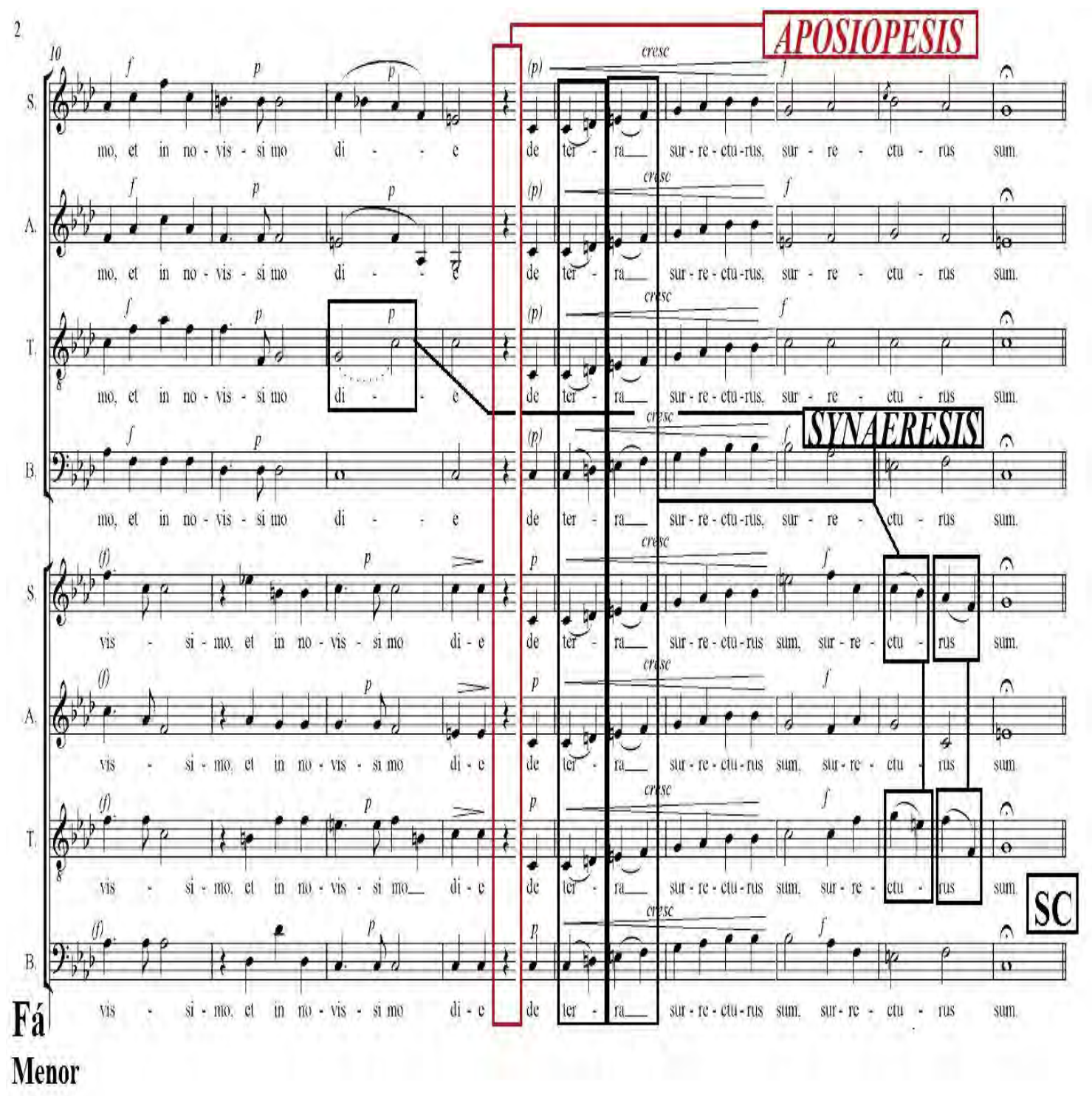

Exemplo 245-Aposiopesis e Synaeresis no $1^{\circ}$ Responsório do Ofício dos DefuntosResponsórios de Matinas - comp.12 a 15.

Nesse exemplo, Nunes Garcia trabalha com a Synaeresis e Polyptoton, utilizando-as de modo recorrente e tendo o mesmo propósito de provocar no ouvinte o afeto de devoção e dependência ao Senhor. Nota-se, de igual 
maneira, que a expressão Salvatorem meum (Salvador meu) é destacada mediante as quatro repetições.

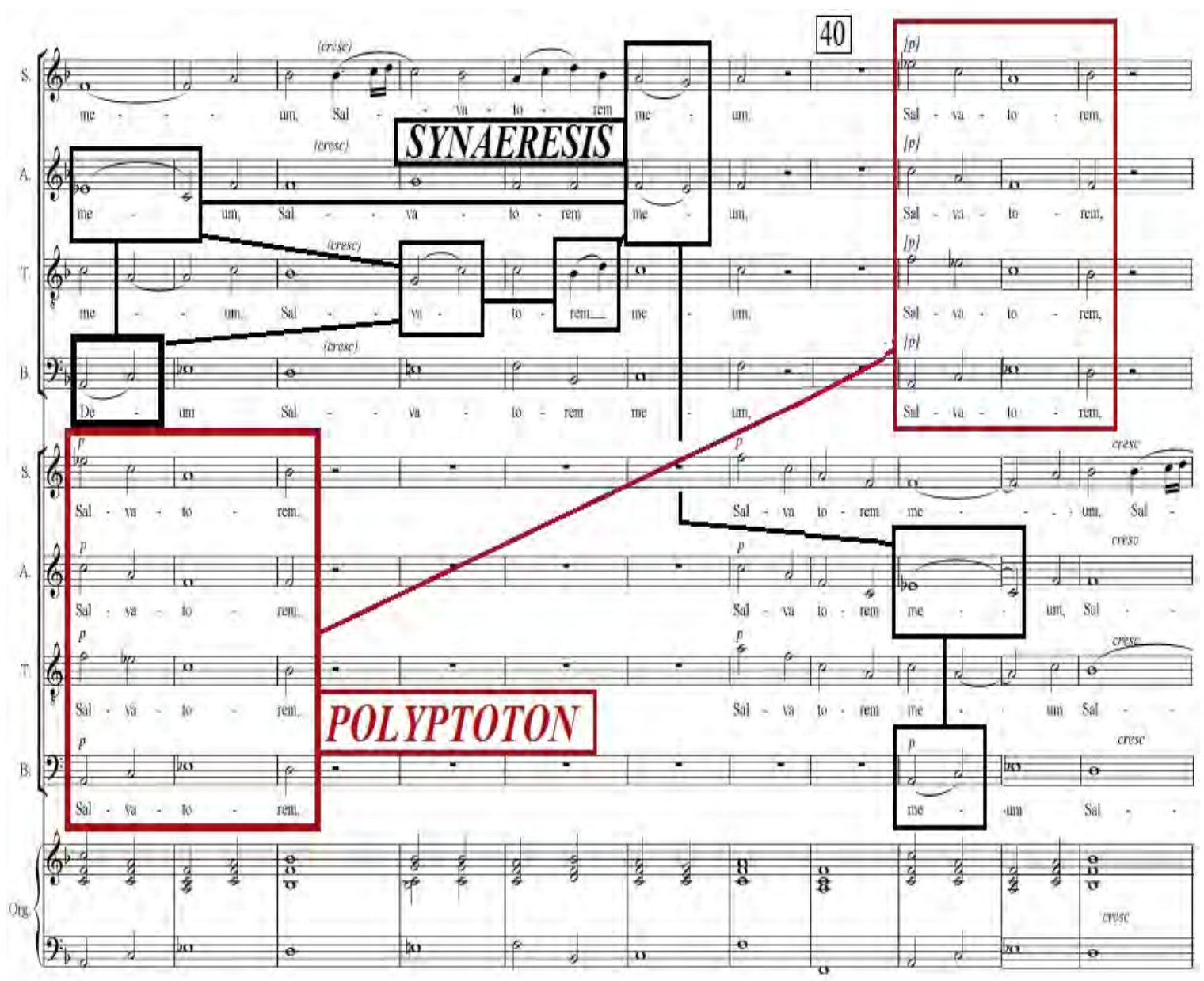

Exemplo 246-Polyptoton e Synaeresis no Ofício dos Defuntos- Responsórios de Matinas$1^{\circ}$ Responsório- comp.33 a 43.

No presente trecho, entre os compassos 1 e 7 , é examinável a repetição melódica na voz do contralto e das palavras memento mei, Deus (Lembrai-Vos de mim, Senhor). Também, vê-se essa reiteração em alturas diferentes, ou seja, em outras vozes, caracterizando o emprego do Polyptoton. De igual modo, é notada a utilização da Synaeresis, onde todas as vozes entoam duas notas numa sílaba, resolvendo depois na Semicadência.

Desse modo, evidencia-se o emprego dessas figuras retóricas para realçar o afeto de angústia e languidez, descrito em Jó 7:7: "Lembra-te, ó Deus, de que a minha vida não passa de um sopro; meus olhos jamais tornarão a ver a felicidade" (ALMEIDA, 2000, p.727). 


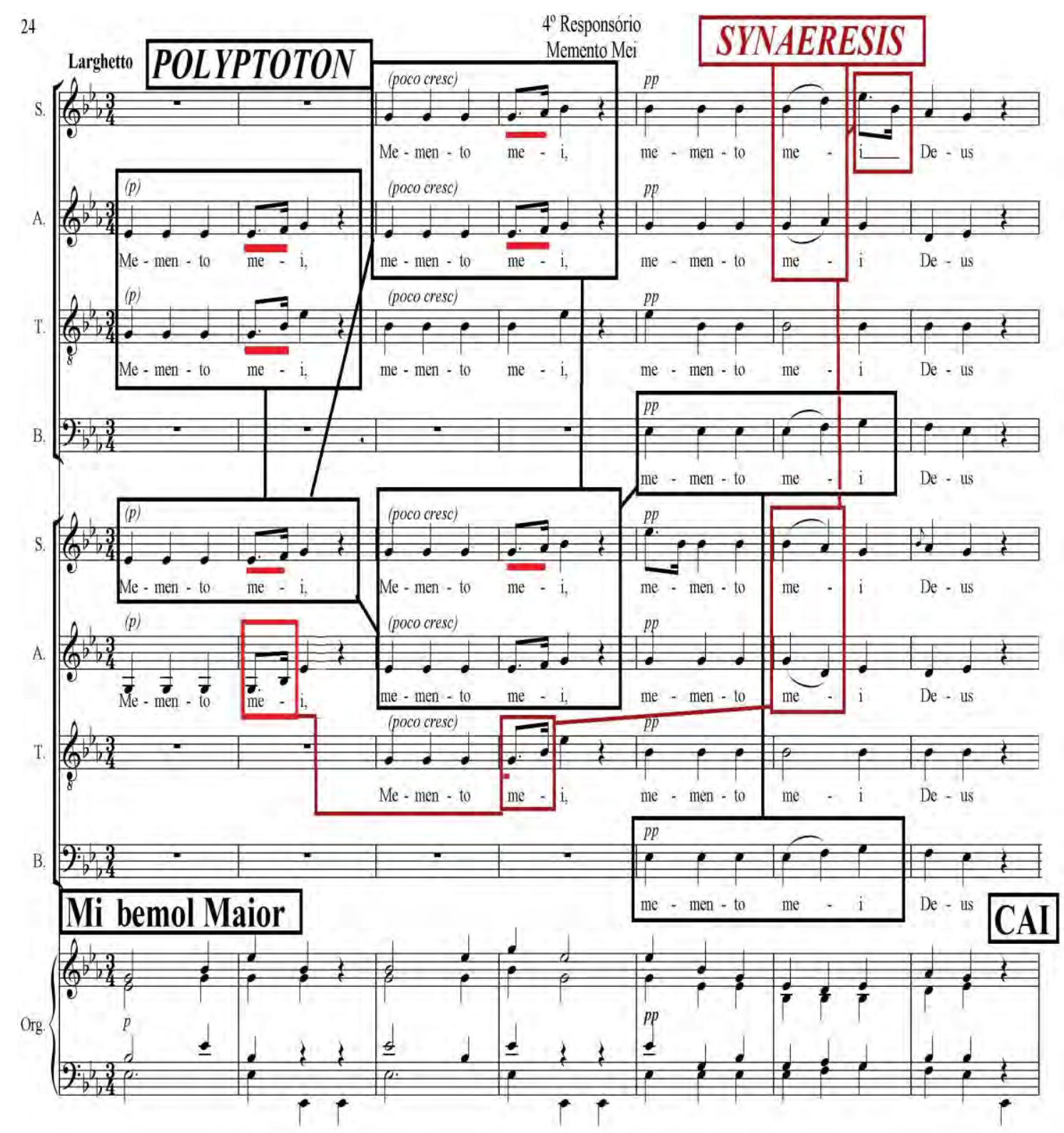

Exemplo 247-Polyptoton e Synaeresis no $4^{\circ}$ Responsório do Ofício dos DefuntosResponsórios de Matinas- comp. 1 a 7.

O $6^{\circ}$ Responsório do Moteto Ascendens Christus baseia-se em Salmos Ps. (46:6/47:5). Tal passagem descreve a ascensão do Senhor ao céu mediante o som de trombeta. Nunes Garcia emprega essa figura de repetição melódica nas vozes da soprano, contralto e tenor, reiterando, desse modo, o afeto de exultação e alegria. Percebe-se, também, a aplicação da Synaeresis em consonância com o Polyptoton, na entrada das vozes e as funções harmônicas. 


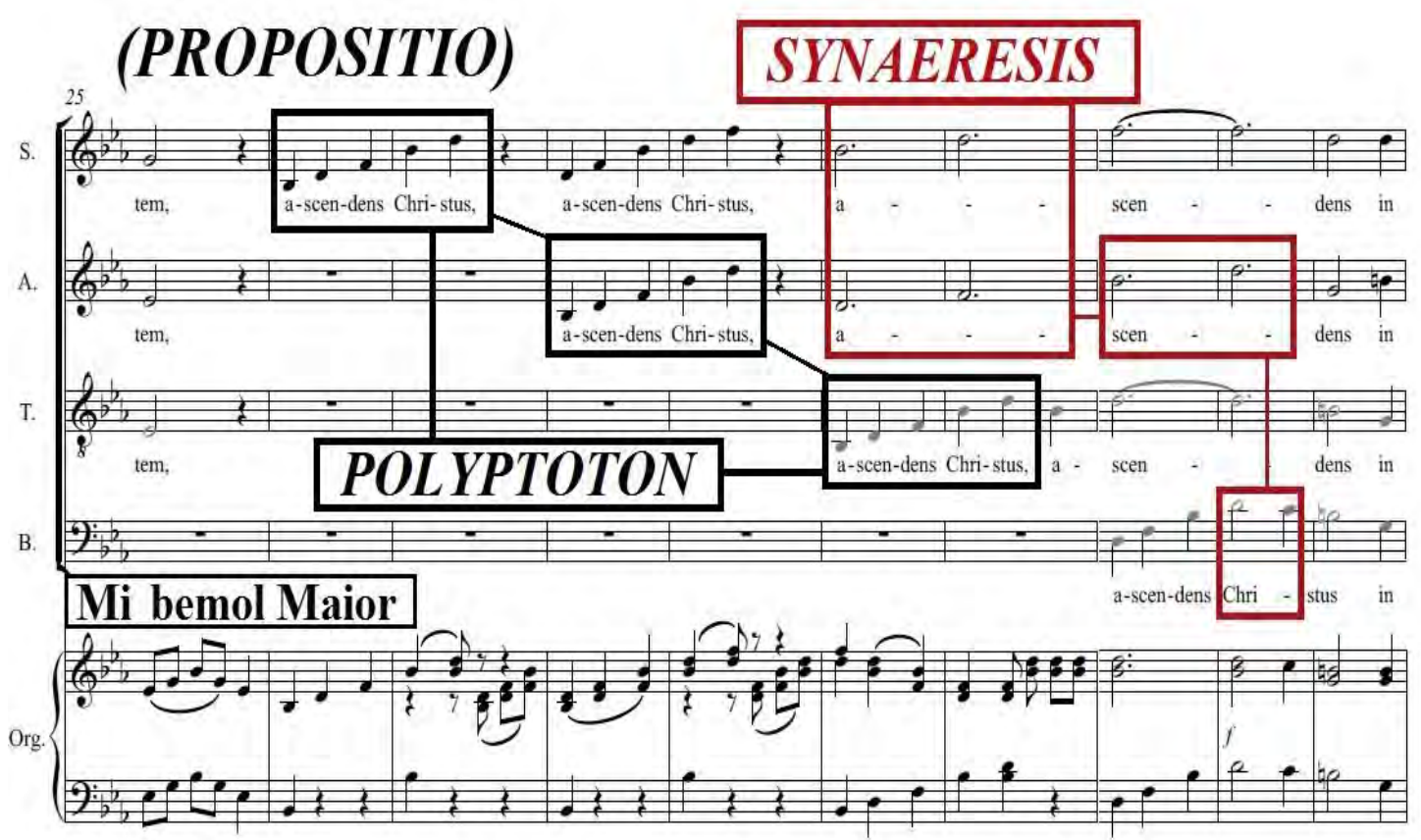

Exemplo 248-Polyptoton e Synaeresis no $6^{\circ}$ Responsório do Moteto Ascendens Christus ( $1^{\circ}$ Movimento)-comp. 26 a 33.

O texto do Verso-I do Responsório-VI, localiza-se em Salmos 5:8, onde é narrada a aflição do rei Davi, as perseguições de seus inimigos e qual direção ele deveria tomar. Para destacar esse afeto de angústia, o compositor utiliza esses dois recursos retóricos realçando a frase Dirige, Domine, Deus meus (Endireitai, Senhor, meu Deus).

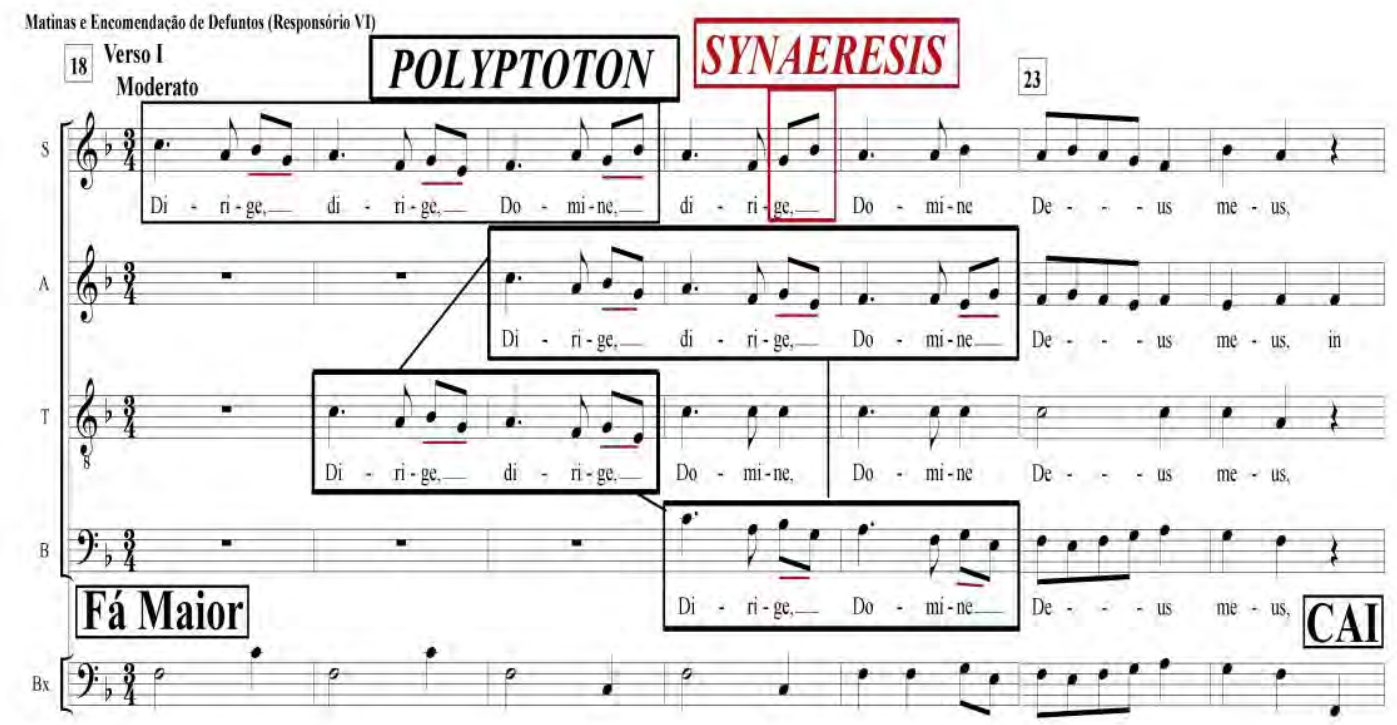

Exemplo 249-Polyptoton e Synaeresis no Verso- I do Responsório-VI das Matinas e Encomendação de Defuntos-comp. 18 a 22. 
Examina-se, na Narratio da presente obra, novamente a figura da Synaeresis, a qual enfatiza a expressão et cilicio jejunemus (pela cinza e o cilício), entoados pela soprano, contralto e tenor, nos compassos 7 e 11.

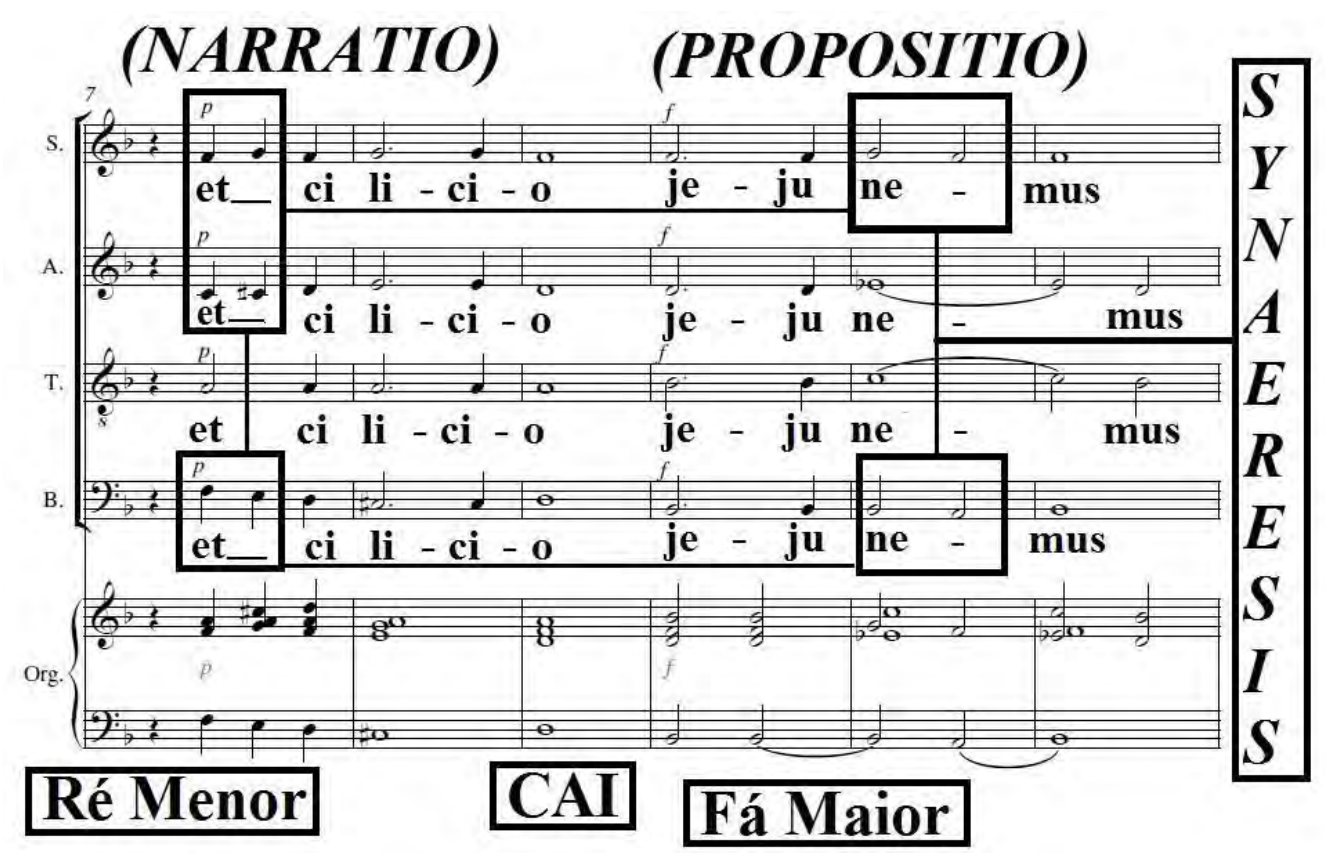

Exemplo 250-Synaeresis no Immutemur Habitu- comp.7 e 11.

Adiante, na mesma obra, verifica-se o uso da Aposiopesis, ressaltando a terminação da Narratio numa Cadência Autêntica Perfeita.

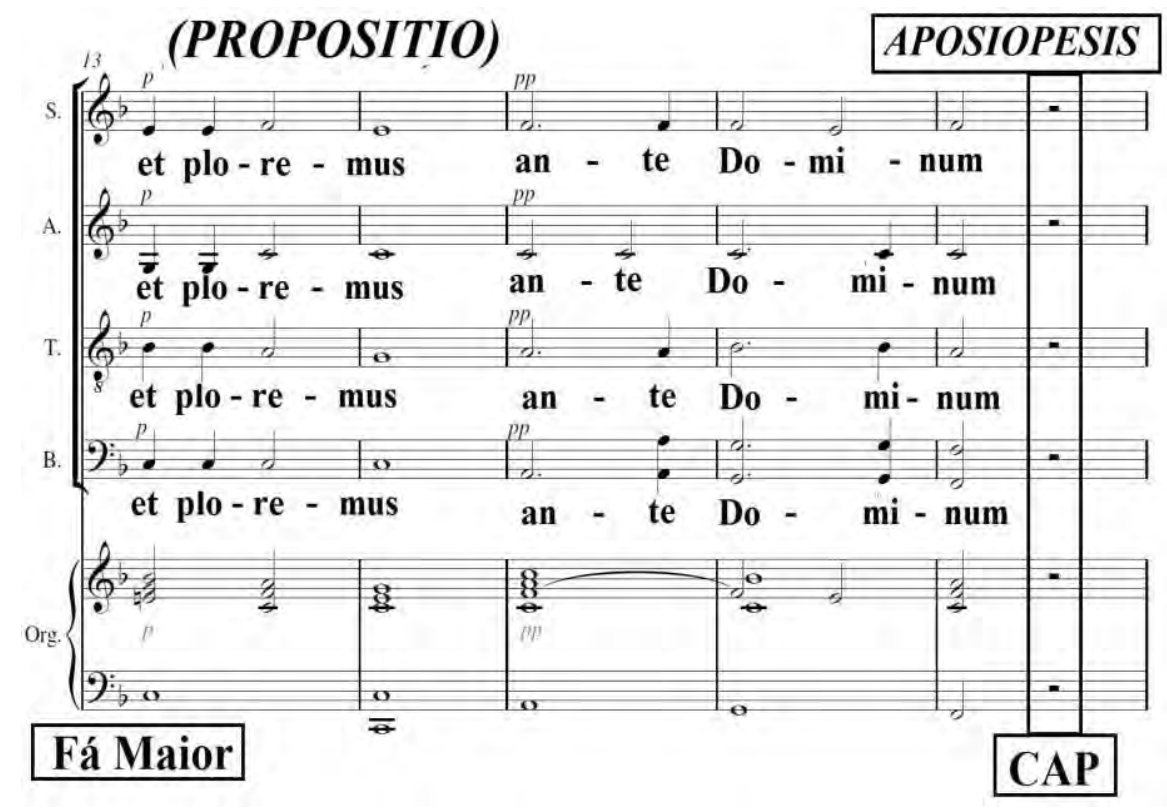

Exemplo 251-Aposiopesis no Immutemur Habitu- comp.17. 
O $2^{\circ}$ Responsório do Ofício dos Defuntos de 1816 assim como o Responsório-Il das Matinas e Encomendação de Defuntos de José Maurício têm o mesmo texto embasado no Evangelho de João (11:1-46), quando o evangelista descreve a doença, morte e ressurreição de Lázaro, amigo de Jesus. Nessa parte examina-se que o compositor atribui ao Polyptoton e a Synaeresis duas funções: de enfatizar e afirmar o enunciado Tu eis, Domine, dona requiemet locum indulgentiæ (Dai-lhes, Senhor, repouso e um lugar de perdão).

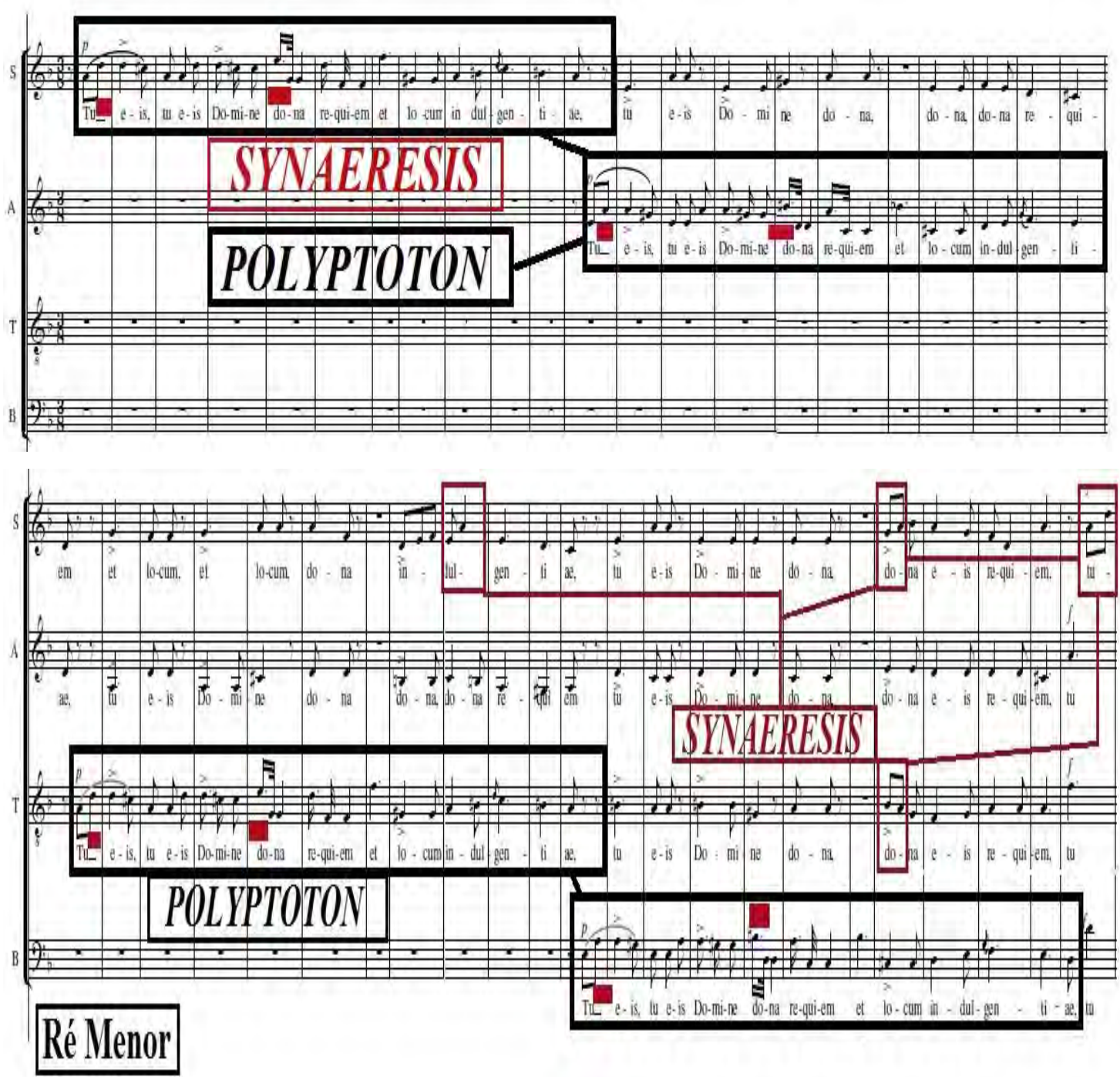

Exemplo 252-Polyptoton e Synaeresis no $2^{\circ}$ Responsório no Ofício dos Defuntos (1816)comp. 1 a 44. 
Nesse excerto notam-se as recorrências das duas figuras supracitadas, ressaltado a expressão Dum vereris judicare (Quando vierdes julgar), na tonalidade Dó Menor, com resolução da Cadência Autêntica Perfeita.

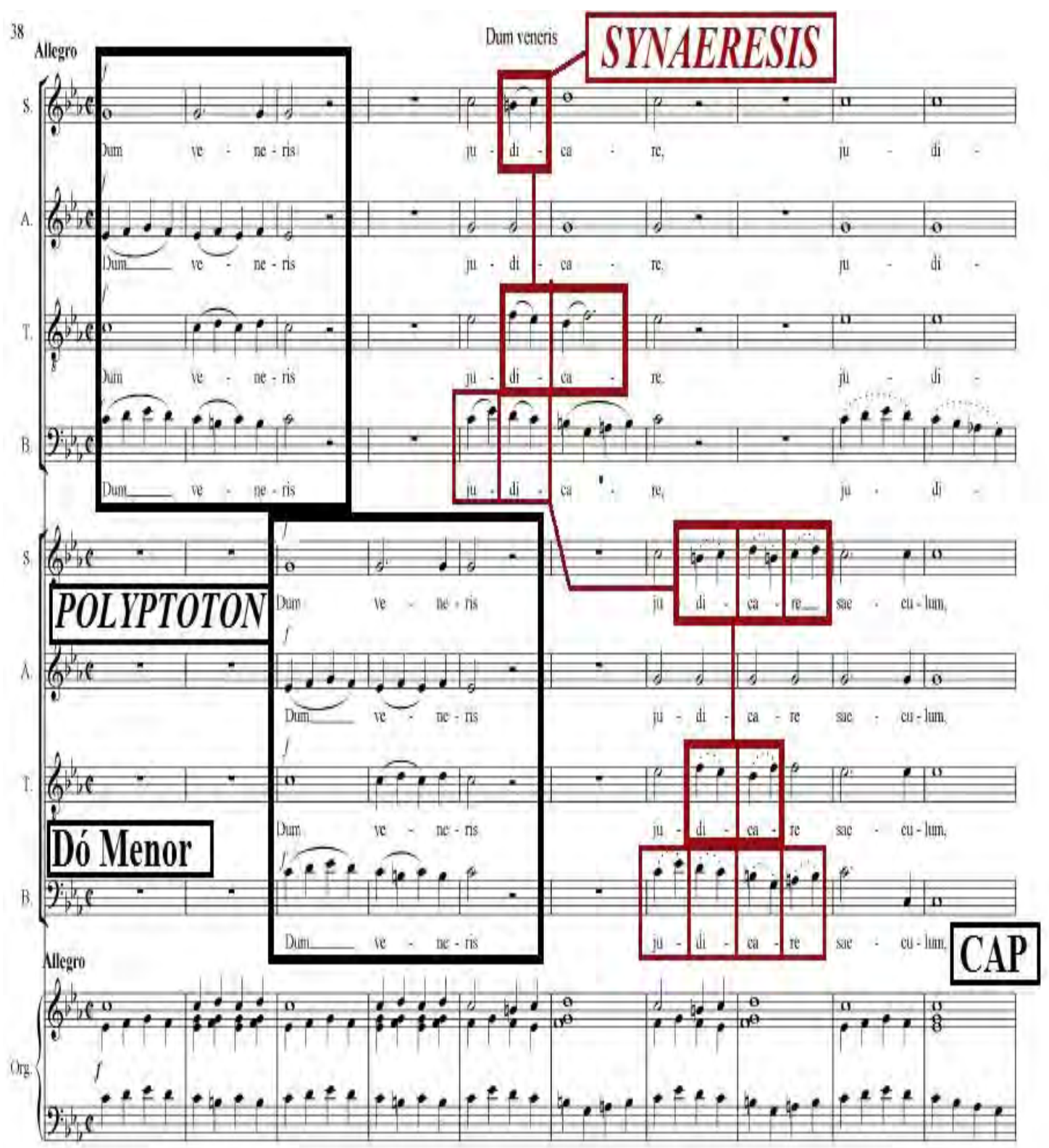

Exemplo 253-Polyptoton e Synaeresis no Dum veneris ( $6^{\circ}$ Responsório)-Responsório de Matinas- comp.1 a 8. 


\section{CONCLUSÃO}

Por ser o discurso musical entre os finais do século XVI e primórdios do século XIX, disposto por meio de elementos retóricos, na música concebida, era o fio condutor: a persuasão e a eloquência sucedida de uma transmissão escolástica, consolidada a partir da Idade Média e Renascença, consubstanciando, assim, um determinado grau de excelência nas composições produzidas na Europa, como no Brasil. Essa sistematização teórica na retórica-musical é proveniente de um cabedal originário em constructos advindos de grandes pensadores, tratadistas e autores de obras musicais, manifestados desde a civilização greco-romana, formando, assim, o arcabouço necessário para a concepção estrutural de uma música.

Dessa forma, seguindo a tradição de proeminentes mestres e tratadistas de retórica musical e música poética, como Heinrich Faber, Nikolaus Listenius, Gioseffo Zarlino, Gallus Dressler, Johannes Nucius, Joachim Burmeister, Johannes Luppius, Marin Mersenne, Johann Andreas Herbst, René Descartes, Joachim Thuringus, Athanasius Kircher, Christoph Bernhard, Johann George Ahle, Mauritius Johann Vogt, Johann Gottfried Walther, Johann Mattheson, Johann Adolf Scheibe, Heinrich Christoph Koch e Johann Nikolaus Forkel, para citar alguns (BARTEL, 1997, pp.93-164, passim; BUELOW, 2001, pp.261-270, passim), a musicologia a partir da metade da década de 1960 iniciou diversas investigações, buscando o entendimento dos caminhos percorridos por esses preceitos, desenvolvendo metodologias apropriadas para o esclarecimento da relação entre música e afeto, mediante a análise retórico-musical.

Certamente, tais estudos credenciaram e qualificaram a retórica musical como uma área de concentração e linha de pesquisa complexa e ao mesmo tempo extensa, onde inúmeras teses, dissertações, livros, capítulos de livros, artigos e trabalhos especializados são editados anualmente, em razão da grande quantidade de tratados musicais produzidos entre a metade final da Renascença e começo do Classicismo, instituírem um vínculo teórico-estrutural da retórica musical, propiciando, assim, fundamentação para as atuais averiguações sobre $o$ assunto.

Todavia, como ressaltado no decorrer deste trabalho, mesmo com o aparente crescimento e atenção investigativa dada pela atual musicologia, a 
maioria dos estudiosos e pesquisadores brasileiros norteiam suas pesquisas dirigidas à recepção retórica de compositores europeus como Orlando di Lasso, Luca Marenzio, Ludovico Viadana, John Dowland, Claudio Monteverdi, Heinrich Schütz, Jean-Baptiste Lully, Dietrich Buxtehude, Marc-Antonie Charpentier, Henry Purcell, Alessandro Scarlatti, Antonio Vivaldi, George Phillip Telemann, Johann Sebastian Bach, George Friedrich Haendel, Giovanni Battista Pergolesi, Carl Philipp Emanuel Bach, Joseph Haydn, Wolfgang Amadeus Mozart, entre outros, em virtude de aplicarem mecanismos retóricos (figuras retóricas e tópicas, por exemplo) nas estruturas de suas composições.

Além disso, mesmo com as numerosas publicações que evidenciam a relevância da retórica no âmbito musical, existem poucas pesquisas e fontes brasileiras sobre o tema.

Por essa razão, a presente tese surgiu com o propósito de considerar a música como uma manifestação intrínseca aos elementos essenciais de sua execução, em outras palavras, num ambiente que exprime a circunstância de raciocinar e refletir questões associadas a uma estrutura contextual e sóciohistórica, estabelecida em processos dualísticos com obras objetivadas em superar os parâmetros figurativos e alegóricos, com uma música mais racional, com métrica e síntese e as obras embasadas na linguagem figurativa, vinculada aos processos de persuasão, resistindo e persistindo na retórica barroca.

Somado a isso, da mesma forma como realizado em nossa dissertação de mestrado, aventamos por intermédio das ferramentas analíticas adequadas, a possiblidade do uso da retórica na música no Brasil Colonial, ou seja, procurou-se observar as semelhanças do estudo de caso efetuado, todavia, aumentando o número de possibilidades de encontrar essa aplicação nos compositores brasileiros dessa época, de modo a aclarar questões essenciais que respondam algumas indagações pertinentes, tal como expresso no tópico 5.5, entretanto, com mais algumas hipóteses.

1. Para lograr êxito em seu ofício, o compositor colonial brasileiro faria uso dos recursos da Retórica, com o objetivo de mover os afetos dos ouvintes?

2. Esses autores teriam alguma formação ou conhecimento de retórica? 
3. Como se dá a utilização dos mecanismos retóricos em suas obras?

4. Essa aplicação ocorre em todas as seções da peça e quais são suas relações com as funções harmônicas, com as cadências, com os motivos, com o texto e com as dinâmicas?

5. Há recorrências no emprego das figuras, se elas acontecem, sua inserção é realizada conscientemente?

6. Quais são os estudos de caso acerca da retórica na música colonial brasileira, até o momento?

Destarte, apresentamos na presente tese, modesta colaboração para a formulação dos argumentos, fatos e dados a serem defendidos, além das ideias e dos questionamentos levantados como hipóteses, embasados em seis séries de estudos ordenados como capítulos, tópicos e subtópicos:

1. A abordagem da ideia inicial do trabalho investigativo, o histórico e justificativa da pesquisa e as metodologias utilizadas;

2. A contextualização sobre a retórica, seu escopo, a utilidade de seus componentes: Ethos, Pathos e Logos, as fases retóricas: Inventio, Dispositio, Elocutio, Memoria, Pronuntatio, além da transmissão e aplicação da retórica entre a Idade Média até a Moderna;

3. A exposição da retórica relacionada com a música e com os afetos, além da apresentação de exemplos dos tratados, bem como do emprego da retórica nas músicas do final do século XVI e início do XIX e, por fim, das tópicas;

4. A teorização retórico-musical em Portugal, de maneira cronológica chegando aos tratadistas Cipriano Soares e Luís António Verney, finalizando com a utilização da arte da eloquência nas músicas desse país.

5. A abordagem da retórica na música colonial brasileira, discutindo questões relativas a implementação do lluminismo tanto em Portugal como no Brasil, além de suas influências nas obras produzidas na época. Igualmente, o levantamento de dados relativos aos compositores selecionados para o exame analítico, aos estudos de caso sobre a aplicação retórica em compositores brasileiros e à consciência de seu uso pelos autores. Concluindo, a discussão e questionamentos acerca 
da retórica, harmonia e relação texto-música como ferramentas convergentes para análise musical;

6. Por fim, as análises retórico-musicais nas obras de Manoel Dias de Oliveira, José Joaquim Emerico Lobo de Mesquita, André da Silva Gomes e José Maurício Nunes Garcia e as recorrências no emprego das figuras retóricas.

Perante esses estudos, abordagens, levantamentos e questões, podemse enfatizar algumas conclusões como resultados de pesquisa, apontadas abaixo.

- A retórica se apresenta essencial para a elaboração de uma argumentação, tese, propositura e discurso.

- A retórica é interdisciplinar e transdisciplinar, ela está presente em várias áreas do conhecimento, por exemplo, no direito, na filosofia, na oratória, na dialética, na literatura, na hermenêutica, na crítica literária, na ciência e nas artes.

- Os diversos tratados de música poética e retórica musical, produzidos entre a metade do século XVI e princípio do século XIX, definem as nomenclaturas das partes do discurso musical, além das figuras. Da mesma forma, abordam quando se deve empregar os elementos e as figuras retóricas nas obras. Entretanto, há dificuldade na categorização, principalmente das figuras, pois as mesmas são classificadas de diferentes modos pelos tratadistas.

- A retórica através de seus mecanismos e recursos, como as metáforas, alegorias, figuras, é indispensável para compreensão dos afetos e do enunciado musical.

- Mesmo a retórica se apresentando como uma nova opção analítica para a linha de pesquisa da musicologia, teoria musical e até mesmo para a performance, para compreensão da constituição do discurso nas músicas dos séculos supracitados, é imprescindível também na aplicação da análise harmônica em consonância ao texto.

- A teorização e sistematização retórica em Portugal, ocorrida desde o medievo, serviu de auxílio para diversos teóricos, tratadistas e compositores no ambiente luso-brasileiro entre os séculos XVII e 
começo do XIX. Por exemplo, na constituição do manual de retórica de Cipriano Soares, para os sermões do padre António Vieira, na obra reformadora de Luís António Verney, para sua transmissão nas instituições escolares e religiosas, como no Real Seminário da Patriarcal, que teve como aluno externo André da Silva Gomes. De igual modo, nas escolas e colégios do Brasil, a partir da segunda metade do século XVIII, tendo como aluno de Silva Alvarenga, o compositor José Maurício Nunes Garcia.

- André da Silva Gomes como José Maurício Nunes Garcia mostram-se detentores de consistente arcabouço teórico, literário e musical ao empregar os elementos retóricos em suas obras. Posto que, em Manoel Dias de Oliveira e José Joaquim Emerico Lobo de Mesquita, mesmo não havendo fontes até o momento que mostrem suas formações retóricas em instituições escolares ou superiores, é mais que evidente a presença de elementos retóricos em suas músicas, por alguns motivos: o contexto político, econômico, social, religioso e musical nos quais eram inseridos; o uso do texto litúrgico em convergência com as funções harmônicas, evidenciando os afetos; a habilidade em valorar esses diferentes sentimentos expressos no texto, ressaltando, assim, as dinâmicas usadas, as melodias, as cadências, bem como as figuras retóricas. Por último, conforme a afirmação do próprio Silva Gomes, contemporâneo dos mesmos, enunciando que os compositores da época observavam, estudavam e imitavam os ótimos tratados dos sábios mestres, além de fundamentarem-se nos preceitos próprios das Faculdades Retórica e Poética (DUPRAT et al., 1998, pp.179-180).

Referente às obras analisadas, objeto desta pesquisa, pode-se asseverar que, mediante os exames minuciosos, localizaram-se diversos elementos e figuras retóricas empregadas em suas estruturas, relacionadas às funções harmônicas, ao texto sacro, aos afetos e ao contraponto.

Por exemplo, tanto no Confitemini das Matinas e Vésperas de Sábado Santo, como no Gloria, da Missa Abreviada em Ré, Manoel Dias de Oliveira trabalha com textos que descrevem afetos de júbilo, alegria, devoção e exultação. Diferentemente, no Pater Mihi, do Moteto dos Passos, utiliza-se de 
um texto que destaca afeto de angústia: Pater mihi, si possibile est, transeat a me calix iste (Meu Pai, se for possível, afasta de mim este cálice), onde podem ser observadas três figuras empregadas também no Confitemini: Anaphora, Polyptoton e Synaeresis e duas usadas no Gloria: Epizeuxis e Synaeresis.

Em José Joaquim Emerico Lobo de Mesquita, observam-se nas três obras examinadas textos que enfatizam afetos de devoção e submissão: Exuadi nos Domine quoniam benigua est misericordia tua (Atende-nos, Senhor porque benigna é a tua misericórdia); Kyrie eleison (Senhor tende piedade de Nós); Cum appropinquaret Dominus Jerosolymam, misit duos ex discipulis, dicens: Ite in castellum, quod contra vos est (Aproximando-se o Senhor de Jerusalém, enviou dois dos seus discípulos, dizendo: Ide à aldeia que está defronte de vós), tendo como destaque as figuras da Epizeuxis, Synaeresis e Abruptio.

Já André da Silva Gomes aplica em suas obras três figuras recorrentes: Epizeuxis, Palilogia e Synaeresis em consonância com o texto e o afeto de exultação e devoção Confitebor tibi Domine (Quero louvar o Senhor); Laudate Dominum (Louvai ao Senhor); Laudate, pueri, Dominum; laudate nomen Domini (Louvai Louvai, ó servos, louvai o nome do Senhor).

Por fim, em José Maurício Nunes Garcia, os textos retratam afetos de confiança no Domine Jesu, et salvus ero (eu serei salvo); de devoção e mansidão no Crux Fidelis, dulce pondus sustinet (doce peso sustentas) e de esperança no $1^{\circ}$ Responsório das Matinas e Encomendação de Defuntos, Et in carne mea videbo Deum Salvatorem meum (E em minha carne verei a Deus, meu Salvador), podendo ser ressaltadas as figuras da Aposiopesis, Polyptoton e Synaeresis.

Após essa verificação, podemos acentuar que, com o objetivo de compreender a utilização de elementos e figuras retóricas em categorias pelos autores já citados do Brasil Colonial, possibilitou, aqui, cruzamentos instigantes sobre aquilo que é uma das maiores dificuldades nesse campo: distinguir gestualidades das figuras e elas dentro de um princípio universal de uso. Nesse sentindo, ressaltamos a necessidade de sempre buscar o aprofundamento da problemática dos empregos retóricos, intensificando ainda mais o número de exemplos examinados e discutidos. 
Em suma, nos excertos aqui observados, há de se enfatizar que a averiguação dessas figuras e elementos retóricos, além do texto sacro, das funções harmônicas e dos afetos, pode ser evidenciada a habilidade desses compositores em elaborar e dispor o discurso musical em suas obras, assim como da possibilidade do emprego da retórica como ferramenta analítica para o entendimento dos processos composicionais na música colonial brasileira. 


\section{REFERÊNCIAS BIBLIOGRÁFICAS}




\section{REFERÊNCIAS BIBLIOGRÁFICAS}

ABBAGNANO, Nicola. Dicionário de Filosofia. Tradução Alfredo Bosi. $2^{\mathrm{a}}$ Edição. São Paulo: Martins Fontes, 1998.1030 p.

. Dicionário de Filosofia. Tradução Alfredo Bosi. Revisão Ivone Castilho Benedetti. Edição Revisada e Ampliada. São Paulo: Martins Fontes, 2007. $1026 \mathrm{p}$.

AFFONSO, Rodrigo Cardoso. Um Estudo sobre a Relação Texto-Música: os Ofícios Fúnebres de José Mauricio Nunes Garcia. 156 f. Dissertação (Mestrado em Música) Programa de Pós-Graduação em Música, Centro de Letras e Artes, Universidade do Estado do Rio de Janeiro (UNIRIO), Rio de Janeiro, 2005.

AGOSTINHO, Santo. A Doutrina Cristã: Manual de exegese e formação cristã. São Paulo: Editora Paulus, 2002. 284 p.

ALMEIDA, João Ferreira de. Bíblia de Estudo Pentecostal. $2^{\text {a }}$ Edição. Rio de Janeiro: Casa Publicadora das Assembléias de Deus, 1996. 2.160 p.

- Bíblia Sagrada com Concordância. $12^{\mathrm{a}}$ Edição. São Paulo: Editora Vida, 1999. 1.302 p.

. Bíblia de Estudo Vida. 2a Edição. São Paulo: Editora Vida, 1999.

$2.134 \mathrm{p}$.

. Bíblia de Estudo de Genebra. São Paulo: Editora Cultura Cristã (Sociedade Bíblica do Brasil), 1999.1728 p.

. Bíblia de Estudo Shedd. São Paulo: Edições Vida Nova Cultura Cristã (Sociedade Bíblica do Brasil), 2000. 1938 p.

AMBIEL. Áurea Helena de Jesus. Lamentationes Jeremiæ Prophetæ de Orlando di Lasso: a aplicação da quinta categoria analítica de Joachim Burmeister. $436 \mathrm{f}$ Tese (Doutorado em Música) Instituto de Artes, IA, Universidade Estadual de Campinas (UNICAMP), Campinas, 2010. Disponível em: <http://cutter.unicamp.br/document/?code $=000615946>$ Acessado em: 21 de Julho de 2013. 
AMOSSY, Ruth (org.). Imagens de Si no Discurso - A Construção do Ethos.

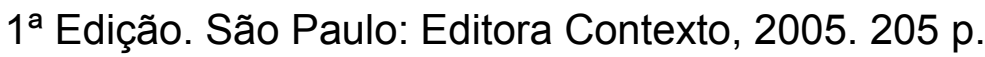

ANDRADE, António Alberto de. Verney e a Cultura de seu Tempo. Coimbra, Universidade de Coimbra, 1965. $2^{a}$ edição: 1966.760 p.

ARISTÓTELES. Arte Retórica e Arte Poética. Tradução de Antônio Pinto de Carvalho. Rio de Janeiro: Edições de Ouro, s/d. 290 p.

Ética à Nicômaco. Tradução Leonel Vallandro e Gerd Bornheim, Coleção Os Pensadores vol.IV Editora Abril Cultural, São Paulo, 1984. 330 p.

Retórica. Prefácio e Introdução Manuel Alexandre Júnior, Tradução e Notas Manuel Alexandre Júnior, Paulo Farmhouse Alberto e Abel do Nascimento Pena. $2^{a}$ Edição. Lisboa, Centro de Filosofia da Universidade de Lisboa, Imprensa Nacional-Casa da Moeda, 2005.318 p.

ASSUMPÇÃO, Sérgio Eduardo Martinelli de. Ascendência Retórica das Formas Musicais. 141 f Dissertação (Mestrado em Música). Programa de PósGraduação em Música, Escola de Comunicações e Artes, Universidade de São Paulo (USP), São Paulo, 2007.

AZEVEDO, João Lúcio de (1855-1933). O Marques de Pombal e sua Época. $2^{a}$ Edição. Anuário do Brasil, Rio de Janeiro, 1922. 412p.

BANDEIRA, Guilherme Jozé de Carvalho. Rhetorica sagrada ou Arte de Pregar. Novamente descoberta entre outros fragmentos Literarios do Grande P. Antonio Vieira. Lisboa: Na Officina de Luiz Joze Correa Lemos. BN: F 7131, 1745. 37p.

BANDEIRA, José Ramos. Universidade de Coimbra: Edifícios do Corpo Central dos Melos vol.2. Coimbra: Coimbra Editora, 1947.310 p.

BARBOSA, Jerónimo Soares. Grammatica Philosophica da Lingua Portugueza. Lisboa: Na Typographia da Academia das Sciencias (BN: L 296 V /purl 128), 1822. 466 p. 
BARROS, Cassiano de Almeida. A orientação retórica no processo de composição do classicismo, observada a partir do tratado Versch einer Anleitung zur Composition (1782-1793) de H.C.Koch. 131 f. Dissertação (Mestrado em Música) Instituto de Artes, IA, Universidade Estadual de Campinas (UNICAMP), Campinas, 2006. Disponível em: <http://libdigi.unicamp.br/document/?code=vtls000380274> Acessado em: 22 de Setembro de 2013.

A teoria fraseológico-musical de H.C. Koch (1749-1816). $193 \mathrm{f}$. Tese (Doutorado em Música) Instituto de Artes, IA, Universidade Estadual de Campinas, Campinas, 2011. Disponivel em: < http://www.bibliotecadigital.unicamp.br/document/?code=000841835\&opt=1> Acessado em: 05 de Maio de 2014.

BARROS, João de. Grammatica da Lingua Portuguesa. Olyssipone: apud Lodovicum Rotorigiu[m] typographum, 1540. 120 p.

BARTEL, Dietrich. Musica Poetica: Musical-Rhetorical Figures in German Baroque Music. Lincoln: University of Nebraska Press, 1997.471p.

BARTHES, Roland. Investigaciones retóricas I: La antigua retórica (1970). Serie Comunicaciones. Tradução de Beatriz Dorriots. Barcelona: Ediciones Buenos Aries, 1982.80p.

BEGHIN, Tom \& Sander M. Goldberg (orgs.) Haydn and the performance of rhetoric. Chicago: University of Chicago Press, 2007. 366 p.

BENT, Ian D. ; POPLE, Anthony. Analysis. In: The New Grove Dictionary of Music and Musicians. New York: Oxford University Press Published, INC, 2001, pp.526 - 589.

BERISTÁIN, Helena. Diccionário de Retórica y Poética. $7^{\text {a }}$ Edição: México. Universidade Nacional Autônoma do México, Editorial Porrua S.A, 1995. 510 p.

BERNARDES, Ricardo (Org.). José Maurício Nunes Garcia e a Real Capela de D. João VI no Rio de Janeiro. $1^{\mathrm{a} E}$ Edição. Rio de Janeiro: Ministério da Cultura, FUNARTE, 2002, vol. 6. 400 p. 
BINDER, Fernando; CASTAGNA, Paulo Augusto. Teoria Musical no Brasil: 1734-1854. I Simpósio Latino- Americano de Musicologia, Curitiba, Janeiro de 1997. Curitiba: Fundação Cultural de Curitiba, 1998. pp. 198-217. Disponível em: <http://people.ufpr.br/ budasz/CD10.pdf> Acessado em: 07 de Abril de 2013.

BLUTEAU, Rafael. Vocabulario Portuguez e Latino (Volume 7-letras Q-S). Lisboa: Officina de Pascoal da Sylva, Impressor de Sua Magestade, 1720. 824 p.

BONDS, Marc Evans. Wordless Rhetoric: Musical Form and Metaphor of the Oration. Cambridge: Harvard University Press, 1991. 237 p.

BORÉM, Fausto \& LIMA, Cecília Nazaré de. Heroe, Egregio, para contrabaixo e cravo: aspectos didáticos e interpretativos em uma transcrição de uma cantata do repertório colonial brasileiro. Revista Acadêmica de Música - Per Musi, Belo Horizonte, vol.18, pp.40-51, 2008. Disponível em: <http://www.musica.ufmg.br/permusi/port/numeros/18/Num18_cap_05.pdf> Acessado em: 14 de Outubro de 2013.

BROWN, Leslie Ellen. Oratorical thought and the tragedie lyrique : a consideration of musical-rhetorical figures: College Music Symposium, $X X / 2$ 1980, p. 99-116.Disponível em: < http://symposium.music.org/index.php?option=com_k2\&view=item\&id=1871:ora torical-thought-and-the-tragédie-lyrique-a-consideration-of-musical-rhetoricalfigures\&Itemid=130>. Acessado em: 25 de Abril de 2015.

BUELOW, George. J. Rhetoric and Music. The New Grove Dictionary of Music and Musicians. Ed. SADIE, Stanley. Londres: Macmillan, 1980 vol.15, pp.793-803. . Rhetoric and Music. In: SADIE, Stanley; TYRRELL, John. The New Grove Dictionary of Music and Musicians. New York: Oxford University Press Published, INC, 2001 vol. 21, pp.260 - 275.

BUKOZFER, Manfred. La Música em lá época Barroca, de Monteverdi a Bach. $3^{a}$ Edição. Madrid: Alianza Editorial, 2002. 524 p. 
BURMEISTER, Joachim. Musica Poetica. Rostock: S. Myliander. 1606. Facsimille. ed. Kassel: Blirenreiter, 1955.72 p.

Musical Poetics. Tradução, introdução e notas, Benito V. Rivera. New Haven and London: Yale University Press, 1993. 306 p.

Musica poetica (1606): augmentée des plus excellentes remarques tirées de Hypomnematum musicæ poeticæ (1599), et de Musica autoschédiastiké (1601). Introdução, tradução e notas Agathe Sueur e Pascal Dubreuil. Wavre: Mardaga, 2007.363 p.

CAPLIN, William E. On The Relation of Musical Topoi to Formal Function. Eighteenth-Century Music. Cambridge University Press, pp.113-124, 2005.

CARDOSO, André. A Música na Corte de D. João VI, 1808-1821. São Paulo: Editora Martins Fontes, 2008. 281p.

CARPENA, Lucia Becker. Sobre a qualidade das tonalidades e seu efeito na expressão dos affecten. (Johann Mattheson, 1713). Tradução e breve introdução. Revista Música, v. 13, pp. 219-241, 2012. Disponível em: <file:///C:/Users/User/Downloads/199-437-1-SM.pdf>. Acessado em: 22 de Abril de 2016.

CARVALHO, Maria do Socorro Fernandes de. Poesia e Agudeza em Portugal. 269 f. Tese (Doutorado em Literatura Portuguesa). Programa de Pós-Graduação de Teoria e História dos Estudos da Linguagem, Universidade Estadual de Campinas (UNICAMP), Campinas, 2004. Disponível em: <http://libdigi.unicamp.br/document/?code=vtls000318262> Acessado em: 04 de Abril de 2013.

CASTAGNA, Paulo Augusto. Sagrado e profano na música mineira e paulista da primeira metade do século XVIII. In: II Simpósio Latino-Americano de Musicologia, 1999, Curitiba. Anais... Curitiba: Fundação Cultural de Curitiba, 1998. pp. 97-125. Disponível em: <http://people.ufpr.br/ budasz/CD08.pdf> Acessado em 17 de Março de 2014. 
O 'Estilo Antigo' no Brasil, nos Séculos XVIII e XIX. In: I Colóquio Internacional a Música no Brasil Colonial, Lisboa, Outubro de 2000. Anais... Lisboa: Fundação Calouste Gulbenkian, 2001. pp.171-215.

CASTAGNA, Paulo Augusto. (org.). Missa (Missa Abreviada em Ré de Manoel Dias de Oliveira): Restauração e Difusão de Partituras. Edição: Paulo Augusto Castagna. $1^{\text {a }}$ Edição. Belo Horizonte: Fundação Cultural e Educacional da Arquidiocese de Mariana, vol. 2. 2002.300 p.

. (org.). Ladainha de Nossa Senhora (Ladainha em Si bemol Maior

de José Joaquim Emerico Lobo de Mesquita): Restauração e Difusão de Partituras. Edição: André Guerra Cotta. $1^{a}$ Edição. Belo Horizonte: Fundação Cultural e Educacional da Arquidiocese de Mariana, v. 8. 2003. 373p.

- (org.). Música Fúnebre $\left(1^{\circ}\right.$ Responsório das Matinas $\mathrm{e}$ Encomendação de Defuntos de José Maurício Nunes Garcia) Edição: Carlos Alberto Figueiredo. Belo Horizonte: Fundação Cultural e Educacional da Arquidiocese de Mariana, v. 9. 2003.272 p.

CASTELEIN, Matthijs de. De const van rhetoriken, allen ancommers ende beminders der zelver. Gent: Jan Cauweel, 1555. 254p.

CASTRO, Aníbal Pinto de. Retórica e Teorização Literária em Portugal: do humanismo ao neoclassicismo. $2^{a}$ Edição Lisboa: Impressa Nacional- Casa da Moeda, 2008. 756 p.

CHASIN, Ibaney. O canto dos Afetos: um dizer humanista. São Paulo: Perspectiva, 2004. 190 p.

CHRISTOVAM, Ozório Bimbato Pereira. Análise Retórico-Musical do Discurso de André da Silva Gomes: do Ambiente Luterano-Germânico ao Católico Português. 116 f. (Trabalho de Conclusão de Curso). Faculdade de Filosofia, Ciências e Letras (FFCLRP), Universidade de São Paulo (USP), Ribeirão Preto, 2012. 
CÍCERO, Marco Tulio. De inventione: De optimo genere oratorum topica. Tradução H. M. Hubbell, Loeb Classical Library, Harvard University Press, $1960.466 \mathrm{p}$.

.De Oratore. 4ª Edição Cambridge: Harvard University Press, 1967. $524 \mathrm{p}$.

]$^{132}$. Retórica a Herênio. Tradução e Introdução. Ana Paula Celestino Faria. São Paulo: Hedra, 2005.315 p.

CIVRA, Ferruccio. Musica poetica: introduzione alla retorica musicale. Torino: UTET, 1991. 215 p.

COLLISANI, Amalia. Musica e Simboli. Sallerio Editora, Palermo: 1988.192 p.

COLUZZI, Seth J. Structure and interpretation in Luca Marenzio's Settings of il pastor fido. $569 \mathrm{f}$. (Tese de Doutorado), University of North Carolina at Chapel Hill. Chapel Hill, 2007. Disponível em: <https://cdr.lib.unc.edu/indexablecontent/uuid:8360e4d1-fd81-41a3-a32a9ac2fd716fb1> Acesso em: 25 de Outubro de 2016.

CORBI, Fernando Marín. Figuras, Gesto, Afeto e Retórica na Música. NASSARE: Revista Aragonesa de Musicologia. Insituición "Fernando el Católico". Zaragoza, Vol. XXIII nº. 1, pp.11-52. 2007.

COSTA, Robson Bessa. O Baixo contínuo no "officio de defuntos" de Lobo de Mesquita. 172 f. (Dissertação em Música), Programa de Pós-Graduação da Escola de Música da Universidade Federal de Minas Gerais (UFMG). Belo Horizonte, 2006.2 Disponivel em:<http://www.dominiopublico.gov.br/download/texto/cp022514.pdf $>$ Acessado em: 04 de Fevereiro de 2013.

CROWL, Harry. La Música en el Brasil Colonial antes de La llegada de La corte de D.João VI. Revista Textos do Brasil (Ministério das Relações Exteriores). Brasília, vol.12, pp.24-31. 2006. Disponível em:

\footnotetext{
${ }^{132}$ Autoria atribuída a Cícero.
} 
<http://www.mre.gov.br/dc/espanol/textos/revistaesp12-mat1-2.pdf> Acessado em: 14 de Abril de 2014.

DAVIS, John. Dicionário da Bíblia. $5^{a}$ Edição. Rio de Janeiro: Casa Publicadora Batista, 1977.

DESCARTES, René. As paixões da alma. Introdução de Gilles-Gaston Granger; prefácio e notas de Gérard Lebrun; tradução de J. Guinsburg e Bento Prado Júnior - São Paulo: Nova Abril Cultural, 1987.324 p.

DICIONÁRIO GROVE DE MÚSICA. Edição Concisa. Rio de Janeiro: Jorge Zahar Editor Ltda., 1994. 1050 p.

DOTTORI, Maurício. Ensaio Sobre a Música Colonial Mineira. $114 \mathrm{f}$. (Dissertação Mestrado em Artes), Programa de Pós-Graduação em Música, Escola de Comunicações e Artes, Universidade de São Paulo (USP), São Paulo, 1992.

.Ut Rhetorica Musica: análise do moteto O Vos Omnes a dois coros, de Manoel Dias de Oliveira. Revista Música, São Paulo, vol. 3, n. 1, pp. 53-69. 1992.

. The Church Music of Davide Perez and Niccolò Jommeli, with especial emphasis on their funeral music. $424 \mathrm{f}$. Tese (Doutorado em Música) - University of Wales, Cardiff, 1999.

DUPRAT, Régis. Música na Matriz e Sé de São Paulo Colonial. Anuário Interamericano de Investigacion Musical, University of Texas. Austin, Vol.11, pp.8-68, 1975.

. Garimpo Musical. São Paulo: Editora Novas Metas, 1985. 181 p.

. Música na Sé de São Paulo Colonial. São Paulo: Editora Paulus, 1995. $231 \mathrm{p}$.

- Musicologia e Interpretação: Teoria e Prática. Guarujá, Revista Eletrônica de Divulgação Científica. Faculdade de Ciências e Letras Don Domenico, Vol.1/2, pp. 29-38. 2001. Disponível em: 
<http://www.faculdadedondomenico.edu.br/revista_don/musicologia_ed1.pdf > Acessado em: 19 de Junho de 2013.

A Música Sacra no Brasil colonial e imperial. Revista do Patrimônio Histórico e Artístico Nacional, Brasília vol. 29, pp. 243-255, 2001. Disponível em: <http://www.iphan.gov.br/revistadopatrimonio> Acessado em: 22 de Março de 2014.

DUPRAT, Régis (org.). Música Sacra Paulista. Marília (SP): Editora Empresa Unimar, 1999. 308 p.

DUPRAT, Régis et al. A Arte Explicada de Contraponto de André da Silva Gomes. São Paulo: Arte \& Ciência, 1998. 192 p.

DURAN, Maria Regina da Cruz. Retórica e Eloquência no Rio de Janeiro: 1759-1834. 195 f. Tese (Doutorado em História) Faculdade de História, Direito e Serviço Social da Universidade Estadual Paulista Júlio de Mesquita Filho (UNESP), Franca, 2009.

ESTEVES, José Manuel Vasconcelos. Ironia e Argumentação. Série Estudos da Comunicação. Lisboa: Livros LabCom, 2009. 136 p.

FAGERLANDE, Marcelo. O Método de Pianoforte de José Maurício Nunes Garcia. 218 f. Dissertação (Mestrado em Musicologia). Conservatório Brasileiro de Música, Rio de Janeiro, 1993.

FAVERO, Leonor Lopes. Relações de poder no Brasil colônia: línguas gerais $x$ língua portuguesa. In: VIII ENI> e II SIACD, 2008, São Paulo. Anais do II Simpósio Internacional de Análise Crítica do Discurso e VIII Encontro Nacional de Interação em Linguagem Verbal e Não-Verbal. 2008. vol. 01, pp.1-9. Disponível em:<http://www.fflch.usp.br/dlcv/enil/pdf/Artigo_Leonor_Lopes_Favero.pdf > Acessado em: 12 de Abril de 2013.

FERNANDES, António. Arte de Musica de canto dorgam, e canto cham, \& proporçoes de musica divididas harmonicamente. Lisboa: Pedro Craesbeeck. BN: purl 65, 1626.206 p. 
FERREIRA, Aurélio Buarque de Holanda. Dicionário Aurélio Século XXI. Rio de Janeiro: Editora Nova Fronteira, 2001. 790 p.

. Novo Dicionário da Língua Portuguesa. $3^{a}$ Edição. Curitiba: Editora Positivo, 2004. 2120 p.

FERREIRA dos SANTOS, Mário. Curso de Oratória e Retórica. São Paulo: 9a Edição, Livraria e Editora Logos, 1962. 232 p.

FERREIRA, Ivone. De uma retórica da persuasão para uma retórica da sedução. 4a SOPCOM Universidade de Beira Interior (UBI), Covilhã Portugal, 2005, pp.1820-1827. Disponível em: <http://www.bocc.ubi.pt/pag/ferreira-ivoneretorica-persuasao-retorica-seducao.pdf> Acessado em: 21 de Novembro de 2013.

FERREIRA, Valéria Maria Pena. Retórica das Lágrimas: sermões e orações fúnebres na Bahia do século XVII. 274 f. Tese (Doutorado em Letras) Programa de Pós- Graduação do Curso de Letras da Universidade Federal de Minas Gerais (UFMG), 2007.2 Disponível em: <http://www.bibliotecadigital.ufmg.br/dspace/bitstream/1843/ECAP76LKJS/1/ver s_o_da_tese_definitiva.pdf> Acessado dia 23 de Fevereiro de 2014.

FUBINI, Enrico. La Estética Música desde La Antigüedad hasta El Siglo XX. 13ª Edição. Madrid: Alianza musical, 2002. 600 p.

GALLO, Alberto. História de la música; el Medievo. Madrid: Tuner Música, 1986, vol.3. 148 p.

GARCIA, Afrânio da Silva. Retórica: A Função Heurística da Linguagem. I Simpósio de Estudos Filológicos e Linguísticos. Periódico. Circulo Fluminense de Estudos Filológicos (CiFEFiL), Faculdade de Formação de Professores (FFP) Universidade Estadual do Rio de Janeiro (UERJ), Rio de Janeiro, pp.1-9, 2008. Disponível em: <http://www.filologia.org.br/revista> Acessado em: 04 de Março de 2014.

GARCIA, José Maurício Nunes. Crux Fidelis. Edição: Marcus Alessi Bittencourt. São Paulo. Choral Public Domain Library, 1995. 2 p. Partitura 
manuscrita.

Disponível

em:

$<$ http://www.music.columbia.edu/ alessi/NunesGarcia_CruxFidelis.pdf >Acessa do em: 13 de Março de 2016.

. Domine Jesu. Edição Álvaro Loreto. São Paulo: Choral Public

Domain Library, 2000. 2 p. Partitura. Disponível em: <http://www3.cpdl.org/wiki/index.php/Domine_Jesu_(Jos\%C3\%A9_Maur\%C3\% ADcio_Nunes_Garcia)> Acessado em: 04 de Outubro de 2014.

GODINHO, Josinéia. Do lluminismo ao Cecilianismo: A Música Mineira para a Missa nos Séculos XVIII e XIX. 145 f Dissertação (Mestrao em Música) Programa de Pós-Graduação da Escola de Música da Universidade Federal de Minas Gerais (UFMG). Belo Horizonte, 2008. Disponível em:< http://www.bibliotecadigital.ufmg.br/dspace/bitstream/handle/1843/GMMA7XPHWU/disserta_o_josin_ia_do_iluminismo_a_cecilianismo.pdf?sequence =1>. Acesso em: 12 de Agosto de 2016 .

GROUT, Donald; PALISCA, Claude. História da Música Ocidental. 4ª Edição. Lisboa: Editora Gradavia, 2007. 759 p.

GUIMARÃES, Elisa. Figuras e Retórica e Argumentação. In: MOSCA, Lineide do Lago Salvador. Retóricas de Ontem e de Hoje. $3^{\text {a }}$ Edição. São Paulo: Associação Editorial Humanistas, 2004. pp. 145-160.

HANSEN, João Adolfo. Alegoria: Construção e Interpretação da Metáfora. São Paulo/Campinas: Hedra/Editora Unicamp, 2006. 320 p.

HATTEN, Robert S. Musical Meaning in Beethoven: Markedness, Correlation, and Interpretation Advances in Semiotics. Bloomington: Indiana University Press, 1994, 382 p.

Interpreting Musical Gestures, Topics, and Tropes: Mozart, Beethoven, Schubert. Bloomington: Indiana University Press, 2004, 358 p.

HEIDEGGER, Martin. Ser e Tempo. Trad. Márcia Sá Cavalcante Schubak. Petrópolis: Editora Vozes, 2005. 325 p. 
HERBST, Johann Andreas. Musica poetica: sive Compendium melopoeticum. Nurnberg: J. Dumlers, 1643.140 p.

HERNÁNDEZ GUERRERO, José Antonio; GARCIA, Maria Del Carmen. Historia Breve de La Retorica - Madrid: Síntesis, 2000.222 p.

HOBSBAWM, Eric. A Era das Revoluções. 16. ${ }^{a}$ edição. São Paulo: Paz e Terra, $2002.229 \mathrm{p}$.

HOUAISS, Antônio. Dicionário Houaiss da Língua Portuguesa. Rio de Janeiro: Objetiva, 2001. 2922 p.

- Dicionário Houaiss da Língua Portuguesa. Rio de Janeiro: Objetiva, 2009. 1986 p.

JANK, Helena. E chorou amargamente...; Figuras retórico-musicais e a expressão de extremo pesar.... In: XVII Congresso da ANPPOM (Associação Nacional de Pesquisa e Pós-Graduação em Música), 2007, Anais... Brasília, 2007, vol.17, pp.1-11. Disponível em: <http://www.anppom.com.br/anais/anaiscongresso_anppom_2007/musicologia/ musicol_HJank.pdf>. Acessado em 22 de Maio de 2013.

Tradução do tratado Das Neueröffnete Orchestre de Johann Mattheson (1713), Campinas, 2009, Parte III, Cap.2. pp.1-6.

JAPIASSÚ, Hilton; MARCONDES, Danilo. Dicionário Básico de Filosofia. $3^{a}$ Edição. Rio de Janeiro: Editora Jorge Zahar, 2001. 296 p.

JOSEPH, Miriam. O Trivium: as artes liberais da lógica, gramática e retórica: entendendo a natureza e a função da linguagem. Tradução e adaptação de Henrique Paul Dmyterko. São Paulo: Editora É Realizações, 2008.321 p.

KIEFER, Bruno. História da Música Brasileira, dos Primórdios ao início do Século XX. 4ª Edição. Porto Alegre: Editora Movimento, 1997. 140 p.

KIFFER, Welington. Análise das Figuras de Repetição Melódicas no Coro Hallelujah de Händel. Revista Música e Linguagem. Vol.1 n 4, 2015, p.77-97. Disponível em: 
<http://www.periodicos.ufes.br/musicaelinguagem/article/view/11590/8136>. Acessado em: 14 de Janeiro de 2016.

KIRCHER, Athanasius. Musurgia Unirsalis sive Ars magna consoni et dissoni. Tomo I. Rome. 1650.700 p.

LANDI, Márcio Spartaco. Lições de Contraponto segundo a Arte Explicada de André da Silva Gomes. Fortaleza: Expressão Gráfica e Editora, 2006.288 p.

LANGE, Francisco Curt. A organização musical durante o período colonial brasileiro. Coimbra: $\mathrm{V}$ Colóquio internacional de estudos luso-brasileiros, 1966. $106 \mathrm{p}$.

. História da Música na Capitania Geral das Minas Gerais: Vila do Serro do Frio e Arraial do Tejuco. Belo Horizonte: Conselho Estadual de Cultura de Minas Gerais, 1983. Vol. VIII. 470 p.

LAUSBERG Heinrich. Elementos de Retórica Literária. Tradução, prefácio e aditamentos de Raul Miguel Rosaldo Fernandes. $5^{\text {a }}$ Ed. Lisboa: Fundação Calouste Gulbernkian, 2004. 294 p.

LENNEBERG, Hans. Johann Mattheson on Affect and Rhetoric in Music (I). In: Journal of Music Theory, vol.2, no.1: Duke University Press em nome de Yale University Department of Music, 1958, p.47-84.Disponivel em: <http://www.jstor.org/stable/842930> Acessado em:16 de Outubro de 2014.

LEONI, Aldo Luiz. Os que vivem da arte da música: Vila Rica, século XVIII. 184 f. Dissertação (Mestrado em História Social), Instituto de Filosofia, Ciências e História, IFCH da Universidade Estadual de Campinas (UNICAMP), Campinas, 2007, Disponível em: <http://libdigi.unicamp.br/document/?code=vtls000415282> Acessado em: 22 de Julho de 2013.

LOBO de MESQUITA. José Joaquim Emerico. Missa para Quarta-feira de Cinzas. Edição Rafael Sales Arantes, São João do Del-Rey: IMSLP Contributor Page, 2014. 86 p. Partitura. Disponível em: 
<http://imslp.org/wiki/Missa_para_Quartafeira_de_Cinzas_(Lobo_de_Mesquita, _Emerico)> Acessado em: 29 de Novembro de 2014.

Procissão de Ramos (Cum Appropinquaret). Edição Rafael Sales Arantes, Três Corações: IMSLP Contributor Page, s/d. 10 p. Partitura. Disponível em: <http://ks.petruccimusiclibrary.org/files/imglnks/usimg/4/43/IMSLP318147PMLP514215-Procissao_de_Ramos_I_-_Lobo_de_Mesquita.pdf>. Acessado em: 28 de Dezembro de 2015.

LÓPEZ CANO, Rubén. Música y Retórica en el Barroco. México, D.F: Gráfica da Universidade Nacional Autônoma do México, 2000, vol.1 e 2. 237p.

LUCAS, Mônica Isabel. Humor e Agudeza nos Quartetos de Cordas Op.33 de Joseph Haydn. 273 f. Tese (Doutorado em Música). Instituto de Artes, IA, Universidade Estadual de Campinas (UNICAMP), Campinas, 2005. Disponível em: <http://libdigi.unicamp.br/document/?code=vtls000391815> Acessado em: 18 de Abril de 2013.

. Retórica e Estética na música no século XVIII. Revista ArtCultura (UFU), Uberlândia, vol. 9, pp. 223-234. 2007.

. Emulação de Retóricas Clássicas em Preceptivas da Musica Poetica. Opus (Porto Alegre. Online), vol. 20, n. 1, pp. 71-94, 2014. Disponível em: <http://www.anppom.com.br/opus/pt-br/issues/20.1>Acessado em: 25 de Outubro de 2014.

MACHADO NETO, Diósnio. Administrando a festa: Música e lluminismo no Brasil Colonial. 470 f. Tese (Doutorado em Musicologia). Programa de PósGraduação em Música, Escola de Comunicações e Artes (ECA), Universidade de São Paulo (USP), São Paulo, 2008.

Em vão vigiam as sentinelas: cânones e rupturas na historiografia musical brasileira sobre o período colonial. 322 f. Tese (LivreDocência). Faculdade de Filosofia, Ciências e Letras (FFCLRP), Universidade de São Paulo (USP), Ribeirão Preto, 2011. 
. A censura das luzes na capela da Sé paulista, em 1774: modelos políticos, modelos musicais. ArtCultura (UFU), v. 14, p. 83-102, 2012. Disponível em: <http://www.artcultura.inhis.ufu.br/PDF25/Diosnio_Neto.pdf> Acessado em: 06 de Março de 2015.

Administrando a Festa: Música e lluminismo no Brasil Colonial. Curitiba: Prismas, $2013.521 \mathrm{p}$.

. A manifestação do lluminismo Católico em José Maurício Nunes Garcia: a Missa de Nossa Senhora da Conceição (1810). In: Diósnio Machado Neto, David Cranmer. (Org.). Música, Cultura e Identidade no bicentenário da elevação do Brasil a Reino Unido. $1^{\text {a }}$ ed. Lisboa: Caravelas - Núcleo de Estudos da História da Música Luso-Brasileira, 2016, vol.2 , p. 132-151.

MACIEL, Ruy Homem de Mello. A forma sonata em descontinuidades e bifurcações. 422 f. Tese (Doutorado em Música). Programa de PósGraduação em Música, Escola de Comunicações e Artes, Universidade de São Paulo (USP), São Paulo, 2010, Disponível em: <http://www.teses.usp.br/teses/disponiveis/27/27158/tde10112010140659/en. pdf > Acessado em: 11 de Dezembro de 2013.

MALEVAL, Maria do Amparo Tavares. Da retórica medieval. In: Gladis MassiniCagliari; Márcio Ricardo Coelho Muniz; Paulo Roberto Sodré; Risonete Batista de Souza. (Org.). Metodologias - Série Estudos Medievais, 1. Rio de Janeiro: Grupo de Trabalho Estudos Medievais da ANPOLL, 2008, vol.1, p. 1-27.

MANACORDA, Mario Alighiero. História da Educação: da Antiguidade aos nossos dias. Tradução de Gaetano Lo Monaco, São Paulo: Cortez Editora e Autores Associados, 6ª Ed., 1997.382 p.

MARCONDES, Danilo. Iniciação à História da Filosofia: Dos pré-socráticos até Wittgenstein. 6ª Edição. Rio de Janeiro: Editora Jorge Zahar, 2001. 298 p.

MARIZ, Vasco. História da Música no Brasil. 6a Edição. Rio de Janeiro: Editora Nova Fronteira, 2005. 550 p. 
MARROQUÍN, Lucía Díaz. La retórica de los afectos. Zaragoza: Estudios de Literatura 110 DeMusica 13, 2008. 330 p.

MATTHESON, Johann. Das Neu- Eröffnete Orchestre. Hamburg, Benjamin Schiller, 1713, 338 p.

.Der Vollkommene Capellmeister. Fac-simile do original de 1739 (Hamburg :Crsitian Herold). Kassel: Basel: Bärenreiter - Verlag, 1954. $484 \mathrm{p}$.

Der Volkommene Cappelmeister. Faksimile-Nachdruck herausgegeben (1739),von Margarete Reimann. Kassel und Basel: Bärenreiter - Verlag, 1965.500 p.

MATTOS, Cleofe Person de. Catálogo Temático das obras do padre José Maurício Nunes Garcia. Rio de Janeiro: Conselho Federal de Cultura, 1970. 413 p.

José Maurício Nunes Garcia: Biografia. Rio de Janeiro: Biblioteca Nacional, 1997.

MAYS, Lawrence John. An investigation of the creation of drama in recitative through comparative analysis: La Serva Padrona set by Pergolesi (1733) and Paisiello (1781). 125 f. Dissertação (Mestrado em Filosofia). The Australian National University, Canberra, Austrália, 2013. Disponível em: $<$ https://openresearch-

repository.anu.edu.au/bitstream/1885/9861/2/02Whole_Mays.pdf>. Acessado em: 21 de Junho de 2016.

MERSENNE, Marin. Harmonie Universelle contenant la théorie et la pratique de la musique. I Parte. Paris, 1636-7. 793 p.

Harmonie Universelle contenant la théorie et la pratique de la musique. II Parte. Paris, 1636-7. 750 p.

MEYER, Michel. A Retórica. Tradução: Marly N. Peres. São Paulo. Editora Ática, 2007.128 p. 
. Principia Rhetorica. Una Teoria Geral de la Argumentación. $1^{a}$ Edição. Buenos Aires: Amorrortu, 2013.347 p.

MICHES, Urich. Atlas da Música. Madri: Alianza Musical Editorial, 1992, vol. 1. $286 \mathrm{p}$.

Atlas da Música do Barroco a Atualidade. Lisboa: Editora Gradavia, 2007, vol. 2.304 p.

MIRANDA, Maria Margarida Lopes. Sem a voz que os animou, ainda ressuscitados são cadáveres. Actio e declamatio na formação de Vieira, pregador. Humanitas LX, pp. 267-282. 2008. Disponível em: $<$ http://www.uc.pt/fluc/eclassicos/publicacoes/ficheiros/humanitas60/17_Mirand a.pdf >Acessado em: 29 de Abril de 2015.

MONTEIRO, Donald Bueno. Música Religiosa no Brasil Colonial. Fides Reformata XIV São Paulo, $\mathrm{n}^{\circ}$. 1, pp.75-100. 2009. Disponível em: <http://www.mackenzie.br/fileadmin/Mantenedora/CPAJ/revista/Fides_v14_n1_ artigo-4.pdf> Acessado em: 09 de Agosto de 2013.

MONTEIRO, Maurício. Música na Corte do Brasil: Entre Apolo e Dionísio 1808 1821 Revista Textos do Brasil (Ministério das Relações Exteriores). Brasília, vol.12, pp.32-39. 2006. Disponível em: <http://www.mre.gov.br/dc/textos/revista12-mat4.pdf> Acessado em 25 de Março de 2014.

MORALES y MARIN, José Luis. Barroco y Rococó. Ed. Historia Universal del Arte. Planeta, Barcelona, 1990. 400p.

MORETZSOHN, Júlio Cesar Rocha. Missa a 4 vozes para Quarta-feira de cinzas com Violoncelo obbligato e Órgão, de J.J. Emerico Lobo de Mesquita: um estudo interpretativo. $147 \mathrm{f}+$ anexos. Dissertação (Mestrado em Música) Programa de Pós-Graduação em Música do Centro de Letras e Artes da Universidade Federal do Estado do Rio de Janeiro, UNIRIO, Rio de Janeiro, 1997. 
As Missas de J. J. Emerico Lobo de Mesquita: um estudo estilístico. 651f. Tese (Doutorado em Música). Universidade Federal do Estado do Rio de Janeiro, UNIRIO, Rio de janeiro, 2008.

MOYLAN, Andrew L. Venerable Style, Form, and the Avant-Garde in Mozart's Minor Key Piano Sonatas K. 310 and K.457: Topic and Structure. 110 f. Dissertação (Mestrado em Música). University of Massachusetts, Amherst, $2014 . \quad$ Disponivel em: $<$ http://scholarworks.umass.edu/cgi/viewcontent.cgi?article=1055\&context=mas ters_theses_2 > Acessado em : 19 de Julho de 2016.

MURPHY, James Jerome. La Retórica en la Edad Media. Historia de la teoría de la retórica desde San Agustín hasta el Renascimiento. Tradução Guillermo Hirata Vaquera. México: Fondo de Cultura Econômica, 1986.407 p.

Sinopsis Historica de la Retórica Clásica. Madri: Editorial Gredos, 1989. $283 \mathrm{p}$.

NIETZSCHE, Friedrich. Escritos sobre Retórica. Edición y Traducción de Luis Enrique de Santiago Gervós Editorial TROTTA, Clásicos de la cultura, Madrid, 2000, 232 p.

NOGUEIRA, Caio Benevolo Sierra. Fontes Retórico-Musicais na era Clássica (1750-1830). Cadernos do Colóquio (UNIRIO), vol.5, p. 68-79, 2005. Disponível em: <http://www.seer.unirio.br/index.php/coloquio/article/view/79/44> Acessado em: 06 de Maio de 2014.

NOVAES, Ronaldo; MACHADO NETO, Diósnio. Alegoria da paixão na festa de domingo de Ramos, análise retórica em André da Silva Gomes. In: IV Semana de Música Antiga da UFMG: bizarra alegoria, 2014, Belo Horizonte. Anais... Belo Horizonte: Universidade Federal de Minas Gerais, 2014. pp. 60-65. Disponível em: <http://www.musica.ufmg.br/textos/Anais/MusAntiga.pdf> Acessado em: 16 de Dezembro de 2014.

OLIVERIA, André Luiz Muniz. O Magnificat de Johann Sebastian Bach: uma leitura à luz do seu significado retórico musical. 142 f. Dissertação (Mestrado em Artes) Instituto de Artes, IA, Universidade Estadual de Campinas 
(UNICAMP), $\quad$ Campinas, $2006 . \quad$ Disponível em:< http://libdigi.unicamp.br/document/?code=vtls000275735> Acessado em: 15 de Março de 2014.

. O uso de Figuras de Retórica Musical no Magnificat de Johann Sebastian Bach. In: XVI Congresso da Associação Nacional de Pesquisa e Pós-Graduação em Música (ANPPOM) Anais... Brasília, 2006. vol.16, pp.360364.

em:< http://www.anppom.com.br/anais/anaiscongresso_anppom_2006/CDROM/CO M/04_Com_Musicologia/sessao02/04COM_MusHist_0205-079.pdf> Acessado em: 13 de Junho de 2014.

OLIVEIRA, Katya Beatriz. A interpretação vocal na Missa em Mi bemol de José Joaquim Emerico Lobo de Mesquita: por uma interpretação historicamente fundamentada, focalizando o solo de soprano quoniam. $346 \mathrm{f}$. Dissertação (Mestrado em Música) Programa de Pós-Graduação em Música, Centro de Letras e Artes, Universidade do Estado do Rio de Janeiro (UNIRIO), Rio de Janeiro, 2011. Disponível em: $<$ https://www.scribd.com/document_downloads/direct/220217807?extension=p $\mathrm{df} \& \mathrm{ft}=1436186671 \& \mathrm{lt}=1436190281$ \&user_id=27955281\&uahk=i8JQKEP8y0LR NSBuMFr1KXtWWW4> Acessado em: 21 de Maio de 2015.

OLIVEIRA, Manoel Dias de. Matinas e Vésperas de Sábado Santo, Edição de Maurício Dottori. São Paulo: EDUSP (Música Brasileira 2), 2000.189 p.

Moteto dos Passos. Restauração: Maurício Dottori. São Paulo: s/d. Partitura. 85p.

OKAMOTO, Kimiko. The Passacalille of Armide Revisited: Rhetorical Aspects of Quinault's/ Lully's tragédie en musique. Historical Dance Society, volume 4, number 2, $2012 . \quad$ pp.11-18. Disponível em: <http://historicaldance.org.uk/jnl/pdf/HistDance-2012-V4N2-pp11-18 Okamoto.pdf>. Acessado em: 02 de Novembro de 2016. 
PAIXÃO, Ana Margarida Madeira Minhós. Retórica e Técnicas de Escrita Literária e Musical em Portugal entre os séculos XVII-XIX-vol. 1.390 f. Tese (Doutorado em Literatura Comparada) Programa em Estudos Comparatistas da Faculdade de Letras da Universidade de Lisboa em Co-Tutela na Univerisade de Nice Sophia Antipolis (França), Lisboa e Nice, 2008.

- Retórica e Técnicas de Escrita Literárias e Musicais em Portugal entre os séculos XVII-XIX-vol. 2. 209 f. (Doutorado em Literatura Comparada) Anexos e Listas de Figuras. Programa em Estudos Comparatistas da Faculdade de Letras da Universidade de Lisboa em CoTutela na Univerisade de Nice Sophia Antipolis (França), Lisboa e Nice, 2008.

PASSOS, Henrique Romaniello. Vieira e Bach: uma retórica do espelhamento. 112 f. Dissertação (Mestrado em Literatura) Programa de Pós- Graduação do Curso de Letras da Universidade Federal de Minas Gerais (UFMG), 2006. Disponível em: <http://www.bibliotecadigital.ufmg.br/dspace/bitstream/1843/ALDR6WEHSE/1/ disserta_o_vers_o_agrupada_pdf>. Acessado em: 20 de Junho de 2013.

PERELMAN, CHAIM. Tratado de Argumentação: A Nova Retórica. Tradução: Maria Ermantina de Almeida Prado Galvão. - $2^{a}$ Edição. - São Paulo: Martins Fontes, 2005.653 p.

PERSONE, Pedro. As Obras 'Non Mesurés' para Cravo, Explicadas Segundo as Leis da Retórica. 160 f. Dissertação (Mestrado em Artes) Instituto de Artes, IA, Universidade Estadual de Campinas (UNICAMP), Campinas, $1996 . \quad$ Disponível em: <http://libdigi.unicamp.br/document/?code=vtls000111845> Acessado em: 12 de Outubro de 2013.

PIRES, Sérgio. Lobo de Mesquita e a Música Colonial Mineira. Dissertação (Mestrado em Música). Conservatório Brasileiro de Música, Rio de Janeiro, 1994.

PLATÃO. A República. Trad. Enrico Corvisieri. São Paulo: Editora Nova Cultural, 1997.259 p. 
PLATOFF, John. Wye Jamison Allanbrook. Rhythmic Gesture in Mozart: Le Nozze di Figaro and Don Giovanni (1983). In: The Journal of Musicology University of California, Vol. 4, No. 4 (Autumn, 1985 - Autumn, 1986), pp. 535538. Disponível em: <http://www.jstor.org/stable/763755> Acessado em: 22 de Abril de 2015.

PLEBE, Armando. Breve História da Retórica Antiga. São Paulo: Editora Pedagógica e Universitária Ldta/ EPU, 1978. 108p.

POLASTRE, Cláudia Aparecida. A música na cidade de São Paulo, 17651822. 255 f. Tese (Doutorado em Ciências Sociais)- Programa de PósGraduação em História Social do Departamento de História da Faculdade de Filosofia, Letras e Ciências Humanas da Universidade de São Paulo, USP, São Paulo, 2008.2 Disponível em: <http://www.teses.usp.br/teses/disponiveis/8/8138/tde13042009154843/es.php $>$ Acessado em: 12 de Setembro de 2014.

QUANTZ, Joahnn Joachim. Essai D'une Methode pour apprendre à jouer dela Flute tranversiere: avec plusieurs remarques pour servir au bon gout dans la musique. le tout éclairci par des exemples et par XXIV. Tailles douces. Berlim: Chez Chretien Fredecic Voss, 1752.351 p.

QUINTILIANO, Marco Fabio. Institutione Oratoria- libri duodecim, cum notis et animadversionibus virorum doctorum. Edição de Pieter Burmann, revisão e publicação de Petrum Burmannum, Lugduni Batavorum, apud Joannem de Vivie, Leiden, 1720 [1416]. 660p.

QUINTILIANO, Marco Fabio; HILD, J.A. Instituitione Oratoria- Libri decimus. Paris: Librairie C. Klincksieck, 1885 [1416].172 p.

RAMOS, Rafael Registro. Discurso e conceitos no tratado de contraponto de André da Silva Gomes: um estudo de recepção. 202 f. (Dissertação de Mestrado em Música)- Pós-Graduação em Música, Escola de Comunicações e Artes, ECA, Universidade de São Paulo, USP, São Paulo, 2014. Disponível em:<http://www.teses.usp.br/teses/disponiveis/27/27157/tde-27012015- 
162939/publico/RAFAELREGISTRORAMOS.pdf> Acessado em: 02 de Maio de 2015.

RATNER, Leonard G. Classic music: expression, form, and style. New York: Schirmer Books; London: Collier Macmillan Publishers, 1980. 475p.

REBOUL, Olivier. Introdução à Retórica. Tradução de Ivone Castilho Benedetti. $2^{a}$ Edição. São Paulo: Ed. Martins Fontes, 2004.253 p.

REZENDE, Antônio Martinzes de. Rompendo o Silêncio: a construção do discurso oratório em Quintiliano. 280 f. Tese (Doutorado em Linguística)Programa de Pós-graduação em Estudos Linguísticos, Universidade Federal de Minas Gerais, UFMG, Belo Horizonte, 2009.Disponível em: <http://www.bibliotecadigital.ufmg.br/dspace/bitstream/handle/1843/ALDR7U8PNU/1432d.pdf?sequence=1>. Acessado em: 4 de Outubro de 2016.

RICCIARDI, Rubens Russomano. Manoel Dias de Oliveira: Um compositor brasileiro em tempos coloniais-documentos e partituras. $142 \mathrm{f}+$ anexos. Tese (Doutorado em Artes)- Pós-Graduação em Música, Escola de Comunicações e Artes, ECA, Universidade de São Paulo, USP, São Paulo, 2000.

RODRIGUES, Ana Carolina. Análise de alguns aspectos retórico-musicais de “Domine, Deus, Agnus Dei” do Glória RV 545 de Antônio Vivaldi. Música Hodie. Programa de Pós-Graduação de Música da Universidade Federal de Minas Gerais (UFMG), Belo Horizonte, vol.6 №. 1. pp. 35-49, 2001. Disponível em: <http://revistas.ufg.br/index.php/musica/article/view/1848/1755> Acessado em: 02 de Setembro de 2013.

RODRIGUES, Maria Machado. Iluminismo e Contra-lluminismo. In: Seminário Superior de Literatura Portuguesa, 2004, Rio de Janeiro. Anais... Cadernos da ABF, 2004. vol. IV. pp. 116-131. Disponível em: <http://www.filologia.org.br/abf/vol4/num1-08.htm> Acessado em: 12de Julho de 2013.

ROSEN, Charles. El Estilo Clássico (Haydn, Mozart e Beethoven). Madrid3ª Edição- Madrid: Alianza Musical Editorial S.A, 1999. 467 p. 
SANTOS, Zulmira C. Entre a "doutrina" e a retórica: os tratados sobre os Quatro Novíssimos (1622) de Frei António Rosado O.P. In: Os "Últimos Fins" na Cultura Ibérica (XV-XVIII) Revista da Faculdade de Letras, Línguas e Literaturas, Universidade do Porto, Porto, pp.161-172,1997. Disponível em: <http://repositorioaberto.up.pt/bitstream/10216/8184/2/artigo5751.pdf>.

Acessado em: 18 de Abril de 2013.

SCHEREINER, Cláudia. Psalmo de anjinhos bem xibantes: representações musicais no salmo Laudate pueri (1813) de José Maurício Nunes Garcia. 96 f. Dissertação (Mestrado em Música) Programa de Pós-Graduação em Música, Universidade Federal da Bahia (UFBA), Salvador, 2008.

SHIBATA, Ricardo Hiroyuki. Retórica e Teorização na carta "a el -rei D. João" de Sá de Miranda.115 f. Dissertação (Mestrado em Letras) Instituto de Linguagem da Universidade Estadual de Campinas (UNICAMP), Campinas, 1996. Disponível em:<http://libdigi.unicamp.br/document/?code=vtls000110440> Acessado em 23 de Outubro de 2013.

SILVA, Cláudio Henrique da. Virtudes e vícios em Aristóteles e Tomás de Aquino: oposição e prudência. In: IV Colóquio do CPA - Política e Ética na Antiguidade Clássica, 1998, Campinas. Boletim do CPA, 1998. vol. 5/6. pp. 129-140.

Disponível

em:

$<$ http://www.ifch.unicamp.br/cpa/boletim/boletim05/08silva.pdf> Acessado em: 15 de Maio de 2013.

SILVA, Flávio Mateus da. "Behold a virgin shall conceive e O thou that tellest good tidigns" do oratório "O Messias" de George Friedrich Haendel- Uma análise retórico-musical. Estudando a Semântica das Paixões. Programa de Pós-Graduação em Música da Universidade Federal de Minas Gerais (UFMG), Belo Horizonte, 2005, pp.33-49. Disponível em: <http://www.musica.ufmg.br/textos/cdsemantica/05Flávio.pdf> Acessado em 21 de Setembro de 2013.

SILVESTRE, João Paulo. A Informação Retórica no Vocabulário Portuguez e Latino (1712-1728) de Rafael Bluteau: da descrição à Composição Literária. In: Retórica. Actas do I Congresso Virtual do Departamento de Literaturas 
Românicas, Faculdade de Letras da Universidade de Lisboa 2005, Anais... Lisboa, 2005, pp.1-14. Disponível em: $<$ http://clp.dlc.ua.pt/Publicacoes/informacao_retorica_vocabulario.pdf $>$ Acessad o em: 29 de Janeiro de 2013.

SOARES, Cipriano. De Arte Rhetorica libri tres ex Aristotele, Cicerone et Quintiliano præcipue deprompti ab eodem Auctore recogniti, et multis in locis loclupetati. Coimbra, Olyssipone, Anno Dñi, 1575.

SOARES, Eliel Almeida. A utilização de elementos e figuras de retórica nos Ofertórios de André da Silva Gomes. 461 f. Dissertação (Mestrado em Música)- Pós-Graduação em Música, Escola de Comunicações e Artes, ECA, Universidade de São Paulo, USP, São Paulo, 2012.

. Retórica: Um Novo Objeto de Estudo na Música Colonial Brasileira. In: III Simpósio Brasileiro de Pós-Graduandos em Música (SIMPOM). Anais... Rio de Janeiro, 2014. pp. 1-11. Disponível em: <http://www.seer.unirio.br/index.php/simpom/article/download/4668/4167>. Acessado em: 23 de Março de 2015.

SOARES, Eliel Almeida; NOVAES, Ronaldo. Figuras de Retórica no Ofertório da Missa do Primeiro Domingo da Quaresma de André da Silva Gomes. VIII SEMPEM (Seminário Nacional de Pesquisa em Música) 2008. Anais... Programa de Pós-Graduação Stricto Sensu da Escola de Música e Artes Cênicas da Universidade Federal de Goiás (UFG), Goiânia: Editora Vieira, vol.8, 2008, pp.101-110. Disponível em: <http://www.musica.ufg.br/mestrado/anais/anais\%20do\%20VIII\%20Sempem/S EMPEM_on-line2008.pdf> Acessado em 22 de Maio de 2013.

SOARES, Eliel Almeida; NOVAES, Ronaldo; MACHADO NETO, Diósnio. Figuras Retóricas no Ofertório da Missa de Quarta-feira de Cinzas de André da Silva Gomes (ano de aprovação 2012/ publicação 2013). Música Hodie, vol. 12, pp. 2012. 71-86, Disponível em: < http://www.musicahodie.mus.br/12.2/artigo_6.pdf> Acessado em: 17 de Setembro de 2013. 
SOARES, Eliel Almeida; MACHADO NETO, Diósnio. A Aplicação de Figuras e Elementos Retóricos em Dois Ofertórios de André da Silva Gomes. DAPesquisa, vol. 4, pp. 391-403, 2011. Disponível em: < http://www.ceart.udesc.br/dapesquisa/files/03MUSICA_Eliel_Almeida_Soares2 212.pdf> Acessado em: 15 de Junho de 2013.

- Figuras Retóricas no Domine Jesu de José Maurício Nunes Garcia. In: XXIV Congresso da ANPPOM, 2014, São Paulo-SP. Anais... Porto Alegre- RS: Editora da ANPPOM, 2014. pp. 1-10. Disponível em: <http://www.anppom.com.br/congressos/index.php/Anppom2014/trabalhosEscr itos2014/paper/view/2897> Acessado em: 13 de Setembro de 2014.

Análise em Manoel Dias de Oliveira: Exemplos de Figuras Retórico-Musicais. DAPesquisa, vol. 9 n.12, pp. 90-106, 2014. Disponível em: <http://www.revistas.udesc.br/index.php/dapesquisa/article/download/5071/396 8> Acessado em: 23 de Dezembro de 2014.

. Figuras Retóricas no Crux Fidelis de José Maurício Nunes Garcia. In: XI Encontro de Musicologia Histórica, 2016, Juiz de Fora-MG. Anais... Juiz de Fora-MG: Editora da UFJF, 2016. pp. 1-11.

. O Uso de Elementos Retóricos no Gloria da Missa Abreviada em Ré de Manoel Dias de Oliveira. In: IV Simpósio Internacional de Música IberoAmericana (SIMIbA) e I Congresso da Associação Brasileira de Musicologia (ABMUS), 2016, Belo Horizonte-MG. Anais... Belo Horizonte-MG, 2016. pp. 649-669.

SOARES, Paulo Augusto. Os Ofertórios de André da Silva Gomes. $183 \mathrm{f}$. Dissertação (Mestrado em Artes). Instituto de Artes, Universidade Estadual Paulista Júlio de Mesquita Filho (UNESP) São Paulo, 2000.

SOARES, Tiago Rodrigues. O contexto criativo em As Variedades de Proteu e sua transcrição musicológica. $164 \mathrm{f}+$ anexos. Dissertação (Mestrado em Letras e Artes) Programa de Pós-Graduação em Letras e Artes, Universidade Estadual do Amazonas (UEA), Manaus, 2016. Disponível em: < http://tede.uea.edu.br/jspui/bitstream/tede/203/5/O\%20contexto\%20criativo\%20 
em $\% 20$ as $\% 20$ variedades $\% 20$ de $\% 20$ proteu $\% 20$ e $\% 20$ sua $\% 20$ transcri\%C3\%A7 \%C3\%A30\%20musicol\%C3\%B3gica\%20Disserta\%C3\%A7\%C3\%A3o.pdf.> Acessado em: 10 de Novembro de 2016.

SOTUYO BLANCO, Pablo. Modelos Pré-Composicionais nas Lamentações de Jeremias no Brasil. 301 f. Tese (Doutorado em Música) Programa de PósGraduação em Música, Universidade Federal da Bahia (UFBA), Salvador, 2003.

Disponível

em: <http://www2.ufba.br/ psotuyo/dir/artigos/Tese\%20PSB\%20\%20MPCLamBrasil \%20-\%20UFBA\%202003> Acessado em: 04 de Abril de 2014.

SOUZA, Ana Guiomar Rêgo. Paixões em Cena: A Semana Santa na Cidade de Goiás (Século. XIX). 420 f. Tese (Doutorado em História). Instituto de Ciência Humanas, Departamento de História da Universidade de Brasília, Brasília, 2007.

SPINOZA, Benectitus. Ethica Ordine Geometrico Demostrata. [1677], In: Harold H. Joachim, Fellow and Tutor of Merton College, Oxford at the Clarendon Press, 1901. 309 p.

TESAURO, Emanuele. II Cannocchiale aristotelico o sia idea dell'arguta et ingeniosa elocutione che serve a tutta l'arte oratória, lapidaria e simbólica, esaminata co' Principii del divino Aristotele [1654], Veneza: presso Passo Baglioni,1669.572 p.

TOLEDO, Benedito Lima de. Essência e Alcance das Manifestações Barrocas no Universo Luso-Brasileiro. Revista Música, São Paulo, vol. 11, pp.29-44, 2006.

TONI, Flávia Carmago (Org.); DUPRAT, Régis; VOLPE, Maria Alice. Recitativo e Ária para José Mascarenhas. São Paulo: EDUSP, 2000. 178 p. THORLEY, Anthony John. Musical Rhetoric and Performance Practice in Dietrich Buxtehude‘s Organ Works. 88 f. Dissertação (Mestrado em Música). University of York Music, Heslington- RU, 2015. Disponível em: 
<http://etheses.whiterose.ac.uk/9661/1/MA\%20Thesis\%20\%20A.Thorley\%20109053048.pdf>. Acessado em: 03 de Novembro de 2016.

THURINGUS, Joachim. Opusculum Bipartitum de Promordiis Musicis. Berlim: Kallius,1624.232p.

UNGER, Hans-Heinrich. Musica e retorica fra XVI e XVIII. Secolo. Firenze: Alinea, 2003, 303p.

VAZ, Henrique Cláudio de Lima. Escritos de Filosofia VII- Raízes da Modernidade. São Paulo: Edições Loyola, 2002. 291 p. (Coleção Filosofia$55)$.

VERNEY, Luís António. O Verdadeiro Método de Estudar para ser Útil. Vol.1 Valensa [Nápoles]: Oficina de Antonio Balle [Genaro e Vicenzo Muzio], 1746. $322 \mathrm{p}$.

VICKERS, Brian. Figures of Rhetoric/Figures of Music? In: Rhetorica. Journal of the History of Rhetoric, vol.2 no.1. University of California Press, 1984, pp.1-44. Disponível em: <http://www.jstor.org/stable/10.1525/rh.1984.2.1.1> Acessado em: 15 de Abril de 2015.

VIDAL, João Vicente. A Idéia do 'Clássico' no classicismo. Retórica e Música no Final do Século XVIII. 171 f. Dissertação (Mestrado em Música). Escola de Música: Centro de Letras e Artes, Universidade Federal do Rio de Janeiro (UFRJ) Rio de Janeiro, 2002.

VIEIRA, António. Sermoens do Padre Antonio Vieira. Primeira parte. Lisboa: Officina de Joam da Costa, 1679.689 p.

VIEIRA, Enesto. Diccionário Biográphico de Músicos Portuguezes. História e Bibliographia da Música em Portugal. vol.1 Lisboa: Mattos, Moreira \& Pinheiro, 1900.559 p.

Diccionário Biográphico de Músicos Portuguezes. História e Bibliographia da Música em Portugal. vol. 2 Lisboa: Mattos, Moreira \& Pinheiro, $1900.519 \mathrm{p}$. 
VILLAVICENCIO, Cesar Marino Grossmann. The Discourse of Free Improvisation: A Rhetorical Perspective on Free Improvised Music. 266 f. Tese (Doutorado em Música). University of East Anglia, Norwich, Inglaterra, 2008.

VOGT, Mauritius Johann. Conclave thesauri magnæ artis musicæ. VeteroPrage, Magno Collegio Carolino, Typis Georgij Labaun Annô, 1719. 223 p.

WESLEY NGA, James. The Exploration and Discovery of Dance Topoi in Franz Schubert's Piano Sonatas. 134 f. Tese (Doutorado em Artes). Texas Tech University, Lubbock, 2015.

WUCHNER, Emily Michelle. An Intricate Simplicity: Contraries as an Evocation of the Sublime in Mozart's Jupiter Symphony, k. $551.137 \mathrm{f}$. Dissertação (Mestrado em Música). University of Tennessee, Knoxville,2011. Disponível em: <http://trace.tennessee.edu/cgi/viewcontent.cgi?article=2034\&context=utk_grad thes>. Acessado em: 12 de Setembro de 2016.

YAMAMURA, Kaoru. Rhetorical Approach to the Performance of Eighteenth-Century Keyboard Music on the Modern Piano: C.P.E. Bach's Fantasia in g minor, wq. 117-13 and Mozart's Fantasia in d minor, K.397. 58 f. Tese (Doutorado em Música). Indiana University, Bloomington, 2013. Disponível em:

https://scholarworks.iu.edu/dspace/bitstream/handle/2022/15570/Yamamura_K aoru_2013\%20final.pdf;sequence=1>. Acessado em: 16 de Agosto de 2014.

ZARLINO, Gioseffo. Le Istitutioni Harmoniche. Reimpressão da edição de 1558.Trnaslations Program of the National Endowment for the Humanities, an independent federal agency,Yale University,1983.150 p.

\subsection{Sites Pesquisados}

\section{José Mauricio Nunes Garcia}

Disponível em: <http://www.arqnet.pt/dicionario/garciajosemauricio.html> Acessado em 12 de Março de 2013. 
Disponível em: <http://www.josemauricio.com.br/> Acessado em 12 de Novembro de 2014.

\section{Figuras de Retórica na Música}

Disponível em:<http://figurasretoricomusicais.com> Acessado em: 11 de Setembro de 2013.

\section{Textos sobre Retórica Musical}

Disponível em:<http://www.retoricamusical.com/home-1> Acessado em: 17 de Abril de 2013.

\section{Sobre História da Música Luso-Brasileira}

Disponível em: <http://www.caravelas.com.pt/Portugues.htm> Acessado em 21 de Janeiro de 2014.

\section{Elementos de Retórica}

Disponível em: <http://www.radames.manosso.nom.br/retorica> Acessado em: 14 de Novembro de 2013.

\subsection{Materiais Didáticos}

LUCAS, Mônica Isabel. Material didático da disciplina: CMU 5942Introdução à Retórica da Música Setecentista, sob-responsabilidade da Profa. Dra. Mônica Isabel Lucas. Programa de Pós-Graduação em Música da Escola de Comunicações e Artes (ECA) da Universidade de São Paulo (USP) 2010.

\subsection{Citação no Exame de Qualificação de Doutorado} LIMA, Edilson V. Arguição no exame de qualificação de doutorado de Eliel Almeida Soares. Programa de Pós-Graduação em Música da Escola de Comunicações e Artes (ECA) da Universidade de São Paulo (USP), 19 de Agosto de 2015. 